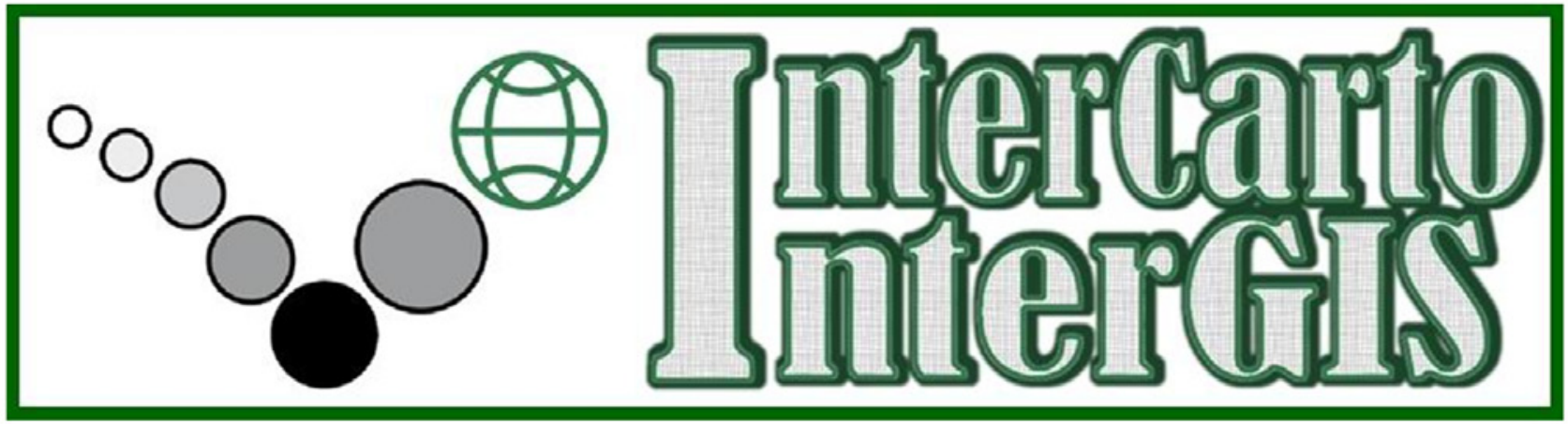

ИнтерКарто. ИнтерГИС

ГЕОИНФОРМАЦИОННОЕ ОБЕСПЕЧЕНИЕ УСТОЙЧИВОГО РАЗВИТИЯ ТЕРРИТОРИЙ

\title{
Материалы Международной конференции
}

Апатиты (Мурманская область, Россия)

21-23 августа

Нур-Султан (Казахстан)

27 августа 2021

\section{Tом 27}

Часть 2

http://intercarto.msu.ru

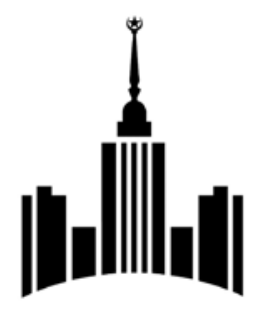

ГЕОГРАФИЧЕСКИЙ ФАКУЛЬТЕТ

МгУ имени М.В. Ломоносова 
ISSN 2414-9179 (Print)

ISSN 2414-9209 (Online)

УДК 911.2:528

Организаторы конференции:

Международная картографическая ассоџиачия, Международная академия наук Евразии, Кольский научныий центр РАН, Институт проблем промыиленной экологии Севера (ИППЭС КНЦ РАН), Научно-исследовательский центр медико-биологических проблем адаптации человека в Арктике, Апатиты (НИЦ МБП КНЦ РАН), Мурманское отделение Русского географического общества, МГУ имени М.В. Ломоносова, Исследовательский центр КАРТФОНД, Российский Университет Дружбы народов (РУДН), Институт океанологии имени П.П. Шириова РАН, Отделение наук о Земле РАН, Центр по исследованию окружающей среды им. Гельмгольй, Республиканское общественное объединение «QazaqGeography» (Казахстан)

ИнтерКарто. ИнтерГИС. Геоинформационное обеспечение устойчивого развития

И 732 территорий: Материалы Междунар. конф. М.: Географический факультет МГУ, 2021. Т. 27. Ч. $2.457 \mathrm{c}$.

Сборник включает материалы, представленные на Международную конференцию «ИнтерКарто. ИнтерГИС 27». В статьях рассматриваются теоретические и методические аспекты геоинформационного и картографического обеспечения экологических, экономических и социальных вопросов устойчивого развития, геоинформатики, картографии, создания атласов, дистанционного зондирования Земли. Также рассматриваются аспекты картографического и геоинформационного обеспечения решения вопросов общественного здоровья, сельского хозяйства и землепользования, туризма, природного и культурного наследия, исторической географии и географического образования. Сборник выпускается 1 раз в год, начиная с 1994 г.

Главный редактор: В.С. Тикунов (МГУ, советник рабочей группы «Картография для устойчивого развития» МКА)

Ответственные редакторы: М.В. Грибок (МГУ), О.Ю. Черешня (МГУ)

Редакционная коллегия: О.Е. Архипова (Южный научный центр РАН, г. Ростов-на-Дону), П.Я. Бакланов (Тихоокеанский ин-т географии РАН, г. Владивосток), А.Р. Батуев (Ин-т географии СО РАН, г. Иркутск), В.С. Белозёров (Северо-Кавказский федеральный ун-т, г. Ставрополь), С.Н. Бобылёв (МГУ), Ц. Вэйхун (Нац. исслед. центр инженерии и геоматики, Китай), Г. Гиенко (Ун-т Аляски, США), М. Говоров (Университетский Колледж Маласпина, Канада), Н. Гойко (Ун-т Черногории), С. Горин (Ун-т Св. Кирилла и Мефодия, Македония), Н. Караниколас (Ун-т Аристотеля, Греция), Т. Кольчугина (Корпорация технологий устойчивого развития, США), А.В. Кошкарев (Институт географии РАН), Х. Кремерс (советник рабочей группы «Картография для устойчивого развития» МКА, Германия), А. Курбан (Синьцзянский ин-т экологии и географии, Китай), Х. Линь (Китайский ун-т Гонконга), Д.В. Лисицкий (Сибирский государственный ун-т геосистем и технологий, г. Новосибирск), И.К. Лурье (МГУ), Ф. Де Мейер (Гентский ун-т, Бельгия), М.В. Нырцов (МГУ), Г. Нямдава (Министерство окружающей среды, зелёного развития и туризма, Монголия), Ф. Ормелинг (Ун-т Утрехта, Нидерланды), Е.А. Паниди (СанктПетербургский государственный ун-т), А.Н. Панин (МГУ), А.В. Погорелов (Кубанский государственный ун-т, г. Краснодар), С.В. Пьянков (Пермский государственный ун-т), И.Н. Ротанова (Алтайский государственный ун-т, г. Барнаул), И.Д. Стрелецкая (МГУ), Н. Улугтекин (Стамбульский технический ун-т, Турция), Н.Н. Филатов (Институт водных проблем Севера РАН, г. Петрозаводск), М.-И. Фрейтас (Гос. ун-т Сан-Паулу, Бразилия), Р. Хусса (Марокко), А.Н. Чумаченко (Саратовский государственный ун-т), Н.А. Щитова (Северо-Кавказский федеральный университет, г. Ставрополь)

При цитировании просим использовать точное наименование сборника.

Образцы цитирования:

Ivanov A.B., Petrov A.B. Title of the article. InterCarto. InterGIS. GI support of sustainable development of territories: Proceedings of the International conference. Moscow: Faculty of Geography MSU, 2021. V. 27. Part 2. P. 110-120. DOI: 10.35595/2414-9179-2021-2-27-110-120 (для цитирования на английском языке). Иванов И.О., Петров И.О. Название статьи. ИнтерКарто. ИнтерГИС. Геоинформационное обеспечение устойчивого развития территорий: Материалы Междунар. конф. М.: Географический факультет МГУ, 2021. T. 27. Ч. 2. С. 110-120. DOI: 10.35595/2414-9179-2021-2-27-110-120 (для цитирования на русском языке).

Адрес редакции:

Лаборатория комплексного картографирования географического факультета МГУ

119991, Москва, Ленинские горы, д. 1, комн. 2209, тел.: +7(495)939-23-54, e-mail: intercarto@yandex.ru Интернет-сайт: intercarto.msu.ru 


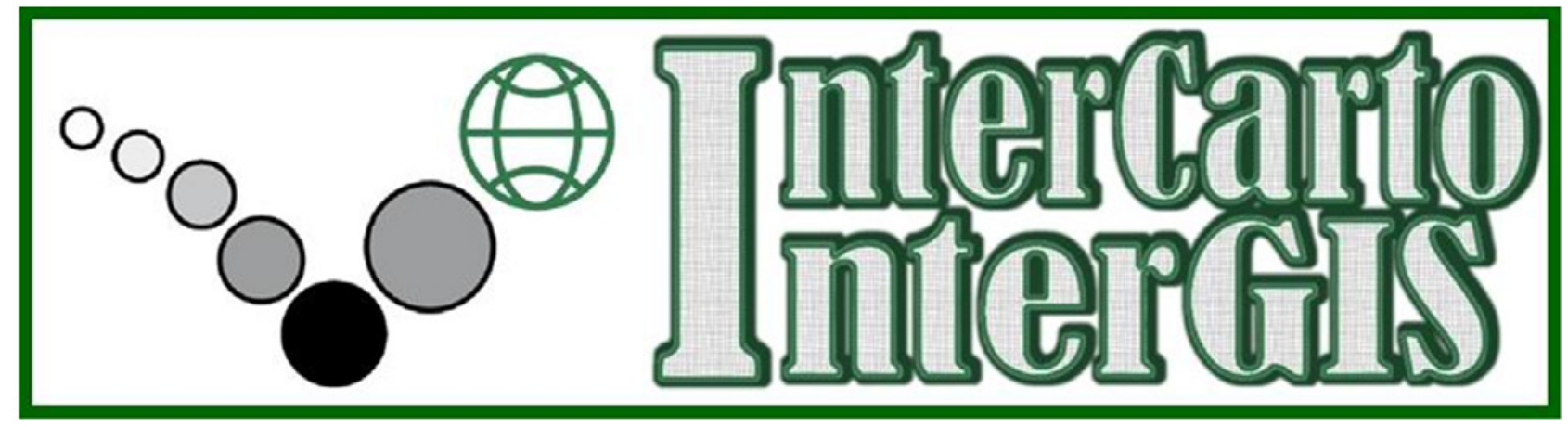

InterCarto. InterGIS

\section{GI SUPPORT OF SUSTAINABLE DEVELOPMENT OF TERRITORIES}

Proceedings of the International conference

Apatity (Murmansk region, Russia)

August 21-23

Nur-Sultan (Kazakhstan)

August 27, 2021

\section{Volume 27}

Part 2

http://intercarto.msu.ru

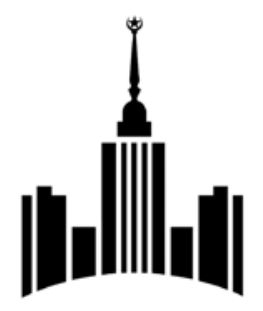

ГЕОГРАФИЧЕСКИЙ ФАКУЛЬТЕТ

МГУ имени М.В. Ломоносова

Moscow, 2021 
ISSN 2414-9179 (Print)

ISSN 2414-9209 (Online)

Organized by:

International Cartographic Association (ICA), International Eurasian Academy of Sciences, Institute of North Industrial Ecology Problems of the Kola Science Center of Russian Academy of Sciences, Research Center for Medical and Biological Problems of Human Adaptation in the Arctic of the Kola Science Center of Russian Academy of Sciences, Murmansk branch of the Russian Geographical Society, Moscow State University named after M.V. Lomonosov (MSU), KARTFOND Research Center, Peoples' friendship university of Russia (RUDN), Shirshov Institute of Oceanology of Russian Academy of Sciences, Department of Earth Sciences of Russian Academy of Sciences, Helmholtz Centre for Environmental Research (UFZ), Republican Public Association "QazaqGeography" (Kazakhstan)

InterCarto. InterGIS. GI support of sustainable development of territories: Proceedings of the International conference. Moscow: Faculty of Geography MSU, 2021. V. 27. Part 2. 457 p.

The Proceedings include papers presented at the "InterCarto. InterGIS 27" International conference. The articles are reviewed theoretical and methodological aspects of geoinformation and cartographic support of ecological, economic and social aspects of sustainable development, geoinformatics, cartography, creation of the atlases, remote sensing of the Earth. Aspects of cartographic and geoinformation providing of issues of public health, agriculture and land use, tourism, natural and cultural heritage, historical geography and geographical education also are considered. The Proceedings have been published once per year since 1994.

Editor-in-Chief: V. Tikunov (MSU, Advisor to the Working Group "Cartography for Sustainable Development" ICA) Executive Editors: O. Chereshnya (MSU), M. Gribok (MSU)

Editorial Board: O. Arkhipova (Southern Scientific Center of Russian Academy of Sciences (RAS), Rostov-on-Don), P. Baklanov (Pacific Institute of Geography RAS, Vladivostok), A. Batuev (Institute of Geography SB RAS, Irkutsk), V. Belozyorov (North-Caucasus Federal University, Stavropol), S. Bobylyov (MSU), A. Chumachenko (Saratov State University), N. Filatov (Institute of Water Problems of the North of RAS, Petrozavodsk), M.I. Freitas (UNESP São Paulo State University, Brazil), G. Gienko (University of Alaska, USA), N. Gojko (University of Montenegro), S. Gorin (St. Cyril and St. Methodius University, Macedonia), M. Govorov (Malaspina University College, Canada), R. Houssa (Morocco), N. Karanikolas (Aristotle University of Thessaloniki, Greece), T. Kolchugina (Sustainable Development Technology Corporation, USA), A. Koshkarev (Institute of Geography RAS, Moscow), H. Kremers (Advisor of ICA Working Group Cartography for Sustainability, Germany), A. Kurban (Xinjiang Institute of Ecology and Geography, China), H. Lin (Chinese University of Hong Kong), D. Lisitsky (Siberian State University of Geosystems and Technologies, Novosibirsk), I. Lourie (MSU), Ph. De Maeyer (Ghent University, Belgium), G. Nyamdavaa (Ministry of Environment, Green Development and Tourism, Mongolia), M. Nyrtsov (MSU), F. Ormeling (Utrecht University, Netherlands), E. Panidi (St. Peterburg State University), A. Panin (MSU), A. Pogorelov (Kuban State University, Krasnodar), S. Pyankov (Perm State University), I. Rotanova (Altai State University, Barnaul), N. Shchitova (North Caucasus Federal University, Stavropol), I. Streletskaya (MSU), N. Ulugtekin (Istanbul Technical University, Turkey), C. Weihong (National Engineering Research Center for Geomatics of China).

Please use the exact name of the Proceedings for citations.

Citation example:

Ivanov A.B., Petrov A.B. Title of the article. InterCarto. InterGIS. GI support of sustainable development of territories: Proceedings of the International conference. Moscow: Faculty of Geography MSU, 2021. V. 27. Part 2. P. 110-120. DOI: 10.35595/2414-9179-2021-2-27-110-120.

Editorial Office:

Integrated Mapping Laboratory, Faculty of Geography, Lomonosov Moscow State University; 119991, Russia, Moscow, Leninskie Gory, 1, of. 2209; tel.: +7(495)939-23-54; e-mail: intercarto@yandex.ru Website: intercarto.msu.ru 


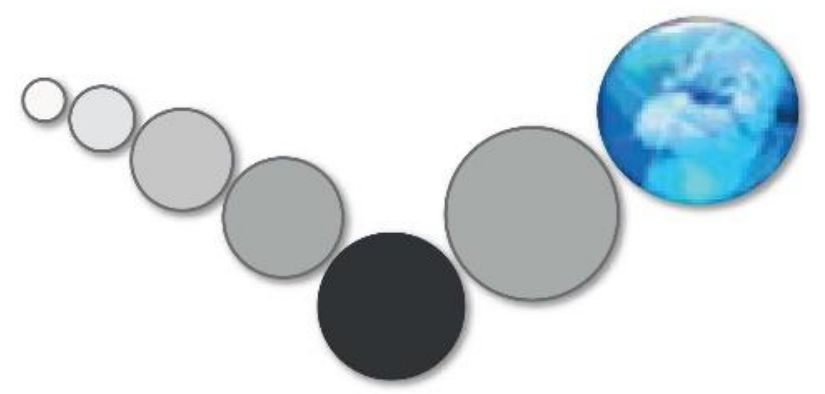

\title{
АТААСНОЕ И ГЕОИНФОРМАЦИОННОЕ КАРТОГРАФИРОВАНИЕ
}

\author{
ATLAS AND GEOINFORMATION MAPPING
}

УДК 528.9; 314

DOI: 10.35595/2414-9179-2021-2-27-5-16

А.А. Черкасов ${ }^{1}$

\section{АТЛАСНАЯ ИНФОРМАЦИОННАЯ СИСТЕМА «БОЛЬШИЕ ГОРОДА РОССИИ»: ОСОБЕННОСТИ РАЗРАБОТКИ И ВОЗМОЖНОСТИ ПРИМЕНЕНИЯ}

\section{АННОТАЦИЯ}

Города, с численностью населения 100 тыс. и более выступают в качестве основных узлов расселенческого каркаса России, максимально аккумулирующих человеческие ресурсы. В настоящее время в таких городах сконцентрировано порядка 52\% населения страны, что подтверждает высокую их роль в формировании системы расселения России. Формирование современной сети городов на современном этапе происходит на фоне продолжающихся депопуляционных процессов, связанных с затяжным демографическим кризисом, сокращением миграционного прироста населения. Таким образом, крайне актуален комплексный взгляд и осмысление проблем формирования современной сети городов такой категории численности, учитывая их географическое положение, выполняющие разные функции. В настоящее время атласные информационные системы (АИС) зарекомендовали себя как эффективный инструмент пространственного мониторинга различных процессов и явлений. Разрабатываемая атласная информационная система «Большие города России» является комплексной ГИС-платформой, способной обеспечить мониторинг демографических, миграционных, социально-экономических процессов в сети городов России. В настоящей работе описан авторский подход создания атласной информационной системы, способной систематизировать актуальные знания о современных демографических, миграционных и др. социально-экономических процессах протекающих в сети больших городов страны. Важно отметить, что организация системы происходила поэтапно, при этом автор подробно раскрывает идею создания АИС через требования, предъявляемые к информационной платформе, базе геоданных, картографической основе, геомоделированию и картографированию, способам внедрения и её апробации.

Атласная информационная система «Большие города России» в первую очередь ориентирована на экспертов-аналитиков в области пространственного планирования, демографических, миграционных процессов.

КЛЮЧЕВЫЕ СЛОВА: атласные информационные системы, ГИС-технологии, картографирование, большие города, города России, пространственный мониторинг.

1 Северо-Кавказский федеральный университет, кафедра картографии и геоинформатики, ул. Пушкина, д. 1, 355000, Ставрополь, Россия; e-mail: cherkasov_stav@mail.ru 


\title{
Aleksandr A. Cherkasov ${ }^{1}$
}

\section{ATLAS INFORMATION SYSTEM "BIG CITIES OF RUSSIA": FEATURES OF DEVELOPMENT AND POSSIBILITIES OF APPLICATION}

\begin{abstract}
Large cities with a population of 100 thousand or more act as the main nodes of the settlement framework of Russia, accumulating human resources as much as possible. At present, about $52 \%$ of the country's population is concentrated in such cities, which confirms their high role in the formation of the settlement system in Russia. The formation of a modern network of cities at the present stage is taking place against the background of continuing depopulation processes associated with a protracted demographic crisis, a decrease in the migration growth of the population. Thus, a comprehensive view and understanding of the problems of forming a modern network of cities of this population category, taking into account their geographical position, performing different functions, is extremely relevant. At present, atlas information systems have established themselves as an effective tool for spatial monitoring of various processes and phenomena. The developed atlas information system "Big cities of Russia" is an integrated GIS platform capable of providing multi-scale monitoring of demographic, migration, socio-economic processes in a network of Russian cities with a population of 100 thousand and more.

This paper describes the author's approach to creating an atlas information system capable of systematizing relevant knowledge about modern demographic, migration, and other socio-economic processes occurring in the network of large cities of the country. It is important to note that the organization of the system took place in stages, while the author reveals in detail the idea of creating AIS through the requirements for an information platform, a geodatabase, a cartographic basis, geomodeling and mapping, methods of implementation and its testing.

The Atlas Information System "Big Cities of Russia" is primarily aimed at expert analysts in the field of spatial planning, demographic and migration processes.
\end{abstract}

KEYWORDS: atlas information systems, GIS-technologies, mapping, big cities, cities of Russia, spatial monitoring.

\section{ВВЕДЕНИЕ}

Города, с численностью населения 100 тыс. и более выступают в качестве основных узлов расселенческого каркаса России, максимально аккумулирующих человеческие ресурсы. В городских поселениях России проживает порядка 70\% населения страны, при этом в больших городах в 2020 году сконцентрировано порядка $52 \%$ населения или $70 \%$ от всего городского населения. Эти цифры подтверждают высокую роль городов данной категории в формировании системы расселения России. Стратегия пространственного развития РФ до 2025 года своей основной идеей также направлена на укрепления социально-экономической роли крупнейших форм расселения²

Укрепление крупнейших форм расселения на современном этапе разворачивается на фоне продолжающихся депопуляционных процессов, связанных с затяжным демографическим кризисом, сокращением миграционного прироста населения. Внутристрановые

\footnotetext{
1 North-Caucasian federal university, department of cartography and geoinformatics, Stavropol, Pushkina str. 1, 355000, Russia; e-mail: cherkasov_stav@mail.ru

2 Стратегия пространственного развития Российской Федерации на период до 2025 года. Электронный peypc: https://www.economy.gov.ru/material/directions/regionalnoe_razvitie/strategicheskoe_planirovanie prostranstvennogo_razvitiya/strategiya_prostranstvennogo_razvitiya_rossiyskoy_federacii_na_period_do_ 2025_goda/ (дата обращения 03.04.2021).
} 
миграции продолжают сохранять центростремительный характер - из села в город, из периферии в центр, что в конечном счете приводит к усилению обозначенной тенденции [Рязанцев и др., 2020]. Демографические, миграционные процессы имеют свои пространственные тенденции, зависящие во многом от социально-экономического положения городов. Комплексный взгляд на проблему возможен с применением современных технологий, способных выполнять задачи по получению новых знаний и выполнению пространственного анализа. К таким технологиям с полной уверенностью относятся атласные информационные системы (АИС). Современные АИС могут систематизировать из разрозненных источников пространственную информацию о демографии, миграции населения, социально-экономические показатели и т.д., готовить пространственно-временные модели [Батуев и др., 2019]. Использование АИС позволяет на основе накопленной и систематизированной информации получать новые знания о фундаментальных процессах, а систематизация многовариантного моделирования в тематические сюжеты повышает уровень пространственной аналитики что, в конечном счете, должно ложиться в основу управленческих решений [Кoлосов и др., 2014; Тикунов, Яблоков, 2013].

Таким образом, разработка атласной информационной системы «Большие города России» имеет потенциал для дальнейшего практического применения, как для получения новых фундаментальных знаний, так и для решения прикладных задач, в том числе пространственного мониторинга реализации национальных проектов, достижение целей заложенных. Стратегией пространственного развития РФ.

\section{МАТЕРИАЛЫ И МЕТОДЫ ИССЛЕДОВАНИЙ}

В последние годы атласные информационные системы активно применяются в различных сферах, в том числе связанных с проблемами комплексного пространственного развития. В основе современных АИС лежат передовые IT-решения обеспечивающие организацию баз данных, в том числе за счет автоматического сбора, хранения пространённой информации. АИС открывают серьезные возможности по систематизации и распространению результатов (карт, ГИС-моделей) через единую Веб-мультимедийную основу.

Атласная информационная система «Большие города России» является комплексной ГИС-платформой, способной обеспечить мониторинг демографических, миграционных и др. социально-экономических процессов в сети городов России. Во главе идеи АИС «Большие города России» находится многоуровневый подход (страна, регион, город, район, квартал), позволяющий, в соответствии с административно-территориальным делением страны подойти к организации геоданных, подготовке картографической основы, а далее и ГИСмоделей, тематических карт, что в последующем повышает качество пространственного анализа. На этапе концептуальной проработки организации атласной информационной системы, использован принцип поэтапного планирования. Такой подход позволяет системно перейти к проектированию АИС, в частности это дает возможность выработать понятийный аппарат, сформулировать цели и задачи, которые должны решиться с помощью АИС, определить набор исходных данных, варианты визуализации и моделирования конечного продукта АИС, итоговые форматы трансляции полученных результатов.

\section{РЕЗУЛЬТАТЫ ИССЛЕДОВАНИЙ И ИХ ОБСУЖДЕНИЕ}

Для того чтобы атласная информационная система корректно выполняла задачи пространственной визуализации демографического, миграционного и социально-экономического развития в сети городов России с численностью населения 100 тыс. и более были определены базовые требования:

- Информационная платформа. Для развертывания атласной информационной системы, необходимо выбрать в качестве базовой, информационную платформу, 
способную выполнять требования по организации базы геоданных и реализации пространного моделирования и картографирования. Подготовленные модели должны иметь возможность интегрироваться в графические редакторы в векторном формате, для оформления визуальных рядов. В последующем It-платформа на которой будет разработана АИС должна иметь возможности интеграции на единую вебмультимедийную основу.

- $\quad$ База геоданных. Проектирование базы геоданных, должно включать в себя, определение источников информации, далее сбора, а затем подготовку пространственных и статистических данных, с возможностью его оперативного редактирования и обеспечения надежного хранения, удобного для расчета показателей, например демографического прогноза, прогноза социально-экономического развития.

- Kартографическая основа. Подготовка картографической основы, должна отвечать следующим требованиям: современное административно-территориальное деление (АТД) (регионы, муниципальные образования и города, внутригородское деление). Каждый уровень АТД необходимо организовать в отдельные тематические слои. Масштаб определить таким образом, чтобы был удобен при прочтении. В случае необходимости предусмотреть при компоновке материалов врезку карт в более детальном масштабе. Предусмотреть на картооснове в соответствии с масштабом, информацию об основных объектах гидрографии, отобразить соседние государства. В качестве географической проекции использовать наиболее традиционные, применяемые в отечественной картографии для подготовки карт Российской Федерации.

- $\quad$ Геомоделирование и картографирование. Определить и разработать набор сюжетов и требований для визуализации с применением картографо-геоинформационных подходов, в том числе графиков разной сложности [Gusein-Zade, Tikunov, 2015].

- $\quad$ Внедрение и апробация АИС. Предусмотреть возможности итогового варианта работы с атласной информационной системой, ориентированной на экспертов в области пространственного планирования, демографических, миграционных процессов.

Информащионная платформа. Для развертывания АИС «Большие города» в качестве базовой информационной платформы выбран ArcGIS Spatial Analyst фирмы ESRI. Данная система достаточно хорошо себя зарекомендовала, в том числе в рамках картографогеоинформационного сопровождения исследований этнодемографических и миграционных процессов. Ранее разработанные, авторские базы геоданных на этой платформе достаточно просто синхронизируются, что позволяет использовать имеющиеся наработки в области исследования различных аспектов народонаселения в России [Черкасов, 2020]. Система позволяет создавать запросы, отображать на карте и анализировать растровые данные, выполнять полную передачу данных из растра в вектор и наоборот, получать новые данные на основе существующих. Немаловажно также и то, что данная платформа имеет широкую линейку инструментов визуализации. Также ArcGIS позволяет выполнять экспорт моделей в векторные форматы .аі и .eps. Данные форматы совместимы с графическим редактором фирмы Adobe - Illustrator. Использование Adobe Illustrator в качестве основного графического редактора дает широкие возможности для подготовки сюжетного ряда выполненных в виде картографических и других визуальных формах. Использование линейки программ Adobe позволяет также работать с программой для компьютерной вёрстки InDesign. Эта программа обладает инструментами для компоновки текста и визуальных образов, в частности картографических произведений, в том числе в виде атласных информационных систем или традиционных атласов, книг, презентационных аналитических отчетов.

База геоданныlx. При проектировании АИС важное место отводится источникам информации, которые во многом определяют возможности последующей реализации 
исследования. Основными источниками информации АИС «Большие города России» выступают материалы: Росстат, Росреестр, переписи населения, ФГИС ТП, Министерство образования РФ, данные ДДЗ. Формирование базы геоданных реализовывалось по принципу тематических блоков: население; социально-экономический потенциал; образование; рейтинги; ДДЗ. Содержание каждого из блоков имеет индивидуальную информацию с возможностью её интегрирования и последующего расчёта в виде индексов и прогнозов.

Блок «Демография» содержит данные о численности населения больших городов, в том числе по возрастным группам; удельный вес численности населения больших городов в структуре населения регионов (с 1989 по 2020 годы); динамические ряды численности населения по периодам 1989-2020 гг., 1989-2000 гг., 2000-2010 гг., 2010-2020 гг. в \%; показатели рождаемости и смертности 2000-2020 гг.; естественный прирост населения 20002020 гг.

Блок «Миграция» содержит данные о прибывших и выбывших мигрантах больших городов, миграционном приросте населения 2000-2020 гг.

Блок «Социально-экономическое развитие» содержит данные о численности работников предприятий, количестве безработных, заработной плате, общей площади жилых помещений, приходящейся в среднем на одного городского жителя, инвестициях в основной капитал, наличиях основных фондов организаций, объемах работ, выполненных по виду деятельности «Строительство», площади ввода в действие жилых домов, оборот розничной торговли. Все показатели представлены за период с 2011 по 2020 год.

Блок «Этническая карта» содержит данные о численности этносов в больших городах, удельном весе этносов в структуре населения городов, динамике удельного веса русских в структуре населения, индексе этнической мозаичности, динамике индекса этнической мозаичности (все показатели за 2002 и 2010 год).

Блок «Человеческий капитал» содержит данные о численности студентов всех форм обучения, о численности иностранных студентов, о доходах вуза из всех источников, общим объеме средств, поступивших (за отчетный год) от выполнения НИОКР, общей численности профессорско-преподавательского состава, общей численности научных работников (все данные за 2019 г.), индексы качества городской среды (за 2018, 2019, 2020 годы).

Блок «Портреты больших городов» содержит данные на уровне внутригородского деления по численности населения за 2010 по 2020 год, а также данные по интенсивности разрастания застроенных территорий больших городов и объектов социальной инфраструктуры (данный раздел разработан для городов Северо-Кавказского федерального округа численность населения которых 100 тыс. и более).

Табл. 1. Пример организации таблищы базы геоданных АИС «Большие города России» с указанием реквизитов полей

Table 2. An example of the organization of the table of the AIS geodatabase

"Big cities of Russia" with the indication of the details of the fields

\begin{tabular}{|c|c|c|c|c|}
\hline $\begin{array}{c}\text { Название } \\
\text { таблицы и } \\
\text { ее описание }\end{array}$ & $\begin{array}{c}\text { Название } \\
\text { поля }\end{array}$ & $\begin{array}{c}\text { Тип } \\
\text { поля }\end{array}$ & $\begin{array}{c}\text { Числ } \\
\text { о } \\
\text { деся- } \\
\text { тич- } \\
\text { ных } \\
\text { зна- } \\
\text { ков }\end{array}$ & Содержание \\
\hline 1 & 2 & 3 & 4 & 5 \\
\hline \multirow{2}{*}{$\begin{array}{l}\text { Population - } \\
\text { население }\end{array}$} & Fid & Object ID & - & Номер города в таблице \\
\hline & Shape & Geometry & - & Геометрия объекта (точка) \\
\hline
\end{tabular}




\begin{tabular}{|c|c|c|c|c|}
\hline \multirow{10}{*}{$\begin{array}{l}\text { (в таблице } \\
\text { содержатся } \\
\text { данные, } \\
\text { характеризую } \\
\text { щие население } \\
\text { больших } \\
\text { городов } \\
\text { России, } \\
\text { численность, } \\
\text { демографичес } \\
\text { кие аспекты) }\end{array}$} & Octmo & Floate $r$ & 10 & $\begin{array}{l}\text { (ОКТМО) Общероссийский классификатор территорий му- } \\
\text { ниципальных образований }\end{array}$ \\
\hline & F_Okrug & Строка & 70 & Наименование федерального округа \\
\hline & Code & Floate & 8 & Автомобильный код региона \\
\hline & Name & Строка & 70 & Наименование региона \\
\hline & Город & Строка & 50 & Название города \\
\hline & $\begin{array}{l}\text { числ. } 2019 \\
\text {.... }\end{array}$ & Floate & 20 & $\begin{array}{l}\text { Численность населения городов (за каждый год с } 1989 \text { по } \\
2019 \text { год по каждому городу с численностью населения } \\
\text { свыше } 100 \text { тыс. чел) }\end{array}$ \\
\hline & $\begin{array}{l}\text { дин._числен. } \\
1989-02\end{array}$ & Floate & 20 & $\begin{array}{l}\text { Динамика численности населения по городам (рассчитано } \\
\text { по периодам, 1990-2000, 2000-2010, 2010-2020 гг.) }\end{array}$ \\
\hline & родившиеся & Floate & 20 & $\begin{array}{l}\text { Численность родившихся по городам (рассчитано по пери- } \\
\text { одам, 1990-2000, 2000-2010, 2010-2020 гг.) }\end{array}$ \\
\hline & умершие & Floate & 20 & $\begin{array}{l}\text { Численность умерших по городам (рассчитано по перио- } \\
\text { дам, 1990-2000, 2000-2010, 2010-2020 гг.) }\end{array}$ \\
\hline & ЕП_2017 ... & Floate & 20 & $\begin{array}{l}\text { Естественный прирост населения по городам (рассчитано } \\
\text { по периодам, 1990-2000, 2000-2010, 2010-2020 гг.) }\end{array}$ \\
\hline
\end{tabular}

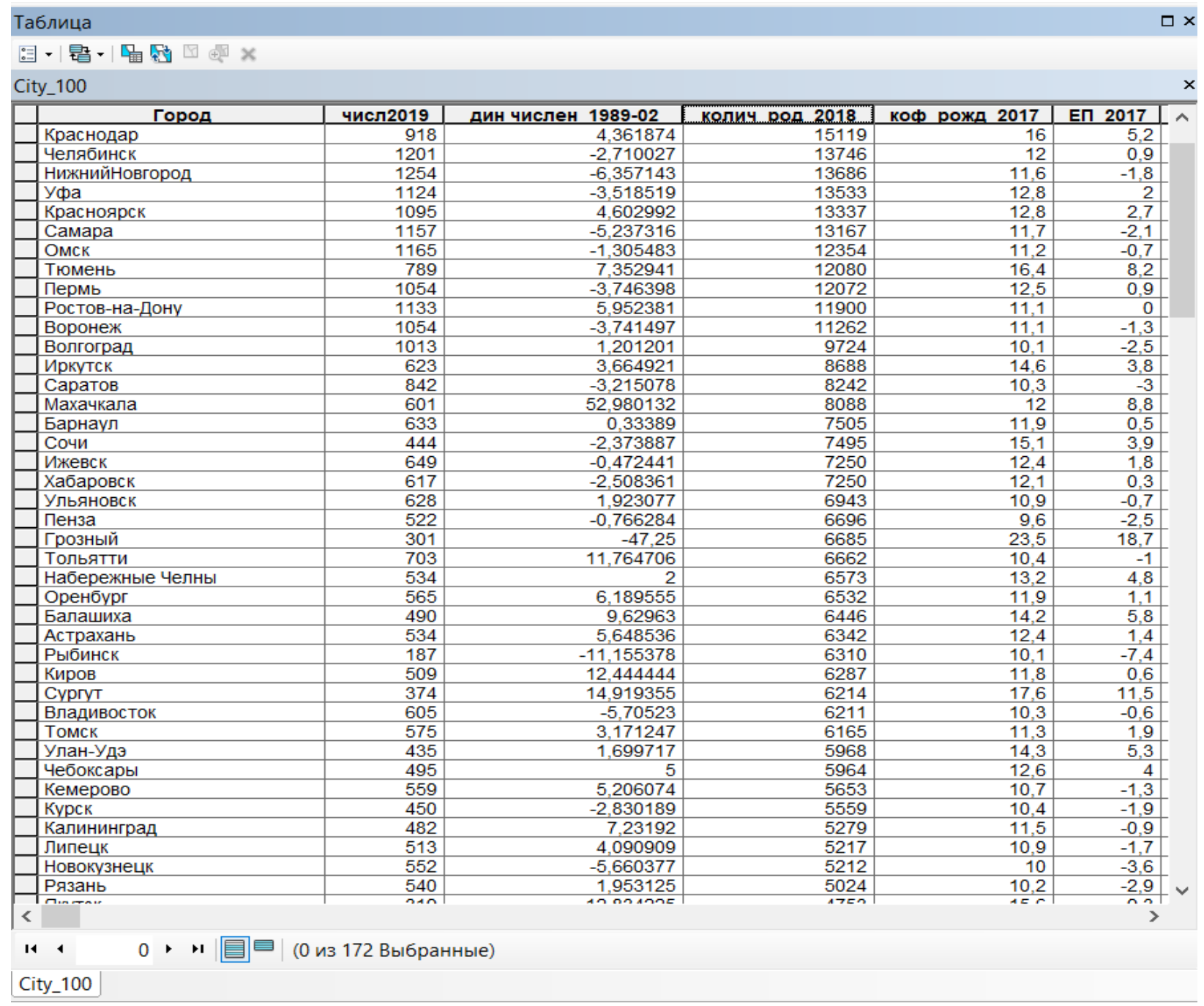

Рис. 1. Фрагмент запоенной таблииы базы геоданных АИС «Больиие города России»

Fig. 1. Fragment of the sealed table of the database of suitable AIS «Big cities of Russia» 
Картографическая основа. Организация картографической основы при проектировании АИС «Большие города России» происходила с учетом иерархии административнотерриториального деления (АТД) Российской Федерации, построена по принципу взаимозависимых векторных слоев. В качестве базовых слоев выделяется региональный уровень субъекты РФ, муниципальный и городской уровень - уровень муниципального района и городского округа, уровень внутригородского деления. При подготовке картографической основы особое место уделялось проработке сети больших городов. Важным было подготовить сеть, как площадными (векторными), так и точечными объектами. Реализация такого подхода позволяет систематизировать как статистические данные, так и данные спутниковых снимков, реализовать многовариантное ГИС-моделирование и картографирование [Краак, Ормелинг, 2005].

На картографической основе воспроизведены наиболее крупные объекты гидрографии (моря, озера, реки), а также нанесен слой государственных образований. Обязательным было и отображение сети меридианов и параллелей. Данный подход в целом повышает качество самой карты, как произведения, а также значительно увеличивает возможности аналитической работы.

В качестве основной выбрана равноугольная коническая проекция Ламберта (LCC) относится к наиболее часто используемой для картографирования территории России. Базовым масштабом определен $1: 250000000$ (в 1 см 250 км) (итоговый размер печатной карты соотносится с листом формата А3). Было принято решение показать в качестве карты врезки, т.к. на этой, относительно масштаба страны небольшой территории, сконцентрирована наиболее плотная сеть городов страны численностью населения 100 тыс. и более. Масштаб определен как $1: 2500000$ (в 1 см 25 км).

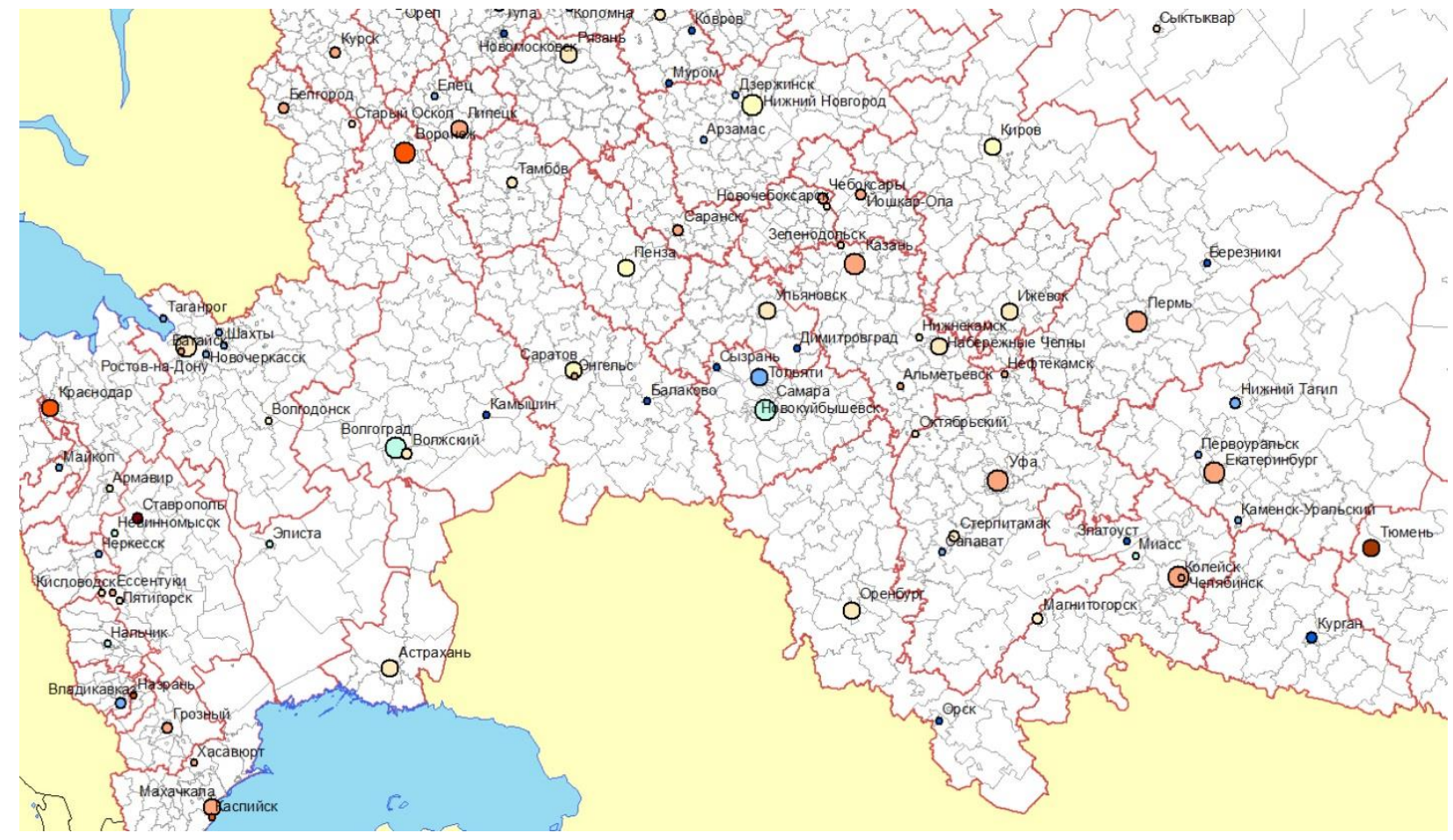

Рис. 2. Прочесс подготовки картографической основы, с соблюдением многоуровневого подхода

Fig. 2. The process of preparing a cartographic base, following a multi-tiered approach 


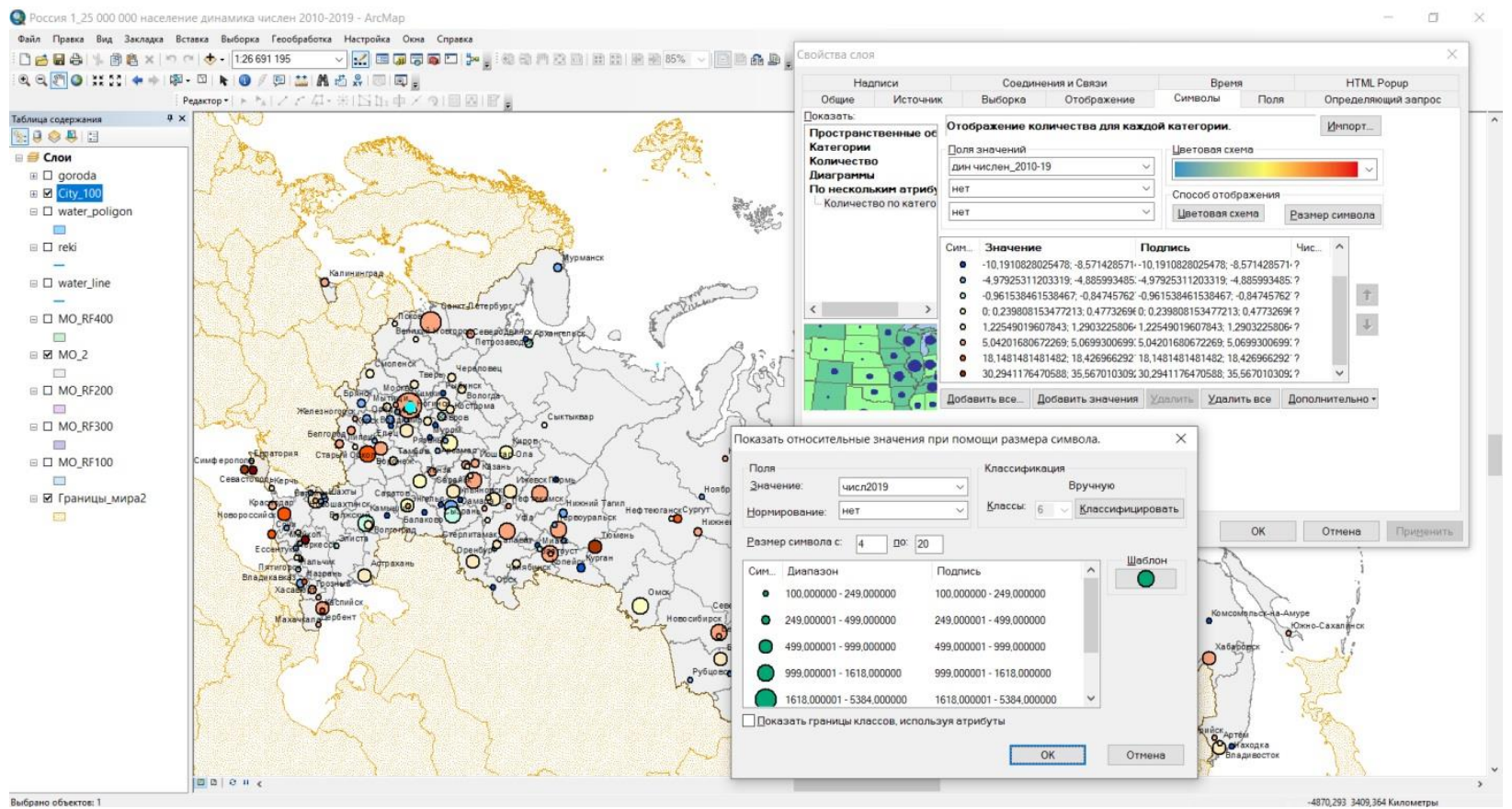

Рис. 3. Пример подготовки картографических сюжетов в рамках АИС «Большие города России»

Fig. 3. An example of preparing cartographic plots of population dynamics within the framework of the AIS "Big cities of Russia"

Для решения задач, связанных с картографической визуализацией, в том числе подготовке печатных карт, применяется дополнительный инструментарий. В качестве основного графического редактора и верстки карт использованы программы фирмы Adobe Illustrator и InDesign. Illustrator - это графический редактор, позволяющий работать с векторными изображениями, повышает качество подготовки тематических картографических изображений и инфографики. Расширение ArcGIS Maps for Adobe Creative Cloud (Photoshop и Illustrator), что позволяет добавлять в проекты Adobe высококачественные векторные карты, снимки, огромное количество тематического географического контента [Field, 2018]. InDesign - это программа для компьютерной вёрстки, позволяет компоновать серию картографических произведений в виде презентационных форм, инфографики или традиционных атласов.

Геомоделирование и картографирование. В рамках создания АИС была подготовлена серия геоинформационных моделей и картографических сюжетов, позволяющих комплексно подойти к пространственно-временному мониторингу формирования сети городов. В частности сюжеты имеют следующее содержание:

- численность населения городов России $(1989,2002,2010,2019)$;

- динамика численности населения городов России (1989-2002, 2002-2010, 20102019);

- продолжительность роста/убыли численности населения (анализ современного состояния);

- миграционная ситуация в городах России (с 2000-х по н.вр.);

- продолжительность миграционного прироста/убыли процессов в городах России (анализ современного состояния);

- демографическая ситуация в городах России; 
- продолжительность естественного прироста/убыли в городах России (анализ современного состояния);

- индекс этнической мозаичность городов России (за 2002 и 2010 год);

- динамика изменения индекса этнической мозаичности городов России (20022010 год);

- этническая карта городов России (2010);

- динамика изменений этнической структуры в городах России (2002, 2010 год);

- карты 1, 2, 3-х этносов в городах России (2002, 2010 год);

- ввод в действие жилых домов;

- объем работ, выполненных по виду экономической деятельности «строительство»;

- общая площадь помещений, приходящаяся в среднем на одного городского жителя;

- заработная плата;

- инвестиции в основной капитал;

- оборот розничной торговли.

A

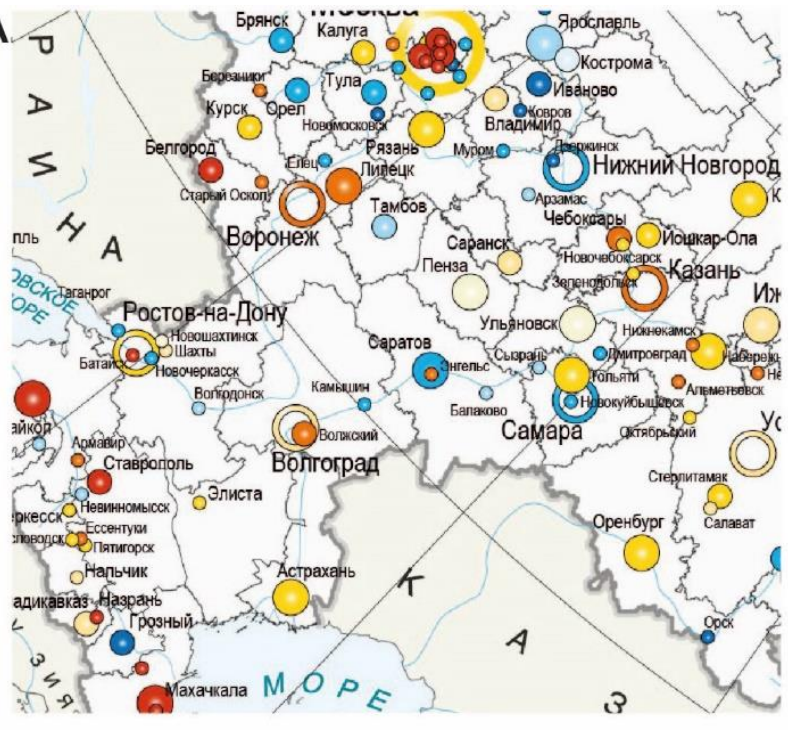

В. Стабильная численность населения:

с незначительным приростом населения: от $0 \%$ до $1 \%$

с незначительной убылью населения: от $-0,1 \%$ до $-1 \%$ от $1 \%$ до $5 \%$ от $5 \%$ до $15 \%$ от $15 \%$ до $30 \%$

\section{Б. МОСККВВСКИЙ РЕГИОН}

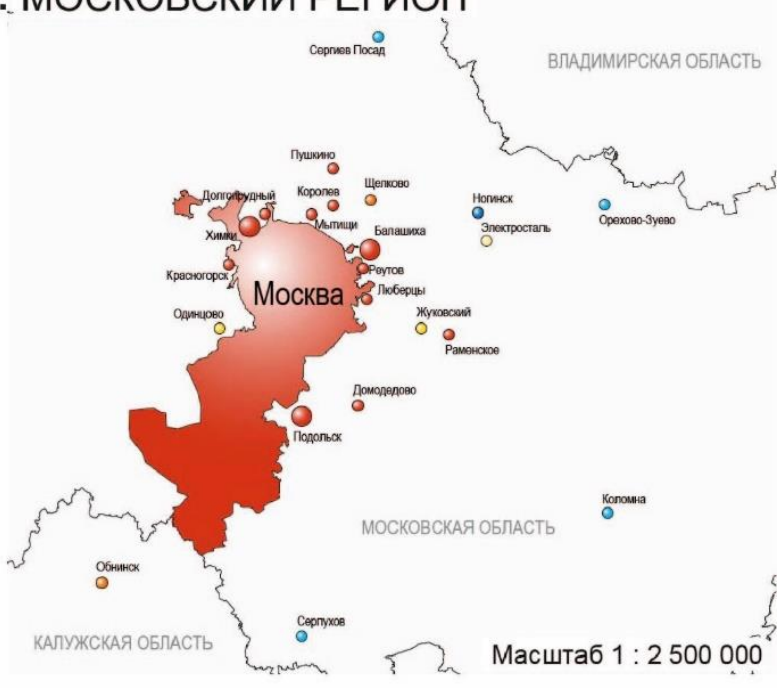

низкие темпы прироста населения:

средние темпы прироста населения:

повышенные темпы прироста населения:

высокие темпы прироста населения: свыше $30 \%$ низкие темпы убыли населения: от $-1 \%$ до $-5 \%$

средние темпы убыли населения: от $-5 \%$ до $-15 \%$

повышенные темпы убыли населения: от $-15 \%$ до $-30 \%$

высокие темпы убыли населения: свыше $-30 \%$

Рис. 4. Пример оформления картографических сюжетов в рамках АИС «Большие города России»: А) Фрагмент оформленной карты России; Б) Оформление карты-врезки Московского региона; В) Оформление условных обозначений

Fig. 4. An example of the design of cartographic plots within the framework of the AIS "Big cities of Russia": A) Fragment of the drawn map of Russia; B) Registration of the inset map of the Moscow region; $C)$ Legend design 
Особенности подготовки картографических материалов рассмотрим на примере подготовки карт динамики численности населения России по периодам 1989-2002, 20022010, 2010-2019 гг. выполненных способом количественного фона. Расчеты показали, что города имеют разную динамику численности населения. На первом этапе картографирования необходимо было совместить два значения - непосредственно динамику изменения численности населения и численность населения городов, которая взята согласно сложившейся шкале: от 100 до 250 тыс. чел (большие), от 250 до 500 тыс. чел (крупные), от 500 до 1 млн чел. (крупнейшие), свыше 1 млн (миллионеры).

При подготовке карты динамики численности населения задана шкала, которая выработалась в процессе подготовки данного сюжета, имеющую следующую градацию:

- стабильная численность населения - делится: с незначительным приростом от 0\% до $1 \%$; с незначительной убылью: от $-0,1 \%$ до $1 \%$;

- с приростом численности населения, делится: низкие темпы прироста населения от 1\% до 5\%; средние темпы прироста населения: от 5\% до 15\%; повышенные темпы прироста населения от 15\% до 30\%; высокие темпы прироста населения свыше $30 \%$

- с убылью численности населения, делится: низкие темпы убыли населения от -1\% до -5\%; средние темпы убыли населения: от $-5 \%$ до -15\%; повышенные темпы прироста населения от $-15 \%$ до - $30 \%$; высокие темпы убыли населения свыше $30 \%$.

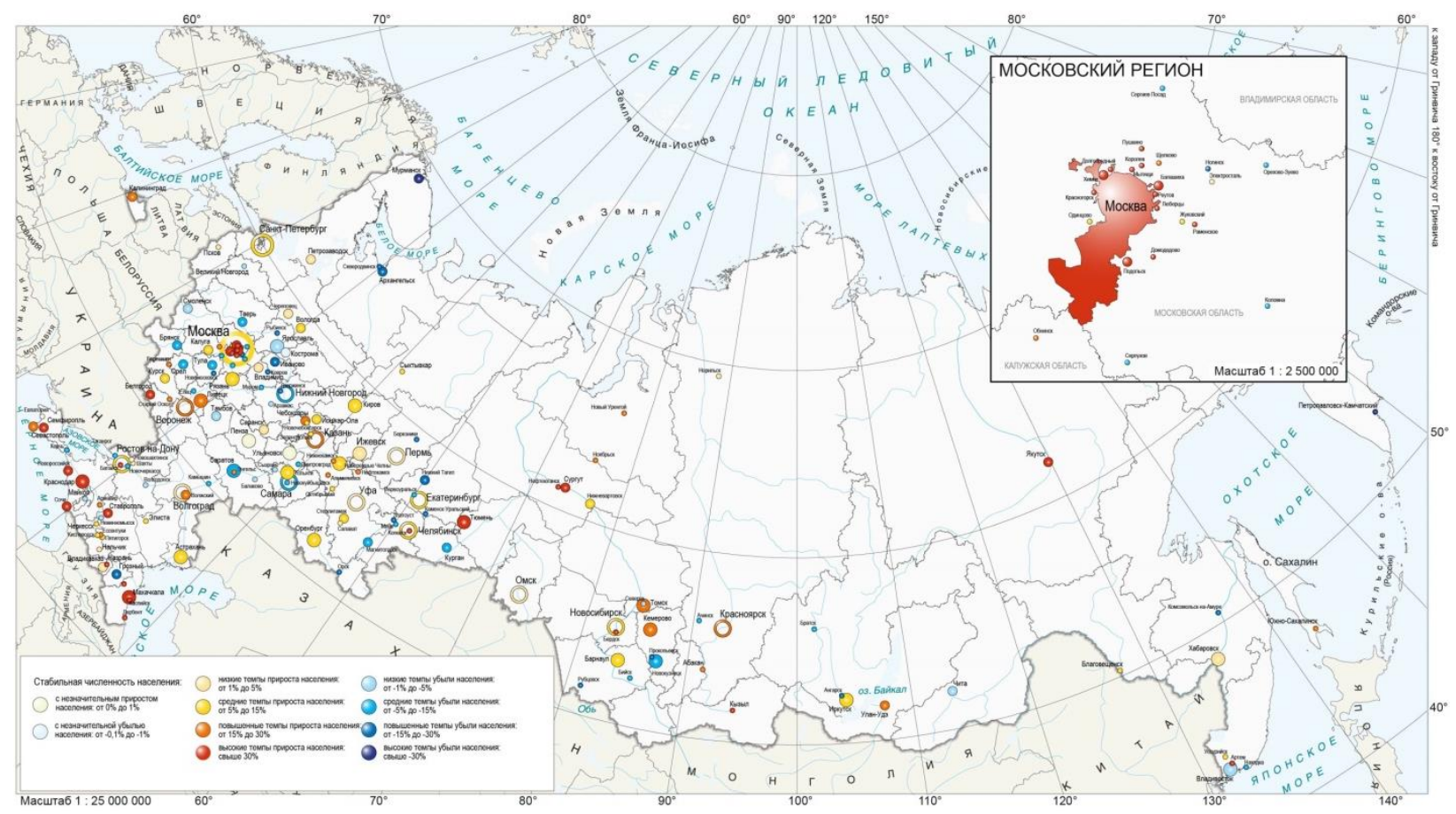

Рис. 5. Общий вид оформленной карть

«Динамика численности населения Больших городов России»,

c 1989 nо 2019 год

Fig. 5. General view of the issued map

"Population dynamics of the Big Cities of Russia", from 1989 to 2019 
Внедрение и апробация АИС. Атласная информационная система «Большие города России» в первую очередь ориентирована на экспертов-аналитиков в области пространственного планирования, демографических, миграционных процессов и т.д., а не узкопрофильных специалистов в области геоинформационных систем. По задумке автора предполагается реализация АИС в двух вариантах. Первый вариант, это организация материалов на единой веб-мультимедийной основе. Этот подход возможен в первую очередь благодаря интегрированной базы геоданных, инструментов пространственного анализа. Второй вариант организация материалов в виде электронной атласной информационной системы, с применением PowerPoint.

АИС «Большие города России» планируется систематизировать в следующие тематические разделы: «Демографические процессы», «Миграционные процессы», «Социально-экономическое развитие», «Этнические черты демографических процессов», «Социальная сфера и человеческий капитал», «Демографические портреты больших городов».

\section{ВЫВОДЫ}

Подготовленная атласная информационная система «Большие города России» и её последующее развитие позволяет комплексно подойти к исследованию демографических, миграционных и социально-экономических процессов в городах страны с численностью населения свыше 100 тыс. чел., что, несомненно, способствует выполнению на более высоком уровне экспертно-аналитической работы. Уже на первом этапе апробации, АИС продемонстрировала большие функциональные возможности, в том числе для реализации пространственно-аналитических задач.

Комбинация атласно-картографического, геоинформационного и статистического подходов, реализуемых в рамках АИС «Большие города России», позволяет создавать форму управляемой визуализации геопространственных данных, а также использовать приложение для анализа и дальнейшего прогнозирования развития демографических и миграционных процессов, что повышает экспертно-аналитические возможности системы [Тикунов u дp., 2019]. Широкими представляются возможности дальнейшего развития АИС в качестве инструмента геомониторинга по оценке эффектов реализации национальных проектов, по направлению «Демография», «Жилье и городская среда». В перспективе АИС способен выступить важным инструментом пространственно-аналитической работы, направленной на создание условий устойчивого пространственного развития Российской Федерации.

\section{БЛАГОДАРНОСТИ}

Исследование выполнено в рамках гранта Президента Российской Федерации для государственной поддержки молодых российских ученых - кандидатов наук МК-858.2020.5 «Геоинформационный мониторинг формирования сети больших городов в условиях современной этнодемографической и миграционной ситуации в России».

\section{ACKNOWLEDGEMENT}

The study was carried out in the framework of grant from the President of the Russian Federation for state support to young Russian scientists - candidates of sciences MK-858.2020.5 «Geoinformation monitoring of the formation of a network of large cities in the current ethnodemographic and migration situation in Russia».

\section{СПИСОК ЛИТЕРАТУРЫ}

1. Б Батуев А.Р., Батуев Д.А., Бешенщев А.Н., Богданов В.Н., Дашпилов Ц.Б., Корытный Л.М., Тикунов В.С., Фёдоров Р.К. Атласная информационная система для обеспечения социально-экономического развития Байкальского региона ИнтерКарто. 
ИнтерГИС. Геоинформационное обеспечение устойчивого развития территорий: Материалы Междунар. конф. Москва: Издательство Московского университета, 2019. Т. 25. Ч. 1. С. 66-80. DOI: 10.35595/2414-9179-2019-1-25-66-80.

2. Краак М.-Я., Ормелинг Ф. Картография: визуализация геопространственных данных. М.: Научный мир, 2005. 325 с.

3. К Колосов В.А., Руденко Л.Г., Тикунов В.С., Гериен А.А., Головина Е.Д., Зотова М.В., Себенцов А.C. Атласная информационная система российско-украинского приграничья. Материалы Междунар. конф. «ИнтерКарто. ИнтерГИС». 2014. Т. 20. С. 24-44.

4. Рязанцев С.В., Архангельский В Н., Воробьева О.Д. [и др.] Демографическое развитие России: тенденции, прогнозы, меры. Национальный демографический доклад2020. Москва, 2020. 156 с.

5. Тикунов В.С., Чихарев И.А., Панин А.Н., Рыльский И.А. Атласная информационная система «Геополитическая ситуация в большем средиземноморье: принципы создания и технология пространственного анализа». Наука. Инновации. Технологии. 2019. № 3. C. 107-114.

6. Тикунов В.С., Яблоков В.М. Атласная информационная система для Байкальского региона. ИнтерКарто. ИнтерГИС. 2013. Т. 19. С. 197-202.

7. Черкасов A.A. ГИС «Города России»: принципы создания и технологии пространственного анализа. Наука. Инновации. Технологии. 2020. № 3. С. 153-167.

8. Gusein-Zade S. M., Tikunov V. S. Visualisation in non-Euclidean metrics. Chinse University of Hong Kong Hong Kong, 2015. 213 p.

9. $\quad$ Field K. Cartography. Esri Press, Redlands, Kalifornia, 2018. 576 p.

\section{REFERENCES}

1. Batuev A.R., Batuev D.A., Beshentsev A.N., Bogdanov V.N., Dashpilov Ts.B., Korytniy L.M., Tikunov V. S., Fedorov R.K. Atlas information system for providing socio-economic development of the Baikal region InterCarto. InterGIS. GI support of sustainable development of territories: Proceedings of the International conference. Moscow: Moscow University Press, 2019. V. 25. Part 1. P. 66-80. DOI: 10.35595/2414-9179-2019-1-25-66-80 (in Russian)

2. Cherkasov A.A. GIS "Cities of Russia": Principles of creation and technologies of spatial analysis. Science. Innovation. Technologies. 2020. No 3. P. 153-167 (in Russian).

3. $\quad$ Field K. Cartography. Esri Press, Redlands, Kalifornia, 2018. 576 p.

4. Gusein-Zade S.M., Tikunov V.S. Visualisation in non-Euclidean metrics. - Chinse University of Hong Kong Hong Kong, 2015. 213 p.

5. Kolosov V.A., Rudenko L.G., Tikunov V.S., Gercen A.A., Golovina E.D., Zotova M.V., Sebentsov A.S. Atlas information system of russian-ukrainian borderland. Proceedings of the International conference "InterCarto. InterGIS". 2014. No 20. P. 24-44. (in Russian).

6. Kraak M.-J., Ormeling F. Mapping: visualization of geospatial data. Moscow: Scientific world, 2005. 325 p. (in Russian).

7. Ryazantsev S.V., Arkhangelsky V.N., Vorobieva O.D. [and others] Demographic development of Russia: trends, forecasts, measures. National demographic report-2020. Moscow, 2020. 156 p. (in Russian).

8. Tikunov V.S., Chikharev I.A., Panin A.N., Rylsky I.A. Atlas information system "Geopolitical situation in the greater Mediterranean: principles of creation and technology of spatial analysis". Science. Innovation. Technologies. 2019. No 3. P. 107-114. (in Russian).

9. Tikunov V.S., Yablokov V.M. Atlas information system for the Baikal region. Proceedings of the International conference "InterCarto. InterGIS". 2013. No 19(1). P. 197-202. (in Russian). 


\section{Т.И. Кузнецова ${ }^{1}$}

\section{ИНФОРМАЦИОННО-КАРТОГРАФИЧЕСКОЕ ОБЕСПЕЧЕНИЕ ИССЛЕДОВАНИЯ ПОТЕНЦИАЛЬНЫХ ТРАНСФОРМАЦИЙ ГЕОСИСТЕМ ДЛЯ ЦИФРОВОГО АТЛАСА «БАЙКАЛЬСКИЙ РЕГИОН: ОБЩЕСТВО И ПРИРОДА»}

\section{АННОТАЦИЯ}

На примере электронного атласа «Байкальский регион: общество и природа» решается проблема ландшафтно-картографического обеспечения изучения трансформаций природы обширной территории. Под трансформацией понимаются изменения природной среды вследствие спонтанного развития или антропогенного вмешательства. При этом различаются потенциальные и актуальные трансформации. Изучение потенциальных трансформаций связано с географическим прогнозом, а изучение актуальных трансформаций предполагает оценку текущего экологического состояния природы. Район исследования включает территорию бассейна озера Байкал, в том числе северные регионы Монголии.

Данный аспект исследования реализуется посредством интеграции множества географических данных о структуре природных систем, их устойчивости и направлениях спонтанных и антропогенных преобразований в единую целевую картографическую информационную систему (КИС). Основным требованием, предъявляемым к содержанию целевого блока карт, является надежность результатов комплексного исследования и их доказательность в случае использования для принятия управленческих решений по оптимизации природной среды.

Разработана логико-методическая последовательность мелкомасштабного целевого картографирования природной среды исследуемой территории. Проведен анализ природных структур и создана базовая инвентаризационная карта геосистем масштаба (M 1:5 000 000). Разработана совокупность геосистемных признаков-индикаторов, выполнена экологическая интерпретация информации и комплексное экологическое картографирование; осуществлено геоэкологическое зонирование территории. На основе информационного синтеза полученных данных и знаний о современной ландшафтной структуре региона, методами полисистемного анализа выявлен характер устойчивости, функции, ценностные характеристики геосистем и закономерности их антропогенных преобразований.

Наличие единого блока карт обеспечит изучение вопросов о потенциальных и актуальных трансформациях геосистем. Составленные в определенной последовательности на основе единой структурно-иерархической специализированной классификации мелкомасштабные карты Байкальского региона отражают комплекс природных условий, важных для принятия конструктивно-географических, проектных, управленческих и природоохранных решений.

КЛЮЧЕВЫЕ СЛОВА: Байкальский регион, цифровой атлас, природная среда, потенциальные трансформации, комплексно-системное картографирование.

\footnotetext{
1 Институт географии имени В.Б. Сочавы СО РАН, Иркутск, 664033, ул. Улан-Баторская, 1, Россия,
} e-mail: kuznetzovad@yandex.ru 


\title{
Tatiana I. Kuznetsova ${ }^{1}$
}

\section{INFORMATION-CARTOGRAPHIC SUPPORT FOR STUDYING OF POTENTIAL TRANSFORMATIONS OF GEOSYSTEMS FOR THE DIGITAL ATLAS «BAIKAL REGION: SOCIETY AND NATURE»}

\begin{abstract}
Based on the electronic atlas "Baikal Region: Society and Nature", the problem of landscape-cartographic support for studying the transformations of vast territories is being solved. The transformation of geosystems is understood as changes in the natural environment due to spontaneous development or anthropogenic interference. In this context, potential and actual transformations are distinguished. The research of potential transformations is associated with a geographic forecast of possible changes in the state of the environment due to external impact, and current transformations include an assessment of its current ecological state. The area under investigation includes the territory of the Baikal basin, and the northern regions of Mongolia.

This aspect is realized through the integration of a multitude of geographical data on the structure of natural systems, their sustainability and trends of anthropogenic transformations into a single target cartographic information system (CIS). The main requirement for the content of the target block of maps is the reliability of the results of a comprehensive research and their evidentiality if used to make management decisions to optimize the environment.

A logical and methodological coherence of small-scale target mapping of the natural environment of a vast territory has been developed. The analysis of natural structures was carried out and a basic inventory map of geosystems of scale (M 1:5 000 000) was created. We developed a set of geosystem characteristics and carried out an environmental interpretation of information and integrated environmental mapping, aside from that implemented geoecological zoning of the territory. Based on the information synthesis of the obtained data and knowledge about the modern landscape structure of the region, the methods of polysystem analysis, we revealed the nature of sustainability, functions, value characteristics of geosystems and the patterns of their anthropogenic transformations.

The presence of a single set of maps will provide a study of questions about potential and relevant transformations of geosystems. The small-scale maps of the Baikal region, compiled in a certain sequence on the basis of a single structural-hierarchical specialized classification, reflect a complex of environmental conditions that are important for making constructive-geographical, design, managerial, and environmental decisions.
\end{abstract}

KEYWORDS: Baikal region, digital atlas, natural environment, potential transformations, integrated system mapping.

\section{ВВЕДЕНИЕ}

На территорию Байкальского региона в период с 1962 по 2019 год были созданы и выпущены в свет более 20 географических атласов [Батуев и дp., 2020], различных по своему назначению, структуре, тематике, масштабу, методам и способам картографирования. Все они имеют важное общенаучное, образовательное и культурное значения как обеспечивающие сбор, хранение, преобразование и представление многочисленных пространственных данных и знаний.

В период с 2017 по 2019 год силами коллективов институтов Сибирского отделения Российской академии наук при участии высших учебных и научных учреждений Монголии

V.B. Sochava Institute of Geography SB RAS 664033 Irkutsk, Ulan-Batorskayast 1, Russia, e-mail: kuznetzova@irigs.irk.ru 
в лаборатории картографии, геоинформатики и дистанционных методов Института географии им. В.Б. Сочавы СО РАН был разработан цифровой атлас «Байкальский регион: общество и природа» [Батуев, Корытный, 2018]. Район исследования включает территорию бассейна озера Байкал, в том числе северные регионы Монголии.

Главной целью создания Атласа было формирование информационной системы обеспечения пространственного развития региона в рамках экологической безопасности взаимодействия общества с природными системами и разработка стратегии и тактики природопользования, которые в данных исторических условиях должны работать на решение сверхзадачи - устойчивое развитие. Конструктивная направленность тематического содержания Атласа и его акценты на отображении возможных последствий активного взаимодействия общества с природой обусловили необходимость развития специального научного знания, которое представлено в виде отдельных тематически завершенных цифровых модулей трех основных направлений:

- социально-экономические факторы формирования экологической обстановки;

- $\quad$ экологическое состояние и трансформация природной среды, медико-географическая обстановка;

• $\quad$ охрана окружающей среды и рациональное природопользование.

Основной особенностью методологии разработки данного атласа является использование системного подхода к созданию многоуровневых картографических моделей как комплекса взаимосвязанных произведений, обеспечивающего эффективную обработку, интерпретацию, анализ и обобщение пространственной информации на различных территориально-иерархических уровнях [Батуев, Корытный, 2018]. Для Атласа были определены основные уровни картографирования и масштабы карт:

- $\quad$ макрорегиональный (M 1: 18000000 - 1: 30000 000);

• $\quad$ межрегиональный (М 1: 5000 000; 1: 7500000 - 1: 10000 000);

- $\quad$ муниципальных образований на уровне субъектов РФ, городских районов и округов (M 1:200 $000-1: 3000000$ );

- локальный уровень для отдельных поселений или физико-географических образований (М 1: $10000-1: 100$ 000).

Целью данного исследования является разработка теоретико-методологических основ создания обзорной картографической информационной системы (КИС) «Природная среда» для цифрового атласа «Байкальский регион: общество и природа», обеспечивающей исследование возможных сценариев трансформаций природы и принятие природоохранных управленческих решений. Изучение потенциальных трансформаций природы связано с географическим прогнозом, а изучение актуальных трансформаций предполагает экологическую оценку её текущего состояния [Сочава, 1986; Михеев, 1987; Иванов и дp., 2009]. В этой связи в задачу исследования входило, с одной стороны, решение вопросов информационно-картографического обеспечения прогноза потенциальных трансформаций природных структур, a, с другой стороны, разработка теории картографирования рекомендательных природоохранных мероприятий для минимизации отрицательных последствий внешних воздействий. Для решения проблемы были необходимы:

- разработка концепции создания КИС «Природная среда» геосистемного содержания, отвечающей требованиям информационного обеспечения географического прогноза трансформаций геосистем, на базе которого будут выявляться, с одной стороны, необходимые ограничения структурно-функционального воздей- 
ствия на природу, а, с другой, разрабатываться мероприятия по ее рациональному использованию и охране;

- $\quad$ разработка тематической структуры целереализующей КИС;

- $\quad$ выбор таксономического ранга исследования геосистем, отвечающего пространственному охвату, масштабу, целям, задачам и способам картографирования; сбор исходного материала и анализ закономерностей пространственной дифференциации природной среды исследуемого региона;

- $\quad$ разработка базовой инвентаризационно-информационной основы для КИС «Природная среда»;

- модификация информации базовой карты и создание производных целереализующих тематических слоев КИС.

Тематика исследования актуальна. До настоящего времени прогнозное и прогнознорекомендательное картографирование геосистем относится к числу менее разработанных направлений атласного картографирования Байкальского региона.

\section{МАТЕРИАЛЫ И МЕТОДЫ ИССЛЕДОВАНИЯ}

Методология исследования определялась требованием, предъявляемым к содержанию блока карт КИС «Природная среда» - надежность результатов комплексного исследования геосистем и их доказательность в случае использования для географического прогноза или принятия управленческих решений по оптимизации природной среды. Данный аспект реализуется посредством полисистемной геоэкологической концепции [Михеев, 1987; Жиров, 2002; Козин, 2009], усовершенствованной в соответствии с масштабом, целью и назначением картографирования. Преимущество данного подхода заключается в возможности выявления и отображения разнообразных аспектов природы при единой группировке пространственных данных, обеспечившей «систематичность, последовательность расположения категориальной структуры аппарата прогнозирования, элементы которого выдаются один за другим, образуя потенциальное доказательство, и линейно-концентрический способ построения всей его процедуры» [Михеев, 1987, с. 8]. В практическом плане задача исследования заключалась в осуществлении сбора, анализа, модификации и интеграции географической информации о природных структурах в единую информационно-картографическую систему.

Создание базовой инвентаризационно-информационной карты геосистем Байкальского региона осуществлялось на основе анализа, синтеза и модификации материалов территориально разрозненных цифровых ландшафтных ${ }^{1}$, ландшафтноэкологических ${ }^{2}$, геоэкологических ${ }^{3}$ карт геосистем, созданных, ранее на исследуемую территорию в лаборатории картографии, геоинформатики и дистанционных методов ИГ им. В.Б. Сочавы СО РАН с использованием продукции ГИС MapInfo Professional. Над созданием базовой карты геосистем Байкальского региона трудился коллектив специалистов. В авторский коллектив входили Т.И. Кузнецова, А.В. Бардаш,

1 Природные ландшафты Байкальского региона и их использование. Карта. М 1:5 000000. [Электронный ресурс]. Режим доступа: http://www.rgo.ru/ru/irkutskoe-oblastnoe-otdelenie/proekty/karty. Русское географическое общество. Карты. Природно-ресурсный потенциал. Карта 9. (дата обращения 13.04.2021).

2 Ландшафтно-экологические комплексы Байкальского региона. Карта. М-б 1:5 000 000. [Электронный pecypc]. Режим доступа: http://atlas.isc.irk.ru. Экологический атлас Байкальского региона. Природные условия формирования экологической обстановки. Карта 68 (дата обращения 13.04.2021).

3 Ландшафтно-экологические комплексы бассейна оз. Байкал. Карта. М-б 1:5 000 000. [Электронный pecypc]. Режим доступа: http://bic.iwlearn.org/ru/atlas/atlas. Атлас. Карта 060 (дата обращения 13.04.2021). 
Д.А. Лопаткин. Кроме них в составлении карт КИС своими консультациями принимал участие А.Р. Батуев.

Информационную основу для проведения эколого-фитоценотической индикации условий природной среды Байкальского региона составляли также материалы опубликованных ранее Корреляционной эколого-фитоценотической карты Азиатской России ${ }^{1}$ и Эколого-географической карты Российской Федерации ${ }^{2}$; а также ряд публикаций, содержащих информацию о зональных типах ландшафтов и о факторах их интегральной интенсивности функционирования [Назимова и др., 2004; Поликарпов и др., 1986; Волкова, 1992].

Разработка специализированной классификации геосистем Байкальского региона для базовой карты связана с именем академика В.Б. Сочавы и его научной деятельностью в период с 1960 по 1978 год по созданию универсальной общенаучной структурнодинамической классификации геосистем. Обзорное картографирование Байкальского региона было проведено по крупным подразделениям геосистем - «геомам и их классификационным объединениям» [Сочава, 2005, с. 90]. Всего было выделено 41 пространственное геосистемное подразделение Байкальского региона.

Для создания базы пространственных данных геоэкологического зонирования территории Байкальского региона использовались методы картографического анализа и геоэкологической интерпретации геосистемной информации базовой карты [Булаева и др., 2015; Haaren, 2004; Hewitt., 2014].

Среди них:

- $\quad$ регионально-типологический, рассматривающий положение геосистемы в окружающей среде;

- иерархический, позволяющий рассматривать каждую вышестоящую в иерархии геосистему как среду формирования стоящей ниже в иерархии геосистемы;

- $\quad$ структурно-функциональный, дающий возможность определить динамические категории геомов в экологическом ряду геосистем конкретной ландшафтной области;

- структурно-динамический, учитывающий многообразие возможных состояний геосистем;

- геоэкологический, позволяющий рассматривать геосистемы как комплекс природных условий для жизнедеятельности людей;

- логико-ситуационный, принимающий во внимание многообразие не только экологических, но и социальных функций геосистем;

- $\quad$ конструктивный, направленный на разработку рекомендаций для решения экологических проблем взаимодействия человека с природой;

- территориальный, нацеленный на картографическое зонирование исследуемой территории по различным экологическим основаниям.

\section{РЕЗУЛЬТАТЫ ИССЛЕДОВАНИЯ И ИХ ОБСУЖДЕНИЕ}

На основе дальнейшего развития и усовершенствования методологии полисистемного геоэкологического картографирования в соответствие пространственному охвату, масштабу, целям и задачам создания цифрового атласа «Байкальский регион: общество и природа» разработана концепция создания КИС «Природная среда».

\footnotetext{
1 Эколого-фитоценотические комплексы Азиатской России. Карта. М 1:7 500 000. Иркутск. Изд-во: ИГ Сибири и Дальнего Востока, 1977.

2 Эколого-географическая карта Российской Федерации. Карта. М 1: 4000000. М.: ФСГК, 1996. 4 л.
} 
По материалам уже существующих разрозненных классификаций природных комплексов на территорию, принадлежащую двум суверенным государствам - России и Монголии, относящуюся к бассейну оз. Байкал, была сформирована единая всеобъемлющая специализированная классификация геосистем структурно-динамического содержания, обеспечившая переход от инвентаризационного и оценочного картографирования к прогнозному и прогнозно-рекомендательному картографированию.

Представлен ряд тематических и пространственных обобщений информации в форме единой КИС «Природная среда», дополняющих уже существующие сведения о природе крупного региона Северной и Центральной Азии. Структурно-иерархическая территориальная организация геосистем данной классификации обеспечила рассмотрение проблемы на нескольких пространственных уровнях, а также сопоставимость базовой карты и системы производных карт природных структур Байкальского региона между собой как в содержательном, так и в пространственном аспекте.

Создана инвентаризационно-информационная основа для КИС «Природная среда» масштаба 1:5 000000 как карта рубежей между геосистемами Байкальского региона региональной размерности, которые представляют собой основу для отображения системных связей, имеющих большое теоретическое значение как отражающие основные географические и эколого-географические особенности региона. Отсюда следует, что все морфотипические характеристики геомов, как основных единиц картографирования, имеют большое индикационное значение; и на их основе была разработана система признаков-индикаторов экологических условий природной среды. В силу своей громоздкости специализированная классификация геосистем и созданная на ее основе легенда карты «Геосистемы Байкальского региона» в данной статье не демонстрируются.

По материалам анализа карты «Геосистемы Байкальского региона» проведено картографическое геоэкологическое зонирование территории как способ группировки геосистем разной структуры, но одного ранга и идентичных экологических условий. Для зонирования обширной территории были разработаны принципы модификации геосистемной информации, в том числе ландшафтной индикации условий природной среды Байкальского региона и система индикационных геосистемных признаков-индикаторов [Кузнецова, 1918]; среди них:

- иерархические, типологические, морфологические характеристики геосистем, их интегральная интенсивность функционирования и ее факторы; экологическая устойчивость (стабильность);

- $\quad$ саморегулирование;

- $\quad$ резистентная устойчивость (чувствительность).

Исследовались экологические и социальные функции, определялась антропогенная нарушенность геосистем, возможные природные экологические риски; экологический потенциал; степень благоприятности условий природной среды для жизнедеятельности людей.

На рисунке демонстрируется карта пространственных группировок геосистем ранга геомов, принадлежащих к различным физико-географическим областям Северной и Центральной Азии (Байкало-Джугджурской, Южно-Сибирской, Амуро-Сахалинской, Среднесибирской, Центрально-Азиатской), но с идентичными эколого-географическими условиями, сформировавшимися под воздействием разных внешних сред, но способных одинаково реагировать на однотипные воздействия. Спектр классификационных признаков территориальных объединений геомов, приведенных в легенде карты достаточно широк (см. подписи к рис., п. I-X), а их качественная оценка выражается относительными оценочными категориями. 

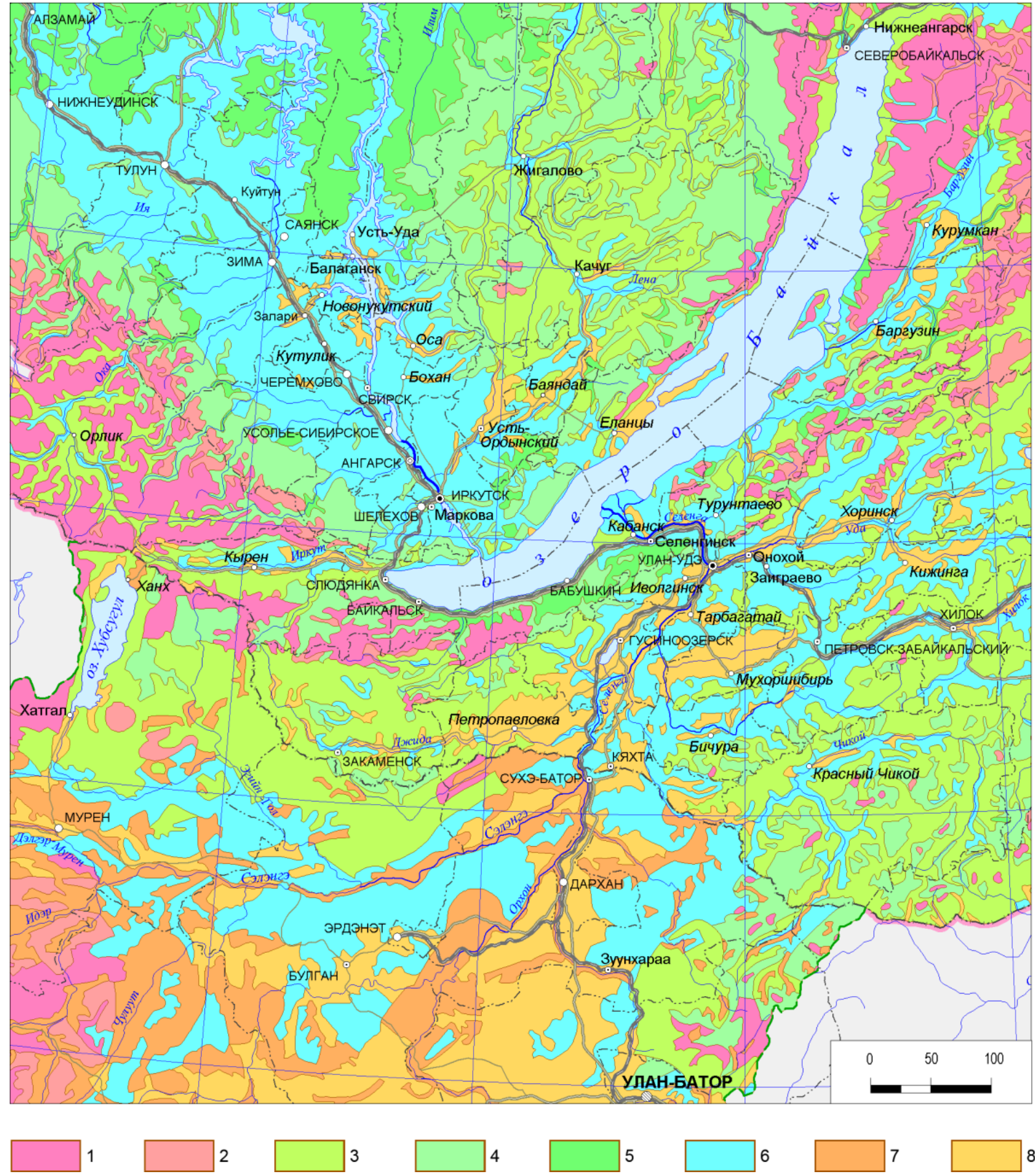

Рис. Геоэкологическое зонирование Байкальского региона

Fig. Geoecological zoning of the Baikal Region

\section{A. Основные природные структуры \\ A. Basic natural structures}

I. Геоэкозоны. Северо-Азиатские. 1. Гольцово-таежные высокогорные восточносибирского и южно-сибирского типа (альпинотипные, субальпинотипные, гольцовые, подгольцовые, редколесные). 2. Горнотаежные и таежные лиственничные байкало-джугджурские, горнотаежные темнохвойные южно-сибирские, лиственничные среднесибирские, 
лиственничные амуро-сахалинские (лиственнично-маревые, мерзлотно-болотные). 3. Горнотаежные и таежные лиственничные байкало-джугджурские, горнотаежные темнохвойные южно-сибирские, горнотаежные светлохвойные южно-сибирские, среднетаежные лиственничные среднесибирские. 4. Горнотаежные темнохвойные южно-сибирские; 5. Южнотаежные среднесибирские, южнотаежные амуро-сахалинские, горнотаежные сосновые южно-сибирские. 6. Горные и подгорные подтаежные байкало-джугджурские, южно-сибирские, среднесибирские и амуро-сахалинские; лугово-степные южносибирские, южнотаежные сосновые, сосновые и боровых равнин среднесибирские. Центрально-Азиатские. 7. Горностепные и степные разнотравно-дерновиннозлаковые и дерновинноразнотравные дауро-монгольские. 8. Горностепные и степные дерновиннозлаковые дауро-монгольские.

Пояснения. Арабскими цифрами (1-8) обозначены группировки геомов, относящиеся к разным физико-географическим областям, но с идентичными условиями.

\section{Б. Интегральная интенсивность функиионирования и ее факторы}

\section{$B$. Integral intensity of functioning and its factors}

II. Категории функционирования. Северо-Азиатские аркто-бореальные. 1. Экстремальных условий развития: холодные*, влажные и избыточно влажные**, минимально и низкопродуктивные***. 2. Редуцированных условий развития: умеренно холодные, избыточно влажные, низко- и среднепродуктивные. 3. Значительно ограниченных условий развития: умеренно теплые, влажные и избыточно влажные, средне- и повышенно продуктивные. 4. Ограниченных условий развития: умеренно теплые, влажные, повышенно продуктивные. 5. Oптимальных условий развития: теплые, избыточно влажные и влажные, повышенно и высокопродуктивные. Северо-Азиатские семиаридные. 6. Относительно оптимальных условий развития: теплые, недостаточно влажные, повышенно и среднепродуктивные. Центрально-Азиатские аридные. 7. Редуцииованных условий развития: сухие очень теплые, средне- и низкопродуктивные. 8. Экстремальных условий развития: очень сухие, жаркие, и низко- и минимально продуктивные.

Пояснения. * - Теплообеспеченность (сумма биологически активных температур воздуха: сумма среднесуточных температур за период с температурами выше 10॰ C): холодные $(600-800$ ॰ C), умеренно холодные (800-1200॰ C), умеренно теплые (1200-1600॰ C), теплые (1600-2000॰ C), очень теплые (2000-2400॰ C), жаркие (более 2400॰ C).

** - Влагообеспеченность (радиационный индекс сухости по М.И. Будыко): избыточно влажные (менее 0,5$)$, влажные $(0,5-1,0)$, умеренно влажные $(1,0-1,5)$, недостаточно влажные $(1,5-2,0)$, сухие $(2,0-2,5)$, очень сухие (более 2,5$)$.

*** - Биологическая продуктивность - годовой прирост, выраженный в весе сухой массы органического вещества надземной и подземной частей растений (ц/га сухой массы): минимальная (менее 20 ц/га), низкая (20-40 ц/га), средняя (40-60 ц/га), повышенная (60-80 ц/га), высокая (более 80 ц/га).

\section{В. Геосистемные индикаторы потенциальной трансформации природной среды}

C. Geosystem indicators of potential transformation of the natural environment

III. Категории саморегулирования: 1 - низкая (с очень большим недостатком тепла); 2 относительно низкая (с большим недостатком тепла); 3 - средняя; 4 - повышенная; 5 - высокая (очень длительный период восстановления); 6 - относительно высокая; 7 - относительно низкая (с большим недостатком влаги); 8 - низкая (с очень большим недостатком влаги).

IV. Категории чувствительности (уязвимости): 1 - очень высокая (с минимальной и низкой продуктивностью растительного покрова); 2 - высокая (с низкой и средней продуктивностью растительного покрова); 3 - относительно высокая (со средней и повышенной продуктивностью растительного покрова); 4 - относительно низкая (с повышенной продуктивностью растительного покрова); 5 - низкая (с повышенной и высокой 
продуктивностью растительного покрова); 6 - относительно высокая (с повышенной и средней продуктивностью растительного покрова); 7 - высокая (с низкой и средней продуктивностью растительного покрова); 8 - очень высокая (с минимальной и низкой продуктивностью растительного покрова).

V. Категории антропогенной нарушенности: 1 - слабо нарушенные; 2 - мало нарушенные; 3 - относительно мало нарушенные; 4 - относительно нарушенные; 5 -нарушенные; 6 преобразованные; 7 - очень сильно нарушенные; 8 - сильно нарушенные.

\section{Г. Возможные трансформации условий природной средь}

D. Possible transformations of environmental conditions

VI. Категории природного экологического риска (ЭР): 1 - очень высокая; 2 - высокая; 3 относительно высокая; 4 - очень низкая; 5 - низкая; 6 - относительно низкая; 7 - высокая; 8 - очень высокая.

VII. Водоохранные экологические функиии:1 - водосборная, водорегулирующая геосферного значения, водоаккумулирующая мерзлотная; 2 - водорегулирующая регионального значения, водоаккумулирующая мерзлотная; 3 - водорегулирующая, водоаккумулирующая мерзлотная и болотная; 4 - водорегулирующая сезонномерзлая, водозащитная зеленомошная; 5 - водорегулирующая сезонномерзлая, водозащитная крупнотравная и зеленомошная; 6 - водозащитная, водорегулирующая сезонномерзлая, иногда водоаккумулирующая мерзлотная; 7 - водозащитная, водорегулирующая сезонномерзлая; 8 - водозащитная, водорегулирующая сезонномерзлая, влагоформирующая за счет контрастности суточных температур.

VIII. Возможные изменения характера увлажнения природной среды: 1 - изменения увлажнения проявляются комплексно, в том числе в смежных структурах; 2 - возможно некоторое увеличение увлажнения в результате незначительного протаивания мерзлоты; 3 - возможно увеличение увлажнения в результате значительного протаивания мерзлоты; 4 - возможно увеличение увлажнения плоских поверхностей и уменьшение увлажнения на склонах в результате усиления инсоляции почво-грунтов; 5 - возможно некоторое увеличение увлажнения на плоских поверхностях и уменьшение на склонах в результате усиления инсоляции; 6 - возможно увеличение аридности условий, иногда увеличение увлажнения; 7 - возможно значительное увеличение аридности условий; 8 - возможно очень значительное увеличение аридности условий.

\section{Д. Благоприятность эколого-географических условий для жизнедеятельности людей}

E. Favorable ecological and geographical conditions for the life of people

IX. Категории экологического потенщиала (ЭП): 1 - очень низкий; 2 - низкий; 3 относительно низкий; 4 - относительно высокий; 5 - очень высокий; 6 - высокий; 7 низкий; 8 - очень низкий.

Х. Категории благоприятности: 1 - максимально неблагоприятные с очень значительным дефицитом тепла; 2 - очень неблагоприятные со значительным дефицитом тепла и значительным избытком влаги; 3 - малоблагоприятные с дефицитом тепла; 4 относительно благоприятные с оптимальны сочетанием тепла и влаги; 5 - благоприятные с незначительным избытком влаги; 6 - относительно благоприятные с некоторым дефицитом влаги; 7 - малоблагоприятные с большим дефицитом влаги; 8 - максимально неблагоприятные с очень большим дефицитом влаги. 
Определяющее значение в изучении потенциальных трансформаций отводилось характеристике интегральной интенсивности функиионирования геосистем (см. подписи к рис., п. II) и ее факторов: тепло-, влагообеспеченности и биологической продуктивности растительного покрова. Относительные категории интенсивности функционирования геосистем определены по соотношениям тепла и влаги, а также значениям биологической продуктивности растительного покрова по принципу максимума: «чем больше, тем лучше» [Григорьев, Будыко, 1965; Базилевич и др., 1986; Исаченко,1990]. Важнейшие категории функционирования соотносятся с соответствующими морфотипами геосистем (см. подписи к рис. п. I).

Характеристикой стабилизирующей динамики геосистем является саморегулирование (см. подписи к рис., П. III), как способность природной среды восстанавливать свою нарушенную структуру после внешнего, в том числе антропогенного воздействия [Крауклис, 1974; Сочава, 2005]. Категории саморегулирования соотносятся с функционированием геосистем (см. подписи к рис., п. II). «Саморегулирование наиболее действенно в оптимальных условиях тепла и влаги» [Сочава, 2005, с. 72]. Его характеристика имеет непосредственное практическое значение при разработке планов использования геосистем, прогнозов их возможного изменения, природоохранных мер и рекомендаций.

Чувствительность геосистем (см. подписи к рис., п. IV) к внешнему воздействию рассматривается как величина обратно пропорциональная свойству саморегулирования и соответственно структурно-функциональным характеристикам геосистем [Михеев, 2001; Кузнецова, 2016]. Высокую чувствительность к внешнему воздействию имеют геосистемы экстремальных условий развития с низкой категорией саморегулирования. С одной стороны, это альпинотипные, субальпинотипные, гольцовые, подгольцовые и редколесные холодных влажных местоположений геосистемы преимущественно минимально и низкопродуктивные, a, с другой стороны, горные и равнинные полупустынные и сухостепные жарких и очень сухих местоположений низко- и минимально продуктивные геосистемы.

Природный экологический риск (ЭР) (см. подписи к рис., п. VI) рассматривается как «вероятность и степень опасности негативных изменений в структуре и функционировании природных и природно-антропогенных систем в случае спонтанного развития или антропогенного воздействия» [Михеев, 1998, с. 3]. Состояния геомов лимитированы конкретными характеристиками интегральной интенсивности функционирования (показателями тепла, влаги, биологической продуктивности) (см. подписи к рис., п. II). Они определяют их чувствительность к воздействию и категорию саморегулирования как способность сохранять и восстанавливать свою структуру. В условиях внешнего воздействия, в том числе антропогенного изменяются эколого-фитоценотические и гидротермические параметры геосистем, которые и определяют возможность трансформации их структуры [Черкашин, Красноштанова, 2011; Кузнецова, 2017].

Цепочка взаимосвязей между характеристиками геосистем «структура функционирование - чувствительность - саморегулирование - ЭР» позволяет раскрывать способность природной системы противостоять действию внешних сил, которые могут вывести её из состояния равновесия. Например, максимально высокий уровень природного ЭР, имеют высокогорные гольцовые, подгольцовые, редколесные геосистемы с экстремальными значениями интегральной интенсивности функционирования, высокой чувствительностью к внешнему воздействию, очень низкой категорией саморегулирования.

Возможные изменения характера увлажнения природной среды. Специализированное исследование позволило установить возможные изменения условий природной среды в результате внешнего воздействия [Кузнецова и др., 2009], исходя из их размерности, и с 
учетом региональных и планетарных факторов территориальной организации геосистем. Картографическое отображение возможных изменений условий природной среды (см. подписи к рис., п. VIII) проводилось путем построения и совокупного сопряженного анализа содержания легенды карты (см. подписи к рис., п. I-VII), основывающихся на классификациях, предусматривающих динамическое начало. При этом прогнозируемое состояние рассматривалось как результат действия природных факторов и антропогенной нарушенности (см. подписи к рис., п. V) как конкретный временной вариант его структуры и функционирования.

Экологический потенцииал (ЭП) (см. подписи к рис., п. IX) рассматривается как комплексная характеристика геосистем, которая, с одной стороны, определяет их потребительский потенциал, или способность обеспечивать условия существования людей, $\mathrm{a}$, с другой стороны, устойчивость геосистем как способность восстанавливать свою структуру и функционирование после внешнего воздействия [Кузнещова, 2016]. В качестве индикаторов категорий ЭП используются параметры структуры, функционирования, чувствительности, саморегулирования, изменчивости геосистем, которые позволяют наиболее полно учитывать стабилизирующую динамику геосистем. Одновременно характеристики структуры (состав) и факторы функционирования (тепло-, влагообеспеченность, биологическая продуктивность) определяют ценностные свойства геосистем.

Категории благоприятности геосистем для жизнедеятельности людей (см. подписи к рис., п. Х) определялись на основе сопряженного географического анализа совокупности характеристик геосистем «структура - функционирование - чувствительность - саморегулирование - изменчивость - ЭР». Наиболее благоприятными являются лугово-степные и подтаежные геомеры. Им соответствуют оптимальная интенсивность функционирования, высокие значения тепло обеспеченности с несколько недостаточным увлажнением, относительно низкая чувствительность к внешнему, в том числе антропогенному воздействию, высокая категория саморегулирования.

\section{ВЫВОДЫ}

Содержание цифровых тематических карт «Геосистемы Байкальского региона» и «Геоэкологическое зонирование Байкальского региона» масштаба 1:5 000 000, созданных на основе полисистемной геоэкологической концепции, полностью отвечает конструктивной направленности тематического содержания Атласа «Байкальский регион: общество и природа» и его акценту на отображение возможных последствий активного взаимодействия общества с природой.

Разработанные карты занимают важное место в единой информационной системе Атласа, с одной стороны, теоретическое - как отражающие основные закономерности и особенности пространственно-временной дифференциации природных условий обширной территории материка Евразия, a, с другой, практическое - как информационный базис создания нового поколения карт геосистем для познания потенциальных трансформаций природной среды региона.

Представленная система карт может стать основой постановки и решения задач не только потенциальных трансформаций природы, но также ее охраны и оптимального управления природопользованием в Байкальском регионе. Она может быть использована при разработке сценариев формирования пространственных структур благоприятной природной среды для улучшения качества жизни населения в условиях усиливающегося влияния факторов глобализации. Наряду с этим, могут быть разработаны системы картографических моделей для обеспечения решения текущих проблем управления природными рисками, чрезвычайными ситуациями в рамках экологической безопасности 
взаимодействия общества с природными системами и разработки стратегии и тактики природопользования.

\section{БЛАГОДАРНОСТИ}

Исследование выполнено за счет средств государственного задания №AAАА-А21121012190063-2 и при финансовой поддержке Гранта РФФИ № 20-05-00253 А.

\section{ACKNOWLEDGEMENTS}

This work was done within the within the framework of a state assignment № AAAA-A21121012190063-28 and with the partial financial support from the Russian Foundation for Basic Research № 20-05-00253 A.

\section{СПИСОК ЛИТЕРАТУРЫ}

1. Базилевич Н.И., Гребенщиков О.С., Тишков А.А. Географические закономерности структуры и функционирования экосистем. Москва: Наука, 1986. 297 с.

2. Батуев А.Р., Корытный Л.М. Многоуровневое атласное экологическое картографирование (на примере Байкальского региона). География и природные ресурсы, 2018. № 4. С. 26-37.

3. Батуев Д.А., Батуев А.Р., Бешенцев А.Н., Корытный Л.М. Атласное картографирование Байкальского региона: структурно-семиотическая организация ИнтерКарто ИнтерГИС. Геоинформационное обеспечение устойчивого развития территорий: Мат-лы Междунар. конф., 2020. Т. 26, ч. 1. С. 385-399.

4. Булаева Н.М., Мусихина Е.А., Михайлова О.С. Информационная система мониторинга и комплексной экологической оценки природной среды регионов (на примере Иркутской области). Геоинформатика, 2015. № 1. С. 9-14.

5. Волкова E.A. Зонально-поясные закономерности распределения растительности Монголии. Известия РГО. Т. 124. Вып. 6. 1992. С. 10-15.

6. Григорьев А.А., Будылк М.И. Связь балансов тепла и влаги с интенсивностью географических процессов. Докл. АН СССР, 1965. Т. 162. № 1. С. 151-154.

7. Жиров А.И. Геоэкология. Методика геоэкологических исследований. Ч. 2. Санкт Петербург: Издательство Российского государственного педагогического университета, 2002. $135 \mathrm{c}$.

8. Иванов Н.И., Фомкин, И.В., Соловьев А.И. Прогнозирование, планирование и организация территории административно-территориальных образований: методические указания и задания для РГР. Москва, 2009. 160 с.

9. Исаченко А.Г. Интенсивность функционирования и продуктивность геосистем. Изв. АН СССР. Сер. геогр. № 5. 1990. С. 5-17.

10. Козин B.B. Средовой подход в ландшафтной экологии. Вестник Тюменского университета, 2009. № 3. С. 4-8.

11. Крауклис A.A. Особенности географических градаций топического порядка. Топологические аспекты учения о геосистемах. Изд-во: Наука. Сиб. отд. Новосибирск, 1974. C. 87-138.

12. Кузнецова Т.И. Создание ГИС «Природная среда» на основе модификации картографической информации. Геодезия и картография, 2018. Т. 79. № 9. С. 20-29. DOI: 10.22389/ 0016-7126-2018-939-9-20-29.

13. Кузнецова Т.И. Анализ и картографирование чувствительности и экологической устойчивости геосистем для информационного обеспечения географического 
прогноза (на примере бассейна оз. Байкал). Проблемы анализа риска. Т. 13. № 3. 2016. C. 28-39.

14. Кузнецова Т.И. Геосистемно-картографический анализ природных факторов экологического риска бассейна озера Байкал (в пределах России и Монголии). Безопасность жизнедеятельности, 2017. №7. С. 50-56.

15. Кузнеиова Т.И., Батуев А.Р., Бардаш А.В. Карта «Природные ландшафты Байкальского региона и их использование»: назначение, структура, содержание. Геодезия и картография, 2009. № 9. С. 18-28.

16. Михеев B.C. Ландшафтно-географическое обеспечение комплексных проблем Сибири. Новосибирск: Наука, 1987. 206 с.

17. Михеев В.С. Ландшафтный синтез географических знаний. Новосибирск: Наука, 2001. $216 \mathrm{c}$.

18. Михеев В.С. Экологический риск: определение, сущность, содержание. Экологический риск: анализ, оценка, прогноз. Материалы Всероссийской конференции. Иркутск, 1998. 148 с.

19. Назимова Д.И., Ермаков Н.Б., Андреева Н.М., Степанов Н.В. Концептуальная модель структурного разнообразия зональных классов лесных экосистем Северной Евразии. Сибирский Экологический журнал. 2004. №5. С. 745-755.

20. Поликарпов Н.П., Чебакова Н.М., Назимова Д.И. Климат и горные леса Южной Сибири. Новосибирск: Наука, 1986. 215 с.

21. Сочава В.Б. Проблемы физической географии и геоботаники. Новосибирск: Наука. Сиб. отделение, $1986.340 \mathrm{c.}$

22. Сочава В.Б. Теоретическая и прикладная география. Новосибирск: Наука, 2005. 287 c.

23. Черкашин А.К., Красноштанова Н.Е. Теоретическая картография и теория создания оценочных карт природных рисков. Геодезия и картография, 2011. № 3. С. 18-23.

24. Hewitt K. Regions of Risk: A geographical introduction to disasters. New York: Routledge, 2014. 410 p.

25. von Haaren C. Landschaftsplanung. Stuttgart: Ulmer, 2004. 527 p.

\section{REFERENCES}

1. Batuev A.R., Korytny L.M. Multilevel atlas ecological mapping (on the example of the Baikal Region). Geography and Natural Resources, 2018. No 4. P. 26-37. (in Russian).

2. Batuev D.A., Batuev A.R., Beshentsev A.N., Korytny L.M. Atlas mapping of the Baikal Region: structural and semiotic organization InterCarto InterGIS. Geo-information provision for sustainable development of the territories: Mat-ly Internar. Conf., 2020. T. 26, h. 1. P. 385-399. (in Russian).

3. Bazilevich N.I., Grebenshhikov O.S., Tishkov A.A. Geographic patterns of ecosystem structure and functioning. M.: Nauka, 1986. 297 p. (in Russian).

4. Bulayeva N.M., Musikhina E.A., Mikhailova O.S. Information System for Monitoring and Iintegrated Environmental Assessment of the Natural Environment of the Region (for example, the Irkutsk region). Geoinformatika, 2015. No 1. P. 9-14. (in Russian).

5. Cherkashin A.K., Krasnoshtanova N.Ye. Theoretical Cartography and Theory of Creating Estimating Maps of Natural Risks, Geodesy and Cartography. 2011. No 3. P. 18-23 (in Russian).

6. Grigoriev A.A., Budyko M.I. Connection of heat and moisture balance with the intensity of geographical processes. Dokl. AN SSSR, 1965. V. 162. No 1. P. 151-154 (in Russian).

7. Hewitt K. Regions of Risk: A geographical introduction to disasters. New York: Routledge, 2014. $410 \mathrm{p}$. 
8. Isachenko A.G. The intensity of operation and productivity of geosystems. Izv. AN SSSR. - Ser. Geogr, 1990. No 5. P. 5-17 (in Russian).

9. Ivanov N.I., Fomkin I.V., Soloviev A.I. Forecasting, Planning and Organization of the Territory of Administrative-territorial Formations: Guidelines and Tasks for RGR. M., 2009. 160 p. (in Russian).

10. Kozin V.V. Environmental approach in landscape ecology. Bulletin of Tyumen University, 2009. No 3. P. 4-8 (in Russian).

11. Krauklis A.A. Features of geographical gradations of the topical order. Topological aspects of the theory of geosystems. Publishing house: Nauka. Sib. otd. Novosibirsk, 1974. P. 87138 (in Russian).

12. Kuznetsova T.I. Geosystem-cartographic analysis of natural environmental risk factors in the Lake Baikal basin (within Russia and Mongolia). Life safety, 2017. No 7. P. 50-56 (in Russian).

13. Kuznetsova T.I. Analysis and mapping of sensitivity and ecological stability of geosystems for information support of geographical forecast (on the example of the lake basin. Baikal). Problems of risk analysis. V. 13. No 3, 2016. P. 28-39 (in Russian).

14. Kuznetsova T.I. Creation of GIS "Natural environment" on the basis of modification of cartographic information. Geodesy and Cartography, 2018. V. 79. No 9. P. 20-29. DOI: 10.22389/0016-7126-2018-939-9-20-29 (in Russian).

15. Kuznetsova T.I., Batuev A.R., Bardash A.V. Map «Natural landscapes of the Baikal region and their use»: purpose. structure, content. Geodesy and cartography, 2009. No 9. P. 1828 (in Russian).

16. Mikheev V.S. Ecological risk: definition, essence, content. Environmental risk: analysis, assessment, forecast. Materials of the All-Russian Conference. Irkutsk, 1998. 148 p. (in Russian).

17. Mikheev V.S. Landscape and geographical support of complex problems of Siberia. Novosibirsk: Nauka, 1987. 206 p. (in Russian).

18. Mikheev V.S. Landscape synthesis of geographical knowledge. Novosibirsk: Nauka, 2001. 216 p. (in Russian)

19. Nazimova D.I., Ermakov N.B., Andreeva N.M., Stepanov N.V. Conceptual model of structural diversity of zonal classes of forest ecosystems in Northern Eurasia. Siberian Ecological Journal. No 5. 2004. P. 745-755 (in Russian).

20. Polikarpov N.P., Chebakova N.M., Nazimova D.I. Climate and mountain forests of Southern Siberia. Novosibirsk: Nauka, 1986. 215 p. (in Russian).

21. Sochava V.B. Problems of physical geography and geobotany. Novosibirsk: Nauka. Sib. otd-nie, 1986. 340 p. (in Russian).

22. Sochava V.B. Theoretical and applied geography. Novosibirsk: Nauka, 2005. 287 p. (in Russian).

23. Volkova E.A. Zonal-zonal patterns of distribution of vegetation in Mongolia. Izvestiya RGO. T. 124. Issue 6. 1992. P. 10-15 (in Russian).

24. von Haaren $C$. Landschaftsplanung. Stuttgart: Ulmer, 2004. 527 p.

25. Zhirov A.I. Geoecology. Methodology of geoecological research. Part 2. St. Petersburg: Publishing House of the Russian State Pedagogical University, 2002. 135 p. (in Russian). 


\section{Т.С. Нокелайнен ${ }^{1}$}

\section{ШКОЛЬНОЕ АТЛАСНОЕ КАРТОГРАФИРОВАНИЕ ДЛЯ ОБРАЗОВАНИЯ В ИНТЕРЕСАХ УСТОЙЧИВОГО РАЗВИТИЯ: ТЕМА «ЛЕСНЫЕ РЕСУРСЫ МИРА И СОХРАНЕНИЕ ИХ БИОРАЗНООБРАЗИЯ»}

\section{АННОТАЦИЯ}

Сегодня образование для устойчивого развития (ОУР) является приоритетным направлением образования во всех странах. Исключительную роль в решении задачи реализации идей ОУР играет школьная география, комплексно изучающая систему «природа - население - хозяйство». Курс «Экономическая и социальная география мира» в старших классах средней школы завершает цикл школьного географического образования и призван сформировать у учащихся понимание основных тенденций и процессов, происходящих в мире.

В 2020 году мир столкнулся с беспрецедентной по своим масштабам пандемией COVID-19. На текущем этапе неотложным глобальным приоритетом является преодоление сложившейся чрезвычайной ситуации в области здравоохранения, однако в долгосрочной перспективе предпринимаемые меры должны быть направлены на устранение первопричин возникновения пандемии. Одной из таких первопричин является деградация и сокращение площади лесов, что ведёт к нарушению природного баланса и усугубляет риск передачи зоонозов человеку.

Основной результат проведённых исследований - включение в содержание школьного атласа «Экономическая и социальная география мира. Природные ресурсы. Население. Экономика» новых картографических сюжетов по теме сохранения биоразнообразия и устойчивого использования лесных ресурсов мира.

Разработаны мировые карты - «Лесные ресурсы» (1:160 000 000), «Сокращение площади лесов» (1:250 000 000), «Лесная промышленность» (1:160 000 000). Кроме того, на карте «Земельные угодья» (1:80 000 000) показаны леса и редколесья, а на карте «Загрязнение и нарушение литосферы и биосферы» $\left(\begin{array}{llll}1: 160 & 000000\end{array}\right)$ - ареалы сохранившихся и вырубленных влажных тропических лесов.

Впервые в отечественных школьных атласах представлена тема сохранения биоразнообразия. Ей посвящены две мировые карты - «Биологическое разнообразие» (1:160 000000$)$ и «Снижение биологического разнообразия» (1:250 000 000). Лесные экосистемы являются одним из важнейших компонентов биоразнообразия мира.

Включение в содержание школьного атласа новых карт, разработанных с позиций устойчивого развития, помогает воспитать у учащихся способность глобально понимать проблемы современности, а также формировать мотивацию принимать участие в их решении.

КЛЮЧЕВЫЕ СЛОВА: образование для устойчивого развития, школьный атлас, новые картографические сюжеты, лесные ресурсы, биологическое разнообразие.

1 Московский государственный университет им. М.В. Ломоносова, Географический факультет, Региональный центр мировой системы данных, Ленинские горы, д. 1, 119991, Москва, Россия, e-mail: nokelta@geogr.msu.su 
Tatiana S. Nokelaynen ${ }^{1}$

\title{
SCHOOL ATLAS MAPPING FOR EDUCATION \\ FOR SUSTAINABLE DEVELOPMENT: \\ TOPIC "WORLD FOREST RESOURCES AND BIODIVERSITY CONSERVATION"
}

\begin{abstract}
Today, education for sustainable development (ESD) is a priority area of education in all countries. School geography, which comprehensively studies the "nature - population - economy" system, plays an exceptional role in implementing the ideas of ESD. The course "Economic and Social Geography of the World" in upper secondary school completes the cycle of school geography education and is designed to form students' understanding of the main trends and processes taking place in the world.

In 2020, the world is facing an unprecedented COVID-19 pandemic. Coping with the current health emergency is an urgent global priority at this stage, but in the long term, action must be taken to address the root causes of the pandemic. One of these root causes is the degradation and reduction of forest area, which disrupts the natural balance and exacerbates the risk of transmission of zoonotic disease from wildlife to humans.

The main result of this research is the inclusion of new cartographic plots that address the topic of biodiversity conservation and sustainable use of the world's forest resources in the content of the school atlas "Economic and Social Geography of the World. Natural resources. Population. Economy".

The World maps that have been developed include "Forest resources" (1: 160,000,000), "Reduction of forest area" (1: 250,000,000), "Timber industry" (1: 160,000,000). In addition, the map "Land cover" (1: 80,000,000) shows forests and woodlands, and the map "Pollution and disturbance of the lithosphere and biosphere" $(1: 160,000,000)$ shows the areas of preserved and cut down tropical rainforests.

For the first time the topic of biodiversity conservation is presented in Russian school atlases. Two world maps are dedicated to it - "Biodiversity" (1: 160,000,000) and "Biodiversity Loss" (1: 250,000,000). Forest ecosystems are one of the most important components of the Earth's biodiversity.

The inclusion of new maps developed from the standpoint of sustainable development in the content of the school atlas helps to develop students' ability to understand global issues and motivates to take part in solving them.
\end{abstract}

KEYWORDS: education for sustainable development, school atlas, new cartographic plots, forest resources, biodiversity.

\section{ВВЕДЕНИЕ}

Цель «образования для устойчивого развития» (ОУР) заключается в том, чтобы помочь учащимся развить такие знания, умения, ценности, которые позволят им принимать решения локального и глобального характера для улучшения качества жизни без экологической угрозы для будущего планеты [http://en.unesco.org/themes/education].

Образование в интересах устойчивого развития отличается междисциплинарным характером (экология, география, экономика, социология, философия, право, этика), а также комплексным рассмотрением глобальных проблем.

M.V. Lomonosov Moscow State University, Faculty of Geography, World Data Center for Geography, Moscow, 119991, Russia, e-mail: nokelta@geogr.msu.su 
Исключительную роль в решении задачи реализации идей образования в интересах устойчивого развития имеет школьная география, комплексно изучающая систему «природа - население - хозяйство».

В современной Концепции географического образования в России география рассматривается как важнейший школьный предмет мировоззренческого характера, на который ложится особая ответственность за формирование у учащихся комплексного, системного и социально-ориентированного представления о Земле как о планете людей [Концепция..., 2018].

Географическое образование в старшей школе призвано, в первую очередь, развивать геосистемное глобальное мышление, направленное на умение человека справляться с обострением глобальных проблем, новыми глобальными вызовами и научно оценивать перспективы будущего человечества [Дронов и др., 2018].

В 2020 году мир столкнулся с беспрецедентной по своим масштабам пандемией COVID-19. На текущем этапе неотложным глобальным приоритетом является преодоление сложившейся чрезвычайной ситуации в области здравоохранения, однако в долгосрочной перспективе предпринимаемые меры должны быть направлены на устранение первопричин возникновения пандемии.

Одной из таких первопричин является деградация и сокращение площади лесов, что ведёт к нарушению природного баланса и усугубляет риск передачи зоонозов человеку [http://www.fao.org/3/ca8642ru/CA8642RU.pdf].

Подавляющее большинство мирового биоразнообразия суши сосредоточено именно в лесах - от бореальных лесов Крайнего Севера до тропических дождевых лесов. Всего в лесах произрастает более 60000 различных древесных видов, они являются средой обитания для $80 \%$ видов земноводных, $75 \%$ видов птиц и $68 \%$ видов млекопитающих. Около $60 \%$ всех сосудистых растений произрастают в тропических лесах [The state..., 2020].

Биоразнообразие лесов - это широкое понятие, которое охватывает все виды жизненных форм, обитающих в занимаемых лесами районах, и выполняемые ими экологические функции. Это не только деревья, но и все многообразие растений, животных и микроорганизмов, населяющих лесные угодья, и связанное с ними генетическое разнообразие [https://www.cbd. int/decision/cop/?id=7082].

В Глобальной поисковой системе деревьев (GlobalTreeSearch) зарегистрировано более 60000 различных видов деревьев [https://tools.bgci.org/global_tree_search.php]. Болеe 20000 из них находятся в Красном списке. Под угрозой полного исчезновения оцениваются около 8000 видов [http://www.iucnredlist.org].

Больше всего видов деревьев в Бразилии, Колумбии и Индонезии. Тенденции разнообразия в более широком плане наглядно проявляются в странах с наибольшим числом эндемичных для них видов деревьев (Австралии, Бразилии и Китае) или на островах, изолированность которых приводит к дополнительному видообразованию (Индонезия, Мадагаскар и Папуа - Новая Гвинея). Почти 58 \% всех видов деревьев являются эндемиками одной страны [Beech et al., 2017].

Естественное биоразнообразие лесов значительно различается в зависимости от таких факторов, как тип лесов, географическое расположение, климат и почвы. Наибольшие показатели значимости для биоразнообразия имеют регионы с большим количеством видов, имеющих малое географическое распространение, например, горные леса Южной Америки, Африки и Юго-Восточной Азии, а также низинные леса островов Юго-Восточной Азии, прибрежных районов Бразилии, Австралии, Центральной Америки и островов Карибского бассейна [Hill et al., 2019]. 
Самую большую угрозу для биоразнообразия лесов представляет сокращение среды обитания и количества видов в результате обезлесения и деградации лесов. Темпы чистого сокращения площади лесов в период 1990-2020 годов заметно снизились в результате уменьшения масштабов обезлесения в одних странах и увеличения площади лесов в других за счет лесоразведения и естественного расширения лесов [Global..., 2020].

В рамках платформы «Глобальный мониторинг лесов» разрабатываются инструменты, сочетающие данные дистанционного зондирования с алгоритмами, предназначенными для моделирования в реальном времени сокращения площади лесов и его последствий для биоразнообразия [www.globalforestwatch.org].

По оценкам исследований, потенциальная площадь лесных земель в районах, где они ранее деградировали, составляет порядка 1,7-1,8 млрд га. Это более $25 \%$ современной площади лесов в мире [Bastin et al., 2019].

В начале 2020 года в рамках Всемирного экономического форума была запущена инициатива, предусматривающая выращивание, восстановление и сохранение одного триллиона деревьев [https://www.weforum.org/agenda/2020/01/one-trillion-trees-worldeconomic-forum-launches-plan-tohelp-nature-and-the-climate/].

Лесные экосистемы являются одним из важнейших компонентов биоразнообразия мира. Поэтому площадь, покрытая лесами, является одним из индикаторов достижения целей устойчивого развития (ЦУР) 15.1.1. В ЦУР определены предельные возможности природы и установлены критические пороги использования природных ресурсов [http://www.un.org/sustainabledevelopment].

Тема Международного дня лесов в 2021 году - «Восстановление лесов: путь к выходу из кризиса и благополучию». Тема этого года вписывается в Десятилетие ООН по восстановлению экосистем (2021-2030 годы) - призыв к защите и возрождению экосистем во всем мире [www.un.org/ru/observances/forests-and-trees-day].

\section{МАТЕРИАЛЫ И МЕТОДЫ ИССЛЕДОВАНИЯ}

Курс «Экономическая и социальная география мира» в старших классах средней школы завершает цикл школьного географического образования и призван сформировать у учащихся понимание основных тенденций и процессов, происходящих в мире.

Без картографической информации немыслимо постижение географического пространства во всем многообразии развивающихся в нем природных, социальноэкономических, демографических и экологических процессов и явлений.

Преподавание курса географии в старшей школе (10-11-й классы) требует современного картографического обеспечения и разработки принципиально новых сюжетов карт школьных атласов. В содержание карт должны быть включены новые актуальные темы, отражающие социальные, экономические и экологические аспекты устойчивого развития.

Карты школьного атласа - это источники географической информации, средство для исследовательских и проектных работ, основа для дискуссий на уроках. Использование атласов при изучении географии способствует более успешному усвоению учащимися географических знаний.

Атлас «Экономическая и социальная география мира. Природные ресурсы. Население. Экономика», созданный в соответствии с ФГОС (Федеральным Государственным образовательным стандартом) учёными географического факультета МГУ, является учебным пособием, дающим общие сведения о международных отношениях, глобальных проблемах человечества и взаимодействии общества и природы, о развитии и размещении населения и хозяйства в мире в целом, в отдельных регионах и странах [Экономическая..., 2018]. Первое издание атласа - 2008 г. 
Структура, содержание и оформление этого атласа разрабатывались в соответствии с самыми современными достижениями географической и картографической науки с учётом новейших тенденций преподавания географии в школе [Тикунов $и$ дp., 2014]. Основные масштабы мировых карт атласа: 1:80 000 000, 1:120 000 000, 1:160 000000 и 1:250000 000 .

Карты школьного атласа отличаются оптимальной детальностью и высоким уровнем согласования. Мировые карты, отражающие различные аспекты устойчивого развития, дополнены диаграммами, графиками, пояснительным текстом.

Включение в содержание учебного географического атласа новых сюжетов и тем один из наиболее оптимальных и перспективных подходов интеграции идей устойчивого развития в школьное образование.

Более чем 25 новых сюжетов карт школьного атласа соответствует целям устойчивого развития (ЦУР). Содержание карт охватывает широкий спектр тем - знакомит с проблематикой устойчивого развития; целями в области устойчивого развития; вопросами и проблемами, связанными с ЦУР [Нокелайнен, 2020].

Для школьного атласа «Экономическая и социальная география мира. Природные ресурсы. Население. Экономика» разработаны новые картографические сюжеты по теме сохранения биоразнообразия и устойчивого использования лесных ресурсов мира.

Лесной тематике посвящены мировые карты - «Лесные ресурсы» (1:160 000 000), «Сокращение площади лесов» (1:250 000 000), «Лесная промышленность» (1:160 000 000). Кроме того, на карте «Земельные угодья» (1:80 000 000) способом качественного фона показаны леса и редколесья, а на карте «Загрязнение и нарушение литосферы и биосферы» (1:160 000000$)$ - ареалы сохранившихся и вырубленных влажных тропических лесов.

Впервые в отечественных школьных атласах представлена тема сохранения биоразнообразия. Ей посвящены две мировые карты - «Биологическое разнообразие» $(1: 160000000)$ и «Снижение биологического разнообразия» $(1: 250000000)$.

При создании карт использованы методологии международных сравнительных сопоставлений, разработанные Статистической комиссией $\mathrm{OOH}$ [http://unstats.un. org/sdgs] и Мировым экономическим форумом [https://www.weforum.org/], показатели развития Мирового Банка [https://datacatalog.worldbank.org/dataset/world-developmentindicators], материалы Всемирного фонда дикой природы [https://www.worldwildlife. org/]; данные продовольственной и сельскохозяйственной организации Объединенных Наций (ФАО) [http://www.fao.org], другие статистические, картографические и литературные источники.

\section{РЕЗУЛЬТАТЫ ИССЛЕДОВАНИЯ И ИХ ОБСУЖДЕНИЕ}

Основной результат проведённых исследований - включение в содержание школьного атласа «Экономическая и социальная география мира. Природные ресурсы. Население. Экономика» новых картографических сюжетов по теме сохранения биоразнообразия и устойчивого использования лесных ресурсов мира.

На карте «Лесные ресурсы» фоном показывается уровень лесистости по странам (в процентах): менее 1, 15, 5-10, 10-20, 20-30, 30-50, 50-70, 70-91. Карта представлена на рис. 1.

На карте дана северная граница распространения лесов. Выделены безлесные территории. Способом картодиаграммы показан общий объём лесной биомассы по странам (6 ступеней). Дополняют карту диаграммы «Запасы древесины» (по регионам мира) и «Доля стран в мировых запасах древесины». 


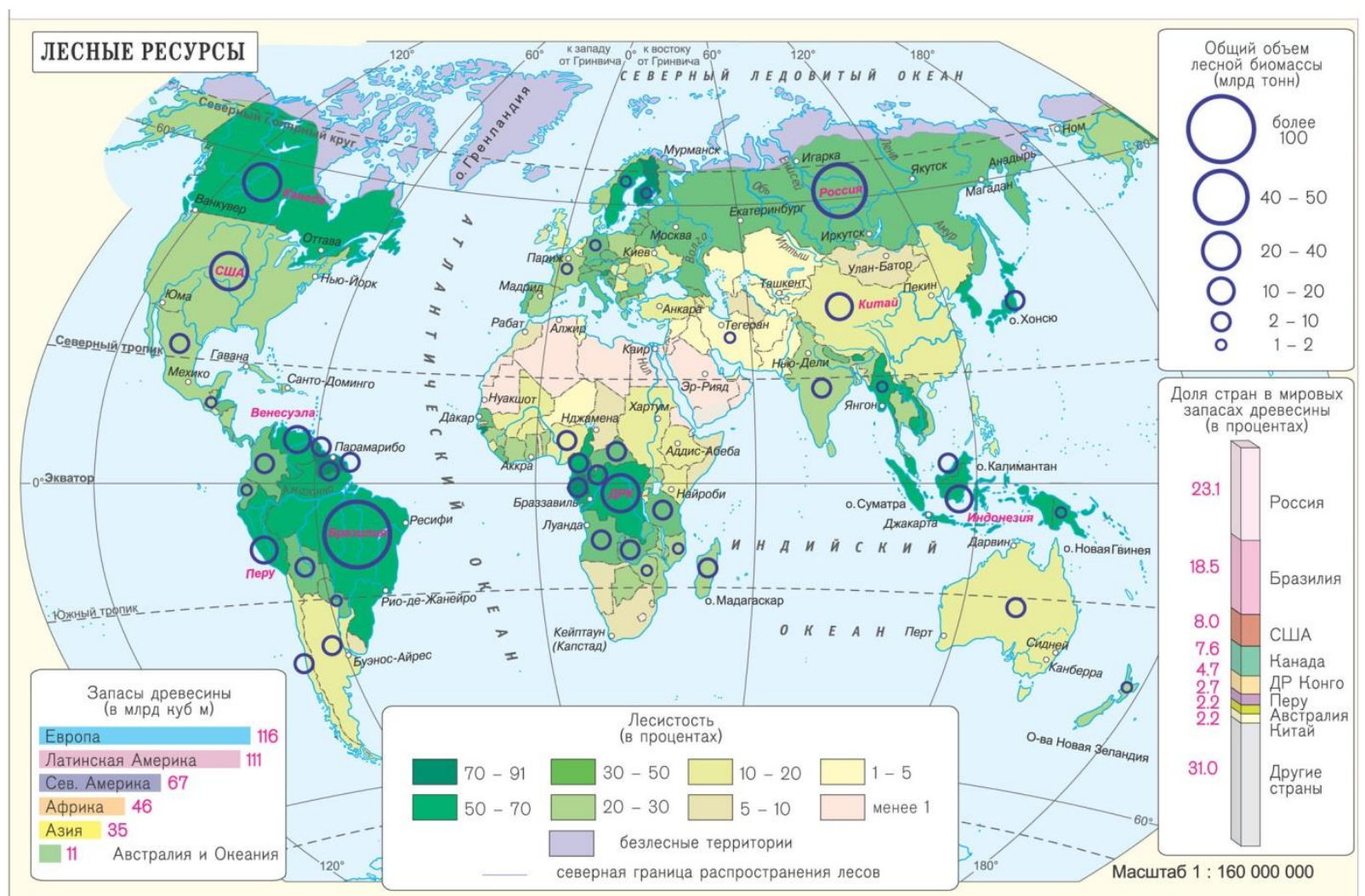

Рис. 1. Карта «Лесные ресурсы» (авторы Киселева Н.М., Нокелайнен Т.С.)

Fig. 1. Map "Forest resources" (authors Kiseleva N.M., Nokelaynen T.S.)

Карта «Биологическое разнообразие» дает характеристику стран по видовому разнообразию высших растений и животных. Фоном показано число видов высших

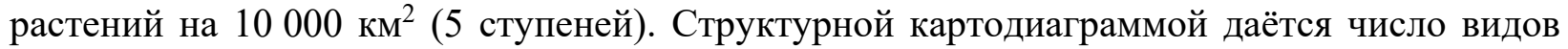
животных (5 ступеней) с подразделением на классы - птицы, млекопитающие, пресмыкающиеся, земноводные. Карта представлена на рис. 2.

Дополнительные диаграммы характеризуют число видов животных на Земле (по классам); биомассу живых организмов Земли; число видов птиц и млекопитающих, находящихся под угрозой исчезновения (по странам).

Самую большую угрозу для биоразнообразия лесов представляет сокращение среды обитания и количества видов в результате обезлесения и деградации лесов.

На карте «Сокращение площади лесов» фоном показывается среднегодовое изменение площади лесов по странам (в процентах от общей площади лесов). Для усиления наглядности использована двухцветная шкала - зеленый цвет соответствует увеличению площади лесов (3 ступени), оранжевый - уменьшению (3 ступени). Абсолютные значения этого показателя (в тыс. га) даны способом картодиаграммы по странам (8 ступеней). Карта представлена на рис. 3.

Дополнительную информацию дают диаграммы главных причин сведения лесов (расширение пахотных угодий, вырубка на экспорт древесины, вырубка на топливо, расширение пастбищ) и изменения лесопокрытой площади по регионам мира.

В период 1990-2020 годов площадь лесов в мире в абсолютном выражении сократилась на 178 млн га.

На долю обезлесения приходится 12-20 \% от мирового объёма выбросов парниковых газов, способствующих глобальному потеплению. 


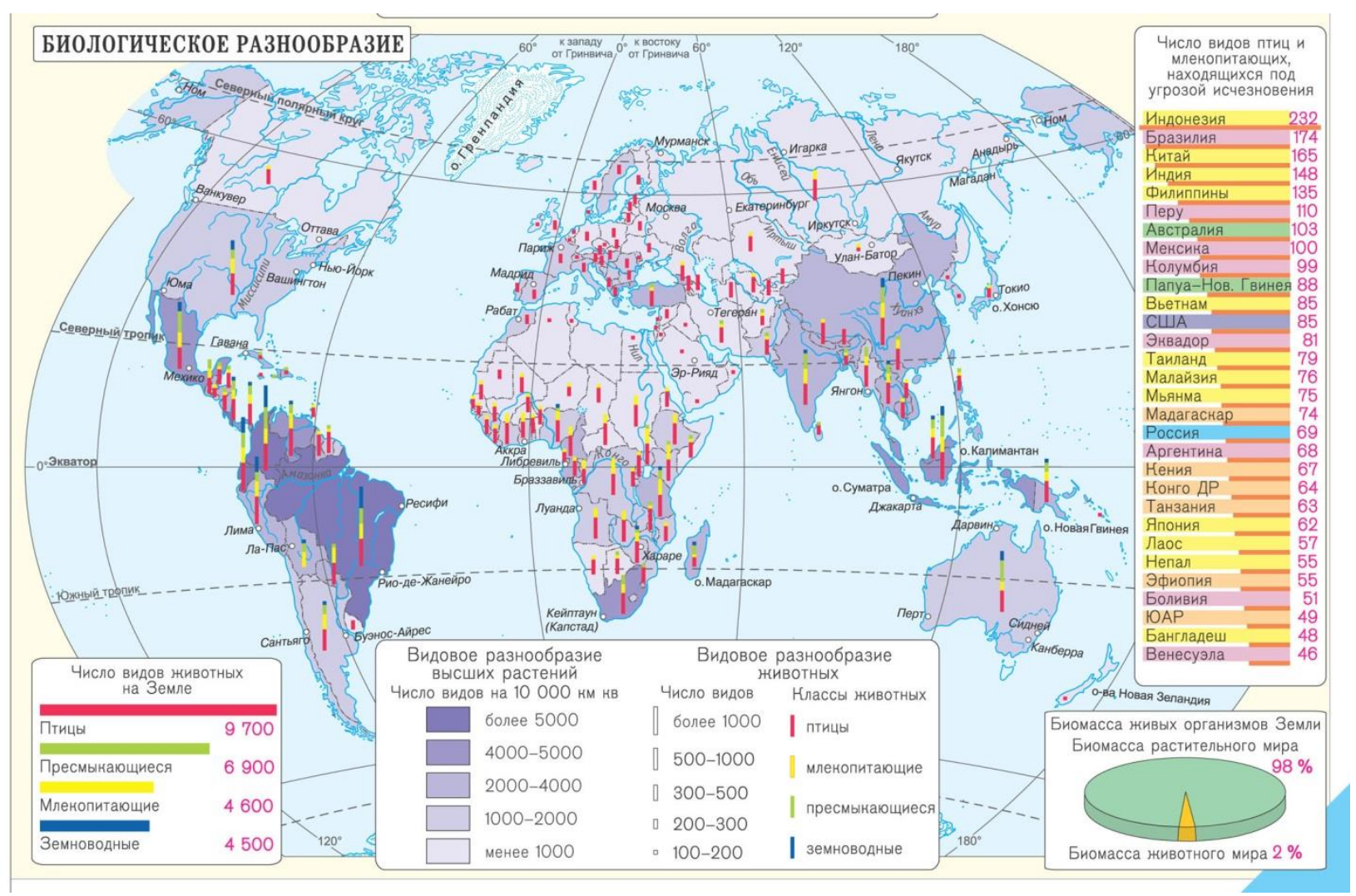

Рис. 2. Карта «Биологическое разнообразие» (автор Нокелайнен Т.С.)

Fig. 2. Map "Biodiversity" (author Nokelaynen T.S.)

Темпы изменения площади лесов представлены в таблице 1 [http:// www. fao.org/3/ca9825en/ca9825en.pdf]. В то время как в некоторых районах происходит обезлесение, в других районах за счет естественного прироста или целенаправленной работы идет лесовозобновление. В результате, показатель чистого сокращения площади лесов меньше темпов обезлесения.

Табл. 1. Годовые темпы изменения площзади лесов Table 1. Annual rate of change in forest area

\begin{tabular}{|c|c|c|}
\hline Период & $\begin{array}{c}\text { Абсолютное изменение } \\
\text { (млн га/год) }\end{array}$ & $\begin{array}{c}\text { Темпы абсолютного } \\
\text { изменения (\%/год) }\end{array}$ \\
\hline $1990-2000$ & $-7,84$ & $-0,19$ \\
\hline $2000-2010$ & $-5,17$ & $-0,13$ \\
\hline $2010-2010$ & $-4,74$ & $-0,12$ \\
\hline
\end{tabular}




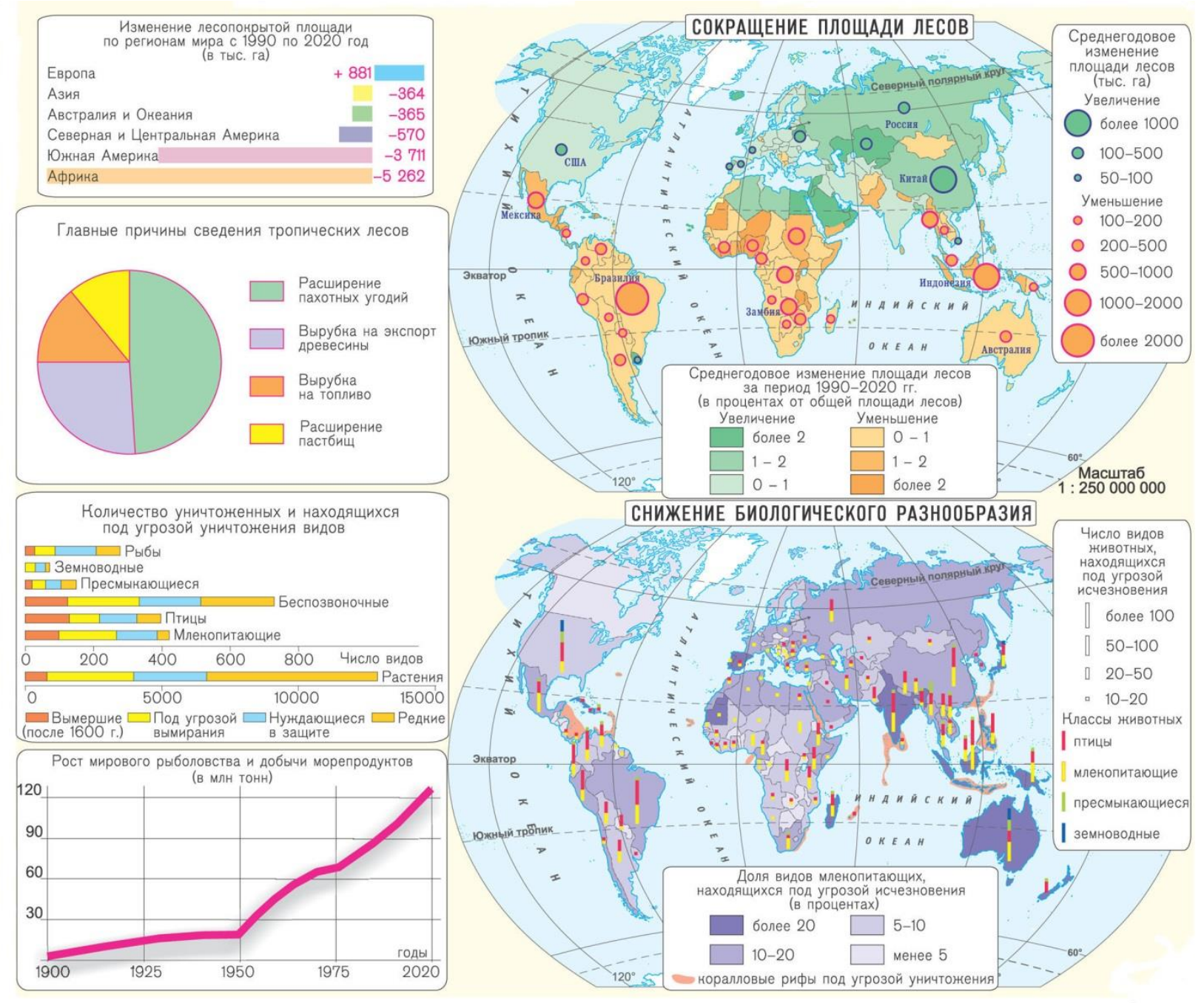

Рис. 3. Карты «Сокращение площади лесов» и «Снижение биологического разнообразия» (автор Нокелайнен T.C.)

Fig. 3. Maps "Reduction of forest area" and "Biodiversity Loss"(author Nokelaynen T.S.)

Комплексный подход и целостность - отличительные условия изучения проблем устойчивого развития. Карты «Сокращение площади лесов» и «Снижение биологического разнообразия» представлены в тематическом разделе «Глобальные ресурсные проблемы».

На карте «Снижение биологического разнообразия» способом структурной диаграммы по странам показано число видов животных, находящихся под угрозой исчезновения (10-20, 20-50, 50-100, более 100 видов) с подразделением по классам. Карта представлена на рис. 3.

Фон карты показывает долю видов млекопитающих (в процентах), находящихся под угрозой исчезновения (4 ступени). Даны ареалы коралловых рифов, находящихся под угрозой уничтожения.

Дополнительная диаграмма дает подробную картину сокращения видового разнообразия на Земле (количества видов животных и растений, вымерших после 1600 года; находящихся под угрозой вымирания; нуждающихся в защите; редких видов). Оценка проведена Международным союзом охраны природы по имеющимся историческим документам, коллекциям, научным описаниям. График демонстрирует резкий рост мирового рыболовства и добычи морепродуктов с середины прошлого века. 


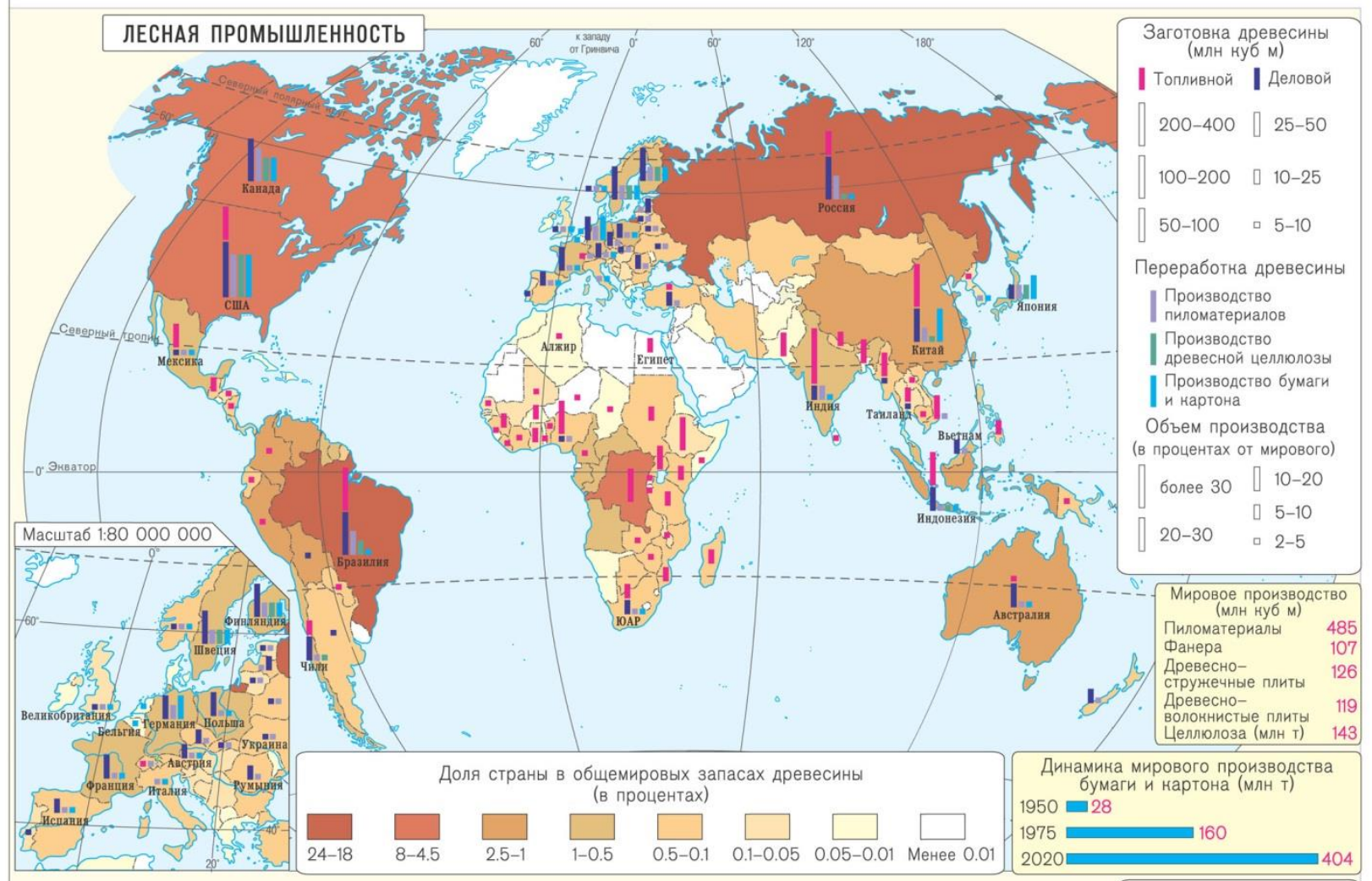

Рис. 4. Карта «Лесная промышленность» (авторы Киселева Н.М, Нокелайнен Т.С.) Fig. 4. Map "Timber Industry"(authors Kiseleva N.M., Nokelaynen T.S.)

Карта «Лесная промышленность» показывает характеристику стран по заготовке и переработке древесины и представлена на рис. 5. Уровень заготовки дается структурной картодиаграммой (6 ступеней) и подразделяется цветом по виду дальнейшего использования древесины (топливная и деловая). На карте четко выделяются регионы мира (развивающиеся государства Азии, Латинской Америки и Африки), где преобладает заготовка топливной древесины, используемой для производства древесного угля. Деловая древесина является конечным продуктом лесозаготовительного производства или используется как полуфабрикат для производства пиломатериалов, целлюлозы, древесностружечных или волокнистых плит и др.

Способом картодиаграммы на карте показан объём производства по странам пиломатериалов, древесной целлюлозы, бумаги и картона (5 ступеней), рассчитанный в процентах от мирового. Дополнительно даётся информация об объёмах мирового производства этих видов продукции лесопромышленного комплекса в абсолютных значениях (млн ${ }^{3}$ ), а также динамике роста производства бумаги и картона.

Рациональное использование лесов и экологически ориентированные сдвиги в мировом хозяйстве определили наибольший рост видов производств, работающих с использованием измельчённой древесины (стружки, щепы, волокон). Так, производство листовых древесных плит за последние двадцать лет выросло практически в два раза.

Фон карты показывает долю страны в общемировых запасах древесины (8 ступеней). В развитых странах Западной Европы и Северной Америки, объем прироста древесины превышает объем лесозаготовок и ресурсный потенциал растёт. Для большинства развивающихся стран характерно снижение обеспеченности лесными ресурсами. 
Изучение с помощью карт ресурсных возможностей нашей планеты неизбежно приводит к выводу о необходимости ответственного потребления и производства (сокращения ресурсо- и энергопотребления, снижения образования отходов, внедрения экологически безопасных технологий).

В мире до сих пор леса рассматривают в первую очередь как источник уникального и незаменимого сырьевого ресурса в виде древесины. Все остальные многочисленные факторы, связанные с функционированием лесов, оцениваются минимально или вообще не отражаются в рыночных оценках лесных ресурсов.

Сложившаяся ситуация увеличивает риски климатических изменений, способствует ухудшению качества водных ресурсов, потерям в сельском хозяйстве, утрате биоразнообразия, деградации рекреационных функций природы и в целом отрицательно влияет на благосостояние человека.

\section{ВЫВОДЫ}

Карты школьного атласа - это источники географической информации, средство для исследовательских и проектных работ, основа для дискуссий на уроках. Использование атласов при изучении географии способствует более успешному усвоению учащимися географических знаний.

Основной результат проведённых исследований - включение в содержание школьного атласа «Экономическая и социальная география мира. Природные ресурсы. Население. Экономика» новых картографических сюжетов по теме сохранения биоразнообразия и устойчивого использования лесных ресурсов мира.

Лесные экосистемы являются одним из важнейших компонентов биоразнообразия мира. Впервые в отечественных школьных атласах представлены карты этой тематики: «Биологическое разнообразие» и «Снижение биологического разнообразия».

Включение в содержание учебного географического атласа новых сюжетов и тем один из наиболее эффективных и перспективных подходов интеграции идей устойчивого развития в школьное образование.

\section{СПИСОК ЛИТЕРАТУРЫ}

1. Дронов В.П., Лобжанидзе А.А., Лопатников Д.Л. Концептуальные подходы к изучению географии в старшей школе. Наука и Школа, 2018. № 3. С. 9-16.

2. Концепция географического образования в Российской Федерации. Москва: Русское географическое общество, 2018, 13 с. Электронный ресурс: https://docs.edu.gov.ru/ document/54daf271f2cc70fc543d88114fa83250/ (дата обращения 24.03.2021).

3. Нокелайнен T. С. Образование для устойчивого развития: новые темы карт в школьном атласе по экономической и социальной географии мира: ИнтерКарто. ИнтерГИС. Геоинформационное обеспечение устойчивого развития территорий: Материалы Междунар. конф. Москва: Издательство Московского университета, 2020. T. 26. Ч. 1. С. 158-166. DOI: 10.35595/2414-9179-2020-1-26-158-166.

4. Тикунов В.С., Губанов М.Н., Карпович Л.Л., Киселева Н.М., Котова Т.В., Масленникова В.В., Нокелайнен Т.С., Тальская Н.Н. Новые обзорные карты России и мира. Геодезия и картография, 2014. № 6. С. 40-49.

5. Экономическая и социальная география мира. Природные ресурсы. Население. Экономика. Атлас для 10-го класса. ФГОС. Омск: Омская картографическая фабрика, 2018. 76 с.

6. Bastin J.-F., Finegold Y., Garcia C., Mollicone D., Rezende M., Routh D., Zohner C.M., Crowther T.W. The global tree restoration potential. Science, 2019. 365(6448). P. 76-79. 
7. Beech E., Rivers M., Oldfield S., Smith, P. GlobalTreeSearch: the first complete global database of tree species and country distributions. Journal of sustainable forestry, 2017. 36(5). P. 454-489.

8. Global forest resources assessment. Main report. Rome: FAO. 2020, 168 p.

9. Hill S.L.L., Arnell A., Maney C., Butchart S.H.M., Hilton-Taylor C., Ciciarelli C., Davis C., Dinerstein E., Purvis A., Burgess N.D. Measuring forest biodiversity status and changes globally. Frontiers in forest and global change, 2019. Web resource: https://doi.org/10.3389/ ffgc.2019.00070 (accessed 12.03.2021).

10. The state of the world's forests. Forests, biodiversity and people. FAO and UNEP. Rome: FAO, 2020. 188 p.

\section{REFERENCES}

1. Bastin J.-F., Finegold Y., Garcia C., Mollicone D., Rezende M., Routh D., Zohner C.M., Crowther T.W. The global tree restoration potential. Science, 2019. 365(6448). P. 76-79.

2. Beech E., Rivers M., Oldfield S., Smith, P. GlobalTreeSearch: the first complete global database of tree species and country distributions. Journal of sustainable forestry, 2017. 36(5). P. 454-489.

3. Concept paper of geography education development in the Russian Federation. M.: Russian geographical society. 2018. 13 p. Web resource: https://docs.edu.gov.ru/document/ 54daf$271 \mathrm{f} 2$ cc $70 \mathrm{fc} 543 \mathrm{~d} 88114 \mathrm{fa} 83250$ (accessed 24.03.2021) (in Russian).

4. Dronov V.P., Lobzhanidze A.A., Lopatnikov D.L. Conceptual approaches to the study of geography at high school. Science and School. 2018. No 3. P. 9-16 (in Russian).

5. Economic and social geography of the world. Natural resources. Population. Economy. Atlas for the 10th grade. FSES. Omsk: Omsk cartographic factory, 2017. 76 p. (in Russian).

6. Global forest resources assessment. Main report. Rome: FAO. 2020. 168 p.

7. Hill S.L.L., Arnell A., Maney C., Butchart S.H.M., Hilton-Taylor C., Ciciarelli C., Davis C., Dinerstein E., Purvis A., Burgess N.D. Measuring forest biodiversity status and changes globally. Frontiers in forest and global change, 2019. Web resource: https://doi.org/10.3389/ ffgc.2019.00070 (accessed 12.03.2021) (in Russian).

8. Nokelaynen T.S. Education for sustainable development: new map topics in school atlas on economic and social geography of the world: InterCarto. InterGIS. GI support of sustainable development of territories: Proceedings of the International conference. Moscow: Moscow University Press, 2020. V. 26. Part 1. P. 158-166. DOI: 10.35595/24149179-2020-1-26-158-166 (in Russian).

9. The state of the world's forests. Forests, biodiversity and people. FAO and UNEP. Rome: FAO, 2020. $188 \mathrm{p}$.

10. Tikunov V.S., Gubanov M.N., Karpovich L.L., Kiseleva N.M., Kotova T.V., Maslennikova V.V., Nokelaynen T.S., Talskaya N.N. New overview maps of Russia and of the world. Geodesy and cartography, 2014. No 6. P. 40-49 (in Russian). 
Д.С. Спесивцев. ${ }^{1}$ Е.Г. Ларин ${ }^{2}$

\title{
РАЗРАБОТКА КАРТОГРАФИЧЕСКОГО ВЕБ-СЕРВИСА ПРИРОДНОГО ПАРКА «КОНДИНСКИЕ ОЗЕРА»
}

\begin{abstract}
АННОТАЦИЯ
В настоящее время многие особо охраняемые природные территории (ООПТ) активно внедряют геоинформационные системы и технологии для структурирования и управления накопленными пространственными данными, а также для геоинформационной поддержки мониторинга и научных исследований.

ГИС ООПТ создаются с применением различных программных средств и характеризуются различным уровнем функциональных возможностей. Разрабатываются также картографические интернет-сервисы по данной тематике, которые предоставляют доступ к данным не только сотрудникам ООПТ, но и внешним пользователям.

В настоящей работе рассматривается создание веб-ГИС природного парка «Кондинские озера», расположенного на территории Тюменской области и обеспечивающего сохранение уникальных речных систем, ландшафтов и культурно-исторических памятников природы. Веб-сервис включает картографические слои и атрибутивные данные, характеризующие основные направления деятельности природного парка. Слои распределены по тематическим группам и отображают информацию о растительном и животном мире, пожарах, вырубках, местах отдыха и объектах нефтегазового комплекса, расположенного на территории парка. Проект реализован с помощью популярной открытой библиотеки для разработки вебприложений Leaflet. Написание кода проводилось с использованием языка разметки HTML5, CSS3 и JavaScript. Управление данными реализовано с помощью СУБД PostgreSQL, a публикация производится на основе открытого ГИС-сервера Geoserver. Также представлена структура данных и функциональность созданного веб-сервиса.

Пользователями данной системы могут быть как сотрудники природного парка (для наполнения базы данных сервиса), так и его посетители, а также организации, работающие в области экологического просвещения и туризма.
\end{abstract}

КЛЮЧЕВЫЕ СЛОВА: ООПТ, природный парк «Кондинские озера», картографический веб-сервис, Geoserver.

Пермский государственный национальный исследовательский университет, кафедра картографии и геоинформатики, 614990, ул. Букирева, 15, Пермь, Россия, e-mail: dspesivcev89@gmail.com

Старший научный сотрудник. Бюджетное учреждение ХМАО-Югры «Природный парк «Кондинские озера» им. Л.Ф. Сташкевича, 628242, пер. Комсомольский, 5. г. Советский Тюменской области ХМАО-Югра, e-mail: larvisim@mail.ru 
Dmitriy S. Spesivtsev ${ }^{1}$, Eugeniy G. Larin ${ }^{2}$

\title{
DESIGN AND DEVELOPMENT OF THE KONDINSKY LAKES NATURE PARK'S WEB MAP SERVICE
}

\begin{abstract}
Currently, many protected natural areas (PNA) implement geographic information systems (GIS) and technologies for structuring and managing collected spatial data to support of monitoring and scientific research.

GIS of protected areas may be developed based on various software products and characterized by different level of functionality. Also, online web map services on this topic are being developed, which provide access to data not for employees only, but also for users. This paper focuses on the development of a web-GIS of the Kondinsky Lakes natural park located in the Tyumen region of Russian Federation and ensuring the preservation of unique river systems, landscapes, cultural and historical natural monuments. The web service includes cartographic layers and attribute data to characterize the main activities of the natural park.

GIS layers are divided into thematic groups and contain information about flora and fauna, forest fires, logged areas, resting places and objects of the oil and gas mining in the park. The project is implemented using Leaflet, a popular open source web application development library. The code was written using the markup language HTML5, CSS3 and JavaScript. Data management is implemented using PostgreSQL DBMS. The publication is created based on the open GIS server Geoserver. The data structure and functionality of the developed web service is also presented.

The developed web service can be used by both employees of the natural park (to develop the content of the databases) and its visitors, as well as organizations working in the field of environmental education and tourism.
\end{abstract}

KEYWORDS: protected natural areas, nature park "Kondinskie lakes", web map service, Geoserver.

\section{ВВЕДЕНИЕ}

В настоящее время многие особо охраняемые природные территории (ООПТ) активно внедряют геоинформационные системы и технологии для структурирования и управления накопленными пространственными данными, а также для геоинформационной поддержки мониторинга и научных исследований. ГИС помогает решать различные задачи ООПТ в зависимости от цели их создания. Как правило, они обладают большим количеством полезных функций от простой демонстрации картографических данных до инструментов решения конкретных сложных задач.

Выделяют природоохранные ГИС по предметной специализации и территориальному охвату ${ }^{3}$. По территориальному охвату они делятся на локальные, региональные и глобальные ГИС. По предметной области, в разделении ГИС, главную роль играют цели образования ООПТ, доступные данные, задачи, которые должна решать ГИС.

Perm State University, Bukirev str., 15, 614990, Perm, Russia; e-mail: dspesivcev89@gmail.com Kondinsky Lakes natural park, Komsomolsky lane, 5, 628242, Sovetsky, Russia, e-mail: larvisim@mail.ru С.В. Ломакин. ГИС для ООПТ в России: состояние и перспективы. [Электронный ресурс] Сайт Мои книги и лекции. Сайт URL: https://www.sites.google.com/site/moiknigiilekcii/lekcii/GIS_technologii/1/oblprim/upravl/gisdlaooptvrossiisostoanieiperspektivy 
В сети интернет представлен широкий перечень подобных задач: регистрация нарушений, учёт флоры и фауны, разработка маршрутов, ведение баз данных и многое другое ${ }^{1}$.

Перечень геоинформационных систем и картографических веб-сервисов, созданных для решения задач ООПТ, весьма обширен. Под картографическим сервисом понимается способ предоставления веб-доступа к картографической информации на основе интерфейсов прикладного программирования [Воробьев и др., 2014].

Для публикации в сети интернет и работы с пространственными данными большой популярностью пользуются специальные программные продукты ГИС-серверы (например, ArcGIS Server, Geoserver и др.), а также облачные инфраструктуры пространственных данных (ArcGIS Online, NextGIS и др.) В частности, они используются в ГИС ГПУ НП „Нарочанский” [Сипач и др., 2018]. Есть ГИС и сервисы регионального уровня, в которых представлена комплексная характеристика ООПТ в пределах субъекта РФ. К ним можно отнести, например, ГИС-карту ООПТ Республики Татарстан [Шагеева и др., 2019] или информационно-аналитическую систему поддержки и сопровождения научных исследований «Природные ресурсы Карелии» [Титов и др., 2011].

Многие ГИС ООПТ являются частью более крупных проектов. Например, ГИС ООПТ Лазовского заповедника является частью геопортала МГУ, а ГИС ГПУ НП «Нарочанский», является частью более крупной ГИС, куда включены Березинский биосферный заповедник и три национальных парка - Беловежская пуща, Браславские озера и Припятский [Алексеенко и др., 2012; Сипач и др., 2018].

Также широко распространена разработка отдельных картографических разделов (страниц) на сайтах ООПТ с помощью языков разметки HTML, CSS, JavaScript посредством подключения готовых блоков кода или написания всего кода с нуля. Однако на сайтах большинства ООПТ часто можно встретить только описание территорий с редким включением каких-либо карт, планов и схем. Например, НП «Смоленское Поозерье» ${ }^{2}$, группа заповедников «Заповедное Приамурье» ${ }^{3}$, Воронинский заповедник ${ }^{4}$ и др. Есть примеры, где реализовано интерактивное окно карты с минимальными функциями (Ленинградский государственный природный биосферный заповедник ${ }^{5}$, «Кандалакшский» государственный заповедник ${ }^{6}$ и др.). Редко встречаются сайты где есть ресурсы для широкого взаимодействия и просмотра данных: НП Кисловодский» ${ }^{7}$.

На сайте национальных парков США можно найти информацию по каждому НП в каждом штате. Там представлена вся основная информация: о природе, истории, культуре, научных исследованиях и т. п. После перехода на страницу парка одним из элементов является ссылка на карты. В отельном окошке представлены картографические материалы в виде отдельных изображений или интерактивного окна с географической информацией

1 Применение ГИС в ООПТ: структурированный перечень задач. [Электронный ресурс] Caйт gis-lab. Сайт URL: https://gis-lab.info/qa/oopt-gis-problems.html.

2 Национальный парк «Смоленское Поозерье». [Электронный ресурс]. Сайт национального парка «Смоленское Поозерье». Сайт URL: http://www.poozerie.ru/turizm/karti/karta-parka/. Заказник «Баджальский». [Электронный ресурс]. Сайт группы заповедников «Заповедное приамурье». Сайт URL: http://www.zapovedamur.ru.

4 Воронинский заповедник. [Электронный ресурс]. Сайт «Воронинский заповедник». Caйт URL: http:// voroninsky.ru/about/maps/.

5 Карта Ленинградского биосферного заповедника. [Электронный ресурс]. Сайт Ленинградского государственного природного биосферного заповедника. Сайт URL: http://www.laplandzap. $\mathrm{ru} / \mathrm{pages} / 33 /$.

6 Карта «Кандалакшского» государственного заповедника. [Электронный ресурс]. Сайт «Кандалакшского» государственного заповедника. Сайт URL: https://kandalaksha-reserve.ru/Karta.

Национальный парк «Кисловодский». [Электронный ресурс]. Сайт национального парка «Кисловодский». Сайт URL: http://kispark.ru/map/\#places. 
(отдельного веб-сервиса). Одним из наиболее известных является сайт Йеллоустонского национального парка ${ }^{1}$.

Объектом исследования в настоящей работе является природный парк «Кондинские озера» ${ }^{2,3}$. Он был образован на территории Советского района Ханты-Мансийского автономного округа 22 июня 1995 г., как муниципальное учреждение. Природный парк создан с целью сохранения водной системы озер Арантур, Пон-Тур, Ранге-Тур Кондинского речного бассейна и прилегающих территорий, а также для охраны и изучения ценных природных комплексов, редких видов растений и животных, сохранения и изучения историкокультурного наследия, сохранения биологического разнообразия и т.п.

Как и для любой ООПТ за время существования парка был накоплен большой объём данных, включая картографические материалы. В 2019 г. автором данной статьи была разработана (на основе открытого программного обеспечения QGIS) и внедрена в рабочий процесс ГИС природного парка «Кондинские озёра». ГИС включает в себя четыре тематические группы и топографическую основу, в которых хранятся более 40 слоёв. Одним из шагов дальнейшего развития было создание картографического веб-сервиса. [Спесивщев и др., 2019; Иутин и др., 2017]. В настоящей статье рассматривается разработка картографического веб-сервиса природного парка «Кондинские озёра».

\section{МАТЕРИАЛЫ И МЕТОДЫ ИССЛЕДОВАНИЯ}

\section{Основа картографического веб-сервиса и источники данных}

Основой для разработки веб-сервиса послужила ранее созданная в программном комплексе QGIS геоинформационная система природного парка (ПП) «Кондинские озера», структура которой приведена в табл. 1. Выделенные в структуре ГИС 4 группы тематических слоев характеризуют основные направления работы парка - охрану природы, работу научного отдела, туризм и взаимодействие с нефтегазовым комплексом.

Для наполнения ГИС использовались данные, предоставленные руководством парка, собранные за период существования ООПТ: слои, созданные в ГИС MapInfo; таблицы MS Excel; данные GPS-съёмки и др. Все слои были собраны в единую систему, актуализированы и дополнены по состоянию на 2018 г. Все данные были приведены к единому формату и объединены в соответствующие группы [Спесивиев и др., 2019].

В частности, в группе охраны приведены слои гарей и вырубок за период с 1974 г. по н.в. Охрана природного парка следит за соблюдением заповедного режима и фиксирует все события природного и антропогенного характера. В группе научного отдела представлены данные об ареалах обитания ключевых видов животных, местах встречи с животными, маршрутах учета животных, а также места произрастания редких видов растений. Научный отдел ведёт планирование, учёт и организацию любой научной деятельности на территории парка. Все туристические маршруты и события, посвященные отдыху, разрабатываются отделом туризма и экопросвещения. В группе туризма представлены все основные места отдыха и досуга, которые в дальнейшем планируется расширять. В отдельную группу отнесены слои, характеризующие объекты нефтегазового комплекса. Также в ГИС присутствует группа топографической основы, расширяющая информацию подключаемой подложки OpenStreetMap (не представлена в табл. 1).

1 «Yellowstone» National Park. [Электронный ресурс]. Сайт National Park Service. Caйт URL: https:// www.nps.gov/yell/planyourvisit/maps.htm.

2 Кондинские озёра. Сайт информационно-аналитической системы [Электронный ресурс] «Особо охраняемые природные территории России» (ИАС «ООПТ РФ»), URL: http://oopt.aari.ru.

3 Природный парк Кондинские озёра. [Электронный ресурс]. Экологический портал Югры. Caйт URL: http://aaningsitir.ru. 


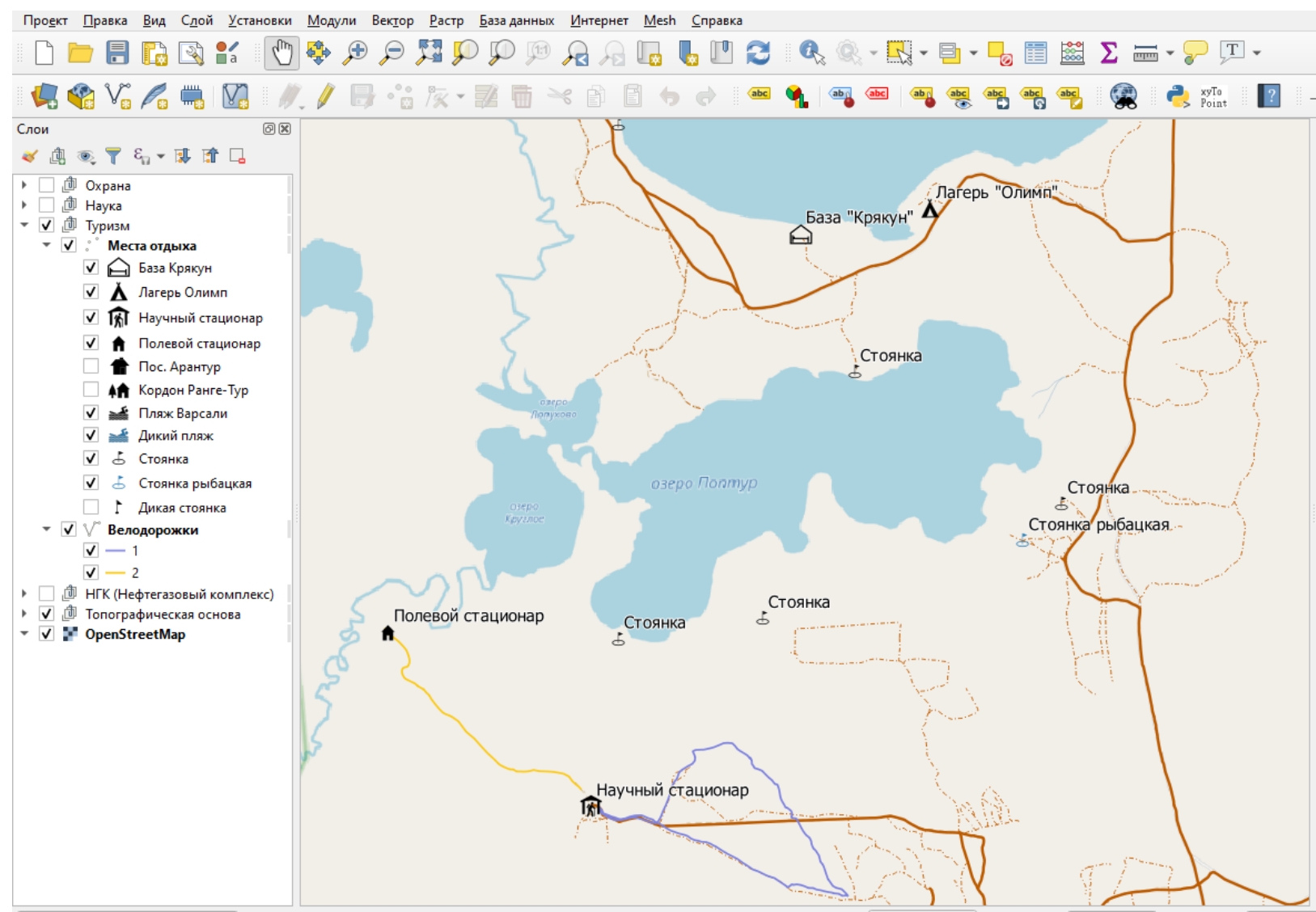

Рис. 1. Фрагмент ГИС природного парка «Кондинские озера»

Fig. 1. Fragment of GIS of the Kondinsky Lakes nature park

\section{Структура картографического веб-сервиса}

Для публикации на веб-сервисе данные природного парка разделены на тематические группы и отображены в отдельных страницах-вкладках. Структура тематических групп и слои, наполняющие их, были пересмотрены. По сравнению с исходной ГИС, всю топографическую основу заменяют базовые слои (подключаемые тайловые подложки). Слои, относящиеся к работе группы охраны, не включены в структуру веб-сервиса. Они открыты для пользования только работникам парка в программном комплексе QGIS. Группа науки разделена на три подгруппы - фауна, флора и ландшафты. Группа Рекреации (Группа Экопросвещения в табл. 1) и НГК перенесена без изменений.

\section{Особенности разработки картографического веб-сервиса}

Существует ряд готовых решений для разработки простых веб-ГИС сервисов, такие как ArcGIS Online, NextGIS и др., которые позволяют хранить, обрабатывать и публиковать данные. Но большинство из них, хотя и предоставляют широкий набор функциональных возможностей (редактирование, статистика и т.п.), имеют некоторые ограничения, например, стандартный функционал, без возможности подключать новые плагины. Стилизация интерфейса, как правило, невозможна, в то время как, при собственной разработке можно изменять стиль подчёркивая особенности того или иного ООПТ. Кроме того, эти продукты являются коммерческими. В связи с этим, разработка велась с использованием бесплатного программного обеспечения. 
Табл. 1. Структура ГИС природного парка «Кондинские озера» (без слоёв топографической основы)

Table 1. Structure of GIS of the Kondinskie lakes nature park (without topographic base layers)

\begin{tabular}{|c|c|c|c|}
\hline $\begin{array}{c}\text { Группа/ } \\
\text { Подгруппа }\end{array}$ & Слой & $\begin{array}{c}\text { Тип } \\
\text { геометрии } \\
\end{array}$ & Описание \\
\hline \multirow{4}{*}{ Группа охраны; } & Граница парка & Полилиния & Граница природного парка \\
\hline & Пожары & Полигон & $\begin{array}{c}\text { Слой пожаров (гарей) с датами их } \\
\text { возникновения }\end{array}$ \\
\hline & Вырубки & Полигон & $\begin{array}{c}\text { Слой вырубок с датами их } \\
\text { образования }\end{array}$ \\
\hline & $\begin{array}{l}\text { Лесоустройство } \\
2006\end{array}$ & Полигон & Лесоустройство ПП на 2006 год \\
\hline \multirow{6}{*}{$\begin{array}{l}\text { Группа науки: } \\
\text { Подгруппа } \\
\text { Фауна; }\end{array}$} & $\begin{array}{c}\text { Места встречи с } \\
\text { животными }\end{array}$ & Точка & Места встречи с животными ПП \\
\hline & $\begin{array}{c}\text { Ареал обитания } \\
\text { оленя }\end{array}$ & Полигон & $\begin{array}{c}\text { Ареал обитания оленя на } \\
\text { территории ПП }\end{array}$ \\
\hline & $\begin{array}{c}\text { Ареал обитания } \\
\text { лося }\end{array}$ & Полигон & $\begin{array}{c}\text { Ареал обитания лося на } \\
\text { территории ПП } \\
\end{array}$ \\
\hline & Учёт животных & Точка & Слой точек учёта животных \\
\hline & 3МУ & Полилиния & Зимние маршруты учёта \\
\hline & Маршрут учёта & Полилиния & Слой маршрутов учёта \\
\hline \multirow[t]{2}{*}{$\begin{array}{l}\text { Подгруппа } \\
\text { Флора; }\end{array}$} & Мхи & Точка & $\begin{array}{c}\text { Местообитания редких видов } \\
\text { мхов }\end{array}$ \\
\hline & Растения & Точка & Местообитания редких растений \\
\hline $\begin{array}{l}\text { Подгруппа } \\
\text { Ландшафт; }\end{array}$ & Ландшафты 2018 & Полигон & Слой ландшафтов на 2018 год \\
\hline \multirow{2}{*}{$\begin{array}{l}\text { Группа } \\
\text { Туризма; }\end{array}$} & Места отдыха & Точка & $\begin{array}{c}\text { Слой баз отдыха, стоянок для } \\
\text { пикника и т.п.; }\end{array}$ \\
\hline & Велотрек & Полилиния & Маршруты велодорожек; \\
\hline \multirow{5}{*}{$\begin{array}{c}\text { НГК } \\
\text { (Нефтегазовый } \\
\text { комплекс); }\end{array}$} & Скважины & Точка & Слой точек скважин; \\
\hline & ЛЭП & Полилиния & Линии электропередач \\
\hline & Трубопровод & Полилиния & Трубопровод \\
\hline & Дороги & Полилиния & Дороги, тропинки, зимники \\
\hline & НГК & Полигон & $\begin{array}{c}\text { Слой буровых площадок и кори- } \\
\text { доров коммуникаций; }\end{array}$ \\
\hline
\end{tabular}

Для хранения, редактирования и трансляции данных используется открытая объектно-реляционная СУБД PostgreSQL ${ }^{1}$. Дополнительно устанавливается расширение PostGIS, чтобы было возможно работать с пространственными дынными. На данном этапе есть возможность работать с базой данных в сторонних приложениях через подключение, например, QGIS. Это в свою очередь упрощает работу сотрудникам парка в наполнении базы данных ГИС. Таким образом, данные хранятся не на одном персональном компьютере, а свободно подключаются с сервера удалённо.

1 СУБД PostgreSQL. [Электронный ресурс]. Официальный сайт PostgreSQL. Сайт URL: https:// www. postgresql.org/. 
Публикация пространственных данных происходит посредством открытого ГИСсервера Geoserver, где также назначаются стили слоёв, заранее подготовленных в формате SLD экспортируемых с ГИС природного парка. При разработке пользовательского интерфейса и функциональных возможностей картографического веб-сервиса использовался стандартный набор технологий HTML5, CSS3 и JavaScript. Для отображения пространственных данных, а также разработки связанных с ними функциональных возможностей применялась открытая JavaScript-библиотека Leaflet.

\section{РЕЗУЛЬТАТЫ И ИХ ОБСУЖДЕНИЕ}

Анализ ГИС, геопорталов, картографических веб-сервисов

Рассматривая примеры реализации ГИС ООПТ, можно отметить, что часто применяются возможности разработки веб-приложений с помощью технологий HTML, CSS и JavaScript и специального ПО для публикации пространственных данных в сети Интернет (Geoserver, Mapserver, ArcGIS Server и др). В частности, широко используются открытые библиотеки JavaScript, такие как OpenLayers, Leaflet и др. Для хранения данных часто используются серверные СУБД.

Основными элементами карты из рассмотренных примеров выделены кнопки зума, кнопки домой (возвещение к первоначальному экстенту), кнопки печать, мини-окно территории, строку информации о подложке, элемент условных обозначений (как базовых слоёв, так и тематических), элементы дополнительной информации и др. В данной работе для установки подходящих элементов карты применены плагины библиотеки Leaflet.

\section{Функциональные возможности веб-сервиса}

Условно страницу сервиса можно разделить на три части, это заголовок, окно карты и контактная информация внизу страницы.

В заголовке (шапке) страницы сервиса отображены: наименование природного парка, четыре тематические группы и две ссылки на информацию о природном парке (Рис. 2). Внизу страницы сервиса предоставлены контакты офиса в городе Советском: полный адрес, телефон и электронная почта. В окне карты отображено всё наполнение данного сервиса: информация о ПП, подключаемые подложки и тематические слои, элементы карты (рис. 3).

\section{Природный парк «Кондинские озера» им.Сташкевича Pекреация Растительность Животные $\underline{\text { НПК }}$ В Контакте}

Рис. 2. Тематические группь веб-сервиса природного парка «Кондинские озера»

Fig. 2. Thematic groups of the web service of the Kondinsky Lakes Natural Park

В настоящее время основной возможностью сервиса является просмотр картографических слоев и атрибутивной информации. Легенда включает в себя базовые слои (OpenStreetMap), спутниковую подложку (kosmosnimki) и группы тематических слоёв. В каждой группе могут присутствовать подгруппы, которые можно сворачивать. Также реализованы стандартные опции масшитабирования, просмотра координат курсора и пр. При нажатии на любой объект отображаемого слоя в окне карты, всплывает окно атрибутивной информации о данном объекте. Атрибутивная информация включает в себя все поля слоя, отдельно добавлено поле со ссылкой на фото или изображение данного объекта. Также добавлено окно с общей информацией о природном парке. 


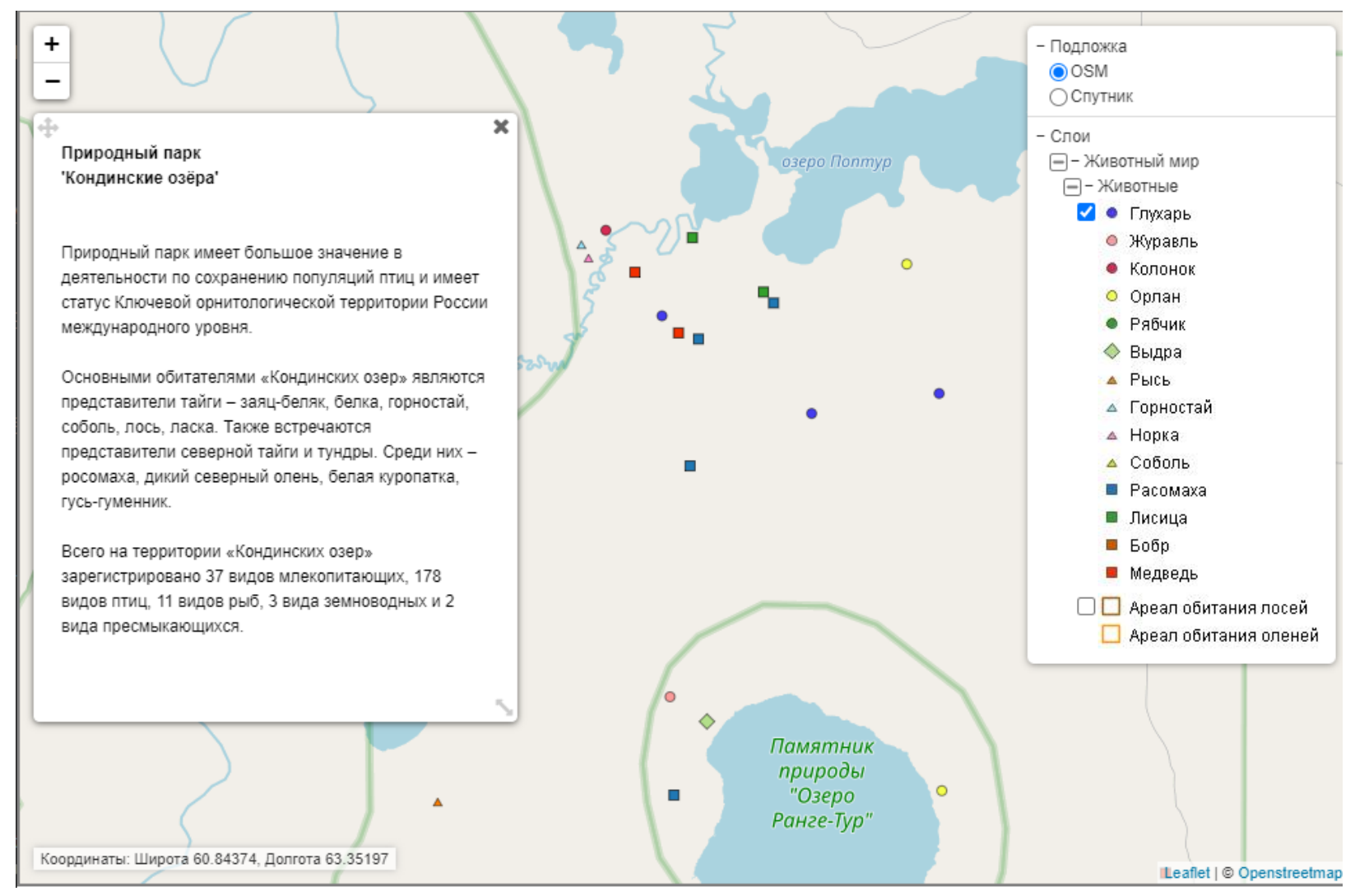

Pис. 3. Окно карты картографического веб-сервиса (OSM-OpenStreetMap) Fig. 3. Open window of the web map service (OSM - OpenStreetMap)

\section{Возможности применения сервиса}

Данная система решает ряд задач сотрудников ООПТ, главная из которых проблема обеспечения единого места хранения данных и удалённого доступа к ним. Это позволяет работникам парка оперативно получить доступ ко всей информации с любого персонального компьютера. Ввиду широких возможностей СУБД PostgreSQL и Geoserver можно подключаться к данным в программах где есть интеграция с PostgreSQL (в данном проекте c QGIS) и проводить манипуляции с ними - дополнение, наполнение, статистика и т.п. Кроме этого, возможно подключение новых плагинов, расширяющих возможности сервиса. Важно и то, что все программные продукты, используемые для реализации проекта абсолютно бесплатны. Также, осуществляется динамичная трансляция данных, где каждое изменение отображается на странице сайта онлайн. Таким образом, данные всегда актуальны, что является плюсом для пользователей.

К недостаткам можно отнести сложность интеграции данной системы в рабочий процесс, т.к. потребуется точная настройка и оптимизация системы, дополнительное техническое и программное обеспечение, а также обучение работников парка работе с данным сервисом.

\section{ВЫВОДЫ}

Картографический веб-сервис разрабатывается в качестве одной из страниц сайта природного парка «Кондинские озера». Он обладает более широким информационным наполнением и функциональными возможностями по сравнению с большинством сайтов ООПТ, на которых из интерактивных возможностей реализован обычно лишь просмотр карт. Помимо этого, разработанный сервис также можно рассматривать как прототип для 
создания подобных ГИС-сервисов для ООПТ. Сервис разработан на основе открытого программного обеспечения по системе подключения отдельных плагинов, а не написания всего кода приложения с нуля. Пользователями сервиса могут быть как сотрудники природного парка (отвечающие за ее поддержку и наполнение базы данных), так и его посетители, а также организации, работающие в области экологического просвещения и туризма.

\section{СПИСОК ЛИТЕРАТУРЫ}

1. Алексеенко Н.А., Балдина Е.А., Грищенко М.Ю. Коньков А.Ю., Хайбрахманов Т.С. Разработка содержания и наполнение вебкартографического сервиса ООПТ (на примере Лазовского заповедника в рамках геопортала МГУ). Геоинформационное картографирование в регионах России: Материалы IV (заочной) Всероссийской научнопрактической конференции (Воронеж, 15 ноября 2012 г). Воронеж: Научная книга, 2012.

2. Воробьев А.В., Шакирова Г.Р., Попкова Е.Е., Суворова В.А. Вопросы построения геоинформационных систем на базе известных картографических веб-сервисов. Академический журнал Западной Сибири. 2014. Т. 10. № 2(51). 10 с.

3. Иутин А.Д., Идрисов И.Р. Тюменский государственный университет, and Институт наук о Земле. Геоинформационное обеспечение деятельности особо охраняемых природных территорий с использованием открытого программного обеспечения (на примере государственного природного заповедника «Малая Сосьва»): выпускная квалификационная работа студента 4 курса очной формы обучения по направлению подготовки 05.03.03 Картография и геоинформатика. Тюмень, 2017.

4. Сипач В.А., Люштык В.С., Семенов О.А., Новиков А.А. Проблемы изучения и восстановления ландшафтов лесостепной зоны: историко-культурные и природные территории: Сборник научных статей, Тульская область, с. Монастырщино, 15-18 октября 2018 года. Государственный музей-заповедник «Куликово поле»; Русское географическое общество. Тула: Федеральное государственное бюджетное учреждение культуры Государственный военно-исторический и природный музей-заповедник «Куликово поле», 2018. С. 223-228.

5. Спесивцев Д.С., Добрякова В.А. Тюменский государственный университет, and Институт наук о Земле. Картографическое и геоинформационное обеспечение деятельности особо охраняемых природных территорий на примере природного парка «Кондинские озера»: выпускная квалификационная работа студента 4 курса очной формы обучения по направлению подготовки 05.03.03 Картография и геоинформатика. Тюмень, 2019.

6. Титов А.Ф., Вдовицын В.Т., Крышень А.М., Лебедев В.А., Полин А.К. Современные информационные технологии и развитие сети особо охраняемых природных территорий (на примере республики Карелия). Труды Карельского научного центра РАН № 1. 2011. С. 82-86.

7. Шагеева Г.М., Рафикова Ф.3. Использование ГИС в управлении ООПТ. Международный молодежный симпозиум по управлению, экономике и финансам: Сборник научных статей, Казань, 28-29 ноября 2019 года. Казань: Издательство Казанского университета, 2019. С. 517-520.

\section{REFERENCES}

1. Alekseenko N.A., Baldina E.A., Grishchenko M.Yu. Konkov A.Yu., Khaibrakhmanov T.S. Development of the content and filling of the web-cartographic service of SPNA (on the example of the Lazovsky reserve within the framework of the geoportal of the Moscow 
State University). Geoinformation mapping in the regions of Russia: materials of the IV (correspondence) All-Russian scientific and pactical conference (Voronezh, November 15, 2012). Scientific book Voronezh. 2012 (in Russian).

2. Iutin A.D., Idrisov I. R. Tyumen State University, and Institute of Earth Sciences. Geoinformation support of the activities of specially protected natural areas using open software (on the example of the Malaya Sosva state natural reserve): final qualification work of a 4th year fulltime student in the direction of training 05.03.03 Cartography and geoinformatics. Tyumen, 2017 (in Russian).

3. Sipach V.A., Lyushtyk V.S., Semenov O.A., Novikov A.A. Problems of study and restoration of landscapes of the forest-steppe zone: historical, cultural and natural territories: Collection of scientific articles, Tula region, p. Monastyrshchino, October 15-18, 2018; Kulikovo Field State Museum-Reserve; Russian Geographical Society. Tula: Federal State Budgetary Institution of Culture Kulikovo Pole's State Military-Historical and Natural MuseumReserve, 2018. P. 223-228 (in Russian).

4. Shageeva G.M., Rafikova F.Z. The use of GIS in the management of protected areas. International Youth Symposium on Management, Economics and Finance: Collection of Scientific Articles, Kazan, November 28-29, 2019. Kazan: Kazan University Publishing House, 2019. P. 517-520 (in Russian).

5. Spesivtsev D.S., Dobryakova V.A. Tyumen State University, and Institute of Earth Sciences. Cartographic and geoinformation support of the activities of specially protected natural areas on the example of the Kondinsky Lakes nature park: final qualification work of a 4-year fulltime student in the direction of training 05.03.03 Cartography and geoinformatics. Tyumen, 2019 (in Russian).

6. Titov A.F., Vdovitsyn V.T., Kryshen A.M., Lebedev V.A., Polin A.K. Modern information technologies and the development of a network of specially protected natural areas (on the example of the Republic of Karelia). Proceedings of the Karelian Scientific Center of the Russian Academy of Sciences. No 1. 2011. P. 82-86 (in Russian).

7. Vorobiev A.V., Shakirova G.R., Popkova E.E., Suvorova V.A. Issues of building geoinformation systems based on known cartographic web services. Academic journal of Western Siberia. 2014. T. 10. No 2 (51). 10 p. (in Russian). 


\title{
Д.А. Вольхин ${ }^{1}$, И.Н. Воронин ${ }^{2}$ Н.А. Собокарь ${ }^{3}$
}

\section{ОПЫТ КАРТОГРАФИРОВАНИЯ КРЫМСКОГО РЕГИОНАЛЬНОГО РЫНКА СМИ}

\begin{abstract}
АННОТАЦИЯ
В работе дана характеристика географических подходов изучения средств массовой информации (СМИ). Определены и описаны основные направления картографирования медиасферы: карты развития телекоммуникационной инфраструктуры, карты деятельности СМИ, карты обеспеченности населения и доступности продуктов СМИ, картографические технологии в деятельности СМИ, картографирование массовой информации и больших данных.

Рассматривается сущность понятия «географический рынок СМИ». Исследовательский интерес данной работы сфокусирован на картографировании традиционных СМИ, а именно региональных газетных изданиях и телевизионных каналах.

Охарактеризована и апробированы на примере Крыма методика картографирования и географической сегментации регионального рынка газетных и телевизионных СМИ. Представлены картографические произведения, отражающие территориальную дифференциацию выпуска местных газет и их реализации, уровень развития инфраструктуры цифрового телевизионного вещания и характер локализации и масштабов деятельности местного телевидения в Крыму. Дана характеристика сегмента национальных и религиозных СМИ, которые являются важным элементом общественного развития полиэтноконфессионального крымского региона.

Выполнено географическое сегментирование рынка печатных и телевизионных СМИ Республики Крым и города федерального значения Севастополя. Выявлены главные медиацентры, акцепторно-креативные и акцепторные территории.

Использование картографического метода позволило определить тип территориальной структуры географического рынка СМИ Крыма. Сделан вывод, что эта сфера деятельности в регионе развивается по модели «центр-периферия», которая усложняется расколом в уровне развития телекоммуникаций в направлении «город-село». Несмотря на достаточно разветвленную сеть предприятий медиасферы в Крыму ряд городов и районов не реализуют имеющийся на их территории потенциал для создания местных СМИ.
\end{abstract}

КЛЮЧЕВЫЕ СЛОВА: картография, региональный рынок СМИ, газетные издания, телевидение, Крым.

ФГАОУ ВО «Крымский федеральный университет имени В.И. Вернадского», Факультет географии, геоэкологии и туризма, пр-т Академика Вернадского, д. 4, 295007, Симферополь, Россия, e-mail: lomden@mail.ru

2 ФГАОУ ВО «Крымский федеральный университет имени В.И. Вернадского», Факультет географии, геоэкологии и туризма, пр-т Академика Вернадского, д. 4, 295007, Симферополь, Россия, e-mail: voronin.igor45@gmail.com

3 ФГАОУ ВО «Крымский федеральный университет имени В.И. Вернадского», Факультет географии, геоэкологии и туризма, пр-т Академика Вернадского, д. 4, 295007, Симферополь, Россия, e-mail: nickgreen721@yandex.ru 


\title{
Denis A. Volkhin ${ }^{1}$, Igor N. Voronin ${ }^{2}$, Nikita S. Sobokar ${ }^{3}$
}

\section{EXPERIENCE OF MAPPING THE CRIMEAN REGIONAL MEDIA MARKET}

\begin{abstract}
The article describes the geographical approaches to the study of mass media. The main directions of mapping the media sphere are defined and described: maps of the development of telecommunications infrastructure, maps of media production, maps of population provision and availability of media products, cartographic technologies in media activities, mapping of mass information and big data.

The essence of the concept of geographical media market is considered. The research interest of this paper is focused on mapping traditional media, namely regional newspaper publications and television channels.

The methods of mapping and geographical segmentation of the regional market of newspaper publications and television media are described and tested on the example of Crimea. The article presents cartographic works that reflect the territorial differentiation of local newspapers and their sales, the level of development of digital television broadcasting infrastructure, and the nature of localization and scope of local television activities in Crimea. The article describes the segment of national and religious mass media, which are an important element of the social development of the polyethnic and polyconfessional Crimean region.

The geographical segmentation of the print and television media market of the Republic of Crimea and the federal city of Sevastopol was performed. As a result, the main media centers, acceptor-creative and acceptor territories were identified.

The use of the cartographic method allowed us to identify the type of territorial structure of the geographical media market of Crimea. It is concluded that this area of activity in the region develops according to the "center-periphery" model, which is complicated by the split in the level of telecommunications development in the "city-village" direction. Despite a fairly extensive network of media enterprises in Crimea, a number of cities and districts do not implement the potential for creating local media on their territory.
\end{abstract}

KEYWORDS: cartography, regional media market, newspaper publications, television, Crimea.

\section{ВВЕДЕНИЕ}

Информационно-коммуникационные технологии развиваются стремительно и оказывают все большее влияние на территориальную организацию общества путем информационного воздействия на население стран и их регионов [Кастельс, 2016]. Изучение этих процессов расширяет объектно-предметное поле социально-экономической географии, в результате чего появляются новые направления науки: география средств массовой информации (СМИ), информационная география [Багров, 2005], географическая имиджелогия и другие [Воронин, 2010]. Деятельность СМИ имеет пространственный характер, т.е. может быть изучена с позиций географической науки с применением картографических методов исследования. Помещая деятельность СМИ в объектное поле картографии, исследователи дополняют тематическую социально-экономическую

\footnotetext{
1 V.I. Vernadsky Crimean Federal University, Faculty of Geography, Geoecology and Tourism, Akademik Vernadsky avenue, 4, 295007, Simferopol, Russia, e-mail: lomden@mail.ru

V.I. Vernadsky Crimean Federal University, Faculty of Geography, Geoecology and Tourism, Akademik Vernadsky avenue, 4, 295007, Simferopol, Russia, e-mail: voronin.igor45@gmail.com

V.I. Vernadsky Crimean Federal University, Faculty of Geography, Geoecology and Tourism, pr-t Akademik Vernadsky avenue, 4, 295007, Simferopol, Russia, e-mail: nickgreen721@yandex.ru
} 
картографию новыми сюжетами. С другой стороны, СМИ выступают генераторами новых картографических технологий [Берлянт, 1998]. Географическое и картографическое изучение деятельности СМИ связано с обнаружением пространственных особенностей распространения информационных потоков, их происхождения, функционирования, развития, управления, потребления и влияния на социально-экономическое развитие территорий (государств, регионов, городов и т.п.).

Информационно-телекоммуникационные системы отличаются высоким динамизмом. В этой связи исследовательский интерес вызывает картографирование особенностей развития рынка СМИ в регионах, сменивших свою государственную принадлежность. В данном исследовании эти процессы изучены на примере Крыма, который в 2014 году вошёл в состав Российской Федерации в виде двух субъектов. Территориальная и отраслевая структуры рынка СМИ Республики Крым и города Севастополя трансформировались в условиях их интеграции в социально-экономическое, политическое и информационное пространства России. Исходя из этого целью данной работы стало картографирование и географическая сегментация крымского регионального рынка СМИ.

\section{МАТЕРИАЛЫ И МЕТОДЫ ИССЛЕДОВАНИЯ}

СМИ как объект географического изучения зарубежными и отечественными исследователями рассматривается с нескольких позиций, которые обобщенно можно представить следующим образом:

1) география СМИ-информационных потоков и коммуникационных сетей;

2) изучение пространственной дифференциации деятельности медиа-организаций как сегмента рынка услуг;

3) политико-географическое изучение СМИ;

4) образно-географические исследования по материалам СМИ (образ и имидж территории);

5) пространственный анализ текстов и видеоконтента СМИ (информационная освоенность территорий, геотегинг и геокодирование в медийной сфере и прочее).

Американский географ П. Адамс (Paul C. Adams) разработал модель исследования медиа, в которой он выделил четыре направления пространственного изучения СМИ: «media in space» (СМИ в пространстве), «spaces in media» (пространства в СМИ), «places in media» (места в СМИ) и «media in place» (СМИ в местах) [Adams, 2009]. Но, на сегодняшний день, существуют и другие подходы географического изучения СМИ.

Пространственные особенности деятельности СМИ часто анализируются в работах географов, филологов, социологов и политологов, но картографическое отображение медиасферы мира, стран и регионов в подобных работах встречается редко. Более того, установлена закономерность, что в новостных текстах в среднем каждые 200-300 слов встречается указание местоположения какого-либо объекта ${ }^{1}$. Таким образом, существует большой и разнообразный массив информации, который может быть положен в тематическую и содержательную основу карт. Картографирование медийной сферы как самостоятельный тематический раздел еще формируется. Чаще всего это направление относят к укрупненной группе карт социальной сферы, объединяя их в рубрику «карты связи и телекоммуникаций» [Прохорова, 2010]. В научной литературе и различных практических видах деятельности, связанных с медийной сферой, к настоящему моменту накоплен опыт картографирования деятельности СМИ, который, на наш взгляд, можно сгруппировать в следующие направления.

Leetaru K. H. Culturomics 2.0: Forecasting large-scale human behavior using global news media tone in time and space. Электронный ресурс: https://firstmonday.org/article/view/3663/3040 (дата обращения 28.03.2021). 
1. Kaрты развития телекоммуникаџионной инфраструктуры. Это наиболее распространённое направление, которое охватывает большое разнообразие сетевых карт мира, отдельных стран, регионов и городов [Козаченко, 2007; Dodge, 2001]. Основной сюжет этих карт - показ территориальной дифференциации и основных характеристик сетей (например, скорость передачи информации, трафик, плотность сетей) мобильной связи, телевидения, Интернета, а также диффузии инноваций в этих направлениях 1 [Нагирная, 2018; Перфильев, 2003; Национальный атлас России, 2008; Warf, 2011]. В связи с развитием цифрового телевидения в России создан Интернет-портал федерального государственного унитарного предприятия (ФГУП) «Российская телевизионная и радиовещательная сеть» (РТРС), на котором есть картографический сервис, отражающий размещение инфраструктуры и зоны покрытия сигналом цифрового телевещания в регионах страны ${ }^{2}$.

2. Карть деятельности СМИ (издательств, редакиий печатной прессы,, телеканалов, Интернет-СМИ, информационных агентств и т.n.). Основные показатели на данных картах: сеть учреждений медиасферы, объемы деятельности (тираж газет, продолжительность эфирного вещания, стоимость оказанных рекламных услуг, совокупный доход от деятельности и т.д.) $)^{3,4}$. Самостоятельные карты подобных тематик встречают редко, чаще они представлены инфографикой и в виде текстовых карт. Еще реже указанные группы карт помещаются в атласы стран и регионов и, как правило, деятельность СМИ отражается на комплексных картах услуг. Примером картографического отражения конкурентного поведения СМИ является представление результатов исследования «как CNN проиграл CШA Fox News», на которой показаны качественным фоном территориальные сдвиги зрительских предпочтений в сторону телеканала «Fox News» в разрезе штатов страны ${ }^{5}$. Географическое сегментирование рынка СМИ - наиболее редкая тематика данной группы карт.

3. Карты обеспеченности населения и доступности продуктов СМИ. Подобные карты отражают охват населения (аудитории) телевизионными каналами, обеспеченностью территории устойчивым сигналом цифрового телевидения, пунктами продажи прессы, выпуском печатных СМИ на душу населения, размещением и количеством учреждений, пользующихся услугами СМИ, и другие показатели [Национальный атлас России, 2008].

4. Картографические технологии в деятельности СМИ. Авторы работ данной тематики изучают существующие и предлагают собственные картографические (геоизобразительные) технологии для представления информации в СМИ [Радамс, 2017; Грибок, 2016; Волкова и др., 2016].

5. Картографирование массовой информаџии и больших данных. Это относительно новое направление, которое один из крупных американских исследователей в сфере пространственных данных Калев Х. Литару (Kalev H. Leetaru) назвал «картографической

1 Green E. Mapping the 'Geography' of the Internet. Электронный pecypc: https://www.theatlantic.com/ technology/archive/2013/09/mapping-the-geography-of-the-internet/279434 (дата обращения 20.02.2021).

2 Картографический сервис РТРС. Электронный pecypc: https://карта.ртрс.рф (дата обращения 15.03.2021).

3 «Российская газета»: Доставка больше, чем жизнь. Электронный ресурс: http://distpress.ru/2009-01-2814-46-37/282367-rossijskaya-gazeta-dostavka-bolshe-chem-zhizn.html (дата обращения 28.03.2021).

Вчера в газете - сегодня в интернете. Электронный ресурс: http:/www.advertology.ru/print82137.htm (дата обращения 28.03.2021).

Jacobs F. Maps show how CNN lost America to Fox News. Электронный pecypc: https:// bigthink. com/strange-maps/cnn-fox-news?rebelltitem=1\#rebelltitem1 (дата обращения 24.03.2021). 
революцией» ${ }^{1}$. Разработанные ныне информационные технологии позволяют представителям данного направления на основе геокодирования контента СМИ и полученных больших данных в виде библиотек текстов крупнейших СМИ стран мира создавать интерактивные и анимированные карты, показывающие географию освещения новостей в разрезе разных языков, тематик, территорий, личностей в режиме реального времени. Такого рода карты - отражение виртуального ландшафта событийной повестки дня, недели, месяца или года на планете.

Данное исследование нацелено на картографирование медиасферы на примере Крыма и рассматривает эту отрасль экономики с позиций географического рынка СМИ. Под географическим рынком СМИ понимается медийное пространство, формирующееся в пределах определенной территории в результате взаимодействия генераторов массовой информации и ее потребителей, а также под влиянием природных и социальноэкономических систем данной территории [Adams, 2009; Geographies of Communication, 2006]. Территориальная структура рынка СМИ, которая является главным объектом картографирования медийной системы региона, представляет собой состав, соотношение и связи локализованных определенным образом территориальных единиц, генерирующих и потребляющих СМИ-продукты.

Исследовательский интерес данной работы сфокусирован на картографировании традиционных СМИ, а именно региональных газетных изданий и телевизионных каналов. Такой выбор обосновывается следующими фактами. Деятельность телеканалов и редакций печатных СМИ, в отличие от Интернет-СМИ, имеют более четкую пространственную привязку: известны расположение редакции, имеется конкретная сеть телевизионной инфраструктуры, зона вещания, которая определяется телеканалу нормативно при регистрации СМИ и частотой передающей аппаратуры, газетные издания регулируют территориальные рамки подписок, сеть пунктов продаж прессы. Подобные характеристики для Интренет-СМИ формализовать сложнее, а иногда и вовсе невозможно. Другой фактор особенность предпочтений в выборе источников новостной информации в России и ее регионах. Несмотря на устойчивый рост пользователей Интернет-СМИ, сегмент традиционных медиа (телевидения и газет) остается по-прежнему влиятельным, что подтверждается социологическими исследованиями. Например, социологический опрос Фонда общественного мнения ${ }^{2}$, проведенный в начале 2021 года, показал, что 63\% опрошенных россиян узнают новости, используя телевидение, новостные сайты - 45\% опрошенных, печатную прессу - только 9\%. Первенство телевидения в новостном сегменте СМИ также констатирует Левада-Центр ${ }^{3 *}$. Согласно указанным источникам уровень доверия к традиционным СМИ также сохраняется на более высоком уровне. Причем, в разрезе возрастных групп респондентов отмечается следующая особенность: приоритет телевизионным СМИ отдают лица старше 30 лет, т.е. наиболее активная когорта населения с точки зрения экономических и электоральных процессов. В крымских реалиях поведение аудитории СМИ мало отличается от общероссийских трендов. Согласно результатам

1 Leetaru K.H. Mapping Libraries: Creating Real-time Maps of Global Information. Электронный ресурс: https://blogs.loc.gov/thesignal/2015/07/mapping-libraries-creating-real-time-maps-of-globalinformation/?loclr=eadpb (дата обращения 28.03.2021).

2 Фонд общественного мнения. Источники информации: ТВ. Электронный pecypc: https://fom.ru/SMIi-internet/14536 (дата обращения 29.03.2021).

3 Левада-Центр. Телевидение стоит на месте, соцсети растут. Электронный pecypc: https://www. levada.ru/2020/04/29/televidenie-stoit-na-meste-sotsseti-rastut (дата обращения 29.03.2021).

* АНО «Левада-Центр» внесена Минюстом РФ в реестр некоммерческих организаций, выполняющих функции иностранного агента. 
опроса $^{1}$ среди молодежи Крыма, которая больше тяготеет к Интернет-ресурсам, более половины для получения новостной информации о полуострове выбирает телевидение.

Картографирование крымского регионального рынка СМИ выполнялось по следующей схеме. На первом этапе составлялись аналитические и полианалитические карты и картосхемы, отражающие характеристики инфраструктуры СМИ и ее доступности населению, сеть предприятий, объёмы деятельности и потребления услуг региональных газетных изданий и телеканалов. Основными источниками количественной и качественной информации для составления карт послужили: данные Федеральной службы по надзору в сфере связи, информационных технологий и массовых коммуникаций (Роскомнадзор), Министерства внутренней политики, информации и связи Республики Крым, Управления информационной политики города Севастополя, Государственного комитета по делам межнациональных отношений Республики Крым, ФГУП «Почта Крыма», а также официальные сайты СМИ и картографический сервис РТРС.

На втором этапе аналитические карты обобщались для составления синтетической карты, отражающей географическое сегментирование рынка СМИ Крыма. Сегментирование любого рынка услуг можно выполнять на основе множества критериев Сегментирование рынка СМИ Крыма осуществлялось с учетом акцепторно-креативных функций территориальных единиц региона, по аналогии с теорией диффузии инноваций [Бабурин, 2017]. Креативная, акцепторная и производные формы этих функций территорий определялись по характеру их участия в формировании рынка телевизионных и печатных СМИ Республики Крым и г. Севастополя. Административные единицы, концентрирующие большую часть наиболее влиятельных СМИ, распространяющих свои медийные продукты на всей территории Крыма, относятся к категории главных медиацентров региона. Креативные территории - административные единицы, генерирующие и реализующие собственные медиапродукты, но не потребляющие услуги СМИ других территорий. Данная категория встречается редко в виду открытости информационного пространства. Акцепторно-креативные территории - административные единицы, которые по одному из видов СМИ являются генераторами собственных медиа-продуктов, но не распространяющие их на весь регион, и потребителями услуг СМИ других территорий региона, а по другому сегменту СМИ - только потребителями. Акцепторные территории - административные единицы, которые не создают собственных местных медиа-продуктов, а только потребляют ресурсы СМИ других территорий региона. Преимущество данного подхода в его комплексности и применимости на любом пространственном уровне.

Для составления картографических произведений и пространственного анализа в качестве основного программного обеспечения выбрана программа ArcGIS 10.2: программный пакет ArcInfo Desktop с набором дополнительных модулей для расширения функциональности системы.

\section{РЕЗУЛЬТАТЫ ИССЛЕДОВАНИЯ И ИХ ОБСУЖДЕНИЕ}

Географический рынок газетных изданий Крыма. Сеть газетных изданий Крыма (без учета журналов) насчитывает более 200 изданий. В период с марта 2014 по 2015 г. их количество резко сократилось (почти в два раза), поскольку из списка ранее издаваемых газет многие не смогли пройти процедуру перерегистрации. Кроме этого, крымские исследователи констатировали, что до 2014 года в Крыму применялась практика сквоттинга в медиасфере, когда 32\% (более 1000 ед.) газет от их общего количества были зарегистрированы с 2011 по 2012 гг. на одного человека, а в последующий период не

1 РИА Новости Крым. Чему верит крымская молодежь: исследование. Электронный ресурс: https://crimea.ria.ru/society/20210310/1119341354/Chemu-verit-krymskaya-molodezh-issledovanie.html (дата обращения 29.03.2021). 
функционировали [Егорова, 2019]. К настоящему моменту рынок газет прошел период адаптации к российскому правовому полю и имеет устоявшуюся территориальноотраслевую структуру. Территориальная дифференциация местных газетных издательств Крыма вписывается в общие закономерности географии местной прессы (рис. 1): чем крупнее по населению территориальная единица, тем более емким и разнообразным является рынок печатных СМИ. В регионе выделяется два главных центра - Симферополь и Севастополь, на них приходится более 50\% всех зарегистрированных газет. Газеты столичного Симферополя и города федерального значения Севастополя отличаются тематическим разнообразием и охватывают практически весь спектр тематик, что отражает структурная картодиаграмма на картосхеме. Центрами второго порядка по количеству газетных изданий являются крупные города и городские округа Керчи, Евпатории, Ялты и Феодосии, в которых также издаются газеты разной тематики. В остальных административных единицах Республики Крым, кроме Джанкойского района, где нет ни одной местной газеты, издается по 1-5 газет преимущественно общественно-политической тематики. По совокупному тиражу газет за год и на 1000 жителей регионы Крыма дифференцируются аналогичным образом.

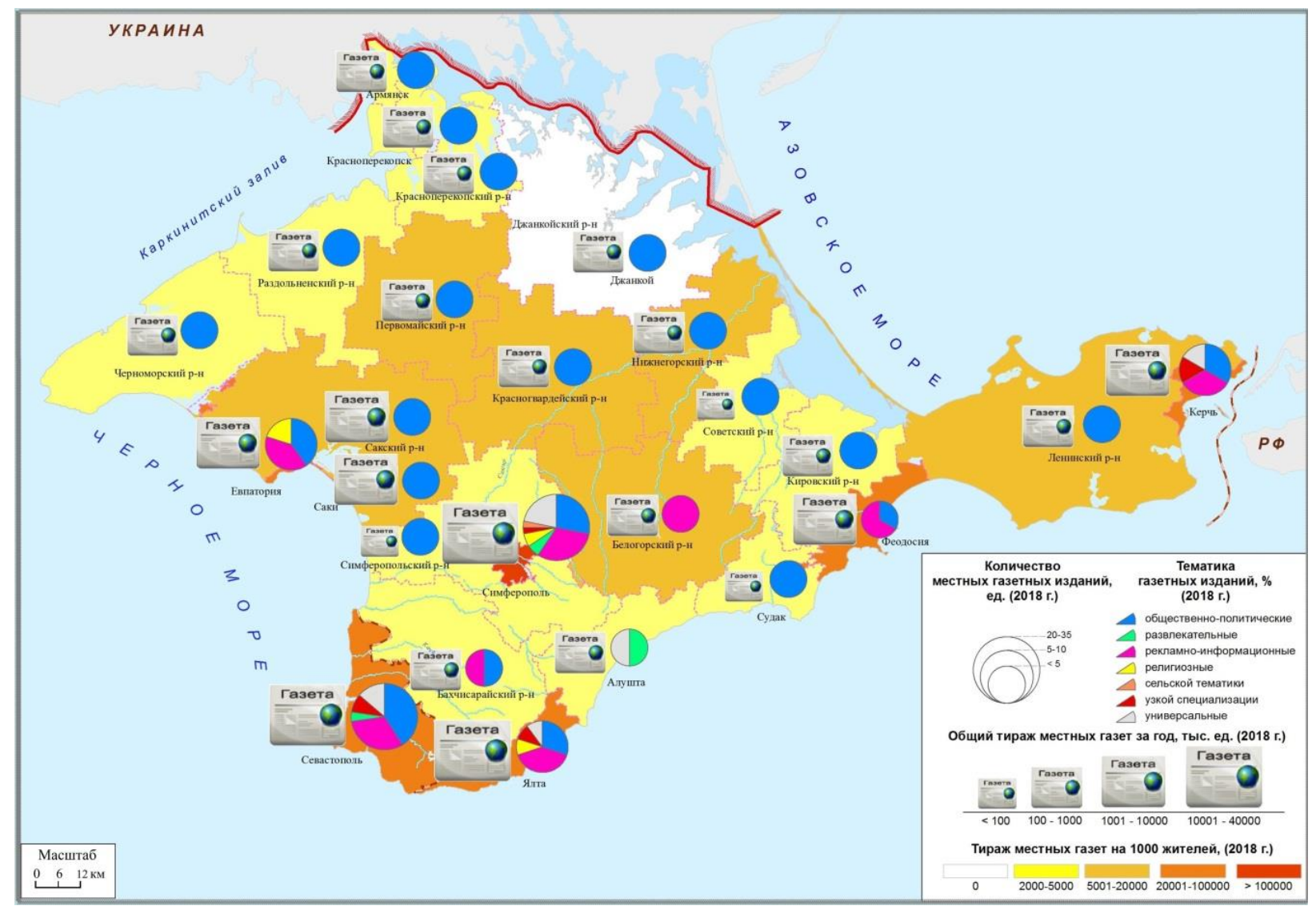

Рис. 1. Территориальная дифференциаџия выпуска местных газет в Крымму, 2018 г. Fig. 1. Territorial differentiation of the Crimean newspaper market, 2018

Анализ динамики выпуска газетных изданий [Егорова, 2013] показал, что трансформационные процессы 2014-2015 гг. практически не отразились на типе его территориальной структуры, данная характеристика медиапространства региона является устойчивой и в большей степени зависит от расселенческой структуры населения, чем от социально-политических процессов, которые влияют на смысловую составляющую газет. 
Потребительская часть рынка печатных изданий имеет иные территориальные соотношения (рис. 2). По объёмам реализованных печатных изданий в абсолютном, стоимостном и душевом выражении лидирует сельская периферия северных и восточных территорий Крыма. Урбанизированные территории им значительно уступают. Население и предприятия преимущественно сельских территорий Красногвардейского, Евпаторийского, Феодосийского и Керченского почтамтов в 2018 г. приобрело печатной продукции в 2 раза больше по сравнению с более урбанизированными территориями Симферопольского, Севастопольского и Ялтинского почтамтов, хотя в первой группе почтамтов проживает на 30 тыс. жителей меньше, чем во второй группе почтамтов.

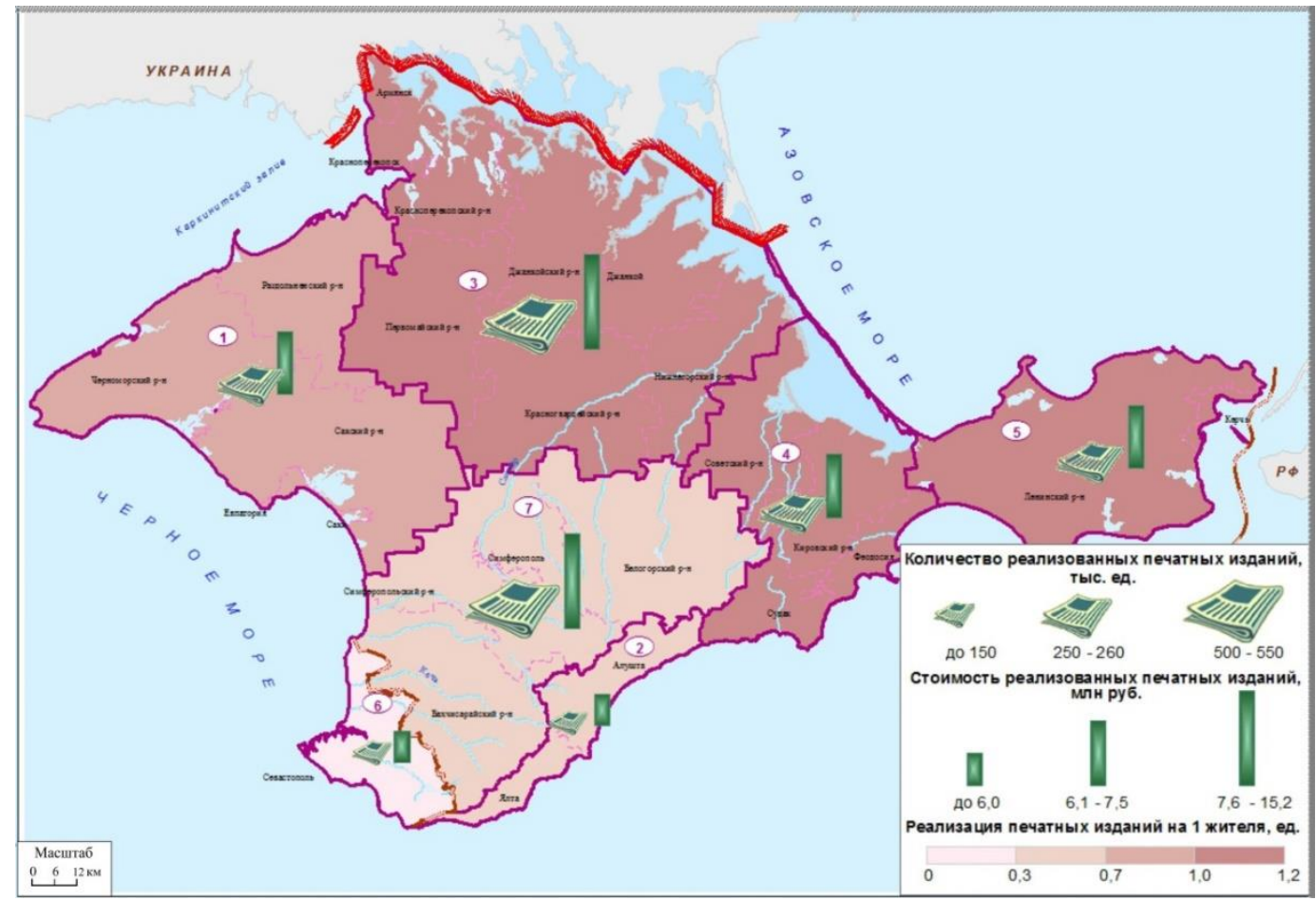

Рис. 2. Реализация печатных изданий почтамтами Крыма, 2018 г.

1 - Евпаторийский почтамт; 2 - Ялтинский почтамт; 3 - Красногвардейский почтамт;

4 - Феодосийский почтамт; 5 - Керченский почтамт; 6 - Севастопольский почтамт;

7 - Симферопольский почтамт.

Fig. 2. Territorial differentiation of local newspapers in Crimea, 2018.

1 - Yevpatoria Post Office; 2 - Yalta Post Office; 3 - Krasnogvardeysky Post Office; 4 - Feodosia Post Office; 5 - Kerch Post Office; 6 - Sevastopol post Office; 7 - Simferopol Post Office.

Таким образом, рынок местных печатных изданий в Крыму характеризуется несовпадением географии производства и потребления газет. Эта особенность объясняется тем, что сельские территории Крыма в меньшей степени обеспечены современными телекоммуникациями (Интернет, цифровое ТВ) ${ }^{1}$, в связи с чем, в качестве альтернативы сельское население по сравнению с городским более активно использует газеты для получения информации.

Географический рынок телевидения Крыма. После вхождения Крыма в состав Российской Федерации произошел переход контроля над медийной сферой полуострова к

Вольхин Д.А. Связь и телекоммуникации. Электронный ресурс: https:/atlas-crimea.ru/all/razdel-5/518-svyaz-i-telekommunikacii/ (дата обращения 29.03.2021). 
федеральным и новым региональными управленческим структурам и организациям [Первых, 2019]. Масштабность и скорость этого процесса подтверждается фактами активной деятельности главных телеканалов России на всей территории полуострова фактически с первых дней «Крымской весны». В марте 2014 года вещание украинских телеканалов на территории Крыма было прекращено, украинская сетка телеканалов была заменена на российскую. В 2014 году телерадиокомпания «Крым» вышла из состава Госкомтелерадио Украины и создала автономную некоммерческую организацию. Прекратили свою деятельность и/или сменили географический центр вещания некоторые крымские СМИ («Черноморская телерадиокомпания» и СМИ медиа-холдинга «АтлантCВ»), которые теперь осуществляют деятельность на территории Украины.

В 2015 году Республика Крым и город Севастополь перешли на цифровой формат телевизионного вещания. Для этого на территории региона была построена соответствующая инфраструктура в виде 44 радиотелевизионных передающих центра (РТРС - 1, 2). В результате оцифровки данных РТРС была получена карта инфраструктуры цифрового телевизионного вещания в Крыму (рис. 3). На сегодняшний день уверенным сигналом цифрового телевидения (ЦТВ) покрыта большая часть территории полуострова. Однако, в Республике Крым по-прежнему остаются зоны с неуверенным сигналом ЦТВ: в горной и предгорной частях региона (связано с горным рельефом), в центральной и южной частях Керченского полуострова, а также на отдельных территориях равнинного Крыма (связано с низкой мощностью действующих или отсутствием передающих центров). С помощью аналитического модуля было определено, что в зонах с неуверенным сигналом ЦТВ расположены более 100 сельских населенных пункта Крыма, в которых проживает около 50 тыс. человек или 2,5\% населения Республики Крым.

На территории Крыма осуществляют вещание 18 местных телеканалов и телестудий. Их территориальная дифференциация еще более поляризована, чем рынок печатных СМИ (рис. 4): по 4 телекомпании расположены в Севастополе и Симферополе, в остальных центрах - городах Алуште, Армянске, Белогорске, Евпатории, Керчи, Красноперекопске, Саках, Ялте и пгт Черноморском - по одном телеканалу. Иные административные единицы местных телеканалов и телестудий не имеют. Вещание на всю территорию Крыма осуществляют только телеканалы столичного Симферополя и города Севастополя, которые входят в третий мультиплекс ЦТВ и осуществляют вещание через спутник на территорию России и сопредельных государств («Первый Крымский», «Крым 24», «Миллет», «Севастопольское телевидение, “Севастополь 24”» (до 2019 г. «Информационный канал Севастополя»)). Численность потенциальной аудитории этих ведущих телеканалов приравнивается к среднегодовой численности населения Крыма в возрасте $12+-$ более 1,9 млн человек, реальный же охват аудитории намного меньше.

Прочие перечисленные в легенде картосхемы телеканалы ограничиваются зоной вещания в пределах административной единицы местонахождения телестудии или захватывают часть сопредельных территорий. Эти небольшие телеканалы продолжают вещать в аналоговом формате и редко имеют круглосуточное вещание, численность их потенциальной зрительской аудитории не превышает 100-500 тыс. человек. Свою зрительскую аудиторию практически все крымские телеканалы расширяют за счет вещания на своих официальных сайтах и группах в социальных сетях.

Для Крыма с его полиэтноконфессиональной структурой населения важной характеристикой медийного рынка является деятельность СМИ, создающих контент на разных языках и для различных конфессий. Указанный сегмент СМИ в Крыму присутствует. В Крыму насчитывается порядка 10 местных печатных СМИ на языках народов региона: армянском (1 издание), болгарском (1 издание), греческом (1 издание), крымско-татарском (5 изданий), немецком (1 издание), украинском (1 издание). 
Этнокультурную направленность имеет «Крымский казачий вестник», издаваемый на русском языке. Большая часть указанных национальных газет издается при поддержке ГАУ РК «Медиацентр имени Исмаила Гаспринского», учрежденного в 2015 году Государственным комитетом по делам межнациональных отношений Республики Крым. Лишь 3 печатаных издания Крыма выходят еженедельно с тиражом, достигающим 52000 копий в год каждая (это крымско-татарские издания «Мераба», «Янъы дюнья», «Йылдыз»), остальные национальные газеты выпускаются с периодичностью раз в 3 месяца, имея тираж около 2000 экземпляров в год каждая. Только 8 газет имеют официальные страницы в сети Интернет с полнотекстовым архивом выпусков на сайте «Медиацентра имени Исмаила Гаспринского».

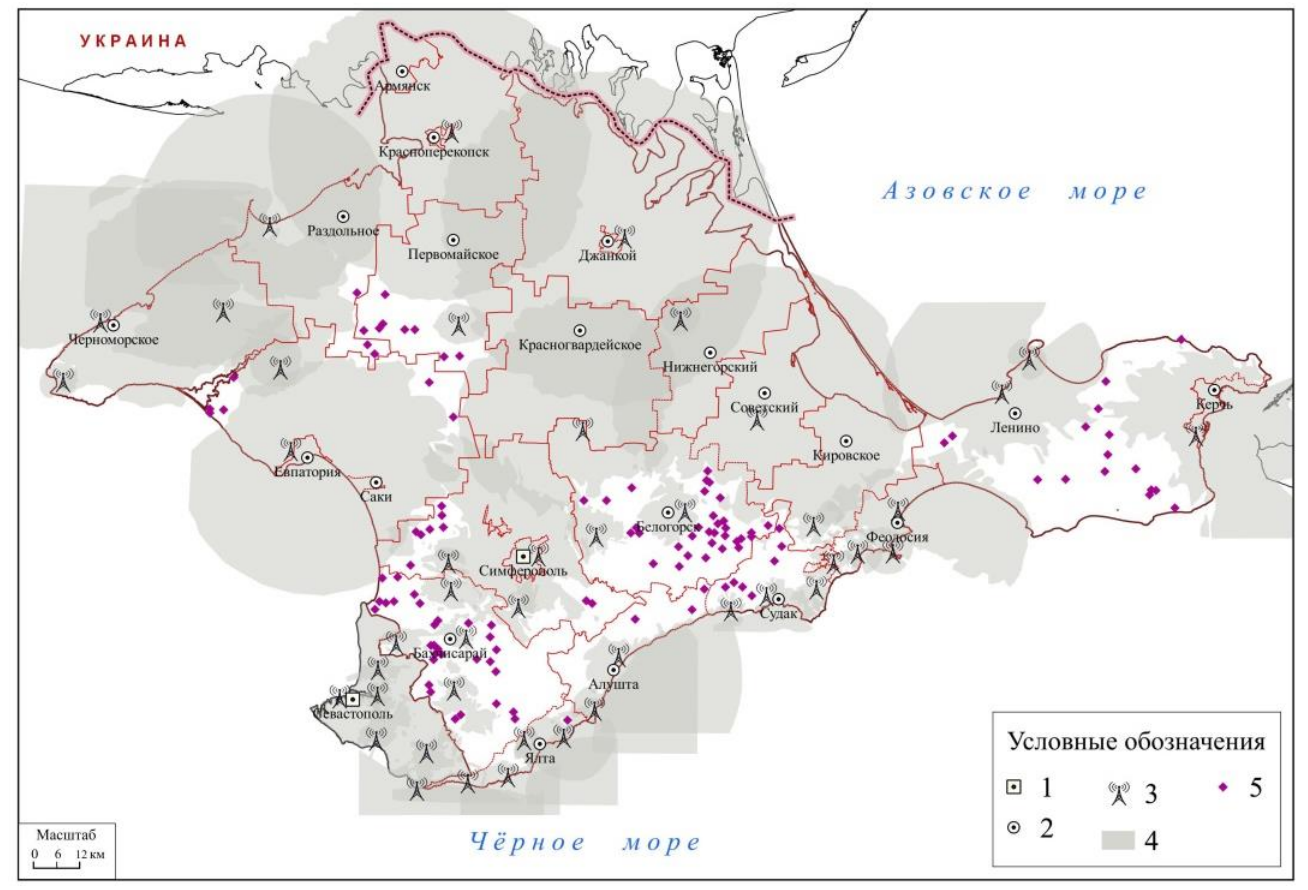

Рис. 3. Инфраструктура цифрового телевизионного вещзания в Крыму

1 - административный центр субъекта; 2 - административный центр муниципального образования; 3 - радиотелевизионные передающие центры (РТРC-1, 2); 4 - зоны покрытия уверенным сигналом цифрового ТВ (по данным филиала РТРС «РТПЦ Республики Крым»); 5 населённые пункты с неуверенным сигналом иифрового ТВ.

Fig. 3. Digital television broadcasting infrastructure in Crimea

1 - the administrative center of the subject; 2 - the administrative center of the municipality; 3-radio and television transmission centers (RTRN-1, 2); 4 - coverage areas with a confident digital TV signal (according to the RTRN branch «RTPC of the Republic of Crimea»); 5 - settlements with an uncertain digital TV signal.

Функцию издания газет на языках малочисленных народов в Крыму выполняет только Симферополь, поскольку все указанные выше издания зарегистрированы в столице Республики Крым.

Сегмент конфессиональных печатаных СМИ в Крыму имеет две основные особенности. Первая особенность связана с преобладанием количества православных религиозных печатаных изданий («Таврида православная», «Херсонесский вестник», «Путь к храму», «Ялта православная»), над количеством мусульманских газет (лишь одно издание «Хидает»). Вторая особенность заключается в большем по сравнению с этноязыковыми 
печатными медиа географическом разнообразии пунктов издания газет религиозного содержания - в городах Евпатория, Симферополь, Севастополь и Ялта.

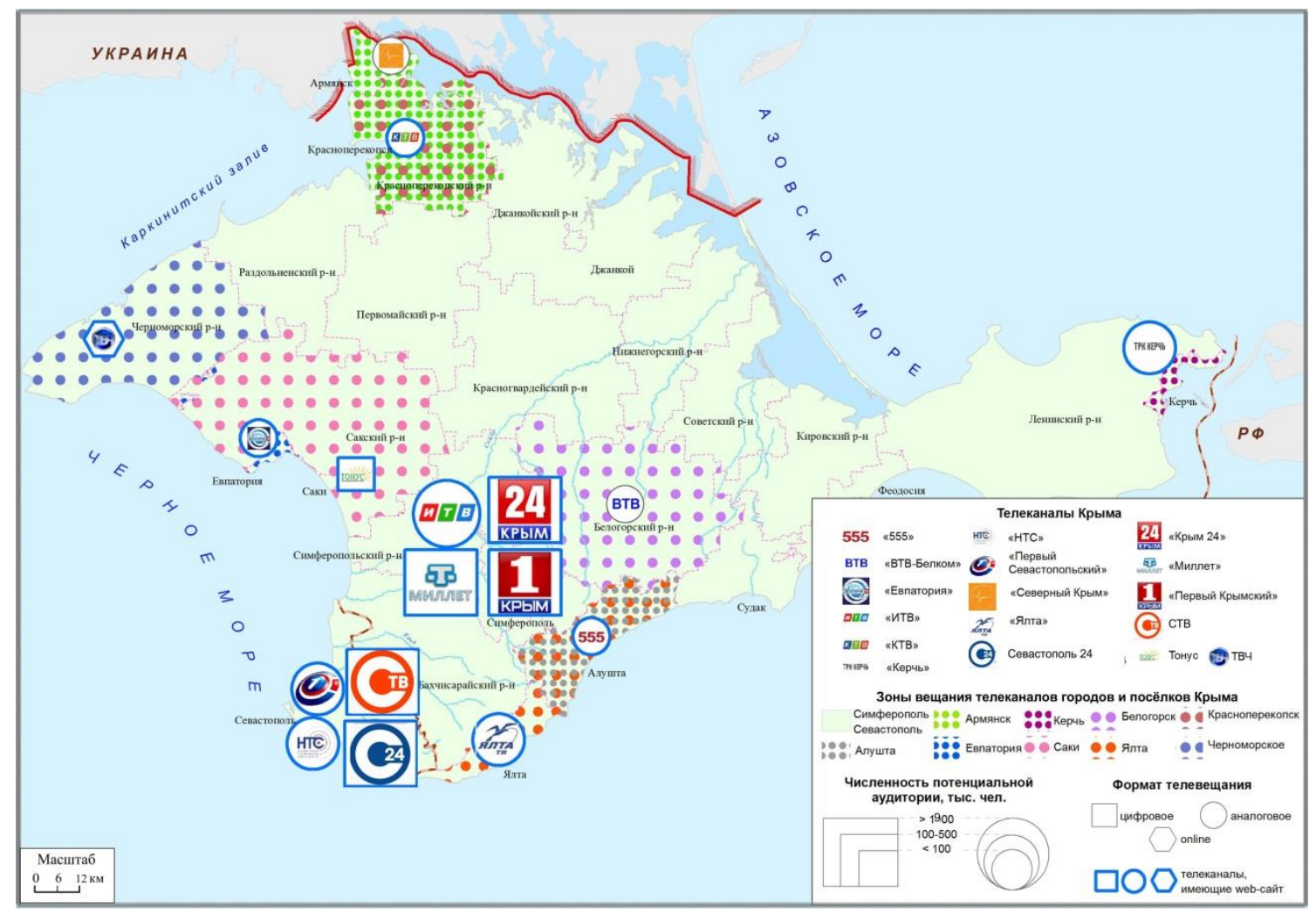

Рис. 4. Территориальная дифференциация местных телеканалов Крыма, 2018 г. Fig. 4. Territorial differentiation of the Crimean local TV channels, 2018

В структуре рынка телеканалов Крыма ряд телеканалов осуществляет вещание не только на русском языке, но и на языках других народов региона. Так, телеканал «Миллет» транслирует передачи на крымско-татарском языке, на других телеканалах, основной язык вещания которых русский, транслируется контент на армянском, болгарском, греческом, украинском и некоторых других языках.

Географическое сегментирование рынка печатных и телевизионных СМИ Крыма. Используя описанный в методическом разделе статьи подход географического сегментирования рынка СМИ, административные единицы Крыма, на наш взгляд, можно разделить на следующие сегменты (рис. 5).

1. Главные медиацентры Крыма: города Севастополь и Симферополь, которые генерируют основную долю медиаконтента в сфере печатных СМИ и телевидения. Эти центры распространяют свою медийную продукцию на территории всего региона и за его пределы.

2. Акцепторно-креативные территории по двум направлениям медиасферы -газет u телевидения: городские округа Алушта, Армянск, Евпатория, Керчь, Красноперекопск, Саки, Ялта, а также Белогорский и Черноморский районы. Эти административные единицы являются генераторами собственных медиа-продуктов (печатной и телевизионной), но не распространяют их на весь регион, а также активно потребляют услуги СМИ других территорий региона.

3. Акиепторно-креативные территории по участию в рынке печатных СМИ и акцепторные территории по участию в рынке телевизионных СМИ: Бахчисарайский, 
Кировский, Красногвардейский, Красноперекопский, Ленинский, Нижнегорский, Сакский, Советский, Симферопольский, Первомайский и Раздольненский муниципальные районы, а также городские округа Джанкой, Судак и Феодосия.

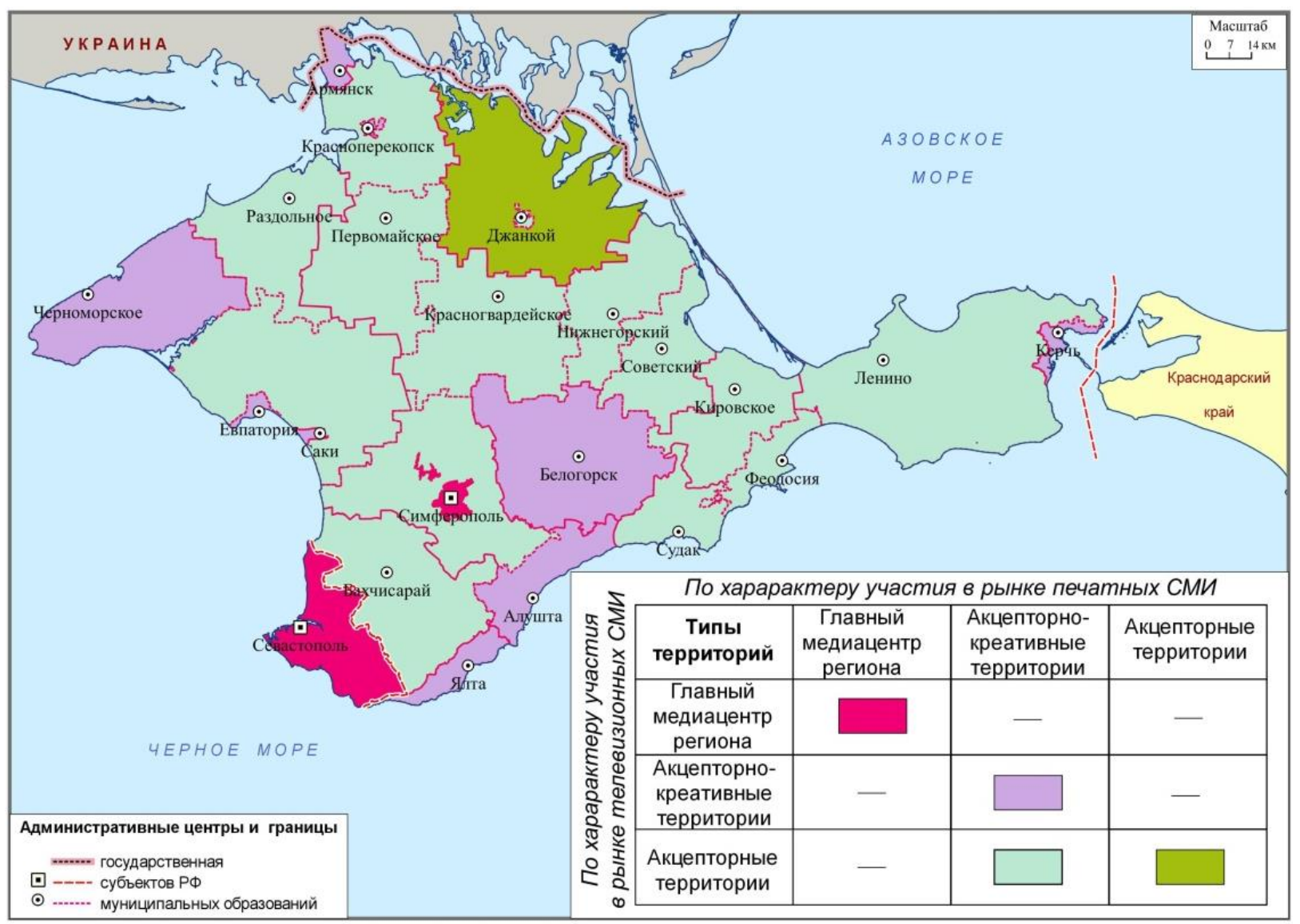

Рис. 5. Географическое сегментирование рынка печатных и телевизионных СМИ Крыма Fig. 5. Geographical segmentation of the Crimean print and television media market

4. Акиепторная территория по двум направлениям медиасферы. Этот географический сегмент представлен только Джанкойским муниципальным районом, не имеющим собственных местных газет и телеканалов.

\section{ВЫВОДЫ}

Современные геоинформационные технологии, существующая источниковая база и новые процессы в медийной сфере стран мира и их регионов формируют предпосылки для расширения объектно-предметной и технологической областей социально-экономической картографии. Представленный в статье вариант картографирования регионального рынка СМИ применим к другим регионам России.

В результате взаимодействия генераторов массовой информации и ее потребителей, а также под влиянием природных и социально-экономических систем определенной территории формируется рынок СМИ с особыми характеристиками - географический рынок СМИ, под которым понимается медийное пространство, формирующееся в пределах данной территории.

Составленные картографические произведения и их анализ позволили выявить следующие особенности и проблемы географического рынка СМИ Крыма: 
- $\quad$ современный рынок СМИ Крыма прошел период адаптации к новым российским условиям функционирования и представляет сформировавшуюся территориальную систему;

- территориальная структура медиасферы региона развивается по модели «центрпериферия», что отражено в представленной географической сегментации рынка СМИ;

- указанная центр-периферийная модель усложняется расколом в уровне развития медийной сферы в направлении «город-село»;

- $\quad$ ряд городов и районов не реализуют существующий на их территории потенциал для создания местных медиа;

- некоторые территории Крыма (глубинные, со сложным рельефом) требуют совершенствования их телекоммуникационной инфраструктуры.

Для более эффективного управления медийной сферой Крыма региональным правительственным структурам рекомендуется разработать и создать онлайн-геоинформационную систему, отражающую пространственные и содержательные особенности функционирования СМИ региона в режиме реального времени. Указанная ГИС способна стать важным ресурсом обоснования управленческих решений не только в медийной сфере, но и в области комплекса социально-политических процессов в Крыму.

\section{БЛАГОДАРНОСТИ}

Исследование выполнено при поддержке РФФИ; проект №20-05-00725 А.

\section{ACKNOWLEDGEMENTS}

This work was supported by RFBR; project No 20-05-00725 A.

\section{СПИСОК ЛИТЕРАТУРЫ}

1. Бабурин В.Л., Земщов С.П. Инновационный потенциал регионов России. Москва: КДУ, Университетская книга, 2017. 358 с.

2. Багров Н.В. География в информационном мире. К.: Лыбидь, 2005. 184 с.

3. Берлянт A.M. Картография и телекоммуникация. Москва, 1998. 76 с.

4. Волкова И.С., Крылов Л.В., Юдова О.А. Телевизионная картография: к вопросу о проблемах визуализации городского пространства. Геопоиск-2016. Материалы I Всероссийского конгресса молодых ученых-географов. 2016. С. 103-106.

5. Вольхин Д.А. Связь и телекоммуникации. Электронный pecypc: https://atlascrimea.ru/all/razdel-5/5-18-svyaz-i-telekommunikacii/ (дата обращения 29.03.2021).

6. Воронин И.Н. География Интернета - новое направление социально-географических исследований. Ученые записки ТНУ им. В.И. Вернадского. Серия: География. 2010. T. 23 (62). №1. C. 115-117.

7. Грибок М.В. Видеоинфографика для устойчивого развития (на примере проекта ВГТРК «Россия в цифрах»). ИнтерКарто. ИнтерГИС. 2016. №1. С. 198-206.

8. Егорова Л.Г. Трансформация медиаполя Республики Крым в новых социополитических условиях. Ученые записки Крымского федерального университета имени В.И. Вернадского. Филологические науки. 2019. Т. 5 (71). №1. С. 25-41.

9. Егорова Л.Г., Чумичёва М.А. Пространство печатных СМИ Крыма: концепция презентации. Ученые записки Таврического национального университета имени В.И. Вернадского. Серия: Филология. Социальные коммуникации. 2013. Т. 26 (65). №3. С. 110-119. 
10. Кастельс М. Власть коммуникации. М.: Изд. дом Высшей школы экономики, 2016. $564 \mathrm{c.}$

11. Козаченко Т.И., Онищенко М.Г. Методологические основы картографирования телекоммуникаций. География и природ. ресурсы. 2007. №2. С. 26-33.

12. Нагирная А.В. География Интернета и вопросы информационной безопасности. Геополитика и экогеодинамика регионов. 2018. Т. 4 (14). №4. С. 44-52.

13. Национальный атлас России: в 4 т. Т. 3. Население. М.: Роскартография, 2008. 495 с.

14. Первых Д.К. Особенности развития крымских СМИ в условиях интеграции в медиапространство России. Ученые записки Крымского федерального университета имени В.И. Вернадского. Филологические науки. 2019. Т. 5 (71). №4. С. 265-285.

15. Перфильев Ю.Ю. Пространственное распространение сети Интернет в России как процесс диффузии инноваций. Вестник Московского университета. Серия. 5. География. 2003. №2. С. 30-36.

16. Прохорова Е.А. Социально-экономические карты. М.: КДУ, 2010. 424 с.

17. Радамс C.K. Методика создания телевизионных картографических анимаций для информационно-аналитических программ телевидения. Известия высших учебных заведений. Геодезия и аэрофотосъемка. 2017. №1. С. 81-87.

18. Adams P.C. Geographies of Media and Communication: Acritical Introduction. L. Wiley. Blackwell, 2009. 264 p.

19. Dodge M., Kitchin R. Mapping Cyberspace. London: Routledge, 2001. 260 p.

20. Geographies of Communication: The Spatial Turn in Media Studies. Edited by J. Falkheimer, A. Jansson. Göteborg: Nordicom, 2006. 316 p.

21. Green E. Mapping the "Geography" of the Internet. Электронный pecypc: https:// www.theatlantic.com/technology/archive/2013/09/mapping-the-geography-of-theinternet/2794 34 (дата обращения 20.02.2021).

22. Jacobs F. Maps show how CNN lost America to Fox News. Электронный ресурс: https://bigthink.com/strange-maps/cnn-fox-news?rebelltitem=1\#rebelltitem1 (дата обращения 24.03.2021).

23. Leetaru K.H. Culturomics 2.0: Forecasting large-scale human behavior using global news media tone in time and space. Электронный ресурс: https:/firstmonday.org/article/view/3663/3040 (дата обращения 28.03.2021).

24. Leetaru K.H. Mapping Libraries: Creating Real-time Maps of Global Information. Электронный ресурс: https://blogs.loc.gov/thesignal/2015/07/mapping-libraries-crea ting- real-time-maps-of-global-information/?loclr=eadpb (дата обращения 28.03.2021).

25. Warf B. Global Geographies of the Internet. Springer Science\&Business Media. 2011. $166 \mathrm{p}$.

\section{REFERENCES}

1. Adams P.C. Geographies of Media and Communication: Acritical Introduction. L. Wiley. Blackwell, 2009. 264 p.

2. Baburin V.L., Zemtsov S.P. Innovation potential region of Russia. Moscow: KDU, Universitetskaya kniga, 2017. 358 p. (in Russian).

3. Bagrov N.V. Geography in the information world. Kiev: Lybid, 2005. 184 p. (in Russian).

4. Berlyant A.M. Cartography and telecommunications. Moscow, 1998. 76 p. (in Russian).

5. Castels M. Power of communication. Moscow: Publishing House of the Higher School of Economics, 2016. 564 p. (in Russian).

6. $\quad$ Dodge M., Kitchin R. Mapping Cyberspace. London: Routledge, 2001. 260 p. 
7. Egorova L.G. Transformation of the media field of the Republic of Crimea in new sociopolitical conditions. Scientific notes of the Crimean Federal V.I. Vernadsky University. Philological sciences. 2019. V. 5 (71). No 1. P. 25-41 (in Russian).

8. Egorova L.G., Chumicheva M.A. The space of printed media of the Crimea: the concept of presentation. Scientific Notes of the Taurida National V.I. Vernadsky University. Series: Philology. Social communications. 2013. V. 26 (65). No 3. P. 110-119 (in Russian).

9. Geographies of Communication: The Spatial Turn in Media Studies. Edited by J. Falkheimer, A. Jansson. Göteborg: Nordicom, 2006. 316 p.

10. Green E. Mapping the "Geography" of the Internet. Web resource: https:// www. theatlantic.com/technology/archive/2013/09/mapping-the-geography-of-theinternet/279434 (accessed 20.02.2021).

11. Gribok M.V. Video Infographics for sustainable aevelopment (on the example of the VGTRK project "Russia in Numbers"). InterCarto. InterGIS. 2016. No 1. P. 198-206 (in Russian).

12. Jacobs F. Maps show how CNN lost America to Fox News. Web resource: https:// bigthink.com/strange-maps/cnn-fox-news?rebelltitem=1\#rebelltitem1 (accessed 24.03. 2021).

13. Kozachenko T.I., Onishchenko M.G. Methodological foundations of telecommunications mapping. Geography and nature. resources. 2007. No 2. P. 26-33 (in Russian).

14. Leetaru K.H. Culturomics 2.0: Forecasting large-scale human behavior using global news media tone in time and space. Web resource: https://firstmonday.org/article/view/ 3663/3040 (accessed 28.03.2021).

15. Leetaru K.H. Mapping Libraries: Creating Real-time Maps of Global Information. Web resource: https://blogs.loc.gov/thesignal/2015/07/mapping-libraries-creating-real-timemaps-of-global-information/?loclr=eadpb (accessed 28.03.2021).

16. Nagirnaya A.V. Geography of the Internet and issues of information security. Geopolitics and Ecogeodynamics of Regions. 2018. V. 4 (14). No 4. P. 44-52 (in Russian).

17. National Atlas of Russia: in 4 vol. T. 3. Population. Moscow: Roskartografiya, 2008. 495 p. (in Russian).

18. Perfiliev Y.Y. Spatial distribution of the Internet in Russia as a process of diffusion of innovations. Bulletin of the Moscow University. Series. 5. Geography. 2003. No 2. P. 3036 (in Russian).

19. Pervuh D.K. Features of the development of the Crimean media in the context of integration into the media space of Russia. Scientific Notes of the V. I. Vernadsky Crimean Federal University. Philological sciences. 2019. V. 5 (71). No 4. P. 265-285 (in Russian).

20. Prokhorova E.A. Socio-economic maps. Moscow: KDU, 2010. 424 p. (in Russian).

21. Radams S.K. Methodology for creating television cartographic animations for information and analytical television programs. News of higher educational institutions. Geodesy and aerial photography. 2017. No 1. P. 81-87 (in Russian).

22. Volkhin D.A. Communication and telecommunications. Web resource: https://atlascrimea.ru/all/razdel-5/5-18-svyaz-i-telekommunikacii/ (accessed 29.03.2021).

23. Volkova I.S., Krylov L.V., Yudova O.A. TV cartography: to the question of problems of visualization of urban space. Geopoisk-2016. Materials of the I All-Russian Congress of Young Geographers. 2016. P. 103-106 (in Russian).

24. Voronin I.N. Geography of the Internet - a new direction of socio-geographical research. Scientific Notes of the Taurida National V.I. Vernadsky University. Series: Geography. 2010. V. 23 (62). No 1. P. 115-117 (in Russian).

25. Warf B. Global Geographies of the Internet. Springer. Science\&Business Media. 2011. $166 \mathrm{p}$. 


\title{
М.В. Цыдыпова ${ }^{1}$
}

\section{СОЗДАНИЕ НАУЧНО-ОБРАЗОВАТЕЛЬНОГО ГЕОПОРТАЛА БУРЯТСКОГО ГОСУДАРСТВЕННОГО УНИВЕРСИТЕТА}

\begin{abstract}
АННОТАЦИЯ
В статье рассматривается методика разработки научно-образовательного геопортала Бурятского государственного университета им. Доржи Банзарова, а также его структура и содержание. Методика создания учебного геопортала включает следующие основные этапы: разработка структуры и содержания геопортала, сбор, создание и адаптация картографических материалов для публикации на геопортале, наполнение геопортала данными, создание веб-карт, настройка интерфейса пользователя, стилей, масштабов и настройка прав доступа к геопорталу. Геопортал предоставляет возможность сбора, хранения, анализа и представления пространственных данных, создания, редактирования и подготовки к печати карт и баз данных в онлайн-режиме для использования в образовательной и научноисследовательской деятельности. В его состав входят данные дистанционного зондирования Земли, цифровые картографические материалы по различным дисциплинам и направлениям обучения и связанные с ними базы данных. Один из разделов геопортала является основой для создания электронного гербария университета, который представляет собой веб-карту мест сбора растений гербария и связанную с ней базу данных описаний, а также сканированные изображения гербарных листов. Электронный гербарий позволяет осуществлять удаленный доступ к материалам гербария университета. Геопортал разрабатывается на основе платформы NextGIS, в которую входят: NextGIS Web (серверная ГИС для хранения, регулирования доступа к пространственным данным и сервисам), NextGIS QGIS (полнофункциональная настольная ГИС для создания данных, аналитики, создания карт) и NextGIS Mobile (мобильное приложение (Android) с неограниченными слоями данных, редактированием и настраиваемыми формами ввода).
\end{abstract}

КЛЮЧЕВЫЕ СЛОВА: научно-образовательный геопортал, веб-ГИС, базы данных, NextGIS.

Marina V. Tsydypova ${ }^{2}$

\section{CREATION OF A SCIENTIFIC AND EDUCATIONAL GEOPORTAL OF THE BURYAT STATE UNIVERSITY}

\begin{abstract}
The article discusses the structure, content and methodology of developing a scientific and educational geoportal created for the Buryat State University named after Dorji Banzarova, based on NextGIS software.

\footnotetext{
1 Федеральное государственное бюджетное образовательное учреждение высшего образования «Бурятский государственный университет имени Доржи Банзарова», ул. Смолина 24a, 67000, г. УланУдэ, Россия, e-mail: ecovie@mail.ru

2 Federal State Budgetary Educational Institution of Higher Education "Buryat State University named after Dorzhi Banzarov”, Smolina 24a, 670000, Ulan-Ude, Russia, e-mail: ecovie@mail.ru
} 
The methodology of creating an educational geoportal includes the following main stages: development of the structure and content of the geoportal, collection, creation and adaptation of cartographic materials for publication on the geoportal, filling the geoportal with data, creating web maps, setting up the user interface, styles, scales and setting access rights to the geoportal.

It includes Earth remote sensing data, digital cartographic materials for various disciplines and areas of study and related databases (cultural, historical, tourist, economic and other educational materials).

Geoportal provides the possibility to collect, store, present, spatial analysis of geospatial and statistical data, as well as upload your data (cartographic, statistical, photographs, etc.), create, edit and prepare online new maps and databases for using in educational and research activities.

One of the sections of the geoportal is the basis for creating an electronic herbarium of the university. It is a web map of herbarium collection sites and associated description database, as well as scanned images of herbarium sheets. The electronic herbarium allows remote access to the materials of the university herbarium.

The geoportal is developed on the basis of NextGIS software, which includes: NextGIS Web (server GIS for storing, regulating access to geodata and services), NextGIS QGIS (fullfeatured desktop GIS for data creation, analytics, creating maps) and NextGIS Mobile (mobile application (Android) with unlimited data layers, editing and customizable input forms).

KEYWORDS: scientific and educational geoportal, web-GIS, data base, NextGIS.

\section{ВВЕДЕНИЕ}

Современную общеобразовательную и высшую школу характеризует активное внедрение новых информационных технологий. В учебном процессе широко применяются методы обучения, основанные на использовании информационно-коммуникационных технологий, создаются электронные учебные пособия, реализуются дисциплины, связанные с компьютерными технологиями, развиваются технологии дистанционного получения образования.

С увеличением интереса к информационным технологиям и их внедрением в учебные планы и образовательные программы высших учебных заведений, становится актуальным внедрение веб-ГИС технологий в образовательный процесс.

Под веб-ГИС подразумевают геоинформационную систему, размещенную в Интернет/Интранет сети, пользователи которой могут просматривать, редактировать и анализировать пространственные данные с помощью обычных веб-браузеров [Быков, Пьянков, 2015]. Для работы в веб-ГИС достаточно наличия веб-браузера и подключения к сети Интернет.

Веб-ГИС-технологии позволяют создавать новый вид электронного образовательного ресурса-научно-образовательный геопортал.

Геопорталы обеспечивают доступ к пространственным данным и геосервисам, поиск данных по метаданным и их картографическую визуализацию. В настоящее время научнообразовательные геопорталы создаются преимущественно вузами и академическими учреждениями для удовлетворения собственных потребностей [Кошкарев, Ротанова, 2014].

Опыт создания научно-образовательных геопорталов и их внедрения в образовательный процесс описан в ряде публикаций [Мидоренко, 2011; Лурье и др., 2013; Христодуло, 2015; Бударова, Медведева, 2017; Millin-Chalabi и др., 2012].

Целью создания научно-образовательного геопортала Бурятского государственного университета им. Доржи Банзарова (далее - БГУ) является создание электронного образовательного ресурса, обеспечивающего онлайн-доступ обучающимся, преподавателям и 
всем заинтересованным лицам к пространственным данным для использования в учебной и научно-исследовательской деятельности.

Задачами создания геопортала являются:

- $\quad$ сбор, хранение, демонстрация, предоставление пространственных данных;

- $\quad$ получения практических навыков по разработке и созданию геопорталов, веб-карт, проведению анализа данных, созданию баз данных, подготовке карт к печати;

- $\quad$ геоинформационное обеспечение совместной работы в рамках межфакультетского и междисциплинарного взаимодействия.

\section{МАТЕРИАЛЫ И МЕТОДЫ ИССЛЕДОВАНИЯ}

Методика создания учебного геопортала включает следующие этапы:

1. Разработка структуры и содержания геопортала;

2. Сбор, создание и адаптация картографических материалов для публикации на геопортале;

3. Наполнение геопортала данными;

4. Создание веб-карт, настройка интерфейса пользователя, стилей и подписей;

5. Настройка прав доступа к геопорталу.

Структура и содержание геопортала находятся в стадии разработки и ориентированы на разностороннюю направленность образовательных программ, реализуемых университетом. В настоящее время на геопортале представлены следующие основные разделы: административно-территориальное деление, карты и данные дистанционного зондирования Земли, рекреация и туризм, охрана окружающей среды, землепользование и кадастр, культурно-историческое наследие, электронный гербарий БГУ. Содержание разделов представлено в таблице 1.

Табл. 1. Содержание основных разделов научно-образовательного геопортала Бурятского государственного университета

Table 1. Contents of the main sections of the scientific and educational geoportal of the Buryat State University

\begin{tabular}{|c|c|c|c|c|}
\hline \multicolumn{5}{|c|}{ Тематические разделы } \\
\hline $\begin{array}{l}\text { Административно- } \\
\text { территориальное } \\
\text { деление }\end{array}$ & $\begin{array}{c}\text { Рекреация и } \\
\text { туризм }\end{array}$ & $\begin{array}{c}\text { Охрана } \\
\text { окружающей } \\
\text { среды }\end{array}$ & $\begin{array}{c}\text { Объекты } \\
\text { культурно- } \\
\text { исторического } \\
\text { наследия }\end{array}$ & $\begin{array}{c}\text { Опасные при- } \\
\text { родные про- } \\
\text { цессы и явле- } \\
\text { ния }\end{array}$ \\
\hline Города & $\begin{array}{c}\text { Туристические } \\
\text { маршруты }\end{array}$ & Заповедники & \multirow{4}{*}{$\begin{array}{c}\text { Объекты куль- } \\
\text { турно-истори- } \\
\text { ческого насле- } \\
\text { дия федераль- } \\
\text { ного и регио- } \\
\text { нального зна- } \\
\text { чения по райо- } \\
\text { нам }\end{array}$} & Селеопасность \\
\hline $\begin{array}{l}\text { Населенные } \\
\text { пункты }\end{array}$ & $\begin{array}{c}\text { Объекты ду- } \\
\text { ховно-религи- } \\
\text { озной деятель- } \\
\text { ности }\end{array}$ & $\begin{array}{c}\text { Национальные } \\
\text { парки }\end{array}$ & & $\begin{array}{c}\text { Места возмож- } \\
\text { ного схода ла- } \\
\text { вин }\end{array}$ \\
\hline \multirow{2}{*}{$\begin{array}{l}\text { Границы админи- } \\
\text { стративных } \\
\text { районов }\end{array}$} & \multirow{2}{*}{$\begin{array}{c}\text { Курортно-баль- } \\
\text { неологические } \\
\text { ресурсы }\end{array}$} & Заказники & & $\begin{array}{l}\text { Криогенные } \\
\text { процессы }\end{array}$ \\
\hline & & $\begin{array}{c}\text { Рекреационные } \\
\text { местности }\end{array}$ & & Эрозия \\
\hline
\end{tabular}


Сбор пространственных данных осуществляется из открытых источников, а также в рамках сотрудничества с другими организациями (НЦ ОМЗ АО «Российские космические системы» и т.д.). Данные о границах особо охраняемых природных территорий Республики Бурятия получены с геопортала «Природа Бурятии». Векторные данные об объектах культурного наследия получены с сайта АУ РБ «НПЦ охраны памятников». Данные об опасных природных процессах получены с сайта ФГИС ТП, где размещены документы территориального планирования РФ и субъектов РФ. Студентами и преподавателями создаются картографические материалы в рамках изучаемых дисциплин и научно-исследовательской деятельности.

Адаптация картографических материалов включает следующие процедуры:

- $\quad$ приведение собранных из различных источников векторных слоев к единому формату данных (.shp);

- $\quad$ трансформация в единую географическую проекцию;

- $\quad$ разработка структуры баз данных тематических слоев и метаданных;

- $\quad$ создание, редактирование баз данных, ввод дополнительной информации и т.д.

\section{РЕЗУЛЬТАТЫ ИССЛЕДОВАНИЯ И ИХ ОБСУЖДЕНИЕ}

Для демонстрации интерфейса (рис. 1), примерного содержания разделов и возможностей геопортала создана предварительная версия учебного геопортала, которая размещена на сервере геопортала «Природа Бурятии» в качестве отдельного ресурса ${ }^{1}$.

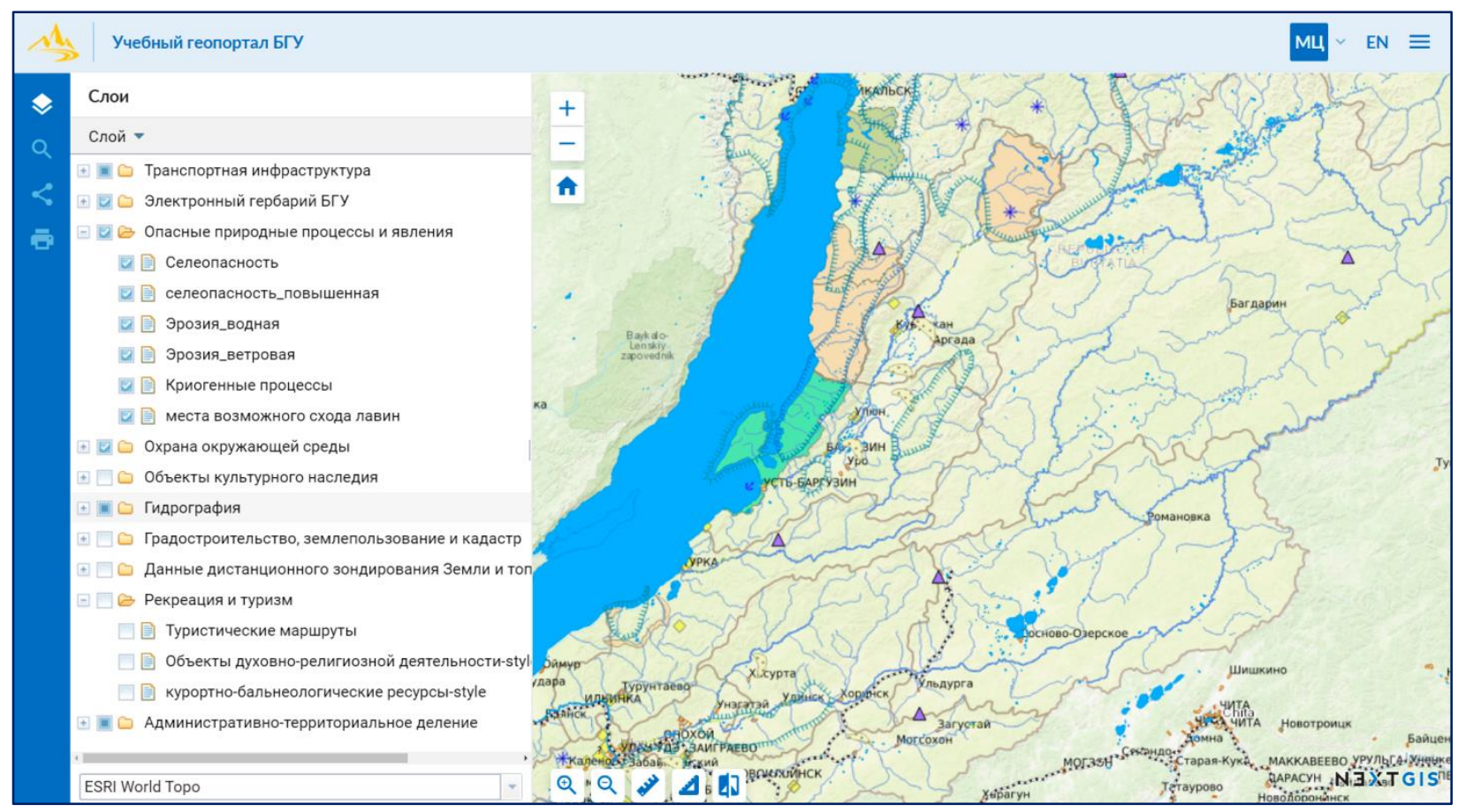

Рис. 1. Интерфейс и структура научно-образовательного геопортала БГУ

Fig. 1. Interface and structure of educational geoportal of BSU

Научно-образовательный геопортал разработан на основе серверной веб-ГИС NextGIS Web, с помощью которой создан геопортал «Природа Бурятии». Программное обеспечение NextGIS Web позволило реализовать следующие функциональные возможности геопортала: 
- $\quad$ ввод, хранение, поиск пространственных данных. Поиск данных производится по двум источникам: по атрибутивной информации добавленных на карту векторных слоёв и по адресной базе OpenStreetMap;

- редактирование векторных данных и связанных с ними баз данных в онлайн-режиме;

- создание неограниченного количества веб-карт;

- $\quad$ совместное редактирование пространственных данных.

- $\quad$ подключение к геопорталу через мобильное приложение (NextGIS Mobile) и загрузка данных на геопортал с мобильных устройств;

- $\quad$ публикация пространственных данных геопортала на основе общепринятых открытых стандартов обмена географической информацией (WMS, WFS);

- $\quad$ поддержка подключения подложек (TMS-сервисов) с внешних серверов и подключение векторных и растровых данных из внешних WMS-сервисов ${ }^{1}$.

Основные типы пользователей, предусмотренные для работы с геопорталом:

- $\quad$ администратор (пользователь, обладающий правами администратора);

- $\quad$ владелец (пользователь, создавший ресурс, на который установлено право доступа);

- $\quad$ гость (пользователь, который обращается к ресурсу, не являясь при этом авторизованным);

Функциональные возможности геопортала позволяют создать на его основе электронный гербарий БГУ в виде веб-карты. Для создания данной веб-карты подготовлен тестовый векторный слой, отображающий места сбора 47 гербарных листов и структуру базы данных описаний этикетов гербарных листов (рис. 2), сканированные гербарные листы (рис. 3).

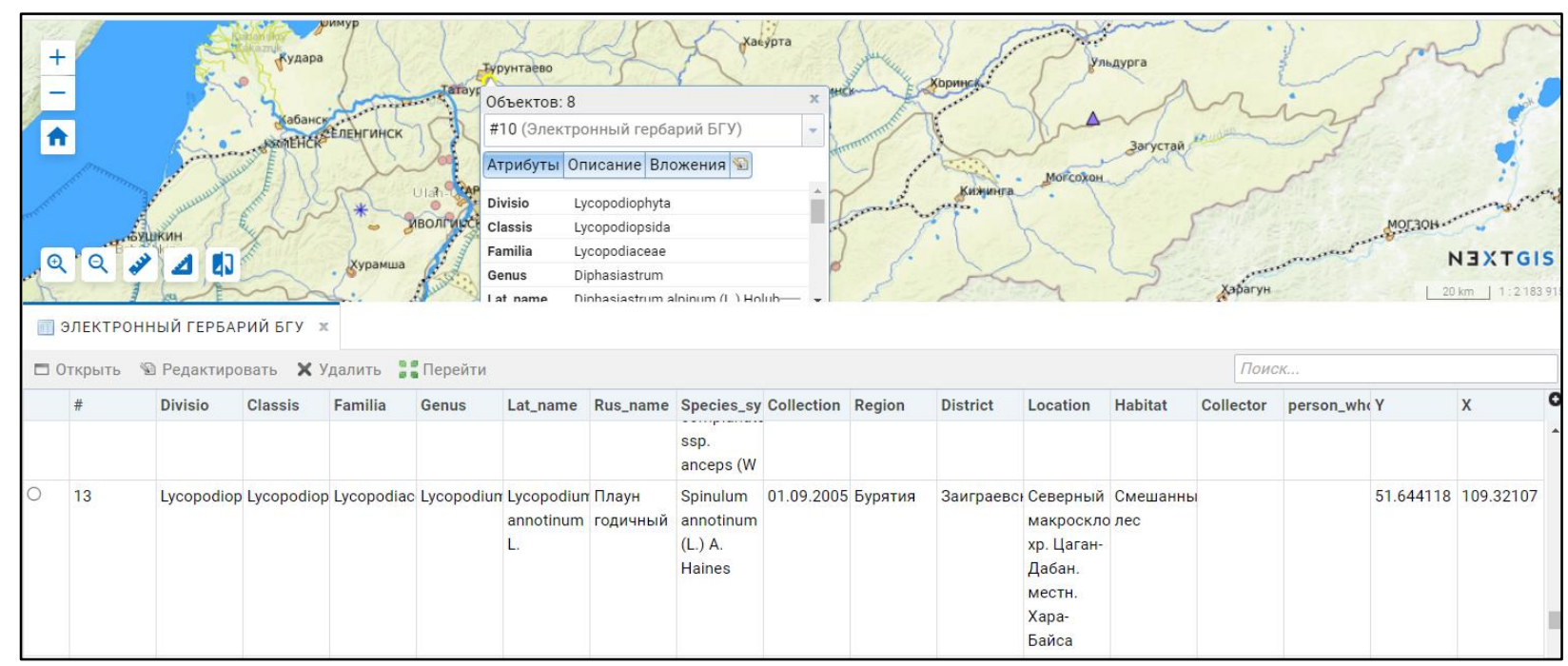

Рис. 2. Информаџионная карточка гербарного листа и структура база данных описаний этикеток растений гербария

Fig. 2. Herbarium leaf information card and herbarium plant label description database structure

1 Документация NextGis Web. Электронный pecypc: https://docs.nextgis.ru/docs_ngweb/source/quick_ tutorial.html (дата обращения 30.04.2021). 


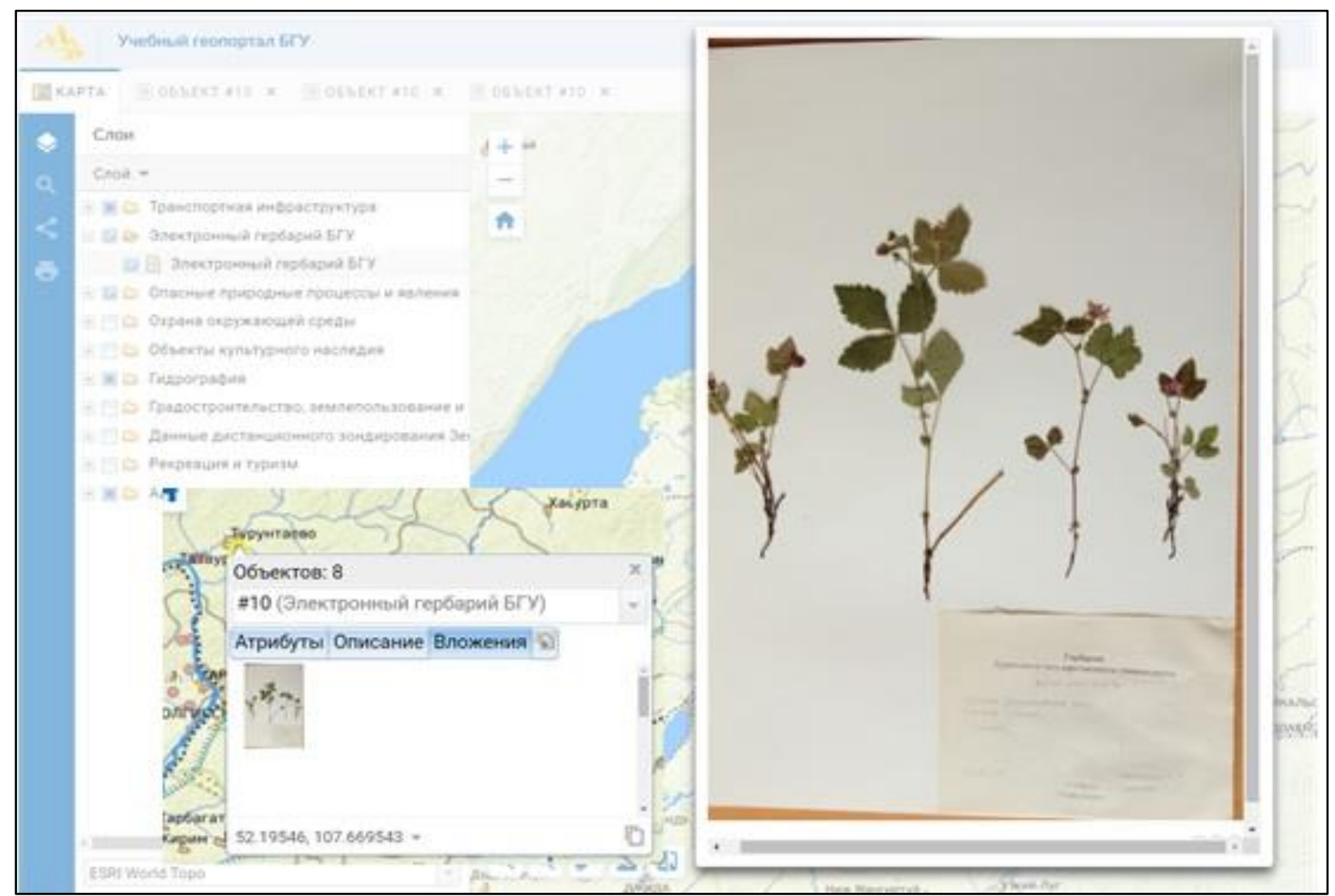

Рис. 3. Отображение сканированного гербарного листа на геопортале

Fig. 3. Displaying the scanned herbarium leaf on the geoportal

\section{ВЫВОДЫ}

Учебный геопортал БГУ создается с целью привлечения информационных технологий в образовательный процесс, повышения интереса студентов и преподавателей к геоинформационным технологиям и получения практических навыков работы с ними.

Ресурсы учебного геопортала БГУ могут использоваться в учебном процессе при проведении лекций, практических занятий и самостоятельной работы студентов, а также в качестве источника информации и программного обеспечения для создания карт, геопорталов и баз данных при написании дипломных и курсовых проектов.

В научно-исследовательской работе геопортал может использоваться в качестве вебсервиса для создания электронного гербария БГУ, а также для хранения, редактирования и создания картографических материалов и баз данных, публикации их в сети Интернет.

Также большое значение имеет возможность использования ресурсов геопортала для полевых практик и исследований, быстрой публикации материалов полевых сборов, маршрутов в онлайн-режиме, при проведении пространственного анализа данных. 


\section{СПИСОК ЛИТЕРАТУРЫ}

1. Б Бударова В.А, Медведева Ю.Д. Научно-образовательный геопортал как пример интеграции разнородных пространственных данных. Интерэкспо Гео-Сибирь, 2017. №2. Электронный pecypc: https://cyberleninka.ru/article/n/nauchno-obrazovatelnyygeoportal-kak-primer-integratsii-raznorodnyh-prostranstvennyh-dannyh (дата обращения: 27.04.2021).

2. Быков А.В., Пьянков С.В. Web-картографирование: учеб. пособие. Пермь: Перм. гос. нац. исслед. университет, 2015. 110 с.

3. Кошкарев А.В., Ротанова И.Н. Российские научно-образовательные и отраслевые геопорталы как элементы инфраструктуры пространственных данных. Вестн. Новосиб. гос. ун-та. Серия: Информационные технологии, 2014. Т. 12. № 4. C. $38-52$.

4. Лурье И.К., Аляутдинов А.Р., Осокин С.А. Интеграция географических информационных ресурсов и обеспечение онлайн-доступа к ним для решения научных и образовательных задач. Электронные библиотеки, 2013. Т. 16. № 4. Электронный ресурс: https://elbib.ru/article/view/332 (дата обращения 27.04.2021).

5. Мидоренко Д.А. Образовательный геоинформационный портал Тверского Государственного Университета. Материалы XVIII Всероссийского форума «Рынок геоинформатики в России. Современное состояние и перспективы развития», 2011. Электронный ресурс: http://www.gisa.ru/77837.html (дата обращения 27.04.2021).

6. Христодуло О.И. Научно-образовательный геопортал как инструмент интеграции результатов научных исследований Республики Башкортостан большим числом пользователей. Открытое образование, 2015. № 3. С. 95-100

7. Millin-Chalabi G., Kitmitto K., Schumm J., Gupta B., Tun, Y. An Academic Spatial Data Infrastructure (SDI): Introducing the Enhanced Kaia Geoportal and Learning Zone. Proceedings of the remote sensing and photogrammetry society conference "Changing how we view the world", 2012. University of Greenwich, London, 12-14 September 2012. Электронный ресурс: https://www.researchgate.net/profile/Gail-Millin-Chalabi/publication/261844235_An_Academic_Spatial_Data_Infrastructure_SDI_Introducing_the_Enhanced_Kaia_Geoportal_and_Learning_Zone/links/0c960535a3433a7695f000000/An-Academic-Spatial-Data-Infrastructure-SDI-Introducing-the-Enhanced-Kaia-Geoportal-andLearning-Zone.pdf

\section{REFERENCES}

1. Budarova V.A, Medvedeva Yu.D. Scientific and educational geoportal as an example of the integration of spatial data. Interexpo GEO-Siberia, 2017. No 2. Web resource: https://cyberleninka.ru/article/n/nauchno-obrazovatelnyy-geoportal-kak-primer-integratsii-raznorodnyh-prostranstvennyh-dannyh (accessed 27.04.2021) (in Russian).

2. Bykov A.V. Web-mapping: tutorial. Perm: Perm. state nat. issled. university, 2015. 110 p. (in Russian).

3. Koshkarev A.V., Rotanova I.N. Russian scientific, educational and industry geoportals as elements of spatial data infrastructure. Vestnik NSU. Series: Information Technologies, 2014. T. 12. No 4. P. 38-52 (in Russian)

4. Lur'e I.K., Alyautdinov A.R., Osokin S.A. Methods of geographical information resources integration and access to them for scientific and educational purposes. The Russian Digital Libraries Journal, 2013. T. 16. No 4. Web resource: https://elbib.ru/article/view/332 (accessed 27.04.2021) (in Russian).

5. Midorenko D.A. Educational geoinformation portal of Tver State University. Proceedings of the XVIII all-Russian forum «Geoinformatics market in Russia. Current state and 
development prospects», 2011. Web resource: http://www.gisa.ru/77837.html (accessed 27.04.2021) (in Russian).

6. Khristodulo O.I. Scientific and educational geoportal as instrument of integration of results of scientific researches of the republic of Bashkortostan by the large number of users. Open Education, 2015. No 3. P. 95-100 (in Russian).

7. Millin-Chalabi G., Kitmitto K., Schumm J., Gupta B., Tun, Y. An Academic Spatial Data Infrastructure (SDI): Introducing the Enhanced Kaia Geoportal and Learning Zone. Proceedings of the remote sensing and photogrammetry society conference "Changing how we view the world", 2012. University of Greenwich, London, 12-14 September 2012. Web resource: https://www.researchgate.net/profile/Gail-Millin-Chalabi/publication/261844235_An_Academic_Spatial_Data_Infrastructure_SDI_Introducing_the_Enhanced_Kaia_Geoportal_and_Learning_Zone/links/0c960535a343a7695f000000/An-Academic-Spatial-Data-Infrastructure-SDI-Introducing-the-Enhanced-Kaia-Geoportal-and-LearningZone.pdf (accessed 27.04.2021) 


\title{
М.Г. Лебедева ${ }^{1}$, А.Г. Корнилов ${ }^{2}$, М.А. Петина ${ }^{3}$, Т.Н. Вендина ${ }^{4}$ \\ «ГЕОГРАФИЧЕСКИЙ АТЛАС БЕЛГОРОДСКОЙ ОБЛАСТИ: ПРИРОДА, ОБЩЕСТВО, ХОЗЯЙСТВО» КАК ИНФОРМАЦИОННАЯ ОСНОВА РЕАЛИЗАЦИИ ПОЛИТИКИ УСТОЙЧИВОГО РАЗВИТИЯ РЕГИОНА
}

\begin{abstract}
АННОТАЦИЯ
В статье рассмотрен вопрос создания обновленного регионального атласа «Географический атлас Белгородской области: природа, общество, хозяйство». Картографическое произведение представляет собой интегральный результат глубокого анализа современных природных условий и ресурсов, хозяйства и населения Белгородской области. В Атласе представлена актуальная географическая информация, которая позволила сделать региональный атлас одним из основных средств информационнообразовательной среды, а также инструментом в реализации политики устойчивого развития региона.

«Географический атлас Белгородской области: природа, общество, хозяйство». был создан коллективом ученых Института наук о Земле ФГАОУ ВО «Белгородский государственный национальный исследовательский университет» (НИУ «БелГУ») с привлечением профильных специалистов при финансовй поддержке ВОО «Русское географическое общество» (РГО). В статье подробно раскрыты этапы создания атласа: информационно-аналитический накопительный; подготовительный картографический; картографический; оформительский; издательский. Приведена структура регионального атласа. Все карты в атласе объединены в 4 раздела: «Вводный раздел», «Природа», «Население», «Хозяйство», они согласованы и взаимодополняют друг друга. Некоторые тематические карты, размещенные в Атласе, были построены для Белгородской области впервые.

Атлас содержит 76 тематических карт, построенных в среде ArcGIS 10.4.1. При создании карт атласа были применены современные методы и приёмы геоинформационного картографирования.

Изданный «Географический атлас Белгородской области: природа, общество, хозяйство» является как научным трудом, так и учебно-справочным пособием, и предназначен для широкого круга пользователей: от учащихся школ и студентов вузов до узкопрофильных специалистов различного уровня.
\end{abstract}

КЛЮЧЕВЫЕ СЛОВА: региональный атлас, Белгородская область, ГИС-технологии, атласное картографирование, тематическая карта, устойчивое развитие.

\footnotetext{
1 Белгородский государственный университет, ул. Победы, 85, 308015, г. Белгород, Россия, e-mail: lebedeva_m@bsu.edu.ru

2 Белгородский государственный университет, ул. Победы, 85, 308015, г. Белгород, Россия, e-mail: kornilov@bsu.edu.ru

3 Белгородский государственный университет, ул. Победы, 85, 308015, г. Белгород, Россия, e-mail: petina_m@bsu.edu.ru

4 Белгородский государственный университет, ул. Победы, 85, 308015, г. Белгород, Россия, e-mail: furmanova@bsu.edu.ru
} 


\title{
Marina G. Lebedeva ${ }^{1}$, Andrey G. Kornilov ${ }^{2}$, Mariya A. Petina ${ }^{3}$, Tatiana N. Vendina ${ }^{4}$ \\ «GEOGRAPHICAL ATLAS OF THE BELGOROD REGION: NATURE, SOCIETY, ECONOMY» AS AN INFORMATION BASIS FOR IMPLEMENTING THE SUSTAINABLE DEVELOPMENT POLICY OF THE REGION
}

\begin{abstract}
The article discusses the issue of creating an updated regional atlas of the Belgorod region «Geographic atlas: nature, society, economy». The cartographic work is an integral result of a deep analysis of modern natural conditions and resources, the economy and the population of the Belgorod region. The Atlas provides relevant geographic information, which made it possible to make the regional atlas one of the main tools of the information and educational environment, as well as a tool in the implementation of the sustainable development policy of the region. The Geographic Atlas: Nature, Society, Economy was created by a team of scientists from the Institute of Earth Sciences of the Belgorod State National Research University with the involvement of specialized specialists with the financial support of the Russian Geographical Society. The article describes in detail the stages of creating an atlas: information-analytical accumulative; preparatory cartographic; cartographic; design; publishing. The structure of the regional atlas is given. All maps in the atlas are combined into 4 sections: «Introductory Section», «Nature», «Population», «Economy», they are consistent and complement each other. A number of thematic maps, placed in the Atlas, were built for the Belgorod Region for the first time. The atlas contains 76 thematic maps built in the ArcGIS 10.4.1 environment. When creating atlas maps, modern techniques and methods of geoinformation mapping were applied.

The published «Geographic Atlas of the Belgorod Region: Nature, Society, Economy» is both a scientific work and an educational reference manual, and is intended for a wide range of users: from school and university students to highly specialized specialists of various levels.
\end{abstract}

KEYWORDS: regional atlas, Belgorod region, GIS technologies, atlas mapping, thematic map, sustainable development.

\section{ВВЕДЕНИЕ}

Устойчивое развитие региона обеспечивается, прежде всего, равновесием между факторами социально-экономического и природно-экологического развития [Корнилов $u$ $\partial p$., 2018]. Под устойчивым развитием региона принято понимать такое состояние социоэколого-экономической системы, при котором существуют необходимые условия и предпосылки для прогрессивного движения вперед, для поддержания внутреннего и внешнего равновесия, для обеспечения постепенного перехода экономики от простых явлений к более сложным, тем самым происходит формирование условий для ее перехода в качественно новое состояние [Антонова, 2013].

Для принятия взвешенных управленческих решений в сфере экономики, охраны окружающей среды и др. необходима упорядоченная актуальная информация - ГИС как нельзя лучше отвечают этим запросам. Современные геоинформационные системы (ГИС) находят широкое применение в различных сферах человеческой деятельности. Одним из направлений прикладного использования ГИС является картографирование: от создания отдельных тематических карт до сложных картографических произведений - атласов, в том

Belgorod state University, Pobedy str., 85, 308015, Belgorod, Russia, e-mail: lebedeva_m@bsu.edu.ru Belgorod state University, Pobedy str., 85, 308015, Belgorod, Russia, e-mail: kornilov@ $@$ bsu.edu.ru Belgorod state University, Pobedy str., 85, 308015, Belgorod, Russia, e-mail: petina_m@bsu.edu.ru Belgorod state University, Pobedy str., 85, 308015, Belgorod, Russia, e-mail: furmanova@bsu.edu.ru 
числе и региональных. ГИС открывают широкие возможности создания региональных атласов качественно нового уровня, причем с меньшими затратами труда и ресурсов.

С точки зрения науки, издание атласа способствует развитию тематического картографирования, формированию отраслевых и универсальных баз данных и географических информационных систем прикладной направленности; в отраслях экономики помогает реализации государственных программ экономического, социального и культурно-образовательного развития региона. Современный комплексный атлас - это система тематически связанной, взаимно согласованной пространственной информации о природе, населении и экономике картографируемой территории, представленной в систематизированном и сопоставимом виде в аналоговой или цифровой форме. Структурированная информация представляется в виде баз географических данных и визуализируется, что обеспечивает её обозримость, наглядность и возможность использования в качестве средства познания окружающей действительности и проведения научных исследований [Савиных и др., 2017; Lechthaler, 2010].

В полной мере оценить возможности применения ГИС-технологий для целей атласного картографирования позволила работа над «Географическим атласом Белгородской области: природа, общество, хозяйство», который вышел в свет в декабре 2018 года [Корнилов и др., 2018]. Региональный атлас Белгородской области был создан коллективом ученых Института наук о Земле ФГАОУ ВО «Белгородский государственный национальный исследовательский университет» (НИУ «БелГУ») с привлечением профильных специалистов при финансовой поддержке ВОО «Русское географическое общество».

\section{МАТЕРИАЛЫ И МЕТОДЫ ИССЛЕДОВАНИЯ}

Работа над созданием обновленного регионального атласа Белгородской области в теоретической части опирается на труды ведущих картографов и географов, исследователей в области теории картографии, атласного, географического и геоинформационного картографирования - К.А. Салищева [1976], А.М. Берлянта [2001], И.П. Заруцкой [1988], Т.Г. Сватковой [2002], И.К. Лурье [2008], Е.А. Прохоровой [2010] и др. учёных.

Актуальность и необходимость применения ГИС-технологий в современных научных исследованиях и в создании карт различной тематики позволяют эффективно агрегировать данные в единой системе координат с возможностью пространственного анализа разнородных карт. В работе используется лицензионное программное обеспечение (ArcGIS 10.4.1, CorelDRAW X6, Adobe Photoshop); космические снимки Белгородской области, картографические, статистические, текстовые материалы; нормативные документы; базы и банки пространственных данных. Все источники информации прошли обязательную проверку.

Геоинформационное картографирование позволяет разнообразить способы изображения, менять стили оформления карт, использовать эффекты машинной графики и компьютерного дизайна [Прохорова, 2010; Berry, 1987]. Одна из важных задач - выбор способов картографического изображения и графических средств, построение карт способствующих формированию выводов и умозаключений, которые было бы трудно сделать из такой же информации в текстовом или табличном виде. Современные геоинформационные программные продукты, такие как ArcGIS, содержат множество базовых инструментов и механизмов для создания и публикации карт.

Весь комплекс работ, проведенных при подготовке регионального атласа Белгородской области, можно объединить в несколько последовательных этапов:

- информационно-аналитический накопительный; 
- подготовительный картографический;

- картографический;

- оформительский;

- $\quad$ издательский.

Остановимся подробнее на содержании каждого из этапов.

\section{РЕЗУЛЬТАТЫ ИССЛЕДОВАНИЯ И ИХ ОБСУЖДЕНИЕ}

По полноте содержания и новизне представленных материалов Атлас Белгородской области является уникальным картографическим произведением. В нем средствами картографического изображения отражены природные и социально-экономические особенности Белгородской области - одного из наиболее динамично развивающихся субъектов Российской Федерации. «Географический атлас Белгородской области: природа, общество, хозяйство» (рис. 1) является вторым, переработанным и дополненным изданием регионального атласа, более ранний атлас Белгородской области - «Природные ресурсы и экологическое состояние Белгородской области» был опубликован в 2005 году.

Первое издание регионального атласа отражало ситуацию в области на конец XX в., новый же атлас демонстрирует количественные и качественные изменения природной среды и общества, произошедшие в регионе в первые десятилетия XXI в., что особенно актуально для приграничных территорий в связи с ростом барьерных функций государственной границы с Украиной в современных геополитических условиях.

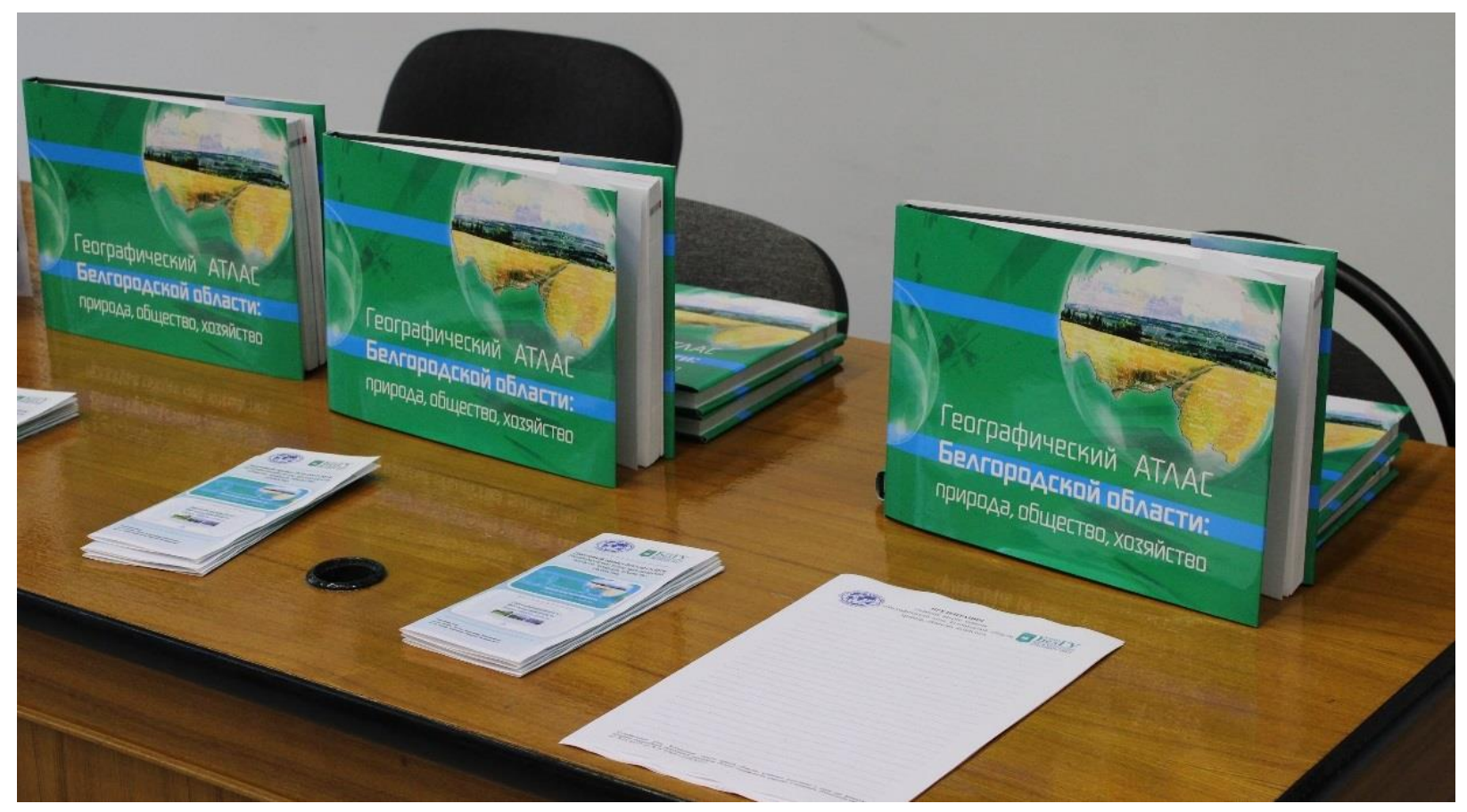

Рис. 1. Обложка картографического произведения «Географический атлас Белгородской области: природа, общество, хозяйство»

Fig. 1. Cover of the cartographic work «Geographic Atlas of the Belgorod Region: Nature, Society, Economy»

Изданный «Географический атлас Белгородской области: природа, общество, хозяйство» отличается своей многофункциональностью и предназначен для широкого круга пользователей: от учащихся школ и студентов вузов до узкопрофильных специалистов различного уровня. Это, в свою очередь, и определило набор и содержание 
карт, применение картографических способов отображения и даже общие подходы к оформлению произведения в целом.

Первый, информационно-аналитический накопительный этап предполагал сбор и обработку фактического материала, в том числе в ходе полевых экспедиционных исследований, а также разработку структуры атласа.

При отборе данных для атласа предпочтение отдавалось тому материалу, который соответствует университетским программам географических и экологических направлений, а также представляет интерес для специалистов и широкого круга пользователей.

Для составления карт атласа Белгородской области использовались материалы фондовых, картографических, статистических данных, предоставленных следующими ведомствами: ТО «Федеральная служба государственной статистики по Белгородской области», Отдел геологии и лицензирования по Белгородской и Курской областям, Департамент по недропользованию по Центральному федеральному округу, Управление Федеральной службы государственной регистрации, кадастра и картографии по Белгородской области, Белгородский центр по гидрометеорологии и мониторингу окружающей среды, Департамент агропромышленного комплекса и воспроизводства окружающей среды Белгородской области, Департамент имущественных и земельных отношений Белгородской области, Управление экологической безопасности и надзора за использованием объектов животного мира, водных биологических ресурсов Белгородской области, УФМС России по Белгородской области, Управление Федеральной службы по надзору в сфере природопользования (Росприроднадзора) по Белгородской области), позволивший определить содержание карт.

На подготовительном картографическом этапе была разработана картографическая основа для всех карт. При создании стандартного набора картографических произведений используются шаблоны компоновки, соответствующие масштабному ряду карт атласа, и унифицированные атрибутивные данные, связанные с тематическими слоями.

Основные объекты на картах атласа (гидрографическая сеть, дорожная сеть, населенные пункты были отвекторизованы с предварительно привязанной к данным OSM топографическое карте M 1:200 000). Для определения масштаба карт атласа границы Белгородской области в проекции Меркатора были вписаны в лист формата A4 симметрично относительно среднего меридиана, перпендикулярного северной и южной сторонам рамки, в результате чего был установлен оптимальный масштаб М 1:1 000000.

Картографическая основа включает в себя постоянный состав элементов содержания (гидрография, населенные пункты, пути сообщения, границы, другие элементы природного ландшафта), в дальнейшем она использовалась во всех разделах атласа с применением различных компоновок карт.

Весь собранный на первом этапе картографический и статистический материал по каждому разделу подвергался моделированию, которое заключалось в:

- $\quad$ послойном разделении элементов содержания;

- выделении главных объектов картографируемой территории, не подлежащих редактированию на создаваемой карте;

- $\quad$ определении пределов массива мелких объектов, лишенных каких-либо признаков значимости.

При моделировании выполнялись следующие общие требования:

1) постоянный состав элементов содержания: картографическая сетка, гидрография, населенные пункты, пути сообщения, границы, другие элементы природного ландшафта; 
2) все элементы содержания отображались избирательно и раздельно (допуск 0,2 0,3 мм в масштабе карты);

3) графическая нагрузка карты, отображающая совокупность элементов содержания, передает целостность внешнего облика картографической территории;

4) точность положения элементов содержания определялась масштабом карты и последовательностью нанесения элементов содержания на карту, при использовании внемасштабных условных знаков точность их положения определялась правильностью взаимного расположения объектов (пространственным соответствием).

Картографический этап предполагал создание серии новых тематических карт атласа путем нанесения на подготовленную основу содержания карт, на основе применения методов геостатистического моделирования, классификации, интерполяции, статистического анализа и др. Работы с материалом осуществлялись с использованием программного обеспечения ArcGIS компании ESRI.

Для обеспечения максимальной наглядности, точности и читаемости карт были применены различные способы картографического изображения: способы значков, линейных знаков, изолиний, качественного фона, количественного фона и др.

К созданию карт атласа были привлечены многочисленные специалисты узких направлений (почвоведы, геологи, экологи, географы, метеорологи, гидрологи, демографы и др.) с целью повышения точности, объективности и всестороннего отражения накопленных данных, что позволило расширить содержание Атласа.

Так, впервые были построены карты биоклиматического потенциала Белгородской области (рис. 2).

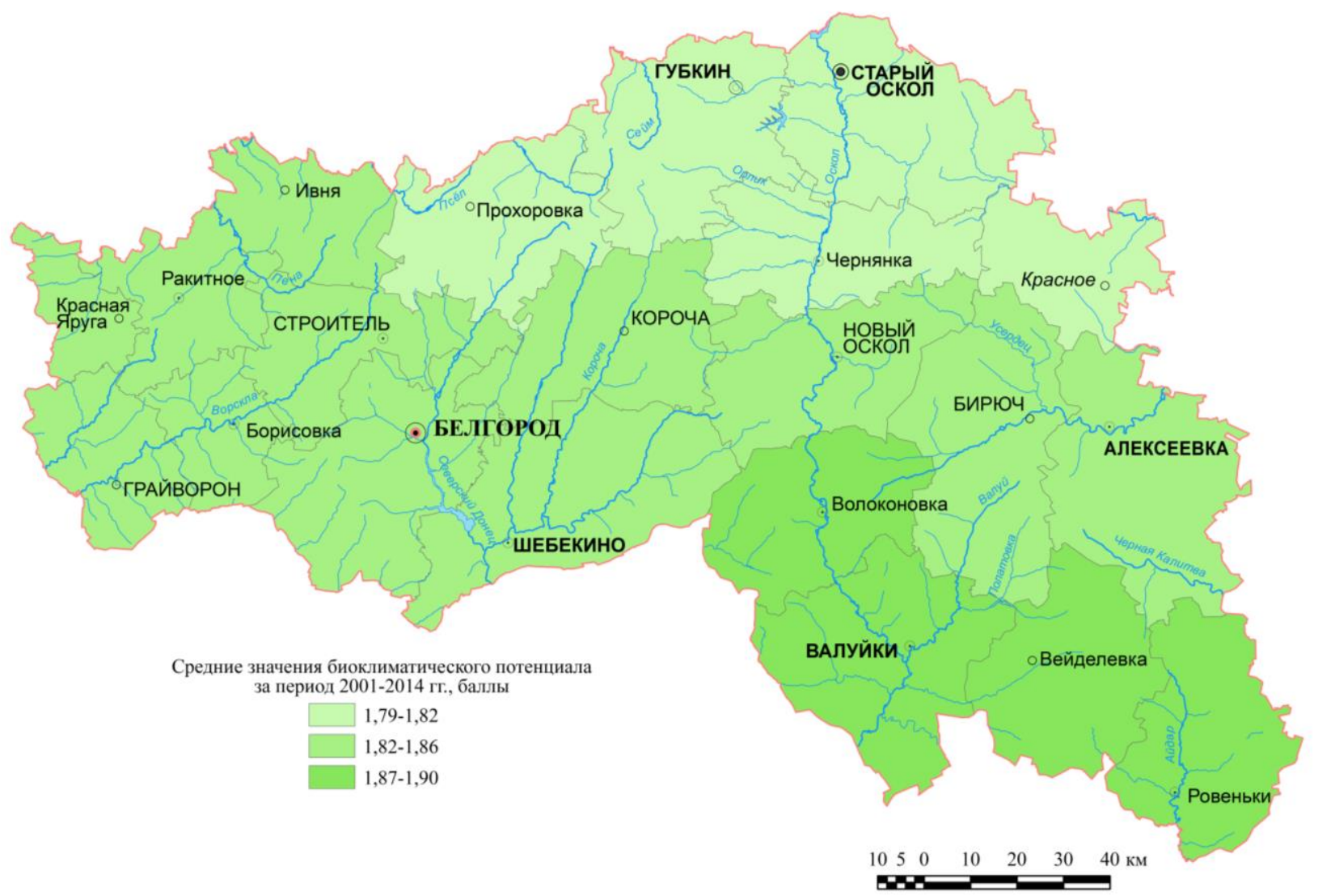

Рис. 2. Биоклиматический потенциал территории за период 2001-2014 г2

Fig. 2. Bioclimatic potential of the territory for the period 2001-2014 
В качестве показателя, характеризующего условия сельскохозяйственного производства в регионе (оценки сельскохозяйственной продуктивности климата), был выбран биоклиматический потенциал (БКП) территории - комплекс метеорологических факторов, определяющих рост и развитие растений, рассчитываемый по методике Д.И. Шашко, выражается в баллах. Качественная оценка биоклиматического потенциала в регионе по двум периодам показала, что на рубеже XX-XXI вв. - вероятность среднего значения БКП снизилась с 96 \% до 81 \%, а повторяемость пониженного и повышенного БКП увеличилась, что свидетельствует о том, что в условиях роста термических ресурсов, отмечаемых в последние десятилетия, недостаточная влагообеспеченность не способствует формированию устойчивых благоприятных агрометеорологических характеристик. На рисунке 3 представлена карта геоморфологических рисков [Корнилов и др., 2018].

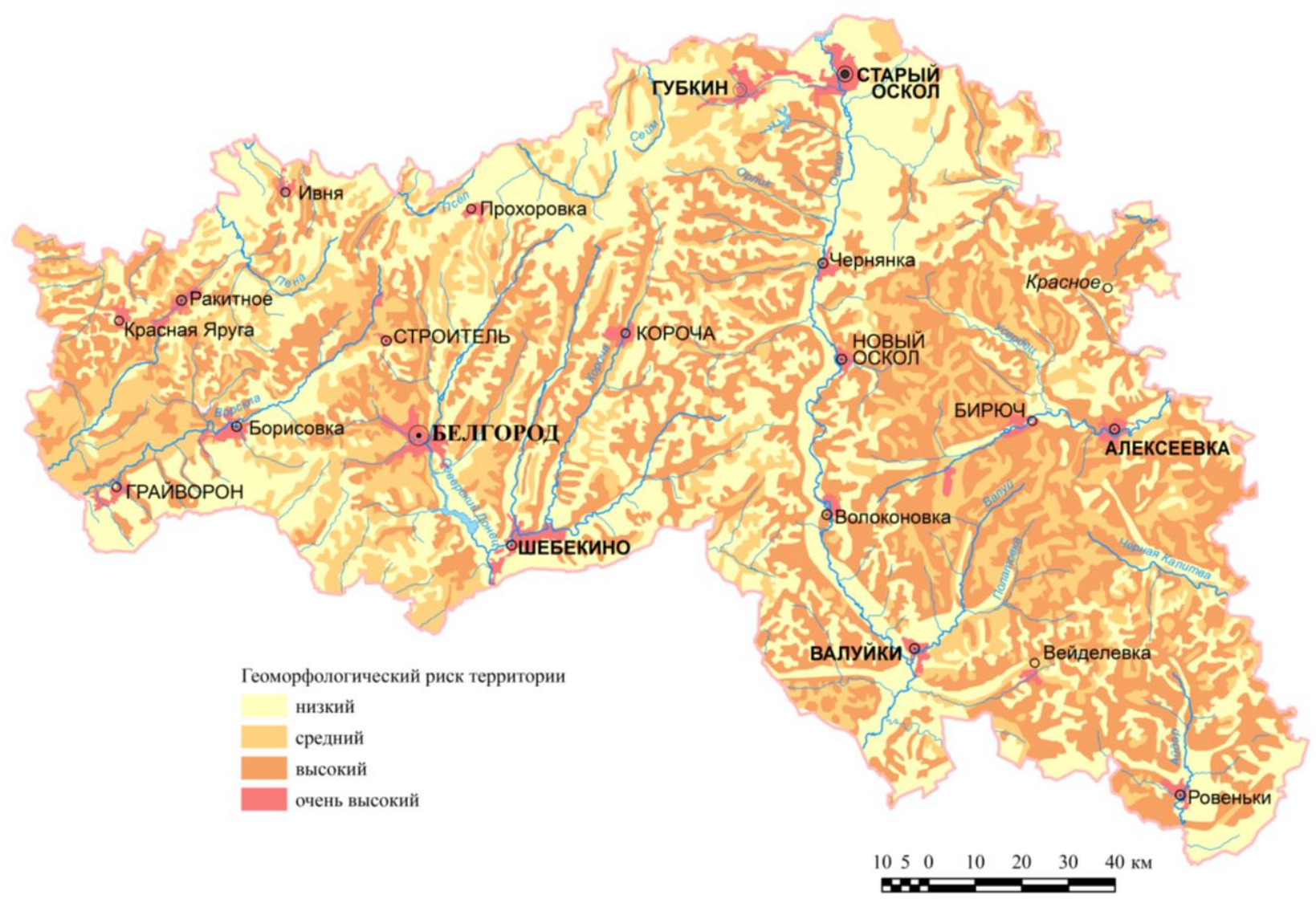

Рис. 3 Геоморфологические риски

Fig. 3. Geomorphological risks

Природно-климатические условия, особенности распространения инженерногеологических комплексов, морфометрические показатели рельефа (уклонов земной поверхности и вертикального расчленения земной поверхности), а также виды хозяйственной деятельности и степени антропогенной нагрузки позволили составить прогноз активизации экзогенных процессов или геоморфологических рисков территории Белгородской области.

На карте выделяется четыре группы ареалов с различным уровнем риска:

1) с низким геоморфологическим риском (водораздельные пространства и слабо покатые склоны с углом наклона земной поверхности до 2-3);

2) со средним геоморфологическим риском (приводораздельные склоны с углом наклона до $5^{\circ}$ ); 
3) с высоким геоморфологическим риском (склоны речных долин и крупных овражнобалочных систем с уклонами от $5-10^{\circ}$ и более), а также береговые уступы водохранилищ;

4) с очень высоким геоморфологическим риском (селитебные и горнопромышленные территории).

Возникновение неблагоприятных экологических ситуаций может быть вызвано экстремальными значениями как отдельных экологически опасных экзогенных процессов, так и их совместным проявлением. Наряду с этим, возникновение сложной экологической ситуации может быть обусловлено длительным действием экзогенных процессов средней интенсивности. В этом случае конфликтная экологическая ситуация вызвана суммарным результатом проявления экзогенных процессов [Корнилов и др., 2018].

На территории Белгородской области, как одного из староосвоенных регионов, эколого-геоморфологические ситуации различной остроты вызваны, главным образом, развитием эрозионных, оползневых, абразионных и техногенных процессов (рис. 4).

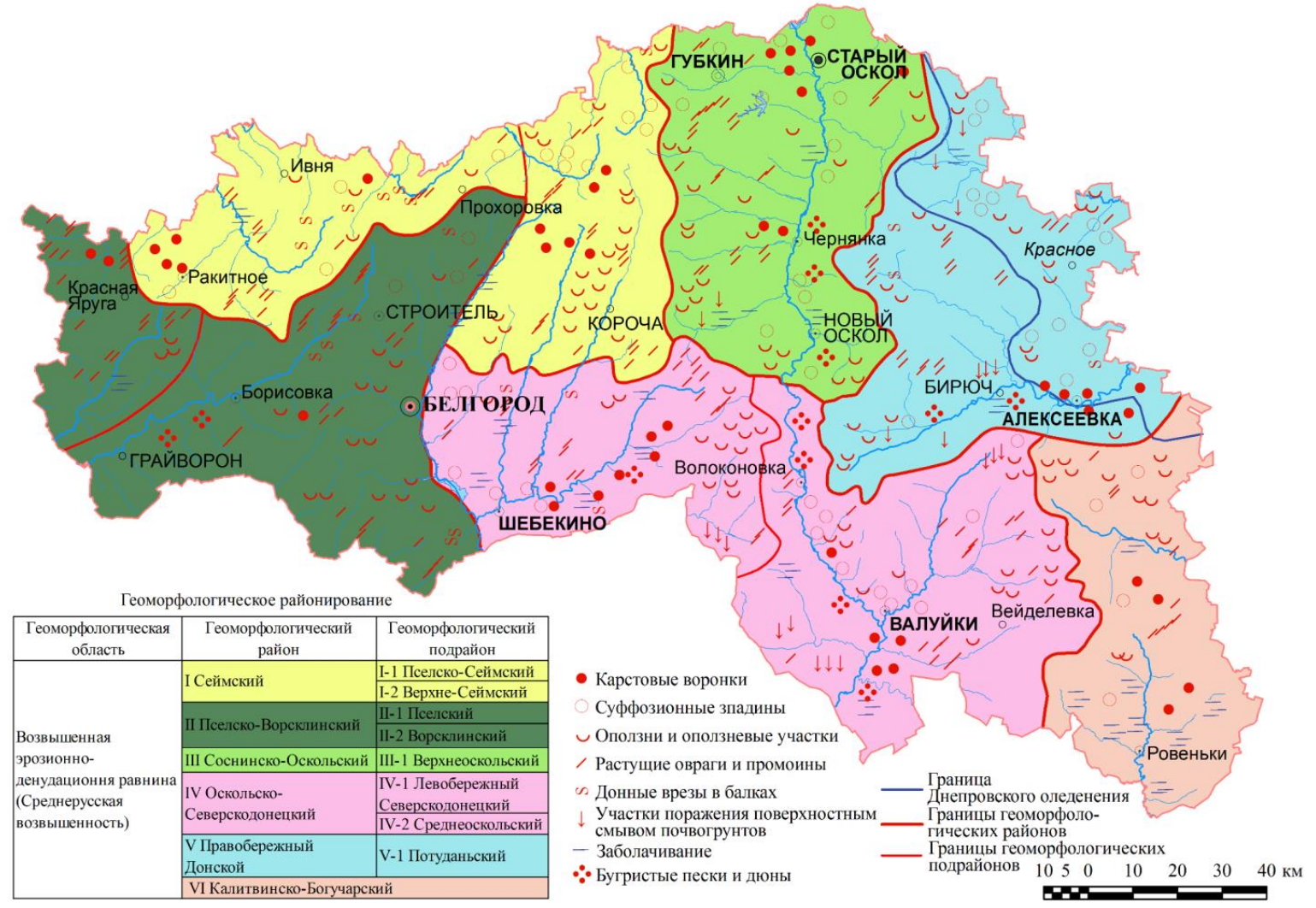

Рис. 4. Экзогенные геологические прочессы

Fig. 4. Exogenous geological processes

Линейная эрозия как доминирующий процесс определяет в целом пораженность территории области экзогенными геологическими процессами. Общая расчлененность территории области эрозионными формами колеблется от 0,2 до 1,9-2,0 км/км². Общая протяженность овражно-балочной сети составляет около 50 тыс. км.

Вторым не менее опасным геологическим процессом является оползнеобразование. Наиболее сильно поражена оползнями восточная и центральная части области. Карстовые формы рельефа на территории Белгородской области распространены спорадически. На одних участках они полностью отсутствуют, на других встречаются довольно часто. Суффозионные явления приурочены в основном к поймам и первым двум надпойменным террасам рек Северский Донец, Оскол, Сейм, а также к бассейнам малых рек северо- 
восточной части области. Абразионные процессы - размыв берегов волнением и течениями. Абразия широко распространена на наиболее крупных водохранилищах Белгородской области: Белгородском, Старооскольском, Корочанском и др. Эоловые процессы на территории области не имеют широкого распространения [Корнилов и дp., 2018; Kornilov, 2019; Prisny, 2019].

Оформительский этап заключался в структурировании подготовленных материалов в единый макет атласа Белгородской области, компоновке карт, сопровождении их пояснительным текстом с иллюстративным наглядным материалом. При компоновке карт применялась различная графическая нагрузка для передачи целостности внешнего облика картографируемой территории. Атлас содержит: 76 карт, 15 диаграмм и графиков; 46 фотографий и рисунков, 54 таблицы.

«Географический атлас Белгородской области: природа, общество, хозяйство» состоит из 4-х разделов: Вводный раздел, Природа, Население, Хозяйство. При размещении карт в разделах и подразделах учитывалась логическая последовательность, отражающая взаимосвязь и взаимообусловленность отображаемых явлений.

Во вводном разделе отражено географическое положение Белгородской области и ее административное устройство. Карта административно-территориального деления имеет актуализированное на 2018 г. стандартное содержание и составлена по Общероссийскому классификатору территорий муниципальных образований (ОКТМО).

Табл. 1. Содержание Вводного раздела регионального атласа

Table 1. Contents of the Introductory Section of the Regional Atlas

\begin{tabular}{|l|}
\hline \multicolumn{1}{|c|}{ ВВОДНЫЙ РАЗДЕЛ } \\
\hline Административное устройство \\
\hline Физическая карта \\
\hline Физико-географические районы \\
\hline Особо охраняемые природные территории \\
\hline
\end{tabular}

Физическая карта также имеет стандартное содержание, но, в отличие от ранее созданных физических карт региона, на ней показаны и подписаны все географические объекты, входящие в обязательную для изучения географическую номенклатуру (объекты орографии, гидрографии и пр.). Большую научную ценность представляет карта особо охраняемых природных территорий, которая в совокупности с текстом легенды позволяет увидеть режим охраны в соответствии с функциональным зонированием. Вводный раздел атласа имеет объём $21 \mathrm{c}$.

Раздел «Природа» состоит из пяти подразделов, отделяемых шмуцтитулами. Общий объём раздела -83 с.

Табл. 2. Содержание раздела «Природа» регионального атласа

Table 2. Contents of the «Nature» section of the regional atlas

\begin{tabular}{|l|}
\hline \multicolumn{1}{|c|}{ I. ПРИРОДА } \\
\hline 1.1. Природные ресурсы и их изменение \\
\hline Природная среда Белгородской области в докультурный период (XVI век) \\
\hline Изменение речной сети за 200 лет \\
\hline Изменение густоты речной сети за 200 лет \\
\hline Возраст земледельческого освоения территории \\
\hline 1.2. Геологическое строение и рельеф \\
\hline Четвертичные отложения \\
\hline Дочетвертичные отложения \\
\hline
\end{tabular}




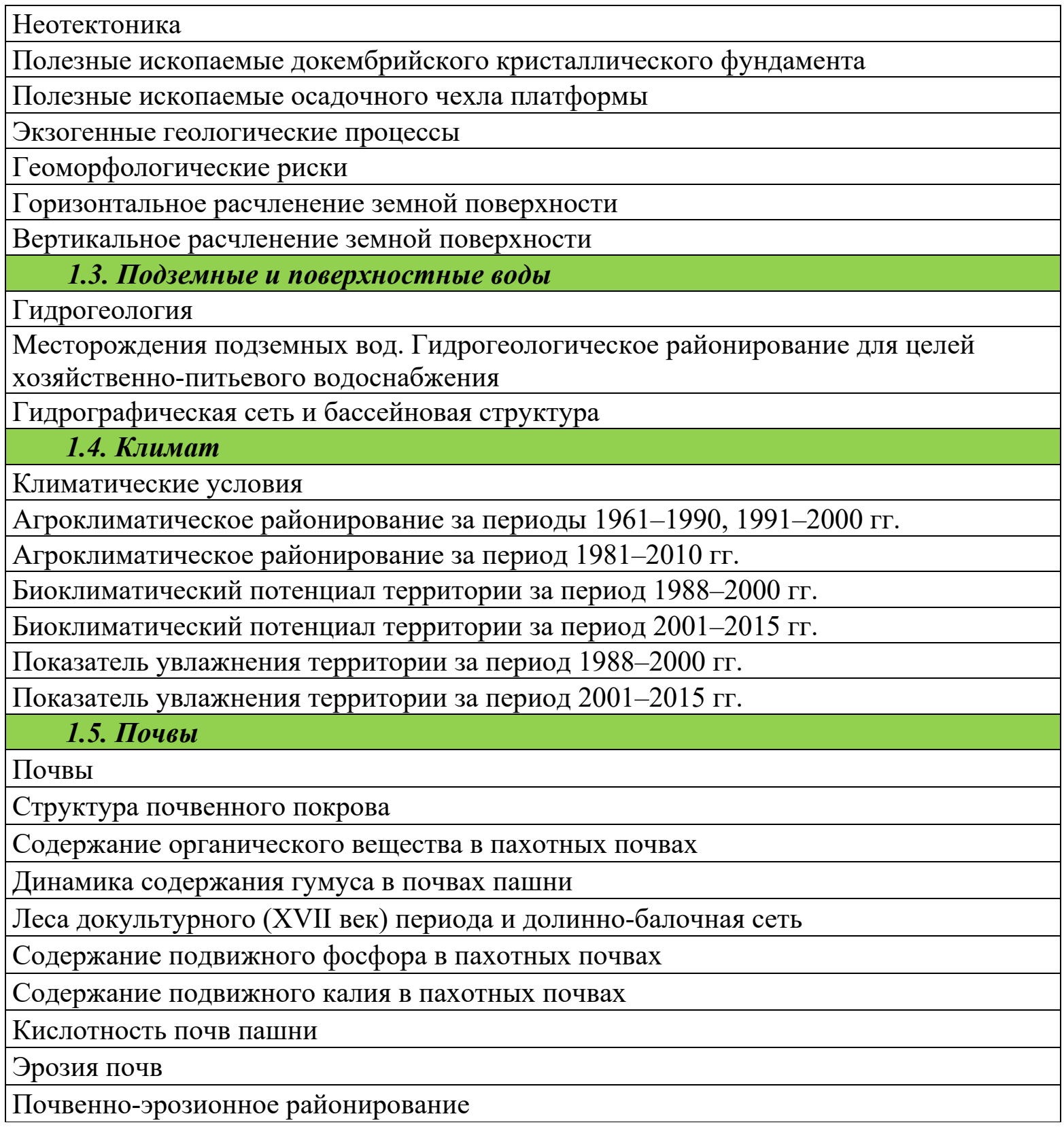

Раздел «Население» состоит из двух подразделов. Общий объём раздела - 38 с.

Табл. 3. Содержание раздела «Население» регионального атласа

Table 3. Contents of the «Population» section of the regional atlas

\section{II. НАСЕЛЕНИЕ}

Динамика численности всего населения, административных центров районов, городских округов. 2002-2017 гг.

Динамика численности сельского населения. 1979-1989 гг.

Динамика численности сельского населения. 1989-2002 гг.

Динамика численности сельского населения. 2002-2010 гг.

Динамика численности сельского населения. 2002-2017 гг.

Миграционный прирост населения Белгородской области на 1000 человек. 2016 г. 
Плотность населения

Региональная система расселения

\section{1. Социальная география}

Уровень и качество жизни населения муниципальных образований

Жилищные условия населения

Образовательный потенциал

Здравоохранение

Культура

Культурно-исторический потенциал

Сельский туризм

Занятость и безработица по организациям, не относящимся к субъектам малого

предпринимательства

Раздел «Хозяйство» состоит из 3 подразделов. Общий объём раздела -53 с.

Табл. 4. Содержание раздела «Хозяйство» регионального атласа Table 4. Contents of the "Economy» section of the regional atlas

\section{III. ХОЗЯЙСТВО}

\section{1. Земельные ресурсы и производственная инфраструктура}

Агроландшафты

Категории земель

Формы собственности на землю

Сельскохозяйственные угодья

Исторические закономерности использования пахотных земель

Распаханность земель

Кормовые угодья

Кадастровая оценка сельскохозяйственных угодий

Земельные платежи

Производственная инфраструктура

\section{2. Биологические ресурсы}

Лесные ресурсы

Эксплуатационные запасы лекарственного растительного сырья

Охотничьи животные

Редкие и исчезающие растения

Редкие и исчезающие наземные животные

\section{3. Экологическая ситуация}

Коэффициент самоочищения атмосферы

Состояние ресурсов подземных вод

Содержание цинка в почвах пашни

Содержание марганца в почвах пашни

Содержание меди в почвах пашни

Загрязнение цезием-137 почв пашни

Загрязнение поверхностных вод

Распределение загрязняющих веществ в реках и водохранилищах на постах

Росгидромета по среднегодовым концентрациям в 2016 г.

Распределение антропогенной нагрузки 
Издательский этап предполагал выполнить печать тиража атласа и представить его широкой общественности. Презентация Географического атласа Белгородской области проходила в несколько этапов. Предварительная презентация регионального атласа состоялась в сентябре 2018 г. на Фестивале науки Юго-Запада России в рамках VIII Всероссийского фестиваля науки NAUKA 0+ на центральной интерактивной выставке.

В ноябре в рамках проведения Международной образовательной акции «Географический диктант» на площадке Федерального государственного образовательного учреждения высшего образования «Белгородский государственный национальный исследовательский университет» (НИУ «БелГУ») (г. Белгород) также прошла предварительная презентация атласа.

Итоговая презентация Атласа состоялась в НИУ «БелГУ» (г. Белгород) состоялась в декабре 2018 г. в формате открытого мероприятия с приглашением широкой общественности: представителей библиотек, профильных ведомств, образовательных учреждений, административных структур, СМИ. Авторский коллектив ученых, принявших участие в создании «Географического атласа Белгородской области: природа, общество, хозяйство» стал дипломантом областного конкурса «Лучшая книга Белгородчины» в номинации «Лучшее учебное и научно-популярное издание», а также был удостоен региональной премии им. А.В. Погорелова в номинации «Образование».

Подобные маетриалы охватывают всесторонние аспекты развития регионов: население, экономику, природные территориальные комплексы и антропогенную нагрузку на них, а также позволяют прогнозировать изменения состояния геосистем в целом в обозримом будущем.

\section{ВЫВОДЫ}

«Географический атлас Белгородской области: природа, общество, хозяйство» представляет собой интегральный результат глубокого анализа современных природных условий и ресурсов, хозяйства и населения Белгородской области.

Разработка и создание комплексного регионального атласа Белгородской области с учётом потребностей высшей и средней школы способствует формированию системных знаний о родном крае. Атлас является как научным трудом, так и учебно-справочным пособием. Представленная в атласе посредством тематических карт актуальная географическая информация позволила сделать региональный атлас одним из основных средств информационно-образовательной среды, а также инструментом в реализации политики устойчивого развития региона.

При создании комплексного картографического произведения «Географический атлас Белгородской области: природа, население, хозяйство» авторами были подробно изучены основные требования современной атласной картографии, а также проанализирован опыт создания региональных атласов. Проведен широкий анализ современных методов и технологий создания атласов, разработаны и апробированы новые технологические решения для создания тематических карт. Создана цифровая картографическая основа территории Белгородской области, которая может быть использована не только для создания тематических карт данного атласа, но также в качестве контурных карт для выполнения практических заданий в разных учебных дисциплинах и создания новых карт. Организованы базы данных в ГИС для последующего наполнения тематическими данными и их использования научными коллективами.

Являясь важной составной частью информационной системы, атлас обеспечивает научную, методическую и информационную поддержку в области образования, просвещения, пропаганды знаний о природе, хозяйстве и населении родного края. 


\section{СПИСОК ЛИТЕРАТУРЫ}

1. Антонова M. A. Теоретико-методологические основы изучения устойчивого развития регионов. Общество: политика, экономика, право, 2013. №4 (36).

2. Берлянт A.M. Картография. М.: Аспект Пресс, 2001. 236 с.

3. Божилина Е.А., Емельянова Л.Г., Котова Т.В., Тальская Н.Н., Тутубалина О.В., Украинцева Н.Г. Географическое картографирование: карты природы. Москва: КДУ, 2010. $316 \mathrm{c}$.

4. Заруцкая И.П., Красильникова Н.В. Картографирование природных условий и ресурсов. Москва: Недра, 1988. 239 с.

5. Лурье И.К. Геоинформационное картографирование. Методы геоинформатики и цифровой обработки космических снимков. М.: КДУ, 2008. 424 с.

6. Корнилов, А.Г., Петин, А.Н., Чендев, Ю.Г., Петина, В.И. Географический атлас Белгородской области: природа, общество, хозяйство. Белгород: Константа, 2018. 69-199 с.

7. Петин А.Н., Нарожняя А.Г., Петина М.А., Фурманова Т.Н. Концепция, структура и содержание комплексного регионального географического атласа Белгородской области. Проблемы природопользования и экологическая ситуация в Европейской России и сопредельных территориях: материалы VII Междунар. науч. конф. (памяти проф. Петина А.Н.). 24-26 октября. Белгород, 2017. С. 218-220.

8. Природные ресурсы и экологическое состояние Белгородской области. Атлас. Под ред. Ф.Н. Лисецкого. Белгород, 2005. 180 с.

9. $\quad$ Прохорова Е.А. Социально-экономические карты. М.: КДУ, 2010. 424 с.

10. Ротанова И.Н., Тикунов В.С., Егорина А.В., Ефремов Г.А., Перемитина С.В., Лхагвасурен Ч. Концепция и базовые карты атласа «Большой Алтай: природа, история, культура». Материалы $\mathrm{X}$ научной конференции по тематической картографии Атласное картографирование: традиции и инновации. Иркутск: Издательство Института географии им. В.Б. Сочавы СО РАН, 2015. С. 45-47.

11. Савиных В.П., Бугаевский Ю.Л., Братков В.В., Верещака Т.В., Билибина Н.А., Биктимирова Н.М., Мельникова Е.Б., Кузьмина Н.А. Концепция географического атласа для учителей как многофункциональной информационной системы. Известия высших учебных заведений. Геодезия и аэрофотосъёмка. 2017. № 4. С. 4-13.

12. Салищев К.A. Комплексные региональные атласы. М.: Издательство Московского университета, 1976. $638 \mathrm{c.}$

13. Сваткова Т.Г. Атласная картография. Москва: Аспект Пресс, 2002. 203 с.

14. Berry J. K. Fundamental operations in computer-assisted map analysis. International Journal of Geographical Information Systems. 1987. V. 1. P. 119-136.

15. Kornilov A.G., Kolmykov S.N., Prisny A.V., Lebedeva M.G., Kornilova E.A., Oskin A.A. Current hydroecological situation of the Starooskolsko-Gubkinsky mining region on the exampl of the Oskolets River. EurAsian Journal of BioSciences. No 13 (2). 2019. P. 865870.

16. Lechthaler M. Interactive and Multimedia Atlas Information System as a Cartographic Geo-communication Platform. Berlin: Springer, 2010. P. 384-402.

17. Prisny A.V., Kornilov A.G., Prisny Y.A., Kolmykov S.N., Macrofauna of hydrobionts in the Gubkinsko-Starooskolsky mining area: the case of the Oskolets River. EurAsian Journal of BioSciences. No 13. 2019. P. 997-1001.

\section{REFERENCES}

1. Antonova M.A. Theoretical and methodological foundations for the study of sustainable development of regions. Society: Politics, Economics, Law. 2013. №4 (36) (in Russian). 
2. Berlyant A.M. Cartography. Moscow: Aspect Press, 2001. 236 p. (in Russian).

3. Berry J.K. Fundamental operations in computer-assisted map analysis. International Journal of Geographical Information Systems. 1987. V. 1. P. 119-136.

4. Bozhilina E.A., Emelyanova L.G., Kotova T.V., Talskaya N.N., Tutubalina O.V., Ukraintseva N.G. Geographic mapping: maps of nature. Moscow: KDU, 2010. 316 p. (in Russian).

5. Kornilov, A.G., Petin, A.N., Chendev, Yu.G., Petina, V.I. Geographical Atlas of the Belgorod region: nature, society, economy. Belgorod: Konstanta, 2018. 69. 199 p. (in Russian).

6. Kornilov A.G., Kolmykov S.N., Prisny A.V., Lebedeva M.G., Kornilova E.A., Oskin A.A. Current hydroecological situation of the Starooskolsko-Gubkinsky mining region on the exampl of the Oskolets River. EurAsian Journal of BioSciences 13 (2), 865-870 (2019).

7. Lechthaler M. Interactive and Multimedia Atlas Information System as a Cartographic Geo-communication Platform. Berlin: Springer, 2010. P. 384-402.

8. Lurie I.K. Geoinformation mapping. Methods of geoinformatics and digital processing of satellite images. Moscow: KDU, 2008. 424 p. (in Russian).

9. Natural resources and ecological state of Belgorod region: atlas. Ed. F.N. Lisetskiy. Belgorod: Belgorod State University, 2005. 179 p. (in Russian).

10. Petin A.N., Narozhnyaya A.G., Petina M.A., Furmanova T.N. The concept, structure and content of the integrated regional geographical atlas of the Belgorod region. Problems of nature management and the ecological situation in European Russia and adjacent territories: materials of the VII international. scientific. conf. (in memory of Professor A. Petin). October 24-26. Belgorod, 2017. P. 218-220. (in Russian).

11. Prisny A.V., Kornilov A.G., Prisny Y.A., Kolmykov S.N., Macrofauna of hydrobionts in the Gubkinsko-Starooskolsky mining area: the case of the Oskolets River. EurAsian Journal of BioSciences. No 13. 2019. P. 997-1001. (in Russian).

12. Prokhorova E.A. Socio-Economic Maps. Moscow: KDU, 2010. 424 p. (in Russian).

13. Rotanova I.N., Tikunov V.S., Egorina A.V., Efremov G.A., Peremitina S.V., Lhagvasuren $C h$. Concept and basic maps of the atlas "Greater Altai: nature, history, culture. Proceedings of the $\mathrm{X}$ scientific conference on thematic cartography Atlas mapping: traditions and innovations. Irkutsk: Publishing house of the Institute of Geography. V.B. Sochava Institute of Geography SB RAS, 2015. P. 45-47 (in Russian).

14. Savinykh V.P., Bugaevsky Y.L., Bratkov V.V., Vereshchaka T.V., Bilibina N.A., Biktimirova N.M., Melnikova E.B., Kuzmina N.A. The concept of geographical atlas for teachers as a multifunctional information system. Proceedings of Higher Education Institutions. Geodesy and aerial photography, 2017. №. 4. P. 4-13 (in Russian).

15. Salishchev K.A. Complex regional atlases. Moscow: Moscow University Press, 1976. 638 p. (in Russian).

16. Svatkova T.G. Atlas Cartography. Moscow: Aspect Press, 2002. 203 p. (in Russian).

17. Zarutskaya I.P., Krasilnikova N.V. Cartography of natural conditions and resources. Moscow: Nedra, 1988. 239 p. (in Russian). 


\section{А.В. Грушина ${ }^{1}$ С.А. Тесленок², А.П. Муштайкин ${ }^{3}$ \\ ИСПОЛЬЗОВАНИЕ СОВРЕМЕННЫХ ТЕХНОЛОГИЙ ДЛЯ СОЗДАНИЯ ЭЛЕКТРОННОГО АТЛАСА АДМИНИСТРАТИВНОГО РАЙОНА}

\section{АННОТАЦИЯ}

Электронная версия традиционного атласа существенно повышает значение и роль информационного продукта как прообраза необходимого компонента современной информационно-технологической инфраструктуры.

Важнейшую роль при разработке электронных атласов играют современные информационные технологии. Но с их помощью зачастую создается специализированный картографический материал для крупных административных единиц: стран и их регионов. При этом зачастую несправедливо игнорируются более мелкие, такие как административные районы, не менее важные для экономической, научной и учебной деятельности.

В предлагаемой статье рассматриваются особенности и результаты разработки и создания инновационного информационного продукта - электронного атласа на территорию Теньгушевского района Республики Мордовия. Актуальность данной работы очевидна, так как накоплены большие объемы разнообразного картографического и справочного материала, который необходимо систематизировать и визуализировать. С этой целью был изучен материал об электронных картах и атласах, подобраны исходные данные и программное обеспечение, сформирован набор пространственных данных ГИС для целей картографирования, реализован сбор разноплановых данных в единый информационный источник, визуализированный в стандартном интернет-браузере. В качестве целевого программного обеспечения для создания картографической основы атласа был использован геоинформационный пакет ArcGIS, для оформительской части графический редактор CorelDRAW, а для создания страниц локальной базы данных текстовый редактор Notepad++.

Результатом работы стал электронный атлас административного района, интегрирующий данные, полученные из различных источников, с использованием возможностей ГИС-технологий в формате, позволившем успешно перенести их на онлайн-портал. Предложенная технологическая схема может служить руководством по созданию аналогичных информационных продуктов для других административных районов.

КЛЮЧЕВЫЕ СЛОВА: электронный атлас, электронная карта, картографирование, ГИСтехнологии, программа атласа, база данных, программное обеспечение, графический редактор, интернет-сайт, административный район.

1 Государственный университет по землеустройству, факультет землеустройства, ул. Казакова, д. 15, 105064, Москва, Россия, e-mail: gruschina_n@mail.ru

2 Национальный исследовательский Мордовский государственный университет имени Н.П. Огарёва, Географический факультет, ул. Большевистская, д. 68, 430005, Саранск, Россия, e-mail: teslserg@mail.ru

3 Национальный исследовательский Мордовский государственный университет имени Н. П. Огарева, Географический факультет, ул. Большевистская, д. 68, 430005, Саранск, Россия, e-mail: anton169@mail.ru 


\title{
Anastasia W. Grushina ${ }^{1}$, Sergey A. Teslenok ${ }^{2}$, Anton P. Mushtaykin ${ }^{3}$ \\ USING MODERN TECHNOLOGIES TO CREATE AN ELECTRONIC ATLAS OF THE ADMINISTRATIVE DISTRICT
}

\begin{abstract}
The electronic version of the atlas significantly increases the importance and role of the information product as a prototype of the necessary component of the information technology infrastructure.

The most important role in the development of electronic atlases is played by modern information technology. But they are often used to create specialized cartographic material, which accounts for large administrative units: countries and regions. At the same time, smaller entities, such as administrative districts, which are also important for economic, scientific, and educational activities, are often unfairly ignored.

The article discusses the features and results of the development and creation of an innovative information product-an electronic atlas for the territory of the Tengushevsky district of the Republic of Mordovia. The relevance of this work is obvious, since a variety of cartographic and reference material has been accumulated, which needs to be systematized and visualized. The material on electronic maps and atlases was studied, source data and software were selected, a set of GIS spatial data was formed for mapping purposes, and data was collected into a single source visualized in a standard Internet browser. As the main software for creating the cartographic basis of the future atlas, the program was chosen as ArcGIS, for the design part - CorelDRAW, and for compiling the pages of the local database - Notepad++.

The result of the work was an electronic atlas of the administrative district, integrating data obtained from various sources using the capabilities of GIS technologies in a format that allowed them to be successfully transferred to an online portal. The proposed technological scheme can serve as a guide for creating similar information products for other administrative districts.
\end{abstract}

KEYWORDS: electronic atlas, electronic map, mapping, GIS technologies, atlas program, database, software, graphic editor, internet site, administrative district.

\section{ВВЕДЕНИЕ}

В настоящее время благодаря современному уровню развития картографии, картографических технологий, методов и средств информатики и геоинформатики, геоинформационных систем (ГИС) и геоинформационных и смежных технологий предполагается создание не только бумажной версии атласа, но и электронной, в т. ч. в виде атласных информационных систем [Комиссарова, Писарев, 2005; Медведев, 2008; Геоинформатика, 2012; Бучацкая и др., 2015; Hurni, 2015; Яблоков, Тикунов, 2016; Маевская и др., 2017; Токарчук, Маевская, 2019; Грушина, Тесленок, 2020; Грушина, Тесленок, 2020; Тесленок, 2020]. В современных условиях происходит совмещение сложившихся и ставших традиционными принципов картографии с современными возможностями интернета. Это в свою очередь способствует формированию новых способов наглядной и эффективной передачи пространственно распределенной информации,

1 State University of Land Management, Faculty of Land Management, 15 Kazakova Str., 105064, Moscow, Russia, e-mail: gruschina_n@mail.ru

2 National Research Ogarev Mordovia State University; 68 Bolshevistskaya Str., Saransk 430005, Republic of Mordovia, Russia, e-mail: teslserg@mail.ru

3 National Research Ogarev Mordovia State University; 68 Bolshevistskaya Str., Saransk 430005, Republic of Mordovia, Russia, e-mail: anton169@mail.ru 
обеспечению доступа к глобальным ресурсам, а также позволяет внедрять собственные массивы геопространственных данных.

Опыт создания электронных локальных и региональных атласов (в т. ч. и на территории административных районов) достаточно велик [Медведев, 2008; Ивлиева, Манухов, 2010; Ковальчук и др., 2011; Бучачкая и др., 2015; Яблоков, Тикунов, 2016; Маевская и др., 2017; Токарчук, Маевская, 2019; Грушина, Тесленок, 2020]. В предлагаемой статье рассматриваются особенности и результаты разработки [Грушина, Тесленок, 2020] и создания электронного атласа на территорию Теньгушевского района Мордовии, находящегося на ее северо-западе, и граничащего с Темниковским и Зубово-Полянским районами республики и с соседними Нижегородской и Рязанской областями.

Таким образом, целью исследования стало создание на основе использования современных технологий инновационного информационного продукта - электронного атласа на территорию административного района, интегрирующего данные, полученные из различных источников, в формате, позволившем успешно перенести их на онлайнпортал. В ходе ее реализации решались задачи как по проектированию слоев в ГИСпрограммах, так и разработке технологии по их переносу в онлайн-среду, для чего был изучен материал об электронных картах и атласах, подобраны исходные данные и программное обеспечение, сформирован набор пространственных данных ГИС для целей картографирования, реализован сбор разноплановых данных в единый информационный источник, визуализированный в стандартном интернет-браузере.

Существует большое число определений понятия «атлас» [Чуркин, 1974; Картоведение, 2003; Геоинформатика, 2005]. Одно из них звучит следующим образом. Атлас - это систематическое собрание карт, выполненное по единой программе как целостное произведение и изданное в виде книги или сайта, размещенного в сети интернет [Чуркин, 1974; Картоведение, 2003]. Сам термин «электронный атлас» известен с 1984 г. $^{1}$ и соответствующим документом ${ }^{2}$ он определяется как система электронных карт, созданных по единой программе как целостное произведение, с общей библиотекой условных знаков. Электронная версия атласа, в отличие от бумажной, с собранными в нем различными данными, информацией и знаниями [Чуркин, 1974; Картоведение, 2003; Ивлиева, Манухов, 2010], существенно повышают значение и роль информационного продукта как прообраза необходимого компонента информационно-технологической инфраструктуры [Комиссарова, Писарев, 2005]. Основу всех электронных атласов составляют электронные карты [Геоинформатика, 2005; Ивлиева, 2005; Комиссарова, Писарев, 2005; Бучацкая и др., 2015; Яблоков, Тикунов, 2016; Тесленок, 2020]. Также, на современном этапе разработки электронных атласов стали внедрять интерактивные и мультимедийные качества. Их внесение в состав электронного атласа - это, прежде всего, привлечение внимания и интереса пользователя, так как динамичная информация, по сравнению со статичной, в большей степени способствует быстрому и полному получению, усвоению и запоминанию информации [Медведев, 2008; Векслер, 2016]. Создание любого атласа (а тем более электронного) обязательно предполагает составление его программы ${ }^{3}$ [Ивлиева, Манухов, 2010; Грушина А. В., Тесленок, 2020].

1 Совершенствование теоретических и методических положений формирования ГИС-атласа для эколого-экономических исследований (на примере Московской области). Электронный ресурс: http:// гузмосква.pф/16. phtml?id=153 (дата обращения 04.01.21).

2 ГОСТ Р 51606-2000. Карты цифровые топографические. Система классификации и кодирования цифровой картографической информации. Общие требования. М.: Стандартинформ, 2005. 13 с. Приказ Министерства экономического развития Российской Федерации № 204 «Об установлении требований к программам картографических атласов» (Зарегистрировано в Министерстве юстиции Российской Федерации 24 июля 2017 г., № 47510). Электронный ресурс: http://docs.cntd.ru/document/ 456064990 (дата обращения 04.01.21). 


\section{МАТЕРИАЛЫ И МЕТОДЫ ИССЛЕДОВАНИЯ}

Целевая аудитория потенциальных пользователей электронного атласа административного района, призванного служить, наряду с комплексом цифровых образовательных ресурсов, учебным, учебно-краеведческим и справочным пособием, представлена субъектами учебной, краеведческой, научной, социально-экономической и туристско-рекреационной деятельности - преподавателями, учащимися общеобразовательных школ, студентами, краеведами, туристами, представителям органов власти и бизнеса и просто всем, интересующимся историей, природой, населением и экономикой района.

В ходе изучения зарубежного опыта создания атласов на территории подобного масштабного уровня [Sanseverino, 2017], было решено включить в его состав следующие карты:

- географического положения района, административно-территориального деления, гипсометрическую, общегеографическую, речных бассейнов (могут быть активно использованы в учебной деятельности, на уроках изучения местной географии) [Gaarder, 2013];

- населения, полезных ископаемых, инфраструктуры (будут крайне полезны местным властям и бизнесу при разработке и реализации проектов социальноэкономического развития района) [Strauss, 2014];

- $\quad$ религии, памятников и особо охраняемых природных объектов (важны для анализа туристского-рекреационного потенциала муниципального района) [Eboy, 2017].

При создании атласа с картами столь разнообразной направленности важно подобрать масштаб, который для всей серии карт позволит как отобразить необходимую информацию в максимально полном объеме и с необходимой степенью детальности отображаемых объектов, так и в ряде случаев избежать возможной излишней загруженности карт и снижения их читаемости. Наиболее подходящим для этих целей и целесообразным по размеру изучаемой территории является масштаб 1:200 000. Использование данного масштаба было обусловлено совокупностью причин: преобладающим образовательным, учебно-краеведческим и туристско-справочным назначением атласа, тематикой карт в его составе, наличием исходных слоев цифровой тематической информации, а также незначительной плотностью картографируемых объектов. Особенность представления атласа в электронном формате позволила избежать проблем такого достаточно мелкого масштаба при помощи встроенных инструментов генерализации. Применение более крупного масштаба в сочетании с инструментами увеличения геоизображений и автоматической генерализацией отображаемых объектов предполагается в дальнейшей работе, при создании последующих вариантов электронного атласа административного района.

В качестве целевого программного обеспечения для создания картографической основы атласа был использован программный пакет ArcGIS, где имеется возможность открытия документов ArcМар и организации работы с ними: изучения информации, рассмотрения карт, подключения и отключения слоев, создания запросов к атрибутам данных, представленных на карте, визуализации географической информации.

Создание и графическое редактирование условных знаков осуществлялось в графическом редакторе векторной графики CorelDRAW. Его популярность объясняется большим набором средств создания и редактирования графических образов, удобным интерфейсом и высоким качеством получаемых изображений. С его помощью можно создавать как простые контурные рисунки, так и очень эффектные иллюстрации.

Создание сайта для просмотра в стандартном интернет-браузере осуществлялось с помощью свободного текстового редактора с открытым исходным кодом Notepad++, 
ориентированного на работу в операционных системах семейства Windows. Это редактор, предназначенный для работы с текстом, включающим огромное количество функций (среди которых подсветка синтаксиса, разметки, языков проектирования, верификации и реализации - описания и моделирования аппаратуры аналоговых, цифровых и смешанных интегральных схем и электронных систем VHDL и Verilog), которые значительной степени помогают работе по написанию документа или текста программы, существенно облегчая ориентирование в кодах.

В качестве основных источников, наряду с данными сайта Росреестра ${ }^{1}$ были использованы слои цифровой топографической основы (ЦТО) масштаба 1:200 000. Они создавались в соответствии с разработанными ГлавНИВЦ МПР России требованиями [Временные требования..., 2001]. Информация по ЦТО дается на сайте ВСЕГЕИ ${ }^{2}$.

Основные слои (административного деления, железных и автомобильных дорог и уличной сети, населенных пунктов, элементов гидрографической сети, горизонталей, лесов (рис. 1)) оцифрованы с топографической карты 1993 г. издания, что потребовало проведения очень кропотливой работы по актуализации пространственных данных.

Она подразумевала обновление не только контурной части, но и атрибутивной составляющей пространственной информации - характеристик картографируемых явлений. Цифровые слои основаны на системе классификации и кодирования ЦТО для карт геологического содержания. При этом каждый объект имеет свой код и значение характеристики ${ }^{3}$.

Для актуализации были использованы данные OpenStreetMap ${ }^{4}$, публичной кадастровой карты Росреестра ${ }^{5}$, а так же разнообразная справочная информация и статистические данные (особенно по людности населенных пунктов, месторождениям полезных ископаемых, сети особо охраняемых природных территорий и акваторий, объектам социальной и транспортной инфраструктуры и культурного наследия и др.). Дополнительно использовались растры листов топографической карты масштаба 1:100 000 на территорию Республики Мордовия из открытых интернет-источников, спутниковые снимки, полученные с помощью навигационной SAS.Planet ${ }^{6}$. Фрагменты подготовленного для создания карт атласа набора данных представлены на рисунке 1 . Кроме того, важным источником информации о картографируемых объектах стал «Географический Атлас Республики Мордовия» [Географический атлас..., 2012], а также его электронная версия, представленная в сети Интернет ${ }^{7}$.

1 Публичная кадастровая карта. [Электронный ресурс]. Режим доступа: http://pkk.rosreestr.ru (дата обрашения 04.01.21).

2 Научно-исследовательский геологический институт. Электронный pecypc: https://vsegei.ru/ru/ (дата обращения: 04.01.2021).

3 ГОСТ Р 51606-2000. Карты цифровые топографические. Система классификации и кодирования цифровой картографической информации. Общие требования. М.: Стандартинформ, 2005. 13 с.

4 OpenStreetMap - wiki-карта мира. Электронный pecypc:: https://www.openstreetmap.org/\#map= 3/69.62/-74.90 (дата обращения: 04.01.2021).

5 Публичная кадастровая карта. [Электронный ресурс]. Режим доступа: http://pkk.rosreestr.ru (дата обращения 04.01.21).

6 SASGIS - Веб-картография и навигация. Электронный pecypc: http:/www.sasgis.org/ (дата обращения: 04.01.2021).

Атлас Мордовии. Электронный ресурс: http:/geo13.ru (дата обращения 04.01.20). 


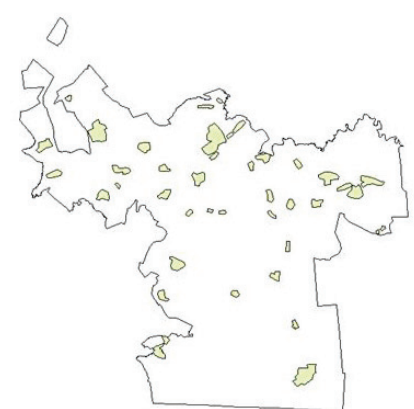

a)

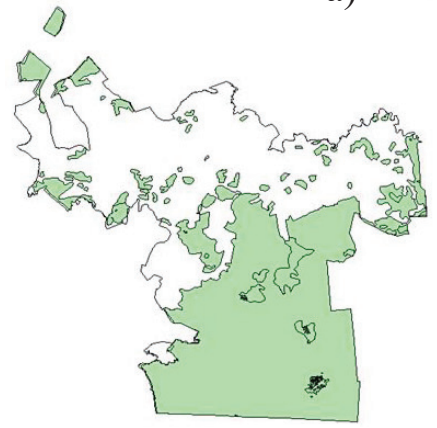

г)

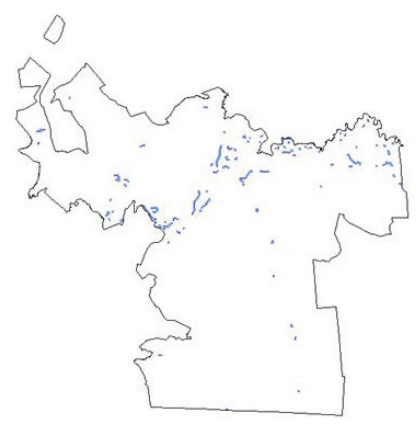

б)

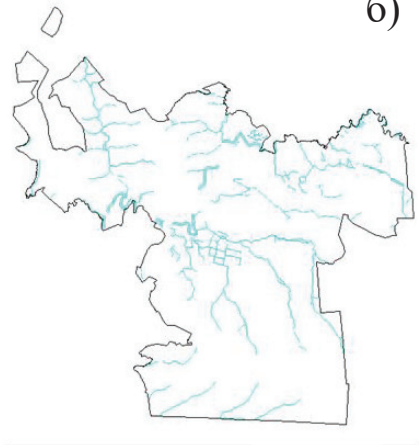

д)

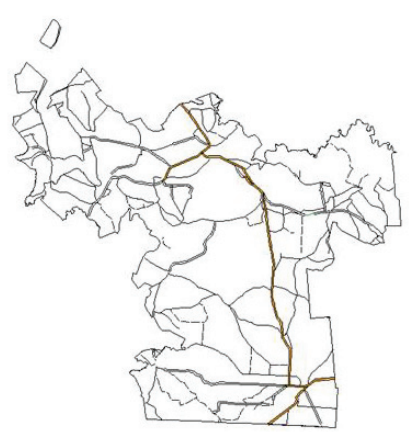

B)

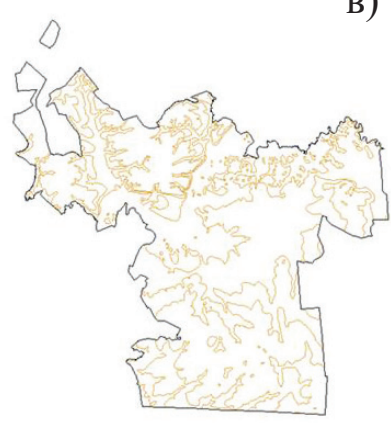

e)

Рис. 1. Некоторые используемые для создания карт атласа ицифровые слои: а, ........ әнные пункты; б) водоемыл; в) дорожная сеть; г) леса; д) речная сеть; е) рельеф

Fig. 1. Some digital layers used to create atlas maps: a) populated areas; b) water bodies; c) road network; d) forests; e) river network; f) relief

\section{РЕЗУЛЬТАТЫ ИССЛЕДОВАНИЙ И ИХ ОБСУЖДЕНИЕ}

Для отображения пространственных объектов цифровых слоев использовалась система координат проекции Гаусса-Крюгера (одна 8-я координатная зона, так как протяженность территории Мордовии по широте менее $6^{\circ}$ ). Искажения длин на территории Теньгушевского района не превышают $0,14 \%$, искажения углов при равноугольной проекции отсутствуют. У координат Y пространственных объектов (в ГИС-среде - X) не указан номер зоны. Поэтому в ArcGIS для всех слоев была установлена система координат Pulkovo_1942_GK_Zone_8N (проекция Gauss_Kruger). Она отличается от системы координат Pulkovo_1942_GK_Zone_8 смещением на восток (false easting), у Pulkovo_1942_GK_Zone_8N - 500000 м, a y Pulkovo_1942_GK_Zone_8 - 8500000 м. В практическом смысле это мало на что влияет, так как это одна и та же проекция. Отличия лишь в том, какими будут значения координат по оси Х. Использование в качестве смещения на восток значения [номер зоны]*106 + 500000 удобно, в частности тем, что координаты с большой степенью вероятности позволяют определить картографическую проекцию и ее параметры [Ивлиева, 2005].

Графическое оформление карт было выполнено с помощью ArcGIS и графического редактора CorelDRAW. Для визуализации в ArcGIS были настроены исходные слои, чтобы они соответствовали условным знакам, используемым в программе.

Так, в атрибутивной таблице были созданы поля с включением характеристик автомобильных дорог. Поле REF содержит официальное название (обозначение) дороги. Поле HIGHWAY обозначает классификатор дороги. В полях ONEWAY, BRIDGE и TUNNEL содержатся сведения об односторонних дорогах, мостах и туннелях. MAXSPEED обозначает официально разрешенную максимальную скорость. Поле LANES отражает 
количество полос, WIDTH - ширину полос. Поле SURFACE показывает тип покрытия. Далее исходный слой настраивался в соответствии с имеющимися в программе стилями.

Аналогичным образом, используя библиотеку условных знаков ArcGIS, настраивались остальные слои. После настройки и подключения необходимых слоев, определения масштаба, было получено необходимое картографическое произведение.

Некоторые карты дополнительно потребовали разработки наглядных условных знаков, выполненной в графическом редакторе CorelDRAW. В качестве их подложки использовалась ранее созданная общегеографическая основа. Для отображения всех элементов был выбран значковый способ (натуралистические значки).

При создании условных знаков, показывающих размещение образовательных объектов, церквей, памятников археологии, искусства и ботанических объектов, использовались растровые изображения (рисунки). Они были дополнительно отредактированы (придание необходимой формы, трассировка). Условные знаки, изображающие водные объекты, памятники архитектуры и медицинские учреждения были разработаны самостоятельно с помощью инструментов, представленных в редакторе. Далее созданным условным знакам придавался необходимый размер, они сопоставлялись с подложкой карты и после этого готовые карты были экспортированы в формате JPG (рис. 2 и 3).
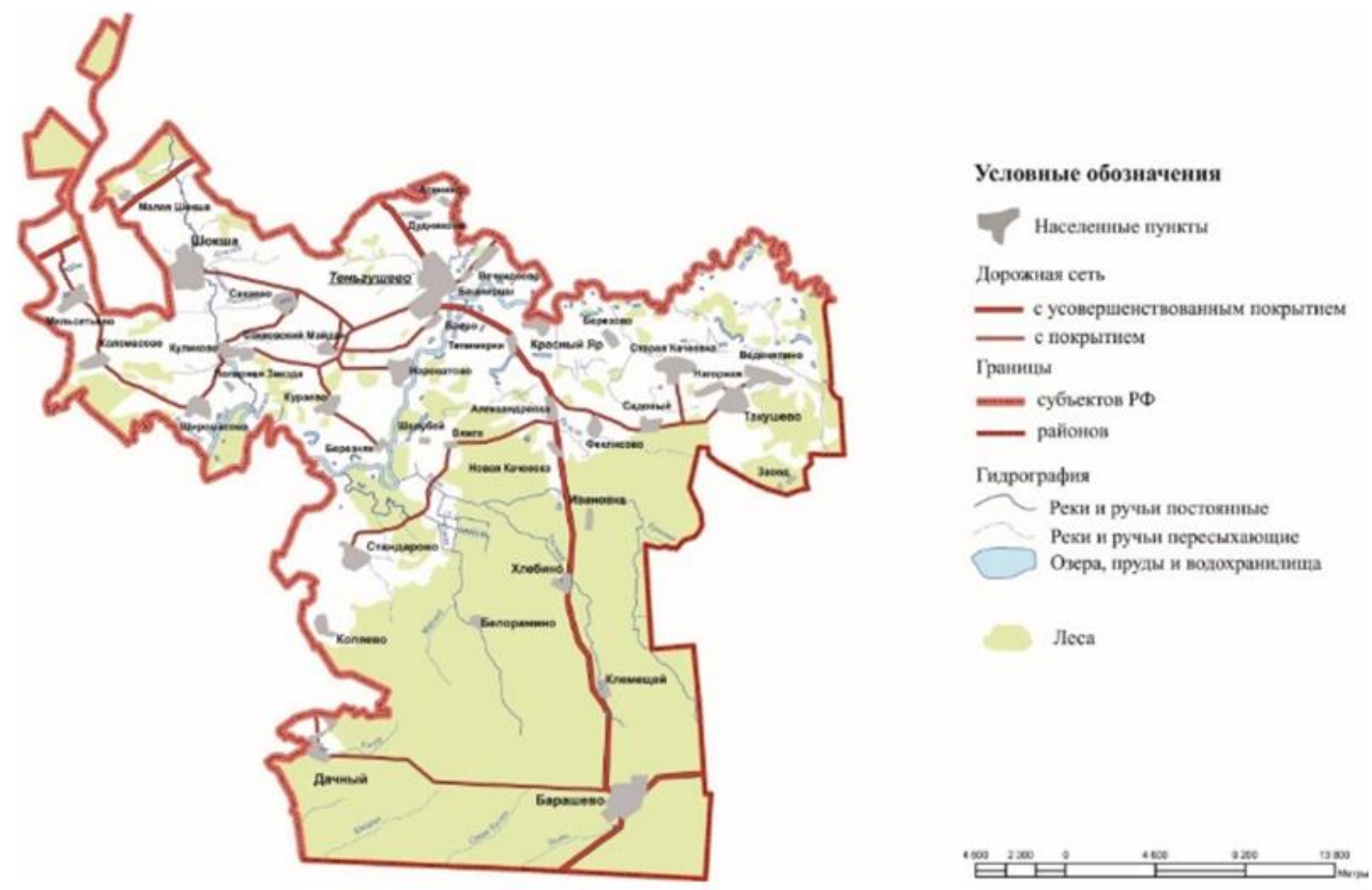

Рис. 2. Карта населенных пунктов, подготовленная для атласа в ArcGIS Fig. 2. Map of populated areas prepared for the atlas in the ArcGIS ке 3 .

Пример графической копии полученных электронных карт представлен на рисун-

Обложка (начальная страница) атласа, служащего учебно-краеведческим и справочным пособием [Грушина, Тесленок, 2020], подготовлена в графическом редакторе CorelDRAW. B eе основе - авторская фотография типичного природного ландшафта района с названием атласа. 
Локальная база данных состоит из отдельных страниц формата HTML, созданных в текстовом редакторе Notepad++. Язык разметки гипертекста HTML является основой всех размешенных в Интернете электронных документов. Это своеобразный фундамент, на базе которого реализуются остальные сетевые программные технологии [Чебыкин, 2013].
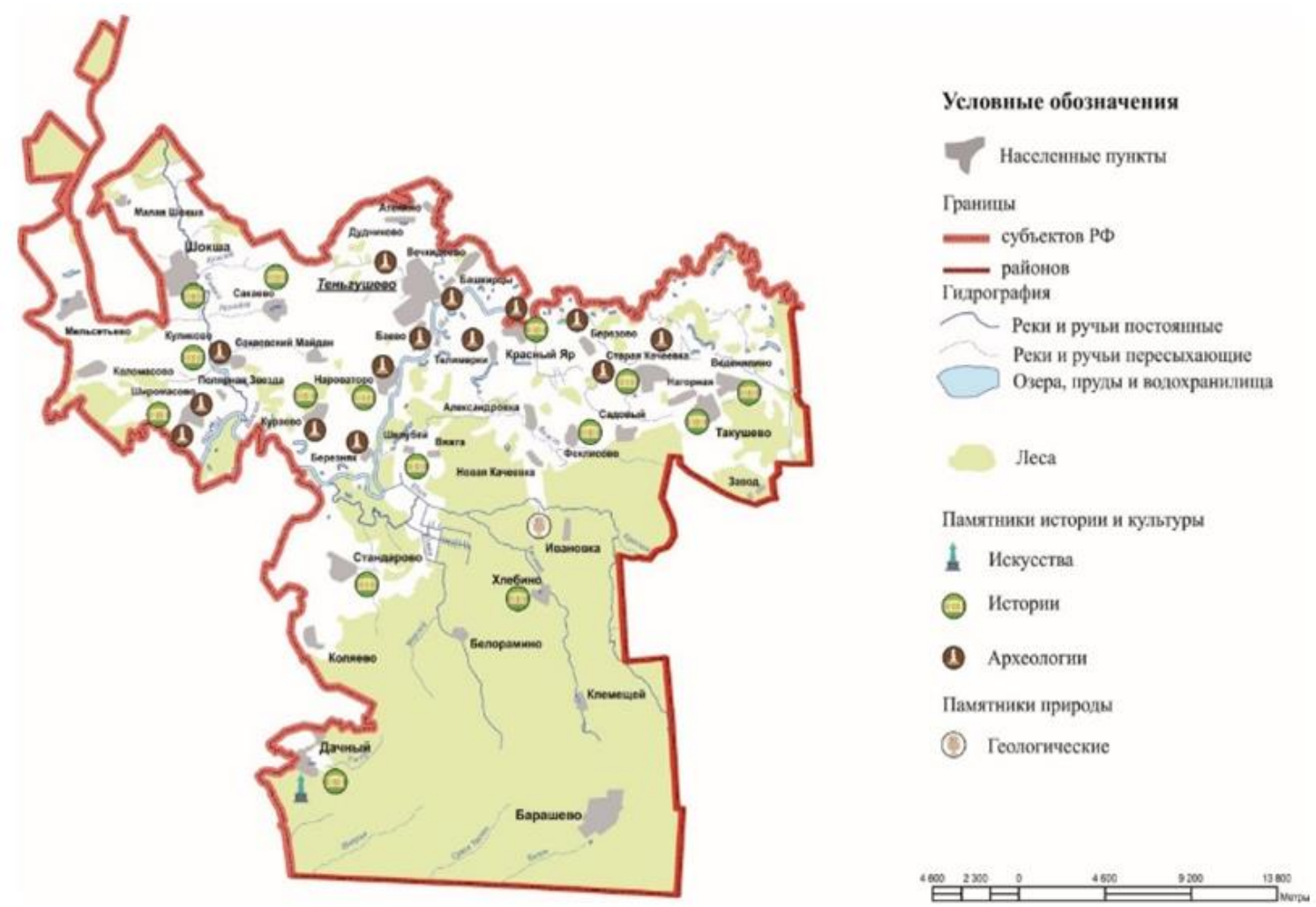

Рис. 3. Карта достопримечательностей, подготовленная для атласа в графическом редакторе CorelDRAW

Fig. 3. Sightseeing map prepared for the atlas in the graphics editor CorelDRAW

Просматривать такую страницу можно в любом Интернет браузере, просто открыв ее двойным щелчком.

Для проведения работы создается отдельная папка на компьютере, в которой будет храниться информация, и открывается программу Notepad ++ .

Структура страницы состоит из набора тегов, которые определяют элементы. Тег имя, заключенными между угловыми скобками $(<>)$. Он обычно входит в состав пары (открывающий и закрывающий теги). Между тегами могут быть заключены элементы страницы, такие как текст или графика, которые необходимо форматировать. Закрывающий тег перед именем содержит прямой слэш, для того чтобы отличить его от открывающего тега [Петюшкин, 2003].

Первое, что необходимо сделать - определить специфику документа. Для этого добавим раздел HTML, который описывается открывающимися и закрывающимися тегами $<\mathrm{html}></ \mathrm{html}>$. Это дает браузеру информацию о том, что документ разработан с помощью языка разметки HTML [Петюшкин, 2003; Чебыкин, 2013]. Внутри данного раздела добавляем раздел $\mathrm{HEAD}$, выполняющий функцию рабочего заголовка и имеющий возможность очень сильно влиять на внешний вид документа. В него с помощью языка CSS, используемого для оформления страниц, указываются стили.

Набор правил имеет следующий формат: 


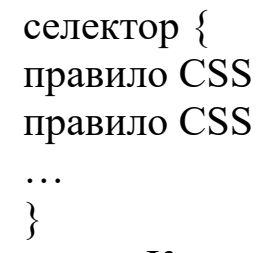

Каждый набор правил состоит из свойств CSS и их значений, имеющих следующий формат записи: свойство: значение.

Формат записи CSS-правила:

селектор \{

свойство: значение;

\}

Следующим шагом добавляем раздел BODY. Это один из важнейших компонентов любой страницы, т. к. в нем находится содержательная часть, которая выводится браузером на экран монитора. Данный тег парный и имеет ряд параметров, которые условно можно разделить на основные группы: параметры текста, графики и гиперссылок [Петюшкин, 2003; Чебыкин, 2013].

Для того чтобы добавить текст, вводим парный тег $<\mathrm{p}></ \mathrm{p}>$, внутри которого будет содержаться необходимая нам информация. Для горизонтального выравнивания текста в окне браузера также добавляем параметр Align= "justify".

Для отображения графики в данной работе используется формат JPG. Для этого в разделе BODY добавляется тег <img src="...jpg">. Здесь указывается наименование изображение, которое предварительно было сохранено в созданную ранее папку. Дополнительно можно добавить параметры изображения (размеры).

На главной странице размещаются разделы. Для того чтобы к ним был возможен переход, необходимо создать гиперссылки. Это ссылки, соединяющие одну Web-страницу с другими, и они являются одним из центральных компонентов. Любая гиперссылка состоит из двух компонентов: указателя ссылки, который может являться текстом или изображением, и URL-адреса Интернет-ресурса, на который необходимо осуществить переход.

По аналогичному сценарию создавались все страницы атласа. В полученной локальной базе данных электронного атласа хранятся отдельно страницы сайта и графическая составляющая.

Для размещения созданного электронного атласа в сети Интернет необходимо создать сайт - узел сети, объединяющий интернет-ресурсы схожей тематики. Для этого были использованы возможности бесплатного конструктора сайтов $\mathrm{UCoz}^{1}$, позволяющего создать и разместить свой сайт бесплатно. Для этого необходимо пройти регистрацию на сайте и заполнить основные сведения, касающиеся его названия и адреса. После этого из предложенного списка шаблонов можно выбрать понравившийся дизайн. По готовности каркаса сайта можно его редактировать и наполнять необходимой информацией, создавая страницы в панели инструментов и используя ранее подготовленные страницы в локальной базе данных. В результате получаем готовый сайт созданного электронного атласа Теньгушевского района, состоящего из начальной страницы и страниц разделов. Примеры страниц сайта электронного атласа представлены на рисунке 4.

1 Бесплатный конструктор сайтов. Создайте свой сайт. Электронный pecypc: https://www.ucoz.ru/ (дата обращения: 04.01.2021). 

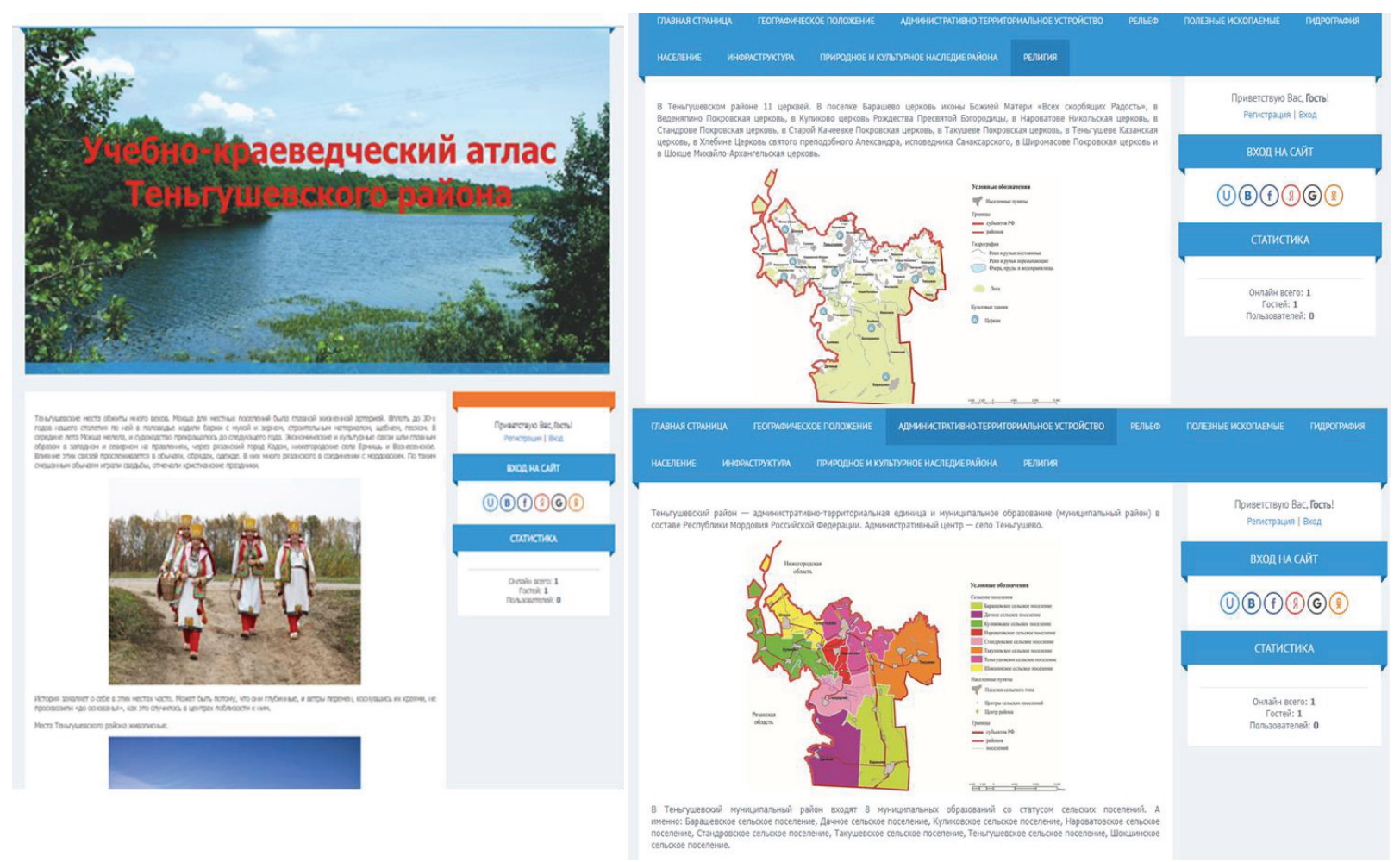

Рис. 4. Пример оформления странии электронного атласа Теньгушевского района Республики Мордовия

Fig. 4. Example of the design of the pages of the electronic atlas of the Tengushevsky district of the Republic of Mordovia

\section{ВЫВОДЫ}

В результате проделанной работы был разработан и создан инновационный информационный продукт - электронный атлас на территорию одного из административных районов Республики Мордовия - Теньгушевского. Данные, полученные из различных источников, были интегрированы и картографированы с использованием возможностей ГИС-технологий в формате, позволяющем успешно перенести их на онлайн-портал.

Созданный атлас, наряду с другими цифровыми образовательными ресурсами (прежде всего такими, как электронные терминологические словари-справочники), будет полезен и интересен в информационно-образовательной среде: преподавателям, учащимся общеобразовательных школ, студентам, краеведам, туристам и людям, интересующихся историей, природой, населением и экономикой района. Он может быть широко использован для образовательной, учебно-краеведческой, социально-экономической и туристической деятельности. Его особенностью является то, что он может дополняться новой информацией, а так же актуализировать уже имеющиеся данные. Предложенная авторами технологическая схема и отработанная технология его создания может служить руководством по разработке и созданию аналогичных информационных продуктов и успешно применяться для схожих административных регионов, как в России, так и за рубежом.

\section{БЛАГОДАРНОСТИ}

Проект реализуется победителем Конкурса на предоставление грантов преподавателям магистратуры благотворительной программы «Стипендиальная программа Владимира Потанина» Благотворительного фонда Владимира Потанина. 


\section{ACKNOWLEDGMENT}

The project is being implemented by the winner of the Master's program faculty grant competition of the Vladimir Potanin fellowship program

\section{СПИСОК ЛИТЕРАТУРЫ}

1. Бучацкая Н.В., Тесленок С.А., Козлов Д.А., Тесленок К.С. Природное компьютерное картографирование на локальном уровне. Материалы Международной конференции «ИнтерКарто. ИнтерГИС», 2015. Т. 21 (1). С. 396-408. DOI 10.24057/24149179-2015-1-21-396-408.

2. Векслер B.A. Построение интерактивных карт для HTML-документов на уроках информатики. NovaInfo, 2016. № 46-3.

3. Временные требования к представлению цифровых моделей топографической основы карт геологического содержания в Государственный банк цифровой геологической информации и информации о недропользовании в России. Сост. А.В. Столпаков. М.: ГлавНИВЦ, 2001. 55 с.

4. Географический Атлас Республики Мордовия. Саранск: Изд-во Мордов. ун-та, 2012. 204 c.

5. Геоинформатика. Под ред. В.С. Тикунова. М.: Издательский центр «Академия», 2005. $480 \mathrm{c}$.

6. Грушина A.B., Тесленок C.A. Картографическая специфика интерактивных атласов. XLVIII Огаревские чтения: Материалы науч. конф. «XLVIII Огаревские чтения», Саранск, 6-13 дек. 2019 г. В 3-х ч. Ч. 2. Естественные науки. Саранск: Изд-во Мордов. ун-та, 2020. С. 153-160.

7. Грушина A.B., Тесленок С.A. Разработка программы электронного атласа на территорию Теньгушевского района Республики Мордовия [Электронный ресурс]. Огарев-online, 2020. № 10. Режим доступа: http://journal.mrsu.ru/arts/razrabotka-programmy-elektron nogo-atlasa-na-territoriyu-tengushevskogo-rajona-respubliki-mordoviya.

8. Ивлиева Н.Г. Создание карт с использованием ГИС-технологий: учеб. пособие. Саранск: Изд-во Мордов. ун-та, 2005. 124 с.

9. Ивлиева Н. Г., Манухов В. Ф. О создании школьно-краеведческого атласа отдельного муниципального района. Геодезия и картография, 2010. № 11. С. 34-42.

10. Картоведение: Учебник для вузов. Под ред. А. М. Берлянта. М.: Аспект Пресс, 2003. $477 \mathrm{c}$.

11. Комиссарова E. В., Писарев B. C. Технология создания электронных картографических атласов. Гео-Сибирь, 2005. Т. 4. С. 94-99.

12. Маевская А.Н., Новик О.И., Токарчук О.В. Создание электронного атласа административного района по результатам комплексных геоэкологических исследований. ГИС-технологии в науках о Земле: материалы конкурса ГИСпроектов студентов и аспирантов УВО Республики Беларусь, проведенного в рамках празднования Международ. дня ГИС 2017, Минск, 15 нояб. 2017 г. Минск: БГУ, 2017. С. 111-115.

13. Медведев A. A. Методика создания мультимедийного регионального атласа (на примере атласа Курильских островов): автореф. дис. ... канд. геогр. наук. М., 2008. $26 \mathrm{c}$.

14. Петюшкин A. HTML. Экспресскурс. СПб.: БХВ-Петербург, 2003. 242 с.

15. Тесленок С.A. Разработка и создание интерактивного электронного атласа «Инновации в регионах России». Инновационное развитие сельского хозяйства России: Монография. Под ред. А.М. Носонова. Саранск: Изд-во Мордов. ун-та, 2020. С. 63-81.

16. Токарчук С.М., Маевская А.Н. Разработка и создание электронного атласа 
памятников природы Брестской области. Псковский регионологический журнал, 2019. Вып. 2 (38). С. 63-77. Электронный pecypc: http://ras.jes.su/ region/ s221979310012058-6-1 (дата обращения: 04.01.2021).

17. Чебыкин P. Самоучитель HTML и CSS. Современные технологии. М.: Мир, 2013. $624 \mathrm{c}$.

18. Чуркин В.Г. Атласная картография. Л.: Наука. Ленингр. отд-ние, 1974. 138 с.

19. Яблоков В.М., Тикунов В.С. Атласные информационные системы для устойчивого развития территорий. Материалы Международной конференции «ИнтерКарто. ИнтерГИС», 2016. Т. 22 (1). С. 13-33.

20. Eboy O. Tourism mapping: an overview of cartography and the use of GIS. Kota Kinabalu: University Malaysia Sabah Publishing house, 2017. P. 12-18.

21. Gaarder M. Evidence Gap Maps. A Tool for Promoting Evidence-Informed Policy and Prioritizing Future Research. Washington: Policy Research Working Papers, 2013. P. 124-127.

22. Hurni L. Atlas Information Systems. Encyclopedia of GIS. Cham. Springer International Publishing, 2015. P. 1-7. DOI 10.1007/978-3-319-23519-6_847-2.

23. Ковальчук І.П., Андрейчук Ю.М., Іванов С.А. Інформачійне $і$ програмне забезпечення створення атласу земельних ресурсів адміністративного району. Часопис картографії: зб. наук. праць. Киів: КНУ ім. Тараса Шевченка, 2011. Вип. 1. C. $88-101$.

24. Sanseverino E. Smart cities atlas. Springer International Publishing, 2017. P. 34-41. DOI 10.1007/978-3-319-47361-1.

25. Strauss $B$. Improving population representation through geographic health information system. Ann Arbor: J Urban Health, 2014. P. 136-150.

\section{REFERENCES}

1. Buchatskaya N.V., Teslenok S.A., Kozlov D.A., Teslenok K.S. Natural computer mapping at the local level. Proceedings of the International conference "InterCarto. InterGIS". 2015. V. 21 (1). P. 396-408. DOI 10.24057/2414-9179-2015-1-21-396-408 (in Russian).

2. Chebykin R. Tutorial HTML and CSS. Modern technologies. Moscow: Mir, 2013. 624 p. (in Russian).

3. Churkin V.G. Atlas cartography. Leningrad: Nauka. Leningr. department, 1974. 138 p. (in Russian).

4. Eboy O. Tourism mapping: an overview of cartography and the use of GIS. Kota Kinabalu: University Malaysia Sabah Publishing house, 2017. P. 12-18.

5. Gaarder M. Evidence Gap Maps. A Tool for Promoting Evidence-Informed Policy and Prioritizing Future Research. Washington: Policy Research Working Papers, 2013. P. 124-127.

6. Geographical Atlas of the Republic of Mordovia. Saransk: Publishing House of Mordovian University, 2012. 204 p. (in Russian).

7. Geoinformatics. Ed. V.S. Tikunov. Moscow: Publishing Center "Academy", 2005. 480 p. (in Russian).

8. Grushina A.V., Teslenok S.A. Cartographic specifics of interactive atlases. XLVIII Ogarev readings: Materials of the scientific conference "XLVIII Ogarev Readings", Saransk, 6อ13 Dec. 2019 In 3 parts. Part 2. Natural Sciences. Saransk: Publishing House of Mordovian University, 2020. P. 153-160 (in Russian).

9. Grushina A.V., Teslenok S.A. The development of electronic atlas program for the territory of the Tengushevsky district of the Republic of Mordovia. Ogarev-online, 2020. No 10. Web resource: http://journal.mrsu.ru/arts/razrabotka-programmy-elektronnogo- 
atlasa-na-territoriyu-tengushevskogo-rajona-respubliki-mordoviya (accessed 04.01.2021) (in Russian).

10. Hurni L. Atlas Information Systems. Encyclopedia of GIS. Cham. Springer International Publishing, 2015. P. 1-7. DOI 10.1007/978-3-319-23519-6_847-2.

11. Ivlieva N.G. Creating maps using GIS technologies: textbook manual. Saransk: Publishing House of Mordovian University, 2005. 124 p. (in Russian).

12. Ivlieva N.G., Manuhov V.F. On the creation of a school and local history atlas of a separate municipal district. Geodesy and cartography, 2010. No 11. P. 34-42 (in Russian).

13. Kartovedenie. Textbook for universities. Ed. Berlyant A.M. Moscow: Aspect Press, 2003. 477 p. (in Russian).

14. Komissarova E.V., Pisarev V.S. Technology for creating electronic cartographic atlases. Geo-Sibir', 2005. V. 4. P. 94-99 (in Russian).

15. Koval'chuk I.P., Andrejchuk Ju.M., Ivanov E.A. Information and software creation of the atlas of land resources of the administrative district. Journal of cartography: sat. scientific works. Kyiv: Taras Shevchenko National University of Kyiv, 2011. Issue 1. P. 88-101.

16. Maevskaya A.N., Novik O.I., Tokarchuk O.V. Creation of an electronic atlas of the administrative district based on the results of complex geoecological studies. GIS-technologies in Earth sciences: materials of the contest of GIS projects of students and postgraduates of the Higher Education Institution of the Republic of Belarus, held in the framework of the celebration of the International Day. GIS Day 2017. Minsk, November 15, 2017. Minsk: BSU, 2017. P. 111-115 (in Russian).

17. Medvedev A.A. Methodology for creating a multimedia regional atlas (using the example of the Kuril Islands Atlas): autoref. dis. ... candidate of geographical sciences. Moscow, 2008. 26 p. (in Russian).

18. Petyushkin A. HTML. Expresskurs. St. Petersburg: "BHV-Petersburg", 2003. 242 p. (in Russian).

19. Sanseverino E. Smart cities atlas. Springer International Publishing, 2017. P. 34-41 DOI: 10.1007/978-3-319-47361-1.

20. Strauss B. Improving population representation through geographic health information system. Ann Arbor: J Urban Health, 2014. P. 136-150.

21. Temporary requirements for the submission of digital models of the topographic basis of maps of geological content to the State Bank of Digital Geological Information and Information on Subsurface Use in Russia. Comp.: A.V. Stolpakov. Moscow: GUGP «GlavNIVC, 2001. 55 p. (in Russian).

22. Teslenok S.A. Development and creation of an interactive electronic atlas "Innovations in the regions of Russia". Innovative development of agriculture in Russia: Monograph. Ed. A.M. Nosonov. Saransk: Publishing House of Mordovian University, 2020. P. 63-81 (in Russian).

23. Tokarchuk S.M., Maevskaya A.N. Development and creation of an electronic atlas of natural monuments of the Brest region using cloud mapping platform. Pskov regional studies journal, 2019. Issue 2 (38). P. 63-77. Web resource: http://ras.jes. su/region/s221979310012058-6-1 (accessed 04.01.2021) (in Russian).

24. Veksler V.A. Building interactive maps for HTML documents at computer science lessons. NovaInfo, 2016. No 46 (3) (in Russian).

25. Yablokov V.M., Tikunov V.S. Atlas information systems for sustainable development of territories. Proceedings of the International conference "InterCarto. InterGIS". 2016. V. 22 (1). P. 13-33 (in Russian). 


\title{
Т.С. Нокелайнен ${ }^{1}$
}

\section{КАРТОГРАФИРОВАНИЕ СЕЗОННОЙ АВТОТРАНСПОРТНОЙ ДОСТУПНОСТИ АРКТИЧЕСКОГО РЕГИОНА РОССИИ}

\begin{abstract}
АННОТАЦИЯ
Транспортная доступность является одной из основных категорий в исследованиях транспорта и планирования социально-экономического развития территорий. Для России, имеющей наибольшую площадь северных и арктических территорий, эта проблема особенно актуальна. Наличие и состояние сети автомобильных дорог определяет территориальную целостность и единство экономического пространства, выполняет важнейшую стратегическую задачу пространственной интеграции страны.

Автомобильный транспорт в Арктической зоне Российской Федерации развит слабо и характеризуется низкой густотой сети общего пользования. Основные его особенности разобщённость сети автодорог, неоднородная степень транспортной освоенности территорий, заметная роль автозимников в дорожной инфраструктуре.

Неотъемлемой частью транспортной логистики арктических регионов России являются автозимники, позволяющие осуществлять перевозки в зимнее время года с наименьшими затратами. Целью настоящего исследования является разработка структуры базы данных и тематическое картографирование автомобильных дорог Арктической зоны Российской Федерации с учетом сезонности их эксплуатации.

В результате проведённых работ разработана классификация зимних автомобильных дорог и ледовых переправ арктических территорий и составлена обзорная карта «Сезонная автотранспортная доступность Арктического региона России» масштаба 1: 20000 000. Карта демонстрирует контраст между относительно хорошей зимней транспортной освоенностью территории и летним бездорожьем.

На основе статистических материалов составлены карты «Плотность всесезонных автомобильных дорог» и «Уровень автомобилизации», дающие представление о дифференциации регионов Арктической зоны РФ по этим показателям. Достаточно высокий уровень автомобилизации значительно опережает возможности существующих дорог. Это объясняется тем, что внедорожный транспорт является единственным гарантом мобильности для жителей труднодоступных населённых пунктов.
\end{abstract}

КЛЮЧЕВЫЕ СЛОВА: тематическое картографирование, автомобильный транспорт, Арктическая зона Российской Федерации, зимние автомобильные дороги.

1 Московский Государственный Университет имени М.В. Ломоносова, Географический факультет, Региональный центр мировой системы данных, Ленинские горы, д. 1, 119991, Москва, Россия, e-mail: nokelta@geogr.msu.su 
Tatiana S. Nokelaynen ${ }^{1}$

\title{
MAPPING OF SEASONAL ROAD TRANSPORT ACCESSIBILITY IN THE ARCTIC REGION OF RUSSIA
}

\begin{abstract}
Transport accessibility is one of the main categories in transport research and planning of socio-economic development of territories. For Russia, which has the largest area of the northern and arctic territories, this problem is especially urgent. The presence and condition of the road network determines the territorial integrity and unity of the economic space, therefore fulfilling the most important strategic task of the spatial integration of the country.

Automobile transport in the Arctic zone of the Russian Federation is poorly developed and is characterized by a low density of the public network. Its main features are the disunity of the road network, the heterogeneous degree of transport development of the territories and the noticeable role of winter roads in the road infrastructure.

An integral part of the transport logistics of the Arctic regions of Russia are winter roads, which allow transportation in the winter season at the lowest cost. The purpose of this study is to develop a database structure and thematic mapping of automobile roads in the Arctic zone of the Russian Federation, taking into account the seasonality of their operation.

As a result of this work, a classification of winter automobile roads and ice crossings of the Arctic territories was developed and an overview map "Seasonal road transport accessibility of the Arctic region of Russia" at a scale of 1:20 000 000 was compiled. The map demonstrates the contrast between the relatively good winter transport development of the territory and summer impassability.

On the basis of statistical materials, maps "Density of all-season motorable roads" and "Level of motorization" were compiled, which give an idea of the differentiation of the regions of the Arctic zone of the Russian Federation by these indicators. A high level of motorization significantly exceeds the capacity of the existing roads. This is due to the fact that off-road transport is the only guarantor of mobility for the population of hard-to-reach settlements.
\end{abstract}

KEYWORDS: thematic mapping, road transport, the Arctic Zone of the Russian Federation, winter automobile roads.

\section{ВВЕДЕНИЕ}

Автомобильный транспорт в Арктической зоне Российской Федерации развит слабо и характеризуется низкой густотой сети общего пользования. Основные его особенности разобщённость сети автодорог, неоднородная степень транспортной освоенности территорий, заметная роль автозимников в дорожной инфраструктуре.

Лимитирующими факторами транспортного освоения выступают различные зональные и азональные природные и социально-экономические факторы: климатические условия, рельеф, распространение мерзлотных явлений, дисперсная система расселения, недостаточный экономический потенциал территорий [Неретин $u д p$., 2019]. Ситуация усугубляется экстремальными природно-климатическими условиями, которые приводят к удорожанию стоимости строительства транспортных коммуникаций, высокой экологической уязвимости северных экосистем, снижению эффективности [Социальноэкономическое..., 2019].

1 Moscow State University named after M.V. Lomonosov, Faculty of Geography, Leninskie Gory 1, 119991, Moscow, Russia, e-mail: nokelta@geogr.msu.su 
Одной из основных задач в сфере развития инфраструктуры Арктической зоны Российской Федерации является «обеспечение транспортной доступности населённых пунктов, не имеющих связи с сетью автомобильных дорог общего пользования» [Основы государственной политики Российской Федерации в Арктике на период до 2035 года от 05.03.2020; http://www.scrf.gov.ru/security/economic/Arctic2035/].

Даже в европейской части Арктической зоны Российской Федерации сохранилось значительное число населённых пунктов, изолированных от магистральной транспортной сети и не имеющих доступа к базовым социальным услугам [Бадина и др., 2020].

Транспортная доступность как экономико-географическая категория определяется в научной литературе различно: по отношению к транспортному комплексу как отраслевой показатель, к социальному развитию как фактор транспортной подвижности населения, к экономическому развитию как фактор эффективности хозяйственных связей [Лавриненко $u$ дp., 2019].

Иногда этот термин максимально упрощается, и единственным критерием транспортной доступности становится сама возможность достижения того или иного пункта из данной точки.

Транспортную доступность можно оценивать различными способами (оценкой доли населения страны, проживающего в определенном радиусе доступности от данной точки, оценкой времени в пути до ключевых центров, показателями транспортной освоенности (обеспеченности) территории и т.д.) [Интегрированная..., 2018].

Для зонирования транспортных систем используются транспортное моделирование и геоинформационные системы. На основе топологического анализа и информации о перемещении автомобилей выявляется соответствие морфологии сети и фактического трафика, производится пространственный кластерный анализ, итогом которого служит проведение границ между полученными районами [Crose et al., 2019].

Одним из основных показателей уровня транспортной освоенности территории является плотность сети автомобильных дорог (как правило, общего пользования), приходящихся на единицу площади. В целом по данному показателю районы Арктической зоны Российской Федерации занимают последние места в рейтинге регионов России [https://rosstat.gov.ru/storage/mediabank/fimgAF33/Region_Pokaz_2020.pdf].

Относительно хорошая ситуация в автодорожной сфере характерна для Европейского Севера, имеющего круглогодичную связь с общероссийской системой дорог. В Мурманской и Архангельской областях обеспеченность связи населённых пунктов дорогами с твёрдым покрытием составляет 74 и $54.5 \%$ соответственно. В Ненецком АО этот показатель гораздо скромнее - 14.3 \% [Социально-экономическое..., 2019].

Общая протяжённость автомобильных дорог федерального значения на территории Арктической зоны РФ - 729,5 километра [Серова и др., 2019]. Магистральные автомобильные дороги выходят в арктическую зону только на порты Мурманск (P-21 «Кола») и Архангельск (М-8 «Холмогоры»).

Федеральные дороги являются наиболее совершенными в техническом отношении, имеют обширный район тяготения и обслуживают широкий спектр транспортных связей от внутрихозяйственных до международных.

На границе Российской Федерации в пределах Мурманской области функционируют 3 постоянно действующих международных автомобильных пропускных пункта (МАПП): Лотта и Сала (Финляндия), Борисоглебский (Норвегия); на территории Карелии (Лоухский район): Суоперя (Финляндия).

Также имеются дороги с твёрдым покрытием в Ненецком автономном округе, но отсутствует выход на автодорожную сеть России. 
Сеть автодорог на востоке Арктической зоны РФ представлена, в основном, дорогами местного значения. Протяжённость дорог с твёрдым покрытием растёт очень медленно, в основном за счёт технологических дорог вдоль трубопроводов. Сезонные трассы (полевые, лесные, автозимники, тракторные) имеют серьёзные ограничения по виду и срокам эксплуатации.

Отсутствие в восточном секторе Арктики сухопутного транспортного сообщения с остальной частью страны обуславливает многозвенность и безальтернативность схем транспортного обслуживания [Серова и др., 2019].

Согласно Стратегии развития Арктической зоны Российской Федерации на период до 2035 года, завершение строительства федеральной дороги Колыма - Омсукчан - Омолон - Анадырь к 2030 году создаст постоянную автомобильную связь Чукотского автономного округа с дорожной сетью Российской Федерации [http://kremlin.ru/acts/ bank/45972/page/4].

Наличие автодороги с возможностью круглогодичного использования резко повышает транспортную доступность территории и способствует переходу пассажиров с воздушного на более доступные (с точки зрения затрат на поездку) виды транспорта: личный автомобильный, автобусный и рейсы частных перевозчиков [Неретин и дp., 2019].

Большинство автодорог в арктических районах - зимники, которые используются там, где строительство регулярных путей сообщения технически сложно или экономически нецелесообразно. Они являются неотъемлемой частью логистической цепи региона [Куклина и др., 2018].

Всего в России ежегодно прокладывают более 28 тысяч км зимников. В сезон 20192020 годов были официально открыты 174 такие дороги [www.rosdornii.ru/news]. Для сравнения: федеральная сеть асфальтовых дорог общего пользования в стране составляет более 50 тысяч км.

В Арктической зоне Российской Федерации находится самый длинный морской зимник в мире. Его протяжённость - 120 км, и проложен он по Восточно-Сибирскому морю между городом Певек и чукотским селом Айон [https://arctic-russia.ru/article/ arkticheskayadoroga-zhizni/].

Самая северная ледовая переправа находится на Таймыре - через пролив Карского моря соединяет посёлок Диксон с одноимённым островом, где расположен аэропорт, обеспечивающий жизнедеятельность посёлка, арктических экспедиций и полярных станций. Ледовая переправа длиной 5,6 км и шириной 20 м работает с ноября по июнь [https://portnews.ru/news/287716/].

В 2020 году впервые введен в действие национальный стандарт ГОСТ Р 58948 - 2020 «Дороги автомобильные общего пользования. Дороги автомобильные зимние и ледовые переправы. Технические правила устройства и содержания».

Новый стандарт устанавливает технические правила устройства зимних автомобильных дорог (автозимников) и ледовых переправ в климатических условиях северных территорий и Заполярья Российской Федерации с устойчивыми низкими температурами и их эксплуатации в зимний период в течение пяти-шести месяцев в году. Появление «арктических стандартов» значительно ускорит внедрение перспективных технологий в арктической зоне.

Традиционные методы строительства зимников наносят экологический ущерб растительному покрову тундры. В последние годы разработана технология прокладки зимников, при которой снег с дороги прогревается и спрессовывается в снеголедяной слой будущее полотно проезжей части дороги. При этом не происходит срыва верхнего слоя грунта и уничтожения мохово-растительного покрова [https://ardexpert.ru/article/5072]. 


\section{МАТЕРИАЛЫ И МЕТОДЫ ИССЛЕДОВАНИЯ}

Для решения целого ряда проблем, сложившихся при освоении Арктического региона России, необходим пространственный анализ и комплексная картографическая оценка современной транспортной ситуации.

Целью настоящего исследования является разработка базы данных и тематическое картографирование автомобильных дорог Арктической зоны Российской Федерации с учетом сезонности их эксплуатации.

Информационной основой для создания карт послужила пространственная база данных автомобильного транспорта Атласной информационной системы устойчивого развития России, создаваемой на географическом факультете МГУ имени М.В. Ломоносова. Система содержит разнообразные ресурсы, позволяющие моделировать, визуализировать и проводить всесторонний анализ устойчивости природной, экономической и социально-демографической ситуации в России и в её регионах [Тикунов и др., 2014; Губанов и др., 2020].

Транспортный раздел системы включает в себя обширную пространственновременную базу данных, разработанную с учётом опыта проектирования баз геоданных этой тематики [Butler, 2008].

Тематическое картографирование автомобильного транспорта России на основе сформированной базы данных реализовано при участии автора в ряде проектов федерального уровня:

- $\quad$ в Экологическом атласе России;

- $\quad$ в Атласе природных и техногенных опасностей и рисков чрезвычайных ситуаций на территории Российской Федерации;

- $\quad$ в Национальном атласе России;

- $\quad$ в Атласе социально-экономического развития России.

Также на основе этой базы данных были проведены работы по картографированию транспортной инфраструктуры Арктической зоны Российской Федерации:

- $\quad$ в Атласе «Российская Арктика в XXI веке: природные условия и риски освоения»;

- $\quad$ в Атласе «Российская Арктика: Пространство. Время. Ресурсы».

При создании карт реализован комплексный метод картографирования, учитывающий природно-экологические, технологические и транспортно-экономические характеристики автомобильного транспорта.

Для «Экологического атласа России» разработана карта воздействия автомобильного транспорта на окружающую среду (1:20 000 000). Основными критериями оценки степени загрязнения территории вдоль дорог послужили интенсивность движения автотранспорта и виды транспортируемых грузов (выделены 4 категории). Площадное загрязнение характеризуется показом на карте степени вероятного автотранспортного загрязнения территорий с различной густотой автомобильных дорог. Густота автодорожной сети показана на карте способом изолиний с послойной окраской (8 ступеней) [Экологический..., 2002; Nokelaynen, 2015].

В «Атласе природных и техногенных опасностей и рисков чрезвычайных ситуаций на территории Российской Федерации» оценивается подверженность автомобильной инфраструктуры воздействию природных источников чрезвычайных ситуаций. Фон карты показывает вероятное число опасных природных явлений, способных вызвать чрезвычайные ситуации на дорогах - размыв, разрушение, занос полотна, обрыв контактных линий [Атлас..., 2010].

На карте «Транспортная доступность Москвы на автомобильном транспорте» из тома «Население. Экономика» Национального атласа России способом изохрон с 
послойной окраской даётся количественная оценка этого показателя (в часах) для всей территории России. Для создания этой карты проведено ГИС-моделирование с использованием базы данных автомобильных дорог. Масштаб карты - 1:15 000 000. [Национальный..., 2008].

Для Атласа социально-экономического развития России разработаны карты динамики перевозок грузов и пассажиров автомобильным транспортом [Атлас социально-экономического..., 2009].

Для Атласа «Российская Арктика: Пространство. Время. Ресурсы» (2019) разработаны сюжеты и темы, раскрывающие основные особенности транспортного освоения Арктической зоны Российской Федерации.

На картах раздела «Инфраструктура» дается разнообразная характеристика функционирования транспортной системы - ледовые условия морского судоходства, сроки навигации и гарантированные глубины арктических рек, техническое состояние сети аэродромов, охват спутниковых систем связи, наличие электронных навигационных карт и т.П. Показаны перспективные арктические проекты формирования сети автомобильных и железных дорог, создания современных объектов логистики [Российская..., 2019; Нокелайнен, 2019].

Карты раздела показывают многоаспектное влияние транспорта на социальноэкономическое развитие Арктической зоны Российской Федерации. Прежде всего, это система жизнеобеспечения удаленных регионов (северный завоз), а также инфраструктура обслуживания населения.

Именно комплексный подход при картографировании даёт возможность получить целостное впечатление о транспортной доступности арктических регионов - сезонность работы водных путей сообщения компенсируется в ряде случаев зимними автомобильными дорогами или ледовыми автозимниками; наличием инфраструктуры всесезонного воздушного транспорта. Оптимизация сочетания использования разных видов транспорта в разные сезоны имеет здесь колоссальное практическое значение.

Картографирование автотранспортной инфраструктуры Российской Арктики с помощью геоинформационного программного продукта ArcGIS включало в себя следующие этапы:

- Обновление базы пространственных данных современной сети автомобильных дорог Арктической зоны Российской Федерации;

- $\quad$ Создание базы пространственных данных сезонных дорог (зимних автомобильных дорог, ледовых автозимников, ледовых переправ);

- $\quad$ Формирование тематической базы данных сезонных дорог и ледовых переправ Арктической зоны Российской Федерации;

- $\quad$ Разработка классификаций и оценочных показателей, выбор условных обозначений;

- Составление тематических карт «Сезонная автотранспортная доступность Арктического региона России» (масштаб - 1:20 000 000), «Плотность всесезонных автомобильных дорог» (1:30 000 000), «Уровень автомобилизации» (1:30 000000$)$.

Основными источниками для работы послужили: официальная статистическая информация Федеральной службы государственной статистики [http://www.gks.ru], материалы Министерства транспорта России [https:/www.mintrans.ru], многочисленные картографические и литературные источники, опубликованные в различных изданиях. Использована информация с официального сайта Госкомиссии по развитию Арктики [http://arctic.gov.ru], материалы официальных сайтов транспортных компаний арктических регионов России [https://karta.yanao.ru/eks/zimnik; http://дорогиарктики.pф/161019-2 и др.]. 


\section{РЕЗУЛЬТАТЫ ИССЛЕДОВАНИЯ И ИХ ОБСУЖДЕНИЕ}

В результате проведённых исследований создана тематическая база данных и разработаны обзорные карты автотранспортной инфраструктуры Арктической зоны Российской Федерации с учетом сезонности эксплуатации дорог.

Разработана классификация зимних автомобильных дорог и ледовых переправ арктических территорий.

Зимняя автомобильная дорога (автозимник) - это сезонная автомобильная дорога, состоящая из конструктивных элементов, предназначенных для движения транспортных средств, с покрытием проезжей части изо льда, уплотнённого снега и льда или проложенная по замёрзшему льду рек и озёр [ГОСТ Р 58948-2020, статья 3.2].

Автозимники классифицируются по значению (федеральные, региональные или межмуниципальные, местные); по принадлежности (государственные, частные автозимники); по категориям в зависимости от технических параметров.

Также автозимники подразделяются по периодичности эксплуатации (регулярные, временные, разового пользования); по продолжительности использования (обычные, с продленным сроком эксплуатации); по расположению на местности (сухопутные и ледовые).

Ледовые переправы классифицируются по протяжённости (малые, средние и большие); по продолжительности эксплуатации (регулярные, разового пользования).

Классификация зимних автомобильных дорог по категориям (I, II, III) в зависимости от технических параметров составлена в соответствии с ГОСТ Р 58948-2020 и представлена на рис. 1 (рис. 1).

\begin{tabular}{|l|c|c|c|}
\hline Параметры автозимников & \multicolumn{2}{|c|}{ Значение параметра в зависимости от категории } \\
\hline Число полос движения & I & II & III \\
\hline Ширина полосы движения, м & 2 & 2 & 2 \\
\hline Ширина проезжей части, м & 4.0 & 3.5 & 3.0 \\
\hline Ширина обочины, м & 8.0 & 7.0 & 6.0 \\
\hline Ширина полотна автозимника, м & 2.0 & 1.5 & 1.5 \\
\hline Основная расчетная скорость, км/ч & 12.0 & 10.0 & 9.0 \\
\hline Грузонапряженность, нетто в год & 70 & 60 & 50 \\
\hline Интенсивность движения, авт/сутки & более 100000 & $50000-100000$ & менее 50000 \\
\hline
\end{tabular}

Рис. 1. Классификация зимних автомобильных дорог

Fig. 1. Winter automobile roads classification

Специальное тематическое содержание карты «Сезонная автотранспортная доступность Арктического региона России» масштаба 1:20 000000 включает автомобильные дороги (с классификацией по значению), главные сезонные автодороги (автозимники), железные дороги и судоходные реки. Фоновая нагрузка карты даёт характеристику густоты сети автомобильных дорог, показанную способом изолиний с послойной окраской (6 ступеней). Карта представлена на рис. 2 (рис. 2).

С помощью разработанной автором методики показатель густоты сети смоделирован для всей территории России по крупномасштабным картографическим материалам [Nokelaynen, 2015]. Конкретные количественные характеристики изолиний густоты позволили провести районирование территории по этому показателю и существенно детализировать, приблизив к реальной, картину автотранспортной освоенности России. 


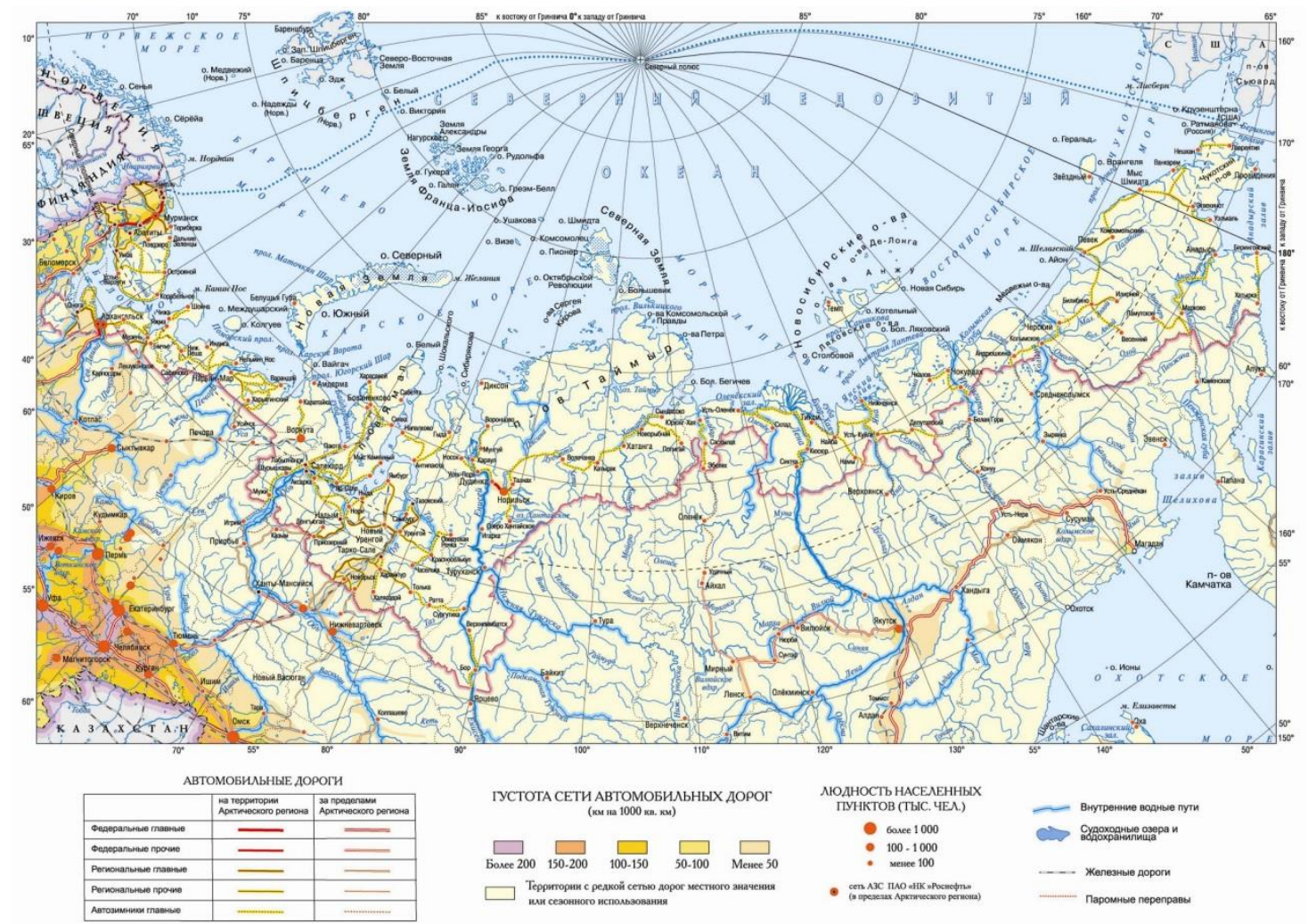

Рис. 2. Карта «Сезонная автотранспортная доступность Арктической зоны Российской Федеращии», масштаб 1:20 000000

Fig. 2. Map "Seasonal road transport accessibility

of the Arctic Zone of the Russian Federation", scale 1:20 000000

На карте показаны автомобильные дороги всесезонного использования, обеспечивающие круглогодичную связь Арктической зоны Российской Федерации с общероссийской сетью дорог (4 градации). Федеральные дороги являются наиболее совершенными в техническом отношении и обслуживают широкий спектр транспортных связей - от внутрихозяйственных до международных.

Неотъемлемой частью транспортной логистики Арктического региона России являются автозимники, позволяющие осуществлять перевозки в зимнее время года с наименьшими затратами. На карте показаны локальные и очаговые сети главных сезонных автодорог, а также их выходы на федеральные трассы.

Карта демонстрирует контраст между относительно хорошей зимней транспортной освоенностью территории и летним бездорожьем.

Классическим и самым распространённым способом оценки транспортной освоенности территории является её расчёт на основе стандартных статистических данных. Одним из основных показателей уровня транспортной освоенности территории является плотность сети автомобильных дорог, приходящихся на единицу площади.

На карте «Плотность всесезонных автомобильных дорог» масштаба 1:30 000000 способом картограммы показана плотность автомобильных дорог общего пользования с твердым покрытием регионов Арктической зоны Российской Федерации. Карта представлена на рис. 3.

Составленная на основе статистических материалов, карта дает представление о дифференциации регионов Арктической зоны РФ по этому показателю. 


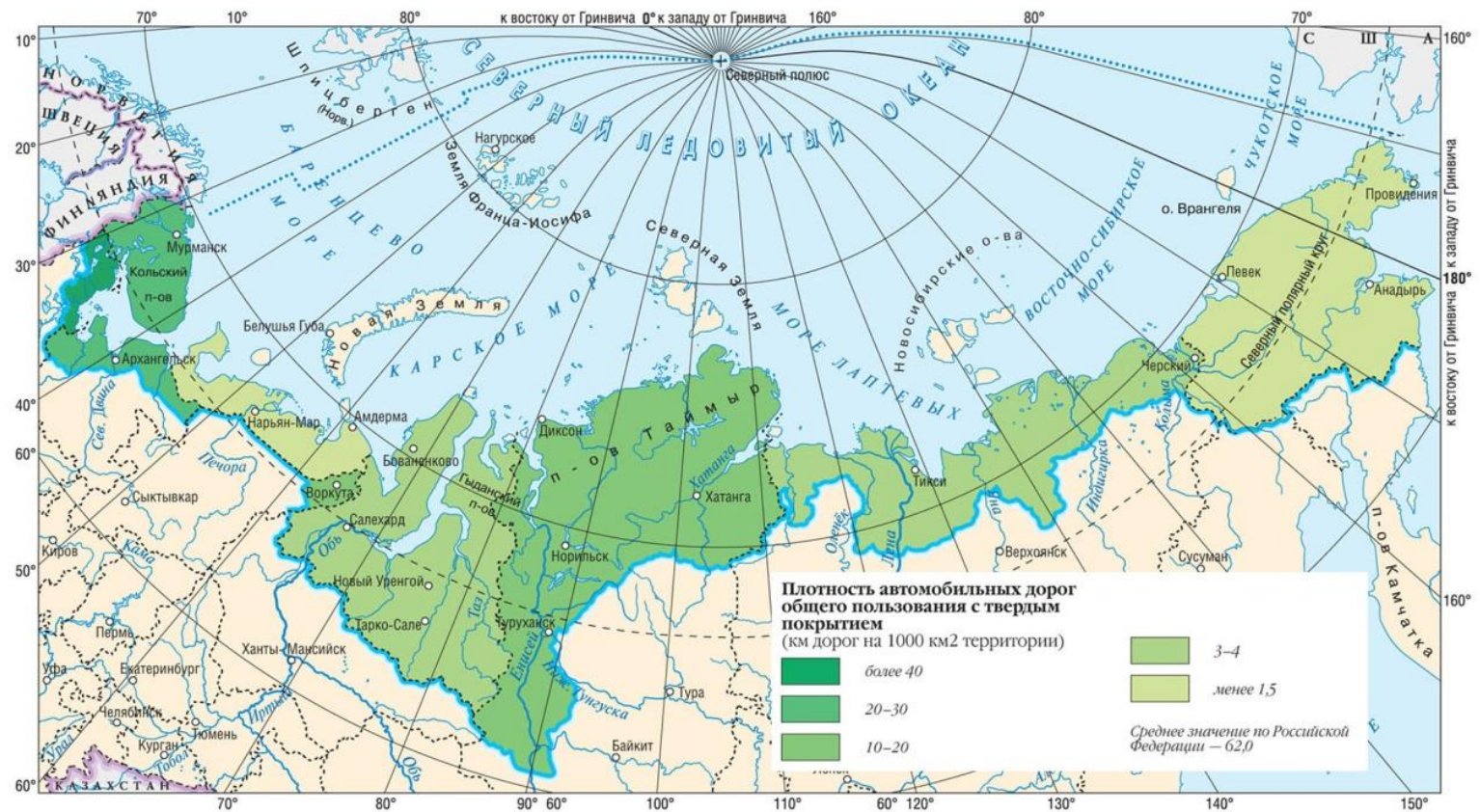

Рис. 3. Карта «Плотность всесезонных автомобильных дорог», масштаб 1:30 000000

Fig. 3. Map "Density of all-season motorable roads", scale 1:30 000000

На карте «Уровень автомобилизации» масштаба 1:30 000000 способом картограммы показано число собственных автомобилей на 1000 человек населения регионов Арктической зоны Российской Федерации. Карта представлена на рис. 4.

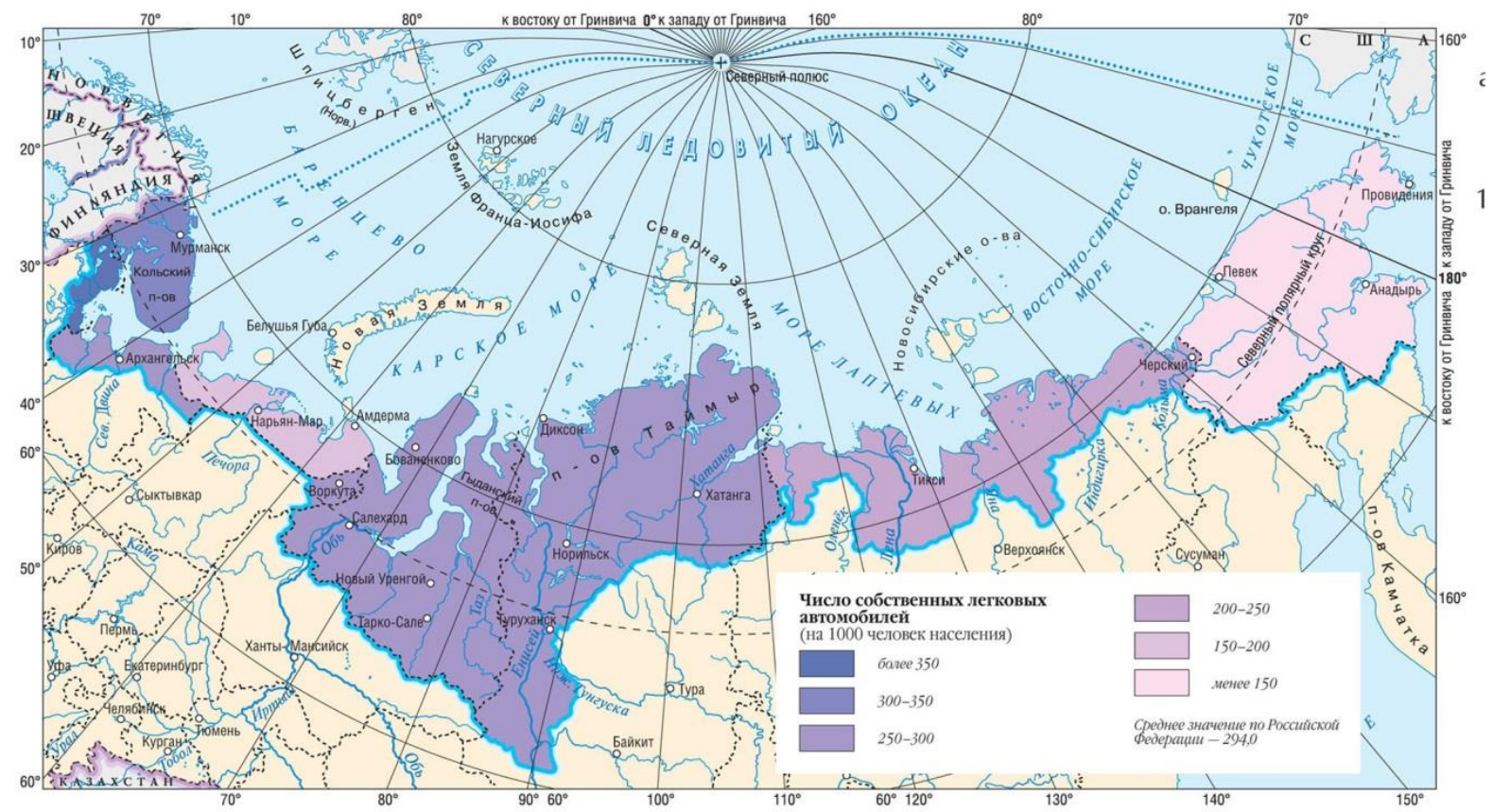

Рис. 4. Карта «Уровень автомобилизации», маситаб 1:30000 000

Fig. 4. Map "Level of motorization", scale 1:30 000000 
Достаточно высокий уровень автомобилизации значительно опережает возможности существующих дорог. Это объясняется тем, что внедорожный транспорт является единственным гарантом мобильности для жителей труднодоступных населённых пунктов.

Так, изучая локальные транспортные системы удалённых территорий Сибири и Дальнего Востока, сделан вывод, что «в этой зоне не случайно возникают парадоксы лучшей джиповой оснащённости населения при худшей плотности автомобильных дорог России». Революция автомобильности в последние десятилетия, которая радикальным образом изменила образ жизни людей, прежде всего, их зимнюю мобильность базируется на массовом использовании мощных внедорожников, кроссоверов, способных к рискованному движению по местным грунтовым дорогам летом и по зимникам в экстремальные холода [Пилясов и др., 2019].

\section{ВЫВОДЫ}

Транспортная доступность является одной из основных категорий в исследованиях транспорта и планирования социально-экономического развития территорий. Для России, имеющей наибольшую площадь северных и арктических территорий, эта проблема особенно актуальна. Наличие и состояние сети автомобильных дорог определяет территориальную целостность и единство экономического пространства, выполняет важнейшую стратегическую задачу пространственной интеграции страны.

Крайне важную коммуникационную роль в Арктическом регионе России играют автозимники. Повышение уровня автомобилизации привело к росту именно зимней мобильности жителей труднодоступных населённых пунктов.

Создание тематических карт с помощью ГИС-технологий позволяет оценить сложившуюся сеть дорог круглогодичного и сезонного использования, как ключевых элементов, формирующих автотранспортную доступность Арктической зоны Российской Федерации.

Разработанные для этой территории тематическая база данных и обзорные карты могут служить существенной частью системы для принятия ответственных решений по модернизации инфраструктуры автодорожного комплекса; для обеспечения устойчивого развития и безопасного функционирования автомобильных дорог.

\section{СПИСОК ЛИТЕРАТУРЫ}

1. Атлас природных и техногенных опасностей и рисков чрезвычайных ситуаций на территории Российской Федерации. М.: Дизайн. Информация. Картография, 2010. 696 с.

2. Атлас социально-экономического развития России. М.: Картография, 2009. 215 с.

3. Бадина С.В., Панкратов А.А., Янков К.В. Проблемы транспортной доступности изолированных населённых пунктов европейского сектора Арктической зоны России: ИнтерКарто. ИнтерГИС. Геоинформационное обеспечение устойчивого развития территорий: Материалы Междунар. конф. М.: Издательство Московского университета, 2020. Т. 26. Ч. 1. С. 305-317. DOI: 10.35595/2414-9179-2020-1-26-305-317.

4. Губанов М.Н., Нокелайнен Т.С., Рыльский И.А. Картографирование трубопроводного транспорта углеводородов арктического региона России: ИнтерКарто. ИнтерГИС Геоинформационное обеспечение устойчивого развития территорий: Материалы Междунар. конф. М.: Издательство Московского университета, 2020. Т. 26. Ч. 1. С. 105-115. DOI 10.35595/2414-9179-2020-1-26-105-115.

5. Интегрированная транспортная система. М.: Центр стратегических разработок, 2018. $278 \mathrm{c.}$ 
6. Куклина В.В., Осипова М.E. Роль зимников в обеспечении транспортной доступности арктических и субарктических районов Республики Саха (Якутия). Общество. Среда. Развитие, 2018. № 2. С. 107-112.

7. Лавриненко П.А., Ромашина А.А., Степанов П.С., Чистяков П.А. Транспортная доступность как индикатор развития региона. Проблемы прогнозирования, 2019. № 6. С. 136146.

8. Национальный атлас России. Т. 3. Население. Экономика. М.: Роскартография, 2008. $495 \mathrm{c}$.

9. Неретин А.С., Зотова М.В., Ломакина А.И., Тархов С.А. Транспортная связность и освоенность восточных регионов России. Известия РАН. Серия географическая, 2019. №6. C. 35-52. DOI: 10.31857/S2587-55662019635-52.

10. Нокелайнен Т.С. Картографирование условий навигации арктических рек России. ИнтерКарто. ИнтерГИС. Геоинформационное обеспечение устойчивого развития территорий. Материалы Междунар. конф. М.: Издательство Московского университета, 2019. T. 25. Ч. 2. C. 175-185. DOI: 10.35595/2414-9179-2019-2-25-175-185.

11. Пилясов А.Н., Замятина Н.Ю., Гончаров Р.В. Без мобильности нет креативности: антропология транспорта Сибири и Дальнего Востока. Пространственная Экономика, 2019. Т. 15. № 4. С. 149-183. DOI 10.14530/se.2019.4.149-183.

12. Российская Арктика в XXI веке: природные условия и риски освоения. Атлас. М.: Феория, 2013. 143 с.

13. Российская Арктика. Пространство, время, ресурсы: атлас. ПАО «НК «Роснефть». М.: Фонд «НИР», Феория, 2019. $796 \mathrm{c}$.

14. Серова Н.A., Серова В.А. Основные тенденции развития транспортной инфраструктуры российской Арктики. Арктика и Север, 2019. № 36. С. 42-56. DOI: 10.17238/issn22212698.2019.36.42.

15. Социально-экономическое развитие северо-арктических территорий России. Апатиты: Кольский научный центр Российской академии наук, 2019. 119 с.

16. Тикунов В.С., Губанов М.Н., Карпович Л.Л., Киселева Н.М., Котова Т.В., Масленникова B.B., Нокелайнен T.C., Тальская Н.Н. Новые обзорные карты России и мира. Геодезия и картография, 2014. № 6. С. 40-49.

17. Экологический атлас России. М.: Карта, 2002. 128 с.

18. Butler J.A. Designing geodatabases for transportation. Redlands. Calif.: ESRI Press, 2008. $461 \mathrm{p}$.

19. Crose A.I., Musolino G., Rindone C., Vitetta A. Transport system models and big data: zoning and graph building with traditional surveys. FCD and GIS. ISPRS Int. J. Geo-Inf., 2019. V. 8. No 4. P. 187-204. DOI: 10.3390/ijgi8040187.

20. Nokelaynen T.S. GIS-mapping of the environmental impacts of road transport in Russia. ИнтерКарто. ИнтерГИС, 2015. V. 21. Р. 97-99. DOI 10.24057/2414-9179-2015-1-21-97-99.

\section{REFERENCES}

1. Atlas of natural and technological hazards and risks of emergencies in the territory of the Russian Federation. Dizajn. Informaciya. Kartografiya, Moscow, 2010. 696 p. (in Russian).

2. Atlas of the socio-economic development of Russia. Moscow, Mapping production association "Kartografija", 2009. 215 p. (in Russian).

3. Badina S.V., Pankratov A.A., Yankov K.V. Transport accessibility problems of the isolated settlements in Russian European Arctic zone: InterCarto. InterGIS. GI support of sustainable development of territories: Proceedings of the International conference. Moscow: Moscow University Press, 2020. V. 26. Part 1. P. 305-317. DOI: 10.35595/2414-9179-2020-1-26-305317 (in Russian). 
4. Butler J.A. Designing geodatabases for transportation. Redlands. Calif.: ESRI Press, 2008. $461 \mathrm{p}$.

5. Crose A.I., Musolino G., Rindone C., Vitetta A. Transport system models and big data: zoning and graph building with traditional surveys, FCD and GIS. ISPRS Int. J. Geo-Inf., 2019. V. 8. No 4. P. 187-204. DOI: 10.3390/ijgi8040187.

6. Ecological Atlas of Russia. Moscow: Karta, 2002. 128 p. (in Russian).

7. Gubanov M.N., Nokelaynen T.S., Rilskiy I.A. Mapping of hydrocarbons pipeline transportation in the Arctic Region of Russia: InterCarto. InterGIS. GI support of sustainable development of territories: Proceedings of the International conference. Moscow: Moscow University Press, 2020. V. 26. Part 1. P. 105-115. DOI: 10.35595/2414-9179-2020-1-26-105-115 (in Russian).

8. Integrated transport system. Moscow: Center for strategic research, 2018. 278 p. (in Russian).

9. Kuklina V.V., Osipova M.E. The role of winter roads in provision of transportation accessibility for the Arctic and Northern districts of the Republic of Sakha (Yakutia). Society. Environment. Development, 2018. No 2. P. 107-112 (in Russian).

10. Lavrinenko P.A., Romashina A.A., Stepanov P.S., Chistyakov P.A. Transport accessibility as an indicator of regional development Studies on Russian Economic Development, 2019. T. 30. No 6. P. 694-701 (in Russian).

11. Neretin A.S., Zotova M.V., Lomakina A.I., Tarkhov S.A. Transport connection and development of the eastern regions of Russia. Izvestiya Rossiiskoi akademii nauk. Seriya geograficheskaya, 2019. No 6. P. 35-52. (in Russian). DOI: 10.31857/S2587-55662019635-52.

12. Nokelaynen T.S. GIS-mapping of the environmental impacts of road transport in Russia. InterCarto. InterGIS, 2015. V. 21. P. 97-99. DOI 10.24057/2414-9179-2015-1-21-97-99.

13. Nokelaynen T.S. Mapping the navigation conditions of Arctic rivers of Russia. InterCarto. InterGIS. GI support of sustainable development of territories: Proceedings of the International conference. Moscow: Moscow University Press, 2019. V. 25. Part 2. P. 175-185. DOI: 10.35595/2414-9179-2019-2-25-175-185 (in Russian).

14. Pilyasov A.N., Zamyatina N.Y., Goncharov R.V. There is no creativity without mobility: anthropology of transport in Siberia and the Far East. Prostranstvennaya Ekonomika. Spatial Economics, 2019. V. 15. No 4. P. 149-183. DOI 10.14530/se.2019.4.149-183 (in Russian).

15. Russian Arctic: Space. Time. Resources. Atlas. Rosneft. Moscow: NIR Foundation, "Feoria", 2019. 796 p. (in Russian).

16. Serova N.A., Serova V.A. Critical tendencies of the transport infrastructure development in the Russian Arctic. Arctic and North, 2019. No 36. P. 42-56. DOI: 10.17238/issn22212698.2019.36.42 (in Russian).

17. Socio-economic development of the north-arctic territories of Russia. Apatity: Kola science centre of the Russian academy of sciences, 2019. 119 p. (in Russian).

18. The National atlas of Russia. V. 3. Population. Economy. Moscow: Roskartografiya, 2008. 495 p. (in Russian).

19. The Russian Arctic in the 21ST century: nature conditions and risks of the development. Atlas. Moscow: Feoria, 2013. 143 p. (in Russian).

20. Tikunov V.S., Gubanov M.N., Karpovich L.L., Kiseleva N.M., Kotova T.V., Maslennikova V.V., Nokelaynen T.S., Talskaya N.N. New overview maps of Russia and of the world. Geodesy and cartography. 2014. No 6. P. 40-49 (in Russian). 


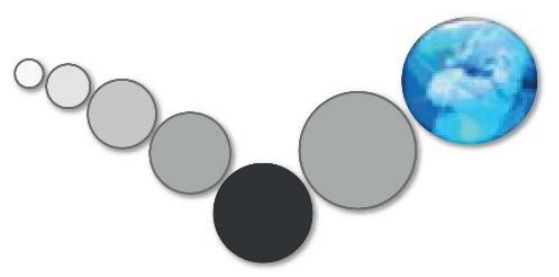

\title{
НОВЫЕ МЕТОДЫ И ПОДХОДЫ В КАРТОГРАФИИ И ГЕОИНФОРМАТИКЕ
}

\section{NEW METHODS AND APPROACHES IN CARTOGRAPHY AND GEOINFORMATICS}

УДК: 528.94

DOI: 10.35595/2414-9179-2021-2-27-114-127

\author{
Л.А. Обухов ${ }^{1}$, Е.А. Паниди ${ }^{2}$ \\ О КОНТРОЛЕ КОРРЕКТНОСТИ ПРИ ГЕОКОДИРОВАНИИ \\ ПОЧТОВЫХ АДРЕСОВ
}

\begin{abstract}
АННОТАЦИЯ
В статье рассмотрено содержание и результаты разработки методики геокодирования почтовых адресов. Задача геокодирования рассмотрена на примере исследования, посвящённого изучению пространственного распределения и динамики случаев инфицирования туберкулёзом и сопутствующими заболеваниями. Исследование выполняется в масштабе крупного города, на примере Санкт-Петербурга (Россия).
\end{abstract}

Предложенная методика основана на дополнении классической схемы геокодирования, предполагающей прямое связывание адресных данных, представленных в составе исходных данных, с адресными данными в справочнике (в базе пространственных данных). Дополнение состоит в использовании эталонного реестра почтовых адресов, в качестве которого задействуется адресная база данных, создаваемая государственными органами. Записи исходных данных связываются с записями эталонного реестра почтовых адресов, а записи реестра, в свою очередь, связываются с записями справочника, используемого для геокодирования (адресами, записанными в атрибуты объектов базы пространственных данных).

Указанный подход позволяет обеспечить контроль корректности структуры и содержания адресных данных, используемых при геокодировании, а также привести адресные данные к унифицированной форме, официально закреплённой на государственном уровне и используемой в официальных документах и информационных системах.

Предложенная методика реализована на примере системы почтовых адресов, используемой в Российской Федерации, однако, она также может быть использована при работе с адресными системами других государств. В таком случае, для реализации методики необходимо иметь официальный реестр почтовых адресов, представленный в структурированном виде (желательно, в форме базы данных). Методика может быть использована как при геокодировании данных медицинской статистики, так и при решении задач в других предметных областях.

КЛЮЧЕВЫЕ СЛОВА: QGIS, ФИАС, Nominatim, KLADR-API, OSM

\footnotetext{
1 Санкт-Петербургский государственный университет, институт наук о Земле, кафедра картографии и геоинформатики, Санкт-Петербург, Россия; e-mail: obuhov.lev@mail.ru, st068972@student.spbu.ru

2 Санкт-Петербургский государственный университет, институт наук о Земле, кафедра картографии и геоинформатики, Санкт-Петербург, Россия; e-mail: panidi@ya.ru, e.panidi@spbu.ru
} 


\title{
Lev Obuhov ${ }^{1}$, Evgeny Panidi $^{2}$
}

\section{TOWARD CORRECTNESS CONTROL OF POSTAL ADDRESSES GEOCODING}

\begin{abstract}
The paper discusses content and results of the methodology elaborated for geocoding of postal addresses. The geocoding issue is considered on the example of study devoted to the exploration of the spatial distribution and dynamics tuberculosis and concomitant diseases infection cases. The study is carried out on a large city scale. The example of St. Petersburg city (Russia) is used.

Proposed methodology is based upon the extending of the classical geocoding scheme that assumes direct linking of the address data presented as a part of initial dataset with the address data presented in the reference dataset (in the geospatial database). The extension consists in the use of a middle reference-standard register of postal addresses. An address database developed by official agencies is used as a reference-standard register. Initial data records are linked with the records of the reference-standard register by postal addresses, and the register records, in turn, are linked with the records of the reference dataset used for geocoding (with the addresses recorded in the attributes of the geospatial database objects).

This approach allows to provide control of structure and content correctness for the address data used for geocoding, as well as to convert address data into a unified form accepted officially at the state level and used in official documents and information systems.

The methodology is implemented on the example of the postal address system used in the Russia. However, it can also be used when operating with the address system of any other states. In such a case, it is necessary to have an official register of postal addresses to implement the methodology. The register have to be presented in a structured form (preferably in the form of a database). The methodology can be used both for medical statistics data geocoding, and for geocoding of other domain data.
\end{abstract}

KEYWORDS: QGIS, FIAS, Nominatim, KLADR-API, OSM

\section{ВВЕДЕНИЕ}

В настоящей статье рассмотрен подход к решению задачи геокодирования данных медицинской статистики при выполнении исследований в области медицинской географии и картографии, предполагающих привлечение первичных медицинских данных, извлекаемых непосредственно из медицинских карт пациентов. В медицинских картах, оформляемых при регистрации пациентов, имеется информация об адресах места жительства. Используя их возможно сформировать базу пространственных данных, которая в дальнейшем может быть использована для выполнения аналитических выкладок средствами географических информационных систем (ГИС) и изучения характера и тенденций территориального распределения различных заболеваний. Для минимизации количества ошибок геокодирования, необходимо обеспечить контроль корректности адресов, извлекаемых из медицинских карт.

Необходимо отметить, что термин «геокодирование» имеет несколько толкований. В настоящей статье идёт речь о так называемом адресном геокодировании, широко применяемом при наполнении географических информационных систем данными [Борис $u$

\footnotetext{
1 Saint Petersburg State University, Institute of Earth Sciences, Department of Cartography and Geoinformatics, St. Petersburg, Russia, e-mail: obuhov.lev@mail.ru, st068972@student.spbu.ru

2 Saint Petersburg State University, Institute of Earth Sciences, Department of Cartography and Geoinformatics, St. Petersburg, Russia,e-mail: panidi@ya.ru, e.panidi@spbu.ru
} 
дp., 2014; Фарафонов, 2014; Wheeler, 2020] и предполагающем автоматическое формирование геометрии (объекта карты) на основе описания местоположения объекта (представленного в форме почтового адреса). При этом принято выделять прямое и обратное геокодирование. Прямое предполагает извлечение из некоторого массива исходных данных описания положения объекта с последующим формированием его геометрической модели в базе пространственных данных и присвоением ей в качестве атрибутов иных данных об объекте, которые могут быть извлечены из массива исходных данных. Обратное геокодирование, в свою очередь, подразумевает получение описания положения (адреса) объекта по его координатам. Геокодирование используется для пространственного поиска, например, по названиям улиц или городов, нахождения расположения домов по их адресу, поиска расположения различных организаций. Использование геокодирования данных медицинской статистики также применяется достаточно часто и имеет свои особенности [Rashidian et al., 2017, 2018; Rizwan, 2018], в том числе связанные с необходимостью обеспечить обезличенность данных [Harris, Delcher, 2019].

С точки зрения алгоритмизации задача геокодирования заключается в поиске наилучшего совпадения описания местоположения с атрибутами в адресной базе имеющейся в составе вспомогательной базы пространственных данных, справочнике, на основе которой и выполняется геокодирование. Поиск строгого совпадения использовать затруднительно, так как синтаксис и грамматика описания местоположения приемлемые для человека и информационной системы, в общем случае, существенно различаются. Например, записи «ул. Ботаническая» и «улица Ботаническая» в понимании человека являются идентичными, однако для программной системы это два разных адреса. В связи с этим, поиск совпадений описания адресов в массиве исходных данных и в атрибутах справочника, как правило, допускает нестрогое соответствие, что в свою очередь, ведёт к появлению ненулевой вероятности возникновения ошибок геокодирования. Кроме того, качество и точность данных, хранимых в справочниках, также влияет на возможность возникновения ошибок геокодирования и, собственно, на возможность выполнения геокодирования.

\section{МАТЕРИАЛЫ И МЕТОДЫ ИССЛЕДОВАНИЯ}

В настоящей работе задача геокодирования рассматривается в контексте исследования выполняемого в 2019-2021 годах и посвящённого картографированию пространственного распределения и динамики заболеваемости туберкулёзом и сопутствующими инфекционными заболеваниями в масштабе города [Kuznetsov et al., 2020]. В качестве исходных данных в исследовании использованы обезличенные регистрационные карточки, заполняемые в районных туберкулёзных диспансерах при выявлении и регистрации случаев инфицирования туберкулёзом. Исследование выполняется на примере Санкт-Петербурга. Исходные данные собраны и предоставлены Санкт-Петербургским НИИ Фтизиопульмонологии ${ }^{1}$. Особенностью исходных данных явилось то, что значительная их часть изначально представлена в аналоговой форме (заполненные вручную бумажные медицинские формы), что существенно повысило возможность появления ошибок в данных (неверное написание названий улиц, ошибочные или отсутствующие номера или корпуса домов, и др.). К моменту подготовки данного текста всего обработано несколько тысяч таких форм. Первоночально данные заносятся в электронную таблицу (рис. 1), которая в дальнейшем подвергается автоматизированному переструктурированию и геокодированию.

https://spbniif.ru 


\begin{tabular}{|c|c|c|c|c|c|c|c|c|c|c|c|c|c|c|}
\hline \multirow{2}{*}{\multicolumn{2}{|c|}{ ID }} & \multirow[t]{2}{*}{ район спб } & \multirow[t]{2}{*}{ тип } & \multirow[t]{2}{*}{ название } & \multirow{2}{*}{$\begin{array}{l}\text { ном. } \\
\text { дома }\end{array}$} & \multirow{2}{*}{$\begin{array}{l}\text { ном. } \\
\text { корп }\end{array}$} & \multirow{2}{*}{ год рожд } & \multirow[t]{2}{*}{ пол } & \multirow[t]{2}{*}{ дата выявл } & \multicolumn{2}{|c|}{ дата снятия бк+ } & \multirow{2}{*}{$\begin{array}{l}\text { млу } \\
\text { шлу }\end{array}$} & \multirow{2}{*}{\begin{tabular}{|l|} 
T6+ \\
823 \\
\end{tabular}} & \multirow{2}{*}{$\begin{array}{l}\text { T6+ } \\
\text { ren B.c }\end{array}$} \\
\hline & & & & & & & & & & & & & & \\
\hline & 1 & петроград & ул & гатчинская & $31 / 33$ & & 06121966 & ж & 27112012 & 18042014 & & & & \\
\hline & 2 & петроград & & кронверский & 27 & & 02011960 & M & 16112012 & 06082013 & & & & \\
\hline & 3 & петроград & & саблинская & $13 / 15$ & & 11071954 & M & 01012013 & 08052014 & $6 k+$ & & & \\
\hline & 4 & петроград & & күйбышева & 10 & & 29111952 & ж & 10122012 & 13092013 & & & & \\
\hline & 5 & петроград & & пионерская & 35 & & 28071963 & ж & 01022013 & 24032014 & $6 k+$ & & & \\
\hline & 6 & петроград & пр & добролюбова & 3 & & 25091980 & ж & 01022013 & 30042014 & $6 k+$ & & & \\
\hline & 7 & петроград & & б.монетная & 9 & & 25071980 & $M$ & 17012013 & 20012017 & $6 k+$ & & & \\
\hline & 8 & петроград & & яблочкова & 3 & & 04051970 & M & 05022013 & & & & & \\
\hline & 9 & петроград & ул & куйбышева & 36 & & 07061965 & M & 29012013 & 11122013 & & & & \\
\hline & 10 & петроград & пер & вяземский & 6 & & 16071987 & ж & 30112012 & 21032014 & & & & \\
\hline & 11 & петроград & & кропоткина & 11 & & 05011963 & ж & 25122012 & 06082013 & & & & \\
\hline & 12 & петроград & ул & съезжинская & $26 / 28$ & & 31071993 & M & 28022013 & & $6 k+$ & млу & & \\
\hline & 13 & петроград & & гатчинская & 18 & & 31081977 & ж & 28022013 & 06062014 & & & & \\
\hline & 14 & петроград & & резная & $19 / 8$ & & 17081958 & ж & 01042013 & & $6 k+$ & & & \\
\hline & 15 & петроград & ул & б.зеленина & 19 & & 18031986 & M & 17012013 & 27022014 & & & B23 & \\
\hline & 16 & петроград & & 6.пушкарская & 39 & & 12011991 & M & 12032013 & 17042014 & & & & \\
\hline & 17 & петроград & ул & м.посадская & 15 & & 08101983 & ж & 07022013 & & $6 k+$ & млу & B23 & \\
\hline
\end{tabular}

Рис. 1. Пример таблицы с исходными данными о зарегистрированных случаях инфицирования

Fig. 1. Example of the table containing initial data on registered infection cases

Почтовый адрес в данном случае разбит на несколько полей, «тип», в котором хранится информация о типе объекта улично-дорожной сети (улица, проспект и т.п.), «название» - собственно наименование улицы, «номер дома» и «номер корпуса» (корпус или литера). В совокупности эти поля позволяют выполнить сопоставление адреса с атрибутами справочного хранилища пространственных данных при выполнении геокодирования.

Вместе с тем, содержание адресных данных в приведённом примере не полностью пригодно для выполнения геокодирования из-за наличия ряда систематических неоднозначностей. В частности, некоторые сокращения толкуются двояко, например, «пр.» может расшифровываться и как «проспект», и как «проезд». Использование же сокращений в наименованиях улиц также может привести к ошибкам геокодирования при наличии адресов со схожими наименованиями. Допустимыми являются только сокращения, принятые на законодательном уровне, например, сокращение «П.С.» (от «Петроградской стороны»). Наконец, далеко не всегда сдвоенные номера домов записываются через знак «/», кроме него может использоваться, к примеру, дефис. Перечисленные систематические неточности неизбежно дополняются грамматическими ошибками в наименованиях улиц, так как массив исходных данных, в описываемом случае, формируется вручную.

Для обеспечения корректного геокодирования необходимо в первую очередь привести запись адресов к унифицированной форме (совместимой с используемой в привлекаемом для геокодирования справочнике). Выявление же и устранение грамматических ошибок целесообразно выполнять уже в процессе геокодирования, формируя списки адресов, для которых в справочнике небыли найдены соответствия.

В последние годы устоявшейся практикой является использование для выполнения адресного геокодирования онлайн-сервисов [Степанова, Зайщева, 2015; Pietro, Rinnone, 2017; Silveira et al., 2017; Макаров, 2019; Маннанов, Агишев, 2020], доступных в глобальной сети, в частности сервисов компаний Яндекс и Google, использующих для геокодирования адресные базы, имеющиеся в составе веб-картографических ресурсов, разрабатываемых и поддерживаемых данными Интернет-компаниями, доступ к которым для выполнения 
геокодирования предоставляется на коммерческих условиях, за плату. Альтернативой является веб-сервис Nominatim и соответствующее программное обеспечение ${ }^{1}$, разрабатываемые как свободно распространяемое программное обеспечение с открытым исходным кодом и использующие в качестве справочника данные OpenStreetMap ${ }^{2}$ (OSM). Последние также лицензируются как открытые и свободно распространяемые данные. Однако, будучи данными, создаваемыми пользователями, данные OSM, во многих случаях, имеют невысокое качество адресной базы (ошибки и пропуски в адресных данных).

Рассматриваемое исследование не предполагало возможность использования коммерческих систем геокодирования, в связи с чем методика геокодирования была разработана на основе использования Nominatim, а для повышения надёжности геокодирования, контроля его корректности и унификации записи адресов были использованы данные Федеральной информационной адресной системы ${ }^{3}$ (ФИАС). ФИАС является государственной информационной системой, предназначенной для формирования, ведения и использования государственного адресного реестра. Базы данных почтовых адресов, формируемые и поддерживаемые в ФИАС, находятся в открытом доступе. Для проверки корректности адреса при геокодировании, в рамках описываемой методики, производится проверка его наличия в базе данных ФИАС. Если совпадение найдено, адрес считается верифицированным.

При автономном использовании ФИАС на настольном компьютере необходимо развернуть базу данных объёмом в несколько гигабайт (файл формата DBF либо XML). Такой вариант организации работы оказывается неудобным, так как предполагает возможность выполнения геокодирования только на подготовленном и оснащённом рабочем месте. В связи с этим, для контроля корректности адресов был применён вебсервис «ФИАС в облаке» ${ }^{4}$ (KLADR-API), являющийся коммерческим, но предоставляющий бесплатный тариф с ограничениями. С использованием данного веб-сервиса данные ФИАС могут быть загружены в автоматическом режиме в формате $\mathrm{JSON}^{5}$.

Контроль корректности адреса и приведение его к унифицированной форме производится следующим образом. Первоначально выполняется НТТР-запрос к сервису KLADR-API (Рис. 2) для проверки корректности названия улицы.

\title{
https://kladr-api.ru/api.php?query=декабристов\&contentType=street\&cityld $=7800000000000$
}

\section{Pис. 2. Пример HTTP-запроса к веб-сервису KLADR-API для поиска по названию улиць}

Fig. 2. Example of the HTTP request to the KLADR-API Web service, street name search

В этом запросе «декабристов» - наименование улицы, взятое из состава данных геокодируемого адреса, запись «contentType=street» указывает на то, что ответом сервиса на запрос должно быть именно название улицы, а не иные наименования, запись «cityId= 7800000000000» указывает, что результаты должны возвращаться только для СанктПетербурга.

Формат ответа сервиса представлен на рисунке 3. Данные возвращаются в виде структурированного текстового массива в формате JSON, включающего несколько разделов. В разделе «searchContext» приведены исходные данные, по которым осуществлён поиск, в разделе «result» - нумерованные разделы с найденными результатами. При этом

\author{
https://nominatim.org \\ https://www.openstreetmap.org \\ https://fias.nalog.ru \\ https://kladr-api.ru \\ https://www.json.org/json-en.html
}


подраздел «0» в составе раздела «result» является служебным, а сами результаты поиска содержатся в подразделе «1» и последующих. Подраздел «2» и следующие за ним будут присутствовать если найдено более одного соответствия. Например, в представленном случае по наименованию «Декабристов» были найдены улица Декабристов и переулок Декабристов.

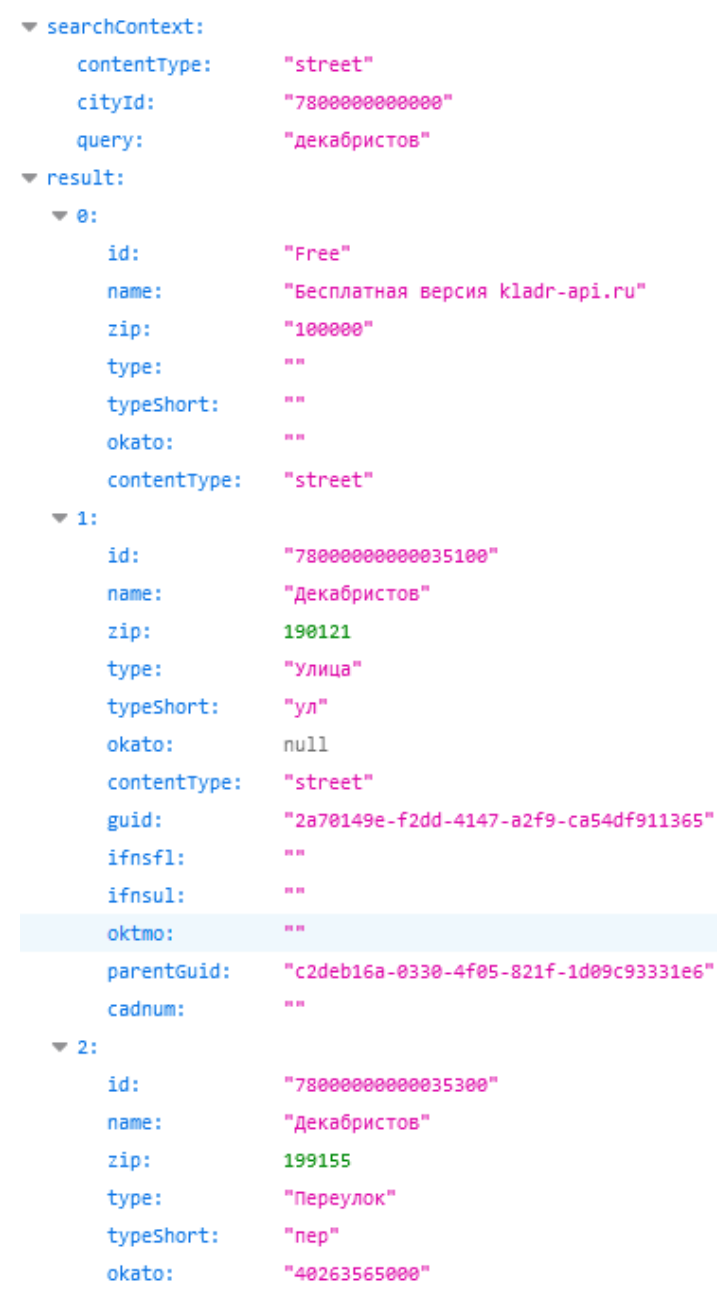

Puc. 3. Пример JSON-ответа на запрос к веб-сервису KLADR-API по наименованию улиць Fig. 3. Example of the JSON response on the street-name-based request to the KLADR-API Web service

Далее, из перечня найденных результатов, производится выбор одного из объектов, с учётом типа объекта улично-дорожной сети, указанного в поле «tуре» геокодируемых данных. Из данных выбранного объекта (подраздела в файле результатов поиска) извлекается значение параметра «id», которое на следующем этапе обработки данных используется для проверки наличия на данной улице номера дома, указанного в составе геокодируемых исходных данных. Для этого выполняется второй НТТР-запрос к сервису KLADR-API (Рис.4).

\section{https://kladr-api.ru/api.php?query=16\&contentType= building \&streetld $=78000000000035300$}

Pис. 4. Пример HTTP-запроса к веб-сервису KLADR-API для поиска по номеру дома Fig. 4. Example of the HTTP request to the KLADR-API Web service, house number search 
В примере запроса, представленном на рис. 4, «16» это искомый (геокодируемый) номер дома, «contentType=building» - ключ, указывающий на то, что ответ сервиса должен содержать в себе данные о зданиях, «streetId=78000000000035300» - ключ, содержащий значение параметра «id», извлечённого на предыдущем этапе, и указывающего на улицу (объект улично-дорожной сети) для которй необходимо выполнить поиск. В результате выполнения запроса, как и в предыдущем случае, возвращается JSON-файл, содержащий, как правило, один найденный объект. Структура файла (рис. 5) схожа со структурой файла, возвращаемого на первом этапе поиска, описание найденного объекта (здания) представлено в подразделе «1» раздела «result» данного файла.

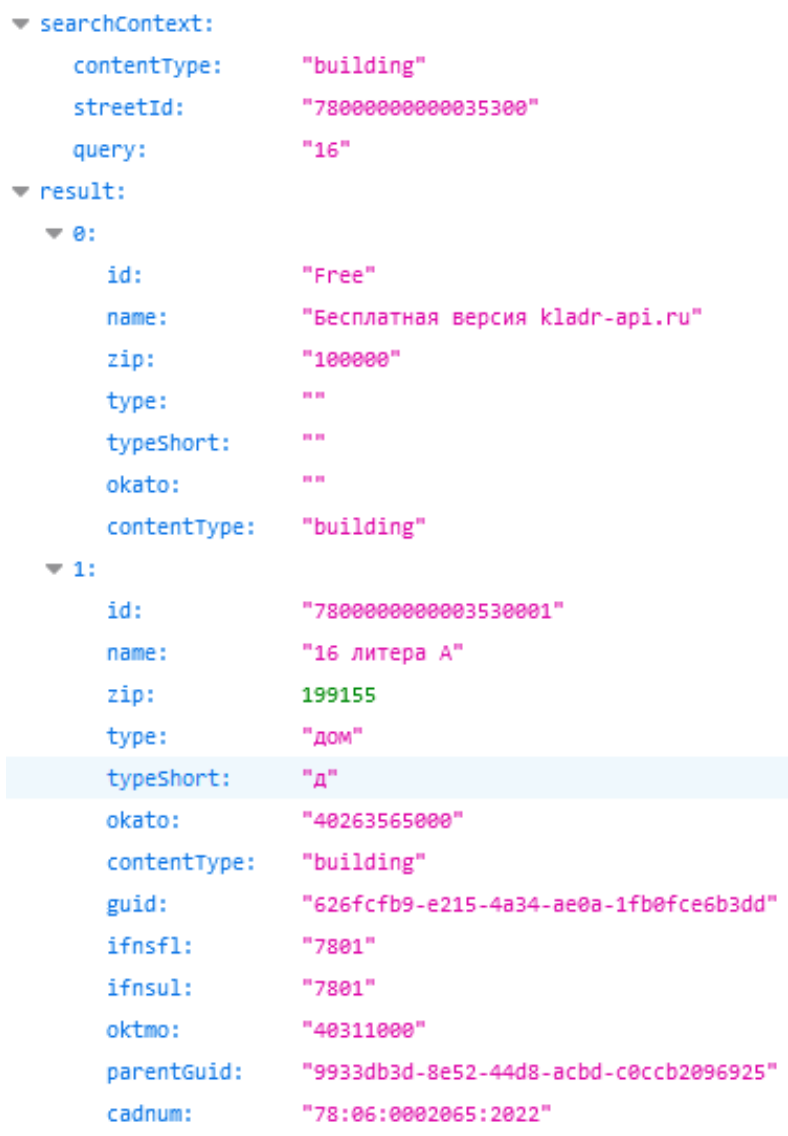

Puc. 5. Пример JSON-ответа на запрос к веб-сервису KLADR-API по номеру дома

Fig. 5. Example of the JSON response on the house-number-based request to the KLADR-API Web service

На данном этапе проводится проверка либо полного совпадения искомого номера дома со значением поля «nате» подраздела «1» в возвращённом файле, либо совпадения со значением части поля «name», содержащей в себе число, так как для адресов с литерой «А» обозначение литеры в исходных данных, как правило, не приводится.

При корректном и результативном выполнении двух первых шагов поиска по базе данных ФИАС описание искомого (геокодируемого) адреса может быть сформировано и представлено в структурированном и унифицированном, соответственно представлению в ФИАС, виде. В таком виде описание адреса и переносится в дальнейшем в базу пространственных данных. 
Следующим этапом обработки исходных данных является собственно операция геокодирования (получения координат объекта и сохранение их в базе пространственных данных совместно со значениями геокодируемых полей исходных данных). Получение координатной информации выполняется при помощи НТТР-запроса к веб-сервису Nominatim $^{1}$ (рис. 6). В данном запросе «self.building_number», «self.type_» и «self.name»это, соответственно, ключи, передающие значения номера дома, типа улицы и наименования улицы, полученные в результате поиска и проверки с использованием ФИАС. Также в составе запроса указывается наименование города и тип данных ответа сервиса (в данном случае JSON-файл).

Рис. 6. Пример НТТР-запроса к веб-сервису Nominatim

Fig. 6. Example of the HTTP request to the Nominatim Web service

Пример JSON-ответа на запрос приведён на рис. 7. Координатные и атрибутивные данные, извлечённые из OSM, содержатся в нумерованных подразделах раздела «features» возвращаемого файла. С точки зрения геокодирования основными являются значения в полях подраздела «coordinates», где поле «0» содержит значение долготы, а поле «1»значение широты центроида найденной по адресу геометрии. Для указания координат используется система координат WGS-84. По извлечённым из данного файла координатам создаётся вспомогательный точечный векторный объект в базе пространственных данных, которому и присваиваются все геокодируемые атрибуты, включая поля почтового адреса, унифицированного на предыдущих этапах обработки данных (рис. 8).

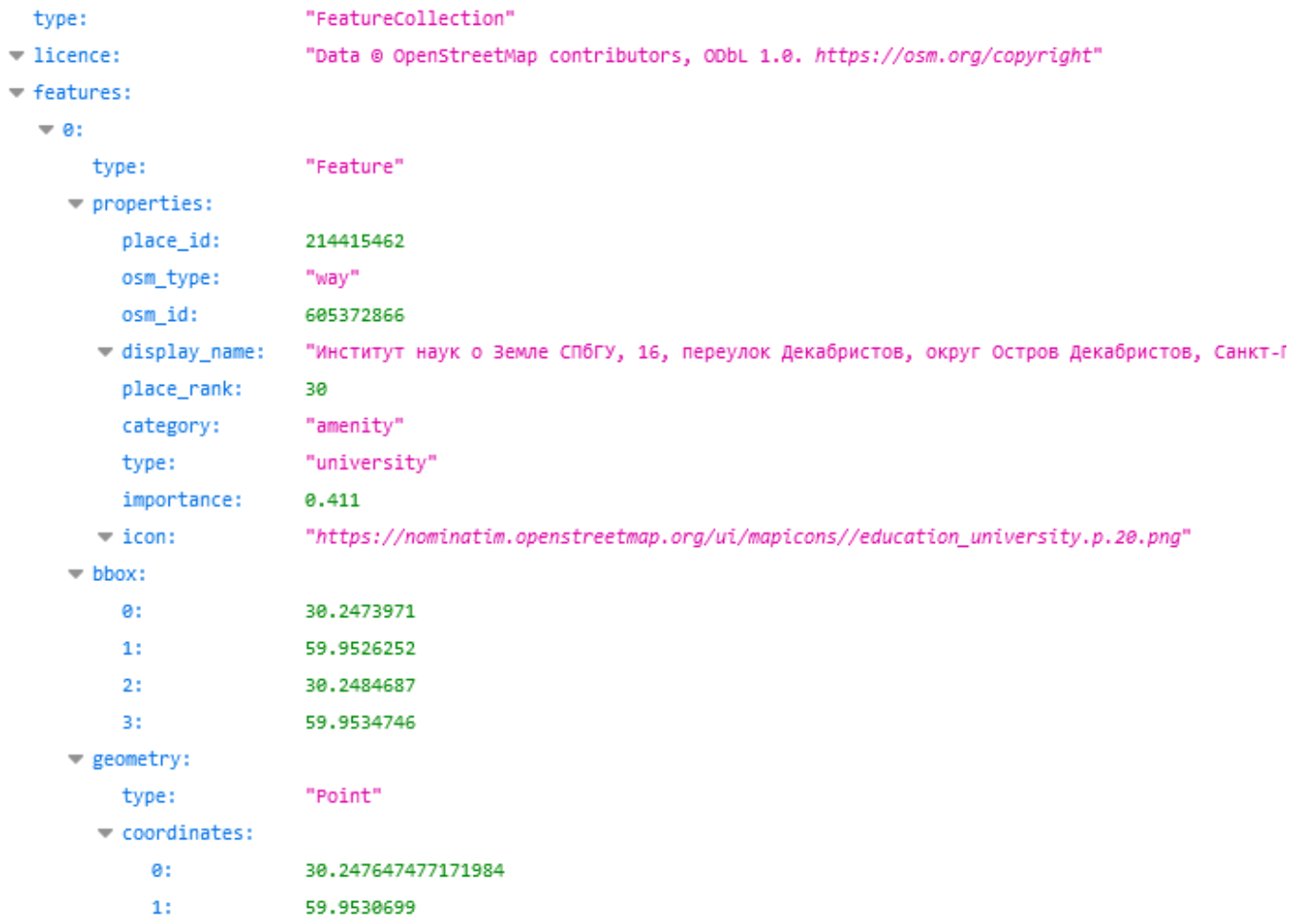

Pис. 7. Пример JSON-ответа на запрос к веб-сервису Nominatim Fig. 7. Example of the JSON response on the request to the Nominatim Web service

$1 \quad$ https://nominatim.openstreetmap.org 


\begin{tabular}{r|r|r|r|l|}
\hline \multicolumn{1}{c|}{ Адрес } & \multicolumn{1}{c|}{ Тип адреса } & Номер дома & id пациента & Дата выявления \\
\hline 1 Гатчинская & улица & 22 корпус ... & 101 & 2015 \\
\hline
\end{tabular}

Рис. 8. Отображение геокодированных исходных данных в атрибутивной таблице векторного слоя в QGIS

Fig. 8. Representation of the geocoded initial data in attribute table of the vector layer in QGIS

На заключительном этапе геокодирования из массива данных OSM, путём выполнения автоматической выборки по расположению, на основе координат центроида, полученного на предыдущих шагах, извлекается полигонольная геометрия, описывающая положение контура здания. Эта геометрия сохраняется во второй векторный (полигональный) слой, с присвоением ей атрибутов аналогичных атрибутам ранее созданного точечного объекта. В результате, геокодированные данные состоят из двух слоёв, точечного и полигонального. Геокодированные атрибуты (исходные данные) оказываются связанными с точечной (центроидом) и полигональной геометрией. Окончательное структурирование данных, предполагающее или не предполагающее (в случае использования реляционной модели данных) дублирование геокодированных атрибутов для двух типов геометрии (рис. 9, 10) геокодированного объекта, может быть выполнено в соответствии с контекстом решаемой задачи.

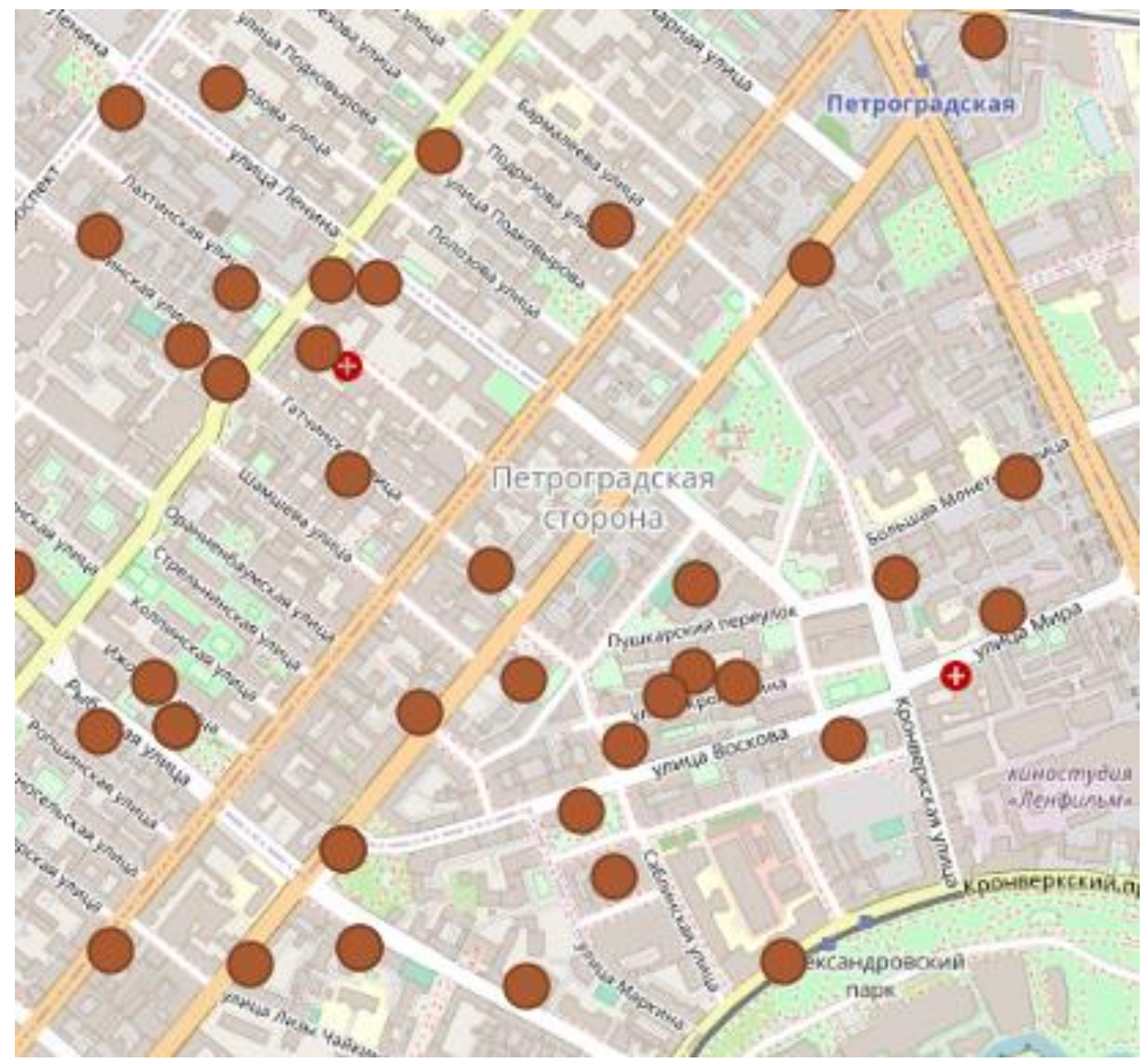

Pис. 9. Отображение слоя геокодированных ичентроидов зданий в QGIS Fig. 9. Representation of the geocoded layer of centroids in QGIS 


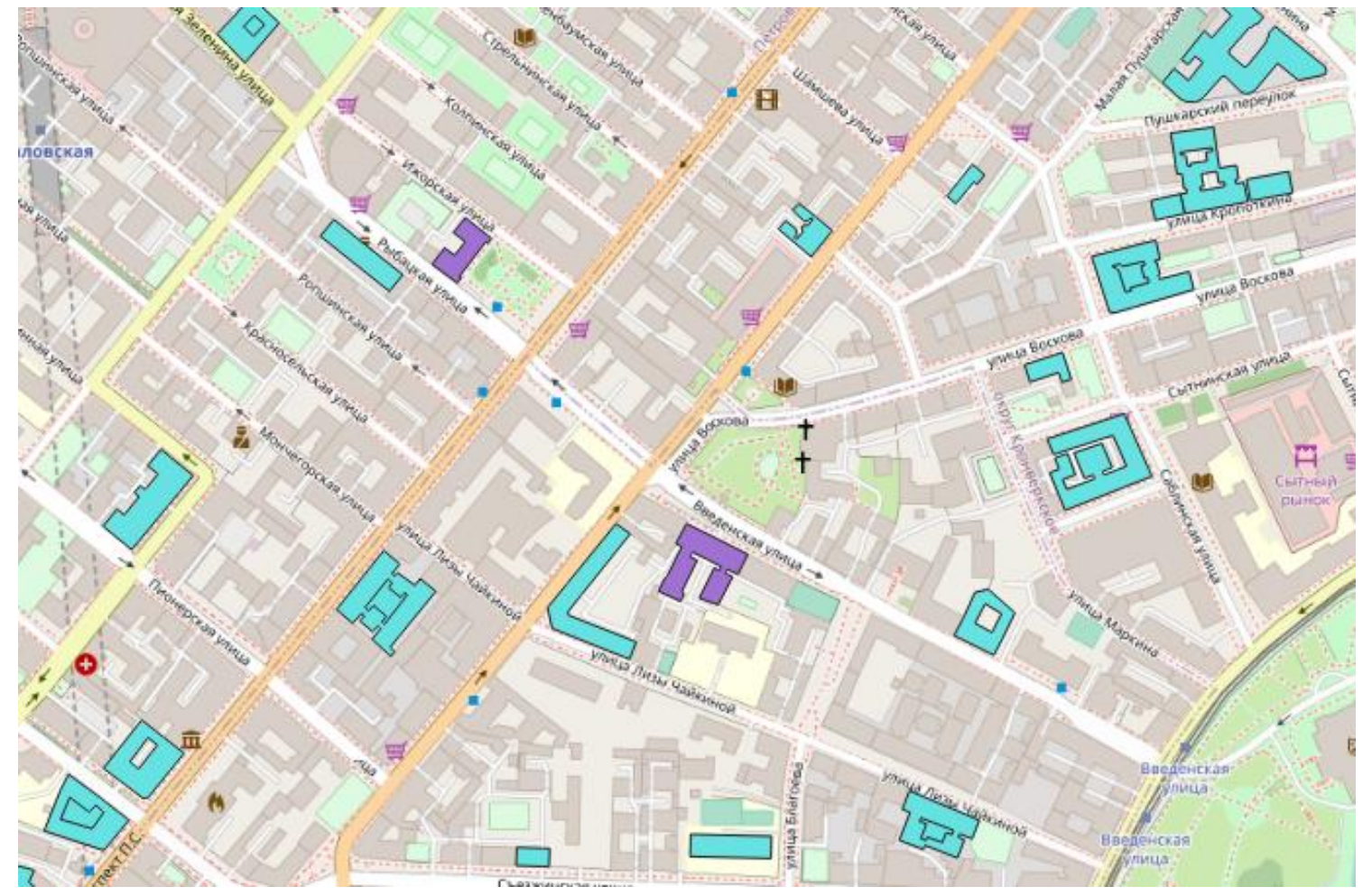

Pис. 10. Отображение слоя геокодированных полигонов зданий в QGIS Fig. 10. Representation of the geocoded layer of building polygons in QGIS

При разработке модуля были использованы следующие программные библиотеки:

1) requests ${ }^{1}$ (для выполнения НТTР-запросов и приёма ответов от веб-сервисов);

2) geojson ${ }^{2}$ (для создания, чтения и редактирования файлов формата GeoJSON);

3) processing $^{3}$ (для автоматизированного применения инструментов обработки данных, доступных в QGIS, в частности для выполнения пространственных запросов);

4) qgis.PyQt ${ }^{4}$ (для реализации графического интерфейса модуля);

5) qgis.core ${ }^{5}$ (для автоматизированного создания и добавления на карту векторных слоёв в QGIS).

\section{РЕЗУЛЬТАТЫ ИССЛЕДОВАНИЯ И ИХ ОБСУЖДЕНИЕ}

Для выполнения тестирования описанной методики геокодирования был разработан модуль QGIS, способный открывать отдельное всплывающее окно (форму) для ввода геокодируемых данных в контексте интерфейса (из интерфейса) QGIS (рис. 11). Модуль разработан с использованием стандартных (для QGIS) средств QGIS Plugin Builder6. После ввода исходных геокодируемых данных в поля формы, в результате автоматического выполнения забросов к необходимым веб-сервисам, модуль сохраняет данные в файл в формате GeoJSON ${ }^{7}$, который может быть отображён в QGIS в виде слоя карты, содержащего геокодированные геометрию и атрибуты.

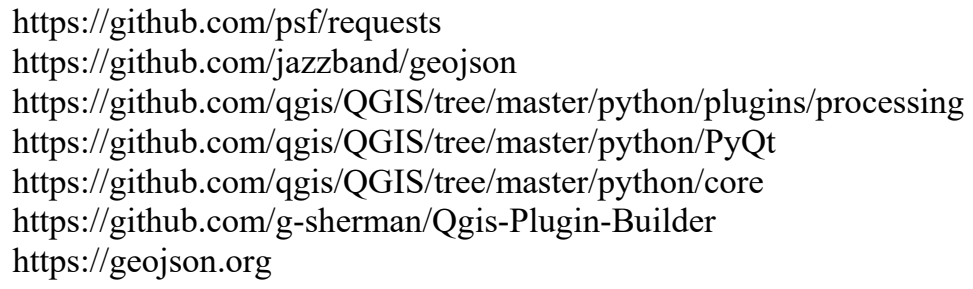




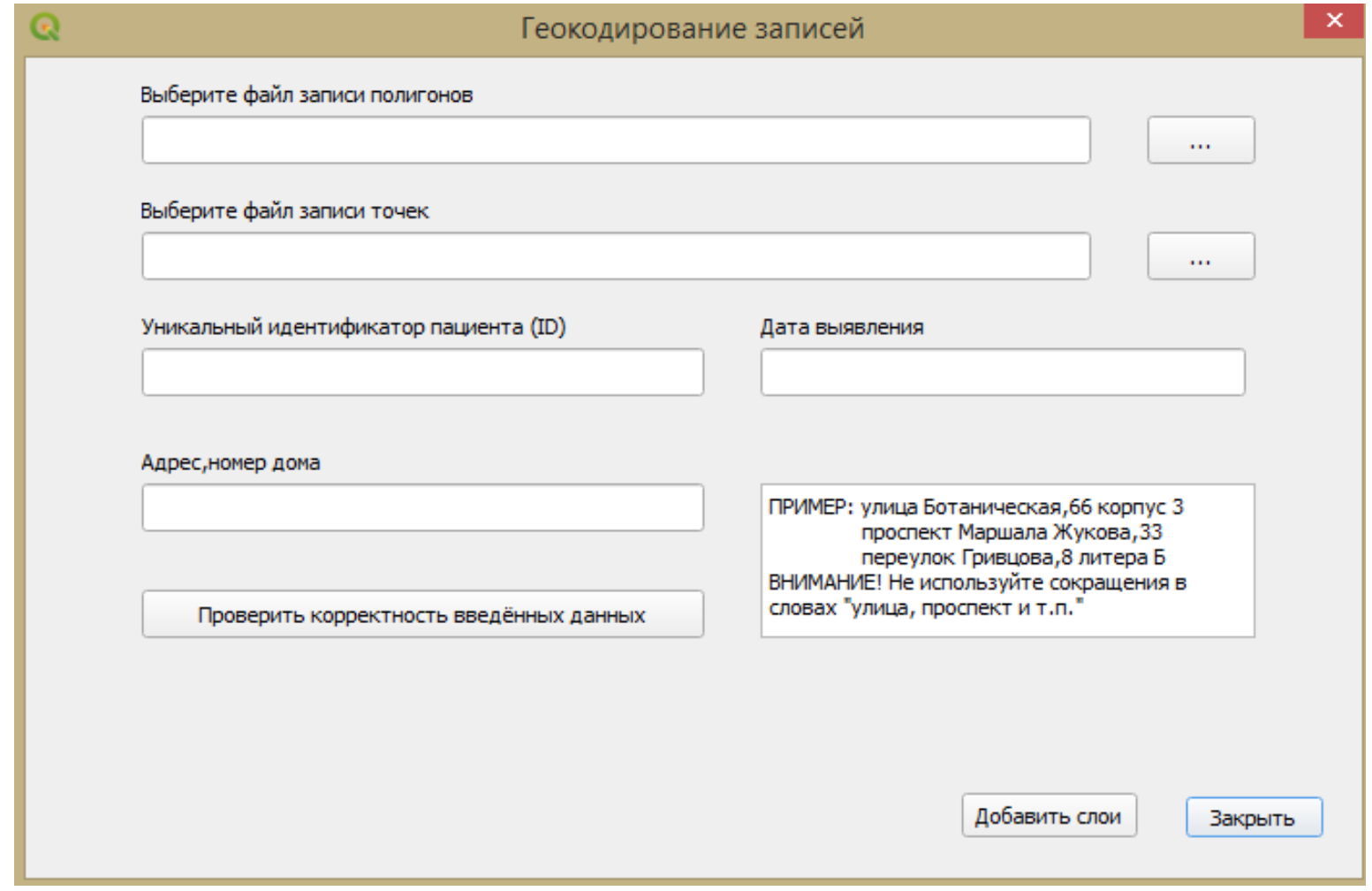

Рис. 11. Интерфейс модуля QGIS, разработанного для тестирования геокодирования Fig. 11. Interface of the QGIS module, developed for the geocoding testing

Предложенная методика геокодирования данных медицинской статистики была апробирована при геокодировании используемых в рамках исследования данных по заболеваемости туберкулёзом. Результаты первичного тестирования продемонстрировали $95 \%$ результативность при проверке и унификации адресов и $87 \%$ результативность при формировании геометрии объектов. Данное различие вызвано ошибками и неполнотой данных OSM. 5 \% данных, в свою очередь, были признаны некорректными в связи с ошибками в адресах, приведённых в составе исходных данных. Следует отметить, что при тестировании применялся последовательный ручной ввод геокодируемых данных и ручной контроль сопоставления данных, процедуры выполнялись в автоматизированном, а не полностью автоматическом режиме. Автоматическое геокодирование, ожидаемо, должно дать худшие результаты.

В ходе выполнения обработки данных были выявлены следующие виды ошибок:

1) Ошибки записи данных в медицинские карточки при регистрации случаев инфицирования - в большинстве случаев неуместное использование знака «/» в номерах домов, а также грамматические ошибки в наименованиях улиц и ошибки в указании типа объекта улично-дорожной сети (например, улица вместо проспекта);

2) Ошибки ФИАС. Госреестр адресов, хоть и в минимальном количестве, но всё же содержит ошибки, причиной появления которых, вероятнее всего, является человеческий фактор. Так, адреса по улице Куйбышева (Санкт-Петербург) при первоначальном геокодировании были полностью признаны некорректными, из-за ошибочного дублирования записей в ФИАС;

3) Ошибки получения координат и ошибки связывания атрибутов с полигональной геометрией. B OSM присутствуют ошибки, связанные, в основном, с присвоением домам номеров (например, присвоение дому номера «17» при официальном номере «15-17»). 


\section{ВЫВОДЫ}

В сущности, разработанная и протестированная в данном исследовании методика предполагает использование в дополнение к справочнику (адресной базе пространственных данных) верифицированного (официального) адресного реестра, созданного и поддерживаемого официальными службами или организациями, официально наделёнными правом таких работ на уровне государства. В рамках методики, указанный реестр используется как эталон адресов, а геокодируемые данные связываются с данными справочника не напрямую, а через реестр. Фактически записи геокодируемых данных и справочника связываются с эталонным реестром, из которого в итоге и извлекается верифицированный почтовый адрес объекта. В свою очередь, геометрия объекта извлекается из используемого справочника, а тематические (геокодируемые) атрибуты из массива исходных геокодируемых данных.

Описанная методика может быть применена для оптимизации процессов и улучшения качества ведения медицинских баз пространственных данных при выполнении медико-географических и медико-картографических исследований. Она позволяет обеспечить контроль формы и содержания адресных данных, а также приведения их к унифицированному виду. Кроме того, использованный подход может быть применён при формировании медицинских баз данных для контроля сохраняемых в базе адресных данных.

\section{СПИСОК ЛИТЕРАТУРЫ}

1. Борис Ф.Н., Maxm В.А., Борис Е.А. Решение задач массовой оценки недвижимости с применением метода геокодирования. Омский научный вестник, 2014. № 2(130). С. 214-216.

2. Макаров О.С. Обзор online-сервисов по формализации адресов. XLVII Огарёвские чтения, Материалы научной конференции, 2019. С. 352-357.

3. Маннанов А.А., Агишев T.X. Геокодирование областей средствами Яндекс карт и поисковой системы данных Openstreetmap Nominatim. Теория и практика модернизации научной деятельности в условиях цифровизации, Сборник статей международной научно-практической конференции, 2020. С. 20-23.

4. Степанова Л.А., Зайцева Е.Н. Геокодирование объектов в Quantum GIS c использованием базы данных Яндекс. Программные продукты и системы, 2015. № 3. C. 199-203. DOI: 10.15827/0236-235X.111.199-203.

5. Фарафонов А.И. Разработка системы автоматического геокодирования в транспортной компании. Вестник ИЖГТУ имени М.Т. Калашникова, 2015. Т. 18. № 1. C. 103-105.

6. Harris D.R., Delcher C. Bench4gis: benchmarking privacy-aware geocoding with open big data. Proceedings - 2019 IEEE International Conference on Big Data, 2019. Article 9006234. P. 4067-4070. DOI:10.1109/BigData47090.2019.9006234.

7. Kuznetsov I., Panidi E., Kolesnikov A., Kikin P., Korovka V., Galkin V. GIS-based infectious disease data management on a city scale, case study of St. Petersburg, Russia. International Archives of the Photogrammetry, Remote Sensing and Spatial Information Sciences, 2020. V. XLIII-B3-2020. P. 1463-1467. DOI:10.5194/isprs-archives-XLIII-B32020-1463-2020.

8. Kuznetsov I., Panidi E., Korovka V., Galkin V. City-scale GIS-based monitoring of infectious disease - contemporary issues, case study of St. Petersburg, Russia. Proceedings of the 6th Internatonal Scientific Conference GEOBALCANICA, 2020. P. 791-796. DOI: 10.18509/GBP. 2020.87. 
9. Kuznetsov I., Panidi E., Korovka V., Galkin V., Voronov D. Web-based representation and management of infectious disease data on a city scale, case study of St. Petersburg, Russia. International Archives of the Photogrammetry, Remote Sensing and Spatial Information Sciences, 2020. V. XLIV-3/W1-2020. P. 87-91. DOI: 10.5194/isprs-archives-XLIV-3W1-2020-87-2020.

10. Pietro G.D., Rinnone F. Online geocoding services: a benchmarking analysis to some European cities. Proceedings of the 2017 Baltic Geodetic Congress (BGC Geomatics), 2017. Article 8071486. P. 273-281. DOI: 10.1109/BGC.Geomatics.2017.12.

11. Rashidian S., Dong X., Avadhani A., Poddar P., Wang F. Effective scalable and integrative geocoding for massive address datasets. Proceedings of the 25th ACM SIGSPATIAL International Conference on Advances in Geographic Information Systems, 2017. Article 26. P. 1-10. DOI: 10.1145/3139958.3139986.

12. Rashidian S., Jain S.K., Dong X., Wang F. EaserGeocoder: integrative geocoding with machine learning. Proceedings of the 26th ACM SIGSPATIAL International Conference on Advances in Geographic Information Systems, 2018. P. 572-575. DOI: $10.1145 / 3274895.3274929$.

13. Rizwan M., Dass S.C., Asirvadam V.S., Gill B.S., Sulaiman L.H. DenMap: a Dengue surveillance system for Malaysia. Journal of Physics: Conference Series, 2018. V. 1123. Issue 1. Article 012045. DOI: 10.1088/1742-6596/1123/1/012045.

14. Silveira I.H.D., Oliveira B.F.A., Junger W.L. Use of Google Maps for geocoding data from the Mortality Information System in Rio de Janeiro municipality, Brazil, 2010-2012. Epidemiologia e servicos de saude : revista do Sistema Unico de Saude do Brasil, 2017. V. 26. Issue 4. P. 881-886. DOI: 10.5123/S1679-49742017000400018.

15. Wheeler A.P., Gerell M., Yoo Y. Testing the spatial accuracy of address-based geocoding for gunshot locations. Professional Geographer, 2020. V. 72. Issue 3. P. 398-410. DOI: 10.1080/00330124.2020.1730195.

\section{REFERENCES}

1. Boris F.N., Makht V.A., Boris E.A. The solution of problems of mass appraisal of real estate with application of the method of geocoding. Omsk Scietntific Bulletin, 2014. V. 2 (130). P. 214-216 (in Russian).

2. Harris D.R., Delcher C. Bench4gis: benchmarking privacy-aware geocoding with open big data. Proceedings - 2019 IEEE International Conference on Big Data, 2019. Article 9006234. P. 4067-4070. DOI:10.1109/BigData47090.2019.9006234.

3. Farafonov A.I. Development of automatic geocoding in transportation company. Vestnik IzGTU imeni M.T. Kalasnikova, 2015. V. 18. Issue 1. P. 103-105 (in Russian).

4. Kuznetsov I., Panidi E., Kolesnikov A., Kikin P., Korovka V., Galkin V. GIS-based infectious disease data management on a city scale, case study of St. Petersburg, Russia. International Archives of the Photogrammetry, Remote Sensing and Spatial Information Sciences, 2020. V. XLIII-B3-2020. P. 1463-1467. DOI: 10.5194/isprs-archives-XLIII-B32020-1463-2020.

5. Kuznetsov I., Panidi E., Korovka V., Galkin V. City-scale GIS-based monitoring of infectious disease - contemporary issues, case study of St. Petersburg, Russia. Proceedings of the 6th Internatonal Scientific Conference GEOBALCANICA, 2020. P. 791-796. DOI: 10.18509/GBP. 2020.87.

6. Kuznetsov I., Panidi E., Korovka V., Galkin V., Voronov D. Web-based representation and management of infectious disease data on a city scale, case study of St. Petersburg, Russia. International Archives of the Photogrammetry, Remote Sensing and Spatial Information 
Sciences, 2020. V. XLIV-3/W1-2020. P. 87-91. DOI: 10.5194/isprs-archives-XLIV-3W1-2020-87-2020

7. Makarov O.S. Overview of online services for addresses formalizing. XLVII Ogarev Readings, Proceedings of the Scientific Conference, 2019. P. 352-357 (in Russian).

8. Mannanov A.A., Agishev T.H. Geocoding of areas using Yandex Maps and the Openstreetmap Nominatim data search engine. Theory and Practice of Modernization of the Scientific Activity in the Conditions of Digitalization, Proceedings of the International Scientific and Practical Conference, 2020. P. 20-23 (in Russian).

9. Pietro G.D., Rinnone F. Online geocoding services: a benchmarking analysis to some European cities. Proceedings of the 2017 Baltic Geodetic Congress (BGC Geomatics), 2017. Article 8071486. P. 273-281. DOI: 10.1109/BGC.Geomatics.2017.12.

10. Rashidian S., Dong X., Avadhani A., Poddar P., Wang F. Effective scalable and integrative geocoding for massive address datasets. Proceedings of the 25th ACM SIGSPATIAL International Conference on Advances in Geographic Information Systems, 2017. Article 26. P. 1-10. DOI: 10.1145/3139958.3139986.

11. Rashidian S., Jain S.K., Dong X., Wang F. EaserGeocoder: integrative geocoding with machine learning. Proceedings of the 26th ACM SIGSPATIAL International Conference on Advances in Geographic Information Systems, 2018. P. 572-575. DOI: 10.1145/3274 895.3274929.

12. Rizwan M., Dass S.C., Asirvadam V.S., Gill B.S., Sulaiman L.H. DenMap: a Dengue surveillance system for Malaysia. Journal of Physics: Conference Series, 2018. V. 1123. Issue 1. Article 012045. DOI: 10.1088/1742-6596/1123/1/012045.

13. Silveira I.H.D., Oliveira B.F.A., Junger W.L. Use of Google Maps for geocoding data from the Mortality Information System in Rio de Janeiro municipality, Brazil, 2010-2012. Epidemiologia e servicos de saude : revista do Sistema Unico de Saude do Brasil, 2017. V. 26. Issue 4. P. 881-886. DOI:10.5123/S1679-49742017000400018.

14. Stepanova L.A., Zaitseva E.N. Geocoding sites in Quantum GIS with the help of Yandex databases. Software \& Systems, 2015. V. 3. P. 199-203 (in Russian). DOI: 10.15827/0236235X.111.199-203.

15. Wheeler A.P., Gerell M., Yoo Y. Testing the spatial accuracy of address-based geocoding for gunshot locations. Professional Geographer, 2020. V. 72. Issue 3. P. 398-410. DOI: 10.1080/ 00330124.2020.1730195. 


\title{
А.П. Карпик ${ }^{1}$, Д.В. Лисицкий ${ }^{2}$, А.Г. Осипов ${ }^{3}$, В.Н. Савиных ${ }^{4}$ \\ ГЕОКОГНИТИВНЫЕ МЕТОДЫ ОБЕСПЕЧЕНИЯ АНАЛИЗА И ПРОГНОЗИРОВАНИЯ СОЦИАЛЬНО-ЭКОНОМИЧЕСКОГО РАЗВИТИЯ ТЕРРИТОРИЙ
}

\begin{abstract}
АННОТАЦИЯ
Рассматриваются вопросы использования геопространственных данных, информации и знаний в процессах анализа и прогнозирования социально-экономического развития территорий. Предлагается расширение состава единого комплекса средств макроэкономического межрегионального межотраслевого планирования за счет более полного учета геопространственных особенностей изучаемой территории и перехода к новой модели пространственно-экономической политики на основе широкого использования цифровых геоплатформ. Приводится информация о значимости геопространственного обеспечения планирования и управления территориями в целях устойчивого развития их экономики и социальной сферы и сведения о поддержке этой индустрии на международном $(\mathrm{OOH})$ и национальном уровнях наиболее развитых стран мира. Указывается цель выполненных исследований - обоснование методологии продуктивного и эффективного геопространственного обеспечения решений аналитических и прогнозных задач, повышающего уровень учета территориальных особенностей регионов. Предлагается новый термин «геокогнитивное моделирование территории» и теоретико-методологические подходы к оценке этого процесса для обеспечения стратегического регионального планирования. Сформулирован ряд исходных концептуальных положений, в том числе: на микроуровне экономики больше востребованы геоданные и геоинформация, на макроуровне экономики - геознания. Геознания относятся к определенным предметно-пространственным неоднородностям и их можно представить как особый вид пространственных объектов и обрабатывать средствами ГИС. Приводится перечень показателей отдельного геофрагмента территории для использования в стратегическом планировании. Описан предлагаемый метод решения геопространственной задачи оценки синергетического эффекта при взаимодействии объектов природных ресурсов с транспортной системой путем увеличения связанности территорий. В качестве примера предложена модель когнитивной индексации геофрагментов и дано ее теоретикомножественное представление. Сделан вывод о необходимости более полного использования геопространственных средств в планировании развития регионов, что позволит снизить риски принятия необоснованных управленческих решений и учесть влияние человеческого фактора.
\end{abstract}

\footnotetext{
1 Сибирский государственный университет геосистем и технологий, ул. Плахотного, д. 10, 630108, Новосибирск, Россия, e-mail: rector@ssga.ru

2 Сибирский государственный университет геосистем и технологий, ул. Плахотного, д. 10, 630108, Новосибирск, Россия, e-mail: dlis@ssga.ru

3 Сибирский государственный университет геосистем и технологий, ул. Плахотного, д. 10, 630108, Новосибирск, Россия, e-mail: a.g.osipov@ssga.ru

4 Новосибирский государственный технический университет, Россия, проспект К. Маркса, д. 20, 630073, Новосибирск, Россия, e-mail: savinslav@inbox.ru
} 
КЛЮЧЕВЫЕ СЛОВА: геопространственное обеспечение планирования, геоданные, геоинформация, геознания, геокогнитивный метод, геофрагмент, модель когнитивной индексации геофрагментов.

\title{
Alexander P. Karpik ${ }^{1}$, Dmitry V. Lisitsky², Aleksey G. Osipov ${ }^{3}$, Vyacheslav N. Savinykh ${ }^{4}$ \\ GEO-COGNITIVE METHODS OF PROVIDING ANALYSIS AND FORECASTING OF SOCIO-ECONOMIC DEVELOPMENT OF TERRITORIES
}

\begin{abstract}
The issues of using geospatial data, information and knowledge in the processes of analysis and forecasting of socio-economic development of territories are considered. It is proposed to expand the composition of a single complex of means for macroeconomic interregional intersectoral planning due to a more complete consideration of the geospatial features of the studied territory and the transition to a new model of spatial and economic policy based on the widespread use of digital geoplatforms. The article provides information on the importance of geospatial support for planning and management of territories for the sustainable development of their economy and social sphere and information on the support of this industry at the international (UN) and national levels of the most developed countries of the world. The purpose of the research is indicated - the substantiation of the methodology for productive and effective geospatial support for the solutions of analytical and forecasting tasks, which increases the level of taking into account the territorial features of the regions. A new term "geocognitive modeling of the territory" and theoretical and methodological approaches to assessing this process to ensure strategic regional planning are proposed. A number of initial conceptual provisions have been formulated, including: geodata and geoinformation are more in demand at the microlevel of the economy, and geoscience at the macrolevel of the economy. Geosciences refer to certain subject-spatial heterogeneities and they can be represented as a special type of spatial objects and processed by means of GIS. A list of indicators of a separate geofragment of the territory for use in strategic planning is given. The proposed method for solving the geospatial problem of assessing the synergetic effect in the interaction of natural resources with the transport system by increasing the connectivity of territories is described. As an example, a model of cognitive indexing of geofragments is proposed and its set-theoretic representation is given. The conclusion is made about the need for a more complete use of geospatial tools in planning the development of regions, which will reduce the risks of making unreasonable managerial decisions and take into account the influence of the human factor.
\end{abstract}

KEYWORDS: geospatial planning support, geodata, geoinformation, geoscience, geocognitive method, geofragment, model of cognitive indexing of geofragments.

\section{ВВЕДЕНИЕ}

\footnotetext{
1 Siberian State University of Geosystems and Technologies, Plakhotnogo St., 10, 630108, Novosibirsk, Russia,e-mail: rector@ssga.ru

2 Siberian State University of Geosystems and Technologies, Plakhotnogo St., 10, 630108, Novosibirsk, Russia,e-mail: dlis@ssga.ru

Siberian State University of Geosystems and Technologies, Plakhotnogo St., 10, 630108, Novosibirsk, Russia, e-mail: a.g.osipov@ssga.ru

Novosibirsk State Technical University, K. Marx Prospect, 20, 630073, Novosibirsk, Russia, e-mail: savinslav@inbox.ru
} 
Представленное исследование выполнено в рамках крупного научного проекта по приоритетному направлению научно-технологического развития России «Социальноэкономическое развитие Азиатской России на основе синергии транспортной доступности, системных знаний о природно-ресурсном потенциале, расширяющегося пространства межрегиональных взаимодействий». Головной разработчик темы - Институт экономики и организации промышленного производства СО РАН (Новосибирск). Проект направлен на разработку современной методологии анализа и оценки направлений пространственного развития Азиатской России (территории Российской Федерации, расположенной в пределах Азии).

Целью проекта является создание научных, методологических и техникоинформационных основ разработки и обоснования направлений социальноэкономического развития регионов Азиатской России в едином народнохозяйственном комплексе национальной экономики России. В состав решаемых задач проекта включены, наряду с другими, такие задачи, как развитие комплекса средств анализа и прогнозирования экономики регионов, разработка базы знаний о природно-ресурсном потенциале регионов и Азиатской России, разработка инструментария для анализа, оценки и выбора направлений развития транспортной сети, взаимодействия научно-индустриальных агломераций и территорий для реализации проектов, связанных с освоением природно-ресурсного потенциала.

Главной особенностью разрабатываемого проекта является его глобальный характер, требующий формирования, развития и применения единого комплекса средств макроэкономического межрегионального межотраслевого анализа и прогнозирования [Крюков и др., 2020]. Одним из направлений развития этого комплекса, на наш взгляд, является более полный учет геопространственных особенностей изучаемой территории и осуществление перехода к новой модели пространственно-экономической политики на основе широкого использования цифровых геоплатформ. Такой подход обеспечивает удовлетворение значительного роста потребностей в пространственных данных, а также услугах, сервисах и продуктах, созданных на их базе, расширение спектра сфер применения технологий сбора, обработки и анализа пространственных и пространственно-временных данных, которые следует отнести к сквозным технологиям цифровой экономики, то есть технологиям, оказывающим наиболее существенное влияние на модернизацию существующих и развитие новых рынков ${ }^{1}$.

Актуальность и значимость такого подхода подтверждается тем, что в современных геоэкономических реалиях для экономического пространства каждой страны критически важным является четкое определение пространственно-экономической политики. Иначе в скором времени это государство может столкнуться с тем, что окажется в списке неконкурентоспособных субъектов международных отношений с зависимой экономикой и ограниченным суверенитетом. Уже сейчас, как показывают расчеты Всемирного банка лишь из-за малоэффективной пространственной организации только развивающиеся страны теряют около 2-3\% ВВП ежегодно [Colombo, 2020]. Значимость геопространственной поддержки планирования и управления территориями в целях устойчивого развития их экономики и социальной сферы в последние годы неоднократно подтверждается на международном и национальном уровнях наиболее развитых стран мира.

Так, по линии ООН, в последние годы созданы Комитет экспертов ООН по глобальному управлению геопространственной информацией (UN-GGIM) и Группа

1 Росреестр предложил сформировать экспертную группу по развитию геоинформационных технологий и пространственных данных. Электронный ресурс: https:/www.cnews.ru/news/line/202002-05_rosreestr_predlozhil_sformirovat (дата обращения 15.03.2021). 
экспертов $\mathrm{OOH}$ по интеграции статистической и геопространственной информации (UN EG-ISGI), принята Глобальная статистическая геопространственная рамочная программа (GSGF), создана Интегрированная система геопространственной информации (IGIF), организуются геопространственные мировые форумы $(\mathrm{GWF})^{1}$. Например, Интегрированная система геопространственной информации используется уже более чем в 100 странах мира в качестве комплексной платформы геопространственной информации, предназначенной для широкого круга заинтересованных сторон, в первую очередь, высокопоставленных политиков и лиц, принимающих решения в правительстве, учреждениях и организациях. Указанная система обеспечивает реализацию стратегических целей стратегические идеи и «является важнейшим элементом национального социального, экономического и экологического развития» ${ }^{2}$. По заданию ООН составлен официальный документ по интеграции геопространственных и ВIM-технологий, в которой отмечается, что «содействие геопространственным технологиям является одним из основных элементов реализации повестки дня в достижении целей устойчивого развития на период до 2030 года» ${ }^{3}$.

На сайте Всемирного банка утверждается, что «в цифровую эпоху геопространственные технологии революционизируют экономику» ${ }^{4}$, а в совместном документе «Повышение роли инфраструктуры геопространственных знаний в Мировой экономике, обществе и окружающей среде», подготовленном международной аккредитованной организацией Geospatial Media and Communications и статистическим отделом Департамента экономических и социальных вопросов OOH (UNSD) отмечается, что «Геопространство» широко распространено в новой экономике, поскольку «местоположение» становится мощным интегратором» и «Инфраструктура геопространственных знаний обеспечивает надежное понимание, знания, решения и автоматизацию путем интеграции геопространственной информации, аналитики и визуализации в среду знаний и автоматизации нашего совместного цифрового будущего». 5 .

В развитие этого направления широкого использования геопространственных данных и информации в планировании и управлении территориями в самое последнее время проявился новый тренд использования в этой сфере геопространственных знаний, который открывает самые широкие перспективы для обеспечения растущих потребностей экономики и общества. Например, на сайте уже упомянутой компании «Geospatial Media» сообщается, что под эгидой ООН развернута международная кампания под названием «Продвижение вперед. Роль инфраструктуры геопространственных знаний в мировой

$1 \quad$ The Integrated Geospatial Information Framework Part 1: The Overarching Strategic Framework. First International Workshop on Operationalizing the Integrated Geospatial Information Framework 9-11 September 2019, Celso Furtado Conference Room, ECLAC, Santiago, Chile. Electronic resource: https:// www. cepal.org/sites/default/files/presentations/igif-part-1-overarching-strategic-framework-greg-scott-unggim.p (дата обращения: 20.03.2021).

2 Экономический и Социальный Совет. Официальные отчеты, 2017. Электронный pecypc: https:// ggim.un.org/ggim_20171012/docs/meetings/GGIM7/GGIM-Report_r.pdf (дата обращения: 20.03.2021). The value of Integrated Geospatial and Building Information Modelling (BIM) solutions to advance the United Nations Sustainable Development Goals (Agenda 2030) with specific focus on resilient infrastructure. Electronic resource: http://www.wfeo.org/wp-content/uploads/members/Webinars/Webinar HLPF/WGICWFEO-UNSD White-Paper/20200709-WGIC-WFEO-UNSD-White-Paper-Resilient-Infrastructure.pdf (дата обращения: 20.03.2021).

4 Geospatial Technology and Information for Development. Electronic resource: https://www.worldbank. org/en/ topic/ land/brief/geospatial-technology-and-information-for-development (дата обращения: 15.09.2020).

5 Advancing Role of Geospatial Knowledge Infrastructure in World Economy, Society and Environment. Version 1.0 | 01/07/2020. Discussion Document. https:/geospatialmedia.net/pdf/GKI-DiscussionDocument-Ver1.0.pdf (дата обращения: 20.03.2021). 
экономике, обществе и окружающей среде», целью которой является «проецирование ценностного предложения геопространственных знаний, прогнозирование их актуальности и связанности с основами экономики и общества следующего поколения и пересмотр роли заинтересованных сторон: правительства, промышленности и гражданского общества» ${ }^{1}$. При этом в целом ряде публикаций обращается внимание на необходимость пересмотра основных представлений, направлений и тенденций в использовании геопространственных данных, информации и знаний для планирования развития и управления территориями, адекватных новой парадигме геопространственной деятельности [Карпик $u$ дp., 2020]. В этой связи интенсификация исследований и разработок, поиск новых подходов, методов и технологий геопространственного обеспечения регионов становится своего рода императивом.

При этом, анализ современных публикаций по данной тематике показывает, что на фоне неуклонного расширения объемов и сфер применения геопространственных данных и информации в решении различных пространственных задач, использование геопространственных знаний при планировании развития территорий все еще находится на самом начальном этапе. Например, в публикации ${ }^{2}$ приведены многочисленные (1000!) ГИС-проекты самого широкого спектра и только несколько узконаправленых проектов для целей пространственного планирования территорий, например:

- $\quad$ распределение производства в пространстве с учетом затрат на транспорт и фактор мобильности (модель Тюнена);

- исследование взаимосвязи между географической близостью к инновационным ресурсам и доходностью акций (индекс географических инноваций);

- $\quad$ определение экономических показателей для бизнеса, промышленности и демографии на основе радиуса, движения и близости (индикатор экономической базы).

Это обстоятельство диктует необходимость более глубокого рассмотрения вопросов геокогнитивного моделирования, основанного на формировании и использовании геопространственных знаний, в решении задач анализа и прогнозирования в процессе планирования пространственного развития регионов.

\section{МАТЕРИАЛЫ И МЕТОДЫ ИССЛЕДОВАНИЯ}

Целью выполненного нами исследования является обоснование методологии продуктивного и эффективного геопространственного обеспечения решений аналитических и прогнозных задач, повышающего уровень учета территориальных особенностей регионов. Для этого решалась задача определения основных особенностей кардинально новых представлений и результатов геопространственной деятельности в связи с формированием и использованием геопространственных знаний о территориях. Основу исследования составил анализ современной технической литературы ведущих стран мира по вопросам концепций, парадигм и стратегических направлений использования геознаний в процессах стратегического планирования пространственного развития территорий с учетом глобальной цифровизации экономики и социальной сферы и достижений надвигающейся 4-й промышленной революции. Методика исследований включала поиск соответствующих публикаций с контент-анализом в режиме онлайн, отбор информативных и полезных для исследования источников, их анализ, осуществление фор-

\footnotetext{
1 Towards a Spatial Knowledge Infrastructure. White Paper. Electronic resource: https://www.crcsi.com.au/ assets/Program-3/CRCSI-Towards-Spatial-Knowledge-Whitepaper-web-May2017.pdf (дата обрашения: 20.03.2021).

21000 GIS Applications \& Uses - How GIS Is Changing the World. [Electronic resource]. - URL: https:// gisgeography.com/gis-applications-uses/ (дата обращения: 10.07.2021).
} 
мально-логического анализа и теоретико-множественного описания выявленных аспектов получения и использования геопространственных знаний, создание геокогнитивных моделей, отражающих геознания о территории, формулирования основных концептов и формирования методологических и технологических решений по непосредственному использованию предлагаемых моделей в процессах пространственного анализа и прогнозирования социально-экономического развития регионов Азиатской России.

\section{РЕЗУЛЬТАТЫ ИССЛЕДОВАНИЙ И ИХ ОБСУЖДЕНИЕ}

В основе геопространственной деятельности по обеспечению решений задач планирования и управления территориями лежит базовое представление о территории как о некоторой неоднородной среде, элементы которой подлежат выявлению и затем геопространственному моделированию.

С позиций хозяйственного использования территорию можно представить как пространственно-временной и инфраструктурный комплекс природных, производственных и трудовых ресурсов, находящихся во взаимодействии, регулируемом законодательными и нормативными актами. То есть здесь имеет место предметная неоднородность экономического пространства. В геопространственном аспекте территория - это комплекс взаимосвязанных между собой в едином географическом пространстве объектов, процессов и явлений, отражающих неоднородность этого пространства и характеризуемых своим местоположением и границами. То есть здесь имеет место и регистрируется пространственная неоднородность. Пересечение этих двух комплексов образует производный комплекс, элементы которого наследуют предметные и пространственные свойства и могут быть обозначены как предметно-пространственные неоднородности.

В процессе геопространственной деятельности свойства каждой выделенной предметно-пространственной неоднородности фиксируются с помощью предметных и пространственных данных - геоданных. Совокупность этих данных образует геоинформационную модель этой неоднородности, которая в технической литературе получила название пространственного или геопространственного объекта. В результате геоинформационной обработки геоданных формируется совокупность геопространственных объектов, заданных своими границами в единой инфраструктуре пространственных данных, в том числе единой координатной системе (например, X,Y,H), и во взаимосвязи, которая и является искомой геоинформационной моделью территории (ГИМТ).

И геоданные, и полученная на их основе геоинформация создают образ территории как объективной реальности. Однако для анализа состояния, планирования пространственного развития и управления территорией необходимы еще определенные знания, представляющие собой оценку, понятия и суждения о сущности, значимости, полезности, ценности и других субъективных качеств территории в целом, находящихся на ней объектов и происходящих на ней процессов и явлений. Такие знания получили название геознаний, а созданный на их основе в результате умозаключений субъективный образ территории, предлагается нами обозначить новым термином «геокогнитивная модель территории» (ГКМТ). При этом сам процесс создания ГКМТ целесообразно обозначить термином «геокогнитивное моделирование территории».

Таким образом, современная концепция геопространственного обеспечений стратегического планирования развития и управления регионами должна основываться на использовании в едином комплексе базовых понятий геопространственного объекта, геоинформационной и геокогнитивной моделей территории, соответствующих фундаментальным понятиям данные, информация и знания. При этом, методы и технологии работы с геоданными и геоинформацией в настоящее время достаточно отработаны, однако 
методология получения и использования геознаний еще не сформирована и требует глубокой проработки. Рассмотрим теоретико-методологические подходы и вопросы оценки геокогнитивного моделирования территории для обеспечения стратегического планирования социально-экономического развития регионов.

Предварительно сформулируем следующие исходные концептуальные положения.

1. Степень и характер использования геоданных, геоинформации и геознаний в процессах анализа и прогнозирования развития территории зависят от уровня решаемых экономических задач - на микроуровне в большей степени востребованы геопространственные данные и геоинформация, на макроуровне - приоритет получают геознания.

2. Поскольку геознания могут рассматриваться относительно к определенным предметно-пространственным неоднородностям их также можно выделить и зафиксировать с помощью геоданных, и, следовательно, представить как особый вид пространственных объектов.

3. На множестве этих пространственных объектов можно выполнить стандартную геоинформационную обработку средствами ГИС и получить в результате геокогнитивную модель территории, в том числе и в виде специальной тематической карты (геокогнитивной карты).

4. Каждый пространственный объект геокогнитивной модели содержит геознания о том или ином природном и/или отраслевом объекте, процессе и явлении, которые находятся, пересекаются, взаимосвязаны и взаимодействуют в каждой точке общего геопространства, формируя интегральные свойства территории, для отображения которых можно использовать ранее введенное нами понятие «геофрагмента» как элементарной единицы геопространства [Karpik, et al., 2020].

5. Для каждого геофрагмента можно установить различные функциональные показатели (индикаторы), отражающие знания и соответствующие требованиям решаемой геопространственной задачи, например в виде индексов. Этот подход широко используется в процессах планирования и управления [Лавриненко и др., 2019; Рубанов, 2019; Федянин и др., 2020; Bobylev, et al., 2018].

Например, при стратегическом планировании развития территорий можно для каждого геофрагмента определить следующие показатели:

- $\quad$ интегральный показатель территориальной ценности, полезности, значимости ресурсный капитал геофрагмента;

- $\quad$ интегральный показатель инженерной сложности с точки зрения освоения и обустройства территории;

- $\quad$ интегральный показатель инфраструктурной обеспеченности территории;

- показатель синергетического эффекта при взаимодействии пространственных объектов;

- показатель наличия, запасов, объемов и стоимости природных ресурсов;

- $\quad$ показатель уровня развитости транспортной сети

- показатель пригодности для осуществления той или иной производственной деятельности.

Рассмотрим решение геопространственной задачи оценки синергетического эффекта при взаимодействии объектов природных ресурсов с транспортной системой путем увеличения связанности территорий за счет создания качественно новых интеллектуальных транспортных и телекоммуникационных систем. 
Сущность предлагаемого метода заключается в выполнении следующей последовательности действий:

1. Создание (или использование готовой) геоинформационной модели территории в масштабе, соответствующем пространственному уровню (размеру) анализируемого региона

2. Составление тематической модели региона методом исключения объектов, процессов и явлений, не влияющих на результат решаемой задачи.

3. Разбиение тематической модели на геофрагменты.

4. Анализ каждого геофрагмента по заданным показателям и определение их значений (отдельно по видам природных ресурсов и по транспорту).

5. Распределение геофрагментов по группам с заданными диапазонами значений показателей (отдельно группы по видам природных ресурсов и группы по транспорту).

6. Поочередное комплексирование геофрагментов из групп видов природных ресурсов и групп транспорта в пространственно-связные кластеры с вычислением интегрального показателя эффекта, в том числе синергетического, для каждого создаваемого кластера.

7. Ранжирование пространственно-связных кластеров по значениям интегрального показателя или индекса эффекта.

8. Составление геокогнитивных моделей и карт с отображением промежуточных и окончательных результатов анализа территории региона.

В зависимости от вида экономического эффекта от взаимодействия объектов природных ресурсов с объектами транспортной сети могут быть использованы и разные показатели оценки геофрагментов и формируемых кластеров:

- $\quad$ увеличение объемов добычи природных ресурсов - натуральные показатели (тонны, кубометры);

- $\quad$ снижение транспортных расходов - в денежном выражении или в процентах (общий оборот, прибыль);

- $\quad$ увеличение финансовых показателей - в денежном выражении или в процентах (общий оборот, прибыль).

Кроме того, следует учесть, что вся описанная процедура анализа территории региона может быть выполнена как для существующей так и для прогнозируемой ситуации.

Рассмотрим более детально представление предлагаемого подхода на примере проблемы транспортировки природных ресурсов, которая занимает особое место в обеспечении пространственной связанности России, особенно ее Азиатской части. Транспортный полиморфизм состоит в том, что постиндустриальное освоение, в отличие от индустриального, как правило, не останавливается на выборе одного, оптимального варианта доставки грузов и пассажиров. Всегда есть стремление использовать различные дополнительные варианты, а не только основной. Поэтому, например, хоть транссибирская инфраструктурная ось и обречена на жесткую конкуренцию с маршрутом из Китая в Европу, проходящим через Казахстан, какая-то часть грузов достанется Транссибу и из тех районов, для которых этот маршрут не является кратчайшим. Разумеется, эта ситуация симметрична - какая-то часть грузов пойдет через Казахстан и от тех грузоотправителей, для которых кратчайший путь проходит по Транссибу. ${ }^{1}$

Шупер В. Будущее России в Большой Евразии. Электронный ресурс: http://mirperemen.net/ 2018/07/ budushhee-rossii-v-bolshoj-evrazii/ (дата обращения: 15.03.2021). 
Разработки более совершенных цифровых моделей обеспечения транспортной связанности регионов страны ведется различными коллективами ученых и специалистов. Исследовательская группа сотрудников Сибирского государственного университете геосистем и технологий (СГУГиТ) предлагает свою «Модель когнитивной индексации геофрагментов», которая позволяет оценивать геофрагменты территории в различных аспектах и может найти применение в формировании цифровых геопространственных платформ. Рассмотрим эту модель в аспекте перемещения природных ресурсов.

Модель представлена так: Предположим, что даны координаты действующего или предполагаемого к освоению объекта производства ресурса $R=\left(R_{1}, R_{2}\right)$. Пусть по какому-либо правилу, с учетом агломераций потребителей этого ресурса, проведена фрагментация географической карты России. Способы фрагментации и ее масштабы нуждаются в отдельном подробном обсуждении и здесь пока рассматриваться не будут.

Обозначим $O_{i}=\left(O_{i 1}, O_{i 2}\right) \quad-$ координаты условных «центров» построенных геофрагментов, причем $i=1, \ldots, N$, где $N$ - общее количество геофрагментов.

Точка $R$ и точка $O_{i}$ как противоположные угловые точки позволяют выделить на географической карте прямоугольную область $\mathrm{D}$, которая имеет координаты левого нижнего угла $\left[\min \left(O_{i 1}, R_{1}\right) ; \min \left(O_{i 2}, R_{2}\right)\right]$, а координаты правого верхнего угла $\left[\max \left(O_{i 1}, R_{1}\right) ; \max \left(O_{i 2}, R_{2}\right)\right]$.

Область D, в свою очередь, содержит некоторый фрагмент функционирующей сети железных дорог (магистральных трубопроводов), к которому нужно виртуально подключиться как со стороны потребителя $O$, так и со стороны объекта производства ресурса $R$. Предположим, что при минимуме затрат на строительство виртуальной «дуги» $\left(w, O_{i}\right)$ в размере $Z_{i}$ д.е., можно подключить потребителя $O_{i}$ к транспортной сети в вершине w.

С другой стороны предположим, что при построении виртуальной «дуги» $(R, s) \mathrm{c}$ минимумом затрат в размере $Z$ д.е. можно подключить объекта производства ресурса $\mathrm{R}$ к той же самой транспортной сети в вершине $s$. В частных случаях либо объект производства peсурса $R$, либо потребитель $O_{i}$, либо оба вместе могут быть уже подключенными к данному фрагменту сети. В общем случае эти необходимые виртуально добавленные подключения позволяют возможную доставку единицы ресурса от объекта производства ресурса $R$ потребителю $O_{i}$ рассматривать в три этапа:

1 этап. Транспортировка единицы ресурса по «дуге» $(R, s)$,

2 этап. Прохождение единицы ресурса через соответствующий фрагмент сети из вершины $s$ до вершины w,

3 этап. Транспортировка единицы ресурса по «дуге» $\left(w, O_{i}\right)$.

Из перечисленных этапов наиболее доступен для оптимального управления в реальном времени 2 этап. Остановимся на нем поподробнее.

Сеть железнодорожных сообщений или магистральных трубопроводов, расположенных в географической области D обычно рассматривается в виде связного ориентированного графа $G_{\mathrm{D}}(V, U)$, где $V=\left\{v_{1}, v_{2}, \ldots, v_{n}\right\}$ - множество вершин, точек разветвления входящих и выходящих дуг, $U=\left\{u_{1}, u_{2}, \ldots, u_{m}\right\}-$ множество дуг вида $u_{i j}=\left(v_{i}\right.$, $\left.v_{j}\right), v_{i}, v_{j} \in V$. Обозначим В $\left(v_{i}\right)-$ множество вершин, соединенных дугами, выходящими из вершины $v_{i}$, а $\underline{\mathrm{B}}\left(v_{i}\right)$ - множество вершин, соединенных дугами, входящими в вершину $v_{i}$.

Связанная вершинами последовательность дуг в ориентированном графе $G_{D}$ образует путь, который также может рассматриваться как соединенная дугами последовательность вершин $d=\left(v_{0}, v_{1}, v_{2}, \ldots, v_{\mathrm{p}}\right)$. 
Пусть длину или вес дуги $u=\left(v_{i}, v_{j}\right)$ представляет число $l\left(x_{i}, x_{j}\right)$, которое в нашем случае определяется по формуле $l\left(v_{i}, v_{j}\right)=c_{i j} \times l_{i j}$, где $c_{i j}$-тариф на доставку единицы ресурса из пункта $v_{i}$ в пункт $v_{j}$, измеряемый как д.е./км, а $l_{i j}$ - длина дуги $\left(v_{i}, v_{j}\right)$, измеряемая в километрах. Тогда вес пути $d=\left(v_{0}, v_{1}, v_{2}, \ldots, v_{\mathrm{p}}\right)$, выражающий затраты на перемещение единицы ресурса по этому пути, будет вычисляться по формуле:

$$
L(d)=\sum_{v_{i}, v_{j} \in d} l\left(v_{i}, v_{j}\right)
$$

Наиболее востребованной для практики задачей является нахождение кратчайшего пути $d^{*}[s, w]$ на заданном графе $G_{D}(V, U)$ из предварительно выбранной вершины $s$ (источника) в другую выбранную вершину w (сток), где $s, \mathrm{w} \in \mathrm{V}$ [6]. Значения булевых переменных $x_{i j} \in\{0,1\}$, которые соответствуют дугам $\left(v_{i}, v_{j}\right) \in U$ и показывают необходимость отбора той или иной дуги для кратчайшего пути, вычисляются как решение следующей задачи дискретного линейного программирования (1) - (4):

$$
L=\sum_{\left(v_{i}, v_{j}\right) \in U} l\left(v_{i}, v_{j}\right) x_{i j} \rightarrow \min .
$$

при ограничениях

$$
\begin{aligned}
& \sum_{v_{j} \in B(s)} x_{s j}=1 ; \\
& \sum_{v_{j} \in B\left(v_{i}\right)} x_{i j}-\sum_{v_{k} \in \underline{B}\left(v_{i}\right)} x_{k i}=0 ; \quad(i=\overline{2, n-1}), \quad v_{i} \neq s, t ; \\
& \sum_{v_{j} \in \underline{B}(t)} x_{j t}=1 ;
\end{aligned}
$$

Нужно отметить, что задача поиска кратчайшего пути $d^{*}[s, w]$ в приведенной формулировке (1) - (4) может быть решена разными алгоритмами, практическая значимость которых для реально существующих транспортных сетей давно и активно обсуждается в специальной литературе [Смирнов, 2020].

В настоящий момент увеличивается поток публикаций по автоматизации поиска оптимальных маршрутов в транспортных сетях с применением ГИС и искусственного интеллекта, что способствует реализации предлагаемой когнитивной индексации выбранных фрагментов географической карты [Caхаров и дp., 2018; Sakharov, et al., 2021].

Под индексом транспортной доступности объекта производства ресурса $R$ для i-го геофрагмента будем понимать величину $I N D_{i t}\left(R, O_{i}\right)$, выражающую оценку суммарных затрат на доставку одной единицы ресурса от объекта производства ресурса $\mathrm{R}$ до «центра» $i$-того геофрагмента $o_{i}$ в году $t$ и вычисляемую по формуле:

$$
I N D_{i t}\left(R, O_{i}\right)=T_{1}+T_{2 t}+T_{3},
$$

где $\quad T_{1}=Z$ д.е. - оценка доставки ед. ресурса по дуге $(R, s)$;

$T_{2 t}=L_{\text {MIN }}^{t}$ д.е. - затраты на доставку ед. ресурса по пути $d^{*}[s, w]$ в году $t$,

$T_{3}=Z_{i}$ д.е. - оценка доставки ед. ресурса по дуге $\left(w, O_{i}\right)$.

Данная модель строится в русле интегративного подход к рассмотрению пространственной экономики и перспектив ее развития. Такой подход позволяет определять пространственное экономическое развитие как структурно-параметрическое и пространственно-временное упорядочение субъектов хозяйствования, базирующееся на 
согласовании элементов и связей, что обеспечивает эффективность использования их потенциала [Rietveld, et al., 2019].

\section{ВЫВОДЫ}

Представленный интегративный подход позволяет в качестве базы экономического развития рассматривать планирование сочетания ресурсов, предприятий и учреждений, для которых территориальная общность их компонентов является синергетическим фактором повышения экономической эффективности за счет значительной стабильности взаимных связей и ритмичности производственного процесса, сокращения транспортных издержек, рационального использования всех видов ресурсов и благоприятных условий маневрирования ними. А для эффективного планирования необходимо использование геоданных, геоинформации и геознаний, привлечение современных инструментов ГИС-обработки и анализа данных, технологий получения и использования геознаний, создание баз геознаний о территории, освоения на этой основе в перспективе технологий искусственного интеллекта и автоматизированных экспертных систем, моделирования процессов и явлений позволит снизить риски принятия необоснованных управленческих решений и влияния человеческого фактора. При этом, в состав комплекса средств макроэкономического межрегионального межотраслевого анализа и прогнозирования должны быть включены геокогнитивные средства представления геознаний о территориях.

\section{БЛАГОДАРНОСТИ}

Статья подготовлена в рамках выполнения гранта, предоставленного в форме субсидии на проведение крупных научных проектов по приоритетным направлениям научно-технологического развития в рамках подпрограммы «Фундаментальные научные исследования для долгосрочного развития и обеспечения конкурентоспособности общества и государства» государственной программы Российской Федерации «Научнотехнологическое развитие Российской Федерации», проект «Социально-экономическое развитие Азиатской России на основе синергии транспортной доступности, системных знаний о природно-ресурсном потенциале, расширяющегося пространства межрегиональных взаимодействий», номер соглашения с Министерством науки и высшего образования Российской Федерации № 075-15-2020-804 (внутренний номер гранта № 13.1902.21.0016).

\section{ACKNOWLEDGEMENTS}

The article was prepared within the grant for carrying out major scientific projects in priority areas of scientific and technological development under the subprogram "Fundamental scientific research for the long-term development and ensuring the competitiveness of society and the state" of the state program of the Russian Federation "Scientific and technological development of the Russian Federation," project "Social and economic development of Asian Russia on the basis of synergy of transport accessibility, system knowledge of natural resource potential, and expanding area of interregional interactions", agreement with the Ministry of Science and Higher Education of the Russian Federation № 075-15-2020-804 (internal number 13.1902.21.0016).

\section{СПИСОК ЛИТЕРАТУРЫ}

1. Карпик А.П., Лисицикий Д.В. Перспективы развития геодезического и картографического производства и новая парадигма геопространственной деятельности. Вестник СГУГиТ. 2020. Т. 25. № 2. С. 19-29.

2. Крюков В.А., Баранов А.О., Павлов В.Н., Суслов В.И., Суслов Н.И. Проблемы развития единого комплекса средств макроэкономического межрегионального 
межотраслевого анализа и прогнозирования. Экономика региона. 2020. Т. 16. Вып. 4. C. 1072-1086. https://doi.org/10.17059/ekon.reg.2020-4-5.

3. Лавриненко П.А., Ромашина А.А., Степанов П.С., Чистяков П.А. Транспортная доступность как индикатор развития региона. Проблемы прогнозирования. 2019. № 6. C. 136-146.

4. $\quad$ Рубанов И.Н. Описание методики разработки интегральных индикаторов для оценки свойств пространственных объектов и анализ типовых ошибок исследований (на примере индикаторов устойчивого развития и регионов России). Материалы Международной конференции «ИнтерКарто.ИнтерГИС». 2019. Т. 25. Ч. 1. С. 5-17. http://intercarto.msu.ru/ jour/articles/article655.pdf.

5. Сахаров В.В., Сикарев И. А., Чертков А.А. Автоматизация поиска оптимальных маршрутов и грузовых потоков в транспортных сетях средствами целочисленного линейного программирования. Вестник государственного университета морского и речного флота им. адмирала СО Макарова. 2018. Т. 10. № 3. С. 647-657. DOI: 10.21821/2309-5180-2018-10-3-647-657.

6. Смирнов С.В. Исследование возможностей применения алгоритмов определения кратчайшего пути в ГИС. Актуальные вопросы современной науки: теория, методология, практика, инноватика. 2020. С. 56-61.

7. Федянин А.А., Грунин А.А., Карасев О.И., Кривцчова А.О., Михайленко Д.А., Петрова T.A. Индекс развития транспортного комплекса. Аналитический доклад. М.: МГУ, 2020. $116 \mathrm{c}$.

8. Bobylev S.N., Chereshnya Olga Yu., Kulmala M., Lappalainen H.K., Petäjä T., Solov'eva S.V., Tikunov V.S., Tynkkynen V.P. Indicators for digitalization of sustainable development goals in peex program. Geography, Environment, Sustainability. 2018. V. 11. No 1. C. $145-156$.

9. Colombo S. Spatial Economics Volume I. Springer, 2020. 365 p.

10. Karpik A., Lisitsky D., Osipov A., Savinykh V. New paradigm of geoinformation space in territorial aspect. Revista TURISMO: Estudos e Práticas. 2020. No 1. Mode of access: http://natal.uern.br/periodicos/index.php/RTEP/article/view/544.

11. Rietveld P., Shefer D. Regional development in an age of structural economic change. Routledge, 2019. 267 p.

12. Sakharov V., Chernyi S., Saburov S., Chertkov A. Automatization Search for the Shortest Routes in the Transport Network Using the Floyd-Warshell Algorithm. Transportation Research Procedia. 2021. V. 54. C. 1-11.

\section{REFERENCES}

1. Bobylev S.N., Chereshnya Olga Yu., Kulmala M., Lappalainen H.K., Petäjä T., Solov'eva S.V., Tikunov V.S., Tynkkynen V.P. Indicators for digitalization of sustainable development goals in peex program. Geography, Environment, Sustainability. 2018. V. 11. No 1. P. 145-156.

2. Colombo S. Spatial Economics Volume I. Springer, 2020. 365 p.

3. Fedyanin A.A., Grunin A.A., Karasev O.I., Krivtsova A.O., Mikhailenko D.A., Petrova T.A. Transport complex development index. Analytical report. Moscow State University. Moscow, 2020. 116 p. (in Russian).

4. Karpik A.P., Lisitsky D.V. Prospects for the development of geodetic and cartographic production and a new paradigm of geospatial activity. Bulletin of SGUGiT. 2020. V. 25. No 2. P. 19-29 (in Russian). 
5. Karpik A., Lisitsky D., Osipov A., Savinykh V. New paradigm of geoinformation space in territorial aspect. Revista TURISMO: Estudos e Práticas. 2020. No 1. Mode of access: http:// natal.uern.br/periodicos/index.php/RTEP/article/view/544.

6. Kryukov V.A., Baranov A.O., Pavlov V.N., Suslov V.I., Suslov N.I. Problems of development of a single complex of means of macroeconomic interregional intersectoral analysis and forecasting. Economy of the region. 2020. V. 16. No 4. P. 1072-1086. https://doi.org/ 10.17059/ ekon.reg.2020-4-5 (in Russian).

7. Lavrinenko P.A., Romashina A.A., Stepanov P.S., Chistyakov P.A. Transport accessibility as an indicator of the development of the region. Forecasting problems. 2019. No 6. P. 136-146 (in Russian).

8. Rietveld P., Shefer D. Regional development in an age of structural economic change. Routledge, 2019. 267 p.

9. Rubanov I.N. Description of the methodology for the development of integral indicators for assessing the properties of spatial objects and analysis of typical research errors (on the example of indicators of sustainable development and regions of Russia). Materials of the International Conference "InterCarto.InterGIS". 2019. V. 25. Part 1. P. 5-17. http:// intercarto.msu.ru/ jour/articles/article655.pdf (in Russian).

10. Sakharov V., Chernyi S., Saburov S., Chertkov A. Automatization Search for the Shortest Routes in the Transport Network Using the Floyd-Warshell Algorithm. Transportation Research Procedia. 2021. V. 54. P. 1-11.

11. Sakharov V.V., Sikarev I.A., Chertkov A.A. Automation of the search for optimal routes and cargo flows in transport networks by means of integer linear programming. Bulletin of the State University of Maritime and River Fleet named after Admiral SO Makarov. 2018. V. 10. No 3. P. 647-657. DOI: 10.21821 / 2309-5180-2018-10-3-647-657 (in Russian).

12. Smirnov S.V. Investigation of the possibilities of using algorithms for determining the shortest path in GIS. Topical issues of modern science: theory, methodology, practice, innovation, 2020. P. 56-61 (in Russian). 


\title{
И.А. Рыльский ${ }^{1}$ Р.В. Груздев ${ }^{2}$, Т.В. Котова ${ }^{3}$ \\ РАСЧЕТ ГРАВИТАЦИОННЫХ ПОПРАВОК С ИСПОЛЬЗОВАНИЕМ ДАННЫХ ВОЗДУШНОГО ЛАЗЕРНОГО СКАНИРОВАНИЯ
}

\begin{abstract}
АННОТАЦИЯ
Расчет поправок в гравитационные измерения является одним из важнейших этапов, определяющих качество проведения подобных работ в целом. Неправильный учет поправок в конечном итоге может сказаться на неверной интерпретации полученных измерений и привести к ложной их интерпретации.

Для достижения высокоточных результатов необходимо учитывать не только высоту, но и непосредственно весь массив сведений о рельефе. Подробность отображения рельефа при этом становится критически важной в том случае, если работы выполняются в районе с высокой степенью расчлененности рельефа и большим количеством вертикально развитых скальных формаций (останцы, скальные сбросы, крутые склоны с перегибами, и тому подобное).

В настоящее время используемые на государственном уровне методики основаны на использовании ранее созданных материалов картографических фондов (топографические карты масштаба 1:100 000 - 1:25 000). Возможно также и использование открытых (бесплатных) моделей рельефа. Эти материалы имеют ряд недостатков, например - низкая детальность отображения микрорельефа и крутых наклонных поверхностей (склонов, стен, сбросов, врезов), оказывающих значительное влияние на значения, измеряемые гравиметрами, размещенными на малой дистанции от подобных форм.

Имеющиеся методы не предполагают возможности вычислений с значительной плотностью высотных отметок. Эти недостатки приводит к недостаточно полному учету поправок при проведении гравиметрических измерений. Однако, технически несложно (при использовании современных методов дистанционного зондирования) в короткие сроки получить высокоточную цифровую модель рельефа на участках большой площади. Наилучшие возможности для этого предоставляет метод воздушного лазерного (лидарного) сканирования. В этой работе рассмотрены различия, возникающие при использовании в расчетах при использовании как материалов воздушного лазерного сканирования рельефа, так и прочих видов данных (топокарты 1:25 000, открытые модели данных), а также выполнен расчет итоговых поправок и сравнение полученных результатов между собой.
\end{abstract}

КЛЮЧЕВЫЕ СЛОВА: аэрофотосъёмка, гравитационная съемка, дистанционное зондирование, лидар, лазерное сканирование, геоинформационные данные.

1 Московский государственный университет, Географический факультет, Ленинские горы, 1, 119991, Москва, Россия, e-mail: rilskiy@mail.ru

2 Московский государственный университет, Географический факультет, Ленинские горы, 1, 119991, Москва, Россия, e-mail: rogruzdev@mail.ru

3 Московский государственный университет, Географический факультет, Ленинские горы, 1, 119991, Москва, Россия, e-mail: tatianav.kotova@yandex.ru 
Ilya A. Rylskiy ${ }^{1}$, Roman V. Gruzdev ${ }^{2}$, Tatiana V. Kotova ${ }^{3}$

\title{
CALCULATION OF GRAVITATIONAL CORRECTIONS USING AIRBORN LASER SCANNING DATA
}

\begin{abstract}
Calculation of corrections to gravity measurements is one of the most important stages that determine the whole quality of research. Wrong corrections can lead to incorrect interpretation of the obtained measurements and lead to their false interpretation.

To achieve highly accurate results, it is necessary to take into account not only the height, but also the entire array of information about the relief. In this case, level of detail of relief model becomes critically important, especially in case of working with rugged terrain with large number of vertically developed rock formations (outliers, rock faults, steep slopes).

Now the methods normally used are based on the use of previously created materials from cartographic archives (topographic maps at a scale of 1: 100,000 1:25,000). It is also possible to use open (free) terrain models. These materials have a number of drawbacks, for example, low detail of the microrelief and steep inclined surfaces (slopes, walls, faults, incisions) that have a significant effect on the values measured by gravimeters located at a small distance from such forms.

The available methods do not assume ability to work with dense terrain models. These shortcomings lead to wrong corrections during gravimetric measurements. However, using of modern remote sensing methods makes possible to obtain a high-precision terrain models easily. The best opportunities are provided by LIDAR technology. Here we describe differences between using LIDAR data and other types of data (1:25 000 maps, open data models), and make comparison between corrections, calculated using different data sources.
\end{abstract}

KEYWORDS: airborne imagery, gravity measurements, remote sensing, GIS, LIDAR.

\section{ВВЕДЕНИЕ}

Гравитационная разведка является одним из важнейших этапов при разработке новых месторождений (в том числе - рудных). Результат этих исследований влияет на итоговую оценку таких параметров как объем запасов, этапность освоения, объем доразведки и т.п.). Наилучшие результаты могут быть получены с использованием наземных гравиметров, выполняющих статические измерения поля на территориях в несколько тысяч га. Количество измерений может составить до 10-12 тысяч и более. По завершении работ, для каждого пикета необходимо ввести ряд поправок, важнейшая из которых - за рельеф местности. Поправка должна учитывать не только абсолютную высоту, но и прилегающие структуры рельефа; в идеале - должно учитываться гравитационное влияние горных формаций на всех дистанциях вплоть до нескольких десятков километров.

Величины поправок за высоту и рельеф порой составляют десятки процентов от измеренных значений, и могут в несколько раз превышать искомые величины гравитационных аномалий. По этой причине проведение высокоточных гравиразведочных работ на месторождении невозможно без всестороннего расчета влияния рельефа.

\footnotetext{
1 M.V. Lomonosov Moscow State University, Faculty of Geography, Moscow, 119991, Russia, e-mail:rilskiy@mail.ru

2 M.V. Lomonosov Moscow State University, Faculty of Geography, Moscow, 119991, Russia, e-mail: rogruzdev@mail.ru

3 M.V. Lomonosov Moscow State University, Faculty of Geography, Moscow, 119991, Russia, e-mail: tatianav.kotova@yandex.ru
} 
В зависимости от целевого масштаба и типа местности, требуемый выход за пределы исследуемой территории может составлять от 1-3 до 30-90 километров (изредка - более). Несомненно, что учет столь большого количества информации требует использования мощной вычислительной техники и длительных расчетов.

Обеспечение подобных расчетов соответствующей им по точности и полноте информацией о рельефе представляет собой проблему. В настоящее время для использования (с определенными оговорками) доступны как открытые модели данных (матрицы высот ASTER DEM, SRTM DTED-1, детальность на уровне 1:100 000 - 1:200 000), так и данные из существующих фондов отечественной картографии - оцифрованные топокарты 1:25000 - 1:50000.

При работе на равнинных участках упомянутые материалы достаточны для решения большинства задач. Однако при работе в горной местности, где рельеф расчленен, наличествуют в изобилии микроформы рельефа и объекты, не отображаемые в масштабах карты или на выбранной для работы модели рельефа общего пользования, необходимы иные, более детальные источники информации. По некоторым оценкам, для получения необходимого уровня точности гравиразведки (50 микрогал и лучше) необходима работа с матрицей высот, обладающей шагом 1ब2 м и точностью по высоте на уровне 30-100 см.

Средства дистанционного зондирования пассивного типа в большинстве случаев непригодны для решения этой задач. Космические съемки обеспечивают нужную точность только при использовании снимков с разрешением 30 см (что крайне затруднительно и дорого). И космические, и аэрофотоаппараты не могут обеспечить получение сведений о рельефе на лесопокрытых территориях - это при том, что 95\% всех проектов по новому освоению местрождений попадает в залесенные районы. Возможность наземных съемок с указанным качеством и полнотой на практике также исключена по техническим и экономическим причинам.

В этом случае представляется, что воздушное лазерное (лидарное) сканирование является наилучшим, и в то же время - безальтернативным методом [Lohr, 1997]. В последние 20 лет на территории РФ именно он являлся основой для получения данных 1:20001:500 при выполнении крупных объемов съемок и реализации крупных национальных проектов (ВСТО, Сила Сибири, Олимпиада в Сочи и т.п.). Точность метода подтверждена сотнями научных работ и тысячами случаев практического применения, оборудование внесено в Реестр средств измерений (в отличие от фотокамер). Лидарное сканирование активный метод, и его результаты никак не зависят от освещенности. Принципиальное преимущество метода - проникновение части импульсов сквозь кроны деревьев. Это дает возможность создать модель именно поверхности грунта, а не видимой поверхности растительности (как при классической аэрофотосъемке). Производительность (до 500 км $^{2}$ на одну съемочную систему в сутки) обеспечивается одновременно с высокой точностью (погрешность по высоте - не хуже 0,1-0,3 м.

Поэтому в данной работе была поставлена задача оценить степень сходства и качества полученных с использованием различных моделей рельефа поправок в гравитационные измерения, и степень их влияния на итоговые результаты геологоразведочных работ.

\section{МАТЕРИАЛЫ И МЕТОДЫ ИССЛЕДОВАНИЯ}

\section{Способы вычисления поправок в гравиметрические измерения.}

Прежде всего, необходимо отметить, что и понижения рельефа (недостаток масс ниже точки наблюдения), и повышения рельефа (избыток масс выше точки наблюдения) приводят к уменьшению наблюденного значения силы тяжести. Таким образом, поправка за влияние рельефа дневной поверхности всегда положительна. Также хотелось бы 
упомянуть об отсутствии унифицированной терминологии и строгих границ для ближней, средней (промежуточной) и дальней зон учета поправки за рельеф [Долгаль, 2010]. Термин «центральная зона», воспринимается и трактуется многими авторами по-разному. В нашем исследовании центральная зона выделяется внутри ближней зоны на расстоянии радиусом до 50 м от пункта наблюдения. Таким образом, полагаем, что центральной зоне следует уделять особое внимание, поэтому ее будем рассматривать в составе ближней зоны, которой традиционно приписывали радиус до 100-300 м.

Обычно используется ряд способов учета влияние рельефа. Они отличаются моделью апрроксимации реальной поверхности грунта вокруг точки, где производятся измерения. Фактическую поверхность описывают набором квадратов разной величины, или сетью узловых точек со значениями высот рельефа. Известные нецифровые методы: Лукавченко, Немцова-Пришивалко, Дергачева, Березкина, Коваля, Мудрецовой, Маловичко. Применение Этих способов сводится к вычислению поправок с использованием соответствующих формул, специальных номограмм и палеток, рассчитанных на основе топокарт. Среди упомянутых способов расчета поправок наилучшие результаты дает способ Маловичко. Общим недостатком всех указанных способов является трудоемкость и невысокая точность определения поправок за влияние рельефа.

В наши дни применяются автоматизированные алгоритмы расчета в нескольких зонах и подзонах вокруг каждой точки измерений, выполняемые на основе регулярной матрицы высот (GRID), детальность которой определяет точность вычислений. При таком подходе возможно использование нескольких зон: центральная, ближняя, средняя и дальняя. Для каждой зоны могут применяться свои алгоритмы расчета и разная степень детальности. Так, для центральной и ближней зон расчеты проводятся с использованием максимально детальной информации, по мере удаления от точки наблюдения (средняя и дальняя зоны) расчеты могут оптимизироваться за счет загрубления детальности исходного GRID и снижения количества расчетов. В результате вычислений полученные поправки во всех зонах для расчетной гравиметрической точки суммируются. На сегодняшний день такой подход является наиболее оптимальным для точного вычисления поправок за рельеф. Во всех случаях крайне важной является точность и детальность цифровой модели рельефа, на основе которой производится вычисление поправок.

При высокоточных гравиметрических работах наиболее важно вычислить точное значение поправок в ближней (условно до 100-300 м) и в центральной зоне на удалении до 50 м от гравиметрического пункта. Гравитационное влияние любых формаций в этих зонах превалирует над более удаленными участками.

Именно по этой причине основным недостатком существующего подхода к расчету поправок за рельеф является производство цифровой модели рельефа по данным топокарт 1:25000 и 1:50000. Учитывая сказанное выше, необходимо в центральной и ближней зонах применять детальные (с ячейкой 1-3 м) цифровые модели рельефа на основе данных, не подвергавшихся генерализации (как в ходе съемки, так и в ходе составления карт). В других зонах (средняя и дальняя) возможно применять группировку ячеек с целью оптимизации и ускорения вычислений, либо работать по данным фондовых материалов. Для дальних зон, где не проводилось лазерное сканирование, рационально использовать модели SRTM DTED-1 (шаг $90 \times 90 \mathrm{~m})$.

\section{Описание территории выполнения работ}

Территория работ, на которой проводилась апробация различных источников данных и методик расчетов поправок в гравиметрические измерения расположена в восточной части Забайкальского края, в пределах одного из рудных месторождений. Территория расположена в низкогорной местности на высотах 450-850 м. Рельеф 
местности сильно расчлененный, основная масса форм рельефа представлена долинными комплексами (с преобладанием аккумулятивных пойменных процессов), окруженными возвышенностями с крутыми, до 45 градусов склонами с развитыми обвально-осыпными процессами. В ряде участков представлены скальные стены высотой до 60-70 м. Территория расположена в таежной зоне и на 70\% покрыта древесно-кустарниковой растительностью. Территория не населена, в районе съемки нет населенных пунктов. Дорожная сеть представлена грунтовыми и полевыми дорогами.

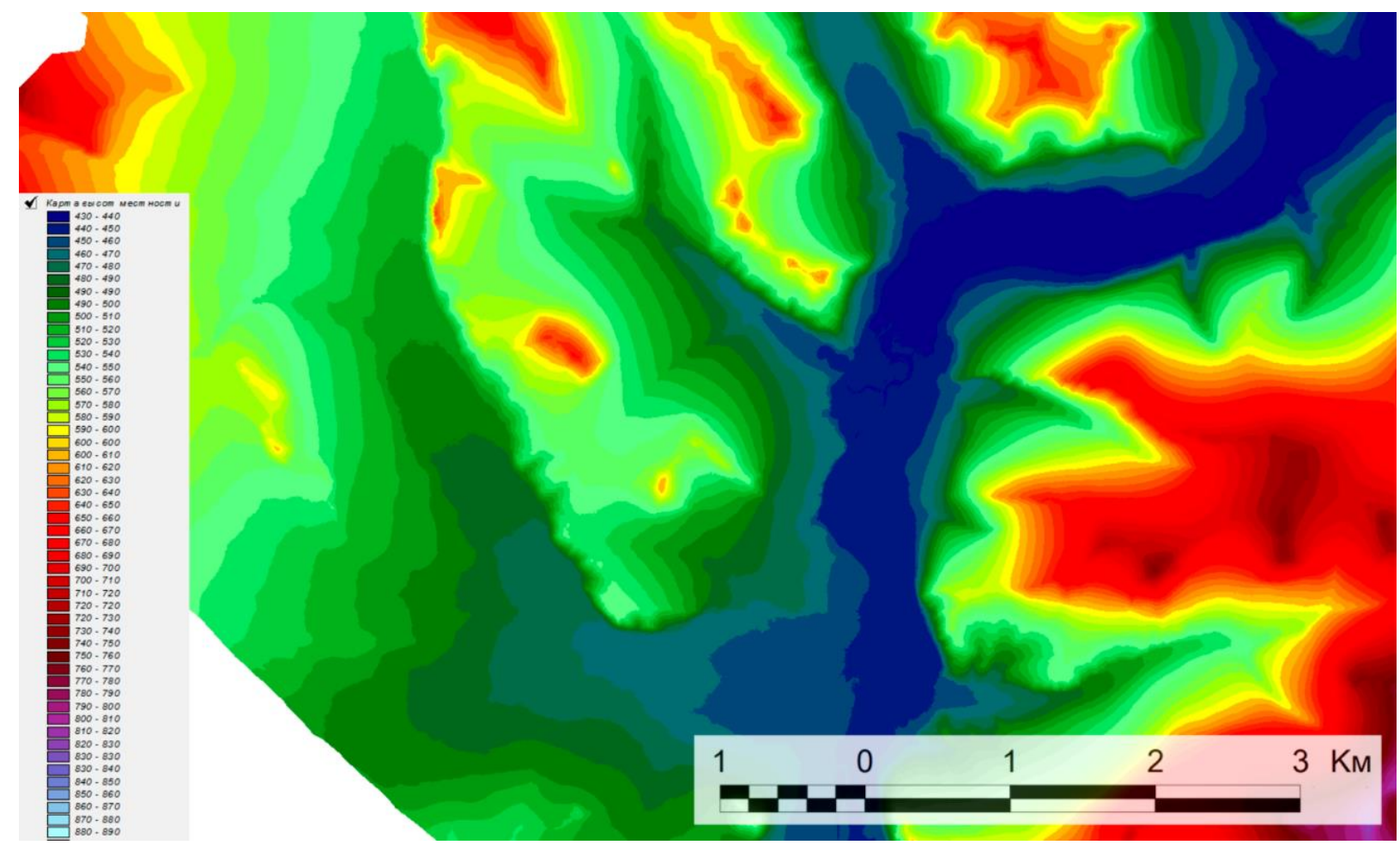

Рис. 1. Карта высот исследуемой территории

Fig. 1. Digital elevation model of the territory

В рамках программы геологоразведочных работ были выполнены площадные высокоточные гравиметрические исследования, количество измерений - свыше 2000 штук (физических точек). Основная сеть наблюдений проведена по сетке с шагом 200 х 100 м, в аномальных интервалах выполнено сгущение сетки до 100 х 50 м. Среднеквадратическая погрешность определения наблюденных значений аномалии силы тяжести составила \pm 11 мкГал. Привязка точек осуществлялась с помощью ГНСС-приемников (погрешность планового и высотного определения положения \pm 12 см). Для учета влияния рельефа местности на участке гравиразведочных работ и за его пределами в радиусе более 2 км выполнено воздушное лазерного сканирование под масштаб 1:2000.

Лазерное сканирование выполнялось с высоты 600 м (+/- 70 м) с одновременной аэрофотосъемкой в видимом диапазоне, продольное перекрытие $60 \%$, поперечное - $30 \%$ [Руководство..., 1986]. Плотность лазерного сканирования составила 4,2 точек на $1 \mathrm{~m}^{2}$, среднее расстояние между прямыми измерениями координат облучаемой поверхности 48 см. Оценочная среднеквадратическая погрешность лазерно-локационной съемки по высоте (по данным наземного контроля по 26 контрольным точкам, определенным методом статических ГНСС-наблюдений) составила 12,5 см, и 24,2 см - в плане [Gorgens, 2017]. 
Время выполнения сканирования - 3 часа. По результатам лазерного сканирования была выполнена классификация точек лазерных отражений (классы «Земля», «Растительность», «Прочее») с использованием средств автоматизации с последующей визуальной проверкой построенной модели [Korpela, 2008]. Из точек класса «Земля» методом триангуляции Делоне (средняя длина ребра - 1,2-1,8 м в зависимости от типа рельефа) была построена TIN-модель местности. Эта модель позднее преобразованная в регулярно-ячеистую модель данных (формат ArcINFO GRID) с шагом 1 м [Holmgren, 2004]. Именно эта модель позднее была использована в расчетах.

В качестве альтернативной модели была использована векторизованная топографическая карта 1:25000 с шагом горизонталей 20 м (шаг изолиний 5 м по высотам) (ожидаемая точность - на уровне 1/3 сечения рельефа, то есть 6,6 м). Построение производилось методом триангуляции Делоне с последующей конвертацией [Капралов, 2004] данных в регулярно-ячеистую модель данных (формат ArcINFO GRID) с шагом 5 м.

\section{Подходы к вычислению поправок за рельеф в гравитационные измерения}

Для вычисления гравитационного влияния рельефа использовался метод, при котором каждая ячейка GRID с шагом 1 м представлялась как материальный стержень сечение 1х1 м с высотой, равной перепаду высот. Полная поправка за рельеф получалась за счет суммирования вклада поправок в каждой ячейке. Общее количество ячеек - 70000000 для модели рельефа по данным лазерного сканирования, около 3000000 ячеек - для модели рельефа по данным топокарты (шаг сетки $5 \times 5$ м).

При вычислении поправок за гравитационное влияние [Министерство..., 1980] ячейки рельефа местности с высотой $\mathrm{z}(\mathrm{x}, \mathrm{y})$, глубины кромок стержня принимают значения: $\xi_{1}=z$ и $\xi_{2}=z_{0}$, где $z_{0}$ - высота точки наблюдения. Формула расчета поправки приобретает вид:

$$
\Delta g=G \lambda K\left[\frac{1}{\sqrt{\left(x-x_{0}\right)^{2}+\left(y-y_{0}\right)^{2}}}-\frac{1}{\sqrt{\left(x-x_{0}\right)^{2}+\left(y-y_{0}\right)^{2}+\left(z-z_{0}\right)^{2}}}\right]
$$

Объёмную плотность $\sigma$ для условий исследуемой территории можно принять $2600 \frac{\text { кг }}{\mathrm{m}^{3}}$. При размере сетки GRID 1 м х 1 м в этом случае $\lambda=2600 \frac{\text { кг }}{\text { м }}$

По формуле (1) необходимо рассчитать GRID $\Delta g(x, y)$, совпадающий по геометрии с исходным GRID рельефа местности. Просуммировав все значения $\Delta g$ получим итоговое значение поправки за гравитационное влияние рельефа местности в точке $x_{0}, y_{0}, z_{0}$ :

$$
\Delta G\left(x_{0}, y_{0}, z_{0}\right)=\sum \Delta g(x, y)
$$

\section{Построение поверхностей поправок}

Общий расчет величины $\Delta G$ невозможен без средств автоматизации. Для этого, используя среду разработки ArcView, было написано программное обеспечение (среда Avenue) для автоматизации расчетов. Расчеты выполнялись в полностью автоматическом режиме для каждой из 2000 точек гравиметрических измерений. Общее количество 
машинного времени, потраченное на расчет - около 8500 минут (около 6 суток), среднее время расчет поправок по всему массиву данных лидарной модели рельефа - 4,25 минуты на один гравиметрический пункт. Для вычислений использовался персональный компьютер (процессоp Intel i7, 32 Гб RAM, без использования видеокарты для расчетов поправок).

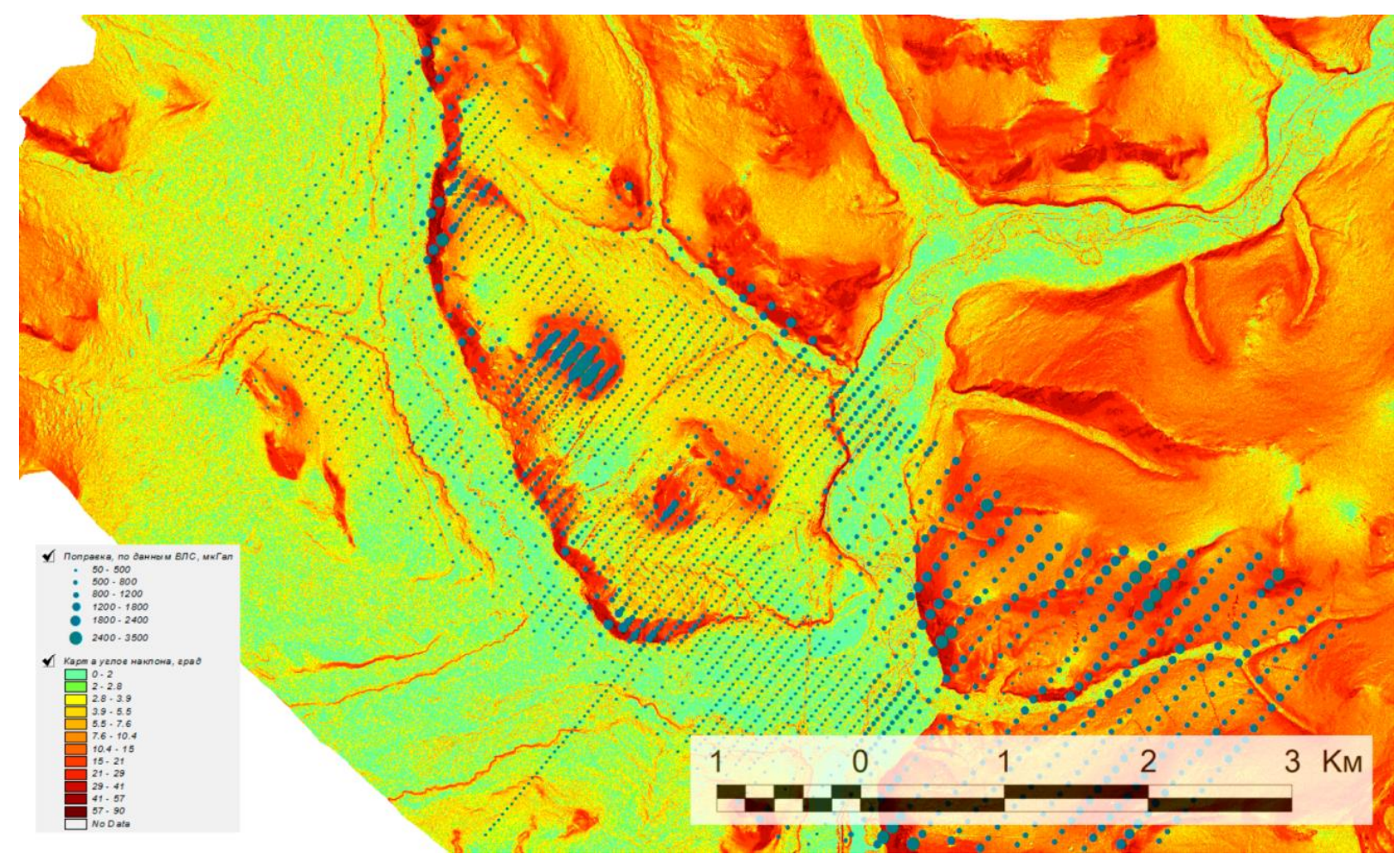

Рис. 2. Распределение по территории величин гравитачионных поправок, рассчитанных по данным лазерного сканирования. На заднем плане - карта углов наклона территории Fig. 2. The distribution over the territory of the values of gravity corrections, calculated using LIDAR data. In the background is a map of the slope angles of the territory

Аналогичным образом был проведен расчет гравитационного влияния поправок с использованием топографических карт 1:25000. Время расчетов - около 6 часов, среднее время расчета одного пикета - около 10 секунд.

Полученные при расчете значения заносились в ГИС-слой (точечный SHP-файл) в соответствующие поля - Gvls и Gtopo (для поправок, рассчитанных по данным лазерного сканирования и топокарт соответственно). Средствами картографической алгебры были вычислены дельты полученных значений, и записаны в третье поле - Gvls-Gtopo.

На приведенных иллюстрациях легко заметить, что районы максимальных отличий полученных поправок приурочены к участкам со значительными (более 15 градусов) углами наклона, а также к участкам, вблизи которых расположены резкие перепады высот. Это хорошо согласуется с теоретическими предположениями о значимом влиянии подобных объектов в случае их расположения в ближней или центральной зоне гравитационного пункта. В то же время, на плоских участках значения различаются крайне незначительно, и могут расцениваться как равноточные.

Отметим, что статистика вычисленных поправок (по данным лидара и топокарты выглядит следующим образом: 
Таблица 1. Статистика поправок, рассчитанных по данным лидара и топокарт 1:25000 Table 1. Statistics of corrections calculated using LIDAR data and topographic maps 1: 25000

\begin{tabular}{|l|l|l|}
\hline Параметр & Поправки по данным LIDAR & Поправки по топо 1:25000 \\
\hline Среднее значение (мкГал) & 582 & 651 \\
\hline Минимум (мкГал) & 86 & 175 \\
\hline Максимум (мкГал) & 3120 & 3213 \\
\hline Разброс ((мкГал) & 3033 & 3038 \\
\hline $\begin{array}{l}\text { Стандартное отклонение } \\
((\text { мкГал) }\end{array}$ & 468 & 440 \\
\hline
\end{tabular}

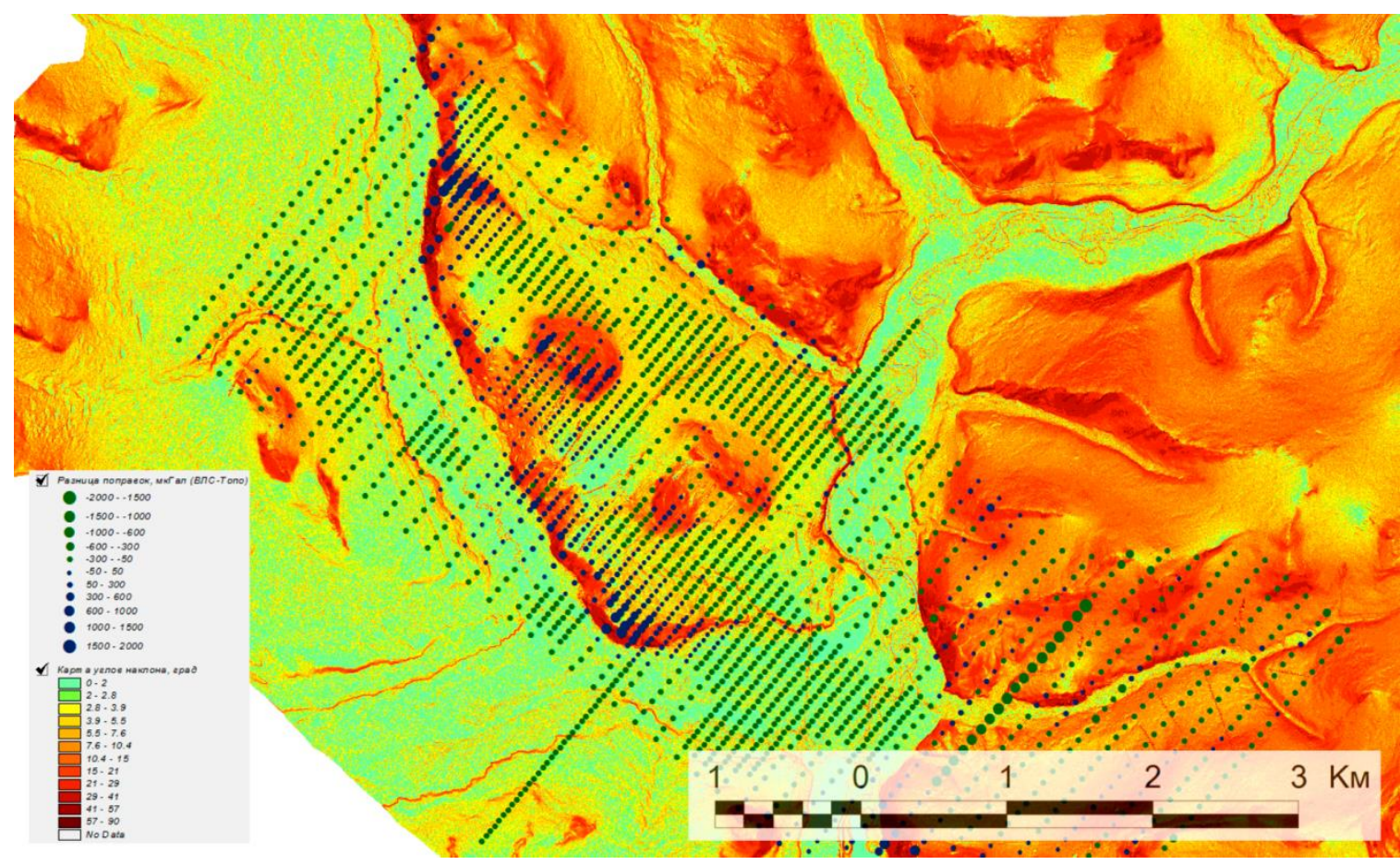

Рис. 3. Схема разности поправок за рельеф, полученных по данных лазерного сканирования и топокартам 1:25000)

Fig. 3. Difference between gravity corrections, calculated using LIDAR data and topographic data (1:25000)

\section{Оценка достоверности результатов расчета поправок.}

Традиционно (ручным способом) оценка точности нахождения поправок за влияние рельефа определялась по результатам повторных вычислений поправок при различном расположении узлов, в которых определяются высоты, или же другими равноценными по точности методами.

Оценка точности определения поправок за влияние рельефа дневной поверхности при компьютерном расчете возможна на основе генерации случайных смещений местоположения гравиметрических пунктов по координатам X и Ү. Подобный способ рассмотрен в пособии. Амплитуда смещения определялась на основе точности привязки гравиметрических пунктов и плановой точности данных лазерного сканирования. Для генерации случайных отклонений координат в плане (X и $\mathrm{Y}$ ) принято значение \pm 1 м (округлили до размера 1 ячейки модели ЦМР). В результате вычислений разность поправок 
за рельеф между фактическими и случайными смещениями изменяются в диапазоне от -38 мкГал до 42 мкГал и характеризуются среднеквадратической погрешностью \pm 5 мкГал (в сопоставлении участвовало 800 гравиметрических точек). Следует отметить, что при относительно небольшом смещении координат точки наблюдения ( \pm 1 м), значение разности поправок на некоторых пунктах составили - -38 и 42 мкГал.

Для сопоставления результатов полученных поправок за рельеф по данным лазерного сканирования и топоданным рассчитаем модель их разности (рис. 3). Статистические показатели GRID разности поправок:

- минимум -418,03 мкГал;

- максимум 1164,35 мкГал;

- среднее арифметическое значение -70,33 мкГал;

- медиана -92,45 мкГал;

- стандартное отклонение 129,65 мкГал.

На рис. 3 наглядно представлено, что максимальные отклонения наблюдаются на крутых склонах и резких перепадах рельефа местности, где значения поправки достигают более 200 мкГал, а на отдельных участках около 1000 мкГал. Последнее является неприемлемым при производстве высокоточных гравиметрических работ.

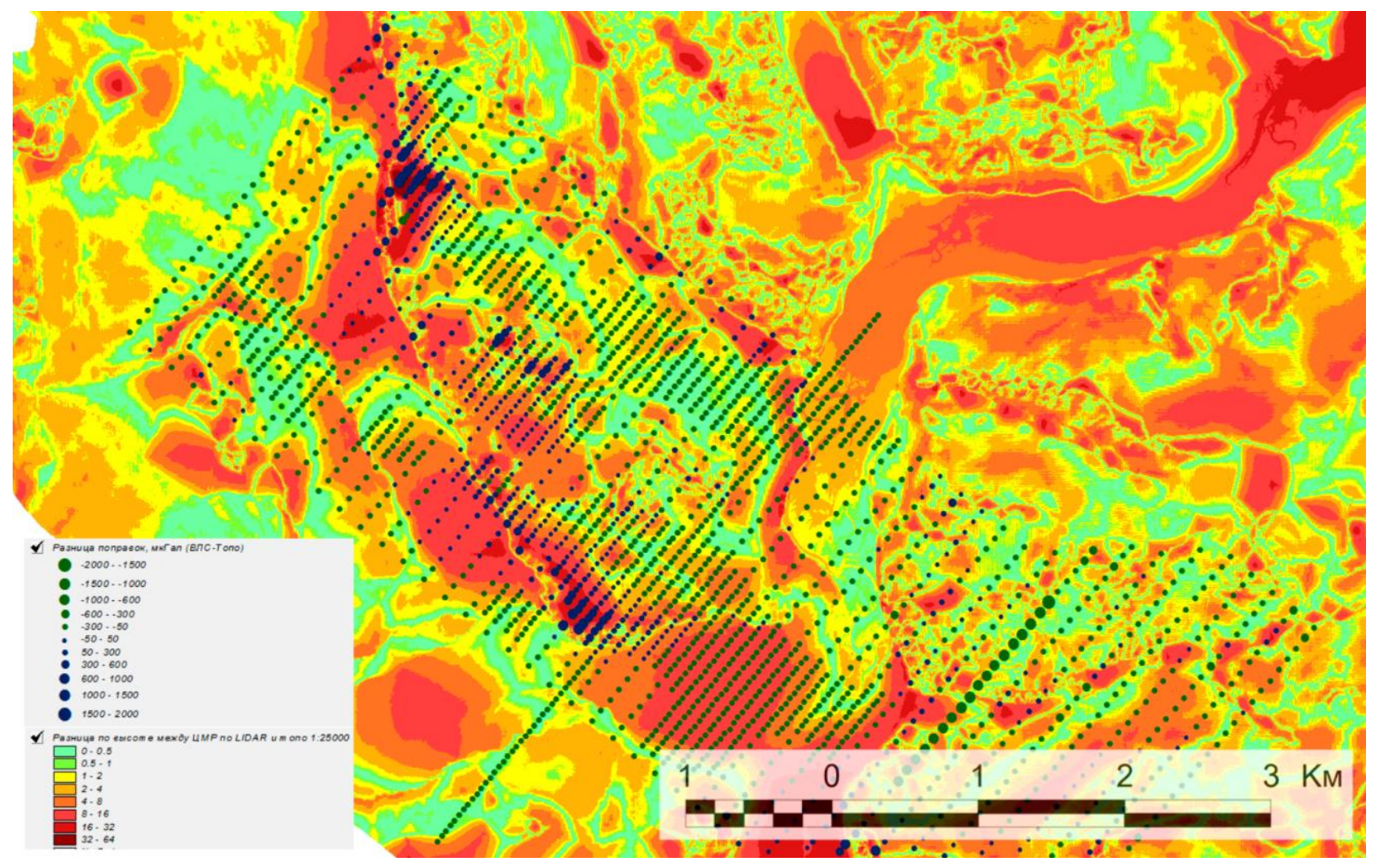

Рис. 4. Распределение различий по высоте между моделями рельефа (по лидару и по топокарте 1:25000) в сравнении с пространственным распределением различий 8 расчетах гравиметрических поправок, использующих эти же модели рельефа

Fig. 5. Distribution of differences in height between elevation models (LIDAR and topographic map 1: 25000) in comparison with the spatial distribution of differences in the calculations of gravimetric corrections using the same elevation models

Для подтверждения выдвинутой гипотезы выполним расчет аномалии силы тяжести на примере фрагмента гравиметрического профиля, проходящего через крутой участок рельефа, где разница высотных отметок на склоне по результатам лазерного сканирования 
и топоданным достигает около 15 м. Разность поправок за влияние рельефа дневной поверхности на этом участке (ПК 190-200) достигает около 800 мкГал (рис. 3, более длинный чем остальные, профиль в центре участка).

В связи с некорректным рельефом на участке ПК 190-200 имеем ложный гравитационный эффект около -500 мкГал, обусловленный не учтенными массами «вышениже» точки наблюдения. Напомним, что для горных районов при масштабе 1: 25000 при гравиметрической съемке допускается погрешность определения аномалии силы тяжести в редукции Буге \pm 250 мкГал, соответственно вклад только поправки за рельеф по топоданным превышает требуемую точность работ.

Таким образом, вполне очевидно, что использование поправки за рельеф на основе топоданных на участке ПК 190-200 не укладывается в требования гравиметрической съемки масштаба 1:25 000 .

\section{Проверка полученных результатов и сравнение их с альтернативными источниками данных}

Полученные модели гравитационных поправок явно различаются, причем принципиально. Какая из них является более правильной? Для этого решим обратную задачу гравиразведки, восстановив строение верхнего участка недр. Для этого произведем моделирование на основе двумерной инверсии в специализированном комплексе ZondMag2D. Параметры инверсии для обоих источников данных примем одинаковыми. В результате решения обратной задачи получены разрезы эффективной избыточной плотности (рис. 4, 5).

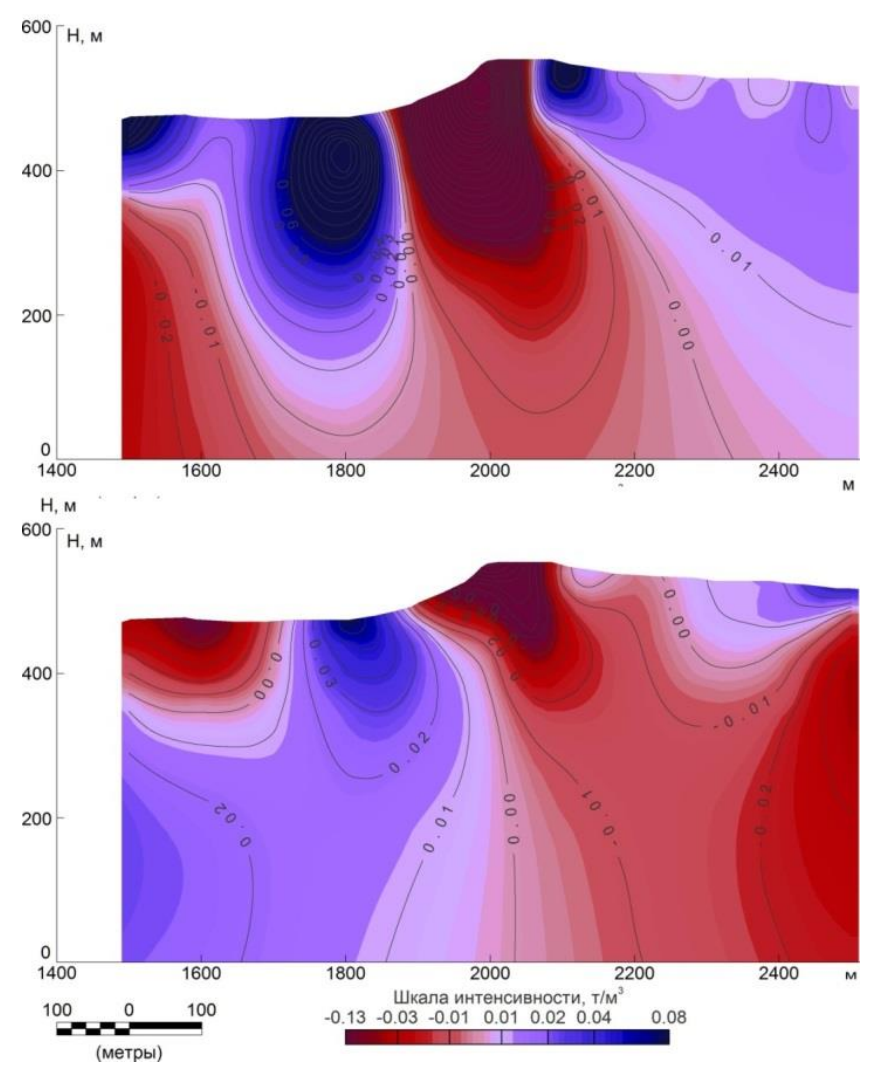

Рис. 5. Результаты двумерной инверсии (вверху - использован рельеф по картам 1:25000, внизу - по данным лазерного сканирования)

Fig. 5. Results of 2D-inversion along profile (up - calculated using topographic maps 1:25000, below - using LIDAR) 
Сравнивая рис. 4 и 5, очевидно значимое расхождение в результатах интерпретации. Форма идентифицируемых аномалий различна, как и значения избыточной плотности в центрах аномалий. Таким образом, геологическая интерпретация полученных плотностных разрезов неоднозначна. Однако при сравнении с имеющейся геологической информацией по интерпретационному профилю (рис. 6) видно, что результаты на основе данных лазерного сканирования показывают хорошую сходимость с эталоном (на уровне структурных форм и плотностей пород), чего нельзя сказать о результатах, полученных по данным моделирования с топокарт.

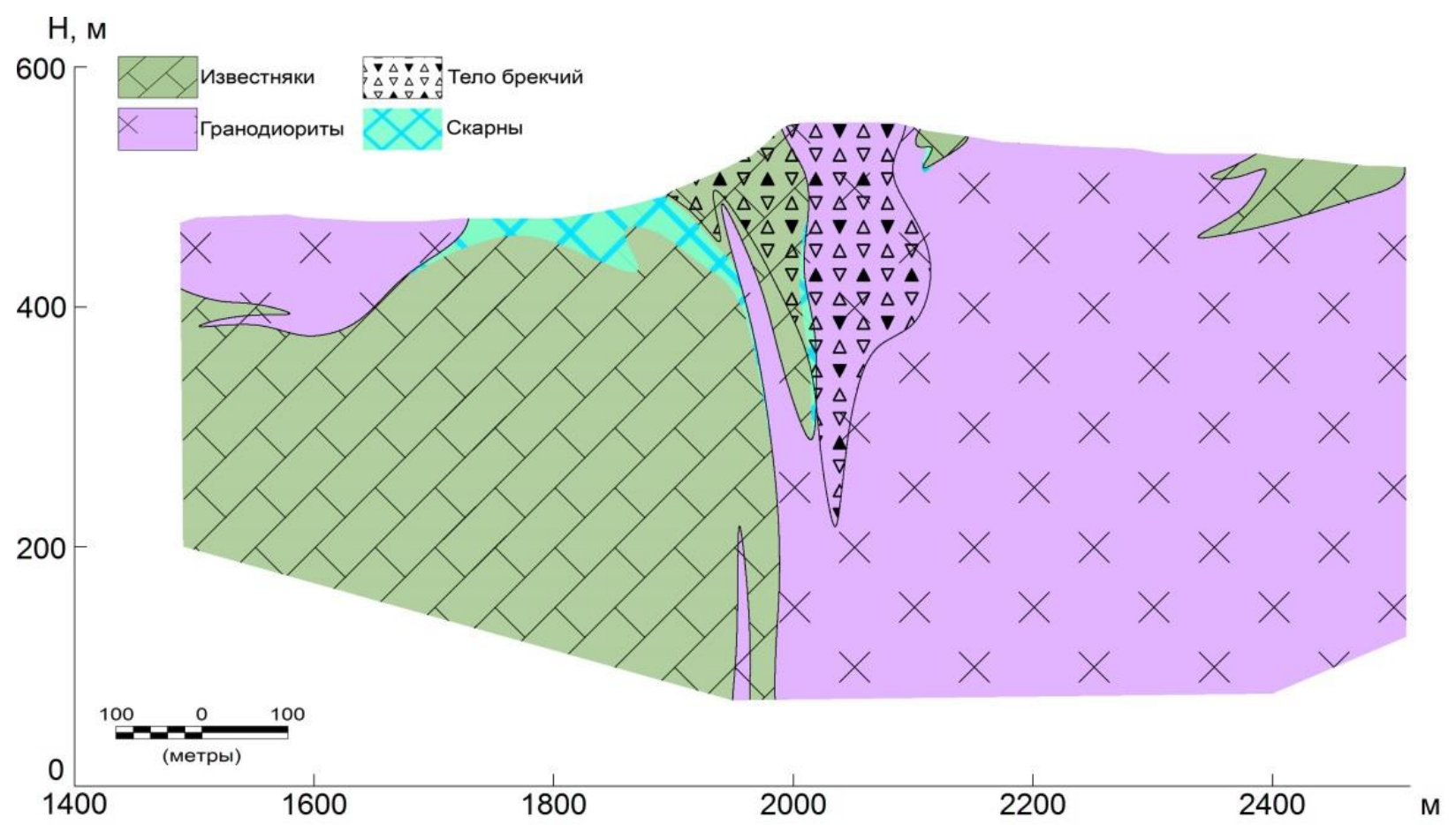

Рис. 6 Схематический геологический разрез по линии интерпретащионного профиля, полученный традиционнылми методами)

Fig. 6. Geological profile, reconstructed using traditional methods

Как видим, вычисление гравитационных поправок по модели рельефа на базе топокарт 1:25000 не обеспечивает возможность точно интерпретировать собственно гравиметрические измерения: налицо явные противоречия с контрольными данными по профилю, подтвержденными другими методами (в том числе бурением). Напротив, применение в расчетах поправок модели рельефа по данным лидарной съемки дает схожие с контрольными данными результаты. В целом, это закономерный результат, ибо в случае с использованием модели рельефа с топокарт профиль был интерпретирован по недостаточно полным материалам, что дало неверные поправки за рельеф. В результате, при некорректном рельефе мы получаем неверные поправки и как следствие - ложные гравитационные аномалии, которые не поддаются адекватной геологической интерпретации. 


\section{РЕЗУЛЬТАТЫ ИССЛЕДОВАНИЯ И ИХ ОБСУЖДЕНИЕ}

По итогам созданного программного обеспечения и комплексного расчета гравитационных поправок удалось решить следующие задачи:

- $\quad$ выполнить расчет поправок с использованием модели рельефа по данным лазерного сканирования и топокарт 1:25000;

- сравнить полученные результаты на 2000 пикетов и картографировать разницу поправок;

- сравнить итоговые модели подземных структур с данными профилирования, полученными другими (традиционными) методами и сделать вывод о значительном превосходстве в качестве расчетов, использующих модель рельефа по данным лазерного сканирования на расчетами по топокартам;

Отметим, что благодаря возможностям современной вычислительной техники, расчеты удалось произвести без их загрублений с целью оптимизации времени расчетов. Например, при расчетах по матрице высот по данным лазерного сканирования для каждого пункта гравиметрических измерений выполнялись отдельные расчеты гравитационного влияния каждой из 70 миллионов ячеек (шаг $1 \times 1$ м); данная операция была повторена для каждого из 2000 гравиметрических пунктов. При расчетах с использованием модели рельефа по топокартам 1:25000 использовались 3 миллиона ячеек размером $5 \times 5$ м создание матрицы высот по карте 1:25000 не представляется сколько-нибудь обоснованным.

Ранее исследователями отмечалась нецелесообразность использования компьютерных технологий для вычисления поправок за рельеф в «центральной» зоне, охватывающей пункт гравиметрических наблюдений и его ближайшие окрестности. Последнее аргументировалось, главным образом, трудоемкостью создания ЦМР на основе топоданных и относительно не высокой точностью самих топографических карт 1:25 000 масштаба. Данное исследование опровергает подобный вывод. Кроме того, отметим, что большинство топографических карт не обновляются, поэтому современные техногенные изменения в них не учтены (отработанные россыпи, карьеры, любое нарушение рельефа, которое влечет за собой перемещение масс).

В исследовании наглядно показано, что полученные результаты расчета поправок по данным лазерного сканирования являются наиболее точными, и принципиально превосходят результаты расчетов, произведенных с использованием цифровых моделей рельефа по любым топографическим картам.

Единственным недостатком использования метода лазерного сканирования может являться его стоимость. Тем не менее, при более детальном исследовании рынка (речь идет

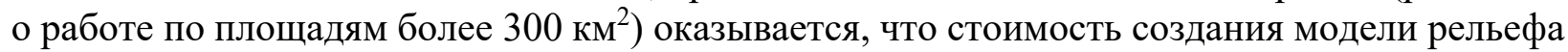
по лидарным данным составляет 12-18 тысяч рублей за 1 км$^{2}$. Стоимость создания модели

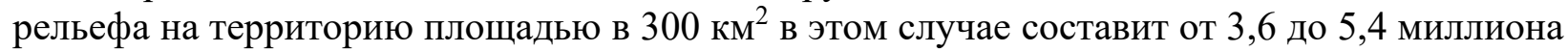
рублей. Принимая во внимание стоимость потенциальной ошибки, это несущественные затраты.

Прочие источники данных дешевле. Так, стоимость космической стереофотосъемки и ее последующей обработки может составлять до 9000 рублей за 1 км² $^{2}$, аэрофотосъемки -

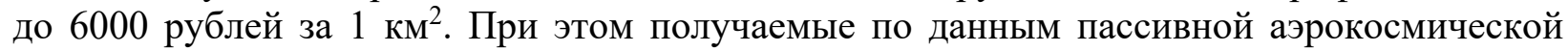
съемки модели рельефа не выдерживают никакой критики ни в части передачи микрорельефа, ни в части точности под пологом деревьев. Несомненно, при использовании

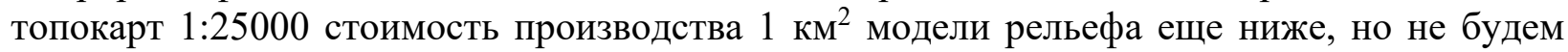
забывать - все эти карты создавались также по данным аэрофосъемки, недостатки которой 
перечислены выше. Использовать для решения крайне важной задачи заведомо непригодную для этого информацию - не лучший способ экономии.

\section{ВЫВОДЫ}

Использование технологий лидарной съемки для получения высокоточных моделей рельефа при выполнении гравиразведочных работ с каждым годом будет становиться все более необходимым этапом информационного обеспечения проектов по добыче рудных ископаемых. Сильная сторона лидарных съемок - это высокая производительность и низкая стоимость получения высокоточных данных о рельефе местности (по сравнению с другими методами); в значительном количестве случаев метод не имеет альтернатив. Именно поэтому отработка способов использования этих данных при обработке гравиметрических измерений является важной задачей и представляет прямой практический интерес.

Нерешенным остается вопрос целесообразности использования цифровых моделей рельефа, построенных по данным лидарной съемки, на участках равнинного типа или смешенных видов рельефа. Также представляется разумным выполнение съемок не только на территорию всего объекта исследования, но и со значительным запасом по буферу - до 8-10 км. Следует отметить, что для достижения описанных в данной работе результатов на практике достаточно выполнить сканирование территории с плотностью на уровне $1,2-1,5$ точек на $1 \mathrm{~m}^{2}$, что позволяет значительно снизить затраты на съемки [Chen, 2007] за счет использования более высоких залетов (с меньшим летным временем и стоимостью).

Помимо высокой значимости данных лазерного сканирования для решения вопросов в части гравиразведки, указанные наборы данных имеют значительный потенциал использования на всех последующих стадиях жизненного цикла разработки месторождения. Так, уже стало нормой создание топографических планов масштаба 1:2000 на территории лицензионных участков в рамках создания проекта разработки месторождения. Помимо этого, данные сканирования местности до начала работ могут быть использованы как базовая поверхность, от которой рассчитываются объемы извлеченной породы (при открытых разработках).

На сегодняшний момент необходимо отметить, что совмещение вычисления поправок за рельеф, рассчитанных компьютерным способом по топокарте (1:25 000 масштаба, расчет для дальней зоны) и воздушного лазерного сканирования (для ближней зоны) показало себя актуальным и оптимальным по точности и себестоимости.

\section{БЛАГОДАРНОСТИ}

Исследование выполнено в рамках госбюджетной тематики исследований Регионального центра Мировой системы данных (Географический факультет МГУ им. М.В. Ломоносова) при содействии АО «Арк-он».

\section{ACKNOWLEDGEMENTS}

The study was performed within the framework of a state budget theme of Regional Center of World Data System (Geographical Faculty of Moscow State University) in a collaboration with JSC «Ark-on» 


\section{СПИСОК ЛИТЕРАТУРЫ}

1. Долгаль А.С. Гравиразведка: способы учета влияния рельефа местности. Учебное пособие. Пермь: Пермский государственный университет, 2010. 88 с.

2. Капралов Е.Г., Кошкарёв А.В., Тикунов В.С. Основы геоинформатики. Учебное пособие для студентов вузов в 2-х книгах. М.: Академия, 2004. 480 с.

3. Руководство по аэрофотосъёмочным работам. Министерство гражданской авиации. M.:, 1986. $176 \mathrm{c.}$

4. Министерство геологии СССР. Инструкция по гравиразведке. Л.: Недра, 1980. 89 с.

5. Chen $Q$. Airborne lidar data processing and information extraction. Photogrammetric Engineering \& Remote Sensing, 2007. P. 109-112.

6. Gorgens E., Valbuena R., Rodriguez L. A method for optimizing height threshold when computing airborne laser scanning metrics. Photogrammetric Engineering \& Remote Sensing, Volume, 2017. P. 343-350.

7. Holmgren A., Persson J. Identifying species of individual trees using airborne laser scanner. Remote Sensing of Environment, 2004. P. 415-423.

8. Korpela I. Mapping of understory lichens with airborne discrete-return LiDAR data. Remote Sensing of Environment, 2008. P. 3891-3897.

9. Lohr U. Digital elevation models by laser scanning: Principle and applications. Third International Airborne Remote Sensing Conference and Exhibition, 1997. P. 174-180.

\section{REFERENCES}

1. Chen $Q$. Airborne lidar data processing and information extraction. Photogrammetric Engineering \& Remote Sensing, 2007. P. 109-112.

2. Dolgal A.S. Gravitation surveys: methods of accounting for influence of relief. Perm: Perm State University, 2010. 88 p. (in Russian).

3. Gorgens E., Valbuena R., Rodriguez L. A method for optimizing height threshold when computing airborne laser scanning metrics. Photogrammetric Engineering \& Remote Sensing, Volume, 2017. P. 343-350.

4. Guidance aerial photography for cartographic purposes. Military topographic administration of High Command. Moscow, Redaktsionno-izdatelskiy otdel, 1986. 176 p. (in Russian).

5. Ministry of geology of USSR: Instruction for gravitation surveys. Leningrad.: Nedra, 1980. P. 1-89 (in Russian).

6. Holmgren A., Persson J. Identifying species of individual trees using airborne laser scanner. Remote Sensing of Environment, 2004. P. 415-423.

7. Kapralov E.G., Koshkarev A.V., Tikunov V.S. Osnovy geoinformatiki. Moscow, Akademia, 2004. 480 p. (in Russian).

8. Korpela I. Mapping of understory lichens with airborne discrete-return LiDAR data. Remote Sensing of Environment, 2008. P. 3891-3897.

9. Lohr U. Digital elevation models by laser scanning: Principle and applications. Third International Airborne Remote Sensing Conference and Exhibition, 1997. P. 174-180. 


\section{Д.Ш. Фазилова ${ }^{1}$, Х.Н. Магдиев ${ }^{2}$}

\section{СОЗДАНИЕ И ОБНОВЛЕНИЕ ВЫСОТНОЙ ОСНОВЫ ТОПОГРАФИЧЕСКИХ КАРТ В НАЦИОНАЛЬНОЙ ПРОСТРАНСТВЕННОЙ СИСТЕМЕ КООРДИНАТ: НА ПРИМЕРЕ ФЕРГАНСКОЙ ДОЛИНЫ}

\section{АННОТАЦИЯ}

Использование высокоточной технологии глобальной навигационной спутниковой системы (ГНСС) поставили задачу разработки основ создания и использования новой национальной открытой системы координат в Республике Узбекистан. Для геодезических работ в республике используется система координат СК42, базированная на эллипсоиде Красовского. В качестве высотной основы принята Балтийская нормальная система высот (1977), привязанная к среднему уровню моря с нулевой отметкой Кронштадтского футштока.

Учитывая, что для территории страны нет информации о точном геоиде, определенным современными методами, построение высотной отсчетной основы является актуальной задачей. Результаты GPS-измерений представляются обычно в системе координат относительно эллипсоида WGS-84, и должны быть преобразованы в национальные, местные системы координат для решения практических задач. И, если горизонтальные координаты GPS могут напрямую использоваться для вычислительных работ, то, получаемые геодезические высоты, должны быть преобразованы в ортометрические (или нормальные) высоты для заданной территории.

В данной работе проводилось исследование методов обновления высотной отсчетной основы топографических карт масштаба $1: 200000$ с использованием матрицы деформаций между двумя опорными системами координат на примере территории Ферганской долины. Для преобразования между геодезическими и нормальными высотами между системами координат CK42 и WGS84 создана матрица вертикальных деформаций в формате GTX Национального управления океанических и атмосферных исследований Канады (NOAA).

Исходными данными для исследования были выбраны результаты классических нивелирных и спутниковых GPS измерений на 144 «общих» точках геодезической сети республики с известными координатами в двух системах. Разница между «реальными» значениями геодезических высот, полученными по GPS измерениям и «смоделированными» колеблется в пределах от $-0,13$ м до 0,67 м. Выявлено, что максимальные расхождения высот находятся в районе Ферганской впадины и, могут быть следствием как аномального гравитационного поля в данной части территории, так и

\footnotetext{
1 Астрономический институт имени Улугбека Академии наук Республики Узбекистан, ул. Астрономическая, д. 33, 100052, Ташкент, Республика Узбекистан, e-mail: dil_faz@yahoo.com

2 Агентство по кадастру, ул. Чупоната, д.5, 100097, Ташкент, Республлика Узбекистан, e-mail: hasan.magdiev@gmail.com
} 
недостаточной плотности станций сети GPS в северо-восточной части исследуемой области. Аномалии высот геоида по глобальной геопотенциальной модели EGM2008 выбраны для вычисления величин нормальных высот для обновленной топографической карты в WGS84. Расхождения между значениями нормальных высот в CК42 и WGS84 находится в пределах $-3,93$ м и 0,31 м.

КЛЮЧЕВЫЕ СЛОВА: CK42, WGS84, преобразование координат, GPS, матрица деформаций высот, система отсчета высот.

\title{
Dilbarkhon Sh. Fazilova ${ }^{1}$, Khasan N. Magdiev²
}

\section{CREATING AND UPDATING OF TOPOGRAPHIC MAPS HEIGHT BASE IN THE NEW NATIONAL SPATIAL COORDINATE SYSTEM: CASE FERGANA VALLEY}

\begin{abstract}
The use of high-precision technology of the global navigation satellite system (GNSS) has put forward the task of developing the methods for the creation and the use of a new national open coordinate system in the Republic of Uzbekistan. In the country, up to now the CS42 coordinate system, based on the Krasovsky ellipsoid used for geodetic works. The Baltic normal system of heights (1977), tied to the mean sea level with the zero mark of the Kronstadt tide gauge, was adopted as a height datum.

Due to lack geoid information for the territory of the country determined by modern methods, the realization of a height reference datum becomes an urgent task. The results of GPS measurements usually presented in a coordinate system relative to the WGS-84 ellipsoid, and have to convert to national, local coordinate systems to solve practical problems. The horizontal GPS coordinates can directly use for computational work, but the geodetic heights have to convert to orthometric (or normal) heights for a given area using geoid information.

In this work, a study was made of methods for updating the height reference datum of topographic maps at a scale of $1: 200,000$ using a deformation matrix between two reference coordinate systems for the territory of the Fergana Valley. To convert between geodetic and normal heights between the CS42 and WGS84 coordinate systems, a vertical deformation matrix in the GTX format of the National Oceanic and Atmospheric Administration of Canada (NOAA) have created.

To create a file of elevation displacements, the results of classical leveling and satellite GPS measurements have used at 144 "common" points of the entire network of the country with known coordinates in two systems. The difference between the "real" values of geodetic heights obtained from GPS measurements and "modeled" ranges from $-0.13 \mathrm{~m}$ to $0.67 \mathrm{~m}$. It has revealed that the maximum differences in heights are in the area of the Fergana basin itself and may be a consequence of both an anomalous gravitational field in this part of the territory, and an insufficient density of stations of the GPS network in the northeastern part of the area. The normal height values for the updated topographic map in WGS84 have computed using the EGM2008 high precision geopotential model. The discrepancy between the values of heights in CS42 and WGS 84 is in the range of $-3.93 \mathrm{~m}$ and $0.31 \mathrm{~m}$.
\end{abstract}

\footnotetext{
$1 \quad$ Ulugh Beg Astronomical Institute of Uzbek Academy of Sciences, Astronomicheskaya str., 33, 100052 , Tashkent, Republic of Uzbekistan, e-mail: dil_faz@yahoo.com

2 Agency for cadastre, Chupon ota str., 5, 100097, Tashkent, Republic of Uzbekistan, e-mail: hasan.magdiev@gmail.com
} 
KEYWORDS: CS42, WGS84, coordinate transformation, GPS, vertical deformation matrix, vertical datum.

\section{ВВЕДЕНИЕ}

Сегодняшний уровень развития геодезических и информационно-коммуникационных технологий в Республике Узбекистан стал основой создания Национальной географической информационной системы (НГИС) для оперативного предоставления пространственных данных, принятия решений с целью достижения максимальной эффективности в решении задач устойчивого использования природных и экономических ресурсов, исследования изменений окружающей среды, управления чрезвычайными ситуациями, контроля территорий, развития культурно-социальной среды и др. Для комплексного представления и анализа информации о территории, природных ресурсах, техногенных объектах, их динамике в НГИС прежде всего необходимо решить задачу модернизации опорной координатной системы (датума). Это обеспечит пользователям на основе высокоточного позиционирования возможность согласовать на необходимом уровне точности с физическим миром соответствующие пространственные данные. В Республике Узбекистане до настоящего времени используется система координат СК 42, базированная на эллипсоиде Красовского и в качестве высотной основы принята Балтийская нормальная система высот (1977), привязанная к среднему уровню моря с нулевой отметкой Кронштадтского футшток. Методы реализации СК42, ее ориентация в пространстве и, особенно, региональные геодинамические особенности привели к различию в определении положения объектов в этих геодезических системах от нескольких до сотен метров [Макаренко и др., 2000]. Широкое использование спутниковых методов, таких как Глобальная навигационная спутниковая система (ГНСС), высокая точность, разрешение которых, позволяют определять малые изменения в геоцентрических координатах наземных пунктов на коротких интервалах времени, стали основой для развития НГИС и поставили задачу разработки основ создания и использования новой национальной открытой системы координат и в Республике Узбекистан ${ }^{1}$. В 2005 году в стране стартовала программа по созданию государственной геодезической сети (ГГС) на основе измерений ГНСС. Достигнуты значительные результаты по созданию Фундаментальной астрономо-геодезической сети (ФАГС), совершенствованию методов ее построения и повышению точности координат за счет внедрения новых технологий измерений и совмещения с существующими станциями Международной сети GNSS (Китаб, Ташкент, Майданак и Майдантал) [Fazilova et al., 2018]. Результаты GPS-измерений представляются обычно в системе координат относительно эллипсоида WGS84, и должны быть преобразованы в национальные, местные системы координаты для решения практических задач. Геодезические широты и долготы GPS могут напрямую использоваться для вычислительных работ и форма поверхности в системе WGS84 в полученной долготно-широтной сетке такая же, как и региональная эллипсоидальная поверхность. А получаемые геодезические высоты должны быть преобразованы в ортометрические (или нормальные) высоты для заданной территории. Разница между локальным и глобальным эллипсоидами, обусловленная их взаимным расположением, включает разность этих высот. И основной задачей координатного преобразования является

1 О применении и открытом использовании на территории Республики Узбекистан международных геодезических систем координат. Постановление Кабинета Министров Республики Узбекистан от 26.12.2017 №1022. Электронный ресурс: http://www.lex.uz/pages/getpage.aspx?lact_id=3481466 (дата обращения 24.03.2021). 
определение размеров и формы нового эллипсоида, наилучшим образом удовлетворявшего для заданной территории. Применение классических методов преобразования координат, таких как 7-параметрический метод Бурша требует высокоточного определения геодезический высоты в СК42 и точной модели геоида. Для улучшения точности конформных преобразований координат во многих странах (США, Канада, Австралия, Хорватия и др.) используют так называемые файлы сеток деформаций (модели преобразования на основе сеток) [Dewhurst, 1990; Junkins, 1990; Collier, 2002; Grgic et al., 2015]. Сетка обеспечивает более точное моделирование преобразований, адаптированное к плотности станций сети. В данной статье рассмотрено построение матрицы деформаций высот формата (GTX) Национального управления океанических и атмосферных исследований Канады (NOAA) между локальной CK42 и пространственной системы координат, базированной на эллипсоиде WGS84 для территории Ферганской долины в Узбекистане.

\section{МАТЕРИАЛЫ И МЕТОДЫ ИССЛЕДОВАНИЯ}

Сетка (грид) вертикальных смещений была сформирована на основе данных измерений классической нивелирной и спутниковой GPS сетей для всей территории республики с использованием следующих данных:

1) Государственная нивелирная сеть (высотная основа) Республики Узбекистан является фрагментом общей сети на территории СНГ и включает линии нивелирования I класса (протяженность 11791 км, 3888 пунктов) и II класса (протяженность 6409 км, 2132 пункта). 975 пункта были восстановлены в 2013-2017 годах при развитии GPS сети.

2) Спутниковая государственная сеть (СГC) GPS была создана в стране на основе наличия инфраструктуры и географических потребностей и, следовательно, не охватывает всю страну (рис. 1). Формирование СГС из более 200 станций проводилось с 2005 по 2015 год. На сегодняшний день функционируют: сеть постояннодействующих референцных пунктов (РГП), спутниковые геодезические сети нулевого (СГС0) и первого (СГС1) классов. Развивается также сеть 50 станций, работающих в режиме дифференциальной коррекции. Измерения на станциях государственной сети выполнялись ранее только с использованием глобальной навигационной системы GPS, поэтому далее будет рассматриваться обработка только данных только этой системы. Для определения координат исследуемых станций использовался программный комплекс GAMIT/GLOBK версии 10.71, разработанный в MIT (Massachusetts Institute of Technology), Harvard-Smithsonian Center of Astrophysics и Scripps Institution of Oceanography [Herring et al., 2018]. Для получения устойчивого решения и точной привязки региональных измерений к международной опорной системе координат ITRF2014 [Altamimi et al., 2016], кроме пунктов KIT3, TASH, в обработку были включены еще 9 станций международной службы GNSS для геодинамики IGS (ARTU, BADG, CHUM, GUAO, HYDE, IISC, IRKT, MDVJ, POL2). Угол отсечки по высоте был взят $15^{\circ}$. Обработка выполнялась согласно рекомендациям и стандартам международной службы вращения Земли IERS2010 [IERS, 2010]. 


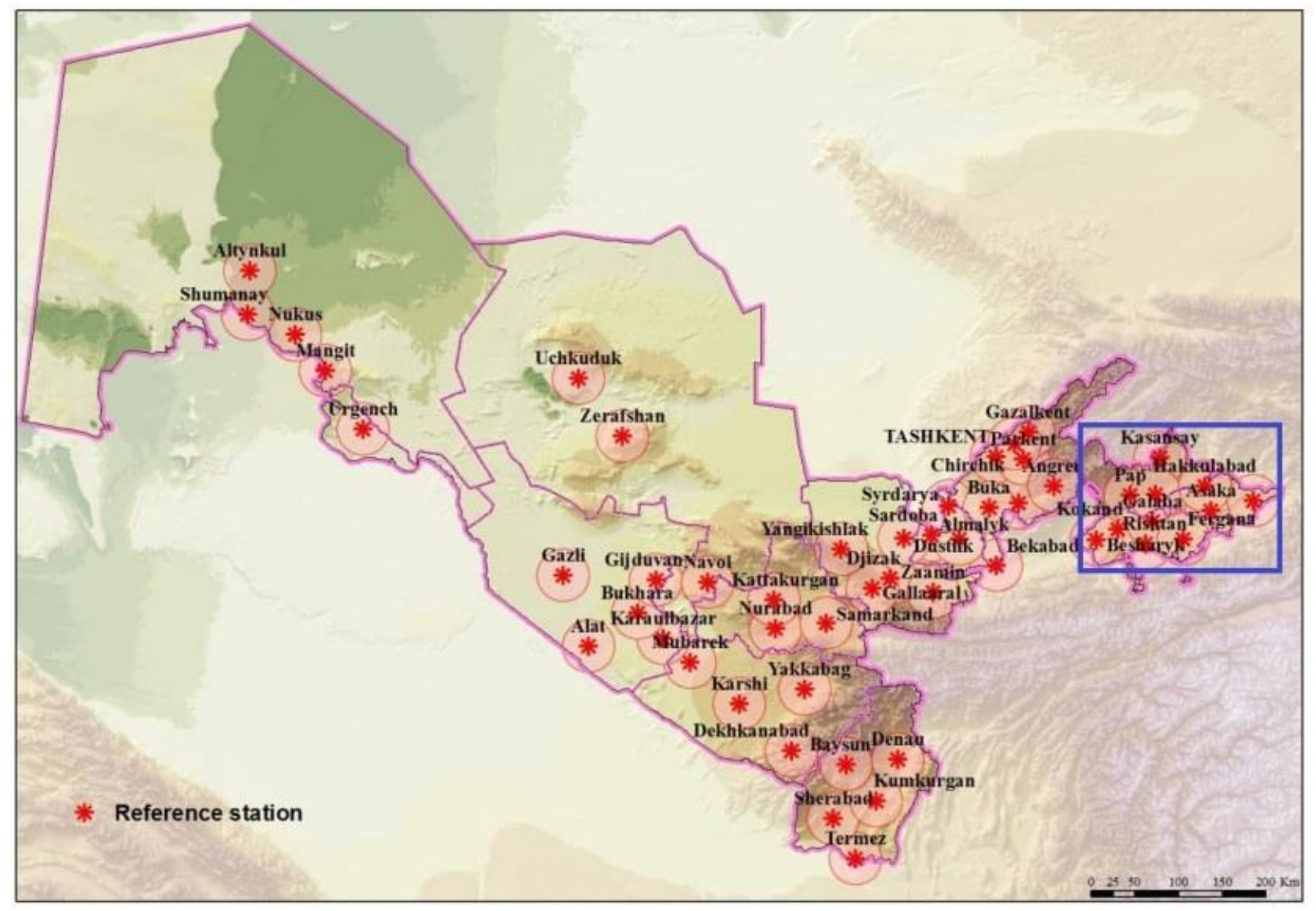

Pис. 1. GPS сеть на территории Республики Узбекистан

Fig. 1. GPS network in the territory of the Republic of Uzbekistan

На сегодняшний день 144 пункта являются пунктами обоих датумов. Для каждой из «общих точек» на основе вычисленной разницы широт, долгот и высот геоида сформированы сетки (гриды) смещений с использованием алгоритма «Minimal Curvature» программы Golden Software Surfer. Разрешение сетки высот геоида (und.grd) было выбрано $2.5^{\prime} \times 2.5^{\prime}$. Полученный грид был конвертирован в матрицу вертикальных деформаций в формате NOAA GTX. Далее использованы утилиты библиотеки GDAL для трансформирования координат из СК42 в систему WGS84. Исследование полученных матриц деформаций проводилось по двум направлениям: оценка точности самого файла смещений на основе сравнения с результатами реальных измерений на GPS станциях и обновление высотной основы карт масштаба 1: 200000 для территории Ферганской долины.

Территория Ферганской долины в Узбекистане была выбрана для обновления топографических карт масштаба 1: 200000 (рис. 2). Бассейн является крупнейшей межгорной впадиной в Центральной Азии, между горными системами Тянь-Шаня на севере и Гиссаро-Алая на юге. Долина имеет длину около 300 км и ширину до 70 км, образуя территорию площадью 22000 квадратных километров. Выбор этой области обусловлен несколькими причинами. Во-первых, первые работы по топографическому обеспечению региона Центральной Азии начались в начале XX века, и большая часть измерений для создания единой системы триангуляции, исследования геоида проводилась здесь. С другой стороны, регион относится к районам с развитой инфраструктурой на территории респуб- 
лики, для которых пока сеть GPS-станций имеет хорошую плотность. И, наконец, разнообразный рельеф местности от равнинной до гористых частей является хорошей моделью для тестирования сетки смещения и оценки точности процедуры преобразования между локальной CK42 и геоцентрической WGS84 системами координат и оценки аномалий высот геоида исследуемой области.

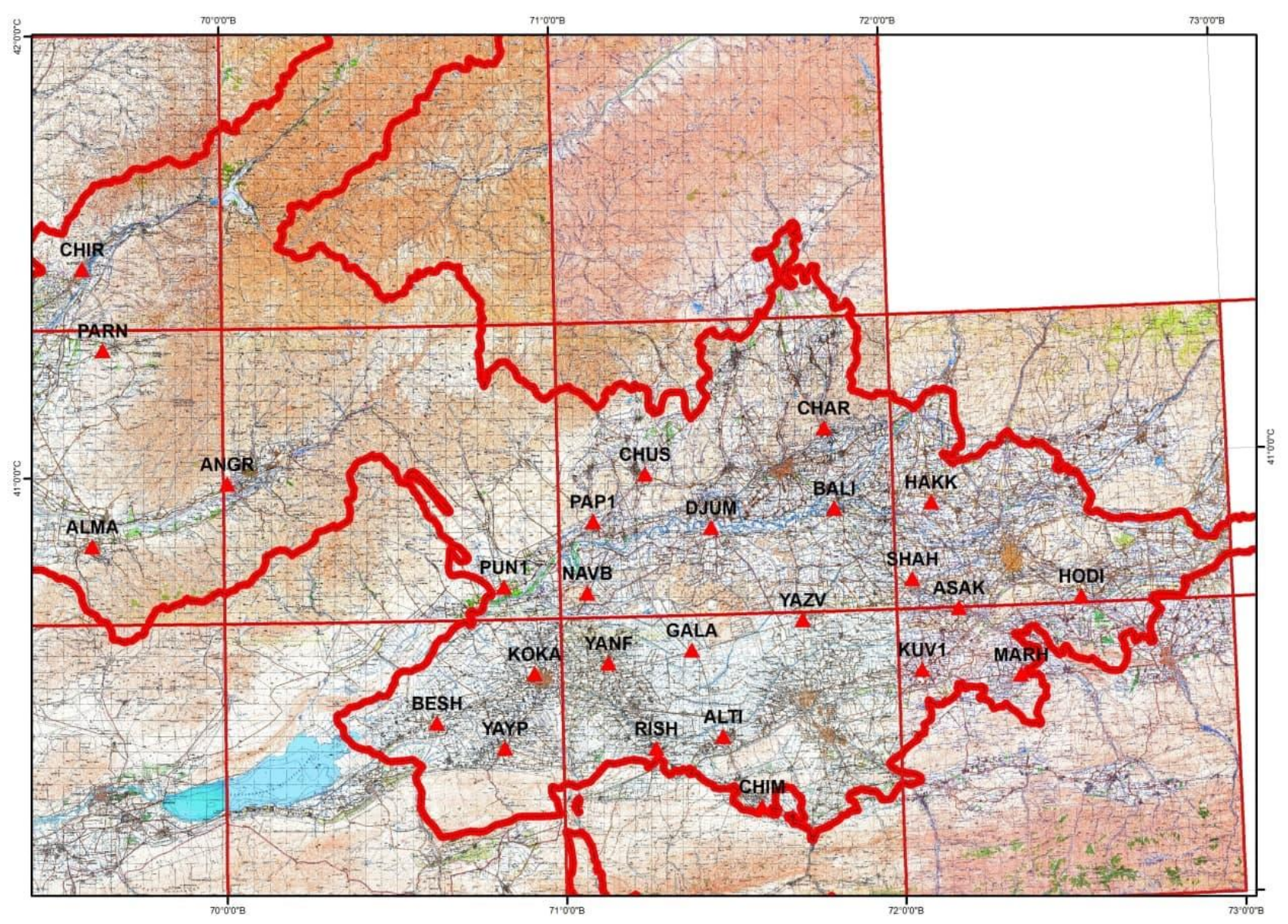

Рис. 2. Фрагмент топографической карты масмтаба 1:200 000 Ферганской долины

Fig. 2. Fragment of a topographic map at a scale of 1:200,000 of the Fergana Valley

\section{РЕЗУЛЬТАТЫ И ИХ ОБСУЖДЕНИЕ}

На первом этапе анализа нами выполнена оценка точности созданного файла смещений высот, использованного далее для обновления топографических карт. На рис. 3 показан созданный грид смещений высот между системами CK42 и WGS84. Полученное смещение между высотами двух системам определяет значения аномалий высот геоида данного региона, которые колеблются от $-38,86$ м до -49,03 м.

Значения вычисленных геодезических высот в WGS84 сравнивались с результатами GPS измерений 27 станций сети СГC, расположенных на территории Ферганской долины. Разница «вычисленных» и «измеренных» геодезических высот в системе WGS84 меняется от -0,13 м до 0,67 м (рис. 4). Как видно из рис. 3-4 максимальные значения аномалий высот преимущественно на территории самой впадины и, как следствие, расхождение геодезических высот для данной области достигает тоже максимума. 


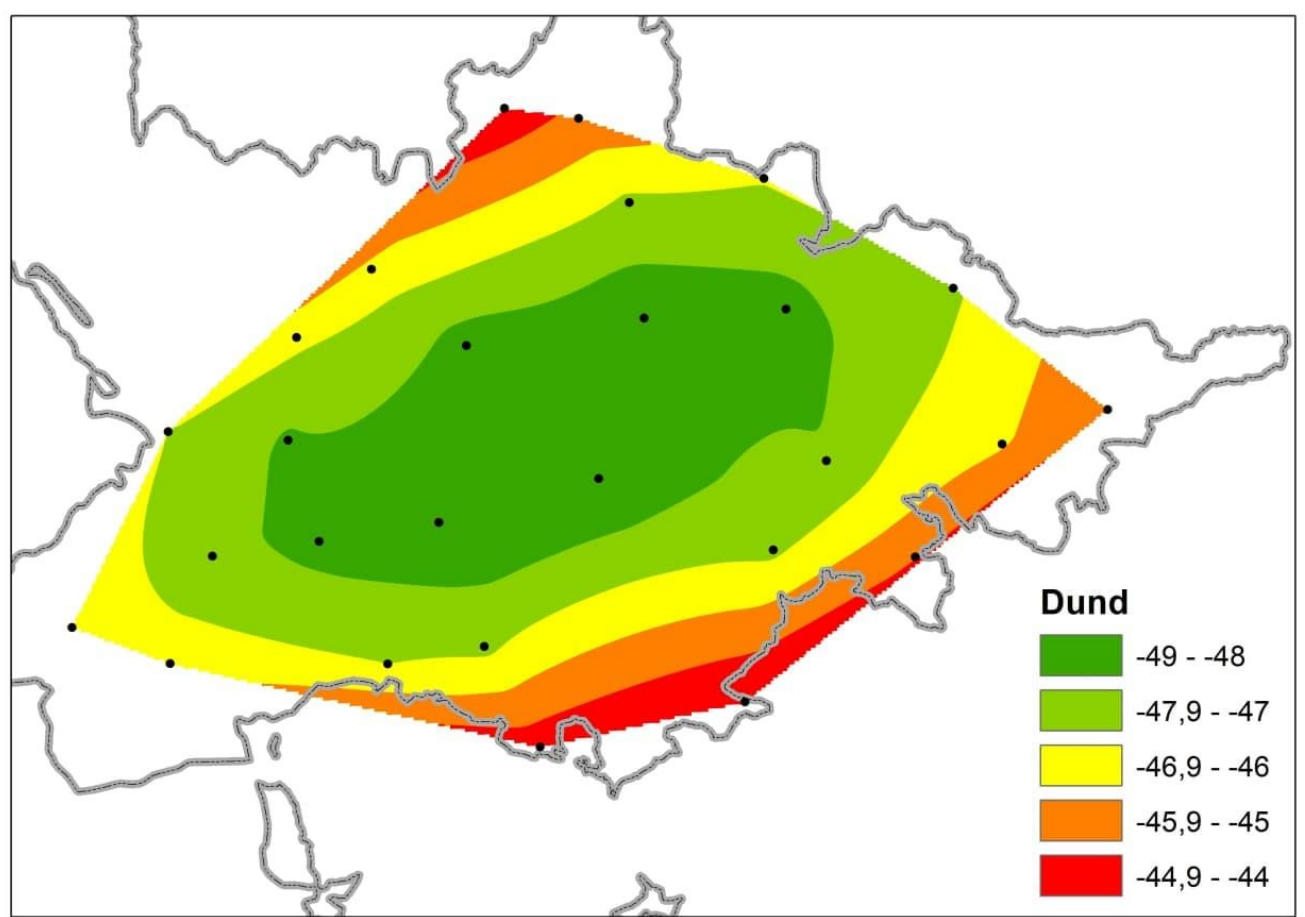

Рис. 3. Аномалии высот геоида для территории Ферганской долинь Fig. 3. Geoid heights anomalies for the territory of the Fergana Valley

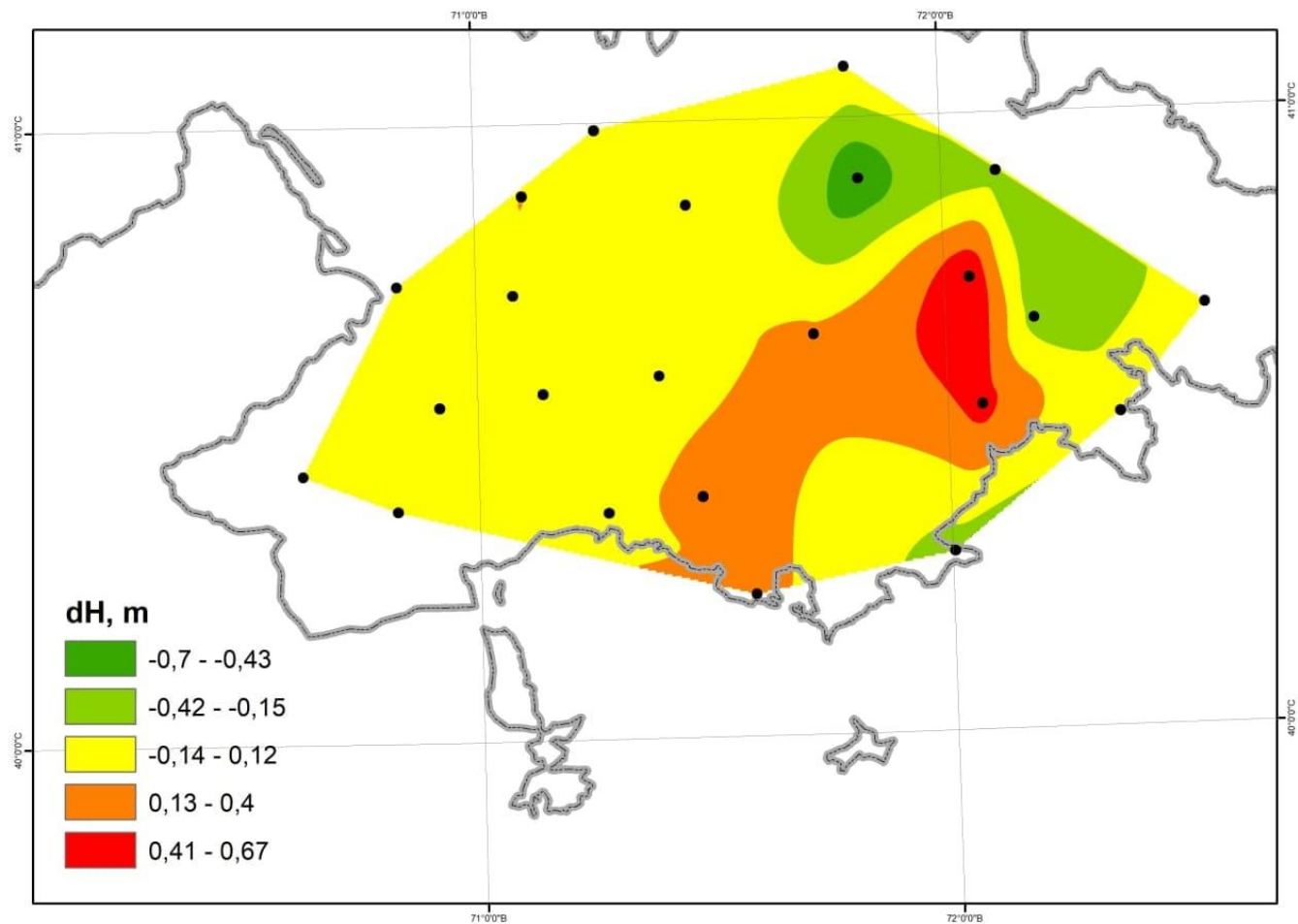

Рис. 4. Разница «вычисленных» и «измеренныхх (в метрах) значений геодезических высот в WGS84

Fig. 4. The difference between "calculated" and "measured" (in meters) values of geodetic heights in WGS84 
Для трансформирования сетки карт выбирались точки преимущественно на узлах сетки (шаг сетки $\left.1^{\circ} \times 40^{\prime \prime}\right)$. Общее количество точек, использованных для преобразования составило 50. Для перехода от полученных геодезических высот к нормальным высотам в системе WGS84 была выбрана модель геоида EGM2008, оценка точности которой выполнялась авторами ранее [Fazilova, Magdiev, 2017]. Значения аномалий высот геоида для EGM2008 определялись с помощью онлайн сервиса International Centre for Global Earth Models (ICGEM) [Barthelmes, Köhler, 2016]. Результаты трансформирования карт представлены на рис. 5. Значения расхождений высот между CK42 и WGS84 при трансформировании колеблятся от $-3,93$ м до 0,31 м. Однако, как видно из полученных результатов для северо-восточной части исследуемой области преобразование не выполняется в виду отсутствия данных в созданном файле смещений. Выявленные ранее аномалии высот геоида в районе самой Ферганской впадины привели к максимальным расхождениям также между значениями высот.

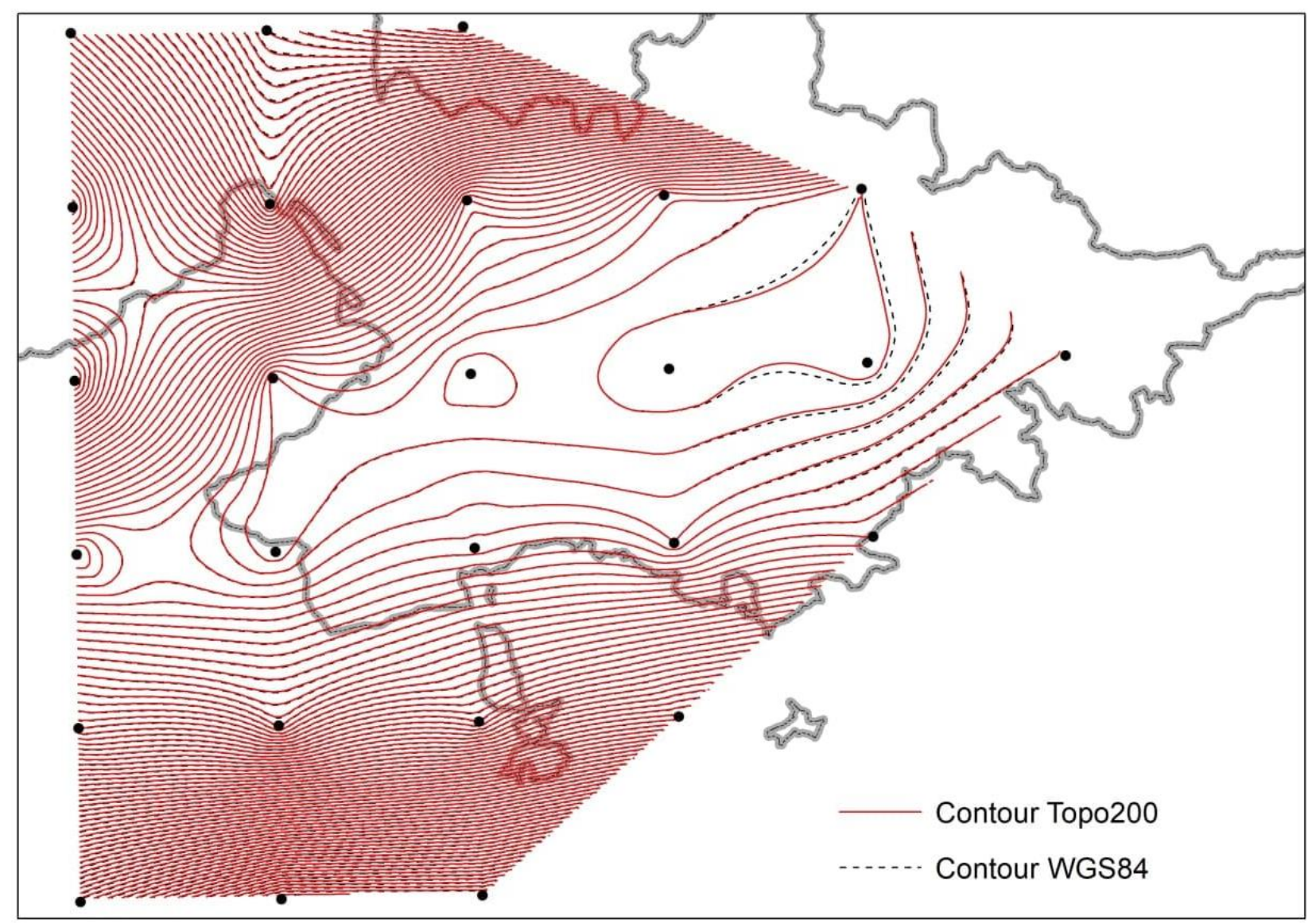

Рис. 5. Изолинии высот топографических карт в СК42 (красная линия) и в WGS84 (серая пунктирная линия)

Fig. 5. Heights contour lines of topographic maps in CS42 (red line) and in WGS84 (gray dashed line) 


\section{ВЫВОДЫ}

В данной работе проводилось создание и обновление высотной отсчетной основы топографических карт для территории Ферганской долины в Узбекистане. Учитывая, что на сегодняшний день не проводятся гравиметрические исследования и отсутствует информация о точном геоиде территории страны, в работе был рассмотрен вариант преобразования между геодезическими и нормальными высотами с использованием файла сетки вертикальных деформаций (GTX) Национального управления океанических и атмосферных исследований Канады (NOAA) между системами координат CK42 и WGS84. К настоящему моменту инсталлированы более 200 станций спутниковой государственной сети, базированной на измерениях навигационной системы GPS. Но, в виду того, что сеть СГС развивалась только для районов с развитой инфраструктурой, она не покрывает полностью всю территорию республики. Поэтому исследование проводилась на примере территории Ферганской долины. Оценка точности полученной матрицы преобразования высот показала разницу между реальными значениями высот, полученных по GPS измерениям и смоделированными колеблется в пределах от -0,13 м до 0,67 м. Выявлено, что максимальные расхождения высот находятся в районе самой Ферганской впадины и могут быть обусловлены как аномальным гравитационным полем в данной области, так и недостаточной плотностью станций сети СГС в северо-восточной части исследуемой области. В результате полученные высоты для обновленной топографической карты в WGS84 имеют расхождения с высотами в CK42 от -3,93 м до 0,31 м и максимальные отклонения находятся преимущественно в данной области Ферганской котловины.

\section{СПИСОК ЛИТЕРАТУРЫ}

1. Макаренко Н.Л., Демьянов Г.В., Новиков Е.В. и др. Единая государственная система геодезических координат 1995 года (СК-95). Под ред. А.А. Дражнюка. М.: Федерал. служба геодезии и картографии России, 2000. 34 с.

2. $\quad$ Altamimi Z., Rebischung P., Métivier L., Collilieux X. ITRF2014: A New Release of the International Terrestrial Reference Frame Modeling Nonlinear Station Motions. Journal of Geophysical Research: Solid Earth, 2016. V. 121. No 8. P. 6109-31. https:// doi.org/10.1002/ 2016jb013098.

3. Barthelmes F., Köhler W. International Centre for Global Earth Models (ICGEM), in: Drewes, H., Kuglitsch, F., Adám, J. et.al. The Geodesists Handbook, Journal of Geodesy, 2016. V. 90. No 10. P. 907-1205. https://doi.org/10.5194/egusphere-egu2020-3511.

4. Collier $P$. Development of Australia's National GDA94 Transformation Grids. Consultant's Report, Dept. of Geomatics, The University of Melbourne, Australia, 2002, 36 р. Электронный ресурс: https://www.icsm.gov.au/sites/default/files/natgrids_0.pdf (дата обращения: 25.03.21).

5. Dewhurst WT. NADCON: The application of minimum-curvature-derived surfaces in the transformation of positional data from the North American Datum of 1927 to the North American Datum of 1983, 1990. NOAA Technical Memorandum NOS NGS 50. Электронный ресурс: www.geodesy. noaa.gov/PUBS_LIB/NOSNGS-50.pdf (дата обращения: 25.03.21).

6. Fazilova D., Ehgamberdiev Sh, Kuzin S. Application of time series modeling to national reference frame realization. Geodesy and Geodynamics. Elsevier: China, 2018. V. 10, Issue 4. P. 281-287. DOI: 10.1016/j.geog.2018.04.003.

7. Fazilova, D., Magdiev, H. Comparative study of interpolation methods in development of local geoid. International Journal of Geoinformatics, 2018. V. 14. No 1. P. 29-33. 
8. Grgic, M., Varga M. and T. Bašić. The empirical comparison of coordinate transformation models and distortion modeling methods based on a case study of Croatia. Survey Review, 2015. No 49 (353). P. 15-27. DOI 10.1080/00396265.2015.1104092.

9. Herring, T.A., King, R.W., Floyd, M., McClusky, S.C. Introduction to GAMIT/GLOBK. Release 10.7. Technical report. Massachusetts Institute of Technology, 2018. Электронный ресурс: http:/geoweb.mit.edu/gg/Intro_GG.pdf (дата обращения: 10.09.20).

10. IERS Conventions. IERS Technical Note 36. Gérard Petit and Brian Luzum (eds.). Frankfurt am Main: Verlag des Bundesamts für Kartographie und Geodäsie, 2010. 179 p.

11. Junkins, D.R. The National Transformation for Converting Between NAD27 and NAD83 in Canada. In D.C. Barnes (ed.), Moving to NAD'83: The New Address for Georeferenced Data in Canada. The Canadian Institute of Surveying and Mapping, Ottawa, 1990. P. 1640 .

\section{REFERENCES}

1. Makarenko N.L. Demyanov E.V., Novikov G.V. et al. Unified State System of Geodetic Coordinates 1995 (SK-95). Drazhnyuk A.A. (ed.). Moscow: Federal service of geodesy and cartography of Russia, 2000. 34 p. (in Russian).

2. $\quad$ Altamimi Z., Rebischung P., Métivier L., Collilieux X. ITRF2014: A New Release of the International Terrestrial Reference Frame Modeling Nonlinear Station Motions. Journal of Geophysical Research: Solid Earth, 2016. V. 121. No 8. P. 6109-31. https://doi.org/10. 1002/2016jb013098.

3. Barthelmes $F$. and Köhler W. International Centre for Global Earth Models (ICGEM), in: Drewes, H., Kuglitsch, F., Adám, J. et.al. The Geodesists Handbook, Journal of Geodesy, 2016. V. 90. No 10. P. 907-1205. https://doi.org/10.5194/egusphere-egu2020-3511.

4. Collier P. Development of Australia's National GDA94 Transformation Grids, 2002. Consultant's Report, Dept. of Geomatics, The University of Melbourne, Australia, 36 p. Web resource: https://www.icsm.gov.au/sites/default/files/natgrids_0.pdf (accessed 25.03.21).

5. Dewhurst WT. NADCON: The application of minimum-curvature-derived surfaces in the transformation of positional data from the North American Datum of 1927 to the North American Datum of 1983, 1990. NOAA Technical Memorandum NOS NGS 50. Web resource: www.geodesy. noaa.gov/PUBS_LIB/NOSNGS-50.pdf (accessed 25.03.21).

6. Fazilova D., Ehgamberdiev Sh, Kuzin S. Application of time series modeling to national reference frame realization. Geodesy and Geodynamics. Elsevier: China, 2018. V. 10, Issue 4. P. 281-287. DOI: 10.1016/j.geog.2018.04.003.

7. Fazilova, D., Magdiev, H. Comparative study of interpolation methods in development of local geoid. International Journal of Geoinformatics, 2018. V. 14. No 1. P. 29-33.

8. Grgic, M., Varga M.and T. Bašić. The empirical comparison of coordinate transformation models and distortion modeling methods based on a case study of Croatia. Survey Review, 2015. No 49 (353). P. 15-27. DOI: 10.1080/00396265.2015.1104092.

9. Herring, T.A., King, R.W., Floyd, M., McClusky, S.C. Introduction to GAMIT/GLOBK. Release 10.7. Technical report. Massachusetts Institute of Technology, 2018. Web resource: http://geoweb.mit.edu/gg/Intro_GG.pdf (accessed 10.09.20).

10. IERS Conventions. IERS Technical Note 36. Gérard Petit and Brian Luzum (eds.). Frankfurt am Main: Verlag des Bundesamts für Kartographie und Geodäsie, 2010. 179 p.

11. Junkins, D.R. The National Transformation for Converting Between NAD27 and NAD83 in Canada. In D.C. Barnes (ed.), Moving to NAD '83: The New Address for Georeferenced Data in Canada. The Canadian Institute of Surveving and Mapping. Ottawa. 1990. P. 16- 


\title{
THE ASSESSMENT OF THE BOSTANLIQ DISTRICT (UZBEKISTAN REPUBLIC) BASED ON THE WIND ENERGY POTENTIAL
}

\begin{abstract}
The idea of achieving energy security and lowering the dependence on the global hydrocarbon market is at the top of the agenda in many countries. Most of them consider switching from traditional energy sources to renewable ones as one of the ways to reduce fuel import. This concept absolutely conforms to one of the UN Sustainable Development Goals (Goal no. 7, "Affordable and Clean Energy"). In May 2019, the Government of Uzbekistan Republic adopted the Law on the Use of Renewable Energy Sources (RES). By 2030, Uzbekistan is going to increase the share of RES in the total structure of electricity generation up to $25 \%$ (currently it is at $10 \%$ ), by building solar and wind farms with a total installed capacity of 5,000 MW and 3,000 MW, respectively. The energy-deficient Bostanliq district of the Tashkent region has become one of the places of interest, where transport infrastructure, recreation services, and renewable energy will be developed. The purpose of this study was a multivariate analysis, considering the meteorological, ecological, and socio-economic characteristics of the Bostanliq district, leading to the selection of the optimal location for the wind farm. The assessment map based on the results of this analysis made it possible to identify areas that are most suitable for the location of wind power plants. The assessment method, that was used in this work, is also applicable to other regions of the world.
\end{abstract}

KEYWORDS: wind energy, spatial analysis, Uzbekistan, Bostanliq district, GIS.

\section{INTRODUCTION}

Renewable energy sources become more prominent in the global energy mix, as they provide more than $10 \%$ of global electricity demand. In developed countries, for example, in Germany, at the beginning of 2020 , the installed capacity of renewable energy plants reached $46 \%$ of all electricity generated (125 GW). Developing countries also showes success in renewable energy development. This is due to the increased demand for energy, the depletion of fossil fuel and energy resources, the constant decline in technology prices, the need to reduce the carbon footprint, and the desire to gain energy independence. The United Nations characterizes the energy transition as one of the main sustainable development goals [Berezkin, Sinyugin, 2018].

Recently, some countries and regions have initiated comprehensive spatial studies wind energy development potential in different parts of their territories. These studies incorporated meteorological, socio-economic, and geoecological parameters. One of the first studies in this area was the research of Rob van Haaren and Vasilis Fthenakis, who assessed the wind energy potential of the New York state. When the organization of renewable energy generation is being prepared, they took into account the degree of visual and noise impact, potential disturbance of vegetation and spawning grounds, distance from wetlands, roads and power lines, etc. [Van Haaren, Fthenakis, 2011]. Their concept of a multivariate assessment was endorsed by scientists from the

Lomonosov Moscow State University, High School of Innovative Business, Leninskie Gory 1, 119991, Moscow, Russia, e-mail: yalbacheva@geogr.msu.ru 
Korea Institute of Energy Research. To assess the regions of South Korea in terms of the potential for the development of wind energy, experts added to the analysis the parameter of the remoteness of potential wind farms from protected areas, habitats of rare and endangered species, assessed the potential damage in case of an emergency, proximity to infrastructure facilities, etc. In total, they considered 57 factors [Kim et al., 2013]. Also in 2019, the analytical company Wind Minds conducted an evaluation of Vietnam territorypotential for wind energy development as government requested. As part of the research, the scientists also applied an integrated approach and, in addition to meteorological indicators, integrated the terrain, the land use characteristics, and even the marine vessel traffic along the coast [Sissingh, Arends, 2019].

It should be noted that multivariate analysis of territories for choosing a site for installing wind turbines is a rare instance; the consideration of meteorological or economic characteristics traditionally prevails. Geological, geomorphological, and environmental factors influencing the choice of the layout of the spatial distribution of wind farms are rarely taken into account.

\section{STUDY AREA}

Bostanliq district is located in the northeast of Uzbekistan, in the Tashkent region, where the spurs of the Western Tien Shan lie. On the north side, the region borders with Kazakhstan, and the border with Kyrgyzstan is on the east and northeast (Fig. 1).

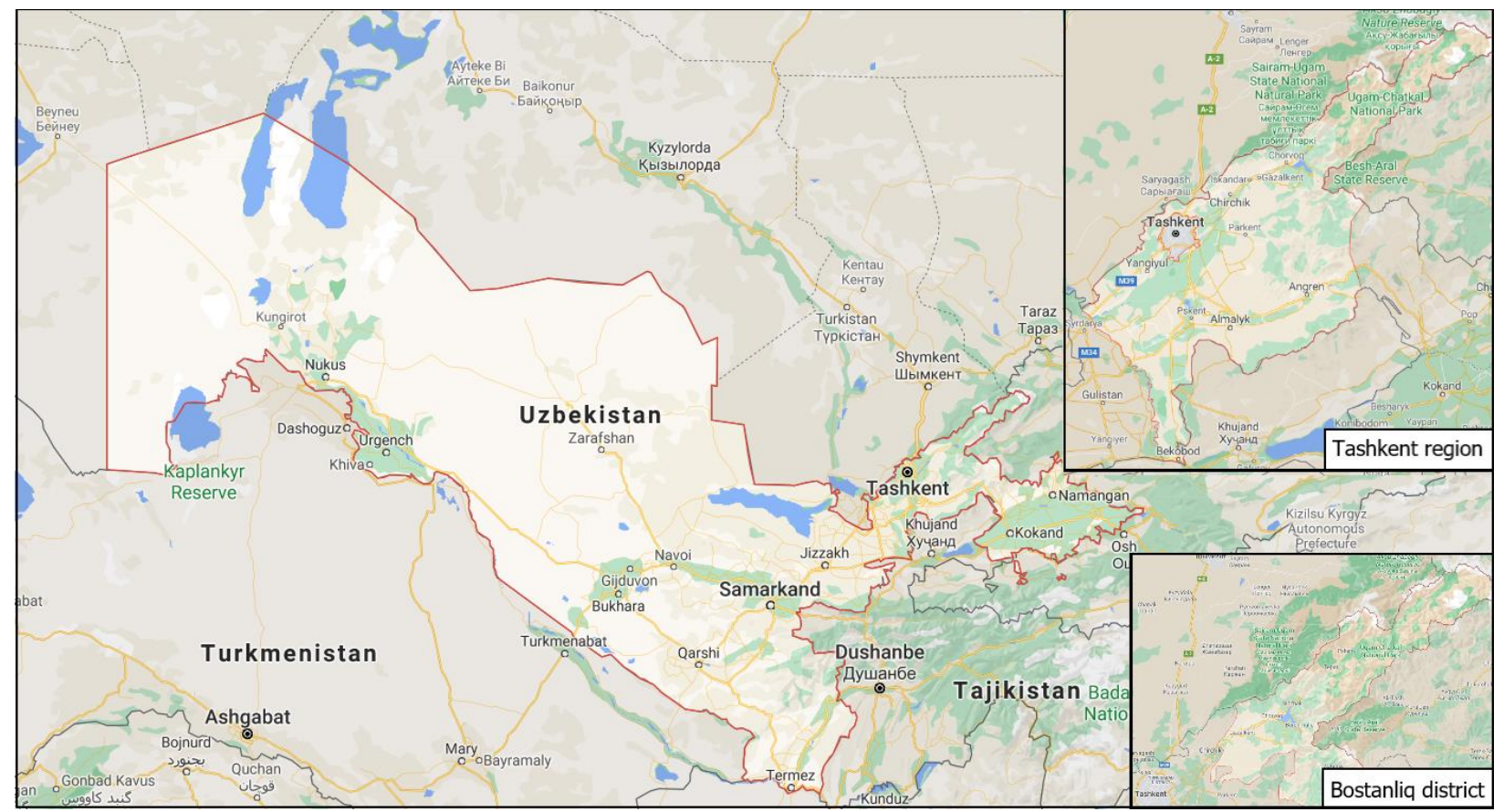

Fig. 1. Study area (Google Maps)

The relief is represented mainly by uplands, midlands, and highlands. The specifics of the bedrock dictate the wide presence of exogenous processes. The climate, in comparison with other regions of the Uzbekistan Republic, is humid; the annual amount of precipitation reaches 500-600 mm per year. The area is characterized by mountain-valley breezes and foehn winds [Belousov, 1986].

In the Bostanliq district, there are 24 rural communities, 17 urban settlements, one city (Gazalkent, the administrative center), and a large number of villages (Fig. 2). The share of the rural population reaches 60\% [Saliev, Fedorko, 2012]. This determines the leading role of agriculture in the current economy of the region; the Bostanliq district is one of the main suppliers of grain for the entire Tashkent region. Melon growing, vegetable growing, horticulture, viticulture, and cotton growing are also developed. Animal farming has also agreat importance. In 
total, there are 140 farms and 22 cooperative farms in the study area with tens of thousands of heads of cattle and small ruminants, poultry, and horses in herds [Islomov, Zhumataev, 2019].

The analysis covers most of the Bostanliq district populated area, with the exception of the frontier highland regions, due to the limitations of the field study of the expedition "Dynamics of landscapes and nature management of northeastern Uzbekistan" of the Department of Physical Geography and Landscape Science (Faculty of Geography, Lomonosov Moscow State University).

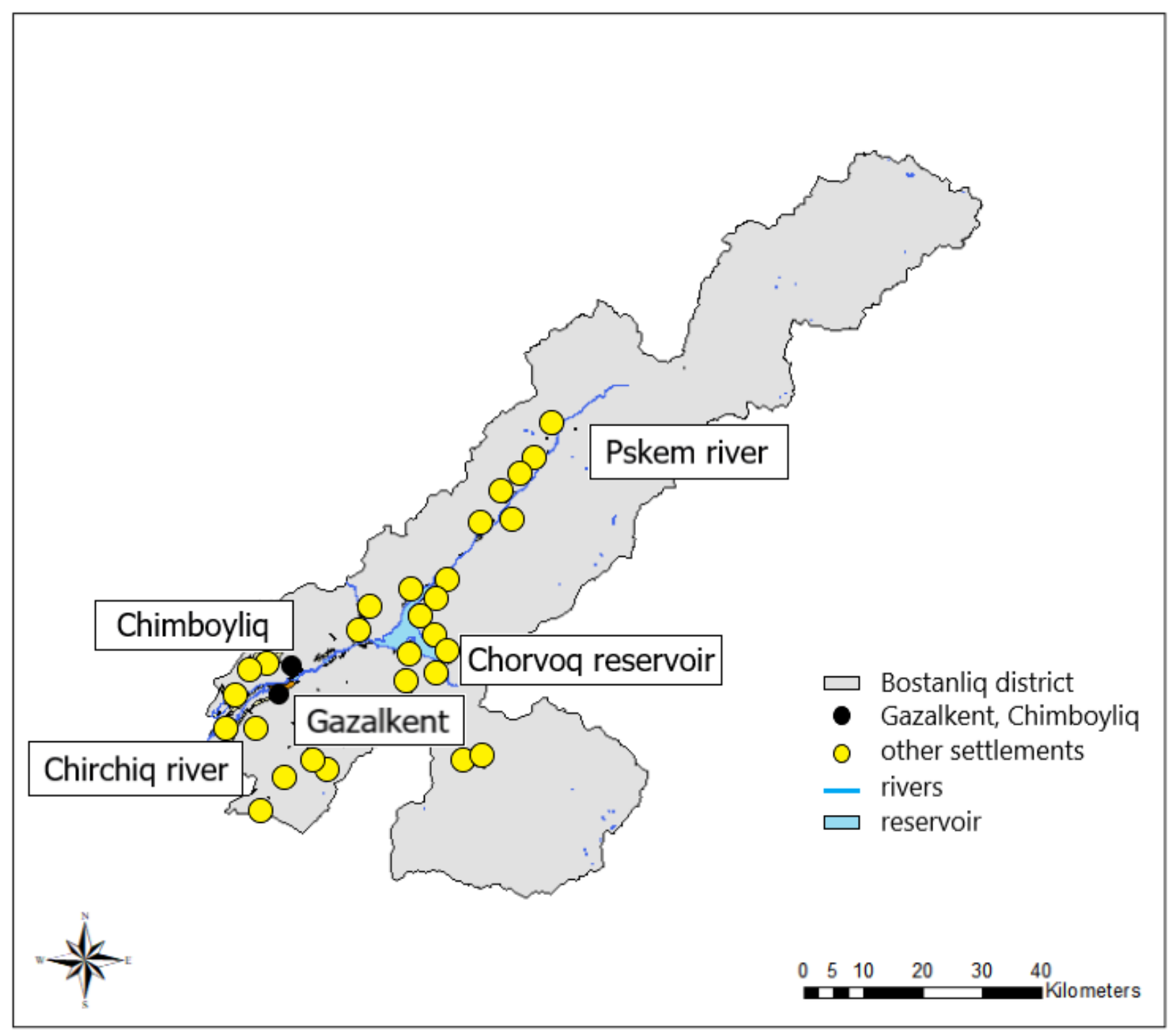

Fig. 2. Bostanliq district (by author)

\section{MATERIALS AND METHODS}

The research materials were based on theoretical and methodological works "Theoretical Framework of Alternative and Renewable Energy" [Elistratov, Kuznetsov, 2003], "Comprehensive renewable energy" [Sayigh, 2012], "Knowledge and landscape in wind energy planning" [Lee, 2017]; reference materials of Global Wind Atlas, NextGIS, data from international organizations (IUCN RedList, BirdLife International), materials of the Institute of Geology and Geophysics of the Academy of Sciences of Uzbekistan, international scientific groups researches [Juliev et al., 2017], data from digital elevation model ALOS, as well as fieldwork results of the 
expedition "Dynamics of landscapes and nature management of northeastern Uzbekistan" of the Department of Physical Geography and Landscape Science (Faculty of Geography, Lomonosov Moscow State University).

The main research methods were fieldwork, cartographic analysis, complex geoecological analysis, and GIS analysis.

\section{RESULTS AND DISCUSSION}

In 2020, the Council of People's Deputies of Uzbekistan discussed the main directions and goals of the integrated development of the Tashkent region for 2021-2022. Energy development is among the potential drivers of the economy. In the Bostanliq district, $\$ 1.048$ billion of foreign investments were attracted towards the construction of two hydroelectric power plants with a total installed capacity of $540 \mathrm{MW}^{1}$. There are also plans to build a wind park (100 hectares) for 36-50 wind power plants near the village of Chimboyliq. The total cost of the project is $\$ 900$ million. Sufficient wind energy potential (specific power up to $300 \mathrm{~W} / \mathrm{m}^{2}$ ), developed transport infrastructure, proximity to the end consumer (Gazalkent city), and the presence of power transmission lines determined the choice of a site for the construction of a wind farm. However, a comprehensive geoecological analysis carried out by the authors shows that the set of used characteristics was insufficient to justify such a choice.

The structure of this analysis included both traditionally used characteristics, as well as geological, geomorphological, and ecological:

1. Meteorological:

- $\quad$ average annual wind speed,

- wind capacity.

2. Socio-economical:

- distance from roads,

- distance from railways,

- distance from railway stations,

- distance from settlements,

- distance from power lines,

- distance from touristic sites.

3. Geological and geomorphological:

- underlying rock structures,

- $\quad$ presence of faults,

- $\quad$ seismicity,

- historical earthquake epicenters,

- presence of landslides,

- slopes,

- $\quad$ relative elevation,

- distance from mining sites.

4. Ecological:

- $\quad$ occurrence of Red List species of plants and animals,

- distance from Important Bird Areas,

- landscape characteristics.

Toshkent viloyati hokimligi: http://toshvil.uz/oz/toskent-viloatini-rivozlantiris-bujica-ustuvor-junalislarmuokama-kilindi (Accessed 22.04.2021). 
The multivariate analysis leads to the following conclusions; ones that made it possible to propose alternative options for the location of the construction site.

1. Meteorological indicators are decisive since they directly affect the efficiency of the wind turbine, and these figures determine whether the selected area will have the necessary wind energy potential for the development of the industry. The study uses calculations for a height of 50 meters from the ground level surface.

It was discovered that in the Bostanliq district the prevailing wind speeds are from 2 to 8 $\mathrm{m} / \mathrm{s}$, and the most favorable is the territory of the Chirchiq River Valley. There are no average annual wind speeds above $16 \mathrm{~m} / \mathrm{s}$ that are considered to be threatening to the wind turbines. Spatial analysis of the wind energy potential within the region based on meteorological characteristics showed that the specific power of the wind flow in a densely populated area with a center of Gazalkent city and smaller settlements reaches $100 \mathrm{~W}$ per sq. meter and creates an unsuitable zone for the wind turbines operation. The maximum wind energy potential (more than $500 \mathrm{~W}$ per sq. meter) is observed in the lower course of the Pskem River; the area on the left bank of the watercourse is especially rich in wind energy resources. In general, the Bostanliq district has average characteristics of wind energy potential, which can satisfy the needs of the administrative territory.

2. In terms of the socio-economic characteristics, the most suitable regions are also located in the Chirchiq River Valley. The end of the Tashkent railway so far is in the administrative center, the city of Gazalkent; both sides of the valley have a developed road and power line network, however, all of this is concentrated below the Chorvoq reservoir. As you move further into the mountains upstream of the Pskem River, the number of roads and power lines is decreasing. However, it is unlikely that it will significantly increase the expenditures for wind energy projects.

3. The geological and geomorphological factors must be taken into account since wind power plants are heavy structures that need a solid foundation protecting them against unfavorable and dangerous endogenous and exogenous geological and geomorphological phenomena. The study area is confined to a network of tectonic faults, which explains the seismicity of magnitude 6.5 on $70 \%$ of the study area. In general, according to the Ministry of Emergency Situations of Uzbekistan and the State Committee for Architecture and Construction, the frequency of 7-point earthquakes repeats once every 50-100 years and 8point earthquakes occur approximately once every $100-400$ years. Yet this is a predictive estimate. The more accurate characterization of the territory was made possible through the listing of the historical earthquake epicenters locations of the 20th century, their magnitude ranging from 4.3 to 6.5 points. As a result, we have identified areas of potential development of the unfavorable or dangerous geological phenomena that pose threats to the strength of wind turbine structures.

Special attention was given to the underlying rock structures, which contribute to ensuring the stability of such enormous structures as modern industrial wind turbines. The ranking was based on the scale of rock hardness developed by M. Protodyakonov ${ }^{1}$, but with the reduced amount of the evaluation categories. Four categories of different hardness were distinguished: a) chalk, gypsum, marls, clays, loess, and gravels have the minimum

1 Classification of rock hardness (Protodyakonov scale): https://rosmining.ru/wpcontent/uploads/2014/11/\%D0\%9A\%D0\%BB\%D0\%B0\%D1\%81\%D1\%81\%D0\%B8\%D1\%84\%D0\%B8\% D0\%BA $\%$ D0\%B0\%D1\%86\%D0\%B8\%D1\%8F-

$\% \mathrm{D} 0 \% \mathrm{~B} 3 \% \mathrm{D} 0 \% \mathrm{BE} \% \mathrm{D} 1 \% 80 \% \mathrm{D} 0 \% \mathrm{BD} \% \mathrm{D} 1 \% 8 \mathrm{~B} \% \mathrm{D} 1 \% 85-$

$\% \mathrm{D} 0 \% \mathrm{BF} \% \mathrm{D} 0 \% \mathrm{BE} \% \mathrm{D} 1 \% 80 \% \mathrm{D} 0 \% \mathrm{BE} \% \mathrm{D} 0 \% \mathrm{~B} 4-\% \mathrm{D} 0 \% \mathrm{BF} \% \mathrm{D} 0 \% \mathrm{BE}-$

$\% \mathrm{D} 0 \% 9 \mathrm{~F} \% \mathrm{D} 1 \% 80 \% \mathrm{D} 0 \% \mathrm{BE} \% \mathrm{D} 1 \% 82 \% \mathrm{D} 0 \% \mathrm{BE} \% \mathrm{D} 0 \% \mathrm{~B} 4 \% \mathrm{D} 1 \% 8 \mathrm{C} \% \mathrm{D} 1 \% 8 \mathrm{~F} \% \mathrm{D} 0 \% \mathrm{BA} \% \mathrm{D} 0 \% \mathrm{BE} \% \mathrm{D} 0$

$\%$ BD $\%$ D0\%BE\%D0\%B2\%D1\%83.pdf (Accessed 27.04.2021) 
hardness, b) sandstones, limestones, conglomerates, and slates have slightly higher hardness, c) dolomites, marble, and shale sandstones are characterized by medium-to-high hardness, and d) quartzite, basalt, andesite, dacite, granite, gneiss, syenite, diorite, and monzonite have the highest degree of hardness. The last category is the most favorable for the construction of wind power plants. Considering a large number of loess formations and the prevalence of unstable Quaternary, Carboniferous, and Paleogene loose sediments and unstable rocks in the valley, such an assessment made it possible to determine risk areas for dangerous exogenous geomorphological processes.

The underlying rock characteristics and the seismicity of the territory allow us to assess the activity of landslide processes. In total 64 landslide concentrated mainly around the Chorvoq reservoir (Fig. 3) bodies of different ages, sizes, and degrees of activity were identified. These geological and geomorphological objects are moving occasionally, posing a danger to the adjacent territories; also, due to the nature of the underlying rocks, they cannot serve as a reliable foundation for wind power plants.

In addition to the specified parameters, this pool considered the steepness of the slopes, which is of decisive technical importance for the construction of wind turbines, the relative height (affecting the wind speed), and the distance from mining sites (anthropogenic enhancement of seismicity).

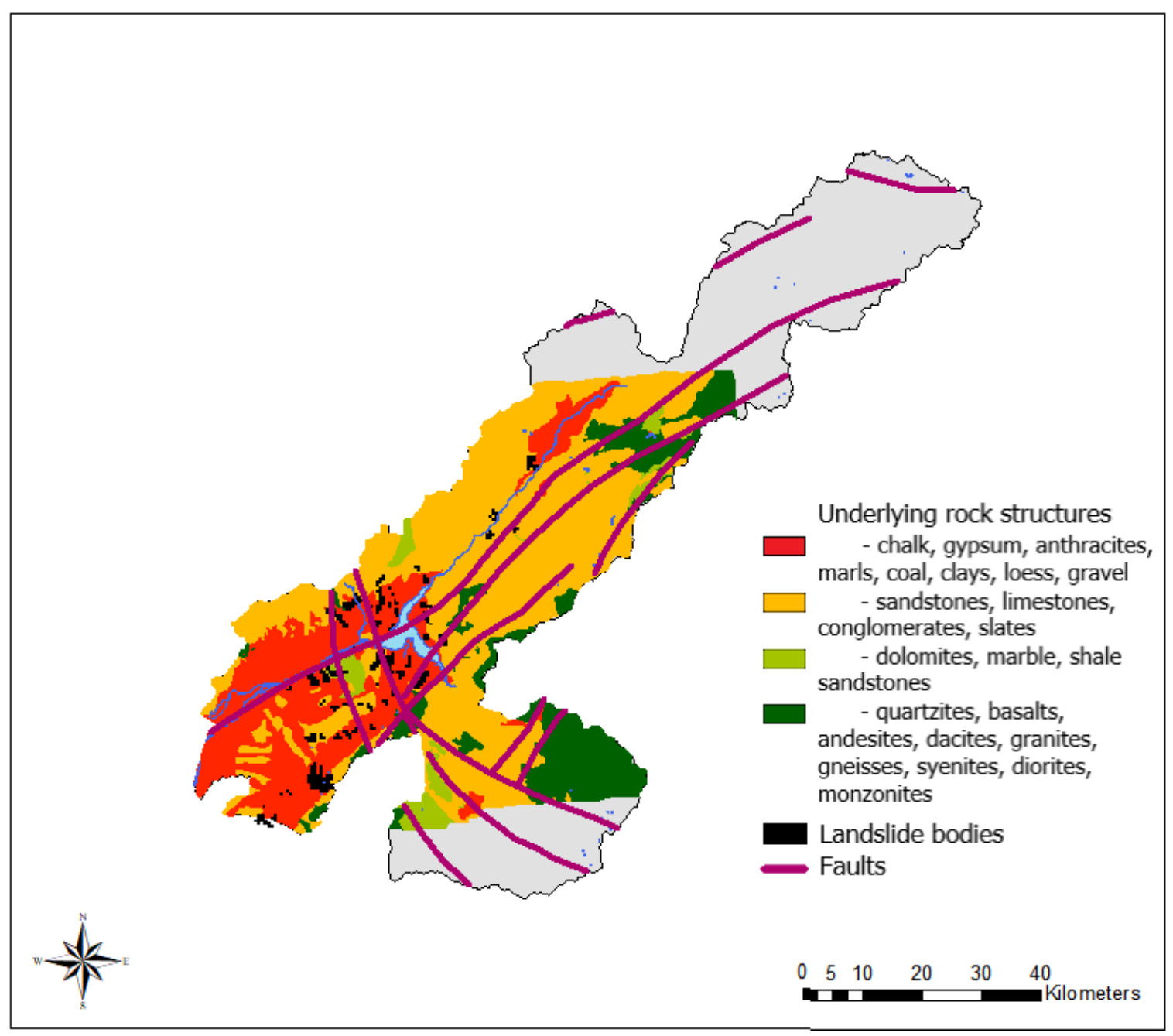

Fig. 3. Faults, underlying rock structures and landslide bodies of the study area (by author) 
4. The ecological analysis is heavily based on the concept of environmental friendliness of renewable energy sources in comparison with traditional sources. Any anthropogenic activity is a violation of the natural conditions of the territory. In this study, we examined the potential impact of the development on the habitats of rare and endangered animal species. Based on the data on the Red List species ranges, the study area was divided into four zones: areas where habitats of 17, 18, 19, and 20 species are located, respectively. Unsurprisingly, more pristine areas that are less suitable for the wind turbines installation turned out to be concentrated in mountainous areas on the territory of the Chatkal reserve; the most suitable areas (with a lower occurrence of rare species) are in the most densely populated part in the southwest of the Bostanliq district. The habitats of locally endemic species, Menzbier's marmot (Marmota menzbieri) are regarded separately. As the marmot lives in the surface soils layer that is most exposed to heavy turbine vibrations, its' range can potentially change, and that can lead to the extinction of this endangered species.

Based on the same reasoning, the location of Important Bird Areas, habitats, and foraging grounds for birds, which is allocated by the international organization for the protection of birds and the preservation of their habitat BirdLife International, was taken into account. The last parameter considered to characterize modern landscapes, which is necessary for predicting possible conflicts of nature management. Taking into consideration the upper mentioned factors, as well as the patterns of modern land use, the landscapes were assessed as follows in terms of the degree of suitability for the installation of wind turbines. The unsuitable areas are water bodies; hilly-ridged low mountains and foothills with a loess cover, with gardens and arable lands, heavily dissected by ravine network; terraced river valleys with loess deposits with gardens and arable lands; as well as valleys with herbshrub communities and deciduous forests along the riverbeds. The moderately suitable areas include the medium-dissected hilly-ridged foothills with gardens and arable lands and more impact-resistant rocks (conglomerates, sandstones), and the slopes of middle highland medium-dissected ridges with a similar substrate. Alpine landscapes are considered suitable due to the hardness of the underlying rocks. The optimal (most suitable) are the middle highland medium-dissected ridges with plateau-like peaks, composed of igneous and hard carbonate rocks.

To visualize and integrate the results of the multivariate analysis, the entire array of maps and data was processed in the ArcMap program of the ArcGIS software package. The Euclidean distances were calculated for linear and point features using the Euclidean Distance tool. Then, the addressed characteristics were normalized as a part of the quantitative and qualitative assessment of the territory. Then the characteristics were ranked according to the degree of suitability for the development of wind farms. As a result, we obtained a four-part general classification scheme, where all parameters were described as follows: unsuitable (1), moderately suitable (2), suitable (3), and optimal (4) (Table 1).

The final step was to synthesize all available normalized and ranked information through the creation of a weighted suitability layer in ArcMap. The procedure consisted of overlaying raster data for each parameter, multiplying each by the weight assigned to them, and then summing them up. The assignment of weight to the characteristics was carried out expertly according to their significance for the final assessment: from 0.0942 to 0.01 . Based on the rules of the Weighted Sum tool, the sum should be equal to 1.0. Following the calculations, a map was built; this map is assessing the potential of the territory of the Bostanliq district for the development of wind energy based on the analysis of 20 physical-geographical and socio-economic parameters (Fig. 4). 
Table 1. Normalization and ranking of the assessed characteristics

\begin{tabular}{|c|c|}
\multicolumn{2}{c}{ Meteorological } \\
\hline Characteristic & $\begin{array}{c}\text { Normalization } \\
\text { and ranking }\end{array}$ \\
\hline & $1-$ less than 250 \\
$\mathrm{~W} / \mathrm{m}^{2} ;$ \\
& $2-200-400 \mathrm{~W} / \mathrm{m}^{2} ;$ \\
& $3-400-600 \mathrm{~W} / \mathrm{m}^{2} ;$ \\
Wind capacity & $4-$ more than 600 \\
& $\mathrm{~W} / \mathrm{m}^{2}$ \\
\hline & $1-$ less than $2 \mathrm{~m} / \mathrm{s} ;$ \\
& $2-2-8 \mathrm{~m} / \mathrm{s} ;$ \\
Average annual & $3-12-16 \mathrm{~m} / \mathrm{s} ;$ \\
wind speed & $4-8-12 \mathrm{~m} / \mathrm{s}$ \\
\hline
\end{tabular}

\begin{tabular}{|c|c|}
\hline Roads & $\begin{array}{c}1-\text { more than } 7500 \\
\mathrm{~m} ; \\
2-3500-7500 \mathrm{~m} ; \\
3-1500-3500 \mathrm{~m} ; \\
4-0-1500 \mathrm{~m}\end{array}$ \\
\hline Railways & $\begin{array}{c}1-\text { more than } \\
15000 \mathrm{~m} ; \\
2-5000-15000 \\
\mathrm{~m} ; \\
3-1500-5000 \mathrm{~m} ; \\
4-0-1500 \mathrm{~m}\end{array}$ \\
\hline Railway stations & $\begin{array}{c}1-\text { more than } \\
15000 \mathrm{~m} ; \\
2-5000-15000 \\
\mathrm{~m} ; \\
3-1500-5000 \mathrm{~m} ; \\
4-0-1500 \mathrm{~m}\end{array}$ \\
\hline Power lines & $\begin{array}{c}1-\text { more than } 7500 \\
\mathrm{~m} ; \\
2-3500-7500 \mathrm{~m} ; \\
3-1500-3500 \mathrm{~m} ; \\
4-0-1500 \mathrm{~m}\end{array}$ \\
\hline Settlements & $\begin{array}{c}1-\text { more than } \\
30000 \mathrm{~m} ; \\
2-10000-30000 \\
\mathrm{~m} ; \\
3-5000-10000 \\
\mathrm{~m} ; \\
4-0-5000 \mathrm{~m}\end{array}$ \\
\hline Touristic sites & $\begin{array}{c}1-0-1000 \mathrm{~m} ; \\
2-1000-3000 \mathrm{~m} ; \\
3-3000-10000 \\
\text { m; } \\
4-\text { more than } \\
10000 \mathrm{~m}\end{array}$ \\
\hline
\end{tabular}

Socio-economic

\begin{tabular}{c|c|} 
Characteristic & $\begin{array}{c}\text { Normalization } \\
\text { and ranking }\end{array}$ \\
\hline
\end{tabular}

Geological and geomorphological

\begin{tabular}{l|c|} 
Characteristic & Normalization \\
\hline
\end{tabular}

and ranking

$6,7,9,10,11$

$2-5,8$

\begin{tabular}{l|l} 
medium-scale & $4-3,4$ \\
\hline
\end{tabular}

the Bostanliq

district

\begin{tabular}{l|l} 
Red List species & $1-20$ species; \\
\hline & $2-19$ species;
\end{tabular}

$2-19$ species;

Menzbier's

marmot (Marmota

menzbieri)

- more than

$-0-10000$

$2-10000-30000$

$\mathrm{m}$;

Important Bird

Areas

4 - more than $60000 \mathrm{~m}$

\begin{tabular}{|c|c|}
\hline Faults & $\begin{array}{c}1-0-3000 \mathrm{~m} ; \\
2-3000-5000 \mathrm{~m} ; \\
3-5000-20000 \\
\mathrm{~m} ; \\
4-\text { more than } \\
20000 \mathrm{~m}\end{array}$ \\
\hline $\begin{array}{l}\text { Earthquake } \\
\text { epicenters }\end{array}$ & $\begin{array}{c}1-0-5000 \mathrm{~m} ; \\
2-5000-10000 \\
\mathrm{~m} ; \\
3-10000-20000 \\
\mathrm{~m} ; \\
4-\text { more than } \\
20000 \mathrm{~m}\end{array}$ \\
\hline Landslide bodies & $\begin{array}{c}1-0-1000 \mathrm{~m} ; \\
2-1000-3500 \mathrm{~m} ; \\
3-3500-5000 \mathrm{~m} ; \\
4-\text { more than } 5000 \\
\mathrm{~m}\end{array}$ \\
\hline $\begin{array}{l}\text { Seismicity } \\
\text { (magnitude) }\end{array}$ & $\begin{array}{c}1-7,5 ; \\
2-6,5 ; \\
4-\text { less than } 6,5 \\
\end{array}$ \\
\hline $\begin{array}{l}\text { Underlying rock } \\
\text { structures }\end{array}$ & $\begin{array}{c}1 \text { - chalk, gypsum, } \\
\text { anthracites, marls, } \\
\text { coal, clays, loess, } \\
\text { gravel } \\
2 \text { - sandstones, } \\
\text { limestones, } \\
\text { conglomerates, } \\
\text { slates } \\
3 \text { - dolomites, } \\
\text { marble, shale } \\
\text { sandstones } \\
4 \text { - quartzites, } \\
\text { basalts, andesites, } \\
\text { dacites, granites, } \\
\text { gneisses, syenites, } \\
\text { diorites, } \\
\text { monzonites }\end{array}$ \\
\hline Slope & $\begin{array}{c}1 \text { - more than } 30 \\
\text { degrees; } \\
2-20-30 \\
\text { degrees; } \\
3-10-20 \\
\text { degrees; } \\
4 \text { - less than } 10 \\
\text { degrees }\end{array}$ \\
\hline $\begin{array}{l}\text { Presence of mining } \\
\text { sites }\end{array}$ & $\begin{array}{c}1-0-1000 \mathrm{~m} ; \\
2-1000-3000 \mathrm{~m} ; \\
3-3000-10000 \\
\mathrm{~m} ; \\
4-\text { more than } \\
10000 \mathrm{~m} \\
\end{array}$ \\
\hline
\end{tabular}




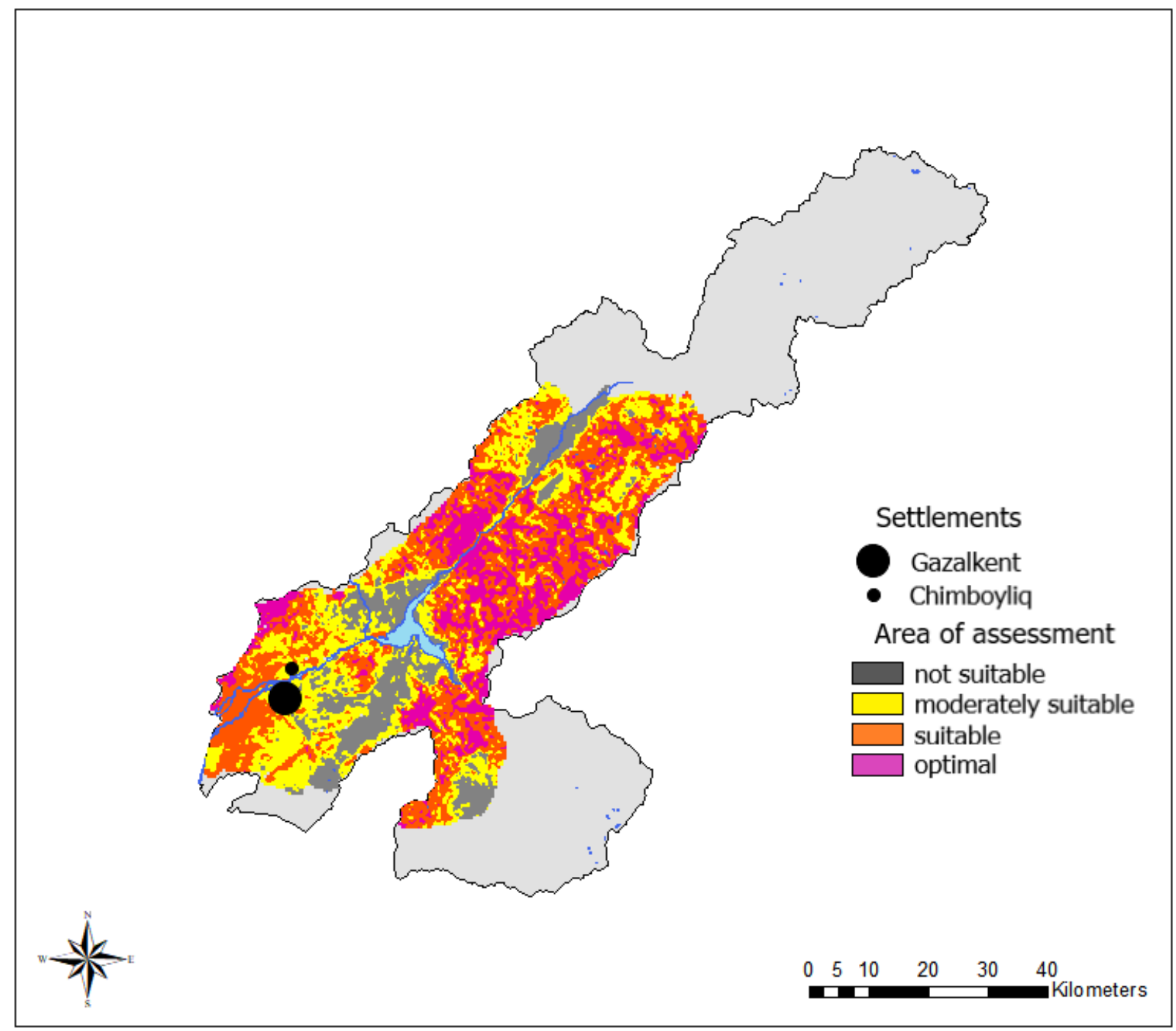

Fig. 4. Assessment of territory of Bostanliq district according to the degree of suitability for the development of wind energy using the GIS analytic (by author)

The map demonstrates that the areas confined to water bodies and the adjacent territory are unfavorable and unsuitable, as they are composed of unstable predominantly Quaternary rocks (clays, sands, and marls), which are at risk of landslide processes. This territories also cause conflicts with agricultural nature management as they're used for arable land and gardens.

Areas in the southwest and southeast of the region can be considered moderately suitable. Mostly, these territories are also composed of slightly unstable rocks (pebbles and conglomerates covered with loess) and heavily dissected by ravine networks, as well as are actively used for agriculture. However, most of them are also favorable in terms of infrastructure, and a significant percentage of end consumers of electricity live here.

Suitable areas are scattered throughout the study site and are characterized by great meteorological conditions, the hardness of underlying rocks, sufficient level of transport and energy infrastructure, presence of a consumer, low landslide activity, and medium relative altitudes (500-1000 meters).

Optimal areas for the potential installation of wind turbines are located mainly in the lower course of the Pskem River valley. However, despite the high wind characteristics and rock 
hardness, some areas that are comprehensively calculated as the most optimal also have several limitations (lack of power lines, the remoteness of nearby railways, partial capture of the Menzbier's marmot habitat, the prevalence of slopes of medium steepness).

\section{CONCLUSIONS}

The energy transition is a recognized global trend. The Republic of Uzbekistan with one of the largest economies of Central Asia demonstrates great interest in the development of renewable energy sources and has already brought it into action through the installation of the first experimental wind turbine with a height of 52 meters in the village of Yubileiny (Bostanliq district) in 2012 [Zhamolov et al., 2019]. The next step is the construction of a wind farm. The development of local renewable energy sources is essential for the Bostanliq district in connection with the emerging trend of economic growth of the region and the popularization of tourism.

Upon the assessment of Bostanliq district the territory based on the wind energy potential, the following was established:

1. due to geological and geomorphological specifics of the region, there are few suitable places for the construction of a wind park;

2. the optimal spots are located mainly in the lower course of the Pskem River valley and are characterized by favorable meteorological characteristics, the absence of landslide bodies, and the hardness of the underlying rocks;

3. the proposed method for assessing territories based on the potential for wind energy development using the ArcMap software can be applied to any region of the world with amendments for the specifics of physical, geographical, and socio-economic conditions of the study area.

\section{ACKNOWLEDGEMENTS}

The study was carried out as part of the expedition "Dynamics of landscapes and nature management of northeastern Uzbekistan" of the Department of Physical Geography and Landscape Science (Faculty of Geography, Lomonosov Moscow State University) in JanuaryFebruary of 2020 with the financial support of the National University of Uzbekistan named after Mirzo Ulugbek (Tashkent).

\section{REFERENCES}

1. Belousov S.L. A guide to short-term weather forecasts. Middle Asia. Russia, St. Petersburg: Gidrometeoizdat, 1986. 320 p. (in Russian)

2. Berezkin M.Yu., Sinyugin O.A. Geography of investment in the renewable energy sector of the world. Vestnik Moskovskogo universiteta. Seriya 5, Geografiya. 2018. V. 4. P. 68-74. (in Russian).

3. Elistratov V.V., Kuznetsov M.V. Theoretical Framework of Alternative and Renewable Energy. Saint Petersburg, Russia: Peter the Great St.Petersburg Polytechnic University, 2003. 55 p. (in Russian).

4. Islomov I.N., Zhumataev R.B. About the most important suburban areas of agricultural production (on the example of the city of Tashkent). Academy, 2019. V. 6. P. 77-79 (in Russian)

5. Juliev M., Pulatov A., Hübl J. Natural hazards in mountain regions of Uzbekistan: A review of mass movement processes in Tashkent province. International Journal of Scientific \& Engineering Research, 2017. V. 8. P. 1102-1108.

6. Kim H.-G., Kang Y.-H., Hwang H.-J., Yun C.-Y. Evaluation of Onshore Wind Resource Potential According to Environmental Conservation Value Assessment. Energy Procedia, 2014. V. 57. P. 773-781. 
7. Lee M. Knowledge and landscape in wind energy planning. Legal Studies, 2017. V. 37. P. 3-24.

8. Prinsloo F.C. Impact of renewable energy structures on tourism. South Africa, Stellenbosch: University of Stellenbosch, 2013. 10 p.

9. Sayigh A. Comprehensive renewable energy. Amsterdam, Netherlands: Elsevier, 2012. $4422 \mathrm{p}$.

10. Sissingh J., Arends E. Wind Energy Potential Vietnam. Utrecht, Netherlands: Netherlands Enterprise Agency, 2019. 81 p.

11. Van Haaren R., Fthenakis $V$. GIS-based wind farm site selection using spatial multi-criteria analysis (SMCA): Evaluating the case for New York State. Renewable and Sustainable Energy Reviews, 2011. V. 15. P. 3332-3340.

12. Zhamolov T.R., Gofurov D.S., Murodov F.B. Analysis of the potential of wind energy in the conditions of the Tashkent region. Universum: Technical science, 2019. V. 61. P. 6367 (in Russian) 


\title{
Т.К. Щербакова, ${ }^{1}$ И.П. Супрунчук²
}

\author{
ИСПОЛЬЗОВАНИЕ ГИС-ТЕХНОЛОГИЙ \\ ДЛЯ ОЦЕНКИ УРОВНЯ \\ ГЕОГРАФИЧЕСКОГО ОБРАЗОВАНИЯ РЕГИОНА \\ (НА ПРИМЕРЕ ОЛИМПИАДЫ \\ СКФУ «45 ПАРАЛЛЕЛЬ»)
}

\section{АННОТАЦИЯ}

В статье представлены возможности использования геоинформационных технологий как инструмента оценки системы образования. Школьное географическое образование обладает рядом специфических черт и проблем, которые сложно или невозможно изучить с помощью официальной статистики. Решением является использование данных, собираемых в ходе крупных географических олимпиад - таких как Олимпиада СКФУ «45 параллель» по географии.

Для обработки и интерпретации получаемых данных предложена концептуальная схема геоинформационной системы. Использование ГИС может идти по нескольким направлениям - сбор, обработка, представление картографических моделей и конкретизация, а также прогнозы при решении образовательных задач в области географического образования региона.

С помощью использования ГИС-технологий получены качественные выводы о состоянии школьного географического образования в Ставропольском крае. География участия территорий в динамике показывает базовый уровень интереса школьников к географии, а также квалификации и вовлеченности педагогических работников. Анализ территориального распределения победителей и призеров, а также специфики подготовки по отдельным блокам географических знаний выявил наиболее развитые территории. Главный фактор их функционирования агломерационный эффект. Самый высокий уровень школьного географического образования наблюдается в больших городах и урбанизированных районах края.

Обратная сторона - самый низкий уровень географических знаний в сельских периферийных районах края. На основе всего массива данных проведена типология территорий по уровню развития географического образования. Выделено 5 типов, для каждого из которых может быть предложена своя система развития школьного географического образования.

КЛЮЧЕВЫЕ СЛОВА: геоинформационные технологии, географические олимпиады, географическое образование, территориальная организация регионального образования.

\footnotetext{
1 Северо-Кавказский федеральный университет, кафедра социально-экономической географии и туризма; 355000, Россия, Ставрополь, ул. Пушкина, 1 e-mail: scherbakovatk@mail.ru

2 Северо-Кавказский федеральный университет, кафедра социально-экономической географии и туризма; 355000, Россия, Ставрополь, ул. Пушкина, 1 e-mail: ilia_suprunchuk@mail.ru
} 


\title{
Tatyana K. Shcherbakova ${ }^{1}$, Ilya P. Suprunchuk ${ }^{2}$
}

\section{THE USE OF GIS TECHNOLOGIES TO ASSESS THE LEVEL OF GEOGRAPHICAL EDUCATION IN THE REGION (ON THE EXAMPLE OF THE NCFU OLYMPIAD «45 PARALLEL»)}

\begin{abstract}
The article presents the possibilities of using geoinformation technologies as a tool for evaluating the education system. School geographical education has a number of specific features and problems that are difficult or impossible to study with the help of official statistics. The solution is to use data collected during major geographical Olympiads - such as the NCFU "45 Parallel" Olympiad in Geography. For the processing and interpretation of the received data, a conceptual scheme of the geoinformation system is proposed. The use of GIS can go in several directions - collection, processing, presentation of cartographic models and specification, as well as forecasts in solving educational problems in the field of geographical education of the region.

Using GIS technologies, we obtained qualitative conclusions about the state of school geographical education in the Stavropol Territory. The geography of the territories 'participation in the dynamics shows the basic level of students' interest in geography, as well as the qualifications and involvement of teachers. The analysis of the territorial distribution of winners and prize-winners, as well as the specifics of training in individual blocks of geographical knowledge, revealed the most developed territories. The main factor of their functioning is the agglomeration effect. The highest level of school geographical education is observed in large cities and urbanized areas of the region. The reverse side is the lowest level of geographical knowledge in the rural peripheral areas of the region. Based on the entire data set, the typology of territories by the level of development of geographical education is carried out. There are 5 types, each of which can be offered its own system of development of school geographical education.
\end{abstract}

KEYWORDS: geoinformation technologies, geographical olympiads, geographical education, territorial organization of regional education.

\section{ВВЕДЕНИЕ}

Образование как отрасль непроизводственной сферы может выступать объектом для географических исследований, если речь идет о территориальной организации объектов образования. Как составную часть социального обслуживания образование можно изучать с помощью нормативного подхода - на предмет обеспеченности учреждениями и их территориальной доступности для населения. Соответствующие показатели очень важны при территориальном проектировании и оценке эффективности муниципальных и региональных властей. Однако, исследуя такую нормативную обеспеченность, невозможно говорить о качественных характеристиках образования - уровне метапредметных и предметных знаний, развитии талантливых и одаренных обучающихся, качестве кадрового состава учебных учреждений и многом другом. Очевидно, что данными для такого исследования располагают Министерство просвещения РФ, региональные министерства образования. По разным причинам, эти данные являются служебными и не могут быть использованы независимыми исследователями. Тем не менее, по нашему мнению,

\footnotetext{
$1 \quad$ North Caucasus Federal University, Department of socio-economic geography and tourism; 355000, Russia, Stavropol, Pushkin street, 1 e-mail: scherbakovatk@mail.ru

2 North Caucasus Federal University, Department of socio-economic geography and tourism; 355000, Russia, Stavropol, Pushkin street, 1 e-mail: ilia_suprunchuk@mail.ru
} 
существуют механизмы для сбора и опосредованного анализа качественных аспектов школьного образования (например, в контексте выявления талантливых школьников). Ими могут стать массивы данных, накапливаемых в ходе крупных предметных олимпиад.

В данной статье предложен определенный исследовательский подход для анализа географического школьного образования в отдельном регионе средствами ГИС. Он может быть адаптирован и для изучения уровня образования по другим школьным предметам. С точки зрения отбора и верификация статистических данных, важным условием для такого исследования является территориальный охват и массовость олимпиады, а также значительный временной интервал выборки.

Наши исследования относятся к системе школьного географического образования на разных уровнях его организации (локальный, региональный, федеральный). При этом, отметим, что в отличие от географических исследований высшей школы [Катровский, 2016; Катровский, 2020], школьному образованию в географической науке уделяется гораздо меньше внимания.

Уровень интереса к географическому образованию в России в последнее время ощутимо повышается. Это связано и с массовыми акциями Русского географического общества, среди которых, в первую очередь, Всероссийский Географический диктант, а также с укреплением в общественном дискурсе важных сфер профессиональной деятельности, связанных с географическими компетенциями. Устоялось мнение, что география наравне с историей и литературой формирует мировоззрение гражданина страны [Беляева, 2019].

Вместе с тем, уменьшается количество выпускников школ, сдающие ЕГЭ по географии, а, следовательно, число абитуриентов, что приводит к сокращению количества географических факультетов в вузах.

Одним из вариантов решения вопроса о повышении интереса к географии и отбора талантливых школьников являются олимпиады и другие аналогичные интеллектуальные конкурсы [Краснова, 2016]. При этом, организаторы олимпиад, особенно таких узкоспециализированных как географические, получают в свое распоряжение огромный массив данных. С течением времени он увеличивается и позволяет на основе его анализа изучать пространственный аспект образовательной деятельности, а также эффективно администрировать олимпиадное движение и работу со школьниками старших классов как потенциальными абитуриентами.

\section{МАТЕРИАЛЫ И МЕТОДЫ ИССЛЕДОВАНИЯ}

В системе образования сегодня возможно использования междисциплинарности, основанной на изначальной сложности проблем и моделировании их решения средствами и методами, способствующими более наглядному представлению, а значит и вариативности их решения. Таким образом, использование ГИС дает наглядное картографическое представление по решению проблем в системе образования.

При рассмотрении процесса образования как услуги, непосредственно предоставляемой населению, общественно-географическое положение учреждений среднего общего (полного) образования становится определяющим фактором формирования их конкурентных преимуществ, что выражается в территориальном распространении масштаба влияния образовательного учреждения и определении их роли в территориальной образовательной системе [Ермоленко, 2014].

Как показывает международный опыт, наибольший эффект накопления новых знаний о пространственно-временных процессах достигается при использовании геоинформационных методов и подходов, которые позволяют детально структурировать 
пространственную статистику на всех масштабных уровнях, в том числе с учетом административно-территориального устройства стран и регионов. Картографический инструментарий ГИС позволят достаточно быстро визуализировать исследуемые процессы, готовить ГИС-модели, карты, схемы. Такой подход дает возможность «синтезировать» процесс исследования и получать качественно новые знания [Черкасов, 2019]. В этой связи представляется возможным использование геоинформационных технологий для анализа результатов географических олимпиад с целью выявления уровня развития географического образования в отдельных территориях.

В рамках исследования разработана геоинформационная система, позволяющая исследовать школьное географическое образование в Ставропольском крае. Геоинформационная система реализована на основе реляционной системы управления базами данных Microsoft SQL Server и семейства программных продуктов ESRI AгcGIS.

\section{РЕЗУЛЬТАТЫ ИССЛЕДОВАНИЯ И ИХ ОБСУЖДЕНИЕ}

Разработанная геоинформационная система включает пять ключевых составляющих: аппаратные средства, программное обеспечение, данные и методы. Программное обеспечение ГИС содержит функции и инструменты, необходимые для хранения, анализа и визуализации географической (пространственной) информации. В данном случае это функции и инструменты, основанные на программной платформе ArcGIS Spatial Analyst фирмы ESRI. Система ArcGIS, подобно другим мощным информационным системам, обладает четко определенной моделью для работы с данными, прежде всего пространственными.

Важными элементами предлагаемой геоинформационной системы являются ее функциональные блоки (рис. 1). Первый блок представляет собой инструменты сбора данных о географическом образовании. Источники таких данных можно разделить на две крупные группы. Первую составляет автоматически собираемая информация об участии школьников в географических олимпиадах (помимо Олимпиады СКФУ «45 параллель» это муниципальный и региональный этап Всероссийской олимпиады по географии). Также используются данные приемной комиссии СКФУ для оценки эффективности работы с абитуриентами. Дополняют эту статистику информация, получаемая от методических объединений учителей географии территорий Ставропольского края. Вторая группа статистики образуется в ходе непосредственного контакта со школьниками в процессе профориентационной деятельности (Дни открытых дверей, конкурсы, конференции и т.п.), работы географических секций и кружков, а также активности в социальных сетях. Каждый из перечисленных источников необходимо критически рассматривать с точки зрения его взаимосвязанности с общим уровнем географического образования.

На основе собранной информации возможно построить структурированную базу данных. В ней отражены пространственные уровни данных - от привязки к региону и его муниципальным образованиям до отдельного образовательного учреждения и конкретного учителя. Главными качественными характеристиками школьников выступают геодемографические (возраст, пол, место проживания), образовательные (школа, класс, учитель, предметные склонности) и социальные (в каких мероприятиях участвует и какие типы активности характерны).

Далее, на основе этой информации возможно конструирование различных статистических показателей. Особенностью базы является «срок годности» данных. В связи с ежегодным выпуском школьников, в следующем отчетном году из базы выбывает соответствующая категория. Наконец, третий блок - геоаналитический, позволяет на основе собранных данных создавать модели, выделять разные типы территорий, проводить разномасштабные исследования школьного географического образования в регионе. 


\section{Блок сбора данных}

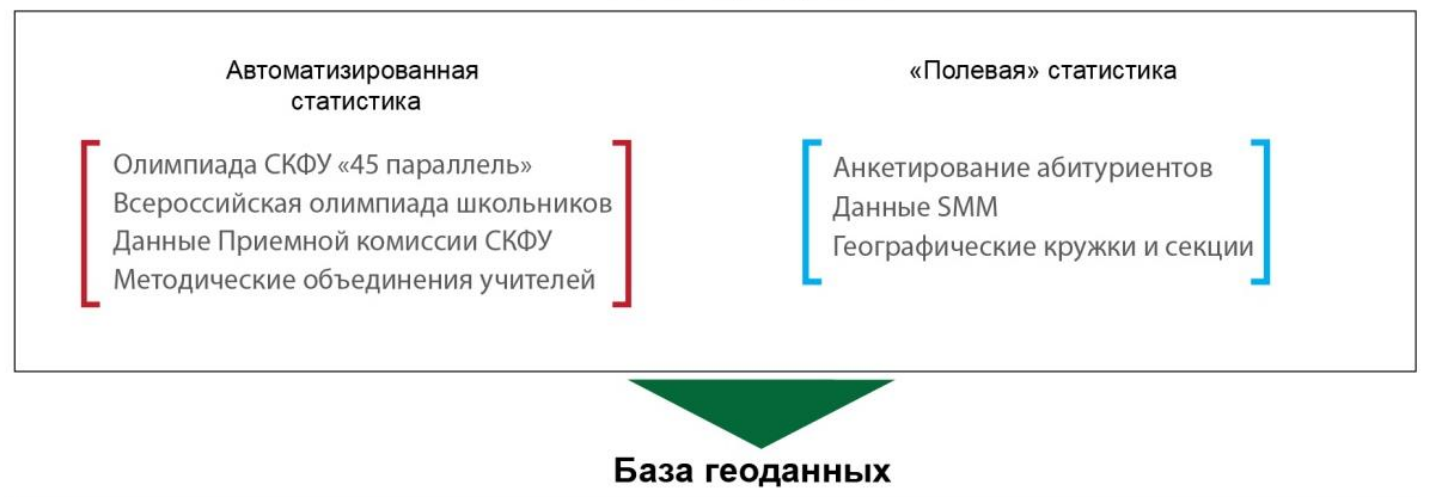

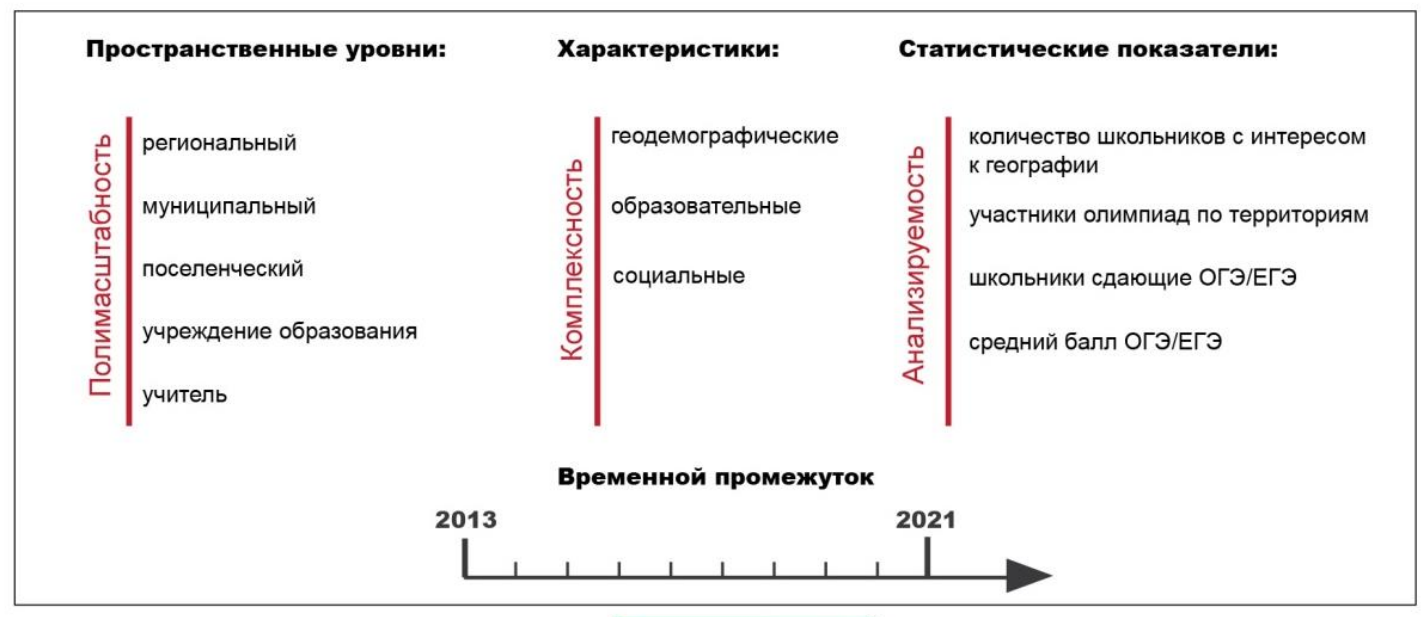

Геоаналитический блок

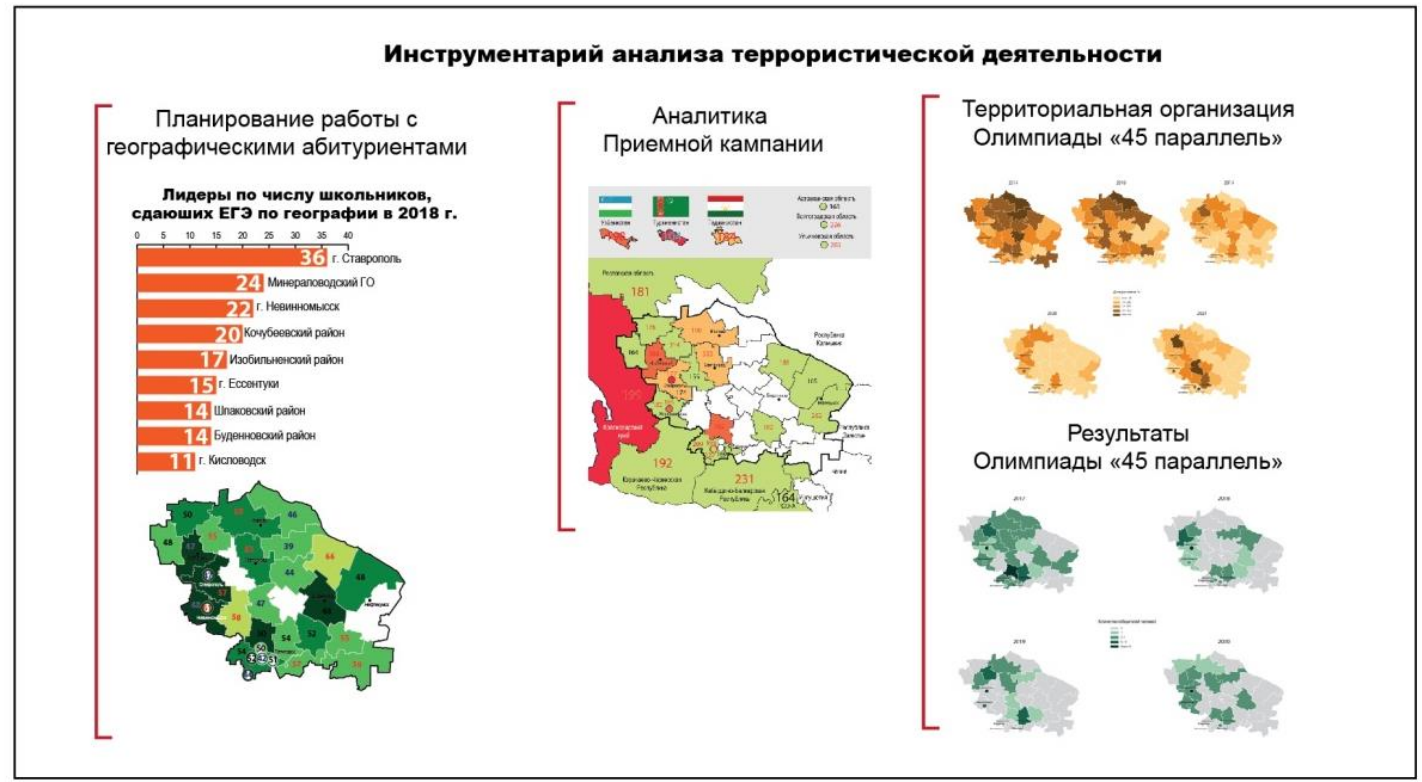

Рис. 1. Схема функиионирования геоинформационной системы анализа географического образования в Ставропольском крае

Fig. 1. The scheme of functioning of the geoinformation system for the analysis of geographical education in the Stavropol territory 
Главное место в данной системе занимает проведение олимпиады СКФУ «45 параллель» по географии. Она проводится ежегодно с 2013 года, привлекая внимание школьников не только Ставропольского края, но и других регионов России. С исследовательской точки зрения, она является самым массовым и всеобъемлющим срезом географических знаний школьников Ставрополья, что позволяет напрямую связывать ее результаты с уровнем географического образования в отдельных территориях.

Организатор олимпиады - Северо-Кавказский федеральный университет (СКФУ, г. Ставрополь) - крупнейший вуз на Северном Кавказе - имеет давние и вполне успешные традиции подготовки географов самого широкого профиля. Олимпиадное движение среди школьников рассматривается в СКФУ как одно из ключевых направлений профориентационной работы. Главная цель - выявление и поддержка творческой молодежи и творческого потенциала учащихся общеобразовательных учреждений [Лысенко, 2019].

Современная история олимпиады началась 9 ноября 2013 г., когда она стартовала в нынешнем формате. Уже тогда мероприятие вызвало большой интерес у школьников не только Ставропольского края, но и других регионов России и зарубежья. В 2014-2015 учебном году олимпиада по географии вошла в состав многопредметной олимпиады СКФУ «45 параллель», что позволило расширить ее масштабы и возможности поощрения победителей и призеров. В последующие годы значительно расширилась география участников олимпиады и их численность.

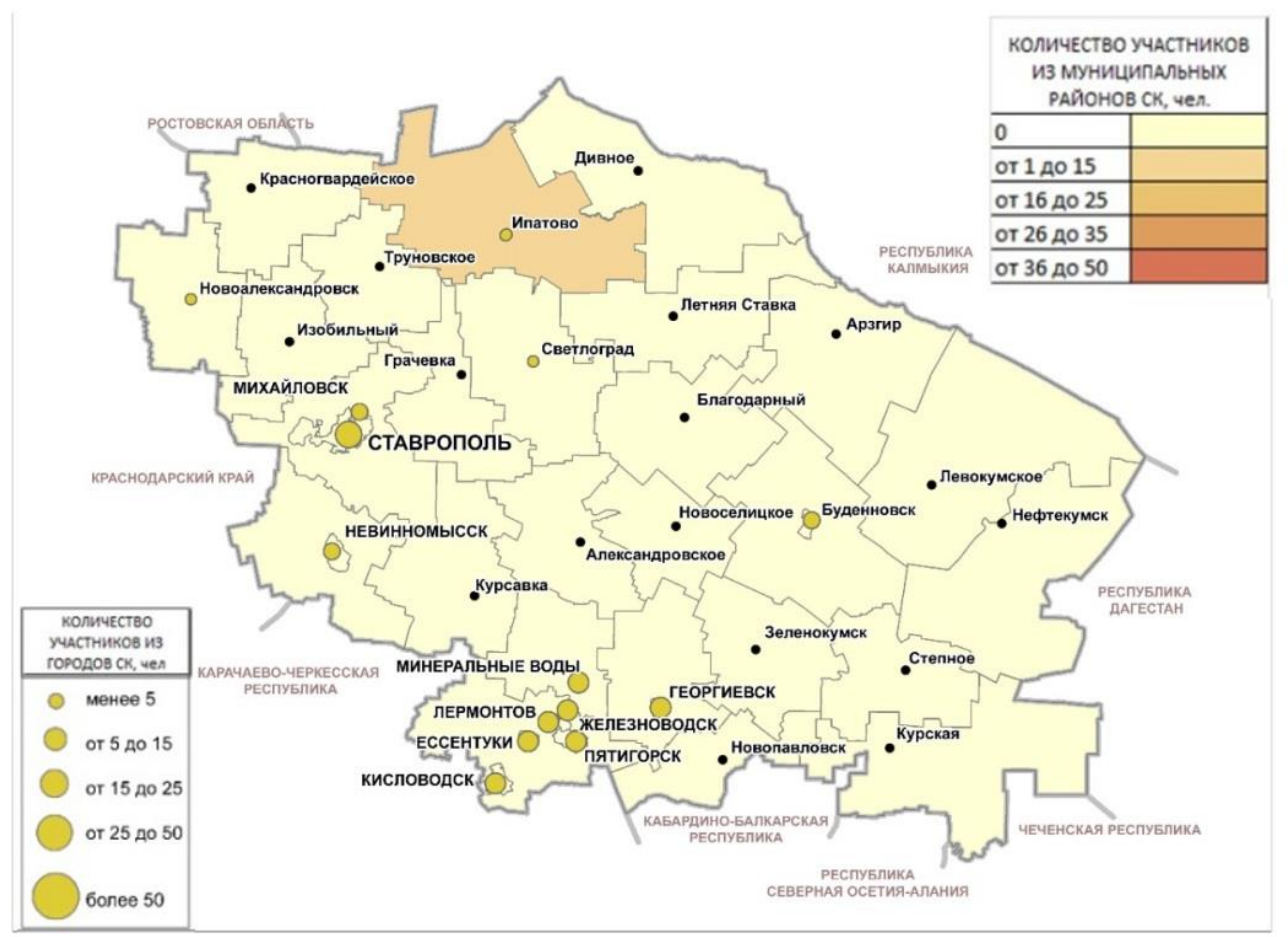

Рис. 2. Количество участников Олимпиады СКФУ «45 параллель» в муниципальных образованиях Ставропольского края в 2013-2014 уч. г2.

Fig. 2. The number of participants of the Olympiad NCFU "45 Parallel" in the municipalities of the Stavropol Territory in 2013-2014 academic years

В 2013-2014 учебном году в олимпиаде приняли участие более 200 учащихся 9-11 классов из 60 школ Ставропольского края. В 2014-2015 учебном году в отборочном туре олимпиады участвовали 309 учащихся 7-11 классов, а во втором туре - более 70 человек. В 2015-2016 году благодаря помощи учителей олимпиада начала приобретать более массовый характер. В отборочном туре участвовало 873 школьника из 20 регионов России. 
Ко второму туру было допущено 368 участников из 16 регионов России. В 2016-2017 учебном году в отборочном этапе приняли участие уже 2523 школьника. Они представляли 24 региона России, а также страны ближнего зарубежья - Украину, Казахстан и Узбекистан [Екименко, 2018].

Территориальная структура участников олимпиады в период с 2013-2016 гг. на примере районов Ставропольского края выглядит следующим образом (рис. 2-4). На этом этапе главной задачей геоинформационной системы было выявление «белых пятен» незатронутых олимпиадой территорий, а также выделение причин этого.

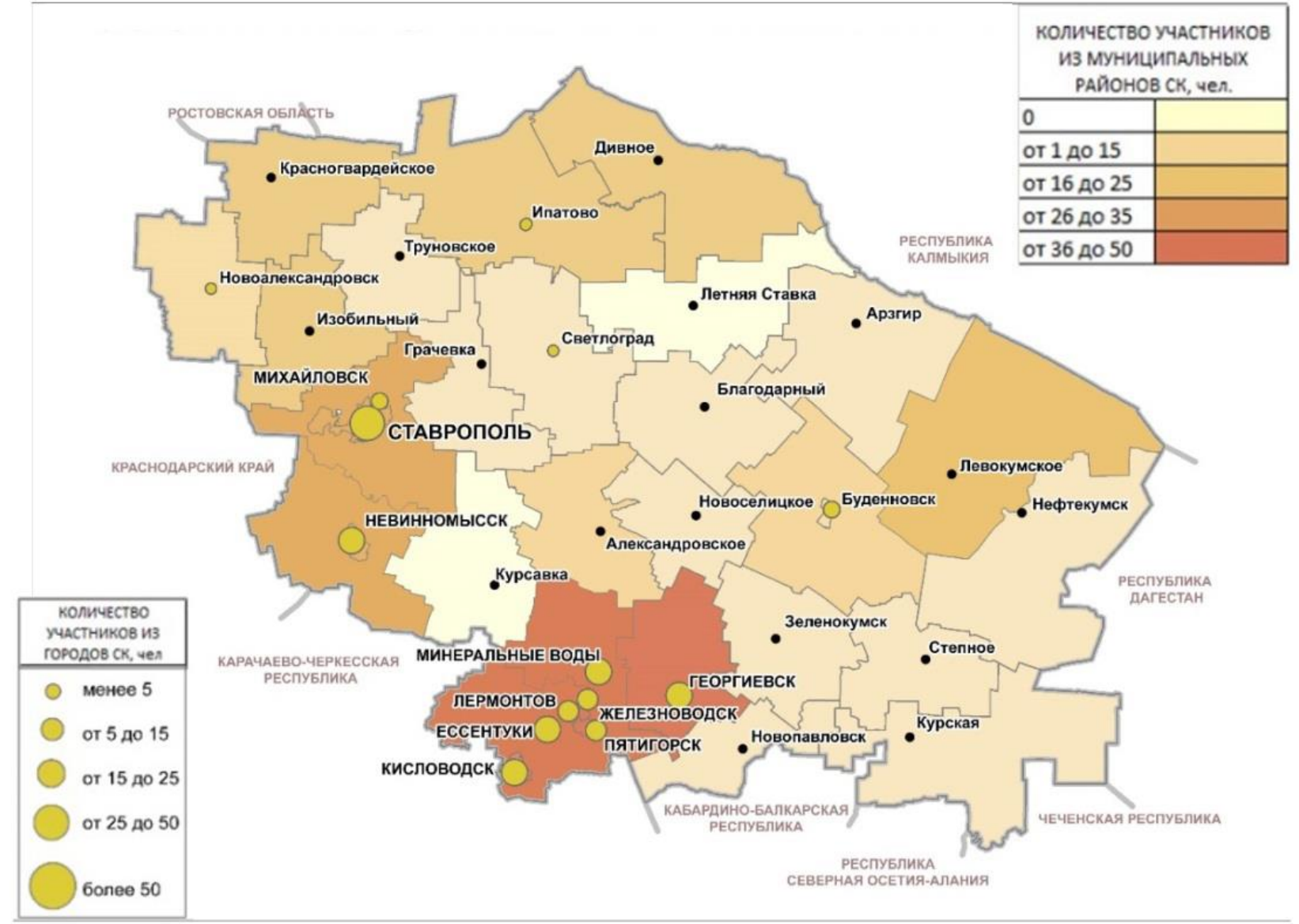

Рис. 3. Количество участников Олимпиады СКФУ «45 параллель» в муниципальных образованиях Ставропольского края в 2014-2015 уч. г2.

Fig. 3. The number of participants of the Olympiad NCFU "45 Parallel" in the municipalities of the Stavropol Territory in 2014-2015 academic years

На данном этапе были вскрыты проблемы и предложены следующие пути решения:

1. Слабое покрытие отдельных (в том числе восточных) районов Ставропольского края, низкая скорость интернета ограничили возможность участия в заочном, отборочном туре олимпиады части школьников. В связи с этим потребовалась корректировка задания в части наглядности и снижения объема загружаемой информации.

2. Отсутствие у части школьники собственных электронных адресов, выполнение заданий с использованием единого IP-адреса образовательного учреждения вызывало сложности с регистрацией в системе [Екименко, 2018]. 
3. При этом, проделанная работа по вовлечению территорий в олимпиадное движение позволило стабилизировать число сдающих ЕГЭ по географии школьников в регионе.

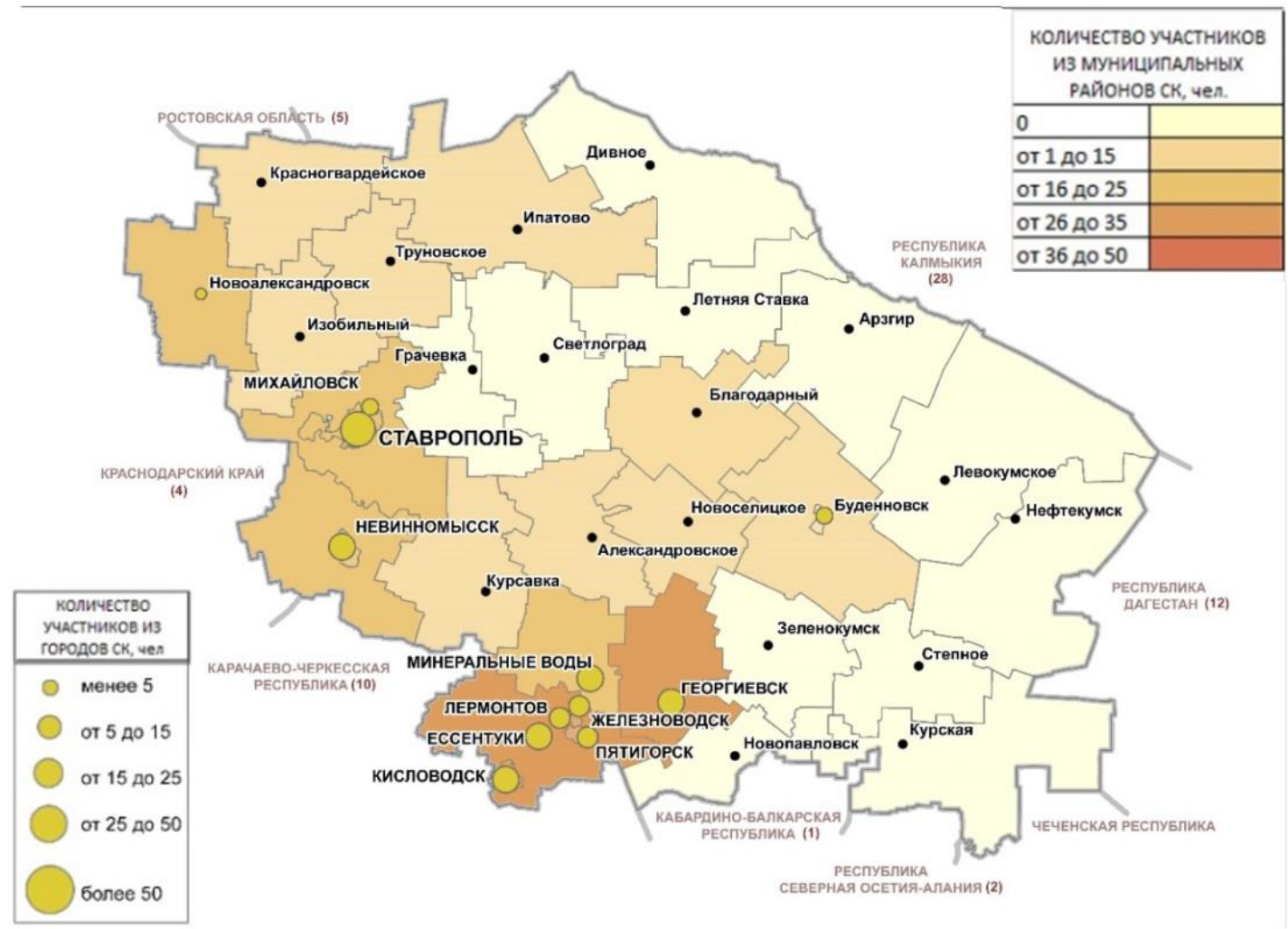

Рис. 4. Количество участников Олимпиады СКФУ «45 параллель» в муниципальных образованиях Ставропольского края в 2015-2016 уч. г2.

Fig. 4. The number of participants of the Olympiad NCFU "45 Parallel" in the municipalities of the Stavropol Territory in 2015-2016 academic years

В 2017-2018 учебном году материалы олимпиады прошли экспертизу, и Олимпиада «45 параллель» по географии вошла в перечень олимпиад Российского совета олимпиад школьников (РСОШ). В отборочном этапе, проходившем в ноябре 2017 г. приняли участие 2132 школьника, представляющие 15 регионов России. В заключительном туре участвовало 450 школьников. По результатам олимпиады 100 школьников были признаны победителями и призерами.

В 2018-2019 учебном году в отборочном туре олимпиады приняли участие более 1800 школьников 6-11 классов из 22 регионов России. Наиболее многочисленное представительство было из регионов: Ставропольский край, Республика Дагестан - по 493, Республика Башкортостан - 43, Калужская область - 31, Республика Калмыкия - 24, Краснодарский край - 19. В очном туре приняли участие 460 человек. Для его проведения было организовано 12 площадок: четыре в Ставропольском крае (Ставрополь, Невинномысск, Минеральные Воды, пос. Новый Георгиевского городского округа), Хасавюрт (Республика Дагестан), Краснодар, Элиста, Тула, Калуга, Уфа, Хабаровск, СанктПетербург. Победителями и призерами олимпиады объявлены 112 учащихся. 


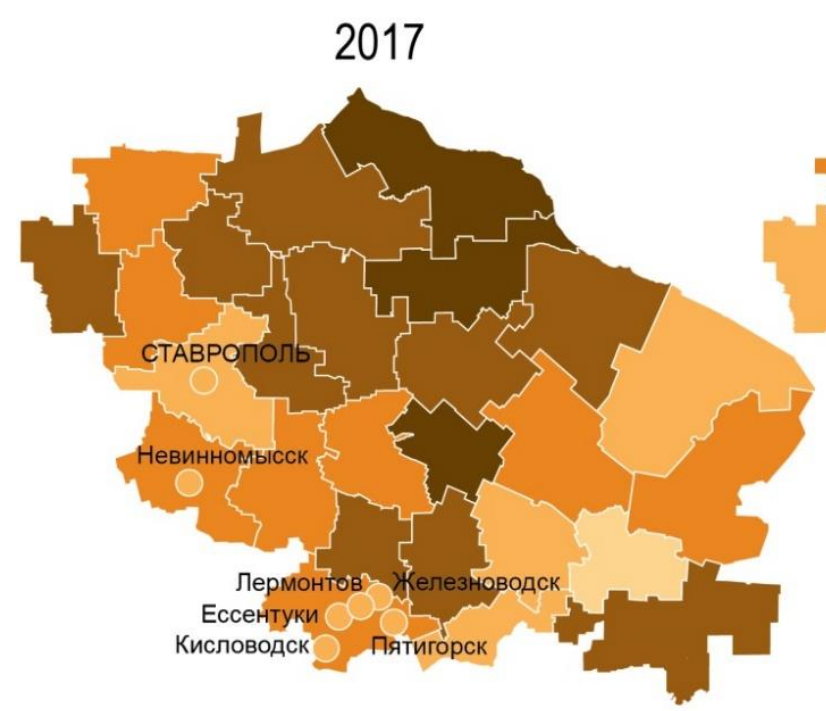

2019

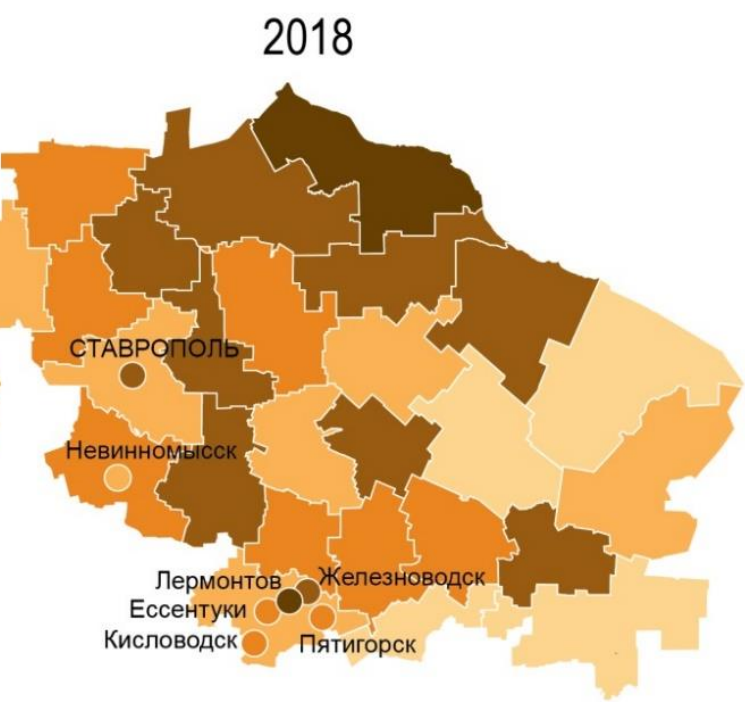

2020

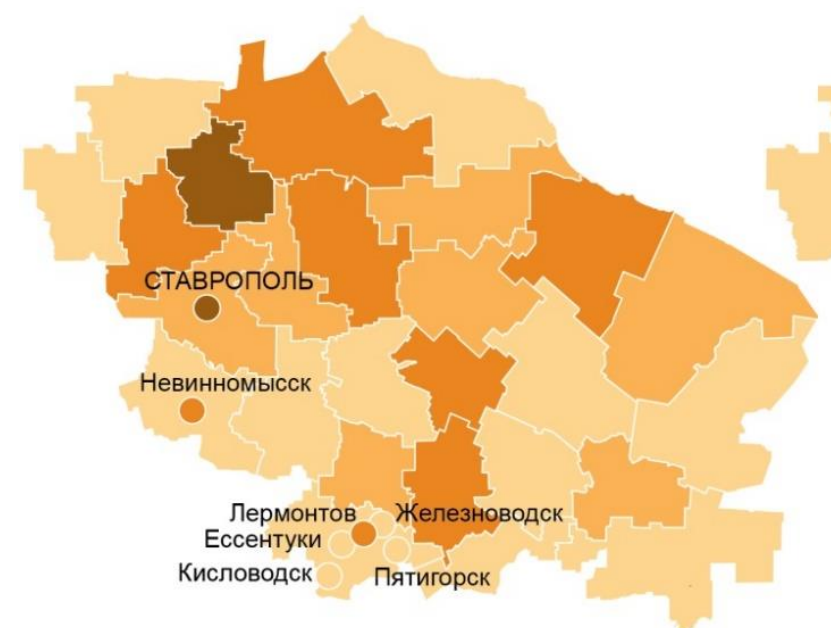

2021

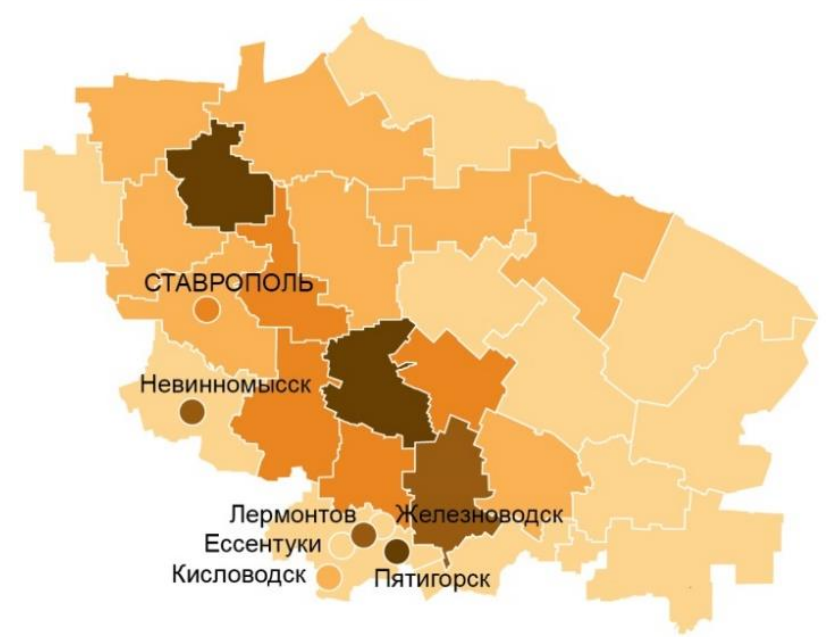

Доля участников, \%:

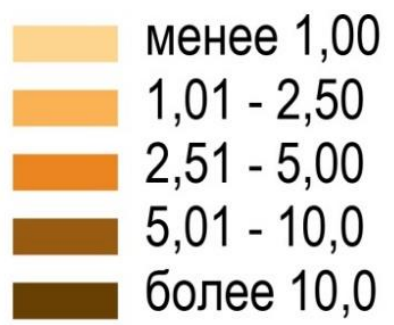

Рис. 5. Доля участников Олимпиады СКФУ «45 параллель» от общего числа детей школьного возраста в муниципальных образованиях Ставропольского края в 2017-2021 г2.

Fig. 5. The share of Olympiad NCFU "45 Parallel" participants from the total number of school-age children in the municipalities of the Stavropol Territory in 2017-2021 
В 2019-2020 учебном году в отборочном заочном туре, проходившем с 1 ноября по 2 декабря 2019 г., приняло участие более 1600 школьников из 26 регионов России. В очном туре приняли участие более 400 человек. Задания очного тура решали школьники в Ставропольском крае, Республике Дагестан, Республике Калмыкия, Краснодарском крае, Республике Башкортостан, Хабаровском крае, Тульской области, Калужской области и городе Санкт-Петербург. Победителями и призерами олимпиады стали 104 учащихся. По результатам экспертизы, олимпиада получила статус олимпиады РСОШ (II уровень) на следующий учебный год. В итоге, в 2020-2021 гг. олимпиада получила максимальный территориальный охват и численность участников (более 3 тыс. человек).

Территориальная структура участников олимпиады в период с 2017-2021 гг. в районах Ставропольского края выглядит следующим образом (рис. 5). С одной стороны, можно предположить о снижении вовлеченности территорий края в олимпиадное движение с 2017 по 2020 г. Однако, есть объективные причины такой тенденции - снижение общей численности школьников среднего и старшего возраста в большинстве территорий; потеря статуса олимпиады РСОШ в 2020 г.; привлечение в олимпиаду школьников новых регионов (в первую очередь Республики Дагестан). С другой стороны, очевидно выделение круга стабильных регионов - постоянных участников олимпиады. В целом, географию участия в олимпиаде можно рассматривать как базовый уровень развития географического образование. Активное систематическое участие подразумевает наличие значительного числа детей, интересующихся географией, высокий уровень профессионализма педагогического состава, занимающегося подготовкой к олимпиадам.

Более интересную картину представляет собой анализ территориального распределения победителей и призеров олимпиады (рис. 6). Здесь очевидна прямая взаимосвязь в качественном географическом образовании школьников и результатами олимпиады.

Систематически собранные данные обладают большим внутренним аналитическим потенциалом. Как пример, существует возможность изучить, какие тематические отрасли географической науки вызывают проблемы у школьников при написании олимпиады. Для этого возьмем старшеклассников (10-11 класс), которые уже освоили почти весь объем школьной географии, и изучим их средний балл по вопросам с учетом территориальной привязки (табл. 1). На уровне Ставропольского края самым сложным является блок экономической географии мира (средний балл 3,3), затем географии населения и работа с топографической картой (по 4,0). Самыми простыми стали вопросы, связанные с экологией и биогеографией, что объясняется большим количеством часов на их изучение и связью этих тематических блоков с другими естественными науками [Осолодкина, 2020].

В территориальном разрезе также наблюдается ряд интересных моментов. По среднему итоговому баллу, превышающему краевой, выделяются Ставрополь, Труновский район и Ипатовский городской округ. В целом, можно говорить об агломерационном эффекте - уровень подготовки по географии выше в городах или урбанизированных территориях [Шульгина, 2015]. В сельских периферийных территориях (Арзгирский район, Кировский и Нефтекумский ГО) средний уровень географических знаний гораздо ниже. Отдельно отметим, что некоторые территории вообще не вошли в данную подборку, так как за две олимпиады не смогли подготовить более 1 финалиста соответствующего возраста. Далее такие результаты можно использовать для более углубленной аналитики в рамках педагогического сообщества [Телепенко, 2014]. Имеют они и прогностическую ценность - например, более высокий уровень умения работать с топографической картой может говорить о системной подготовке к ЕГЭ по географии в муниципальном образовании [Шахарьяни, 2010]. 

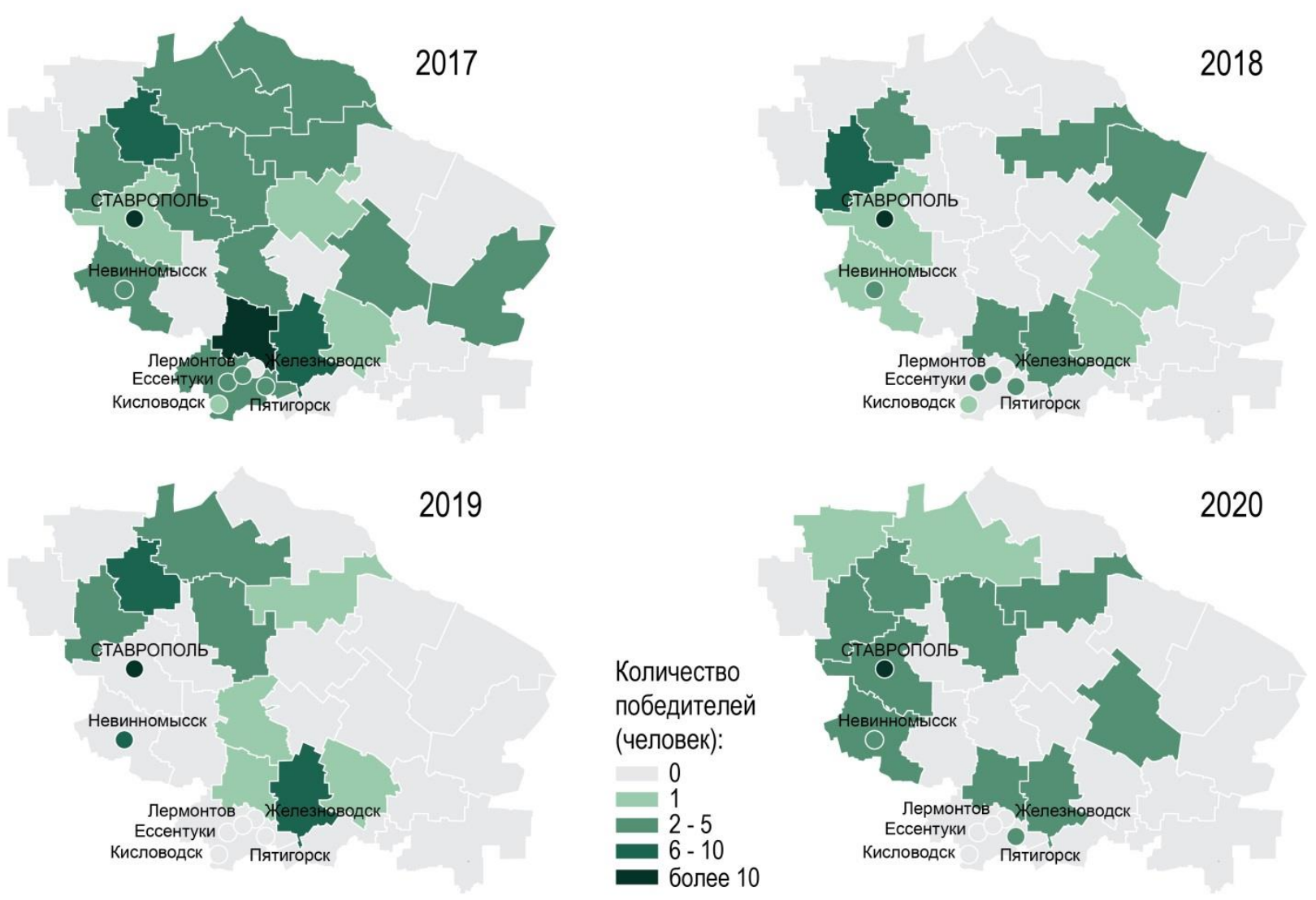

Рис. 6. Количество победителей и призеров Олимпиады СКФУ «45 параллель» в муниципальных образованиях Ставропольского края в 2017-2020 г2.

Fig. 6. The number of winners and prize-winners of the Olympiad NCFU "45 Parallel" in the municipalities of the Stavropol Territory in 2017-2020

Табл. 1. Средний балл по отдельньмм заданиям среди школьников 10-11 классов в мунииипальных образованиях Ставропольского края в 2017-2019 г2.

Table 1. Average score on individual tasks among students of grades 10-11 in the municipalities of the Stavropol Territory in 2017-2019

\begin{tabular}{|c|c|c|c|c|c|c|c|c|}
\hline $\begin{array}{c}\text { Муниципальное } \\
\text { образование }\end{array}$ & 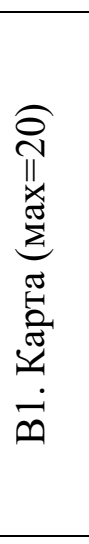 & 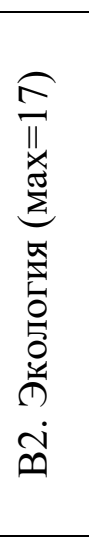 & 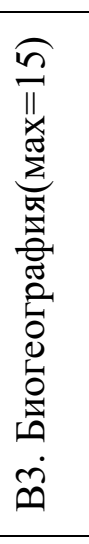 & 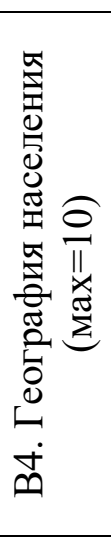 & 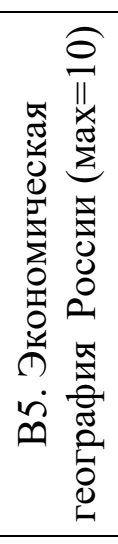 & 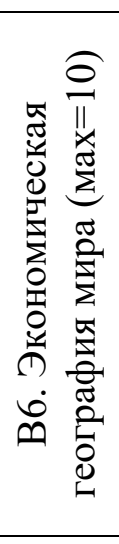 & 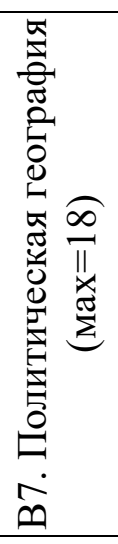 & 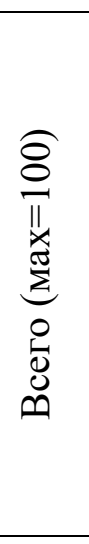 \\
\hline Арзгирский & 0,3 & 4,2 & 4,3 & 0,3 & 4,0 & 0,0 & 0,2 & 13,0 \\
\hline Буденновский ГО & 4,4 & 5,8 & 8,4 & 5,0 & 2,0 & 3,8 & 2,8 & 32,3 \\
\hline Кисловодск & 4,2 & 5,5 & 6,3 & 1,7 & 4,3 & 0,0 & 2,0 & 24,0 \\
\hline
\end{tabular}




\begin{tabular}{|l|r|r|r|r|r|r|r|r|}
\hline Лермонтов & 1,4 & 2,4 & 5,9 & 1,8 & 2,5 & 0,9 & 0,8 & 15,7 \\
\hline Невинномысск & 4,8 & 7,1 & 8,2 & 3,6 & 4,2 & 2,8 & 3,6 & 34,2 \\
\hline Пятигорск & 2,1 & 5,3 & 7,6 & 2,6 & 0,9 & 2,5 & 2,9 & 24,0 \\
\hline Ставрополь & 5,5 & 11,3 & 8,6 & 5,0 & 6,3 & 4,4 & 6,5 & 47,6 \\
\hline Георгиевский ГО & 2,5 & 5,6 & 7,0 & 3,0 & 3,3 & 2,3 & 3,5 & 27,2 \\
\hline Грачевский & 3,2 & 10,0 & 5,6 & 2,3 & 1,0 & 0,8 & 1,5 & 24,4 \\
\hline Изобильненский ГО & 5,0 & 8,6 & 7,7 & 3,5 & 2,4 & 2,4 & 5,7 & 35,1 \\
\hline Ипатовский ГО & 5,2 & 9,0 & 7,9 & 3,4 & 7,0 & 4,6 & 8,2 & 45,3 \\
\hline Кировский ГО & 0,8 & 2,8 & 7,1 & 3,5 & 2,0 & 0,0 & 3,3 & 19,4 \\
\hline Кочубеевский & 3,9 & 5,6 & 7,9 & 3,8 & 2,3 & 1,8 & 3,9 & 28,4 \\
\hline Минераловодский ГО & 3,7 & 5,5 & 7,0 & 1,3 & 4,6 & 2,7 & 1,8 & 26,6 \\
\hline Нефтекумский ГО & 0,3 & 1,0 & 5,3 & 3,0 & 1,0 & 0,0 & 0,0 & 10,5 \\
\hline Предгорный & 2,8 & 5,0 & 6,8 & 3,3 & 0,7 & 1,6 & 0,5 & 19,0 \\
\hline Советский ГО & 3,6 & 4,3 & 6,8 & 0,0 & 2,3 & 2,8 & 3,9 & 23,5 \\
\hline Труновский & 5,3 & 11,1 & 8,7 & 1,6 & 8,5 & 7,2 & 9,1 & 51,6 \\
\hline Шпаковский & 3,8 & 9,8 & 8,6 & 2,6 & 2,9 & 0,8 & 3,9 & 32,4 \\
\hline В целом по краю & 4,0 & 9,1 & 8,2 & 4,0 & 4,3 & 3,3 & 4,9 & 37,8 \\
\hline
\end{tabular}

Наконец, совокупность приведенных данных и исследовательских подходов позволяет проводить типологию территорий Ставропольского края по уровню географического образования, и предлагать разные механизмы дальнейшего взаимодействия [Щербакова, 2005]. Исходя из всех имеющихся показателей, была проведена рейтинговая оценка территорий Ставропольского края, и на ее основе предложена их типология по уровню географического образования (рис. 7).

Уровень развития географического образования

низкий

ниже среднего

средний

выше среднего

высокий

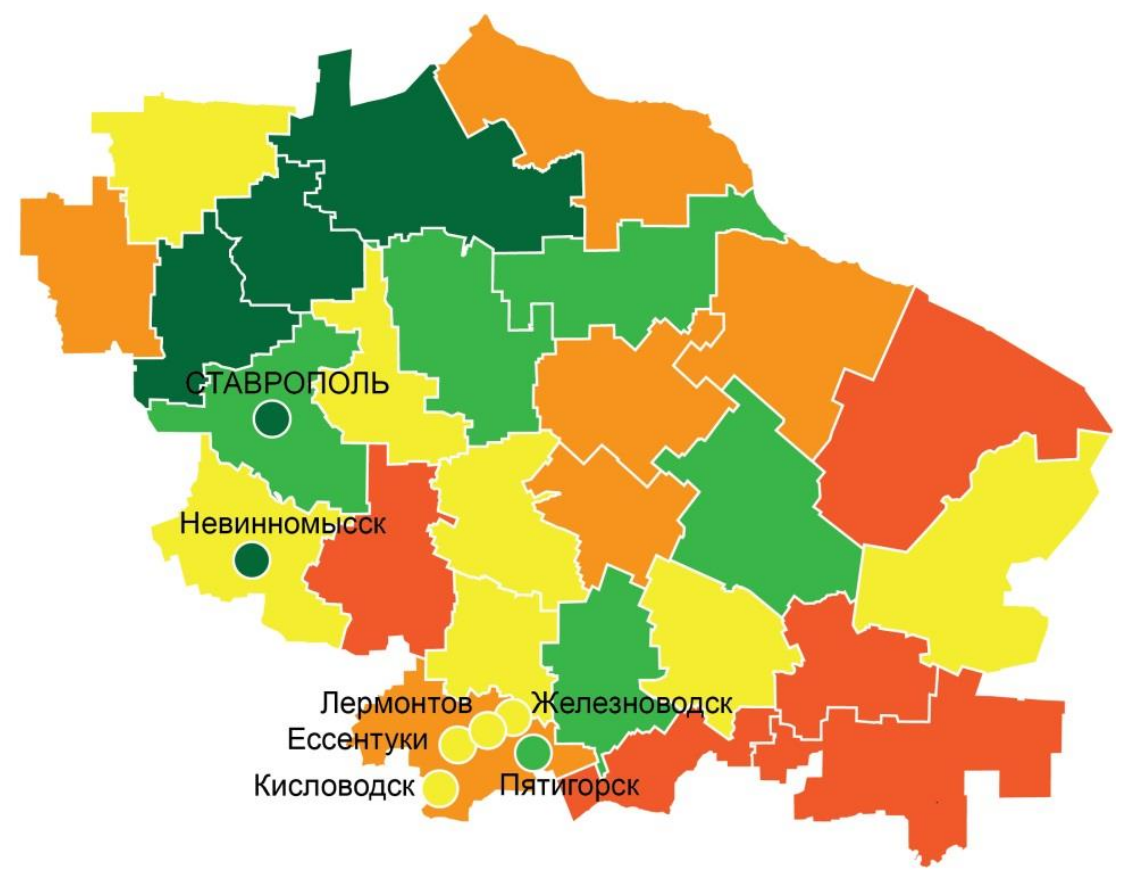

Рис. 7. Типология территорий Ставропольского края по уровню развития географического образования

Fig. 7. Typology of the territories of the Stavropol Territory by the level of development of geographical education 
Предложенная типология состоит из 5 типов. К территориям с высоким уровнем развития географического образования отнесены города Ставрополь и Невинномысск, Изобильненский и Ипатовский ГО, Труновский район. Они стабильно и качественно участвуют в олимпиаде во все последние годы, готовят победителей и призеров. О высоком уровне образования можно судить и по успешной и массовой сдаче ЕГЭ по географии, подготовке победителей регионального этапа Всероссийской олимпиады школьников по географии, поступлении абитуриентов из этих территорий на географические направления в ведущие вузы страны. Уровень географического образования выше среднего имеют еще 6 территорий - город Пятигорск, Георгиевский, Буденновский и Петровский ГО, Шпаковский и Туркменский районы. Они уступают по отдельным показателям лидерам, но в целом имеют довольно качественную систему географического образования.

Большинство территорий края отнесены к категориям среднего и ниже среднего уровня развития географического образования. Очевидно, здесь существуют проблемы разного характера: кадровый состав педагогов; инфраструктурный фактор; экономическое развитие и многое другое [Щербакова, 2005]. В отдельные годы территории этих двух групп могут показывать неплохие результаты, однако скорее их можно отнести к индивидуальным усилиям отдельных школьников. Наконец, можно выделить группу отстающих территорий с низким уровнем географического образования. Анализ их участия и работы в различных видах географических активностей ставит под сомнение вообще наличие системы географического образования на их территории.

\section{ВЫВОДЫ}

1. Рассмотрев территориальную организацию географических олимпиад в Ставропольском крае, можно сделать вывод о востребованности такой формы интеллектуальных испытаний на современном этапе развития географического образования.

2. $\quad$ ГИС-технологии как междисциплинарный инструмент позволяет наглядно видеть не только территориальную организацию образовательного процесса, но и анализировать изменение качественных показателей. Географические информационные системы, как средства обработки данных, способствуют выявлению образовательных проблем и их решению путем картографического представления складывающихся конкретных ситуации.

3. Результаты участия школьников в олимпиаде по географии «45 параллель» дают возможность территориального анализа и выводов по дальнейшему взаимодействию с образовательными учреждениями в активизации этого процесса.

\section{СПИСОК ЛИТЕРАТУРЫ}

1. Беляева М.В., Дятлова А.Н. Место географического образования на первой ступени общего образования. Сборник статей XVI Международной научно-практической конференции. 2019. С. 113-122.

2. Екименко С.С. Об олимпиаде школьников «Моя планета». Сборник статей Международной научно-практической конференции «Психолого-педагогические аспекты личности и межличностных отношений». Уфа: Омега сайнс, 2018. 210 с.

3. Екименко С.С. Олимпиады как основа портфолио выпускника школы. Сборник статей Международной научно-практической конференции «Научно-технический прогресс: социальные, технические и общественные факторы». М.: Импульс, 2018. $222 \mathrm{c}$. 
4. Ермоленко E.E. Пространственная структура конкурентной среды города (на примере учреждений среднего общего образования Читы). Чита: Издательство ЗабГУ, 2014. 257 с.

5. Катровский А.П. Высшая школа как фактор инновационного регионального развития России. Социально-экономическая география. Вестник Ассоциации российских географов-обществоведов. 2016. № 5. С. 248-254.

6. Катровский А.П., Яськова Т.И. География высшей школы регионов России. Смоленск: Изд-во Смоленского государственного университета, 2020. 322 с.

7. Краснова М.П. Роль геотурниров в непрерывном географическом образовании. Трешниковские чтения 2016. Фундаментальные прикладные проблемы поверхностных вод суши. материалы всероссийской научно-практической конференции с международным участием. 2016. С. 169-170.

8. Лысенко А.В., Супрунчук И.П., Чихичин В.В. Открытая олимпиада Северо-Кавказского федерального университета для школьников «45 параллель» по географии: история и современность. География и экология в школе XXI века. 2019. №9. С. 5470

9. Осолодкина А.Ф. Географическое образование как современная педагогическая категория. Вестник научных конференций. 2020. № 10-4 (62). С. 112-114.

10. Телепенко Ю.А. Реализация географического образования при переходе на ФГОС основного общего образования. Наука и образование в XXI веке. Сборник научных трудов по материалам Международной научно-практической конференции. 2014. C. $142-143$.

11. Черкасов А.А., Чернова И.В., Сопнев Н.В. Геоинформационно-картографическое моделирование расселения народов в России. ИнтерКарто. ИнтерГИС. Геоинформационное обеспечение устойчивого развития территорий: Материалы Междунар. конф. М.: Издательство Московского университета, 2019. Т. 25. Ч. 1. С. 298-307. DOI: $10.24057 / 2414-9179-2016-1-22-42-49$.

12. Шахарьяни Е.В. ЕГЭ как форма оценки учебных достижений. Сборник материалов IV Международной студенческой научно-практической конференции «Интеллектуальный потенциал XXI века: Ступени познания». Новосибирск: Издательство «НГТУ». 2010.

13. Шульгина O.B. Роль информационно-коммуникационных технологий в развитии географии и в модернизации географического образования. Вестник Московского городского педагогического университета. Серия: Информатика и информатизация образования. 2015. № 1 (31). С. 85-91.

14. Щербакова T.К. Структурно-функциональная модель содержания профессиональной деятельности учителя (на примере учителя географии). Дис. ... докт. пед. н. М., 2005. 394 c.

15. Щербакова T.K. Территориальная структура подготовки учителя географии на Северном Кавказе. Вестник СГУ. Вып. 40. 2005. С. 85-90.

\section{REFERENCES}

1. Belyaeva M.V., Dyatlova A.N. The place of geographical education at the first stage of general education. Collection of articles of the XVI International Scientific and Practical Conference. 2019. P. 113-122 (in Russian).

2. Cherkasov A.A., Chernova I.V., Sopnev N.V. Geoinformation and cartographic modeling of the settlement of peoples in Russia. InterCarto. InterGIS. Geoinformational support of sustainable development of territories: Materials of the International Conference Moscow: 
Moscow University Press, 2019. V. 25. Ch. 1. P. 298-307. DOI: 10.24057/2414-91792016-1-22-42-49 (in Russian).

3. Ekimenko S.S. About the Olympiad of schoolchildren "My planet". Collection of articles of the International Scientific and practical conference"Psychological and pedagogical aspects of personality and interpersonal relations". Ufa: Omega Sciences, 2018. 210 p. (in Russian).

4. Ekimenko S.S. Olympiads as the basis of the school graduate portfolio. Collection of articles of the International Scientific and Practical conference "Scientific and technical progress: social, technical and social factors". Moscow: Impulse, 2018. 222 p. (in Russian).

5. Ermolenko E.E. Spatial structure of the competitive environment of the city (on the example of institutions of secondary general education in Chita). Chita: ZabGU Publishing House, 2014. 257 p. (in Russian).

6. Katrovsky A. P. Higher school as a factor of innovative regional development of Russia. Socio-economic Geography. Bulletin of the Association of Russian Geographers and Social Scientists. 2016. No 5. P. 248-254. (in Russian).

7. Katrovsky A.P., Yaskova T.I. Geography of the higher school of the regions of Russia. Smolensk: Publishing House of the Smolensk State University. 2020. 322 p. (in Russian).

8. Krasnova M.P. The role of geotourniers in continuous geographical education. Treshnikov Readings 2016. Fundamental applied problems of land surface waters. materials of the AllRussian scientific and practical conference with international participation. 2016. P. 169170 (in Russian).

9. Lysenko A.V., Suprunchuk I.P., Chikhichin V.V. Open Olympiad of the North Caucasus Federal University for schoolchildren "45 Parallel" in geography: history and modernity. Geography and ecology in the school of the XXI century. 2019. No 9. P. 54-70 (in Russian).

10. Osolodkina A.F. Geographical education as a modern pedagogical category. Bulletin of scientific conferences. 2020. No 10-4 (62). P. 112-114 (in Russian).

11. Shakharyants E.V. USE as a form of evaluation of educational achievements. Collection of materials of the IV International Student Scientific and Practical Conference "Intellectual potential of the XXI century: Stages of knowledge". Novosibirsk: NSTU Publishing House. 2010 (in Russian).

12. Shcherbakova T.K. Structural and functional model of the content of the teacher's professional activity (on the example of a geography teacher): diss. Doctor of Pedagogical Sciences. M., 2005. 394 p. (in Russian).

13. Shcherbakova T.K. Territorial structure of teacher training in geography in the North Caucasus. Bulletin of the SSU. Issue 40. 2005. P. 85-90 (in Russian).

14. Shulgina O.V. The role of information and communication technologies in the development of geography and in the modernization of geographical education. Bulletin of the Moscow City Pedagogical University. Series: Informatics and Informatization of Education. 2015. No 1 (31). P. 85-91 (in Russian).

15. Telepenko Yu.A. Implementation of geographical education in the transition to the Federal State Educational Standard of Basic General Education. Science and education in the XXI century. Collection of scientific papers based on the materials of the International Scientific and Practical Conference. 2014. P. 142-143 (in Russian). 


\title{
Э.А. Шеремет ${ }^{1}$, Н.Н. Калуцкова ${ }^{2}$, В.С. Дехнич ${ }^{3}$

\author{
ВИЗУАЛЬНЫЕ СВОЙСТВА ЛАНДШАФТОВ \\ И МЕТОДЫ ИХ ОЦЕНКИ С ПРИМЕНЕНИЕМ ГИС
} (НА ПРИМЕРЕ БЕЛОГРАДЧИШСКИХ СКАЛ (БОЛГАРИЯ))
}

\begin{abstract}
АННОТАЦИЯ
Визуальные характеристики ландшафтов являются важными факторами, определяющими туристско-рекреационный потенциал территорий. В настоящее время применяется ряд методологических подходов для оценки визуальных свойств ландшафтов. Их можно разделить на традиционные, связанные исключительно с полевыми исследованиями, и инновационные, использующие данные дистанционного зондирования (ДД3) высокого пространственного разрешения и ГИС-технологий. Полевая оценка визуального качества ландшафтов использует систему многочисленных элементарных показателей, что необходимо для минимизации субъективности оценки. Проводятся они в пределах отдельных участков или туристических маршрутов. В свою очередь, современные ГИС и высококачественные ДДЗ позволяют провести оценку визуальных свойств ландшафтов из любой точки наблюдения на территории. Основная задача нашего исследования заключалась в верификации полученных результатов автоматизированной обработки аэрофотоснимков сверхвысокого разрешения, полученных с беспилотных летательных аппаратов (БПЛА) с данными полевых наблюдений по туристическому маршруту. Исследование проводилось на территории геопарка Белоградчишские скалы (Северо-Западная Болгария).

В качестве примера в работе более подробно рассмотрены 4 из 28 эстетических показателей - обилие горных вершин в зоне видимости, обилие горных вершин на линии горизонта, общая лесистость пейзажа и обилие открытых пространств в лесистом пейзаже. Полученные результаты ГИС-оценки с применением разработанных алгоритмов для каждого оценочного показателя подтвердили, что данный метод оценки позволяет произвести расчет многих показателей с высоким уровнем точности, сопоставимым с данными полевых исследований.
\end{abstract}

КЛЮЧЕВЫЕ СЛОВА: визуальные свойства ландшафтов, эстетика ландшафта, ГИСтехнологии, беспилотные летательные аппараты, Белоградчишские скалы (Болгария).

\footnotetext{
1 Московский государственный университет имени М.В. Ломоносова, Географический факультет, Ленинские горы, д. 1, 119991, Москва, Россия, e-mail: elina7-sheremet@mail.ru

2 Московский государственный университет имени М.В. Ломоносова, Географический факультет, Ленинские горы, д. 1, 119991, Москва, Россия, e-mail: kalutskova@gmail.com

3 Московский государственный университет имени М.В. Ломоносова, Географический факультет, Ленинские горы, д. 1, 119991, Москва, Россия, e-mail: vodo.ast@gmail.com
} 


\title{
Elina A. Sheremet ${ }^{1}$, Natalia N. Kalutskova ${ }^{2}$, Vladimir S. Dekhnich ${ }^{3}$ \\ VISUAL CHARACTERISTICS OF LANDSCAPES AND METHODS FOR THEIR ASSESSMENT ON GIS \\ (BELOGRADCHIK ROCKS (BULGARIA) AS AN EXAMPLE)
}

\begin{abstract}
Visual characteristics of landscapes are important factors for the assessment of tourist and recreational potential of territories. At present, a number of methodological approaches are applied to assess the visual characteristics of landscapes. They can be divided into traditional, associated exclusively with field research, and innovative, which is based on remote sensing data (RSD) of high spatial resolution and GIS technologies. Field assessment of the visual quality of landscapes utilizes a system of numerous elementary indicators to minimize subjectivity of assessment. They are conducted within separate areas or touristic routes. In its turn, modern GIS and high quality of remote sensing data allow assessing of most indicators of the visual quality of landscapes for any observation point on the entire territory. The main task of our research is to verify the results of automated processing of ultra-high resolution aerial photographs obtained from unmanned aerial vehicles (UAV) by field observations on a touristic route. The research was carried out on the territory of the "Belogradchik Rocks" Geopark (North-West Bulgaria). In our study, we estimated 4 out of 28 aesthetic indicators - the amount of mountain peaks visible from a site, the amount of mountain peaks on the skyline, the percentage of the forest-covered area, and the amount of open spaces in the wooded landscape. The obtained results confirmed that our approach allows calculating these aesthetic indicators at an accuracy level comparable to field observations.
\end{abstract}

KEYWORDS: visual characteristics of landscapes, landscape aesthetics, GIS technologies, unmanned aerial vehicles, Belogradchik Rocks (Bulgaria).

\section{ВВЕДЕНИЕ}

В настоящее время оценка эстетической привлекательности территории играет ключевую роль в области развития туризма и организации туристических маршрутов. Говоря об эстетической оценке ландшафта, прежде всего оцениваются его визуальные качества, которые во многом определяют туристско-рекреационный потенциал территории, а также влияют на размещение элементов инфраструктуры в будущем.

Сегодня помимо традиционных методов оценки, наблюдается активное внедрение комбинированных методов оценки визуальных свойств ландшафтов с использованием ГИС-технологий. В данном случае применение ГИС предоставляет многокомпонентные возможности для исследования эстетической ценности ландшафтов, а визуализация пространственных данных обеспечивает наглядное отображение полученных результатов эстетической привлекательности территории исследования в целом.

Существенно увеличить точность подобного рода исследований позволяет использование данных сверхвысокого разрешения путем аэрофотосъемки с беспилотных летательных аппаратов (БПЛА), которые активно применяются в исследованиях в

\footnotetext{
1 Lomonosov Moscow State University, Faculty of Geography, Leninskie Gory 1, 119991, Moscow, Russia, e-mail: elina7-sheremet@mail.ru

2 Lomonosov Moscow State University, Faculty of Geography, Leninskie Gory 1, 119991, Moscow, Russia, e-mail: kalutskova@gmail.com

3 Lomonosov Moscow State University, Faculty of Geography, Leninskie Gory 1, 119991, Moscow, Russia, e-mail: vodo.ast@gmail.com
} 
последнее десятилетие. Функциональные возможности современных ГИС позволяют создавать детальные цифровые модели местности (ЦММ) при помощи комбинирования данных аэрофотосъемки высокого пространственного разрешения по туристическим маршрутам и моделей SRTM c покрытием на всю территорию исследования. Усовершенствованные методы эстетической оценки ландшафтов на основе обработки высокодетальных данных дистанционного зондирования с применением ГИС позволяют определить эстетическую привлекательность любой обзорной точки, что можно использовать для оптимизации существующих сетей туристических маршрутов и организации новых маршрутов.

Основная задача нашего исследования заключалась в верификации полученных результатов автоматизированной обработки аэрофотоснимков сверхвысокого разрешения, полученных с беспилотных летательных аппаратов с данными полевых наблюдений. Наше исследование проводилось на территории Белоградчишских скал в Северо-Западной Болгарии в летний сезон 2019 года. Это самое крупное скальное образование в районе Предбалкан, получившее мировую известность и номинируемое на включение в систему геопарков (геологических парков) ЮНЕСКО [Калуиякова и др., 2019]. Развитие устойчивого туризма является одним из приоритетных направлений, поэтому здесь должна быть организована сеть туристических маршрутов, охватывающая наибольшее количество уникальных геологических объектов (геотопов) и эстетически привлекательных ландшафтов [Шеремет и др., 2020] (рис. 1).

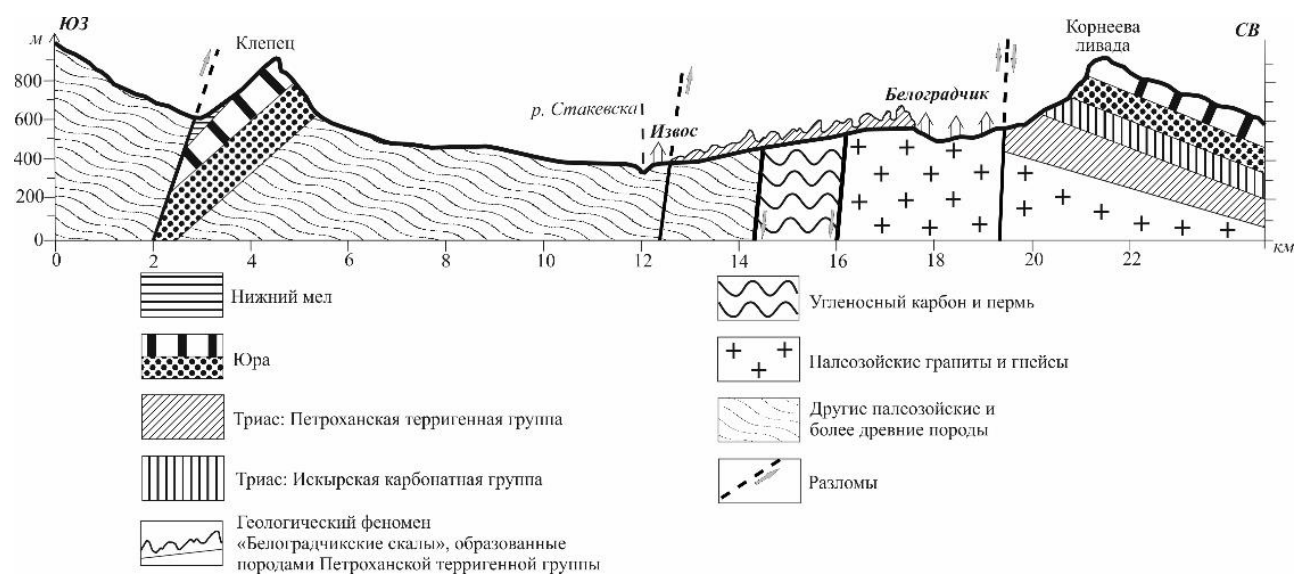

Рис. 1. Геологический профиль Белоградчишского антиклонория [Tronkov, 1998 ]

Fig. 1. Geological profile of the Belogradchik Anticlinorium [Tronkov, 1998]

Территория исследования отличается достаточно сложным геологическим строением. Она входит в состав крупного Белоградчишского антиклинория Предбалканской морфометрической зоны. В ядре антиклинория вскрываются и выходят на поверхность древние докембрийские и палеозойские породы, для его крыльев характерны типичные карбонатные мезозойские породы [Tronkov et al., 2012]. Это привело к формированию Белоградчишских скал - как геологического феномена, так как в качестве его ядра выступает комплекс скальных останцов.

Современный облик ландшафтов территории был сформирован мезозойскими породами Петроханской терригенной группы. В северо-восточной и западной части скального комплекса выделяется ландшафт куэст, сложенный песчаниковыми известняками и мергелями юрского, триасового и мелового возраста под грабово-буковыми и кленово-грабовыми лесами на горных дерново-карбонатных почвах. Большую часть комплекса занимает ландшафт складчатых предгорий, сложенный красноцветными 
конгломератами и грубозернистыми песчаниками триасового возраста под дубовыми и дубово-грабовыми лесами с подлеском на горных бурых лесных почвах [Калуцккова, 2008].

На территории Белоградчишских скал имеется 5 туристических маршрутов. Нами для исследования был выбран туристический маршрут «Мир скал». Данный маршрут имеет протяженность около 6 км. Проходит в пределах ландшафта складчатых предгорий. На маршруте имеется 9 обзорных точек, с которых открываются панорамные виды. В данной статье мы более подробно рассматриваем результаты оценки визуальных свойств ландшафтов н примере двух обзорных точек. Обзорная точка № 3 находится на высоте 510 м н.у.м, на покатом коренном склоне гряды, обзорная точка № 6 находится на вершинной поверхности останца, но занимает более низкое положение 448 м н.у.м (рис. 2).

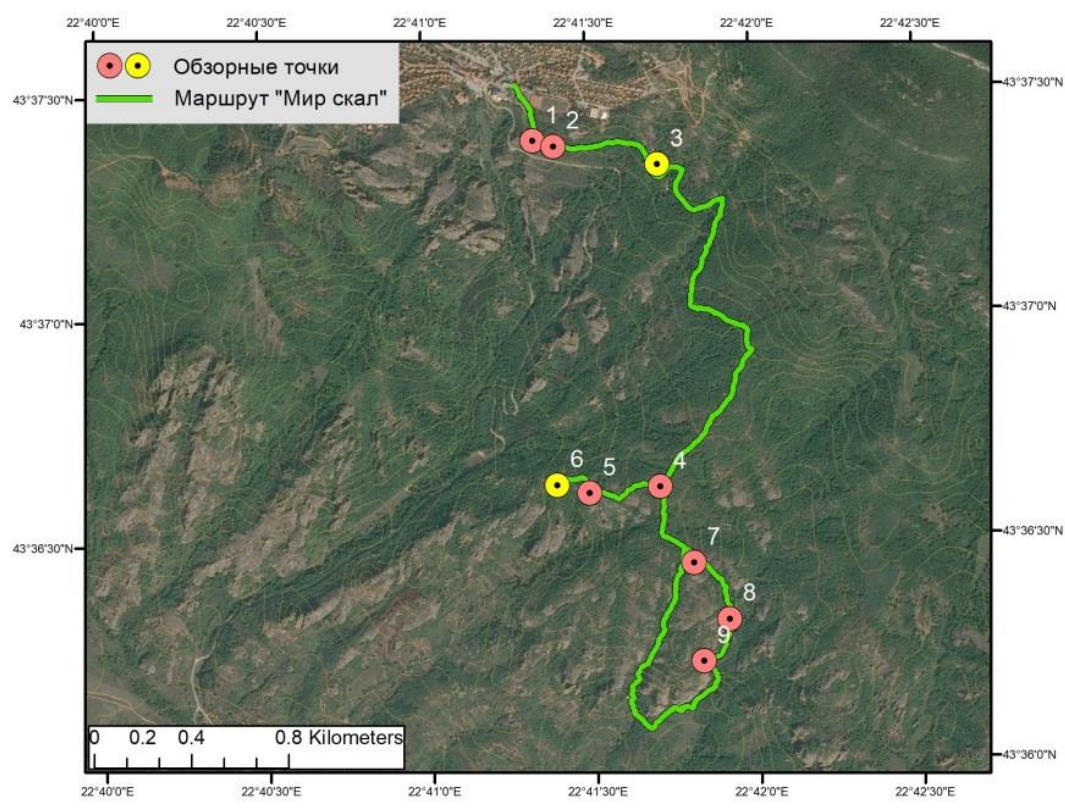

Pис. 2. Туристический марирут «Мир скал»

Fig. 2. Tourist route "World of the Rocks"

\section{ОБЗОР ЛИТЕРАТУРЫ}

Научная основа визуального восприятия ландшафта была заложена в конце XIX в. в работах А. Гумбольдта, А. Геттнера, В.П. Семенова-Тян-Шанского и др. А. Гумбольдт ввел первое представление о ландшафте, под которым понималась визуально воспринимаемая и эстетически оцениваемая красота окружающей среды [Гумбольдт, 1959]. В работе А. Геттнера «География: ее история, сущность и методы» раскрыто определение термина «эстетическая география», который «взвешивает эстетическую ценность и красоту» различных ландшафтов и местностей [Геттнер, 1930, с. 140]. В.П. Семенов-Тян-Шанский в фундаментальном труде «Район и страна» [Семенов-Тян-Шанский, 1928] рассматривал связи между географией, эстетикой и искусством.

В XX в. в англоязычных странах Запада и США начинает формироваться «поведенческая география». По мнению Дж. Голда, «...огромное внимание в поведенческой географии уделяется изучению представлений о пространстве, исследованию его образа в сознании» [Голд, 1990, с. 9]. Подобные взгляды можно найти в работах Д. Лоуэнталя (1961, 1967), У. Кирка (1963), Э. Пеннинг-Роуселла (1973, 1974), Д. Харди (1973) и др. Было установлено, что феномен пространственного восприятия территории связан с аттрактивностью ландшафтов, и можно выделить и описать как наиболее, так и наименее привлекательные для визуального восприятия ландшафты. Теме восприятия ландшафта 
посвящены работы Д. Мейнига (1979), К. Фута (1979), Д. Косгроува (1984), Э. Релпа (1987), Дж. Гибсон (1988) и др.

На становление эстетического направления в отечественной географии большое влияние оказали работы В.С. Преображенского, В.А. Николаева, Б.Б. Родомана, Ю.А. Веденина, К.И. Эрингиса, А.Р.-А. Будрюнаса, О.В. Калашниковой, В.В. Савельевой, М.Ю. Фроловой, Н.Н. Назарова, Ю.П. Хрусталев, А.В. Белова, А.В. Бредихина и др. В.А. Николаев предлагает рассматривать эстетику ландшафта в качестве особого направления ландшафтоведения, связанного с изучением красоты, живописности природных и природноантропогенных ландшафтов, а также с особенностями их эстетического восприятия. Эстетической оценке подлежит визуальная картина, открывающаяся перед наблюдателем из любой точки географического пространства. Под этой картиной понимается пейзаж «внешний облик ландшафта, воспринимаемый с той или иной видовой точки...» [Николаев, 2005 , с. 68]. В данном случае эстетика ландшафта направлена на изучение гармонии и красоты ландшафта. Это довольно сложный процесс взаимосвязи между человеком и ландшафтом, представляющий психологическое отражение красоты природной среды посредством чувственного восприятия [Аткина, 2017].

В первую очередь, в процессе оценки визуальных свойств ландшафта важно учитывать его привлекательность - аттрактивность. Наблюдатель без всякой сложности может выделить объективный фон и фигуры, а также их очертания [Дирин и др., 2010]. Основные качества аттрактивности напрямую зависят от цвета, яркости и пространственной структуры. Так, например, от особенностей цветовых комбинаций в пейзаже зависит характер их воздействия на наблюдателя. Помимо аттрактивности в ландшафтной географии вводится понятие перцепции ландшафта - чувственного восприятия окружающего, несущего для субъекта некую эстетическую ценность - по сущности близкое к термину «эстетическое восприятие» [Аткина, 2017]. Действующим лицом в процессе восприятия ландшафтов является субъект восприятия - наблюдатель, который воспринимает и оценивает объект восприятия, а именно сам ландшафт.

Таким образом, эстетическое наслаждение наблюдателя напрямую зависит от гармонических взаимосвязей в системе воспринимаемых объектов [Birkhoff, 1933]. В основу любого пейзажа заложена внутренняя структура с основополагающими элементами, но главным свойством является его целостность [Николаев, 2005]. По мнению П. Гобстера, все слагающие эстетической оценки, а именно сам индивидуум, ландшафт, объекты и результаты оценки, должны быть объединены в единую систему [Gobster, 1999]. Эстетическая оценка должна затрагивать объекты как природной, так и искусственной среды.

Визуальное восприятие во многом зависит от физиологических особенностей человека. Более 90\% пространственной информации он получает преимущественно через зрительный анализатор. Воспринимаемый пейзаж может значительно трансформироваться при изменении местоположения самого наблюдателя даже на несколько метров [Гибсон, 1988; Филин, 2006]. Кроме этого, на восприятие окружающего оказывают влияние свет, звуковые импульсы, запахи, пространственные формы и их соотношение. Как отмечает К. Норберг-Шульц, свет может выступать в качестве одного из главных факторов дифференциации форм в ландшафте [Норберг-Шульц, 1995].

Визуальное восприятие ландшафта устанавливается через дистанцию между субъектом и пейзажем. Любая дистанция зависит от местоположения точки пейзажного обзора и протяженности ее перспективы [Николаев, 2005]. Главная роль в восприятие пейзажа отводится оптимальному выбору смотровых площадок - обзорных точек, с которых открывается видимая панорама. Каждая обзорная точка должна быть по своему привлекательной, максимально охватывать все разнообразие территории и быть доступной для массового посещения. 


\section{МАТЕРИАЛЫ И МЕТОДЫ ИССЛЕДОВАНИЯ}

Методы исследований визуальных свойств ландшафтов с каждым годом все более усовершенствуются. Как было отмечено, большое значение придается ГИС-технологиям и обработке данных дистанционного зондирования (ДДЗ). Некоторые современные методики предусматривают синтез экспертных балльных оценок и ГИС-анализа, которые позволяют обрабатывать большие массивы пространственных данных и верифицировать их с данными полевых исследований.

Так, например, в современных исследованиях проводится оценка обзорных точек с позиции привлекательности открывающихся ландшафтов в зонах видимости с использованием ЦМР - как главного фактора формирования условий восприятия и общей структуры пейзажной картины, что позволяет в дальнейшем оценить эстетический потенциал исследуемой территории [Ротанова и др., 2017]. Большинство исследований направлены на разработку комплексных ландшафтно-эстетических оценок на основе частных оценочных показателей [Кочуров и др., 2007; Бибаева и др., 2018; Дирин, 2007].

Во многих зарубежных работах раскрываются возможности использования аэрофотоснимков с БПЛА, так как высокая точность пространственных данных позволяет учесть влияние всех видимых объектов на зону видимости, а также провести эстетическую оценку открывающихся перед наблюдателем ландшафтов. Подобные исследования осуществляются для оценки безопасности маршрутов, комфортности их прохождения и эстетической привлекательности панорам видимости [Hackney et al., 2015; Cwiakala et al., 2017; Shiou et al., 2020]. Помимо этого, построенные на основе аэрофотоснимков ортофотопланы, позволяют воспроизводить детальные 3D-модели, которые могут быть использованы в целях планирования туризма и проектирования туристско-рекреационной инфраструктуры [Shaoyu et al., 2018].

Методику нашего исследования можно разделить на три этапа. Первый этап полевой - включал в себя оценку эстетических показателей ландшафта по традиционной методике К.И. Эрингиса и А.Р. Будрюнаса [Эрингис $и$ др., 1975], которая нами была адаптирована для территории Белоградчишских скал. Если К.И. Эрингис и А.Р. Будрюнас оценивали 80 показателей, то мы уменьшили количество показателей до 28, объединенных в четыре крупных блока: общее восприятие пейзажа, выразительность рельефа, пространственное разнообразие растительности и степень антропогенной трансформации ландшафта. В качестве примера нами приводится оценка только четырех показателей: «Обилие горных вершин в зоне видимости», «Обилие горных вершин на линии горизонта», «Общая лесистость пейзажа» и «Обилие открытых пространств в лесистом пейзаже».

Одновременно с полевыми описаниями обзорных точек нами была проведена аэрофотосъемка сверхвысокого разрешения с использованием двух беспилотных летательных аппаратов с двух высот: с высоты 100 м, охватывающая территорию маршрута «Мир скал» и с высоты 400 м, охватывающая территорию всего скального комплекса «Белоградчишские скалы».

Второй этап заключался в предварительной обработке данных дистанционного зондирования для дальнейшего ГИС-анализа. Был проведен расчет зон видимости с каждой обзорной точки по туристическому маршруту, создана DTM (цифровая модель местности), а также рассчитаны дополнительные пространственные данные (TPI - Topography Position Index, PCA - Principal Component Analysis и др.). На третьем этапе - были созданы специальные алгоритмы визуальной оценки ландшафтов. Заключительный этап представляет собой верификацию данных, полученных при автоматизированной оценке, с данными полевых исследований. 
Исходными данными для выполнения нашего исследования являлись:

1. Полевые данные (GPS-треки, полученные при следовании вдоль туристических маршрутов, координаты обзорных точек, полевые оценки эстетических свойств ландшафтов, наблюдаемых с обзорных точек).

2. $\quad$ Результаты аэрофотосъемки с применением квадрокоптеров DJI Phantom 4 Pro и DJI Mavic Pro (произведенные облака точек, ортофотопланы и DTM).

3. Цифровые модели рельефа SRTM DEM (пространственное разрешение 30 м).

4. Спутниковые снимки Landsat-8 OLI (пространственное разрешение 30 м).

5. Производные индексы (ТРI и т.д.).

6. Информация о расположении объектов инфраструктуры, предоставленная открытыми картографическими сервисами (Google-карты, Яндекс-карты, OpenStreetMap).

Предварительная обработка изображений аэрофотосъемки и создание DTM проводились в программном обеспечение AGISOFT «Photoscan». Основной массив пространственных данных анализировался в программном обеспечение ESRI «ArcGIS».

\section{РЕЗУЛЬТАТЫ ИССЛЕДОВАНИЯ И ИХ ОБСУЖДЕНИЕ}

Предварительная обработка данных и построение зон видимости. После проведения разномасштабной съемки с БПЛА нами были созданы ортофотопланы и цифровые модели местности (DTM - Digital Terrain Model) с пространственным разрешением около 1 м., охватывающие как всю территорию Белоградчишских скал, так и территорию, по которой непосредственно проходит туристический маршрут «Мир скал». Это обеспечило высокую детальность открывающихся зон видимости в ближней и средней перспективе. После совмещения полученных DTM с данными радарной топографической съемки SRTM была создана базовая модель, обеспечившая охват территории с учетом построения линий горизонта со всех обзорных точек (в радиусе 40 км).

Наиболее аттрактивным элементом ландшафта является рельеф поверхности [Бредихин, 2005]. Итоговая DTM была взята за основу оценки визуального восприятия территории с учетом высоты форм рельефа. Построение зон видимости проводилось в программе ArcMap 10.3 при помощи инструмента «Visibility», с возможностью определения части территории, видимой из каждой обзорной точки наблюдения. После совмещения зон видимости со всех обзорных точек, появилась возможность создания общей панорамы видимости для маршрута в целом.

Показатель «Обилие горных вершин в зоне видимости». Обилие горных вершин оценивалось на основе индекса топографического положения (TPI - Topographic position index) - разницы между абсолютной высотой определенной точки и средней высотой точек в буфере вокруг исходной точки. Таким образом, для выпуклых поверхностей характерны положительные значения индекса, для равнинных поверхностей и средних частей склонов близкие к 0 , для понижений - отрицательные значения. Идентификация горных вершин для каждой обзорной точки проводилась при помощи пересечения с соответствующими им зонами видимости (рис. 3).

Нами было проведено сравнение количества горных вершин, которые видели наблюдатели с обзорных точек в ходе полевых исследований, и количества горных вершин, полученных при использовании ГИС-анализа. Во втором случае количество горных вершин было значительно больше. Это связано с высоким пространственным разрешением исходных данных (DTM), что позволяет определить их точное количество, а во-вторых, с особенностями зрительного восприятия наблюдателей, поскольку горные вершины дальних перспектив теряют свое очертание и начинают сливаться. 

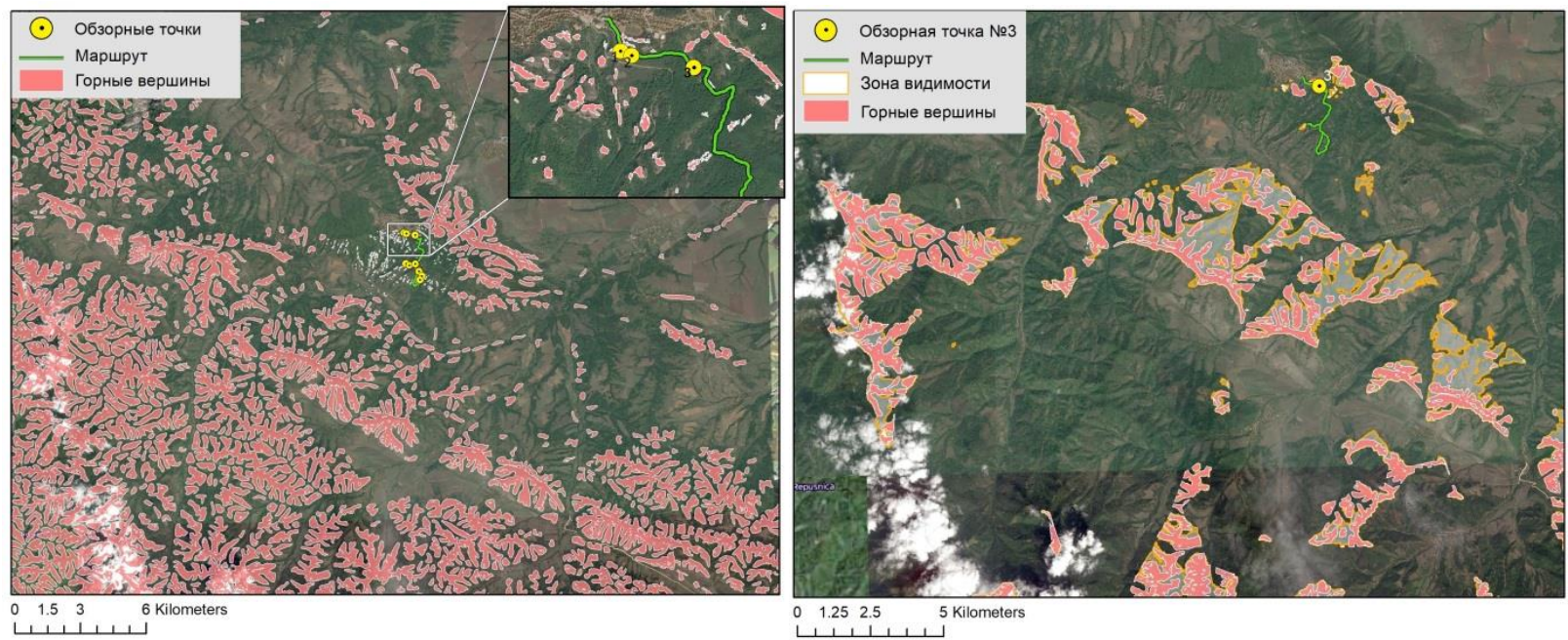

Рис. 3. Идентификачия горных вершин в зоне видимости (на примере обзорной точки 3)

Fig. 3. Identification of mountain peaks in the visibility zone (example of observation point 3)

Для подсчета нами была проведена агрегация горных вершин в небольшие, близко расположенные группы (инструмент «Aggregate Polygons»). Горные вершины группировались в соответствии с оптимальными условиями, подобранными вручную с учетом пространственного разрешения исходных данных в пределах средней и дальней перспектив. Прежде всего необходимо было учесть разницу между горными вершинами внутри группы («Aggregation distance»), после чего определялась площадь отдельно стоящей горной вершины, не входящей ни в одну группу («Minimum area»- минимальная площадь). Таким образом, значение расстояния между вершинами внутри группы для средней перспективы не должно было превышать 70 м, для дальней перспективы - 1000 м. Площадь отдельно расположенной горной вершины для средней перспективы должна быть не менее 1500 кв. м., а для дальней перспективы - не менее 10000 кв. м (рис. 4).
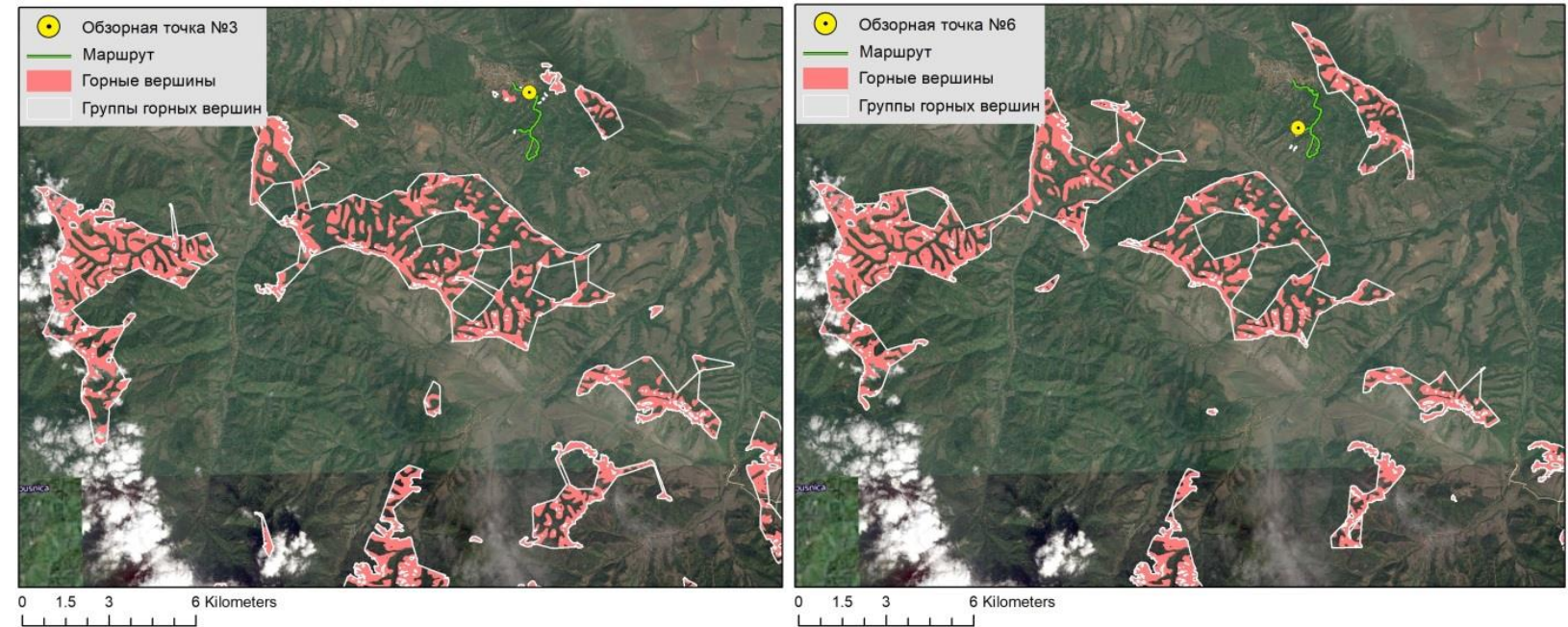

Рис. 4. Агрегирование горных вершин в группы для обзорных точек 3 (слева) и 6 (справа) Fig. 4. Aggregation of mountain peaks into groups for observation points 3 (left) and 6 (right)

Сравнивая результаты оценки показателя «Обилия горных вершин в зоне видимости», было установлено, что с обзорной точки № 3 наблюдатель видит 30 горных 
вершин, а в результате автоматизированной обработки - 32; для обзорной точки № 6 - эти показатели составляют 22 и 23 , соответственно.

Показатель «Обилие горных вершин на линии горизонта». Для оценки показателя в первую очередь производилось построение линии горизонта для каждой точки обзора (инструмент «Skyline»). Данный инструмент позволяет сгенерировать трехмерную линию небосвода, представляющую собой отрезок между обзорной точкой и наблюдаемой точкой с учетом поверхности рельефа. В этом случае конфигурация линии горизонта будет зависеть от положения обзорных точек и высоты наблюдаемых точек. Построенная линия горизонта совмещалась с ранее выделенными группами горных вершин в зоне видимости, что позволило определить количество горных вершин на линии горизонта для каждой точки обзора (рис. 5).
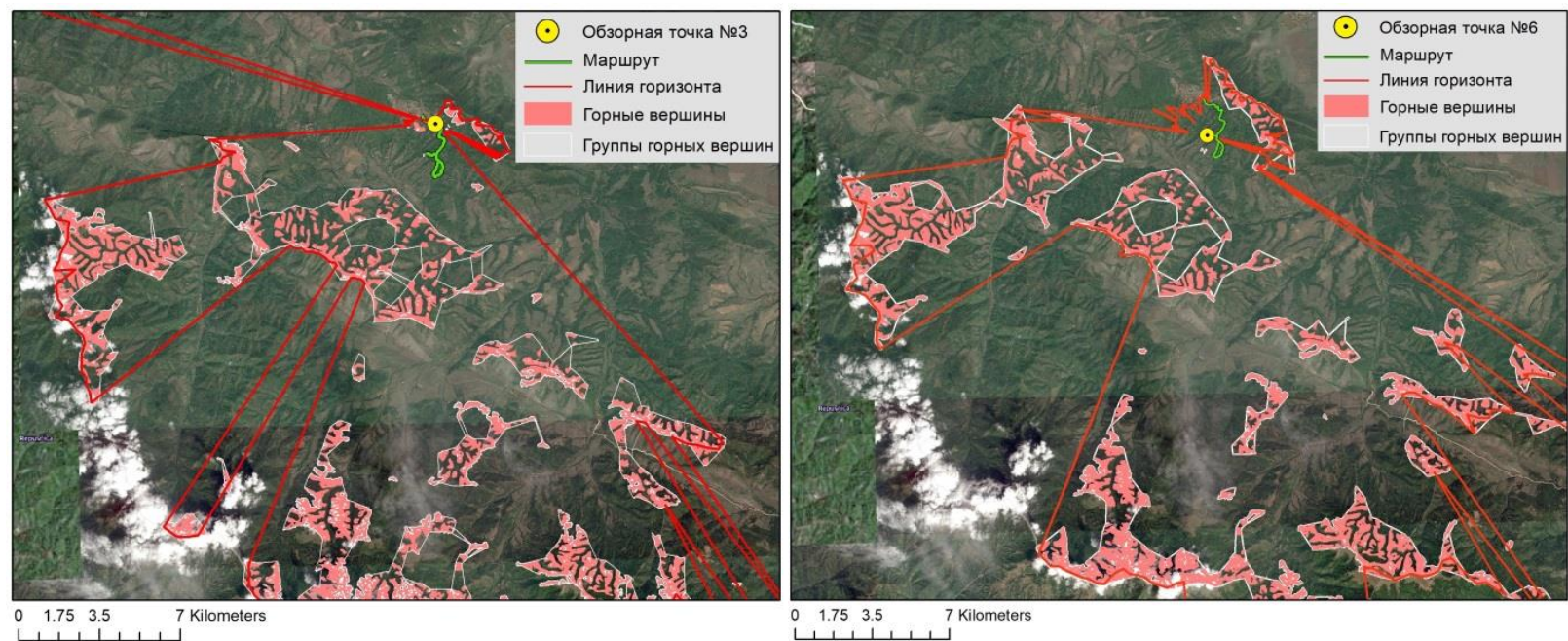

Рис. 5. Обилие горных вершин на линии горизонта для обзорных точек 3 (слева) и 6 (справа)

Fig. 5. Amount of mountain peaks on the skyline for observation points 3 (left) and 6 (right)

Таким образом, с обзорной точки № 3 наблюдатель видит на линии горизонта 15 горных вершин, при автоматизированной обработке их количество увеличивается до 18; для обзорной точки № 6 данный показатель составляет соответственно 12 и 13 горных вершин.

Показатель «Общุая лесистость пейзажа». Данный показатель определяется отношением залесенной площади к общей площади зоны видимости вплоть до линии горизонта отдельно для каждой точки обзора. Согласно методике К.И. Эрингиса и А.Р. Будрюнаса [Эрингис и др., 1975], этот показатель оценивается в баллах. Таким образом, при низкой степени залесенности территории, т.е. до 50 \%, показатель получал 0 баллов, при средней степени залесенности - 50-70 \%, оценка составляла 1 балл, при высокой, т.е. более $75 \%$ - 2 балла.

Автоматическая оценка лесистости проводилась на основе ортофотоплана. Для территории, которая не попала в зону съемки с БПЛА, использовались безоблачные спутниковые снимки Landsat-8 за 2017-2020 гг. с более низким пространственным разрешением. На начальном этапе проводился расчет площади зон видимости для всех обзорных точек (инструмент «Calculate Areas»). Залесенные территории выделялись при помощи классификации типов ландшафтного покрова. Классификация ландшафтного покрова на основе ортофотоплана осуществлялась при помощи инструмента «Classify Raster». Классификация ландшафтного покрова на основе снимков Landsat-8 
осуществлялась посредством метода главных компонент (Principal component analysis PCA), представляющего собой снижение размерности набора каналов растра с созданием одного многоканального растра.

Для того чтобы избавиться от небольших ошибочных данных растра полученные растровые изображения были генерализованы (инструмент «Majority Filter»), затем векторизованы (инструмент «Raster to Polygon»). Из общего векторного слоя в отдельный слой был извлечен класс с лесными насаждениями. При помощи инструмента наложения данных («Intersect») получен итоговый векторный слой, содержащий зоны видимости и полигоны с лесами. Это позволило провести вычисление площади и доли лесных насаждений в пределах каждой зоны видимости (рис. 6).
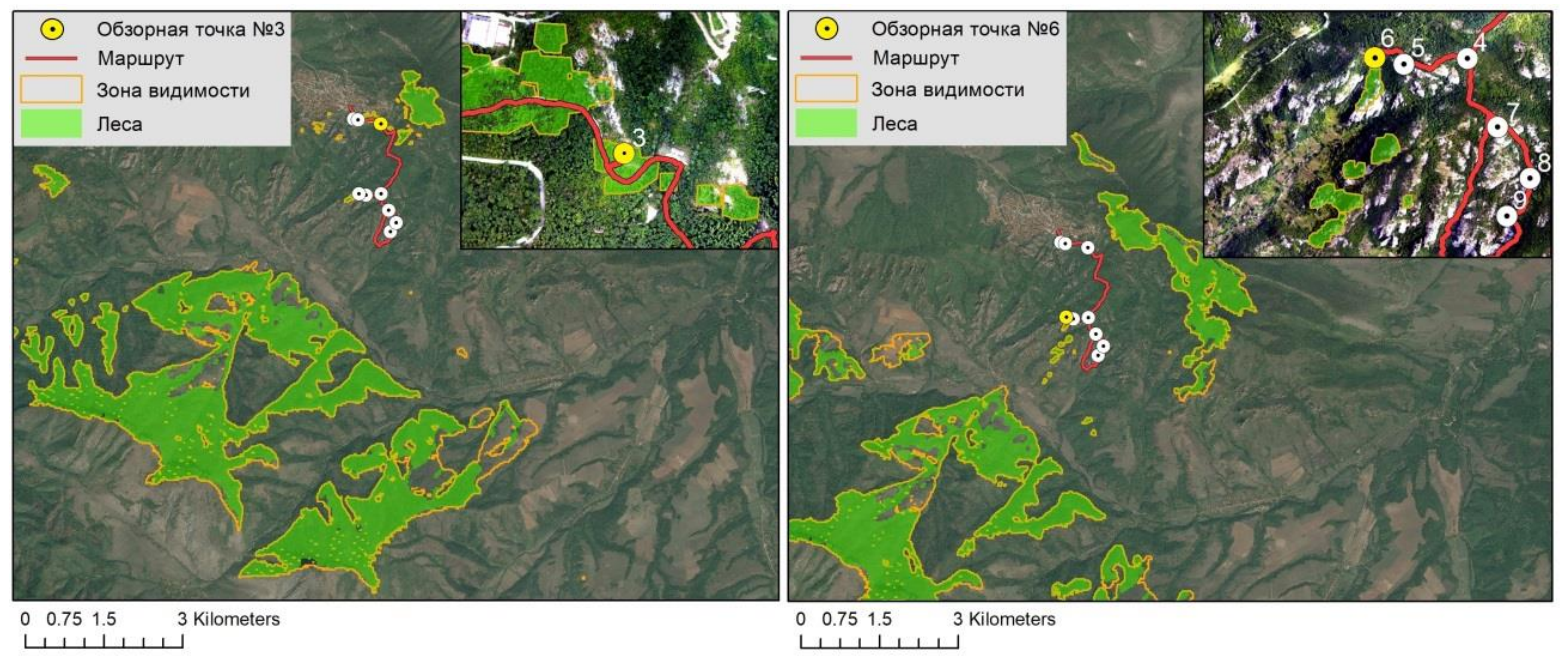

Рис. 6. Залесенные территории в пределах зон видимости для обзорных точек 3 (слева) и 6 (справа)

Fig. 6. Forest areas within the visibility zones for observation points 3 (left) and 6 (right)

Сравнивая полученные показатели при полевых исследованиях, и результаты, полученные в ходе автоматизированной обработки, можно констатировать, что оценки довольно близки. Так, доля залесенной площади для обзорной точки № 3 составляет 84 \%, для обзорной точки № $6-81,6$ \%. При оценке данного показателя нами также был поставлен максимальный балл для обеих точек.

Показатель «Обилие открытых пространств в лесистом пейзаже». Этот показатель очень важен для лесных территорий, поскольку наличие открытых пространств (луговин, вырубок и др.) усложняет пейзаж и повышает его аттрактивность. Открытые пространства, согласно К.И. Эрингису и А.Р. Будрюнасу, должны быть не менее чем с трех сторон окружены лесными массивами. В ближней и средней перспективах открытые пространства воспринимаются наблюдателем достаточно четко. В дальней же перспективе отрытые пространства, как и горные вершины, начинают сливаться. При автоматическом распознавании открытые участки выделяются достаточно четко. Операция выявления открытых пространств похожа на операцию выявления горных вершин. Нами было проведено объединение близкорасположенных открытых участков в группы (инструмент «Aggregate Polygons») с учетом расстояния между ними и их наименьшей площади. Таким образом, расстояние между открытыми пространствами внутри группы не должно было превышать 500 м, а минимальная площадь открытых участков должна быть не менее 70000 кв. м. Сама оценка представляла собой совмещение полученных полигонов с зоной видимости с каждой обзорной точки (рис. 7). 

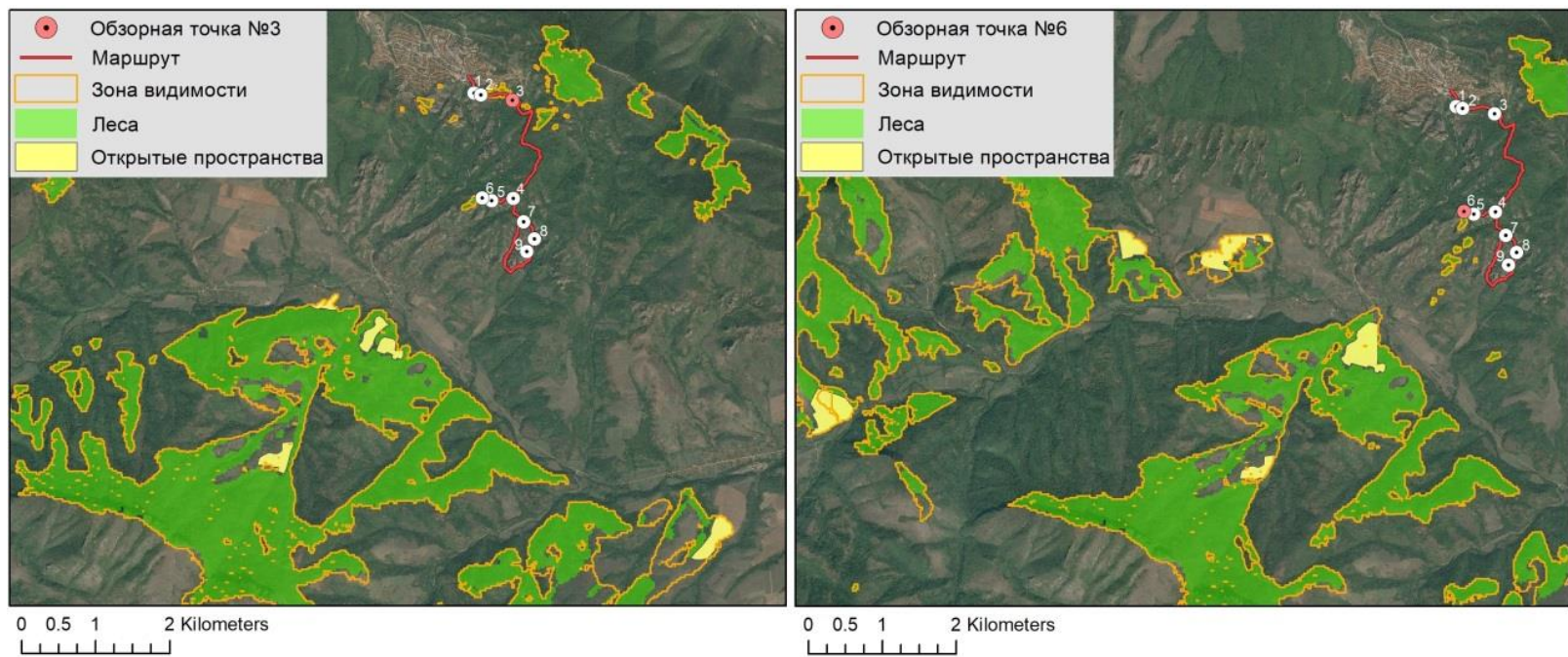

Рис. 7. Обилие открытых пространств в лесистом пейзаже для обзорных точек 3 (слева) и 6 (справа)

Fig 7. Amount of open spaces in the wooded landscape for observation points 3 (left) and 6 (right)

Оценка показателя «Обилие открытых пространств в лесистом пейзаже» также имеет значительную корреляцию при полевых исследованиях и при автоматизированной обработке. С обзорной точки № 3 наблюдателем было выделено 4 открытых участка, при автоматизированной обработке - 5; с обзорной точки № 6 - соответственно 5 и 6 открытых участков. Таким образом, результаты оценки визуальных свойств, полученные при автоматизированной обработке аэрофотоснимков высокого разрешения с применением ГИС-анализа, сопоставимы с данными полевых исследований.

\section{ВЫВОДЫ}

Современные методы обработки данных дистанционного зондирования высокого пространственного разрешения с применением ГИС-технологий повышают эффективность проведения визуальной оценки ландшафтов, а также позволяют минимизировать субъективную оценку во время проведения полевых исследований.

Несмотря на то, что обработка снимков с БПЛА и ГИС-анализ являются несколько трудоемкими этапами автоматизированной оценки визуальных свойств ландшафтов, так как основная задача заключается в разработке оптимальных алгоритмов для каждого оценочного показателя, итоговые результаты ГИС-оценки имеют высокий уровень точности, сопоставимый с данными полевых исследований на местности. В нашем исследовании это было доказано для территории планируемого геопарка Белоградчишские скалы на примере четырех показателей визуальной оценки ландшафтов - «Обилие горных вершин в зоне видимости», «Обилие горных вершин на линии горизонта», «Общая лесистость пейзажа» и «Обилие открытых пространств в лесистом пейзаже».

Предлагаемый метод оценки позволяет определить эстетическую привлекательность любой обзорной точки в пределах исследуемой территории, что дает возможность разрабатывать туристические маршруты с учетом визуальных свойств ландшафтов.

\section{БЛАГОДАРНОСТИ}

Исследование выполнено в рамках государственной научно-исследовательской программы 1.8. «Факторы и процессы пространственно-временной организации природных и антропогенных ландшафтов (ГЗ)». 


\section{ACKNOWLEDGEMENTS}

The study was performed in the framework of a state research programme 1.8. "Factors and processes of the Spatio-temporal organization of natural and anthropogenic landscapes (SA)".

\section{СПИСОК ЛИТЕРАТУРЫ}

1. Аткина Л.И. Эстетика ландшафта: учебное пособие. Екатеринбург: Уральский государственный лесотехнический университет, 2017. 74 с.

2. Б Бибаева А.Ю., Макаров А.А. Применение ГИС для расчёта комплексных показателей эстетической оценки ландшафтов. Известия Иркутского государственного университета. Серия: Науки о Земле, 2018. Т. 24. С. 17-33. DOI: 10.26516/20733402.2018.24.17.

3. Бредихин A.B. Эстетическая оценка рельефа при рекреационно-геоморфологических исследованиях. Вестник Московского университета. Серия 5: География, 2005. № 3. C. 7-13.

4. Геттнер А. География. Ее история, сущность и методы. М.; Л.: Государственное издательство, 1930. 416 с.

5. $\quad$ Гибсон Дж. Экологический подход к зрительному восприятию. М.: Прогресс, 1988. $464 \mathrm{c}$.

6. Голд Дж. Психология и география: Основы поведенческой географии. М.: Прогресс, $1990.304 \mathrm{c}$.

7. $\quad$ Гумбольдm A. Картины природы. М.: Географгиз, 1959. 270 с.

8. Дирин Д.А. Оценка и рекреационное использование пейзажно-эстетических ресурсов Усть-Коксинского района Республики Алтай. Новосибирск: Издательство Сибирского отделения РАН, 2007. 206 с.

9. Дирин Д.А., Попов Е.С. Оценка пейзажно-эстетической привлекательности ландшафтов: методологический обзор. Известия Алтайского государственного университета, 2010. № 3. С. 120-124.

10. Калуцикова Н.Н., Синьовски Д., Дронин Н.М., Синьовска Д., Шеремет Э.А. Опыт номинирования геологических парков в глобальную сеть ЮНЕСКО. Вестник Московского государственного областного университета. Серия: Естественные науки, 2019. № 2. C. 80-93. DOI: 10.18384/2310-7189-2019-2-80-93.

11. Калуикова Н.Н., Сафонова А.А., Сморжок М.А. Оценка природной привлекательности туристических маршрутов Белоградчишских скал (Болгария). Лесные экосистемы и урбанизация. М.: Товарищество научных изданий КМК, 2008. C. 219-225.

12. Кочуров Б.И., Бучацкая Н.В. Оценка эстетического потенциала ландшафта. Юг России: экология и развитие, 2007. Вып. 2. № 4. C. 25-34. DOI:10.18470/1992-10982007-4-25-34.

13. Николаев В.А. Ландшафтоведение: Эстетика и дизайн. М.: Аспект-Пресс, 2005. 176 с. 14. Норберг-Шульи К. Жизнь имеет место. Известия высших учебных заведений. Architecton, 1995. № 1-2. C. 24-31.

15. Ротанова И.Н., Васильева О.А. Оценка эстетической привлекательности ландшафтов проектируемого природного парка «Предгорье Алтая» с применением геоинформационных технологий. Наука и туризм: стратегии взаимодействия. Барнаул: Издательство Алтайского университета, 2017. Вып. 7 (5). С. 29-36.

16. Семенов-Тян-Шанский В. Район и страна. М.;Л.: Государственное изд-во, 1928. 311 с.

17. Филин B.A. Видеоэкология что для глаза хорошо, а что - плохо. М.: Видеоэкология, 2006. $512 \mathrm{c}$. 
18. Шеремет Э.А., Дехнич В.С., Калуцุкова Н.Н. Возможности применения ГИС-технологий для оценки визуальных свойств ландшафтов при организации геопарков. Известия Русского географического общества, 2020. T. 152. № 6. C. 69-78. DOI: $10.31857 /$ S086 9607120060063.

19. Эрингис К.И., Будрюнас А.-Р.А. Сущность и методика детального экологоэстетического исследования пейзажей. Экология и эстетика ландшафта. Вильнюс: Минтис, 1975. С. 107-160.

20. Birkhoff G. Aesthetic measure. Cambridge: Harvard University Press, 1933. 292 p.

21. Cwiakala P., Kocierz R., Puniach E., Nedzka M., Mamczarz K., Niewiem W., Wiacek P. Assessment of the possibility of using unmanned aerial vehicles (UAVs) for the documentation of hiking trails in Alpine areas. MDPI International Journal, 2017. V. 18. Iss. 1. P. 1-28. DOI: 10.3390/s18010081.

22. Gobster P.H. An ecological aesthetic for forest landscape management. Landscape Journal, 1999. No 18(1). P. 54-64.

23. Hackney C., Clayton A. Unmanned aerial vehicles (UAVs) and their application in geomorphic mapping. Geomorphological Techniques, 2015. Chap. 1. Sec. 1.7. P. 1-12.

24. Shaoyu L., Weijie D., Yongbo Y. Application of UAV oblique photograph modeling technology in mountain tourism planning. 3rd International Symposium on EEEMS. Francis Academic Press, 2018. P. 240-245.

25. Shiou Y., Chengju D., Zhihui C., Hao W., Kailang G., Yirong L., Yongjie C., Wenyan L., Qiang F., Wenbo L. Assessing safety and suitability of old trails for hiking using ground and drone surveys. International Journal Geo-Informational, 2020. V. 9. Iss. 4. P. 1-17.

26. Tronkov D. Belogradchik Rock Sculptures - a child of erosional power of nature and of geological controls. Geologica Balc., 1998. V. 3 (4). No 28. P. 153-158.

27. Tronkov D., Sinnyovsky D. Belogradchik rocks in Bulgaria - geological setting, genesis and geoconservation value. Geoheritage, 2012. V. 4. No 3. P. 153-164.

\section{REFERENCES}

1. Atkina L.I. Landscape aesthetics: tutorial. Yekaterinburg: Ural State Forestry University, 2017. 74 p. (in Russian).

2. Bibaeva A.Yu., Makarov A.A. Application of Information Systems for Calculations of Indicators of Aesthetic Assessment of Landscapes. The Bulletin of the Irkutsk State University. Earth Science series, 2018. V. 24. P. 17-33. DOI: 10.26516/20733402.2018.24.17 (in Russian).

3. Birkhoff G. Aesthetic measure. Cambridge: Harvard University Press, 1933. 292 p.

4. Bredikhin A.V. Aesthetic assessment of the relief in recreational geomorphological research. Bulletin of Moscow University. Series 5. Geography, 2005. No 3. P. 7-13 (in Russian).

5. Cwiakala P., Kocierz R., Puniach E., Nedzka M., Mamczarz K., Niewiem W., Wiacek P. Assessment of the possibility of using unmanned aerial vehicles (UAVs) for the documentation of hiking trails in Alpine areas. MDPI International Journal, 2017. V. 18. Iss. 1. P. 1-28. DOI: 10.3390/s18010081.

6. Dirin D.A. Assessment and recreational use of landscape and aesthetic resources of the Ust-Koksinsky district of the Altai Republic. Novosibirsk: Publishing House of Siberian Branch of the Russian Academy of Sciences, 2007. 206 p. (in Russian).

7. Dirin D.A., Popov E.S. Assessment of landscape and aesthetic attractiveness of landscapes: methodological review. News of the Altai state University, 2010. No 3. P. 120-124 (in Russian). 
8. Eringis K.I., Budryunas A.-R.A. The essence and methodology of a detailed ecological and aesthetic study of landscapes. Ecology and aesthetics of the landscape. Vilnius: Mintis, 1975, P. 107-160 (in Russian).

9. Filin V.A. Videoecology: what is good for the eye, and what is bad. Moscow: Videoecology, 2006. 512 p. (in Russian).

10. Gibson J. The Ecological Approach to Visual Perception. Moscow: Progress, 1988. 464 p. (in Russian).

11. Gobster P.H. An ecological aesthetic for forest landscape management. Landscape Journal, 1999. No 18(1). P. 54-64.

12. Gold J. Psychology and Geography: Foundations of Behavioural Geography. Moscow: Progress, 1990. 304 p. (in Russian).

13. Hackney C., Clayton A. Unmanned aerial vehicles (UAVs) and their application in geomorphic mapping. Geomorphological Techniques, 2015. Chap. 1. Sec. 1.7. P. 1-12.

14. Hettner A. Geography. Her history, essence and methods. Moscow; Leningrad: State publishing house, $1930.416 \mathrm{p}$.

15. Humboldt A. Pictures of nature. Moscow: Geografgiz, 1959. 270 p.

16. Kalutskova N.N., Safonova A.A., Smorzhok M.A. Assessment of the natural attractiveness of the tourist routes of the Belogradchik rocks (Bulgaria). Forest ecosystems and urbanization. Moscow: KMK Scientific Press Ltd., 2008. P. 219-225 (in Russian).

17. Kalutskova N.N., Sinovski D., Dronin N.M., Sinovska D., Sheremet E.A. Experience of nomination of geological parks into the UNESCO global network. Bulletin of the Moscow Region State University. Series: Natural Sciences, 2019. No 2. P. 80-93. DOI: 10.18384/2310-7189-2019-2-80-93 (in Russian).

18. Kochurov B.I., Buchatskaya N.V. Assessment of aesthetic potential of the landscape. South of Russia: ecology, development, 2007. V. 2. No 4. P. 25-34. DOI: 10.18470/1992-10982007-4-25-34 (in Russian).

19. Nikolaev V.A. Landscape Science: Aesthetics and Design. Moscow: Aspect Press Publishing House, 2005. 176 p. (in Russian).

20. Norberg-Schultz C. Life takes place. News of higher educational institutions. Architecton, 1995. No 1-2. P. 24-31. (in Russian).

21. Rotanova I.N., Vasilyeva O.A. Aesthetic attractiveness assessment of the natural park "Foothills of the Altai" landscapes with use geoinformation technologies. Journal Science and Tourism: Interaction Strategies. Barnaul: Altai University Publishing House, 2017. V. 7 (5). P. 29-36 (in Russian).

22. Semenov-Tyan-Shansky V.P. Region and country. Moscow; Leningrad: State publishing house, 1928. 311 p. (in Russian).

23. Shaoyu L., Weijie D., Yongbo Y. Application of UAV oblique photograph modeling technology in mountain tourism planning. 3rd International Symposium on EEEMS. Francis Academic Press, 2018. P. 240-245.

24. Sheremet E.A., Dekhnich V.S., Kalutskova N.N. Perspectives of GIS-technology application for visual evaluation of landscapes for organization of geopark. Bulletin of the Russian Geographical Society, 2020. V. 152. No 6. P. 69-78. DOI: 10.31857/S0869607120060063.

25. Shiou Y., Chengju D., Zhihui C., Hao W., Kailang G., Yirong L., Yongjie C., Wenyan L., Qiang F., Wenbo L. Assessing safety and suitability of old trails for hiking using ground and drone surveys. International Journal Geo-Informational, 2020. V. 9. Iss. 4. P. 1-17.

26. Tronkov D. Belogradchik Rock Sculptures - a child of erosional power of nature and of geological controls. Geologica Balc., 1998. V. 3 (4). No 28. P. 153-158.

27. Tronkov D., Sinnyovsky D. Belogradchik rocks in Bulgaria - geological setting, genesis and geoconservation value. Geoheritage, 2012. V. 4. No 3. P. 153-164. 


\title{
А.А. Кадочников ${ }^{1}$
}

\section{РАЗРАБОТКА СИСТЕМЫ СБОРА ДАННЫХ ДЛЯ МОНИТОРИНГА СОСТОЯНИЯ АТМОСФЕРНОГО ВОЗДУХА В КРАСНОЯРСКОМ КРАЕ}

\begin{abstract}
АННОТАЦИЯ
Загрязнение атмосферного воздуха представляет угрозу для природной среды и здоровья людей. В России существует система федерального мониторинга атмосферного воздуха, обеспечивающая его оценку по ряду характеристик, а также дающая прогноз и предписания для органов власти. В России и во многих европейских странах помимо мониторинга качества атмосферного воздуха, осуществляемого федеральными организациями, осуществляется и общественный мониторинг, производимый независимыми организациями и заинтересованными гражданами. Общественный мониторинг и доступность простых средств для измерения качества воздуха в последние годы привело к возникновению альтернативной сети, позволяющей получить доступные и более детальные данные. Результаты измерений в упрощенной форме доступны большому числу людей, что вызывает широкий резонанс среди населения в ряде регионов страны.

В работе рассматривается задача разработки и поддержки специализированной системы для экологического мониторинга состояния природной среды и ресурсов, построенной на основе технологий ГИС, Интернет, обработки данных дистанционного зондирования (ДДЗ) и данных со стационарных и подвижных станций наблюдения. Существенное внимание уделяется веб-сервисам и программным интерфейсам. Рассматривается задача формирования геоинформационной веб-системы мониторинга состояния окружающей природной среды для систем поддержки принятия решений на уровне Красноярского края. Важную роль играет использование современных средств визуализации данных с использованием ГИС-технологий. Основное внимание уделяется описанию проблем и решений, связанных с разработкой веб-сервисов и приложений для таких Интернет-систем.

Решение задачи сбора, обработки и оперативной оценки данных о загрязнении атмосферного воздуха рассмотрено на примере Красноярского края и города Красноярска, попавшего в список наиболее загрязненных городов страны. Однако предложенное решение может быть использовано и в других городах и регионах.
\end{abstract}

КЛЮЧЕВЫЕ СЛОВА: ГИС, веб-сервисы, система мониторинга, атмосферный воздух, данные наблюдения.

1 Институт вычислительного моделирования СО РАН, Академгородок 50/44, 660036, Красноярск, Россия, e-mail: scorant@icm.krasn.ru 


\title{
Alexey A. Kadochnikov ${ }^{1}$ \\ DEVELOPMENT OF DATA COLLECTION SYSTEM FOR MONITORING THE ATMOSPHERIC AIR STATE IN KRASNOYARSK REGION
}

\begin{abstract}
Air pollution is a threat to the natural environment and human health. In Russia, there is a federal monitoring system for atmospheric air, which provides its assessment for a number of characteristics, as well as provides a forecast and prescriptions for government. In Russia and in many European countries, in addition to monitoring the quality of atmospheric air carried out by federal organizations, public monitoring is also carried out by independent organizations and interested residents of settlements. Public monitoring and the availability of simple air quality measurement tools in recent years has led to the emergence of an alternative network that provides accessible and more detailed data. The measurement results in a simplified form are available to a large number of peoples, which causes a wide resonance among the population in a number of regions of the country.

The paper considers the task of developing and supporting a specialized system for environmental monitoring of the state of the natural environment and resources, built on the basis of GIS technologies, the Internet, processing remote sensing data and data from stationary and mobile observation stations. Considerable attention is paid to web services and APIs. The problem of the formation of a geoinformation web-system for monitoring the state of the natural environment for the decision-making support system at the level of the Krasnoyarsk region is considered. An important role is played by the use of modern data visualization tools using GIS technologies. The main focus is on describing the problems and solutions associated with the development of web services and applications for such Internet systems.

The solution to the problem of collecting, processing and efficiently assessing data on air pollution is considered on the example of the Krasnoyarsk region and the city of Krasnoyarsk, which is included in the list of the most polluted cities in the country. However, the proposed solution can be used in other cities and regions.
\end{abstract}

KEYWORDS: GIS, web-services, monitoring system, atmospheric air, observation data.

\section{ВВЕДЕНИЕ}

На территории Красноярского края первые наблюдения за состоянием окружающей среды начались в 1950 году с изучения химического состава поверхностных вод в пунктах, расположенных в наиболее густонаселенных районах. Рост промышленного потенциала и освоение природных ресурсов дали дальнейший толчок в развитии сети наблюдений за состоянием окружающей среды и в 1965 году начались работы по изучению загрязнения воздушного бассейна в Красноярске 2 .

Наблюдения за загрязнением атмосферного воздуха проводится в городе Красноярске на 8 стационарных постах подразделения ФГБУ «Среднесибирское УГМС» (аккредитованный территориальный Центр по мониторингу загрязнения окружающей среды), который работает в соответствии с требованиями РД 52.04.186-89. Оценка уровня загрязнения атмосферного воздуха по городам края проводится по 27 вредным веществам

\footnotetext{
1 Institute of Computational Modelling of the Siberian Branch of the Russian Academy of Sciences, Akademgorodok 50/44, 660036, Krasnoyarsk, Russia, e-mail: scorant@icm.krasn.ru

2 Территориального Центр по мониторингу загрязнения окружающей среды. Электронный ресурс: http:// meteo.krasnoyarsk.ru/Центрмониторинга/tabid/218/Default.aspx (дата обращения 02.04.2021)
} 
и осуществляется прогнозирование загрязнения атмосферного воздуха. Территориальный Центр регулярно информирует администрацию Красноярска и промышленные предприятия краевого центра о возникновении неблагоприятных метеорологических условий, способствующих накоплению вредных примесей в атмосферном воздухе, для дальнейшего принятия мер промышленными предприятиями по регулированию выбросов в атмосферу.

Однако для полноценной оценки состояния атмосферного воздуха и дальнейшего анализа причин и последствий недостаточно 8 стационарных постов федерального подразделения для города с населением более одного миллиона человек. Вместе с федеральной системой мониторинга в Красноярске и крае существует краевая ведомственная информационно-аналитическая система данных о состоянии окружающей среды Красноярского края (КВИАС). Эта система включается в себя подсистему мониторинга воздуха по данным 12 стационарных постов, 9 из которых находятся в Красноярске и его окрестностях. В последние годы в дополнение к федеральной и краевой системе появилось две системы общественного мониторинга и одна система на базе Федерального исследовательского центра «Красноярский научный центр Сибирского отделения Российской академии наук» (ФИЦ КНЦ СО РАН). В общей сумме в этих системах ведется мониторинг за атмосферным воздухом с десятков стационарных постов на территории города и края. Фрагмент карты с постами наблюдений на территории Красноярска и окрестности представлен на рисунке 1.

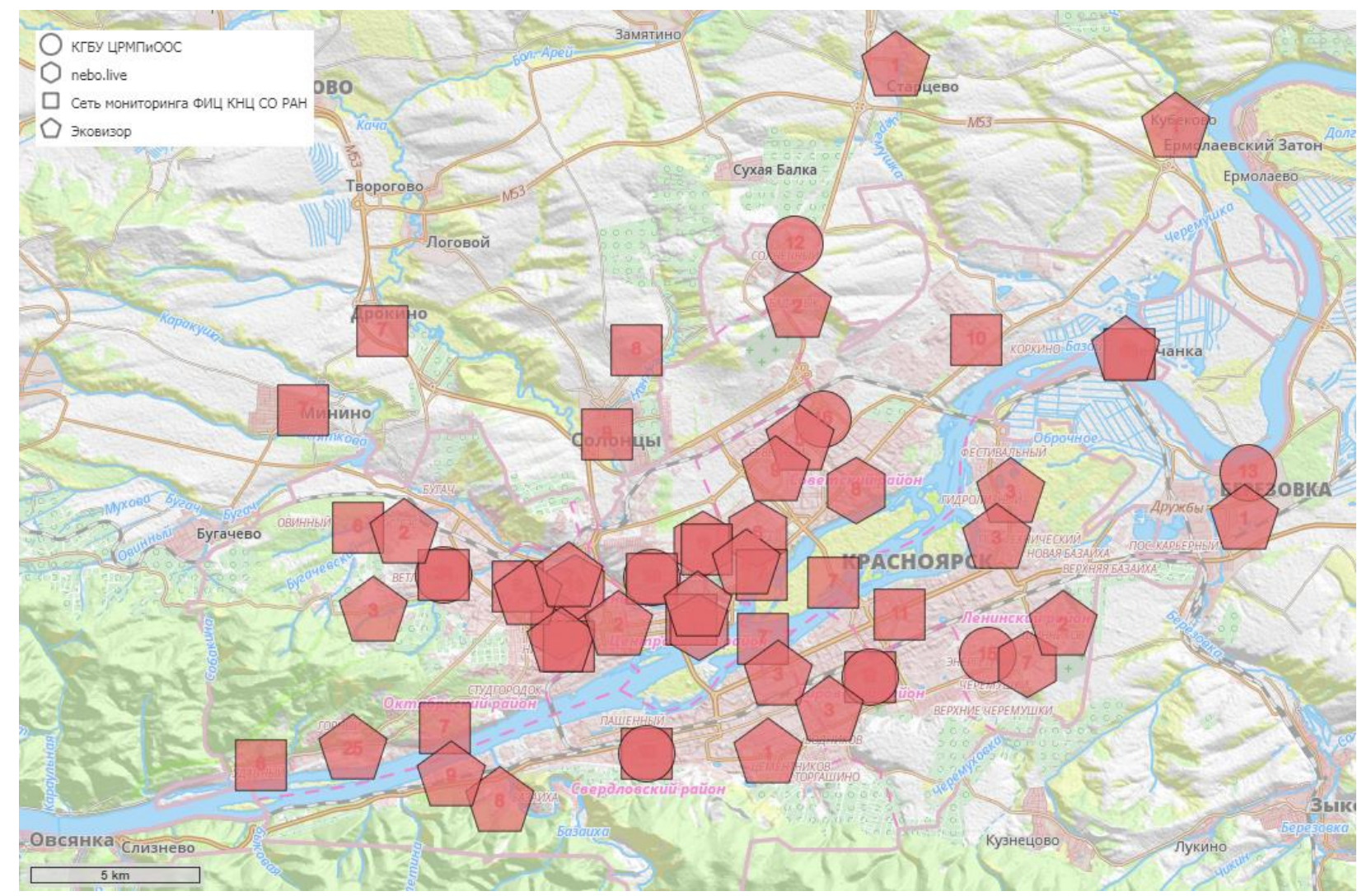

Рис. 1. Схема расположения постов наблюдений в Красноярске Fig. 1. Scheme of observation posts in Krasnoyarsk

По данным Государственного доклада «О состоянии и охране окружающей среды в Красноярском крае в 2019 году», опубликованного осенью 2020 года, в 2019 году уровень загрязнения Красноярска характеризуется как «высокий». Комплексный индекс 
загрязнения атмосферы ИЗА5 меньше 13, стандартный индекс (СИ) - 22,0 (по бенз(а)пирену), наибольшая повторяемость (НП) превышения ПДКм.р. - 9,0 \% (по формальдегиду). Основной вклад в уровень загрязнения внесли взвешенные вещества, диоксид азота, аммиак, формальдегид, бенз(а)пирен. В атмосфере города в 2019 г. зафиксированы случаи превышений: ПДКм.р. по взвешенным веществам, оксиду углерода, диоксиду и оксиду азота, фенолу, фториду водорода, хлориду водорода, формальдегиду, ксилолу и этилбензолу ${ }^{1}$.

Наиболее высокие значения СИ отмечались в холодное время года. Максимум был зафиксирован в январе $(22,0)$. Теплый период года характеризовался высокими значениями НП (\%), наибольшая повторяемость отмечалась в июне - 38,5 \%.

В зимнее время в Красноярске периодически вводится режим неблагоприятных метеорологических условий (НМУ) на протяжении многих лет. Определение периода действия и категории режима НМУ находится в ведении Федеральной службы по гидрометеорологии и мониторингу окружающей среды, в обязанность которой входит оповещение предприятий о наступлении и завершении периода НМУ и категории режима НМУ. В соответствии со статьей 19 Федерального закона «Об охране атмосферного воздуха» № 96-Ф3 юридические лица, имеющие источники выбросов вредных (загрязняющих) веществ в атмосферный воздух, при получении прогнозов НМУ обязаны проводить мероприятия по уменьшению выбросов вредных (загрязняющих) веществ в атмосферный воздух.

Расширение сети мониторинга и сбор данных в единую систему позволит создать модель по прогнозированию загрязнений и значительно улучшить алгоритм по выявлению точечных источников загрязнения.

\section{МАТЕРИАЛЫ И МЕТОДЫ ИССЛЕДОВАНИЯ}

Для анализа данных и создания модели по прогнозированию загрязнений атмосферного воздуха в крае важную роль играет система сбора оперативных данных наблюдения от различных веб-сервисов, станций наблюдения и датчиков [Yakubailik, 2018]. В рамках геопортала Института вычислительного моделирования СО РАН (ИВМ CO РАН), работа над которым ведется уже много лет, разработан блок для сбора, обработки и представления данных различных наблюдений со стационарных постов. Организован доступ к данным наблюдений с помощью стандартных средств геопортала, включающих набор веб-сервисов, экспорт, просмотр табличных данных и диаграмм, просмотр данных на картах с возможностью выбора временных интервалов и организован доступ с помощью общепринятых стандартов и технологий.

Уже несколько лет сотрудниками ИВМ СО РАН продолжается работа по поддержке и развитию системы сбора оперативной информации о состоянии атмосферного воздуха в городе Красноярск и Красноярском крае. Сбор оперативных данных для научных исследований и мониторинга состояния атмосферного воздуха осуществляется в единую систему «Данные оперативного мониторинга» Института вычислительного моделирования СО РАН (http://sensor.krasn.ru/sc/).

На начало 2021 года реализован сбор оперативных данных по атмосферному воздуху в Красноярском крае с нескольких источников и созданы следующие разделы:

- Система мониторинга состояния атмосферного воздуха ФИЦ КНЦ СО РАН.

- Подсистема мониторинга атмосферного воздуха КВИАС КГБУ «ЦРМПиООС».

Государственный доклад «О состоянии и охране окружающей среды в Красноярском крае в 2019 году», Красноярск, 2020. Министерство экологии и рационального природопользования Красноярского края. Электронный ресурс: http://www.mpr.krskstate.ru/envir/page5849/0/id/45884 (дата обращения 02.04.2021). 
- $\quad$ Данные системы мониторинга ФГБУ «Среднесибирское УГМС».

- $\quad$ Оперативные данные метеонаблюдений СИНОП.

- $\quad$ Данные проекта Krasnoyarsk.nebo.

- Данные проекта Эковизор.

- $\quad$ Данные с ряда метеостанций и беспилотных летательных аппаратов (БПЛА).

На старте создания системы данные об атмосферном воздухе загружались из федеральной и краевой сети постов наблюдения. Данные федеральной сети формируются на основе данных, полученных с сайта ФГБУ «Среднесибирское УГМС» (http://meteo.krasnoyarsk.ru/). Метеоданные, поступающие в реальном времени от автоматических станций, размещаются в единой системе с частотой 1-3 часа. Данные собираются по следующим показателям: атмосферное давление, влажность, направление ветра, скорость ветра, температура воздуха. Архив ведется с начала 2013 года. Данных по загрязняющим веществам в открытом доступе нет.

Данные краевой сети формируются из Краевой ведомственной информационноаналитической системы о состоянии окружающей среды Красноярского края. Наблюдения за качеством атмосферного воздуха в Красноярском крае проводятся на 12 автоматизированных постах наблюдений (АПН). Большинство загружаемых данных по стационарным постам наблюдения на удаленном сервере формируются каждые 20 минут. Помимо метеоданных доступны данные по большому числу загрязняющих веществ, включая данные по содержанию взвешенных частиц.

Осуществляется сбор данных с собственной сети станций Федерального исследовательского центра «КНЦ СО РАН». Данные собираются с 24 постов с помощью API для доступа к данным устройств измерений автоматизированной информационной системы мониторинга качества воздуха. Интервал сбора данных для большинства приборов пять минут, для остальных одна минута. Приборы разработаны платформой «CityAir» (https://cityair.io/) и позволяют получать данные измерений содержания взвешенных веществ в атмосферном воздухе $\left(\mathrm{PM}_{2.5}, \mathrm{PM}_{10}\right)$ и основные метеорологические параметры за исключением данных о ветре: температура, влажность и атмосферное давление.

Собираются данные двух общественных проектов. Данные проекта Nebo community (https://nebo.live), созданного активистами из Красноярска. И данные открытой экологической платформы «Российские зеленые», проект «Эковизор» (http:// online.russiangreens.ru). Оба проекта осуществляют сбор с приборов данных измерений содержания взвешенных веществ в атмосферном воздухе $\mathrm{PM}_{2.5}$ и основных метеорологических параметров: температуру, влажность и атмосферное давление. Часть приборов проекта «Эковизор» оборудованы анемометрами, что позволяет получать информацию о ветре.

В среднем около двух раз в неделю сотрудниками лаборатории ФИЦ КНЦ СО РАН выполняются полеты с помощью квадрокоптера с датчиками метеоданных (температура, влажность, атмосферное давление) и датчиком концентрации мелкодисперсных взвешенных частиц $\mathrm{PM}_{2.5}$ над Красноярском и рекой Енисей. Полеты выполняются при погоде, позволяющей эксплуатацию БПЛА (отсутствие сильного ветра, осадков и ограничение по температуре воздуха). Полеты осуществляются вдоль и поперек русла реки Енисей на определенной высоте, а также проводятся измерения в вертикальном направлении на разных высотах в разных точках города. Дополнительно измеряются метеоданные, включая данные по ветру, в месте взлета БПЛА.

Разработана общая единая система с набором модулей для загрузки данных с перечисленных выше систем для дальнейшего доступа к этим данным. Общая схема сбора данных представлена на рисунке 2. Данные в систему поступают из различных архивов 
(файлы, базы данных) при разовой загрузке, данные передаются от различных вебсервисов и постов мониторинга, данные периодически загружаются по запросу от самой системы, данные загружаются с постов мониторинга и с БПЛА без возможности удаленной передачи данных по Интернет-каналу.

Недостатком существующей сети станций ФИЦ КНЦ СО РАН и станций общественных проектов для дальнейших научных исследований является отсутствие метеорологических данных по ветру (скорость и направление). В связи с этим был организован сбор метеорологических данных, включающих данные о ветре (скорость и направление). Была установлена на здании Института и организован сбор данных с сертифицированной метеостанции DAVIS Vantage Pro2, запущенной в эксплуатацию в 2020 году. Разработан комплекс новых модулей для сбора данных из различных открытых источников. На основе Python библиотеки PyVantagePro (https:// pyvantagepro. readthedocs.io/), обеспечивающий низкоуровневый доступ к потоку данных с консоли метеостанции, разработан комплекс программ для сбора, настройки и калибровки данных. Необходимость в разработке возникла в связи с тем, что собственное программное обеспечение метеостанции работало только под операционной системой Windows и не позволяло напрямую загружать данные в нашу систему. Данные формируются с шагом раз в 10 минут и загружаются в систему раз в час.

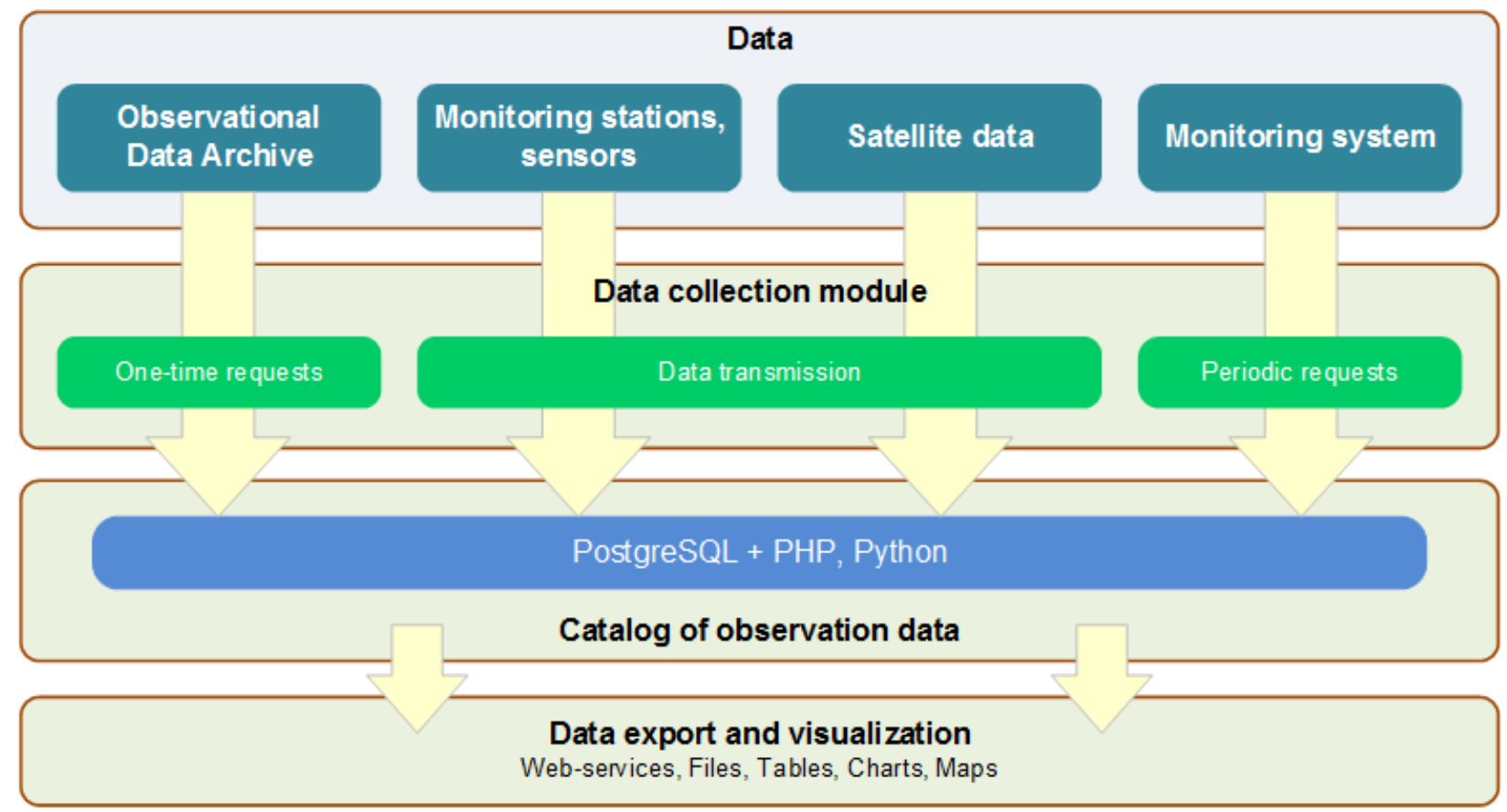

Рис. 2. Схема сбора данных наблюдений

Fig. 2. Observational data collection scheme

Для проведения Зимней универсиады 2019 в Красноярске была создана комплексная система ее метеорологического обеспечения, соответствующая требованиям международной федерации студенческого спорта (FISU), международных и общероссийских федераций по зимним видам спорта, а также уровню проведения подобных мероприятий. Точное определение текущей погоды на трассах осуществлялось с 11 автоматических метеорологических станций (AMC) производства Vaisala. AMC комплектовались широким набором датчиков, включающие данные по ветру. Данные от АМС поступали в 10-минутном режиме в Центр сбора данных наблюдений, расположенный в Среднесибирском УГМС (http://www.meteorf.ru/press/news/18967/). 
Удалось организовать сбор этих данных на сервер сбора данных наблюдений ИВМ СО РАН. Для этого было разработано программное обеспечение, позволяющее оперативно получать метеоданные с этих станций. Данные можно получать только в онлайн режиме без возможности загрузить архив. В связи с этим был расширен набор инструментов системы для оперативного обнаружения проблем со сбором данных, т.к. при простое системы или отсутствия связи данные терялись. Доступ был организован к трем станциям с выносными модулями, что позволило получать метеорологическую информацию в 9 точках. Это станции на таких объектах, как Академия Биатлона, комплексы «Сопка» и «Радуга». Метеостанция в парке «Бобровый лог» на момент старта сбора данных уже не функционировала. Станция в кластере «Сопка» на данный момент также не работает. С остальных станции данные сохраняются. Данные собираются с шагом 10 минут.

Был организован сбор данных авиационных метеорологических кодов METAR (METeorological Aerodrome Report), используемых для обмена метеорологической информацией между метеорологическими подразделениями гражданской авиации. Разработан программный модуль для сбора таких данных на территории Красноярского края и Хакасии. Сводки в коде METAR содержат данные о скорости и направлении ветра, дальности видимости, атмосферных явлениях, облачности, температуре воздуха, точке росы, атмосферном давлении. Сводки в коде METAR используются пилотами во время предполетной подготовки в метеорологической службе аэродрома вылета, а также могут использоваться при комплексном анализе данных по атмосферному воздуху в Красноярске. Регулярные наблюдения на аэродромах доступны по региональному аэро-навигационному соглашению с шагом в 30 минут.

Разработан модуль для сбора оперативных данных метеонаблюдений FM-12 IX SYNOP, включающих данные о ветре, температуре воздуха, видимость и др. Данные загружаются с портала ЕСИМО (межведомственная информационная система для доступа к ресурсам морских информационных систем и комплексного информационного обеспечения морской деятельности). ЕСИМО разрабатывается в рамках Федеральной целевой программы «Мировой океан» Информация SYNOP собирается более чем 7600 пилотируемыми и автоматическими метеорологическими станциями и более чем 2500 подвижными станциями по всему миру и используется для прогнозирования погоды и климатической статистики. Данные собираются по метеостанциям на территории Красноярского края и соседних с ним регионам.

Дополнительно был разработан модуль для загрузки архивных данных метеонаблюдений по ряду метеостанций на территории Красноярского края за 20ый век. Данные были загружены из системы NOAA's National Centers for Environmental Information (NCEI), которая хранит и предоставляет открытый доступ к одному из самых больших архивов экологических данных (https://gis.ncdc.noaa.gov/maps/ncei/cdo/hourly). Набор данных Integrated Surface Dataset (ISD) состоит из наблюдений за приземной погодой со всего мира с более чем 35000 станций. Включенные параметры: качество воздуха, атмосферное давление, температура / точка росы атмосферы, атмосферные ветры, облака, осадки, приливы и многое другое. ISD содержит данные в цифровой базе в формате, в котором хранятся ежечасные, синоптические (3-часовые) и ежедневные наблюдения за погодой. Формат данных соответствует Федеральным стандартам обработки информации (FIPS). ISD предоставляет доступ к данным, которые можно использовать в широком диапазоне климатологических приложений. Загруженный архив содержит данные за разные промежутки времени по всем доступным метеостанциям на территории Красноярского края. 
Для изучения влияния работы Красноярской ГЭС на атмосферный воздух в городе Красноярск разработан модуль для сбора данных, передаваемых Красноярской ГЭС, включая данные по температуре воды и объемам водосброса. Модуль работает в пассивном режиме и загружает данные в нашу систему сбора данных наблюдений по запросу сервиса со стороны Красноярской ГЭС.

Дополнительно для ряда других научных исследований организован сбор некоторых наборов данных:

- $\quad$ ежедневные данные наблюдений на гидрологических постах в Красноярском крае;

- $\quad$ климатические данные GSOD на территорию Красноярского края;

- $\quad$ база данных ГИС мониторинга состояния окружающей природной среды в зоне действия предприятий нефтегазовой отрасли Красноярского края за 2009-2010 гг.;

- $\quad$ и др.

\section{РЕЗУЛЬТАТЫ ИССЛЕДОВАНИЯ И ИХ ОБСУЖДЕНИЕ}

В рамках исследования уделено внимание проблеме, возникающей при разработке совместных проектов различных общественных организаций, научных институтов и подразделений органов власти, связанной с обменом данными и метаданными о пространственной информации, а также данными наблюдений за окружающей средой. Коллективом сотрудников Института вычислительного моделирования СО РАН разработана и развивается технология организации хранилища пространственной информации для более эффективного взаимодействия различных организаций. Разработаны программные средства для анализа пространственных данных в среде геопортала ИВМ CO РАН с использованием открытого программного обеспечения и технологий, предлагаемых международным консорциумом Open Geospatial Consortium (OGC) [Botts, 2006; Boulos, 2011].

При разработке инструментальных средств программные блоки были разбиты на несколько групп по способу загрузки и обработки данных из внешних источников:

1. Веб-сервисы - доступ к внешним данных организован с помощью вебсервисов, которые позволяют получать информацию в структурированном виде, обычно в форматах json, xml или csv [Manuel, 2017]. Такие данные легко обрабатывать, т.к. существуют уже готовые библиотеки для работы с такими форматами данных и такие данные проще проверять на наличие ошибок [Schmitt, 2018]. Особым преимуществом является наличие дополнительных параметров у веб-сервиса, позволяющих применять некоторые фильтры при загрузке данных с ограничением по времени, постам, сенсорам и т.д. Однако не все сервисы имеют такие инструменты и в этом случае приходится решать задачу по хранению временных меток и разделению новой информации от загруженной ранее.

2. Служебные веб-сервисы - такие сервисы обычно используются мобильными платформами или различными веб-приложениями для обеспечения работы своего функционала в интерактивном режиме. Например, веб-сервисы для построения вывода табличных данных или создания графиков и диаграмм в веб-интерфейсе с использованием клиентских языков программирования, инструменты экспорта данных и др. Такие сервисы тоже можно использовать для извлечения данных [Azemov, 2016]. При этом необходимо разработать ряд инструментов для проверки и анализа таких данных: проверка изменения структуры данных, изменение внутренних идентификаторов, доступность сервиса, формат вывода данных, размерность данных и т.д.

3. Обычный веб-сайт - данные наблюдений формируются на сервере в виде статичной информации и представлены в формате html страницы Интернет-ресурса. Для извлечения таких данных требуется выполнять периодическую загрузку html страницы и 
обычно нет возможности получить архив за определенный период времени, только текущие данные. Но бывают ресурсы, которые содержат данные не только за текущий момент, но и за последние сутки. Основной задачей при загрузке таких данных является анализ страницы с целью поиска некоторых опорных текстовых блоков, с помощью которых можно всегда найти необходимую информацию на странице. В таком случае из страницы извлекается определенный текстовый блок и выполняется его дальнейшая обработка. Упрощает задачу схожесть xml и $\mathrm{html}$ форматов, что позволяет работать с фрагментами страницы, как с xml документом, что существенно упрощает извлечение информации.

4. Станция со своими интерфейсами доступа к потоку данных. Обычно подключение к станции осуществляется по СОМ (интерфейс стандарта RS-232), USB (Universal Serial Bus) или Ethernet (пакетная технология передачи данных по Интернет сети) портам [Man Sing Wong, 2014], [Shifeng Fang, 2014]. Для извлечения таких данных используется программные модули, позволяющие напрямую работать с потоком данных из самого устройства. Обычно станции позволяют хранить некоторый объем данных за ограниченный период времени на внутреннем носителе и позволяют его выгрузить.

Общая схема сбора данных представлена на рисунке 3. В ряде случаев может использоваться комбинация из перечисленных групп, т.к. для работы некоторых служебных сервисов может понадобиться информация, содержащаяся в самой странице, для которой эти сервисы создавались. Отдельное внимание необходимо уделить целостности и структурным изменениям в данных. Для этого разрабатывается серия блоков проверки, включающая изменение количества датчиков и постов наблюдения, целостность и полноту переданных данных и др.

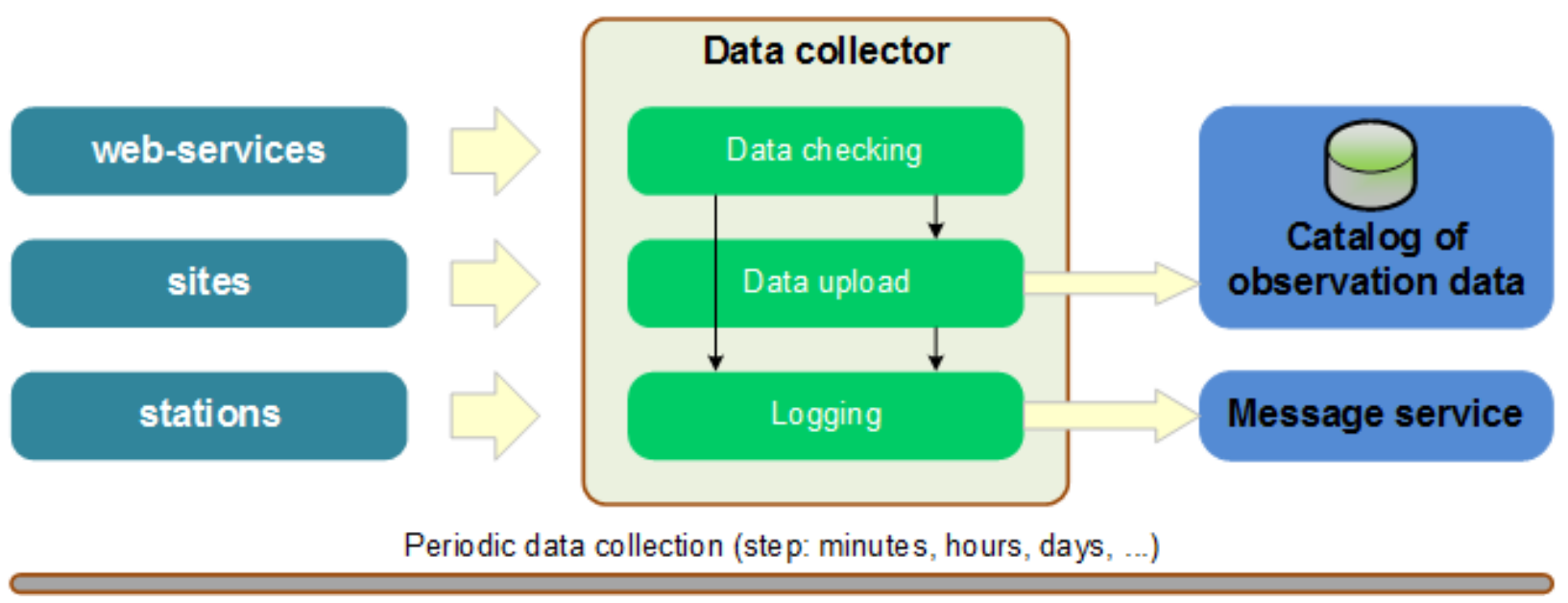

Рис. 3. Схема обработки поступающих данных мониторинга

Fig. 3. Scheme processing incoming data monitoring

В связи с большим количеством постоянных источников данных и объёмом самих данных, возникла необходимость в создании и дальнейшем развитии системы мониторинга загрузки и анализа ошибок в удобном виде для оперативного принятия решений и исправления ошибок. А также для отслеживания объема поступающих данных в систему. Для оперативной доработки программных модулей сбора данных созданы средства сбора текстовой информации о процессе работы модулей и инструменты оповещения оператора. Такие средства позволять получать информацию об изменениях на удаленном ресурсе и его состоянии постоянно. Оперативно внося исправления в программный код, можно обеспечить целостность и корректность полученной информации. Системой формируется ежедневный отчет по работе системы сбора. Предусмотрен механизм информирования 
оператора системы по электронной почте (рис. 4). Такое решение повышает качество инструментов и сервисов для разработки систем мониторинга окружающей природной среды и повышает стабильность и надежность работы системы в целом.

В системе разработан модуль для работы с данными различных беспилотных летательных аппаратов (БЛПА). Создан модуль для сбора официальных прогнозов погоды с федеральных и региональных ресурсов Служб по гидрометеорологии и мониторингу окружающей среды для текущих задач, связанных с полетами БЛПА, выполняемых сотрудниками ФИЦ «КНЦ СО РАН».

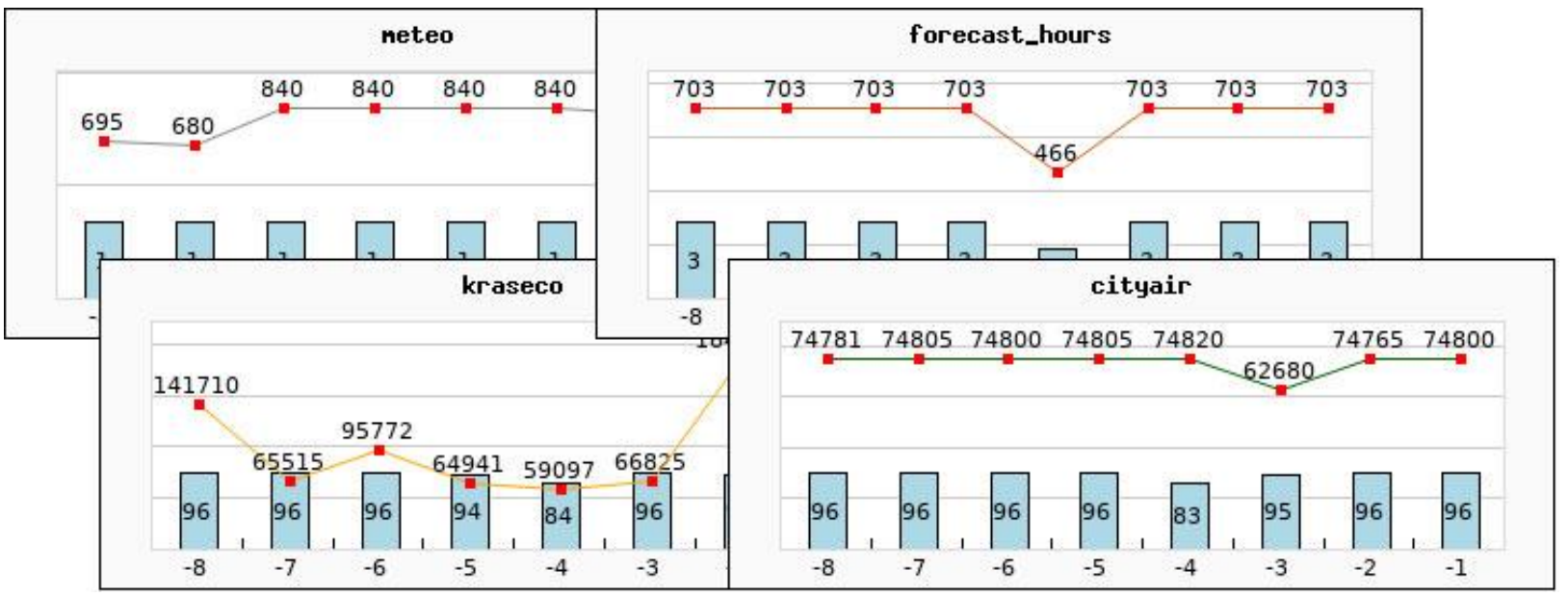

Pис. 4. Фрагмент отчета системы сбора данных

Fig. 4. Fragment of the data collection system report

Сбор данных измерений содержания взвешенных веществ в атмосферном воздухе $\left(\mathrm{PM}_{2.5}, \mathrm{PM}_{10}\right)$ и основных метеорологических параметров: температуры, влажности и атмосферного давления с приборов ФИЦ КНЦ СО РАН осуществляется на протяжении трех лет и в декабре 2019 был запущен сайт с оперативной информацией по состоянию атмосферного воздуха, доступный по адресу http://air.krasn.ru/.

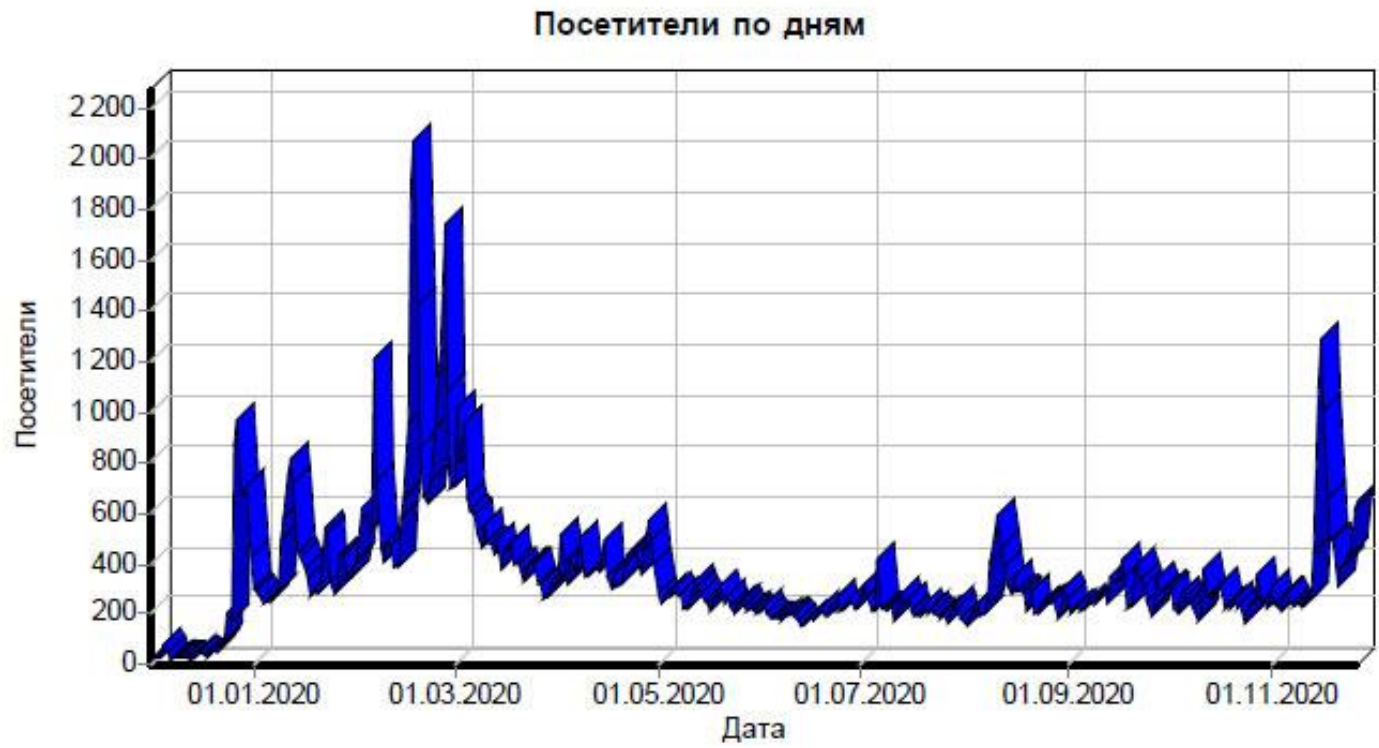

Рис. 5. Посещземость сайта проекта air.krasn.ru

Fig. 5. Website traffic air.krasn.ru 
На рисунке 5 представлена диаграмма посещаемости сайта. С момента первого запуска и до окончания зимы в 2020 году наблюдался интерес к сайту со стороны обычных пользователей. В основном это связано с установкой НМУ в городе Красноярск. Периоды режима НМУ в основном объявлялись в зимние месяцы. В 2020 году предупреждения были объявлены 10.01, 14.02, 17.02, 25.02, 27.04, 16.11, 27.11, 25.12, $29.12,30.12^{1}$.

На диаграмме посещаемости сайта проекта видно совпадение интереса со стороны пользователей к проекту в дни НМУ. Начиная с первого сентября 2020 года оперативные данные с сайта ежедневно в будние дни транслирует одна из телекомпаний города Красноярск в рубрике после вечерних новостей. Однако это никак не отразилось на посещаемости сайта.

Все данные наблюдений имеют пространственную привязку. Доступ к данным наблюдений из единой системы организован с помощью веб-сервисов, что позволяет использовать их в сторонних системах. Геопортал ИВМ СО РАН (http://gis.krasn.ru/) имеет встроенную поддержку веб-сервисов и набор инструментов для представления данных из нескольких источников на карте с инструментами для их анализа. С использованием вебсервисов системы разработан ряд проектов с данными наблюдений, включая сайт с оперативной информацией об атмосферном воздухе в Красноярске и других городах и муниципальных образованиях Красноярского края (http://air.krasn.ru/). Инструменты экспорта в Microsoft Excel позволяют загружать данные за выбранный промежуток времени в исходном и агрегированном формате, что позволяет пользователям работать с данными в удобном для них программном обеспечении.

Приложения геоинформационной системы разработаны в архитектурных схемах «клиент - сервер» и «клиент - сервер приложений - сервер» с использованием реляционной СУБД с расширением для хранения и обработки пространственных данных [Song, 2010]. Интеграционные сервисы разработаны в соответствии с общепринятыми подходами на разработку веб-сервисов, работающих на принципах REST и SOAP.

B результате проведенных исследований и многолетнего опыта решение было построено на основе свободно распространяемых технологий и программного обеспечения:

- платформа для публикации картографических данных - MapServer 7 (http:// www.mapserver.org);

- основной язык разработки - PHP 7 (http://www.php.net) и Python 3 (https:// www.python.org);

- СУБД PostgreSQL 12 (http://www.postgresql.org) с расширением PostGIS 3.0 (http:// www.postgis.org).

\section{ВЫВОДЫ}

Сегодня существует ряд систем для сбора и представления данных мониторинга атмосферного воздуха. Ряд проектов позволяет загружать данные с пользовательских устройств по заданному протоколу и затем просматривать их на общей карте. К таким проектам можно отнести немецкие проекты LuftDaten (https://luftdaten.info) и OpenSenseMap (https://opensensemap.org/), Российские проекты «Народный мониторинг» (https://narodmon.ru/), проект экологической группы «Челябинск, Дыши!» (https:// aircms.online/, https://chelbreathe.ru). Другие проекты собирают данные со станций определенных производителей, например, проект "World Air Quality Index" (https://

Оповещение о наступлении НМУ в 2020 году на территории города. Электронный ресурс: http://www. admkrsk. ru/citytoday/ecology/Pages/NMU.aspx (дата обращения 01.04.2021) 
aqicn.org/map/krasnoyarsk/ru/), включающий данные со станций по всему Миру. Существует «Единая информационная система мониторинга загрязнения атмосферного воздуха г. Красноярска» (http://www.feerc.ru/uisem/krasnoyarsk/) от научно-производственного объединение «Тайфун», объединяющая данные краевой и федеральной системы мониторинга в Красноярске, однако эта система частично не работает.

В работе было предложено решение, которое позволило собирать все данные в одном хранилище с возможностью дальнейшего анализа. Комплекс предлагаемых решений успешно зарекомендовал себя как программно-технологическая основа для информационно-аналитических систем регионального уровня. Рассмотренное решение может быть использовано не только для территории Красноярского края, но и в других городах и регионах. В начале апреля 2021 года между министерством экологии Красноярского края, Сибирским отделением РАН и общественными организациями было достигнуто соглашение о создании единой системы мониторинга атмосферного воздуха ${ }^{1}$.

\section{СПИСОК ЛИТЕРАТУРЫ}

1. Azemov D. Saint-Petersburg air pollution monitoring system. Environment of SaintPetersburg, 2016. V. 2 (2). P. 8-14.

2. Botts M., Percivall G., Reed C., Davidson J. OGC® Sensor Web Enablement: Overview and High Level Architecture. In: Nittel S., Labrinidis A., Stefanidis A. (eds) GeoSensor Networks. GSN 2006. Lecture Notes in Computer Science. V. 4540. Springer, Berlin, Heidelberg.

3. Kamel Boulos, Bernd Resch, David N Crowley, John G Breslin, Gunho Sohn, Russ Burtner, William A Pike, Eduardo Jezierski, Kuo-Yu Slayer Chuang. Crowdsourcing, citizen sensing and sensor web technologies for public and environmental health surveillance and crisis management: trends, OGC standards and application examples. International Journal of Health Geographics, 2011. 10:67.

4. Man Sing Wong, Tsan Pong Yip, Esmond Mok. Development of a Personal Integrated Environmental Monitoring System. Sensors. 2014. V. 14. P. 22065-22081. DOI: $10.3390 / \mathrm{s} 141122065$.

5. Manuel A. Regueiro, José R.R. Viqueira, Christoph Stasch, José A. Taboada. Semantic mediation of observation datasets through Sensor Observation Services. Future Generation Computer Systems. 2017. V. 67. P. 47-56.

6. Schmitt R.H. and Voigtmann C. Sensor information as a service - component of networked production. J. Sens. Sens. Syst. 2018. V. 7. P. 389-402.

7. Shifeng Fang, Li Da Xu, Yunqiang Zhu, Jiaerheng Ahati, Huan Pei, Jianwu Yan, Zhihui Liu. An Integrated System for Regional Environmental Monitoring and Management Based on Internet of Things. IEEE Transactions on Industrial Informatics, 2014. V. 10 (2). DOI: 10.1109/TII.2014.2302638.

8. X. Song, C. Wang, M. Kagawa, V. Raghavan. Real-time monitoring portal for urban environment using sensor web technology. 18th International Conference on Geoinformatics, Beijing, China, 2010. P. 1-5, DOI: 10.1109/GEOINFORMATICS.2010.5568192.

9. Yakubailik O.E., Kadochnikov A.A., Tokarev A.V. Web geographic information system and the hardware and software ensuring rapid assessment of air pollution. Optoelectronics, Instrumentation and Data Processin. 2018. V. 54 (3). P. 243-249. 


\section{REFERENCES}

1. Azemov D. Saint-Petersburg air pollution monitoring system. Environment of SaintPetersburg, 2016. V. 2 (2). P. 8-14.

2. Botts M., Percivall G, Reed C, Davidson J. OGC® Sensor Web Enablement: Overview and High Level Architecture. In: Nittel S., Labrinidis A., Stefanidis A. (eds) GeoSensor Networks. GSN 2006. Lecture Notes in Computer Science. V. 4540. Springer, Berlin, Heidelberg.

3. Kamel Boulos, Bernd Resch, David N Crowley, John G Breslin, Gunho Sohn, Russ Burtner, William A Pike, Eduardo Jezierski, Kuo-Yu Slayer Chuang. Crowdsourcing, citizen sensing and sensor web technologies for public and environmental health surveillance and crisis management: trends, OGC standards and application examples. International Journal of Health Geographics, 2011. 10:67.

4. Man Sing Wong, Tsan Pong Yip, Esmond Mok. Development of a Personal Integrated Environmental Monitoring System. Sensors, 2014. V. 14. P. 22065-22081. DOI: 10.3390/s 141122065.

5. Manuel A. Regueiro, José R.R. Viqueira, Christoph Stasch, José A. Taboada. Semantic mediation of observation datasets through Sensor Observation Services. Future Generation Computer Systems, 2017. V. 67. P. 47-56.

6. Schmitt R.H. and Voigtmann C. Sensor information as a service - component of networked production. J. Sens. Sens. Syst., 2018. V. 7. P. 389-402.

7. Shifeng Fang, Li Da Xu, Yunqiang Zhu, Jiaerheng Ahati, Huan Pei, Jianwu Yan, Zhihui Liu. An Integrated System for Regional Environmental Monitoring and Management Based on Internet of Things. IEEE Transactions on Industrial Informatics, 2014. V. 10 (2). DOI: 10.1109/TII.2014.2302638.

8. Song X., Wang C., Kagawa M., Raghavan $V$. Real-time monitoring portal for urban environment using sensor web technology. 18th International Conference on Geoinformatics, Beijing, China, 2010. P. 1-5. DOI: 10.1109/GEOINFORMATICS. 2010. 5568192.

9. Yakubailik O.E., Kadochnikov A.A., Tokarev A.V. Web geographic information system and the hardware and software ensuring rapid assessment of air pollution. Optoelectronics, Instrumentation and Data Processing, 2018. V. 54 (3). P. 243-249. 


\title{
А.Г. Нарожняя ${ }^{1}$
}

\section{МОРФОМЕТРИЧЕСКИЙ АНАЛИЗ РЕЛЬЕФА БАССЕЙНОВ РЕК КРЫМА С ИСПОЛЬЗОВАНИЕМ ГИС}

\begin{abstract}
АННОТАЦИЯ
Для территории Крыма планируется разработать проекты бассейнового природопользования, важным этапом предпроектного обоснования которых является характеристика рельефа в пределах речных бассейнов. Для исследования использован программный комплекс ArcGIS 10.5. Инструменты поднабора «Гидрология», «Поверхность», «Зональные», «Алгебра карт» в автоматизированном режиме создают морфометрические характеристики рельефа, а их визуальное представление в среде ГИС позволяет устанавливать пространственные закономерности и обосновывать почвоводоохранные мероприятия. В качестве исходных данных выбраны данные Shuttle radar topographic mission разрешением 3 угловые секунды, которые соответствует масштабу исследования. Морфометрический анализ рельефа 1534 разнопорядковых бассейновых структур показал, что высота 64 \% бассейнов 3-6 порядков не превышает 300 м, для них выделены пять ступеней вертикального расчленения равнинных территорий. $37 \%$ бассейнов по вертикальному расчленению относятся к высокогорным территориям. В равнинной части Крыма, где развиты дефляционные процессы, средняя крутизна склона $1^{\circ}$, преобладают бассейны с поперечно-прямым продольно-прямым склонами, линейные рубежи на которых могут быть прямолинейными. На предгорных территориях в условиях сельскохозяйственного использования, к дефляции почв добавляются процессы водной эрозии, вызванные наличием длинных склонов с крутизной свыше $3^{\circ}$ со значениями рельефного фактора (LS) превышающими 2, а в отдельных сельскохозяйственных бассейнах средние значение рельефного фактора близки к критическому значению $-4,3$. На этих территориях преобладают поперечно-выпуклые склоны, для которых необходимо проектирование контурных линейных рубежей. В горной части Крыма густота речной сети в среднем составляет - 0,11 км/км ${ }^{2}$, но вследствие климатических, геоморфологических и почвенных условий перераспределение наносов идет в верхнем звене эрозионной сети (более развитой на территории полуострова). В равнинной части Крыма значения густоты речной сети не превышает 0,2 км/км².
\end{abstract}

КЛЮЧЕВЫЕ СЛОВА: морфометрический анализ рельефа, ЦМР, бассейн реки, бассейновое природопользование, ГИС.

\section{Anastasiya G. Narozhnyaya ${ }^{2,}$}

\section{MORPHOMETRIC ANALYSIS OF THE CRIMEAN RIVER BASINS RELIEF BY USING GIS}

\section{ABSTRACT}

It is planned to develop projects of basin nature management for the Crimean peninsula. The characteristics of the relief within the river basins is an important stage in the pre-project

1 Белгородский государственный национальный исследовательский университет, Институт наук о Земле, ул. Победы, д. 85, 308015, Белгород, Россия, e-mail: narozhnyaya_a@bsu.edu.ru

2 Belgorod National Research University, Institute of Earth Sciences, Pobedy, 85, 308015, Belgorod, Russia, e-mail: narozhnyaya_a@bsu.edu.ru 
justification. ArcGIS 10.5 is used for research. The tools of the subset "Hydrology", "Surface", "Zonal", "Algebra of maps" made it possible to create morphometric characteristics of the relief, and their visual representation in the GIS environment made it possible to establish spatial patterns and substantiate soil-water conservation measures. Shuttle radar topographic mission with a resolution of 3 arc seconds is selected as input data. Its resolution is consistent with the scale of the study. The morphometric analysis of the relief of 1534 different-order basin structures showed that the height of $64 \%$ of the 3-6-order basins does not exceed $300 \mathrm{~m}$; for them, five steps of vertical dissection of plain territories have been identified. $37 \%$ of the basins are vertically divided into high-mountainous areas. In the plain part of Crimea, where deflationary processes are developed, the average slope steepness is $1^{\circ}$, basins with transversely straight longitudinal-straight slopes prevail, the linear boundaries on which can be rectilinear. In the foothill areas under conditions of agricultural use, soil deflation is added to the processes of water erosion caused by the presence of long slopes with a steepness of more than $3^{\circ}$ with the values of the relief factor (LS) exceeding 2, and in some agricultural basins the average value of the relief factor is close to the critical value -4.3 . Transversely convex slopes prevail in these territories, here it is necessary to design contour linear boundaries. The density of the river network is on average $-0.11 \mathrm{~km} / \mathrm{km}^{2}$ in the mountainous part of Crimea, but due to climatic, geomorphological and soil conditions, the redistribution of sediments occurs in the upper link of the erosion network (more developed on the territory of the peninsula). the density of the river network does not exceed $0.2 \mathrm{~km} / \mathrm{km}^{2}$ in the flat part of the Crimea. Morphometric analysis of the relief allows describing the hydrogeomorphology of the river basin, identifying the causes of erosion, and substantiating the functioning of ecosystems.

KEYWORDS: morphometric analysis of relief, DEM, river basin, basin nature management, GIS.

\section{ВВЕДЕНИЕ}

Вследствие несоблюдения обоснованной системы севооборотов и технологий возделывания сельскохозяйственных культур, сокращения доли лесозащитных насаждений, низких объемов внесения удобрений почвы Крыма подвержены различным видам деградационных процессов ${ }^{1}$, среди которых не только снижение в почвах органических и минеральных веществ, но и развитие эрозии. Дефляционно опасными являются $73 \%$ земель, подвержены водной эрозии - $14 \%$, совместное воздействие ветровой и водной выявляется на $6 \%$ земель ${ }^{2}$.

Изменить ситуацию может внедрение комплексных проектов почвоводоохранного обустройства, выполненных на бассейновых принципах [Кузьменко, 2012]. Внедренные на территории Белгородской области проекты бассейнового природопользования показывают свою эффективность [Лисеикий, Буряк, 2020]. Первым этапом таких работ является предпроектное обоснование, важное место в котором отведено анализу рельефа.

Характеристики рельефа позволяют оценивать гидрогеологические процессы и структуру водосбора [Gizachew, Berhan, 2018], предоставляют информацию о характере эрозии, переносе наносов и др. [Khare et al., 2014]. Широко представлены работы [Farhan, et al., 2017; Prasad et al., 2008; Yunus et al., 2014; Khare et al. 2014 и др.], в которых изучается от 14 до 28 морфометрических параметров речных бассейнов. Большинство

1 Доклад о состоянии и охране окружающей среды на территории республики Крым в 2019 году. Симферополь, 2020. 360 с. Режим доступа: https://meco.rk.gov.ru/uploads/txteditor/meco/attachments// d4/1d/8c/ d98f00b204e 98 00998ecf8427e/phpCCpsTg_1.pdf.

2 Ергина Е.И. Состояние и перспективы мониторинговых наблюдений почв и земель Крыма // Круглый стол «Охрана и использование почв и земель Крыма в условиях интенсификации земледелия и обеспечения продовольственной безопасности Крыма. Симферополь, 2016. Режим доступа: https:// meco.rk.gov.ru/file/6sostoyanie_i_perspektivi_monitoringovih_nablyudeniy_pochv_i_zemelj_krima.pdf. 
этих параметров предложены Стралером и Хортоном в 30-60 гг. ХХ в. и рассчитываются как средние значения. ГИС-технологии позволяют получить морфометрические характеристики в каждой единице (пикселе) пространства, рассчитывать средневзвешенные значения, оценивать отдельные элементы бассейнов, что особенно важно при проектировании почвоводоохранных систем.

Развитие геоинформационных систем позволяет сократить время и повысить качество морфометрического анализа рельефа [Das, S., 2016; Мамедов, 2017; Харченко, 2020]. При этом многие процессы становятся автоматизированными, но требуют индивидуальной настройки специалиста в зависимости от масштаба и целей исследования, a также обоснованной интерпретации [Sukristiyant, 2018]. Так для региональных исследований исходными картографическими материалами должны стать карты M 1:200000 и крупнее, а для территорий сельскохозяйственных предприятий - M 1:50000 и крупнее. Также данные о рельефе возможно получить из глобальных моделей, имеющих открытый доступ (например, https://lta.cr.usgs.gov/). Их подробный анализ приведен в [Ermolaev, 2017].

В работах [Das, 2016; Ahmed et al., 2010] обосновано, что данные Shuttle Radar Topography Mission (SRTM) 4-й версии, разрешением 3 угловые секунды соответствуют топографическим картам M 1:50000 и даже превосходят их при отображении перегибов рельефа. Это открывает перспективы использования таких данных для морфометрического анализа рельефа больших по площади территорий с высокой точностью.

Следует отметить, что для Крыма проведен анализ рельефа отдельных территорий [Позаченюк, 2016; Табунщик, 2018] или его отдельных характеристик [Токарев, 2015; Табунщик, 2019]. Но данные исследования выполнены в разных масштабах и для разных целей, что не способствует их применению в комплексных исследованиях.

Целью работы стало проведение морфометрического анализа рельефа территории бассейнов Крыма с использованием автоматизированного геоинформационного анализа для предпроектного обоснования бассейнового природопользования.

\section{МАТЕРИАЛЫ И МЕТОДЫ ИССЛЕДОВАНИЯ}

Крымский полуостров расположен на юге Восточной Европы в центре Причерноморья. На севере полуострова расположена Северо-Крымская плоская, местами слабоволнистая низменная равнина или Присивашская низменность. Центральная часть Равнинного Крыма представлена возвышенной аккумулятивной равниной. Приподнятая в середине, к западу и востоку она переходит в Альминскую и Индольскую низменности. К югу Центрально-Крымская равнина плавно повышается и переходит в северный структурный склон Внешней гряды Крымских гор. На западе Равнинного Крыма находится Тарханкутский полуостров, большую часть которого занимает возвышенная равнина из миоцен-плиоценовых известняков. Восток Крыма относится к Керченскому полуострову, юго-западную часть которого занимает полого-волнистая, аккумулятивно-денудационная равнина, а северо-восточную - Индоло-Кубанский предгорный прогиб Скифской платформы с пластовыми и пластово-аккумулятивными синклинальными равнинами, разделенными антиклинальными складками диапирового генезиса [Современные ландшафты..., 2009].

Крымские горы являются западной частью Крымско-Кавказского горно-складчатого региона. Располагаясь на юге полуострова, они состоят из трех параллельных друг другу гряд: Главной гряды и двух Предгорных (Внутренней и Внешней), слагающих северный

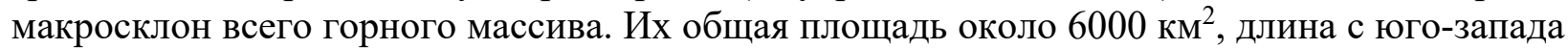
на северо-восток - 180 км, максимальная ширина в центральной части 45-50 км. 
При проектировании региональных систем бассейнового природопользования логично использовать картографический материал М 1:100000 и крупнее для территорий, подверженных водной эрозии. Таким данным соответствуют данные SRTM [Das, 2016; Ahmed, 2010]. Наиболее объективной и естественной единицей для почвоводоохранного проектирования может выступить бассейн реки 4-го порядка [Смольянинов, 2007; Кузьменко, 2012], для которого и следует проводить морфометрический анализ рельефа.

Для проведения исследования на территории Крыма выделено 1534 бассейновые структуры и эрозионная сеть [Лисеикий, Буряк, 2020]. Для этого авторы, используя инструменты поднабора «Гидрология» набора Spatial Analyst программы ArcGIS, произвели обработку SRTM, которая позволила заполнить локальные понижения, определить места внутреннего дренажа, построить растры направлений поверхностного стока воды и суммарной аккумуляции стока. Для построения эрозионной сети применили модель аккумуляции стока: ячейки с высоким суммарным стоком (свыше 200) использованы для определения овражнобалочных форм и русел водотоков. Сеть водотоков уточнена по топографической карте M 1:100000, так как по данным SRTM их определить невозможно. Классификацию эрозионной сети и установление порядков бассейнов проводили по системе Стралера-Философова, начиная с форм овражно-балочной сети, как это принято у геоморфологов [Корытный, 2001]. Нами данные [Лисеикий, Буряк, 2020] взяты за основу исследования.

Дополнительно нами были определены территории, склоны которых обращены в сторону моря, но не имеющие в заданном масштабе эрозионной сети. Нами они идентифицированы как «морские» (рис. 1).

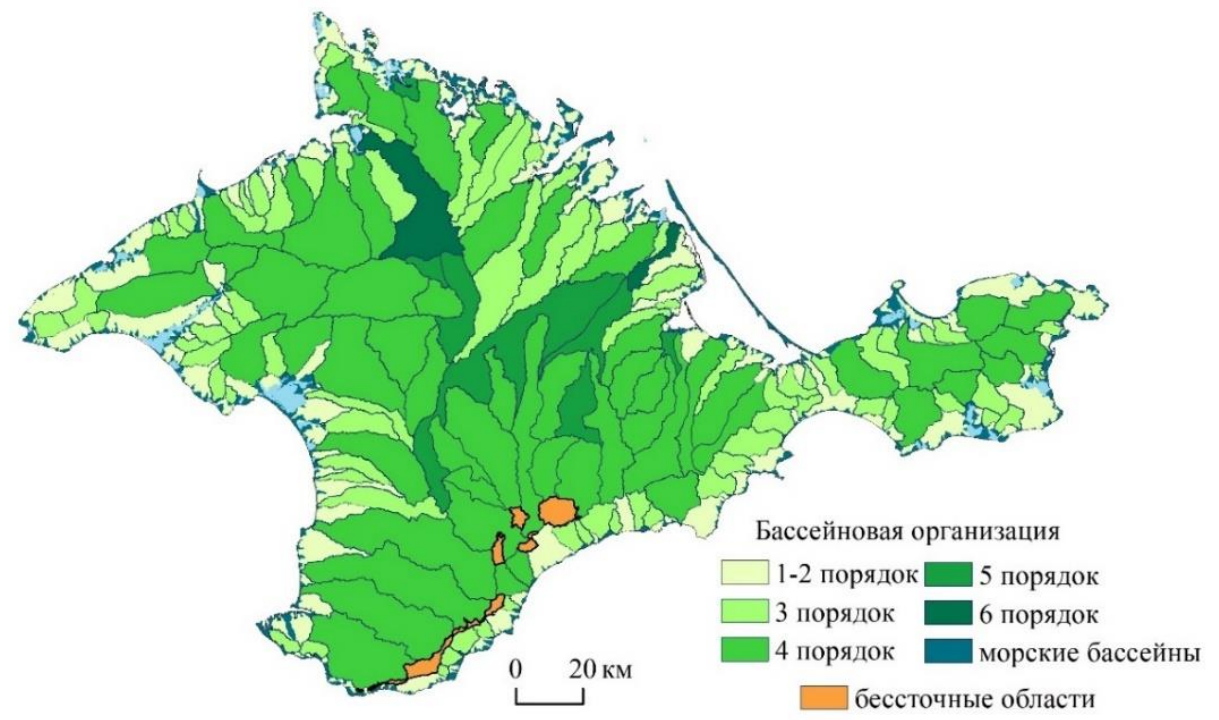

Рис. 1. Структура речных бассейнов Крымского полуострова

Fig. 1. The structure of the river basins of the Crimean peninsula

В горной части Крыма на вершинной поверхности (яйлах) развиты карстовые процессы, чему способствуют трещины и растворимость известняков и гипсов, затрудненные условия стока. Здесь нами выделены бессточные области без определения порядка, так как классификация имеющейся эрозионной сети затруднена и не имеет поверхностной связи с нижележащими бассейнами.

Из-за масштаба карты (см. рис. 1) бассейны первого и второго порядка объединены, но их количество и площадь считались раздельно (табл. 1). Следует также понимать, что при создании бассейновых структур, в выделенных бассейнах 4-го порядка находятся бассейны 1-3 порядков, 3-го порядка - 1-2-го, а их выделение привело к тому, что суммарная площадь 5-го и 6-го порядка занижена. Выделенные бассейны 3-го и 1-2-го порядков не являются составной частью бассейнов более высокого порядка. 
Для решения почвоводоохранных задач региона для анализа были отобраны такие характеристики рельефа как крутизна склона, вертикальное расчленение, горизонтальное расчленение, экспозиция, рельефный фактор, типы склонов. Эти параметры предопределяют возможные землеустроительные мероприятия [Lisetskii et al., 2014].

В качестве программного комплекса использован ArcGIS 10.5, имеющий богатый функционал для решения поставленных задач. Карты крутизны, экспозиции, кривизны, длины склонов построены с использованием поднабора инструментов «Поверхность» набора Spatial Analyst. Карты густоты горизонтального и вертикального расчленения построены путем вычислений в границах выделенных бассейнов с использованием инструментов «Зональная статистика».

Изучение типов склонов выполняли по методике, предложенной в работе [Смирнова, 2017]. Но, так как исходная цифровая модель использовалась отличная от указанной в работе [Смирнова, 2017], был проведен дополнительный экспертный анализ по установлению значений перехода от прямому к вогнутому и выпуклому типу склонов. Было установлено, что поперечно прямым склонам соответствуют значения плановой кривизны от $-0,002$ до $0,002 \mathrm{~m}^{-1}$, продольно прямым - профильной кривизны от $-0,02$ до 0,02 $\mathrm{m}^{-1}$. Кривизна выпуклых склонов больше верхних пределов этих градаций, а вогнутых - меньше нижних. С использованием инструмента «Переклассификация» полученные непрерывные гриды плановой и профильной кривизны были трансформированы в дискретные по указанным значениям. Такие гриды конвертируются в векторный формат, что позволяет объединять данные, в т.ч. атрибутивные (инструмент «Пересечение»). В объединенном шейп-файле данные о типах кривизны классифицировали на типы склонов согласно методике, предложенной М.И. Лопыревым [Проектирование..., 1999].

Инструмент «Алгебра карт» позволил рассчитать значение рельефной функции (LS). Среди большого разнообразия формул фактора LS в эрозионной модели нами проанализированы четыре [Швебс, 1974; Wischmeier, 1978; Morgan, 1979, ГОСТ ${ }^{1}$ ]. Анализ полученных данных показал, что по модели [Wischmeier, 1978] получаются заниженные результаты в горной территории, уравнение [Швебс, 1974] дало в целом завышенные результаты. Средние значения LS, полученные по ГОСТ ${ }^{5}$ и [Morgan, 1979] показывают сравнимые результаты. Как указано в [Буряк, 2016] наиболее подходящей для черноземных условий является [Morgan, 1979], поэтому на основании нашего анализа и предложенных формул была выбрана эта формула.

Средние значения морфометрических характеристик рельефа занесены в атрибутивную таблицу речных бассейнов полуострова Крым. Это позволяет работать с данными как в геоинформационной среде, так и экспортировать данные в таблицы для их анализа.

\section{РЕЗУЛЬТАТЫ ИССЛЕДОВАНИЯ И ИХ ОБСУЖДЕНИЕ}

Для проведения исследования на территории Крыма выделено 1534 бассейновые структуры, среди которых в большом количестве представлены бассейны без эрозионной сети со склоном в сторону моря (далее морские бассейны), бассейны 1-го и 2-го порядков, сток которых в большинстве случаев также обращен в море (табл. 1, рис. 1).

Табл. 1. Основные бассейны полуострова Крым

Table 1. Main basins of the Crimea Peninsula

\begin{tabular}{|l|l|l|l|l|l|}
\hline Порядок & \multicolumn{1}{|c|}{ Количество, шт } & \multicolumn{1}{|c|}{ Площадь, км ${ }^{2}$} & Порядок & \multicolumn{1}{|c|}{ Количество, шт } & Площадь, км $^{2}$ \\
\hline морские & 783 & 1200,5 & 4 & 57 & 13233,7 \\
\hline 1 & 444 & 1260,9 & 5 & 7 & 1603,1 \\
\hline 2 & 164 & 2171,6 & 6 & 2 & 565,3 \\
\hline 3 & 77 & 4969,4 & \multicolumn{2}{|l}{ Бессточные области } & 240,2 \\
\hline
\end{tabular}


Около 55 \% территории занимают бассейны 4-го порядка, 20 \% приходится на 3-ий порядок. Более полное понимание о структуре эрозионной сети дает табл. 2.

Табл. 2. Порядковый состав долинной и овражно-балочной сети Крыма

Table 2. The ordinal composition of the valley and ravine-girder network of Crimea

\begin{tabular}{|l|c|c|c|c|c|c|c|}
\hline Показатель & 1 & 2 & 3 & 4 & 5 & 6 & Всего \\
\hline Количество, шт. & 5059 & 986 & 232 & 57 & 7 & 2 & 6340 \\
\hline Длина, км & 8824,7 & 4018,4 & 2020,7 & 783,3 & 247,8 & 86,0 & 15978,8 \\
\hline
\end{tabular}

Из таблицы 2 видно, что на территории Крыма хорошо развито верхнее звено эрозионной сети, но вследствие засушливости климата низкие звенья не получили своего развития, и, хотя соотношение количества эрозионных форм близко к модальному бассейну, незначительные значения длин низких порядков позволяют говорить о перераспределении наносов в верхнем звене.

Геоинформационные системы позволяют автоматизировать процесс расчета густоты эрозионной сети, которая отражает инфильтрационную способность грунта, потенциал эрозионного стока, растительность и пр. Северная часть полуострова имеет меньшую густоту эрозионной сети (рис. 1 с), а, следовательно, выше вероятность подпитки или потенциальной зоны подземных вод. Кроме того, это приводит к грубой текстуре бассейна с высокопроницаемым грунтом и относительно лучшим растительным покровом и низким рельефом [Prasad et al., 2008; Prasad et al., 2008].

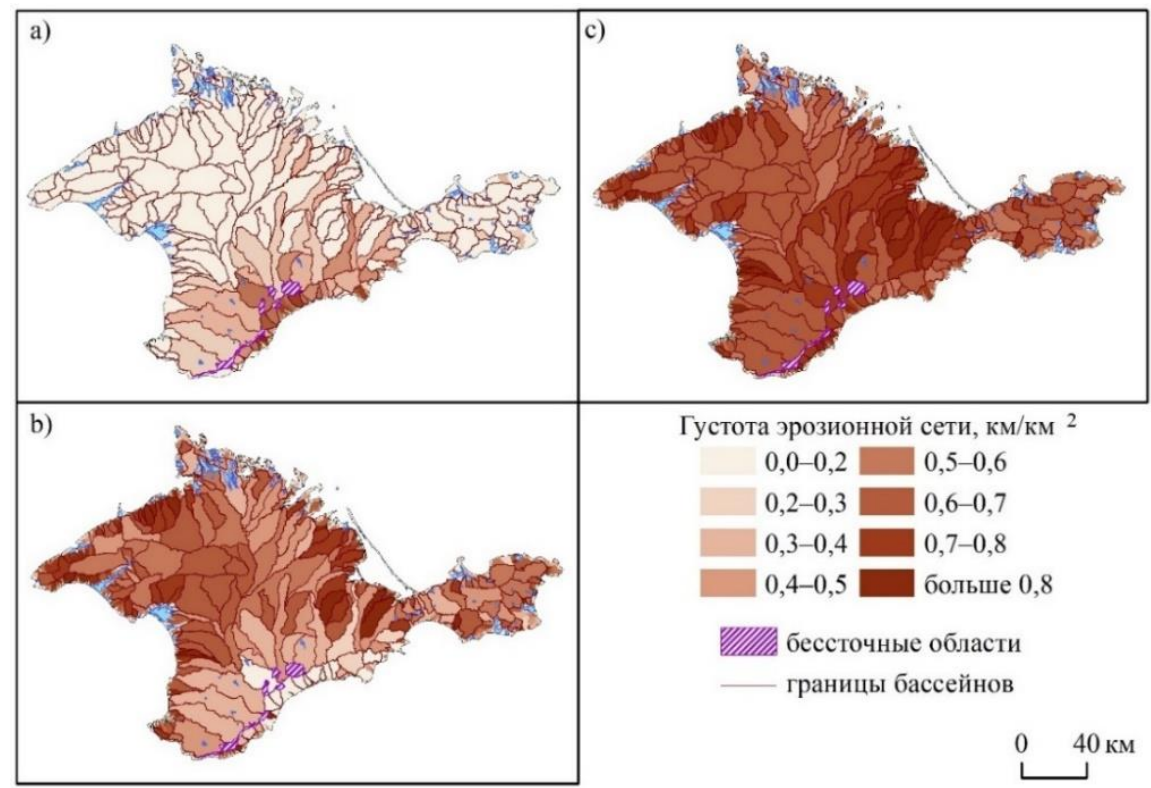

Рис. 1. Густота долинной и овражно-балочной сети бассейнов Крымского полуострова: a) речной сети; b) овражно-балочной сети; с) эрозионной сети

Fig. 1. Density of the valley and gully-ravine network of the Crimean Peninsula basins:

a) river network; b) gully-girder network; c) erosion network

В центральной и западной части равнинного Крыма развита овражно-балочная сеть при низких значениях густоты речной сети, т.е. большое количество осадков не задерживаются на данной территории. Важно при проектировании бассейнового природопользования не допустить развитие овражно-балочной сети и сохранить как можно больше почвенной влаги для сельскохозяйственного производства.

В среднем густота эрозионной сети исследовательской территории составляет $0,61 \pm 0,19$ км/км² (см. рис. 1 с). В равнинной части Крыма эрозионная сеть представлена 
ложбинами, неглубокими оврагами и балками, реками. В прибрежных бассейнах овражнобалочная сеть проявляется сильнее (см. рис. 1 b). Кроме того, в районе Индольской впадины также отмечаются значения густоты-овражно-балочной сети выше средних $-0,71 \mathrm{\kappa m} / \mathrm{\kappa м}^{2}$.

Южная часть Крымских гор чрезвычайна расчленена, но при бассейновой организации этих территории этот фактор не является лимитирующим и заданный порог «суммарного стока» при автоматизированном выделении эрозионной сети был занижен для верного отражения в равнинной зоне. В среднем горизонтальное расчленение бассейнов горной части составляет 0,32 км/км². При этом здесь значительно развита речная сеть, густота которой выше равнинной и составляет 0,11 км/км ${ }^{2}$. Высокими значениями горизонтального расчленения характеризуются бассейны рек Бирюк-Курасу, Булганак, Субаш, Чурук-Су.

Средняя высота полуострова Крым 135 м (рис. 2).

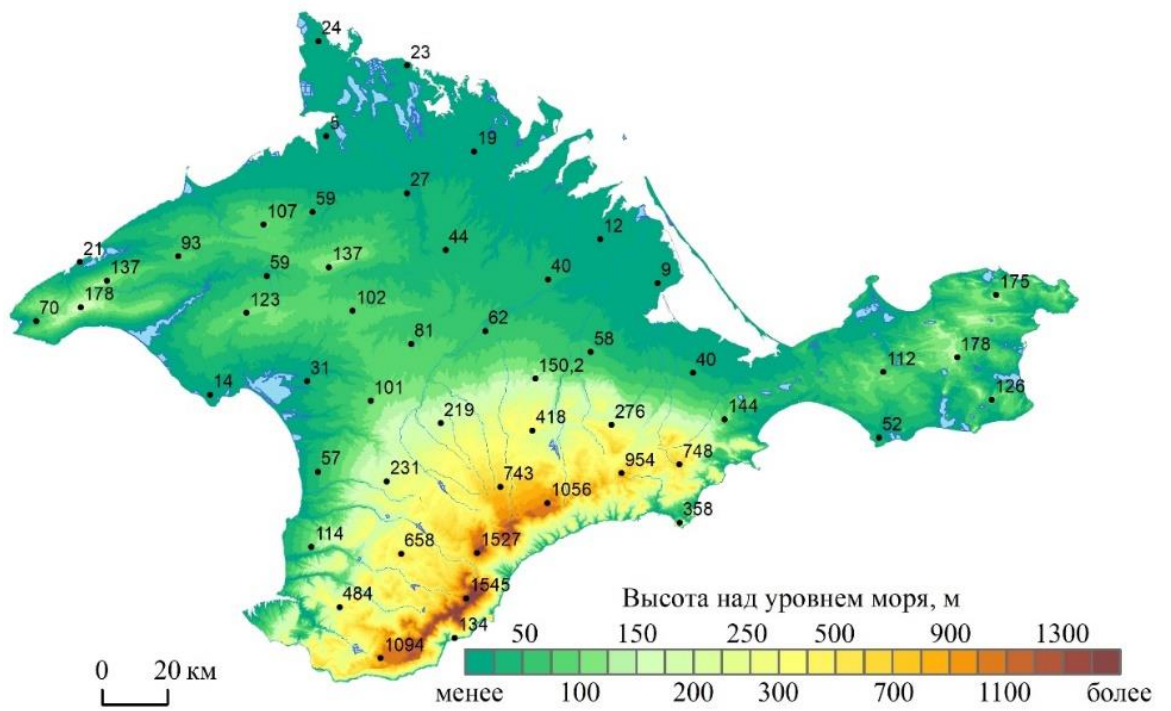

Рис. 2. Физическая карта Крымского полуострова

Fig. 2. Physical map of the Crimean peninsula

Равнинный Крым по абсолютным высотам относится к низким равнинам с понижением высот к северу, средняя абсолютная высота здесь составляет 55 м. На Тарханкутском полуострове абсолютная высота достигает 178 м. Керченский полуостров имеет неоднородный рельеф, средняя абсолютная высота - 53 м. Горная часть Крыма имеет среднюю высоту 412 м. 82 \% бассейнов расположены на территориях с абсолютной высотой, не превышающей 300 м, из которых 45 \% относятся к бассейнам 4-го порядка (табл. 3).

Табл. 3. Распределение бассейнов Крыма по абсолютным высотам, км² Table 3. Distribution of Crimean basins by absolute heights, $\mathrm{km}^{2}$

\begin{tabular}{|c|c|c|c|c|c|c|c|c|}
\hline \multirow{2}{*}{$\begin{array}{c}\text { Средняя вы- } \\
\text { сота над уров- } \\
\text { нем моря, м }\end{array}$} & \multicolumn{5}{|c|}{ Порядок речного бассейна } & \multirow{2}{*}{$\begin{array}{c}\text { Бессточные } \\
\text { области }\end{array}$} & \multirow{2}{*}{$\begin{array}{c}\text { Морские } \\
\text { водосборы }\end{array}$} & \multirow{2}{*}{$\begin{array}{c}\text { Вся территория } \\
\text { без деления на } \\
\text { бассейны }\end{array}$} \\
\hline & $1-2$ & 3 & 4 & 5 & 6 & & & \\
\hline $0-300$ & 3189,4 & 4656,7 & 9458,8 & 1603,0 & 565,3 & 0,9 & 1193,7 & 21807,8 \\
\hline $300-500$ & 175,3 & 220,4 & 3485,3 & 0 & 0 & 1,3 & 6,8 & 1773,6 \\
\hline $500-1000$ & 67,9 & 92,3 & 289,6 & 0 & 0 & 101,7 & 0 & 1364,0 \\
\hline выше 1000 & 0 & 0 & 0 & 0 & 0 & 136,3 & 0 & 299,3 \\
\hline
\end{tabular}

В предгорных областях по высотной зональности расположено 15 \% бассейнов, в горных $-2,3 \%$.

Значительную площадь (30 \%) занимают бассейны с вертикальным расчленением 100-200 м. (рис. 3). 


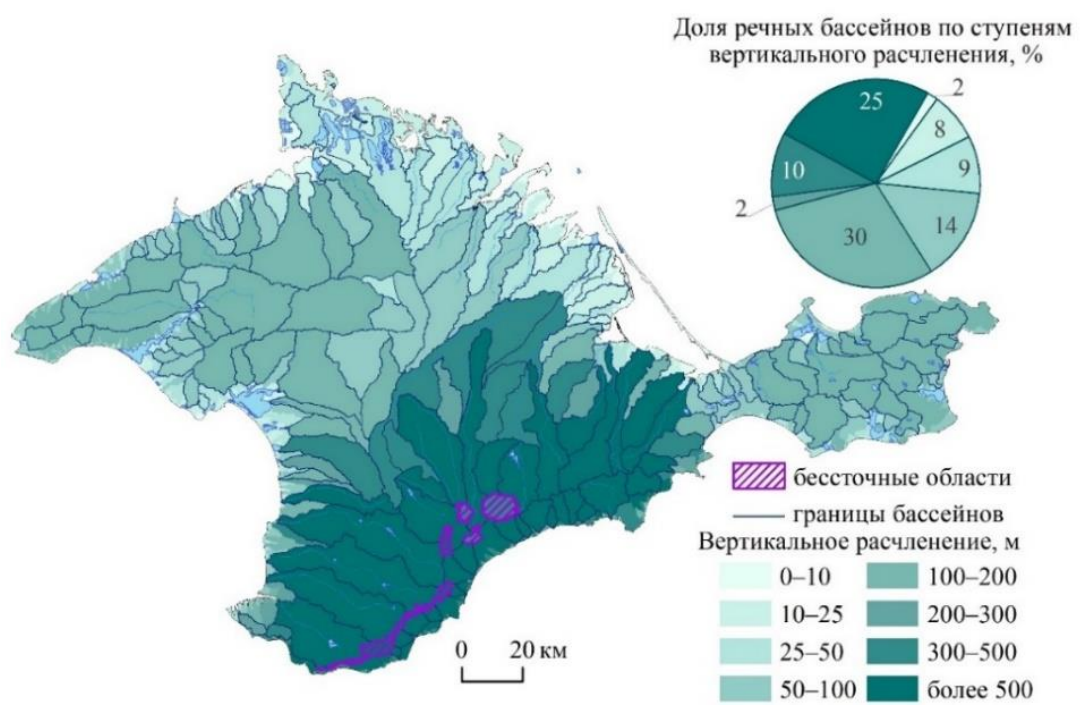

Рис. 3. Вертикальное расчленение бассейнов Крымского полуострова

Fig. 3. Vertical subdivision of the Crimean Peninsula basins

Бассейны горного Крыма и предгорий занимают ступень со средним превышением более 500 м площадью 25 \% территории. Горный Крым характеризуется вертикальным расчленением, характерным для среднегорного (превышение 25-200 м) и высокогорного (превышение 100 и более метров) рельефа. Для территории равнинного Крыма выделены пять ступеней вертикального расчленения. Максимальные значения на Тарханкутском и Керченском полуострове, минимальные - в восточной и северной частях Северо-Крымской низменности.

Между значениями вертикального расчленения в бассейне и средними значениями крутизны склонов установлена значительная линейная связь $(\mathrm{r}=0,71)$, что можно видеть и при сравнении рис. 3 и 4.

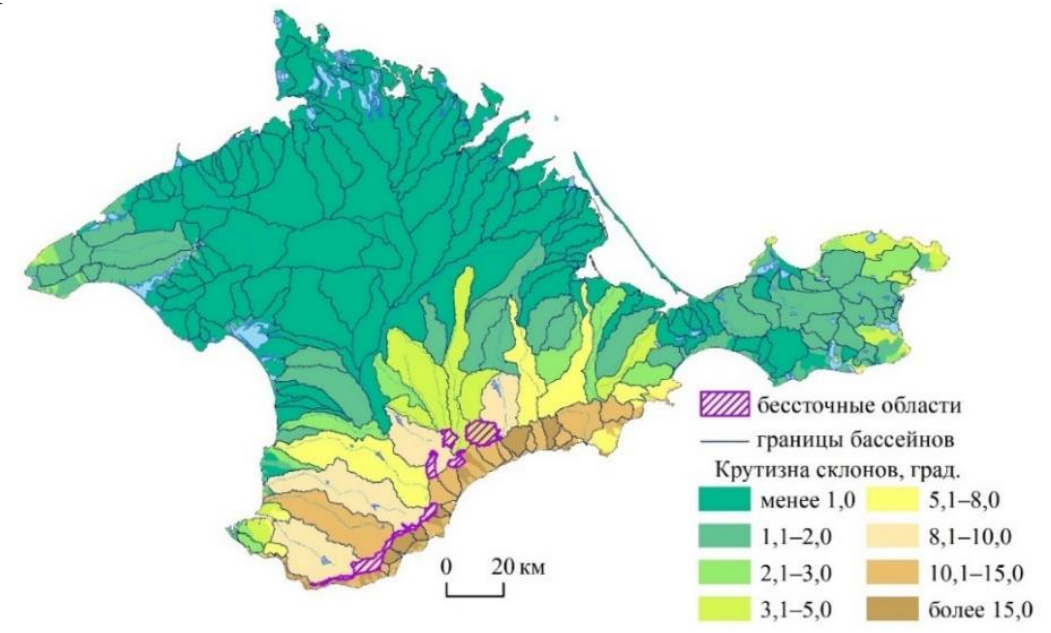

Рис. 4. Средняя крутизна склонов в бассейнах рек Крымского полуострова

Fig. 4. Average steepness of slopes in the river basins of the Crimean Peninsula

Крутизна склона - один из факторов, контролирующих проникновение подземных вод в недра; следовательно, показатель пригодности для разведки подземных вод, в т.ч. для сельскохозяйственного использования. На пологих склонах поверхностный сток является медленным, что дает больше времени для просачивания дождевой воды, в то время как на крутых склонах обеспечивается значительный сток, сокращающий время пребывания дождевой воды, следовательно, сравнительно меньше инфильтрация [Prasad et al., 2008], что отражается на растительности [Ukrainskiy, et al., 2020]. 
Крутизна склонов на территории Крыма варьирует в широких диапазонах (см. рис. 4), что связано с различными ландшафтными условиями. В горах она достигает $78^{\circ}$ (при средней крутизне $9^{\circ}$ ), на равнинных участках крутизна склонов в среднем составляет $1^{\circ}$ и занимает более половины всей территории (табл. 4). Эти территории активно используются в сельскохозяйственном производстве. Здесь преобладают процессы ветровой эрозии.

Табл. 4. Распределение склонов бассейнов Крыма по крутизне, км ${ }^{2}$ Table 4. Distribution of slopes of Crimean basins by steepness, $\mathrm{km}^{2}$

\begin{tabular}{|l|c|c|c|c|c|c|c|c|}
\hline \multirow{2}{*}{$\begin{array}{c}\text { Крутизна } \\
\text { склонов, град }\end{array}$} & \multicolumn{5}{|c|}{ Порядок речного бассейна } & Бессточные & Морские & Всяя \\
\cline { 2 - 7 } & $1-2$ & 3 & 4 & 5 & 6 & 0 оласти & водосборы & территория \\
\hline $0,0-1,0$ & 1723,9 & 3342,3 & 5439,1 & 1229,9 & 565,3 & 0 & 651,8 & 13510,1 \\
\hline $1,1-2,0$ & 725,6 & 745,8 & 2465,0 & 373,1 & 0 & 0 & 245,1 & 4928,6 \\
\hline $2,1-3,0$ & 192,8 & 325,7 & 668,1 & 0 & 0 & 0 & 47,4 & 1469,1 \\
\hline $3,1-5,0$ & 272,9 & 23,7 & 1165,7 & 0 & 0 & 79,6 & 74,7 & 1363,7 \\
\hline $5,1-8,0$ & 162,3 & 96,8 & 1211,2 & 0 & 0 & 22,1 & 47,7 & 1192,8 \\
\hline $8,1-10,0$ & 9,4 & 0 & 1516,2 & 0 & 0 & 136,3 & 14,5 & 588,3 \\
\hline $10,1-15,0$ & 228,3 & 205,9 & 768,5 & 0 & 0 & 0 & 66,8 & 1115,7 \\
\hline$>15,0$ & 117,3 & 229,2 & 0 & 0 & 0 & 2,2 & 52,5 & 1076,4 \\
\hline
\end{tabular}

Около $20 \%$ бассейнов имеют среднюю крутизну склонов 3-10 (см. табл. 4). Это территории предгорий, которые также используются для возделывания сельскохозяйственных культур и здесь совместно с дефляцией почв проявляются процессы водной эрозии. В данных бассейнах необходимо проектирование противоэрозионных рубежей, почвозащитных севооборотов, гидротехнических сооружений и т.п.

Преобладающим направлением склонов на полуострове является северное $(20,0$ \% территории), южных склонов на 4,4 \% меньше (табл. 5).

Табл. 5. Распределение территории Крыма по экспозищии

Table 5. Distribution of the territory of Crimea by exposure

\begin{tabular}{|l|c|l|c|}
\hline Экспозиция склона & Площадь, км & Экспозиция склона & Площадь, км \\
\hline Плоские поверхности & 13510,1 & Южная & 1475,3 \\
\hline Северная & 1833,2 & Юго-западная & 1211,9 \\
\hline Северо-восточная & 1482,6 & Западная & 1461,8 \\
\hline Восточная & 1275,7 & Северо-западная & 1747,1 \\
\hline Юго-восточная & 1247 & & \\
\hline
\end{tabular}

Площадь западных склонов незначительно больше восточных (на 0,8 \%) и составляет 5,8 \% территории. Они более теплые, и лучше подходят для возделывания позднеспелых культур.

Сочетание в равнинной части незначительных превышений и плоских поверхностей формирует низкие значения рельефной функции, составляющие в среднем 0,61 (рис. 5).

В равнинном Крыму рельефная функция не достигает критических значений (4,35,2), установленных в работе [Мальшев, Голеусов, 2019]. В предгорных территориях и южной части черноморского побережья, где также развито сельскохозяйственное производство, значения рельефной функции достигают 10 и более, что является критическим для ведения сельскохозяйственной деятельности.

Типы склонов, влияющие на скорость эрозионные процессов, являются важным аспектом при определении перспективных землеустроительных мероприятий, но ввиду трудоемкости их выделения в ручном режиме зачастую игнорируются. 


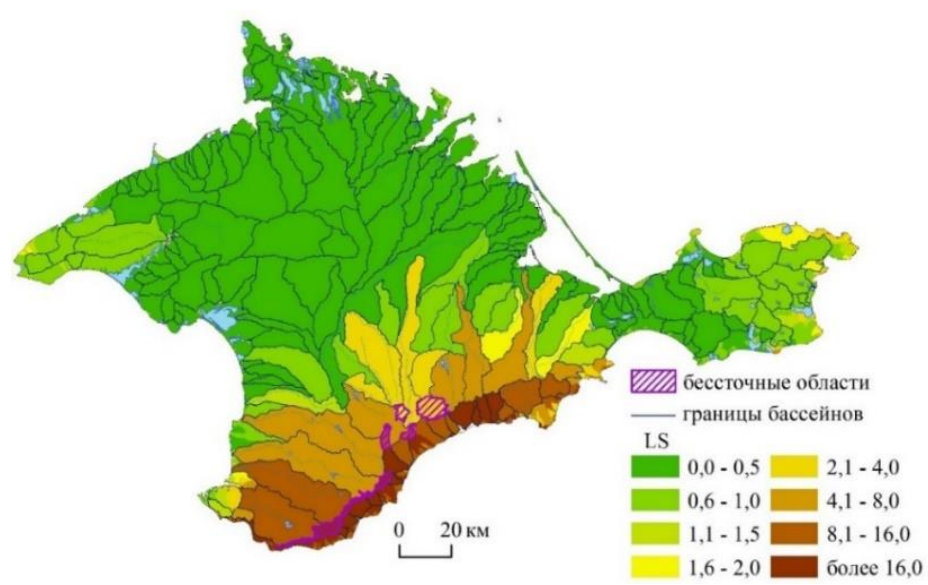

Рис. 5. Средние значения рельефного фактора (LS) в пределах бассейнов Крыма Fig. 5. Average values of the relief factor (LS) within the Crimean basins

Геоинформационные системы позволяют определить типы склонов и их площади, но на предварительном этапе нужна экспертная оценка для установления граничных значений кривизны, которые могут меняться в зависимости от масштаба используемых данных. Для территории Крыма впервые определены типы склонов, среди которых наиболее распространены поперечно вогнутые продольно-выпуклые, поперечно-выпуклые продольно-вогнутые склоны (19,4 и 19,0% соответственно) (табл. 6).

Табл. 6. Типь склонов полуострова Крым Table 6. Types of slopes of the Crimean Peninsula

\begin{tabular}{|c|l|c|c|}
\hline $\begin{array}{c}\text { Индекс } \\
\text { склона }\end{array}$ & \multicolumn{1}{|c|}{ Тип склона } & $\begin{array}{c}\text { Суммарная площадь, } \\
\text { тыс. га }\end{array}$ & $\begin{array}{c}\text { Доля от площади } \\
\text { полуострова, \% }\end{array}$ \\
\hline IA & поперечно-прямые, продольно-прямые & 4038,6 & 16,0 \\
\hline IB & поперечно-прямые, продольно-вогнутые & 496,2 & 2,0 \\
\hline IC & поперечно-прямые, продольно-выпуклые & 1096,5 & 4,3 \\
\hline IIA & поперечно-выпуклые, продольно-прямые & 3798,3 & 15,0 \\
\hline IIB & поперечно-выпуклые, продольно-вогнутые & 4807,5 & 19,0 \\
\hline IIC & поперечно-выпуклые, продольно-выпуклые & 1562,2 & 13,3 \\
\hline IIIA & поперечно-вогнутые, продольно-прямые & 3358,5 & 4,7 \\
\hline IIIВ & поперечно-вогнутые, продольно-вогнутые & 1179,6 & 19,4 \\
\hline IIIC & поперечно-вогнутые, продольно-выпуклые & 4907,3 & \\
\hline
\end{tabular}

Поперечно прямых склонов на исследовательской территории выделено 22,3 \%. Эти склоны преимущественно размещены в равнинной части Крыма (рис. 6). Площадь территорий с собирающим стоком (тип III) на 2,9 \% меньше, чем с рассеивающим (тип II) и составляет 37,4 \% (см. табл. 6). Эти территории наиболее подвержены смыву почв, но большая их часть размещена в горной части Крыма (см. рис. 6).

Анализ рис. 6 и табл. 6 показывает, что преобладают бассейны с поперечновыпуклыми продольно-выпуклыми склонами (38,8 \% бассейнов) и поперечно-прямые продольно-прямые (33,6 \%). В последних процессы водной эрозии развиты меньше, а при планировании мероприятий против дефляции возможно применение линейных рубежей без учета контурности рельефа. 12,8 \% бассейнов равнинного Крыма имеют поперечно-прямые продольно-выпуклые склоны, на которых также рекомендуется прямолинейная организация линейных рубежей. В пределах всех бассейнов в большинстве случаев встречаются все девять типов бассейнов. В мелких морских бассейнах выделяются 3-4 типа склонов, тогда доля отдельного типа может достигать $65 \%$. В среднем коэффициент вариации доли типов ІБ, ІВ, ІІБ и ІІІВ, в бассейнах равен 40,3 \%. 


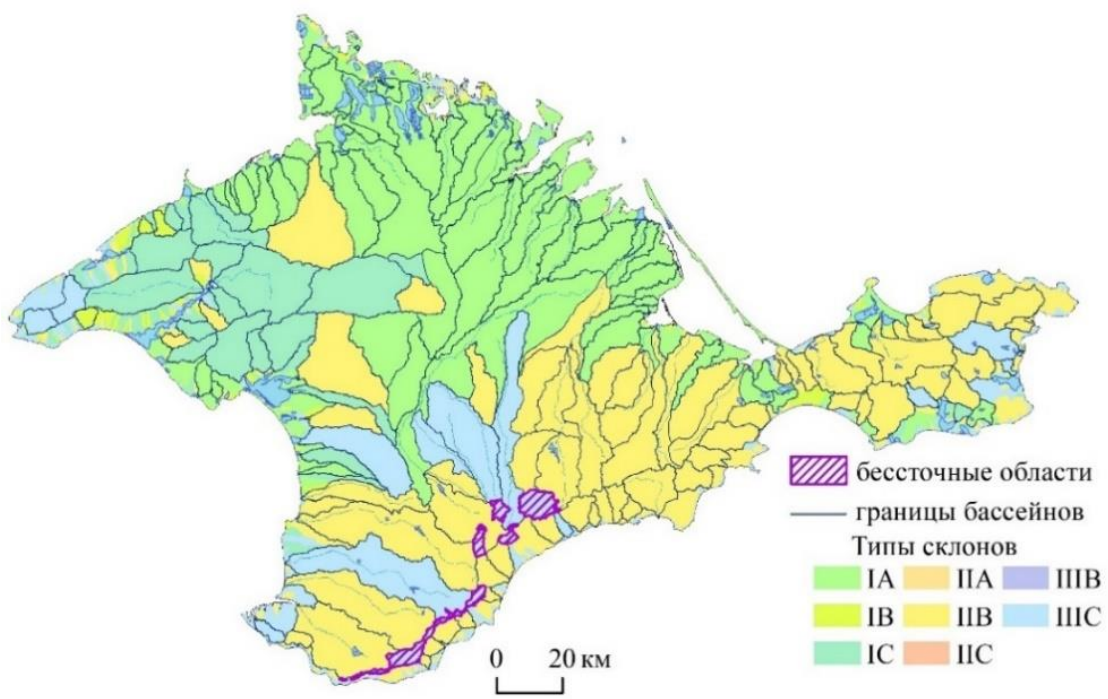

Рис. 6. Преобладающие типь склонов бассейнов Крыма (обозначения в табл. 6)

Fig. 6. Prevailing types of slopes of the Crimean basins (designations correspond to Table 6)

\section{ВЫВОДЫ}

В данном исследовании геоинформационные системы рассмотрены как инструмент для проведения морфометрического анализа рельефа, являющегося предпроектным обоснованием почвоводоохранного обустройства территории бассейнов Крыма. В изученных отечественных и зарубежных источниках не находит отражение (или частично оговариваются) применяемые инструменты используемых программ, методы интерполяции, разрешение гридов, используемые классификации, значение суммарного стока и пр. Тогда как представленная статья имеет эти данные, что позволяет использовать описанные инструменты и методы их применения для других территорий, сопоставлять полученные данные с имеющимися для Крыма. Проведенный морфометрический анализ рельефа позволил выделить основные особенности рельефа бассейнов Крымского полуострова. Эти параметры будут использованы при проектировании бассейнового природопользования Крыма. ГИС-методы и цифровые данные о местности являются ценным ресурсом для изучения эрозионной сети и территории водосбора, а также для количественного анализа гидроморфометрических параметров из-за их гибкости, рентабельности, эффективности времени и возможностей манипулирования и анализа пространственной информации.

\section{БЛАГОДАРНОСТИ}

Исследование выполнено при поддержке РНФ, грант 20-67-46017.

\section{ACKNOWLEDGEMENTS}

The study was funded by the Russian Science Foundation, grant No 20-67-46017.

\section{СПИСОК ЛИТЕРАТУРЫ}

1. Буряк Ж.А., Нарожняя А.Г. Выбор модели оценки эрозионного потенциала рельефа для условий Белгородской области. Эрозионные, русловые и устьевые процессы (исследования молодых ученых университетов): сборник статей по материалам XI семинара молодых ученых вузов, объединяемых советом по проблеме эрозионных, русловых и устьевых процессов, 2016. С. 59-64.

2. Ергина Е.И., Тронза Г.Е. Современное почвенно-экологическое состояние Крымского полуострова. Ученые записки Крымского федерального университета имени В.И. Вернадского. География. Геология, 2016. Т. 2. № 3. С. 196. 
3. Ергина Е.И., Кошлатый С.Д. Методико-технологические аспекты моделирования допустимых норм эрозии как основного критерия почвозащитных систем земледелия в Крыму. Культура народов Причерноморья, 2005. № 73. С. 148-151.

4. Корытный Л.М. Бассейновая концепция в природопользовании. Иркутск: Изд-во Института географии СО Ран, 2001. 163 с.

5. Кузьменко Я.В., Лисеикий Ф.Н., Нарожняя А.Г. Применение бассейновой концепции природопользования для почвоводоохранного обустройства агроландшафтов. Известия Самарского научного центра Российской академии наук, 2012. Т. 14. № 1-9. С. 2432-2435.

6. Лисеикий Ф.Н. Буряк Ж.А., Маринина О.А., Полетаев А.О. Бассейновая дифференциация ландшафтов равнинного Крыма как основа проектов почвоводоохранных систем земледелия. Ландшафтоведение и ландшафтная экология: коадаптация ландшафта и хозяйственной деятельности: материалы Междунар. науч.-практ. конф. «Четвертые ландшафтно-экологические чтения, посвященные Г. Е. Гришанкову», Симферополь, 22-25 сентября 2020 г. Симферополь, 2020. С. 42-47.

7. Мальшев А.В., Голеусов П.В. Критическое значение фактора рельефа и эрозионная опасность агроландшафтов Белгородской области. Научные ведомости Белгородского государственного университета. Серия: Естественные науки, 2019. Т. 43. № 1. C. 63-75. DOI: 10.18413/2075-4671-2019-43-1-63-75.

8. Мамедов С.Г., Алекберова С.О., Гамидова З.А., Исмайлова Л.А. Изучение морфометрических показателей рельефа селеопасных бассейнов по данным радарных спутниковых снимков (на примере междуречья Шанчай-Дамирапаранчай). Вестник Московского государственного областного университета. Серия: Естественный науки, 2017. № 2. C. 59-70. DOI: 10.18384/2310-7189-2017-2-59-70.

9. Позаченюк E.A., Петлюкова E.A. ГИС-анализ морфометрических показателей рельефа центрального предгорья главной гряды Крымских гор для целей ландшафтного планирования. Ученые записки Крымского федерального университета имени В.И. Вернадского. География. Геология, 2016. Т. 2 (68). №2. С. 95-111.

10. Проектирование и внедрение эколого-ландшафтных систем земледелия в сельскохозяйственных предприятиях Воронежской области. Под ред. М.И. Лопырева. Воронеж, 1999. $186 \mathrm{c.}$

11. Смирнова Л.Г., Украинский П.А., Нарожняя А.Г., Кожушков А.А. Анализ распределения типов склонов на региональном уровне с использованием методов топографического моделирования. Достижение науки и техники АПК, 2017. Т. 31. № 11. C. 17-21.

12. Смольянинов В.М., Дегтярев С.Д., Щербинина С.В. Эколого-гидрологическая оценка состояния речных водосборов Воронежской области. Воронеж: ИСТОКИ, 2007. 133 с.

13. Современные ландшафты Крыма и сопредельных акваторий. Под ред. Е.А. Позаченок. Симферополь: Бизнес-Информ, 2009. 668 с.

14. Табунщик B.A., Петлюкова E.A. Густота расчленения рельефа на территории Крымского полуострова. Известия высших учебных заведений. Северо-Кавказский регион. Серия: Естественные науки, 2019. № 1 (201). С. 95-100.

15. Табунщзик B.A. Рельеф бассейнов рек северо-западного склона крымских гор (на примере бассейнов рек Западный Ббулганак, Альма, Кача, Бельбек, Черная). Геополитика и экогеодинамика регионов, 2018. Т. 4 (14). № 3. С. 78-87.

16. Токарев C.В., Рощина К.Н. Картирование элементов рельефа земной поверхности с использованием индекса топографической позиции (на примере Крымского полуострова). Ученые записки Крымского федерального университета имени В.И. Вернадского. География. Геология, 2015. Т. 1(67). № 4. С. 64-85. 
17. Харченко C.B. Новые задачи морфометрии рельефа и автоматизированные морфологические классификации в геоморфологии. Геоморфология, 2020. № 1. С. 3-21. DOI: $10.31857 / \mathrm{S} 043542812001006 \mathrm{X}$.

18. Швебс Г.И. Формирование водной эрозии стока наносов и их оценка. Л.: Гидрометеоиздат, 1974. $184 \mathrm{c.}$

19. Ahmed S.A., Chandrashekarappa, K.N., Raj, S.K., Nischitha V., Kavitha G. Evaluation of morphometric parameters derived from ASTER and SRTM DEM - A study on Bandihole sub-watershed basin in Karnataka. J Indian Soc Remote Sens, 2010. No 38. P. 227-238. DOI: 10.1007/s12524-010-0029-3.

20. Das S., Patel P.P., Sengupta S. Evaluation of different digital elevation models for analyzing drainage morphometric parameters in a mountainous terrain: a case study of the Supin-Upper Tons Basin, Indian Himalayas. SpringerPlus, 2016. No 5. P. 1544. DOI: 10.1186/s40064-0163207-0.

21. Ermolaev O.P., Mal'tsev K.A., Mukharamova S.S., Kharchenko S.V., Vedeneeva E.A. Cartographic model of river basins of european Russia. Geography and Natural Resources, 2017. V. 38. No 2. P. 131-138. DOI: 10.21782/GIPR0206-1619-2017-2(27-36).

22. Farhan Y., Anbar A., Al-Shaikh N., Mousa R. Prioritization of Semi-Arid Agricultural Watershed Using Morphometric and Principal Component Analysis, Remote Sensing, and GIS Techniques, the Zerqa River Watershed, Northern Jordan. Agricultural Sciences, 2017. V. 8. No 1. DOI: 10.4236/as.2017.81009.

23. Gizachew, K., Berhan, G. Hydro-geomorphological characterization of Dhidhessa River Basin, Ethiopia. International soil and water conservation research, 2018. V. 6. P. 175-183. DOI: $10.1016 /$ j.iswcr.2018.02.003.

24. Khare D., Mondal, A., Mishra, P. K., Kundu, S., Meena, P. K. Morphometric analysis for prioritization using remote sensing and GIS techniques in a Hilly catchment in the state of Uttarakhand, India. Indian Journal of Science and Technology, 2014. V. 7(10). P. 16501662.

25. Lisetskii F.N., Zemlyakova A.V., Terekhin E.A., Naroznyaya A.G., Pavlyuk Y.V., Ukrainskii P.A., Kirilenko Z.A., Marinina O.A., Samofalova O.M. New opportunities of geoplanning in the rural area with the implementing of geoinformational technologies and remote sensing. Advances in Environmental Biology, 2014. V. 8. No 10. P. 536-539.

26. Morgan R.P.C. Soil Erosion. London, New York: Longman, 1979. 113 p.

27. Prasad R.K., Mondal, N.C., Banerjee, P. Nandakumar M.V., Singh V.S. Deciphering potential groundwater zone in hard rock through the application of GIS. Environ Geol, 2008. No 55. P. 467-475. DOI: 10.1007/s00254-007-0992-3.

28. Sukristiyant S., Maria R., Lestiana H. Watershed-based morphometric analysis: A review. IOP Conf. Series: Earth and Environmental Science, 2018. DOI: 10.1088/17551315/118/1/012028.

29. Wischmeier W.H., Smith D.D. Predictng rainfall erosion losses: A guide to conservation planning. Agriculture Handbook U.S. Department of Agriculture. Washington, DC, 1978. No $537.543 \mathrm{p}$.

30. Yunus A., Oguchi T., Hayakawa Y. Morphometric analysis of drainage basins in the western arabian peninsula using multivariate statistics international. Journal of Geosciences, 2014. V. 5 No 5. DOI: 10.4236/ijg.2014.55049.

\section{REFERENCES}

1. Ahmed S.A., Chandrashekarappa, K.N., Raj, S.K., Nischitha V., Kavitha G. Evaluation of morphometric parameters derived from ASTER and SRTM DEM - A study on Bandihole 
sub-watershed basin in Karnataka. J Indian Soc Remote Sens, 2010. No 38. P. 227-238. DOI: $10.1007 / \mathrm{s} 12524-010-0029-3$.

2. Buriak Zh.A., Narozhnyaya A.G. The choice of a model for assessing the erosion potential of the relief for the conditions of the Belgorod region. Erosion, channel and estuarine processes (research of young scientists of universities): a collection of articles based on the materials of the XI seminar of young scientists of universities, united by the council on the problem of erosion, channel and estuarine processes, 2016. P. 59-64 (in Russian).

3. Das S., Patel P.P. Sengupta S. Evaluation of different digital elevation models for analyzing drainage morphometric parameters in a mountainous terrain: a case study of the Supin-Upper Tons Basin, Indian Himalayas. SpringerPlus, 2016. No 5. P. 1544. DOI: 10.1186/s40064-0163207-0.

4. Design and implementation of ecological and landscape farming systems in agricultural enterprises of the Voronezh region. Ed. M.I. Lopyreva. Voronezh, 1999. 168 p. (in Russian).

5. Ergina E.I., Koshlatiy S.D. Methodological and technological aspects of modeling permissible erosion rates as the main criterion for soil-protective farming systems in Crimea. Culture of the peoples of the Black Sea region, 2005. No 73. P. 148-151 (in Russian).

6. Ergina E.I., Tronza G.E. The current soil and ecological state of the Crimean Peninsula. cientific Notes of the Crimean Federal V.I. Vernadsky University. Geography. Geology, 2016. V. 2. No 3. P. 196 (in Russian).

7. Ermolaev O.P., Mal'tsev K.A., Mukharamova S.S., Kharchenko S.V., Vedeneeva E.A. Cartographic model of river basins of European Russia. Geography and Natural Resources, 2017. V. 38. No 2. P. 131-138. DOI: 10.21782/GIPR0206-1619-2017-2(27-36).

8. Farhan Y., Anbar A., Al-Shaikh N., Mousa R. Prioritization of Semi-Arid Agricultural Watershed Using Morphometric and Principal Component Analysis, Remote Sensing, and GIS Techniques, the Zerqa River Watershed, Northern Jordan. Agricultural Sciences, 2017. V. 8. No 1. DOI: 10.4236/as.2017.81009.

9. Gizachew K., Berhan G. Hydro-geomorphological characterization of Dhidhessa River Basin, Ethiopia. International soil and water conservation research, 2018. V. 6. P. 175-183. DOI: 10.1016/j.iswcr.2018.02.003.

10. Kharchenko S.V. New tasks of relief morphometry and automated morphological classifications in geomorphology. Geomorphology, 2020. No 1. P. 3-21 (in Russian). DOI: 10.31857/S043542812001006X.

11. Khare D., Mondal, A., Mishra, P.K., Kundu, S., Meena, P. K. Morphometric analysis for prioritization using remote sensing and GIS techniques in a Hilly catchment in the state of Uttarakhand, India. Indian Journal of Science and Technology, 2014. V. 7(10). P. 1650-1662.

12. Korytnyi L.M. Basin concept in nature management. Irkutsk: Izd-vo Instituta geografii SO Ran, 2001. 163 p. (in Russia).

13. Kuzmenko Ya.V., Lisetskii F.N., Narozhnyaya A.G. Application of the basin concept of nature management for soil and water protection arrangement of agricultural landscapes. Izvestiya Samarskogo nauchnogo tsentra Rossiyskoy akademii nauk, 2012. V. 14. No 19. P. 2432-2435 (in Russian).

14. Lisetskii F.N. Buriak Zh.A., Marinina O.A., Poletaev A.O. Basin differentiation of landscapes of the lowland Crimea as the basis for projects of soil protection systems of agriculture. Landscape science and landscape ecology: coadaptation of landscape and economic activity: materials of the international. scientific-practical conf. "The fourth landscape-ecological readings dedicated to G.E. Grishankov", Simferopol, September 2225, 2020 Simferopol, 2020. P. 42-47 (in Russian). 
15. Lisetskii F.N., Zemlyakova A.V., Terekhin E.A., Naroznyaya A.G., Pavlyuk Y.V., Ukrainskii P.A., Kirilenko Z.A., Marinina O.A., Samofalova O.M. New opportunities of geoplanning in the rural area with the implementing of geoinformational technologies and remote sensing. Advances in Environmental Biology, 2014. V. 8. No 10. P. 536-539.

16. Malyshev A.V., Goleusov P.V. The critical value of the relief factor and the erosion hazard of the agricultural landscapes of the Belgorod region. Belgorod state university scientific bulletin natural sciences, 2019. V. 43. No 1. P. 63-75 (in Russian). DOI: 10.18413/20754671-2019-43-1-63-75.

17. Mamedov S.G., Alekberova S.O., Gamidova Z.A., Ismaylova L.A. Study of morphometric indicators of the relief of mudflow-prone basins according to radar satellite images (on the example of the Shanchai-Damiraparanchay interfluve). Bulletin of the Moscow Region state University. Series: Natural Sciences, 2017. No 2. P. 59-70 (in Russian). DOI: 10.18384/23107189-2017-2-59-70.

18. Modern landscapes of the Crimea and adjacent water areas. Editor Y.A. Pozachenok.; Simferopol': Biznes-Inform, 2009. 668 p. (in Russia).

19. Morgan R.P.C. Soil Erosion. London, New York: Longman, 1979. 113 p.

20. Pozachenyuk E.A., Petlyukova E.A. GIS analysis of morphometric indicators of the relief of the central foothills of the main ridge of the Crimean Mountains for the purposes of landscape planning. Scientific Notes of the Crimean Federal V.I. Vernadsky University. Geography. Geology, 2016. V. 2 (68). No 2. P. 95-111 (in Russian).

21. Prasad R.K., Mondal, N.C., Banerjee, P. Nandakumar M.V., Singh V.S. Deciphering potential groundwater zone in hard rock through the application of GIS. Environ Geol, 2008. No 55. P. 467-475. DOI: 10.1007/s00254-007-0992-3.

22. Shwebs G.I. Formation of water erosion of sediment runoff and their assessment. Leningrad: Gidrometeoizdat, 1974. 184 p. (in Russian).

23. Smirnova L.G., Ukrainskii P.A., Narozhnyaya A.G., Kozhushkov A.A. Analysis of distribution of slope types at the regional level using methods of topographical modeling. Achievements of Science and Technology of ArcGIS, 2017. V. 31. No 11. P. 17-21. (in Russian).

24. Smolyaninov V.M., Degtyarev S.D., Shcherbinina S.V. Ecological and hydrological assessment of the state of the river catchments of the Voronezh region. Voronezh: Istoki, 2007. 133 p. (in Russian)

25. Sukristiyant S., Maria R., Lestiana H. Watershed-based morphometric analysis: A review. IOP Conf. Series: Earth and Environmental Science, 2018. DOI: 10.1088/1755-1315/118/1/012028.

26. Tabunshchik V.A. Relief of river basins on the northwestern slope of the Crimean mountains (for example, the basins of the Western Bbulganak, Alma, Kacha, Belbek, Chernaya rivers). Geopolitics and ecogeodynamics of regions, 2018.V. 4 (14). No 3. P. 7887 (in Russian).

27. Tabunshchik V.A., Petlyukova E.A. Density of the relief dissection on the territory of the Crimean Peninsula. Bulletin of higher education institutes north Caucasus region natural sciences, 2019. No 1 (201). P. 95-100 (in Russian).

28. Tokarev S.V., Roshchina K.N. Mapping relief elements of the earth's surface using the index of the topographic position (on the example of the Crimean peninsula). Scientific Notes of the Crimean Federal V.I. Vernadsky University. Geography. Geology, 2015. V. 1 (67). No 4. P. 64-85 (in Russian).

29. Wischmeier W.H., Smith D.D. Predictng rainfall erosion losses: A guide to conservation planning. Agriculture Handbook U.S. Department of Agriculture. Washington, DC, 1978. No 537. 543 p.

30. Yunus A., Oguchi T., Hayakawa Y. Morphometric analysis of drainage basins in the western arabian peninsula using multivariate statistics international. Journal of Geosciences, 2014. V. 5. No 5. DOI: 10.4236/ijg.2014.55049. 


\title{
USING SOCIAL MEDIA DATA TO MAP MORTAR SHELLS FALLING IN DAMASCUS, SYRIA
}

\begin{abstract}
The paper analyzes the use of social media data in geographical information systems to map the areas most affected by mortar shells in the capital of Syria, Damascus, by using geocoded and parsed social media data in geographical information systems. This paper describes a created algorithm to collecting and store data from social media sites. For the data store both a NoSQL database to save JSON format document and an RDBMS is used to save other spatial data types. A python script was written to collect the data in social media based on certain keywords related to the search. A geocoding algorithm to locate social media posts that normalize, standardize and tokenize the text was developed. The result of the developed diagram provided a year by year from 2013 to 2018 maps for mortar shell falling locations in Damascus. These layers give an overview for the changing of the numbers of mortar shells falls or in hot spot analysis for the city. Finally, social media data can prove to be useful when creating maps for dynamic social phenomena, for example, mortar shells' location falling in Damascus, Syria. Moreover, social media data provide easy, massive, and timestamped data which makes these phenomena easier to study.
\end{abstract}

KEYWORDS: Data mining, Geocoding, NoSQL databases, Social Media.

\section{INTRODUCTION}

From the beginning of the Syrian war, the civilian people were struck by mortar shelling, bombing and artillery bombardment. Shelling of the city of Damascus started since the battle of Damascus in 2011 with the attempt of the armed opposition to take control of the city. There are multiple new articles since 2011 about the shelling neighborhoods of Damascus and the causalities of the shelling. These shelling became a characterization of the Syrian civil war, to the point where improvised artillery canons have emerged, which were modified to create maximum distraction ${ }^{2}$. In addition to the mortar and artillery shelling, the capital was struck by multiple rockets. With the rise of jihadists and radical groups in Syria after the civil war, a series of suicide attackers and car bombs exploded in the capital. Social media users whether news anchors or usual users often wrote about any of these effects either to question about it or to inform others.

Social media users can share messages, videos, pictures, and even news links on their own social media pages. Social media networks can be classified by many aspects, as a series of web applications that allow users to create blogs (e.g., Twitter), social networks (e.g., Facebook), or photo, audio, and video sharing services (e.g., YouTube and Instagram) [Kaplan, 2010]. Since web applications have emerged, Social media networks have allowed their users to create and exchange generated huge amounts of content. By the end of 2018, Twitter claimed to have about 326 million monthly active users worldwide ${ }^{2}$, while Facebook claimed to have 2.32 billion monthly active users ${ }^{2}$. With such huge quantities of users, the data are being generated

\footnotetext{
1 Saint Petersburg University, Sredniy Prospekt V.o., 41, 199034, Saint-Petersburg, Russia, e-mail:mo-hasan89@hotmail.com

https://en.wikipedia.org/wiki/Improvised_artillery_in_the_Syrian_Civil_War

Statista: url: https://www.statista.com/
} 
continuously and dynamically to study different social phenomena. Also, the shared data can be used to study geographical phenomena since data on these social networks usually have geotags (i.e. coordinate of post location), and if not a geocoding process of the text content is necessary to get the coordinate for the data [Hecht, 2011]. Using sentiment analysis on social media data, many studies have been conducted on predicting disaster responses in cities [Alexander, 2014], tracking disease spread [Hung, 2015], monitoring special events [8], and measuring public opinions on political issues without a survey [Sakaki, 2010].

In times of disasters both natural (e.g. hurricanes) and man-made (e.g. terrorist attacks) the usage of social media increases which is followed by a larger than the usual number of posts, and with such increase researchers can study human behavior in times of disasters [Soulis, 2013]. Therefore, geolocated data from social media became a main source of data in times of disasters such as disaster response [Simon, 2015] and disaster relief [Goodchild. 2010], as well as in spatiotemporal crime analysis and crime predictions [Barbier, 2011]. Also, social media data have been used in counter-terrorism applications [Alharith, 2018]. With such wide applications, social media data can be used to analyze mortar shelling falls in Syria since more social media data in some areas means a larger effect for the mortar shelling on the population for that area.

Even though social media can provide dynamical, huge, and easy to obtain data with many advantages, but using these data still have it limitation and drawbacks. For example, it is hard to collect data that are representative of the whole population, due to the digital divide which is the inability or lack of desire to use or access the whole internet or write about certain topics. The digital divide affects the social media data since content creators are young people (especially, university graduates) who tend to share data on the internet [Brake, 2014]. Moreover, Social media data are subjected also to inequality in representation because certain topics such as politics are more shared on social media websites based on the creators [Schradie, 2011]. Researchers estimate that the number of who use and share data on social media cannot represent the full number of the population. The percentage of Twitter users represents about $66 \%$ of the USA [Smith, 2019].

Using social media data to analyze geographical activities is getting mere popular with the spread of using mobile devices that can get users' coordinates. Although geo-referenced data from mobile phones have quality issues, such as noises and spam spots, the data can prove to be crucial to some researchers. It is required; therefore, additional parsing for the data or implementation of NoSQL data stores. Finally, Social media sites do not provide full and direct access to all their datastores. Therefore, researchers often create their mechanisms to collect data via designated access interfaces provided by social media services.

Even though there are some challenges to using social media data in analyzing geospatial activities, these challenges should not prevent using social media data in GIS applications, since the benefits of using dynamic and timestamped data overcome these drawbacks. Moreover, the amount needed to collect a huge amount of data is much less than traditional methods which have their drawbacks as well. Therefore, Social media should not be excluded as a data source for GIS analysis.

\section{MATERIALS AND METHODS}

Although most social media services have commercial solutions to fully access their content in their databases, these commercial uses can prove to be costly. Most social media sites provide an application programming interface (API) that allows limited access to their data for free. Twitter's API is a free interface that allows extracting data from Twitter's datastore up to 7 days before the query, while Facebook's graph API allows only access on public pages using their Facebook ID. A solution to these problems is to use third-party applications which allow collecting data through requesting it using an internet browser. 


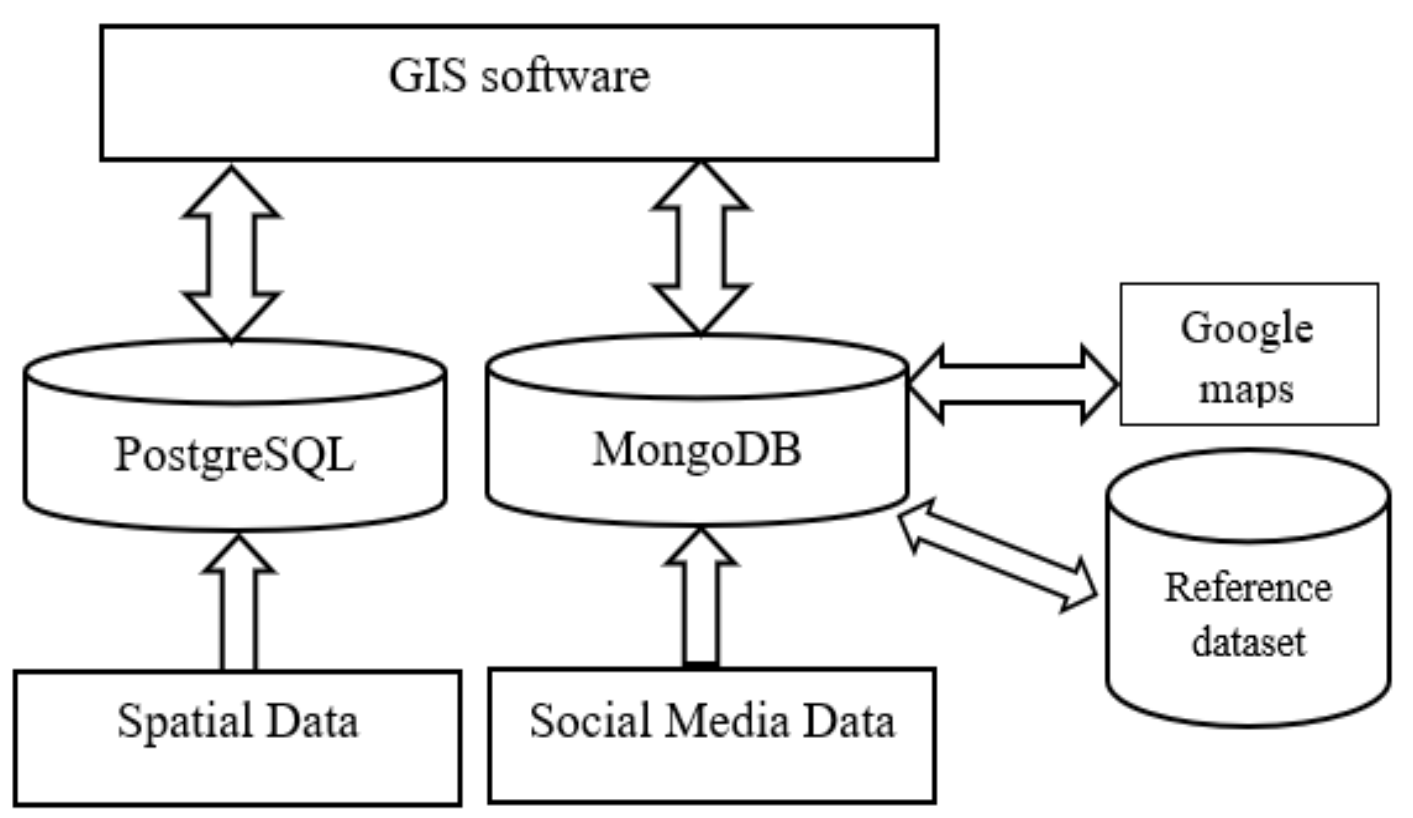

Fig. 1. Architecture for collecting and using Social media data

The designed architecture uses a python script to collect and store social media data in BJSON format in MongoDB which is an open-source NoSQL document database. Other geospatial data were stored in PostgreSQL, another open-source relational database. Google geocode API was used to get the location to the social media data. Google geocode API uses tokenized words as input to get the coordinates. The tokenized words are selected from a preselected set of words that have a location meaning.

The extracted social media data of Syria were approximately 14 million tweets and 1 million posts from Facebook gathered from 80 local news network pages. The social media data were generated for 6 years since 2013 and amassed over 15 GB in size. When using data from social media there is always a question about the validity of the data, since every user can spread information. The data mined from Facebook were collected from only trusted sources. These trusted sources included local news networks and pages with a high number of followings. These pages are assumed to have more accurate data. Data from Twitter collected from regular users without any restriction. Although in Syria laws incriminate the spread of fake news on social networks since 2012, but the overall accuracy of the data could not be guaranteed.

The data mined from social media have a JSON (JavaScript Object Notation) which is a key, value format to save data. Figure 2 shows an example of the data mined from Twitter. Data retrieved from Facebook have a similar data structure but with different key names. The "geo" key in the figure represents the geotag in Twitter's data. The key can have either a null value or an object with the latitude and longitude values. Although the geotag can prove to be useful in some applications, in this study the algorithm focuses on geocoding the text of the tweet of the Facebook post as the user could be writing about the event far from it.

Both the keys "Message" in Facebook's data and "Text" contain the text data of the post which will be used to feed the geocoding algorithm to obtain the coordinates. Another important key in the data is the "created_at" key which contains the date on which the data were created. This key can be used to provide a time series for mortar falling. 
"created at": "Thur Apr 09 12:59:37 +0000 2015",

"id" : "1069533912605630464",

"id_str" : "1069533912605630464",

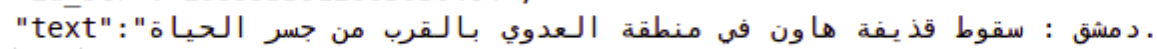

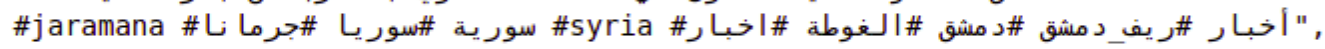

"truncated": "False",

"entities": "\{hashtags: [list of hash tags], symbols: [], user_mentions: [list of user's menstions],

urls: [\{url: tweet's url, expanded_url: long link,

display_url: long data, indices: $[\overline{]}\}]\} "$,

"metadata":" \{iso_language_code: ar, result_type: recent\}",

"source" : "null",

"in_reply_to_status_id": "None",

"in_reply_to_status_id_str": "None",

"in reply to user id" : "None",

"in_reply_to_user_id_str": "None",

"in_reply_to_screen_name" : "None",

"usēer": "user's information e.g. user's id, image link, status, etc.",

"geo" : "None",

"coordinates": "None",

"place" : "None",

"contributors" : "None",

"retweeted_status": [

],

"list of retweets "

"is_quote_status": "False",

"retweet_count": "2282",

"favorite count": "०",

"favorited" : "False",

" retweeted": "False",

"possibly_sensitive" : "False",

"lang" : "ar"

\}

Fig. 2. Example of a mined tweet.

Geocoding forms a fundamental part of spatial analysis in a variety of research disciplines especially in extracting spatial coordinates from social media [Golubovic, 2017]. The algorithm used to solve geocoding the data is similar to the gazetteer algorithm [Churches, 2002]. The gazetteer algorithm cannot generate the coordinates itself, where google maps geocode API query is used on the output to have the coordinate needed. If Google mas API did not return any results by the algorithm the data is thrown away, since not every social media feed should have a geospatial location.

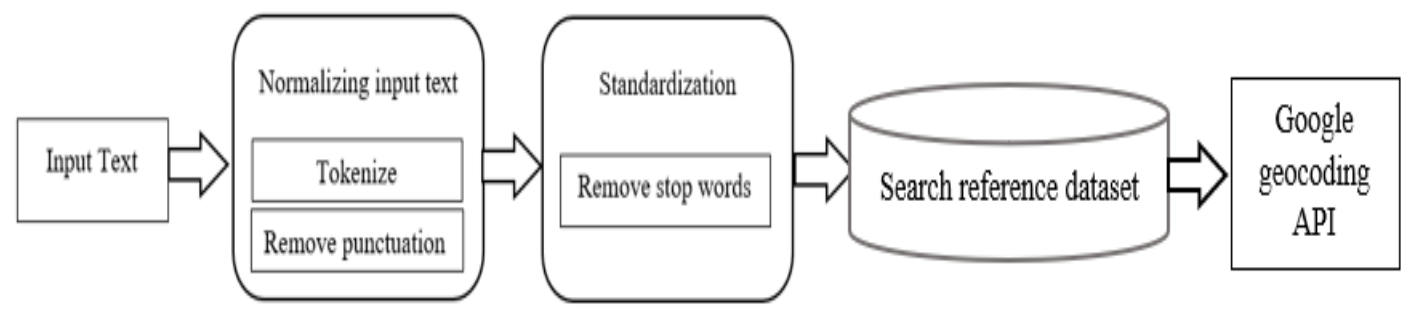

Fig. 3. Schematic of geocodeing social media data

Geocoding forms a fundamental part of spatial analysis in a variety of research disciplines especially in extracting spatial coordinates from social media [Golubovic, 2017]. The algorithm 
used to solve geocoding the data is similar to the gazetteer algorithm [Hill, 2000]. The gazetteer algorithm cannot generate the coordinates itself, where google maps geocode API query is used on the output to have the coordinate needed. If Google mas API did not return any results by the algorithm the data is thrown away, since not every social media feed should have a geospatial location.

Figure 3 demonstrates the diagram of the algorithm in which the algorithm standardizes and normalizes the input to get the tokenized sentiment the algorithm removes stop words, corrects typos, and removes punctuation marks. The algorithm then makes a 2-gram word set since most cities, towns, street names and squares in Syria consist of two words. Then, the 2-grams and the words are compared with two datasets. The first dataset is the most important points in Syria, such as names of cities, towns, villages, city squares, etc. While the second dataset came from analyzing the social media datasets and picking the words which have a geospatial meaning, i. e. have in Arabic words such as school, road, hospital, etc. After the normalization and standardization to be compatible to be searchable on google maps geocoding API, the algorithm queries the text through the API to derive the final output coordinates. The results of the geocoding algorithm are shown in figure 4.

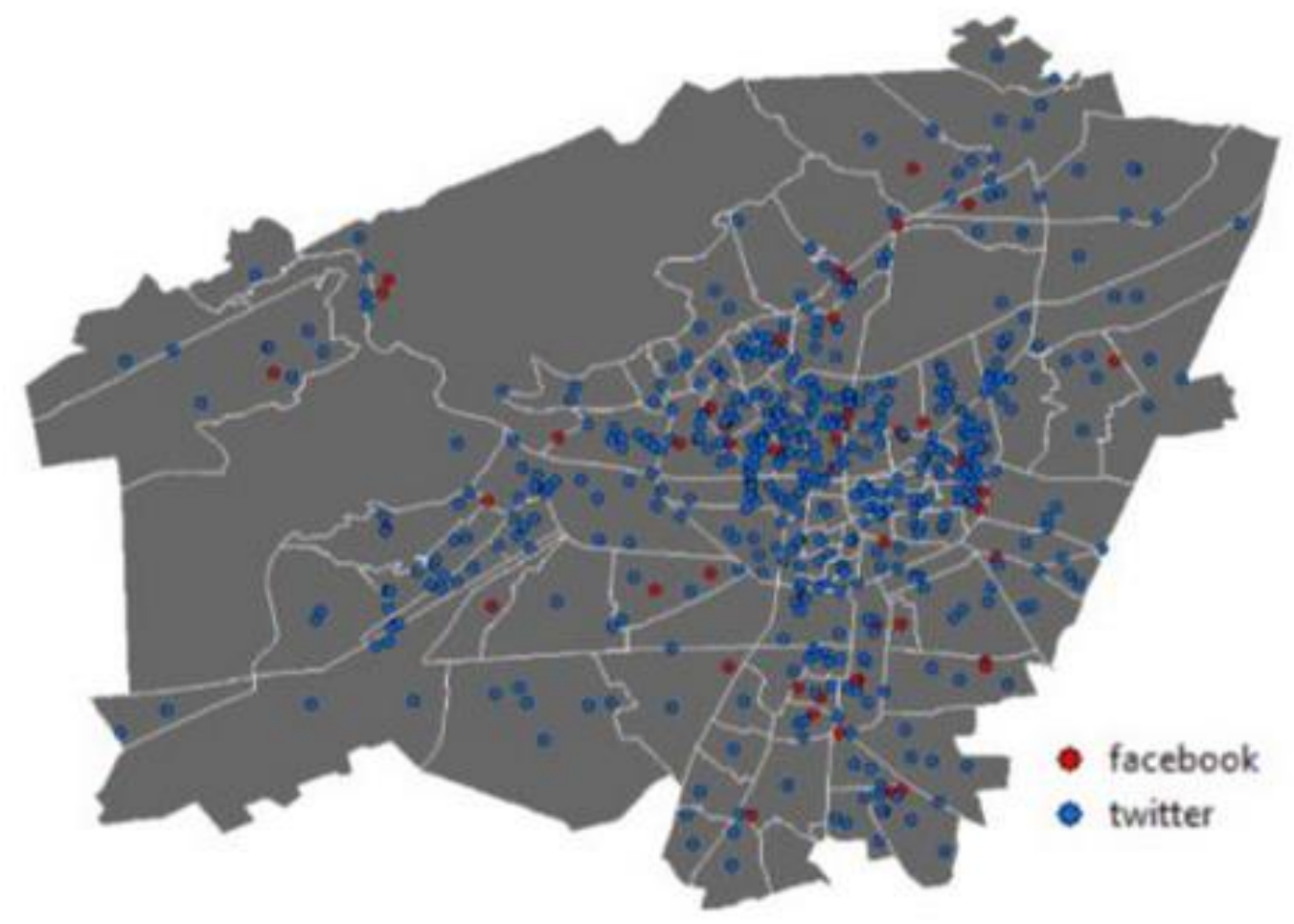

Fig. 4. Map of geocoded social media data in Damascus about Mortar falling

\section{RESULTS AND DISCUSSION}

The data which were processed by the geocoding algorithm mentioned in the algorithm used in geocoding was able to find the coordinates for $15 \%$ for Twitter data and $48 \%$ of the Facebook data. Some of the posts were found out the borders of Damascus, this can be attributed to the fact that both level 1 geocoding data which is neighborhood names, and other place names such as schools, streets, and mosques, are repeated in other cities, therefore, an additional 


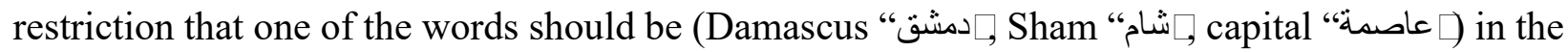
posts and tweets to ensure that the geocoding results are within the city.

One hundred random posts and tweets were randomly selected to check the accuracy of the geocoding algorithm. Feeding these data to the geocoding algorithm returns the words used in the google maps API and by checking manually the location of these words. It was found that about 83 of the 100 inputs were placed correctly. It should be noted that if google maps API returned only the coordinates of the city the data were removed from the database, as such data does not add any additional information.

Many processes of the geocoding algorithm gave only the coordinates of the neighborhood center because many of the social media data are written only with the name of the neighborhood in the post. since most data posts mentions only the name of populations places without mentioning the whole address of these conflicts. The geocoded mined data from social media were divided between $36 \%$ of the data were geocoded using the first level, i.e. names of neighborhoods only, and $13 \%$ that were geocoded using the second level of geocoding, i.e. names of point of interests, such as schools and city squares.

Table 1. Percentage of geocoded social media data of the total mined data Social Media Type Only nebierhood centers Nebierhoods + points of intrests

$\begin{array}{lll}\text { Facebook } & 45 \% & 32 \% \\ \text { Twitter } & 35 \% & 11 \% \\ \text { Facebook+Twitter } & 36 \% & 13 \%\end{array}$
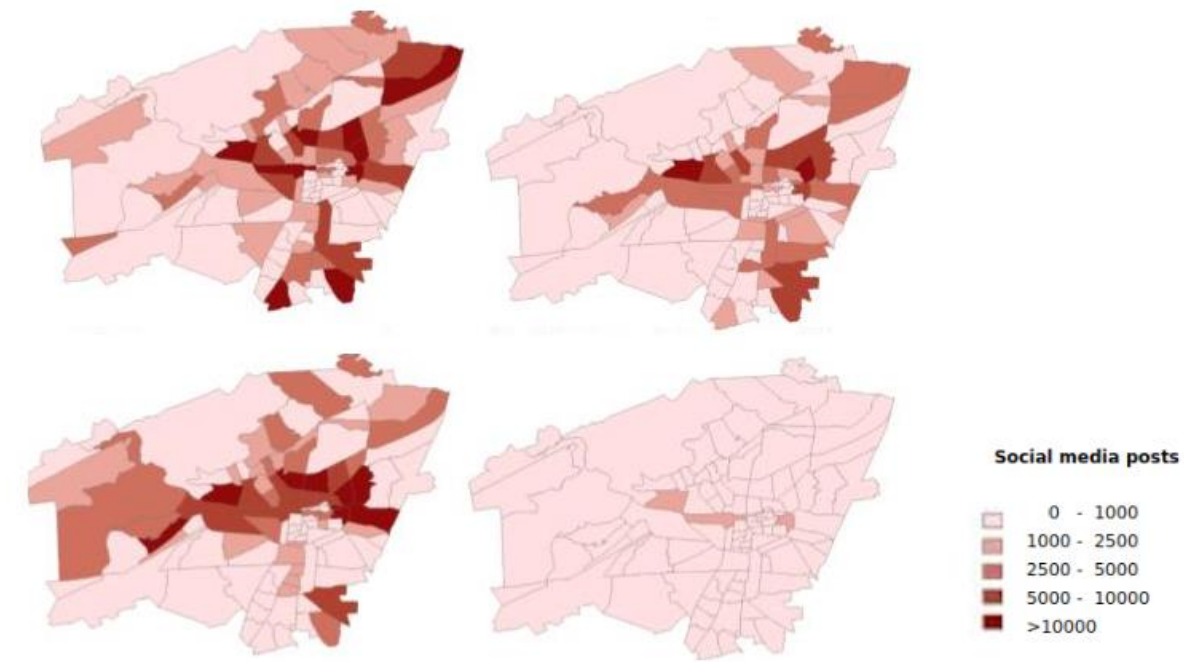

[ᄆ $0 \cdot 1000$

$1000 \cdot 2500$

- $2500 \cdot 5000$

$5000 \cdot 10000$
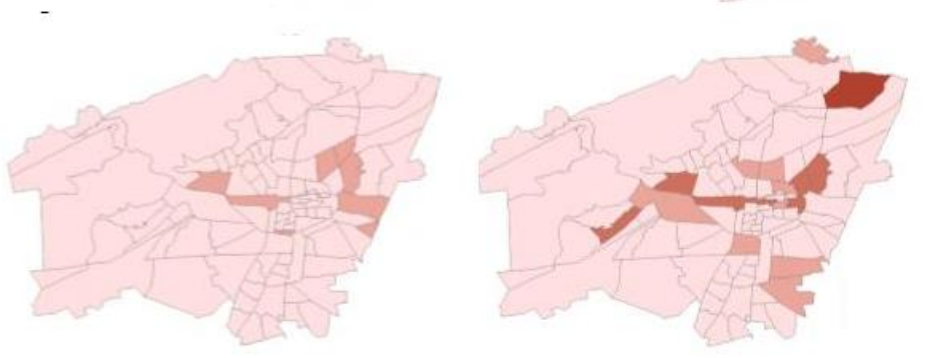

$>10000$

Fig. 5. Mortar shells posts by neighborhood between 2013- 2018 in Damascus, Syria 


\section{CONCLUSION}

Social media sites provide a data source for GIS to butter analyze complex social and environmental systems. Social media structure which is massive and semi-structured requires nontraditional methods to process the data for GIS software, such as NoSQL and parsing JSON documents. The proposed architecture showed to be reliable when processing Twitter and Facebook data for GIS analysis. The study was conducted to analyze mortar shell effects on the population-based on social media data for revealing spatiotemporal patterns of risks. Such insights are difficult to acquire, especially when studying the effects of mortar falling on population, a topic that could not be hard to analyze using traditional methods of GIS data collecting and acquiring. Secondly, the results show that using social media data can be used in counter-terrorism and humanitarian proposes to study the area most hit by mortar shelling.

\section{REFERENCES}

1. Alexander, D. E., Social media in disaster risk reduction and crisis management. Science and engineering. 2014. V. 20, issue. 3. P. 717-733.

2. Alharith, A., Samak, Y. Fighting terrorism more effectively with the aid of GIS: Kingdom of Saudi Arabia case study. American journal of geographic information system, 2018. V. 7, issue. 1. P. 15-31.

3. Barbier, G., Goolsby, R., Gao, H., Harnessing the Crowdsourcing power of social media for disaster relief. IEEE intelligent systems, 2011. V. 26, issue. 3. P. 10-14.

4. Brake, DR., Are we all online content creators now? web 2.0 and digital divides. Journal of computer-mediated communication, 2014. V. 19, issue. 3. P. 591-609.

5. Churches, T., Christen, P., Lim, K., Zhu, J. X., Preparation of name and address data for record linkage using hidden Markov models. BMC Medical Informatics and Decision Making, 2002. V. 2. P. 1-16.

6. Golubovic N., Krintz, C., Wolski, R., Lafia, S., Hervey, T., Kuhn, W., Extracting spatial information from social media in support of agricultural management decisions. Proceedings of the 10th Workshop on Geographic Information Retrieval, 2017, Burlingame, California: GIR '16.

7. Goodchild, M., Glennon, A., Crowdsourcing geographic information for disaster response: A research frontier. International journal of digital earth, 2010. V. 3, issue. 3. P. 231-241.

8. Hay, S.I., George, D.B., Moyes, C.L., Brownstein, J. S., Big data opportunities for global infectious disease surveillance. PLoS medicine, 2013. V. 10, issue. 4, doi: 10.1371/ journal.pmed.1001413.

9. Hecht, B., Hong, L., Suh, B., Tweets from Justin Bieber's heart: The dynamics of the location field in user profiles. Proceedings of the 2011 annual conference on human factors in computing systems, 2011, P. 237-246.

10. Hill L., Core elements of digital gazetteers: placenames, categories, and footprints. Research and advanced technology for digital libraries, 2000. V. 1923. P. 280-290.

11. Huang, Q., Yu Xiao, Y., Geographic situational awareness: mining tweets for disaster preparedness, emergency response, impact, and recovery. ISPRS international journal of geo-information, 2015. V. 4, issue: 3. P. 1549-1568.

12. Kaplan, A., Haenlein, M., Users of the world, unite! the challenges and opportunities of social media. Business Horizons, 2010. V. 53. P. 59-68.

13. Sakaki, T., Okazaki, M., Earthquake shakes twitter users: Real-time event detection by social sensors. Proceedings of the 19th international conference on world wide web, 2010. P. 851-860. 
14. Schradie, J., The digital production gap: The digital divide and web 2.0 collide. Poetics, 2011. V. 39, issue. 2. P. 145-168.

15. Simon, T., Goldberg, A., Adini, B., Socializing in emergencies, A review of the use of social media in emergency situations. International journal of information management, 2015. V. 35, issue. 1. P. 609-619.

16. Soulis, K., Varlamis, I., Giannakoulopoulos, A., Charatsev, F., A tool for the visualization of public opinion. International journal of electronic governance, 2013. V. 6, issue. 3. P. 218-231.

17. Smith, A., Why Americans use social media. Technical report, Pew Research Centre. URL: http://www.pewinternet.org/Reports/2011/WhyAmericans-Use-Social-Media.aspx， visit date: 12/4/2019. 


\title{
М.А. Кондратьева ${ }^{1}$, А.Н. Чащин ${ }^{1}$ \\ ОЦЕНКА ЭРОЗИОННОЙ ОПАСНОСТИ РЕЛЬЕФА НА ОСНОВЕ ЦИФРОВОГО МОДЕЛИРОВАНИЯ
}

\begin{abstract}
АННОТАЦИЯ
На базе цифровой модели рельефа (ЦМР) по обобщенным данным из USGS STRM DEM и ASTER GDEM c разрешением 3" с помощью ГИС-технологий выполнен морфометрический анализ территории Пермского края в масштабе 1:2,5 млн и создана серия морфометрических карт, а также оценочная карта эрозионной опасности рельефа. Согласно результатам морфометрического анализа, значения показателя вертикального расчленения рельефа в регионе варьируют в пределах 0-623 м при средних значениях показателя 44 м. Крутизна склонов изменяется от 0 до $40^{\circ}$ при средних значениях $3^{\circ}$. Горизонтальное расчленение, рассчитанное на основе сети тальвегов постоянных и временных водотоков, изменяется в интервале 0,145-1,202 км/км². Сравнение указанных морфометрических показателей на ключевых участках с данными, полученными традиционными методами морфометрического анализа, выявило их совпадение на уровне выделяемых градаций. Формированию значительного эрозионного потенциала территории Пермского края способствуют следующие геоморфологические факторы: широкое развитие склоновых поверхностей с перепадом высот свыше 50 м и уклонами, превышающими $3^{\circ}$. В соответствии с результатами картометрического анализа такие условия характеризуют 35 \% площади региона. Более половины площади региона (60\%) имеют среднюю густоту эрозионного расчленения $0,5-0,8$ км/км ${ }^{2}$, еще $36 \%$ площади характеризуется умеренными значениями показателя $0,2-0,5$ км/км².

Рассчитанный индекс энергии рельефа имеет значения 3-13 баллов, на его основе выделены 4 категории эрозионной опасности рельефа. В соответствии с полученными результатами, большая часть территории Пермского края $(63,0 \%)$ характеризуются слабоэрозионноопасным рельефом, 36,6 \% средне- и сильноэрозионноопасным. Доля земель, рельеф которых характеризуется нулевым эрозионным потенциалом, составляет $0,4 \%$ площади края.
\end{abstract}

КЛЮЧЕВЫЕ СЛОВА: эрозионная опасность, цифровая модель рельефа, SRTM, ASTER, ГИС-технологии, Пермский край, морфометрический анализ.

Mariya A. Kondrateva ${ }^{2}$, Aleksey N. Chashchin ${ }^{2}$

\section{ASSESSMENT OF EROSION RISK OF RELIEF BASED ON THE DIGITAL MODELING}

\author{
ABSTRACT \\ On the basis of a digital elevation model (DEM) based on generalized data from USGS \\ STRM DEM and ASTER GDEM with a resolution of 3" with the help of GIS technologies, a

\footnotetext{
1 Пермский государственный аграрно-технологический университет, ул. Петропавловская, д. 23, 614000, Пермь, Россияе-mail: pochva@pgsha.ru

2 Perm State Agro-Technological University, Petropavlovskaya str., 23, 614000, Perm, Russia, e-mail: pochva@pgsha.ru
} 
morphometric analysis of the territory of the Perm Territory at a scale of 1:2.5 million was carried out and a series of morphometric maps was created, as well as an assessment map of the erosion hazard of the relief. According to the results of morphometric analysis, the values of the index of vertical dissection of the relief in the region vary within the range of $0-623 \mathrm{~m}$ with an average value of $44 \mathrm{~m}$. The steepness of slopes varies from 0 to $40^{\circ}$ with average values of $3^{\circ}$. The horizontal dissection, determined on the basis of the thalweg network of permanent and temporary streams, varies in the range of $0.145-1.202 \mathrm{~km} / \mathrm{km}^{2}$. Comparison of morphometric indicators in key areas with the data obtained by traditional methods of morphometric analysis revealed their coincidence at the level of gradations. The following geomorphological factions curtains: wide development of slope surfaces with elevation differences over $50 \mathrm{~m}$ and slopes exceeding $3^{\circ}$. According to the results of cartometric analysis, such conditions characterize $35 \%$ of the region's area. More than half of the region's area $(60 \%)$ has an average density of erosional dissection of $0.5-0.8 \mathrm{~km} / \mathrm{km}^{2}$, another $36 \%$ of the area is characterized by moderate values of $0.2-0.5 \mathrm{~km} / \mathrm{km}^{2}$.

The calculated relief energy index has a value of 3-13 points; on its basis, 4 categories of relief erosion hazard were identified. In accordance with the results obtained, most of the Perm Territory $(63.0 \%)$ is characterized by a low erosion hazardous relief, $36.6 \%$ by a medium and highly erosion hazardous. The share of land, the relief of which is characterized by zero erosion potential, is $0.4 \%$ of the region's area.

KEYWORDS: erosion hazard, digital elevation model, SRTM, ASTER, GIS technologies, Perm region, morphometric analysis.

\section{ВВЕДЕНИЕ}

В Пермском крае водная эрозия является одним из наиболее негативных факторов деградации почв и агроландшафтов, источником загрязнения поверхностных вод, нарушения экологического равновесия в природно-антропогенных геосистемах. По масштабу проявления эрозионных процессов регион занимает одно из первых мест в зоне Нечерноземья, площади эродированных пахотных угодий оцениваются в 932 тыс. га, еще 219 тыс. га кормовых угодий являются потенциально эрозионноопасными [Скрябина, 1990]. Одним из важнейших факторов, определяющих эрозионный потенциал территории, является рельеф. Его влияние определяется воздействием на формирование и перераспределение атмосферных осадков, распределение почв, растительности, типов использования земель [Осинцева, 2003; Papaiordanidi and etc., 2019]. Расчёт эрозионного потенциала рельефа в зависимости от используемой методики смыва может быть разным, однако все исследователи сходятся во мнении, что это функция от крутизны и длины склонов. Оценка потенциальной опасности эрозии по условиям рельефа может быть выполнена на основе комплекса морфометрических показателей, таких как вертикальное и горизонтальное расчленения рельефа, уклоны поверхности. Геоинформационные технологии и глобальные ЦМР существенно упрощают получение количественного материала о рельефе и успешно используются в морфометрическом анализе [Mondal and etc., 2017; Ramesh. Dikpal and etc., 2017; Bogale, 2021]. Для расчёта морфометрических характеристик в настоящее время используют ЦМР, построенные на регулярной растровой основе. Наиболее востребованными большинством исследователей на сегодняшний день являются модели рельефа, полученные в ходе выполнения миссий SRTM. Радарная топографическая съёмка Shuttle Radar Topographic Mission (SRTM) - глобальная ЦМР с разрешением 1" и 3". ЦMP SRTM покрывает территорию, расположенную между $60^{\circ}$ с.ш и $56^{\circ}$ ю.ш. Съемка проводилась в период с 11 по 22 февраля 2000 г с помощью SIR-C- и XSAR-сенсоров, работающих по технологии радиолокационного синтезирования апертуры [Farr and etc., 2017]. 
Однако STRM не обеспечивает полного покрытия данными для всех регионов России. В частности, для северных территорий страны (выше $60^{\circ}$ с.ш.) используются ЦМР из других источников, имеющих больший охват покрытия. Наиболее часто упоминаемый пример - модель рельефа «ASTER GDEM». Глобальная цифровая модель рельефа ASTER GDEM создана на основе сопоставления стереоснимков, выполненных посредством усовершенствованного спутникового радиометра теплового излучения и отражения (Advanced Spaceborne Thermal Emission and Reflection Radiometer). Охват съёмки миссии ASTER покрывает территорию между $83^{\circ}$ северной и южной широт фрагментами с разрешением 1". В настоящее время модель существует в двух версиях [Reuter and etc., 2009]. Все версии моделей SRTM и ASTER GDEM распространяются с использованием географических координат на основе референц-элипсоида WGS84.

Обобщение таких разнородных данных: USGS STRM DEM и ASTER GDEM, а также информацию о рельефе из топографических карт представляет проект Viewfinder Panoramas, автором которого является Jonathan de Ferranti [Ferranti, 2014]. Результат его работы содержит синтез цифровой информации о высотах, охватывающей почти всю планету. Эти открытые данные представлены на сайте ${ }^{1}$.

Основной характеристикой ЦМР, которая определяет точность производных морфометрических величин, является ошибка определения абсолютной высоты. Средние ошибки по высоте в различных версиях моделей колеблются от долей метра до 10-11 м по модулю [Думит, 2007; Оньков и др., 2012; Мальцев и др., 2018; Frey, 2018], средние ошибки уклонов варьируют от $2.54^{\circ}$ до $7.37^{\circ}$ для SRTM и $1.21-4.73^{\circ}$ для ASTER GDEM [Szabó G. and etc., 2015].

\section{МАТЕРИАЛЫ И МЕТОДЫ ИССЛЕДОВАНИЯ}

В работе были использованы цифровые данные о рельефе собранные из глобальных ЦMP USGS STRM DEM и ASTER GDEM в проекте Viewfinder Panoramas [Ferranti, 2014] с разрешением 3" (размер ячейки $90 \times 90$ м).

Расчет морфометрических показателей рельефа осуществлялся в соответствии с методиками, описанными в работах Д.М. Курловича [2013, 2014], В.А. Михайлова [2015]. Оценка эрозионной опасности рельефа производилась на основе методических подходов, изложенных в работах Н.В. Осинцевой [2003], Е.А. Позаченюк [2016], А.И. Павловой [2016].

Расчет морфометрических показателей рельефа, все карты и атрибутивные базы данных к ним созданы с помощью программы QGIS версии 3.16.6 в системе координат: EPSG:32640-WGS 84 / UTM zone 40N; координатная сетка построена на основе системы координат: EPSG:4326-WGS 84. При выполнении карты эрозионной опасности использовался метод классификации «Переклассификация значений в наборе растров по единой шкале».

\section{РЕЗУЛЬТАТЫ ИССЛЕДОВАНИЯ И ИХ ОБСУЖДЕНИЕ}

Территории Пермского края располагается в пределах северо-восточной окраины Восточно-Европейской равнины и западных склонов Среднего и Северного Урала. Отметки высот в равнинной части края составляют 200-400 м. В центральной и южной частях Восточно-Европейской равнины преобладает возвышенный рельеф с высотами 250-446 м.

Viewfinder Panoramas. Электронный pecypc: http://www.viewfinderpanoramas.org (дата обращения 20.01.2021). 
Низменный рельеф с отметками 110-200 м характерен для северных районов, долины реки Кама и её притоков. Минимальная высота 66 м над уровнем моря соответствует урезу воды Камы на юго-западе края. Рельеф Среднего Урала низкогорный с высотами 600-800 м и наивысшей отметкой 994 м (г. Средний Басег). Для Северного Урала типичны высоты 8001400 м, здесь же находится наивысшая высотная отметка региона 1469 м (г. Тулымский Камень).

Для оценки эрозионной опасности рельефа была создана серия базовых морфометрических карт: крутизны склонов, вертикального и горизонтального расчленения.

Крутизна склонов относится к числу важнейших базовых морфометрических показателей. Геоморфологическое значение этого параметра состоит в том, что он определяет скорость перемещения потоков вдоль земной поверхности под действием гравитации. В условиях таежно-лесной зоны начальные признаки эрозии почв появляются при уклонах поверхности чуть более $2^{\circ}$, а при уклонах более $3^{\circ}$ в следствии значительного развития эрозии рекомендовано исключение из севооборотов пропашных культур и проведение противоэрозионных мероприятий. Значения данного параметра, установленные традиционными методами, для территории Пермского края изменяются от 1 до 6-7 в равнинной части и достигают $10-35^{\circ}$ в горной [Шимановский, 1985].

Построение карты крутизны склонов на основе растра ЦМР выполнено с помощью инструмента «Крутизна» в модуле QGIS «Морфометрический анализ». Полученные значения уклонов поверхности на территории края варьируют от 0 до $40^{\circ}$ (табл. 1). Незначительные уклоны поверхности до $1^{\circ}$ преобладают на севере равнинной части, на юге крутизна склонов возрастает до значений 5-8․ Максимальные значения показателя характерны для горной части края, где они достигают 15 и более градусов (рис. 1a). В целом на долю поверхностей с крутизной более $3^{\circ}$ приходится $35 \%$ площади региона.

Карта вертикального расчленения рельефа (базисов эрозии) характеризует амплитуду колебания высот в пределах участка местности и является важным фактором, определяющим эрозионную опасность рельефа. Расчёт вертикального расчленения выполнен в среде QGIS для сетки квадратов $1 \times 1$ км. Для расчёта глубины расчленения использован инструмент программы QGIS «Зональная статистика». С помощью растра ЦМР создана атрибутивная таблица векторной сетки, содержащая информацию о минимальной и максимальной высотах и в которой выполнялась операция «вычесть». На основе векторного полигонального слоя был создан вектор центроидов с атрибутом разности максимальной и минимальной абсолютных высот в пределах каждого квадрата. Грид-модель «Вертикальное расчленение рельефа» выполнена путём интерполяции данных слоя центроидов по методу «Регуляризованный сплайн с натяжением» (рис. 1a).

Вертикальное расчленения имеет тесную связь с гипсометрией, наивысшие показатели вертикального расчленения приурочены к максимальным отметкам рельефа [Шимановский, 1985; Копылов, 2019]. Полученные минимальные и максимальные значения показателя составили 0 и 623 м при средних значениях 44 м (табл. 1). Приводимые в литературе данные о крайних значениях показателя существенно разняться. Так, по данным Л.А. Шимановского [1985], минимальные и максимальные значения составляют соответственно 4 и 1077 м, по материалам И.С. Копылова [2019], - это 1 и 1240 м. Вместе с тем, анализ распределения значений вертикального расчленения удовлетворительно согласуется с данными Л.А. Шимановского [1985], приводимыми для основных геоморфологических районов региона. В равнинной части края вертикальное расчленение рельефа изменяется от 0-50 м на севере до 100-200 м на юге, в горной возрастает до максимальных величин 400-600 м. 


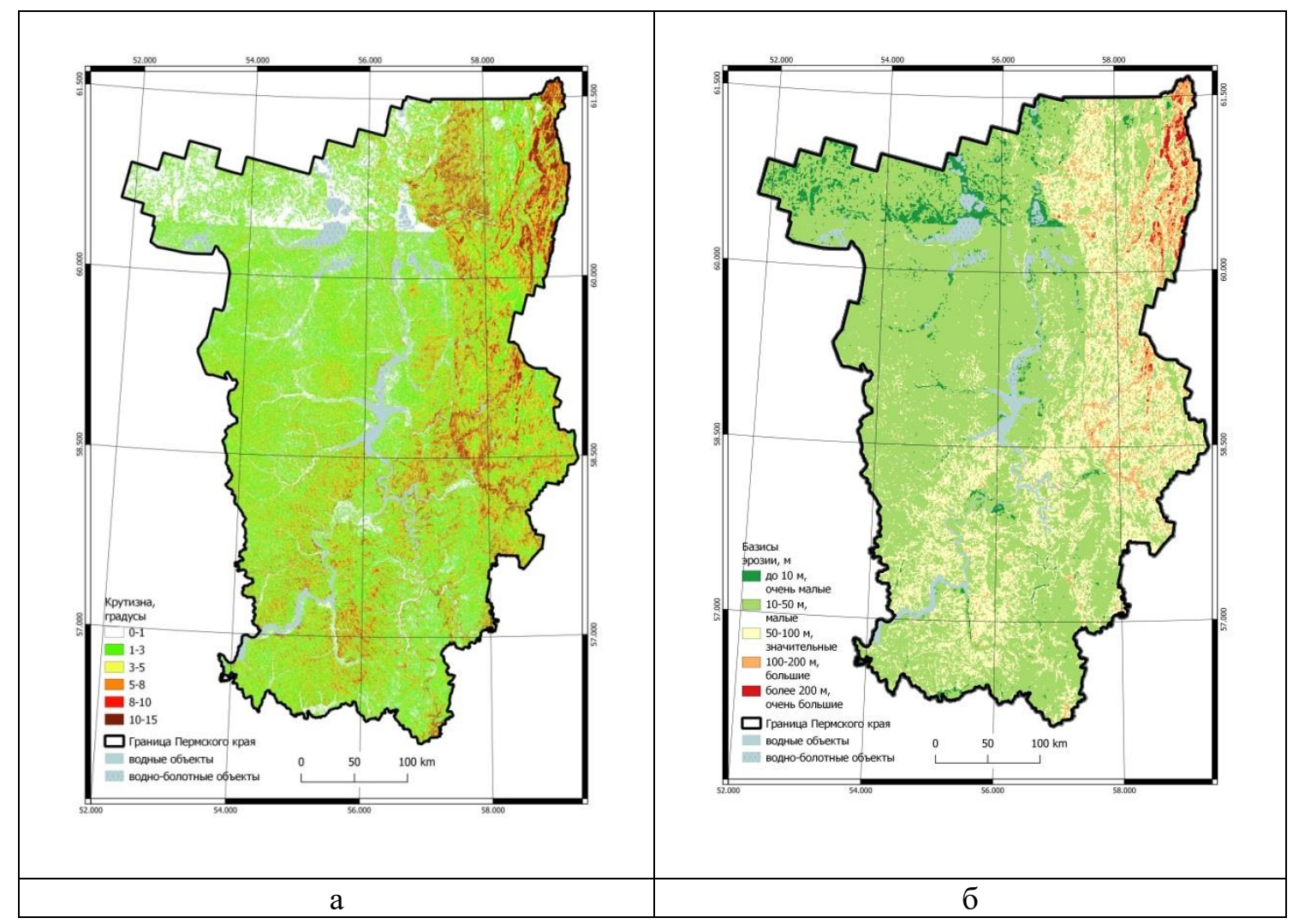

Рис. 1. Карты крутизны склонов (а) и вертикального расчленения (б)

Fig. 1. Slope steepness (a) and vertical dismemberment of a territory (b) maps

Горизонтальное расчленение поверхности рельефа характеризуется суммарной длиной линий тальвегов, приходящихся на единицу площади. Данный мрфометрический параметр позволяет оценить величину площади водосборов и длину склонов. Так, формирование объема воды, способного к размыву дернового слоя, может происходить при густоте расчленения 0,4-0,8 м/км² при условии значительного перепада высот [Путилин, 1988]. Величины горизонтального расчленения находятся в обратной зависимости с вертикальным расчленением рельефа, поскольку распределение водной массы по многочисленным водотокам снижает энергию глубинного расчленения территории [Шимановский, Шимановская, 1970].

Для определения густоты эрозионного расчленения рельефа с помощью инструмента QGIS SAGA Basic terrain analysis из растра SRTM в векторный слой извлекались линии тальвегов постоянных и временных водотоков. Общее количество извлечённых линий тальвегов составило 46920 с минимальной и максимальной длиной 64 и 34615 м соответственно (рис. 2a).

Табл. 1. Данные описательной статистики морфометрических показателей Table 1. Descriptive statistics of morphometric indicators

\begin{tabular}{|l|c|c|c|}
\hline \multirow{2}{*}{ Морфометрические показатели } & \multicolumn{3}{c|}{ Значения } \\
\cline { 2 - 4 } & мин. & макс. & среднее \\
\hline Длина линий тальвегов, м & 64 & 34615 & 1804 \\
\hline Вертикальное расчленение, м & 0 & 623 & 44 \\
\hline Горизонтальное расчленение, км/км² & 0,145 & 1,202 & 0,516 \\
\hline Крутизна склонов, градусы & 0 & 40 & 3 \\
\hline
\end{tabular}


Расчет густоты расчленения рельефа осуществлялся для сетки квадратов 8х8 км векторного полигонального слоя с последующим преобразованием данных в векторный слой центроидов, на основе которого была создана грид-модель «Горизонтальное расчленение рельефа».

Густота эрозионного расчленения изменяется от 0,145 до 1,202 км/км², составляя в среднем 0,516 км/км². Фоновыми значениями для территории региона являются величины 0,5-0,8 км/км² (рис. 2б). Максимальная густота эрозионного расчленения, превышающая 1,0 км/км², отмечается в центральных и южных районах равнинной части края, в то время как север и восток края характеризуются низкой и умеренной величиной горизонтального расчленения 0,2-0,5 км/км² и менее. Имеющиеся в научных источниках данные, полученных на основе анализа картографических материалов, характеризуются значительным разбросом значений. Так, по данным О.Л. Шимановской, Л.А. Шимановского [1970], густота речной сети в крае колеблется в пределах 0,01-1,73 км/км ${ }^{2}$, составляя в среднем 0,66 км/км². По данным О.Л. Алексеевой [1982] и И.С. Копылова [2019], значения данного показателя находятся в пределах 0,2-1,5 и 0,1-1,5 км/км² соответственно. В работе О.А. Скрябиной [1990] приводятся значения густоты долиннобалочной сети в регионе $0,26-0,96$ км/км².

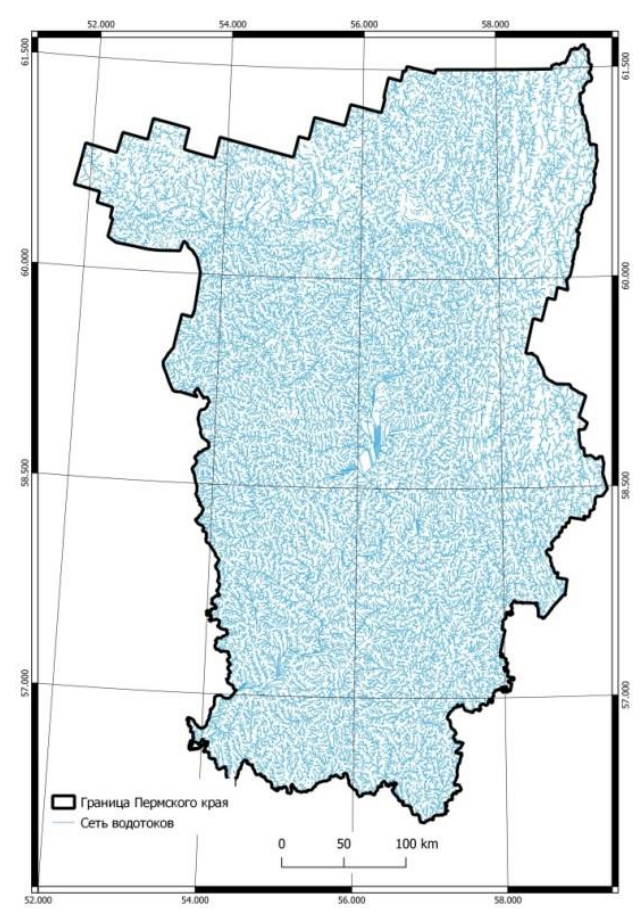

a

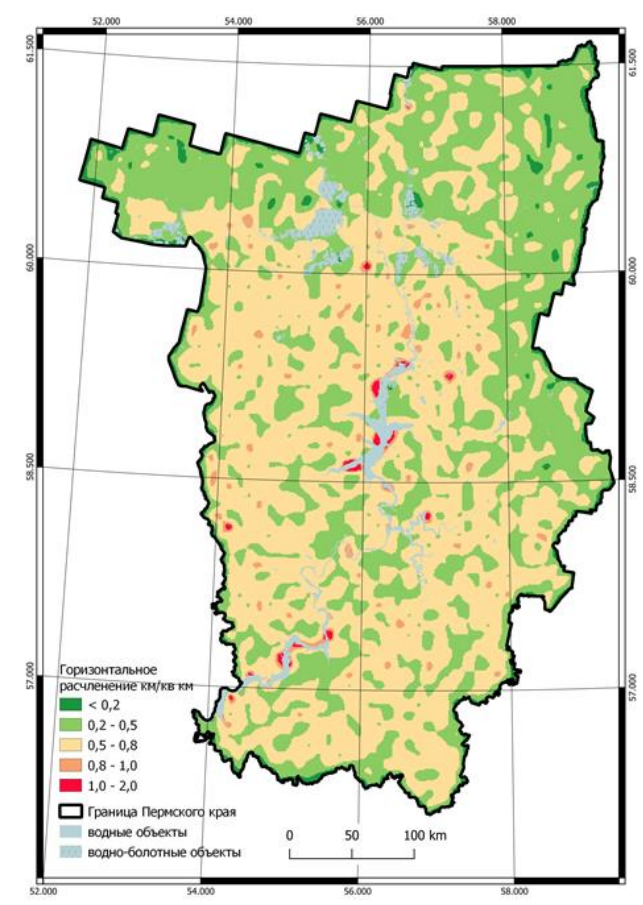

б

Рис. 2. Карты эрозионной сети (а) и горизонтального расчленения (б)

Fig. 2. Maps of the erosion network (a) and of the horizontal dismemberment (b)

Оценка эрозионной опасности рельефа выполнена на основе комплекса рассчитанных морфометрических показателей. Их индивидуальная оценка производилась по шестибалльной шкале в соответствии с градациями, принятыми в почвеннокартометрической практике (табл. 2). Категории эрозионной опасности рельефа выделены на основе интегрального показателя энергии рельефа, определяемого как сумма индивидуальных оценочных баллов показателей вертикального и горизонтального 
расчленения, а также преобладающей крутизны склонов. Данный показатель позволяет судить о вероятности и динамике проявления процессов водной эрозии.

Табл. 2. Оченочные шкаль морфометрических показателей рельефа

Table 2. Evaluation scales of morphometric parameters of the relief

\begin{tabular}{|c|c|c|c|}
\hline Балл & $\begin{array}{c}\text { Горизонтальное расчленения } \\
\text { рельефа, км/км }\end{array}$ & $\begin{array}{c}\text { Вертикальное } \\
\text { расчленения рельефа, } \mathrm{M}\end{array}$ & $\begin{array}{c}\text { Уклоны } \\
\text { поверхности, }\end{array}$ \\
\hline 1 & $<0,2$ & $<10$ & $<1,5$ \\
\hline 2 & $0,2-0,5$ & $10-50$ & $1,5-3$ \\
\hline 3 & $0,5-0,8$ & $50-100$ & $3-6$ \\
\hline 4 & $0,8-1,0$ & $100-200$ & $6-8$ \\
\hline 5 & $1-2$ & $>200$ & $8-12$ \\
\hline 6 & $>2$ & - & $>12$ \\
\hline
\end{tabular}

Преобразование непрерывных растров морфометрических характеристик рельефа в дискретные растры баллов осуществлялось методом переклассификации (по типу «Переклассификация значений в наборе растров по единой шкале») в растровом калькуляторе QGIS. В ходе процесса геообработки было создано 4 промежуточных дискретных растра с балльными оценками показателей крутизны склонов, вертикального и горизонтального расчленения, а также интегральной оценки энергии рельефа (рис. 3a). Последующий пересчёт в категории эрозионной опасности (рис. 3б) выполнен из растра интегральной оценки энергии рельефа.

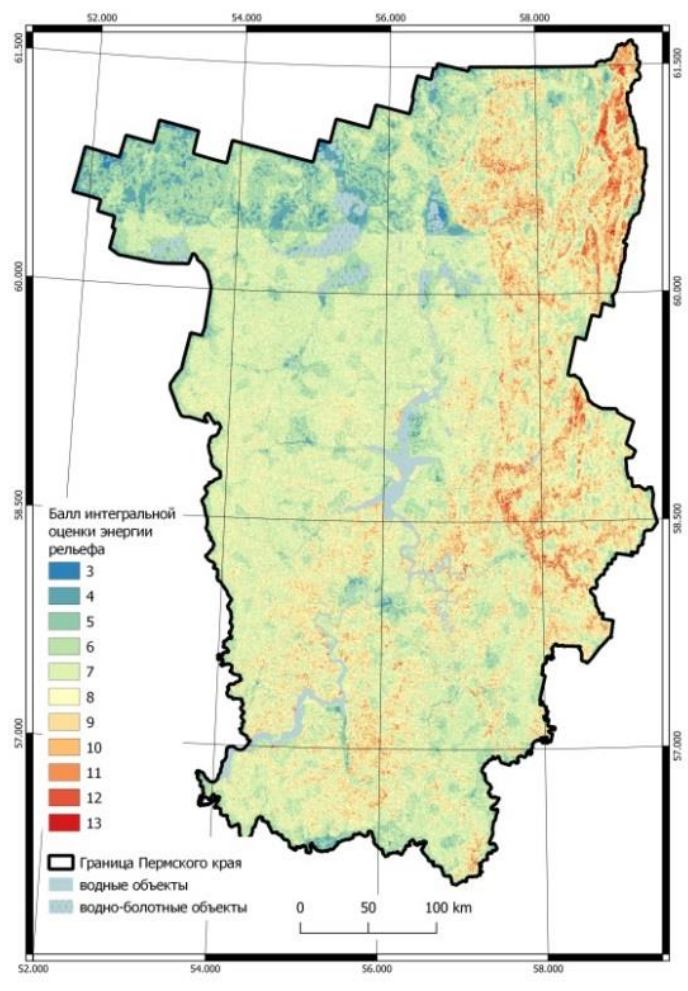

a

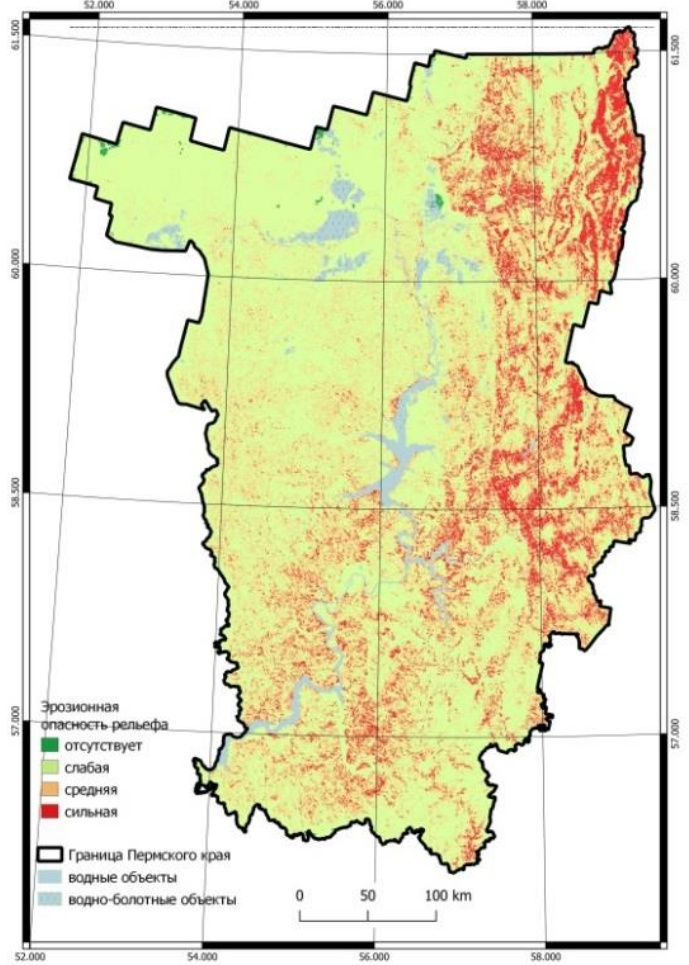

б

Рис. 3. Карты интегральной оченки энергии рельефа (а) и эрозионной опасности рельефа (б)

Fig. 3. Maps of the integrated assessment of the energy of the relief (a) and categories of erosion hazard (b) 
Интегральная оценка энергии рельефа (табл. 3) изменяется в диапазоне значений 3 13 при средних значениях 7 баллов. Минимальные значения 3-5 баллов соответствуют низменному рельефу севера края, долины Камы и ее притоков, максимальные 11-13 баллов получены для горного рельефа на востоке региона.

Табл. 3. Распределение территории Пермского края по категориям эрозионной опасности рельефа

Table 3. Distribution of the area of the Perm Territory by categories of erosion hazard of the relief

\begin{tabular}{|c|c|c|c|}
\hline \multirow{2}{*}{$\begin{array}{c}\text { Категории эрозионной } \\
\text { опасности рельефа }\end{array}$} & \multirow{2}{*}{$\begin{array}{c}\text { Интегральная } \\
\text { оценка эрозионной } \\
\text { опасности, баллы }\end{array}$} & \multicolumn{2}{|c|}{ Площадь, } \\
\hline & & $\mathrm{KM}^{2}$ & $\begin{array}{c}\text { \% от общей } \\
\text { площади }\end{array}$ \\
\hline Отсутствует & 3 & 559,03 & 0,4 \\
\hline Слабая & $4-7$ & 101190,80 & 63,0 \\
\hline Средняя & $8-9$ & 43784,64 & 27,3 \\
\hline Сильная & $10-13$ & 15006,21 & 9,3 \\
\hline
\end{tabular}

В соответствии со значениями интегрального балла эрозионной опасности путём экспертного оценивания на территории региона выделено 4 категории рельефа (табл. 3). На долю земель со средней и сильной эрозионной опасностью рельефа приходится около 37 \% площади региона. Основные ареалы земель с сильной эрозионной опасностью сосредоточены на юге и востоке края. Этому способствуют преобладание уклонов свыше $3^{\circ}$ и значительные базисы эрозии, превышающие 50 м. Учитывая тот факт, что основные площади обрабатываемых земель располагаются на юге равнинной части края, риск развития водной эрозии почв в этой части региона здесь наиболее высок. Это подтверждают данные о смытых почвах: в южных районах края доля средне- и сильносмытых почв на пашне достигает 55 \% от её площади [Скрябина, 1990]. Слабая эрозионная опасность характерна для рельефа севера и крайнего северо-востока равнинной части региона, долины Камы и ее притоков. Низкий эрозионный потенциал связан с незначительными уклонами, не превышающими $3^{\circ}$, и слабым вертикальным расчленением рельефа в пределах 0-50 м. При общей невысокой распаханности в этой части региона доля слабосмытых почв на пашне не превышает 25 \% [Скрябина, 1990].

\section{ВЫВОДЫ}

Разнообразие геоморфологических условий на территории Пермского края определяют различия в потенциале её эрозионной опасности. Для оценки эрозионной опасности рельефа на основе глобальной ЦМР построена серия мелкомасштабных карт, отображающие базовые морфометрические показатели: крутизна склонов, вертикальное и горизонтальное расчленение. Формированию значительного эрозионного потенциала на территории края способствуют следующие условия: значительное участие поверхностей рельефа с вертикальным расчленением более 50 м и уклонами поверхности свыше $3^{\circ}$, на долю которых приходится 35 \% площади. Низкая эрозионная опасность характеризует рельеф с вертикальным расчленением в пределах 10-50 м и уклонами поверхности 1-3․ Полученные с помощью ЦМР значения горизонтального расчленения отличаются слабым варьированием: 96 \% территории края отнесены к двум градациям показателя с умеренным и средним расчленением 0,2-0,8 км/км². Таким образом, их влияние на интегральную оценку эрозионной опасности рельефа следует признать незначительным.

Построенная карта эрозионной опасности рельефа содержит 4 категории, выделенные на основе экспертного оценивания: 63 \% площади края характеризуются 
слабоэрозионнопасным рельефом, 35 \% средне- и сильноэрозионноопасным. Доля земель, рельеф которых характеризуется нулевым эрозионным потенциалом, составляет менее $0,5 \%$ площади региона.

Полученные морфометрические карты, а также оценочная карта эрозионной опасности рельефа региона могут быть использованы для оценки рисков развития эрозии при планировании хозяйственной деятельности в сфере сельского и лесного хозяйства, промышленного и коммунального строительства. Опробованная методика оценки эрозионной опасности рельефа на основе данных глобальных ЦMP USGS STRM DEM и ASTER GDEM, может быть успешно реализована в других регионах.

\section{СПИСОК ЛИТЕРАТУРЫ}

1. Алексеева О.Л. Суммарная расчлененность рельефа Пермской области. Физикогеографические основы развития и размещения производительных сил Нечерноземного Урала: Междувед. сб. науч. трудов. Пермь: Перм. ун-т, 1982. С. 54 63.

2. Думит Ж.А. К вопросу об ошибках цифрового моделирования рельефа (морфометрический аспект). Географические исследования Краснодарского края: Сб. науч. тр. Краснодар: КубГУ, 2007. Вып. 2. С. 49-53.

3. Копылов И.С. Морфонеотектоническая система оценки геодинамической активности: монография. Пермь, 2019. 131 с. Электронный ресурс: http:// www.psu.ru/files/ docs/science/books/mono/kopylov-morfoneotektonicheskaya-sistemaocenkigeodinamicheskoj-aktivnosti.pdf (дата обращения 20.01.2021)

4. Курлович Д.М. Морфометрический ГИС-анализ рельефа Беларуси. Земля Беларуси. 2013. № 4. C. 42-48.

5. Курлович Д.М. Пространственная дифференциация и динамика морфоструктур Белорусского Поозерья. Минск: БГУ, 2014. 158 с.

6. Мальцев К.А., Голосов В.Н., Гафуров А.М. Цифровые модели рельефа и их использование в расчётах темпов смыва почв на пахотных землях. Ученые записки Казанского университета. Сер. Естественные науки. 2018. Т. 160. Кн. 3. С. 514-530.

7. Михайлов B.A. Комплексный морфометрический анализ Тарханкутского полуострова с помощью ГИС. Современные научные исследования и инновации. 2015.№ 2. Электронный pecypc: http://web.snauka.ru/issues/2015/02/46640 (дата обращения 20.01.2021).

8. Оньков И.В., Онянова Т.Я., Шиляева О.Ю. Исследование точности радарных ЦМР, построенных по снимкам ALOS PALSAR и модели SRTM, в зависимости от вида отражающей поверхности. Геоматика. 2012. № 4. С. 33-36.

9. Осинцева Н.В. Оценка эрозионной опасности рельефа территории г. Томска. Вопросы географии Сибири. Вып. 25. Томск: Томский гос. ун-т, 2003. С. 56-66.

10. Павлова А.И. Применение методов цифрового моделирования рельефа для картографирования эрозионных земель. В мире научных открытий. 2016. №2(74) C. $159-167$.

11. Позаченюк E.А., Петлюкова E.A. ГИС-анализ морфометрических показателей рельефа Центрального предгорья главной гряды Крымских гор для целей ландшафтного планирования. Учёные записки Крымского федерального университета имени В.И. Вернадского. География. Геология. Т. 2 (68). 2016. №2. С. 95-111.

12. Путилин А.Ф. Оврагообразование на юго-востоке Западной Сибири. Новосибирск, $1988.81 \mathrm{c}$. 
13. Скрябина О.А. Водная эрозия почв и борьба с ней. Пермь: Пермское книжное издательство, 1990. 246 с.

14. Шимановская О.Л., Шимановский Л.А. Густота речной сети Пермской области и закономерности ее формирования. Физико-географические основы развития и размещения производительных сил Нечерноземного Урала: Межвуз. сб. науч. трудов. Пермь: Перм. ун-т, 1970. С. 102-110.

15. Шимановский Л.А. Геоморфологическое районирование Пермской области. Физикогеографические основы развития и размещения производительных сил Нечерноземного Урала: Межвуз. сб. науч. трудов. Пермь: Перм. ун-т, 1985. С. 66-79.

16. Bogale A. Morphometric analysis of a drainage basin using geographical information system in Gilgel Abay watershed, Lake Tana Basin, upper Blue Nile Basin, Ethiopia. Appl. Water Sci. 2021. V. 11 (122). P. 1-7. DOI: 10.1007/s13201-021-01447-9.

17. Farr T.G., Rosen P.A., Caro E. and etc. The Shuttle Radar Topography Mission. Rev. Geophys. 2007. V. 45. No 2. Art. RG2004. P. 1-33. DOI: 10.1029/2005RG000183.

18. Ferranti J. Viewfinder panoramas. 2014: Digital elevations data. Электронный ресурс: URL: http://viewfinderpanoramas.org/dem3.html (дата обращения 10.04.2021).

19. Frey H., Paul F. On the suitability of the SRTM DEM and ASTER GDEM for the compilation of topographic parameters in glacier inventories. Int. J. Appl. Earth Obs. Geoinf. 2012. V. 18. P. 480-490. DOI: 10.1016/j.jag.2011.09.020.

20. Mondal A., Khare D., Kundu S., Mukherjee S., Mukhopadhyay A., Mondal S. Uncertainty of soil erosion modelling using open source high resolution and aggregated DEMs. Geosci. Frontiers. 2017. V. 8. No 3. P. 425-436. DOI: 10.1016/j.gsf.2016.03.004.

21. Papaiordanidis S., Gitas I.Z., Katagis T. Soil erosion prediction using the Revised Universal Soil Loss Equation (RUSLE) in Google Earth Engine (GEE) cloud-based platform. Dokuchaev Soil Bulletin. 2019. V. 100. P. 36-52. DOI: 10.19047/0136-16942019-100-36-52.

22. Ramesh L. Dikpal, Renuka Prasad T. J., Satish K. Evaluation of morphometric parameters derived from Cartosat-1 DEM using remote sensing and GIS techniques for Budigere Amanikere watershed, Dakshina Pinakini Basin, Karnataka, India. Appl. Water Sci. 2017. V. 7. P. 4401-4414. DOI: 10.1007/s13201-017-0585-6.

23. Reuter H.I., Nelson A., Strobl P., Mehl W., Jarvis A. A first assessment of Aster GDEM tiles for absolute accuracy, relative accuracy and terrain parameters. 2009 IEEE Int. Geoscience and Remote Sensing Symposium. IEEE, 2009. V. 5. P. 240-243. DOI: 10.1109/IGARSS.2009. 5417688.

24. Szabó G., Singh S.K., Szabó S. Slope angle and aspect as influencing factors on the accuracy of the SRTM and the ASTER GDEM database. Phys. Chem. Earth, Parts A/B/C. 2015. V. 83-84. P. 137-145. DOI: 10.1016/j.pce.2015.06.003.

\section{REFERENCES}

1. Alekseeva O.L. The total dissection of the relief of the Perm region. Physical and geographical bases of development and distribution of productive forces of the NonChernozem Urals: Interved. Sat. scientific. works. Perm: Izdatel'stvo Permskogo universiteta, 1982. P. 54-63 (in Russian).

2. Bogale A. Morphometric analysis of a drainage basin using geographical information system in Gilgel Abay watershed, Lake Tana Basin, upper Blue Nile Basin, Ethiopia. Appl. Water Sci. 2021. V. 11 (122). P. 1-7. DOI: 10.1007/s13201-021-01447-9. 
3. Dumit Zh.A. On the issue of errors in digital modeling of relief (morphometric aspect). Geographic studies of the Krasnodar Territory: Ser. Natural Sciences. Krasnodar: KubSU, 2007. Issue. 2. P. 49-53.

4. Farr T.G., Rosen P.A., Caro E. and etc. The Shuttle Radar Topography Mission. Rev. Geophys. 2007. V. 45. No 2. Art. RG2004. P. 1-33. DOI: 10.1029/2005RG000183.

5. Ferranti J. Viewfinder panoramas. 2014: Digital elevations data. Web resource. URL: http://viewfinderpanoramas.org/dem3.html (accessed 10.04.2021).

6. Frey H., Paul F. On the suitability of the SRTM DEM and ASTER GDEM for the compilation of topographic parameters in glacier inventories. Int. J. Appl. Earth Obs. Geoinf. 2012. V. 18. P. 480-490. DOI: 10.1016/j.jag.2011.09.020.

7. Kopylov I.S. Morphoneotectonic system for assessing geodynamic activity: monograph Perm, 2019. 131 p. Web resource: http://www.psu.ru/files/docs/science/books/mono/ kopylov-morfoneotektonicheskaya-sistema-ocenkigeodinamicheskoj-aktivnosti.pdf (accessed 20.01. 2021) (in Russian).

8. Kurlovich D.M. Morphometric GIS analysis of the relief of Belarus. Land of Belarus. 2013. No 4. P. 42-48 (in Russian).

9. Kurlovich D.M. Spatial differentiation and dynamics of morphostructures of the Belarusian Poozerie. Minsk: BSU, 2014. 158 p. (in Russian).

10. Maltsev K.A., Golosov V.N., Gafurov A.M. Digital Elevation Models and Their Use for Assessing Soil Erosion Rates on Arable Lands. Proceedings of Kazan University. Natural Sciences Series. Ser. Natural Sciences. 2018. V. 160. No 3. P. 514-530 (in Russian).

11. Mikhailov V.A. Complex morphometric analysis of the Tarkhankut peninsula using GIS. Modern scientific research and innovations. 2015. No 2. Web resource: http://web.snauka.ru/ issues/2015/02/46640 (accessed 20.01.2021) (in Russian).

12. Mondal A., Khare D., Kundu S., Mukherjee S., Mukhopadhyay A., Mondal S. Uncertainty of soil erosion modelling using open source high resolution and aggregated DEMs. Geosci. Frontiers. 2017. V. 8. No 3. P. 425-436. DOI: 10.1016/j.gsf.2016.03.004.

13. Onkov I.V., Onyanova T.Ya., Shilyaeva O.Yu. Investigation of the accuracy of radar DEMs built from ALOS PALSAR images and SRTM model, depending on the type of reflecting surface. Geomatics. 2012. No 4. P. 33-36 (in Russian).

14. Osintseva N.V. Assessment of the erosion hazard of the relief of the territory of Tomsk. Questions of the geography of Siberia. Issue 25. Tomsk: Tomsk state. un-t, 2003. P. 56-66 (in Russian).

15. Papaiordanidis S., Gitas I.Z., Katagis T. Soil erosion prediction using the Revised Universal Soil Loss Equation (RUSLE) in Google Earth Engine (GEE) cloud-based platform. Dokuchaev Soil Bulletin. 2019. V. 100. P. 36-52. DOI: 10.19047/0136-16942019-100-36-52.

16. Pavlova A.I. Application of digital terrain modeling methods for mapping erosional lands. In the world of scientific discoveries. 2016. No 2(74). P. 159-167 (in Russian).

17. Pozachenyuk E.A., Petlyukova E.A. GIS analysis of morphometric indicators of the relief of the Central foothills of the main ridge of the Crimean mountains for the purposes of landscape planning. Scientific notes of the Crimean Federal University named after V.I. Vernadsky. Geography. Geology. V. 2(68). 2016. No 2. P. 95-111 (in Russian).

18. Putilin A.F. Gully formation in the southeast of Western Siberia. Novosibirsk, 1988. 81 p. (in Russian).

19. Ramesh L. Dikpal, Renuka Prasad T.J., Satish K. Evaluation of morphometric parameters derived from Cartosat-1 DEM using remote sensing and GIS techniques for Budigere Amanikere watershed, Dakshina Pinakini Basin, Karnataka, India. Appl. Water Sci. 2017. V. 7. P. 4401-4414. DOI: 10.1007/s13201-017-0585-6. 
20. Reuter H.I., Neison A., Strobl P., Mehl W., Jarvis A. A first assessment of Aster GDEM tiles for absolute accuracy, relative accuracy and terrain parameters. 2009 IEEE Int. Geoscience and Remote Sensing Symposium. IEEE, 2009. V. 5. P. 240-243. DOI: 10.1109/IGARSS. 2009.5417688.

21. Scriabina O.A. Water erosion of soil and its control. Perm: Permskoye knizhnoye izdatel'stvo, 1990. 24 p. (in Russian).

22. Shimanovskaya O.L., Shimanovsky L.A. The density of the river network of the Perm region and the patterns of its formation. Physical and geographical bases of development and distribution of productive forces of the Non-Chernozem Urals. Perm: Izdatel'stvo Permskogo universiteta, 1970. P. 102-110 (in Russian).

23. Shimanovsky L.A. Geomorphological zoning of the Perm region. Physical and geographical bases of development and distribution of productive forces of the Non-Chernozem Urals. Perm: Izdatel'stvo Permskogo universiteta, 1985. P. 66-79 (in Russian).

24. Szabó G., Singh S.K., Szabó S. Slope angle and aspect as influencing factors on the accuracy of the SRTM and the ASTER GDEM databases. Phys. Chem. Earth. Parts A/B/C. 2015. V. 83-84. P. 137-145. DOI: 10.1016/j.pce.2015.06.003. 


\title{
Т.Е. Самсонов ${ }^{1}$, О.П. Якимова ${ }^{2}$
}

\section{АНАЛИЗ ЭФФЕКТИВНОСТИ ОГРАНИЧИВАЮЩИХ МЕТРИК АЛГОРИТМОВ ГЕОМЕТРИЧЕСКОГО УПРОЩЕНИЯ НА ОСНОВЕ ЭКСПЕРТНОЙ ОЦЕНКИ ДЕТАЛИЗАЦИИ ЛИНИЙ}

\begin{abstract}
АННОТАЦИЯ
Представлены результаты исследования, проведенного в форме экспертного опроса с целью выявить наличие зависимостей между характером линии и сочетанием метрик, позволяющим достичь сопоставимых по детализации результатов разными алгоритмами геометрического упрощения.

Для выполнения опроса подготовлены геометрически упрощенные версии трех береговых линий тремя разными алгоритмами геометрического упрощения - ДугласаПейкера, Висвалингам-Уайатта и Ли-Оупеншоу. Упрощение производилось при условии одинаковой величины модифицированного расстояния Хаусдорфа (линейное смещение) и уменьшения количества изгибов линии (компрессия количества деталей). Задачей респондентов было дать численную оценку детализации каждого изображения, основываясь на личном восприятии по шкале от 1 до 10.

Результаты опроса показали, что линии, воспринимаемые респондентами как имеющие схожую детализацию, могут быть получены разными алгоритмами, однако выбор метрики, использующейся в качестве ограничения, зависит от характера линии. Для линий, имеющих неглубокую иерархию изгибов, размеры которых малы в сравнении с длиной всей линии, наиболее схожие по детализации результаты получаются при использовании линейного смещения в качестве ограничивающей метрики.

При увеличении сложности линии большую роль в восприятии детализации начинает играть метрика компрессии количества деталей (изгибов). Для одной из трех линий наилучший результат устойчиво получился при взвешенной комбинации анализируемых метрик в качестве ограничения при выполнении геометрического упрощения.

Было установлено, что метрика линейного смещения является более показательной при характеристике изменения детализации линии, поскольку ни один из результатов опроса не показал возможность применения только уменьшения количества изгибов как эффективной характеристики изменения детализации.
\end{abstract}

КЛЮЧЕВЫЕ СЛОВА: детализация пространственных данных; геометрическое упрощение линий; экспертный опрос.

\footnotetext{
1 Московский государственный университет имени М.В. Ломоносова, Географический факультет, Ленинские горы, д. 1, 119991, Москва, Россия, e-mail: tsamsonov@geogr.msu.ru

2 Ярославский государственный университет имени П.Г. Демидова, Математический факультет, ул. Союзная, д. 144, 150008, Ярославль, Россия, e-mail: polya@uniyar.ac.ru
} 


\section{Timofey E. Samsonov ${ }^{3}$, Olga P. Yakimova ${ }^{4}$}

\section{ANALYSIS OF THE EFFECTIVENESS OF CONSTRAINING METRICS OF GEOMETRIC SIMPLIFICATION ALGORITHMS BASED ON EXPERT EVALUATION OF LINE DETAIL}

\section{ABSTRACT}

The paper reveals dependencies between the character of the line shape and combination of constraining metrics that allows comparable reduction in detail by different geometric simplification algorithms. The study was conducted in a form of the expert survey. Geometrically simplified versions of three coastline fragments were prepared using three different geometric simplification algorithms - Douglas-Peucker, Visvalingam-Whyatt and Li-Openshaw. Simplification was constrained by similar value of modified Hausdorff distance (linear offset) and similar reduction of number of line bends (compression of the number of detail elements). Respondents were asked to give a numerical estimate of the detail of each image, based on personal perception, using a scale from one to ten. The results of the survey showed that lines perceived by respondents as having similar detail can be obtained by different algorithms. However, the choice of the metric used as a constraint depends on the nature of the line. Simplification of lines that have a shallow hierarchy of small bends is most effectively constrained by linear offset. As the line complexity increases, the compression metric for the number of detail elements (bends) increases its influence in the perception of detail. For one of the three lines, the best result was consistently obtained with a weighted combination of the analyzed metrics as a constraint. None of the survey results showed that only reducing the number of bends can be used as an effective characteristic of similar reduction in detail. It was therefore found that the linear offset metric is more indicative when describing changes in line detail.

KEYWORDS: spatial data detail; geometric line simplification; expert survey.

\section{ВВЕДЕНИЕ}

Разнообразие форм географических объектов и их сочетаний на местности обуславливает необходимость выбора методов и технологий составления карт, которые бы достоверно передавали географические особенности территории. Одной из ключевых технологий является автоматизированная генерализация, которая реализуется в виде комплекса алгоритмов, направленных на обобщение содержания карты. Известно, что алгоритмы генерализации неодинаково воздействуют на форму объектов, и результаты их работы обладают особым картографическим рисунком [Samsonov, Yakimova, 2017]. По этой причине алгоритмы генерализации подбираются таким образом, чтобы обобщенное картографическое представление территории по своему рисунку соответствовало исходному. На высоком уровне это проявляется в том, что разные наборы процедур генерализации параллельно выполняются в разных географических ландшафтах (например, урабанизированных и природных), а итоговая карта получается путем объединения результатов их работы [Touya et al., 2010]. На среднем уровне это проявляется в выборе оптимальных алгоритмов для каждого объекта в зависимости от его типа $[A i, 2007$; Bayer, 2009; Mustiere, 2005; Wang, Muller, 1993]. На низком уровне — в разбиении контуров индивидуальных объектов на морфологически однородные участки, для каждого из которых применяется процедура геометрического упрощения, позволяющая максимально

\footnotetext{
3 Lomonosov Moscow State University, Faculty of Geography, Leninskie Gory 1, 119991, Moscow, Russia, e-mail: tsamsonov@geogr.msu.ru

4 Demidov Yaroslavl State University, Soyuznaya str., 144, 150008, Yaroslavl, Russia, e-mail: polya@uniyar.ac.ru
} 
правдоподобно воспроизвести характер линии в обобщенном виде и тем самым сохранить его неоднородность [Park, Yu, 2011; Samsonov, Yakimova, 2017]. Такой подход назвают коллаборативным (совместным) [Touya, Duchêne, \& Ruas, 2010].

При использовании коллаборативного подхода, однако, возникает проблема однородности результатов. В частности, детализация линий, полученных разными алгоритмами геометрического упрощения, должна быть быть уменьшена в одинаковое (или по крайней мере близкое) количество раз. Возникает вопрос, можно ли управлять этим уменьшением, при условии, что каждый алгоритм имеет собственный набор параметров и действует по собственной процедуре. В работе [Samsonov, Yakimova, 2020] было показано, что различными алгоритмами может быть достигнуто сопоставимое (с точностью до ошибок регрессии) изменение метрик, характеризующих геометрическую точность, размер и количество деталей в линии. В эксперименте анализировались алгоритмы ДугласаПейкера [Douglas, Peucker, 1973], Висвалинагм-Уайатта [Visvalingam, Whyatt, 1993] и ЛиОупеншоу [Li, Openshaw, 1992], а также три линии, представляющие участки побережья Ботнического залива (Финляндия), Норвегии и Исландии (рис. 1). В качестве метрик анализировалось изменение модифицированного расстояния Хаусдорфа MHD [Dubuisson, Jain, 1994] (геометрическая точность как линейное смещение), изменение количества точек, изгибов и длины линии (компрессия деталей), а также изменение извилистости (контроль морфологии линии).

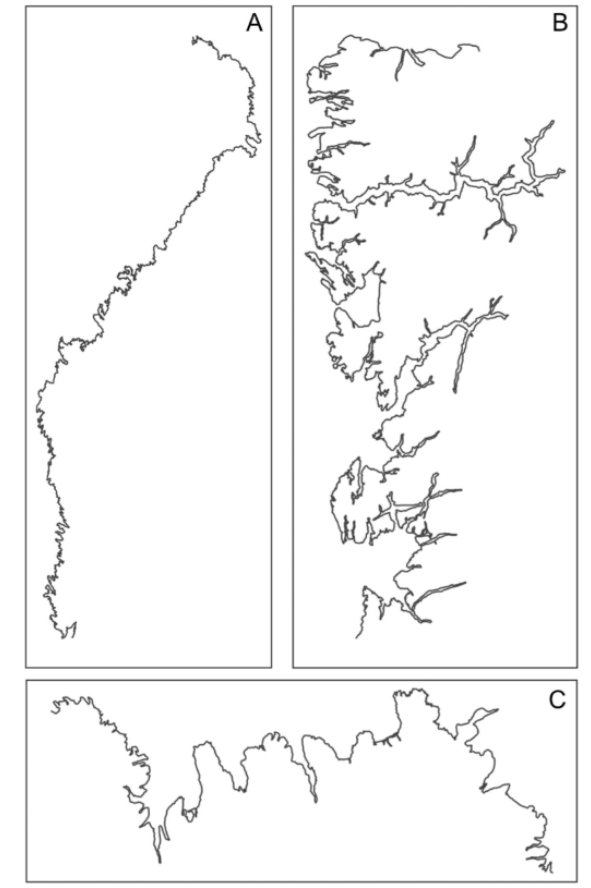

Рис. 1. Исходные линии: (А) Ботния, (В) Норвегия, (С) Исландия [Samsonov, Yakimova, 2020]

Fig. 1. Source lines: (A) Bothnia, (B) Norway, (C) Iceland [Samsonov, Yakimova, 2020]

Результаты экспериментов показали, что характер линии оказывает существенное влияние на то, как изменения метрик зависят от величины параметра каждого алгоритма и на то, насколько существенно эти изменения влияют на восприятие детализации линии. Так, например, для линий, обладающих большим количеством малых изгибов и неглубокой иерархией изгибов уменьшение их числа при росте допуска упрощения происходит 
существенно быстрее, чем для линий с крупными изгибами и развитой иерархией изгибов вне зависимости от алгоритма. В то же время, линии, обработанные разными алгоритмами при условии равенства одной из ограничивающих метрик, визуально могут существенно отличаться по детализации. При этом для одной линии наиболее похожи по детализации результаты, полученные при фиксированном линейном смещении (модифицированное расстояние Хаусдорфа между исходной и генерализованной линией), а для другой линии более похожи результаты, полученные при фиксированном изменении количества изгибов.

Исходя из этого была выдвинута гипотеза о том, что управляемое изменение детализации линий должно принимать в расчет морфологические особенности линии, а также о том, что необходимо комбинировать разные метрики для достижения сопоставимого уменьшения детализации. В статье [Samsonov, Yakimova, 2020] данная гипотеза была проверена на примере геометрического упрощения линий Финляндии, Исландии и Норвегии, где для первой линии упрощение контролировалось метрикой MHD, для третьей линии оно контролировалось одинаковым уменьшением количества изгибов, и для второй линии балансировало между ними в соотношении $0,7 / 0,3$. С указанными весами метрик удалось достичь визуально похожей детализации линии, однако объективность оценок осталась под вопросом.

\section{МАТЕРИАЛЫ И МЕТОДЫ ИССЛЕДОВАНИЯ}

В настоящей статье представлены результаты исследования, проведенного в форме экспертного опроса с целью выявить наличие зависимостей между характером линии и сочетанием метрик, позволяющим достичь сопоставимых по детализации результатов разными алгоритмами геометрического упрощения.

Для достижения цели был выполнен экспертный опрос студентов, в котором участвовало 20 человек: 9 бакалавров 4 года и 11 магистров 1 года обучения по направлению «Картография и геоинформатика» на Географическом факультете МГУ имени М.В.Ломоносова. На момент прохождения опроса участники уже прошли курс «Картографические базы данных», в рамках которого они подробно знакомятся с алгоритмами картографической генерализации. Таким образом, аудиторию опроса можно считать квалифицированной.

Для выполнения опроса были подготовлены геометрически упрощенные версии исходных трех линий. На первом этапе для алгоритмов Висвалингам-Уайатта и ЛиОупеншоу были получены регрессионные зависимости между их параметрами и параметром алгоритма Дугласа-Пейкера, обеспечивающие сопоставимое изменение модифицированного расстояния Хаусдорфа и количества изгибов для каждой линии. После этого каждая линия трижды упрощалась каждым алгоритмом при последовательном увеличении допуска алгоритма Дугласа-Пейкера $(\mathrm{d}=5,10,20)$ и вычислении соответствующих параметров для двух оставшихся алгоритмов на основе полученных регрессий. При вычислении параметров использовалось три комбинации регрессий с весовыми коэффициентами $[0 ; 1],[0,5 ; 0,5]$ и $[1 ; 0]$ для регрессий по MHD и количеству изгибов соответственно. Таким образом, для каждой линии было получено 27 генерализованных изображений, отличающихся как по степени упрощения, так и по метрике, которая сохраняется в процессе упрощения. Итого суммарно 81 изображение.

Изображения были упорядочены группами по 4 шт, где крайнее левое изображение соответствует исходной линии, а последующие три являются его генерализованными версиями, полученными алгоритмами Дугласа-Пейкера, Висвалингам-Уайатта и ЛиОупеншоу соответственно. Всего на листе А4 располагалось 3 таких группы сверху вних, соответствующих величине параметра алгоритма Дугласа-Пейкера $(\mathrm{d}=5,10,20)$, а каждый лист соответствовал используемой комбинации весовых коэффициентов регрессий $[0 ; 1]$, 
$[0,5 ; 0,5]$ и $[1 ; 0]$. Таким образом, студентам было роздано 9 листов по 12 изображений. Примеры опросных листов приведены на рис. 2.

Задачей респондентов было дать численную оценку детализации каждого изображения, основываясь на личном восприятии. Число необходимо было подписать рядом с самим изображением. Шкала измерения уровня детализации подчинялась следующим принципам:

- от 1 до 10, где 1 - самое детальное изображение, 10 - самое обобщенное.

- детализация исходного изображения (№1) принимается равной 1. Это изображение повторяется в каждой группе из четырех изображений.

- баллы проставляются кратно 0,5. То есть, возможна величина как 5, так и 5,5.

- несколько изображений могут иметь одинаковую детализацию (как из одной строки, так и из разных строк).

- максимальная величина может быть меньше 10. Допустимо присвоить максимально генерализованному изображению более низкий балл (например, 8) и распределить все баллы между ним и 1 (исходное изображение).

Критериями оценки детализации служили две характеристики:

- количество деталей (изгибов линии): чем их больше, тем меньше будет балл детализации. На обобщенных изображениях не должно быть много деталей.

- размер деталей (ширина, глубина): чем меньше самый малый видимый изгиб, тем меньше будет балл детализации. На обобщенных изображениях не должно быть мелких деталей.

Морфология деталей (их гладкость/угловатость) не должна была оказывать большого влияния на выбор. Респондентов просили абстрагироваться от оценки угловатости линий и сравнивать их только по количеству и размеру отображаемых деталей.
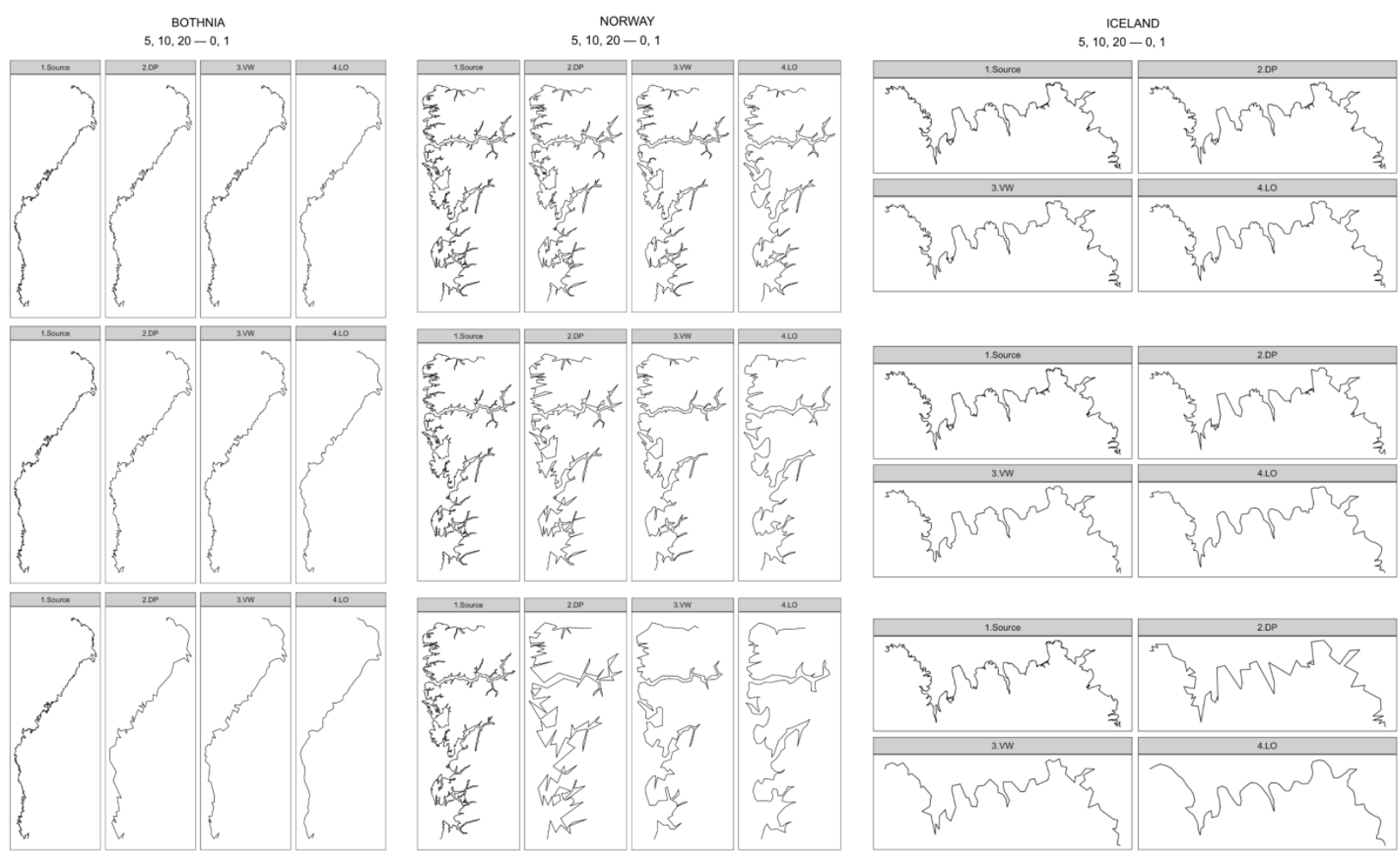

Рис. 2. Примеры опросных листов для оценки детализащии линий

Fig. 2. Example of a questionnaires for line detail assessment 
Результаты опроса были упорядочены в виде таблицы, фрагмент которой для одного респондента представлен в табл. 1.

Табл. 1. Фрагмент таблиџы результатов оиенки уровня детализаџии

Table 1. Fragment of the table of results of the detail assessment

\begin{tabular}{|c|c|c|c|c|c|c|c|}
\hline Группа & Студент & Участок & w1 & w2 & Метод & d & Детализация \\
\hline $\mathrm{B}$ & 1 & Norway & 0,0 & 1,0 & DP & 5 & 2,0 \\
\hline $\mathrm{B}$ & 1 & Norway & 0,0 & 1,0 & DP & 10 & 6,5 \\
\hline $\mathrm{B}$ & 1 & Norway & 0,0 & 1,0 & DP & 20 & 8,0 \\
\hline $\mathrm{B}$ & 1 & Norway & 0,0 & 1,0 & VW & 5 & 4,0 \\
\hline $\mathrm{B}$ & 1 & Norway & 0,0 & 1,0 & VW & 10 & 6,0 \\
\hline $\mathrm{B}$ & 1 & Norway & 0,0 & 1,0 & VW & 20 & 9,0 \\
\hline $\mathrm{B}$ & 1 & Norway & 0,0 & 1,0 & $\mathrm{LO}$ & 5 & 7,0 \\
\hline $\mathrm{B}$ & 1 & Norway & 0,0 & 1,0 & $\mathrm{LO}$ & 10 & 8,0 \\
\hline $\mathrm{B}$ & 1 & Norway & 0,0 & 1,0 & $\mathrm{LO}$ & 20 & 8,5 \\
\hline $\mathrm{B}$ & 1 & Norway & 0,5 & 0,5 & $\mathrm{DP}$ & 5 & 3,0 \\
\hline B & 1 & Norway & 0,5 & 0,5 & DP & 10 & 6,5 \\
\hline $\mathrm{B}$ & 1 & Norway & 0,5 & 0,5 & $\mathrm{DP}$ & 20 & 8,5 \\
\hline B & 1 & Norway & 0,5 & 0,5 & VW & 5 & 2,0 \\
\hline $\mathrm{B}$ & 1 & Norway & 0,5 & 0,5 & VW & 10 & 7,0 \\
\hline $\mathrm{B}$ & 1 & Norway & 0,5 & 0,5 & VW & 20 & 8,0 \\
\hline $\mathrm{B}$ & 1 & Norway & 0,5 & 0,5 & $\mathrm{LO}$ & 5 & 5,0 \\
\hline B & 1 & Norway & 0,5 & 0,5 & $\mathrm{LO}$ & 10 & 7,5 \\
\hline B & 1 & Norway & 0,5 & 0,5 & $\mathrm{LO}$ & 20 & 8,5 \\
\hline B & 1 & Norway & 1,0 & 0,0 & DP & 5 & 3,0 \\
\hline $\mathrm{B}$ & 1 & Norway & 1,0 & 0,0 & DP & 10 & 7,0 \\
\hline B & 1 & Norway & 1,0 & 0,0 & DP & 20 & 9,0 \\
\hline $\mathrm{B}$ & 1 & Norway & 1,0 & 0,0 & VW & 5 & 2,0 \\
\hline $\mathrm{B}$ & 1 & Norway & 1,0 & 0,0 & VW & 10 & 3,0 \\
\hline $\mathrm{B}$ & 1 & Norway & 1,0 & 0,0 & VW & 20 & 7,0 \\
\hline $\mathrm{B}$ & 1 & Norway & 1,0 & 0,0 & $\mathrm{LO}$ & 5 & 3,0 \\
\hline $\mathrm{B}$ & 1 & Norway & 1,0 & 0,0 & $\mathrm{LO}$ & 10 & 4,0 \\
\hline B & 1 & Norway & 1,0 & 0,0 & $\mathrm{LO}$ & 20 & 8,0 \\
\hline
\end{tabular}

Перед выполнением анализа данные были подвержены фильтрации, которая заключалась в исключении случаев, когда оценки детализации трех изображений одной линии на одной странице, соответствующих допускам упрощения 5, 10, 20, не образуют монотонно растущей прогрессии. С учетом очевидности уменьшения детализации в этих прогрессиях, подобные случаи могли быть следствием невнимательности, усталости или недобросовестного выполнения задания. Также встречались случаи, когда оценка вообе не была проставлена. Из 1620 оценок таким образом было отбраковано 23 (2 \%).

\section{РЕЗУЛЬТАТЫ ИССЛЕДОВАНИЯ И ИХ ОБСУЖДЕНИЕ}

Анализируя полученные оценки, мы пытались понять, при каких условиях респонденты оценивают изображения как имеющие одинаковую детализацию. Для этого сначала агрегировали оценки, полученные для каждого изображения (в среднем по 20 
оценок, за исключением отбракованных случаев). На рис. 4 представлены диаграммы размаха по всем 27 группам линий. Заголовок каждого графика построен по шаблону $<$ участок $><$ вес MHD $><$ вес изгибов $><$ допуск упрощения $>$. Например, самый первый заголовок Bothnia 0105 означает, что это оценки для линии Ботния, полученной при нулевом весе MHD и единичном весе изгибов с допуском упрощения для алгоритма Дугласа-Пейкера $\mathrm{d}=5$. Таким образом, каждая тройка соседних по горизонтали графиков соответствует одному опросному листу.

Анализ данных графиков позволяет видеть, что даже с учетом независимой простановки оценок во всех случаях по мнению респондентов детализация уменьшается при увеличении допуска упрощения, если сравнивать диаграммы для одного алгоритма. В то же время, есть случаи, когда детализация, полученная одним алгоритмом при меньшем допуске, оценивалась в среднем как менее детальная, чем детализация, полученная другим алгоритмом при вдвое большей величине допуска. Таким примером является линия Norway (левый нижний угол рис. 3), которая наглядно показывает, что алгоритм Ли-Оупеншоу очень быстро уменьшает детализацию сложной по структуре линии в случае, когда ограничивающим критерием является совпадение количества изгибов.

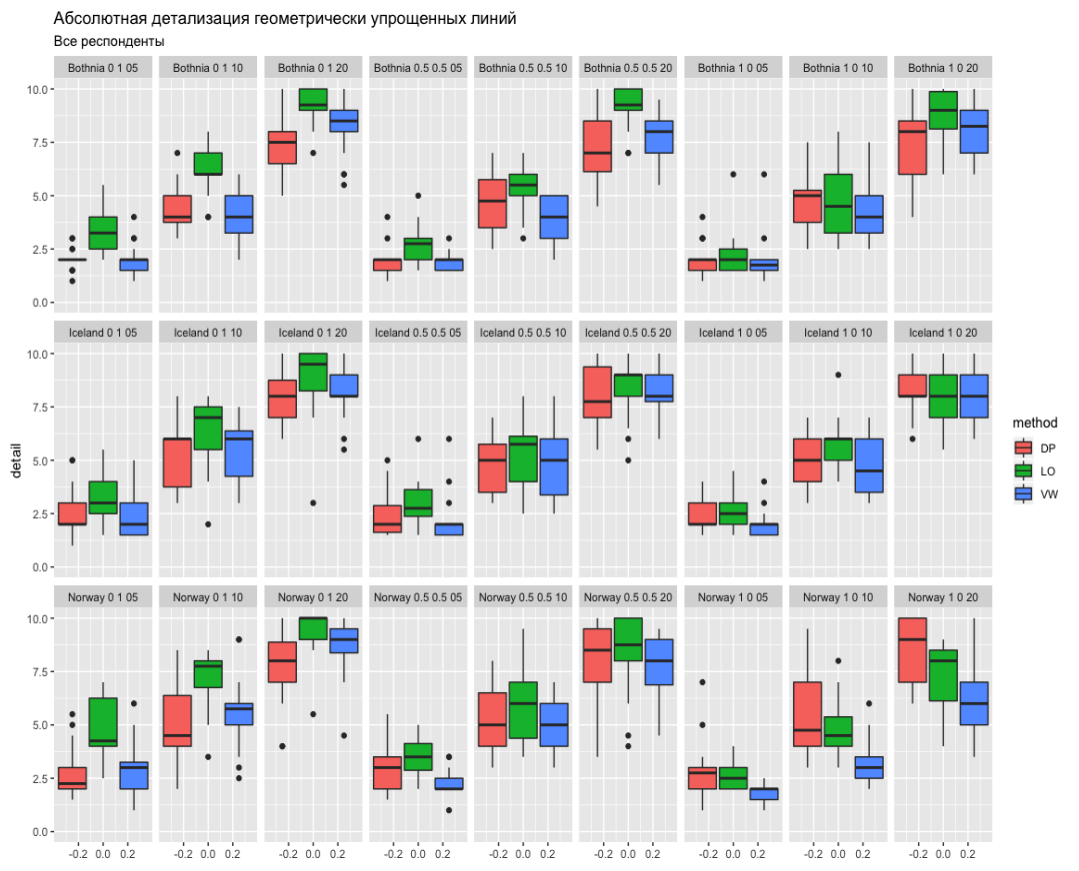

Рис. 3. Абсолютная детализация геометрически упрощенных линий (все респонденты)

Fig. 3. Absolute detail of geometrically simplified lines (all respondents)

Также можно обратить внимание на то, что в большинстве случаев алгоритм Дугласа-Пейкера дает наиболее детальное изображение и практически никогда не оценивается как самый грубый, за исключением случая с приоритетом геометрической точности (MHD), который располагается в правом нижнем углу рис. 3. Данный случай наглядно характеризует особенности алгоритма Дугласа-Пейкера, который при сопоставимых других характеристиках всегда «обыгрывает» другие алгоритмы по показателям геометрической точности, то есть дает линию, наименее отклоняющуюся от исходной по метрике линейного смещения. В обратном случае - когда это отклонение сопоставимо с результатами других алгоритмов, линия, полученная алгоритмом ДугласаПейкера, получается существенно более грубой для восприятия. Однако, как видно из графиков, это суждение верно только для линии со сложной иерархией изгибов. Для 
Исландии и Ботнии такого эффекта не наблюдается, что свидетельствует о влиянии морфологии линии на результат оценки детализации.

Чтобы оценить, нет ли систематических отличий в выборках, полученных для бакалавров и магистров, мы выполнили аналогичный анализ для них по отдельности, полученные графики представлены на рис. 4 и рис. 5. Можно видеть, что основным отличием выборок является более высокое среднеквадратическое отклонение оценок для бакалавров («ящики» на диаграммах размаха у них более широкие). В остальном же картина получилась схожая.

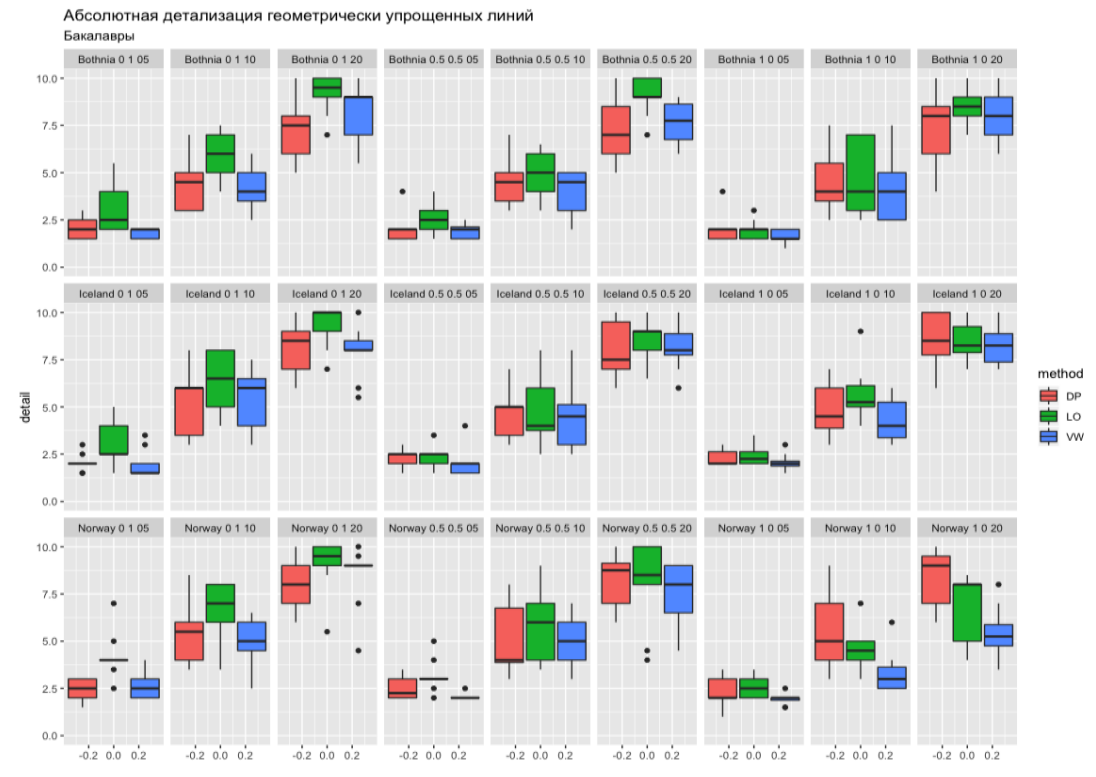

Рис. 4. Абсолютная детализация геометрически упрощенных линий (бакалавры) Fig. 4. Absolute detail of geometrically simplified lines (bachelor students)

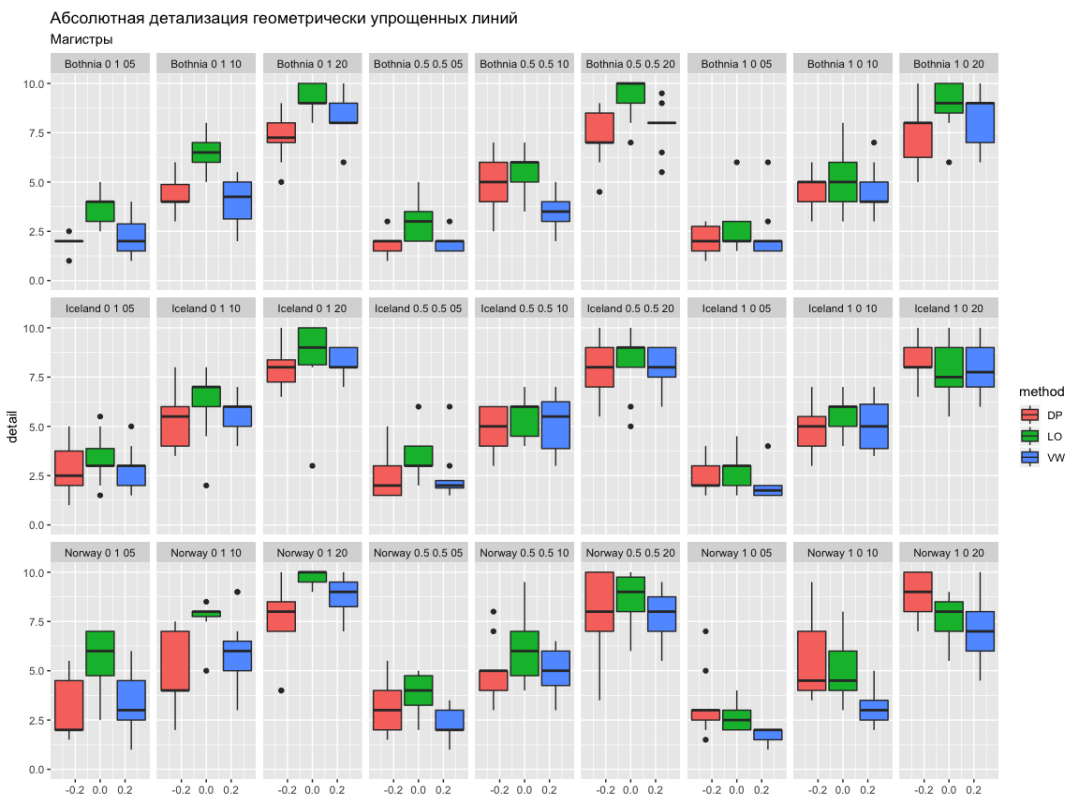

Рис. 5. Абсолютная детализачия геометрически упрощенных линий (магистры) Fig. 5. Absolute detail of geometrically simplified lines (master students) 
Основной вывод, который был сделан по результатам первичного анализа абсолютных метрик, заключается в том, что, несмотря на то что интерквартильные размахи на графиках во многих случаях существенно пересекаются, практически ни в одном из них не наблюдается совпадение медиан или средних значений детализации. Одной из причин, которые обуславливают нестабильность оценок, является то, что каждый респондент посвоему распределял баллы детализации между тремя уровнями упрощения, и линия, которая получала балл 4 у одного респондента, могла получить баллы 2,5 и 6 у других. В то же время, целью эксперимента являлось не сравнение абсолютных отметок разных респондентов, а выявление случаев, когда респондент ставил изображениям в одной группе одинаковые баллы - то есть, оценивал их детализацию как идентичную. Поэтому на следующем этапе анализа мы перешли от абсолютных баллов к относительным.

Относительные баллы детализации были получены в каждой группе из трех изображений (одинаковые параметры, но разные алгоритмы) путем разности их детализации и детализации изображения, полученного алгоритмом Дугласа-Пейкера. В этом случае все линии, полученные указанным алгоритмом, получали оценку 0, a для оставшихся двух могли принимать как положительные, так и отрицательные значения в зависимости от величины отклонения. Результирующие графики представлены на рис. 6.

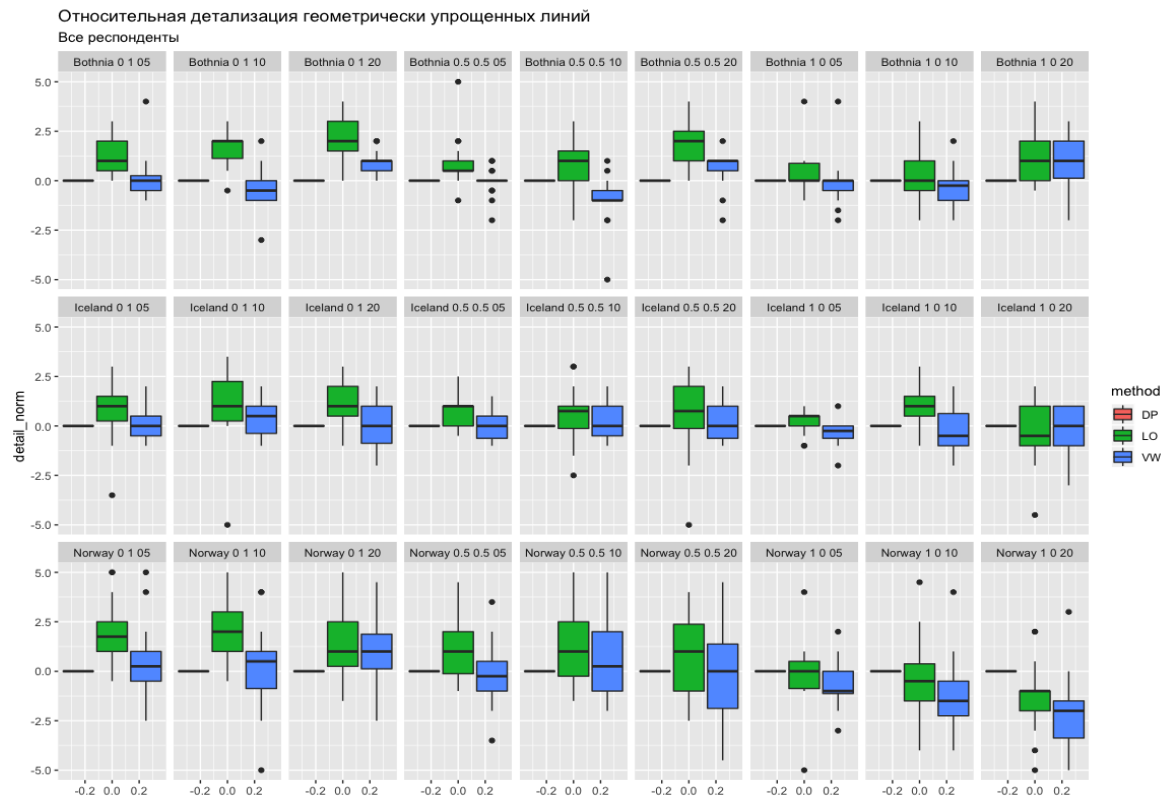

Рис. 6. Относительная детализация геометрически упрощенных линий (все респонденты) Fig. 6. Relative detail of geometrically simplified lines (all respondents)

Анализ графиков относительной детализации позволил сделать следующие выводы: - при более грубых уровнях детализации увеличивается нестабильность оценок: медиана сильнее отклоняется от 0 , увеличивается интерквартильный размах.

- алгоритм Висвалингам оказался в среднем более управляемым, нежели алгоритм ЛиОупеншоу, его оценки детализации в большем количестве случае оказались близкими к оценкам алгоритма Дугласа-Пейкера.

- для каждой из трех линий можно наметить комбинации весов регрессий, которые дают наиболее удовлетворительные результаты. Для Ботнии это комбинация [1;0], для Норвегии $[0,5 ; 0,5]$, а для Исландии результат до конца не очевиден, необходим дальнейший анализ для выбора между $[0,5 ; 0,5]$ и $[1 ; 0]$. 
Так же, как и для абсолютных оценок, аналогичные визуализации по относительным оценкам были сделаны отдельно по выборкам для групп бакалавров и магистров. Они представлены на рис. 7 и рис. 8. Выводы, сделанные по общей выборке, они подтверждают, однако показывают, что оценки, сделанные магистрами, отличаются меньшей стабильностью, особенно для линии Норвегия, для которой большинство графиков имеют интерквартильный размах в 2 и более балла.

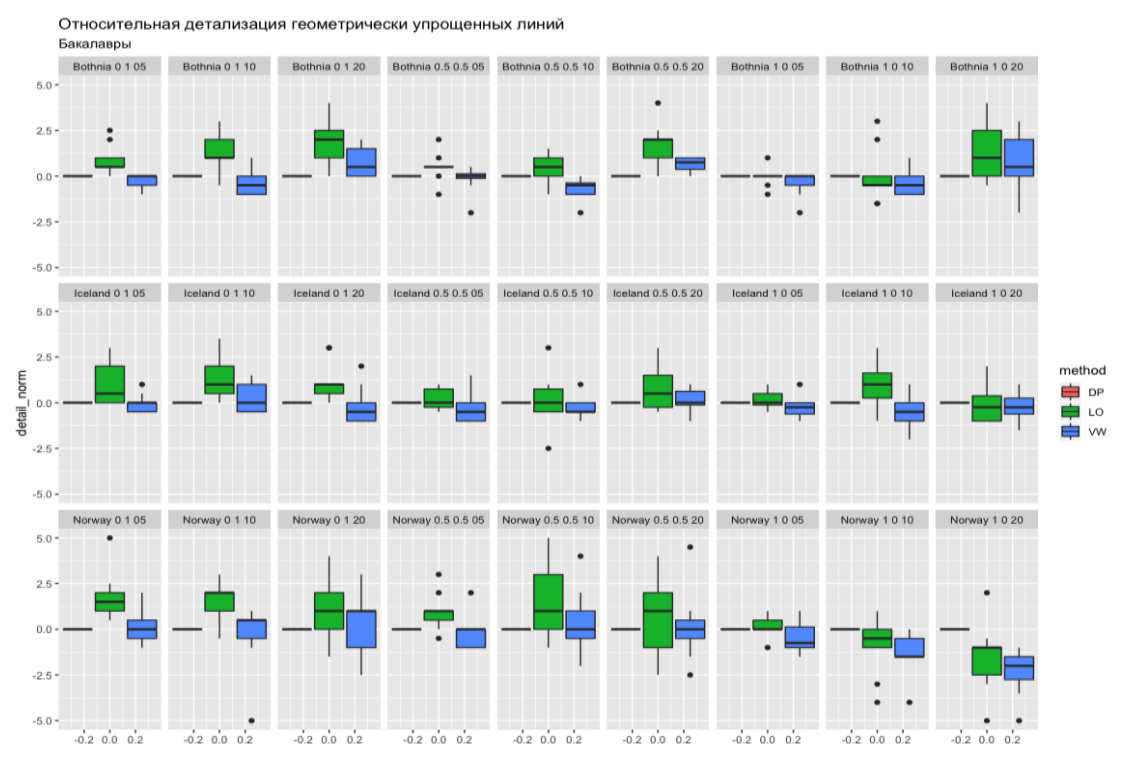

Рис. 7. Относительная детализация геометрически упрощенных линий (бакалавры) Fig. 7. Relative detail of geometrically simplified lines (bachelor students)

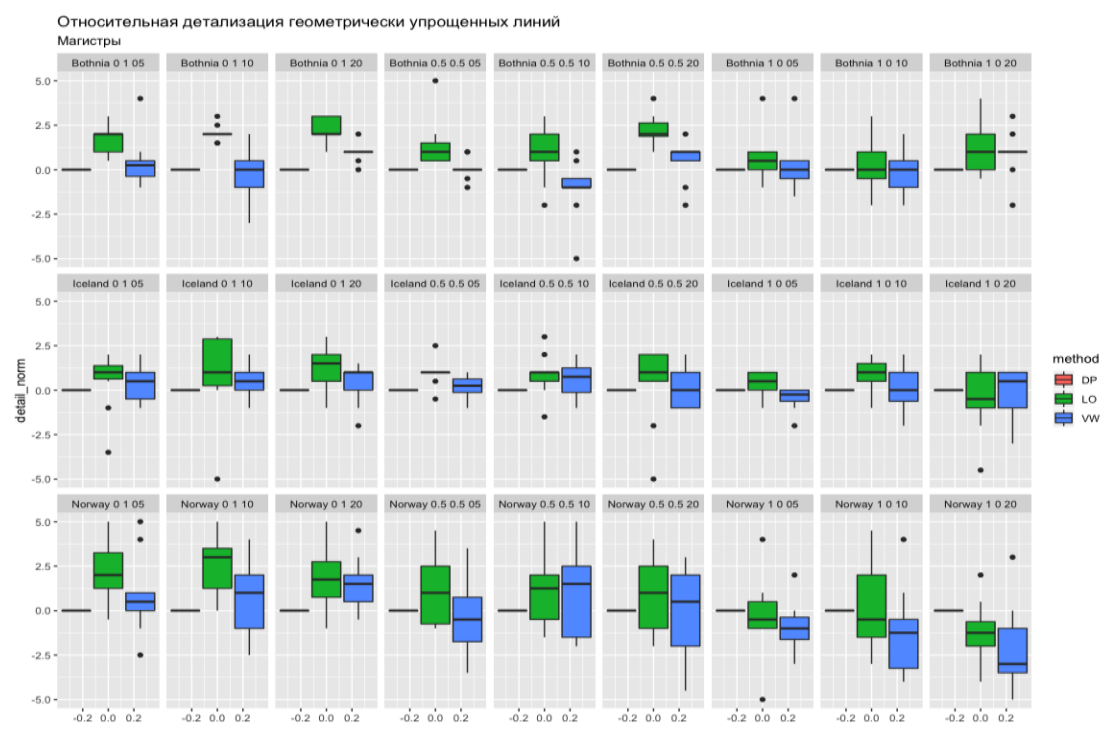

Рис. 8. Относительная детализачия геометрически упрощенных линий (магистры) Fig. 8. Relative detail of geometrically simplified lines (master students)

Получилось, что бакалавры подошли более разнопланово к шкалированию уровней детализации (большой разброс баллов между респондентами для одного изображения), но при этом более часто чем магистры оценивали расположенные рядом изображения как 
имеющие близкую детализацию (меньший разброс баллов для одного респондента, но между изображениями).

На заключительном этапе анализа мы выполнили еще две итерации агрегирования относительных данных. Для начала мы исключили данные по алгоритму Дугласа-Пейкера (которые равны 0) и построили общие диаграммы размаха, чтобы посмотреть на совокупный разброс по двум оставшимся алгоритмам для каждого случая. Полученные результаты представлены на рис. 9. На данном рисунке каждой линии отведен свой столбец графиков и нанесена красная линия, показывающая желаемое (эталонное) значение относительного отклонения по детализации, равное нулю. Группа из трех соседних по вертикали графиков соответствует последовательности геометрических упрощений, полученных для одной линии при фиксированном сочетании весов регрессий.

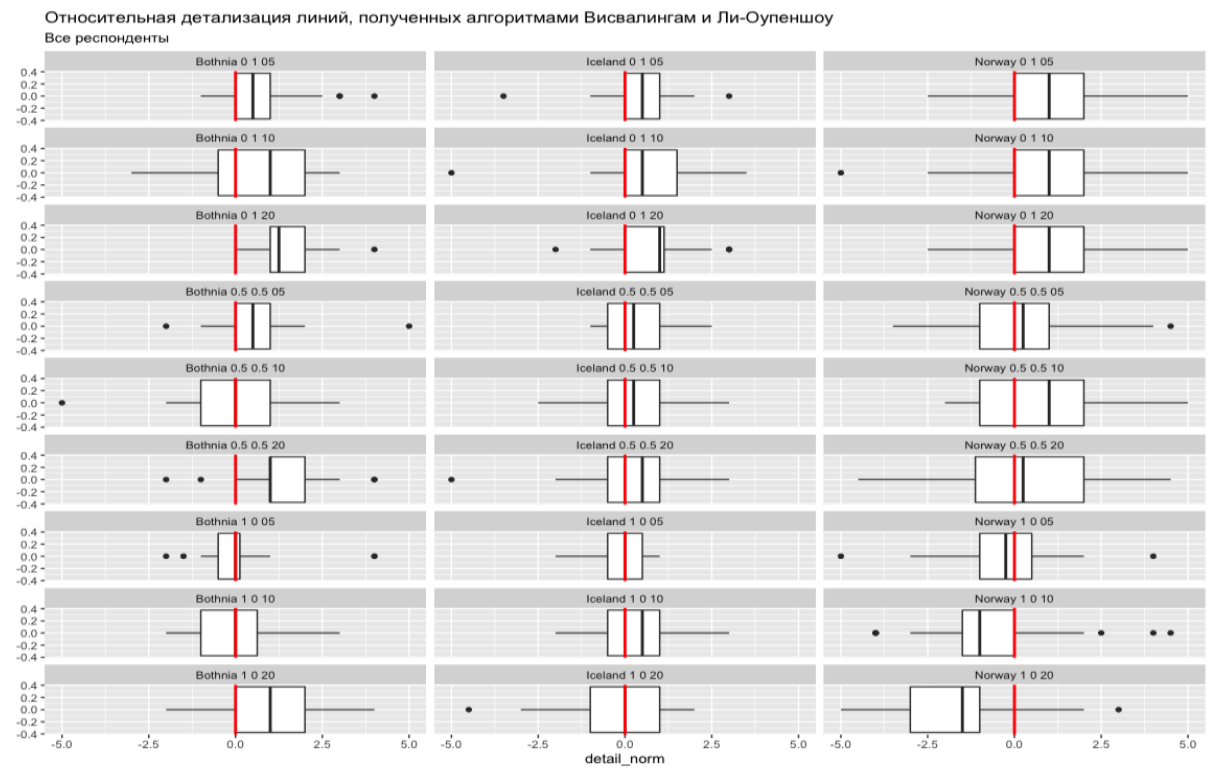

Рис. 9. Относительная детализация линий, полученных алгоритмами Висвалингам и ЛиОупеншоу (все респонденты)

Fig. 9. Relative detail of lines obtained by the Visvalingam and Li-Openshaw algorithms (all respondents)

Анализ рис. 9 подтверждает ранее сделанное предположение, что наиболее близкие по детализации линии получаются для Ботнии и Норвегии при весах регрессий, равных соответственно $[1 ; 0]$ и $[0,5 ; 0,5]$. Также данный уровень агрегирования позволил сделать вывод о том, что для Исландии оптимальным является сочетание весов [1;0], так как для него сразу по двум уровням детализации медиана относительного отклонения равна нулю, в то время как для комбинации $[0,5 ; 0,5]$ на всех уровнях медиана ненулевая. Построение аналогичных графиков отдельно для бакалавров (рис. 10) и магистров (рис. 11) в целом подтверждает данный вывод, но по данным бакалавров детализация по Ислан-дии для случая $[0,5 ; 0,5]$ успешно конкурирует по устойчивости с комбинацией $[1 ; 0]$.

Финальная серия графиков, представленная на рис. 12 показывает данные, агрегированные не только по алгоритмам, но и по уровням детализации. Из нее можно сделать вывод о наиболее оптимальном сочетании весов $[1 ; 0],[1 ; 0]$ и $[0,5 ; 0,5]$ для Ботнии, Исландии и Норвегии. Как и на предыдущих стадиях анализа, выборка по бакалаврам (рис. 13) не позволяет сделать однозначного выбора между $[1 ; 0]$ и $[0,5 ; 0,5]$ для Исландии, а выборка по магистрам (рис. 14) дает тот же результат, хотя и менее устойчивый (ни одна медиана не равняется нулю). 


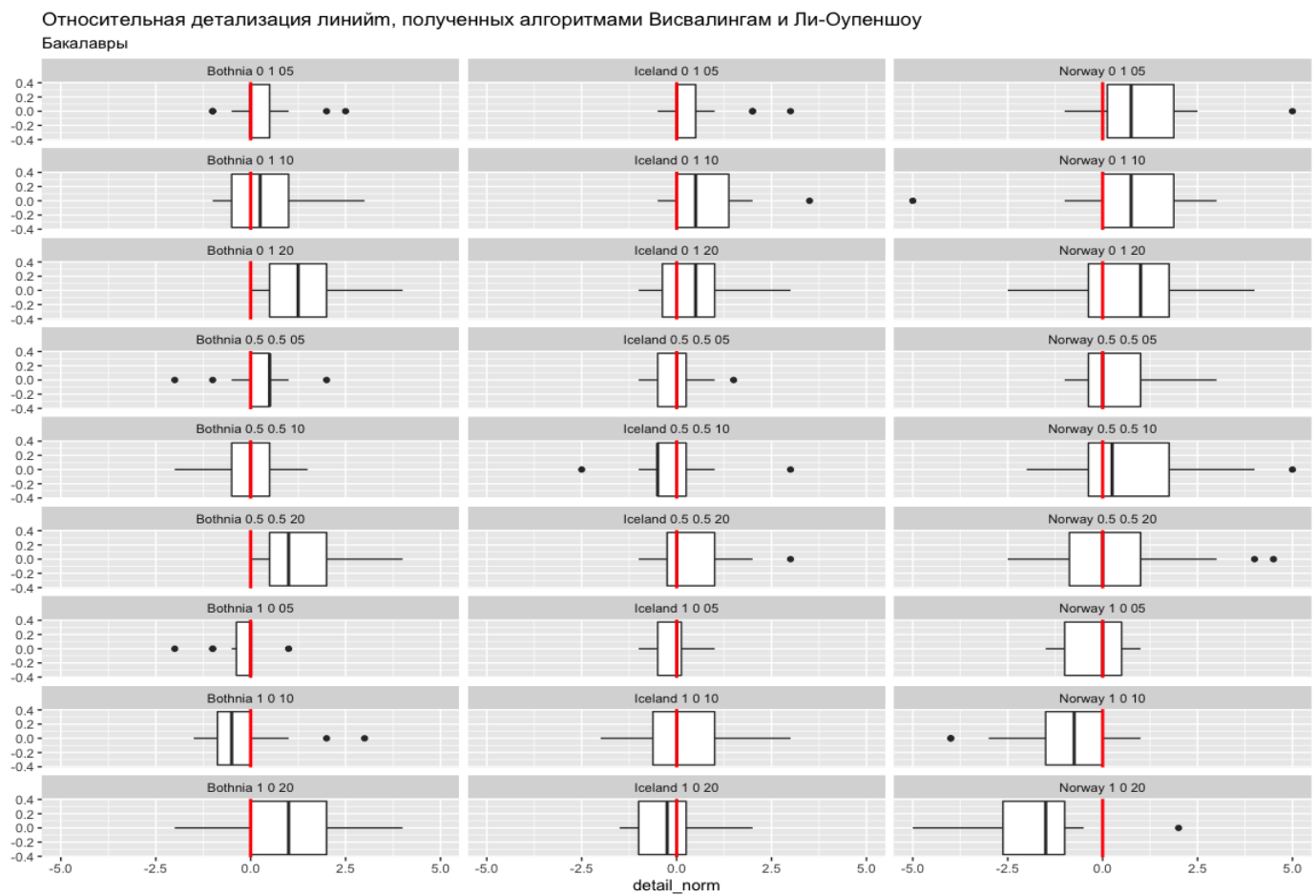

Рис. 10. Относительная детализация линий, полученных алгоритмами Висвалингам и ЛиОупеншоу (бакалавры)

Fig. 10. Relative detail of lines obtained by the Visvalingam and Li-Openshaw algorithms (bachelor students)

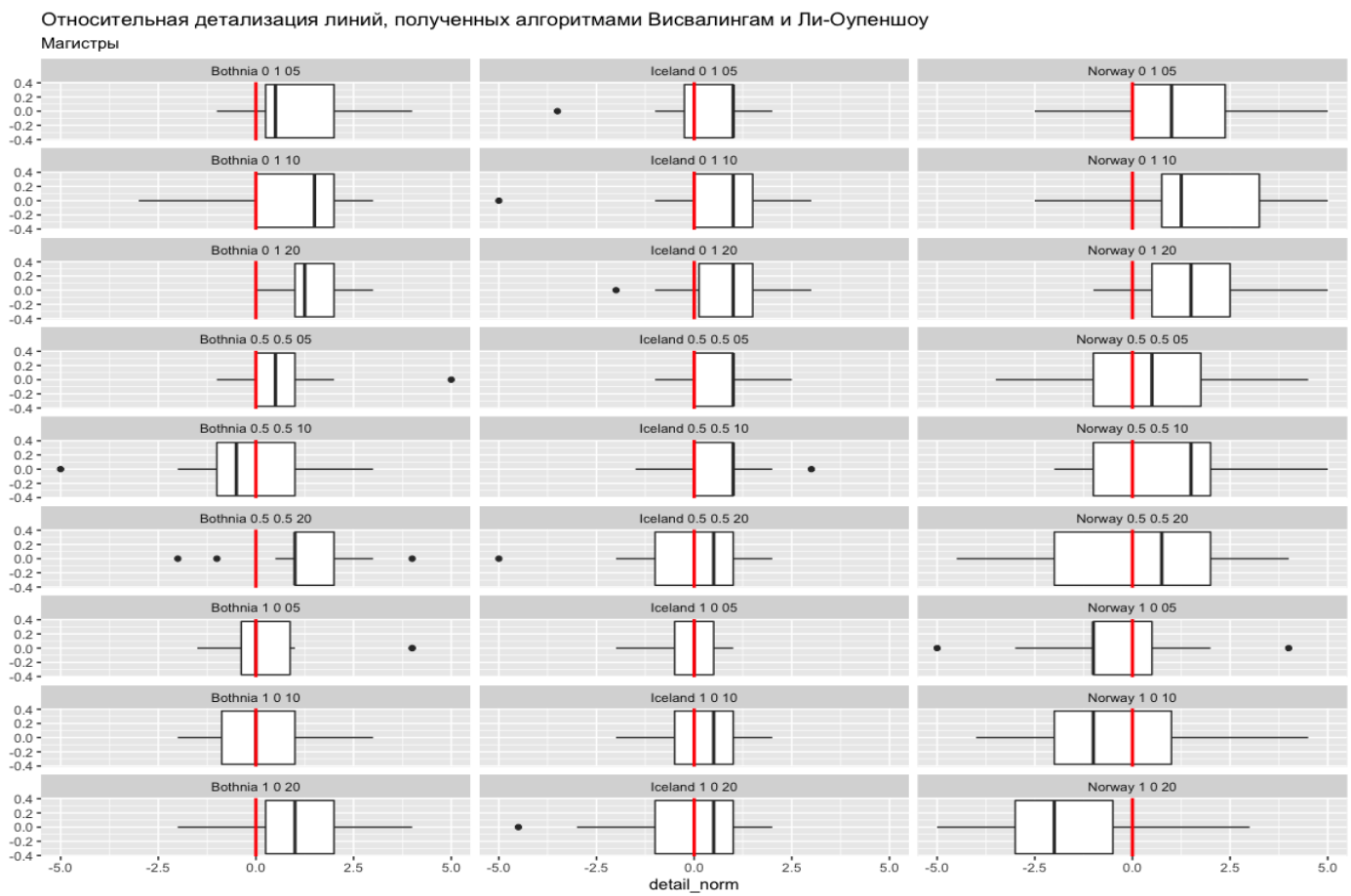

Рис. 11. Относительная детализация линий, полученных алгоритмами Висвалингам и ЛиОупеншоу (магистры)

Fig. 11. Relative detail of lines obtained by the Visvalingam and Li-Openshaw algorithms (master students) 


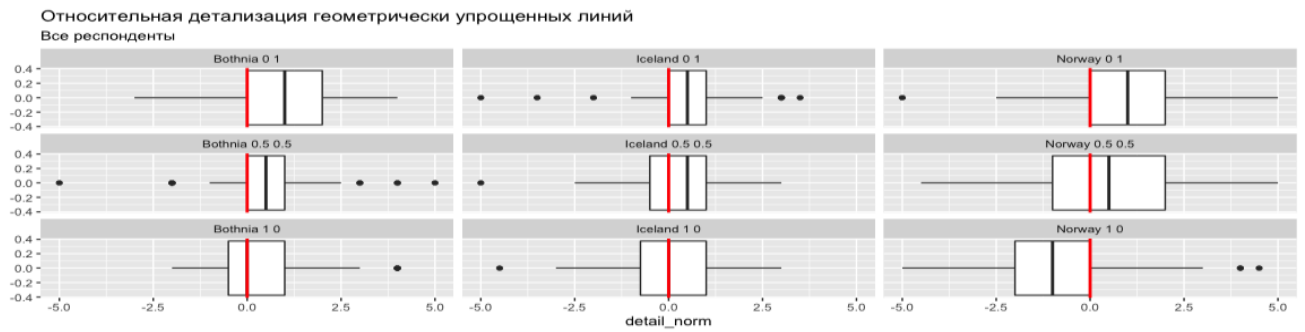

Рис. 12. Относительная детализачия линий, полученных алгоритмами Висвалингам и ЛиОупеншоу на всех уровнях детализаџии (все респонденты)

Fig. 12. Relative detail of lines obtained by the Visvalingam and Li-Openshaw algorithms on all levels of detail (all respondents)

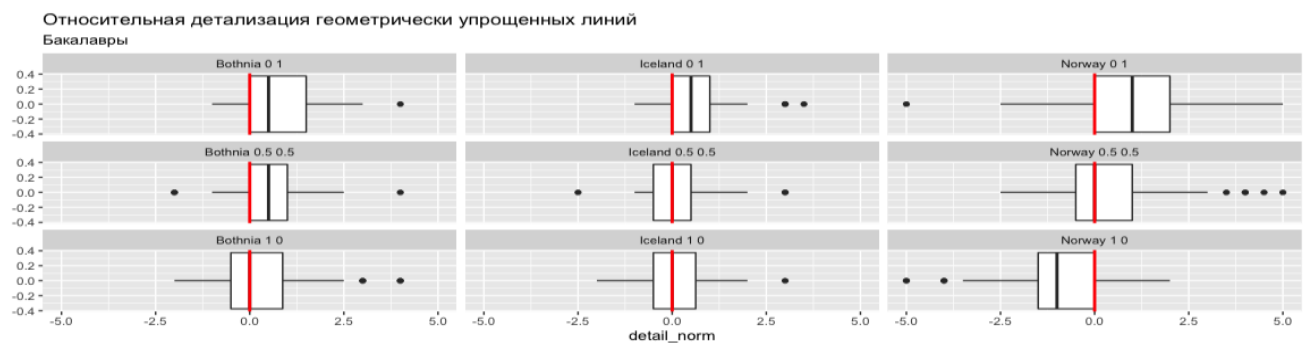

Рис. 13. Относительная детализация линий, полученных алгоритмами Висвалингам и ЛиОупеншоу на всех уровнях детализачии (бакалавры)

Fig. 13. Relative detail of lines obtained by the Visvalingam and Li-Openshaw algorithms on all levels of detail (bachelor students)
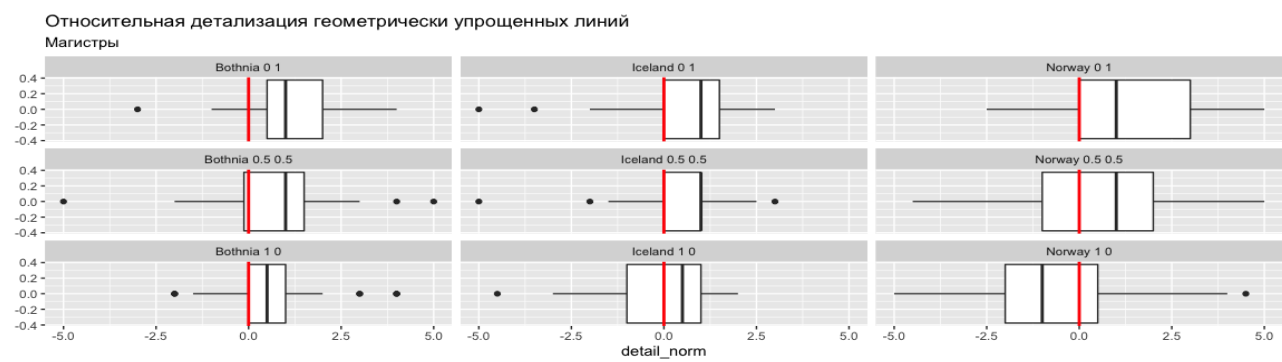

Рис. 14. Относительная детализачия линий, полученньх алгоритмами Висвалингам и ЛиОупеншоу на всех уровнях детализации (магистры)

Fig. 14. Relative detail of lines obtained by the Visvalingam and Li-Openshaw algorithms on all levels of detail (master students)

\section{ВЫВОДЫ}

На основании проведенного анализа были сделаны следующие выводы:

1. Линии, воспринимаемые респондентами как имеющие схожую детализацию, могут быть получены разными алгоритмами, однако выбор метрики, использующейся в качестве ограничения, зависит от характера линии. В частности, для линий, имеющих неглубокую иерархию изгибов, размеры которых малы в сравнении с длиной всей линии (Ботния), наиболее схожие по детализации результаты получаются при использовании линейного смещения в качестве ограничивающей метрики (в нашем случае за его оценку отвечает модифицированное расстояние Хаусдорфа). При увеличении сложности линии большую роль начинает играть такая метрика как уменьшение количества изгибов. Для участка береговой линии Норвегии наиболее оптимальным среди проанализированных 
оказалось равное соотношение весов между расстоянием и количеством изгибов $[0,5 ; 0,5]$, в то время как для Исландии, занимающей промежуточное положение по сложности иерархии изгибов, это соотношение колеблется между $[1 ; 0]$ и $[0,5 ; 0,5]$ в зависимости от того, используется ли полная выборка или одна из двух однородных подвыборок респондентов (бакалавры, магистры).

2. $\quad$ Гипотеза о соотношении весов ограничивающих метрик (используемых при осреднении параметров уравнений регрессии), ранее выдвинутая в статье [Samsonov, Yakimova, 2020], подтвердилась частично. Наше предположение состояло в том, что для Ботнии, Исландии и Норвегии оно составляет $[1 ; 0],[0,7 ; 0,3]$ и $[0,5 ; 0,5]$. Сравнивая эти цифры с результатами анализа экспертного опроса, можно сделать вывод, что для Ботнии и Исландии оно оправдалось, а для Норвегии мы недооценили важность контроля отклонения линии от исходной как косвенной характеристики уменьшения детализации.

3. Гипотеза о возможности комбинирования разных метрик для получения линий сопоставимой детализации, подтвердилась, поскольку для одной из трех линий наилучший результат устойчиво получился при взвешенной комбинации анализируемых метрик.

4. Из двух метрик - линейного смещения по метрике модифицированного расстояния Хаусдорфа и уменьшения количества изгибов - метрика линейного смещения является более показательной при характеристике изменения детализации линии, поскольку ни один из результатов опроса не показал возможность применения только уменьшения количества изгибов как эффективной характеристики изменения детализации.

\section{БЛАГОДАРНОСТИ}

Исследование выполнено при поддержке РФФИ, грант № 18-07-01459.

\section{ACKNOWLEDGEMENTS}

The study was funded by the Russian Foundation of Basic Research grant No 18-07-01459.

\section{СПИСОК ЛИТЕРАТУРЫ}

1. Ai T. The drainage network extraction from contour lines for contour line generalization. ISPRS Journal of Photogrammetry and Remote Sensing, 2007. V. 62. No 2. P. 93-103. DOI: $10.1016 /$ j.isprsjprs.2007.04.002.

2. Bayer T. Automated Building Simplification Using a Recursive Approach. Advances in Cartography and GIScience. Berlin, Heidelberg: Springer Berlin Heidelberg, 2009. V. 1. P. 121-146. DOI:10.1007/978-3-642-03294-3_8.

3. Douglas D.H., Peucker T.K. Algorithms for the reduction of the number of points required to represent a digitized line or its caricature.The Canadian Cartographer, 1973. No 10(2). P. 112-122.

4. Dubuisson M.-P., Jain A.K. A Modified Hausdorff Distance for Object. Proceedings of 12th International Conference on Pattern Recognition. IEEE Comput. Soc. Press, 1994. V. 1. P. 566-568. DOI: 10.1109/ICPR.1994.576361.

5. Li Z., Openshaw S. Algorithms for Automated Line Generalization Based on a Natural Principle of Objective Generalization. International journal of geographical information systems, 1992. V. 6. No 5. P. 373-389. DOI:10.1080/02693799208901921.

6. Mustiere S. Cartographic generalization of roads in a local and adaptive approach: A knowledge acquistion problem. International Journal of Geographical Information Science, 2005. V. 19. No 8-9. P. 937-955. DOI: 10.1080/13658810509161245.

7. Park $W$., $Y u K$. Hybrid line simplification for cartographic generalization. Pattern Recognition Letters, 2011. V. 32. No 9. P. 1267-1273. DOI: 10.1016/j.patrec.2011.03.013. 
8. Samsonov T.E., Yakimova O.P. Regression modeling of reduction in spatial accuracy and detail for multiple geometric line simplification procedures. International Journal of Cartography, 2020. V. 6. No 1. P. 47-70. DOI: 10.1080/23729333.2019.1615745.

9. Samsonov T.E., Yakimova O.P. Shape-Adaptive Geometric Simplification of Heterogeneous Line Datasets. International Journal of Geographical Information Science, 2017. V. 31. No 8. P. 1485-1520. DOI:10.1080/13658816.2017.1306864.

10. Touya G., Duchêne C., Ruas A. Collaborative Generalisation: Formalisation of Generalisation Knowledge to Orchestrate Different Cartographic Generalisation Processes. Theories and Methods of Spatio-Temporal Reasoning in Geographic Space. Berlin, Heidelberg: Springer Berlin Heidelberg, 2010. P. 264-278. DOI: 10.1007/978-3-642-15300-6_19.

11. Visvalingam M., Whyatt J.D. Line Generalisation by Repeated Elimination of Points. The Cartographic Journal, 1993. V. 30. No 1. P. 46-51. DOI:10.1179/000870493786962263.

12. Wang Z., Muller J.C. Complex Coastline Generalization. Cartography and Geographic Information Science, 1993. V. 20. No 2. P. 96-106.

\section{REFERENCES}

1. Ai T. The drainage network extraction from contour lines for contour line generalization. ISPRS Journal of Photogrammetry and Remote Sensing, 2007. V. 62. No 2. P. 93-103. DOI: 10.1016/j.isprsjprs.2007.04.002.

2. Bayer T. Automated Building Simplification Using a Recursive Approach. Advances in Cartography and GIScience. Berlin, Heidelberg: Springer Berlin Heidelberg, 2009. V. 1. P. 121-146. DOI: 10.1007/978-3-642-03294-3 8.

3. Douglas D.H., Peucker T.K. Algorithms for the reduction of the number of points required to represent a digitized line or its caricature. The Canadian Cartographer, 1973. No 10(2). P. 112-122.

4. Dubuisson M.-P., Jain A.K. A Modified Hausdorff Distance for Object. Proceedings of 12th International Conference on Pattern Recognition. IEEE Comput. Soc. Press, 1994. V. 1. P. 566-568. DOI: 10.1109/ICPR.1994.576361.

5. Li Z., Openshaw S. Algorithms for Automated Line Generalization Based on a Natural Principle of Objective Generalization. International journal of geographical information systems, 1992. V. 6. No 5. P. 373-389. DOI: 10.1080/02693799208901921.

6. Mustiere $S$. Cartographic generalization of roads in a local and adaptive approach: A knowledge acquistion problem. International Journal of Geographical Information Science, 2005. V. 19. No 8-9. P. 937-955. DOI: 10.1080/13658810509161245.

7. Park $W$., Yu $K$. Hybrid line simplification for cartographic generalization. Pattern Recognition Letters, 2011. V. 32. No 9. P. 1267-1273. DOI: 10.1016/j.patrec. 2011.03.013.

8. Samsonov T.E., Yakimova O.P. Regression modeling of reduction in spatial accuracy and detail for multiple geometric line simplification procedures. International Journal of Cartography, 2020. V. 6. No 1. P. 47-70. DOI: 10.1080/23729333.2019.1615745.

9. Samsonov T.E., Yakimova O.P. Shape-Adaptive Geometric Simplification of Heterogeneous Line Datasets. International Journal of Geographical Information Science, 2017. V. 31. No 8. P. 1485-1520. DOI: 10.1080/13658816.2017.1306864.

10. Touya G., Duchêne C., Ruas A. Collaborative Generalisation: Formalisation of Generalisation Knowledge to Orchestrate Different Cartographic Generalisation Processes. Theories and Methods of Spatio-Temporal Reasoning in Geographic Space. Berlin, Heidelberg: Springer Berlin Heidelberg, 2010. P. 264-278. DOI: 10.1007/978-3-642-15300-6_19.

11. Visvalingam M., Whyatt J.D. Line Generalisation by Repeated Elimination of Points. The Cartographic Journal. 1993. V. 30. No 1. P. 46-51. DOI: 10.1179/0008704937 86962263.

12. Wang Z., Muller J.C. Complex Coastline Generalization. Cartography and Geographic Information Science, 1993. V. 20. No 2. P. 96-106. 


\title{
О.П. Якимова ${ }^{1}$, Т.Е. Самсонов ${ }^{2}$, Д.А. Потемкин ${ }^{3}$, Э. Усманова ${ }^{4}$
ИНСТРУМЕНТЫ ДЛЯ ОЦЕНКИ ДЕТАЛИЗАЦИИ КАРТ ДЛЯ ГЕОИНФОРМАЦИОННОЙ СИСТЕМЫ QGIS

\begin{abstract}
АННОТАЦИЯ
Работа посвящена проблеме оценки детализации пространственных данных. В геоинформатике детализация пространственных данных определяет то, насколько подробно тот или иной объект представлен на картографическом изображении, оценка детализации позволяет проанализировать допустимую точность пространственных объектов для определенной задачи пользователя. Предлагается подход к определению понятия детализации. Оценка детализации объекта зависит от его характеристик: геометрических, семантических, топологических. Проводится исследование по отбору геометрических характеристик объекта, отражающих его детализацию. Для линейных объектов, помимо характеристик линии в целом (длина, количество точек, извилистость, средний угол поворота) предлагается рассмотреть более мелкие ее детали, такие как изгибы и триплеты. Под изгибом понимается участок линии, на котором угол поворота сохраняет свой знак. Триплетом считают комбинацию из трех последовательно идущих точек. На основе результатов проведенного исследования были отобраны геометрические характеристики, которые изменяются в тренде в зависимости от масштаба.

В работе представляется разработанное программное обеспечение для оценки детализации карты - панель инструментов MapAnalyser для геоинформационной системы QGIS. Описываются функциональные возможности разработанного программного обеспечения. Панель инструментов позволяет получить геометрические, семантические и топологические характеристики слоя или набора слоев, а также оценить графическую сложность картографического изображения на основе RLE- кодирования. Код программы написан на языке PyQGIS. Программное обеспечение прошло государственную регистрацию и размещено на сервере github. С его помощью были получены новые результаты по оценке детализации пространственных данных. Разработанное программное обеспечение может использоваться при интеграции данных, полученных из разных источников, для оценки соответствия детализации данных и масштаба картографирования, оценки сложности карты для различных целей и масштабов.
\end{abstract}

КЛЮЧЕВЫЕ СЛОВА: детализация пространственных данных, геоинформационные системы, панель инструментов MapAnalyzer.

\footnotetext{
1 Ярославский государственный университет имени П.Г. Демидова, Математический факультет, ул. Союзная, д. 144, 150008, Ярославль, Россия, e-mail: polya@uniyar.ac.ru

2 Московский государственный университет имени М.В. Ломоносова, Географический факультет, Ленинские горы, д. 1, 119991, Москва, Россия, e-mail: tsamsonov@geogr.msu.ru

3 Ярославский государственный университет имени П.Г. Демидова, Математический факультет, ул. Союзная, д. 144, 150008, Ярославль, Россия, e-mail: daniilpot@yandex.ru

4 Берлинский технический университет, Kaiserin-Augusta-Allee 104-106, 10553, Берлин, Германия, e-mail: elina-usmanova-97@mail.ru
} 


\title{
Olga P. Yakimova ${ }^{1}$, Timofey E. Samsonov ${ }^{2}$, Daniil A. Potemkin ${ }^{3}$, Elina Usmanova ${ }^{4}$ \\ QGIS PROCESSING TOOL FOR SPATIAL DATA DETAIL ASSESSMENT
}

\begin{abstract}
The article is devoted to the problem of evaluating the detailing of spatial data. In geoinformatics, spatial data detailing determines how detailed a particular object is represented in a map image, and the detail score allows you to analyze the permissible accuracy of spatial objects for a specific user task. An approach to the definition of detailing concept is proposed. The evaluation of the object's detail depends on its characteristics: geometric, semantic, and topological. A study is being conducted to select the geometric characteristics of the object that reflect its detail. For linear objects, in addition to the characteristics of the line as a whole (length, number of points, sinuosity, average rotation angle), it is suggested to consider its smaller details, such as bends and triplets. A bend is a section of a line where the angle of rotation retains its sign. A triplet is a combination of three consecutive points. Based on the results of the study, the geometric characteristics that change in the trend depending on the scale were selected.

The paper presents the developed software for assessing map detail - the MapAnalyser toolbar for the QGIS geoinformation system. The functional capabilities of the developed software are described. The toolbar allows you to get the geometric, semantic, and topological characteristics of a layer or set of layers, as well as to evaluate the graphical complexity of a map image based on RLE encoding. The program code is written in the PyQGIS language. The software has passed state registration and is hosted on the github server. With its help, new results were obtained on the evaluation of spatial data granularity.

New software, embedded in QGIS, to assess the detail of the map and spatial data, based on taking into account geometric and symbolic (used in the display) parameters. The software allows to calculate the metrics of spatial data detail, as well as to assess the complexity of the cartographic image. It's can be used in the integration of data obtained from different sources, to assess the compliance of data detail and the map scale, to assess the complexity of the map for different purposes and scales.
\end{abstract}

KEYWORDS: spatial data detail, Geographic information system, processing tool.

\section{ВВЕДЕНИЕ}

С активным внедрением цифровых технологий в картографию стала возникать проблема оценки детализации пространственных данных. В геоинформатике детализация пространственных данных определяет то, насколько подробно тот или иной объект представлен на картографическом изображении, оценка детализации позволяет проанализировать допустимую точность пространственных объектов для определенной задачи пользователя. На практике оценка уровня детализации представляет из себя довольно сложную задачу. В мультимасштабном картографировании при смене масштаба текущая детализация пространственных объектов должна соответствовать масштабу, но это не всегда так. Возникают ситуации, когда два различных класса пространственных объектов в

\footnotetext{
1 Demidov Yaroslavl State University, Soyuznaya str., 144, 150008, Yaroslavl, Russia, e-mail: polya@uniyar.ac.ru

2 Lomonosov Moscow State University, Faculty of Geography, Leninskie Gory 1, 119991, Moscow, Russia, e-mail: tsamsonov@geogr.msu.ru

3 Demidov Yaroslavl State University, Soyuznaya str., 144, 150008, Yaroslavl, Russia, e-mail: daniilpot@yandex.ru

4 Technical University of Berlin, Kaiserin-Augusta-Allee 104-106, 10553, Berlin, Germany, e-mail: elina-usmanova-97@mail.ru
} 
одном и том же масштабе имеют разные уровни детализации. Так, в работе [Touya, BrandoEscobar, 2013] приводятся примеры несогласованности уровней детализации для тематических классов, по своему семантическому значению связанные друг с другом.

Проблема несогласованности уровней детализации для разных пространственных объектов является серьезным препятствием к получению высококачественного картографического продукта. Отсюда требуется формализовать понятие детализации или уровень детализации (Level of Detail - LoD) и разработать способы его оценки.

В геоинформатике термин уровень детализации не имеет устоявшегося определения. В работе [Meng, Forberg, 2007] уровень детализации определяется изменением подробности представления объектов при рассмотрении определенного масштабного ряда. [Glander, Döllner, 2008] принимают за уровень детализации степень генерализации пространственных объектов. В работе [Forberg, 2007] принимает уровень детализации за стандартный способ повышения эффективности представления многогранных данных. [Sester, 2007] и [Goetz, 2013] считают, что уровни детализации - это мультимасштабные модели для различных приложений, также рассматриваемое понятие может относиться не только к пространству, но и к времени и семантике.

В настоящее время к оценке уровня детализации существует несколько подходов. Прежде всего, для этой цели можно использовать масштаб. Очевидно, что один и тот же объект не может одинаково показан на картах разного масштаба. Но в то же время, масштаб не может быть использован для характеристики баз геоданных, так как последние предназначены не только для картографического представления, следовательно, для них масштаб не является постоянной характеристикой и не может служить надежным критерием при оценке уровня детализации.

Под детализацией пространственного объекта, набора пространственных объектов или карты мы понимаем подробность их представления. Для каждого уровня рассмотрения подробность определяется по-разному.

Детализация представления пространственного объекта определяется количеством его структурных элементов, таких как вершины, изгибы и компоненты (для многосвязных объектов), величиной чувствительных к компрессии данных геометрических характеристик этих элементов, а также количеством семантических характеристик, привязанных к объекту.

Детализация представления множества пространственных объектов определяется мощностью множества, разнообразием и количеством возникающих между его элементами топологических отношений, а также разнообразием значений семантических атрибутов, привязанных к этим объектам.

Детализация карты определяется сочетанием детализации входящих в нее объектов, детализации множества этих объектов, а также разнообразием символов и графических переменных, используемых для визуализации объектов.

Для оценки детализации объектов, множеств объектов и карт необходимо определить: а) конкретный состав рассчитываемых показателей и б) методы их агрегирования в скалярные либо векторные величины, характеризующие детализацию в численном виде.

\section{МАТЕРИАЛЫ И МЕТОДЫ ИССЛЕДОВАНИЯ}

Оценка детализации объекта зависит от его характеристик: геометрических, семантических, топологических. Для линейных объектов, помимо характеристик линии в целом (длина, количество точек, извилистость, средний угол поворота) предлагается рассмотреть более мелкие ее детали, такие как изгибы и триплеты. Под изгибом понимается участок линии, на котором угол поворота сохраняет свой знак. Триплетом считают 
комбинацию из трех последовательно идущих точек. Рассмотрение изгибов при оценке детализации целесообразно, так как они играют важную роль при визуальном анализе и геометрическом упрощении объекта. В процессе генерализации необходимо сохранить крупные или значимые изгибы, поэтому изучение их свойств крайне важно при оценке детализации линейных объектов. Триплеты позволяют подробнее проанализировать характеристики и особенности линии.

Для каждой детали (изгиба и триплета) линии были вычислены следующие параметры:

1) длина базовой линии - отрезка, соединяющего начальную и конечную точки изгиба (триплета);

2) длина - сумма длин всех отрезков, составляющих изгиб (триплет);

3) площадь изгиба(триплета);

4) высота - отрезок, соединяющий точку на базовой линии с наиболее удаленной точкой на любом из отрезков, составляющих изгиб (триплет);

5) отношение высоты к длине базовой линии. Этот показатель позволяет судить о конфигурации детали, наиболее вытянутые вдоль базовой линии изгибы (триплеты) будут иметь малое (менее 1) значение данной характеристики. В то же время вытянутым по направлению высоты деталям соответствует значение, большее 1;

6) кривизна (отношение длины к длине базовой линии) определяет значение поворотов линии. Показатель всегда больше 1, причем чем ближе к 1 , тем меньшее значение имеет данная деталь при генерализации;

7) компактность указывает на стремление полигонального объекта занять минимальную площадь: $4 \pi \mathrm{S} /(\mathrm{len}+\mathrm{l})^{2}$, где $\mathrm{S}$ - площадь изгиба, len - длина изгиба, $\mathrm{lb}$ - длина базовой линии;

8) открытость. Эта характеристика описывает, как длина базовой линии соотносится с размерами изгиба. При небольшой базовой линии и значительной длине изгиба этот показатель будет иметь малое значение: $\mathrm{h}(2 * \mathrm{len} / \mathrm{lb}-1) /\left(\mathrm{h}+\mathrm{ll}_{\mathrm{b}}\right)$.

Для экспериментов были использованы административные границы субъектов РФ в масштабах 1:200 000, 1:500 000, 1:1 000 000, 1:2 500 000, 1:8 000 000, генерализованные вручную.

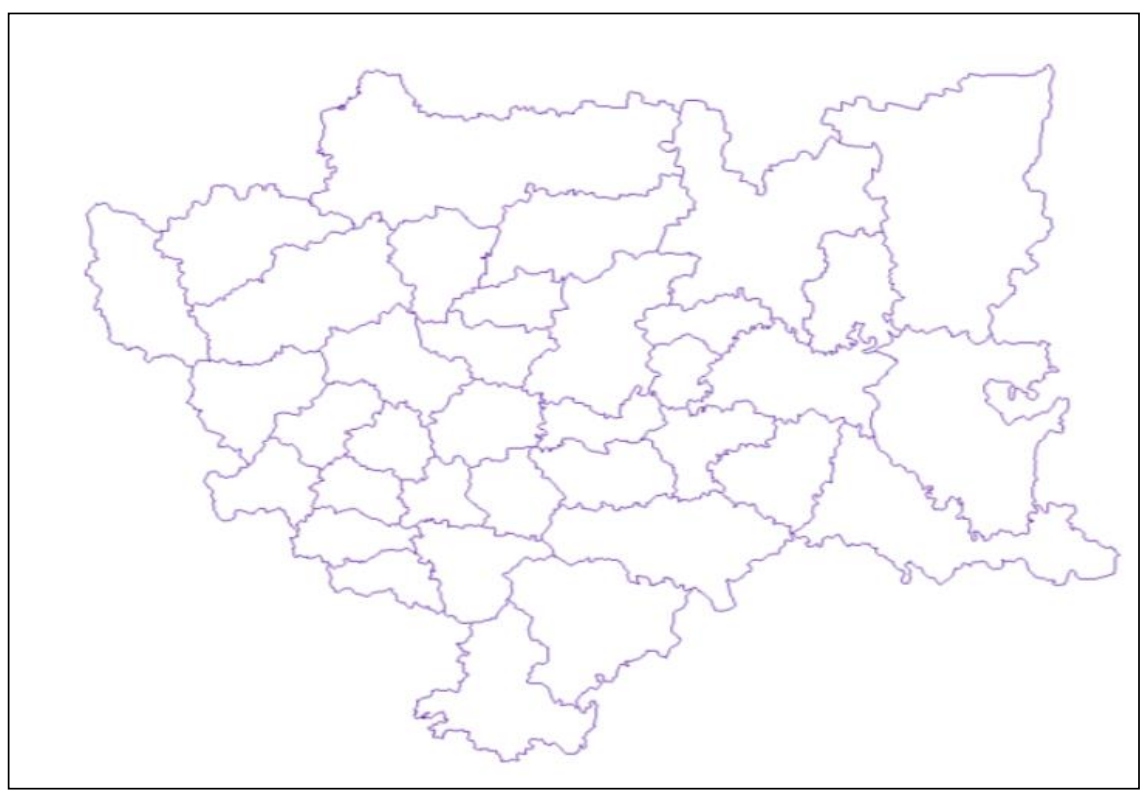

Рис. 1. Исходные данные для экспериментов

Fig. 1. Initial data for experiments 
Разработанное нами приложение на языке С\# в качестве исходных данных принимает набор шейп-файлов, в каждом из которых находится векторное представление только одной линии. Результатом работы программы является текстовый файл с вычисленными характеристиками. Все значения характеристик для деталей линии усреднены.

\section{РЕЗУЛЬТАТЫ ИССЛЕДОВАНИЯ И ИХ ОБСУЖДЕНИЕ}

Результаты исследования были обработаны и по ним построены графики, отражающие изменение конкретной характеристики в зависимости от масштаба. Бокс-плот (boxplot) отображает медианное значение характеристики (синяя линия внутри прямоугольника), границы прямоугольника представляют первый и третий квартили, максимальный и минимальный разбросы значений отображаются прямыми, расходящимися от прямоугольника вверх и вниз. Часть графиков приведена на рисунках 2-7.

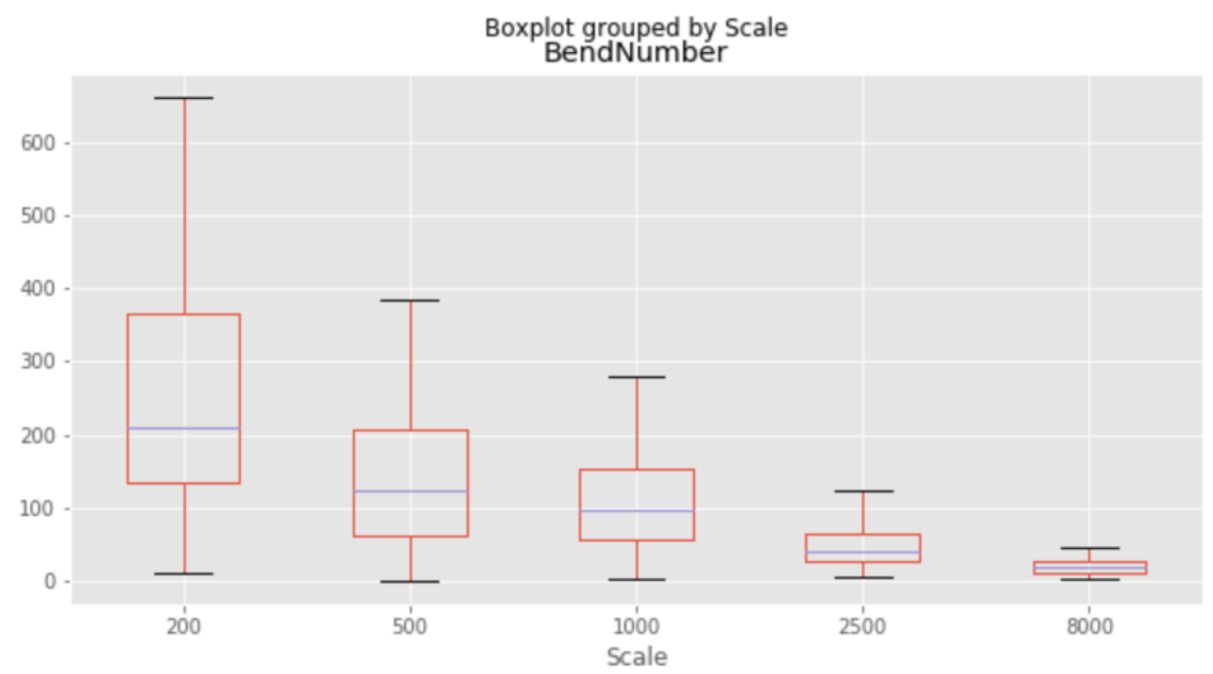

Рис. 2. Изменение количества изгибов в зависимости от маситаба

Fig. 2. Changing the number of bends depending on the scale

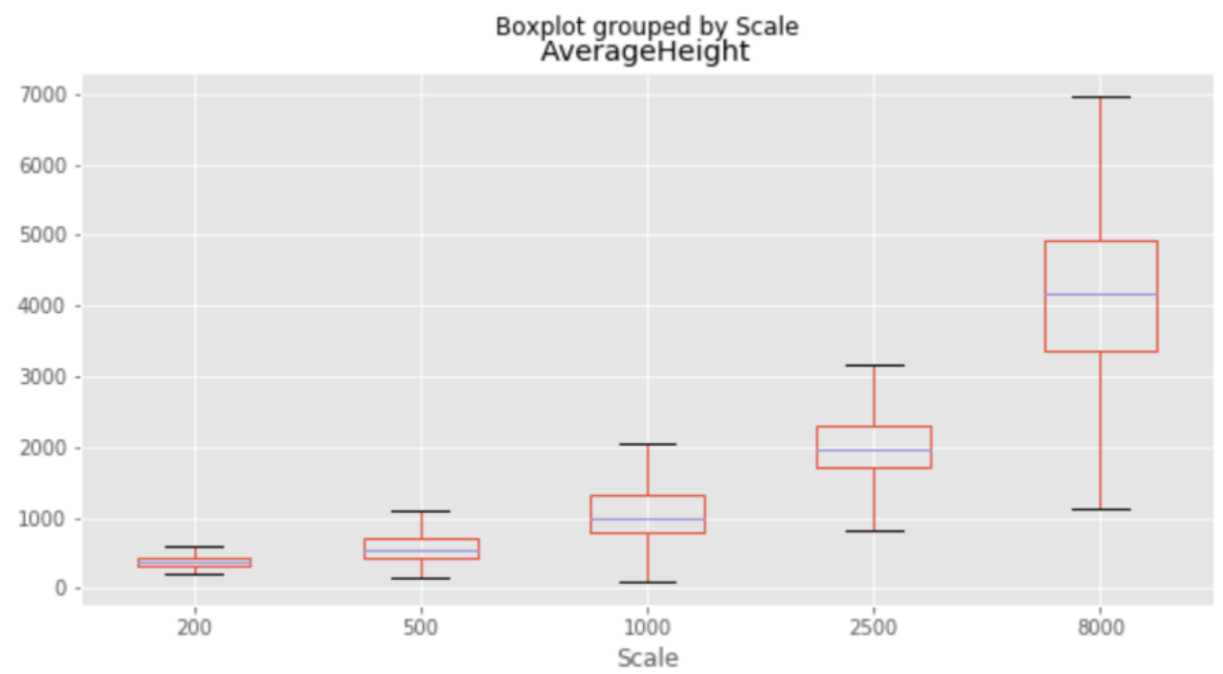

Рис. 3. Изменение средней высоты изгиба в зависимости от масштаба

Fig. 3. Changing the average bend height depending on the scale 


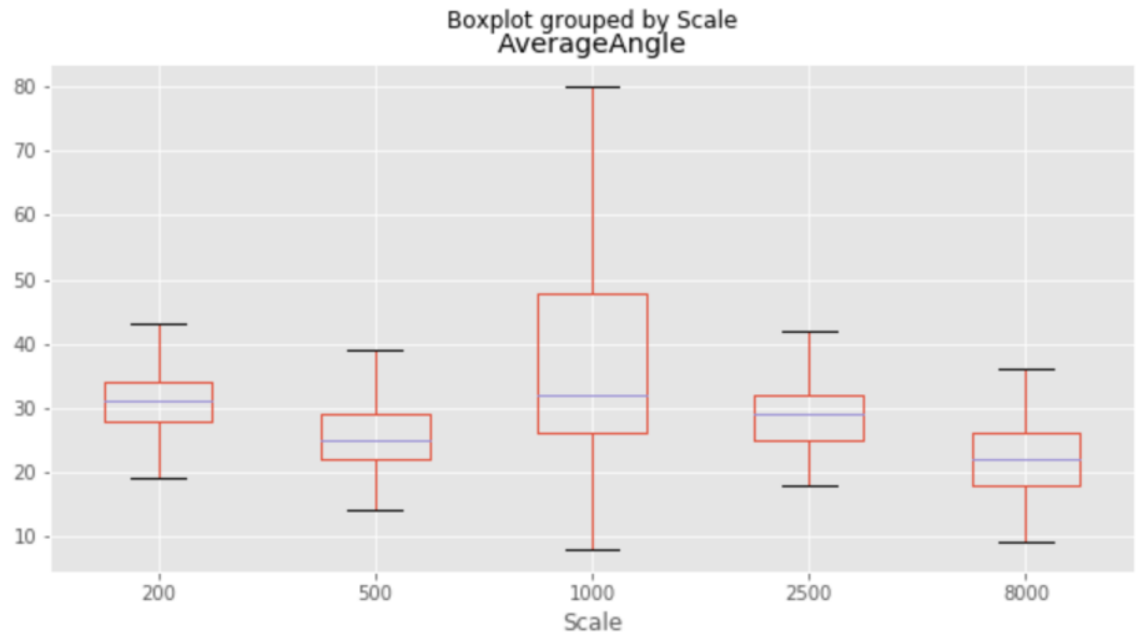

Рис. 4. Изменение среднего угла поворота в зависимости от масштаба

Fig. 4. Changing the average angle of rotation depending on the scale

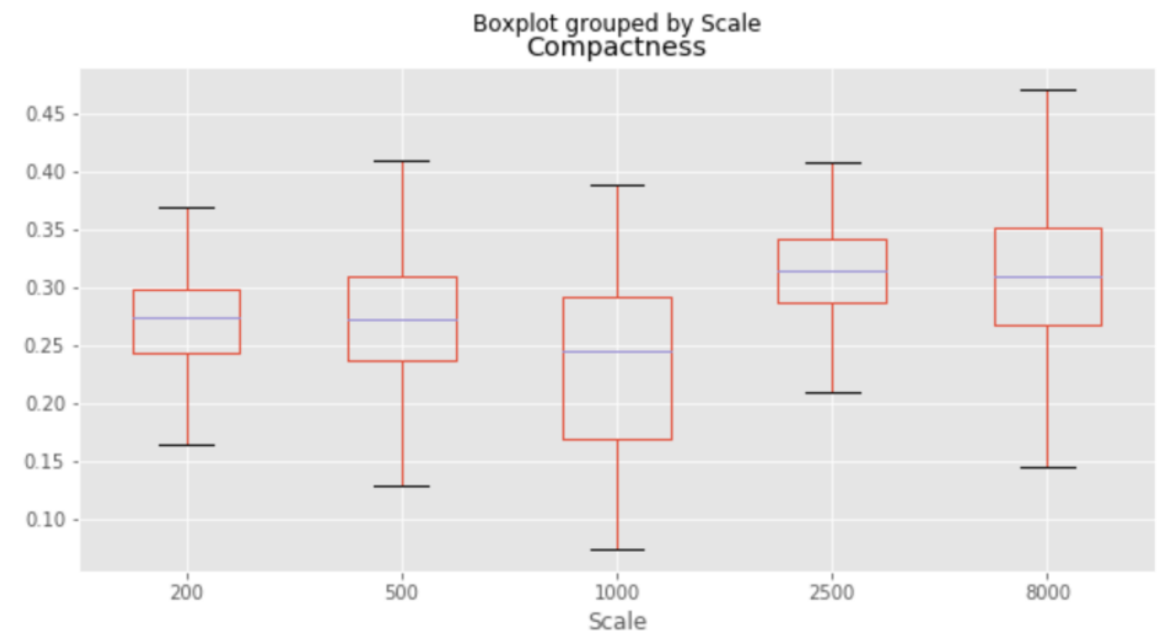

Рис. 5. Изменение компактности в зависимости от масштаба Fig. 5. Changing the compactness depending on the scale

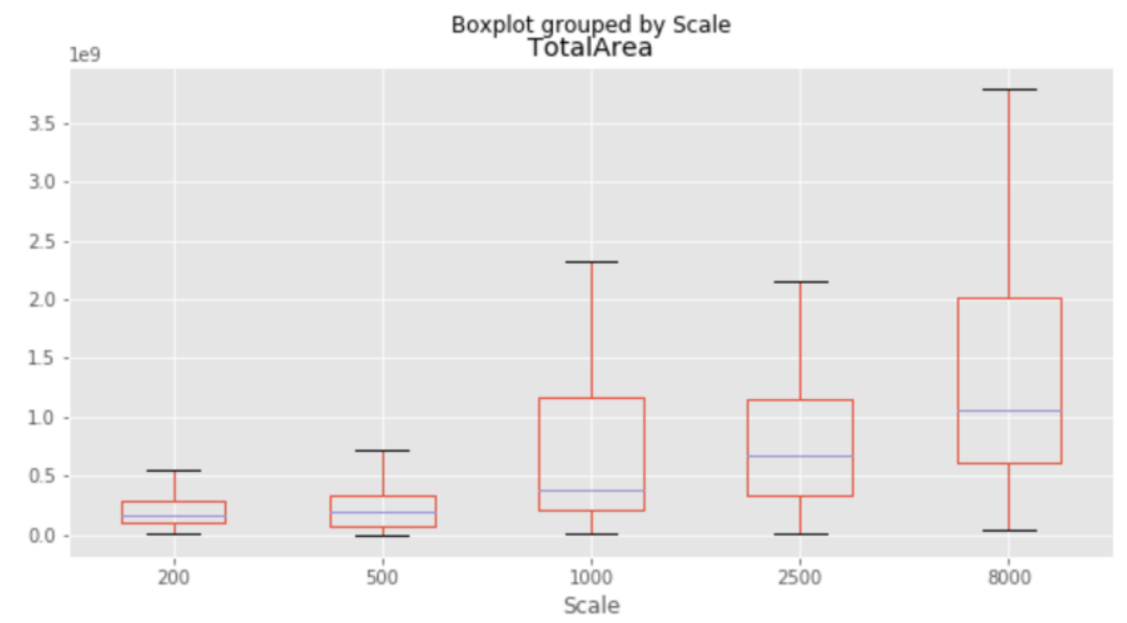

Рис. 6. Изменение суммарной площади изгибов в зависимости от масмтаба Fig. 6. Changing the total bend area depending on the scale 


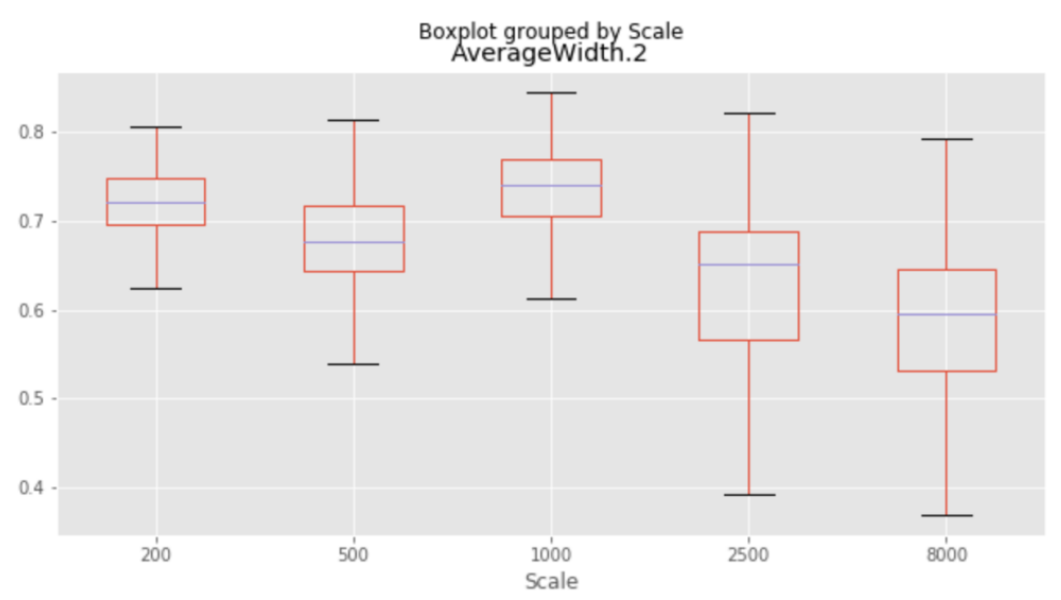

Рис. 7. Изменение средней ширины триплетов в зависимости от масштаба Fig. 7. Changing the average triplet width depending on the scale

Проведенные эксперименты показали, что часть характеристик при изменении масштаба монотонно изменяется, другие же изменяются в тренде или остаются стабильными. Для целей оценки детализации подходит только первая группа. Таким образом для дальнейшей работы были выбраны следующие характеристики линейных объектов:

- общее количество точек;

- количество изгибов;

- общая площадь (сумма площадей всех изгибов, образующих линию);

- длина линии;

- средняя длина изгиба;

- средняя длина базовой линии изгиба;

- средняя высота изгиба;

- средняя площадь изгиба.

Для слоев полигональных объектов дополнительно были выбраны следующие характеристики:

- общая площадь (сумма площадей всех полигонов слоя);

- общий периметр (сумма периметров всех полигональных объектов слоя);

- средняя площадь полигона слоя;

- средний периметр полигона конкретного слоя.

Кроме геометрических характеристик для всех слоев высчитывались семантические характеристики, а именно:

- количество атрибутов в таблице атрибутов слоя (featCount);

- количество уникальных объектов слоя, которое определялось следующим образом: numberOfUniqueValues $=\left(\Sigma\right.$ num $\left._{\mathrm{n}}\right) /$ featCount, где сумма берется по количеству полей в таблице атрибутов слоя, num $\mathrm{m}_{\mathrm{n}}$ - количество уникальных атрибутов n-го поля;

- среднее количество уникальных объектов слоя, которое вычисляется как отношение величины numberOfUniqueValues к количеству полей в атрибуте слоя;

- количество объектов в слое.

Для каждого множества пространственных объектов (участка карты) были разработаны топологические характеристики, а именно количество пересечений линий 
внутри слоя и между всеми слоями выбранного участка. Последняя характеристика определялась следующим образом:

1. Выбор слоев для анализа;

2. Объединение слоев в один слой;

3. Поиск крайних точек линий: из геометрии линии берутся первая точка и последняя.

4. Поиск пересечений линий;

5. Отбор точек пересечений: если точка пересечения встречается два раза в списке крайних точек, то данную точку пересечения отбрасываем.

Количество точек, оставшихся после пункта 5, является результатом работы алгоритма - количество пересечений линий слоев.

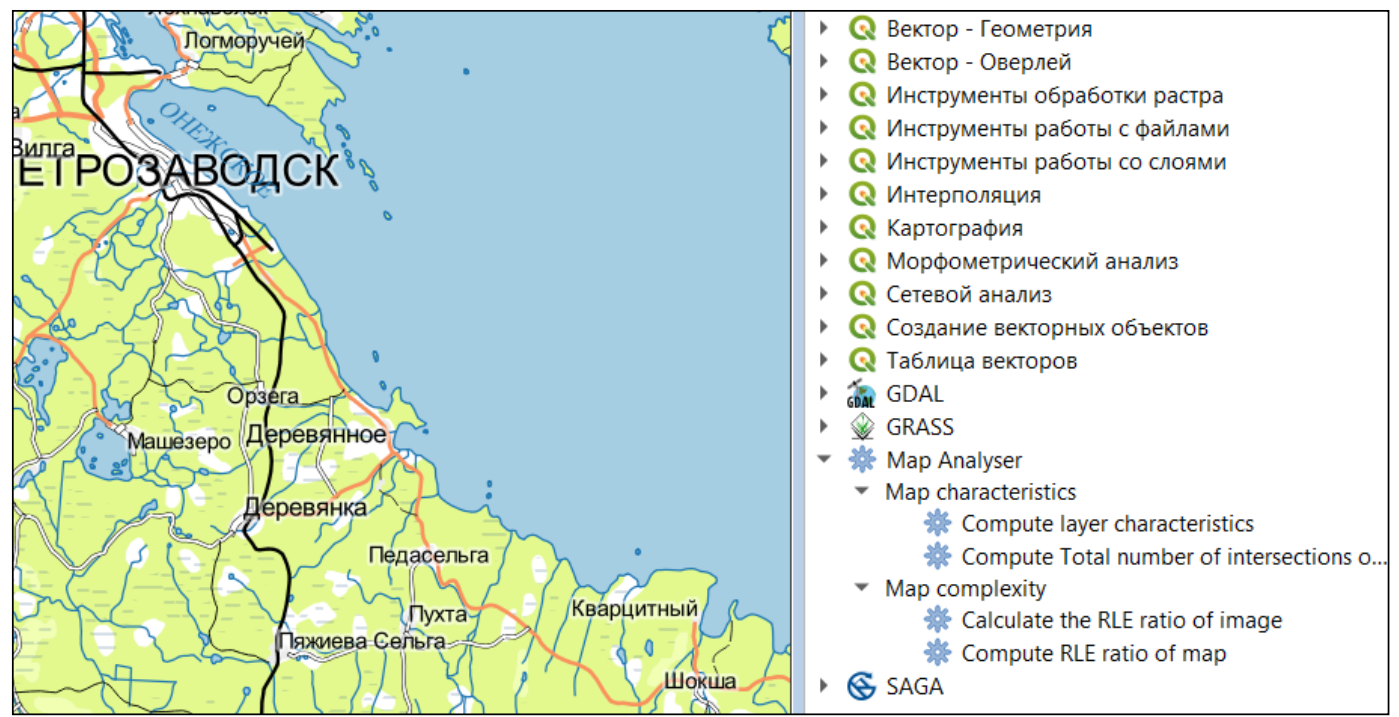

Рис. 8. Панель инструментов MарAnalyser

Fig. 8. Processing tool MapAnalyser

Была разработана панель инструментов MapAnalyser ${ }^{1}$ (см. рис. 8) для геоинформационной системы QGIS, которая позволяет оценить детализацию карты или ее отдельного слоя.

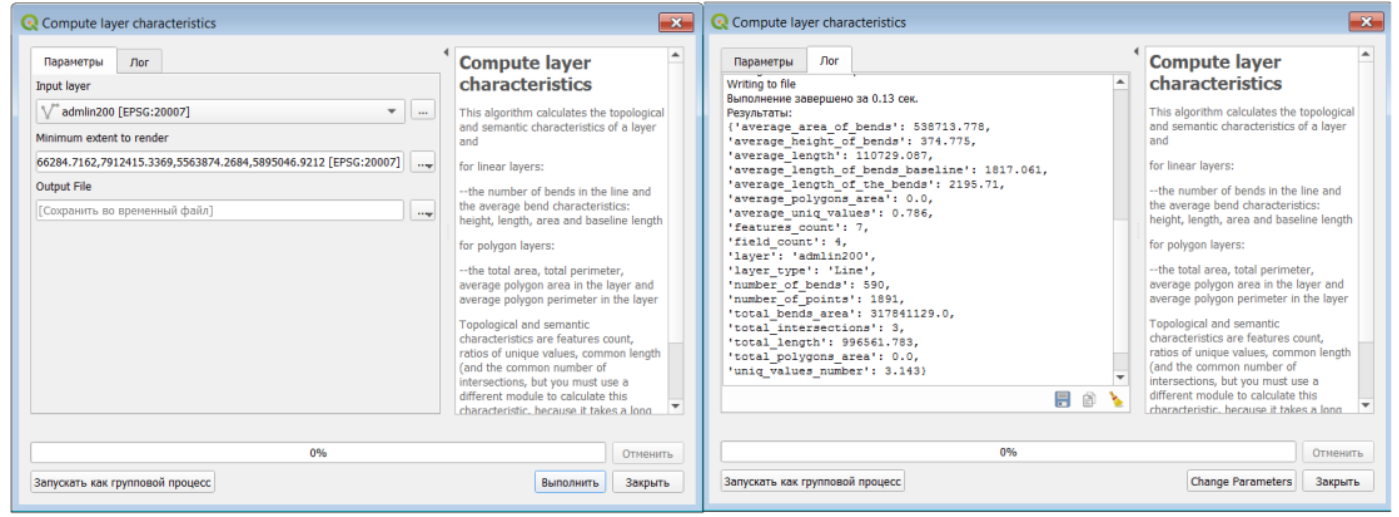

Pис. 9. Инструмент "Cотриte layer characteristics"

Fig. 9. "Compute layer characteristics" tool

$1 \quad$ https://github.com/danmoka/MapAnalyser. 
Инструмент "Compute layer characteristics" позволяет получить геометрические, семантические и топологические характеристики выбранного слоя или группы слоев (см. рис. 9). Результаты выводятся в окне инструмента либо их можно сохранить в файл в формате csv. Ниже представлен небольшой фрагмент базы пространственных данных масштаба 1:500000 (см. рис. 10) и часть таблицы характеристик, полученных для него.

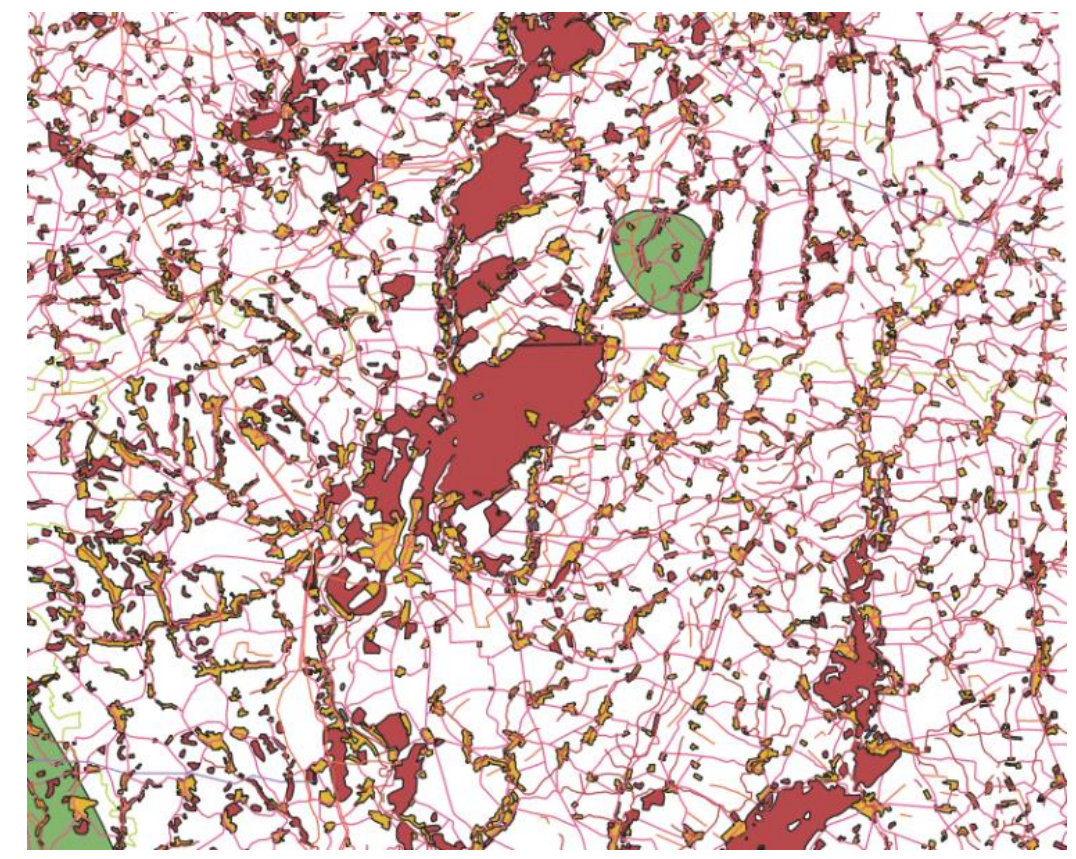

Рис. 10. Фрагмент пространственных данных

Fig. 10. Some spatial data

Табл. 1. Значения геометрических, семантических и топологических характеристик

Table 1. Values of geometric, semantic, and topological characteristics

\begin{tabular}{|c|c|c|c|c|c|c|c|c|c|c|}
\hline $\begin{array}{l}\overrightarrow{\mathrm{D}} \\
\text { 空 }\end{array}$ & $\begin{array}{l}\vec{\Xi} \\
0 \\
0 \\
0 \\
0 \\
0\end{array}$ & 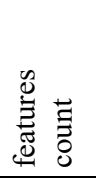 & 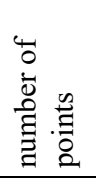 & 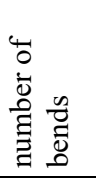 & 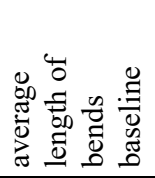 & 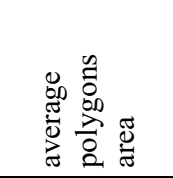 & 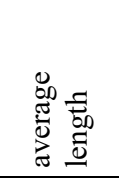 & 离完 & 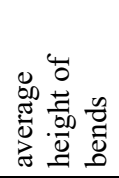 & 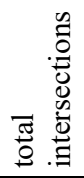 \\
\hline blkpol500 & 9 & 8849 & 50588 & 12577 & 262,376 & 134569,442 & 1757,16 & Polygon & 279,264 & 4 \\
\hline comlin500 & 8 & 5 & 76 & 14 & 20023,571 & 0 & 48102,4 & Line & 1851 & 1 \\
\hline comlin500 & 8 & 5 & 76 & 14 & 20023,571 & 0 & 48102,4 & Line & 1851 & 1 \\
\hline forlin 500 & 5 & 43 & 222 & 48 & 8162,021 & 0 & 9807,33 & Line & 291,854 & 57 \\
\hline ghppol500 & 6 & 2 & 64 & 4 & 62748,25 & 1294264882 & 158754 & Polygon & 13524 & 0 \\
\hline gndpol500 & 7 & 103 & 1413 & 310 & 966,5 & 1068438,68 & 4509,85 & Polygon & 326,103 & 0 \\
\hline hdclin 500 & 13 & 6 & 14 & 4 & 2307,75 & 0 & 3542,27 & Line & 308,25 & 0 \\
\hline hrdlin500 & 9 & 622 & 15149 & 2892 & 1884,433 & 0 & 8811,59 & Line & 268,207 & 532 \\
\hline piplin500 & 12 & 22 & 510 & 114 & 7559,904 & 0 & 36709,4 & Line & 969,579 & 16 \\
\hline poppol500 & 14 & 1075 & 26792 & 12207 & 773,372 & 2924335,87 & 9515,48 & Polygon & 278,439 & 17 \\
\hline rdclin 500 & 13 & 5 & 40 & 6 & 1897,333 & 0 & 4581,39 & Line & 211,333 & 0 \\
\hline rdslin 500 & 12 & 1607 & 18346 & 2829 & 3373,791 & 0 & 6461,54 & Line & 333,365 & 1545 \\
\hline rlfpol500 & 8 & 5 & 52 & 14 & 583,571 & 405181,1 & 3350,76 & Polygon & 214 & 0 \\
\hline veglin 500 & 9 & 80 & 247 & 69 & 3569,377 & 0 & 5263,13 & Line & 475,014 & 0 \\
\hline vegpol500 & 9 & 421 & 14312 & 3738 & 1234,01 & 7769671,78 & 11220,2 & Polygon & 296,189 & 0 \\
\hline
\end{tabular}


Инструмент "Compute Total number of intersections of linear and polygon layers" позволяет получить топологическую характеристику выбранного слоя или группы слоев с линейными или полигональными объектами - общее число пересечений линий (контуров) объектов. Результаты выводятся в окне инструмента либо их можно сохранить в файл в формате csv.

Инструменты "Compute RLE ratio of map" и "Calculate the RLE ratio of image" предназначены для получения оценки графической сложности картографического изображения на основе одного из универсальных методов - RLE кодирования. В методе кодирования к картографическому изображению применяется сжатие информации какимлибо методом. Показателем сложности карты является отношение длины сжатого и исходного файлов. Если на карте много "пустого" места, закрашенного фоновым цветом, то при сжатии его размер сильно уменьшится, иначе практически не изменится. В работе [Fairbairn, 2006] проведено сравнение различных методов сжатия и рекомендован метод кодирования серий (RLE - run-length encoding), который и реализован для панели инструментов МарAnalyser. Инструмент "Compute RLE ratio of map" (см. рис. 11) получает от пользователя охват загруженной карты, преобразует его в изображение средствами QGIS, потом выполняет подсчет коэффициента сжатия. Инструмент "Calculate the RLE ratio of image" позволяет указать существующие в файловой системе пользователя картографические изображения и для каждого из них рассчитывает коэффициент сжатия. Результаты можно как увидеть на экране, так и сохранить в файл в формате csv.

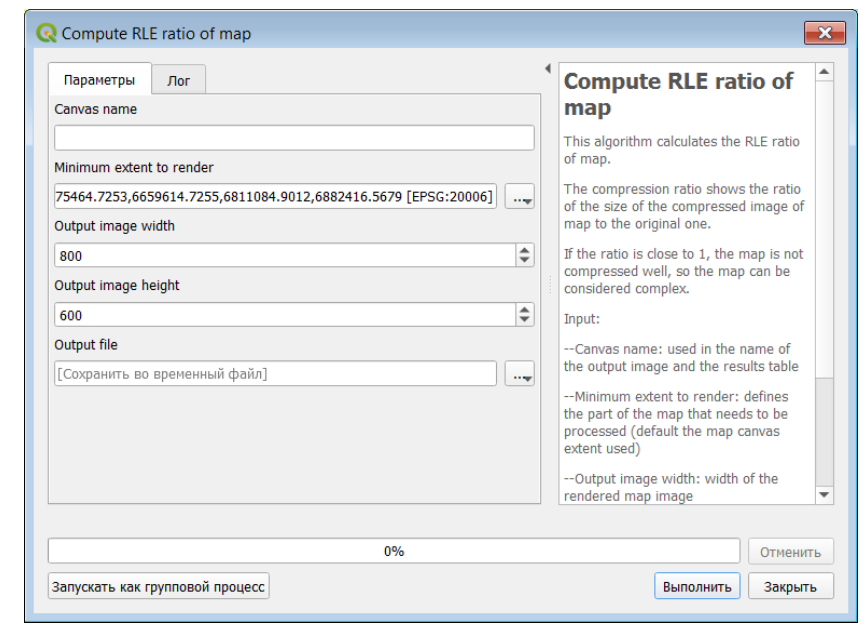

Puc. 11. Инструмент "Cотрите RLE ratio of map" Fig. 11. "Compute RLE ratio of map" tool
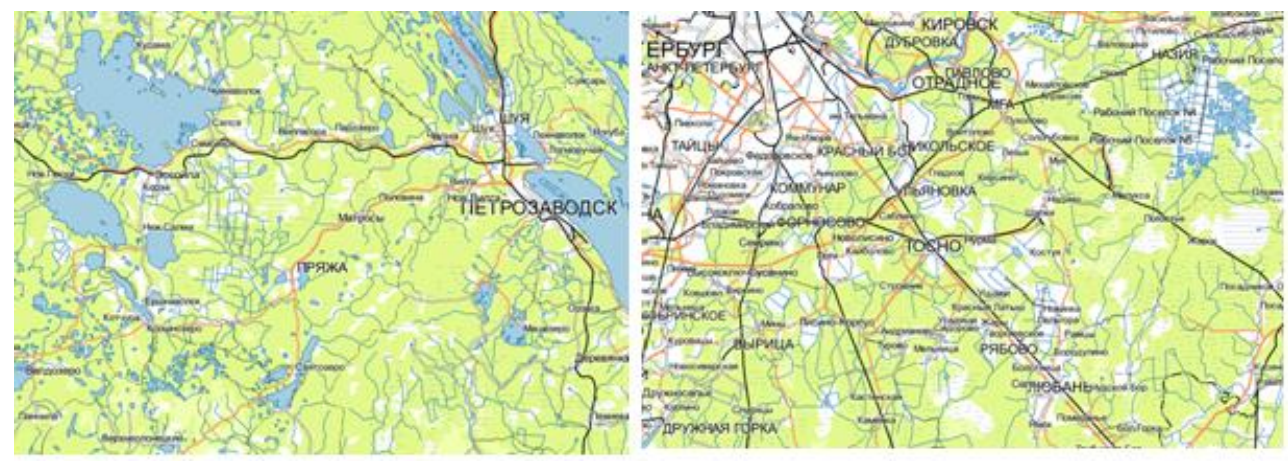

Рис. 12. Петрозаводск и Санкт-Петербург. 1:500000

Fig. 12. Petrozavodsk and Sanct-Pereburg. 1:500000 
На рисунке 12 представлены два фрагмента топографической карты масштаба 1:500000. Сложность левого фрагмента - Петрозаводск - 0,425, в то время как правого Санкт- Петербург - 0,519.

Программный код для панели инструментов написан на языке PyQGIS, программа прошла государственную регистрацию ${ }^{1}$.

\section{ВЫВОДЫ}

Процесс картографической генерализации, представляющий собой обобщение изображаемых на карте объектов (геометрическое упрощение, классификация и прочие операции приводящие к снижению информационной нагрузки), играет важную роль в представлении карт и пространственных данных в геоинформационных системах. Генерализация необходима для того чтобы убрать детали, не соответствующие масштабу анализа или отображения информации, выявить наиболее типические черты объектов.

Вместе с тем, отсутствие четких метрик для определения степени подробности результата не позволяет автоматически настраивать алгоритмы генерализации данных, чтобы получить данные и карты требуемой детализации. Определение (формализация) понятия детализации цифровых пространственных моделей является фундаментальной теоретической проблемой геоинформатики, решение которой позволит по-новому взглянуть на весь процесс геоинформационного моделирования в общем, и процесс создания карт в частности.

Проведенное исследование позволило выделить набор геометрических характеристик картографических объектов, позволяющих оценить детализацию карты. Разработано программное обеспечение, встраиваемое в QGIS, для оценки детализации карты (базы пространственных данных) в целом на основе учета геометрических и символьных (применяемых при отображении) параметров. Панель инструментов MapAnalyser позволяет вычислять метрики детализации пространственных данных, а также давать оценку сложности картографического изображения.

С помощью разработанного программного обеспечения было выполнено исследование по распознаванию уровня детализации топографических данных на основе плотности ландшафтных объектов ${ }^{2}$.

\section{БЛАГОДАРНОСТИ}

Исследование выполнено при поддержке РФФИ, грант № 18-07-01459.

\section{ACKNOWLEDGEMENTS}

The study was funded by the Russian Foundation of Basic Research, grant No 18-0701459.

\section{СПИСОК ЛИТЕРАТУРЫ}

1. Glander T., Döllner J. Abstract representations for interactive visualization of virtual 3D city models. Computers, Environment and Urban Systems, 2009. V. 33. P. 375-387.

2. Goetz M. Towards generating highly detailed 3D CityGML models from OpenStreetMap. International Journal of Geographical Information Science, 2013. V. 27. P. 845-865.

3. Fairbairn D. Measuring Map Complexity. The Cartographic Journal. 2006. V. 43. No 3. P. 224-238.

4. Forberg $A$. Generalization of 3D building data based on a scale-space approach. ISPRS Journal of Photogrammetry and Remote Sensing, 2007. V. 62. P. 104-111. 
5. Meng L., Forbeng A. 3D building generalisation. In W. Mackaness, A. Ruas, T.Sarjakoski (Eds.) Challenges in the portrayal of geographic information: Issues of generalisation and multi scale representation, 2007. P. 211-232, Amsterdam, the Netherlands: Elsevier Science.

6. Sester, M. 3D visualization and generalization. In D. Fritsch (Ed.), Proceedings of the 51st photogrammetric week '07. Stuttgart, Germany. 2007. P. 285-295.

7. Touya G., Brando-Escobar C. Detecting level-of-detail inconsistencies in volunteered geographic information data sets. Cartogr Int J Geogr Inf Geovisual, 2013. V. 48. No 2. P. 134-143.

\section{REFERENCES}

1. Glander T., Döllner J. Abstract representations for interactive visualization of virtual 3D city models. Computers, Environment and Urban Systems, 2009. V. 33. P. 375-387.

2. Goetz M. Towards generating highly detailed 3D CityGML models from OpenStreetMap. International Journal of Geographical Information Science, 2013. V. 27. P. 845-865.

3. Fairbairn D. Measuring Map Complexity. The Cartographic Journal. 2006. V. 43. No 3. P. 224-238.

4. Forberg $A$. Generalization of 3D building data based on a scale-space approach. ISPRS Journal of Photogrammetry and Remote Sensing, 2007. V. 62. P. 104-111.

5. Meng L., Forbeng A. 3D building generalisation. In W. Mackaness, A. Ruas, T.Sarjakoski (Eds.) Challenges in the portrayal of geographic information: Issues of generalisation and multi scale representation, 2007. P. 211-232, Amsterdam, the Netherlands: Elsevier Science.

6. Sester, M. 3D visualization and generalization. In D. Fritsch (Ed.), Proceedings of the 51st photogrammetric week '07. Stuttgart, Germany. 2007. P. 285-295.

7. Touya G., Brando-Escobar C. Detecting level-of-detail inconsistencies in volunteered geographic information data sets. Cartogr Int J Geogr Inf Geovisual, 2013. V. 48. No 2. P. 134-143. 


\title{
Н.Г. Ивлиева ${ }^{1}$, В.Ф. Манухов $^{2}$, Е.И. Примаченко ${ }^{3}$ \\ ОБ ИСПОЛЬЗОВАНИИ ГИС-ИНСТРУМЕНТАРИЯ В ПРАКТИЧЕСКОМ КУРСЕ МАТЕМАТИКО-КАРТОГРАФИЧЕСКОГО МОДЕЛИРОВАНИЯ
}

\begin{abstract}
АННОТАЦИЯ
ГИС тесно связаны с математико-картографическим моделированием, так как работают с пространственно координированными данными. Геоинформационные технологии, используемые для изучения пространственно-временной структуры, связей и динамики геосистем, в основном опираются на методы картографического анализа и математико-картографического моделирования.

Цель освоения дисциплины «Математико-картографическое моделирование» формирование у студентов теоретических знаний и практических навыков в области математико-картографического моделирования, приобретение студентами общих и специальных знаний, а также практических навыков по конструированию тематического содержания карт на основе современных компьютерных и геоинформационных технологий. Курс должен соответствовать требованиям времени и предполагать использование современных ГИС-технологий при выполнении практических заданий. При изучении дисциплины студенты знакомятся с местом и ролью математико-картографического моделирования в структурах геоинформационных систем, приобретают навыки работы с различными источниками пространственной информации, самостоятельно систематизируют, анализируют данные. Функциональные возможности ГИСпакетов позволяют конструировать тематическое содержание карт на основе анализа пространственных данных и геоинформационного моделирования. Некоторые математикокартографические модели создаются легко и просто, построение отдельных моделей требуют разработки дополнительных скриптов, программ и т.п. Приобретение студентами практических навыков по конструированию тематического содержания карт на основе современных компьютерных и геоинформационных технологий должно сопровождаться формированием представлений об используемых математических методах, знаний о том, как работает тот или иной инструмент.

Данная статья посвящена проведению исследований возможностей применения ГИС-технологий в практическом курсе математико-картографического моделирования. Основное внимание уделено конструированию моделей структуры пространственных характеристик географических явлений.
\end{abstract}

КЛЮЧЕВЫЕ СЛОВА: ГИС-технологии, компетентность, математико-картографическое моделирование, обучение.

\footnotetext{
1 Национальный исследовательский Мордовский государственный университет имени Н.П. Огарёва, Саранск, Россия, e-mail: gkg_mrsu@mail.ru

2 Национальный исследовательский Мордовский государственный университет имени Н.П. Огарёва, Саранск, Россия, e-mail: gkg_mrsu@mail.ru

3 Национальный исследовательский Мордовский государственный университет имени Н.П. Огарёва, Саранск, Россия, e-mail: gkg_mrsu@mail.ru
} 


\title{
Natalia G. Ivlieva ${ }^{1}$, Vladimir F. Manukhov ${ }^{2}$, Elena I. Primachenko ${ }^{3}$ \\ ABOUT USING GIS TOOLS IN THE PRACTICAL COURSE OF MATHEMATICAL AND MAPPING MODELING
}

\begin{abstract}
GIS is closely related to mathematical cartographic modeling, as they work with spatially coordinated data. Geoinformation technologies used to study the spatio-temporal structure, connections and dynamics of geosystems are mainly based on the methods of cartographic analysis and mathematical-cartographic modeling.

The purpose of mastering the discipline "Mathematical and cartographic modeling" is to form students' theoretical knowledge and practical skills in the field of mathematical and cartographic modeling, the acquisition of general and special knowledge by students, as well as practical skills in constructing thematic content of maps based on modern computer and geoinformation technologies. The course must meet the requirements of the time and assume the use of modern GIS technologies when performing practical tasks. When studying the discipline, students get acquainted with the place and role of mathematical and cartographic modeling in the structures of geographic information systems, acquire skills in working with various sources of spatial information, independently systematize and analyze data. The functionality of GIS packages allows you to construct thematic content of maps based on the analysis of spatial data and geoinformation modeling. Some mathematical and cartographic models are created easily and simply, the construction of individual models requires the development of additional scripts, programs, etc. The acquisition by students of practical skills in constructing thematic content of maps based on modern computer and geoinformation technologies should be accompanied by the formation of ideas about the mathematical methods used, knowledge of how a particular tool works.

This article is devoted to researching the possibilities of using GIS technologies in the practical course of mathematical and cartographic modeling. The main attention is paid to the construction of models of the structure of the spatial characteristics of geographic phenomena.
\end{abstract}

KEYWORDS: GIS-technologies, competence, mathematical and cartographic modeling, training.

\section{ВВЕДЕНИЕ}

В настоящее время Министерством науки и высшего образования Российской Федерации утвержден новый федеральный государственный образовательный стандарт высшего образования - бакалавриат по направлению подготовки 05.03.03 Картография и геоинформатика (ФГОС ВО 3++). Он содержит совокупность обязательных требований при реализации основных профессиональных образовательных программ высшего образования - программ бакалавриата.

В основу содержания ФГОС ВО (3++) нового поколения заложен компетентностный подход к образовательному процессу с учетом профессиональных стандартов. Выпускники могут осуществлять профессиональную деятельность в той или иной области и сфере

\footnotetext{
1 N.P. Ogarev Mordovia State University, Bolshevistskaya Str., 68, 4300005, Saransk, Russia, e-mail: gkg_mrsu@mail.ru

2 N.P. Ogarev Mordovia State University, Bolshevistskaya Str., 68, 4300005, Saransk, Russia, e-mail: gkg_mrsu@mail.ru

3 N.P. Ogarev Mordovia State University, Bolshevistskaya Str., 68, 4300005, Saransk, Russia, e-mail: gkg_mrsu@mail.ru
} 
деятельности при условии соответствия уровня их образования и полученных компетенций требованиям к квалификации работника.

Формирование общепрофессиональной компетентности обучаемых выступает как одна из главных целей в подготовке квалифицированного специалиста в области картографии и геоинформатики, конкурентоспособного на рынке труда, владеющего своей профессией и ориентированного в смежных областях знаний, способного к эффективной работе по специальности. Интенсивное развитие геоинформационных технологий, широкое использование данных дистанционного зондирования Земли требуют от конкурентоспособного на рынке труда выпускника - бакалавра картографии и геоинформатики - владения соответствующими знаниями, умениями, навыками. Важным приоритетом в современных образовательных условиях становится развитие информационной компетентности.

В наши дни научно-исследовательская, проектно-производственная деятельность квалифицированных бакалавров картографии и геоинформатики практически немыслима без применения ГИС-пакетов. С помощью ГИС создаются различные карты, формируется система информационной поддержки многочисленных исследований, базирующихся на пространственных данных. Поэтому приобретение обучающимися по направлению подготовки 05.03.03 Картография и геоинформатика соответствующих знаний, умений, навыков позволит им в дальнейшим более грамотно вести профессиональную деятельность. Одна из ключевых целей картографо-геоинформационного образования - получение студентами практического опыта решения географических задач с использованием геоинформационных методов и технологий, развитие у них пространственного мышления [Лурье u $\partial p ., 2011]$. Проблемы ГИС-образования картографов и специалистов по геоинформатике ранее были подробно освещены в статье преподавателей СПбГУ [Сидорина и др., 2016], актуальны они и сейчас.

\section{МАТЕРИАЛЫ И МЕТОДЫ ИССЛЕДОВАНИЙ}

В новом ФГОС ВО 3++ по направлению подготовки 05.03.03 Картография и геоинформатика формирование фундаментальных основ профессиональной деятельности увязывается со следующими общепрофессиональными компетенциями (ОПК): способен использовать базовые знания в области картографии и геоинформатики при создании картографических произведений и геоинформационных систем (ОПК-2), способен применять базовые картографические и геоинформационные методы при анализе географической информации и ее представлении в базах пространственных данных (ОПК3). Отличительным признаком качества образования становится информационная компетентность, устанавливаемая в ФГОС ВО (3++) как способность решать стандартные задачи профессиональной деятельности с использованием информационнокоммуникационных технологий, в том числе технологии геоинформационных систем (ОПК-4).

Формирование определяемых ФГОС $\mathrm{BO}$ (3++) общепрофессиональных компетенций обеспечивает целый ряд дисциплин и практик, входящих в обязательную часть программы бакалавриата. В нашей работе рассматривалась одна из возможных дисциплин этой части программы - «Математико-картографическое моделирование». В рамках исследования проводился анализ возможностей применения геоинформационных технологий при изучении студентами этой дисциплины, освоения базовых знаний в области картографии сквозь призму их геоинформационной направленности в целях качественной подготовки выпускников по программе бакалавриата. 


\section{РЕЗУЛЬТАТЫ ИССЛЕДОВАНИЙ И ИХ ОБСУЖДЕНИЕ}

Цель освоения дисциплины «Математико-картографическое моделирование» формирование у студентов теоретических знаний и практических навыков в области математико-картографического моделирования, приобретение студентами общих и специальных знаний, а также практических навыков по конструированию тематического содержания карт на основе современных компьютерных и геоинформационных технологий.

Задачи дисциплины:

- ознакомить студентов с основными принципами и критериями моделирования тематического содержания карт с использованием математических моделей, разработки методов математико-картографического моделирования;

- $\quad$ сформировать представление о методах моделирования структуры, взаимосвязи и динамики географических явлений и процессов, сложных математико-картографических моделей;

- научить конструировать математико-картографические модели структуры, взаимосвязи и динамики географических явлений и процессов, создавать сложные математико-картографические модели и применять ГИС-технологии.

В процессе изучения дисциплины «Математико-картографическое моделирование» у обучающихся в соответствии с ФГОС ВО по направлению подготовки 05.03.03 Картография и геоинформатика формируются отдельные составные части общепрофессиональных компетенций. Результат освоения дисциплины с точки зрения формирования той или иной компетенции можно увязать с соответствующими компонентами в виде знаний, умений и навыков.

Практический курс математико-картографического моделирования должен соответствовать требованиям времени и опираться на применение современных ГИСтехнологий. При изучении дисциплины студенты знакомятся с местом и ролью математикокартографического моделирования в структурах геоинформационных систем, приобретают навыки работы с различными источниками пространственной информации, самостоятельно систематизируют, анализируют данные, применяют геоинформационные технологии. При выполнении практических заданий они пользуются стандартными инструментами ГИС-приложений.

Важно заметить, что при обучении еще до использования того или иного инструмента, студентам нужно выяснить какой метод расчета реализован в выбранном инструменте, какой тип модели у входных данных, какими будут выходные данные (векторный слой, растр, таблица, график или диаграмма, число) и др. Использование стандартных ГИС-программ значительно облегчило процесс создания тематических карт, но нельзя это считать «делом техники».

На двух примерах нами подробно рассмотрено применение ГИС-инструментария ArcGIS в целях математико-картографического моделирования.

В модуле Spatial Analyst для вычисления плотности точечных и линейных объектов (самих объектов или их количественных признаков) служат инструменты набора Плотность. Один из них - инструмент Плотность ядер (Kernel Density) - нередко применяется для построения различных карт плотности какой-либо характеристики явления или густоты точечных или линейных объектов. В случае точечного слоя результатом работы инструмента является растр, значениям ячеек которого присвоены рассчитанные показатели плотности (или густоты) в области осреднения, представляющий собой круг заданного радиуса с центром в текущей ячейке. С помощью инструмента Плотность ядер рассчитывается взвешенное среднее, при этом большая степень доверия отводится объектам (или их значениям), ближайшим к центру текущей ячейки. 
B Spatial Analyst реализован алгоритм Силвермана, основанный на керн-функции [Silverman, 1986]. Весовые коэффициенты wi рассчитываются по формуле

$$
w_{i}=3\left(1-\frac{\left(x_{i}-x\right)^{2}+\left(y_{i}-y\right)^{2}}{R^{2}}\right)^{2},
$$

где $\quad x_{i}, y_{i}$ и $x, y$ - соответственно координаты $i$-го объекта, попавшего в окрестность текущей ячейки, и центра этой ячейки, $R$ - радиус круга, представляющего собой рассматриваемую окрестность.

Если точечный объект находится точно в центре текущей ячейки, то ему назначают вес равный 3, если на границе круга, то - 0; всем остальным точкам присваивается вес в зависимости от их удаленности от центра в соответствии с заданным ядром преобразования (рис. 1).

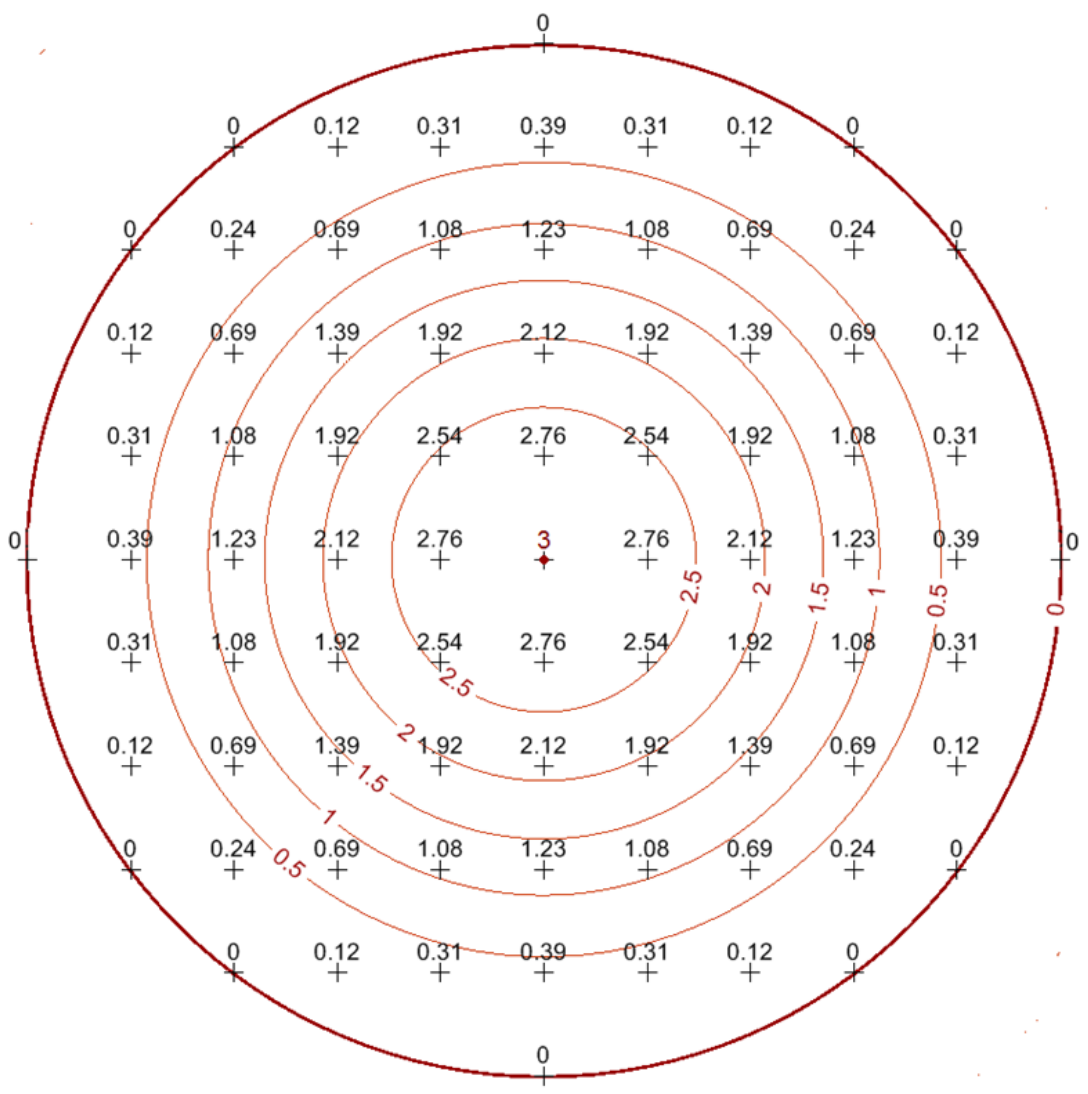

Рис. 1. Ядро преобразования, реализованное в инструменте Плотность ядер модуля Spatial Analyst

Fig. 1. Transformation kernel implemented in Kernel Density tool of Spatial Analyst

Радиус этого круга служит настраиваемым параметром инструмента. Использование большего радиуса ведет к более обобщенному отображению статистической поверхности плотности (густоты), меньшего - к более детальному показу локальных вариаций значений показателя.

Метод взвешенного среднего (Плотность ядер) создает гладкую поверхность, поэтому является привлекательным для пользователей ГИС. Однако следует знать, какая математическая модель реализована в данном инструменте, и что результат его работы 
может видоизмениться при задании другого значения параметра (радиуса кружка). Тем не менее студентам может быть полезным применение этого инструмента, например, при математико-картографическом моделировании, проводимом в целях изучения пространственно-временных особенностей плотности населения, что часто требуется в географии населения.

С помощью рассматриваемого инструмента были созданы цифровые модели плотности сельского населения Республики Мордовия на 1989 и 2005 гг., и на их основе составлены картографические модели (рис. 2).

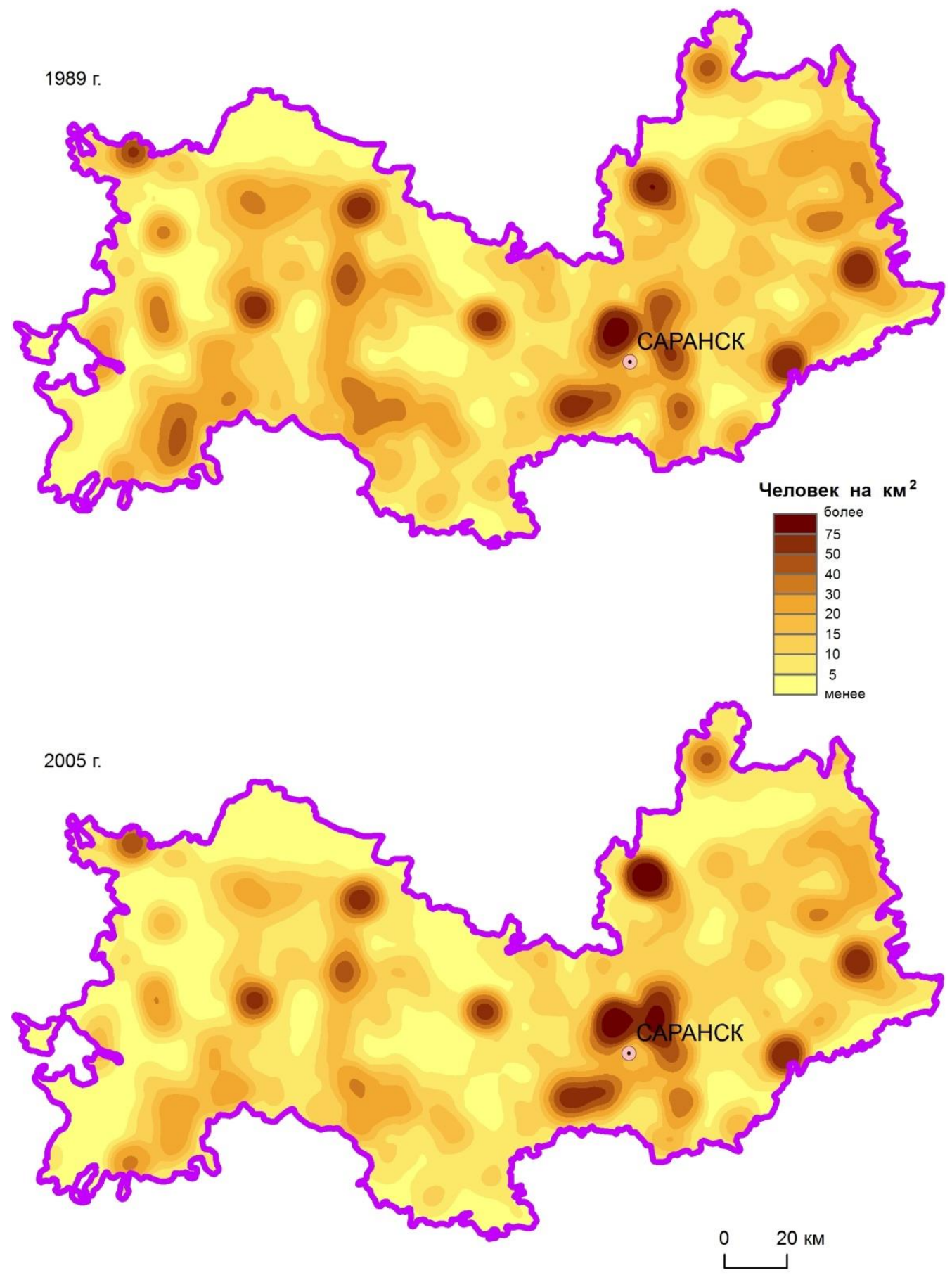

Рис. 2. Построенные модели плотности сельского населения Мордовии Fig. 2. Created models of the density of the rural population of Mordovia 
Исходными данными для моделирования карт плотности сельского населения Республики Мордовия служили ранее оцифрованные сельские населенные пункты, представленные в виде точек, и их людность. Радиус кружка принимался равным 10 км. Легенда к картам едина, поскольку карты предназначены для их сопоставления и прослеживания динамики исследуемого показателя. Далее с помощью Калькулятора pacтра путем вычитания одной статистической поверхности из другой был создан растр, показывающий изменение пространственно-временного варьирования значений плотности сельского населения Мордовии в 2005 г. по сравнению с 1989 г. (рис. 3).

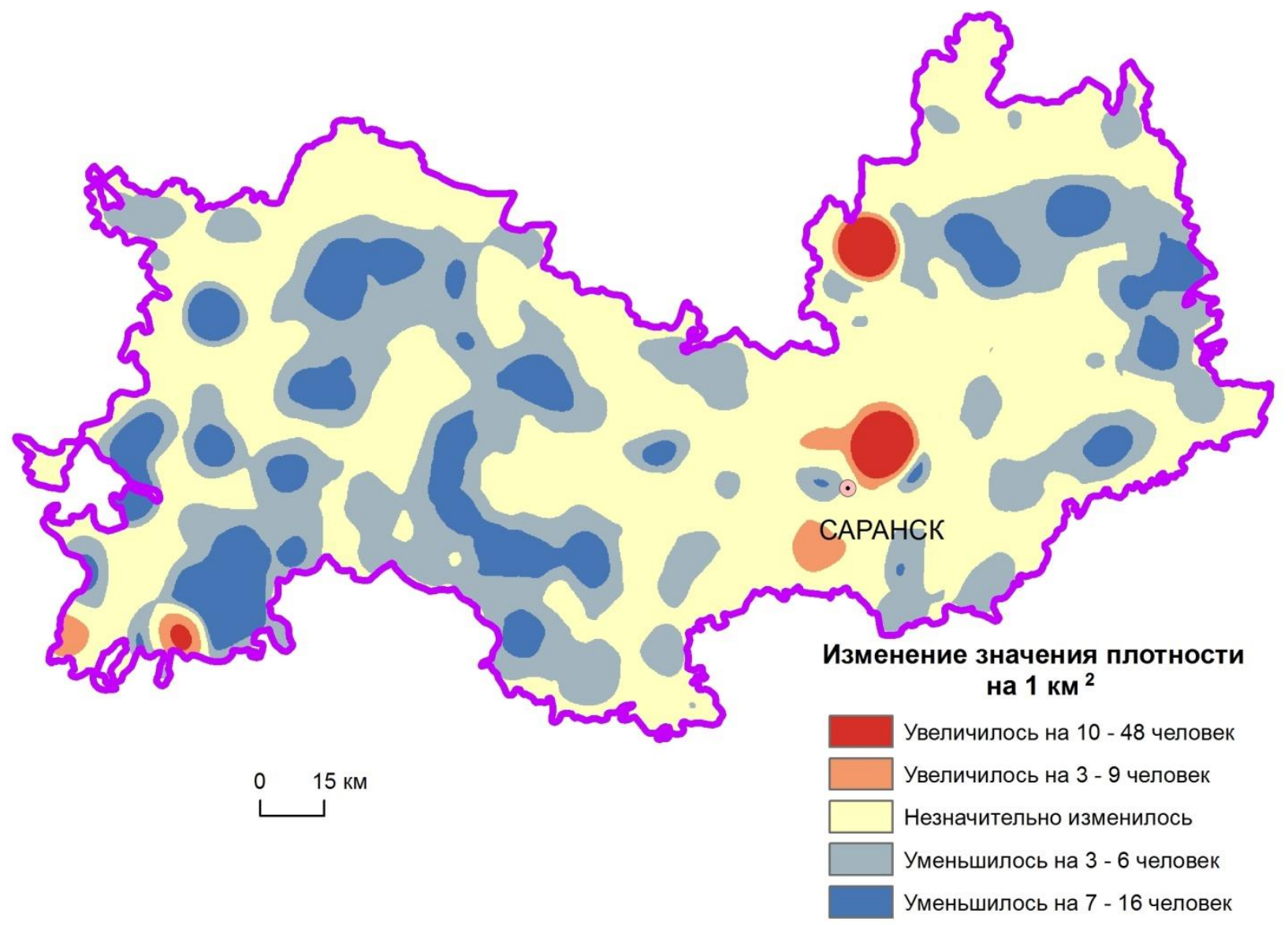

Рис. 3. Изменение плотности сельского населения. 1989-2005 г2.

Fig. 3. Changes of density of the rural population. 1989-2005

Исходные объекты (населенные пункты) дискретны по своей природе, посредством рассматриваемого инструмента Spatial Analyst созданы непрерывные статистические поверхности плотности населения. Получается, что в этом случае на них распространяется концепция поля. При этом поле плотности населения рассматривается как упрощенная модель явления, построенная с целью отображения особенностей географического распределения изучаемой характеристики с той или иной степенью условности. Рассчитанные упрощенные модели позволяют проанализировать пространственно-временное изменение изучаемого показателя. В целом можно видеть тенденцию сокращения сельского населения республики. Далее необходимо провести содержательную интерпретацию полученных результатов математико-картографического моделирования. Заметим, что растр с разностями значений построенных поверхностей, который был быстро и легко 
вычислен с помощью современного ГИС-инструментария, позволил сразу обнаружить интересный факт. Положительная динамика на отдельных территориях объясняется главным образом изменением статуса городских поселений, переведенных в сельские. Это Кемля, Большая Елховка, Зыково, Выша, Ширингуши. Их показатели людности несколько улучшили сложившуюся ранее ситуацию на селе, но убыль сельского населения региона продолжается.

Следующий пример применения ГИС-инструментария ArcGIS в курсе математикокартографического моделирования связан с конструированием модели потенциала поля расселения (гравитационного потенциала, демографического потенциала) [Тикунов, 1997].

Значение гравитационного потенциала $v_{j}$ в $j$-ой точке определяется по формуле [Тикунов, 1997]

$$
v_{j}=\sum_{i=1}^{n} \frac{P_{i}}{D_{i j}}
$$

где $P_{i}$ - людность населенного пункта, $D i j-$ расстояние между ним и $j$-ой точкой, $n-$ число населенных пунктов.

К сожалению, в стандартном наборе ArcToolbox и в модуле Spatial Analyst нет инструмента, который может построить модель гравитационного потенциала. Для его создания требуется разработка специальной программы [Тимонин $u$ др., 2014]. Однако расчет потенциала поля расселения можно провести и в среде ArcGIS с использованием ряда операций и инструментов [Фалейчик $u$ дp., 2014]. Студентам при освоении дисциплины «Математико-картографическое моделировании» полезно будет провести такое конструирование с целью формирования представления, как о самом методе моделирования, так и о возможностях его реализации посредством отдельных элементов ГИС-технологий.

Моделирование в ГИС-пакете ArcGIS можно провести с использованием инструмента Расстояние между точками, присоединения данных по атрибутивному полю, вычисления производных полей в таблице на основе Калькулятора поля, суммирования атрибутивных данных, выполнения инструмента Интерполячия из набора инструментов Spatial Analyst.

Ключевым моментом является применение инструмента Расстояние между точками из набора Анализ. Результат выводится в виде таблицы PointDistance, в которой содержатся поля INPUT_FID и NEAR_FID с идентификаторами соответственно входных объектов и объектов слоя, установленного как ближайшие объекты, поле DISTANCE с вычисленными расстояниями. Расстояния определяются в тех же единицах измерения, что и координаты объектов, и чаще всего это метры. Если не задан радиус поиска, вычисляются расстояния от всех входных объектов до всех ближайших объектов. Выходная таблица может быть достаточно большой.

Если демографический потенциал рассчитывается не по всем точкам, а лишь для населенных пунктов, расположенных на исследуемой территории, то тогда и входные объекты, и ближайшие объекты представляет один и тот же слой населенных пунктов. А в формуле добавляется еще слагаемое, равное людности $j$-го населенного пункта (условно отнесенное к 1000 м).

Таким образом, для построения потенциала поля расселения нужно выполнить следующие действия:

- с помощью инструмента Расстояние между точками вычислить кратчайшие расстояния между всеми парами населенных пунктов исходного слоя; 
- $\quad$ присоединить к полученной таблице PointDistance атрибутивную таблицу исходного слоя по общему полю $N E A R \_F I D$;

в новом поле $V$ (тип данных Double) с помощью Калькулятора поля вычислить $V=P o p / D I S T A N C E$. Поле Рор должно содержать данные о людности населенных пунктов;

- выполнить Суммирование данных поля INPUT_FID таблицы PointDistance c вычислением итоговой статистики - суммы значений поля $V$;

- $\quad$ выбрать исходный точечный слой и присоединить к нему полученную таблицу по общему полю (FID и INPUT_FID);

в новом поле $G$ (тип данных Double) точечного слоя с помощью Калькулятора поля вычислить $G=$ Sum_V+Pop / 1000 .

После выполнения расчетов нужно создать карту потенциала поля расселения на основе поля $G$ слоя населенных пунктов с помощью интерполяции одним из встроенных в программу методов.

Студенты должны четко уяснить, что потенциал поля расселения можно вычислить для любой произвольной точки как сумму численности населения всех населенных пунктов, отнесенной к расстояниям от них до данной точки. Поэтому полученная вышеописанным способом модель является неточной.

Далее можно построить еще несколько приближенных моделей потенциала поля расселения населения одной и той же территории. Для этой цели нужно создать дополнительный набор точек, например по регулярной сетке. Вновь последовательно выполнить вышеуказанные действия с учетом небольших изменений: на первом шаге в качестве исходного слоя входных точек указать созданный слой, на последнем - убрать второе слагаемое. Затем на основе поля $G$ точечного слоя с помощью интерполяции построить другой вариант модели потенциала поля расселения. Легко получить еще один вариант путем слияния слоя населенных пунктов и созданного точечного слоя. Значения $G$ уже вычислены, поэтому нужно провести только интерполяцию, чтобы получить непрерывную поверхность потенциала поля расселения.

Моделирование потенциала поля расселения в среде ArcGIS можно провести и с использованием инструмента из набора Расстояние модуля Spatial Analyst. Но в этом случае нужно специально написать скрипт или создать модель-инструмент в приложении ModelBuilder.

Использование ГИС значительно упростило процесс картографического представления результатов моделирования [Манухов и др., 2015]. Картографическая визуализация геопространственных данных подробно рассмотрена в работе [Kraak M.-J. et al., 2010]. Возможность создания той или иной шкалы при визуализации данных определяется функционалом ГИС-пакета.

\section{ВЫВОДЫ}

Построение математико-картографической модели в ГИС-пакете - это геоинформационное моделирование, основанное на преобразовании пространственных данных, использующем их организацию в БД ГИС. Поэтому студенты предварительно должны ознакомиться с тем, какая модель пространственных данных требуется для входных данных (векторная или растровая), поддерживаемый программой формат данных, определить состав атрибутивных данных пространственных объектов. Затем подобрать необходимые данные и, если необходимо, выполнить соответствующие операции по их приведению к требуемому типу и формату. Если проводится построение моделей структуры, взаимосвязей или динамики пространственных характеристик, то особенно важна 
информация о системах координат, в которых хранятся исходные данные, и системе координат визуализации данных (изображения, выведенного на экран).

Основанные на логико-математической переработке информации встроенные алгоритмы реализовывают конкретный метод расчета. Часто требуются ввести необходимые параметры для применяемого метода. Студентам, изучающим курс математико-картографического моделирования, важно исследовать, как конкретное значение параметра повлияет на результат моделирования.

Встроенные в ГИС-пакеты алгоритмы, хотя и реализовывают основные приемы построения картографических изображений, но имеют формальный характер, так как отсутствует согласование смыслового аспекта существа предмета и его графического изображения на карте. Поэтому важно проводить содержательную интерпретацию полученных результатов моделирования. При их воспроизведении в картографической форме в системах знаков карт, созданных в ГИС, нередко встречаются ошибки из-за неправильной классификации картографируемых объектов. Приемы оформления карт, построенных компьютерными средствами, могут противоречить традиционной картографии. Поэтому образовательные программы должны учитывать риск быстрого и поверхностного овладения картографическими технологиями и незнания традиционных методов проектирования и составления карт [Лурье и др., 2017].

Использование ГИС-технологий для реализации математико-картографического моделирования в учебном процессе способствует реализации компетентностного подхода в обучении в целом, повышению качества подготовки бакалавров, формированию у них навыков и умений геоинформационной направленности, приобретению опыта их применения при самостоятельном решении задач, связанных с будущей профессиональной деятельностью.

\section{СПИСОК ЛИТЕРАТУРЫ}

1. Лурье И.К., Прасолова А.И. Университетское картографическое образование в эпоху перемен. Геодезия и картография, 2017. Т. 78. Спецвыпуск. С. 4-15. DOI: 10.22389/ 0016-7126-2017-4-15.

2. Лурье И.К., Самсонов Т.Е. Развитие геоинформационного образования на географическом факультете МГУ имени М.В. Ломоносова. ArcReview, 2011. № 3 (58). C. $12-13$.

3. Манухов В.Ф., Ивлиева Н.Г. О построении картографических изображений средствами ГИС-пакетов. Педагогическая информатика, 2015. № 1. С. 55-63.

4. Сидорина И.Е., Казаков Э.Э., Позднякова Н.А., Золотова Т.И., Андреева Т.А. Проблемы и задачи образовательного процесса при подготовке картографов и специалистов по геоинформатике в Санкт-Петербургском государственном университете. Известия высших учебных заведений. Геодезия и аэрофотосъемка, 2016. Т. 60. № 5. С. 68-71.

5. $\quad$ Тикунов В.С. Моделирование в картографии. М.: Издательство МГУ, 1997. 405 с.

6. Тимонин С.А., Яблоков В.М. Геоинформационные модели расселения населения и их применение. ArcReview, 2011. № 3. С. 7.

7. Фалейчик Л.М., Горина К.В. Использование ГИС-инструментария в анализе демографических показателей системы расселения Забайкальского края. Вестник ЗабГУ, 2014. № 3 (106). С. 45-55.

8. Kraak M.-J., Ormeling F. Cartography: visualization of geospatial data. 3th edition. Pearson Education Limited, 2010. 249 p. 
9. Silverman B.W. Density Estimation for Statistics and Data Analysis. London: Chapman and Hall, 1986. 175 p.

\section{REFERENCES}

1. Faleychik L.M., Gorina K. V. The GIS tools usage in the analysis of demographic features of the settlement system of the transbaikal region. Vestnik Zab. gos. univ. (Transbaikal State University Journal), 2014. No 3 (106). P. 45-55 (in Russian).

2. Kraak M.-J., Ormeling F. Cartography: visualization of geospatial data. 3th edition. Pearson Education Limited, 2010. 249 p.

3. Lurie I.K., Prasolova A.I. University cartographic education in an era of change. Geodesy and Cartography, 2017. V. 78. Specvypusk. P. 4-15 (in Russian). DOI: 10.22389/00167126-2017-4-15.

4. Lurie I.K., Samsonov T.E. Development of geoinformational Education Practices at Faculty of Geography, Moscow State University. ArcReview, 2011. No 3 (58). P. 12-13 (in Russian).

5. Manuhov V.F., Ivlieva N.G. Creation of cartographic images GIS packages means. Pedagogical Informatics, 2015. No 1. P. 55-63 (in Russian).

6. Sidorina I.E., Kazakov E.E., Pozdnyakova N.A., Zolotova T.I., Andreeva T.A. Problems and challenges of educational process in the training of cartographers and specialists in geoinformatics at St. Petersburg State University. Izvestia Vuzov. Geodesy and Aerophotosurveying, 2016. V. 60 (5). P. 68-71 (in Russian).

7. Silverman B.W. Density Estimation for Statistics and Data Analysis. London: Chapman and Hall, 1986. 175 p.

8. Tikunov V.S. Modelling in cartography. Moscow: Moscow University Press, 1997. 405 p. (in Russian).

9. Timonin S.A., Yablokov V.M. GIS models of population settlement and their application. ArcReview, 2011. No 3 (58). P. 7 (in Russian). 


\title{
С.С. Козин ${ }^{1}$, С.М. Макеев ${ }^{2}$, Д.О. Маркин ${ }^{3}$
}

\section{МОДЕЛИРОВАНИЕ ПРОЦЕССА ПОЗИЦИОНИРОВАНИЯ ИСТОЧНИКОВ РАДИОСИГНАЛОВ В ГЕОИНФОРМАЦИОННЫХ СИСТЕМАХ}

\begin{abstract}
АННОТАЦИЯ
Описано применение средств моделирования среды разработки имитационных моделей AnyLogic, позволяющих наглядно понять основные принципы определения местоположения подвижных объектов наблюдения, являющихся источниками радиоизлучения. В статье приводятся основные результаты исследований различных подходов к решению задачи позиционирования источников радиосигналов на основе измерения уровня его мощности базовыми станциями беспроводных сетей передачи данных. Задача позиционирования решалась в условиях высокой подвижности источника радиосигналов. Для решения задачи применялся комплекс методов: трилатерация, нечеткая логика, метод статистических испытаний (Монте-Карло), метод дроблений, а также эвристический. Полученные результаты апробировались в разработанных прототипах в форме имитационных моделей в среде AnyLogic. В качестве исходных данных использовались натурные измерения, произведенные в реальных условиях эксплуатации систем позиционирования. В рамках проведенной работы получены следующие основные результаты: реализация комплекса моделирующих алгоритмов, осуществляющих ряд случайных процессов: движение источников радиосигналов и распространение радиоволн; алгоритмы, реализующие аналитический расчет предполагаемой области местоположения на основе различных методов. Разработан комплекс имитационных моделей систем позиционирования, позволяющий наглядно представить определение местоположения источника радиосигнала в городских условиях с учётом его подвижности. Сформулированы выводы в отношении результатов проведённых исследований. Научная значимость работы заключается в разработке эвристического алгоритма позиционирования, основанного на секторном разбиении и нечёткой логике. Практическая ценность работы состоит в разработке комплекса алгоритмов и их практической реализации в виде приложений на языке Java для среды моделирования AnyLogic, позволяющих исследовать эффективность различных алгоритмов прогнозирования на точность позиционирования.
\end{abstract}

КЛЮЧЕВЫЕ СЛОВА: моделирование, система позиционирования, трилатерация, нечёткая логика.

Академия Федеральной службы охраны Российской Федерации, ул. Приборостроительная, д. 35, 302015, Орёл, Россия, e-mail: sergei_kozin@mail.ru

Академия Федеральной службы охраны Российской Федерации, ул. Приборостроительная, д. 35, 302015, Орёл, Россия, e-mail: maksm57@yandex.ru

Академия Федеральной службы охраны Российской Федерации, ул. Приборостроительная, д. 35, 302015, Орёл, Россия, e-mail mdo@academ.msk.rsnet.ru 


\title{
Sergey S. Kozin ${ }^{1}$, Sergey M. Makeev ${ }^{2}$, Dmitriy O. Markin ${ }^{3}$ \\ MODELING THE PROCESS OF POSITIONING OF RADIO SIGNAL SOURCES IN GEOINFORMATION SYSTEMS
}

\begin{abstract}
The application of the tools of the AnyLogic simulation model development environment is described, which makes it possible to clearly understand the basic principles of identifying mobile objects that are sources of radio emission. The article presents the main research results of various approaches to solving the problem of positioning radio signal sources based on measuring the level of its power by base stations of wireless data transmission networks. The positioning problem was solved under conditions of high mobility of the radio signal source. To solve the problem, a set of methods was used: trilateration, fuzzy logic, statistical test method (Monte Carlo), splitting method, as well as heuristic. The results obtained were tested in the developed prototypes in the form of simulation models in the AnyLogic environment. Field measurements made in real operating conditions of positioning systems were used as initial data. Within the framework of this work, the following main results were obtained: implementation of a complex of modeling algorithms that carry out a number of random processes: motion of radio signal sources and propagation of radio waves; algorithms that implement the analytical calculation of the estimated location area based on various methods. A complex of simulation models of positioning systems has been developed, which makes it possible to visualize the determination of the location of a radio signal source in an urban environment, taking into account its mobility. Conclusions are formulated regarding the results of the conducted research. The scientific significance of the work lies in the development of a heuristic positioning algorithm based on sector partitioning and fuzzy logic. The practical value of the work lies in the development of a set of algorithms and their practical implementation in the form of applications in the Java language for the AnyLogic modeling environment, which allow investigating the effectiveness of various predictive algorithms for positioning accuracy.
\end{abstract}

KEYWORDS: modeling, positioning system, trilateration, fuzzy logic.

\section{ВВЕДЕНИЕ}

Современный уровень развития инфотелекоммуникационных технологий предоставляют все больше возможностей по доступу к услугам и данным с использованием беспроводных сетей передачи данных (БСПД). Вместе с тем возникает и угроза использования данных сетей в незаконных целях, связанных с распространением запрещенных сведений, несанкционированным доступом к защищаемой информации, сбором сведений о гражданах, организациях и других. Данное обстоятельство обуславливает объективную потребность в решении задачи оперативного определения местоположения (позиционирования) вероятного источника угрозы нарушения безопасности, в первую очередь, средствами самой беспроводной сети передачи данных.

Federal Security Guard of the Russian Federation Academy, st. Priborostroitelnaya, 35, 302015, Oryol, Russia, e-mail: sergei_kozin@mail.ru

2 Federal Security Guard of the Russian Federation Academy, st. Priborostroitelnaya, 35, 302015, Oryol, Russia, e-mail: maksm57@yandex.ru

3 Federal Security Guard of the Russian Federation Academy, st. Priborostroitelnaya, 35, 302015, Oryol, Russia, e-mail: mdo@academ.msk.rsnet.ru 
Исследованиям вопросов использования БСПД в целях позиционирования источников радиоизлучения посвящены многочисленные исследования как отечественных, так и зарубежных ученых [Basiri, 2017, p. 1-12; Curran, 2011, p. 61-78; Mautz, 2009, p. 1822; Uradzinski, 2017, p. 6509-6518]. Применение аппарата нечеткой логики для решения задачи позиционирования описано в трудах [Chen, 2016, p. 97-102; Koyuncu, 2016, p. 121128; Onofre, 2016, p. 169-177; Orujov, 2018, p. 335-348; Socha, 2016, p. 1-15]. Вопросами имитационного моделирования систем позиционирования посвящены работы [Камалов, 2020; Фокин, 2020].

Вместе с тем, точность современных систем позиционирования в совокупности с их сложностью, предъявляют повышенные требования к системам определения местоположения, которые в достаточной степени на данный момент не удовлетворены. Всё перечисленное выше обуславливает актуальность разработки новых алгоритмов определения местоположения подвижных источников радиосигналов, позволяющих повысить точность позиционирования.

\section{МАТЕРИАЛЫ И МЕТОДЫ ИССЛЕДОВАНИЯ}

Для разработки имитационной модели необходимо разработать алгоритмы, осуществляющие моделирование следующих процессов:

- $\quad$ моделирование псевдослучайного движения подвижного источника радиосигналов по территории города;

- моделирование скорости и ускорения подвижного источника радиосигналов по территории города;

- моделирование псевдослучайного процесса распространения радиосигналов в условиях города.

Для осуществления данных функций выбрана платформа имитационного моделирования AnyLogic. Схема модели представлена на рисунке 1.

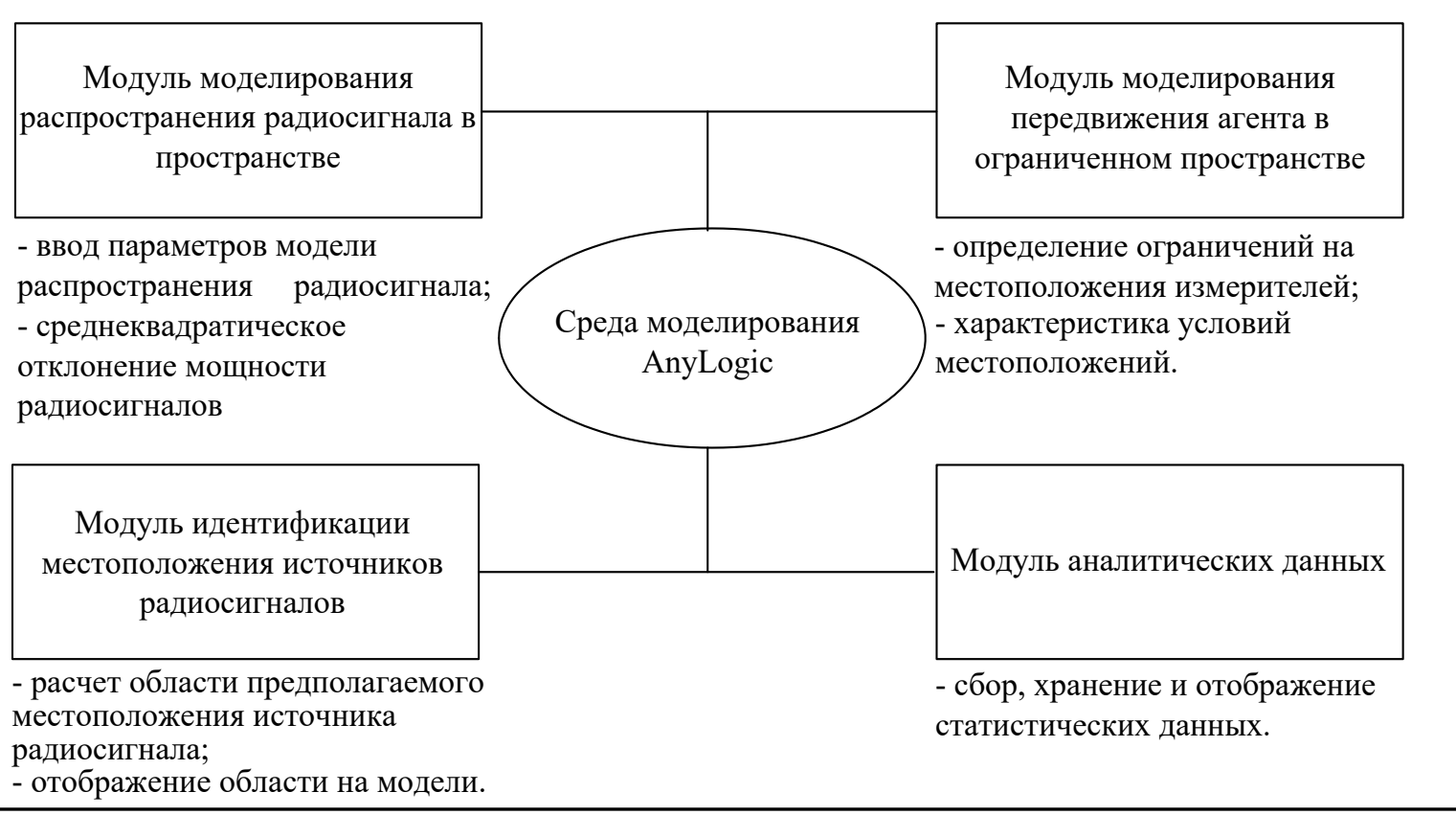

Pис. 1. Схема имитаџионной модели в среде AnyLogic 
Fig. 1. Scheme of the simulation model in the AnyLogic environment

Блок-схема описанного выше алгоритма представлена на рисунке 2.

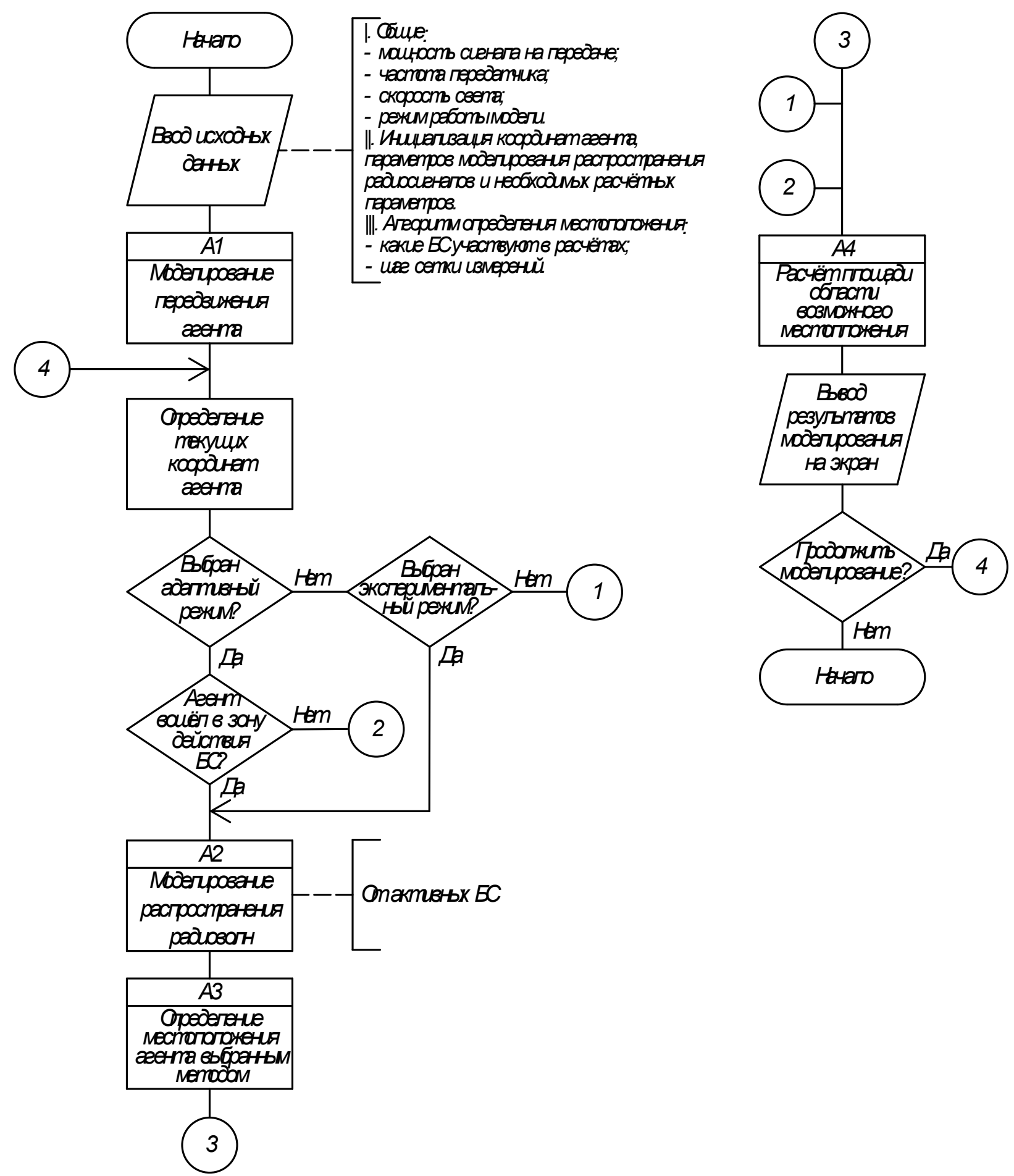

Рис. 2. Общий моделирующий алгоритм функциионирования системы позиционирования подвижных источников радиосигналов

Fig. 2. General modeling algorithm for the functioning of the positioning system of mobile radio signal sources 
В качестве местности, в которой происходит процесс моделирования, выбрана часть города Орла. Некоторые участки местности, используемые при моделировании, представлены на рисунках 3 и 4.

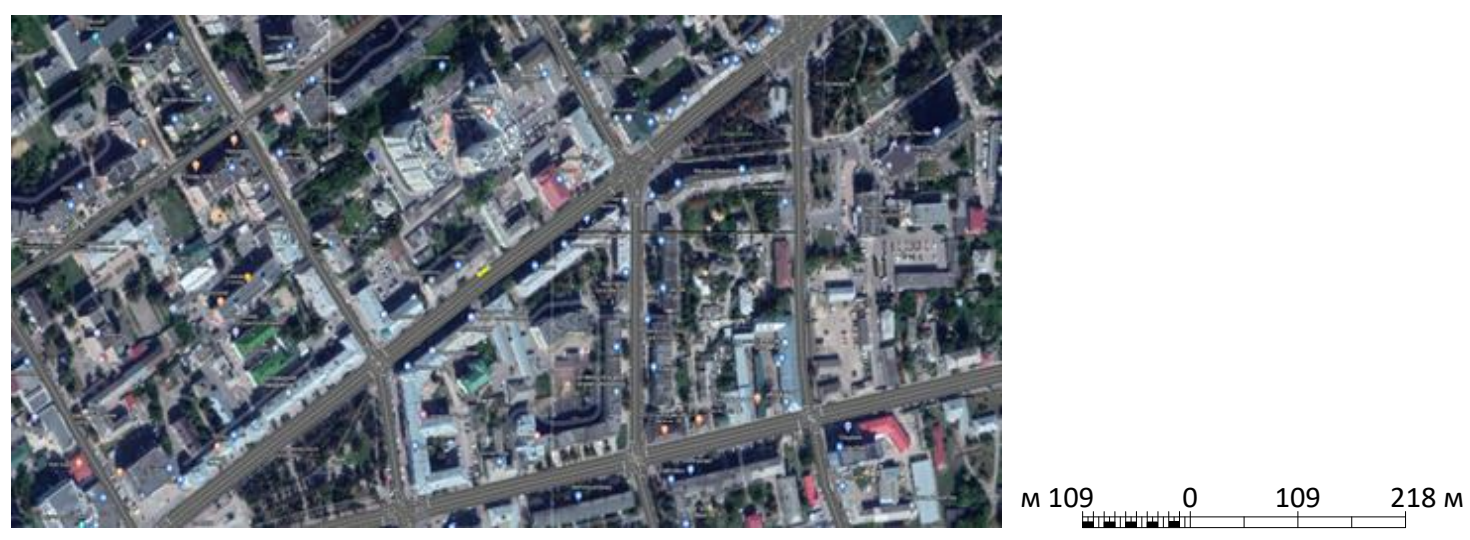

Рис. 3. Участок местности моделирования

Fig. 3. Area modeling terrain
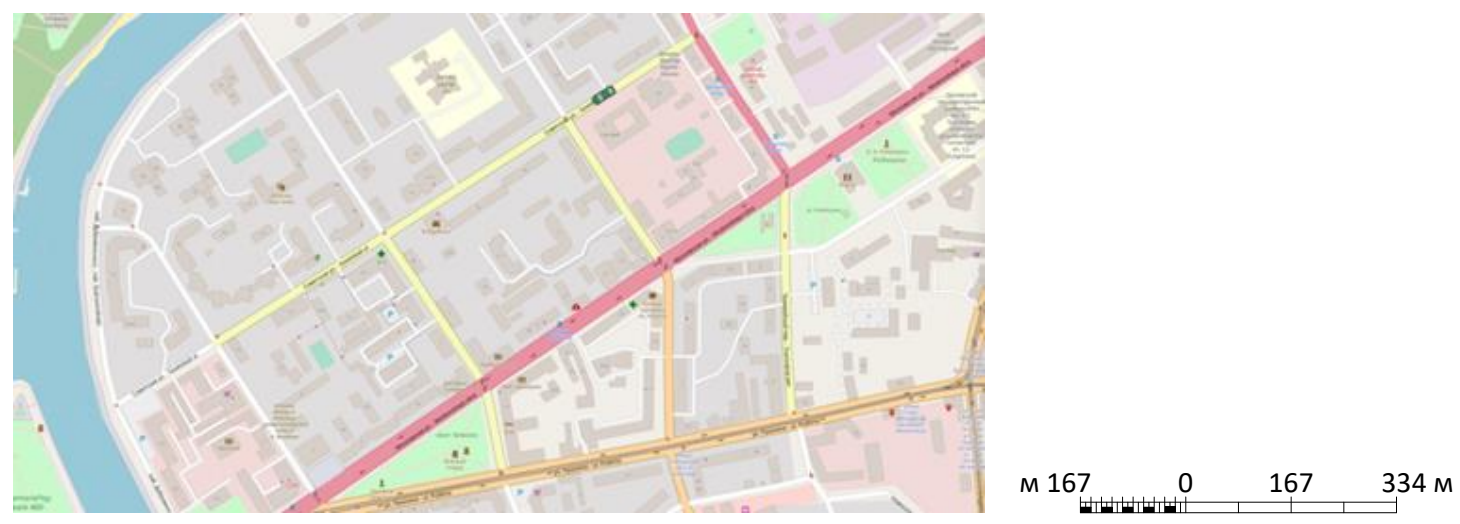

Рис. 4. Фрагмент карты города Орла

Fig. 4. Fragment of the map of the city of Oryol

В разработанном программном обеспечении предусмотрено два основных режима отображения. Первый, представленный на рисунке 3, представляет собой изображение некоторого участка города, в котором предполагается перемещение объекта наблюдения. Изображение является некоторым слоем в среде имитационного моделирования AnyLogic, поверх которого вручную прорисовываются функциональные объекты, на которых в дальнейшем предусматривается перемещение агента, в основном в их число входят дороги и перекрёстки (карта рассматриваемого участка города, в котором предполагается перемещение объекта наблюдения, преобразованная в отдельный шейп-файл).

Далее при помощи инструментов среды имитационного моделирования AnyLogic, изображения дорог в данном файле преобразуются в участки дорог, по которым и передвигается агент, представляющий собой подвижный источник радиосигналов). Второй режим отображения, изображённый на рисунке 4, представляет собой ГИС-карту, подгружаемую в режиме онлайн с сервера при помощи сервиса OpenStreetMap. В данном случае все объекты представляют собой не просто отдельно взятые изображения, а являются самостоятельными функциональными объектами являющимися объектами 
реального мира, т.е. агент моделирования перемещается по реально существующим маршрутам, которого представлены в настоящем мире, данный функционал обеспечивает постоянно обновляемые карта и поставщик маршрутов сервиса OpenStreetMap.

С точки зрения адекватности модели и наиболее полного её соответствия реальному миру, более выгодным является второй режим работы системы, однако, в случае необходимости отображения окружающего мира и самого объекта в $3 D$, пример представлен на рисунке 5, пользователю необходимо выбирать первый режим работы.
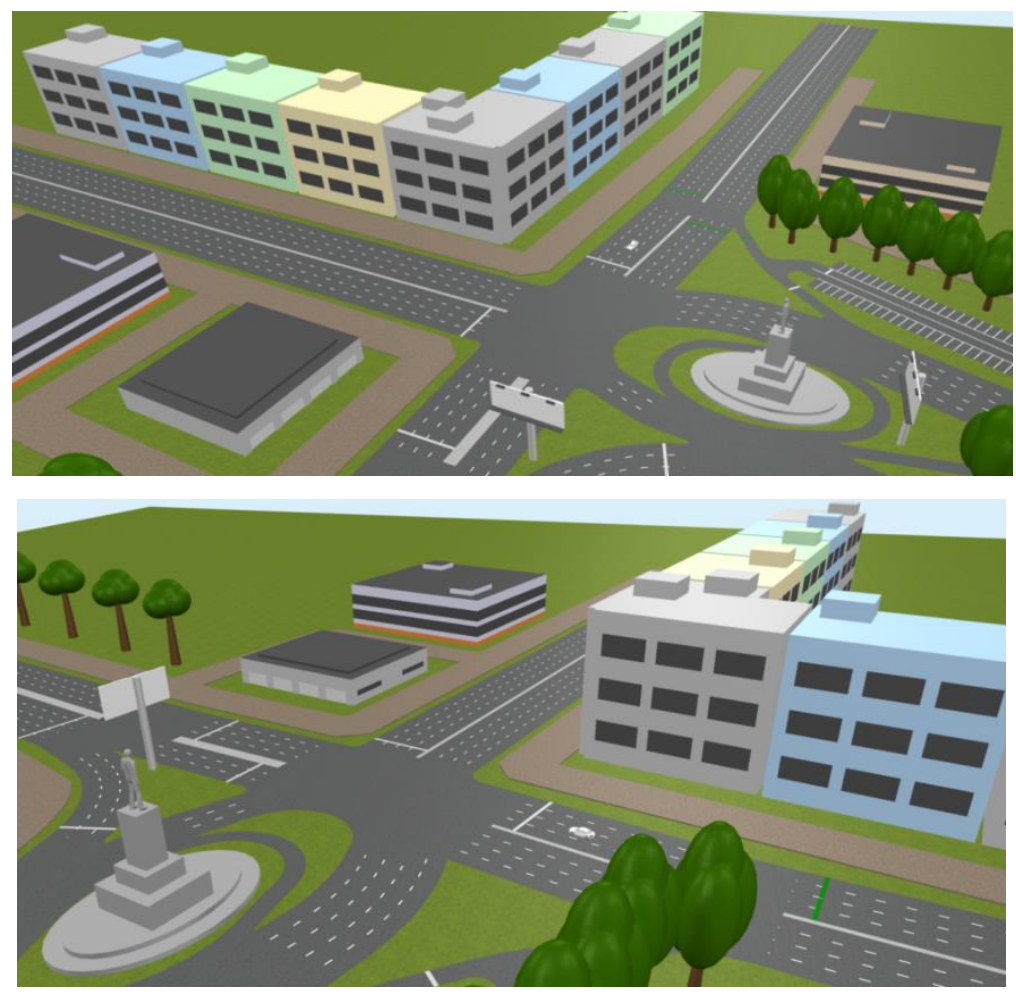

Рис. 5. 3D-модель рассматриваемого участка местности

Fig. 5. 3D-model of the considered area of the terrain

Последовательность точек траектории движения реализована в виде цепи Маркова. Модель перемещения пользователей получена за счет анализа статистики перемещения пользователя мобильного устройства и с использованием встроенного приложения [Маркин, 2013] сбора данных о его перемещениях.

Для имитации перемещения источника радиосигналов в условиях города применялся некий конечный автомат, в котором решения о поворотах, разворотах и перемещении объекта по прямой принимались на основе матрицы вероятностей. То есть в случаях передвижения объекта наблюдения по определённому маршруту и приближения его к участку, на котором имеется возможность изменения траектории движения (в условиях города таковыми чаще всего являются перекрёстки, повороты, пересечения улиц и т.д.) решение о траектории дальнейшего следования выбирается на основе вероятности, сопоставленной с каждым из смежный путей возможного дальнейшего перемещения. Данные вероятности распределены по равномерному закону распределения, что позволяет смоделировать случайное перемещение объекта в условиях города. Модули формирования движения объекта представлены на рисунках 6 и 7. 


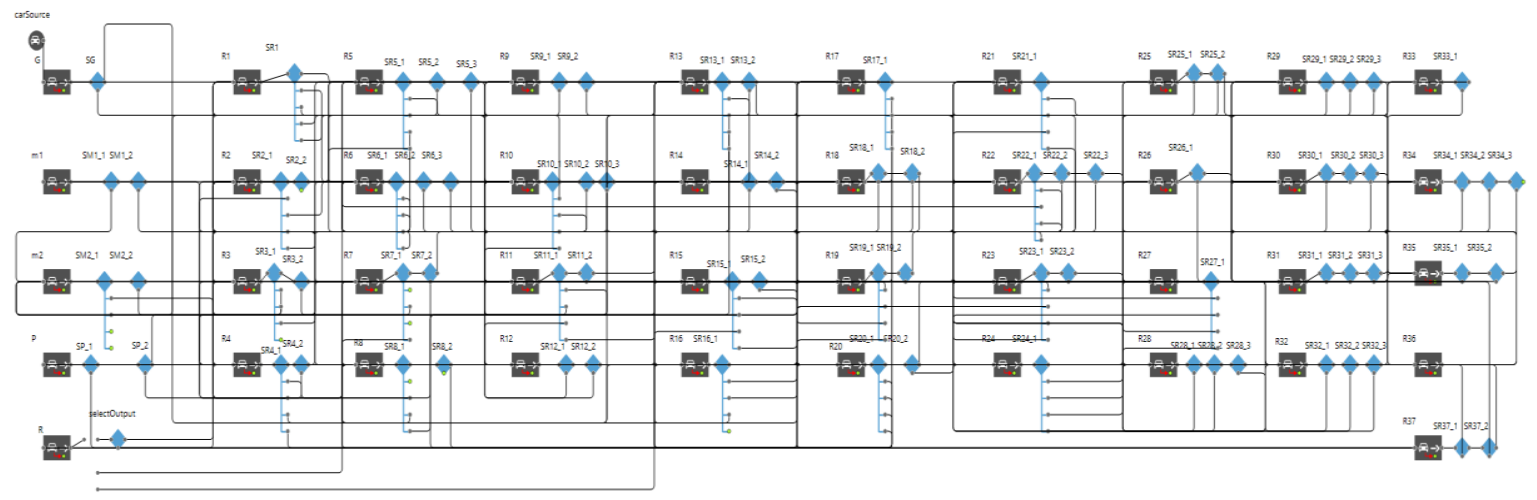

Рис. 6. Модель движения источника радиоизлучения в городских условиях на базе графических элементов управления в среде имитачионного моделирования AnyLogic Fig. 6. A model of the movement of a radio emission source in an urban environment based on graphical controls in the AnyLogic simulation environment

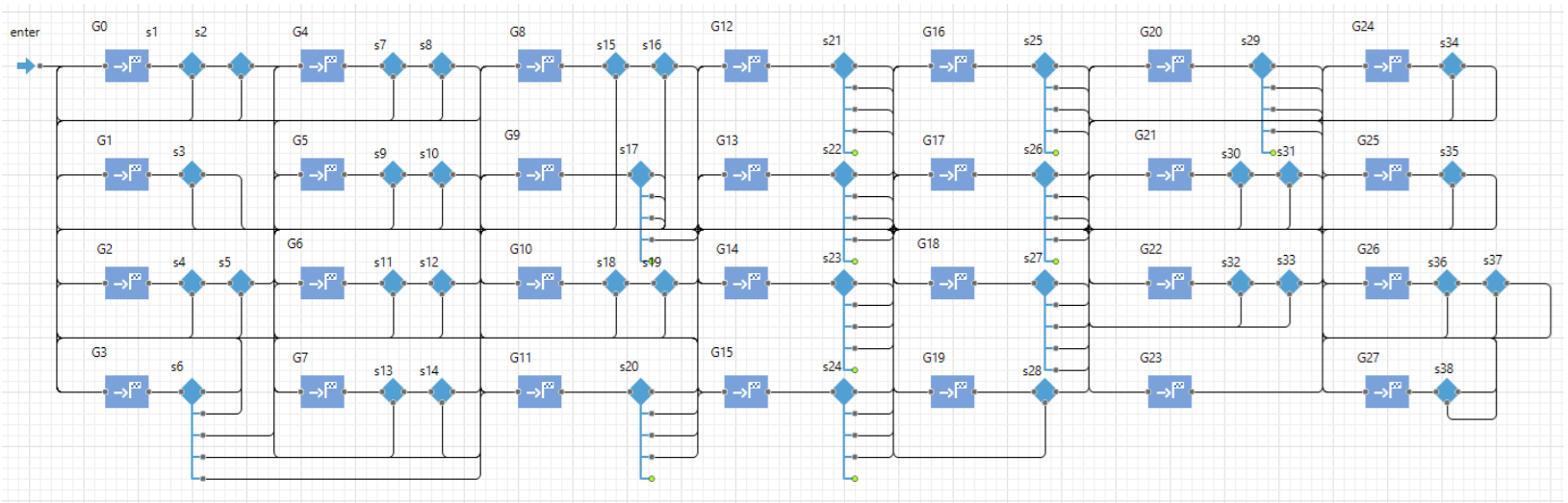

Рис. 7. Модель движения источника радиоизлучения в городских условиях на базе графических элементов управления в среде имитачионного моделирования AnyLogic Fig. 7. A model of the movement of a radio emission source in an urban environment based on graphical controls in the AnyLogic simulation environment

Отличием данных модулей, реализованных в среде имитационного моделирования AnyLogic и соотнесённых как модели движения источника радиоизлучения в городских условиях в случае работы программного средства в различных режимах отображения (в виде слоя моделирования или в виде онлайн-подгружаемой карты геоинформационной системы (ГИС)), является то, что в первом случае объект выбирает необходимый дальнейший маршрут движения из тех, которые определены разработчиком (пользователем) заранее, а во втором случае выбор осуществляется из действительно существующих в реальном мире маршрутов, при этом в данном механизме движения указываются лишь конечные точки, до которых может добраться объект наблюдения, маршруты выбираются случайно, т.е. объект может добраться до указанного места назначения как по автомобильной, так по пешеходной, велосипедной или железнодорожной дроге. Данная особенность обеспечивает бо'льшую случайность передвижения источника радиоизлучения, что говорит о более высоком уровне адекватности модели.

Для имитации распространения радиосигналов в пространстве используется формула потерь для идеальной изотропной антенны: 


$$
\frac{P_{t}}{P_{r}}=\frac{(4 \pi R)^{2}}{\lambda^{2}},
$$

где $P_{t}$ - мощность сигнала передающей антенны; $P_{r}$ - мощность сигнала на приемной антенне; $\lambda$ - длина волны радиосигнала, находящаяся из соотношения скорости света к частоте, несущей радиосигнала; $R$ - расстояние, пройденное сигналом между двумя антеннами.

В качестве основных методов определения местоположения подвижного источника радиосигналов были выбраны метод трилатерации и нечёткой логики. Применение данных технологий для решения задач позиционирования подробно описано в работах [Вишнякова, 2013; Кондюрина, 2018; Маркин, 2015; Маркин, 2016]. В идеальных условиях уравнение для нахождения координат точки пересечения выглядят так:

$$
\left\{\begin{array}{l}
\left(x-x_{1}\right)^{2}+\left(y-y_{1}\right)^{2}=R_{1}^{2} \\
\left(x-x_{2}\right)^{2}+\left(y-y_{2}\right)^{2}=R_{2}^{2} \\
\cdots \\
\left(x-x_{n}\right)^{2}+\left(y-y_{n}\right)^{2}=R_{n}^{2}
\end{array}\right.
$$

где $(x, y)$ - координаты источника БСПД; $\left(x_{i}, y_{i}\right)$ - координаты точек измерений агента, а $n$ - их количество; $R_{i}$ - рассчитанное расстояние от источника радиосигналов до точек измерения.

Из (1) получаем формулу для расчета радиуса для заранее известного источника радиосигналов:

$$
R=\frac{\lambda}{4 \pi} \sqrt{\frac{P_{t}}{P_{r}}} \text {. прямоугольник ограниченный }
$$

Реализация метода трилатерации в разрабатываемой системе представлена на рисунке 8 .
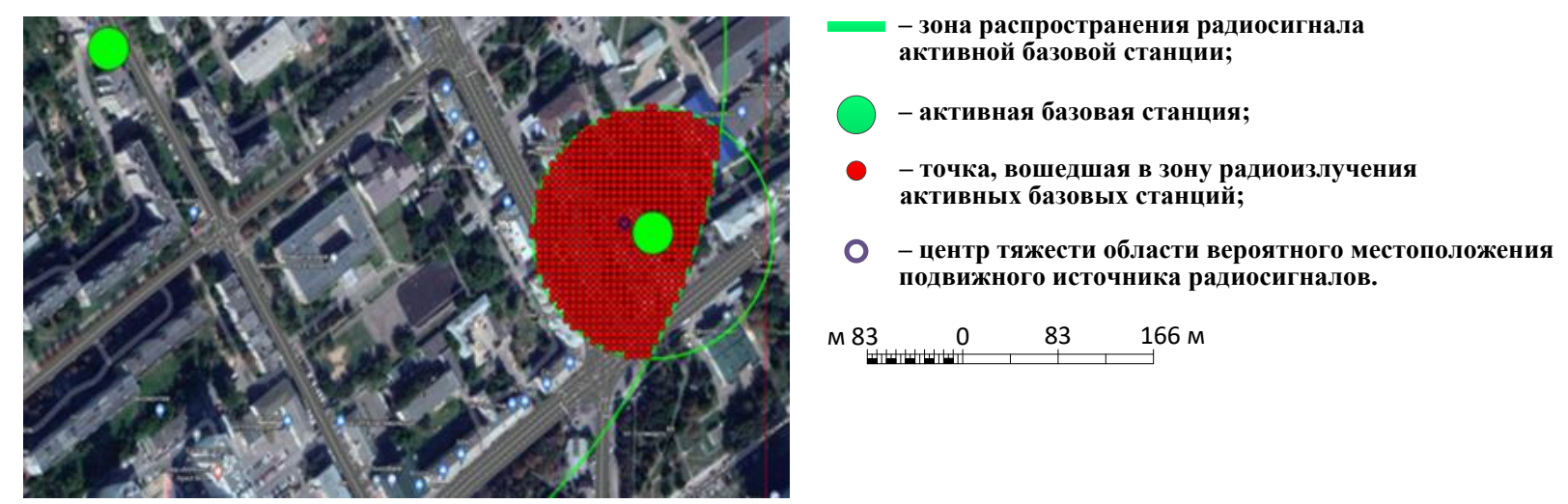

Рис. 8. Работа алгоритма трилатерации в разрабатываемой системе

Fig. 8. Operation of the trilateration algorithm in the developed system 
В идеальных условиях радиусы, вычисленные по формулам (2) и (3) будут равны, так как не вноситься погрешность. Математический аппарат, позволяющий учитывать погрешность в расчётах, реализован в нечёткой логике. Для поиска местоположения на основе нечеткой логики используется накопленная статистика с данными о максимальной и минимальной ошибке позиционирования. Благодаря такому подходу, зона предполагаемого местонахождения объекта из круга уменьшается до кольца (в двумерной плоскости). Демонстрация данного эффекта и работа данного метода в разрабатываемой системе показаны на рисунке 9.
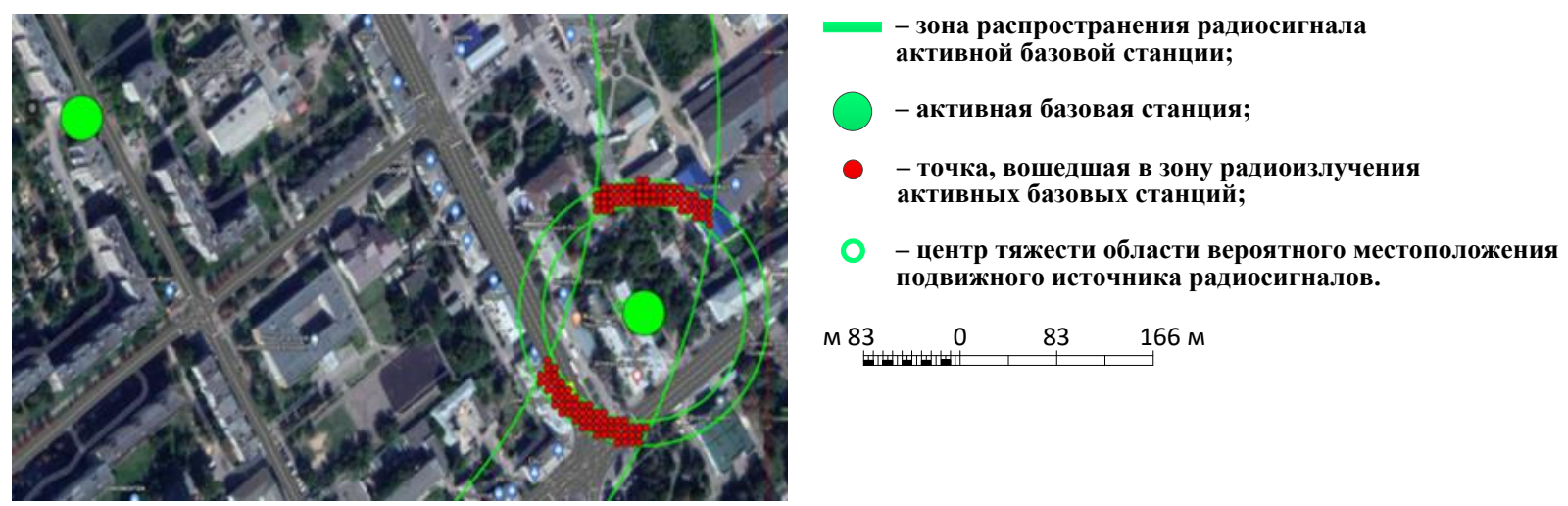

Рис. 9. Работа алгоритма нечёткой логики в разрабатываемой системе

Fig. 9. Operation of the fuzzy logic algorithm in the developed system

Для определения более точного местоположения, необходимо произвести несколько расчетов, так как при большем количестве измерений, площадь поиска потенциального местоположения подвижного источника радиоизлучения уменьшается.

При построении множества окружностей, необходимо выбрать способ расчета площади криволинейных сложных фигур. Существуют различные способы расчета площади криволинейных фигур, необходимо выбрать менее затратный с точки зрения потребления памяти и более точный с точки зрения расчета, так как площадь является основным показателем качества алгоритма. Для расчета площади был выбран метод МонтеКарло. Данный метод работает по алгоритму, приведенному ниже.

1. Криволинейная площадь вносится в простую фигуру, чья площадь заранее известна, в нашем случае это прямоугольник ограниченный контролируемой зоной и горизонтом исследования.

2. Случайно вносятся точки на данную простую фигуру так, что координаты принадлежат простой фигуре и они случайны, так же координаты не должны повторяться. Для нашей системы случайность убрана, с целью более точного расчета площади. Для этого были перебраны все пиксели в простой фигуре.

3. После построения сложной фигуры, рассчитывается площадь по формуле:

$$
S_{\text {иск }}=S \frac{K}{N},
$$

где $S_{\text {иск }}$ - площадь искомой (сложной) фигуры; $S$ - площадь известной фигуры; $K$ - количество точек, попавших в сложную фигуру; $N$ - количество всех сгенерированных точек.

Для полной картины понимания, представлен рисунок 10 для двух точек измерения агентом. 


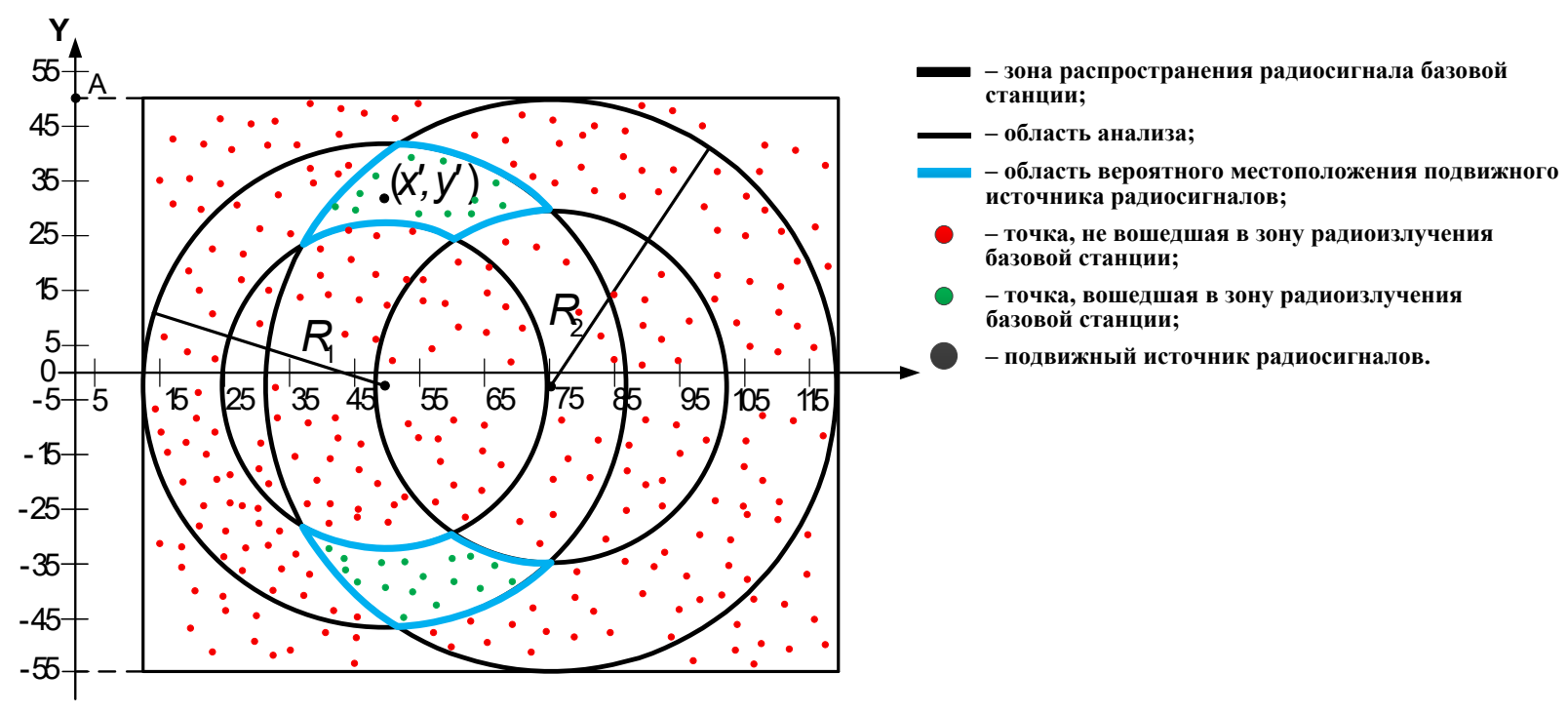

Рис. 10. Демонстрация работы метода Монте-Карло

Fig. 10. Demonstration of the Monte Carlo method

Как видно из рисунков 9 и 10, при работе двух базовых станций (БС) возникают ситуации, в которых при работе алгоритма нечёткой логики область возможного нахождения подвижного объекта. Для устранения таких погрешностей и общего увеличения точности работы системы определения местоположения подвижного источника радиосигналов, был разработан эвристический алгоритм позиционирования (рис. 11) на основе разбиения области возможного местонахождения объекта.

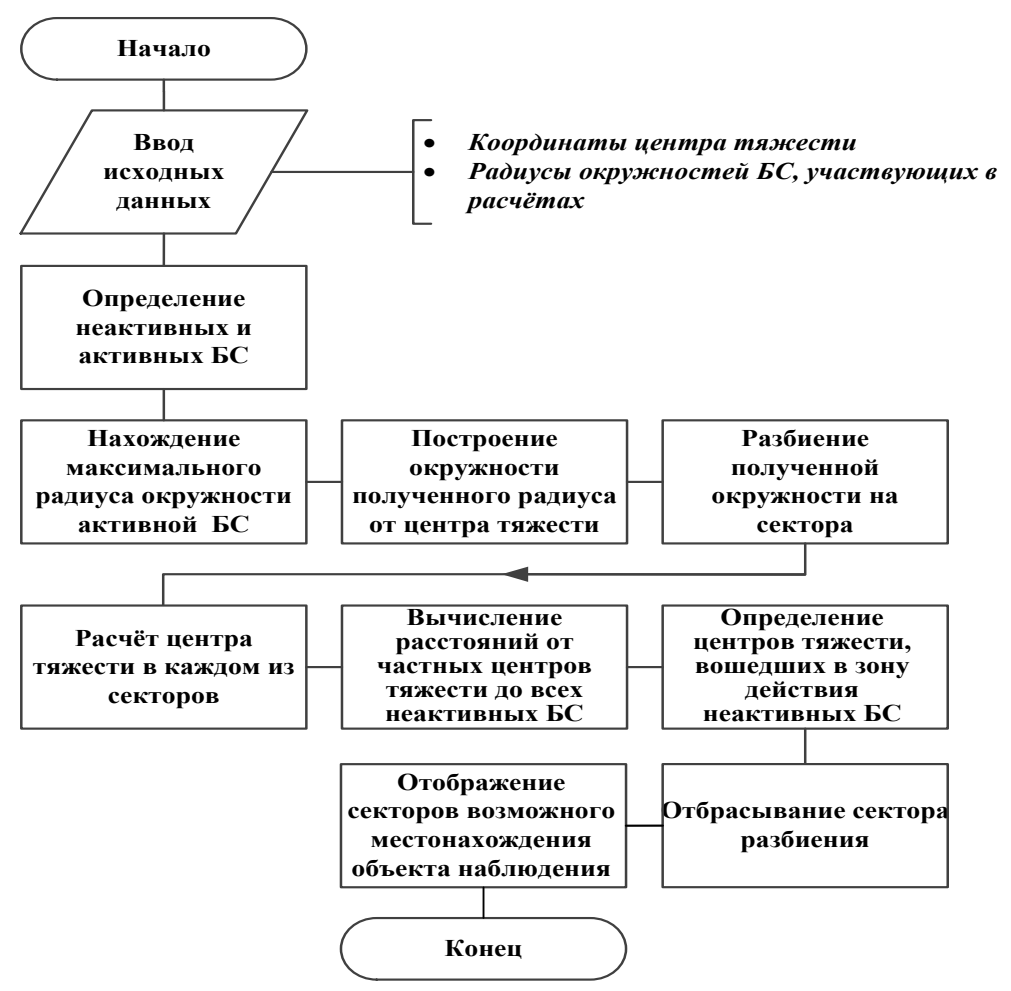

Рис. 11. Блок-схема эвристического алгоритма позиционирования Fig. 11. Block diagram of a heuristic positioning algorithm 
Центром тяжести области в рассматриваемой системе является точка, координаты которой вычисляются как среднее арифметической между всеми точками, попавшими в заданную область. Центр тяжести может быть основным (без учета секторного разбиения) и частным (с учётом границ сектора разбиения).

Выбор сектора зависит от вычисленных расстояний между частными центрами тяжести каждого сектора и точкой, соотнесённой с местоположением БС, предпочтительным является меньшее значение расстояния из получившихся.

Реализация данного алгоритма в разрабатываемой системе определения местоположения подвижного объекта представлена на рисунке 12 (в момент проведения вычислений).
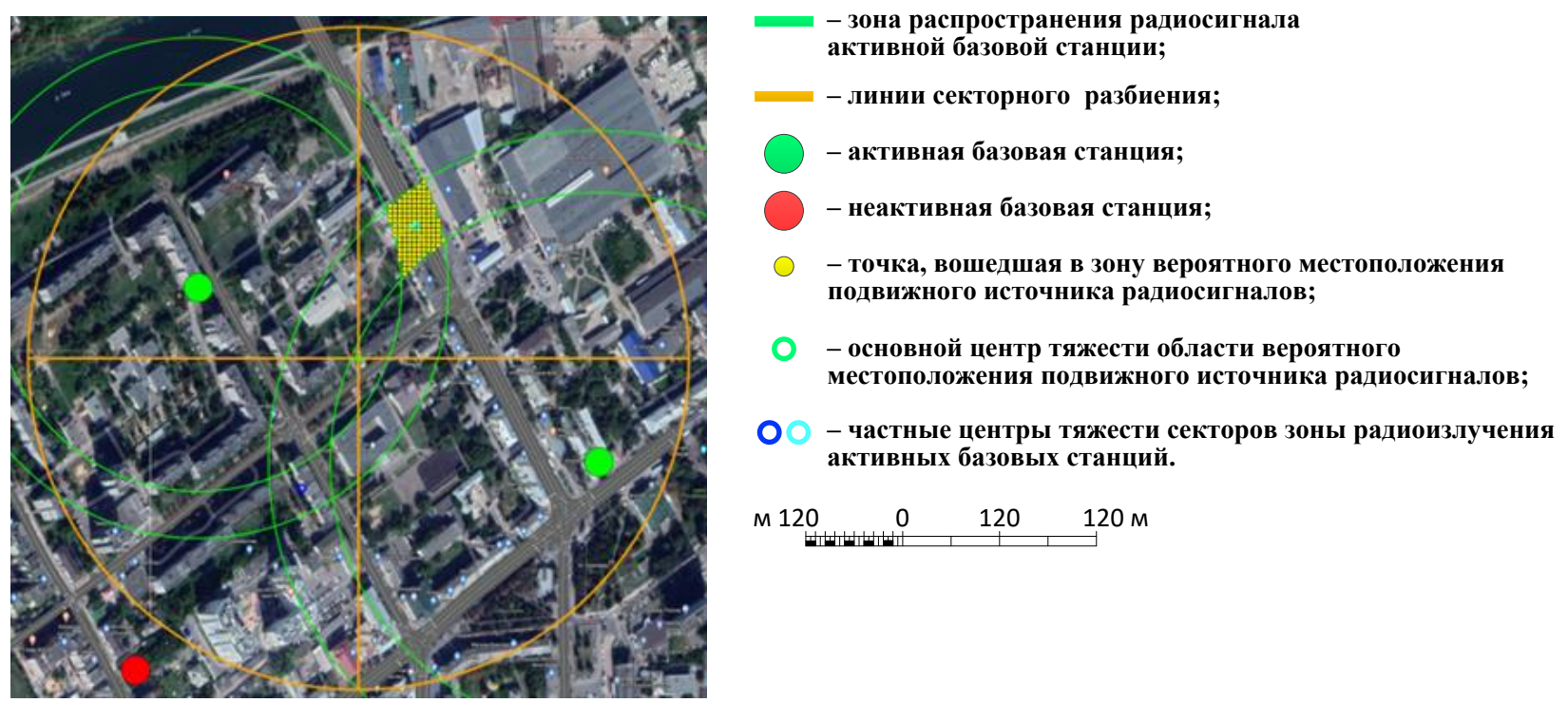

\section{Рис. 12. Работа эвристического алгоритма позиционирования в разрабатываемой системе}

Fig. 12. The operation of the heuristic positioning algorithm in the developed system

\section{РЕЗУЛЬТАТЫ ИССЛЕДОВАНИЯ И ИХ ОБСУЖДЕНИЕ}

Для оценки эффективности методов и алгоритмов в разработанной системе определения местоположения подвижного источника радиосигналов был проведён ряд экспериментов при работе различного числа БС и различных алгоритмах определения местоположения.

Основными параметрами, относительно которых производится расчет эффективности разработанного прототипа программного средства, являются площадь области предполагаемого местоположения объекта наблюдения, а также расстояние от самого объекта до прогнозируемой, при помощи различных алгоритмов, точки.

Среднее число экспериментов для каждого из рассматриваемых случаев различно, и выбирается таким образом, чтобы именно при таком количестве испытаний процесс изменения параметров был наиболее приближен к эргодическому. Результаты эксперимента приведены в таблицах 1 и 2. 
Табл. 1. Среднее значение площзади возможного местоположения подвижного источника радиосигналов

Table 1. The average value of the area of the possible location of a mobile source of radio signals

\begin{tabular}{|l|l|l|l|}
\hline $\begin{array}{l}\text { Кол- } \\
\text { во БС }\end{array}$ & $\begin{array}{l}\text { Тлгоритм } \\
\mathbf{м}^{\mathbf{2}}\end{array}$ & $\begin{array}{l}\text { Нечёткая } \\
\text { логика, } \mathbf{m}^{2}\end{array}$ & $\begin{array}{l}\text { Эвристический } \\
\text { алг. прогн., } \mathbf{m}^{\mathbf{2}}\end{array}$ \\
\hline Одна БС & 7859,7 & 2092 & 2092 \\
\hline Две БС & 1343,5 & 247 & 131,6 \\
\hline Три БС & 386 & 33 & 16 \\
\hline
\end{tabular}

Табл. 2. Среднее значение расстояния от прогнозируемой точки до подвижного источника радиосигналов

Table 2. The average value of the distance from the predicted point to the mobile source of radio signals

\begin{tabular}{|c|c|c|c|}
\hline $\begin{array}{ll}\begin{array}{l}\text { Кол- } \\
\text { во БС }\end{array} & \text { Алгоритм } \\
\end{array}$ & Трилатерация, м & $\begin{array}{l}\text { Нечёткая } \\
\text { логика, м }\end{array}$ & $\begin{array}{l}\text { Эвристический } \\
\text { алг. прогн., м }\end{array}$ \\
\hline Одна БС & 487,5 & 487,5 & 487,5 \\
\hline Две БС & 286 & 270,7 & 11.2 \\
\hline Три БС & 133 & 8,74 & 3,52 \\
\hline
\end{tabular}

Из таблиц, представленных выше, видно, что наиболее точные результаты по двум рассматриваемым критериям эффективности разрабатываемой системы даёт использование эвристического алгоритма позиционирования. В свою очередь, метод трилатерации даёт наименее точные результаты по сравнению с другими алгоритмами рассматриваемой системы определения местоположения подвижных источников радиоизлучения, связано это с простотой реализации данного алгоритма по сравнению с другими предложенными.

Результаты исследования вопросов моделирования систем позиционирования подвижных источников радиосигналов на основе беспроводных сетей передачи данных показали следующее:

1. Алгоритм трилатерации позволяет определить местоположение подвижного объекта, но является наименее точным. Данный вывод обосновывается результатами экспериментов, проведённых в рамках работы данной системы, результаты, которых приведены выше.

2. Метод позиционирования на основе нечеткой логики позволяет значительно сузить область потенциального местоположения искомого подвижного источника радиосигналов, при этом, чем больше базовых станций предоставляют данные об уровне мощности радиосигнала от источника, тем меньше область потенциального местоположения и, соответственно, выше точность позиционирования.

3. Исследованный эвристический алгоритм позиционирования при совместной его работе с аппаратом нечёткой логики, а также применении метода линейного предсказания обеспечивает высокую точность определения местоположения подвижного источника радиосигналов. Обоснование данного вывода связано с тем, что данный алгоритм, основываясь на разбиении области, полученной при помощи нечёткой логики, позволяет убирать из рассмотрения те области, которые 
удовлетворяют условиям распространения радиосигналов от БС, но в которых сам объект наблюдения не находится, что и обеспечивает бо'льшую точность позиционирования по сравнению с ранее рассмотренными алгоритмами.

\section{ВЫВОДЫ}

Работоспособность данной системы определения местоположения подвижных источников радиосигналов экспериментально проверена и подтверждена. Программные реализации методов, представленных в данной системе, зарегистрированы в ФИПС [Козин, 2020].

Основными направлениями дальнейшего совершенствования разработанного программного средства являются применение новых алгоритмов определения местоположения подвижного источника радиосигналов, направленных на большее уменьшение погрешностей при расчёте местоположения, предоставление пользователю программы возможности выбирать любой участок карты мира с высокой точностью детализации при помощи сервисов OpenStreetMap.

Реализованное программное средство может быть использовано для исследования, разработки и совершенствования систем определения местоположения подвижных источников радиосигналов. Полученные результаты могут быть использованы в области картографии и геоинформационных систем.

\section{СПИСОК ЛИТЕРАТУРЫ}

1. Вишнякова О.А., Лавров Д.Н., Лаврова С.Ю. Математическая модель обнаружения точки беспроводного доступа по измерениям мощности излучения разнесенными наблюдателям. Математические структуры и моделирование. 2013. № 2(28). С. 4959.

2. Камалов Ю.Ю., Служивый М.Н. Имитационное моделирования мобильных систем связи в условиях городской застройки. Известия Самарского научного центра РАН, 2010. T. 12. № 4(2). С. 341-345.

3. К Козин С.С., Кузькин А.А., Маркин Д.О., Рябоконь В.В., Свечников Д.А., Субботенко $O . A$. Программное средство определения местоположения подвижных источников радиосигналов на основе методов прогнозирования: свидетельство о государственной регистрации программы для ЭВМ № 2020666496 Российская Федерация. Зарегистрировано в Реестре программ для ЭВМ 10.12.2020 г.

4. Кондюрина А.А., Лавров Д.Н. Результаты эксперимента по обнаружению беспроводной точки доступа модифицированным методом трилатерации. Математические структуры и моделирование, 2018. № 2. С. 62-65.

5. Маркин Д.О. Исследование эффективности алгоритмов определения местоположения мобильных устройств внутри помещений. Вестник РГРТУ, 2015. № 54(1). С. 32-39.

6. Маркин Д.О., Комашинский В.В., Шекшуев С.В. Анализатор контекста доступа мобильного устройства: свидетельство о государственной регистрации программы для ЭВМ № 2013618388 Российская Федерация. Зарегистрировано в Реестре программ для ЭВМ 06.09.2013 г.

7. Маркин Д.О., Макеев С.М. Модель системы определения местоположения мобильного устройства на основе метода статистических испытаний. Известия Тульского государственного университета. Технические науки, 2016. № 2. С. 150165. 
8. Фокин Г.А. Технологии сетевого позиционирования 5G. СПб.: СПбГУТ, 2020. 466 с. DOI: $10.236724 / 2072-8735-2020-14-12-4-17$.

9. Basiri A., Lohan E.S., Moore T., Winstanley A., Petolta P., Hill C., Amirian P., Silva P. Indoor location based services challenges, requirements and usability of current solutions. Computer Science Review, 2017. V. 24. P. 1-12. DOI: 10.1016/j.cosrev.2017.03.002.

10. Chen C.Y., Chen Y.J, Chen S.W., Shen C.Y., Hwang R.C. A Fuzzy Indoor Positioning System with ZigBee Wireless Sensors. Journal of Electrical and Electronic Engineering, 2016. No 4(5). P. 97-102. DOI: 10.11648/j.jeee.20160405.12.

11. Curran K., Furey E., Lunney T., Santos J., Woods D., McCaughey A. An evaluation of indoor location determination technologies. Journal of Location Based Services, 2011. V. 5. No 2. P. 61-78. DOI: 10.1080/17489725.2011.562927.

12. Koyuncu H., Yang S.H. A Survey of Indoor Positioning and Object Locating Systems. IJCSNS International Journal of Computer Science and Network Security, 2019. V. 10. No 5. P. 121-128. DOI: 10.1016/j.procs.2019.04.007.

13. Mautz R. Overview of current indoor positioning systems. Geodezija ir kartografija, 2009. V. 35. No 1. P. 18-22.

14. Onofre S., Caseiro B., Pimentão J.P., Sousa P. Using Fuzzy Logic to Improve BLE Indoor Positioning System. Proc. of Doctoral Conference on Computing, Electrical and Industrial Systems. Technological Innovation for Cyber-Physical Systems, 2016. P. 169-177. DOI: 10.1007/978-3-319-31165-4 18.

15. Orujov F., Maskeli R., Damaševičius R., Ye Li W.W. Smartphone based intelligent indoor positioning using fuzzy logic. Future Generation Computer Systems, 2018. No 89. P. 335-348. DOI:10.1016/j.future.2018.06.030.

16. Socha M., Górka W., Kostorz I. Fuzzy logic in indoor position determination system. Theoretical and Applied Informatics, 2016. V. 27. P. 1-15. DOI: 10.20904/272001.

17. Uradzinski M., Guo H., Liu X., Yu M. Advanced indoor positioning using zigbee wireless technology. Wireless Personal Communications, 2017. V. 97. No 4. P. 6509-6518.

\section{REFERENCES}

1. Basiri A., Lohan E.S., Moore T., Winstanley A., Petolta P., Hill C., Amirian P., Silva P. Indoor location based services challenges, requirements and usability of current solutions. Computer Science Review, 2017. V. 24. P. 1-12. DOI: 10.1016/j.cosrev.2017.03.002.

2. Chen C.Y., Chen Y.J, Chen S.W., Shen C.Y., Hwang R.C. A Fuzzy Indoor Positioning System with ZigBee Wireless Sensors. Journal of Electrical and Electronic Engineering, 2016. No 4(5). P. 97-102. DOI: 10.11648/j.jeee.20160405.12.

3. Curran K., Furey E., Lunney T., Santos J., Woods D., McCaughey A. An evaluation of indoor location determination technologies. Journal of Location Based Services, 2011. V. 5. No 2. P. 61-78. DOI: 10.1080/17489725.2011.562927.

4. Fokin G.A. Technologies of 5G network positioning. Saint-Petersburg: SPbSUT, 2020. 466 p. (in Russian). DOI: 10.236724/2072-8735-2020-14-12-4-17.

5. Kamalov Yu.Yu., Sluzhivy M.N. Simulation modeling of mobile communication systems in urban development. Bulletin of the Samara Scientific Center of the Russian Academy of Sciences, 2016. T. 12. No 4 (2). P. 341-345. (in Russian).

6. Koyuncu H., Yang S.H. A Survey of Indoor Positioning and Object Locating Systems. IJCSNS International Journal of Computer Science and Network Security, 2019. V. 10. No 5. P. 121-128. DOI: 10.1016/j.procs.2019.04.007.

7. Kozin S.S., Kuzkin A.A., Markin D.O., Ryabokon V.V., Svechnikov D.A., Subbotenko O.A. Software for determining the location of mobile sources of radio signals based on 
forecasting methods: certificate of state registration of a computer program No 2020666496 Russian Federation. Registered in the Register of computer programs on 10.12.2020 (in Russian).

8. Kondyurina A.A., Lavrov D.N. Results of an experiment on detecting a wireless access point by a modified trilateration method. Mathematical structures and modeling, 2018. No 2. P. $62-65$ (in Russian).

9. Markin D.O. Study of the effectiveness of algorithms for determining the location of mobile devices in the room. Vestnik of Ryazan State Radio Engineering University, 2015. No 54-1. P. 32-39 (in Russian).

10. Markin D.O., Komashinsky V.V., Shekshuev S.V. Access context analyzer for a mobile device: certificate of state registration of a computer program No 2013618388 Russian Federation. Registered in the Register of computer programs 09.06.2013 (in Russian).

11. Markin D.O., Makeev S.M. Model of a system for determining the location of a mobile device based on a statistical test method. Bulletin of the Tula State University. Technical sciences, 2016. No 2. P. 150-165 (in Russian).

12. Mautz R. Overview of current indoor positioning systems. Geodezija ir kartografija, 2009. V. 35. No 1. P. 18-22.

13. Onofre S., Caseiro B., Pimentão J.P., Sousa P. Using Fuzzy Logic to Improve BLE Indoor Positioning System. Proc. of Doctoral Conference on Computing, Electrical and Industrial Systems. Technological Innovation for Cyber-Physical Systems, 2016. P. 169-177. DOI: 10.1007/978-3-319-31165-4_18.

14. Orujov F., Maskeli R., Damaševičius R., Ye Li W.W. Smartphone based intelligent indoor positioning using fuzzy logic. Future Generation Computer Systems, 2018. No 89. P. 335-348. DOI:10.1016/j.future.2018.06.030.

15. Socha M., Górka W., Kostorz I. Fuzzy logic in indoor position determination system. Theoretical and Applied Informatics, 2016. V. 27. P. 1-15. DOI: 10.20904/272001.

16. Vishnyakova O.A., Lavrov D.N., Lavrova S.Yu. Mathematical model of detection of wireless access by measuring the radiation power by spaced observers. Mathematical structures and modeling. Omsk: Omsk State University, 2013. No 2 (28). P. 49-59 (in Russian).

17. Uradzinski M., Guo H., Liu X., Yи M. Advanced indoor positioning using zigbee wireless technology. Wireless Personal Communications, 2017. V. 97. No 4. P. 6509-6518. 


\title{
А.М. Карпачевский ${ }^{1}$, Г.С. Титов ${ }^{2}$
}

\section{ПРОЕКТИРОВАНИЕ БАЗЫ ПРОСТРАНСТВЕННО-ВРЕМЕННЫХ ДАННЫХ О МАГИСТРАЛЬНЫХ ЭЛЕКТРИЧЕСКИХ СЕТЯХ РОССИИ}

\begin{abstract}
АННОТАЦИЯ
Магистральные линии электропередач России имеют сложную пространственную структуру. Систематизированные и топологически согласованные пространственновременные данные о них отсутствуют. При этом изучение их эволюции требует не только кропотливого сбора данных, но и детального проектирования структуры базы пространственно-временных данных. Структура должна обеспечивать экономичное хранение данных, быть удобной для заполнения базы и редактирования данных, предоставлять возможности реконструирования состояния сети на заданный период и применения методов пространственного анализа. Сбор данных выполняется на основе открытых источников, например, отчётов системного оператора ЕЭС, схем и программ развития электроэнергетики ЕЭС и отдельных регионов, материалов Публичной кадастровой карты, информации Ситуационно-аналитического центра Минэнерго, и данных дистанционного зондирования очень высокого пространственного разрешения.

Пользователи не имеют прямого доступа к базе данных, а обращаются к ней с помощью типовых запросов. Взаимодействие с базой данных осуществляется через программный интерфейс (API, Application Programming Interface). Это позволяет не только выгружать данные из базы, но и встраивать их во внешние системы, в частности подключать к ним инструменты анализа, создавать на их основе картографические веб-приложения.
\end{abstract}

Предварительная обработка данных выполняется с использованием языка программирования Python, модуля Аrсру, база данных создаётся с использованием СУБД PostgreSQL, работа программного интерфейса для обращения пользователей к сведениям из базы данных обеспечивается PostgREST.

Согласованная многовременная пространственную база данных, которая послужит основой для анализа структурных особенностей электрических сетей, даст возможность визуализировать историю развития энергосистемы с привязкой к территории в рамках интерактивного картографического веб-приложения, позволит выполнять геоинформационную обработку и расчёты с помощью специальных инструментов сетевого анализа. Возможность детального изучения эволюции магистральных электросетей необходима в долгосрочных стратегиях развития электросетевого комплекса.

За рубежом исследования эволюции электрических сетей, как правило, оперируют схематичным графом сети без привязки к реальной пространственной геометрии, поэтому проблема проектирования структуры пространственно-временных данных не стоит так остро. Однако игнорирование топоморфологических отношений в сети ведёт к потере

1 Московский государственный университет имени М.В. Ломоносова, Географический факультет, Ленинские горы, д. 1, 119991, Москва, Россия, e-mail: karpach-am@yandex.ru

2 Московский государственный университет имени М.В. Ломоносова, Географический факультет, Ленинские горы, д. 1, 119991, Москва, Россия, e-mail: gherman.s.titov@gmail.com 
информации о своеобразной мозаичности электрических сетей, что в свою очередь обуславливает ухудшение качества пространственного анализа.

КЛЮЧЕВЫЕ СЛОВА: географические сети, геоинформационный анализ, сетевой анализ, эволюция сети, энергосистема.

Andrey M. Karpachevskiy ${ }^{1}$, German S. Titov ${ }^{2}$

\title{
SPATIO-TEMPORAL DATABASE DESIGN FOR BACKBONE POWER GRID OF RUSSIA
}

\begin{abstract}
Backbone power lines in Russia have a complex spatial structure. There are no systematized and topologically consistent spatio-temporal data about them. However, the study of their evolution requires not only data mining, but also a comprehensive design of the structure of the spatio-temporal database. The structure should provide effective data storage, be convenient for filling the database and editing data, provide the ability to reconstruct the network for a given period and apply spatial analysis methods.

Open sources like power grid operator reports, schemes and programs of power grid development, public cadastral map, information from Situational and Analytical Center of the Ministry of Energy and very high spatial resolution remote sensing data are the main data sources.

Users do not have direct access to the database but refer to it using queries. Interaction with the database is carried out through Application Programming Interface (API). This allows downloading data from the database as well as embedding them into external systems, for example, connecting analysis tools to them, creating cartographic web applications with this data.

Data preprocessing is performed in Python using the Arcpy module, the database is created with PostgreSQL, the API works on PostgREST.

Consistent multi-temporal spatial database serves as the basis for analyzing the structural features of electrical networks, makes it possible to visualize the history of the development of the power grid of the territory in an interactive web-based mapping application, allows to apply geoprocessing tools and special network analysis tools. The detailed study of the evolution of backbone power grids is crucial in long-term strategies for the development of the power grid.

Abroad, studies of the evolution of electrical networks usually operate with a schematic graph of a network without reference to real spatial geometry, therefore, there is no problem of designing the structure of spatio-temporal database. Yet, ignoring topomorphological relationships in the network leads to the loss of information about electrical networks, which leads to a loss in the quality of spatial analysis.
\end{abstract}

KEYWORDS: geographical networks, GIS-analysis, network analysis, network evolution, power grid.

\section{ВВЕДЕНИЕ}

Изучение электрических сетей в их пространственном и временном аспекте выявляет ряд серьезных проблем, например, отсутствие систематизированных и топологически согласованных пространственно-временных данных по магистральным

Lomonosov Moscow State University, Faculty of Geography, Leninskie Gory 1, 119991, Moscow, Russia, e-mail: karpach-am@yandex.ru

Lomonosov Moscow State University, Faculty of Geography, Leninskie Gory 1, 119991, Moscow, Russia, e-mail: gherman.s.titov@gmail.com 
электрическим сетям России, а также геоинформационных инструментов их анализа и общедоступной интерактивной картографической визуализации данных. Кроме того, пространственная эволюция электрических сетей - это слабо проработанное направление в географии на текущий момент не только в России, но и в мире. Это можно объяснить тем, что до недавнего времени подобная информация была недоступна для исследователей. В рамках исследования пространственно-временных особенностей развития магистральных сетей представляется критически важной разработка, во-первых, базы пространственных данных, которая была бы удобна для таких исследований, во-вторых, комплекса картографо-геоинформационных инструментов для изучения особенностей пространственно-временного развития магистральных электрических сетей России, которые отражаются в пространственной структуре сети и её топологических особенностях. Немаловажную роль такая база данных будет играть для анализа структурной уязвимости сети [Rosas-Casals et al., 2007; Crucitti et al., 2005; Фаддеев, 2016].

Сбор пространственных данных о сетях 220-750 кВ осуществлялся по мозаикам космических снимков очень высокого пространственного разрешения. По этим же данными мы выделили участки различного возраста, различных применяемых видов опор, количества цепей на общих опорах, марок проводов определенной пропускной способности. Реконструкция исторического развития электрических сетей осуществляется с использованием различных архивных и пространственных данных (карты, схемы, публикации). Собранные данные на территорию всей России планируется свести, структурировать и согласовать в единую многовременную базу пространственных данных.

В данной работе целью исследования является разработка структуры базы данных, которая была бы удобна для наполнения, хранения, редактирования и анализа пространственно-временных данных о магистральных электрических сетях. Конечным результатом нашего исследования станет картографический веб-ресурс, размещенный в сети Интернет. Для пользователей будут доступны как инструменты визуализации данных, так и аналитические инструменты для расчёта различных структурных показателей сети. На основе разработанного ресурса впервые откроется возможность детального изучения эволюции магистральных электросетей. Данный ресурс может представлять значительный интерес и для прикладного использования, например, при долгосрочном планировании развития электросетевого комплекса

Актуальными остаются вопросы проектирования базы для хранения пространственно-временных данных об электросетях. В отличие от многочисленных отечественных и зарубежных исследований структурных особенностей электрических сетей впервые в данном проекте за основу будет взята пространственная составляющая, которая играет решающую роль в территориальном планировании. Помимо пространственной составляющей в сетевых моделях будут учтены топологические особенности электрических сетей, которые практически никогда не учитываются в подобных исследованиях, но могут существенно влиять на точность и достоверность результатов сетевого анализа.

\section{МАТЕРИАЛЫ И МЕТОДЫ ИССЛЕДОВАНИЯ}

Прикладной задачей исследования является создание информационной системы, к которой пользователь может обратиться, чтобы получить желаемые данные об электрической сети. Она должна обеспечивать возможность восстановления векторного набора данных на конкретный временной срез, а также применение геоинформационных методов к хранящимся данным. Создание информационной системы включает проектирование и наполнение базы данных и разработку программного интерфейса (AРI, Application Programming Interface) для обращения к ней. 
Проектирование базы данных заключается в формулировании и обосновании её структуры. В основу проектирования ложится следующий принцип: каждый атрибут является отдельным полем, каждое наблюдение является отдельной строкой, каждый класс наблюдаемых объектов является отдельной таблицей [Wickham, 2014]. Для многовременных данных ситуация усложняется, но принципы остаются теми же [Wang, Cook, Hyndman, 2020]. Для электрических сетей на данный момент нет серьёзных наработок по созданию пространственно-временных баз данных, поскольку для исследований и для решения производственных задач зачастую используют только данные, отражающие текущее состояние сети. Так, например, известна попытка создания базы данных для оценки уязвимости сети на основе открытых данных Open Street Map [Medjroubi W., Vogt, 2017]. Что касается применения пространственно-временных моделей данных для других видов сетей, например, автодорожных, следует понимать, что они акцентируют внимание на изменении параметров сети со временем (динамика), а не на появлении или исчезновении отдельных элементов сети (эволюция) [George, Shekhar, 2008].

Основная проблематика хранения многовременных данных заключается в том, что мы должны представить один и тот же объект в разных состояниях в разные моменты времени. Например, если делать отдельные наборы данных для каждого года существования энергосистемы, то это приведёт к избыточности хранимой информации, а также усложнит её редактирование и проведение аналитических операций. Наблюдение в нашем случае - это элементарная, неизменяемая единица базы данных, объект класса. Например, чтобы сделать запись об электростанции мы наблюдаем уникальный набор значений атрибутов и геометрию. Если значения атрибутов или геометрия изменяются, то мы наблюдаем новый объект. Новый объект может совпадать с другим в пространстве (геометрия не меняется), но они будут наблюдаться в разные периоды и обладать разными атрибутами, потому что, например, в определённый год произошло изменение установленной мощности электростанции. До этого момента мы наблюдали старый объект, а после - новый.

Классами объектов в базе данных являются участки ЛЭП, электростанции, подстанции, прочие коммутирующие пункты (Рис. 1).

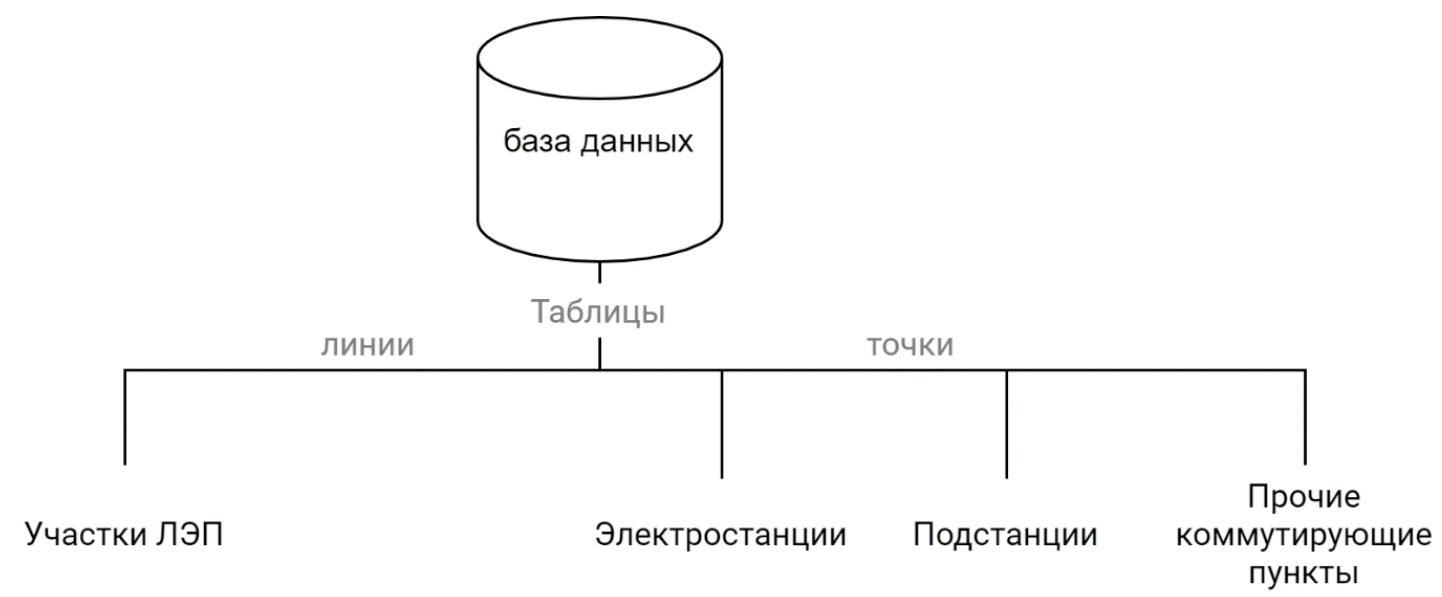

Рис. 1. Структура базы данных

Fig. 1. Database structure

Наборы полей в таблицах характеризуют атрибуты объектов (Табл. 1-4). Они подбираются с учётом того, что должна быть обеспечена уникальность и неизменность каждого наблюдения объекта. Временная составляющая данных разбивается на два поля, одно из которых отвечает за время появления объекта (его первого наблюдения) и за время 
исчезновения объекта (наблюдения его отсутствия). При этом имеется в виду необязательно физический объект, а участки, обладающие постоянным и неизменным набором характеристик. Для атрибутов напряжения и типа используется домен значений в силу особенностей атрибута, например, в электросетях есть только два типа подстанций обычные электрические с возможностью понижения напряжения, и распределительные, на которых напряжение не понижается). Пунктом начала и пунктом конца участка ЛЭП может быть только электростанция или подстанция. Этими пространственными (топологическими, сетевыми) отношениями выражается связь между сущностями в базе данных. Она не выражается напрямую в отношениях атрибутивных таблиц, а содержится их геометрической составляющей. Наличие этой связи гарантируется корректным процессом сбора и подготовки данных. Поэтому важным является удобство работы с БД в ГИС. Следует отметить, что в предлагаемой структуре отношений базы данных все атрибуты вводятся пользователем, а расчётных полей нет, но они могут появиться при дальнейшем использовании данных для расчёта различных сетевых и структурных показателей.

Табл. 1. Структура таблиць электростанциий

Table 1. Table structure for power plants

\begin{tabular}{|l|l|}
\hline Поле & Тип поля \\
\hline идентификатор & целое \\
\hline геометрия & геометрия \\
\hline тип & текст \\
\hline электрическая мощность & действительное \\
\hline наименование & текст \\
\hline альтернативное & \\
\hline наименование & текст \\
\hline год ввода в эксплуатацию & целое \\
\hline год вывода из эксплуатации & целое \\
\hline
\end{tabular}

Табл. 2. Структура таблиџы электрических подстанций

Table 2. Table structure for electrical substations

\begin{tabular}{|l|l|}
\hline Поле & Тип поля \\
\hline идентификатор & целое \\
\hline геометрия & геометрия \\
\hline тип & текст \\
\hline высшее напряжение & целое \\
\hline наименование & текст \\
\hline альтернативное наименование & текст \\
\hline номер & текст \\
\hline год ввода в эксплуатацию & целое \\
\hline год вывода из эксплуатации & целое \\
\hline
\end{tabular}


Табл. 3. Структура таблищы прочих коммутирующих пунктов

Table 3. Table structure for other commutating devices

\begin{tabular}{|l|l|}
\hline Поле & Тип поля \\
\hline идентификатор & целое \\
\hline геометрия & геометрия \\
\hline тип & текст \\
\hline напряжение & целое \\
\hline наименование & текст \\
\hline год ввода в эксплуатацию & целое \\
\hline год вывода из эксплуатации & целое \\
\hline
\end{tabular}

Табл. 4. Структура таблицы участков ЛЭП

Table 4. Table structure for power line segments

\begin{tabular}{|l|l|}
\hline Поле & Тип поля \\
\hline идентификатор & целое \\
\hline геометрия & геометрия \\
\hline тип линии & текст \\
\hline напряжение & целое \\
\hline наименование & текст \\
\hline пункт начала & текст \\
\hline пункт конца & текст \\
\hline номер цепи & целое \\
\hline наличие отпайки & текст \\
\hline перечень пунктов отпаек & текст \\
\hline год ввода в эксплуатацию & целое \\
\hline год вывода из эксплуатации & целое \\
\hline пропускная способность & действительное \\
\hline
\end{tabular}

На этапе сбора исходных данных существующие векторные данные об электрических сетях, собранные в рамках предыдущего проекта (РФФИ-РГО №17-05$41115)$ будут уточнены и детализированы методами визуального дешифрирования мозаик космических снимков очень высокого и сверхвысокого пространственного разрешения. На данный момент линейные объекты в базе данных включают в себя геометрию объекта, номинальное напряжение, диспетчерское наименование, диспетчерский номер, номер цепи, наименование пункта начала и пункта конца. В ходе дешифрирования для каждой ЛЭП будут присвоены характеристики цепности (количества цепей, подвешенных в составе данной линии на опоры), видовой состав опор (сочетание видов опор на участках). На основе видовых составов опор, а также архивных данных линии будут разбиты на участки 
однородного видового состава, который говорит об одном времени строительства. По архивным данным, а также косвенным дешифровочным признакам будет восстановлено историческое размещение сетей 220-750 кВ.

Для того чтобы избежать краевого эффекта модели, нами также будут собраны пространственные данные о магистральных электрических сетях приграничных регионов стран-соседей на основе мозаик космических снимков очень высокого и сверхвысокого разрешения на общедоступных сервисах. Для этого также будут использованы схемы сетей и архивные данные, в том числе аналоговые (публикации, отчёты, схемы и программы развития), об истории развития электрических сетей. Существующие пространственные данные, отражающие современное размещение магистральных сетей России будут детализированы с точки зрения семантики, т.е. для отдельных участков будут присвоены атрибуты времени строительства, реконструкции, демонтажа, пропускной способности.

Перед импортом данных в базу выполняется предварительная обработка исходных данных. Её основными операциями являются:

1) проецирование данных;

2) топологическая коррекция сети - соединение концов линий с соответствующими подстанциями или электростанциями;

3) обработка сложной геометрии - гиперрёбер, которые описывают роль отпаек в электрических сетях;

4) семантический разбор названий объектов и наполнение атрибутивной таблицы на основе топологических правил.

Для чтения информации из базы данных пользователями разрабатывается программный интерфейс обращения к базе. Он включает набор типовых запросов, с помощью которых пользователь может получить интересующую его информацию. При этом в качестве пользователя может выступать внешняя система, которая, например, запрашивает данные, чтобы на их основе построить карту электрической сети региона на определённый год или подсчитать характеристики надёжности/уязвимости узла электросети за несколько лет. Обращение к программному интерфейсу выполняется по URL.

Для получения исходных данных используется программа Google Earth. Предварительная обработка данных выполняется с помощью скриптов на языке программирования Python с использованием модуля Аrсру. В роли системы управления базой данных выступает PostgreSQL, а для формирования программного интерфейса применяется PostgREST.

\section{РЕЗУЛЬТАТЫ ИССЛЕДОВАНИЯ И ИХ ОБСУЖДЕНИЕ}

В рамках проекта впервые планируется создать согласованную многовременную пространственную базу данных, которая послужит основой для анализа структурных особенностей электрических сетей.

Безусловно, за рубежом есть исследования эволюции электрических сетей, но, как правило, эти исследования оперируют схематичным графом сети без привязки к реальной пространственной геометрии [Buzna, 2009; Rosas-Casals, 2010]. В результате такого подхода не учитываются особенности метахронного развития сети, т.е. когда одна линия, являющаяся единым ребром графа, состоит из участков разного времени строительства [Каргашин и дp., 2016]. Неучёт топоморфологических отношений в сети ведёт к потере информации о своеобразной мозаичности электрических сетей, что в свою очередь обуславливает ухудшение качества пространственного анализа.

На основе обозначенной структуры базы данных пользователь сможет, например, запрашивать состояние сети на конкретный год, либо увидеть, как менялась трасса в 
результате реконструкции. Он сможет запускать инструменты расчёта структурных показателей либо для всей сети в целом на конкретный год, либо их изменение за определённый период времени.

Эволюционный взгляд на состояние структуры сети позволит сделать выводы о том, какие элементы становятся более или менее структурно уязвимы. Это в свою очередь поможет делать рекомендации по развитию сети в будущем.

\section{ВЫВОДЫ}

Предложенная структура базы данных позволяет систематизировать многовременной массив исходной пространственной и атрибутивной информации о магистральных электрических. Структура позволяет добавлять вновь получаемые данные об исследуемых объектах. Параметры ввода/вывода из эксплуатации могут использоваться для запросов с учётом временного аспекта наборов данных и при этом сохраняется возможность ручного редактирования, дополнения данных через ГИС интерфейс. Например, в результате запроса по времени можно будет получить поднабор сетевых данных по состоянию на конкретный год, что применимо для дальнейшего сетевого анализа. Выполняя запрос по названию линии, можно будет получать множество всех трасс этой линии за все годы её существования. Более сложные запросы позволят выявлять такие структурные изменения в сети, как появление разрезок, отпаек, их количество за каждый год, рассчитывать изменения центральности по промежуточности и других показателей для конкретного ребра сети с течением времени.

База данных, обладающая данной структурой, с программным интерфейсом запросов применима для выполнения расчётов параметров устойчивости электросети, использования геоинформационных методов обработки данных, картографической визуализации данных.

Разработана структура удобная для редактирования и наполнения и вполне пригодная для дальнейшей работы в качестве фундамента информационной системы.

\section{БЛАГОДАРНОСТИ}

Исследование выполнено при поддержке Совета по грантам Президента Российской Федерации, грант № МК-5343.2021.1.5.

\section{ACKNOWLEDGEMENTS}

The study was funded by the Council for Grants of the President of the Russian Federation, grant No MK-5343.2021.1.5.

\section{СПИСОК ЛИТЕРАТУРЫ}

1. Каргашин П.Е., Новаковский Б.А., Прасолова А.И., Карпачевский А.М. Изучение пространственной конфигурации электросетей по космическим снимкам. Геодезия и картография, 2016. №3. С. 50-55.

2. Фаддеев А.М. Оценка уязвимости энергосистем России, стран ближнего зарубежья и Европы к каскадным авариям. Вестник Московского университета. Серия 5: География, 2016. № 1. С. 46-53.

3. Buzna L. The evolution of the topology of high-voltage electricity. International Journal of Critical Infrastructures, 2009. V. 5. No 1/2. P. 72-85.

4. Crucitti P., Latora V., Marchiori M. Locating critical lines in high-voltage electrical power grids. Fluctuation and Noise Letters, 2005. No 2(5). P. 201-208. 
5. George B., Shekhar S. Time-Aggregated Graphs for Modeling Spatio-temporal Networks. Journal on Data Semantics XI. Lecture Notes in Computer Science, 2008, V. 5383. P. 191213. DOI: $10.1007 / 978-3-540-92148-6$ 7.

6. Medjroubi $W$., Vogt T. Open source data and models for a sustainable power grid modelling and analysis. 1st Int. Conf. on Large-Scale Grid Integration of Renewable Energy, New Delhi, India, 2017.

7. Rosas-Casals M. Power Grids as Complex Networks: Topology and Fragility. Complexity in Engineering, 2010. P. 21-26. DOI: 10.1109/COMPENG.2010.23.

8. Rosas-Casals M., Valverde S., Solé R.V. Topological vulnerability of the European power grid under errors and attacks. International Journal of Bifurcation and Chaos in Applied Sciences and Engineering, 2007. V. 17(7). P. 2465-2475.

9. Wang E., Cook D., Hyndman R. J. A new tidy data structure to support exploration and modeling of temporal data. Journal of Computational and Graphical Statistics, 2020. V. 29. No 3. P. 466-478.

10. Wickham H. Tidy data. Journal of statistical software. 2014. V. 59. No 10. P. 1-23.

\section{REFERENCES}

1. Buzna L. The evolution of the topology of high-voltage electricity. International Journal of Critical Infrastructures, 2009. V. 5. No. 1/2. P. 72-85.

2. $\quad C r u c i t t i ~ P .$, Latora $V$., Marchiori $M$. Locating critical lines in high-voltage electrical power grids. Fluctuation and Noise Letters, 2005. No 2(5). P. 201-208.

3. Faddeev A. Assessment of vulnerability of power systems of Russia, CIS countries and Europe to cascade accidents. Bulletin of Moscow University. Series 5: Geography, 2016. No 1. P. 46-53 (in Russian).

4. Kargashin P.E., Novakovsky B.A., Prasolova A.I., Karpachevskiy A.M. Study of the spatial configuration of power grids from satellite images. Geodesy and cartography, 2016. No 3. P. 50-55 (in Russian).

5. George B., Shekhar S. Time-Aggregated Graphs for Modeling Spatio-temporal Networks. Journal on Data Semantics XI. Lecture Notes in Computer Science, 2008. V. 5383. P. 191213. DOI: $10.1007 / 978-3-540-92148-6$ 7.

6. Medjroubi $W$., Vogt T. Open source data and models for a sustainable power grid modelling and analysis. 1st Int. Conf. on Large-Scale Grid Integration of Renewable Energy, New Delhi, India, 2017.

7. Rosas-Casals M. Power Grids as Complex Networks: Topology and Fragility. Complexity in Engineering, 2010. P. 21-26. DOI: 10.1109/COMPENG.2010.23.

8. Rosas-Casals M., Valverde S., Solé R.V. Topological vulnerability of the European power grid under errors and attacks. International Journal of Bifurcation and Chaos in Applied Sciences and Engineering, 2007. V. 17(7). P. 2465-2475.

9. Wang E., Cook D., Hyndman R. J. A new tidy data structure to support exploration and modeling of temporal data. Journal of Computational and Graphical Statistics, 2020. V. 29. No 3. P. 466-478.

10. Wickham H. Tidy data. Journal of statistical software. 2014. V. 59. No 10. P. 1-23. 


\title{
М.В. Грибок ${ }^{1}$
}

\section{ВЫБРОСЫ ЗАГРЯЗНЯЮЩИХ ВЕЩЕСТВ В АТМОСФЕРУ ОТ СТАЦИОНАРНЫХ ИСТОЧНИКОВ: АНАЛИЗ ВОЗМОЖНОСТЕЙ ВИЗУАЛИЗАЦИИ С ПОМОЩЬЮ ИНТЕРАКТИВНОЙ ИНФОГРАФИКИ}

\begin{abstract}
АННОТАЦИЯ
В статье представлен анализ возможностей визуализации данных о выбросах загрязняющих веществ в атмосферу от стационарных источников при помощи интерактивной инфографики. Использованы данные, размещённые на официальном сайте Росприроднадзора, о различных характеристиках выбросов предприятий от уровня муниципальных образований до России в целом. Рассмотрены примеры визуализации аналогичных и близких к ним данных, в т.ч. представленные в докладах Минприроды, Национальном атласе России и Экологическом атласе России. Рассмотрен ряд программных продуктов, предназначенных для создания интерактивной инфографики, в т.ч. геоинфографики. Среди них выбран онлайн-сервис Datawrapper, где пользователям доступен шаблон карты России в её современных границах. Представлены методические рекомендации по отображению данных о выбросах при помощи интерактивной инфографики для разных уровней обобщения информации. Также созданы примеры интерактивной инфографики: картографическое отображение выбросов загрязняющих веществ по муниципалитетам и столбчатые диаграммы динамики выбросов некоторых специфических загрязняющих веществ. В статье содержатся ссылки на онлайнверсии полученной интерактивной графики. Сделан вывод, что интерактивная инфографика является технологичным, удобным и доступным для широкого круга пользователей инструментом для визуализации данных о выбросах загрязняющих веществ в атмосферу. Наглядная визуализация данных такого типа необходима в сфере экологического мониторинга и управления, в сфере экологического образования и просветительской деятельности. Интеграция геоинформационных методов и технологий для создания интерактивной инфографики представляет собой перспективное направление для дальнейших исследований.
\end{abstract}

КЛЮЧЕВЫЕ СЛОВА: выбросы, загрязнение атмосферы, интерактивная инфографика, визуализация, геоинфографика.

\section{Marina V. Gribok ${ }^{2}$}

\section{AIR POLLUTION FROM STATIONARY SOURCES: ANALYSIS OF VISUALIZATION CAPABILITIES USING INTERACTIVE INFOGRAPHICS}

\begin{abstract}
The article presents an analysis of the possibilities of visualizing data on emissions of pollutants into the atmosphere from stationary sources using interactive infographics. We used data posted on the official website of Rosprirodnadzor on various characteristics of emissions from

\footnotetext{
1 Московский государственный университет имени М.В. Ломоносова, географический факультет, Ленинские горы, д. 1, 119991, Москва, Россия, e-mail: gribok.marina@gmail.com

2 Lomonosov Moscow State University, Faculty of Geography, Leninskie Gory 1, 119991, Moscow, Russia, e-mail: gribok.marina@gmail.com
} 
the level of municipalities to Russia as a whole. Examples of visualization of similar data are presented in the reports of the Ministry of Natural Resources, the National Atlas of Russia and the Environmental Atlas of Russia. We have reviewed software products for creating interactive infographics, including geo-infographics. Among them, we chose the online service Datawrapper, where a template for a map of Russia in its modern borders is available to users. Methodological recommendations for displaying emission data using interactive infographics for different levels of information generalization are presented. Examples of interactive infographics have also been created: a map of polluting emissions by municipalities and bar charts of the dynamics of some specific pollutants emissions.

The article contains links to online versions of the resulting interactive graphics. It is concluded that interactive infographics are a technological, convenient and accessible tool for a wide range of users to visualize data on emissions of pollutants into the atmosphere. Visualization of this type of data is necessary for the field of environmental monitoring and management, in the field of environmental education and enlightenment activities. The integration of geoinformation technologies and technologies for creating interactive infographics is a promising direction for further research.

KEYWORDS: emissions, atmospheric pollution, interactive infographics, visualization, geoinfographics.

\section{ВВЕДЕНИЕ}

Наглядное графическое представление экологической информации - один из важнейших аспектов в решении задач, связанных с принятием стратегических решений на основе представляемых данных, а также в образовательной [Кузнеиова, 2015] и просветительской деятельности [Соловьева, 2010]. Географическая карта или серия карт только один из возможных вариантов отображения информации, который не всегда является оптимальным с точки зрения наглядности. Помимо карт могут применяться различные типы графиков, диаграмм или более сложные виды инфографики, в том числе интерактивная инфографика. Её отличие от статичного отображения данных в том, что пользователь может каким-либо образом взаимодействовать с изображением на экране компьютера или мобильного устройства. В наиболее простом случае это взаимодействие заключается в том, что при нажатии на отдельные элементы графики на экране появляется какая-либо дополнительная информация. Более сложные варианты интерактивности могут подразумевать выбор пользователем отдельных параметров для визуализации, например, временного интервала отображаемых данных или открытие дополнительных вкладок с графикой.

В настоящее время функционирует большое количество разнообразных интернетресурсов, где пользователи могут получить информацию о загрязнении окружающей среды и других экологических проблемах отдельных городов, стран или планеты в целом через просмотр и взаимодействие с интерактивной инфографикой. Например, это проект Greenpeace о загрязнении воздуха Москвы ${ }^{1}$ или проект World Air Quality Index². Оба интернет-ресурса представляют собой интерактивную карту, на которой пользователь может менять масштаб, приближаясь к интересующей его территории, и нажимать на отдельные точки, получая по ним дополнительные графики.

Также интерактивная инфографика в последние годы всё чаще используется в качестве иллюстраций к онлайн-публикациям на экологическую тематику и становится неотъемлемой частью экологической журналистики [Деева, Клеменова, 2021]. В качестве

\footnotetext{
Электронный pecypc: https://maps.greenpeace.org/air/ (дата обращения 13.05.2021).
}

Электронный ресурc: https://waqi.info/ (дата обращения 13.05.2021). 
примера журналистского материала по теме загрязнения воздуха можно привести материал «Непрозрачно, как воздух» ${ }^{1}$ (автор - Ангелина Давыдова), где в доступной форме подробно разъясняется, чем опасно загрязнение воздуха разными группами веществ, как происходит мониторинг качества воздуха и где можно получить данные. Текстовые описания здесь дополнены наглядными иллюстрациями, ссылками на различные интернет-ресурсы и элементами интерактивной инфографики. Подобные материалы, рассчитанные на широкий круг читателей, играют важную роль в популяризации знаний о проблеме загрязнения атмосферы и повышают вовлечённость населения в борьбу за чистоту воздуха.

Основной источник загрязнения атмосферного воздуха в России - выбросы загрязняющих веществ от стационарных объектов, среди которых в 2020 году наибольший вклад в совокупный объём выбросов, согласно данным Росприроднадзора, внесли предприятия добывающей промышленности. Данные о динамике и структуре выбросов, представленные в виде инфографики, могут использоваться в качестве наглядных материалов, рассказывающих о проблеме загрязнения воздуха на разных масштабных уровнях - от муниципальных образований до России в целом.

2020 год - первый в ходе реализации национального проекта «Экология», в состав которого входит федеральный проект «Чистый воздух». Поэтому именно сейчас на всероссийской повестке дня стоят вопросы о том, достигнуты ли первые целевые показатели проекта и как за прошедший год изменилась ситуация с выбросами загрязняющих веществ в атмосферу.

Целью данного исследования является разработка подходов к отображению официальных данных о выбросах загрязняющих веществ в атмосферу при помощи интерактивной инфографики. Для достижения цели необходимо решить ряд задач:

- изучить открытые официальные данные о выбросах загрязняющих веществ в атмосферу от стационарных источников на всю территорию России,

- изучить имеющийся опыт визуализации аналогичных данных при помощи инфографики и карт, а также опыт их анализа,

- $\quad$ выбрать программные продукты для создания интерактивной инфографики, в т.ч. геоинфографики,

- подобрать оптимальные способы визуализации выбранных данных с позиции наглядности и удобства просмотра.

Проектируемая инфографика рассчитана на широкий круг пользователей, интересующихся проблемами загрязнения атмосферного воздуха, и создаётся в т.ч. в рамках разработки атласной информационной системы нового поколения, предназначенной для мониторинга характеристик экологического состояния регионов и городов Европы и России, при поддержке Российского научного фонда.

\section{МАТЕРИАЛЫ И МЕТОДЫ ИССЛЕДОВАНИЯ}

Наиболее подробные данные о выбросах загрязняющих веществ в атмосферу, имеющиеся в открытом доступе, опубликованы на сайте Росприроднадзора ${ }^{2}$ и являются обобщением материалов отчетности по форме «2-ТП (воздух)», предоставляемой российскими предприятиями. Частично данные представлены на уровне муниципалитетов, частично - на уровне субъектов федерации и всей страны. По каждому муниципалитету указаны данные об общем объёме выбросов загрязняющих веществ в атмосферу и структуре выбросов по восьми группам веществ: диоксиду серы, оксиду углерода, оксиду

1 Электронный pecypc: http://vozdukh.takiedela.ru/ (дата обращения 13.05.2021).

2 Федеральная служба по надзору в сфере природопользования. Отчет по форме 2-ТП (воздух).

Электронный pecypc: https://rpn.gov.ru/activity/reports-receiving/air/ (дата обращения 13.05.2021) 
азота, углеводородам (без летучих органических соединений), летучим органическим соединениям, прочим газообразным и жидким веществам, а также твёрдым веществам.

На уровне субъектов федерации представлены данные по выбросам отдельных загрязняющих веществ, таких как сажа, бенз(а)пирен, формальдегид, метан и т.д. (всего более 20 веществ и их групп). Также на уровне субъектов РФ на сайте Росприроднадзора содержатся данные о выбросах по отраслям экономики. В настоящее время доступны массивы данных за 2019 и 2020 гг.

Данные за более ранние годы представлены на сайте Росстата в разделе «База данных показателей муниципальных образований». А в разделе «Окружающая среда» опубликованы обобщённые данные о выбросах по России в целом и по субъектам РФ, также включая структуру по отраслям экономики и основным группам загрязняющих веществ.

Для понимания возможностей использования перечисленных данных были изучены научные публикации, в основе которых лежит анализ массивов данных о выбросах загрязняющих веществ в атмосферу по всей России [Битюкова, Петухова, 2018; Тикунов и дp., 2017] и отдельным регионам [Аюржанаев и др., 2016; Черногаева и др., 2019].

Примеры графического отображения данных о выбросах представлены в Государственных докладах Минприроды «О состоянии и об охране окружающей среды Российской Федерации» ${ }^{1}$. На рис. 1 собраны иллюстрации из госдоклада за 2019 год, демонстрирующие данные о выбросах загрязняющих веществ в атмосферу от стационарных источников. Основной используемый графический приём - линейные графики динамики, совмещённые со структурой выбросов по группам веществ. В других источниках, как правило, используются схожие графические приёмы, иногда дополняемые круговыми диаграммами, иллюстрирующими структуру выбросов - как, например, структура по отраслям экономики в докладе Министерства экологии Челябинской областиㄴ

Аналогичный Госдоклад Минприроды за 2017 год дополнен интерактивной версией, доступной на отдельном сайте 3 . Здесь представлен более широкий набор визуализаций. В частности, добавлена визуализация сравнения выбросов по федеральным округам, расширен перечень тяжёлых металлов. Отдельные графики выполнены с использованием интерактивных элементов - показа значений и подписей при нажатии на отдельные точки.

Что касается картографирования выбросов загрязняющих веществ в атмосферу, наиболее информативные, на наш взгляд, карты представлены в Экологическом атласе России [2017, с. 190-193]. На первой карте при помощи кружков разного размера представлен валовой объём выбросов по городам, цвет кружков обозначает долю выбросов от стационарных источников в валовом объёме выбросов. При помощи способа картограмм показана доля выбросов от стационарных источников по субъектам федерации. На второй карте совмещены способы картограмм и картодиаграмм по субъектам РФ. При помощи картограмм показан индекс токсичности (отношение приведённого выброса к валовому), а при помощи картодиаграмм - структура выбросов по основным группам веществ.

1 Государственный доклад о состоянии и об охране окружающей среды Российской Федерации в 2019 году. Электронный ресурс:

https://www.mnr.gov.ru/docs/gosudarstvennye_doklady/proekt_gosudarstvennogo_doklada_o_sostoyanii_i _ob_okhrane_okruzhayushchey_sredy_rossiyskoy_federat2019/(дата обращения 13.05.2021)

2 Министерство экологии Челябинской области. Вклад отраслей экономики в загрязнение воздушного бассейна, 2016 г. Электронный ресурс:

https://mineco174.eps74.ru/htmlpages/Show/protectingthepublic/2016/211Vkladotraslejekonomikivza (дата обращения 13.05.2021).

3 Государственный доклад о состоянии и об охране окружающей среды Российской Федерации в 2017 году, интерактивная версия. Электронный ресурс: https:/gosdoklad-ecology.ru// (дата обращения 13.05.2021). 
Рисунок 2.31 - Динамика объема выбросов от стационарных источников по видам экономической деятельности, 2010-2019 гг.

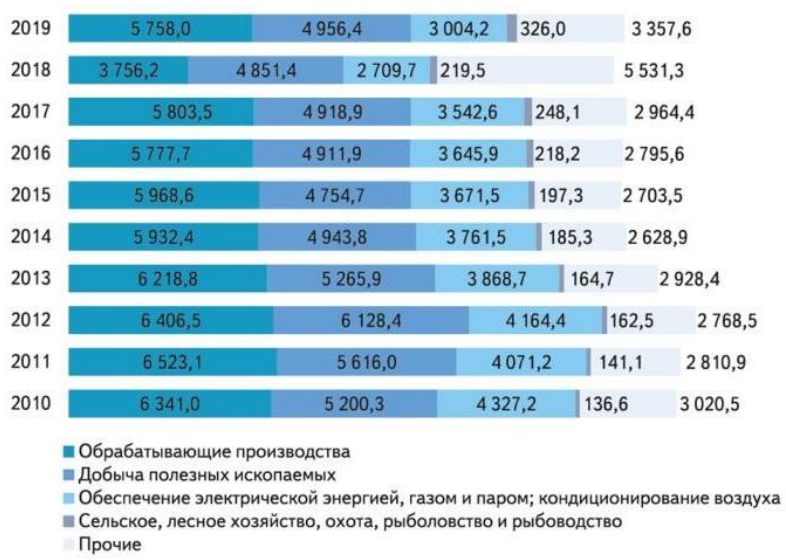

Рисунок 2.33 - Динамика выбросов основных загрязняющих веществ в атмосферный воздух от стационарных источников, 2010-2019 гг., тыс. т

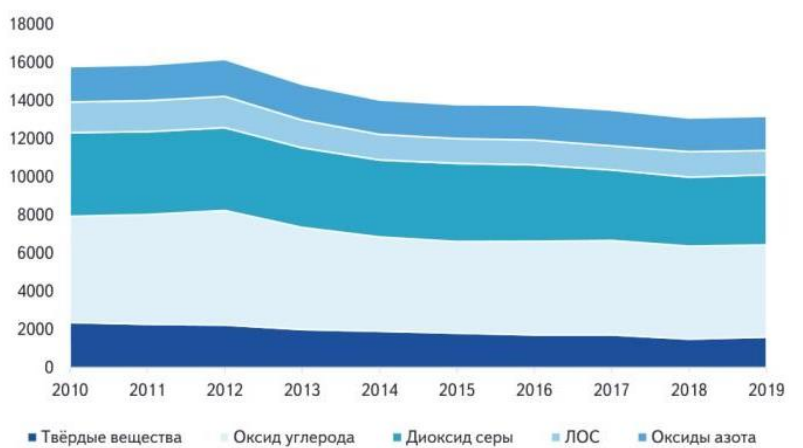

Рисунок 2.32 - Динамика выбросов твердых, газообразных и жидких веществ, отходящих от стационарных источников, 2010-2019 гг., тыс. т

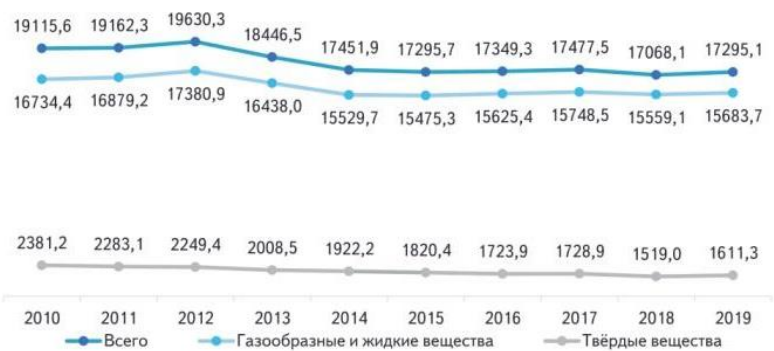

Рисунок 2.35 - Динамика выбросов тяжелых металлов от стационарных источников, 2010-2019 гг., тыс. т

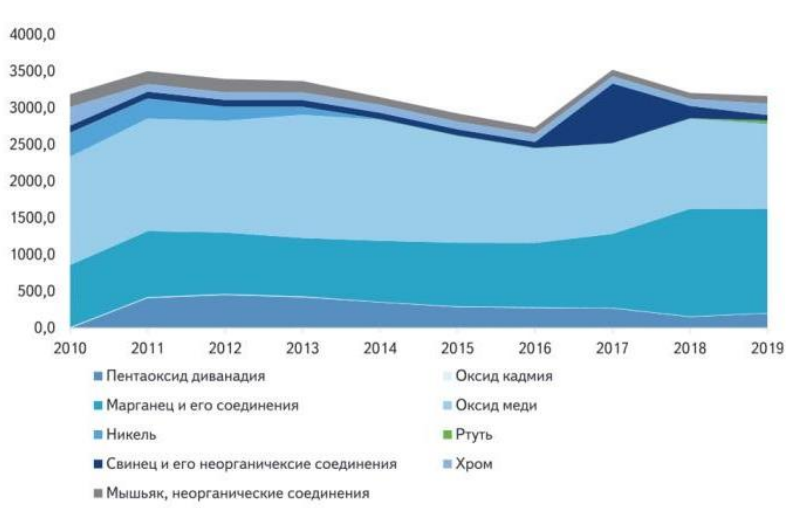

Рис. 1. Иллюстрации о выюросах в атмосферу из Государственного доклада о состоянии и об охране окружающей среды Российской Федеращии в 2019 году

Fig. 1. Illustrations with atmospheric emissions from the State Report on the State and Environmental Protection of the Russian Federation in 2019

Карта такой же тематики есть и в Национальном атласе России (2-й том, карта «Выбросы загрязняющих веществ в атмосферный воздух городов»1 ${ }^{1}$. При помощи кружков на ней отображены города, суммарный объём выбросов в которых иллюстрируют одновременно и цвет, и размер кружка. Площадные условные знаки на данной карте отсутствуют.

Рассмотренные примеры иллюстрируют основные способы показа данных о выбросах загрязняющих веществ в России при помощи графиков и карт. Интерактивная инфографика для показа подобных данных используется крайне редко, хотя именно она даёт возможность совмещать показ и территориального распределения, и динамики, и структуры выбросов, делая визуализацию комплексной, более информативной и наглядной.

1 Национальный Атлас России. Том 2. Раздел «Состояние окружающей среды». Электронный ресурс: https://nationalatlas.ru/tom2/444.html (дата обращения 13.05.2021) 
Для решения задач данного исследования подходы к созданию инфографики разрабатывалась в основном на концептуальном уровне в виде описаний, дополненных образцами интерактивной визуализации. В дальнейшем для создания инфографики в рамках проекта по разработке АИС планируется использовать специально разработанное программное обеспечение, а на данном этапе выбор программного продукта для создания образцов графики происходил с учётом следующих условий:

- многофункциональный и удобный интерфейс для разработки и оформления интерактивной инфографики, в т.ч. геоинфографики на территорию России;

- бесплатный доступ;

- возможность создания онлайн-версий графики.

Выбор осуществлялся среди программных продуктов, упоминания о которых содержатся в современных научных публикациях по теме интерактивных визуализаций геоданных [Toural-Bran et al., 2020; Bernasconi, Grandi, 2021]. Несмотря на обширность перечней существующих в настоящее время программ и онлайн-ресурсов для создания инфографики, большинство из них не удовлетворяют одному или нескольким условиям, перечисленным выше. От использования нескольких программ для создания разных видов графики было решено отказаться из-за трудоёмкости их единообразного оформления при совместном использовании.

Почти полностью подходящим по всем параметрам признан один из наиболее популярных программных продуктов для создания инфографики Tableau Public ${ }^{1}$. Он предоставляет широкий набор возможностей для визуализации данных с помощью разнообразных средств инфографики и позволяет совмещать их на одном экране, создавая сложные сочетания интерактивной графики, текста, растровых иллюстраций и других элементов. Среди шаблонов графики Tableau Public содержит картографическую основу на весь мир, на которую можно наносить площадные или точечные условные знаки в выбранном масштабе. Однако существенным минусом является невозможность замены встроенной проекции Меркатора на другие проекции - для территории всей России это весьма критичный недостаток, из-за которого пришлось отказаться от использования Tableau Public в данном исследовании. Однако для территорий отдельных регионов или большинства других стран этот программный продукт представляется весьма удобным для создания интерактивной геоинфографики.

Похожая проблема имеется и у сервиса Flourish² ${ }^{2}$ В отличие от Tableau Public, здесь доступно несколько шаблонов с географическими основами на разные страны и макрорегионы, а также есть некоторые ограниченные возможности настройки проекции карты, однако для территории России этот сервис нам представляется не слишком удобным. Преимуществами Flourish являются отсутствие необходимости установки программы на своём ПК (работает полностью онлайн, нужна только регистрация), а также большое количество шаблонов разнообразных данных и графики, благодаря которым подготовка собственных данных к визуализации существенно упрощается.

Для целей данного исследования выбран онлайн-сервис Datawrapper ${ }^{3}$. Он содержит основу для карты современной России и ряд основных шаблонов для инфографики, среди которых разные типы столбчатых и круговых диаграмм, линейные графики и другие базовые шаблоны (рис. 2). Каждый из шаблонов настраивается под потребности пользователя по ряду параметров, касающихся отображения графики, её шрифтового и цветового оформления. Графика, построенная в Datawrapper, нередко встречается в

\footnotetext{
Электронный pecypc: https://public.tableau.com/ (дата обращения 13.05.2021)

Электронный ресурс: https://flourish.studio/ (дата обращения 13.05.2021)

Электронный pecypc: https://www.datawrapper.de/ (дата обращения 13.05.2021)
} 
различных онлайн-публикациях - например, в отчёте Всемирного Банка ${ }^{1}$, иллюстрирующем данные о глобальном потеплении.

Split Bars Stacked Bars $\begin{gathered}\text { Grouped } \\ \text { Bars }\end{gathered}$

Рис. 2. Шаблоны инфографики в Datawrapper

Fig. 2. Infographic templates in Datawrapper

Таким образом, при разработке подходов к созданию интерактивной инфографики учитывались особенности имеющихся данных о выбросах загрязняющих веществ в атмосферу, предшествующий опыт их анализа и визуализации, а также функциональные возможности Datawrapper.

\section{РЕЗУЛЬТАТЫ ИССЛЕДОВАНИЯ И ИХ ОБСУЖДЕНИЕ}

Результатом исследования стал перечень методических подходов и рекомендаций, относящихся к производству интерактивной инфографики о выбросах загрязняющих веществ в атмосферу.

1. Данные на уровне муниципальных образований для отображения в виде инфографики нуждаются в отборе и обобщении, т.к. невозможно наглядно отобразить в одной графике более 2500 муниципалитетов, данные по которым содержатся в таблицах Росприроднадзора. Наиболее наглядным способом отображения таких данных, по нашему

1 The World Bank. Towards a Climate-Smart World: 12 Ways for a Resilient Future. Электронный ресурс: https://www.worldbank.org/en/news/immersive-story/2017/12/01/towards-a-climate-smart-world-12-waysfor-a-resilient-future (дата обращения 13.05.2021). 
мнению, являются картодиаграммы. При этом интерактивность инфографики дает возможность не размещать на карте одновременно множество подписей, а показывать их только при нажатии пользователем на соответствующую точку. В качестве примера создана интерактивная геоинфографика, скриншот которой представленная на рис. 3 .

Для отображения выбраны только те муниципалитеты, где объем выбросов в 2020 году превысил 5000 тонн. Размер кружка обозначает объем выбросов, а цвет - годовое изменение объёма выбросов. При нажатии на каждый кружок появляется название субъекта РФ, название муниципалитета, а также информация об объёме выбросов в 2019 и 2020 гг.

\section{Выбросы загрязняющих веществ в атмосферу}

Размер кружка - объём выбросов в 2020 г., цвет - изменение с 2019 по 2020 г.

口ост более чем в 1,5 раза Рост менее чем в 1,5 раза Снижение более чем в 1,5 раза Снижение менее чем в 1,5 раза

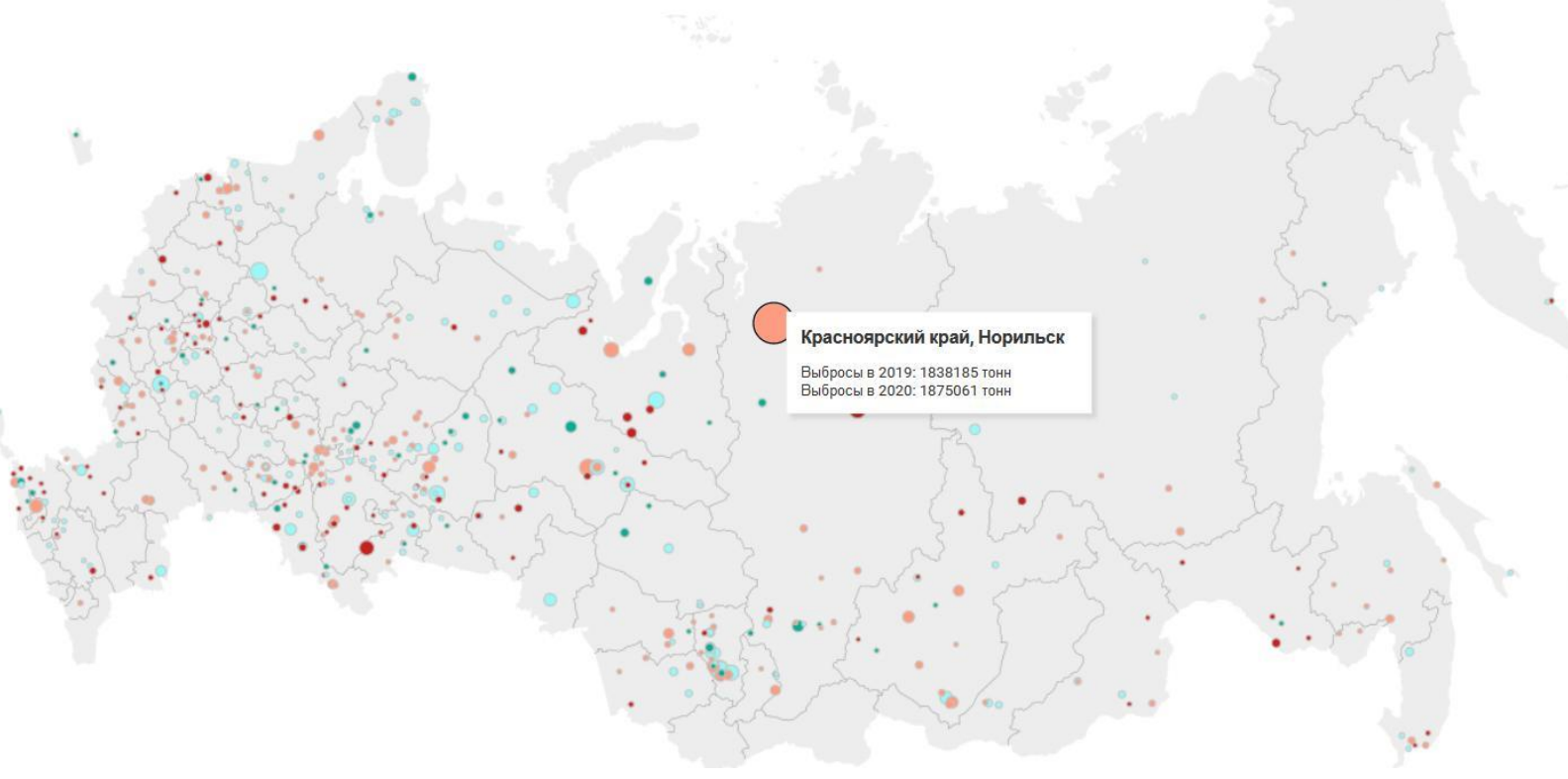

Рис. 3. Интерактивная геоинфографика об объёме выбросов загрязняющих вещчеств в 2019 и 2020 г2. по муниципальным образованиям (скриншот), режим доступа: https://datawrapper.dwcdn.net/3ifOx/3/ (дата обращения 13.05.2021)

Fig. 3. Interactive infographics on the volume of air pollutant emissions in 2019 and 2020 by municipalities (screenshot), access link: https://datawrapper.dwcdn.net/3ifOx/3/ (access date:

$$
\text { 13.05.2021) }
$$

Аналогичные карты за разные годы могут быть сделаны также по отдельным группам загрязняющих веществ. Благодаря функционалу Datawrapper карта при сохранении сразу становится доступна онлайн, что весьма удобно для совместной работы с данными и визуализациями.

2. Данные на уровне субъектов федерации также нагляднее всего иллюстрировать при помощи интерактивных карт, содержащих вкладки с расширенной информацией о каждом регионе. Это могут быть картодиаграммы (например, аналогичные показанным в предыдущем пункте), либо картограммы, для использования которых необходим расчётный относительный показатель [Берлянт, 2002]. В качестве такого показателя может 
быть использована доля выбросов данного региона в общероссийском объёме выбросов. Также в качестве фона могут быть выбраны значения прироста или убыли выбросов за какой-либо период. Расчётные показатели, полученные при делении объёма выбросов на численность населения или на площадь, представляются менее удачными, т.к. могут искажать и усложнять восприятие информации о выбросах загрязняющих веществ пользователем геоинфографики.

Внутри информационных вкладок, открывающихся при нажатии на территорию субъекта РФ, может быть помещена инфографика о динамике выбросов и (или) структуре выбросов по разным признакам: типам загрязняющих веществ, видам экономической деятельности, муниципальным образованиям внутри субъекта РФ. В Datawrapper предусмотрено несколько способов визуализации структуры, в т.ч. совместного показа структуры и динамики, как было показано на рис. 2.

Также уместным для наглядного показа объёма выбросов нам представляется использование анаморфоз [Гусейн-Заде, Тикунов, 1999]. С их помощью регионы, лидирующие по объёму выбросов, будут показаны с наибольшим преувеличением, что в данном случае повысит наглядность визуализации и даст возможность оценить, насколько сильно различаются субъекты РФ по данному показателю.

3. Данные на уровне России в целом - наиболее обширная группа показателей. Так, например, структура выбросов может быть представлена по следующим признакам:

- основные группы загрязняющих веществ;

- сферы экономики;

- технологические процессы (сжигание топлива либо другие процессы);

- типы предприятий;

- территориальная принадлежность (например, федеральные округа).

Bce перечисленные типы структур могут быть также показаны в динамике с помощью более сложных видов графики, доступных в Datawrapper.

Отдельного внимания, на наш взгляд, требует такая группа показателей как выбросы т.н. специфических загрязняющих веществ. Это более 100 различных загрязнителей, по некоторым из которых есть данные также в разрезе субъектов РФ. Объёмы выбросов этих веществ очень сильно варьируются. Например, выбросы метана в 2020 году составили 3,7 миллионов тонн, а бенз(а)пирена - 324 тонны. Таким образов, сравнивать при помощи инфографики выбросы этих веществ друг с другом без дополнительной нормировки данных не имеет смысла (а нормированные данные воспринимаются сложнее, чем исходные показатели) однако, динамика выбросов каждого из веществ может стать важной информацией для пользователей. Поэтому в данном случае при создания интерактивной инфографики нами принято решение предоставить выбор вещества самому пользователю. В отдельной вкладке он может выбрать интересующее вещество и посмотреть динамику его выбросов. Скриншот полученной инфографики представлен на рис. 4.

В качестве дополнительной информации, появляющейся при нажатии на столбцы, можно добавить перечень субъектов РФ, где выбросы соответствующего вещества наибольшие.

Данный пример показывает, что выбор показателей для отображения тоже может быть элементом интерактивности инфографики. Особенно такая опция актуальна в тех случаях, когда показателей много и они одновременно не помещаются на экране при визуализации, либо когда одновременная визуализация не является наглядной. 


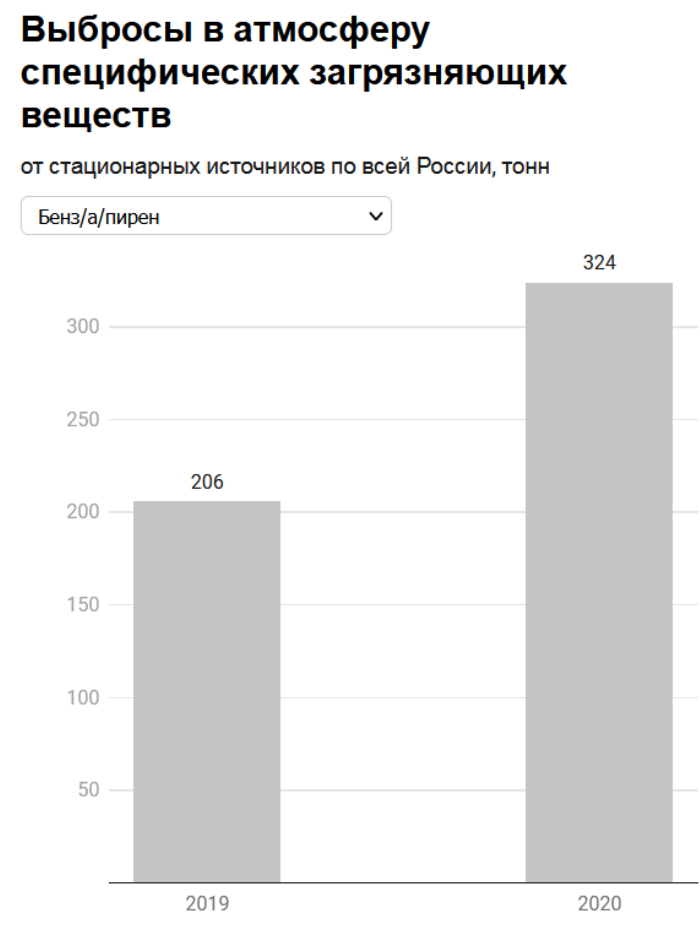

Рис. 4. Интерактивная инфографика о выбросах специфических загрязняющих веществ в 2019 и 2020 г2. (скриншот), режим доступа: https://www.datawrapper.de/_C5Tdz/

(дата обращения 13.05.2021)

Fig. 4. Interactive infographics on emissions of specific pollutants in 2019 and 2020 (screenshot), access link: https://www.datawrapper.de/_CS5Tdz/(access date: 13.05.2021)

\section{ВЫВОДЫ}

Интерактивная инфографика - это простой в исполнении и наглядный способ отображения данных о выбросах загрязняющих веществ в атмосферу. Данные Росприроднадзора о структуре и динамике объёма выбросов стали удобным «полигоном» для анализа возможностей создания интерактивной инфографики разных типов, в т.ч. геоинфографики. На примере этих данных разработан ряд подходов и рекомендаций к отображению информации разных уровней - от муниципальных районов до России в целом.

В настоящее время существуют и активно развиваются онлайн-сервисы, позволяющие бесплатно и даже без установки какого-либо программного обеспечения создавать интерактивную геоинфографику. По итогам исследования пригодным и удобным для создания интерактивных карт России признан онлайн-сервис Datawrapper.

Совместное использование и дальнейшая интеграция геоинформационных технологий и технологий для создания интерактивной инфографики представляет собой перспективное направление для дальнейших исследований в области визуализации пространственных данных.

\section{БЛАГОДАРНОСТИ}

Исследование выполнено при поддержке РНФ, грант № 20-47-01001.

\section{ACKNOWLEDGEMENTS}

The study was funded by the Russian Science Foundation, grant No 20-47-01001. 


\section{СПИСОК ЛИТЕРАТУРЫ}

1. Аюржанаев А.А., Аюшеева С.Н., Батомункуев В.С., Белозериева И.А., Бешениев А.Н., Дарбалаева Д.А., Еремко 3.С., Михеева А.С., Санжиева С.Г., Цылыпов Б.З. Изменение выбросов загрязняющих веществ в атмосферу Байкальской природной территории. География и природные ресурсы, 2016. №5. Р. 225-233.

2. Берлянт A. M. Картография: Учебник для вузов. М.: Аспект Пресс, 2002. 336 с.

3. Битюкова B.P., Петухова Н.B. Региональные и субрегиональные контрасты промышленного загрязнения воздушного бассейна России в 2008-2016 гг. Экология и промышленность России. 2018. №22 (5). С. 17-23. DOI: 10.18412/1816-0395-20185-17-23.

4. Гусейн-Заде С.М., Тикунов В.С. Анаморфозы: что это такое. УРСС Москва, 1999. $168 \mathrm{c}$.

5. Деева И.В., Клеменова Е.Н. Особенности эко-контента в новых медиа. Вестник Волжского университета им. В.Н. Татищева, 2021, №2 (35). С. 101-108.

6. Кузнецова Е.Ю. Инфографика как образное средство наглядности в экологическом образовании. Материалы междунар. конф. Современные ландшафтные исследования в контексте оптимизации рационального природопользования. Курск, 7-8 октября 2015. С. 303.

7. Соловьева T.В. Инфографика в медийном и учебном текстах. Вестник Новгородского государственного университета им. Ярослава Мудрого. 2010. №57. С. 76-79.

8. Тикунов В.С., Черешня О.Ю., Грибок М.В., Яблоков В.М. Методика оценки регионов России по уровню загрязнения воздуха. Вестник Московского университета. Серия 5: География. 2017. № 5. С. 43-48.

9. Черногаева Г.М., Жадановская Е.А., Малеванов Ю.А. Источники загрязнения и качество атмосферного воздуха Московского региона. Известия Российской академии наук. Серия географическая, 2019. №2. С. 109-116.

10. Экологический атлас России. М.: Феория, 2017. 510 с.

11. Bernasconi A., Grandi S.A Conceptual Model for Geo-Online Exploratory Data Visualization: The Case of the COVID-19 Pandemic. Information, 2021. No 12(2). P. 69. DOI: 10.3390/info12020069.

12. Toural-Bran C., Vizoso Á., Pérez-Seijo S., Rodríguez-Castro M., Negreira-Rey M.C. Information Visualization in the Era of Innovative Journalism. London, Routledge, 2020. $192 \mathrm{p}$.

\section{REFERENCES}

1. Ayurzhanaev A.A., Ayusheeva S. N., Batomunkuev V.S., Belozertseva I.A., Beshentsev A.N., Darbalaeva D.A., Eremko Z.S., Mikheeva A.S., Sanzhieva S.G., Tsydypov B.Z. Changes in emissions of pollutants into the atmosphere of the Baikal natural territory. Geography and Natural Resources, 2016. No 5. P. 225-233 (in Russian).

2. Berlyant A.M. Cartography: Textbook for universities. M.: Aspect Press, 2002. 336 p. (in Russian).

3. Bernasconi A., Grandi S. A Conceptual Model for Geo-Online Exploratory Data Visualization: The Case of the COVID-19 Pandemic. Information, 2021. No 12 (2). P. 69. DOI: 10.3390/info12020069.

4. Bityukova V.R., Petukhova N.V. Regional and sub-regional contrasts of industrial pollution of the Russian air basin in 2008-2016. Ecology and industry of Russia. 2018. No 22 (5). P. 17-23. DOI: 10.18412/1816-0395-2018-5-17-23 (in Russian). 
5. Chernogaeva G.M., Zhadanovskaya E.A., Malevanov Yu.A. Sources of pollution and the quality of atmospheric air in the Moscow region. Proceedings of the Russian Academy of Sciences. Geographical series. 2019. No 2. P. 109-116 (in Russian).

6. Deeva I.V., Klemenova E.N. Features of eco-content in new media. Bulletin of the V.N. Tatishchev Volga State University, 2021. No 2 (35), P. 101-108 (in Russian).

7. Ecological Atlas of Russia. Moscow: Feoriya, 2017. 510 p.

8. Guseyn-Zadeh S.M., Tikunov V.S. Anamorphoses: what is it. URSS Moscow, 1999. 168 p. (in Russian).

9. Kuznetsova E.Yu. Infographics as a figurative means of visibility in environmental education. Materials of the International conference. Modern landscape research in the context of optimization of rational nature management. Kursk, October 7-8. 2015. P. 303 (in Russian).

10. Solovyova T.V. Infographics in media and educational texts. Bulletin of the Novgorod State University named after Yaroslav the Wise. 2010. No 57. P. 76-79 (in Russian).

11. Tikunov V.S., Chereshnya O.Yu., Gribok M.V., Yablokov V.M. Assesment of Russian regions in terms of the air pollution level. Vestnik Moskovskogo universiteta. Seriya 5, Geografiya. 2017. No 5. P. 43-48 (in Russian).

12. Toural-Bran C., Vizoso Á., Pérez-Seijo S., Rodríguez-Castro M., Negreira-Rey M.C. Information Visualization in the Era of Innovative Journalism. London, Routledge, 2020. 192 p. 


\title{
А.М. Гафуров ${ }^{1}$, О.П. Ермолаев ${ }^{2}$, Б.М. Усманов ${ }^{3}$, П.В. Хомяков ${ }^{4}$ \\ СОЗДАНИЕ ВЫСОКОТОЧНЫХ ЦИФРОВЫХ МОДЕЛЕЙ ВЫСОТ С ИСПОЛЬЗОВАНИЕМ ГНСС-БПЛА
}

\begin{abstract}
АННОТАЦИЯ
Беспилотные летательные аппараты (БПЛА) все больше вовлечены в геодезические работы, становясь надежной основой для получения информации о трехмерных характеристиках местности. До недавнего времени для надежного планово-высотного обоснования измерений с беспилотных аппаратов использовались наземные опорные точки. Установка подобных марок занимает достаточно продолжительное время, которое увеличивается пропорционально размеру изучаемой территории. Помимо того, что установка марок и их координатная съемка занимают продолжительное время, использование марок приводит (в особенности на больших территориях от 1 кв. км) к искажениям модели, приводящим, в свою очередь, к появлению областей локальных понижений и возвышений там, где их нет на местности. Данные искажения возникают из-за алгоритмов минимизации погрешности при оптимизации положений камер и не поддаются корректировке. Отказ от использования опорных точек без использования иных, уточняющих положения центра проекции снимков, средств приводит к иным геометрическим искажениям, связанным с дисторсией объективов съемочных систем, установленных на БПЛА (так называемые «седловидные» модели). В настоящей работе представлены результаты апробации методики создания высокоточных цифровых моделей высот (ЦМВ) с использованием встроенных в БПЛА приемников глобальной навигационной спутниковой системы (ГНСС). Апробация производилась на 10 объектах Закамья Республики Татарстан (Россия) с площадью, варьирующейся от 4 до 58 гектар. Корректировка положения ГНСС-ровера производилась в постобработке от сети виртуальных базовых станций, расположенных на удалении от 6 до 70 км от места съемки. Для всех объектов погрешности ЦМВ не превышали 0,05 м по осям X, Y и Z, при этом зависимости величины погрешности от размера изучаемой территории выявлено не было. Полученные результаты анализа погрешностей могут говорить о перспективе использования дешевых ГНСС-БПЛА без необходимости организации сети наземных опорных точек, ограничившись только необходимостью установки контрольных точек, что позволит многократно сократить временные затраты на производство работ, в особенности на труднодоступных объектах.
\end{abstract}

КЛЮЧЕВЫЕ СЛОВА: БПЛА, ГНСС, ЦМВ, оценка точности, рельеф, фотограмметрия, болгарские городища.

\footnotetext{
1 Казанский (Приволжский) федеральный университет, Институт экологии и природопользования, Товарищеская, д. 5, 420097, Казань, Россия, e-mail: amgafurov@kpfu.ru

2 Казанский (Приволжский) федеральный университет, Институт экологии и природопользования, Товарищеская, д. 5, 420097, Казань, Россия, e-mail: oleg.yermolayev@kpfu.ru

Казанский (Приволжский) федеральный университет, Институт экологии и природопользования, Товарищеская, д. 5, 420097, Казань, Россия, e-mail: busmanof@kpfu.ru

Казанский (Приволжский) федеральный университет, Институт экологии и природопользования, Товарищеская, д. 5, 420097, Казань, Россия, e-mail: petr.khomyakov@kpfu.ru
} 


\title{
Artur M. Gafurov ${ }^{1}$, Oleg P. Yermolayev ${ }^{2}$, Bulat M. Usmanov ${ }^{3}$, Petr V. Khomyakov ${ }^{4}$ \\ CREATION OF HIGH-PRECISION DIGITAL ELEVATION MODELS USING THE GNSS UAV
}

\begin{abstract}
Unmanned Aerial Vehicles (UAVs) are increasingly involved in surveying work, becoming a reliable basis for information on three-dimensional terrain features. Until now, ground reference points have been used to provide reliable planimetric evidence for measurements from drones. Their placement and coordinates measurement takes quite a long time, which increases proportionally to the area under study. In addition, the use of these marks produces model distortions (especially over large areas of $1 \mathrm{sq}$. $\mathrm{km}$ or more), which then lead to the appearance of areas of local depressions and uplifts where they are not present in the terrain. These distortions arise due to camera position optimization error minimization algorithms and cannot be corrected. Refusing to use ground control points leads to other geometric distortions associated with characteristics of survey system lenses mounted on UAVs (so-called "saddle-shaped" models). This paper presents the results of high-precision digital elevation models creation using built-in UAV Global Navigation Satellite System (GNSS) receivers. The methodology has been tested at ten sites in the Zakamye region of the Republic of Tatarstan (Russia) with an area ranging from 4 to 58 hectares. Correction of GNSS rover position was performed in post-processing from a virtual base station network located at a 6 to $70 \mathrm{~km}$ range from the surveyed sites. For all objects, DEM errors did not exceed $0.05 \mathrm{~m}$ on axes $\mathrm{X}, \mathrm{Y}$, and $\mathrm{Z}$. At the same time, the dependence of the error value on the study area size was not revealed. The received results of the analysis of errors can indicate the prospect of the use of low-cost GNSS-UAVs without the necessity of organizing a network of ground reference points, being limited only to the necessity of installing control points will repeatedly reduce the time of the field works, in particular on hardly accessible objects.
\end{abstract}

KEYWORDS: UAV, GNSS, DEM, accuracy assessment, topography, photogrammetry, Bulgarian settlements.

\section{ВВЕДЕНИЕ}

Беспилотные летательные аппараты (БПЛА) в настоящее время становятся все более распространенным источников трехмерной информации о рельефе. Имея сопоставимую с лидарной съемкой точность и разрешающую способность, БПЛА, благодаря, в том числе, своей доступности, все чаще используются при решении задач динамической геоморфологии, картографии и геодезии. Глобальная навигационная спутниковая система (ГНСС) используется для определения точного положения результатов съемки с беспилотных летательных аппаратов в пространстве [Groves, 2013]. Более точное позиционирование результатов съемки позволяет получить корректную конечную трехмерную модель или ортофотоплан. До недавнего времени использовался подход, основанный на позиционировании на основе координат опорных наземных точек.

\footnotetext{
1 Kazan Federal University, Institute of Ecology and Environmental Sciences, Tovarishcheskaya st. 5, 420097, Kazan, Russia, e-mail: amgafurov@kpfu.ru

2 Kazan Federal University, Institute of Ecology and Environmental Sciences, Tovarishcheskaya st. 5, 420097, Kazan, Russia, e-mail: oleg.yermolayev@kpfu.ru

Kazan Federal University, Institute of Ecology and Environmental Sciences, Tovarishcheskaya st. 5, 420097, Kazan, Russia, e-mail: busmanof@kpfu.ru

$4 \quad$ Kazan Federal University, Institute of Ecology and Environmental Sciences, Tovarishcheskaya st. 5, 420097, Kazan, Russia, e-mail: petr.khomyakov@kpfu.ru
} 
В качестве подобных точек могут выступать как характерные объекты на местности (углы зданий, трубы, неподвижные объекты - крупные валуны и т.д.), так и специально расставленные геодезические марки [Villanueva, Blanco, 2019]. Основное требование к таким маркам - хорошая видимость на снимках, снятых камерой БПЛА на заданной высоте полета. Исследования, проводимые во всем мире, подробно описывают применяемые подходы. Например, используются черно-белые шахматные квадратные полотна различного размера, в зависимости от высоты полета и используемых камер [Dewez, Leroux, Morelli, 2016]. Черно-белые опорные точки хорошо различимы на любой поверхности и позволяют четко определить центр марки. Для камеры с разрешением 12 мегапикселей марки размером 0,5 х 0,5 м отчетливо различаются с высоты 100 м, опорные знаки размером 0,7 х 0,7 м видны с высоты 150 м над точкой взлета [Gafurov, 2021]. Съемка центров марок осуществляется специальным геодезическим ГНСС-приемником, работа которого возможна как в режиме кинематики реального времени (RTK - real time kinematic) [Langley, 1998], так и в режиме кинематики в постобработке (PPK - post-processing kinematic) [Gafurov, 2021]. Основное отличие этих режимов заключается в способе получения устойчивого решения - в случае RTK точные координаты получаются в поле непосредственно во время проведения работы, в случае $\mathrm{PPK}$ - при камеральной обработке. В обоих случаях коррекция положения перемещаемой станции - ровера осуществляется от референсной базовой станции с известными координатами. Для получения наиболее точных результатов, в качестве базовых используют станции, находящиеся на удалении не более 35 км при использовании одночастотных приемников в качестве роверов, и не более 70 км при использовании двухчастотных [Bolkas, 2019].

Количество наземных опорных точек напрямую влияет на качество получаемых результатов. Однако, существуют пороговые значения количества марок, после достижения которых точность определения положения данных, полученных с БПЛА, увеличивается несущественно. Так или иначе, многие исследователи приходят к выводу, что использование для геодезического обоснования более 10 марок не привносит существенных улучшений в точность определения положения модели или ортофотоплана [Tahar, 2013; Villanueva, Blanco, 2019; Gafurov, 2021].

Основной проблемой при использовании наземных опорных точек для позиционирования результатов является трудоемкость их размещения на местности, в особенности, на больших по площади объектах. Отсутствие опорных точек в случае большого расстояния (500 м и больше) между опорными точками, приводит к неопределенности и большим погрешностям определения координат в узлах сетки модели высот [Mancini et al., 2013; Benassi et al., 2017].

Для преодоления проблем трудоемкости проведения полевых работ, а также решения задачи обеспечения передачи точных координат снимков, полученных при аэрофотосъемке, в настоящее время все чаще используются БПЛА с встроенными ГНСС решениями. Как и при классической ГНСС съемки точек, работа с ГНСС-БПЛА возможна как в режиме кинематики реального времени, так и кинематики в постобработке. Из-за специфических особенностей проведения работ в RTK-режиме, требующий устойчивого радио- или Интернет-соединения, наиболее распространен подход при работе в режиме PPK [Dinkov, 2019; Tomaštik et al., 2019; Yu et al., 2019; Zhang et al., 2019]. Постепенному повсеместному развития применения подобного подхода способствует и возрастающая доступность соответствующего оборудования и программного обеспечения.

Целью исследования является апробация методики построения высокоточных цифровых моделей высот (ЦМВ) с использованием доступных ГНСС-БПЛА с учетом имеющегося опыта построения моделей с использованием наземных опорных точек. 


\section{МАТЕРИАЛЫ И МЕТОДЫ}

Апробация методики построения высокоточных ЦМР с использованием ГНССБПЛА была проведена на территории Закамья Республики Татарстан (рис. 1). Закамье Республики Татарстан располагается в лесостепной зоне. Средняя высота на выбранной территории составляет 150 м с максимумом 381 м. Средняя крутизна склонов составляет 1.8 градусов [Ermolaev et al., 2017]. Климат - умеренно-континентальный со среднегодовой температурой 4 градуса Цельсия. Среднегодовое количество осадков умеренное, составляет 454 мм с преобладанием жидких осадков в теплый период. Лесистость Закамья РТ сопоставима со средней лесистостью в Республике Татарстан и составляет 18\%. Распаханность склонов речных бассейнов средняя, составляет 49\% [Ermolaev et al., 2017; Gafurov, Yermolayev, 2020]. Почвенный покров разнообразный, присутствуют основные зональные типы почв от боровых песков до черноземов типичных, однако, большая часть территории покрыта черноземами выщелоченными.

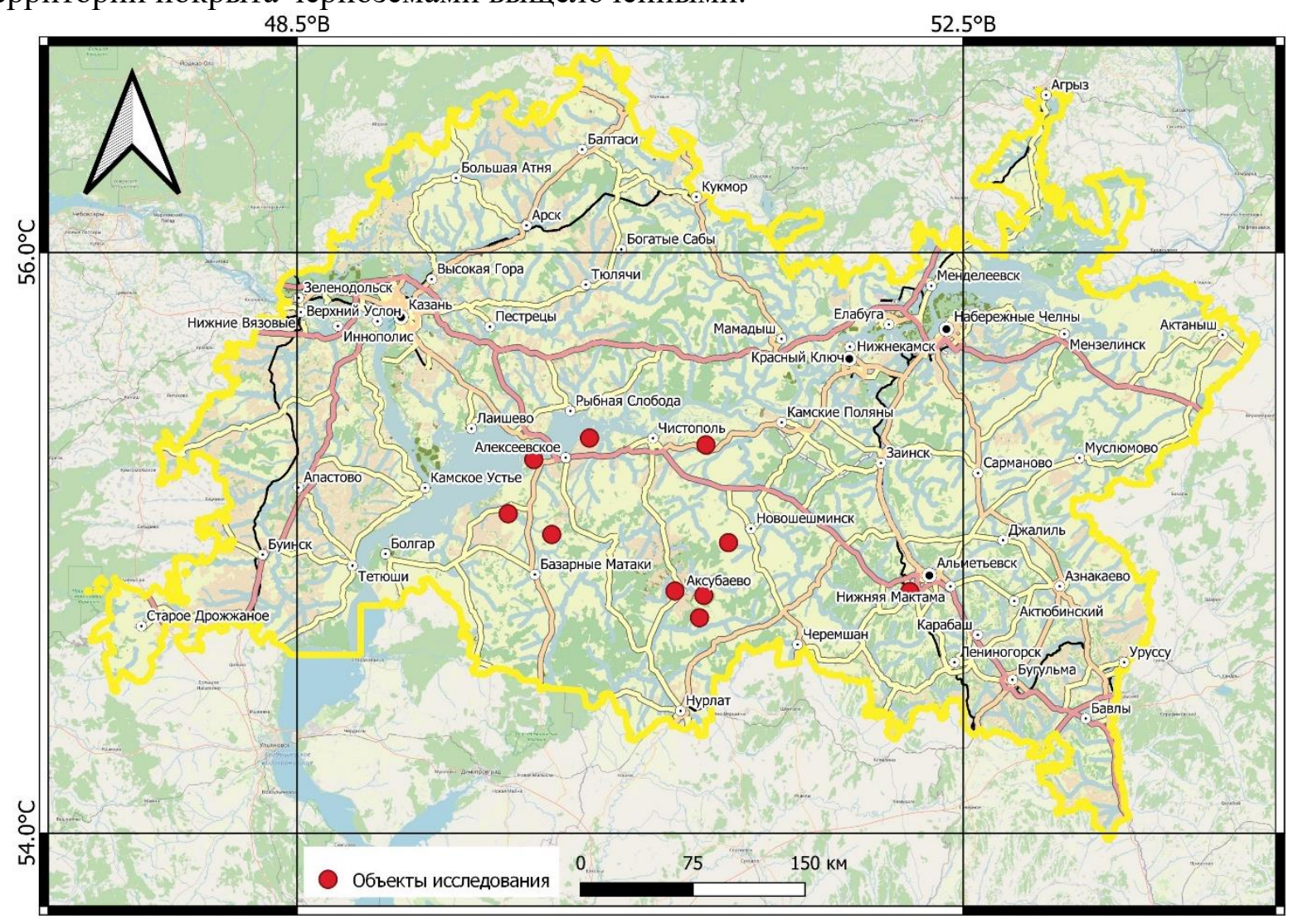

Рис. 1. Территория исследования с отметками тестовых участков Fig. 1. The study area with the test site locations

Для апробации было выбрано 10 объектов различной площади и типа землепользования. Площадь объектов варьируется от 1 до 25 га. 9 объектов представлены территориями средневековых городищ времен Волжской Булгарии [Gainullin et al., 2017] с сохранившимися укрепительными валами, один объект представлен полигоном твёрдых бытовых отходов.

Работы производились с использованием беспилотного летательного аппарата DJI Phantom 4 PRO v2, оснащенного 20-ти мегапиксельной камерой. В модификацию квадрокоптера были внесены изменения с использованием разработанной отечественной компанией TeoDrone системой синхронизации затвора камеры, также позволяющей заменить встроенную систему позиционирования на ГНСС-решение производства 
отечественной фирмы EMLID (рис. 2). В качестве ГНСС приемника выступал модуль EMLID Reach M+ со спиральной антенной TOPGNSS TOP508. Внесенные изменения позволяют осуществлять запись координат с частотой 1 Гц, а время срабатывания затвора камеры сокращено до 0,05 секунд.

Полет и съемка объектов исследования производились полностью в автоматизированном режиме. Для этого с помощью мобильного ПО DroneDeploy в контроллер БПЛА загружалось полетное задание, включающее в себя высоту полета над точкой взлета, а также продольное и поперечное перекрытие между соседними снимками. Для соблюдения единства методики осуществления полетов, на каждом объекте высота полета составила 150 м над точкой взлета, продольное и поперечное перекрытие соседних снимков составило $70 \%$ [Gafurov et al., 2019].

Благодаря произведенным модификациям, во время записи лог-файлов ГНСС приемник в момент срабатывания затвора записывает специальную временную марку. Однако, при камеральной обработке полученных материалов в лог-файл ровера необходимо внести коррекцию с учетом времени задержки срабатывания затвора. Для этого используется программное обеспечение (ПО) UAV Design Tools. RINEX файл с внесенными изменениями в дальнейшем обрабатывается методом PPК в специализированном геодезическом ПО для уравнивания базовых линий. Нами для этого была использована библиотека RTK LIB [Takasu, Yasuda, 2009].

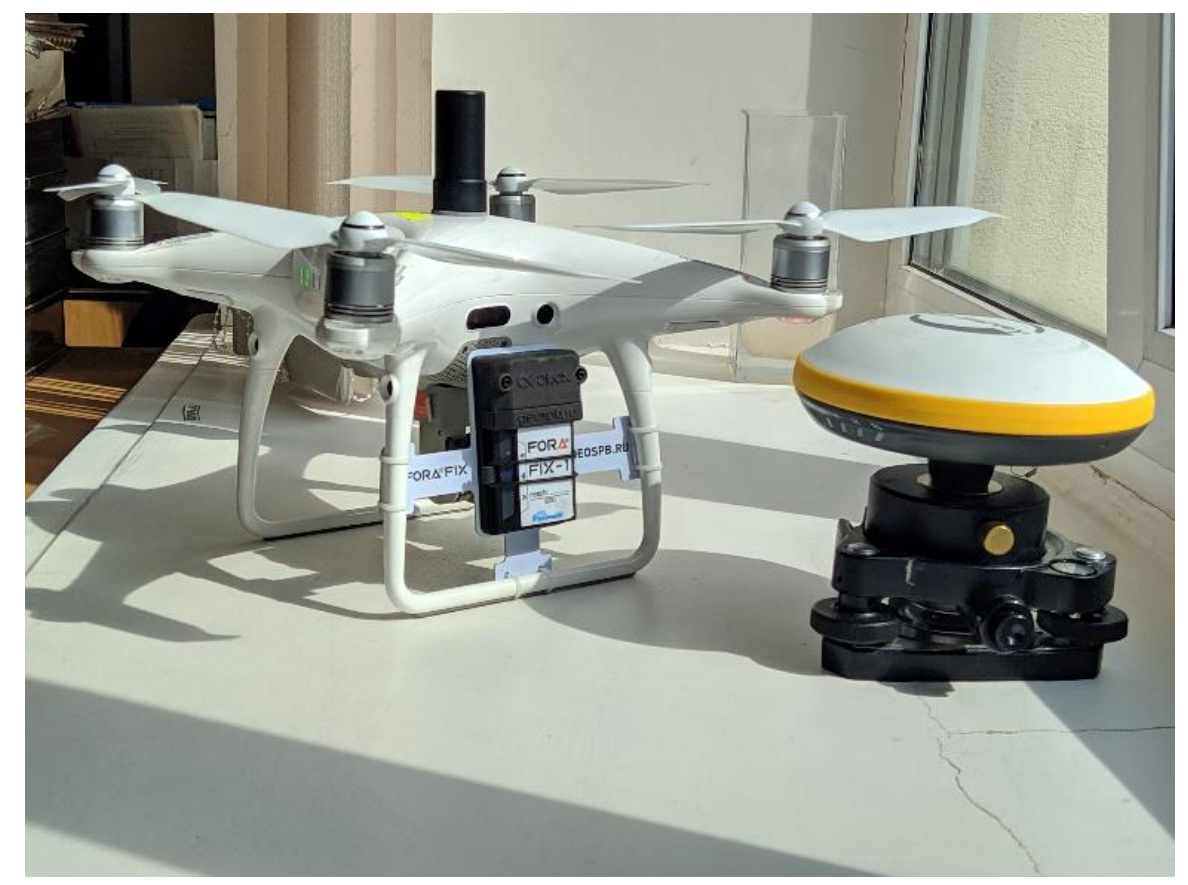

Puc. 2. БПЛА DJI Phantom 4 Pro v2 с внесенными изменениями Fig. 2. DJI Phantom 4 Pro v2 UAV with the implemented modifications

Данные с ГНСС-ровера были пересчитаны на основе данных с базовой станции. Для этого выбиралась ближайшая к участку базовая станция. Среднеквадратические отклонения (СКО) уравнивания координат центров проекций снимков по осям $\mathrm{X}, \mathrm{Y}, \mathrm{Z}$ представлены в табл. 1.

Полученные координаты центров проекций снимков в дальнейшем сопоставлялись с файлами снимков с БПЛА, после чего обрабатывались в фотограмметрическом ПО Agisoft Metashape. Методика обработки данных с ГНСС-БПЛА в данном ПО принципиально не 
отличается от методики обработки с учетом наземных опорных точек: на первом этапе материалы с БПЛА загружаются в Agisoft Metashape, одновременно с этим подгружается сформированный на предыдущем этапе файл с уточненными координатами центров снимков, в который вносятся поправки положения антенны. Далее производится фототриангуляция и создание плотного облака точек, после чего создаются ЦММ и ортофотоплан.

Табл. 1. СКО уравнивания центров проекиий снимков относительно базовой станщии Table 1. RMSE of alignment of image projection centers to the reference station

\begin{tabular}{|l|c|c|c|l|}
\hline \multirow{2}{*}{\multicolumn{1}{c|}{ Участок }} & \multirow{2}{*}{$\begin{array}{c}\text { Расстояние до } \\
\text { базовой станции (км) }\end{array}$} & \multicolumn{3}{|c|}{$\begin{array}{c}\text { Погрешность } \\
\text { уравнивания (м) }\end{array}$} \\
\cline { 3 - 5 } & & $\mathrm{x}$ & $\mathrm{y}$ & \multicolumn{1}{c|}{$\mathrm{z}$} \\
\hline Аксубаевское городище & 4,7 & 0,005 & 0,004 & 0,007 \\
\hline Альметьевский ПТБО & 6,6 & 0,005 & 0,003 & 0,009 \\
\hline Балахчинское городище & 45,8 & 0,006 & 0,005 & 0,01 \\
\hline Восточно-Войкинское городище & 36,0 & 0,005 & 0,004 & 0,009 \\
\hline Екатеринослободкинское городище 1 & 24,6 & 0,006 & 0,005 & 0,01 \\
\hline Малотолкишское городище & 57,1 & 0,007 & 0,005 & 0,001 \\
\hline Новоаксубаевское городище & 6,5 & 0,006 & 0,005 & 0,01 \\
\hline Новомокшинское городище & 10,5 & 0,005 & 0,004 & 0,008 \\
\hline Осталоповское городище & 70,2 & 0,009 & 0,007 & 0,015 \\
\hline Ромодановское городище 1 & 52,8 & 0,005 & 0,004 & 0,007 \\
\hline
\end{tabular}

\section{РЕЗУЛЬТАТЫ ИССЛЕДОВАНИЯ И ИХ ОБСУЖДЕНИЕ}

Ключевой задачей, которую должен решать метод, основанный на съемке ГНССБПЛА, является построение высокоточных и корректных ЦМВ с минимальными трудозатратами. Для оценки точности построения моделей, полученных с БПЛА, был использован подход, основанный на сравнении расчетных модельных координат в точках с известными координатами. Подробно остановимся на сравнении, которое производилось на территории Альметьевского полигона ТБО, на котором было установлено шесть контрольных точек. Контрольные точки закладывались равномерно и на разных высотах (рис. 3). Сравнение координат производилось в ПО QGIS, где и накалывались контрольные точки на ортофотоплане и ЦМВ, после чего полученные координаты сравнивались с исходными значениями, взятыми из каталога.

Координаты наземных контрольных точек были получены с помощью ГНССприемника Emlid Reach RS+, и, как и данные с ГНСС-БПЛА были уравнены относительно референсной станции, расположенной в 6.6 км. Погрешности определения координат ( $\delta)$ представлены в табл. 2.

Точность ЦМВ Альметьевского ПТБО относительно контрольных точек составила 0,032 м, что находится в пределах точности ГНСС-приемника Emlid Reach RS+ и установленного на БПЛА ГНСС-приемника Emlid M+. Минимальная погрешность характерна для определения координаты X, определение координат $\mathrm{Y}$ и $\mathrm{Z}$ имеет несколько большие неточности. Максимальная ошибка приходится на определение контрольной точки Point 5, находящейся в низине, минимальная - на точки Point 3, находящейся на открытом участке на возвышенности. Полученные значения отклонений по большей части связаны, по всей видимости, с погрешностями определения координат контрольных точек, нежели с погрешностями модели, полученной в результате аэрофотосъемочных работ. 
Табл. 2. Средняя квадратическая погрешность определение планового и высотного положения маркированных контрольных точек Альметьевского ПТБО

Table 2. RMS error in determining the horizontal and vertical coordinates of the Almetyevsk municipal solid waste landfill control points

\begin{tabular}{|l|c|c|c|c|}
\hline Контрольная точка & $\delta \mathrm{X}(\mathrm{M})$ & $\delta \mathrm{Y}(\mathrm{M})$ & $\delta \mathrm{Z}(\mathrm{M})$ & Итого (м) \\
\hline Point 1 & 0.008 & 0.023 & 0.000 & $\mathbf{0 . 0 2 4}$ \\
\hline Point 2 & 0.003 & -0.026 & -0.024 & $\mathbf{0 . 0 3 5}$ \\
\hline Point 3 & 0.002 & -0.009 & 0.013 & $\mathbf{0 . 0 1 6}$ \\
\hline Point 4 & -0.001 & 0.007 & -0.027 & $\mathbf{0 . 0 2 8}$ \\
\hline Point 5 & 0.021 & 0.034 & 0.029 & $\mathbf{0 . 0 4 9}$ \\
\hline Point 6 & -0.019 & -0.016 & -0.012 & $\mathbf{0 . 0 2 8}$ \\
\hline Итого (м) & $\mathbf{0 . 0 1 2}$ & $\mathbf{0 . 0 2 1}$ & $\mathbf{0 . 0 2 0}$ & $\mathbf{0 . 0 3 2}$ \\
\hline
\end{tabular}

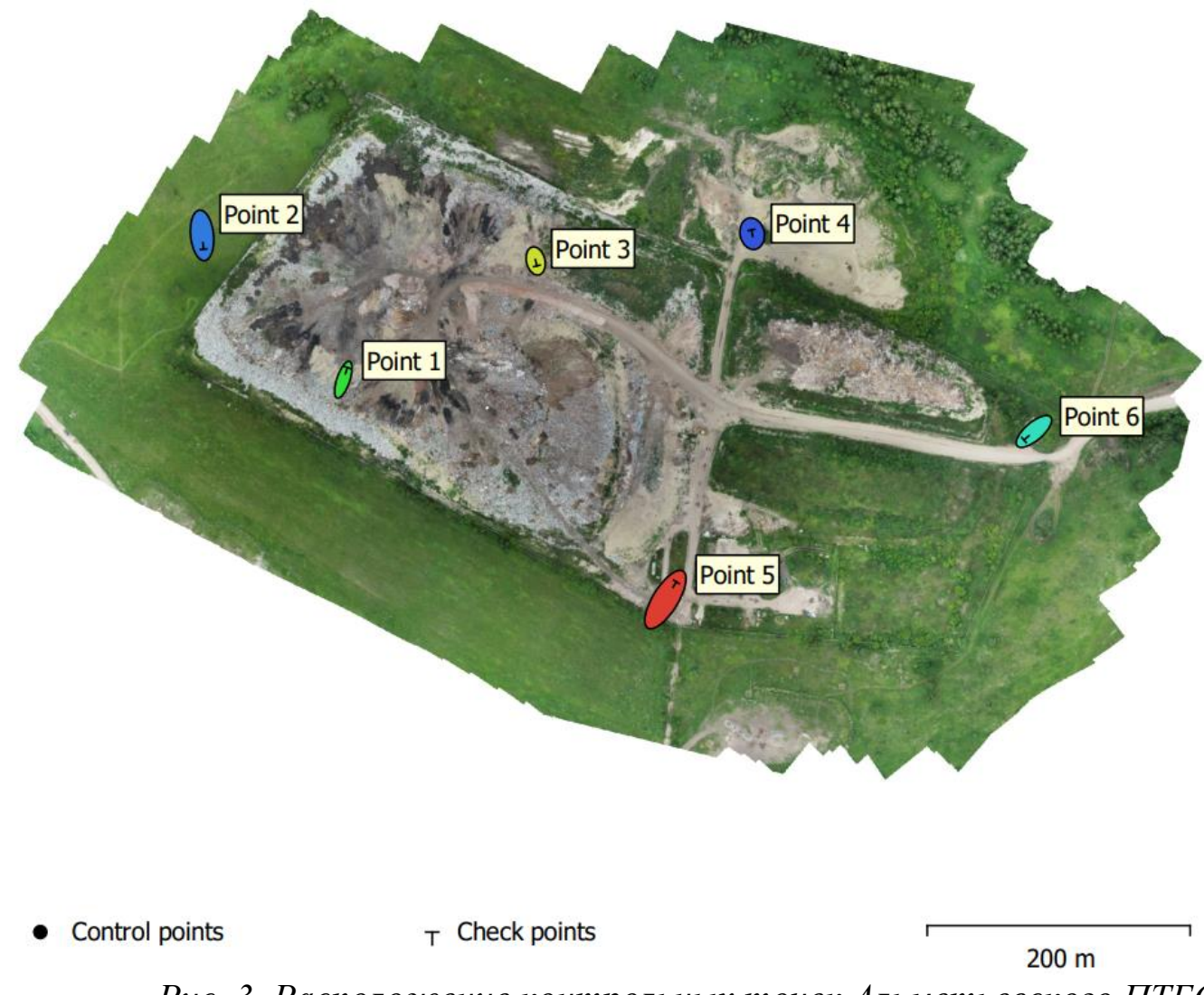

РИс. 3. Расположение контрольных точек Альметьевского ПТБО

Fig. 3. Check point location on the Almetyevsk municipal solid waste landfill

Апробация методики построения высокоточных ЦМВ с помощью ГНСС-БПЛА производилась дополнительно на девяти объектах (рис. 4), представляющих собой фортификационные сооружения XI-XIII вв. различной площади. Методика оценки погрешности определения координат в контрольных точках применялась аналогично той, что была использована на Альметьевском ПТБО. 
По результатам проведенных оценок, погрешности моделей высот находятся в пределах допустимых отклонений ${ }^{1}$, и не превышают 5 см по всем осям (табл. 3 ).

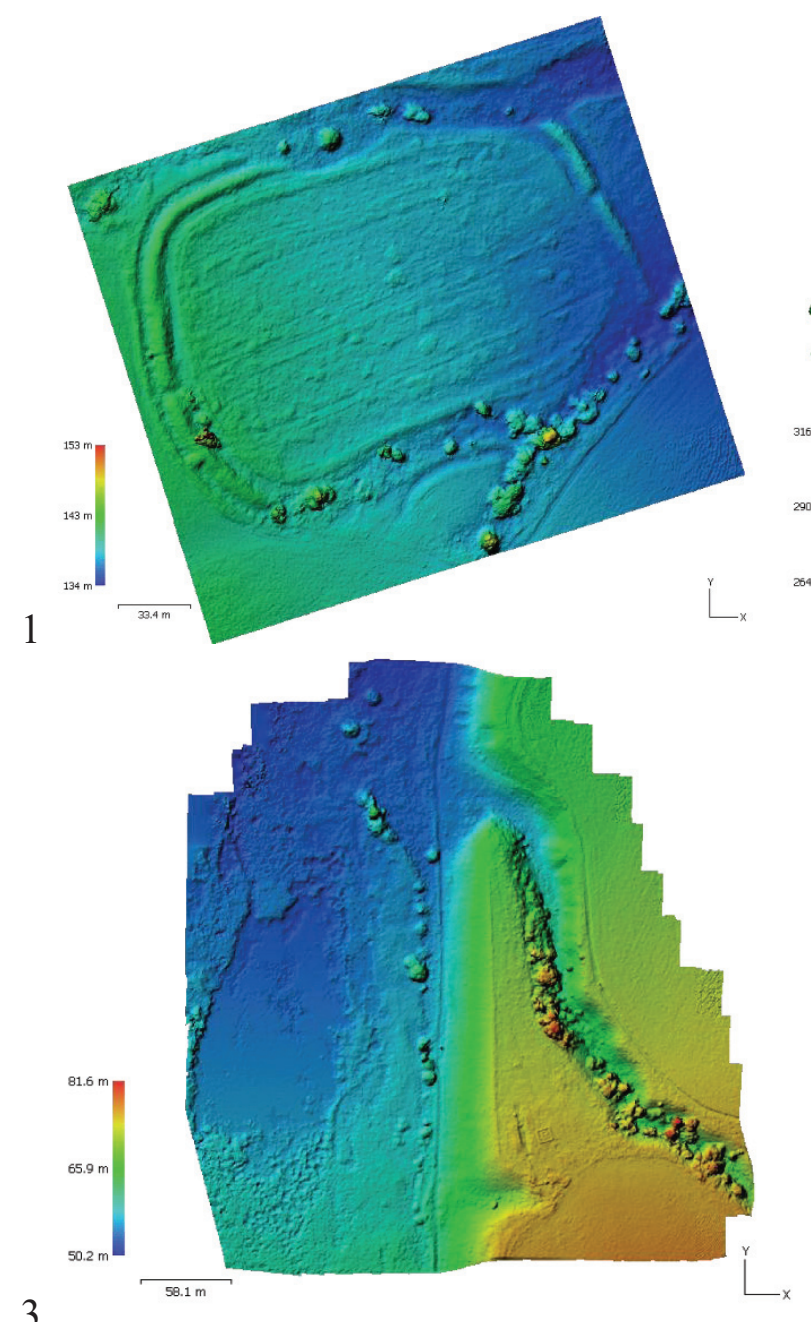

3
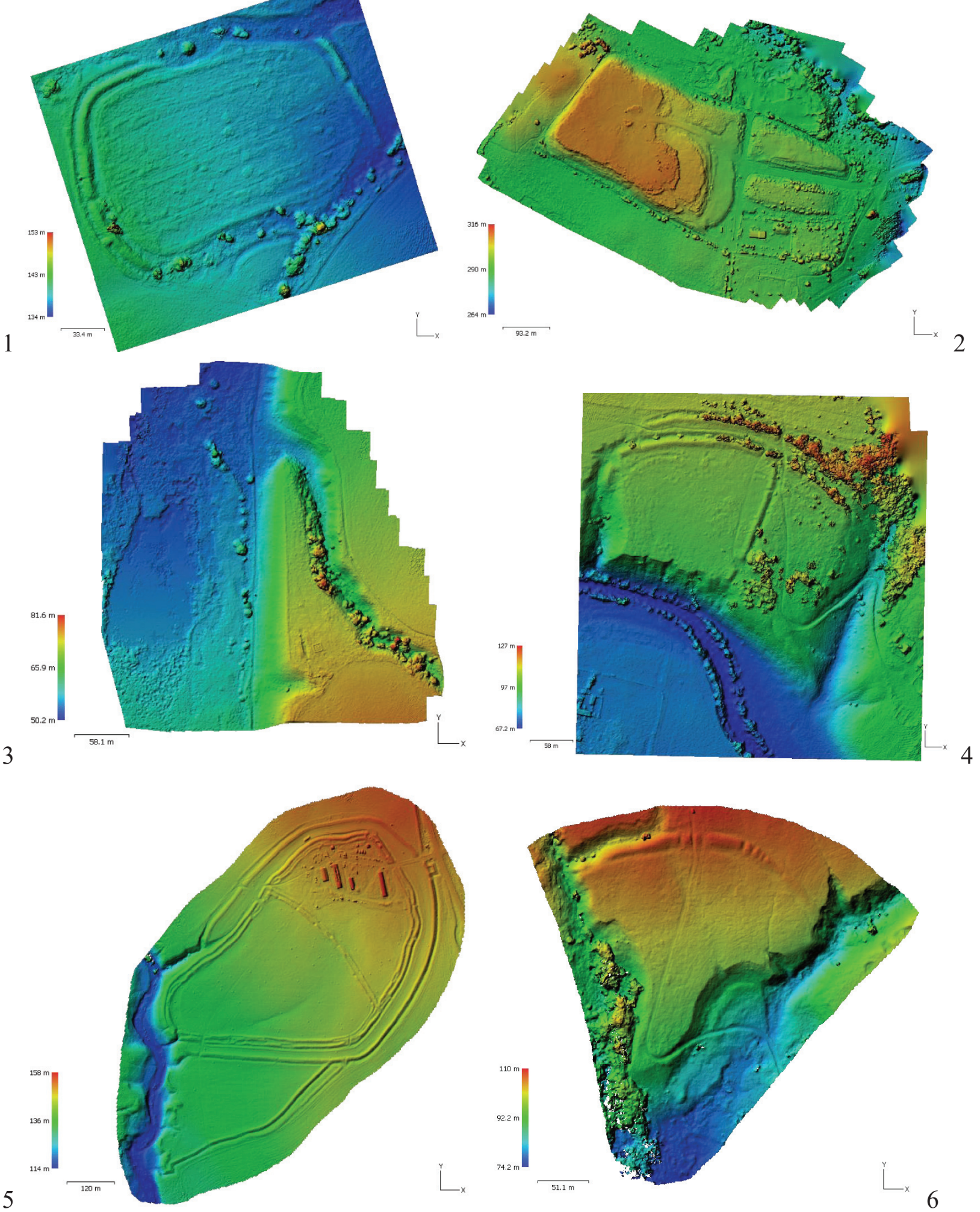

5

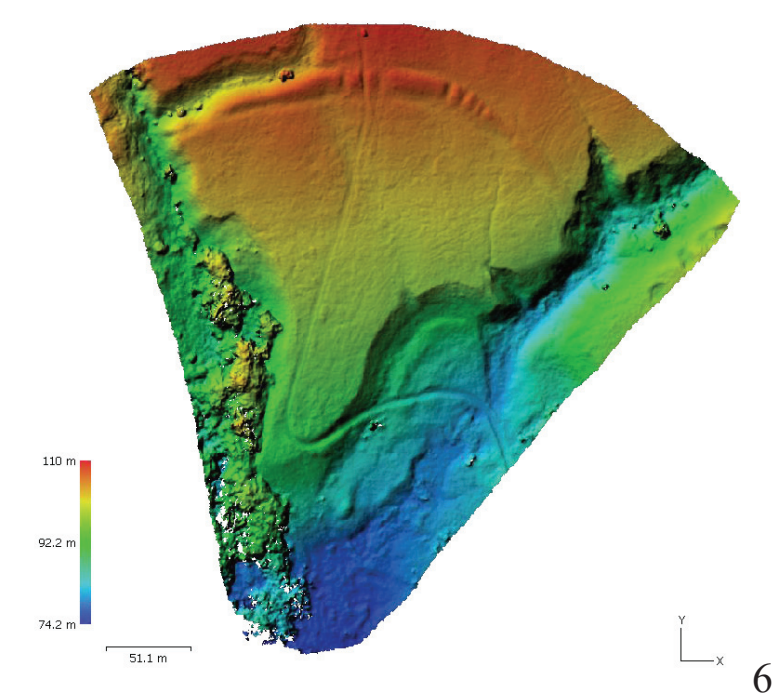



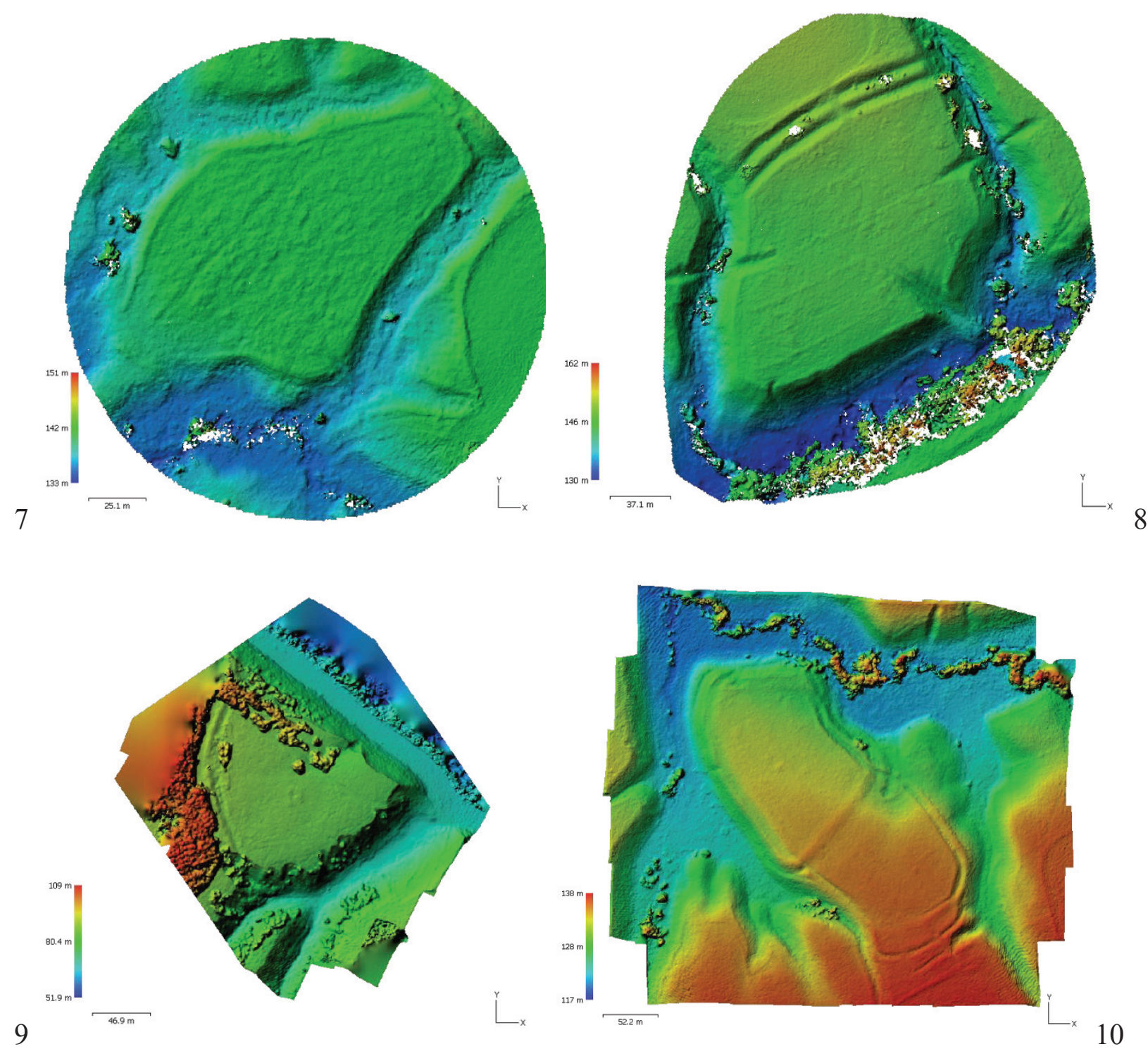

Рис. 4. Цифровые модели, полученные с помощью ГНСС-БПЛА

(1 - Аксубаевское городище; 2 - Альметьевский ПТБО; 3 - Балахчинское городище; 4 Восточно-Войкинское городище; 5 - Екатерино-Слободкинское городище 1; 6-Малотолкишское городище; 7 - Новоаксубаевское городище; 8 - Новомокиинское городище;

9 - Остолоповское городище; 10 - Ромодановское городище 1)

Fig. 4. Digital models obtained using GNSS-UAV

(1 - Aksubaevskoe ancient settlement; 2 - Almetyevskoe PTBO; 3 - Balakhchinskoe ancient settlement; 4 -Eastern-Voykinskoe ancient settlement; 5 -Ekaterino-Slobodkinskoe 1 ancient settlement; 6-Malotolkishskoe ancient settlement; 7 - Novoaksubaevskoe ancient settlement; 8 Novomokshinskoe ancient settlement; 9 - Ostolopovskoe ancient settlement; 10 -Romodanovskoe 1 ancient settlement) 
Табл. 3. Погрешность моделей, полученных с помощью ГНСС-БПЛА Table 3. Accuracy of models obtained using GNSS-UAV

\begin{tabular}{|l|c|c|c|}
\hline Участок & $\begin{array}{l}\text { Количество } \\
\text { снимков }\end{array}$ & Площадь (га) & Погрешность \\
\hline Аксубаевское городище & 60 & 5.54 & $0.01 \mathrm{м}$ \\
\hline Альметьевский ПТБО & 291 & 36.00 & $0.03 \mathrm{м}$ \\
\hline Балахчинское городище & 147 & 11.40 & $0.05 \mathrm{м}$ \\
\hline Восточно-Войкинское городище & 100 & 22.30 & $0.05 \mathrm{м}$ \\
\hline Екатерино-слободкинское городище 1 & 185 & 58.50 & $0.05 \mathrm{м}$ \\
\hline Малотолкишское городище & 62 & 8.71 & $0.05 \mathrm{м}$ \\
\hline Новоаксубаевское городище & 29 & 3.43 & $0.05 \mathrm{м}$ \\
\hline Новомокшинское городище & 59 & 5.88 & $0.01 \mathrm{м}$ \\
\hline Остолоповское городище & 33 & 4.45 & $0.05 \mathrm{м}$ \\
\hline Ромодановское городище 1 & 66 & 15.70 & $0.05 \mathrm{м}$ \\
\hline
\end{tabular}

В среднем, одна аккумуляторная батарея DJI Phantom 4 PRO V2 позволяет производить измерения на протяжении 15 минут, что, в зависимости от высоты полета и процента продольного и поперечного перекрытия соседних снимков позволяешь охватить до 1 кв. км. территории. Расстановка и измерение координат опорных точек занимает от получаса и, увеличивается пропорционально количеству марок, при этом, число последних увеличивается в зависимости от площади исследования. Таким образом, использование ГНСС-БПЛА позволяет увеличивать производительность многократно. Отсутствие опорных точек позволяет получить модель без локальных понижений и искажений, что в перспективе позволяет производить работы по многолетним измерениям динамики экзогенных процессов.

\section{ВЫВОДЫ}

Апробированная методика построения высокоточных моделей рельефа на основе съемки с оснащенного ГНСС-приемником беспилотным летательным аппаратом позволяет получить детальную и корректную модель. Ни на одном из тестовых участков не было обнаружено геометрических искажений или областей с локальными искажениями высот, вне зависимости от площади участков. Разрешение получаемых моделей варьируется от необходимого для конкретного исследования уровня и может достигать 1 см на пиксель. Погрешности геопозиционирования позволяют полностью отказаться от использования наземных опорных точек, многократно уменьшив тем самым время проведения съемочных полевых работ, а также в перспективе позволят организовывать сети мониторинга за динамическими процессами на основе повторных наблюдений. Однако, для верификации произведенных измерений и для оценок погрешностей ЦМВ все же рекомендуется установка контрольных точек или контроль по характерным объектам.

С точки зрения выбора конкретного инструментального решения можно отметить, что используемый модифицированный беспилотный летательный аппарат DJI Phantom 4 PRO V2 позволяет добиться точности, сопоставимой с готовыми решениями, в том числе разработки DJI. Использованный ГНСС-БПЛА многократно доступнее, однако, уступает в простоте эксплуатации готовым решениям. 


\section{БЛАГОДАРНОСТИ}

Работа выполнена при финансовой поддержке грантов РФФИ № 18-09-40114 (разработка и апробация методики съемки с ГНСС-БПЛА) и РНФ №19-17-00064 (разработка и апробация методики камеральной обработки полевых данных)

\section{ACKNOWLEDGEMENTS}

This work was supported by Russian Foundation for Basic Research (project No 18-0940114) (development and approbation of methods of GNSS-UAV surveying) and Russian Science Foundation (project No 19-17-00064) (development and approbation of methods of field data processing).

\section{СПИСОК ЛИТЕРАТУРЫ}

1. Benassi F., Dall'Asta E., Diotri F., Forlani G., Morra di Cella U., Roncella R., Santise M. Testing Accuracy and Repeatability of UAV Blocks Oriented with GNSS-Supported Aerial Triangulation. Remote Sens, 2017. T. 9. No 2. C. 172. DOI: 10.3390/rs9020172.

2. Bolkas D. Assessment of GCP Number and Separation Distance for Small UAS Surveys with and without GNSS-PPK Positioning. J. Surv. Eng, 2019. T. 145. No 3. C. 04019007. DOI: 10.1061/(ASCE)SU.1943-5428.0000283.

3. Dewez T.J.B., Leroux J., Morelli S. Cliff collapse hazard from repeated multicopter UAV acquisitions: return on experience. ISPRS - Int. Arch. Photogramm. Remote Sens. Spat. Inf. Sci, 2016. T. XLI-B5. C. 805-811. DOI: 10.5194/isprsarchives-XLI-B5-805-2016.

4. Dinkov D. A Low Cost Method UAV-PPK-Accuracy and Application, 2019. DOI: 10.13140/RG.2.2.31557.81123.

5. Ermolaev O.P., Mal'tsev K.A., Mukharamova S.S., Kharchenko S.V., Vedeneeva E.A. Cartographic model of river basins of European Russia. Geogr. Nat. Resour, 2017. T. 38. No 2. C. 131-138. DOI: 10.1134/S1875372817020032.

6. Gafurov A., Gainullin I., Usmanov B., Khomyakov P., Kasimov A. Impacts of fluvial processes on medieval settlement Lukovskoe (Tatarstan, Russia). Proc. Int. Assoc. Hydrol. Sci, 2019. T. 381. C. 31-35. DOI: 10.5194/piahs-381-31-2019.

7. Gafurov A. The Methodological Aspects of Constructing a High-Resolution DEM of Large Territories Using Low-Cost UAVs on the Example of the Sarycum Aeolian Complex, Dagestan, Russia. Drones, 2021. T. 5. № 1. C. 7. DOI: 10.3390/drones5010007.

8. Gafurov A.M., Yermolayev O. P. Automatic Gully Detection: Neural Networks and Computer Vision. Remote Sens, 2020. T. 12. No 11. C. 1743. DOI: 10.3390/rs12111743.

9. Gainullin I.I., Khomyakov P.V., Sitdikov A.G., Usmanov B.M. Qualitative assessment of the medieval fortifications condition with the use of remote sensing data (Republic of Tatarstan). Fifth International Conference on Remote Sensing and Geoinformation of the Environment (RSCy2017), 2017. C. 104440X. DOI: 10.1117/12.2279136.

10. Groves P.D. Principles of GNSS, inertial, and multisensor integrated navigation systems. Boston/London: Artech house, 2013. $776 \mathrm{c}$.

11. Langley R.B. Rtk gps. Gps World, 1998. T. 9. No 9. C. 70-76.

12. Mancini F., Dubbini M., Gattelli M., Stecchi F., Fabbri S., Gabbianelli G. Using Unmanned Aerial Vehicles (UAV) for High-Resolution Reconstruction of Topography: The Structure from Motion Approach on Coastal Environments. Remote Sens, 2013. T. 5. No 12. C. 6880-6898. DOI: 10.3390/rs5126880. 
13. Tahar K.N. An evaluation on different number of ground control points in unmanned aerial vehicle photogrammetric block. Int Arch Photogramm Remote Sens Spat Inf Sci, 2013. T. 40. C. 93-98. DOI: 10.5194/isprsarchives-XL-2-W2-93-2013.

14. Takasu T., Yasuda A. Development of the low-cost RTK-GPS receiver with an open source program package RTKLIB. Int. Symp. GPSGNSS, 2009. C. 4-6.

15. Tomaštík J., Mokroš M., Surový P., Grznárová A., Merganič J. UAV RTK/PPK method an optimal solution for mapping inaccessible forested areas? Remote Sens, 2019. T. 11. No 6. C. 721. DOI: 10.3390/rs11060721.

16. Villanueva J.K.S., Blanco A. C. Optimization of ground control point (GCP) configuration for unmanned aerial vehicle (UAV) survey using structure from motion (SFM). Int Arch Photogramm Remote Sens Spat Inf Sci, 2019. C. 167-174. DOI: 10.5194/isprs-archivesXLII-4-W12-167-2019.

17. Yu G., Su Y., Yu L., Gong L., Zhao D. Optimizing Pose of UAV Image Based on PPK Technology. China High Resolution Earth Observation Conference: Springer, 2019. C. 1135. DOI: 10.1007/978-981-15-3947-3 2.

18. Zhang H., Aldana-Jague E., Clapuyt F., Wilken F., Vanacker V., Van Oos, K. Evaluating the Potential of PPK Direct Georeferencing for UAV-SfM Photogrammetry and Precise Topographic Mapping. Earth Surf Dyn Discuss, 2019. C. 1-34. DOI: 10.5194/esurf-20192.

\section{REFERENSCES}

1. Benassi F., Dall'Asta E., Diotri F., Forlani G., Morra di Cella U., Roncella R., Santise M. Testing Accuracy and Repeatability of UAV Blocks Oriented with GNSS-Supported Aerial Triangulation. Remote Sens, 2017. V. 9. No 2. P. 172. DOI: 10.3390/rs9020172.

2. Bolkas D. Assessment of GCP Number and Separation Distance for Small UAS Surveys with and without GNSS-PPK Positioning. J. Surv. Eng, 2019. V. 145. No 3. P. 04019007. DOI: 10.1061/(ASCE)SU.1943-5428.0000283.

3. Dewez T.J.B., Leroux J., Morelli S. Cliff collapse hazard from repeated multicopter UAV acquisitions: return on experience. ISPRS - Int. Arch. Photogramm. Remote Sens. Spat. Inf. Sci, 2016. V. XLI-B5. P. 805-811. DOI: 10.5194/isprsarchives-XLI-B5-805-2016.

4. Dinkov D. A Low Cost Method UAV-PPK-Accuracy and Application. 2019. DOI: 10.13140/RG.2.2.31557.81123.

5. Ermolaev O.P., Mal'tsev K.A., Mukharamova S.S., Kharchenko S.V., Vedeneeva E.A. Cartographic model of river basins of European Russia. Geogr. Nat. Resour, 2017. V. 38. No 2. P. 131-138. DOI: 10.1134/S1875372817020032.

6. Gafurov A., Gainullin I., Usmanov B., Khomyakov P., Kasimov A. Impacts of fluvial processes on medieval settlement Lukovskoe (Tatarstan, Russia). Proc. Int. Assoc. Hydrol. Sci, 2019. V. 381. P. 31-35. DOI: 10.5194/piahs-381-31-2019.

7. Gafurov A. The Methodological Aspects of Constructing a High-Resolution DEM of Large Territories Using Low-Cost UAVs on the Example of the Sarycum Aeolian Complex, Dagestan, Russia. Drones, 2021. V. 5. No 1. P. 7. DOI: 10.3390/drones5010007.

8. Gafurov A. M., Yermolayev O. P. Automatic Gully Detection: Neural Networks and Computer Vision. Remote Sens, 2020. V. 12. No 11. P. 1743. DOI: 10.3390/rs12111743.

9. Gainullin I.I., Khomyakov P.V., Sitdikov A.G., Usmanov B.M. Qualitative assessment of the medieval fortifications condition with the use of remote sensing data (Republic of Tatarstan). Fifth International Conference on Remote Sensing and Geoinformation of the Environment (RSCy2017), 2017. P. 104440X. DOI: 10.1117/12.2279136. 
10. Groves P.D. Principles of GNSS, inertial, and multisensor integrated navigation systems. Boston/London: Artech house, 2013. 776 p.

11. Langley R.B. Rtk gps. Gps World, 1998. V. 9. No 9. P. 70-76.

12. Mancini F., Dubbini M., Gattelli M., Stecchi F., Fabbri S., Gabbianelli G. Using Unmanned Aerial Vehicles (UAV) for High-Resolution Reconstruction of Topography: The Structure from Motion Approach on Coastal Environments. Remote Sens, 2013. V. 5. No 12. P. 6880-6898. DOI: 10.3390/rs5126880.

13. Tahar K.N. An evaluation on different number of ground control points in unmanned aerial vehicle photogrammetric block. Int Arch Photogramm Remote Sens Spat Inf Sci, 2013. T. 40. C. 93-98. DOI: 10.5194/isprsarchives-XL-2-W2-93-2013.

14. Takasu T., Yasuda A. Development of the low-cost RTK-GPS receiver with an open source program package RTKLIB. Int. Symp. GPSGNSS. 2009. C. 4-6.

15. Tomaštík J., Mokroš M., Surový P., Grznárová A., Merganič J. UAV RTK/PPK methodan optimal solution for mapping inaccessible forested areas? Remote Sens, 2019. T. 11. No 6. C. 721. DOI: 10.3390/rs11060721.

16. Villanueva J. K. S., Blanco A. C. Optimization of ground control point (gcp) configuration for unmanned aerial vehicle (uav) survey using structure from motion (SFM). Int Arch Photogramm Remote Sens Spat Inf Sci. 2019. C. 167-174. DOI: 10.5194/isprs-archivesXLII-4-W12-167-2019

17. $Y u$ G., Su Y., Yu L., Gong L., Zhao D. Optimizing Pose of UAV Image Based on PPK Technology. China High Resolution Earth Observation Conference: Springer, 2019. C. 1135. DOI: 10.1007/978-981-15-3947-3 2.

18. Zhang H., Aldana-Jague E., Clapuyt F., Wilken F., Vanacker V., Van Oos, K. Evaluating the Potential of PPK Direct Georeferencing for UAV-SfM Photogrammetry and Precise Topographic Mapping. Earth Surf Dyn Discuss, 2019. C. 1-34. DOI: 10.5194/esurf-2019-2. 


\title{
А.Т. Гизатуллин ${ }^{1}$
}

\section{РАЗРАБОТКА МЕТОДИКИ ПРЕДУПРЕЖДЕНИЯ ПРИРОДНЫХ ПОЖАРОВ ПО ДАННЫМ ДИСТАНЦИОННОГО ЗОНДИРОВАНИЯ НА ПРИМЕРЕ ЛЕСОВ КРАСНОЯРСКОГО КРАЯ}

\begin{abstract}
АННОТАЦИЯ
Рассматриваются этапы разработки методики предупреждения природных пожаров по данным дистанционного зондирования на примере лесов Красноярского края. Приводится обоснование выбора территории исследования на основе статистических данных о пожарах (термоточки FIRMS 2016-2018 гг.) с точки зрения разнообразия условий возгорания. В основу оценки пожарной опасности закладываются наиболее информативные факторы возгорания - температура поверхности, неоднородность растительного покрова и антропогенная нагрузка, выведенные на основе природно-пожарной характеристики территории. Эти факторы оценены путем измерения близких к них показателей соответственно радиояркостной температуры на основе теплового излучения, вегетационного индекса NDVI и интегрального показателя расстояния до населенных пунктов и дорог. В качестве источников данных использовались материалы со спутников Terra/Aqua, Sentinel-3, Landsat-8, Sentinel-2 и векторные картографические слои Open Street Maps. С помощью статистических данных была проанализирована взаимосвязь показателей с фактической возгораемостью территории Красноярского края. В результате были получены различные по лесным районам и времени пожароопасного сезона коэффициенты корреляции, описывающие вклад отдельных факторов в пожарную опасность, а также пороговые значения показателей для предупреждения пожаров. В соответствии с ними была построена методика в виде последовательности этапов аналитической и синтетической оценки пожарной опасности. Тестирование методики было произведено в наиболее пожароопасном и репрезентативном с точки зрения условий возгорания участке на юго-западе Красноярского края в период с 1 апреля по 10 мая 2019 года. По итогам тестирования подтвердилась достаточная достоверность (65 \%) и надежность (58 \%) прогноза природных возгораний.
\end{abstract}

КЛЮЧЕВЫЕ СЛОВА: оценка пожарной опасности, данные ДЗ3, факторы пожарной опасности, пороговые значения.

\section{Almaz T. Gizatullin²}

\section{DEVELOPMENT OF NATURAL FIRE PREVENTION METHOD BASED ON REMOTE SENSING DATA: CASE STUDY OF KRASNOYARSK REGION FORESTS}

\section{ABSTRACT}

The stages of development of natural fire prevention method based on remote sensing data were considered. The case study is focused on Krasnoyarsk region forests. There was a rationale

\footnotetext{
1 Московский государственный университет имени М.В. Ломоносова, Географический факультет, кафедра картографии и геоинформатики, Ленинские горы, д. 1, 119991, Москва, Россия, e-mail: almazgiz1995@yandex.ru

2 Lomonosov Moscow State University, Faculty of Geography, Department of Cartography and Geoinformatics, Leninskie Gory 1, 119991, Moscow, Russia, e-mail: almazgiz1995@yandex.ru
} 
for selecting a study area on the basis of statistical fire data (FIRMS thermal hot spots 2016-2018) and a variety of fire conditions. The fire assessment was founded on the most informative fire factors - surface temperature, vegetation cover inhomogenuity and man-made load, which are derived by the natural-fire characteristics of the territory. These factors were evaluated by measuring parameters closed to them, respectively - radiobrightness temperature based on thermal emission, vegetation index NDVI and integral indicator of distance to settlements and roads. Materials from the Terra/Aqua, Sentinel-3, Landsat-8, Sentinel-2 satellites and Open Street Maps vector map layers were used as data sources. With use of statistical data, the relationship between above parameters and the present fire danger of Krasnoyarsk region was analyzed. Based on the results, we obtained different by forest rayon and fire season month correlation coefficients that described the contribution of individual factors to a fire danger, and threshold values of parameters for preventing fires. Then a sequence of stages of analytical and synthetic fire danger assessment as a study method was built. Validation of the method was performed in the most fire dangerous and representative in terms of fire conditions area in the south-west of the Krasnoyarsk Territory from April 1 to May 10, 2019. It showed sufficient accuracy (65\%) and reliability (58 \%) of fire forecast.

KEYWORDS: fire danger assessment, remote sensing data, fire danger factors, threshold values.

\section{ВВЕДЕНИЕ}

Данные дистанционного зондирования успешно используются в области исследования природных возгораний уже несколько десятилетий. Первые применения ДДЗ относятся к 1960-м гг., когда для раннего обнаружения пожаров на самолеты устанавливали тепловые инфракрасные сканеры [Hirsch et al., 1971]. Запуск спутников Landsat в 1970-х дал начало применению космических ДДЗ, которые эффективно использовались для оценки показателя пожарной опасности [Bradshaw et al., 1984]. В это же время разработка первых геоинформационных систем позволила объединить факторы пожарной опасности и получить пространственную комбинацию в виде пожароопасных зон [Calabri, 1984]. В качестве основных переменных использовались характерные факторы, такие как растительность, рельеф, инсоляция, параметры погоды и др. [Rabii et al., 1979].

Дальнейшее развитие области использования ДДЗ для предупреждения пожаров подразделяется на несколько направлений и связано:

- $\quad$ с расширением типов ДДЗ и технологий их обработки;

- $\quad$ с интерпретацией процесса возгорания в связи с особенностями территории.

По мере развития вводились новые типы данных: радиолокационные, обеспечивающие мониторинг температуры и влажности приповерхностного слоя почвы [Rignot et al., 1994; Verbesselt et al., 2007]; лидарные, позволяющие детально исследовать пространственную структуру объектов потенциального возгорания [Skowronski et al., 2011]; данные с БПЛА, отличающиеся маневренностью и оперативностью получения [Yuan et al., 2015], и др.

Однако эффективность методик предупреждения также сильно зависит от учета территориальных условий, которые определяют готовность к возгоранию. В России с обширными лесными территориями для оценки пожарной опасности принят комплексный индекс Нестерова ${ }^{1}$, который рассчитывается в зависимости от условий погоды, в частности, от температуры воздуха. На сегодняшний день разработаны аналоги индекса, основанные на измерениях радиационных температур по космическим снимкам [Сухинин, Пономарев, 2003]. Подобные методы по условиям погоды разработаны и используются в странах с

ГОСТ Р 22.1.09-99. Безопасность в чрезвычайных ситуациях. Мониторинг и прогнозирование лесных пожаров. Общие требования. 
острыми проблемами лесных пожаров: FWI (Fire Weather Index), рейтинговые системы в США и Канаде ${ }^{1}$, индекс Макартура в Австралии [Dowdy et al., 2009] и др.

Важное значение уделяется изучению проводников горения, которым выступает лесная растительность, обладающая различными свойствами и, как следствие, разным риском воспламенения [Софронова, Волокитина, 2017]. Оригинальную интерпретацию учета растительности предложили [Chéret, Denux, 2011], которые при оценке пожарной опасности средиземноморского побережья использовали временные профили NDVI 20002006 гг. и разработали два производных индекса. Они основаны на статистических отклонениях исходного показателя от среднего и показывают недостаток или переизбыток развития зеленой массы и, как следствие, влагосодержания растительности. В исследованиях различных территорий Греции, Италии, Китая и Ирана [Stergiopoulos et al., 2007; Marchi et al., 2007; Dong et al., 2005] к классификации растительности, как проводников возгорания разной опасности, добавляют такие факторы, как рельеф (уклон и экспозиция), близость к антропогенным источникам возгорания (населенные пункты, дороги) и тушения (пожарные базы). Все эти методы используют взвешенную оценку факторов и последующее их комбинирование в единый показатель пожарного риска. Вероятностные исследования и выявление различных предикторов (причин возгораний) провели [Amatulli et al., 2007]: на основе обширного архива пожаров в Испании за 1983-2001 гг. было выявлено 34 наиболее вероятных параметра, которые влияют на риски возгорания (густота антропогенных объектов, высота местности, NDVI и др.).

Текущий обзор показывает разнообразие методов оценки пожарной опасности, но, тем не менее, возрастающие разнообразие и объем данных дистанционного зондирования позволяют совершенствовать и уточнять методы их обработки для выявления потенциальных пожаров. При этом, несмотря на их разнообразие набор и веса факторов для достаточно крупных территорий остаются постоянными, тогда как они обладают пространственной и сезонной изменчивостью, что в конечном счете понижает достоверность прогноза.

Целью текущего исследования является разработка методики предупреждения природных пожаров с использованием данных дистанционного зондирования на примере лесов Красноярского края, которая будет учитывать пространственно-временную дифференциацию факторов пожарной опасности. Для достижения цели были поставлены следующие задачи:

- обосновать выбор территории применения методики;

- подобрать и уточнить показатели оценки пожарной опасности;

- п протестировать эффективность методики.

Красноярский край характеризуется высоким значением лесистости территории: леса покрывают более 70 \% площади и занимают 168,1 млн га². Столь обширная лесная территория, которая имеет достаточно широкую меридиональную протяженность, располагается в пределах нескольких природных зон: притундровых лесов и редколесий, таежной (северной, средней и южной) и лесостепной, местами осложняется высотной поясностью и дифференцируется на 7 лесных районов (рис. 1).

Ежегодно на территории Красноярского края происходит большое количество лесных пожаров, что обуславливает актуальность исследования и обеспечивает совокупность эталонных участков для их изучения на основе ДДЗ. Для подтверждения

\footnotetext{
1 Fire Weather Index (FWI) System. National Wildfire Coordinating Group. Электронный ресурс: https://www. nwcg.gov/publications/pms437/cffdrs/fire-weather-index-system (дата обращения 21.03.2021).

2 Официальные статистические показатели. ЕМИСС - Государственная статистика. Электронный pecypc: https://fedstat.ru/ (дата обращения 23.03.2021).
} 
этого положения был проведен оверлейный анализ на основе пересечения сетки административно-территориального деления РФ и совокупности термоточек, интерпретируемых как местоположения пожаров за 2016-2018 гг. и сформированных системой FIRMS ${ }^{1}$ по данным MODIS с коэффициентом надежности более 95 \% (см рис. 1). Как видим, наибольшее количество пожаров достигается в Восточной Сибири: в республике Саха (149 686 точек), в Красноярском крае (140 743 точки). Однако, как уже было отмечено, меридиональная протяженность Красноярского края обуславливает большее разнообразие породного состава лесов, что увеличивает репрезентативность его территории для распространения методики на всю Россию.

С точки зрения, природно-пожарной характеристики [Фуряев $u$ dp. 2017] Красноярский край описывается существенными различиями в условиях возгорания, которые определяются разнообразием и плотностью распространения древесных пород, а также растительностью напочвенного покрова, которые служат горючим материалом. Горимость лесов также зависит от количества приходящей солнечной радиации, и, как следствие, от температуры нагреваемой ею поверхности. Немаловажным фактором является антропогенная нагрузка на территорию. Таким образом, для последующего исследования были выбраны три фактора пожарной опасности: неоднородность растительного покрова, температура поверхности и антропогенная нагрузка.

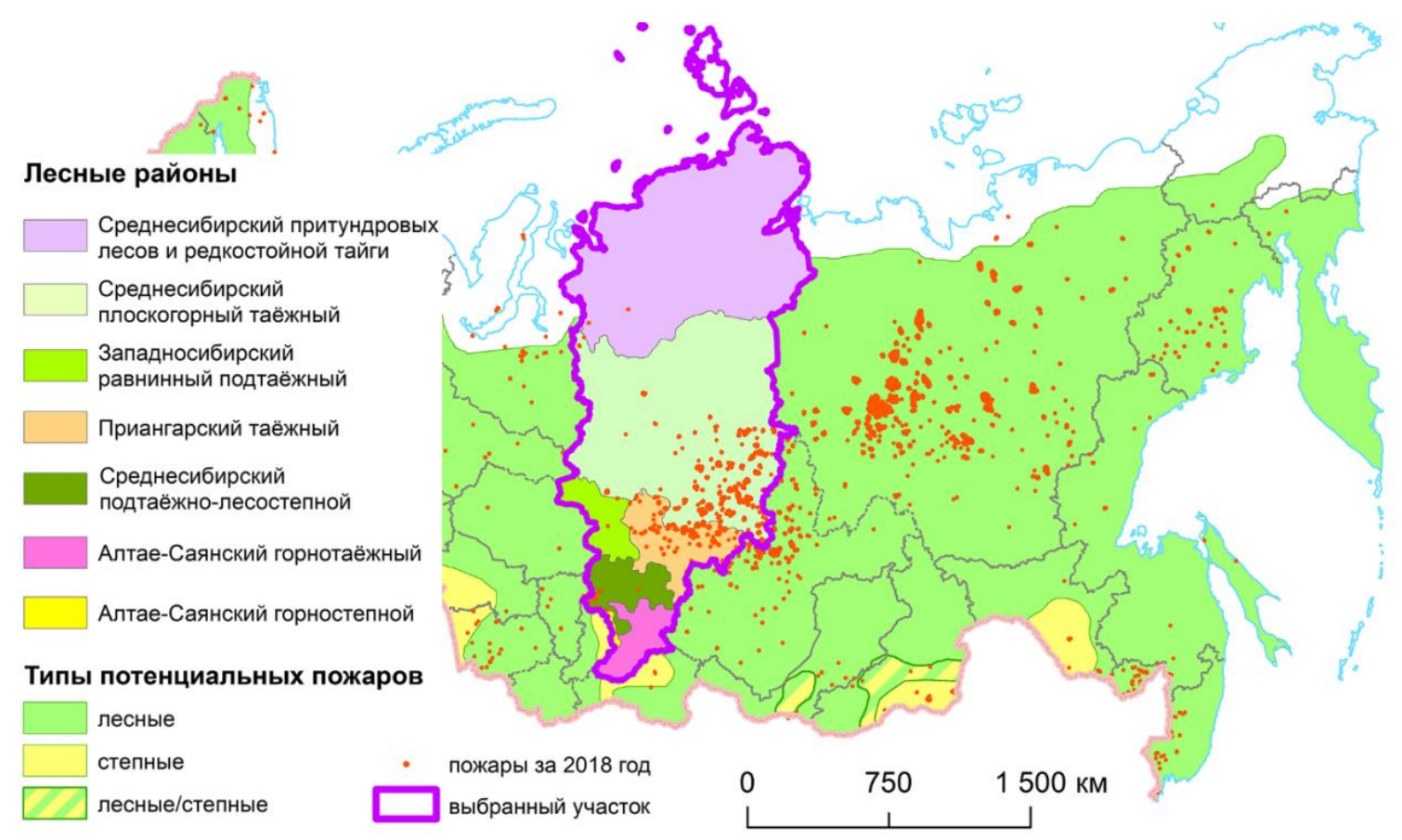

Рис. 1. Красноярский край в разрезе исследования пожарной опасности Fig. 1. Krasnoyarsk region in terms of fire danger research

\section{МАТЕРИАЛЫ И МЕТОДЫ ИССЛЕДОВАНИЯ}

Методика предупреждения лесных пожаров на основе оценки пожарной опасности предполагает собой определенную последовательность операций по обработке исходных

1 Fire Information for Resource Management System. Электронный ресурс:

https://firms.modaps.eosdis.nasa.gov/ (дата обращения 15.01.2021). 
данных для численного расчета факторов пожарной опасности, их интерпретации и сведения значений в единый показатель.

\section{Исходные данные}

В качестве исходных данных были использованы данные дистанционного зондирования спутников Terra/Aqua, Sentinel-3, Sentinel-2, Landsat-8 (табл. 1). В совокупности эти данные отвечают таким требованиям, как свободный и практически нелимитированный доступ (в некоммерческих целях), регулярное обновление и актуальность, возможность автоматизации обработки. Кроме того, они взаимодополняют друг друга с точки зрения пространственного охвата (Terra/Aqua и Sentinel-3) и детальности (Landsat-8, Sentinel-2), алгоритмической базы, преемственности и перспектив использования (Terra/Aqua $\rightarrow$ Sentinel-3, Landsat-8 $\rightarrow$ Sentinel-2, потенциальный Landsat-9). Все это обеспечивает достоверные и надежные результаты их обработки в рамках разрабатываемой методики.

В дополнение к ДДЗ, применялись векторные картографические слои Open Street $\operatorname{Maps}^{1}$ (OSM), отражающие распределение антропогенных объектов на территории исследования. Выбор этих данных обуславливается открытой лицензией на их использование при сопоставимой достоверности по сравнению с другими сервисами общегеографических карт и более актуальным изображением местности по сравнению с топографическими картами. Также они представлены в векторном формате, удобном для осуществления последующего автоматизированного анализа по ним.

Табл. 1. Основные характеристики исходных данных ДЗ3 (составлено по источнику $\left.{ }^{2}\right)$

Table 1. Principal characteristics of used remote sensing data (compiled based on source ${ }^{8}$ )

\begin{tabular}{|l|c|c|c|c|c|}
\hline \multicolumn{1}{|c|}{ Спутник } & $\begin{array}{c}\text { Съемочная } \\
\text { система }\end{array}$ & $\begin{array}{c}\text { Дата } \\
\text { запуска }\end{array}$ & $\begin{array}{c}\text { Пространственное } \\
\text { разрешение, } \mathrm{M}\end{array}$ & $\begin{array}{c}\text { Полоса } \\
\text { обзора, км }\end{array}$ & $\begin{array}{c}\text { Частота } \\
\text { съемки, сут. }\end{array}$ \\
\hline Terra/Aqua & MODIS & 1999,2002 & $250,500,1000$ & 2330 & $\approx 0,5-2$ \\
\hline Sentinel-3 & SLSTR & $\begin{array}{c}\mathrm{A}-2016 \\
\mathrm{~B}-2018\end{array}$ & 500 & 1420 & $\approx 1$ \\
\hline Landsat-8 & OLI/TIRS & 2013 & $15,30,100$ & 185 & до 16 \\
\hline Sentinel-2 & MSI & $\begin{array}{c}\mathrm{A}-2015 \\
\mathrm{~B}-2017\end{array}$ & $10,20,60$ & 290 & до 5 \\
\hline
\end{tabular}

\section{Численный расчет факторов пожарной опасности}

Ранее было выделено 3 фактора пожарной опасности - неоднородность растительного покрова, температура поверхности и антропогенная нагрузка. Для их количественного измерения введем понятие показателя пожарной опасности - метрически описываемая с помощью ДДЗ или их производных и наиболее точно по смыслу как фактор пожарной опасности характеристика.

Для описания неоднородности растительности, в частности, ее горизонтальной составляющей зачастую используют вегетационные индексы [Chéret, Denux, 2011], самым распространенным из которых является индекс NDVI (Normalized Difference Vegetation Index). Расчет этого индекса основывается на двух наиболее стабильных и информативных участках спектральной кривой растительности - красном видимом и ближнем инфракрасном [Rouse et al., 1974]:

\footnotetext{
1 RU:Highway classification. OSM-Wiki. Электронный pecypc: https://wiki.openstreetmap.org/wiki/RU: Highway_classification (дата обращения: 16.03.2021).

2 Пространственные данные - космическая съемка. Совзонд. Электронный pecypc: https://sovzond.ru/ products/spatial-data/satellites/ (дата обращения 19.02.2021).
} 


$$
N D V I=\frac{B_{\sim 0,8-0,9 \text { мкм }}-B_{\sim 0,63-0,75 \text { мкм }}}{B_{\sim 0,8-0,9 \text { мкм }}+B_{\sim 0,63-0,75 \text { мкм }}},
$$

где $B$ - интенсивность спектрального излучения в соответствующих диапазонах.

Существует устойчивая взаимосвязь между NDVI и многими природными характеристиками - состояние и плотность растительности, продуктивность экосистем, их биомасса [Рязанова, Сорокин, 2017]. При этом, он достаточно чувствителен к изменениям погодных условий (объем осадков, количество приходящей солнечной радиации) и, как следствие, может быть индикатором степени увлажнения. Все это указывает на его пригодность для общего описания неоднородности растительного покрова и, более того, изменений ее состояния, что повышает информативность показателя для оценки пожарной опасности. При использовании космических снимков выбранных спутников для вычисления NDVI были использованы следующие каналы:

- $\quad$ Terra/Aqua - 1 (Red) и 2 (NIR), пространственное разрешение - 250 м;

- $\quad$ Sentinel-3 - 2 (Red) и 3 (NIR), 500 м;

- $\quad$ Landsat-8 - 4 (Red) и 5 (NIR), 30 м;

- Sentinel-2 - 4 (Red) и 8a (NIR), 10 м.

Температура поверхности - физическая характеристика, отражающая степень прогрева потенциальных проводников горения, и косвенно интерпретируемая как их готовность к возгоранию. Для предупреждения пожаров важно проследить текущие значения температур поверхности $\left(0 \ldots 100^{\circ} \mathrm{C}\right)$, которые наблюдаются в спектральном диапазоне $10 \ldots 13$ мкм. Как правило, значения спектрального отражения в каналах этого диапазона применяют при формировании продуктов 2-го уровня MODIS и SLSTR по температурным данным 8 . Тепловые изображения из этих продуктов включают в себя пространственные распределения температур в ${ }^{\circ} \mathrm{K}$, для перевода в ${ }^{\circ} \mathrm{C}$ необходимо выполнить смещение шкалы на -273,15.

На высокодетальном уровне (десятки м) съемка в тепловом диапазоне ведется только системой TIRS (Landsat-8), продукты которой поставляются в виде изображений спектрального отражения в каналах 10,3...12,5 мкм. Для получения физических значений температуры была использована следующая формула"

$$
T=\frac{K_{2}}{\ln \left(\frac{K_{1}}{B}+1\right)}-273,15^{\circ} \mathrm{C},
$$

где $K 1$ и $K 2$ - постоянные значения из метаданных, $B$ - интенсивность излучения в тепловом канале.

Антропогенная нагрузка - показатель, характеризующий воздействие человека на природную среду, в данном случае, рассматривается его влияние на пожарную опасность территории. Закономерность ее проявления в общих чертах описывается следующим образом: чем выше вероятность нахождения человека как потенциального инициатора возгорания в точке, тем выше в ней вероятность возникновения пожара. Поэтому для ее оценки были выбраны два типа объектов, которые наиболее всего характеризуют присутствие человека в той или иной точке - населенные пункты и дороги. В качестве метрической характеристики было использовано расстояние от указанных объектов.

Населенные пункты как место постоянной локализации людей имеют большую значимость, чем дороги как место с переменным их присутствием. Для распределения весовых коэффициентов был использован способ ранжированной оценки, причем в связи с большей важностью населенных пунктов, значимости объектов измерялись порядками:

1 Landsat Provisional Surface Temperature. Landsat Science Products. USGS. Электронный ресурс: https://www.usgs.gov/core-science-systems/nli/landsat/landsat-provisional-surface-temperature (дата обращения 16.04.2021). 
населенные пункты - 10, дороги - 1 . Следовательно, их весовые коэффициенты составили 0,91 и 0,09 соответственно. Для детализации вероятности нахождения человека категории населенных пунктов по численности населения и дорог по типу/классу также были проранжированы, для каждой из категорий в зависимости от значимости вычислен вес (табл. 2).

Исходя из вышеперечисленного, расчет распределения антропогенной нагрузки сводится к следующей последовательности операций:

1) расчет расстояния от каждой точки пространства (ячейки растра в 10 м разрешение наиболее космической системы - Sentinel-2), интерпретируемой как потенциальная точка возгорания, до ближайшего объекта - отдельно для населенных пунктов и отдельно для дорог в пределах Красноярского края;

2) растровое умножение полученных расстояний на веса из табл. 2 ;

3) взвешенное сложение полученных растров для населенных пунктов (вес 0,91$)$ и дорог $(0,09)$;

4) пересчет в относительные значения с масштабированием к диапазону $[0,1]$ путем деления значений всех ячеек растра на максимальное значение растра. Физически это значение должно достигаться в точке, наиболее удаленной с учетом весов от населенных пунктов и дорог. В итоге, антропогенная нагрузка будет стремиться к 0 в удаленных от указанных объектов точках, а 1 - в точках, наиболее близких к ним. Соответственно, пожарная опасность с точки зрения антропогенной составляющей будет минимальной в первом случае и максимальной - во втором.

Табл. 2. Весовые коэффициенты объектов при расчете антропогенной нагрузки Table 2. Feature weights for man-made load calculation

\begin{tabular}{|c|c|c|c|c|c|}
\hline \multicolumn{3}{|c|}{ Населённые пункты $(0,91)$} & \multicolumn{3}{|c|}{ Дороги $(0,09)$} \\
\hline Людность, тыс. чел & Знач-ть & $\mathrm{Bec}$ & Тип/класс & Знач-ть & $\mathrm{Bec}$ \\
\hline более 1000 & 6 & 0,29 & Железные дороги (railways) & 3 & 0,33 \\
\hline $500 \ldots 1000$ & 5 & 0,24 & Автомобильные дороги: & & \\
\hline $100 \ldots 500$ & 4 & 0,19 & I класса (motorway, trunk, & 3 & 0,33 \\
\hline $50 \ldots 100$ & 3 & 0,14 & primary*) & & \\
\hline $10 \ldots 50$ & 2 & 0,09 & II класса (secondary) & 2 & 0,22 \\
\hline менее 10 & 1 & 0,05 & III класса (tertiary) & 1 & 0,12 \\
\hline
\end{tabular}

* классы автомобильных дорог в соответствии с классификатором $\mathrm{OSM}^{7}$

Таким образом, все вышерассмотренные факторы и показатели пожарной опасности с учетом их особенностей можно разделить на две группы:

- nеременные - NDVI и температура поверхности - обладают изменчивостью в течение суток и более крупных временных промежутков и вычисляются по регулярно поступающим данным;

- nостоянные - антропогенная нагрузка - изменяются эпизодически и достаточно медленно (в задачах прогноза пожарной опасности можно считать их постоянными) и требуют обновления только по мере необходимости.

Такая классификация факторов и показателей представляет собой способ описания общей пожарной опасности. Её использование в основе синтезирования факторов в единую оценку пожарной опасности позволяет учитывать разностороннее влияние на формирование вероятности возгорания.

Интерпретация показателей пожарной опасности 
Для предупреждения пожаров по значениям показателей опасности была исследована их связь с возгораемостью территории, которая представляет собой пространственную характеристику, выражающую готовность проводников горения к воспламенению на том или ином участке. Был использован коэффициент корреляции, который характеризует тесноту связи между явлениями А и В. При отсутствии знаний об истинной форме связи между показателями и возгораемостью предполагается, что она является линейной: чем выше NDVI и температура поверхности, тем выше вероятность возгорания. Расчёт коэффициента корреляции $r$ выполняется по совокупности соответственных значений явлений А и В:

$$
r=\frac{\sum_{i=1}^{n}\left(a_{i}-M_{a}\right)\left(b_{i}-M_{b}\right)}{n \sigma_{a} \sigma_{b}}
$$

где $M_{a}$ и $M_{b}$ - среднее арифметическое значений А и В соответственно, $\sigma_{a}$ и $\sigma_{b}-$ их среднеквадратические отклонения, $n$ - число пространственно распределенных точек $i$, в которых были измерены значения $a_{i}$ и $b_{i}$.

В качестве первого явления выступают переменные показатели NDVI и температура, а второго - возгораемость территории. Исходными точками для набора значений этих явлений были приняты термоточки 2016-2018 гг. (период функционирования выбранных спутников). Для повышения достоверности и уменьшения объема выборки с сохранением репрезентативности эта совокупность, которая составляет сотни тысяч точек в пределах Красноярского края, была обработана следующим образом:

- произведен отбор с применением информационных источников МЧС, Гринпис России и региональных центров мониторинга пожарной ситуации (Лесопожарный центр Красноярского края), то есть в последующем были использованы только те термоточки, которые были зафиксированы как пожары с помощью аэро- и наземных служб;

- $\quad$ в связи с исследованием возгораемости территории в конечную совокупность были включены только первые по времени точки пожаров, в то время как последующие не несут смысловой нагрузки для выявления прогнозных закономерностей.

В качестве численного выражения возгораемости была использована условная вероятность возгорания, аппроксимированная с помощью линейной функции, причем максимальное ее значение $100 \%$ или 1 достигается в момент первого выявления пространственной точки пожара. Пороговым значением, когда условия для возгорания максимальны, принимается значение 90 \%, которое фиксировалось за 2-4 дня в зависимости от наличия данных и градиента изменения показателя. Для исследования взаимосвязи на низкодетальном уровне с учетом высокого временного разрешения были использованы космические снимки MODIS и SLSTR за 7 дней до пожара, на высокодетальном - данные OLI/TIRS, MSI за 1 месяц ( два периода получения снимков Landsat-8 на одну и ту же территорию).

Для учета пространственной дифференциации физико-географических условий и факторов пожарной опасности взаимосвязь между показателями и вероятностью возгорания была исследована отдельно в пределах каждого лесного района в Красноярской области (см. рис. 1). Во временном отношении были установлены анализируемые промежутки, которые составили 1 месяц в течение пожароопасного сезона с достаточным количеством статистических данных (с апреля по октябрь).

В результате были получены коэффициенты корреляции каждого переменного показателя с вероятностью возгорания, а также зафиксированы их пороговые значения при условной вероятности в $90 \%$ (табл. 3). Из двух проанализированных показателей наиболее ярко пожарную опасность характеризует температура (коэффициент корреляции от 0,75 до $0,93$, детерминации $\sim 0,56 \ldots 0,86)$, тогда как NDVI имеет менее выраженную связь 
$(\sim 0,5 \ldots 0,7, \sim 0,25 \ldots 0,5)$. Пороговые значения температуры растут с севера на юг в пространственном отношении, а во временном - увеличиваются с апреля по июль, затем убывают до октября. Такая закономерность учитывает сезонную изменчивость метеорологических параметров, которые влияют на факторы пожарной опасности, и свидетельствует об адаптивности выявленных значений.

Анализ корреляции между антропогенной нагрузкой и фактической возгораемостью территории был проведен с использованием всей совокупности термоточек MODIS за 20162018 годы. Это обеспечивает максимальную полноту данных при допустимой достоверности. В основу анализа был заложен следующий математический аппарат:

нагрузки;

- $\quad$ пространство показателя было разделено на равные классы - 0,1 по значениям

- в пределах каждого класса была рассчитана статистическая вероятность/частота случаев возгораний (количество термоточек) - как и в случае с переменными показателями для учета пространственно-временной дифференциации явлений вычисления проводились в пределах лесных районов/степных зон за каждый месяц (см. табл. 3).

Влияние антропогенной нагрузки на возгораемость в пределах Красноярского края является различным в зависимости от особенностей лесного района и времени в который он действует. Однозначное воздействие антропогенной нагрузки на пожарную опасность прослеживается в густозаселенной южной части, а также в районе освоения нефтегазоносных районов.

Табл. 3. Результаты исследования взаимосвязи показателей пожарной опасности с возгораемостью территории на примере Приангарского таежного района в апреле Table 3. Correlation analysis results: fire danger indicators and flammability of the territory. Case study of the Priangarsky taiga region in April

\begin{tabular}{|c|c|c|c|c|c|c|c|}
\hline \multicolumn{8}{|c|}{ Переменные факторы пожарной опасности } \\
\hline \multirow{2}{*}{ Фактор } & \multirow{2}{*}{ Показатель } & \multicolumn{2}{|c|}{$\begin{array}{c}\text { Коэффициент } \\
\text { корреляции (детерм.) }\end{array}$} & \multicolumn{4}{|c|}{ Пороговое значение } \\
\hline & & $\begin{array}{c}\text { низкодет. } \\
\text { уровень }\end{array}$ & $\begin{array}{c}\text { высокодет. } \\
\text { уровень }\end{array}$ & \multicolumn{2}{|c|}{$\begin{array}{l}\text { низкодет. } \\
\text { уровень }\end{array}$} & \multicolumn{2}{|c|}{$\begin{array}{c}\text { высокодет. } \\
\text { уровень }\end{array}$} \\
\hline $\begin{array}{l}\text { Неоднородность } \\
\text { раст. покрова }\end{array}$ & NDVI & $0,59(0,35)$ & $\begin{array}{c}0,62 \\
(0,38)\end{array}$ & \multicolumn{2}{|c|}{0,31} & \multicolumn{2}{|r|}{0,31} \\
\hline $\begin{array}{l}\text { Температура } \\
\text { поверхности }\end{array}$ & $\begin{array}{c}\text { Радиояркостная } \\
\text { температура }\end{array}$ & $0,85(0,72)$ & $\begin{array}{c}0,86 \\
(0,74) \\
\end{array}$ & \multicolumn{2}{|c|}{$13,6^{\circ} \mathrm{C}$} & \multicolumn{2}{|c|}{$13,5^{\circ} \mathrm{C}$} \\
\hline \multicolumn{8}{|c|}{ Постоянные факторы пожарной опасности } \\
\hline \multicolumn{2}{|c|}{ Антропогенная нагрузка } & $0,5 \ldots 0,6$ & $0,6 \ldots 0,7$ & $\begin{array}{c}0,7 \ldots \\
0,8\end{array}$ & \multicolumn{2}{|c|}{$\begin{array}{c}0,8 \ldots 0 \\
9 \\
\end{array}$} & $\begin{array}{c}0,9 \ldots 1 \\
0\end{array}$ \\
\hline \multicolumn{2}{|c|}{ Количество термоточек } & 41 & 100 & 182 & \multicolumn{2}{|c|}{406} & 314 \\
\hline \multicolumn{2}{|c|}{$\begin{array}{l}\text { Статистическая частота/ } \\
\text { вес класса }\end{array}$} & 0,04 & 0,10 & 0,17 & \multicolumn{2}{|c|}{0,39} & 0,30 \\
\hline
\end{tabular}

На основе полученных данных (коэффициентов корреляции, пороговых значений и статистических вероятностей) показатели конвертируются в частные оценки пожарной опасности. Для обеспечения последующих расчётов показатели в собственных единицах измерения необходимо пересчитать в общий диапазон изменения вероятности возникновения пожаров $-0 \ldots 1$ или $0 \ldots 100 \%$. Формулы пересчета также были установлены на основе результатов корреляционного анализа: для совокупности точек были построены 
линии регрессии, уравнения которых выражают линейную связь между условной вероятностью возгорания и показателем пожарной опасности (рис. 2).

В общем виде уравнение преобразования записывается следующим образом:

$$
Y=k \cdot X+b \text {, }
$$

где $Y$ - частная оценка пожарной опасности, $X$ - значения показателя, выражающего фактор опасности, $k$ и $b$ - коэффициенты пересчета.

Учитывая, что анализ проводился для каждой пространственно-временной единицы, то коэффициенты в составе формул будут обладать как географической, так и сезонной изменчивостью. При объединении этих коэффициентов в пространстве и времени функция будет представлять дискретную пространственно-временную модель оценки пожарной опасности, единицами которой являются лесные районы в каждый месяц пожароопасного сезона.

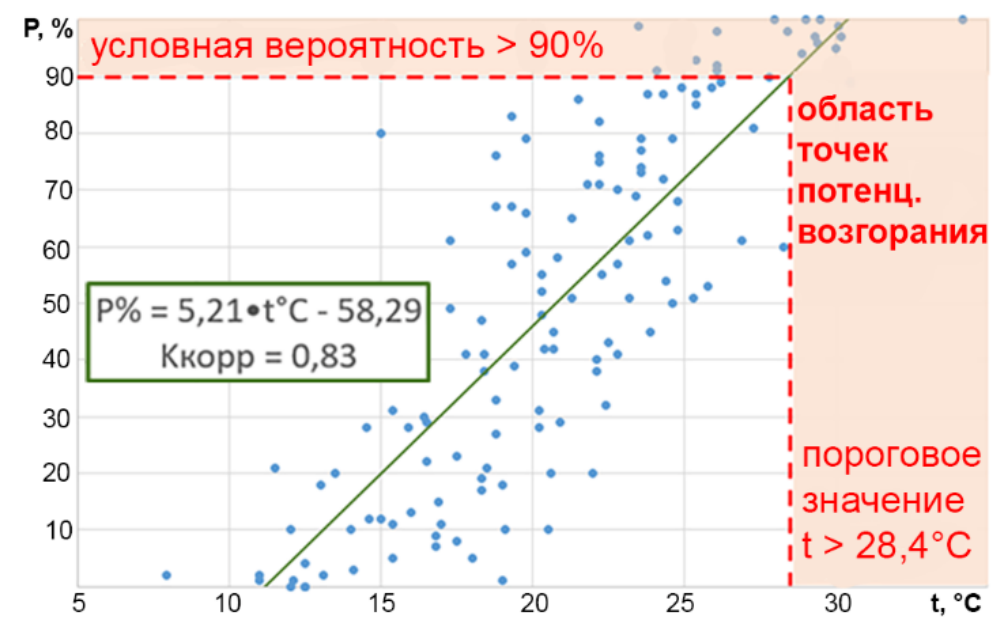

Рис. 2. Порядок расчета частной оченки пожарной опасности (пример - Алтае-Саянский горнотаёжный лесной район в мае)

Fig. 2. Calculation of partial fire danger assessment (case study-Altai-Sayan mountain taiga forest region in May)

\section{Сведение в общий показатель пожарной опасности}

Общзая оценка пожарной опасности представляет собой численный показатель, который также выражает вероятность возгорания, однако учитывает несколько наиболее информативных факторов. Порядок ее вычисления основывается на постепенной интеграции частных оценок переменной опасности (по температуре и NDVI) и статистических вероятностей по антропогенной нагрузке с помощью весовых функций. На самом высоком иерархическом уровне объединяются оценки переменных и постоянных факторов. Диапазоны значений частных оценок и статистических вероятностей совпадают, поэтому их веса зависят только от их информативности. Для определения весов был использован метод ранжированной оценки по значимости факторов: для переменных как наиболее информативных общий вес составил 0,67, а для постоянных - 0,33.

На следующем уровне были распределены веса внутри групп. Для переменных факторов вес был определен в зависимости от коэффициента их корреляции с возгораемостью: чем больше его значение, тем больше вес. Он рассчитывался как отношение коэффициента текущего показателя на сумму коэффициентов корреляции всех переменных факторов. Например, корреляция возгораемости с температурой в пределах Среднесибирского района притундровых лесов и редкостойной тайги за май составила 0,81 , a c NDVI 0,56; таким образом, вес температурного фактора будет 0,59, а неоднородности расти- 
тельного покрова - 0,41. Внутри группы постоянных факторов антропогенная нагрузка является единственным показателем, поэтому его вес равен 1. Исходя из вышеописанного, запишем весовую функцию для расчета общей оценки пожарной опасности:

$$
\text { FireDanger }=0,67 \bullet \sum_{i=1}^{n} w_{i} X_{i}+0,33 \sum_{j=1}^{m} v_{j} Z_{j},
$$

где $\underline{X_{i}}$ и $Y_{j}$ - значения частных оценок переменных и постоянных факторов соответственно, $w_{i}$ и $\underline{v}_{j}-$ их весовые коэффициенты, $n$ и $m$ - количество используемых факторов в пределах групп.

После вычисления общей оценки пожарной опасности ее значения в каждом пикселе изображения проверяются на превышение 0,9 . При положительном результате координаты центра пикселя интерпретируются как местоположения потенциального возгорания.

Таким образом, в результате исследования пожарной опасности, влияющих на нее факторов и их изменчивости была разработана методика оценки пожарной опасности природных территорий (рис. 3).

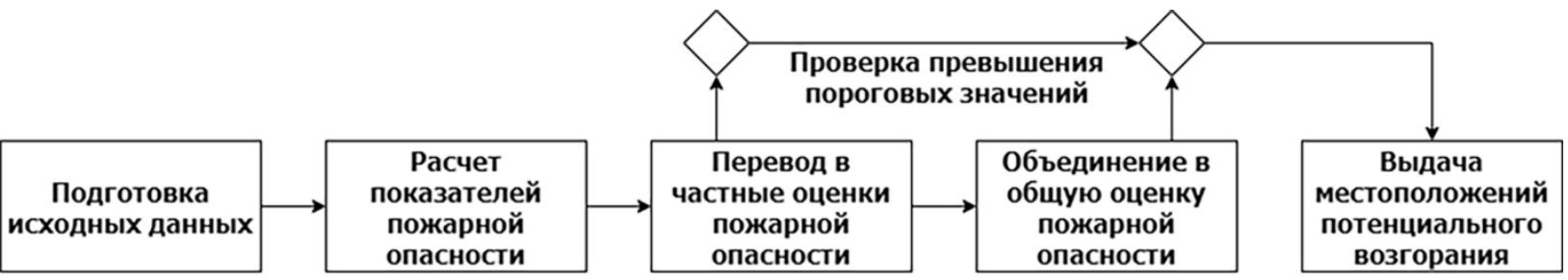

Рис. 3. Последовательность этапов методики предупреждения природных пожаров Fig. 3. Stages of natural fire prevention method

Ее преимущественным свойством является адаптивная применимость практически для любого участка в пределах лесных районов Красноярского края, что возможно благодаря учету пространственно-временной изменчивости факторов пожарной опасности и дифференциации условий возгорания на основе особенностей растительности как основного проводника горения.

\section{РЕЗУЛЬТАТЫ ИССЛЕДОВАНИЯ И ИХ ОБСУЖДЕНИЕ}

Основным результатом исследования является методика предупреждения лесных пожаров на территории Красноярского края, обоснованная с учетом физикогеографических условий и статистических данных. Как и ранее рассмотренные методы [Stergiopoulos et al., 2007; Marchi et al., 2007; Dong et al., 2005 и др.], текущая разработка также использует взвешенную оценку факторов пожарной опасности, выведенных с учетом особенностей возгорания на исследуемой территории. Однако главным отличием является ввод пространственных и временных единиц, которые позволяют учитывать изменчивость пожарных рисков, как по территории, так и в течение пожароопасного сезона путем изменения весов и пороговых значений показателей.

Для контроля эффективности методики было произведено ее тестирование задачей мониторинга небольших районов Красноярского края. При выборе тестовых районов основным критерием являлось разнообразие условий при небольшой площади отбираемых участков. Требование к минимальным размерам участков исходит из вычислительных возможностей: чем меньше район и больше разнообразие условий, тем более информативными будут результаты при минимальных вычислениях. В итоге, были выбраны Балахтинский, Новосёловский, Краснотурьинский и Идринский районы на югозападе Красноярского края: с одной стороны, южные районы характеризуются большим 
количеством возгораний и максимальной антропогенной нагрузкой, а с другой - выбранная территория лежит в пределах трех лесных районов - Среднесибирском подтаёжнолесостепном, Алтае-Саянском горнотаежном и Алтае-Саянском горностепном.

Временным промежутком тестирования был выбран период с 1 апреля по 10 мая 2019 г., в пределах которого оценивалась пожарная опасность тестовых участков и были получены точки вероятных пожаров. Вместе с этим, контролировась текущая пожароопасная ситуации с использованием достоверных источников пожарных данных (FIRMS, Космоснимки-Пожары, МЧС, Гринпис России, Лесопожарный центр Красноярского края). Проведем пространственно-временной анализ полученных результатов (рис. 4).

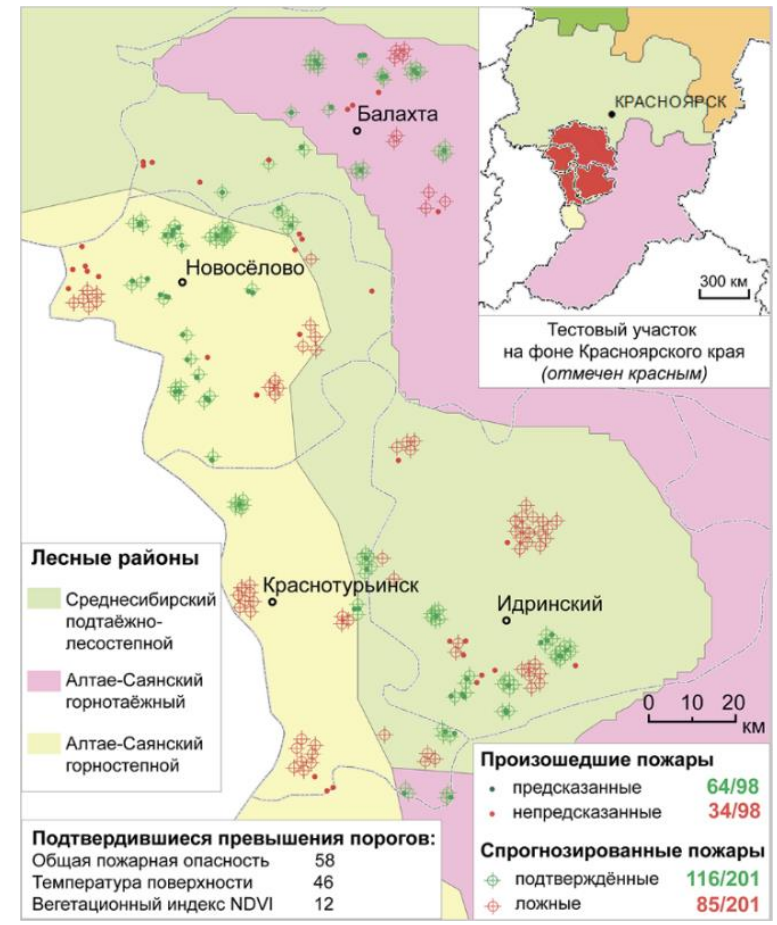

Рис. 4. Прогноз лесных пожаров на юге Красноярского края (1 апреля - 10 мая 2019 г.) Fig. 4. Forecast of forest fires in the south of the Krasnoyarsk region (April 1-May 10, 2019)

На тестовом участке Красноярского края была получена 201 прогнозная точка, в то время как системами детектирования пожаров было выявлено 98 пожаров. На основе данных низкодетального уровня (SLSTR, MODIS) был предупреждён 51 пожар из 98, тогда как более детальные данные Landsat-8 и Sentinel-2 выдали прогноз на 60 правильных возгораний. В общей совокупности, было предупреждено 64 лесных пожара. Однако относительно общего количества спрогнозированных точек - более 200 - немногим более половины (116) совпали со случаями реальных возгораний. Наибольшее количество возгораний было выявлено с помощью общего показателя пожарной опасности - 58, 46 - с превышением температуры, и всего 12 - с помощью NDVI.

Общая достоверность прогноза (отношение числа предсказанных возгораний к числу всех возгораний) составила $65 \%$, а его надежность (отношение числа потенциальных точек возгорания, совпавших с реальными, к числу всех точек прогноза) $58 \%$. Однако в абсолютном количестве число ложных точек сопоставимо с количеством реальных случаев возгорания, что является недостатком пороговых значений показателей пожарной опасности. Также следует отметить, что использование данных различного уровня охвата и детализации повышает достоверность прогноза: пожары, не 
спрогнозированные на одном уровне, могут быть предупреждены на другом. Таким образом, результаты тестирования показали успешную применимость методики как в техническом, так и в научно-методическом плане.

\section{ВЫВОДЫ}

- $\quad$ в основу методики предупреждения природных пожаров на примере лесов Красноярского края были заложены факторы пожарной опасности - температура поверхности, индекс NDVI и антропогенная нагрузка, которые были выделены как наиболее влияющие на условия возгорания в пределах рассматриваемой территории; несмотря на постоянство набора показателей пожарной опасности меняются их веса в зависимости от лесного района и месяца в течение пожароопасного сезона, что учитывает пространственно-временную изменчивость условий возгорания;

комбинирование данных дистанционного зондирования с различными характеристиками (Terra/Aqua, Sentinel-2 и 3, Landsat-8), а также картографических слоев обеспечивает большой охват и высокую детальность результатов предупреждения пожаров, как следствие, возможность прогноза на региональном и локальном уровнях;

- $\quad$ аналитическая (частные показатели) и синтетическая (общие показатели) оценка пожарной опасности увеличивает достоверность и надежность предупреждения возгораний;

- $\quad$ репрезентативность Красноярского края с точки зрения условий возгорания является основанием для применения методики для других регионов России с некоторым уточнением весов показателей пожарной опасности.

\section{СПИСОК ЛИТЕРАТУРЫ}

1. Рязанова Н.Е., Сорокин П.А. Опыт применения дистанционного зондирования растительности при исследовании динамики экосистем российской Арктики. Науки о Земле: вчера, сегодня, завтра. Материалы III Междунар. науч. конф., 2017. С. 7-12.

2. Софронова A.B., Волокитина А.В. Оценка природной пожарной опасности лесных участков на территории нефтегазовых комплексов с использованием данных дистанционного зондирования Земли. Сибирский лесной журнал, 2017. № 5. С. 84-94. DOI: 10.153 72/SJFS20170508.

3. Сухинин А.И., Пономарев Е.И. Картирование и краткосрочное прогнозирование пожарной опасности в лесах Восточной Сибири по спутниковым данным. Сибирский экологический журнал, 2003. Т. 10, № 6. С. 669-677.

4. Фуряев В.В., Цветков П.А., Фуряев И.В., Злобина Л.П. Условия возникновения и распространения пожаров в лесных районах Красноярского края. Хвойные бореальной зоны, 2017. Т. 35. № 1-2. С. 66-74.

5. Amatulli G., Peréz-Cabello F., de la Riva J. Mapping lightning/human-caused wildfires occurrence under ignition point location uncertainty. Ecological Modelling, 2007. V. 200. No 3. P. 321-333. DOI: 10.1016/j.ecolmodel.2006.08.001.

6. Bradshaw L.S., Deeming J.E., Burgan R.E., Cohen, J.D. The 1978 National Fire-Danger Rating System: technical documentation. General Technical Report INT-169. Ogden: U.S. Department of Agriculture, Forest Service, 1984. 44 p.

7. Calabri G. La Prevenzione degli Incendi Boschivi. I Problemi e le Tecniche della Difesa. Bologna: Edagricole, 1984.

8. Chéret V., Denux J.P. Analysis of MODIS NDVI Time Series to Calculate Indicators of Mediterranean Forest Fire Susceptibility. GIScience \& Remote Sensing, 2011. V. 48. No 2. P. 171-194. DOI: 10.2747/1548-1603.48.2.171. 
9. Dong X., Li-min D., Guo-fan S., Lei T., Hui W. Forest fire risk zone mapping from satellite images and GIS for Baihe Forestry Bureau. Journal of Forestry Research. Jilin, 2005. No 16. P. 169-174. DOI: 10.1007/BF02856809.

10. Dowdy A.J., Mills A.G., Finkele K., de Groot W. Australian fire weather as represented by the McArthur Forest Fire Danger Index and the Canadian Forest Fire Weather Index. CAWCR Technical Report, 2009. No 10.91 p.

11. Hirsch S.N., Kruckeberg R.F., Madden F.H. The bi-spectral forest detection system. Proceeding 7th International Symposium on Remote Sensing of Environment. Ann Arbor, 1971. P. 2253-2259.

12. Marchi E., Tesi E., Montorselli N.B. Forest fire prevention: a GIS tool for fire-fighting planning and management. Proceedings of the 6th International Workshop of The EARSeL Special Interest Group on Forest Fires. Thesalonniki, 2007. P. 102-106.

13. Rabii H.A. An Investigation of the utility of Landsat-2 MSS data to the fire-danger rating area, and forest fuel analysis within Crater Lake National Park: Ph.D. thes. Oregon, 1979. 410 p.

14. Rignot E., Way J.B., McDonald K., Viereck L., Williams C., Adams P., Payne C., Wood W., Shi J. Monitoring of environmental conditions in taiga forests using ERS-1 SAR. Remote Sensing of the Environment, 1994. No 49. P. 145-154. DOI: 10.1016/00344257(94)90051-5.

15. Rouse J.W., Haas R.H., Schell J.A., Deering D.W. Monitoring vegetation systems in the Great Plains with ERTS. Proceedings of the Third Earth Resources Technology Satellite1 Symposium, 1974. No 1. P. 309-317.

16. Skowronski N.S., Clark K.L., Duveneck M., Hom J. Three- dimensional canopy fuel loading predicted using upward and downward sensing LiDAR systems. Remote Sensing of Environment, 2011. V. 115. P. 703-714. DOI: 10.1016/j.rse.2010.10.012.

17. Stergiopoulos I., Mallinis G., Gitas I.Z. Fuel type mapping using medium resolution imagery and GIS, considering radiometric, spatial and spectral enhancements of the original dataset. Proceedings of the 6th International Workshop of The EARSeL Special Interest Group on Forest Fires. Thesalonniki, 2007. P. 107-110.

18. Verbesselt J., Somers B., Lhermite S., Jonckheere I., van Aardt J., Coppin P. Monitoring herbaceous fuel moisture content with SPOT VEGETATION time-series for fire risk prediction in savanna ecosystems. Remote Sensing of Environment, 2007. No 108. P. 357368. DOI: 10.1016/j.rse.2006.11.019.

19. Yuan C., Zhang Y., Liu Z. A survey on technologies for automatic forest fire monitoring, detection, and fighting using unmanned aerial vehicles and remote sensing techniques. Canadian journal of forest research, 2015. V. 45. No 7. P. 783-792. DOI: $10.1139 / \mathrm{cjfr}-$ 2014-0347.

\section{REFERENCES}

1. Amatulli G., Peréz-Cabello F., de la Riva J. Mapping lightning/human-caused wildfires occurrence under ignition point location uncertainty. Ecological Modelling, 2007. V. 200. No 3. P. 321-333. DOI: 10.1016/j.ecolmodel.2006.08.001.

2. Bradshaw L.S., Deeming J.E., Burgan R.E., Cohen J.D. The 1978 National Fire-Danger Rating System: technical documentation. General Technical Report INT-169. Ogden: U.S. Department of Agriculture, Forest Service, 1984. 44 p.

3. Calabri G. La Prevenzione degli Incendi Boschivi. I Problemi e le Tecniche della Difesa. Bologna: Edagricole, 1984.

4. Chéret V., Denux J.P. Analysis of MODIS NDVI Time Series to Calculate Indicators of Mediterranean Forest Fire Susceptibility. GIScience \& Remote Sensing, 2011. V. 48. No 2. P. 171-194. DOI: 10.2747/1548-1603.48.2.171. 
5. Dong X., Li-min D., Guo-fan S., Lei T., Hui W. Forest fire risk zone mapping from satellite images and GIS for Baihe Forestry Bureau. Journal of Forestry Research. Jilin, 2005. No 16. P. 169-174. DOI: $10.1007 /$ BF02856809.

6. Dowdy A.J., Mills A.G., Finkele K., de Groot W. Australian fire weather as represented by the McArthur Forest Fire Danger Index and the Canadian Forest Fire Weather Index. CAWCR Technical Report, 2009. No 10.91 p.

7. Furjaev V.V., Cvetkov P.A., Furjaev I.V., Zlobina L.P. Conditions of fire origin and spreading in forest regions of Krasnoyarsk krai. Conifers of the boreal area, 2017. V. 35. No 1-2. P. 66-74 (in Russian).

8. Hirsch S.N., Kruckeberg R.F., Madden F.H. The bi-spectral forest detection system. Proceeding 7th International Symposium on Remote Sensing of Environment. Ann Arbor, 1971. P. 2253-2259.

9. Marchi E., Tesi E., Montorselli N.B. Forest fire prevention: a GIS tool for fire-fighting planning and management. Proceedings of the 6th International Workshop of The EARSeL Special Interest Group on Forest Fires. Thesalonniki, 2007. P. 102-106.

10. Rabii H.A. An Investigation of the utility of Landsat-2 MSS data to the fire-danger rating area, and forest fuel analysis within Crater Lake National Park: Ph.D. thes. Oregon, 1979. $410 \mathrm{p}$.

11. Rignot E., Way J.B., McDonald K., Viereck L., Williams C., Adams P., Payne C., Wood W., Shi $J$. Monitoring of environmental conditions in taiga forests using ERS-1 SAR. Remote Sensing of the Environment, 1994. No 49. P. 145-154. DOI: 10.1016/00344257(94)90051-5.

12. Rouse J.W., Haas R.H., Schell J.A., Deering D.W. Monitoring vegetation systems in the Great Plains with ERTS. Proceedings of the Third Earth Resources Technology Satellite1 Symposium, 1974. No 1. P. 309-317.

13. Rjazanova N. E., Sorokin P. A. The experience of remote vegetation sensing application in the Russian Arctic Ecosystems dynamics study. Earth sciences: yesterday, today, tomorrow. Proceeding of III International scientific conference, 2017. P. 7-12 (in Russian).

14. Skowronski N.S., Clark K.L., Duveneck M., Hom J. Three-dimensional canopy fuel loading predicted using upward and downward sensing LiDAR systems. Remote Sensing of Environment, 2011. V. 115. P. 703-714. DOI: 10.1016/j.rse.2010.10.012.

15. Sofronova A.V., Volokitina A.V. Assessment of fire hazard for forest sites at the territory of oil and gas complexes using Earth remote sensing data. Siberian Journal of Forest Science, 2017. No 5. P. 84-94 (in Russian). DOI: 10.15372/SJFS20170508.

16. Stergiopoulos I., Mallinis G., Gitas I.Z. Fuel type mapping using medium resolution imagery and GIS, considering radiometric, spatial and spectral enhancements of the original dataset. Proceedings of the 6th International Workshop of The EARSeL Special Interest Group on Forest Fires. Thesalonniki, 2007. P. 107-110.

17. Suhinin A.I., Ponomarev E.I. Mapping and Short-Term Forecast of Fire Risk in the Forests of East Siberia according to Satellite Data. Siberian Journal of Ecology, 2003. V. 10. No 6. P. 669-677 (in Russian).

18. Verbesselt J., Somers B., Lhermite S., Jonckheere I., van Aardt J., Coppin P. Monitoring herbaceous fuel moisture content with SPOT VEGETATION time-series for fire risk prediction in savanna ecosystems. Remote Sensing of Environment, 2007. No 108. P. 357368. DOI: 10.1016/j.rse.2006.11.019.

19. Yuan C., Zhang Y., Liu Z. A survey on technologies for automatic forest fire monitoring, detection, and fighting using unmanned aerial vehicles and remote sensing techniques. Canadian journal of forest research, 2015. V. 45. No 7. P. 783-792. DOI: $10.1139 /$ jfr2014-0347. 


\title{
Н.В. Рыгалова ${ }^{1}$, Т.Г. Плуталова \\ ОЦЕНКА СВЯЗИ NDVI СТЕПНОЙ РАСТИТЕЛЬНОСТИ И РАДИАЛЬНОГО ПРИРОСТА СОСНЫ ЛЕНТОЧНЫХ БОРОВ В ЗАСУШЛИВЫХ УСЛОВИЯХ ЮГА ЗАПАДНОЙ СИБИРИ
}

\begin{abstract}
АННОТАЦИЯ
В работе представлен пространственно-временной анализ рядов вегетационных индексов NDVI (по данным спутника MODIS) и дендрохронологических данных, полученных для степных районов Алтайского края. Серии NDVI рассчитаны по пяти полигонам естественных и природно-антропогенных степных ландшафтов за период 20002018 гг.

Экспериментальные участки естественных ландшафтов расположены на прибрежных и особо охраняемых природных территориях, природно-антропогенных пашнях. Большинство точек расположено с сухостепных подпровинциях степной зональной области, меньшая часть - засушливостепной (в том числе дендрохронологический участок).

Хронология ширины годичных колец построена для сосны обыкновенной степной части экстразональных ленточных боров. Для рядов NDVI практически всех полигонов за исследуемый период выявлен положительный тренд изменения вегетационных индексов, слабый положительный тренд зафиксирован и для древесно-кольцевой хронологии сосны. Более выраженный положительный тренд характерен для участка с наиболее низкими средними значениями NDVI, отрицательный тренд - для участка с наиболее высокими средними значениями вегетационного индекса.

Корреляция осредненных по полигонам рядов NDVI друг с другом составила от 0,54 до 0,64 (значимы при $р<0,05$ ). Выявлена зависимость анализируемых рядов от динамики увлажнения территории. Коэффициенты корреляции гидротермического коэффициента Селянинова с рядами NDVI составили от 0,51 до 0,76, а с древесно-кольцевой хронологией 0,63 (значимы при $\mathrm{p}<0,05$ ). Установлены единичные статистически значимые связи между хронологией сосны и рядами NDVI, относящимися в основном к растительным сообществам сухой степи.
\end{abstract}

КЛЮЧЕВЫЕ СЛОВА: NDVI, гидротермический коэффициент, древесно-кольцевая хронология, сухая степь, ленточные боры.

\footnotetext{
1 Алтайский государственный университет, Институт географии, проспект Ленина, 61, 656049 Барнаул, Россия, e-mail: natalia.ml@mail.ru

2 Институт водных и экологических проблем СО РАН, ул. Молодежная, 1, 656038, Барнаул, Россия, e-mail: plutalova.tg@gmail.com
} 


\title{
Natalia V. Rygalova', Tatiana G. Plutalova² \\ ESTIMATION OF THE RELATION OF NDVI STEPPE VEGETATION AND RADIAL GROWTH OF PINE BELT FORESTS IN ARID CONDITIONS OF THE SOUTH OF WESTERN SIBERIA
}

\begin{abstract}
This article presents a spatial-temporal analysis of the NDVI vegetation series (based on the MODIS satellite data) and dendrochronological data obtained for the steppe regions of the Altai Territory. NDVI series are built for five polygons of natural and natural-anthropogenic steppe landscapes for the period 2000-2018. Experimental areas of natural landscapes are located in coastal and specially protected natural areas, natural and anthropogenic arable lands. Most of the points are located in the dry-steppe sub-provinces of the steppe zonal area, a smaller part is in the arid-steppe (including the dendrochronological area). The chronology of the tree ring width is built for the Scots pine in the steppe part of extrazonal belt pine forests. A positive trend in vegetation indices change and a weak positive trend for the tree-ring chronology of the pine were found for the NDVI series of almost all polygons for the study period. A more pronounced positive trend is characteristic of the area with the lowest average NDVI values, while a negative trend is characteristic of the area with the highest average values of the vegetation index. The correlation of the NDVI series averaged over polygons with each other ranged from 0.54 to 0.64 (significant at $\mathrm{p}<0.05$ ). The dependence of the analyzed series on the dynamics of moistening of the territory was revealed. The correlation coefficients of the Selyaninov hydrothermal coefficient with the NDVI series ranged from 0.51 to 0.76 , and with the tree-ring chronology was 0.63 (significant at $\mathrm{p}<0.05$ ). A statistically significant relationship was established for some points between the chronology of the pine and the NDVI series, mostly related to dry steppe vegetation.
\end{abstract}

KEYWORDS: NDVI, hydrothermal coefficient, tree-ring chronology, dry steppe, pine belt forests.

\section{ВВЕДЕНИЕ}

Изучение ширины годичных колец деревьев позволяет оценить изменчивость их стволовой продуктивности в условиях изменяющегося климата достаточно точно и локально. Однако для древостоев, произрастающих в переходных биомах или на границах своих зональных ареалов, характерна региональная согласованность радиального прироста, обусловленная влиянием лимитирующих климатических факторов среды. Для получения пространственно-временной информации о динамике продуктивности степной растительности возможно использовать данные дистанционного зондирования, которые обеспечивают более масштабный охват анализируемых ландшафтов (прежде всего из-за пространственного разрешения имеющихся в наличии космических снимков). В качестве показателя продуктивности растительности могут быть использованы значения NDVI [Золотокрылин и дp., 2013]. Поиск связи между показателями продуктивности степной растительности и древесных сообществ, полученных разными методами, представляет научный интерес.

\footnotetext{
1 AltayStateUniversity, Institute of Geography, Lenin Avenue, 61, 656049 Barnaul, Russia, e-mail: natalia.ml@mail.ru

2 Institute for Water and Environmental Problems SB RAS, Molodezhnaya str., 1, 656038, Barnaul, Russia, e-mail: plutalova.tg@gmail.com
} 
Пространственное сочетание древесных сообществ и сухостепной растительности отмечено на юге Западной Сибири (юго-запад Алтайского края), это обстоятельство определило территорию данного исследования. Сосна обыкновенная (Pinus sylvestris L.) представлена здесь в ленточных борах, которые как экстразональные образования отклоняются на юг от основного ареала произрастания данного вида [Вангнии, 1953; Правдин, 1964] по долинам древнего стока.

Использование вегетационного индекса растительности NDVI и древеснокольцевых хронологий деревьев в сопряженном анализе изменчивости продуктивности растительных сообществ проводилось ранее [Coulthard et al., 2017; Liu et al., 2021; Malmström et al., 1997; Vicente-Serrano et al., 2016; Wang et al., 2004], в рамках которых исследовалась связь радиального прироста деревьев и NDVI лесных сообществ или климатически опосредованная связь древесно-кольцевых хронологий и NDVI степной растительности.

Исследование изменения вегетационных индексов степных сообществ и радиального прироста деревьев в засушливой зоне позволит оценить реакцию растительности на потепление климата, фиксируемое в мире и России ${ }^{1}$, и усиливающуюся аридизацию данных территорий. Несмотря на поступательное увеличение среднемноголетней температуры ${ }^{3}$, отмечаются разнонаправленные флуктуации временной динамики NDVI [Тельнова, 2017], обусловленные в том числе изменчивостью осадков. В условиях степи, в наибольшей степени сухой степи, пространственно-временные колебания величины атмосферных осадков могут достигать больших значений по территории.

Установление связи между древесно-кольцевыми хронологиями (ДКХ) деревьев и вегетационными индексами степной растительности проводится с целью выявления общих тенденций в динамике погодичной продуктивности разных растительных сообществ в условиях дефицита влаги. В случае, если связь будет достоверно установлена, то будет возможна реконструкции продуктивности степных сообществ в прошлое [Wang et al., 2010].

\section{МАТЕРИАЛЫ И МЕТОДЫ ИССЛЕДОВАНИЯ}

Основой исследований продуктивности степных сообществ являются методы, основанные расчете и оценке вегетационных индексов, представляющих собой комбинации спектральных каналов в видимом и ближнем инфракрасном диапазонах спектра. В данной работе для анализа используется наиболее распространенный вегетационный индекс NDVI [Rouse et al., 1973]:

$$
\frac{N I R-R E D}{N I R+R E D}=N D V I, \text { где }
$$

NIR - отражение в ближней инфракрасной области спектра, $\mathrm{RED}$ - отражение в красной области спектра.

NDVI рассчитывался на основе продукта MOD13Q1 (2000) (16-дневный композит с пространственным разрешением $250 \mathrm{M}$ ), полученного с помощью спектрорадиометра TERRA/MODIS за первую половину июня 2000-2018 гг. ${ }^{23}$. Эти даты соответствуют повышенной вегетационной активностью на степных территориях, так как в середине июня

\footnotetext{
1 Доклад об особенностях климата на территории Российской Федерации за 2019 год. М., 2020. 97 с. Электронный pecypc: http://www.meteorf.ru/press/news/20626/ (дата обращения: 30.02.2021).

2 MODIS Vegetation Index Products (NDVI and EVI). Электронный pecypc: https:// modis. gsfc.nasa.gov/data/ dataprod/mod13.php (дата обращения: 10.01.2021).

3 USGS Global Visualization Viewer. Электронный pecypc: http:/glovis.usgs.gov/ (дата обращения: 15.01.2021).
} 
разнотравье начинает сменяться ксерофитными дерновинными злаками [Мордкович, 2014; Сайб и др., 2020]. Обработка данных проводилась с помощью QGIS 3.16.3.

В степной зональной области были выбраны 5 тестовых полигонов по 10 точек в каждом: один в границах пахотных угодий, один - в береговой зоне степных озер (в данном случае при выборе точек использован типологический подход, точки расположены на значительном расстоянии друг от друга), три полигона - на территориях ООПТ (использован индивидуальный подход, точки в каждом полигоне расположены концентрировано в связи с небольшим размером ООПТ) (рис. 1). Выбор полигонов осуществлялся по принципу выделения антропогенно нарушенных ландшафтов (пашни), ненарушенных (береговые территории и малопригодные для распашки в связи с заболоченностью и засоленностью) и особо охраняемые природные территории, которые в настоящее время представляют собой ареалы сохранения естественной степной растительности.

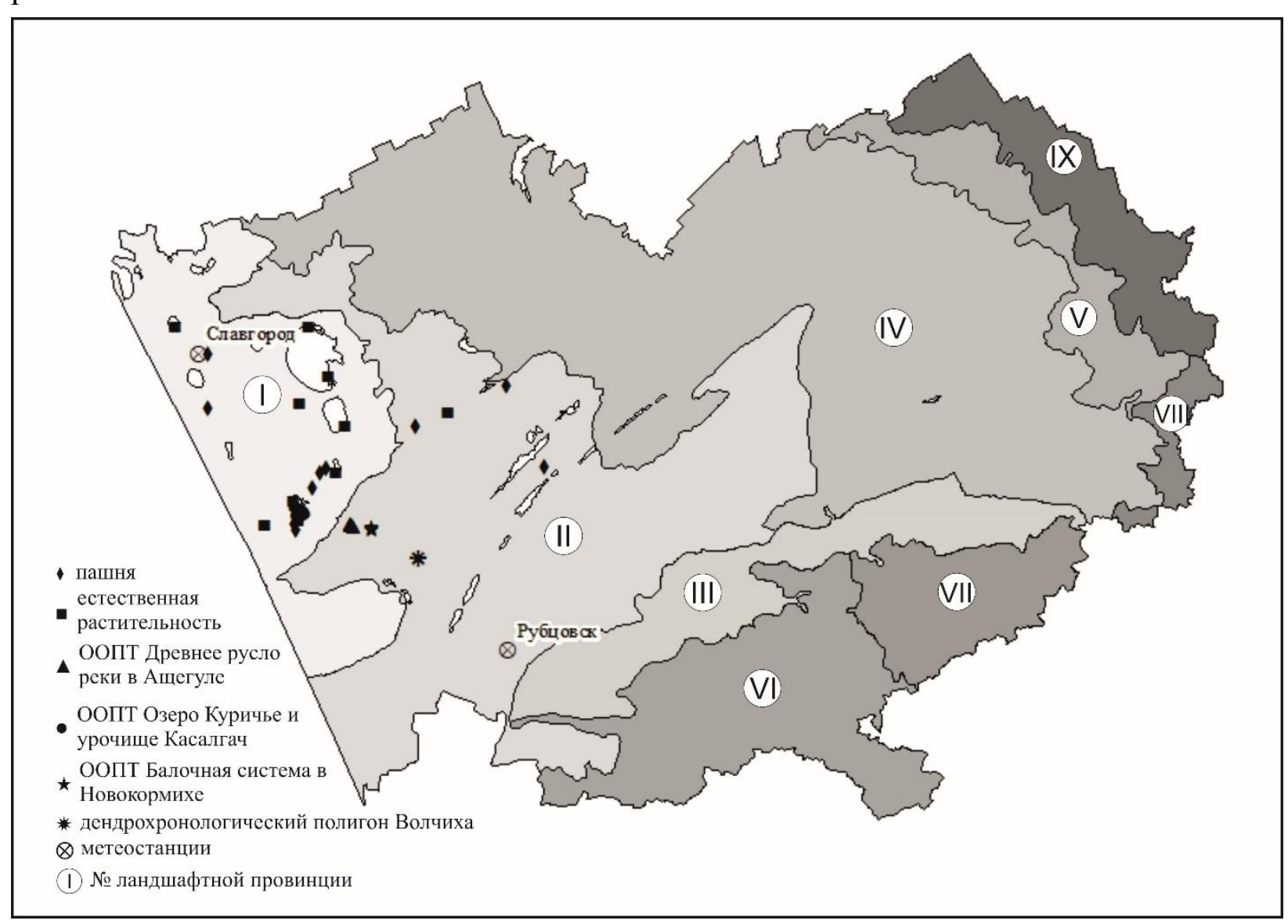

Рис. 1. Территория исследования в границах Алтайского края (ландшафтная основа ${ }^{1}$ ) Ландиафтные провинции:

I. Кулундинская, II. Южно-Приалейская, III. Предалтайская, IV Верхне-Обская, V. Предсалаирская, VI. Северо-Западная Алтайская, VII. Северо-Алтайская, VIII. СевероВосточная Алтайская, IX. Салаирская.

Fig. 1. Geographical location of research area in the Altai Krai (landscapes) Landscapes: I. Kuluna, II. South-Pri-Aleysk, III. Pre-Altai, IV. Upper Ob, V. Pre-Salair, VI. North-West Altai, VII. North Altai, VIII. North-Eastern Altai, IX. Salair 
Для отображения разнообразных условий ведения сельского хозяйства пахотные угодья были выбраны в трех подпровинциях: сухо-, засушливо- и умеренно засушливостепных, отличающихся по количеству осадков, температурному режиму, почвенным характеристикам (рис. 2). Высота по отдельным точкам колеблется от 125 м (озерноаллювиальные плоские равнины) до 268 м (плоские и слабоволнистые водораздельные поверхности плато). Основными возделываемыми культурами являются пшеница яровая, овес и подсолнечник.

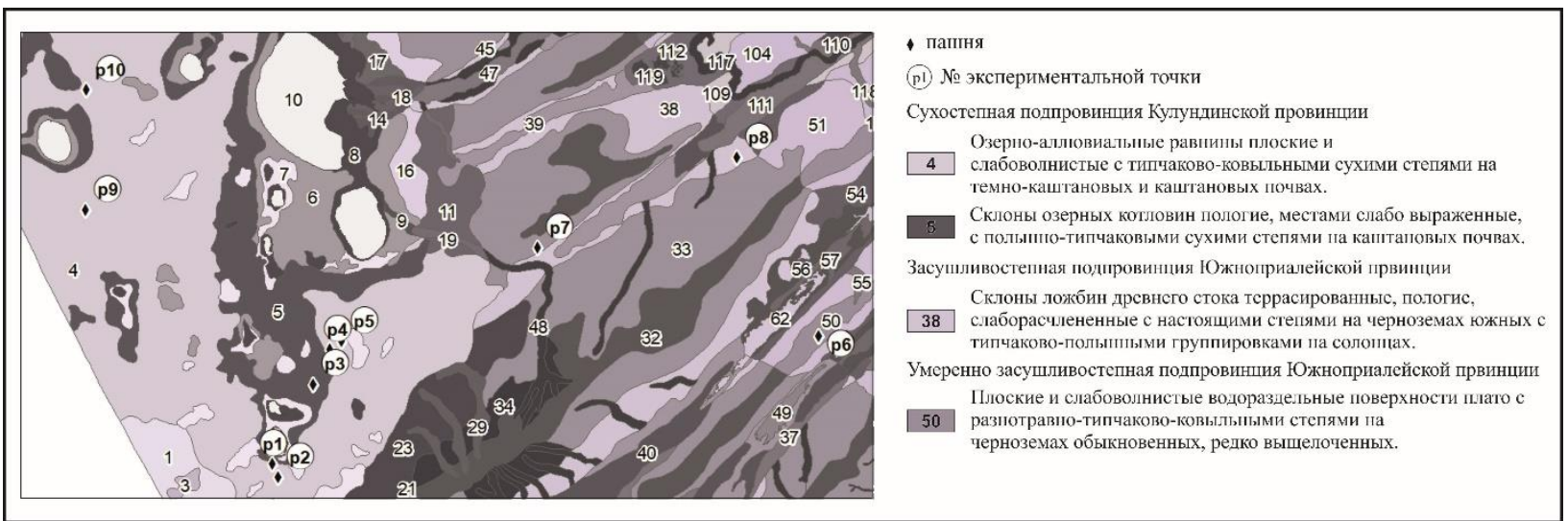

Рис. 2. Местоположение экспериментальных точек категории пашня ${ }^{1}$

Fig. 2. Geographical location of experimental points of the arable land category

Береговые участки расположены на берегах озер Кулундинское, Кучукское, Большое Яровое, Петухово, Скрипун (рис. 3). Высота по отдельным точкам колеблется от 100 до 176 м. Большая часть точек (9 из 10) расположена в границах сухостепной подпровинции Кулундинской провинции и представлена низкими озерными террасами плоскими и плоско-западинными с солонцово-солончаковыми лугами в комплексе со злаково-разнотравными болотно-солончаковыми лугами.
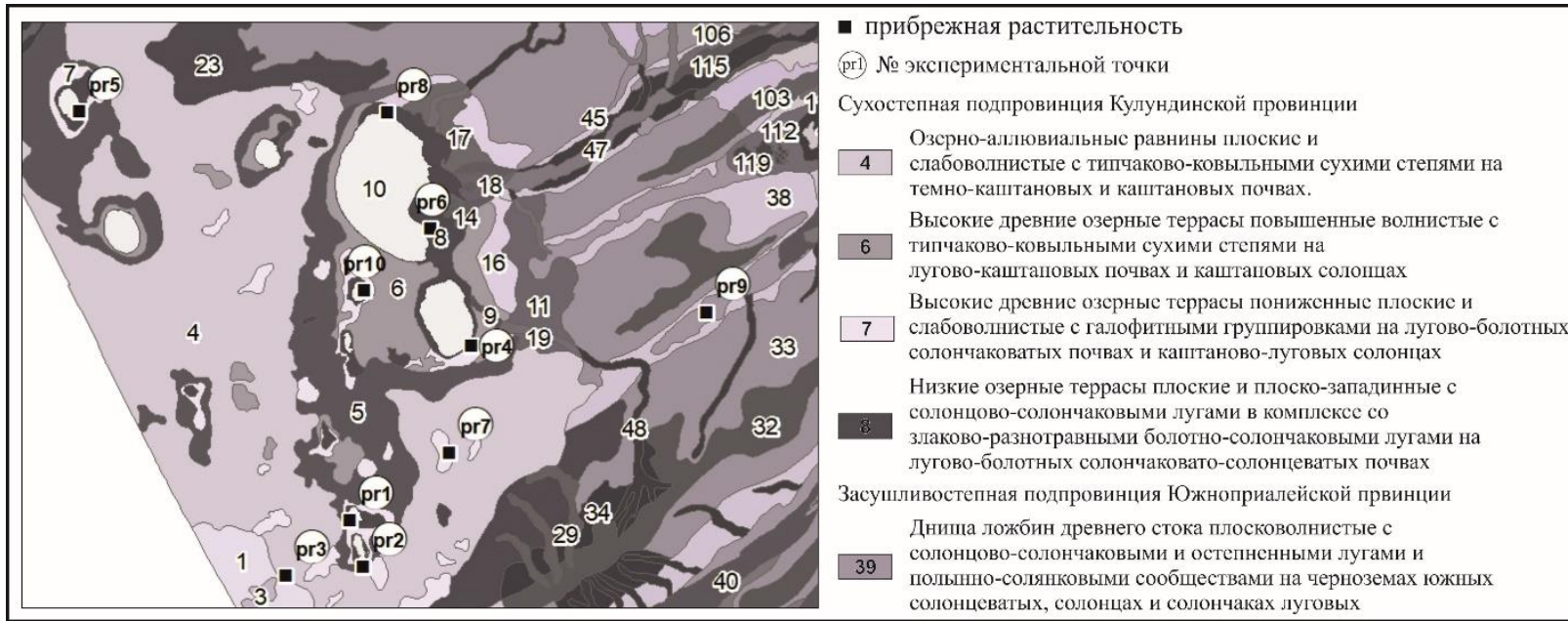
солонцеватых, солонцах и солончаках луговых

Рис. 3. Местоположение экспериментальных точек категории прибрежная растительность

Fig. 3. Geographical location of experimental points of the coastal vegetation category

1 Здесь и далее приведены ландшафтные местности, в границах которых расположены точки. Ландшафтная карта Алтайского края. Масштаб 1:500000. Науч. рук. Ю.И. Винокуров. ИВЭП СО РАН, 2016. 
Памятник природы краевого значения «Древнее русло реки в Ащегуле» образован 6 мая 2014 г. в Михайловском районе Алтайского края (рис. 4). Представляет собой фрагмент эрозионно-балочного рельефа: заросшее растительностью русло пересохшего водотока, которое пересекает плоскую поверхность с небольшими уклонами (менее $0,5^{\circ}$ ) и высотой от 142 до 201 м. Расположен в нижней части северо-западного значительно выположенного склона юго-западного окончания Кулундинско-Касмалинского увала Приобского плато, постепенно переходящего в Кулундинскую равнину. Значительные площади занимают фрагменты разнотравно-ковыльно-типчаковых степей с доминированием ковыляволосатика (Stipa capillata), овсяницы валисской (Festuca valesiaca).

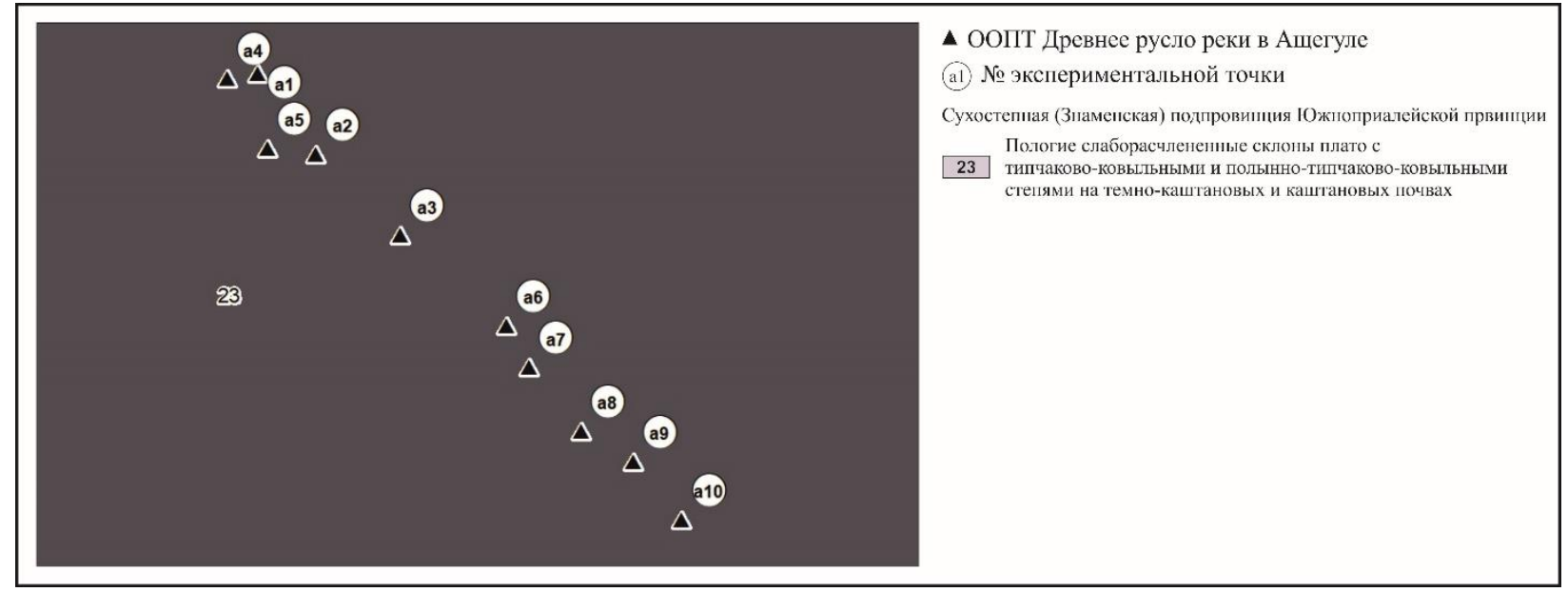

Рис. 4. Местоположение экспериментальных точек категории ООПТ "Древнее русло реки в Ащегуле»

Fig. 4. Geographical location of experimental points of the protected areas category in the «Ancient river bed in Ashchegul» territory

Памятник природы краевого значения «Озеро Куричье и урочище Касалгач» образован 13 апреля 1998 г. в Ключевском районе Алтайского края (рис. 5). Высоты изменяются незначительно - 128-131 м. Граница урочища Касалгач совпадают с естественными границами березового заболоченного леса имеют ивовый подлесок до 2 м. В травяном покрове доминирует осока дернистая (Carex caespitosa). На восточном берегу озера - песчаные дюны, переходящие в кочкарник, к юго-востоку - тростник (Phragmites communis).

Памятник природы краевого значения «Балочная система в Новокормихе» образован 6 мая 2014 г (рис. 6). Представляет собой фрагмент эрозионно-балочного рельефа с перепадом высот от 276 м до 285 м. Расположен в верхней части северо-западного склона юго-западного окончания Кулундинско-Касмалинского увала Приобского плато на стыке с Кулундинской равниной. Степные участки представлены полынно-тырсоковыльными и тырсоковыльными настоящими сухими степями с доминированием плотно дерновинного злака ковыля-волосатика (Stipa capillata). Древесная растительность занимает дно балки и её северные склоны, где формируется березово-осиновый крупнотравный орляковый лес с подлеском. В понижении, на более увлажненных участках расположены лугово-болотные комплексы. 


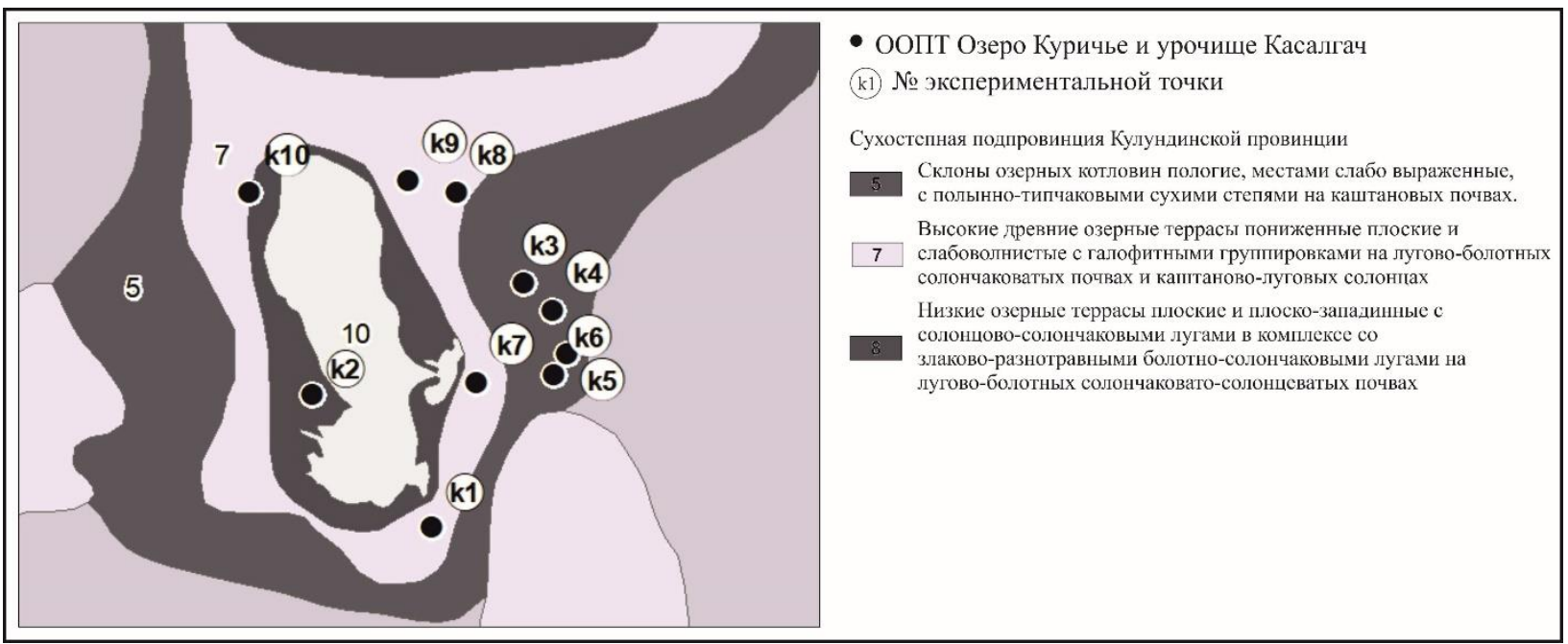

Рис. 5. Местоположение экспериментальных точек категории ООПТ «Озеро Куричье и урочище Касалгач»

Fig. 5. Geographical location of experimental points of the protected areas category in the [Kurichye lake and Kasalgach urochishche» territory

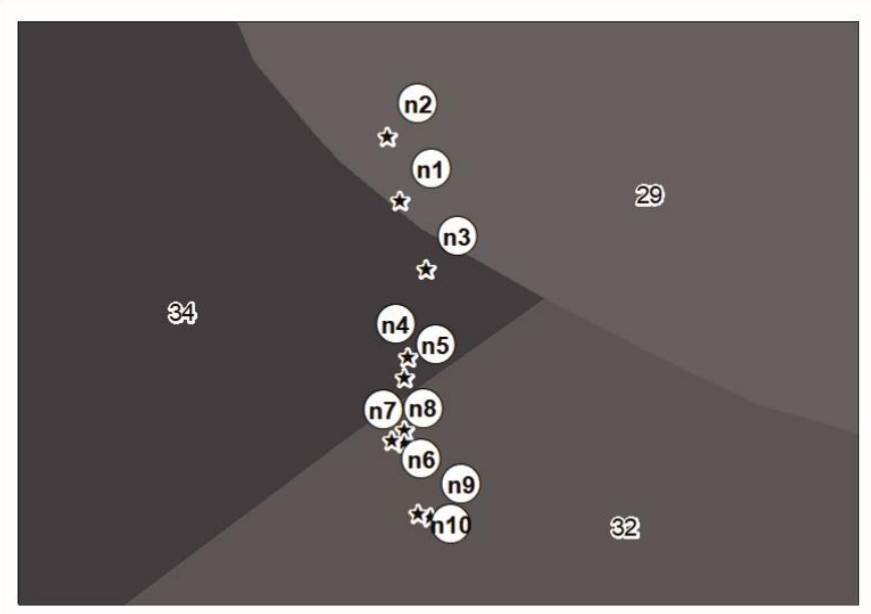

$\star$ ООПТ Балочная система в Новокормихе

(n1) № экспериментальной точки

Сухостепная (Руббцвская) подпровиншия Южноприалейской првинции Пологосклошныс долишы и балки с пирокими лиишами,

м. мелкими временными водотоками, с галофитными разнотравно-злаковыми лугами на лугово-каштановых солонцеватых почвах и солонцах лугово-каштановых

Засушливостепная полпровинция Южноприалсйской првинции

32 Плоские пологоволнистыс водораздельные поверхности плато с разнотравно-типчаково-ковыльными степями на черноземах южных Расчлененные склоны плато с разногравно-злаково-полынно-типчаковыми степями на черноземах южных и солонцах степных

Рис. 6. Местоположение экспериментальных точек категории ООПТ «Балочная система в Новокормихе»

Fig. 6. Geographical location of experimental points of the protected areas category in the «Balka system in Novokormikha» territory

В качестве дендрохронологического материала использована обобщенная древеснокольцевая хронология (ДКХ) Волчиха продолжительностью 251 год (1768-2018 гг.), построенная по сосне ленточных боров в Волчихинском районе Алтайского края. Модельный участок расположен на высоте примерно 220 м (днище долины древнего стока) и принадлежит засушливостепной подпровинции Южноприалейской провинции Кулундинской степной зональной области. Образцы были собраны с 18 деревьев (по 2 радиуса с дерева) по стандартной методике [Шиятов и др., 2000], измерение проводилось на установке LINTAB в программе TSAP [Rinn, 1996], обработка данных проводилась в 
программном пакете DPL. B качестве аппроксимирующих кривых выбраны негативные экспоненты (и для отдельных индивидуальных хронологий применен кубический сплайн 2/3), в работе использована остаточная (выбеленная - с удаленным автокорреляционным шумом) обобщенная хронология. Коэффициент чувствительности ДКХ за анализируемый период (2000-2018 гг.) составил 0,32, что превышает пороговый уровень [Ferguson, 1969] и подтверждает возможность использования ряда в дендроклиматическом анализе.

В качестве метеорологических данных в работе были использованы месячные значений температуры воздуха и атмосферных осадков ГМС Славгород и Рубцовск (20002018 гг.), которые находятся в открытом доступе ${ }^{1}$ [12] и рассчитанные на их основе значения гидротермического коэффициента Г.Т. Селянинова. Обе метеостанции расположены в степной зональной области, Славгород - в сухостепной подпровинции Кулундинской провинции, Рубцовск - засушливостепной подпровинции Южноприалейской провинции.

В работе использованы метод дистанционного зондирования Земли (получение значений вегетационного индекса NDVI), дендрохронологический (включающий от сбора первичных данных до получения ДКХ), статистический метод (расчет коэффициентов корреляции в программе Statistica 13.3) и картографический (использование в анализе ландшафтной карты территории исследования и создание картографического иллюстрирующего материала)

\section{РЕЗУЛЬТАТЫ ИССЛЕДОВАНИЯ И ИХ ОБСУЖДЕНИЕ}

Линейные тренды изменений осредненных по 10 точкам значений NDVI для всех полигонов (исключение ООПТ Новокормиха) за период 2000-2018 гг. положительные (рис.7). На данном временном отрезке ДКХ Волчиха также демонстрирует слабый положительный тренд. Полигон ООПТ Новокормиха единственный из всех модельных участков, которые находится полностью в засушливостепной подпровинции Южноприалейской провинции, остальные (полигоны Береговой и Пашня по большинству точек) приурочены к сухостепной подпровинции. Динамика значений гидротермического коэффициента Селянинова, рассчитанных по данным метеостанции Славгород, за период 2000?2018 гг. имеет отрицательный тренд (хотя если рассматривать динамику значения с 2003 года, то тренд меняет вектор на положительный), а значений ГТК, рассчитанных для ГМС Рубцовск, характерна положительная тенденция изменения.

Стоит также отметить, что наиболее выраженный положительный тренд вегетационного индекса у ряда ООПТ Ащегуль, который характеризуется наименьшими средними арифметическими значениями (табл.), что свидетельствует о более угнетенном состоянии растительности по сравнению с другими участками. Одновременно для ряда Новокормиха (продемонстрировавшего отрицательный тренд) отмечены наибольшие значения среднего. Можно заключить, что на рост увлажнения территории более интенсивно реагируют растительные сообщества, характеризующиеся недостаточным уровнем образования фитомассы (в сухостепных условиях, вероятно, в результате недостатка влаги). Положительный тренд также может объясняться увеличением закустаренности участков, что также получает большее развитие в приросте количества осадков.

Специализированные массивы. Всероссийский научно-исследовательский институт гидрометеорологической информации - Мировой центр данных (ВНИИГМИ-МЦД). Электронный ресурс: http:// meteo.ru/data (дата обращения: 10.01.2021). 

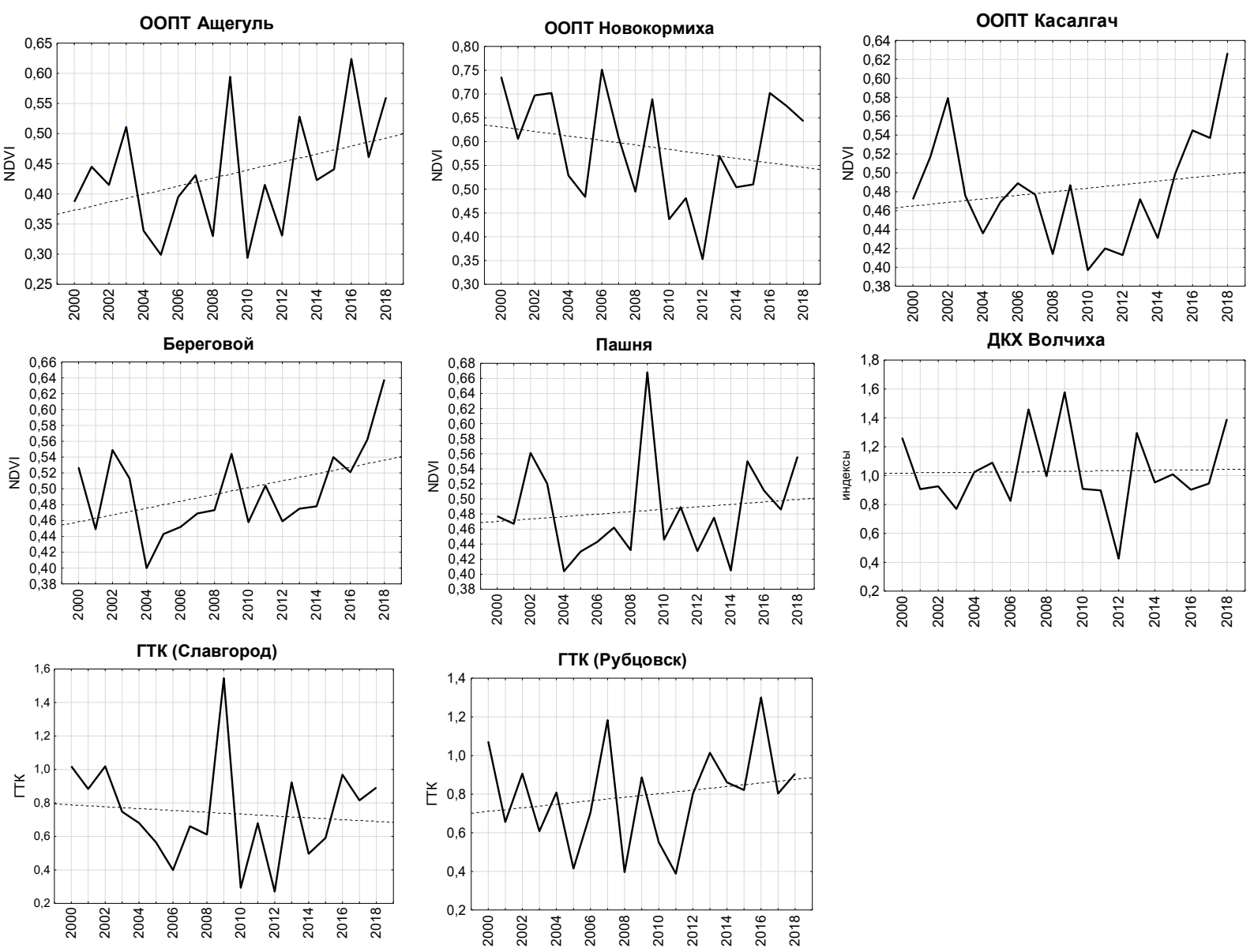

Рис. 7. Осредненные (по 10 точкам) значения NDVI степной растительности, ДКХ Волчиха и ГТК Селянинова (по ГМС Славгород и Рубиовск) за период 2000-2018 г2.

Fig. 7. Averaged (over 10 points) NDVI values of steppe vegetation, Volchikha tree-ring chronology, and Selyaninov hydrothermal coefficient (Slavgorod and Rubtsovsk weather stations) for the period 2000-2018.

Корреляционный анализ рядов продуктивности растительности (осредненных по 10 точкам серий NDVI каждого полигона и ДКХ Волчиха) показал статистически значимую положительную связь с ГТК (данные ГМС Славгород): для Берегового и ООПТ Касалгач составил 0,51, для ООПТ Новокормиха и ДКХ Волчиха - 0,63, для полигонов Пашня и Ащегуль - выше 0,7. Следовательно, справедливо говорить о наличии общего лимитирующего климатического фактора формирования биомассы травянистой растительности и радиального роста деревьев в условиях сухой степи. О пространственной специфике изменения увлажнения по территории говорит тот факт, что серии NDVI также, как и ДКХ, не показали значимой связи с рядом ГТК метеостанции Рубцовск, находящейся в засушливой степной подпровинции.

На основании того, что динамика продуктивность деревьев и степных сообществ зависит от колебаний увлажнения территории была проанализирована климатообусловенная связь между ними: рассчитаны коэффициенты корреляции хронологии сосны и серий NDVI по 5 полигонам (использовались как осредненные ряды по 10 точкам, так и по всем точкам отдельно). 
Табл. Характеристика рядов NDVI и коррелящии с ДКХ сосны

Table. Characteristics of NDVI series and correlations with tree-ring chronology pine

\begin{tabular}{|c|c|c|c|c|c|}
\hline \multirow[t]{2}{*}{ Полигоны NDVI } & \multicolumn{4}{|c|}{ осредненные по 10 точкам полигона } & \multirow{2}{*}{$\begin{array}{l}\text { Статистически } \\
\text { значимые связи ДКХ } \\
\text { Волчиха с рядами } \\
\text { NDVI по отдельным } \\
\text { точкам полигонов }\end{array}$} \\
\hline & $\begin{array}{l}\text { Сред- } \\
\text { нее } \\
\text { значе- } \\
\text { ние }\end{array}$ & $\begin{array}{l}\text { Станд. } \\
\text { откл. }\end{array}$ & $\begin{array}{l}\text { Осредн. r* } \\
\text { с рядами } \\
\text { NDVI } \\
\text { других } \\
\text { полигонов }\end{array}$ & $\begin{array}{l}r^{*} c \\
Д К Х\end{array}$ & \\
\hline Береговой & 0,50 & 0,06 & $\mathbf{0 , 6 3}$ & 0,33 & т. $2(\mathbf{0 , 4 6 )}$ \\
\hline Пашня & 0,48 & 0,07 & 0,62 & $\mathbf{0 , 4 5}$ & $\begin{array}{l}\text { т. } 2(\mathbf{0 , 6 3}) ; \text { т. } 3(\mathbf{0 , 4 8}) \text {; } \\
\text { т. } 10(\mathbf{0 , 4 5})\end{array}$ \\
\hline ООПТ Ащегуль & 0,43 & 0,10 & $\mathbf{0 , 6 3}$ & 0,40 & т. $3(\mathbf{0 , 5 4 )}$; т. $5(\mathbf{0 , 4 6 )}$ \\
\hline ООПТ Новокормиха & 0,59 & 0,11 & 0,54 & 0,35 & т. $1(\mathbf{0 , 5 5}) ;$ т. $4(\mathbf{0 , 4 6 )}$ \\
\hline ООПТ Касалгач & 0,48 & 0,06 & 0,64 & 0,30 & т. $1(\mathbf{0 , 7 4})$ \\
\hline
\end{tabular}

$\mathrm{r}^{*}$ - коэффициенты корреляции (жирным выделены статистически значимые при $\mathrm{p}<0.05$ ).

В результате единственная значимая связь с осредненными значениями по полигонам была получена только по пахотным угодьям (табл.). В границах выделенных полигонов от 1 до 3 точек показали значимую корреляцию NDVI с ДКХ Волчиха, при этом коэффициенты скорее свидетельствовали об умеренной связи (до $|0,5|$ ), реже о значительной $(|0,5|-|0,7|)$.

Большинство точек, показавших максимальную корреляционную связь, относятся к Кулундинскому ландшафтному району сухостепной подпровинции Кулундинской провинции (5 из 9) и Бель-Агачскому району сухостепной (Рубцовской) подпровинции Южноприалейской првинции (2 из 9).

Низкие значения корреляции древесно-кольцевых хронологий возможно могут быть связаны с неоднородностью продуцирования степной растительности на локальном уровне. В условиях дефицита влаги микрорельеф перераспределяет ее и определяет интенсивность формирования зеленой массы растениями. На это может указывать средние коэффициенты корреляции рядов NDVI друг с другом (при $\mathrm{r} \approx 0,6$, доля объясненной дисперсии составляет около $40 \%$ ), несмотря на то, что большинство из них представлено сходными растительными сообществами (за исключением пахотных угодий). При такой мозаичности микроландшафтных условий возможно необходимо увеличить разрешение используемых космических снимков за счет привлечения данных других спутников. Сложности в оценке продуктивности из-за низкого разрешения снимков MODIS отмечалось ранее [Золотокрылин и др., 2013].

Также важным моментом является сезон получения анализируемых данных дистанционного зондирования. Если для зональной сухостепной растительности май-июнь является периодом максимальных объемов продуцирования фитомассы, а в июле-августе отмечается усыхание растений целинной степи [Немщева $и$ др., 2018], то в июне годичное кольцо деревьев еще формируется. Пик радиального прироста сосны в лесостепной зоне Сибири приходится на конец мая [Arzac et al., 2018], таким образом в июне формируется ранняя древесина, которая занимает значительную часть годичного кольца и определяет его ширину, но тем не менее формирование кольца продолжается на протяжение июля-августа [там же]. 


\section{ВЫВОДЫ}

Выполненное исследование позволило определить тенденции изменения вегетационных индексов для различных растительных сообществ природно-антропогенных и естественных ландшафтов в степной зоне юга Западной Сибири за последние два десятилетия. Динамика гидротермического коэффициента, определяющего увлажнение территории, в XXI в. показала по данным метеостанций Рубцовск и Славгород (по последней ГМС только с 2003 года) положительный тренд, который был зафиксирован и в рядах NDVI всех сухостепных (или преимущественно, сухостепных по большинству точек) полигонов. Динамика NDVI для участка, расположенного в условиях засушливой степи, продемонстрировала отрицательный тренд. Для остаточной древесно-кольцевой хронологии сосны ленточных боров также отмечен слабый положительный тренд.

Наличие общего лимитирующего фактора (увлажнения территории), определяющего динамику вегетационного индекса и радиального прироста деревьев в степной зоне, позволил провести их корреляционный анализ. Была выявлена умеренная связь ДКХ и рядов NDVI от 1 до 3 точек по каждому полигону ( $\mathrm{r}$ от 0,45 до 0,74 при $\mathrm{p}<0,05$ ). Наибольший отклик был получен по точкам, приуроченных в основном к сухостепным подпровинциям степной зональной области.

Причиной того, что были обнаружены лишь единичные случаи связи ДКХ и NDVI, может быть низкое разрешение снимков спектрорадиометра MODIS $(250 \times 250$ м), которые не могут дать детальную информацию по продуктивности степных и сухостепных растительных сообществ. Образование фитомассы в сухостепных местообитаниях зависит от доступности влаги, перераспределяемой микрорельефом территории. При этом необходимы дополнительные исследования для понимания характера связи между этими двумя показателями. Перспективным направлением является рассмотрение значений NDVI за разные месяцы для сезонной оценки изменчивости вегетационного индекса степной растительности.

\section{БЛАГОДАРНОСТИ}

Работа выполнена в рамках научно-исследовательской программы ИВЭП СО РАН (проект № 0306-2021-0007).

\section{ACKNOWLEDGEMENTS}

This work was carried out within the framework of the Research Program of the Institute for Water and Environmental Problems SB RAS (Project 0306-2021-0007).

\section{СПИСОК ЛИТЕРАТУРЫ}

1. Вангнии П.Р. Ленточные боры. М.: Гослесбумиздат, 1953. 153 с.

2. Золотокрылин А.Н., Титкова Т.Б., Уланова С.С., Федорова Н.Л. Наземные и спутниковые исследования продуктивности пастбищ республики Калмыкии с различной степенью деградации растительных сообществ. Аридные системы. 2013. Т. 19. №4(57). С. 31-39.

3. Мордкович В.Г. Степные экосистемы. Новосибирск. 2014. 170 с.

4. Немцева Л.Д., Беспалова Л.А., Голубева Е.И., Михайлов С.И. Оценка состояния растительного покрова сухостепных ландшафтов в условиях выпаса с применением методов дистанционного зондирования Земли. Труды ЮНЦ РАН. 2018. Т. VII. С. 151-164. DOI: 10.23885/1993-6621-2018-7-151-164.

5. Правдин Л.Ф. Сосна обыкновенная. Изменчивость, внутривидовая систематика и селекция. М.: Наука, 1964. 191 с.

6. Сайб Е. А., Безбородова А. Н., Соловьев С. В., Миллер Г. Ф., Филимонова Д. А. Выявление разновозрастных залежей на эрозионно-опасных территориях юга Западной 
Сибири с применением геоинформационных технологий. Современные проблемы дистанционного зондирования Земли из космоса. 2020. Т. 17. №4. С. 129-136.

7. Тельнова Н.О. Выявление и картографирование многолетних трендов NDVI для оценки вклада изменений климата в динамику биологической продуктивности агроэкосистем лесостепной и степной зон Северной Евразии. Современные проблемы дистанционного зондирования Земли из космоса. 2017. Т. 14. №6. С. 97-107.

8. Шиятов С.Г., Ваганов Е.А., Кирдянов А.В., Круглов В.Б., Мазепа В.С., Наурзбаев M.M., Хантемиров Р.М. Методы дендрохронологии. Ч. І. Красноярск: Изд-во КрасГУ, 2000. 80 с.

9. Arzac A., Babushkina E.A., Fonti P., Slobodchikova V., SviderskayaI.V., Vaganov E.A. Evidences of wider latewood in Pinus sylvestris from a forest-steppe of Southern Siberia. Dendrochronologia. 2018. V. 49. P. 1-8. DOI: 10.1016/j.dendro.2018.02.007.

10. Coulthard B.L., Touchan R., Anchukaitis K.J., Meko D.M., Sivrikaya F. Tree growth and vegetation activity at the ecosystem-scale in the eastern Mediterranean. Environmental Research Letters. 2017. No 12. 084008. DOI: 10.1088/1748-9326/aa7b26.

11. Ferguson C.W. A 7104-year annual tree-ring chronology for Bristlecone pine, Pinusaristata, from the White Mountains, California. Tree-Ring Bull. 1969. V. 29. No 3-4. P. 3-29.

12. Liu R., Song Y., Liu Y., Li X., Song H., Sun C., Li Q., Cai Q., Ren M., Wang L. Changes in the Tree-Ring Width-Derived Cumulative Normalized Difference Vegetation Index over Northeast China during 1825 to 2013 CE. Forests. 2021. No 12. 241. DOI: 10.3390/f12020241.

13. Malmström C.M., Thompson M.V., Juday G.P., Los S.O., Randerson J.T., Field C.B. Interannual variation in global-scale net primary production: testing model estimates. Global Biogeochemical Cycles. 1997. V. 11. No 3. P. 367-392. DOI: 10.1029/97GB01419.

14. Rouse J.W., Haas R.H., Schell J.A., Deering D.W. Monitoring vegetation systems in the Great Plains with ERTS / In 3rd ERTS Symposium, NASA SP-351 I. 1973. P. 309-317.

15. Rinn F. TSAP V3.5. Computer program for tree-ring analysis and presentation. Heidelberg: Frank Rinn Distribution, 1996. 264 p.

16. Vicente-Serrano S.M., Camarero J.J., Olano J.M., Martín-Hernández N., Peña-Gallardo M., Tomás-Burguera M., Gazol A., Azorin-Molina C., Bhuyan U., Kenawy A. Diverse relationships between forest growth and the Normalized Difference Vegetation Index at a global scale. Remote Sensing of Environment. 2016. 187. P. 14-29. DOI: 10.1016/j.rse.2016.10.001.

17. Wang J., Rich P.M., Price K.P., Kettle W.D. Relations between NDVI and tree productivity in the central Great Plains. Int. J. Remote Sensing. 2004. V. 25. No 16. P. 3127-3138. DOI: 10.1080/0143116032000160499.

18. Wang W. Z., Liu X.H., Chen T., An $W$., Xu G. Reconstruction of regional NDVI using treering width chronologies in the Qilian Mountains, northwestern China. Chinese Journal of Plant Ecology. 2010. V. 34. No 9. P. 1033-1044. DOI: 10.3773/j.issn.1005264x.2010.09.004.

\section{REFERENCES}

1. Arzac A., Babushkina E.A., Fonti P., Slobodchikova V., SviderskayaI.V., Vaganov E.A. Evidences of wider latewood in Pinus sylvestris from a forest-steppe of Southern Siberia. Dendrochronologia. 2018. V. 49. P. 1-8. DOI: 10.1016/j.dendro.2018.02.007.

2. Coulthard B.L., Touchan R., Anchukaitis K.J., Meko D.M., Sivrikaya F. Tree growth and vegetation activity at the ecosystem-scale in the eastern Mediterranean. Environmental Research Letters. 2017. No 12. 084008. DOI: 10.1088/1748-9326/aa7b26. 
3. Ferguson C.W. A 7104-year annual tree-ring chronology for Bristlecone pine, Pinusaristata, from the White Mountains, California. Tree-Ring Bull. 1969. V. 29. No 3-4. P. 3-29.

4. Liu R., Song Y., Liu Y., Li X., Song H., Sun C., Li Q., Cai Q., Ren M., Wang L. Changes in the Tree-Ring Width-Derived Cumulative Normalized Difference Vegetation Index over Northeast China during 1825 to 2013 CE. Forests. 2021. No 12. 241. DOI: 10.3390/f12020241.

5. Malmström C.M., Thompson M.V., Juday G.P., Los S.O., Randerson J.T., Field C.B. Interannual variation in global-scale net primary production: testing model estimates. Global Biogeochemical Cycles. 1997. V. 11. No 3. P. 367-392. DOI: 10.1029/97GB01419.

6. Mordkovich V.G. Steppe ecosystems. Novosibirsk. 2014. 170 p. (in Russian).

7. Nemtseva L.D., Bespalova L.A., Golubeva E.I., Mikhailov S.I. Assessment of the status of vegetation cover of dry steppe landscapes under the conditions of cattle grazing applying the methods of remote sensing of the Earth. Proceedings of the Southern scientific center of the Russian Academy of Sciences. 2018. V. VII. P. 151-164 (in Russian). DOI: 10.23885/1993-6621-2018-7-151-164.

8. Pravdin L.F. Scots Pine. Variability, intraspecific systematics and selection. Moskow: Nauka, 1964. 191 p. (in Russian).

9. Rouse J.W., Haas R.H., Schell J.A., Deering D.W. Monitoring vegetation systems in the Great Plains with ERTS / In 3rd ERTS Symposium, NASA SP-351 I. 1973. P. 309-317.

10. Rinn F. TSAP V3.5. Computer program for tree-ring analysis and presentation. Heidelberg: Frank Rinn Distribution, 1996. 264 p.

11. Sajb E. A., Bezborodova A. N., Solov'ev S. V., Miller G.F., Filimonova D.A. Identification of different age fallows on erosion-hazardous territories of the south of Western Siberia using geo-information technologies. Sovremennye problemy distantsionnogo zondirovaniya Zemli iz kosmosa. 2020. V. 17. No 4. P. 129-136 (in Russian).

12. Shijatov S.G., Vaganov E.A., Kirdyanov A.V., Kruglov V.B., Mazepa V.S., Naurzbaev M.M., Hantemirov R.M. Metody dendrohronologii (Methods of dendrochronology). V.I. Krasnojarsk: Krasnojarsk University Publ., 2000. 80 p. (in Russian).

13. Telnova N.O. Revealing and mapping long-term NDVI trends for the analysis of climate change contribution to agroecosystems' productivity dynamics in the Northern Eurasian forest-steppe and steppe. Sovremennye problemy distantsionnogo zondirovaniya Zemli iz kosmosa. 2017. V. 14. No 6. P. 97-107 (in Russian).

14. Vangnic P.R. Pine belt Forests. Moskow: Goslesbumizdat, 1953. 153 p. (in Russian).

15. Vicente-Serrano S.M., Camarero J.J., Olano J.M., Martín-Hernández N., Peña-Gallardo M., Tomás-Burguera M., Gazol A., Azorin-Molina C., Bhuyan U., Kenawy A. Diverse relationships between forest growth and the Normalized Difference Vegetation Index at a global scale. Remote Sensing of Environment. 2016. 187. P. 14-29. DOI: 10.1016/j.rse.2016.10.001.

16. Wang J., Rich P.M., Price K.P., Kettle W.D. Relations between NDVI and tree productivity in the central Great Plains. Int. J. Remote Sensing. 2004. V. 25. No 16. P. 3127-3138. DOI: 10.1080/0143116032000160499.

17. Wang W. Z., Liu X.H., Chen T., An W., Xu G. Reconstruction of regional NDVI using treering width chronologies in the Qilian Mountains, northwestern China. Chinese Journal of Plant Ecology. 2010. V. 34. No 9. P. 1033-1044. DOI: 10.3773/j.issn.1005264x.2010.09.004.

18. Zolotokrylin A.N., Titkova T.B., Ulanova S.S., Fedorova N.L. Ground-based and satellite investigation of production of pastures in Kalmykia that vary in degree of vegetation degradation. Arid Ecosystems. 2013. V. 3. No 4. P. 212-219. 


\title{
П.А. Украинский ${ }^{1}$
}

\section{ЭМПИРИЧЕСКИЙ МЕТОД ОПРЕДЕЛЕНИЕ ОПТИМАЛЬНОГО РАЗМЕРА СЛУЧАЙНОЙ ТОЧЕЧНОЙ ВЫБОРКИ ДЛЯ ОЦЕНКИ ПЛОЩАДЕЙ ЗЕМЕЛЬНЫХ УГОДИЙ ПО КОСМИЧЕСКИМ СНИМКАМ}

\begin{abstract}
АННОТАЦИЯ
Перспективным экспресс-методом для оценки площадей земельных угодий по космическим снимкам является использование случайной точечной выборки. Этот метод позволяет получить значения площадей без сплошного картографирования земельных угодий. При этом точность оценки площадей зависит от размера выборки. В представленной работе описан метод эмпирического определения оптимального размера выборки. Для использования этого метода необходимо выбрать ключевой участок с существующим эталонным слоем угодий. Далее производится многократная генерация выборок разного размера, по которым оценивается площадь угодий. Полученные площади сравниваются с эталонными и вычисляется относительная ошибка измерения. Анализ среднего значения и разброса ошибок при разных размерах выборки позволяет выявить тот момент, когда при увеличении размера выборки перестаёт существенно снижаться ошибка. Такой размер выборки является оптимальным. Предложенный метод опробован на примере Калачской возвышенности. Проанализирован размерный ряд от 100 до 3000 точек выборки на ключевой участок (величина выборки в ряду увеличивается на 100 точек). Для каждого элемента этого ряда было сгенерировано по 1000 выборок соответствующего размера. Проанализировано влияние размера выборки на общую относительную ошибку оценки площадей. Анализ показал, что для исследованного ключевого участка оптимальным является размер выборки равный 1000 точек $(1,1$ точка/км²). При таком размере выборки общая относительная ошибка определения площадей в среднем составила 4,0 \%, а максимальная ошибка - 9,9\%. Схожую точность следует ожидать при таком же размере выборки для других возвышенностей в лесостепной и степной зоне Восточно-Европейской равнины.
\end{abstract}

КЛЮЧЕВЫЕ СЛОВА: земельные угодья, измерение площади, случайная выборка, ошибки измерений, метод локтевого сгиба.

\section{Pavel A. Ukrainskiy ${ }^{2}$}

\section{EMPIRICAL METHOD FOR ESTIMATION OF THE OPTIMUM SIZE OF RANDOM POINT SAMPLES FOR ASSESSMENT AREAS OF LAND COVER FROM SPACE IMAGES}

\begin{abstract}
A promising fast method for estimating land cover areas from satellite imagery is the use of random point sampling. This method allows you to obtain area values without spatially

1 Белгородский государственный национальный исследовательский университет, Федеральнорегиональный центр аэрокосмического и наземного мониторинга объектов и природных ресурсов, ул. Победы, д. 85, 308015, Белгород, Россия; e-mail: pa.ukrainski@gmail.com

2 Belgorod State National Research University, Federal and Regional Centre for aerospace and ground monitoring of objects and natural resources, Pobedy str., 85, 308015, Belgorod, Russia; e-mail: pa.ukrainski@gmail.com
\end{abstract}


continuous mapping of land areas. The accuracy of the area estimate by this method depends on the sample size. The presented work describes a method for empirically finding the optimal sample size. To use this method, you must select a key site for which a reference land cover exists. For the key site, we perform multiple generation of samples of different sizes. Further, using these samples, we estimate the area of land cover. Comparison of the obtained areas with the reference areas allows you to calculate the measurement error. Analysis of the mean and the range of errors for different sample sizes allows us to identify the moment when the error ceases to decrease significantly with an increase in the sample size. This sample size is optimal. We tested the proposed method on the example of the Kalach Upland. The size range from 100 to 3000 sampling points per key site is analyzed (the size of the sampling in the row increases by 100 points). For each element of this row, we created 1000 samples of the corresponding size. We then analyzed the effect of sample size on the overall relative error in area estimates. The analysis showed that for the investigated key site the optimal sample size is 1000 points $\left(1.1\right.$ points $\left./ \mathrm{km}^{2}\right)$. With this sample size, the overall relative error in determining areas was $4.0 \%$ on average, and the maximum error was $9.9 \%$. Similar accuracy should be at the same sample size for other uplands in the foreststeppe and steppe zones of the East European Plain.

KEYWORDS: land cover, area measurement, random sample, measurement error, elbow method.

\section{ВВЕДЕНИЕ}

Изучение распределения земельных угодий - одна из самых распространённых задач в практике использования космических снимков [Thyagharajan, 2019]. Обычно решение этой задачи подразумевает картографирование земельных угодий на основе визуального или автоматизированного дешифрирования снимков. Но иногда интерес могут представлять только площади угодий, а карта создаётся исключительно как промежуточный продукт, необходимый для измерения площадей. В таких случаях можно обойтись без сплошного картографирования изучаемой территории. Вместо этого для оценки площади угодий достаточно сделать случайную точечную выборку [Gallego, 2006].

При использовании точечной выборки в каждой точке по космическому снимку определяют угодье. Затем суммируют количество точек для каждого угодья и, зная общую площадь исследуемой территории, по пропорции вычисляют площади угодий. Если космические снимки дешифрируются визуальным способом, то использование случайной выборки играет роль экспресс-метода, который позволяет существенно сократить затраты времени. При автоматизированном дешифрировании применение такой метод позволяет избежать искажения площадей, вызванного эффектом смешанных пикселей. Точечную выборку имеет смысл использовать при наличии на снимке множества малых по площади объектов, размер которых превышает размер пикселя не более чем в 10-20 раз.

Перед использованием случайной точечной выборки для оценки площадей угодий требуется ответить на два вопроса. Первый вопрос - это как генерировать точки случайной выборки? Второй вопрос - сколько точек должно быть в выборке, чтобы полученная оценка площадей имела приемлемую точность? Первый вопрос не представляет большого интереса для специалистов в области геоинформатики. В большинстве ГИС-программ реализованы инструменты для генерации слоёв случайно расположенных точек. Стоит отметить лишь то, что качество работы этих инструментов в отдельных программах вызывает споры [Van Niel et al., 2003; Barry, 2011]. Но в случае сомнений можно воспользоваться альтернативой в виде программ для статистического анализа, где генерация случайных выборок реализована на более серьёзном уровне.

Второй вопрос является ключевым при выборочной оценке площадей угодий. Ведь чем больше точек в выборке, тем точнее результат. Однако размер выборки невозможно 
увеличивать до бесконечности. Необходимо найти оптимальный размер. В этой работе мы предлагаем способ эмпирического определения оптимального размера случайной точечной выборки.

\section{МАТЕРИАЛЫ И МЕТОДЫ ИССЛЕДОВАНИЯ}

Если с помощью случайной точечной выборки по космическим снимкам определяются площади земельных угодий на значительных территориях, то оптимальный размер выборки можно определить опытным путём на небольшом ключевом участке. Он должен отражать разнообразие угодий и сложность их пространственной структуры, присущие всей исследуемой территории в целом. Для ключевого участка проводится эксперимент, состоящих из пяти этапов. На первом этапе выполняется картографирование земельных угодий на основе дешифрирования космических снимков (может быть заменено использованием уже существующих пространственных данных об угодьях). В результате получается слой угодий с полигональной геометрией, который в дальнейшем будет использоваться как эталон. На его основе рассчитываются площади угодий, с которыми будут сравниваться площади, оценённые с помощью точечных выборок.

На втором этапе выбирается ряд размеров выборки. Для каждого элемента в этом ряду выполняется множественная генерация случайных выборок соответствующего размера. На третьем этапе слои точечных выборок накладываются на полигональный эталонный слой. В атрибутивные таблицы точечных слоёв извлекаются названия угодий из эталонного слоя. В каждой из множества выборок суммируются число точек с различными угодьями. Затем по пропорции количество точек пересчитывается в площади угодий.

На четвёртом этапе для каждой выборки вычисляется общая относительная ошибка измерения площадей угодий. Расчёт проводится по формуле 1.

$$
E=\frac{\sum_{i=1}^{n}\left|a_{i}-s_{i}\right|}{A} \cdot 100
$$

В формуле 1 использованы следующие обозначения: Е - относительная ошибка, А сумма площадей всех угодий (она же общая площадь ключевого участка); $a_{i}$ - эталонная

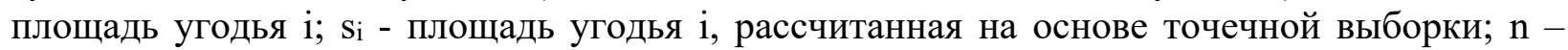
количество угодий на ключевом участке. Умножение на 100 производится чтобы выразить относительную ошибку в процентах.

На пятом этапе анализируется, как изменяется ошибка в зависимости от размера выборки. Для каждого размера выборки вычисляется описательная статистика ошибок среднее, максимальное и минимальное значение, стандартное отклонение ошибки. Далее строится график, по вертикальной оси которого откладываются характеристики ошибок, а по горизонтальной размер выборки. Полученные кривые на графике будут иметь вогнутую форму, т.к. с увеличением размера выборки ошибки до определённого предела интенсивно уменьшаются, а затем начинают уменьшаться уже постепенно. Точка сгиба указывает на оптимальный размер выборки. Для разных характеристик ошибки точка сгиба может наблюдаться при разных размерах выборки. В таком случае следует считать оптимальным самый большой размер выборки из полученных вариантов.

Описанный выше графический метод в статистике известен как метод «локтевого сгиба». Графики с «локтевым сгибом» используют в кластерном анализе для определения оптимального числа кластеров, в преобразовании главных компонент для определения оптимального числа главных компонент, в факторном анализе для определения числа извлекаемых факторов. При визуальном анализе графиков точка сгиба не всегда однозначно идентифицируется, и интерпретация графиков может носить субъективных характер [Украинский, 2020]. Но в настоящее время уже существуют количественные 
методы определения точки «локтевого сгиба» на кривой. Мы предлагаем использовать анализ кривых методом UIK (Unit Invariant Knee), описанный в 2016 году Demetris Christopoulos $^{1}$. В дополнение к методу «локтевого сгиба» также полезным может быть построение коробчатых диаграмм (боксплотов) относительной ошибки для разных размеров выборки. Этот способ является хорошей визуализацией существующего разброса значений.

Чтобы продемонстрировать работу описанного выше способа определения оптимального размера случайной точечной выборки, мы выбрали ключевой участок (рис. 1) расположенный на северо-востоке Калачской возвышенности [Мильков и др., 1972].

A
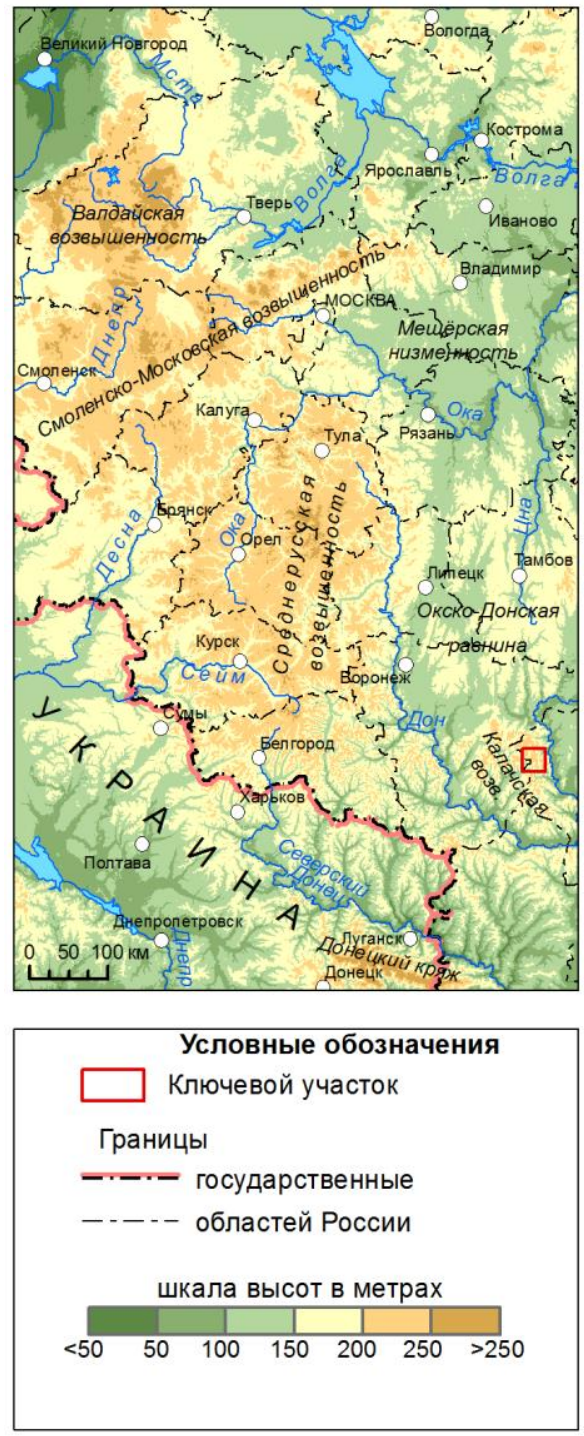

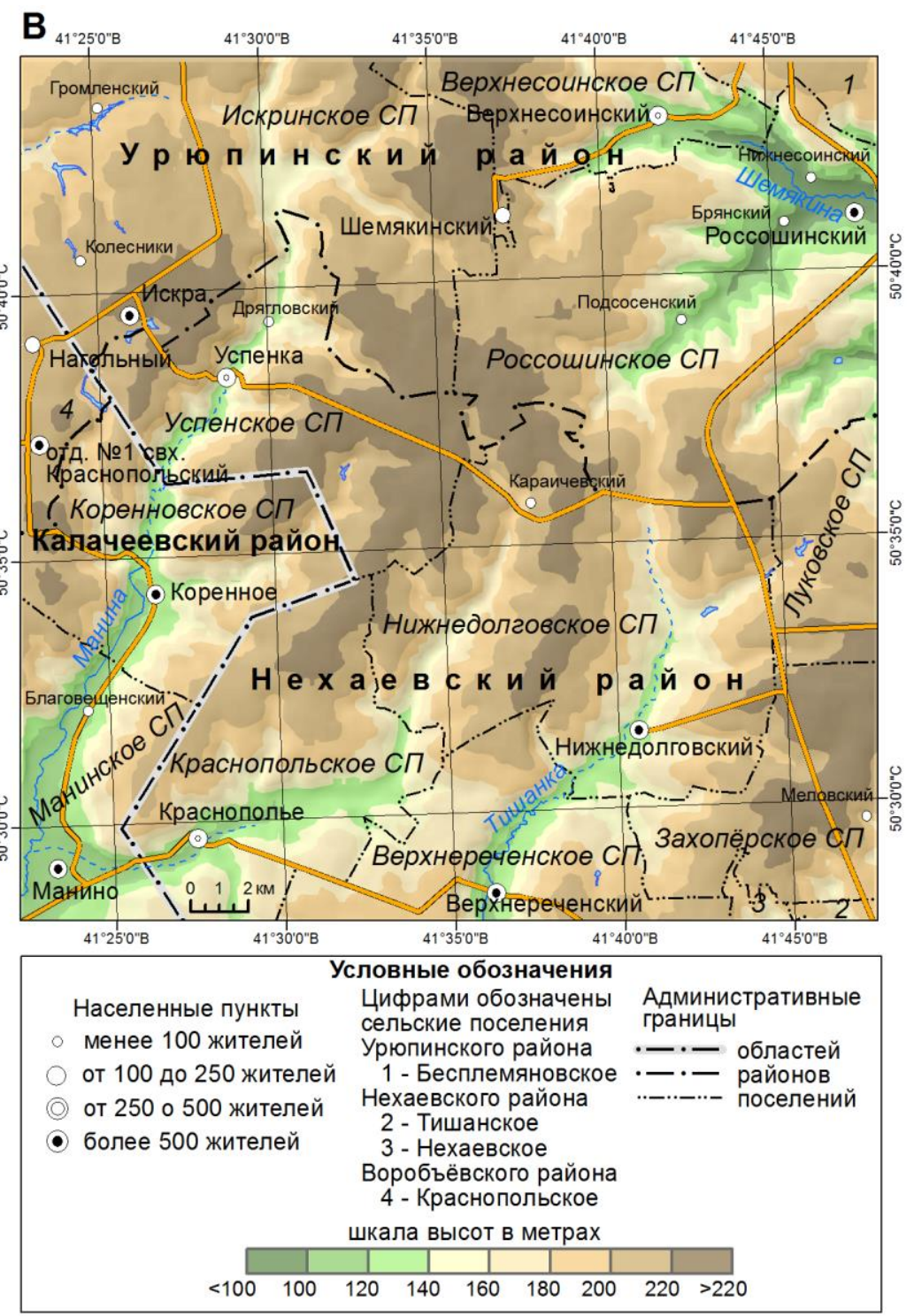

Рис. 1. Схема расположения (A) и карта (B) исследуемого участка

Fig. 1. Location (A) and map (B) of the study area

1 Christopoulos D.T. Introducing unit invariant knee (UIK) As an objective choice for elbow point in multivariate data analysis techniques. SSRN, 2016. URL: https://ssrn.com/abstract=3043076 (Available at 30.04.2021). DOI: 10.2139/ssrn.3043076. 
Пространственная структура угодий на ключевом участке характерна для возвышенностей в лесостепной и степной зоне Русской равнины (Калачская, Среднерусская, Приволжская возвышенность). Участок представляет собой квадрат размером 30 на 30 км, находящийся на стыке Воронежской (Воробъевский и Калачеевский район) и Волгоградской области (Урюпинский и Нехаевский район) (рис. 1).

По снимкам со спутников Sentinel-2A и Sentinel-2B на ключевом участке были закартографированы (отвекторизованы) земельные угодья. Использовалась серия безоблачных снимков, снятых в разные сезоны 20192020 года (табл. 1). Необходимость набора разносезонных снимков обусловлена тем, что для различных угодий есть сезоны, в которые они лучше или хуже распознаются. Кроме того, сезонная динамика изображения является одним из дешифровочных признаков земельных угодий.

Снимки получены из веб-сервиса Land Viewer ${ }^{1}$. С помощью этого сервиса снимки в режиме онлайн были обрезаны по экстенту исследуемого участка, и в формате geotiff выгружены отдельные каналы снимков $(2,3,4,8,11$ и 12 каналы). При дешифрировании снимков использовалось несколько комбинаций каналов Sentinel-2. Комбинация каналов 4-3-2 обеспечивает отображение объектов в натуральных цветах. В комбинации каналов 8-11-4 лучше всего выделяются водоёмы. В комбинации каналов 12-11-4 хорошо распознаются искусственные поверхности в населённых пунктах и открытая поверхность почвы на полях. Комбинации каналов 8-11-2 и 8-4-3 эффективны при дешифрировании растительности.

Табл. 1. Космические снимки, использованные для картографирования земельных угодий на ключевом участке

Table 1. Satellite imagery used to map land cover at the key site

\begin{tabular}{|l|l|l|l|}
\hline Дата съёмки & Спутник & Номер сцены & Номер тайла \\
\hline 07.03 .2019 & Sentinel-2B & N0207/R121 & 37UFC \\
\hline 31.03 .2020 & Sentinel-2B & N0209/R121 & 37UFC \\
\hline 30.04 .2020 & Sentinel-2B & N0209/R121 & 37UFC \\
\hline 4.07 .2020 & Sentinel-2A & N0209/R121 & 37UFC \\
\hline 07.10 .2020 & Sentinel-2B & N0209/R121 & 37UFC \\
\hline 01.12 .2020 & Sentinel-2A & N0209_R121 & 37UFC \\
\hline
\end{tabular}

Предварительная обработка снимков выполнена в программе ENVI 4.8. В ней отдельные каналы снимков были объединены в многоканальные файлы и пространственное разрешение приведено к 10 м/пиксель. Векторизация земельных угодий выполнена в программе ArcGIS 10.5. В результате был создан векторный слой (шейп-файл) угодий с полигональной геометрией. Для него был осуществлен поиск и исправление топологических ошибок двух типов - накладывающихся полигонов и пробелов между полигонами. В дальнейшем полученный слой рассматривался нами в качестве эталона. По нему были рассчитаны площади угодий, используемые для определения ошибки выборочных оценок площадей.

При дешифрировании все многообразие угодий было сведено к семи классам: пашня, сады, травянистая растительность, леса, застройка, водоёмы, болота. К застроенным территориям на ключевом участке были отнесены сельская застройка вместе огородами, животноводческие фермы, асфальтированные автомобильные дороги. В класс травостоев

$1 \quad$ Land Viewer. URL: https://eos.com/landviewer (Available at 30.04.2021) 
включены различные угодья с травянистой растительностью ?] пастбища и сенокосы (как используемые, так и неиспользуемые), залежи, участки травянистой растительности на месте исчезнувших населённых пунктов, лесные поляны и вырубки, на которых ещё не началось возобновление древесной растительности.

В состав класса лесов включены все леса, в том числе и не входящие в лесной фонд, а также заросли кустарников. Сомкнутые древостои на заболоченных территориях (в основном ольшаники) отнесены тоже к лесам, а не к болотам. Также к лесам причислены лесополосы.

В состав пашни при дешифрировании включались только те участки, на которых фактически возделываются сельскохозяйственные культуры (то есть все участки, кроме залежей). К садам при дешифрировании причислялись только промышленные сады насаждения многолетних плодовых культур, возделываемые агропредприятиями. Сады на приусадебных участках в населённых пунктах были отнесены к застроенным территориям. В состав класса водоемов включены озера, искусственные водоемы (пруды) и водотоки (реки). Болота на ключевом участке представлены низинными осоковыми и тростниковыми болотами.

После векторизации слоя угодий дальнейшая обработка данных проводилась с помощью языка программирования R $3.4 .4^{1}$ в интегрированной среде разработки RStudio 1.1.453. Необходимость использования R вызвана тем, что предлагаемая нами методика поиска оптимального размера точечной выборки основана на последовательной генерации многих тысяч случайных выборок. При использовании ГИС-программ этот процесс будет занимать слишком много времени. А в $\mathrm{R}$ имеются удобные функции автоматизации однотипных повторяющихся процессов.

Импорт шейп-файла угодий в R произведён с помощью библиотек GDAL/OGR, реализованных в дополнительном пакете $\mathrm{rgdal}^{2}$. Для поиска оптимального размера выборки была проанализирована серия из 30 размеров. Размер выборки в этой серии увеличивается на 100 точек. Самая маленькая выборка включает 100 точек, самая большая ? 3000 точек. Для каждого размера было сгенерировано 1000 выборок. На этом этапе использовались функции из дополнительного пакета sp [Pebesma et al., 2005: Bivand et al., 2013]. Функция spsample применялась для генерации случайных точечных выборок, функция over - для извлечения по точкам выборки названия угодий из полигонального слоя угодий. Для определения точек сгиба на графике характеристик относительной ошибки использовался анализ кривых методом UIK, реализованным в дополнительном пакете inflection ${ }^{3}$.

\section{РЕЗУЛЬТАТЫ ИССЛЕДОВАНИЯ И ИХ ОБСУЖДЕНИЕ}

По результатам дешифрирования космических снимков для исследуемой территории получены следующие площади земельных угодий. Леса занимают 102,0 га, травостои - 217,4 га, сады - 0,9 га, пашня - 542,2 га, застройка - 26,7 га, болота - 9,1 га, водоемы - 1,7 га. Эти значения были использованы в качестве эталонных для расчёта относительной ошибки выборочной оценки площадей земельных угодий. Распределение угодий в пространстве показано на рисунке 2. Видно, что пространственная структура

1 R Core Team (2018). The R project for statistical computing. Web resource: https:/www.R-project.org/ (accessed 30.04.2021).

2 R. Bivand, T. Keitt, B. Rowlingson. Rgdal: bindings for the geospatial data abstraction library. R package version 1.3-6. URL: https:/CRAN.R-projec t.org/package=rgdal (Available at 30.04.2021).

3 D.T. Christopoulos (2019). inflection: Finds the Inflection Point of a Curve. R package version 1.3.5. URL: https://CRAN.R-project.org/package=inflection (Available at 30.04.2021). 
угодий отличается сильной мозаичностью. Такая картина характерна в целом для всех возвышенностей в лесостепной и степной зоне Восточно-Европейской равнины.

График зависимости величины ошибки от размера выборки показан на рисунке 3. На нем видно, что с увеличением числа точек в выборке повышается точность определения площадей угодий. Чем больше выборка, тем меньше средняя величина ошибки и тем меньше размах возможных значений ошибки. Так при 100 точках выборки ошибка в среднем составляет 12,3\%, максимальная ошибка равна 34,5\%, а стандартное отклонение ошибки равно 1,3\%. При 3000 точках выборка средняя ошибка снижается до $2,3 \%$, максимальная ошибка составляет $5,9 \%$, а стандартное отклонение ошибки равно $1,0 \%$.

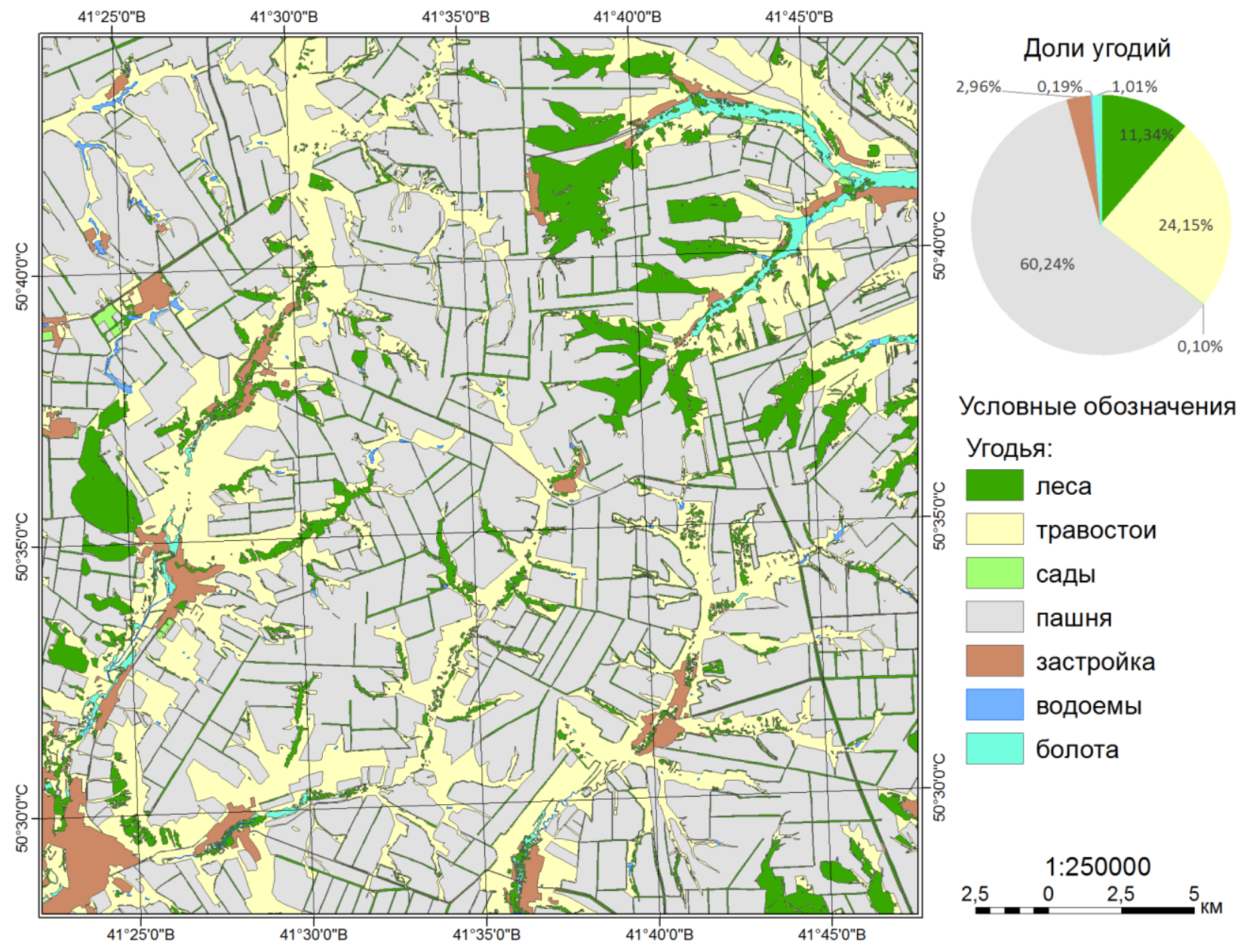

Рис. 2. Карта земельных угодий ключевого участка, составленная по результатам дешифрирования снимков со спутников Sentinel-2A/B

Fig. 2. Map of land cover of the key site, created based on the analysis of images from the Sentinel-2A/B satellites

С увеличением размера выборки ошибка оценки площадей угодий уменьшается неравномерно. Вначале происходит резкое уменьшение, затем оно сменяется на плавное. Наблюдается характерная форма кривых на графике - в виде так называемого «локтевого сгиба». При этом точка сгиба для кривых среднего значения ошибки и стандартного 
отклонения ошибки различается не чётко. Она расположена где-то между размерами выборки в 500 и 1000 точек. Для максимального значения ошибки ситуация более однозначная. Здесь перегиб кривой на графике четко наблюдается при размере выборки в 1000 точек.

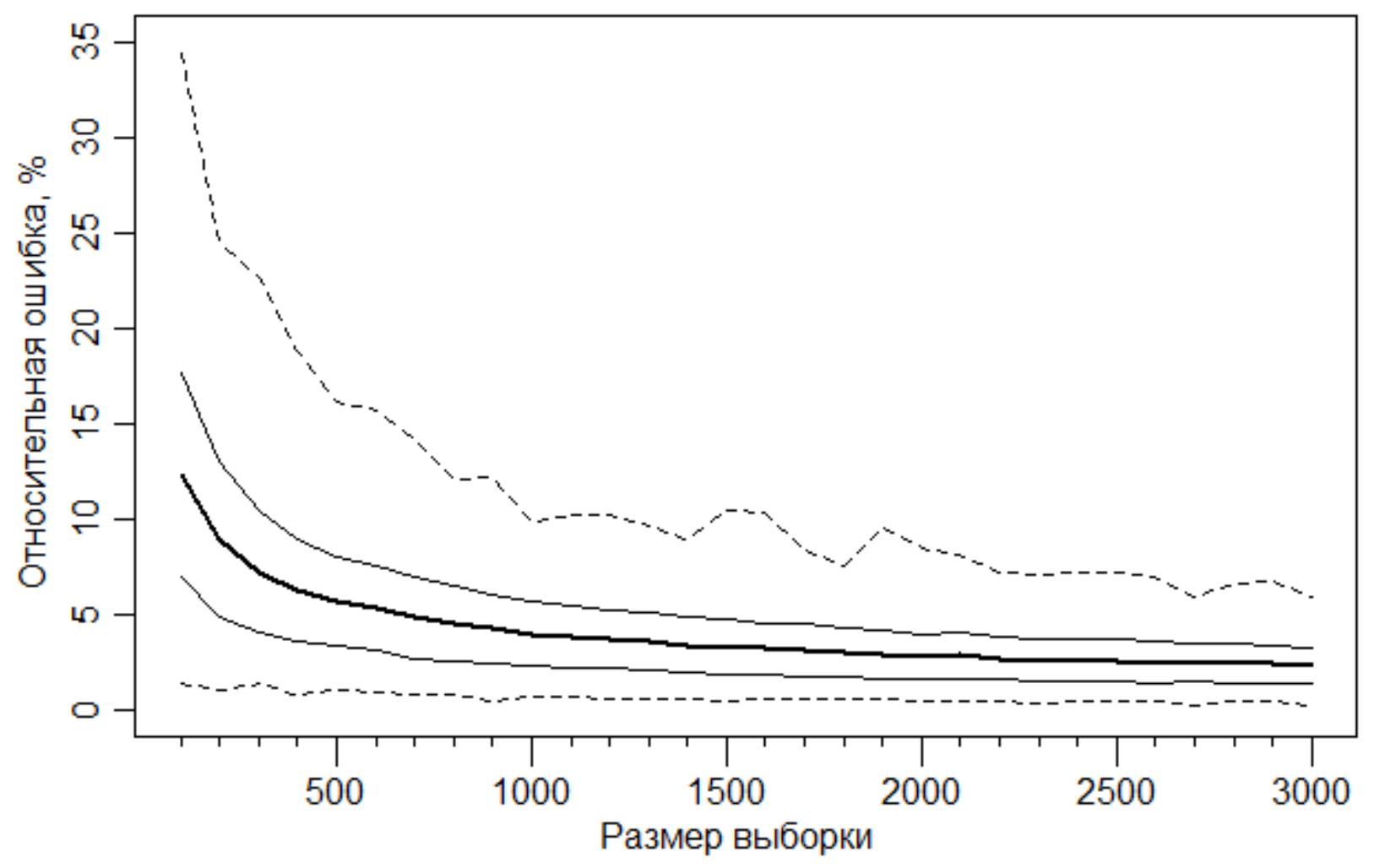

Рис. 3. Зависимость относительной ошибки определения площадей угодий от размера выборки. Толстая линия - среднее значение, тонкая линия стандартное отклонение, пунктирная линия минимальное и максимальное значение

Fig. 3. Dependence of the relative error in the assessment of land cover areas on the sample size. The thick line is the mean, the thin line is the standard deviation, and the dashed line is the minimum and maximum values

В качестве альтернативного метода графического анализа были построены боксплоты (коробчатые диаграммы, диаграммы размахов). Использовался вариант графика с насечками, показывающими доверительный интервал для медианы (рис. 4). Если доверительные интервалы боксплотов не перекрываются, то медианы статистически значимо отличаются.

На рисунке 4 можно наблюдать что медианы соседних боксплотов значимо отличаются при размерах выборки от 100 до 1000 точек. А начиная с размера в 1000 точек доверительные интервалы медиан начинают перекрываться. Это можно рассматривать как дополнительный аргумент в пользу того, что 1000 точек является оптимальным размером выборки.

Анализ с помощью UIK-метода показал, что для кривой среднего значения точкой сгиба является размер выборки равный 700 точек, для кривой стандартного отклонения - 
500 точек, для кривой максимального значения - 1000 точек, для кривой минимального значения - 900 точек.

Помимо показателей описательной статистики ошибок, показанных на рисунки 3 , с помощью UIK-метода были проанализированы медиана, межквартильных размах и среднее абсолютное отклонение ошибок. Для кривой медианы ошибок точкой сгиба является размер выборки в 700 точек, для межквартильного размаха - 700 точек, для среднего абсолютного отклонения ошибок - 500 точек.

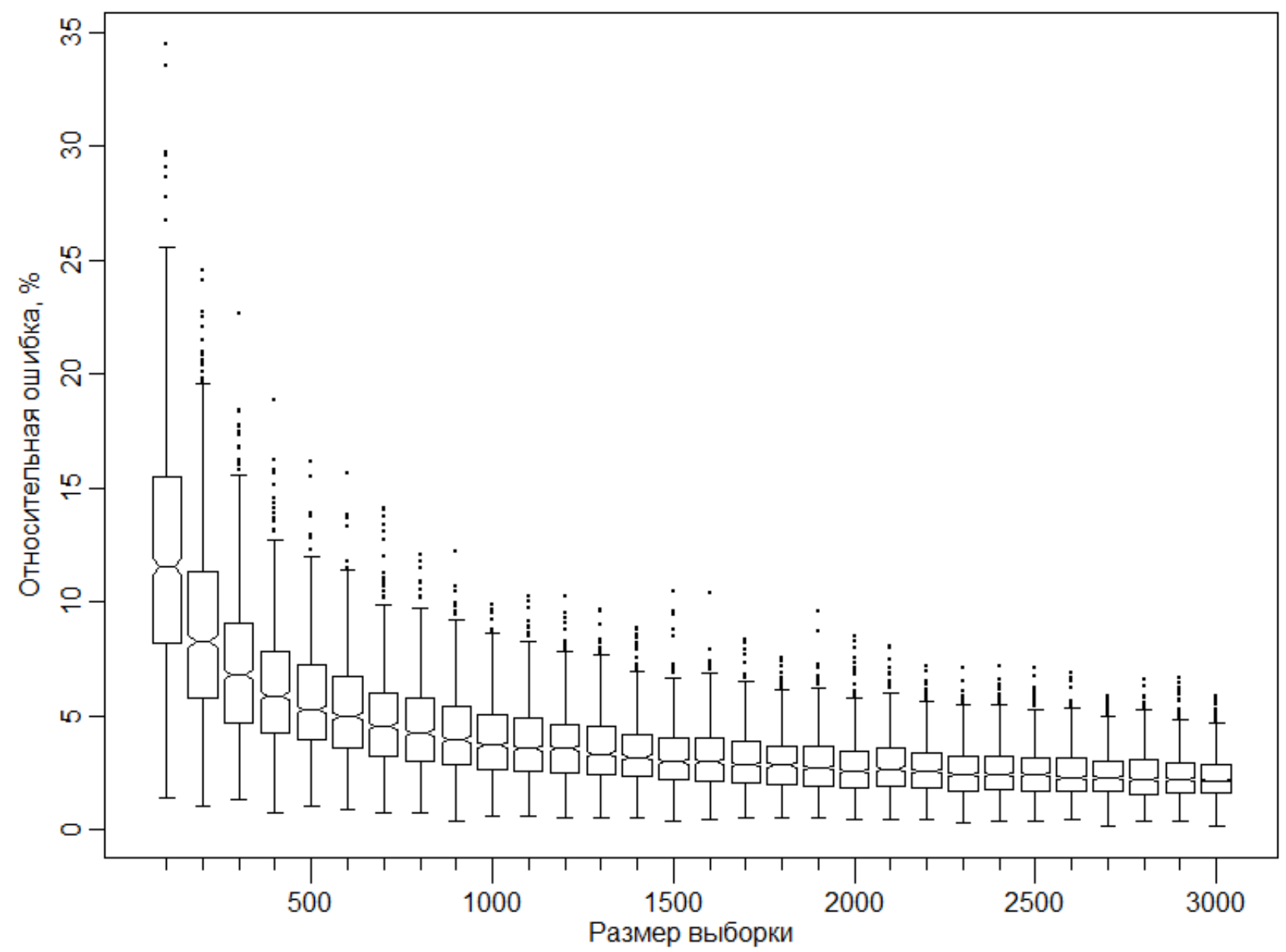

Рис. 4. Диаграммы размахов (боксплоты) значений относительной ошибки определения плошадей угодий

Fig. 4. Boxplots of the values of the relative error in determining the areas of land cover

Поскольку самым большим значением точки сгиба, полученным с помощью UIKанализа кривых ошибок, является 1000 точек, то это значение следует принять в качестве оптимального размера выборки. В пересчёте на единицу площади это составляет 1,1 точка/км². При таком размере выборки общая относительная ошибка определения площадей в среднем составила 4,0 \%, а максимальная ошибка - 9,9\%, минимальная ошибка - 0,6\%, стандартное отклонение ошибок - 1,7\%. Схожую точность следует ожидать при таком же размере выборки для других возвышенностей в лесостепной и степной зоне Восточно-Европейской равнины. 


\section{ВЫВОДЫ}

Использование случайной точечной выборки позволяет оценить по космическим снимкам площади земельных угодий без выполнения сплошного картографирования. При правильно подобранном размере выборки достижима высокая точность определения площадей. При изучении крупных территорий размер выборки можно определить эмпирическим путём, поставив эксперимент на локальном ключевом участке для которого есть эталонный слой земельных угодий. Для этого необходимо произвести многократную генерацию случайных выборок, в точках которых по эталонному слою определяются угодья. Полученные данные позволят проследить, как меняется ошибка оценки площади в зависимости от размера выборки. Такой эксперимент будет слишком трудоемок при использовании ГИС-программ. Поэтому необходимы средства, позволяющие эффективно автоматизировать вычислительные процессы. В качестве такого средства хорошо зарекомендовала себя среда для статистических вычислений R с дополнительным пакетом sp.

\section{БЛАГОДАРНОСТИ}

Исследование выполнено при финансовой поддержке РНФ, грант 20-67-46017.

\section{ACKNOWLEDGEMENTS}

The study was funded by the Russian Science Foundation, grant No 20-67-46017.

\section{СПИСОК ЛИТЕРАТУРЫ}

1. Мильков Ф.Н., Ахтыриева Н.И., Ахтыриев Б.П. Калачская возвышенность Воронеж: Издательство Воронежского университета, 1972. 178 с.

2. Украинский П.А. Выбор оптимального порядка соседства для разделения пространственного точечного образа на кластерную и шумовую составляющую (на примере анализа размещения античных поселений на Керченском полуострове). ИнтерКарто. ИнтерГИС. 2020. Т. 26. Ч. 4. С. 257-265. DOI: 10.35595/2414-91792020-4-26-257国265.

3. Barry S.C. How much impact does the choice of a random number generator really have? International Journal of Geographical Information Science. 2011. V. 25. No 4. P. 523]530. DOI: 10.1080/13658810903093185.

4. Bivand R.S., Pebesma E., Gomez-Rubio V. Applied spatial data analysis with R. New York: Springer-Verlag, 2013. 405 p. DOI: 10.1007/978-1-4614-7618-4.

5. Gallego F.J. Review of the main remote sensing methods for crop area estimates. ISPRS Archives, 2006. V. XXXVI. No 8/W48. P. 65ㄱ70.

6. Pebesma E.J., Bivand R.S. Classes and methods for spatial data in R. R News, 2005. V. 5. No 2. P. 9?13.

7. Thyagharajan K.K., Vignesh T. Soft computing techniques for land use and land cover monitoring with multispectral remote sensing images: a review. Archives of Computational

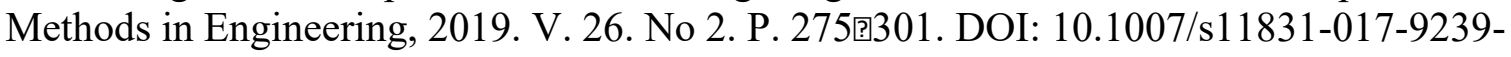
y.

8. Van Niel K.P., Laffan S.W. Gambling with randomness: the use of pseudorandom number generators in GIS. International Journal of Geographical Information Science, 2003. V. 17. No 1. P. 49-68. DOI: 10.1080/713811743. 


\section{REFERENCES}

1. Barry S.C. How much impact does the choice of a random number generator really have? International Journal of Geographical Information Science. 2011. V. 25. No 4. P. 523 ?530. DOI: $10.1080 / 13658810903093185$.

2. Bivand R.S., Pebesma E., Gomez-Rubio V. Applied spatial data analysis with R. New York: Springer-Verlag, 2013. 405 p. DOI: 10.1007/978-1-4614-7618-4.

3. Gallego F.J. Review of the main remote sensing methods for crop area estimates. ISPRS Archives, 2006. V. XXXVI. No 8/W48. P. 65回70.

4. Milkov F.N., Akhtyrtseva N.I., Akhtyrtsev B.P. Kalachskaya Upland Voronezh: Voronezh University Publishing House, 1972. 178 p.

5. Pebesma E.J., Bivand R.S. Classes and methods for spatial data in R. R News, 2005. V. 5. No 2. P. 9?13.

6. Thyagharajan K.K., Vignesh T. Soft computing techniques for land use and land cover monitoring with multispectral remote sensing images: a review. Archives of Computational Methods in Engineering, 2019. V. 26. No 2. P. 275]301. DOI: 10.1007/s11831-017-9239y.

7. Ukrainskiy P.A. The choice of the optimal order of the neighborhood for separation a spatial point pattern into a cluster and noise component (by the example of analysis of location of antique settlements in the Kerch Peninsula). InterCarto. InterGIS. 2020. V. 26 (4). P. 257-265.

8. Van Niel K.P., Laffan S.W. Gambling with randomness: the use of pseudorandom number generators in GIS. International Journal of Geographical Information Science. 2003. V. 17. No 1. P. 49-68. DOI: 10.1080/713811743. 


\title{
К.С. Тесленок ${ }^{1}$, С. А. Тесленок ${ }^{2}$, И.П. Терешкин ${ }^{3}$, П.С. Дмитриев ${ }^{4}$ \\ ВОЗМОЖНОСТИ ИСПОЛЬЗОВАНИЯ СЕРВИСА GООGLЕ (МОИ КАРТЫ) ДЛЯ КАРТОГРАФИЧЕСКОЙ ВИЗУАЛИЗАЦИИ ТУРИСТИЧЕСКИХ МАРШРУТОВ
}

\begin{abstract}
АННОТАЦИЯ
Рассматривается возможности использования бесплатного сервиса «Google Мои карты» для картографической визуализации самостоятельно разработанных туристических маршрутов. Исследования выполнены на примере одного из вариантов авторского туристско-краеведческого велосипедного маршрута выходного дня - по территории крупнейшего на территории Республики Мордовия Саранско-Рузаевского промышленного узла. Ключевые станции маршрута - опорные точки, приуроченные к историкокультурным и/или природным достопримечательностям, расположены в городах Саранске и Рузаевке, а также их ближайших окрестностях.

Результат визуализации маршрута представлен в виде карты, с наложением его отдельных участков, инфраструктурных и рекреационных объектов. Последовательное подключение слоев со значками условных обозначений и/или подготовленных ранее маршрутов позволяет пользователю легко сориентироваться в особенностях пространственного перемещения от одной ключевой станции маршрута к другой.

В процессе изучения особенностей использования сервиса выяснены и применены возможности добавления семантики отдельных объектов маршрута, что позволяет пользователю в рамках только одного сервиса подробно ознакомиться со всей достоверной информацией об интересующем его объекте. Сервис «Google Мои карты» может содержать в одном слое все типы векторного представления пространственных данных, что позволило создать подробные детализированные планы экскурсий по туристско-рекреационным объектам и территориям. В случае, если соответствующий значок расположен в непосредственной близости от транспортной магистрали, приложение выдает соответствующую панорамную фотографию.

Описанные возможности сервиса могут быть полезны органам государственной власти, предприятиям сферы туризма и гостеприимства, администрациям учебных заведений; учащимся и всем заинтересованными лицам.
\end{abstract}

КЛЮЧЕВЫЕ СЛОВА: сервис «Google Мои карты», картографическая визуализация,

1 Сурская горно-геологическая компания, ул. Ст. Разина, д. 17a, 430011, г. Саранск, Россия, e-mail: kirilltesl@mail.ru

2 Национальный исследовательский Мордовский государственный университет имени Н.П. Огарева, географический факультет, ул. Большевистская, д. 68, 430005, Саранск, Россия, e-mail: teslserg@mail.ru

3 Национальный исследовательский Мордовский государственный университет имени Н.П. Огарева, географический факультет, ул. Большевистская, д. 68, 430005, Саранск, Россия, e-mail: tereshkinigor@mail.ru

4 Северо-Казахстанский университет имени Манаша Козыбаева, факультет математики и естественных наук, ул. Пушкина, д. 86, 150000, Петропавловск, Казахстан, e-mail: dmitriev_pavel@mail.ru 
туристический маршрут, велосипедный туризм, Саранско-Рузаевский промышленный узел, Республика Мордовия.

\title{
Kirill S. Teslenok ${ }^{1}$, Sergey A. Teslenok ${ }^{2}$, Igor P. Tereshkin ${ }^{3}$, Pavel S. Dmitriyev ${ }^{4}$ POSSIBILITIES OF USING GOOGLE (MY MAPS) FOR CARTOGRAPHIC VISUALIZATION OF TOURIST ROUTES
}

\begin{abstract}
The possibilities of using the free Google My Maps service for cartographic visualization of independently developed tourist routes are considered. The research is carried out on the example of one of the variants of the author's tourist and local history bicycle route of the weekend-on the territory of the Saransk-Ruzaevka industrial hub, the largest in the Republic of Mordovia. Key stations of the route - reference points, confined to historical, cultural and/or natural attractions, are located in the cities of Saransk and Ruzaevka, and their immediate surroundings. The result of the visualization of the route is presented in the form of a map, with the overlay of its individual sections, infrastructure and recreational facilities. The sequential connection of layers and/or previously prepared routes in the service allows the user to easily navigate the features of the spatial movement of key route stations.

In the process of studying the features of using the service, the possibilities of adding the semantics of individual route objects were clarified, which allows the user, within the framework of one service, to get acquainted in detail with all reliable information about the object of interest. The Google My Maps service can contain in one layer all types of vector representation of spatial data, which makes it possible to create detailed detailed excursion plans for tourist and recreational objects and territories. If the corresponding icon is located in the immediate vicinity of the transport highway, the application will display the corresponding panoramic photo. This allows the user to get acquainted with all the reliable information about the object of interest within one service.

The possibilities of the service may be useful to public authorities, enterprises in the sphere of tourism and hospitality, administrations of educational institutions; students and all interested parties.
\end{abstract}

KEYWORDS: service "Google My Maps", cartographic visualization, tourist route, bicycle tourism, Saransk-Ruzaevka industrial hub, Republic of Mordovia.

\section{ВВЕДЕНИЕ}

В условиях современной политической и экономической обстановки, обусловленной действием разного рода экономических и политических санкций в отношении Российской Федерации, а так же наличием существенных ограничений по перемещению населения между странами и их регионами (вплоть до локдаунов) в условиях пандемии болезни COVID-19, вызываемой коронавирусом SARS-CoV-2 (2019-nCoV), четко проявились новые возможности для развития отечественного туристического рынка. При

\footnotetext{
1 Surskaya gorno-geologicheskaya kompaniya, ул. Ст. Разина, д. 17a, 430011, г. Саранск, Россия, e-mail: kirilltesl@mail.ru

2 National Research Ogarev Mordovia State University; 68 Bolshevistskaya Str., Saransk 430005, Republic of Mordovia, Russia, e-mail: teslserg@mail.ru

3 National Research Ogarev Mordovia State University; 68 Bolshevistskaya Str., Saransk 430005, Republic of Mordovia, Russia, e-mail: tereshkin-igor@mail.ru

4 M. KozybayevNorth Kazakhstan University; 68 Bolshevistskaya Str., Saransk 430005, Republic of Mordovia, Russia, e-mail: dmitriev_pavel@mail.ru
} 
этом выезд на выходные и праздничные дни за пределы населенных пунктов, в которых проживают и работают их жители, становится одним из важнейших элементов современного стиля жизни [Семина, Уварова, 2010; Семина и др., 2016]. Это крайне перспективно для местного населения [Фоломейкина, 2016]) и гостей Республики Мордовии, значительный приток которых был стимулирован проведением в столице региона г. Саранске четырех матчей группового этапа Чемпионата Мира по футболу FIFA-2018 (FIFA WORLD CUP-2018).

Тем самым актуализируются задачи разработки (в т. ч. самостоятельной) разнообразных туристических маршрутов с их последующей картографической визуализацией после определения пригодности и потенциала использования соответствующего программного обеспечения.

В связи с этим целью исследования стала разработка туристско-краеведческого велосипедного маршрута выходного дня по территории Саранско-Рузаевского промышленного узла и определение возможностей картографической визуализации одного из его вариантов с использованием современных картографических сервисов. В ходе ее реализации решались задачи сбора и изучения исходных данных о районе прохождения туристско-краеведческого велосипедного маршрута выходного дня, ключевых станциях и объектах на нем; сравнительного анализа, отбора и определения функциональных возможностей программного обеспечения современных картографических сервисов; картографической визуализации разработанного маршрута с использованием сервисе «Google Мои карты».

Подобного рода работы по выводу разнообразной, имеющей пространственную привязку картографической информации, осуществляются в специализированных информационных системах, предоставляющих пользователям географические данные [Тикунов, 1997; Dransch, 2000; Erle et al., 2005; Gibin et al., 2008]. В настоящее время наиболее популярным и перспективным способом картографической визуализации пространственных данных является их реализация в виде интерактивных карт картографических веб-сервисов с динамичной информацией [Кадочников, 2014; Касьянова, 2014; Кочитов, 2019]. Мультимедийные и интерактивные качества таких картографических материалов в первую очередь привлекают внимание и инициируют интерес пользователя, способствуя более активному и качественному усвоению и запоминанию тех или иных сведений [Dransch, 2000; Векслер, 2016].

\section{МАТЕРИАЛЫ И МЕТОДЫ ИССЛЕДОВАНИЯ}

Предварительно авторами была выполнена работа по отбору в разнообразных литературных, картографических и интернет-источниках информации о роли и значении, особенностях и проблемах, современном состоянии, перспективах развития, значимости и актуальности туризма вообще, и велосипедного туризма - в частности, о природной и социально-экономической специфике территории и ее объектах.

Республика Мордовия обладает поистине уникальным сочетанием ландшафтного, культурно-этнографического и архитектурного наследия, а также значительным потенциалом и существенными возможностями для развития различных видов туризма [Терешкин, Тесленок, 2016]. Кроме того, в регионе в преддверие Чемпионата мира по футболу 2018 г. широко внедрены новые информационные технологии разработки и визуализации разнообразных туристических маршрутов [Примаченко и др., 2008; Тесленок, Тесленок, 2011; Тесленок, Тесленок, 2014; Мынов, Тесленок, 2016; Терешкин, Тесленок, 2016; Тесленок и др., 2017], разработаны пешеходные маршруты по центральной части г. Саранск ${ }^{1}$ [Гусев, Ивлиева, 2014], созданы тематические буклеты на английском,

Саранск туристический. Электронный ресурс: http://welcome2018.com/cities/saransk/the-picturesquesaransk/ (дата обращения 04.01.2021). 
французском, итальянском, арабском и других основных языках мира. Значительный вклад в геоинформационно-картографическое обеспечение туристической деятельности внесла кафедра геодезии, картографии и геоинформатики Национального исследовательского Мордовского государственного университета им. Н.П. Огарева [Примаченко $u$ др., 2008; Тесленок, Тесленок, 2011; Гусев, Ивлиева, 2014; Тесленок, Тесленок, 2014; Мынов, Тесленок, 2016; Терешкин, Тесленок, 2016; Тесленок и др., 2017].

Исследования технологии картографической визуализации самостоятельно разработанных туристических маршрутов производились с использованием бесплатного для некоммерческого использования (но с некоторыми ограничениями на количество запросов к отдельным функциям ${ }^{1}$ ) картографического сервиса «Google Мои карты»². (ранее «GoogleMapsEngine»). Google $\mathrm{Maps}^{3}$, функционируя с 2005 г., является безусловным лидером среди картографических и справочных сервисов и порталов сети Интернет (Яндекс.Карты ${ }^{4}, 2$ ИС (2GIS, ранее ДубльГИС ${ }^{5}$ ), Карты Bing (Bing maps) ${ }^{6}$, OpenStreetMap ${ }^{7}$, Nokia HERE Maps ${ }^{8}$, Maps.Me. (ранее Карты@Mail.Ru) ${ }^{9}$, MapQuest ${ }^{10}$, Yahoo! Maps ${ }^{11}$ и др.). Включая три основные части - непосредственно сами карты, спутниковые снимки и Google Street View, он - один из первых, один из самых известных и занимает соответствующее место по популярности в мире.

Именно разнообразные картографические порталы и веб-сервисы сейчас наиболее распространены и популярны, а их основная задача - обеспечение полноценного доступа к картографической информации на основе интерфейсов прикладного программирования (или интерфейсов программирования приложений) - Application Programming Interface, API [Erle, Gibson, Walsh, 2005; Gibin, Singleton, Milton, Mateos, Longle, 2008; Кадочников, 2014; Зубехин, Рыбанов, 2016; Кочитов, 2019; Садохов, Вицентий, 2019].

API - это набор средств, позволяющих осуществлять запрос к какому-либо сервису для доступа к функционалу программы, библиотеки, модуля [Gibin et al., 2008; Kaдочников, 2014; Кочитов, 2019]. В составе этих средств - следующие АРI с соответствующими функциями: Android API (создание и добавление пользовательских карт для приложений на базе устройств с операционной системой Android); Directions API (организация маршрутов, определение продолжительности поездки и расстояний); Geocoding API (доступ к службам геокодирования статичных адресов посредством НТТР-запросов для последующего размещения на карте пользовательского контента); Javascript API (создание пользовательских карт и их добавление на веб-сайты); Places API Web Service (получение информации посредством НТТР-запросов о местах (географических объектах), определенных в данном API) [Gibin et al., 2008; Зубехин, Рығбанов, 2016; Кочитов, 2019; Садохов, Вицентий, 2019].

Набор функциональных средств Google Maps API ${ }^{12}$, исходя из анализа имеющегося

1 Дополнительные условия использования сервисов «GoogleКарты» и «GoogleПланетаЗемля». Электронный ресурс: https://: htt p s:// www.google.com/i ntl/ru/help/terms_maps/ (дата обращения 04.01. 2021).

Google Мои карты. Электронный pecypc: https://www.google.ru/maps/about/mymaps/ (дата обращения 04.01.2021).

Google Maps. Электронный pecypc: http://maps.google.com (дата обращения 04.01.2021).

Яндекс.Карты. Электронный ресурс: (http://maps.yandex.ru / (дата обращения 04.01.2021).

2ГИС. Электронный ресурс: https://2gis.ru/ (дата обращения 04.01.2021).

Карты Bing. Электронный ресурс: http://www.bing.com/maps/ (дата обращения 04.01.2021).

OpenStreetMap. Электронный pecypc: https://www.openstreetmap.org/ (дата обращения 04.01.2021).

Nokia Here Maps. Электронный pecypc: https://mobile.here.com/?x=ep (дата обращения 04.01.2021).

Maps.Me. Электронный ресурс: https://maps.me/ (дата обращения 04.01.2021).

MapQuest. Электронный pecypc: http://www.mapquest.com/ (дата обращения 04.01.2021).

Yahoo! Maps. Электронный pecypc: https://maps.yahoo.com/ (дата обращения 04.01.2021).

http://code.google.com/intl/ru/apis/maps// (дата обращения 04.01.2021). 
опыта [Gibin, Singleton, Milton, Mateos, Longle, 2008; Садохов, Вицентий, 2019], в нашем случае применялся двояко: и для создания авторских картографических материалов маршрута и для их размещения (как на Google Картах, так и на внешних сторонних сервисах с возможностью управления ими через JavaScript API).

Технологии картографической визуализации определялись на примере туристскокраеведческого велосипедного маршрута выходного дня по территории СаранскоРузаевского промышленного узла. Он сосредотачивает до 45 \% населения, производя до $90 \%$ валовой промышленной продукции. Это крупнейший в республике транспортный центр с магистральными железнодорожными линиями и станциями, автомобильными дорогами федерального, республиканского и местного значения, ведущая отрасль промышленности которого - электротехническое и автомобильное машиностроение, а так же переработка продукции сельского хозяйства.

Эти факты, а также результаты анализа указанных выше источников, и определили выбор ключевых мест - станций разработанного маршрута. Это опорные точки, приуроченные к историко-культурным и/или природным достопримечательностям: «Вокзал. Привокзальная площадь» (ст. 1) и «Площадь Тысячелетия» (ст. 2) в г. Саранске, «ИоанноБогословский Макаровский мужской монастырь» (ст. 3) в с. Макаровка, «Набережная реки Саранки, Пушкинский парк, Фонтанный спуск» (ст. 4) в г. Саранск, «г. Рузаевка» (ст. 5), «Параскево-Вознесенский женский общежительный монастырь» (ст. 6) и «Сузгарский водоем» (ст. 7) в г. Рузаевка и его окрестностях (рис. 1).

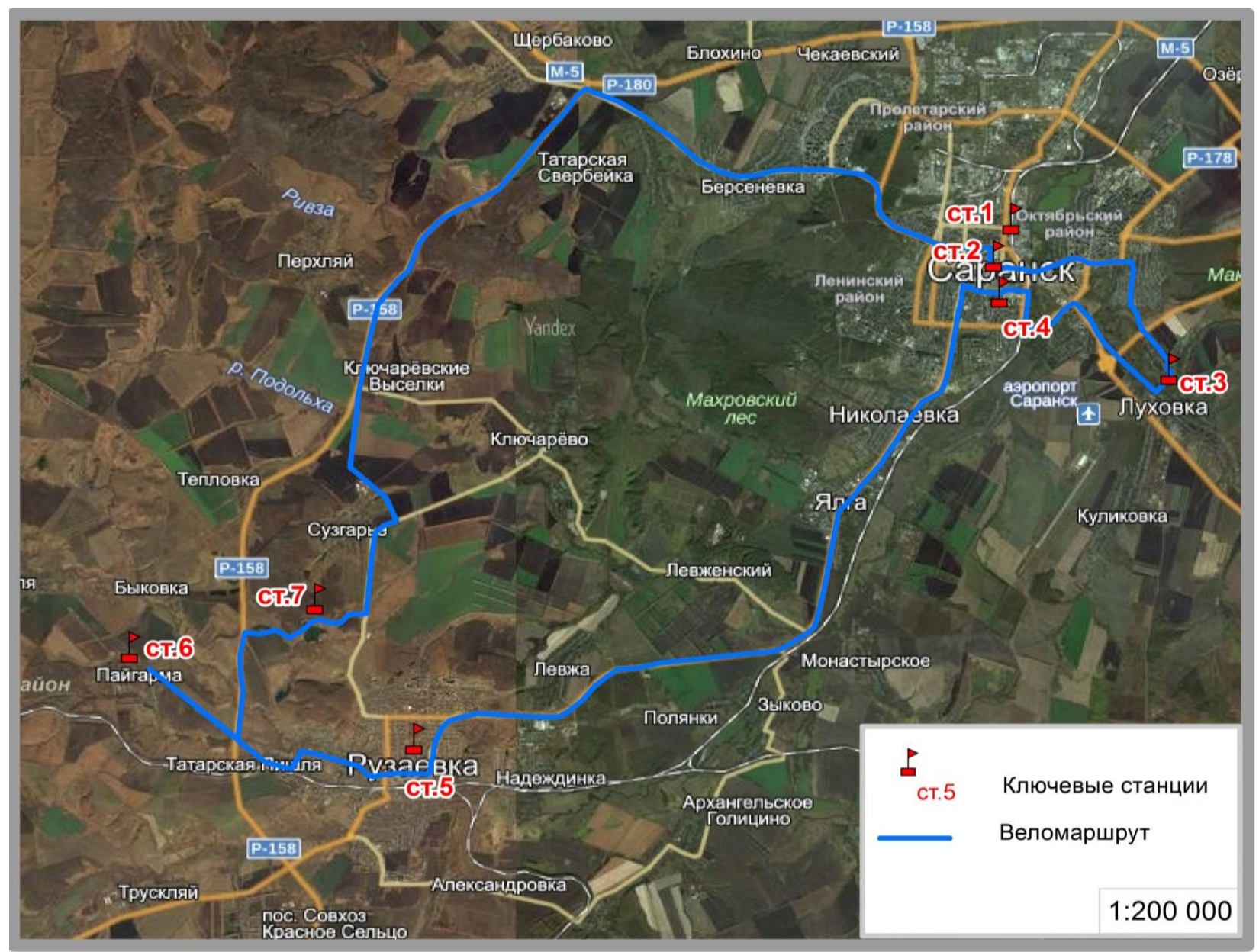

Рис. 1. Ключевые станции маршрута

Fig. 1. Key stations of the route 


\section{РЕЗУЛЬТАТЫ ИССЛЕДОВАНИЙ И ИХ ОБСУЖДЕНИЕ}

Графическая визуализация маршрута осуществлялась с использованием возможностей картографического сервиса «Google Мои карты» ${ }^{1}$, установленного в нашем случае на мобильном устройстве (смартфоне) с операционной системой Android 4.0.2. В разделах общедоступных карт сервиса возможен просмотр различных экскурсий, причем для большей части территории земного шара в 3D 2 [Терешкин. Тесленок, 2016].

Начальный этап работы заключается в регистрации и создании аккаунта Google 3 , после чего на экране мобильного устройства не только отобразятся пользовательские метки и маршруты, но и будут доступны возможности геолокации с помощью мобильной сотовой GSM-связи. После загрузки на рабочем столе появится соответствующая иконка и, если пройдена процедура авторизации, - станет доступной панель меню Google My Maps, позволяющая создать свою собственную карту, просмотреть ранее созданные авторские карты или воспользоваться любыми доступными картами других пользователей (рис. 2).

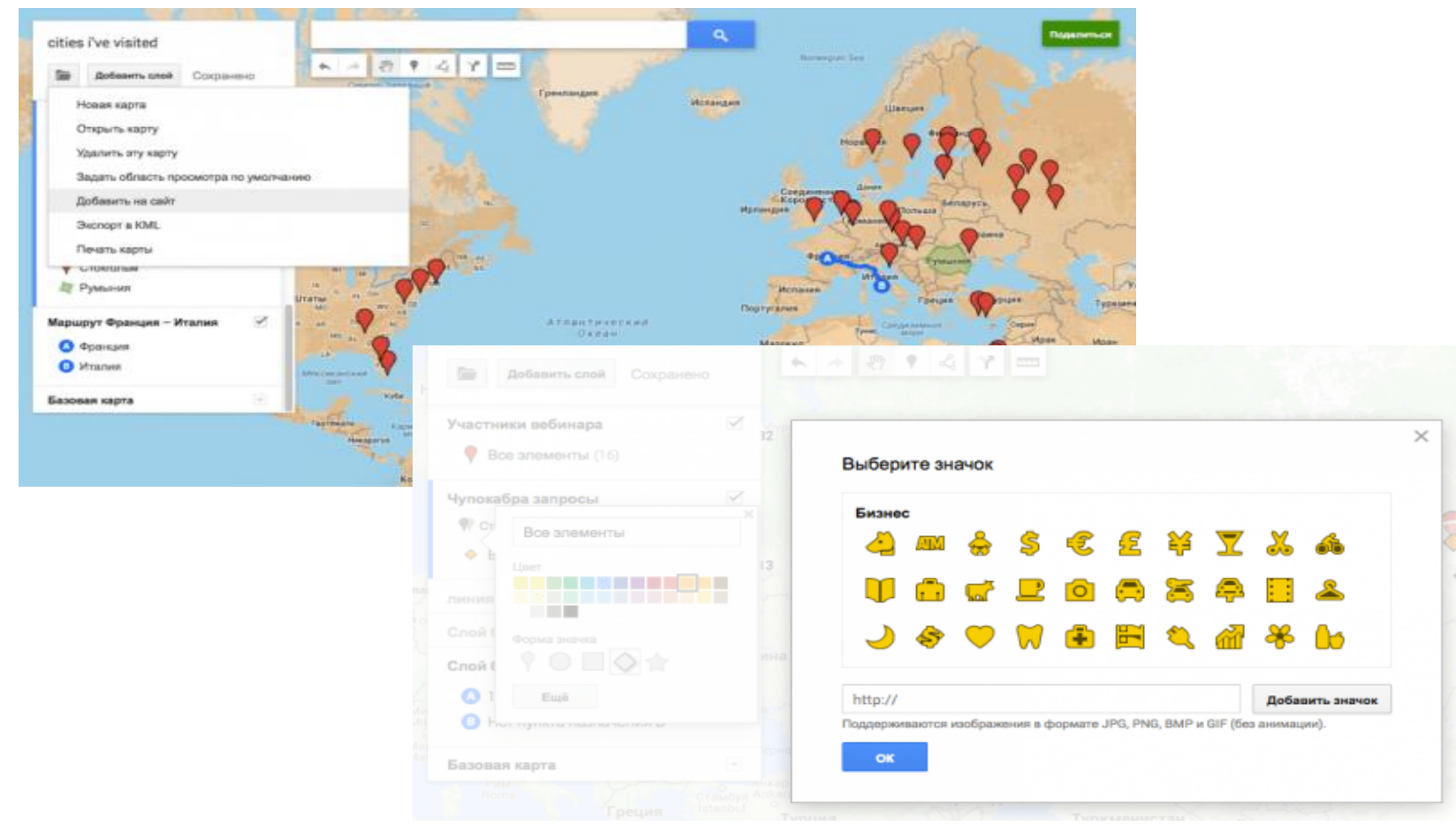

Рис. 2. Просмотр доступной карты маршрута, созданной другим пользователем Fig. 2. View an available route map created by another user

Выбор значка (строки меню) «Доступные мне» в меню «Google Мои карты» (см. рис. 2), в открывшемся окне дает возможность увидеть маршрут, добавленный с чужой учетной записи. Для получения дополнительной информации выбирается значок (строка меню) «Справка / отзыв», после чего в появившемся текстовом окне представляется более подробное описание (см. рис. 2).

1 Google Мои карты. Электронный pecypc: https://www.google.ru/maps/about/mymaps/ (дата обращения 04.01.2021).

2 Справка - Мои карты. Электронный pecypc: https://support.google.com/mymaps/?hl=ru\#topic=3188329 (дата обращения 04.01.2021).

3 Вход в аккаунт Google. Электронный pecypc: https:/www.google.com/maps/d/u/0// (дата обращения 04.01.2021). 
В сервисе имеется возможность ознакомиться с предварительно созданными пользователем слоями, для чего выбирается значок (строка меню) «Созданные мной» (рис. 3), и в появившемся окне показывается результат визуализации велосипедного маршрута в виде карты, с наложением его отдельных участков, инфраструктурных и рекреационных объектов.
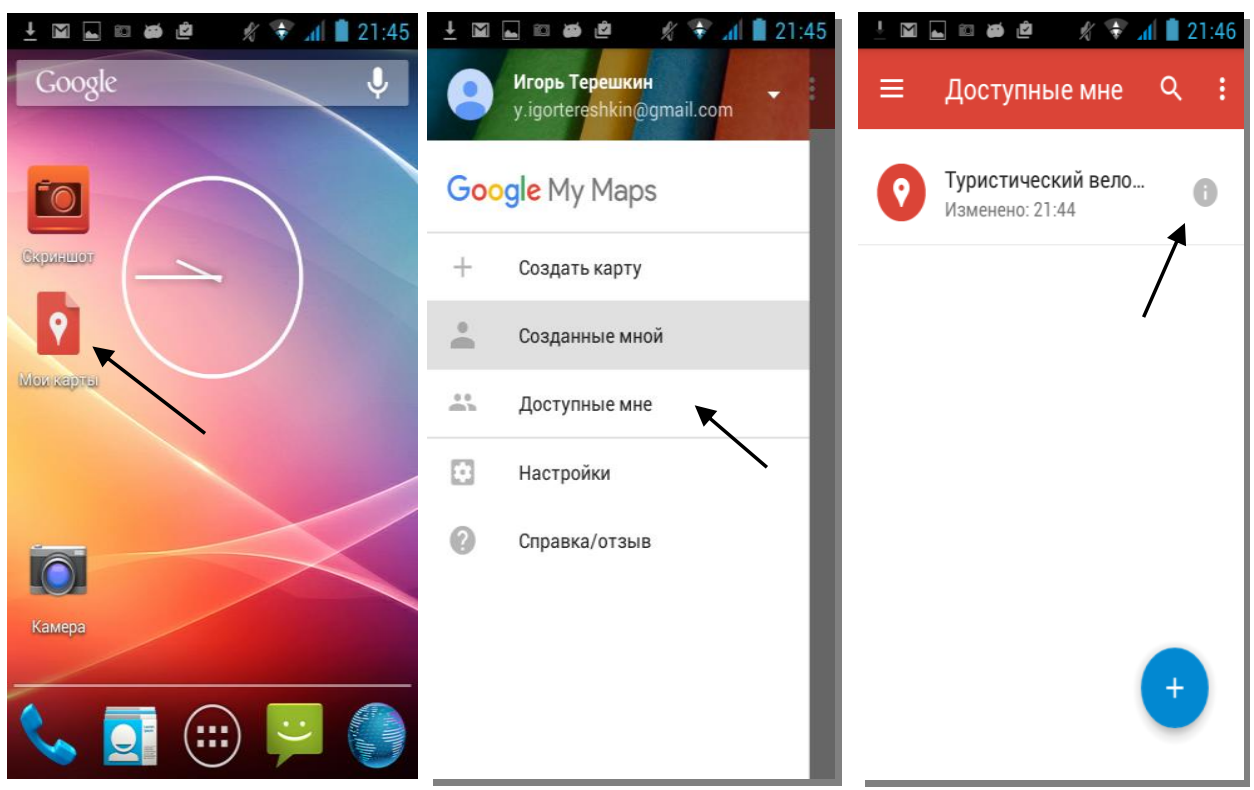

Информация о карте
$\leftarrow$ Инф
Туристический веломаршрут
Территория Саранско-Рузаевского
промышленного узла
сосредотачивает до $45 \%$ населения
и $90 \%$ валовой промышленной
продукции региона всего лишь на 5
\% его территории. Формируясь в
процессе сложного взаимодействия
природной, социальной и
производственной систем, он
являесся главным звеном опорного
хозяйственного каркаса
(совокупности центров - ядер
концентрации и ребер -
коммуникаций). Это крупнейший в
республике транспортный центр с
магистральными
железнодорожными линиями и
станциями, автомобильными
дорогами федерального и
республиканского значения,
ведущая отрасль промышленности

Рис. 3. Возможность просмотра пользовательской карты маршрута Fig. 3. Ability to view custom route map

Последовательное подключение слоев со значками условных обозначений и/или подготовленных ранее маршрутов позволяет легко сориентироваться в особенностях пространственного перемещения от одной ключевой станции маршрута к другой (рис. 4).

Ознакомление с маршрутом и/или получение дополнительной информации о нем, его ключевых станциях и достопримечательностях возможны не только до выезда или во время остановки. В приложении «Google Мои карты» имеется функция голосового навигатора, облегчающая ориентирование туриста на маршруте в момент движения и дающая в режиме навигации голосовые подсказки с учетом информация о загруженности дорог в режиме реального времени с определением наиболее оптимальных альтернативных маршрутов. Выбор одного из имеющихся вариантов навигации предполагает перемещение именно на велосипеде. Однако нужно иметь ввиду, что навигация в ряде стран и для отдельных языков временно недоступна. Это же относиться и к имеющимся в приложении функциям голосового ассистента Google Aссистент, позволяющего осуществлять поиск дополнительной необходимой информации, ставить и решать различные задачи в «Google Мои карты», находясь за рулем и не отвлекаясь от вождения.

В процессе изучения особенностей использования сервиса были выяснены возможности добавления семантики отдельных объектов маршрута (дополнительно характеризующей объект атрибутивной информации: текста, графических и видеоизображений и др.). Эта функция дает пользователю возможность в рамках одного сервиса подробно ознакомиться со всей достоверной информацией об интересующем его объекте (см. рис. 4). 


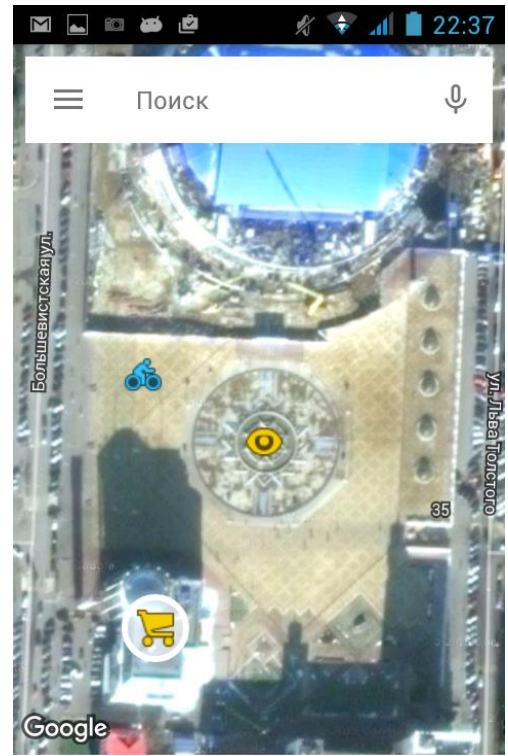

TPK "Огарев Плаза"

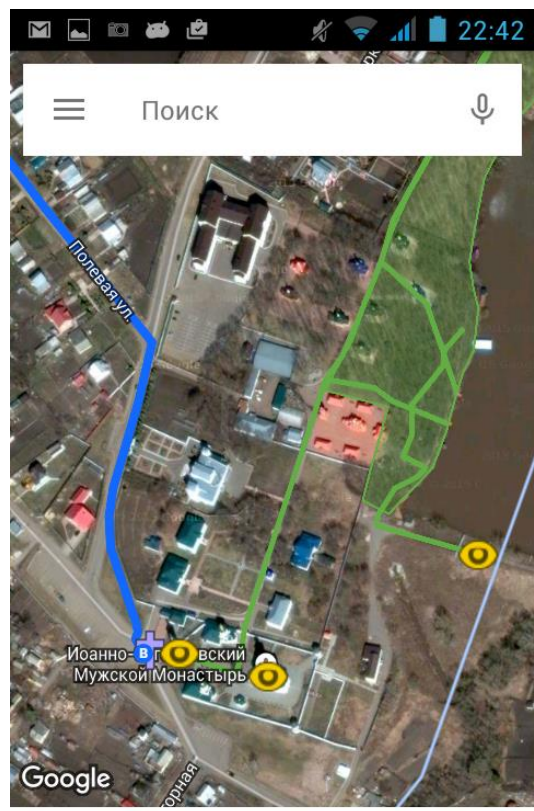

Стоянка велосипедов

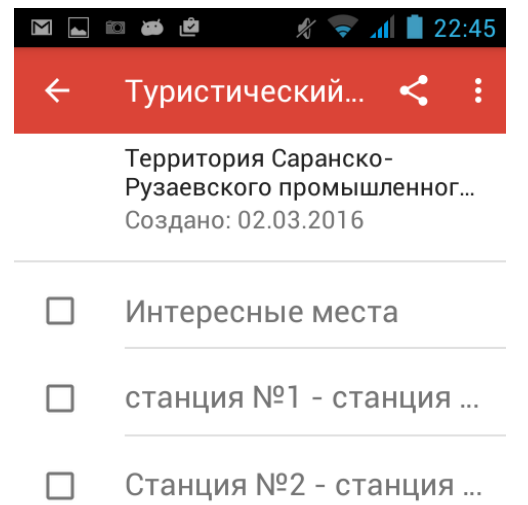

План экскурсии Иоано-...

Станция №3 - станция ...

План экскурсии "Пушки... $00 \quad r \ldots \ldots+\ldots$

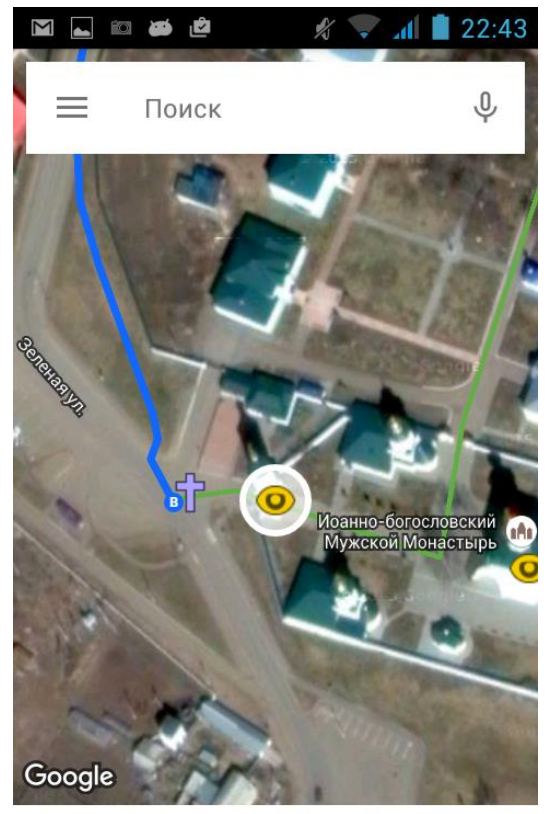

Надвратная колокольня

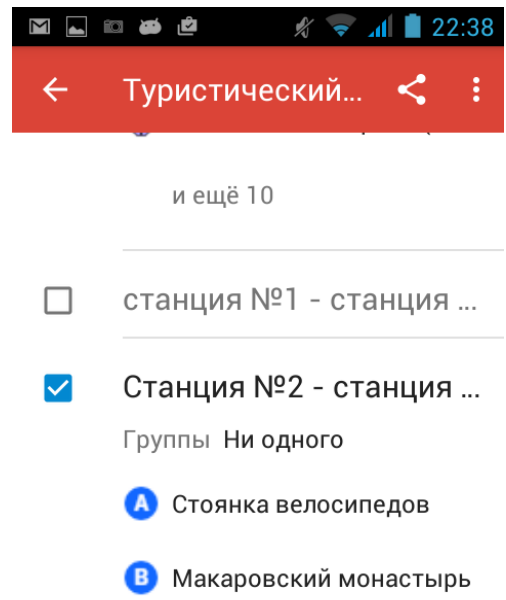

$\checkmark$ План экскурсии Иоано-... Группы Одинаковый

$\checkmark \quad \&$ Все объекты

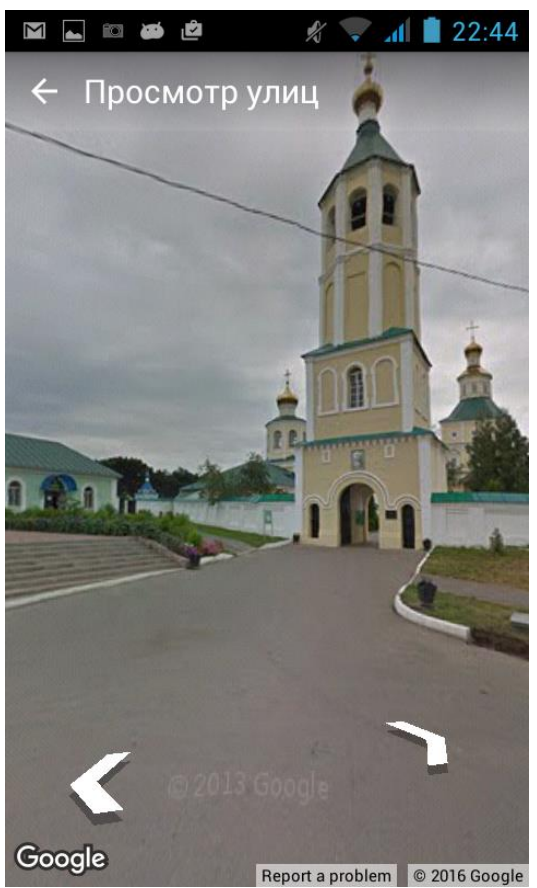

Рис. 4. Получение дополнительной информации об объектах маршрута Fig. 4. Getting more information about route features

Необходимо заметить, что в процессе сбора исходных данных, планирования, разработки, подготовки и практического осуществления туристских маршрутов могут быть крайне полезными и интересными функции отдельных интернет-сервисов с фотографическими материалами (например, аналогичные «Panoramio» [Тесленок, Тесленок, 2011; Терешкин, Тесленок, 2016]). Они существенно расширяют перечень и облегчают выбор туристско-рекреационных объектов, дающих, прежде всего визуальное представление о территории в целом и об отдельных ее участках и объектах, их специфике, привносят элементы мультимедийности и интерактивные качества в 
существующие для изучаемой территории цифровые картографические материалы ${ }^{1}[\Pi p u-$ маченко и др., 2008; Гусев, Ивлиева, 2014; Терешкин, Тесленок, 2016].

Cервис «Google Мои карты» позволяет содержать в одном слое все типы векторного представления пространственных данных (точка, полилиния, полигон) ${ }^{2}$, что позволило создать подробные детализированные планы экскурсий по туристскорекреационным объектам и территориям. Если соответствующий значок расположен в непосредственной близости от транспортной магистрали, приложение выдает соответствующую панорамную фотографию (рис. 5).
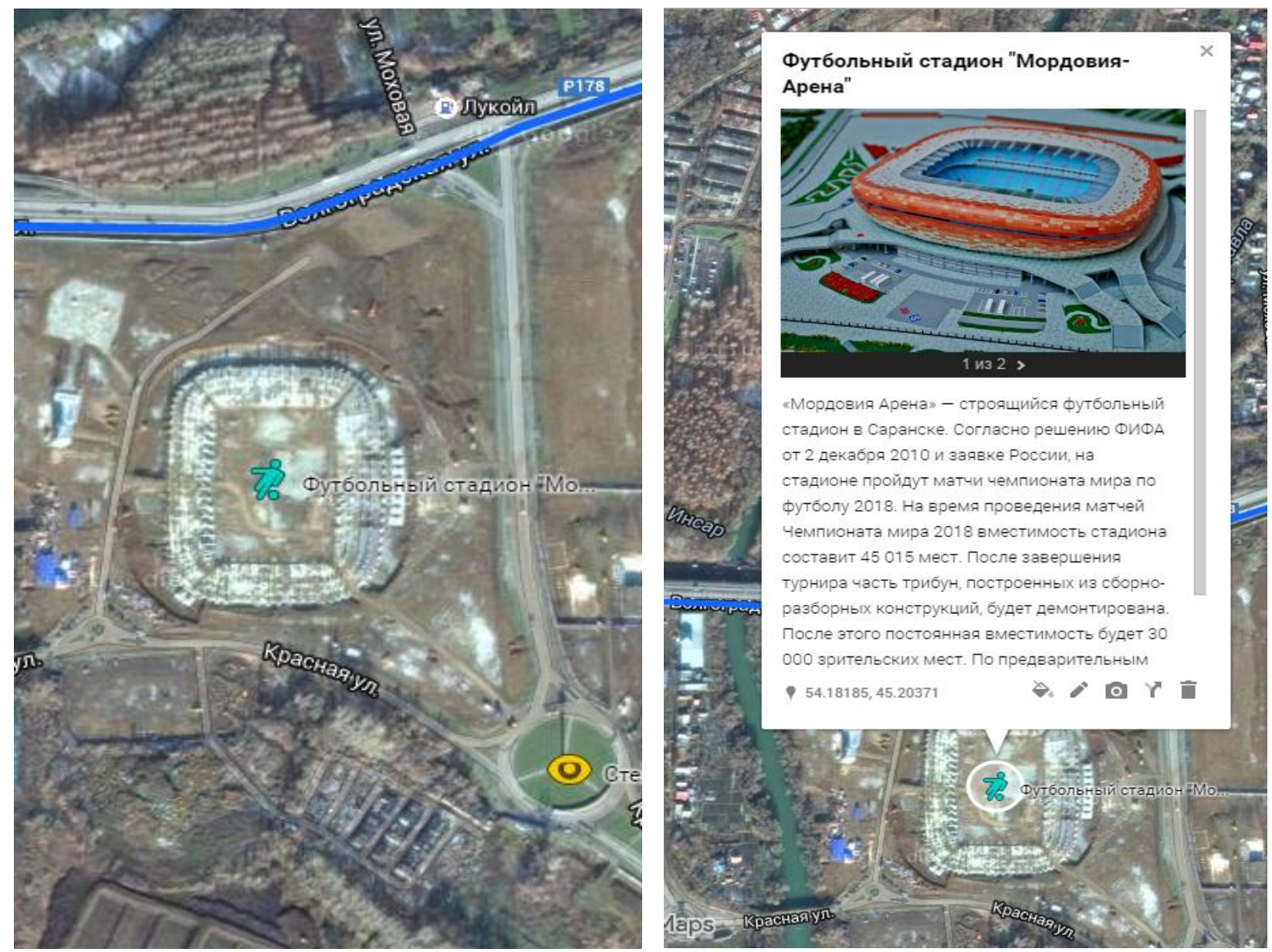

Рис. 5. Получение панорамной фотографии объекта маршрута Fig. 5. Getting a panoramic photo of a route object

После завершения работы над созданным при помощи «Google Мои карты» маршрутом, его распространение среди других туристов потенциальных пользователей осуществлялось с помощью функций, аналогичных другим сервисам Google - высылкой приглашения или ссылки электронной почтой либо размещением на личном сайте (в настройках доступа должна быть установлена доступность документа для чтения всем пользователям сети), а также после скачивания данных о метках маршрута в формате *.kml с последующим использованием в других программах и сервисах.

1 Саранск туристический. Электронный ресурс: http://welcome2018.com/cities/saransk/the-picturesquesaransk/ (дата обращения 04.01.2021).

2 Google Мои карты. Электронный pecypc: https://www.google.ru/maps/about/mymaps/ (дата обращения 04.01.2021). 
Дополнительно необходимо осветить еще ряд моментов. Так, важным фактором, определяющим сложность любого велосипедного маршрута, является рельеф и, в первую очередь, - амплитуды высот, средний уклон на его отдельных участках, количество подъемов и спусков, ожидаемые общий (суммарный) набор и сброс высоты, необходимые для оценки сложности и, соответственно - правильного расчета сил велосипедиста. В этом плане аналогично ряду специализированных спортивных приложений, «Google Мои карты» в некоторых странах визуализирует данные об особенностях рельефа местности, имеющих значение именно с точки зрения оценки сложности велосипедного маршрута.

Для доступа к данным используются возможности двух сервисов - Google Maps и Google Earth, работающих с общей базой данных. Так, один из режимов отображения Ландшафт позволяет использовать карты, визуализирующие особенности местного рельефа (трехмерное отображение земной поверхности, изолинии с указанием высот над уровнем моря, светотеневая отмывка (псевдо 3D-рельеф)). Google использует все доступные цифровые модели рельефа (ЦМР, Digital Elevation Model) разного пространственного разрешения. Это могут быть данные глобальных - SRTM, GTOPO30 (paдарная съемка), ASTER GDEM (стереосцены), более детальные - некоторых местных картографических агентств (США - модель NED [лидарная съемка], Япония - AW3D30 [сочетание оптических, радарных и лидарных съемок] и др. $)^{1-4}$.

Можно не просто исследовать особенности рельефа местности, но и получить и просмотреть в «Google Мои карты» его профиль в любом заданном направлении, используя вкладку «Путь» и установив доступность показа профиля рельефа. После прокладки линии профиля в контекстном меню можно определить расстояние и просмотреть пункт «Показать рельеф местности», где профиль наглядно демонстрирует колебания высот по заданному направлению. Кроме того, перемещение курсора мыши визуализирует на карте стрелку, указывающую для анализируемой точки ее абсолютную высоту и расстояние от начальной точки профиля 5 .

При этом необходимо отметить еще один момент. Интересны и характерные результаты опыта сравнения в разных приложениях показателя суммарного набора высоты по одному и тому же однодневному горному 33-километровому велосипедному маршруту в окрестностях Сочи, записанному с помощью приложения Strava. Один и тот же маршрут показал значение суммарного набора высоты в Strava - 859 м, в nakarte.me 1471 м (на 71,2 \% больше), в Google Earth - 1595 м (на 85,7 \%) $)^{6}$. Остается открытым вопрос - каким из этих показателей можно доверять, если получить максимально точные сведения можно по результатам топографической съемки всей трассы маршрута, что нереально по причине значительной стоимости и длительности? И это - предмет отдельного исследования.

Если для анализа маршрута используется картографический сервис (как в нашем случае «Google Мои карты»), суммарный набор высоты рассчитывается на основе ЦМР разного пространственного разрешения, некоторые из которых были указанных выше. В топографических базах данных каждая из таких моделей для конкретной точки земной поверхности содержится свое значение измеренной абсолютной высоты. Подобные

\footnotetext{
1 Google Мои карты. Электронный pecypc: https://www.google.ru/maps/about/mymaps/ (дата обращения 04.01.2021.

2 https://qna.habr.com/q/568578 / (дата обращения 04.01.2021).

3 https://ru.wikipedia.org/wiki/Shuttle_Radar_Topography_Mission (дата обращения 04.01.2021).

4 https://wiki.openstreetmap.org/wiki/SRTM (дата обращения 04.01.2021).

5 https://urklad.ru/karty/kak-posmotret-relef-mestnosti-v-google-earth/ (дата обращения 04.01.2021).

6 https://sport-marafon.ru/article/poleznaya-informatsiya/kak-pravilno-poschitat-nabor-vysoty-na-marshrute/ (дата обращения 04.01.2021).
} 
сервисы, как правило, игнорируют значения высот, записанные устройством с помощью альтиметра или навигатора систем глобального позиционирования, и при выгрузке маршрута задействуют так называемый «плоский трек» - координаты точек маршрута без данных об их высоте. И лишь после этого они определяют высоту точек по своей базе, что позволяет проанализировать амплитуды высот и автоматически рассчитать их суммарные набор и сброс. Но для одного и того же региона могут использоваться разные доступные модели, а так же различные регионы в одной и той же модели могут быть сняты с различной точностью ${ }^{1}$ и иметь ошибка определения абсолютной высоты.

Наиболее активно велосипедистами используются такие популярные навигационные, картографические программы, сервисы и специализированные приложения, как Strava, Komoot, Endomondo, Runtastic, Map My Ride, Naviki, Maps.Me, nakarte.me, Ride With GPS, OsmAnd, Plotaroute.com, BikeComputer, Runtastic Road Bike, Trailforks, Locus Map Free - Outdoor GPS, TrailForks, ViewRanger, TrainerRoad, TrainingPeaks, Велоспорт Велосипед Treкер, Мy Campy, Cyclemeter, CardioCast (CycleCast), Kudo Coach, Motosumo, Peloton, Wahoo Fitness, Suunto App, MyFitnessPal и др. Они имеют возможность прокладывания и расчета индивидуальных велосипедных маршрутов с учетом типа велосипеда (горный или гоночный) как онлайн, так и для загруженных карт, с учетом желаемых стартовых и конечные точек, а также разной продолжительности. Маршруты можно записывать и документировать, что позволяет фиксировать, получать и отслеживать подробную статистику физической активности, скорости и темпа цикла передвижения, пройденного расстояния, перепадов высот, набранного подъема, частоты сердечного ритма, затраченных калорий и многие другие показатели. Функции синхронизации позволяют поддерживать связь и общение с единомышленниками, следить за их успехами, сравнивать результаты, устраивать групповые заезды и обсуждать их. Некоторые приложения имеют полезную функцию Keep me Safe, позволяющую отправлять уведомления о местах опасных падений ${ }^{2,3,4,5,6}$.

Google (Мои карты), обладают аналогичным функционалом. Вместе с тем, являясь мощным навигационным инструментом, сервис иногда может работать достаточно медленно, а при его монопольном использовании - значительно осложнять ориентирование, особенно условиях крупного города. Тот же самый Komoot лишен названных недостатков.

Главными причинами использования в нашем исследовании именно сервиса «Google Мои карты» стали его безусловное лидерство, известность и популярность среди картографических и справочных сервисов и порталов сети Интернет; бесплатность для некоммерческого использования, а соответственно - максимальная доступность; функционал, не уступающий другим аналогичным популярным навигационным, картографическим программам, сервисам и специализированным приложениям.

\footnotetext{
1 https://sport-marafon.ru/article/poleznaya-informatsiya/kak-pravilno-poschitat-nabor-vysoty-na-marshrute/ (дата обращения 04.01.2021).

2 https://lifehacker.ru/prilozheniya-dlya-velosipedistov/ (дата обращения 04.01.2021)

3 https://ichip.ru/podborki/top-5-luchshie-navigatsionnye-prilozheniya-dlya-velosipedistov-601802 (дата обращения 04.01.2021).

4 https://xpcom.ru/prilozheniye-dlya-yezdy-na-velosipede.html (дата обращения 04.01.2021).

5 https://bikeandme.com.ua/novickam/vybor-aksessuarov/1843498-best-of-the-best-14-luchshikhprilozhenij-dlya-velosipedistov (дата обращения 04.01.2021).

6 https://bikeandme.com.ua/novickam/vybor-aksessuarov/1843498-best-of-the-best-14-luchshikhprilozhenij-dlya-velosipedistov (дата обращения 04.01.2021).
} 


\section{ВЫВОДЫ}

Выявлены возможности использования бесплатного сервиса «Google Мои карты» для картографической визуализации самостоятельно разработанных туристических маршрутов.

Визуализированный туристско-краеведческий велосипедный маршрут выходного дня изначально разрабатывался авторами как демократичный, бюджетный, доступный для широкого круга пользователей способ ознакомления с особенностями природы и хозяйства и рекреационными объектами территории крупнейшего в Мордовии СаранскоРузаевского промышленного узла. Он может использоваться республиканскими министерствами: экономики, торговли и предпринимательства (осуществляющим полномочия и региональную политику в сфере туризма и занимающимся проблемами развития туристической отрасли республики); культуры, национальной политики и архивного дела; спорта и физической культуры; а так же предприятиями и организациями сферы туризма и гостеприимства; администрациями учебных заведений городов Саранска и Рузаевки; студентами и студенческими советами для организации массовых мероприятий, а также всеми заинтересованными лицами.

Таким образом, на конкретном примере территории Саранско-Рузаевского промышленного узла по выявлены, протестированы и проиллюстрированы возможности cервиса «Google Мои карты» ${ }^{1}$ по картографической визуализации варианта туристскокраеведческого велосипедного маршрута выходного дня, с использованием в качестве мобильного устройства смартфона с операционной системой Android 4.0.2. Результат визуализации маршрута представлен в виде карты, с наложением его отдельных участков, инфраструктурных и рекреационных объектов.

В процессе изучения особенностей использования сервиса выяснены и практически применены возможности добавления семантики отдельных объектов маршрута, что позволяет пользователю в рамках только одного сервиса подробно ознакомиться со всей достоверной и актуальной информацией об интересующем его объекте. Сервис «Google Мои карты» может содержать в одном слое все типы векторного представления пространственных данных, что позволило создать подробные детализированные планы экскурсий по туристско-рекреационным объектам и территориям

Подтверждено, что функционал сервиса нисколько не уступает, а в ряде случаев даже превосходит навигационные возможности аналогичных широко используемых велотуристами популярных сервисов и приложений.

Планируется дальнейшее более детальное изучение возможностей использованного веб-сервиса «Google Мои карты» и аналогичных, осуществление максимальной степени картографирования разработанного велосипедного маршрута и его разных вариантов, нанесение на веб-карту дополнительных объектов-достопримечательностей и расширенной информации о них.

\section{СПИСОК ЛИТЕРАТУРЫ}

1. Векслер B.A. Построение интерактивных карт для HTML-документов на уроках информатики. NovaInfo, 2016. № 46-3.

2. Гусев И.А., Ивлиева Н.Г. Об опыте интеграции трехмерного компьютерного моделирования и ГИС. Картография и геодезия в современном мире: материалы 2й Всерос. науч.-практ. конф., Саранск, 8 апр. 2014 г. Саранск, 2014. С. 193-197.

3. Зубехин A.A., Рыббанов А.А. Применение средств MySQL и Google Maps API для вывода картографической информации. Современная техника и технологии, 2016.

Google Мои карты. Электронный ресурс: https://www.google.ru/maps/about/mymaps/ (дата обращения 04.01.2021). 
№ 7. Электронный pecypc: http://technology.snauka.ru/2016/07/10384 (дата обращения: 04.01. 2021).

4. Кадочников А.А. Организация и визуализация данных наблюдений с помощью картографических веб-сервисов. Материалы Международной конференции «ИнтерКарто. ИнтерГИС». 2014. Т. 20. С. 201-209.

5. Касьянова E.Л. Создание интерактивных картографических веб-сервисов // Известия высших учебных заведений. Геодезия и аэрофотосъемка, 2014. № 3. С. 87-92.

6. Кочитов M.E. Использование интерактивных карт с помощью сервиса Яндекс.Карты на JavaScript. Биробиджан: Постулат, 2019. № 1. С. 19-26.

7. Мынов А.А., Тесленок К.С. Цифровое моделирование рельефа как первый этап выявления мест возможного размещения центров горнолыжного туризма в Республике Мордовия. Огарев-оnline, 2016. № 24 (65). Электронный ресурс: http://journal.mrsu. ru/arts/cifrovoe-modelirovanie-relefa-kak-pervyj-etap-vyyavleniyamest-vozmozhnogo-razmeshheniya-centrov-gornolyzhnogo-turizma-v-respublikemordoviya-5 (дата обращения: 04.01. 2021).

8. Примаченко Е.И., Ивлиева Н.Г., Манухов В.Ф. и др. Разработка содержания и оформления «Карты достопримечательных мест Республики Мордовия». Картография - туризму: мат-лы науч.-практич. конф. СПб.: Карта, 2008. С. 128 132.

9. Садохов М.A., Вицентий А.В. Использование геосервисов для решения задач анализа и динамической визуализации логистических потоков. XXI век: итоги прошлого и проблемы настоящего плюс, 2019. Т. 8. № 4 (48). С. 26-32.

10. Семина И.А., Уварова О.Н. Туризм в экономике региона. Материалы XIV науч. конф. молодых ученых, аспирантов и студентов Мордовского государственного университета им. Н.П. Огарева: в 2-х частях. Ч. 1. Технические и естественные науки. Саранск: Изд-во Мордовск. ун-та, 2010. С. 200-201.

11. Семина И.А., Фоломейкина Л.Н., Кильдишова Н.А. Факторы формирования транспортной подвижности населения. Региональные аспекты географических исследований и образования: Сб. статей XII Всерос. научн.-практич. конф. «Региональные аспекты географических исследований и образования», Пенза, 17-19 нояб. 2016 г. Пенза: Издательство Пензенского государственного университета, 2016. C. 81-84.

12. Терешкин И.П. Тесленок С.А. Отбор и характеристика объектов для разработки и картографирования туристического велосипедного маршрута по монастырям Мордовии. Огарев-online, 2016. № 16. Электронный pecypc: http://journal.mrsu. ru/arts/otbor-i-xarakteristika-obektov-dlya-razrabotki-i-kartografirovaniya-

turisticheskogo-velosipednogo-marshruta-po-monastyryam-mordovii (дата обращения: 04.01.2021).

13. Тесленок С.А. Тесленок К.С. Сервис «Раnoramio» в выявлении особенностей природных объектов при разработке туристских маршрутов на основе ландшафтной ГИС. Финно-угорское пространство в туристском измерении: материалы 1-й Межд. научно-практич. конф., Саранск, 27-28 апр. 2011 г. Саранск: НИИ Регионологии, 2011. С. 89-95.

14. Тесленок С.А., Мынов А.А., Тесленок К.С. Геоинформационные технологии в определении перспективных районов размещения горнолыжных центров и комплексов в Республике Мордовия. Геоинформационное картографирование в регионах России: мат-лы IX Bсерос. науч.-практ. конф. (Воронеж, 5 декабря 2017 г.). Воронеж: Издательство «Научная книга», 2017. С. 69-76. 
15. Тесленок С.А., Тесленок К. С. Использование новых информационных технологий при разработке туристских маршрутов. Туризм Казахстана: проблемы и перспективы: Материалы V Междунар. научно-практической конференции 9-11 окт., 2014 г., г. Алматы, Казахстан. Алматы, 2014. С. 103-109.

16. Тикунов В.С. Моделирование в картографии. М.: Изд-во Моск. ун-та, 1997. 405 с.

17. Фоломейкина Л. $H$. Об особенностях развития детской рекреации. Наука и образование XXI века: Материалы X Междунар. научно-практ. конф., Т. II, 28 окт. 2016 г., СТИ, г. Рязань. Рязань: СТИ, 2016. С. 59-62.

18. Dransch $D$. The use of different media in visualizing spatial data. Computer \& Geosciences, 2000. V. 26. I. 1. P. 5-9.

19. Erle S., Gibson R., Walsh J. Mapping Hacks Tips \& Tools for Electronic Cartography. Sebastopol, CA: O’Reilly Media, Inc., 2005. 568 p.

20. Gibin M., Singleton A., Milton R., Mateos P., Longle P. An Exploratory Cartographic Visualisation of London through the Google Maps API. Applied Spatial Analysis and Policy, 2008. V. 1, I. 2. Pp. 85-97. DOI: 10.1007/s12061-008-9005-5.

\section{REFERENCES}

1. Dransch $D$. The use of different media in visualizing spatial data. Computer \& Geosciences, 2000. V. 26. I. 1. P. 5-9.

2. Erle S., Gibson R., Walsh J. Mapping Hacks Tips \& Tools for Electronic Cartography. Sebastopol, CA: O’Reilly Media, Inc., 2005. 568 p.

3. Folomejkina L. N. About the peculiarities of the development of children's recreation. Science and Education of the XXI century: Proceedings of the X International Scientific and Practical Conference, V. II, October 28, 2016, STI, Ryazan. Ryazan: STI. P. 59-62 (in Russian).

4. Gibin M., Singleton A., Milton R., Mateos P., Longle P. An Exploratory Cartographic Visualisation of London through the Google Maps API. Applied Spatial Analysis and Policy. 2008. V. 1. I. 2. P. 85-97. DOI: 10.1007/s12061-008-9005-5.

5. Gusev I.A., Ivlieva N. G. On the experience of integrating of 3D computer modeling and GIS. Cartography and Geodesy in the modern world: materials of the 2nd All-Russian Scientific and Practical Conference, Saransk, April 8, 2014. Saransk, 2014. P. 193-197 (in Russian).

6. Kadochnikov A. A. Organization and visualization to observational data using web mapping services. Proceedings of the International conference "InterCarto. InterGIS". 2014. V. 20. P. 201-209 (in Russian).

7. Kas yanova E.L. Creation of interactive web mapping services. News of higher educational institutions. Geodesy and aerial photography. 2014. No 3. P. 87-92 (in Russian).

8. Kochitov M. E. Using interactive maps using the Yandex.Maps service in JavaScript. Birobidzhan: Postulate, 2019. No 1. P. 19-26 (in Russian).

9. Mynov A. A., Teslenok K. S. Digital terrain modeling as a first step in placing of alpine skiing tourism centers in Mordovia republic. Ogarev-online, 2016. No 24 (65). Web resource: http://journal.mrsu.ru/arts/cifrovoe-modelirovanie-relefa-kak-pervyj-etap-vyyavleniya-mest-vozmozhnogo-razmeshheniya-centrov-gornolyzhnogo-turizma-vrespublike-mordoviya-5 (accessed 04.01.2021) (in Russian).

10. Primachenko E.I., Ivlieva N.G., Manuxov V.F. et al. Development of the content and design of the "Map of places of interest of the Republic of Mordovia". Cartography tourism: materials of scientific-practical. conf. St. Petersburg: Map, 2008. P. 128-132 (in Russian). 
11. Sadohov M.A., Vicentij A.V. Use of geoservices for solving problems of analysis and dynamic visualization of logistics flows. XXI century: the results of the past and the problems of the present plus. 2019. V. 8. No 4 (48). P. 26-32 (in Russian).

12. Semina I.A., Folomejkina L.N., Kildishova N.A. Factors of the formation of transport mobility of the population. Regional aspects of geographical research and education: Collection of articles of the XII All-Russian scientific and practical conf. "Regional Aspects of Geographical Research and Education", Penza, 17-19 Nov. 2016. Penza: Penza State University Publishing House, 2016. P. 81-84 (in Russian).

13. Semina I.A., Uvarova O.N. Tourism in the economy of the region. Materials of the XIV scientific Conference of young scientists, postgraduates and students of the N.P. Ogarev Mordovian State University: in 2 parts. Part 1. Technical and Natural Sciences. Saransk: Publishing House of Mordovian University, 2010. P. 200-201 (in Russian).

14. Tereshkin I.P., Teslenok S.A. Selection and characterization of objects for the developing and mapping of tourist cycling route around monasteries of Mordovia. Ogarev-online, 2016. No 16. Web resource http://journal.mrsu.ru/arts/otbor-i-xarakteristika-obektovdlya-razrabotki-i-kartografirovaniya-turisticheskogo-velosipednogo-marshruta-pomonastyryam-mordovii (accessed 04.01.2021) (in Russian).

15. Teslenok S.A., Mynov A.A., Teslenok K.S. Geoinformation technologies in identifying promising areas for the placement of ski centers and complexes in the Republic of Mordovia. Geoinformation mapping in the regions of Russia: materials of the IX All-Rus. scientific-practical conf. (Voronezh, December 5, 2017). Voronezh: Publishing House "Scientific Book", 2017. P. 69-76 (in Russian).

16. Teslenok S.A., Teslenok K.S. "Panoramio" service in identifying features of natural objects when developing tourist routes based on landscape GIS. Finno-Ugric space in the tourist dimension: materials of the 1st Inter.scientific and practical Conf., Saransk, April 27-28.2011. Saransk: Research Institute of Regionology, 2011. P. 89-95 (in Russian).

17. Teslenok S.A., Teslenok K.S. The use of new information technologies in the development of tourist routes. Tourism of Kazakhstan: problems and prospects: Proceedings of the V Intern. Scientific and Practical Conference, October 9-11, 2014. Almaty, Kazakhstan. Almaty, 2014. P. 103-109 (in Russian).

18. Tikunov V.S. Modeling in cartography. Moscow: Moscow University Press, 1997. 405 p. (in Russian).

19. Veksler V.A. Building interactive maps for HTML documents at computer science lessons. NovaInfo, 2016. No 46-3 (in Russian).

20. Zubehin A.A., Rybanov A.A. Using the MySQL and Google Maps API tools to display map information. Modern equipment and technologies, 2016. No 7. Web resource: http:// technology.snauka.ru/2016/07/10384 (accessed 04.01.2021) (in Russian). 


\title{
И.В. Флоринский ${ }^{1}$
}

\section{ГЕОМОРФОМЕТРИЯ СЕГОДНЯ}

\begin{abstract}
АННОТАЦИЯ
Рельеф является важнейшим компонентом географической оболочки, одним из основных элементов геосистем, каркасом ландшафта. Геоморфометрия - научная дисциплина, предметом которой является моделирование и анализ рельефа, а также взаимосвязей между ним и другими компонентами геосистем. В настоящее время аппарат геоморфометрии широко применяется для решения различных разномасштабных задач в науках о Земле. В рамках конкурса РФФИ «Экспансия» представлен аналитический обзор развития теории, методов и приложений геоморфометрии за период 2016-2021 гг. Для анализа использовалась выборка из 485 наиболее сильных и оригинальных работ, опубликованных в международных журналах I и II квартиля (Q1-Q2) JCR Web of Science Core Collection, a также монографии ведущих международных издательств. Проанализированы факторы, вызвавшие прогресс геоморфометрии: распространение беспилотной аэрофотосъемки, развитие средств и методов съемки подводного рельефа, появление новых глобальных цифровых моделей рельефа (ЦМР), разработка новых методов предобработки ЦМР для их фильтрации и подавления шума, развитие методов двумерной и трехмерной визуализации ЦМР, внедрение методов машинного обучения и др. Рассмотрены аспекты геоморфометрической теории, получившие развитие в 20162021 гг. В частности, представлена новая классификация морфометрических величин. Обсуждаются новые вычислительные методы, позволяющие рассчитывать по ЦМР модели морфометрических величин, а также проблемы, стоящие перед разработчиками и пользователями таких методов. Рассмотрено применение аппарата геоморфометрии для решения задач геоморфологии, гидрологии, почвоведения, геологии, гляциологии, спелеологии, геоботаники, лесоведения, зоогеографии, океанологии, планетологии, оползневедения, дистанционного зондирования, урбанистики и археологии.
\end{abstract}

КЛЮЧЕВЫЕ СЛОВА: геоморфометрия, обзор, рельеф, цифровое моделирование рельефа.

\section{Igor V. Florinsky²}

\section{GEOMORPHOMETRY TODAY}

\begin{abstract}
Topography is the most important component of the geographical shell, one of the main elements of geosystems, and the framework of a landscape. Geomorphometry is a science, the subject of which is modeling and analyzing the topography and the relationships between topography and other components of geosystems. Currently, the apparatus of geomorphometry is widely used to solve various multi-scale problems of the Earth sciences. As part of the RFBR competition 'Expansion', we present an analytical review of the development of theory,

\footnotetext{
1 Институт математических проблем биологии РАН - филиал Института прикладной математики им. M.В. Келдыша РАН, Пущино, Московская обл., 142290, Россия, e-mail: iflor@mail.ru

2 Institute of Mathematical Problems of Biology, Keldysh Institute of Applied Mathematics, Russian Academy of Sciences, Pushchino, Moscow Region, 142290, Russia, e-mail: iflor@mail.ru
} 
methods, and applications of geomorphometry for the period of 2016-2021. For the analysis, we used a sample of 485 of the strongest and most original papers published in international journals belonging to the JCR Web of Science Core Collection quartile I and II (Q1-Q2), as well as monographs from leading international publishers. We analyze factors caused a progress in geomorphometry in recent years. These include widespread use of unmanned aerial survey and digital photogrammetry, development of tools and methods for survey of submarine topography, emergence of new publicly available digital elevation models (DEMs), development of new methods of DEM preprocessing for their filtering and noise suppression, development of methods of two-dimensional and three-dimensional visualization of DEMs, introduction of machine learning techniques, etc. We consider some aspects of the geomorphometric theory developed in 2016-2021. In particular, a new classification of morphometric values is presented. We discuss new computational methods for calculating morphometric models from DEM, as well as the problems facing the developers and users of such methods. We consider application of geomorphometry for solving multiscale problems of geomorphology, hydrology, soil science, geology, glaciology, speleology, plant science and forestry, zoogeography, oceanology, planetology, landslide studies, remote sensing, urban studies, and archaeology.

KEYWORDS: geomorphometry, review, topography, digital terrain modeling.

\section{ВВЕДЕНИЕ}

Рельеф является важнейшим компонентом географической оболочки, одним из основных элементов геосистем, каркасом ландшафта. Будучи результатом взаимодействия эндо- и экзогенных процессов различного масштабного уровня и отражая геологическое строение, рельеф определяет предпосылки миграции и аккумуляции влаги и других веществ вдоль земной поверхности и в почве под действием гравитации, контролирует тепловой и гидрологический режим, распределение почвенного и растительного покрова, и пр.

В конце XX века сформировалась геоморфометрия - научная дисциплина с развитой физико-математической теорией и мощным аппаратом вычислительных методов, предметом которой является математическое моделирование и анализ рельефа, а также взаимосвязей между ним и другими компонентами геосистем [Evans, 1972; Shary, 1995; Florinsky, 2017a]. Исходными данными для моделирования являются цифровые модели рельефа (ЦМР). Объектами моделирования являются рельеф суши, подводный рельеф, рельеф поверхности ледников, подледный рельеф, рельеф внеземных территорий, а также рельеф стратиграфических горизонтов и геологических тел [Florinsky, 2016]. Эти негладкие объекты обычно аппроксимируются топографической поверхностью, которой называется замкнутое ориентированное бесконечно дифференцируемое двумерное многообразие в трехмерном евклидовом пространстве [Shary, 1995; Florinsky, 2016].

В настоящее время аппарат геоморфометрии широко применяется для решения различных разномасштабных задач геоморфологии, гидрологии, почвоведения, геоботаники, геологии, океанологии, климатологии, планетологии, археологии и других наук. Международный опыт исследований в области геоморфометрии до 2016 г. обобщен в серии аналитических обзоров и монографий [Moore et al., 1991; Florinsky, 1998; Pike, 2000; Wilson, Gallant, 2000; Li et al., 2005; Deng, 2007; Hengl, Reuter, 2009; Wilson, 2012; Florinsky, 2016; Minár et al., 2016; Lv et al., 2017].

Целью нашего обзора является анализ развития теории, методов и приложений геоморфометрии в 2016-2021 гг. Для анализа использовались статьи в международных журналах I и II квартиля (Q1-Q2) JCR Web of Science Core Collection, а также монографии ведущих международных издательств. Такой подход позволил выделить 485 наиболее 
сильных и оригинальных работ из нескольких тысяч публикаций этого периода по геоморфометрической тематике. В обзоре также цитируется 15 важных работ, опубликованных до 2016 г.

\section{ФАКТОРЫ РАЗВИТИЯ ГЕОМОРФОМЕТРИИ В ПЕРИОД 2016-2021}

Существенный прогресс геоморфометрии был вызван следующими факторами:

1. Широкое распространение беспилотной аэрофотосъемки [Toth, Jóźków, 2016; Bhardwaj et al., 2016b; Singh, Frazier, 2018; Xiang et al., 2019; Yao et al., 2019; Gaffey, Bhardwaj, 2020] и методов цифровой фотограмметрии [Eltner et al., 2016; Smith et al., 2016; Anderson et al., 2019], которые позволяют воспроизводимо [Clapuyt et al., 2016; Hendrickx et al., 2019] получать ЦМР сверхвысокого разрешения (1-25 см) и высокой точности [Gindraux et al., 2017; James et al., 2017; Florinsky et al., 2018a; Guisado-Pintado et al., 2019]. При сложности или невозможности выполнения условий планово-высотного обоснования в качестве опорной информации используются центры проекций снимков [Gabrlik et al., 2018; Bliakharskii et al., 2019; Chudley et al., 2019]. Создаваемые ЦМР применяются при исследованиях относительно небольших участков.

2. Широкое распространение технологии воздушного лазерного сканирования [Toth, Jóźków, 2016], что, в частности, обеспечило возможность появления в открытом бесплатном доступе ЦМР высокого разрешения (1-2 м) на многие обширные территории Западной Европы и Северной Америки [Florinsky et al., 2019].

3. Развитие средств и методов получения батиметрических ЦМР высокого разрешения и точности для глубоководных и шельфовых зон морей и океанов [Wölfl et al., 2019; Zwolak et al., 2020; Zhao et al., 2021], прибрежного мелководья [Collin et al., 2018; Hodúl et al., 2018; Agrafiotis et al., 2019], а также русел рек [Alvarez et al., 2018; Kasvi et al., 2019; Legleiter et al., 2019]. В первом случае используется многолучевое эхолотирование с надводных и подводных управляемых и автономных платформ, во втором фотограмметрическая обработка аэро- и космических снимков и лидарная аэросъемка, а в третьем - в основном, лидары и контролируемые беспилотными авиационными системами сонары. Получаемые ЦМР используются в широком диапазоне масштабов.

4. Появление новых, более точных и качественных, оригинальных и компилированных, квазиглобальных, глобальных и региональных общедоступных ЦМР среднего и высокого разрешения. Хотя точность и качество таких ЦМР все еще оставляет желать лучшего, важность именно общедоступных, а не коммерческих ЦМР для научного сообщества сложно переоценить [Schumann, Bates, 2018]: такие ЦМР позволяют без дополнительных затрат проводить исследования различной направленности на региональном, континентальном и глобальном уровнях.

К новым оригинальным общедоступным ЦМР относятся: 1) Квазиглобальные ЦМР суши с разрешением 1": AW3D30 DSM v. 1-3.2 [Tadono et al., 2016] и ASTER GDEM v. 3 [Abrams et al., 2020], созданные фотограмметрическим методом по снимкам космических аппаратов (KA) ALOS и Terra. AW3D30 является наиболее точной оригинальной квазиглобальной ЦМР среди аналогов [Boulton et al., 2018; Caglar et al., 2018; Florinsky et al., 2018b; Jain et al., 2018; Li, Zhao, 2018; Florinsky et al., 2019; Liu et al., 2019; GonzálezMoradas, Viveen, 2020]. Популярная в России ASTER GDEM имеет низкую точность и переполнена артефактами [Purinton, Bookhagen, 2017; Boulton, Stokes, 2018; Florinsky et al., 2018b, 2019; Grohmann, 2018; Liu et al., 2019; González-Moradas, Viveen, 2020], поэтому международное совещание экспертов “Global DEM Benchmarking” (2019, JRC EC, Испра, Италия) рекомендовало отказаться от ее использования. 2) ЦMP суши Арктики ArcticDEM [Porter et al., 2018] и Антарктики REMA [Howat et al., 2019] (разрешение 2 и 8 м), полученные по снимкам KA WorldView и GeoEye. 
Целями создания компилированных ЦМР являются: а) составление глобальных ЦМР, описывающих весь рельеф планеты - рельеф суши, подводный и подледный рельеф; и б) улучшение существующих ЦМР (фильтрация шума и ошибок, заполнение пробелов). Эти цели достигаются с использованием разнородных взаимодополняющих источников данных.

К новым компилированным глобальным ЦМР относятся: 1) SRTM15+ v. 2 с разрешением 15" [Tozer et al., 2019], в которой для описания рельефа суши использованы SRTM-3 DEM, ASTER GDEM, ArcticDEM и REMA, a рельефа дна - данные батиметрических измерений и предсказательные модели рельефа дна по данным спутниковой альтиметрии. 2) GEBCO_2019 и _2020 (разрешение 15") [Wölfl et al., 2019], в основе которых лежит существенно уточненная SRTM15+.

К новым улучшенным компилированным квазиглобальным ЦМР суши относятся: 1) MERIT DEM [Yamazaki et al., 2017] (разрешение 3"), созданная путем слияния и последующего редактирования AW3D30 и SRTM-3. 2) ЦMP, созданная на основе SRTM-1 DEM и ASTER GDEM v. 2 (разрешение 1") [Yue et al., 2017]. 3) ЦMР Copernicus DEM GLO-30 и GLO-90 [Strobl, 2020] (разрешение 1" и 3"), в основе которых лежит коммерческая квазиглобальная ЦМР WorldDEM [Rizzoli et al., 2017] с разрешением 0,4". Эта модель, полученная радарграмметрическим методом по данным съемки KA TanDEMХ, является самой точной квазиглобальной ЦМР [Rizzoli et al., 2017; Gonzalez, Rizzoli, 2018; Grohmann, 2018; González-Moradas, Viveen, 2020; Vassilaki, Stamos, 2020].

К новым компилированным региональным ЦМР относятся: 1) Модель подледного и подводного рельефа Гренландии BedMachine v. 3 [Morlighem et al., 2017] с разрешением 150 м, созданная на основе данных ледопроникающих радиолокационных измерений и многолучевого эхолотирования. 2) Батиметрическая ЦМР Северного Ледовитого океана IBCAO v. 4 [Jakobsson et al., 2020] (разрешение 200 м), построенная на основе данных эхолотирования, а также оцифрованных изобат.

5. Разработка новых методов обработки данных дистанционного зондирования (ДДЗ) для создания квазиглобальных и региональных ЦМР [Tadono et al., 2016; Rizzoli et al., 2017; Porter et al., 2018; Howat et al., 2019; Novaczek et al., 2019; Abrams et al., 2020].

6. Разработка новых методов предобработки ЦМР, к функциям которых относятся: 1) слияние взаимодополняющих ЦМР и заполнение в них пробелов [Fuss et al., 2016; Yue et al., 2017; Tozer et al., 2019; Jakobsson et al., 2020]; 2) коррекция ЦМР за растительный покров и техногенные объекты [Lindsay, 2016c; O'Loughlin et al., 2016; Yamazaki et al., 2017; Gevaert et al., 2018; Meddens et al., 2018; Pijl et al., 2020; Van Nieuwenhuizen et al., 2021]; 3) фильтрация шума, ошибок и артефактов [Yamazaki et al., 2017; Yue et al., 2017; Tozer et al., 2019; Jakobsson et al., 2020]; 4) согласование ЦМР и гидрографической сети [Barnes, 2016; Lindsay, 2016а, 2016b; Zhou et al., 2016; Zhou et al., 2017]; 5) оценка точности ЦМР [Polidori, El Hage, 2020]. Эти методы важны, так как шум и ошибки, которые есть в любой ЦМР, существенно усиливаются в морфометрических моделях, рассчитываемых по ЦМР [Florinsky, 2016; Lecours et al., 2017a, 2017b; Moudrý et al., 2018; O'Neil et al., 2019].

7. Развитие методов двумерной (2D) и трехмерной (3D) визуализации ЦМР. 2D методы сфокусированы на совершенствовании цифровой реализации классических картографических подходов изображения рельефа - метода горизонталей [Arundel et al., 2018; Samsonov et al., 2019], отмывки рельефа [Jenny, 2020; Jenny et al., 2020; Kennelly et al., 2021], а также генерализации рельефа [Duan et al., 2017; Behrens et al., 2018; Wu et al., 2019] и одновременного отображения нескольких характеристик рельефа [Chu et al., 2019]. Методы второй группы позволяют проводить 3D визуализацию больших ЦМР в реальном режиме времени [Müller et al., 2016; Zhai et al., 2016; Bladin et al., 2018; Chen et al., 2018; Thornton et al., 2018; Florinsky, Filippov, 2019, 2021]. 
8. Развитие методов машинного обучения [Guo et al., 2016], в частности алгоритмов случайного леса [Belgiu, Drăguţ, 2016; Hengl et al., 2018], и их адаптация к пространственным данным [Valentine, Kalnins, 2016; Zhang et al., 2016; Ma et al., 2019]. Эти методы применяются с целью создания моделей прогнозного картографирования почв, растительности и др., в которых одной из групп предикторов (ковариат обучающих выборок) являются цифровые модели морфометрических величин, рассчитываемые по ЦМР.

\section{ТЕОРЕТИЧЕСКИЕ АСПЕКТЫ}

В работах, использующих аппарат геоморфометрии, применяется расчет, визуализация и анализ цифровых моделей и карт морфометрических величин [Florinsky, 2016, 2017a]. Описано несколько десятков морфометрических величин, причем многие из них известны под разными названиями [Hengl, Reuter, 2009; Lecours et al., 2016b, 2017c; Favalli, Fornaciai, 2017; Amatulli et al., 2018, 2020; Newman et al., 2018; Wilson, 2018; Minár et al., 2020]. Для успешного применения методов геоморфометрии пользователь должен ориентироваться в этих величинах, понимать их физико-математический смысл и знать их интерпретации. В этой связи важную роль играет классификация морфометрических величин [Florinsky, 2017a], в основе которой лежит критерий их физико-математического смысла, и которая включает 4 основных класса величин: локальные, нелокальные, двухполевые и комбинированные величины.

Локальной морфометрической величиной называют однозначную функцию двух переменных, описывающую геометрию топографической поверхности в окрестностях данной точки вдоль направлений, заданных одной из двух значимых пар взаимно перпендикулярных нормальных сечений [Shary, 1995; Florinsky, 2016, 2017а]. Первой парой являются главные сечения (обладают максимальным и минимальным изгибом в данной точке). Вторая пара нормальных сечений выделена гравитацией: одно из них включает вектор ускорения силы тяжести и общую касательную с линией скольжения, а другое - тангенциально горизонтали в данной точке.

Двум парам нормальных сечений соответствуют две группы локальных величин: атрибуты форм и потоков [Shary, 1995; Shary et al., 2002; Florinsky, 2016, 2017 a]. Атрибуты форм связаны с главными сечениями и не зависят от направления вектора ускорения силы тяжести. К ним относятся кривизны: минимальная, максимальная, средняя и др. Атрибуты потоков связаны с нормальными сечениями, выделенными гравитацией и зависят от направления вектора ускорения силы тяжести. К ним относятся крутизна, экспозиция и кривизны: горизонтальная, вертикальная и др.

Нелокальной морфометрической величиной называют однозначную функцию двух переменных, описывающую относительное положение точки на поверхности [Florinsky, 2016, 2017a]. Для определения значений нелокальной величины необходим анализ территории, границы которой могут быть существенно удалены от данной точки (напр., всего водосборного бассейна). К нелокальным величинам относится, в частности, водосборная площадь [Florinsky, 2017a].

Двухполевой морфометрической величиной называют однозначную функцию двух переменных, описывающую взаимоотношение между топографической поверхностью (находящейся по определению в поле гравитации) и другими полями (полем солнечной радиации, ветрового потока, обзора) в данной точке [Florinsky, 2017a]. К этому классу величин относятся отражательная способность [Horn, 1981], инсоляция [Florinsky, 2017а], видимость [Cervilla et al., 2017], индекс открытости [Alonso-Sarría et al., 2018] и др.

Комбинированными называют морфометрические величины, которые являются математической комбинацией двух или нескольких локальных и нелокальных величин 
[Florinsky, 2016, 2017a]. Такие величины учитывают как локальную геометрию поверхности, так и относительное положение данной точки. К ним относятся топографический индекс [Meles et al., 2020] и др.

Вне рассмотренной классификации остается семейство индексов шероховатости [Trevisani, Cavalli, 2016; Groom et al., 2018; Korzeniowska et al., 2018], которые, в целом, представляют собой различные статистические функции морфометрических величин. Основной проблемой является неясность физико-математического смысла этих индексов и эмпирический характер их интерпретаций.

При проведении исследований актуален вопрос выбора разрешения ЦМР. Универсального решения не существует, компетентное разрешение ЦМР зависит от характерных размеров изучаемых объектов [Florinsky, 2016], а результаты моделирования зависят от разрешения ЦМР [Florinsky, 2016; Penižek et al., 2016; Gruber et al., 2017; Mondal et al., 2017; Grimm et al., 2018; Groom et al., 2018; Dai et al., 2019b; Guo et al., 2019; Sirbu et al., 2019]. Доступность лидарных и беспилотных технологий вызывает соблазн использовать максимально детальные ЦМР. Иногда это позволяет получать более правдоподобные результаты моделирования [Woodrow et al., 2016; Kasprak et al., 2019; Žabota et al., 2019], но часто гонка за максимальным разрешением неоправданна, так как моделирование с менее детальным разрешением дает аналогичные или даже лучшие результаты [Jacobs et al., 2018; Chang et al., 2019; Maxwell et al., 2019]. Кроме того, ЦМР с разрешением 1-25 см насыщены высокочастотным шумом, который сложно удалить без серьезного повреждения сигнала. Такие ЦМР для геоморфометрии бесполезны [Florinsky, Bliakharskii, 2019a].

\section{ВЫЧИСЛИТЕЛЬНЫЕ МЕТОДЫ}

Локальные морфометрические величины являются функциями частных производных высоты. Обычно их расчет по ЦМР проводится конечно-разностными алгоритмами с использованием скользящих окон $n \times n$ [Evans, 1972; Florinsky, 2016]. Альтернативой стал универсальный спектрально-аналитический метод [Florinsky, Pankratov, 2016], который основан на ортогональных разложениях высокого порядка с использованием многочленов Чебышева I рода с суммированием Фейера. Метод предназначен для обработки ЦМР в рамках схемы, включающей глобальную аппроксимацию ЦМР, сглаживание, вычисление частных производных и локальных морфометрических величин. Аппроксимация характеризуется монотонной сходимостью и возможностью быстрого глубокого разложения функции высоты (до 50 млн коэффициентов разложения).

Еще одной альтернативой традиционным скалярным вычислениям локальных величин стал метод векторных вычислений этих функций [Hu G. et al., 2020, 2021]. Он позволяет получать более реалистичные и гладкие морфометрические модели, чем традиционные подходы, причем результаты расчетов меньше зависят от ошибок и разрешения ЦМР.

Достижения в разработке методов расчета локальных величин стали возможны благодаря тому, что 30 лет назад была создана строгая и ясная физико-математическая теория топографической поверхности [Shary, 1995], которая является расширением раздела дифференциальной геометрии, посвященного кривизне поверхности. Разработка теории нелокальной морфометрии увенчались успехом 10 лет назад [Gallant, Hutchinson, 2011]. Однако до сих пор расчет нелокальных величин проводится по ЦМР с помощью логических алгоритмов маршрутизации потоков [Hengl, Reuter, 2009; Grimm et al., 2018; Wilson, 2018; Zhang et al., 2018], которые математически не обоснованы, формальны и, поэтому, часто приводят к получению неправдоподобных результатов [Huang, Lee, 2016; 
Clarke, Romero, 2017]. Разработанные аналитические методы расчета нелокальных величин [Qin et al., 2017; Bonetti et al., 2018], реализующие решения дифференциального уравнения Галланта-Хатчинсона, должны вытеснить эти устаревшие алгоритмы.

Сходная ситуация сложилась с известным подходом выделения тальвегов: вначале в ЦМР заполняются мелкие депрессии [Barnes, 2016; Lindsay, 2016а; Wei et al., 2018; Xiong et al., 2019], затем с помощью алгоритма маршрутизации потоков рассчитывается водосборная площадь, после чего подбирается ее пороговое значение, которое обеспечивает визуализацию тальвегов. Теоретически не обоснованы формализация выбора этого значения [Qin et al., 2016] и альтернативные способы построения сети тальвегов [Freitas et al., 2016; Hooshyar et al., 2016; Zhang et al., 2017; Romero, Clarke, 2018; Zhou et al., 2019; Xu et al., 2020]. Пока не будет создана строгая математическая теория структурных линий рельефа (а ее до сих пор нет [Florinsky, 2016]), корректное и воспроизводимое выделение сети тальвегов и водоразделов будет невозможно.

Аппарат геоморфометрии корректно работает с ЦМР, заданными на плоских квадратных сетках [Florinsky, 2016] и сетках сфероидических трапеций на поверхности сферы и эллипсоида вращения [Florinsky, 2017b]. Геоморфометрические расчеты тривиальны при моделировании Земли, Марса, Луны, Венеры и Меркурия, так как форма этих тел может быть описана эллипсоидом вращения или сферой, для которых существуют алгоритмы решения обратной геодезической задачи и определения площади сфероидической трапеции (решение обратной геодезической задачи требуется для размеров скользящего окна в зависимости от широты при расчете локальных величин, а площадь трапеции - при расчете нелокальных величин [Florinsky, 2017b]). Для малых небесных тел, которые могут быть описаны трехосным эллипсоидом, разработан метод, в котором эти параметры определяются по формулам Беспалова [Florinsky, 2018].

Достижения вычислительных методов и 3D визуализации реализованы в аппаратно-программном комплексе «Осязаемый ландшафт» [Petrasova et al., 2018]. В нем макет и цифровая модель ландшафта соединены циклом 3D сканирования макета, цифрового моделирования и проецирования результатов на макет. Пользователь может вручную изменять макет, вылепливая новые формы рельефа, размещать элементы растительности и др. Эти изменения вносятся сканером в цифровую модель, после чего происходит перерасчет моделируемых процессов (напр., эрозии склонов), а затем - проецирование полученных результатов на макет.

\section{ПРИМЕНЕНИЕ АППАРАТА ГЕОМОРФОМЕТРИИ}

В рассматриваемый период 2016-2021 гг. методы геоморфометрии применялись в геоморфологии, гидрологии, почвоведении, геологии, гляциологии, спелеологии, геоботанике, лесоведении, зоогеографии, океанологии, планетологии, оползневедении, дистанционном зондировании, урбанистике и археологии.

\section{Геоморфология}

Аппарат геоморфометрии настолько часто применяется в геоморфологии [Moore et al., 1991; Sofia, 2020], что некоторые российские исследователи ошибочно считают геоморфометрию количественной геоморфологией. Наибольшее распространение геоморфометрическое моделирование, часто интегрированное с машинным обучением, получило при решении следующих задач:

1) Классификация форм и элементов рельефа на основе знака или значений морфометрических величин. Методы классификации (сегментации ЦМР) МакМиллана, Дикау, Шмидта, геоморфон и пр. [Hengl, Reuter, 2009; Florinsky, 2016; Libohova et al., 2016; Gruber et al., 2017; Arundel, Sinha, 2019; Li et al., 2020] применяются как для 
геоморфологического картографирования [Argyriou et al., 2016; Gorini et al., 2016; Luo et al., 2016; Dekavalla, Argialas, 2017; Amatulli et al., 2018; Bugnicourt et al., 2018; Iwahashi et al., 2018; Mithan et al., 2019; Alvioli et al., 2020], так и в почвоведении и других науках (см. следующие разделы). Например, сегментация «геоморфон» (геоморфологический фонотип) позволяет выделять 10 элементарных форм: вершина, хребет, отрог, бровка, склон, подножье, долина, незамкнутая и замкнутая депрессии, плоский участок [Atkinson et al., 2020].

2) Автоматическое выявление современных и реликтовых форм рельефа: террас [Clubb et al., 2017; Dai et al., 2019a, 2020], друмлинов [Sărăşan et al., 2019], перигляциальных структурных грунтов [Mather et al., 2019], гляциовулканических построек [Pedersen, 2016], а также ледниковых валунов [Nevalainen et al., 2016], палеоморен и следов палеосейсмического разжижения грунта [Middleton et al., 2020].

3) Изучение флювиальных процессов и форм рельефа, в частности - анализ эволюции долин и русел рек с использованием разновременных ЦМР [Bakker, Lane, 2017; Kasprak et al., 2017], а также классификация геометрии речных русел [Lane et al., 2017].

4) Моделирование связности водных и седиментационных потоков водосборных бассейнов [Heckmann et al., 2018]. Такие работы имеют значение для понимания связей между разными частями водосбора и влияния его конфигурация, форм рельефа и техногенных объектов на непрерывность миграции и аккумуляции веществ под действием гравитации [Bigelow et al., 2016; Nicoll, Brierley, 2017; Cucchiaro et al., 2019; Marchi et al., 2019; Martini et al., 2019].

5) Моделирование и прогноз овражной эрозии [Bergonse et al., 2016; Mitusov et al., 2017; Shary et al., 2017; Garosi et al., 2018; Liu et al., 2018; Zabihi et al., 2018; Tien Bui et al., 2019; Dai et al., 2019b; Orti et al., 2019; Walker et al., 2020]. Исследования часто проводятся с использованием разновременных ЦМР и их разностей, по которым оценивается объем вынесенного материала и скорость эрозии [Cavalli et al., 2017; Cucchiaro et al., 2020]. К этим работам примыкают исследования переноса материала селевыми потоками [Loye et al., 2016], а также почвенной эрозии [Tarolli et al., 2019; Jenčo et al., 2020; Lu S. et al., 2020], в том числе - в зависимости от технологии обработки почвы. В этих работах используются ЦМР сверхвысокого разрешения (0,5-5 см).

6) Моделирование и изучение эоловых процессов и форм рельефа. К таким работам относятся анализ миграции блуждающих дюн и происходящих при этом изменений объемов песка [Brunier et al., 2016; Danchenkov et al., 2019; Grohmann et al., 2020; Rotnicka et al., 2020], изучение эволюции песчаных островов [Houser et al., 2017; Patton et al., 2019], классификация закрепленных дюн и определение направлений сформировавшего их палеоветра [Bernhardson, Alexanderson, 2017].

7) Изучение карстовых форм рельефа и процессов [Silva et al., 2017; Yang et al., 2019], включая выявление и картографирование карстовых воронок [Wu et al., 2016; Zumpano et al., 2019; Kim et al., 2019; Moreno-Gómez et al., 2019; Vajedian, Motagh, 2019], в том числе под лесным пологом [Hofierka et al., 2018] и замаскированных сельскохозяйственной деятельностью [Čeru et al., 2017].

8) Изучение криолитогенных и перигляциальных процессов и форм рельефа солифлюкционных наплывов и террас, структурных грунтов, полигонально-блочного микрорельефа и бугров пучения [Dąbski et al., 2017; Van der Sluijs et al., 2018; Queen et al., 2021], коллювиальных и аллювиальных конусов выноса [Tomczyk et al., 2017], эволюции морен [Tonkin et al., 2016; Westoby et al., 2016; Ely et al., 2017; Midgley et al., 2018], динамики каменных ледников [Colucci et al., 2016; Piermattei et al., 2016; Dall'Asta et al., 2017], а также мезо- и микрорельефа вокруг кратеров газовых выбросов [Kizyakov et al., 2017, 2018]. 
9) Изучение рельефа вулканических областей [Gomez, 2018] и его изменений после извержений, в частности - анализ лавовых потоков и каналов [Favalli, Fornaciai, 2017; Dirscherl, Rossi, 2018; Dai, Howat, 2017], обрушенных кальдер вулканов [Dirscherl, Rossi, 2018], площадей и объемов тефровых отложений и их эрозии [Dai C. et al., 2020]. Бо́льшая часть таких работ подразумевает анализ разновременных ЦМР. Кроме того, геоморфометрическое моделирование позволяет изучать типологию и эволюцию гляциовулканических форм рельефа [Pedersen et al., 2020], а также реконструировать рельеф эродированных палеовулканов [Karátson et al., 2016].

10) Количественная оценка влияния человеческой деятельности на ландшафт [Tarolli, Sofia, 2016; Tarolli et al., 2019]. Геоморфометрический анализ позволяет выявлять древние и современные антропогенные ландшафты, так как по морфометрическим характеристикам они, как правило, статистически значимо отличаются от естественных ландшафтов [Brecheisen et al., 2019; Xiang et al., 2019; Cao et al., 2020].

11) Моделирование эволюции ландшафта как результата взаимодействия тектонических и эрозионных процессов. Бо́льшая часть работ посвящена реальным территориям [Andreani et al., 2016; Elez et al., 2016; Grieve et al., 2016; Hergarten et al., 2016; Owono et al., 2016; Xiong et al., 2016, 2017; Zhang et al., 2017; Blomdin et al., 2018; Szymanowski et al., 2019; Noriega-Londoño et al., 2020; Różycka et al., 2021]. Для анализа и изучения их эволюции, помимо ЦМР, используются геологические, геофизические и климатические данные. Разрабатываются математические модели эволюции ландшафта [Clubb et al., 2016; Moon et al., 2017; Theodoratos et al., 2018; Keylock et al., 2021]. Объектом моделирования является ЦМР абстрактной территории, которая в ходе расчетов постепенно изменяется. Такой подход удобен и нагляден: визуализация изменений ЦМР и морфометрических моделей дает возможность оценить адекватность математической модели, видеть, как работают изменения ее параметров, и, при необходимости, их корректировать.

Сложными для съемки, построения ЦМР, визуализации и анализа являются ландшафты, на которых сконцентрированы песчаниковые скалы-останцы и глинистые эрозионные столбы (напр., долина Монументов и каньон Брайс в Юте). Типичными элементами этих объектов являются отвесные стены, отрицательные уклоны и навесы, а для ландшафтов характерно отсутствие гидрологической связности, каменные хаосы и замкнутые микродепрессии [Jancewicz et al., 2019]. Получение ЦМР возможно путем совместного воздушного и наземного лазерного сканирования (как в случае курумов [Šašak et al., 2019]), оптимальна 3D визуализация, а при моделировании [Migoń et al., 2016; Duszyński et al., 2017] могут возникать те же ограничения, что и для пещер (см. Cneлеология).

\section{Гидрология}

Систематическое применение аппарата геоморфометрии в гидрологии началось в 1980-е для моделирования гидрологического режима водосборных бассейнов [Moore et al., 1991; Wilson, 2018]. Широко известна пространственно-распределенная гидрологическая модель TOPMODEL [Beven et al., 2021], в которой для учета влияния рельефа используется комбинированная величина - топографический индекс [Meles et al., 2020]. Связь геоморфометрии и гидрологии закрепилась в названиях морфометрических величин (атрибуты потоков, водосборная площадь), хотя они и используются для анализа любой поверхности, вне зависимости от наличия на ней воды (см. Планетология).

Математическое моделирование гидрологического режима подразумевает анализ ЦМР и морфометрических моделей, почвенных, литологических и метеорологических данных, и позволяет моделировать процессы выпадения осадков, поверхностного стока, 
испарения, инфильтрации и др. [Guida et al., 2016; Wiekenkamp et al., 2016; Peckham et al., 2017]. Для прогноза грунтовых вод в аридных регионах неплохие результаты дает машинное обучение (алгоритмы случайного леса и максимальной энтропии) с использованием в обучающей выборке морфометрических величин [Rahmati et al., 2016].

Распространен анализ ЦМР для выявления водосборных бассейнов [Lindsay, 2016c; Liu et al., 2020a], их классификации по гидрологическим характеристикам [Gaucherel et al., 2017; Gao et al., 2018] и отклику на осадки [Papageorgaki, Nalbantis, 2016], выявления заболоченных территорий [O’Neil et al., 2018], определения объема водохранилищ [Zhang et al., 2016, Liu et al., 2020b], а также прогноза затопления из-за подъема уровня воды в реках, озерах и водохранилищах [Koriche et al., 2016; Abdel-Fattah et al., 2017; Cunha et al., 2017; Khosravi et al., 2018; Medvedev et al., 2020], в том числе - с учетом защитных сооружений [Wing et al., 2019]. Анализ ЦМР сверхвысокого разрешения позволяет исследовать сезонные поверхностные микропотоки рассолов и сопутствующие изменения поверхности солончаков [Bhardwaj et al., 2019b].

ЦМР высокого разрешения ArcticDEM оказалась полезна для картографирования гидрографической сети Арктики [Lu et al., 2020], а также для изучения сезонных колебаний уровня воды в малых арктических реках, мониторинг которых логистически затруднен [Dai et al., 2018].

\section{Почвоведение}

Рельеф является одним из главных факторов почвообразования. Уже около 40 лет геоморфометрическое моделирование широко применяется для изучения пространственного распределения физических, химических и биологических свойств почв [Florinsky, 2016], является одним из краеугольных камней педометрики - современного количественного почвоведения [McBratney et al., 2018], и лежит в основе прогнозного почвенного картографирования [Minasny, McBratney, 2016].

Объектами исследования и прогнозного почвенного картографирования выступают следующие количественные характеристики почвы:

- глубина почвенных горизонтов [Angelini et al., 2016; Drăgut,, Dornik, 2016; Mulder et al., 2016a; Hengl et al., 2017b; Libohova et al., 2016; Bock et al., 2018; Marques et al., 2018; Nussbaum et al., 2018; Patton et al., 2018; Flynn et al., 2019; Piccini et al., 2019; Atkinson et al., 2020];

- объемная плотность [Ballabio et al., 2016; Hengl et al., 2017b, 2021; Ramcharan et al., 2018];

- гранулометрический состав [Angelini et al., 2016, 2017; Ballabio et al., 2016; Drăguţ, Dornik, 2016; Mulder et al., 2016a; Viloria et al., 2016; Hengl et al., 2017b, 2021; Stumpf et al., 2017; Sun et al., 2017; Behrens et al., 2018a, 2018b; Marques et al., 2018; Nussbaum et al., 2018; Ramcharan et al., 2018; Caubet et al., 2019; Piccini et al., 2019; Wadoux, 2019; Atkinson et al., 2020; Riza et al., 2021];

- кислотность (рH) [Mulder et al., 2016a; Dharumarajan et al., 2017; Hengl et al., 2017b, 2021; Sun et al., 2017; Marques et al., 2018; Nussbaum et al., 2018; Ramcharan et al., 2018; Wadoux, 2019];

- температура [Fan et al., 2020];

- влажность [Lei et al., 2016; Baldwin et al., 2017; Carreno-Luengo et al., 2019; Guevara, Vargas, 2019; Luo W. et al., 2019; Fan et al., 2020; Mallet et al., 2020];

- влагоемкость [Ballabio et al., 2016];

- содержание органического углерода [Akpa et al., 2016; Angelini et al., 2016; Lin et al., 2016; Mulder et al., 2016a, 2016b; Song et al., 2016; Viloria et al., 2016; Angelini et al., 2017; Dharumarajan et al., 2017; Fissore et al., 2017; Hengl et al., 2017a, 2017b, 2021; Malone 
et al., 2017; Roudier et al., 2017; Sun et al., 2017; Nussbaum et al., 2018; Pejović et al., 2018; Ramcharan et al., 2018; Guo et al., 2019; Padarian et al., 2019; Piccini et al., 2019; Wadoux, 2019; Wadoux et al., 2019; Guevara et al., 2020];

- содержание азота [Lin et al., 2016; Hengl et al., 2017a, 2021; Ramcharan et al., 2018; Wadoux, 2019];

- содержание фосфора [Hengl et al., 2017a; Shen et al., 2019]

- содержание макро- и микроэлементов [Viloria et al., 2016; Hengl et al., 2017a, 2021];

- емкость катионного обмена [Mulder et al., 2016a; Angelini et al., 2017; Hengl et al., 2017b, 2021; Marques et al., 2018; Nussbaum et al., 2018; Piccini et al., 2019];

- электропроводность [Dharumarajan et al., 2017; Vermeulen et., 2017];

- гамма-излучение [Malone et al., 2016; Wadoux et al., 2018].

Кроме того, создаются прогнозные почвенные карты различного масштаба, на которых почвенный покров отображается в виде контуров с классификационной принадлежностью почв [Chaney et al., 2016; Drăguţ, Dornik, 2016; Silva et al., 2016; Hengl et al., 2017b; Sarmento et al., 2017; Cunha et al., 2018; Dornik et al., 2018; Horáček et al., 2018; Ramcharan et al., 2018; Vincent et al., 2018].

При проведении таких исследований основными предикторами (ковариатами) служат рассчитанные по ЦМР модели морфометрических величин. Помимо них могут использоваться данные о других факторах почвообразования (литологии, растительности, климате).

Для прогнозного почвенного моделирования используются методы статистики, геостатистики и машинного обучения [Heung et al., 2016], в частности:

- линейная регрессия [Malone et al., 2016; Song et al., 2016; Fissore et al., 2017; Sun et al., 2017; Pejović et al., 2018; Luo W. et al., 2019; Shen et al., 2019; Mallet et al., 2020; Riza et al., 2021];

- географически взвешенная регрессия [Song et al., 2016];

- мультиномиальная логистическая регрессия [Heung et al., 2017b; Piccini et al., 2019];

- кригинг [Ballabio et al., 2016; Sun et al., 2017; Nussbaum et al., 2018; Wadoux et al., 2018; Shen et al., 2019; Mallet et al., 2020];

- многоточечная статистика [Malone et al., 2016];

- дисперсионный анализ и анализ главных компонент [Piccini et al., 2019; Fan et al., 2020];

- нечеткая кластеризация [Viloria et al., 2016; Horáček et al., 2018];

- обобщенная аддитивная модель [Malone et al., 2017; Roudier et al., 2017; Nussbaum et al., 2018];

- нейронные сети [Viloria et al., 2016; Behrens et al., 2018b; Padarian et al., 2019; Wadoux, 2019; Wadoux et al., 2019];

- ансамблевое моделирование [Caubet et al., 2019; Heung et al., 2021];

- метод опорных векторов [Vermeulen, van Niekerk, 2017];

- метод взвешенных ближайших соседей [Vermeulen, van Niekerk, 2017; Guevara, Vargas, 2019];

• метод ядерной оценки плотности [Silva et al., 2016];

- алгоритмы случайного леса [Akpa et al., 2016; Chaney et al., 2016; Baldwin et al., 2017; Dharumarajan et al., 2017; Hengl et al., 2017a, 2017b; Stumpf et al., 2017; Vermeulen, van Niekerk, 2017; Behrens et al., 2018a, 2018b; Dornik et al., 2018; Nussbaum et al., 2018; 
Ramcharan et al., 2018; Behrens et al., 2019; Guevara et al., 2020];

- алгоритмы дерева решений [Akpa et al., 2016; Mulder et al., 2016a, 2016b; Silva et al., 2016; Sarmento et al., 2017; Vermeulen, van Niekerk, 2017; Nussbaum et al., 2018; Vincent et al., 2018]; 2018];

• алгоритмы повышения градиента [Hengl et al., 2017a, 2017b; Ramcharan et al.,

• моделирование структурными уравнениями [Angelini et al., 2016, 2017].

Применяются также подходы сегментации ЦМР, прежде всего - геоморфон (см. Геоморфология) [Drăguţ, Dornik, 2016; Libohova et al., 2016; Cunha et al., 2018; Dornik et al., 2018; Marques et al., 2018; Flynn et al., 2019; Atkinson et al., 2020].

Анализ почвенно-геоморфометрических работ, выполненных в 2016-2021 гг., показывает, что их отличительной чертой является переход от статистических и геостатистических подходов моделирования к геоинформационному машинному обучению. Необходимо, однако, подчеркнуть, что для получения адекватной прогнозной почвенной модели определяющую роль играет правильный подбор предикторов, а не математический аппарат.

Почвы и отложения на плотных глинистых или скальных породах испытывают воздействие не только поверхностных потоков воды и растворенных и взвешенных в ней веществ, но и внутрипочвенных потоков вдоль поверхности подстилающих пород. Для моделирования свойств таких почв необходимо анализировать микрорельеф как дневной поверхности, так и подстилающего горизонта. ЦМР этой поверхности может быть получена с помощью наземных проникающих радаров. Такой подход применялся, в частности, для определения мощности торфяных отложений и запасов связанного в них углерода [Carless et al., 2021].

Перспективным направлением стала концепция дальних связей в пространственном моделировании почвенного покрова [Behrens et al., 2019], в рамках которой рассматриваются межрегиональные связи между геосистемами. Эта концепция близка к моделированию связности потоков (см. Геоморфология). Использование в таких работах аппарата геоморфометрии естественно, так как нелокальные и комбинированные величины (водосборная площадь, топографический индекс и др.) могут служить метриками массопереноса на большие расстояния.

\section{Геология}

В геологии геоморфометрия применяется для анализа ЦМР как дневной поверхности, так и поверхностей стратиграфических горизонтов и геологических тел [Florinsky, 2016]. В последнем случае для получения ЦМР используется 3D сейсмическая съемка [Tesch et al., 2018]. Основными задачами являются анализ геологического строения и выявление зон активных разломов [Ren et al., 2018], а также слабовыраженных в рельефе структур (линеаментов [Yeomans et al., 2019], зон трещиноватости, складок и даек [Воoуsen et al., 2019]). Последняя задача решается благодаря высокой чувствительности локальных морфометрических величин к незначительным изменениям высоты [Florinsky, 2016].

Морфометрические модели применяются для уточнения геологических карт осадочных бассейнов труднодоступных территорий с лесным покровом [Valeriano, Rossetti, 2017], а также выявления и картографирования зон неотектонических деформаций для оценки сейсмического риска [Argyriou et al., 2016, 2017b]. Анализ разномасштабных данных - ЦMP AW3D30, архивных снимков Corona, материалов беспилотной аэрофотосъемки, а также морфометрических моделей - позволил уточнить условия развития грязевого вулканизма на Тамани и обнаружить неактивные грязевулканические 
образования, замаскированные сельскохозяйственной деятельностью [Skrypitsyna et al., 2020].

С помощью аппарата геоморфометрии успешно реализован классический подход поисковой геологии, методика Философова - выявление аномального рисунка тальвеговой сети, который может индицировать погребенные структуры - «ловушки» углеводородов [Ibanez et al., 2016].

\section{Гляциология}

Гляциологические процессы отображаются в рельефе поверхности ледника и зависят от характеристик рельефа его ложа. Поэтому аппарат геоморфометрии применяется для анализа как рельефа ледниковой поверхности, так и подледного рельефа [Morlighem et al., 2017].

ЦМР поверхности ледников могут быть созданы фотограмметрическим методом по архивным аэрофотоснимкам [Mertes et al., 2017; Mölg et al., 2017], спутниковым [Dehecq et al., 2016; Ragettli et al., 2016; Podgórski et al., 2019] и наземным снимкам [Piermattei et al., 2016; Watson et al., 2017], а также по данным лазерного сканирования [Bhardwaj et al., 2016а]. Однако развитие ледниковой геоморфометрии [Bhardwaj et al., 2016b; Gaffey, Bhardwaj, 2020] стало возможным благодаря прогрессу технологий беспилотной аэрофотосъемки, адаптированной к условиям высокогорья и заполярья [Bliakharskii et al., 2019; Ewertowski et al., 2019].

Взаимосвязанными задачами гляциологии, которые решаются с применением аппарата геоморфометрии, являются изучение динамики изменений ледника [Seier et al., 2017; Rossini et al., 2018; Chudley et al., 2019; Xue et al., 2021], определение горизонтальной и вертикальной скорости его движения [Kraaijenbrink et al., 2016a; Vincent et al., 2016; Gibson et al., 2017; Wigmore, Mark, 2017], оценка скорости таяния ледника [Ragettli et al., 2016; Thompson et al., 2016; Watson et al., 2017; Zhou Y. et al., 2017; Bash, Moorman, 2020] и, в частности, его языка [Brun et al., 2016, 2018; Mallalieu et al., 2017], определение баланса массы ледника [Brun et al., 2017], а также температуры его поверхности [Kraaijenbrink, et al., 2018]. Применение ЦМР сверхвысокого разрешения и точности, полученных по результатам беспилотной аэрофотосъемки, позволяет выявлять высокую пространственную неравномерность движения ледника [Wigmore, Mark, 2017], неравномерность его таяния [Buri et al., 2016] и даже незначительные изменения геометрии его поверхности, происходящие за короткие (от 24 ч) промежутки времени [Bash et al., 2018]. При решении этих задач обычно используется расчет разности разновременных ЦМР. Вместе с тем, более тонкий геоморфометрический анализ позволяет изучать зависимость динамики ледников от геометрии склонов [Li et al., 2017; Sam et al., 2018].

Карты морфометрических величин, рассчитанных по ЦМР ледниковой поверхности высокого разрешения, позволяет выявлять слабовыраженные, замаскированные снегом ледниковые трещины, которые представляют опасность для полярников и гляциологов [Florinsky, Bliakharskii, 2019a; Foroutan et al., 2019]. Оперативная беспилотная аэрофотосъемка и геоморфометрическое моделирование обеспечивают возможность исследования риска гляциологических катастроф [Fugazza et al., 2018], например, проседание участка ледника Долк (Восточная Антарктида) в январе 2017 г. [Florinsky, Bliakharskii, 2019b].

В отличие от других приложений геоморфометрии, ЦМР и морфометрические модели редко используются при машинном обучении для решения гляциологических задач. В частности, этот подход применялся для выявления и классификации ледников, покрытых плотной поверхностной мореной, которые на снимках сливаются с прилегающими долинами [Alifu et al., 2016, 2020], а также для выявления ледяных утесов 
и запруд на ледниках такого типа [Kraaijenbrink et al., 2016b].

Очевидно, что задачи, решаемые ледниковой геоморфометрией, частично пересекаются с работами по изучению перигляциальных процессов и форм рельефа (см. Геоморфология). К этому же направлению геоморфометрии можно отнести популярную задачу по определению толщины снежного покрова [Bühler et al., 2016, 2017; De Michele et al., 2016; Cimoli et al., 2017; Avanzi et al., 2018], которая решается с помощью анализа ЦМР, полученных в разные сезоны (обычно осенью и весной). Математическая модель Snow_Blow, использующая в качестве одного из входных параметров ЦМР, позволяет рассчитывать накопление и перераспределение снега под действием ветра [Mills et al., 2019].

\section{Спелеология}

Пещеры обладают рядом свойств, затрудняющих моделирование их рельефа: объемная замкнутость пространства, сложность форм рельефа, наличие спелеоскульптур и др. Для создания ЦМР пещер используют технологии наземного лазерного сканирования [Idrees, Pradhan, 2016].

Геоморфометрическое моделирование пещер применяется для выявления подземной гидрографической сети, фреатических каналов, минеральных корок на стенах и др. [Gallay et al., 2016; Fabbri et al., 2017; De Waele et al., 2018]. Однако теория геоморфометрии разработана в приближении топографической поверхности, одним из ограничений которой является однозначность функции [Shary et al., 2002; Florinsky, 2016]: одной плановой координате соответствует одно значение высоты. В случае пещеры функция многозначна: одной плановой координате соответствует не менее двух значений высоты. Поэтому не все морфометрические величины могут корректно использоваться для анализа рельефа пещер. Для этих целей без ограничений подходят атрибуты форм [Gallay et al., 2016]. Атрибуты потоков могут применяться только для анализа рельефа пола пещеры и нижней части ее стен.

\section{Геоботаника и лесоведение}

Рельеф оказывает как прямое, так и косвенное влияние на растительный покров в целом и отдельные растительные сообщества, так как контролирует гидрологический и тепловой режим склонов, а также свойства почвы. Существенно влияние рельефа на показатели плодородия почвы, от которого, в свою очередь, зависит функционирование лесных экосистем [Scholten et al., 2017]. В геоботанике геоморфометрия применяется, в основном, при прогнозном картографировании свойств растительного покрова на основе статистических и обучающих моделей, в которых предикторами являются рассчитанные по ЦМР морфометрические модели, а также спектральные и текстурные характеристики спутниковых изображений [Franklin, 1995; Wilson, 2018]. Для моделирования широко применяется алгоритм случайного леса.

Морфометрические величины являются хорошими предикторами характеристик структуры тропического дождевого леса (базальная площадь деревьев) даже на равнинных территориях [Bispo et al., 2016]. Морфометрические модели совместно со спектральными и текстурными характеристиками спутниковых снимков применяются для прогноза объема древостоя на плантациях эвкалипта [Dos Reis et al., 2019], картографирования доминирующих растительных сообществ смешанных лесов [Liu et al., 2018] и саванны [Hurskainen et al., 2019]. Георазнообразие как функция морфометрических величин является контролирующим фактором богатства видового разнообразия сосудистых растений [Bailey et al., 2017, 2018]. Построена модель надземной биомассы бореальной зоны Норвегии, для чего использовались модель высоты лесного полога 
(разность ArcticDEM и ЦМР Норвегии), мозаика Sentinel-2 и данные лесного кадастра [Puliti et al., 2020]. Анализ связи распределения кустарников аридного редколесья с зонами трещиноватости, выделенными по картам отмывки рельефа, позволяет выявлять зависящие от подземных вод экосистемы аридных территорий [Guirado et al., 2018].

Отметим, что использование морфометрических и других предикторов для объяснения и прогноза пространственной вариабельности характеристик древесного сообщества дает хорошие результаты только для сообщества в целом и для распространенных видов; для редких же видов прогноз затруднен [Bispo et al., 2017]. При этом прогнозные карты степных травянистых сообществ могут быть получены на основе анализа лишь морфометрических моделей [Alexander et al., 2016].

Сравнение трех методов статистического моделирования (усиленной регрессии дерева решений, обобщенной аддитивной модели и случайного леса), показало, что при прогнозном картографировании пожарной опасности лесов необходимо использовать морфометрические величины, контролирующие пространственное распределение влаги в ландшафте [Pourtaghi et al., 2016].

\section{Зоогеография}

Известны единичные примеры использования геоморфометрии в зоогеографии для изучения влияния рельефа суши на пространственное распределение или поведение животных. Редкость таких работ связана со сложностью получения статистически репрезентативных зоологических выборок, мобильностью объектов исследования и высоким уровнем адаптивности животных к условиям окружающей среды: чем выше организация вида, тем меньше на его представителей влияет рельеф (за очевидным исключением высотной зональности).

Так, были изучены связи между характеристиками рельефа и выживаемостью в зимний сезон популяций пятнистокрылой дрозофилы на северо-западном побережье Северной Америки [Thistlewood et al., 2018], а также между характеристиками рельефа и местообитаниями южноамериканских плодоядных копытных, грызунов и птиц [Nagy-Reis et al., 2017a], а также мелких кошек [Nagy-Reis et al., 2017b]. Если для дрозофилы была найдена некоторая зависимость от высоты над уровнем моря и топографического индекса (мера степени увлажненности почвы), то в случае с плодоядными и кошачьими зависимость от рельефа оказалась пренебрежимо мала.

\section{Океанология}

Развитию морской геоморфометрии [Lecours et al., 2016а] способствовало начало работ по международному проекту Nippon Foundation-GEBCO Seabed 2030 по созданию глобальной общедоступной батиметрической ЦМР высокого разрешения и точности [Wölfl et al., 2019], а также развитие технологии автономных подводных аппаратов [González-García et al., 2020]. Анализ батиметрических ЦМР востребован в морских геоморфологических и биологических исследованиях.

Разработаны методики классификации форм подводного рельефа [Dekavalla, Argialas, 2017] и иерархического картографирования рельефа континентальных окраин [Sowers et al., 2020], в основе которых лежит метод сегментации ЦМР геоморфон (см. Геоморфология). Применение метода усиленной регрессии дерева решений (предикторы локальные морфометрические величины) позволяет строить прогнозные карты распределения донных осадков с подразделением на иловую, песчаную и гравийную фракции [Misiuk et al., 2018]. Другой подход классификации рельефа, основанный на индексе относительного превышения, позволил составить прогнозные карты бентических местообитаний авандельты Амазонки [Lavagnino et al., 2020] и средиземноморских 
водорослевых рифов [Marchese et al., 2020]. Использование моделей локальных величин и индексов шероховатости позволяет прогнозировать распределение колоний холодноводных кораллов [Tong et al., 2016; Bargain et al., 2017].

Для Северного Ледовитого океана показана роль рельефа дна в контроле глубинных течений (там они имеют решающее значение для распределения тепла), а также свойств морской воды: даже незначительные элементы подводного рельефа оказывают влияние на водообмен между соседними бассейнами с различной плотностью и соленостью [Björk et al., 2018].

Геоморфометрический анализ позволил установить причины скоплений китовых акул в некоторых прибрежных районах [Copping et al., 2018]. Эти участки значительно мельче, чем соседние, но при этом они располагаются гораздо ближе к глубоководным зонам, а склоны значительно круче, чем в других местах. Такие особенности подводного рельефа вызывают апвеллинг (подъем обогащенных питательными веществами холодных вод), развитие планктона и, потому, привлекают виды с фильтрационным типом питания, к которым относятся и китовые акулы.

Геоморфометрическое моделирование данных разновременных батиметрических съемок пролива Лидо, соединяющего Адриатическое море с Венецианской лагуной, позволил изучить изменения рельефа морского дна, вызванные строительством и эксплуатацией гидротехнических сооружений для защиты Венеции от наводнений, в частности - эволюцию подводных дюн в канале пролива и промоин у оконечностей волноломов [Toso et al., 2019].

\section{Планетология}

В планетологии аппарат геоморфометрии применяется для решения следующих разномасштабных задач: 1) Выявление геологических структур и изучение геологического строения. 2) Анализ шероховатости рельефа как косвенного признака генезиса и относительного возраста территории и подстилающих пород [Fa et al., 2016]. 3) Анализ морфометрии кратеров, которая дает информацию о возрасте, реологических свойствах пород и скорости эрозии [Robbins et al., 2017; Wang et al., 2020; Villaça et al., 2021]. 4) Анализ строения палеодельт и конусов выноса [Goudge et al., 2017], овражной сети [Conway et al., 2016], миграции дюн [Cardinale et al., 2016; Runyon et al., 2017; Vaz et al., 2017] и эрозионных паттернов [Brusnikin et al., 2016] при изучении флювиальных, эоловых и склоновых процессов на Марсе. 5) Анализ и картографирование мест прошлых и планируемых посадок космических аппаратов [Karachevtseva et al., 2017; Bhardwaj et al., 2019a]. 6) Геоморфологическое картографирование [Wang et al., 2017]. При этом используются известные общедоступные глобальные ЦМР небесных тел и ЦМР высокого разрешения, которые составляются фотограмметрическим методом.

Интригующей работой последних лет было изучение углеводородного озера Онтарио Лакус на спутнике Сатурна Титане [Dhingra et al., 2018]. Было неясно, по какой причине в южном полушарии Титана существует только одно крупное озеро, а соседние более глубокие депрессии остаются сухими. Расчет модели водосборной площади по ЦМР Титана показал, что водосбор Онтарио Лакус составляет 5,5\% площади поверхности Титана, причем отношение площадей водосбор/озеро равно 83. После углеводородных дождей этот водосбор может обеспечить поверхностных сток такого объема метана и этана, которого вполне достаточно, чтобы заполнить Онтарио Лакус меньше, чем за полгода Титана (14,5 земных лет). Сухие депрессии могли быть сформированы карстоподобными процессами растворения пород [Hayes et al., 2017]. 


\section{Оползневедение}

Аппарат геоморфометрии давно и систематически применяется для выявления и прогнозного картографирования оползней и оползневой опасности [Zhong et al., 2020], a также для инвентаризации и классификации оползней [Niculiţă, 2016; Migoń et al., 2017; Pánek et al., 2019], так как при прочих равных условиях (характеристики грунтов и горных пород, гидрологический режим, количество осадков, антропогенная нагрузка), решающую роль в формировании оползней, как правило, играет геометрия склонов. Даже если основным фактором развития оползней являются свойства пород (напр., моноклинальных флишевых пластов), анализ ЦМР остается необходимым элементом изучения таких объектов [Břežný et al., 2017].

Отличительной чертой работ этого направления в 2016-2021 гг. стало широкое использование методов машинного обучения, в которых одной из групп предикторов являются цифровые морфометрические модели (крутизна и экспозиция склона, горизонтальная и вертикальная кривизна, топографический индекс и др.), рассчитываемые по ЦМР преимущественно лидарного происхождения. Помимо них используется информация о других факторах формирования оползней (литологии, гидрологии, осадках, растительном покрове).

Для прогнозного картографирования оползневой опасности используются логистическая регрессия [Chen et al., 2017; Chang et al., 2019; Tanyas et al., 2019; Jacobs et al., 2020], нейронные сети [Ghorbanzadeh et al., 2019], алгоритмы случайного леса [Chen et al., 2017; Chang et al., 2019; Ghorbanzadeh et al., 2019; Sîrbu et al., 2019; Maxwell et al., 2020] и дерева решений [Chen et al., 2017], методы опорных векторов [Chang et al., 2019; Ghorbanzadeh et al., 2019; Hu Q. et al., 2020], нечеткой логики [Feizizadeh et al., 2017; Hong et al., 2017] и анализа иерархий [Nicu, Asăndulesei, 2018; Nachappa et al., 2020], объектноориентированный анализ изображений [Feizizadeh et al., 2017] и его разновидность «геон» [Nachappa et al., 2020]. Также применяются метод горячих точек [Shi W. et al., 2018] и метод сегментации ЦМР геоморфон (см. Геоморфология) [Luo, Liu, 2018].

В тех случаях, когда лидарная съемка участка проводилась до и после смещения масс горных пород и имеется серия разновременных ЦМР, возможен детальный анализ произошедших изменений рельефа и распределения перемещенных масс по склону [Gatter et al., 2018]. Совместный анализ карт отмывки рельефа, по которым выделяются древние неактивные оползни, и данных об археологических памятниках, расположенных на этих оползнях, позволяет определять хронологию активности оползней и устанавливать этапы их развития [Niculiţă et al., 2019].

Близкой к задаче выявления оползней является прогноз лавинной опасности: геометрия склонов во многом контролирует накопление снежных масс, а сход лавины можно рассматривать как гравитационный склоновый процесс. В этой связи методы выявления лавиноопасных участков с использованием морфометрических моделей сходны с рассмотренными выше подходами к выявлению и прогнозному картографированию оползней [Veitinger et al., 2016; Bühler et al., 2018; Rahmati et al., 2019].

\section{Дистанционное зондирование}

Причины использования ЦМР и морфометрических моделей при анализе ДДЗ очевидны: 1) рельеф влияет на формирование дистанционных изображений; 2) геометрия земной поверхности определяет сложность распределения яркостных и спектральных характеристик ландшафта, что повышает вероятность ошибок дешифрирования; 3) для удовлетворительного дешифрирования дистанционных изображений природных объектов не всегда достаточно только ДД3; 4) учет известных связей между характеристиками 
рельефа и других компонентов геосистем позволяет повышать качество тематического дешифрирования [Florinsky, 1998].

ЦМР и морфометрические модели много лет рутинно используется в технологиях обработки ДДЗ для коррекции топографического эффекта и дисторсии снимков, при 3D моделировании ландшафта (драпировка ЦМР дистанционными изображениями), а также при автоматизированном дешифрировании ДДЗ (прежде всего - в геоботанике, лесоведении, и в других приложениях, рассмотренных в этом обзоре) [Franklin, 2020].

\section{Урбанистика}

Использование аппарата геоморфометрии в урбанистике сопряжено со сложностями. Естественный рельеф в городе изменен и дополнен искусственными элементами с различным покрытием [Łajczak et al., 2021]. Роль «рельефа» играют строения, дорожная сеть и другие объекты. Все это оказывает влияние на тепловой и гидрологический режим территории. Поэтому в качестве исходных данных должны использоваться не ЦМР, а цифровые модели поверхности (ЦМП), включающей в себя огибающую поверхность построек. Хотя получение ЦМП и 3D моделей города стало рутинной процедурой [Liang et al., 2017], их геоморфометрический анализ нетривиален хотя бы из-за насыщенности этих моделей разрывами функции высоты (стены домов), что неизбежно приводит к появлению артефактов из-за явления Гиббса [Florinsky, 2016].

Основными направлениями городской геоморфометрии являются анализ рельефа при размещении новых строений и дорог с целью минимизации воздействия на ландшафт [Loro et al., 2017], моделирование поверхностных водных потоков [Leitão et al., 2016; Qin et al., 2018] и наводнений [Huang et al., 2019; Muthusamy et al., 2021], ветрового [Shi et al., 2017; García-Romero et al., 2019] и температурного [Shi Y. et al., 2018; Hofierka et al., 2020; Chang et al., 2021] режима, а также их влияния на показатели комфорта проживания в городе. Начаты работы по адаптации к городским условиям методов прогнозного почвенного картографирования [Mohamed, 2020]. Развитию городской геоморфометрии способствует модное направление урбинистики - т.н. «концепция умного города».

В рамках оценки эстетических и рекреационных свойств городского ландшафта предложен метод картографирования реабилитационного потенциала пейзажей парков [Tabrizian et al., 2020]. По текстурированной ЦМП высокого разрешения проводится анализ полей обзора, а также рассчитываются морфометрические показатели композиции пейзажей. Прогнозная карта строится на основе статистической модели, рассчитанной по результатам сравнения показателей для выборки пейзажей и субъективных оценок их реабилитационного потенциала, полученных путем опроса с использованием технологии виртуальной реальности.

\section{Археология}

В археологии аппарат геоморфометрии применятся, прежде всего, для поиска следов деятельности человека (погребенных под наносами руин поселений и фортификационных сооружений, заброшенных дорог и т.п.), которые, как правило, слабо выражены в микрорельефе [Luo L. et al., 2019; Gillings et al., 2020]. Решение этой задачи возможно благодаря чувствительности частных производных высоты, которые используются для расчета по ЦМР локальных морфометрических величин. Даже обычная отмывка рельефа [Horn, 1981] позволяет выявлять руины поселений [Canuto et al., 2018; Masini et al., 2018] и храмов [Evans, 2016], заброшенные горные выработки [Gallwey et al., 2019], погребальные курганы [Freeland et al., 2016; Wang et al., 2017], следы боевых действий (траншеи, взрывные воронки, блиндажи и т.п.) [Gheyle et al., 2018] и пр. 
При проведении археологических работ на суше обычно используются ЦМР, полученные по данным воздушной лидарной съемки, что дает возможность изучать территории с плотным лесным покровом [Evans, 2016; Freeland et al., 2016; Wang et al., 2017; Canuto et al., 2018; Guyot et al., 2018; Inomata et al., 2018; Masini et al., 2018; Gallwey et al., 2019; Luo L. et al., 2019]. Для анализа рассчитанных по ЦМР морфометрических моделей применяют не только традиционные методы обработки изображений и распознавания образов [Wang et al., 2017; Masini et al., 2018], но все чаще - методы машинного обучения [Guyot et al., 2018]. Так, для автоматического выявления погребальных курганов культур бронзового века был применен алгоритм случайного леса [Niculiţă, 2020], а для картографирования пробных шурфов и неглубоких выработок заброшенных оловянных и медных рудников - свёрточная нейронная сеть, ранее обученная выявлять лунные кратеры [Gallwey et al., 2019].

Вместе с тем, для археологических разведок территорий, находящихся под сильным антропогенным давлением, могут быть полезны ЦМР, полученные фотограмметрическим путем по архивным аэрофотоснимкам [Papworth et al., 2016; Sevara et al., 2018]. Для документирования ведущихся раскопок и их доразведки проще работать с ЦМР по данным беспилотной аэрофотосъемки [Waagen, 2019].

При планировании подводных археологических работ оптимально использовать батиметрические ЦМР высокого разрешения, полученные по данным многолучевого эхолотирования [Menna et al., 2018]. Для документирования подводных раскопок и 3D визуализации изучаемых объектов (затопленных строений и затонувших кораблей) могут применяться ЦМР, полученные фотограмметрическим методом по материалам подводной фотосъемки [Yamafune et al., 2017; Pacheco-Ruiz et al., 2018].

Моделирование и визуализация рельефа археологических памятников и прилегающих территорий помогает реконструкции социальных и хозяйственных отношений в древних обществах [Evans, 2016; Chase, Chase, 2017; O’Reilly et al., 2017; Richards-Rissetto, 2017; Inomata et al., 2018; Garrison et al., 2019], палеоусловий среды обитания [Popa, Knitter, 2016; Tapete et al., 2017], а также восприятия палеоландшафта населением [Knitter et al., 2019]. Частной задачей является анализ влияния рельефа на выбор мест поселения в древности. Так, для минойской цивилизации (Крит) показано, что связь между местами поселений и рельефом в раннеминойский период отсутствовала, но возникла в поздние периоды, когда уровень организации общества повысился [Argyriou et al., 2017a].

Методы моделирования и 3D визуализации рельефа применяются также в работах для документирования, музеефикации и анализа геометрии и текстуры археологических артефактов (напр., керамики [Garstki, 2017] и петроглифов [Horn et al., 2021]). Это направление смыкается с работами, в которых аппарат геоморфометрии используется для метрологического и дефектоскопического контроля микро- и нанорельефа поверхностей различных материалов и деталей [Pike, 2001]. Однако эти приложения геоморфометрии лежат уже за пределами нашего обзора.

\section{ЗАКЛЮЧЕНИЕ}

Последние 5,5 лет ознаменовались развитием технологий беспилотной аэрофотосъемки и батиметрической съемки, а также методов обработки ДД3, что привело к распространению новых, более качественных ЦМР. Эти факторы, а также адаптация методов машинного обучения привели к стремительному росту количества и качества работ с использованием аппарата геоморфометрии для решения разномасштабных задач многих наук.

Лидирующие позиции в геоморфометрии занимают США, Канада, Австралия, Италия, Словакия, Германия, Нидерланды, Румыния, Бразилия и (количественно) Китай. 
Из 485 работ, опубликованных в 2016-2021 гг. в ведущих международных изданиях, в России или с участием российских ученых выполнены 27 работ (6\%), причем 16 из них ( 2/3) - представителями Пущинской школы геоморфометрии в ИМПБ РАН - филиале ИПМ им. М.В. Келдыша РАН [Florinsky, 2016, 2017a, 2017b, 2018; Florinsky, Pankratov, 2016; Florinsky et al., 2018a, 2018b, 2019; Bliakharskii et al., 2019; Florinsky, Bliakharskii, 2019a, 2019b; Florinsky, Filippov, 2019, 2021; Skrypitsyna et al., 2020], ИФХиБПП РАН [Shary et al., 2017] и ИФПБ РАН [Mitusov et al., 2017] (часть - в соавторстве с сотрудниками Кафедры фотограмметрии МИИГАиК [Florinsky et al., 2018a; Bliakharskii et al., 2019; Florinsky et al., 2018b, 2019; Skrypitsyna et al., 2020] и Кафедры картографии и геоинформатики СПбГУ [Florinsky et al., 2018a; Bliakharskii et al., 2019; Florinsky, Bliakharskii, 2019a, 2019b]). Точки роста есть на Географическом факультете МГУ [Blomdin et al., 2018; Kizyakov et al., 2017, 2018; Samsonov et al., 2019], в Комплексной лаборатории исследования внеземных территорий МИИГАиК [Brusnikin et al., 2016; Karachevtseva et al., 2017; Wang et al., 2020], Лаборатории геоморфологии и тектоники дна океанов ГИН РАН [Jakobsson et al., 2020; Zwolak et al., 2020], ИГ РАН [Medvedev et al., 2020] и ИО РАН [Danchenkov et al., 2019].

Теория и методы геоморфометрии достигли уровня, который соответствует ее статусу самостоятельного междисциплинарного направления. Однако еще требуется разработка строгой математической теории структурных линий рельефа, а также переход к строгим алгоритмам расчета нелокальных морфометрических величин, которые уже существуют, но не реализованы в распространенном программном обеспечении.

Дальнейшее развитие геоморфометрии во многом связано с появлением новых ЦМР высокого разрешения и точности. В геоморфологии, почвоведении, гидрологии и лесоведении уже сложно себе представить работы по пространственному моделированию, которые проводились бы без применения методов геоморфометрии. В этом отношении наибольшие перспективы в ближайшие 5 лет имеют морская, городская и подземная геоморфометрия.

\section{БЛАГОДАРНОСТИ}

Исследование выполнено при финансовой поддержке РФФИ, проект № 20-1750036.

\section{ACKNOWLEDGMENTS}

The study was funded by the Russian Foundation for Basic Research, project \# 20-1750036.

\section{СПИСОК ЛИТЕРАТУРЫ / REFERENCES}

1. Abdel-Fattah M., Saber M., Kantoush S.A., Khalil M.F., Sumi T., Sefelnasr A.M. A hydrological and geomorphometric approach to understanding the generation of wadi flash floods. Water, 2017. V. 9. No 7. \# 553. DOI: 10.3390/w9070553.

2. Abrams M., Crippen R., Fujisada H. ASTER Global Digital Elevation Model (GDEM) and ASTER Global Water Body Dataset (ASTWBD). Remote Sensing, 2020. V. 12. No 7. \# 1156. DOI: 10.3390/rs12071156.

3. Agrafiotis P., Skarlatos D., Georgopoulos A., Karantzalos K. DepthLearn: learning to correct the refraction on point clouds derived from aerial imagery for accurate dense shallow water bathymetry based on SVMs-fusion with LiDAR point clouds. Remote Sensing, 2019. V. 11. No 19. \# 2225. DOI: 10.3390/rs11192225. 
4. Akpa S.I.C., Odeh I.O.A., Bishop T.F.A., Hartemink A.E., Amapu I.Y. Total soil organic carbon and carbon sequestration potential in Nigeria. Geoderma, 2016. V. 271. P. 202215. DOI: 10.1016/j.geoderma.2016.02.021.

5. Alexander C., Deák B., Heilmeier H. Micro-topography driven vegetation patterns in open mosaic landscapes. Ecological Indicators, 2016. V. 60. P. 906-920. DOI: 10.1016/j.ecolind. 2015.08.030.

6. Alifu H., Johnson B.A., Tateishi R. Delineation of debris-covered glaciers based on a combination of geomorphometric parameters and a TIR/NIR/SWIR band ratio. IEEE Journal of Selected Topics in Applied Earth Observations and Remote Sensing, 2016. V. 9. No 2. P. 781-792. DOI: 10.1109/JSTARS.2015.2500906.

7. Alifu H., Vuillaume J.-F., Johnson B.A., Hirabayashi Y. Machine-learning classification of debris-covered glaciers using a combination of Sentinel-1/-2 (SAR/optical), Landsat 8 (thermal) and digital elevation data. Geomorphology, 2020. V. 369. \# 107365. DOI: 10.1016/j. geomorph.2020.107365.

8. Alonso-Sarría F., Gomariz-Castillo F., Cánovas-García F. A new approach to the openness index for landform characterisation. Computers and Geosciences, 2018. V. 119. P. 68-79. DOI: 10.1016/j.cageo.2018.06.010.

9. Alvarez L., Moreno H., Segales A., Pham T., Pillar-Little E., Chilson P. Merging unmanned aerial systems (UAS) imagery and echo soundings with an adaptive sampling technique for bathymetric surveys. Remote Sensing, 2018. V. 10. No 9. \# 1362. DOI: 10.3390/rs10091362.

10. Alvioli M., Guzzetti F., Marchesini I. Parameter-free delineation of slope units and terrain subdivision of Italy. Geomorphology, 2020. V. 358. \# 107124. DOI: 10.1016/j.geomorph.2020.107124.

11. Amatulli G., Domisch S., Tuanmu M.N., Parmentier B., Ranipeta A., Malczyk J., Jetz W. A suite of global, cross-scale topographic variables for environmental and biodiversity modeling. Scientific Data, 2018. V. 5. \# 180040. DOI: 10.1038/sdata.2018.40.

12. Amatulli G., McInerney D., Sethi T., Strobl P., Domisch S. Geomorpho90m, empirical evaluation and accuracy assessment of global high-resolution geomorphometric layers. Scientific Data, 2020. V. 7. \# 162. DOI: 10.1038/s41597-020-0479-6.

13. Anderson K., Westoby M.J., James M.R. Low-budget topographic surveying comes of age: structure from motion photogrammetry in geography and the geosciences. Progress in Physical Geography, 2019. V. 43. No 2. P. 163-173. DOI: 10.1177/0309133319837454.

14. Andreani L., Gloaguen R. Geomorphic analysis of transient landscapes in the Sierra Madre de Chiapas and Maya Mountains (northern Central America): implications for the North American-Caribbean-Cocos plate boundary. Earth Surface Dynamics, 2016. V. 4. No

P. 71-102. DOI: 10.5194/esurf-4-71-2016.

15. Angelini M.E., Heuvelink G.B.M., Kempen B., Morrás H.J.M. Mapping the soils of an Argentine Pampas region using structural equation modelling. Geoderma, 2016. V. 281. P. 102-118. DOI: 10.1016/j.geoderma.2016.06.031.

16. Angelini M.E., Heuvelink G.B.M., Kempen B. Multivariate mapping of soil with structural equation modelling. European Journal of Soil Science, 2017. V. 68. No 5. P. 575-591. DOI: 10.1111 ejss.12446.

17. Argyriou A.V., Sarris A., Teeuw R.M. Using geoinformatics and geomorphometrics to quantify the geodiversity of Crete, Greece. International Journal of Applied Earth Observation and Geoinformation, 2016. V. 51. P. 47-59. DOI: 10.1016/j.jag.2016. 04.006 . 
18. Argyriou A.V., Teeuw R.M., Rust D., Sarris A. GIS multi-criteria decision analysis for assessment and mapping of neotectonic landscape deformation: a case study from Crete. Geomorphology, 2016. V. 253. P. 262-274. DOI: 10.1016/j.geomorph.2015.10.018.

19. Argyriou A.V., Teeuw R.M., Sarris A. GIS-based landform classification of Bronze Age archaeological sites on Crete Island. PLoS ONE, 2017a. V. 12. No 2. \# e0170727. DOI: 10.1371/ journal.pone.0170727.

20. Argyriou A.V., Teeuw R.M., Soupios P., Sarris A. Neotectonic control on drainage systems: GIS-based geomorphometric and morphotectonic assessment for Crete, Greece. Journal of Structural Geology, 2017b. V. 104. P. 93-111. DOI: 10.1016/j.jsg. 2017.10.002.

21. Arundel S.T., Sinha G. Validating the use of object-based image analysis to map commonly recognized landform features in the United States. Cartography and Geographic Information Science, 2019. V. 46. No 5. P. 441-455. DOI: 10.1080/ 15230406. 2018.1526652.

22. Arundel S.T., Thiem P.T., Constance E.W. Automated extraction of hydrographically corrected contours for the conterminous United States: the US Geological Survey US Topo product. Cartography and Geographic Information Science, 2018. V. 45. No 1. P. 31-55. DOI: 10.1080/17538947.2020.1754936.

23. Atkinson J., de Clercq W., Rozanov A. Multi-resolution soil-landscape characterisation in KwaZulu Natal: using geomorphons to classify local soilscapes for improved digital geomorphological modelling. Geoderma Regional, 2020. V. 22. \# e00291. DOI: 10.1016/j.ge odrs.2020.e00291.

24. Avanzi F., Bianchi A., Cina A., de Michele C., Maschio P., Pagliari D., Passoni D., Pinto L., Piras M., Rossi L. Centimetric accuracy in snow depth using unmanned aerial system photogrammetry and a MultiStation. Remote Sensing, 2018. V. 10. No 5. \# 765. DOI: 10.3390/rs10050765.

25. Bailey J.J., Boyd D.S., Hjort J., Lavers C.P., Field R. Modelling native and alien vascular plant species richness: at which scales is geodiversity most relevant? Global Ecology and Biogeography, 2017. V. 26. No 7. P. 763-776. DOI: 10.1111/geb.12574.

26. Bailey J.J., Boyd D.S., Field R. Models of upland species' distributions are improved by accounting for geodiversity. Landscape Ecology, 2018. V. 33. No 12. P. 2071-2087. DOI: 10.1007/s10980-018-0723-z.

27. Bakker M., Lane S.N. Archival photogrammetric analysis of river-floodplain systems using Structure from Motion (SfM) methods. Earth Surface Processes and Landforms, 2017.

V. 42. No 8. P. 1274-1286. DOI: 10.1002/esp.4085.

28. Baldwin D., Naithani K.J., Lin H. Combined soil-terrain stratification for characterizing catchment-scale soil moisture variation. Geoderma, 2017. V. 285. P. 260-269. DOI: 10.1016/j.geoderma.2016.09.031.

29. Ballabio C., Panagos P., Monatanarella L. Mapping topsoil physical properties at European scale using the LUCAS database. Geoderma, 2016. V. 261. P. 110-123. DOI: 10.1016/j.geoderma.2015.07.006.

30. Bargain A., Marchese F., Savini A., Taviani M., Fabri M.-C. Santa Maria di Leuca Province (Mediterranean Sea): identification of suitable mounds for cold-water coral settlement using geomorphometric proxies and maxent methods. Frontiers in Marine Science, 2017. V. 4. \# 338. DOI: fmars.2017.00338.

31. Parallel Priority-Flood depression filling for trillion cell digital elevation models on desktops or clusters. Computers and Geosciences, 2016. V. 96. P. 56-68. DOI: 10.1016/j. cageo.2016.07.001. 
32. Bash E.A., Moorman B.J. Surface melt and the importance of water flow - an analysis based on high-resolution unmanned aerial vehicle (UAV) data for an Arctic glacier. Cryosphere, 2020. V. 14. No 2. P. 549-563. DOI: 10.5194/tc-14-549-2020.

33. Bash E.A., Moorman B.J., Gunther A. Detecting short-term surface melt on an Arctic glacier using UAV surveys. Remote Sensing, 2018. V. 10. No 10. \# 1547. DOI: 10.3390/rs 10101547.

34. Behrens T., MacMillan R.A., Rossel R.A.V., Schmidt K., Lee J. Teleconnections in spatial modelling. Geoderma, 2019. V. 354. \# 113854. DOI: 10.1016/j.geoderma.2019.07.012.

35. Behrens T., Schmidt K., Macmillan R.A., Viscarra Rossel R.A. Multiscale contextual spatial modelling with the Gaussian scale space. Geoderma, 2018a. V. 310. P. 128-137. DOI: 10.1016/j.geoderma.2017.09.015.

36. Behrens T., Schmidt K., MacMillan R.A., Viscarra Rossel R.A. Multi-scale digital soil mapping with deep learning. Scientific Reports, 2018b. V. 8. \# 15244. DOI: 10.1038/ s41598-018-33516-6.

37. Belgiu M., Drăguţ L. Random forest in remote sensing: a review of applications and future directions. ISPRS Journal of Photogrammetry and Remote Sensing, 2016. V. 114. P. 24-31. DOI: 10.1016/j.isprsjprs.2016.01.011.

38. Bernhardson M., Alexanderson H. Early Holocene dune field development in Dalarna, central Sweden: a geomorphological and geophysical case study. Earth Surface Processes and Landforms, 2017. V. 42. No 12. P. 1847-1859. DOI: 10.1002/esp.4141.

39. Bergonse R., Reis E. Controlling factors of the size and location of large gully systems: a regression-based exploration using reconstructed pre-erosion topography. Catena, 2016. V. 147. P. 621-631. DOI: 10.1016/j.catena.2016.08.014.

40. Beven K.J., Kirkby M.J., Freer J.E., Lamb R. A history of TOPMODEL. Hydrology and Earth System Sciences, 2021. V. 25. No 2. P. 527-549. DOI: 10.5194/hess-25-527-2021.

41. Bhardwaj A., Sam L., Bhardwaj A., Martin-Torres F.J. LiDAR remote sensing of the cryosphere: present applications and future prospects. Remote Sensing of Environment, 2016a. V. 177. P. 125-143. DOI: 10.1016/j.rse.2016.02.031.

42. Bhardwaj A., Sam L., Akanksha, Martín-Torres F.J., Kumar R. UAVs as remote sensing platform in glaciology: present applications and future prospects. Remote Sensing of Environment, 2016b. V. 175. P. 196-204. DOI: 10.1016/j.rse.2015.12.029.

43. Bhardwaj A., Sam L., Martin-Torres F.J., Zorzano M.-P. Distribution and morphologies of transverse aeolian ridges in ExoMars 2020 Rover landing site. Remote Sensing, 2019a. V. 11. No 8. \# 912. DOI: 10.3390/rs11080912.

44. Bhardwaj A., Sam L., Martín-Torres F.J., Zorzano M.-P., Ramírez Luque J.A. UAV imaging of a Martian brine analogue environment in a fluvio-aeolian setting. Remote Sensing, 2019b. V. 11. No 18. \# 2104. DOI: 10.3390/rs11182104.

45. Bigelow P., Benda L., Pearce S. Delineating incised stream sediment sources within a San Francisco Bay tributary basin. Earth Surface Dynamics, 2016. V. 4. No 2. P. 531547. DOI: 10.5194/esurf-4-531-2016.

46. Bispo P.d.C., dos Santos J.R., Valeriano M.d.M., Graça P.M.L.d.A., Balzter H., França H., Bispo P.d.C. Predictive models of primary tropical forest structure from geomorphometric variables based on SRTM in the Tapajós Region, Brazilian Amazon. PLoS ONE, 2016. V. 11. No 6. \# e0152009. DOI: 10.1371/journal.pone.0152009.

47. Bispo P.d.C., Balzter H., Malhi Y., Slik J.W.F., dos Santos J.R., Rennó C.D., EspíritoSanto F.D., Aragão L.E.O.C., Ximenes A.C., Bispo P.d.C. Drivers of metacommunity structure diverge for common and rare Amazonian tree species. PLoS ONE, 2017. V. 12. No 11. \# e0188300. DOI: 10.1371/journal.pone.0188300.

48. Björk G., Jakobsson M., Assmann K., Andersson L.G., Nilsson J., Stranne C., Mayer L. Bathymetry and oceanic flow structure at two deep passages crossing the Lomonosov 
Ridge. Ocean Science, 2018. V. 14. No 1. P. 1-13. DOI: 10.5194/os-14-1-2018.

49. Bladin K., Axelsson E., Broberg E., Emmart C., Ljung P., Bock A., Ynnerman A. Globe browsing: contextualized spatio-temporal planetary surface visualization. IEEE Transactions on Visualization and Computer Graphics, 2018. V. 24. No 1. P. 802-811. DOI: 10.1109/ TVCG.2017.2743958.

50. Bliakharskii D.P., Florinsky I.V., Skrypitsyna T.N. Modelling glacier topography in Antarctica using unmanned aerial survey: assessment of opportunities. International Journal of Remote Sensing, 2019. V. 40. No 7. P. 2517-2541. DOI: 10.1080/01431161 .2019.1584926.

51. Blomdin R., Stroeven A.P., Harbor J.M., Gribenski N., Caffee M.W., Heyman J., Rogozhina I., Ivanov M.N., Petrakov D.A., Walther M., Rudoy A.N., Zhang W., Orkhonselenge A., Hättestrand C., Lifton N.A., Jansson K.N. Timing and dynamics of glaciation in the Ikh Turgen Mountains, Altai region, High Asia. Quaternary Geochronology, 2018. V. 47. P. 54-71. DOI: 10.1016/j.quageo.2018.05.008.

52. Bock M., Conrad O., Günther A., Gehrt E., Baritz R., Böhner J. SaLEM (v1.0) - the Soil and Landscape Evolution Model (SaLEM) for simulation of regolith depth in periglacial environments. Geoscientific Model Development, 2018. V. 11. P. 1641-1652. DOI: 10.5194/gmd-11-1641-2018.

53. Bonetti S., Bragg A.D., Porporato A. On the theory of drainage area for regular and nonregular points. Proceedings of the Royal Society A - Mathematical Physical and Engineering Sciences, 2018. V. 474. No 2211. \# 20170693. DOI: 10.1098/rspa. 2017.0693.

54. Booysen R., Zimmerman R., Lorenz S., Gloaguen R., Nex P.A.M., Andreani L., Mockel R. Towards multiscale and multisource remote sensing mineral exploration using RPAS: a case study in the Lofdal carbonatite-hosted REE deposit, Namibia. Remote Sensing, 2019. V. 11. No 21. \# 2500. DOI: 10.3390/rs11212500.

55. Boulton S.J., Stokes M. Which DEM is best for analyzing fluvial landscape development in mountainous terrains? Geomorphology, 2018. V. 310. P. 168-187. DOI: 10.1016/J.GEOMORPH.2018.03.002.

56. Brecheisen Z.S., Cook C.W., Heine P.R., Richter D. deB. Micro-topographic roughness analysis (MTRA) highlights minimally eroded terrain in a landscape severely impacted by historic agriculture. Remote Sensing of Environment, 2019. V. 222. P. 78-89. DOI: 10.1016/j.rse.2018.12.025.

57. Břžný M., Pánek T. Deep-seated landslides affecting monoclinal flysch morphostructure: Evaluation of LiDAR-derived topography of the highest range of the Czech Carpathians. Geomorphology, 2017. V. 285. P. 44-57. DOI: 10.1016/j.geomorph.2017.02.007.

58. Brun F., Berthier E., Wagnon P., Kääb A., Treichler D. A spatially resolved estimate of High Mountain Asia glacier mass balances from 2000 to 2016. Nature Geoscience, 2017. V. 10, 9. P. 668-673. DOI: 10.1038/ngeo2999.

59. Brun F., Buri P., Miles E.S., Wagnon P., Steiner J., Berthier E., Ragettli S., Kraaijenbrink P., Immerzeel $W . W$., Pellicciotti $F$. Quantifying volume loss from ice cliffs on debris-covered glaciers using high-resolution terrestrial and aerial photogrammetry. Journal of Glaciology, 2016. V. 62. No 234. P. 684-695. DOI: 10.1017/jog.2016.54.

60. Brun F., Wagnon P., Berthier E., Shea J.M., Immerzeel W.W., Kraaijenbrink P.D.A., Vincent C., Reverchon C., Shrestha D., Arnaud Y. Ice cliffs contribution to the tonguewide ablation of Changri Nup Glacier, Nepal, central Himalaya. Cryosphere, 2018. V. 12. No 11. P. 3439-3457. DOI: 10.5194/tc-12-3439-2018.

61. Brunier G., Fleury J., Anthony E.J., Gardel A., Dussouillez P. Close-range airborne structure-from-motion photogrammetry for high-resolution beach morphometric surveys: 
examples from an embayed rotating beach. Geomorphology, 2016. V. 261. P. 76-88. DOI: 10.1016/j.geomorph.2016.02.025.

62. Brusnikin E.S., Kreslavsky M.A., Zubarev A.E., Patratiy V.D., Krasilnikov S.S., Head J.W., Karachevtseva I.P. Topographic measurements of slope streaks on Mars. Icarus, 2016.

V. 278. P. 52-61. DOI: 10.1016/j.icarus.2016.06.005.

63. Bugnicourt P., Guitet S., Santos V.F., Blanc L., Sotta E.D., Barbier N., Couteron P. Using textural analysis for regional landform and landscape mapping, Eastern Guiana Shield. Geomorphology, 2018. V. 317. P. 23-44. DOI: 10.1016/j.geomorph.2018.03.017.

64. Bühler Y., Adams M.S., Bösch R., Stoffel A. Mapping snow depth in alpine terrain with unmanned aerial systems (UASs): potential and limitations. Cryosphere, 2016. V. 10. No 3. P. 1075-1088. DOI: 10.5194/tc-10-1075-2016.

65. Bühler Y., Adams M., Stoffel A., Boesch R. Photogrammetric reconstruction of homogenous snow surfaces in alpine terrain applying near-infrared UAS imagery. International Journal of Remote Sensing, 2017. V. 38. No 8/10. P. 3135-3158. DOI: 10.1080/ 01431161. 2016.1275060.

66. Bühler Y., von Rickenbach D., Stoffel A., Margreth S., Stoffel L., Christen M. Automated snow avalanche release area delineation - validation of existing algorithms and proposition of a new object-based approach for large scale hazard indication mapping. Natural Hazards and Earth System Sciences, 2018. V. 18. No 12. P. 3235-3251. DOI: 10.5194/nhess-18-3235-2018.

67. Buri P., Pellicciotti F., Steiner J.F., Miles E.S., Immerzeel W.W. A grid-based model of backwasting of supraglacial ice cliffs on debris-covered glaciers. Annals of Glaciology, 2016. V. 57. No 71. P. 199-211. DOI: 10.3189/2016AoG71A059.

68. Caglar B., Becek K., Mekik C., Ozendi M. On the vertical accuracy of the ALOS World 3D-30m digital elevation model. Remote Sensing Letters, 2018. V. 9. No 6. P. 607-615. DOI: $10.1080 / 2150704 X .2018 .1453174$.

69. Canuto M.A., Estrada-Belli F., Garrison T.G., Houston S.D., Acuna M.J., Kovac M., Marken D., Nondedeo P., Auld-Thomas L., Castanet C., Chatelain D., Chiriboga C.R., Drapela T., Lieskovsky T., Tokovinine A., Velasquez A., Fernandez-Diaz J.C., Shrestha R. Ancient lowland Maya complexity as revealed by airborne laser scanning of northern Guatemala. Science, 2018. V. 361. No 6409. \# eaau0137. DOI: 10.1126/science.aau0137.

70. Cao W., Sofia G., Tarolli P. Geomorphometric characterisation of natural and anthropogenic land covers. Progress in Earth and Planetary Science, 2020. V. 7. \# 2. DOI: 10.1186/s40645-0190314.

71. Cardinale M., Silvestro S., Vaz D.A., Michaels T., Bourke M.C., Komatsu G., Marinangeli L. Present-day aeolian activity in Herschel Crater, Mars. Icarus, 2016. V.265. P. 139-148. DOI: 10.1016/j.icarus.2015.10.022.

72. Carless D., Kulessa B., Booth A.D., Drocourt Y., Sinnadurai P., Street-Perrott F.A., Jansson $P$. An integrated geophysical and GIS based approach improves estimation of peatland carbon stocks. Geoderma, 2021. V. 402. \# 115176. DOI: 10.1016/j.geoderma. 2021.115176.

73. Carreno-Luengo H., Luzi G., Crosetto M. First evaluation of topography on GNSS-R: an empirical study based on a digital elevation model. Remote Sensing, 2019. V. 11. No 21. \# 2556. DOI: $10.3390 /$ rs11212556.

74. Caubet M., Dobarco M.R., Arrouays D., Minasny B., Saby N.P. Merging country, continental and global predictions of soil texture: lessons from ensemble modelling in France. Geoderma, 2019. V. 337. P. 99-110. DOI: 10.1016/j.geoderma.2018.09.007.

75. Cavalli M., Goldin B., Comiti F., Brardinoni F., Marchi L. Assessment of erosion and 
deposition in steep mountain basins by differencing sequential digital terrain models. Geomorphology, 2017. V. 291. P. 4-16. DOI: 10.1016/j.geomorph.2016.04.009.

76. Čeru T., Šegina E., Gosar A. Geomorphological dating of pleistocene conglomerates in central Slovenia based on spatial analyses of dolines using LiDAR and ground penetrating radar. Remote Sensing, 2017. V. 9. No 12. \# 1213. DOI: 10.3390/rs9121213.

77. Cervilla A.R., Tabik S., Vías J., Mérida M., Romero L.F. Total 3D-viewshed map: quantifying the visible volume in digital elevation models. Transactions in GIS, 2017. V. 21. No 3. P. 591-607. DOI: 10.1111/tgis.12216.

78. Chaney N.W., Wood E.F., McBratney A.B., Hempel J.W., Nauman T.W., Brungard C.W., Odgers N.P. POLARIS: a 30-meter probabilistic soil series map of the contiguous United States. Geoderma, 2016. V. 274. P. 54-67. DOI: 10.1016/j.geoderma.2016.03.025.

79. Chang J.M.-H., Lam Y.F., Lau S.P.-W., Wong W.-K. Development of fine-scale spatiotemporal temperature forecast model with urban climatology and geomorphometry in Hong Kong. Urban Climate, 2021. V. 37. \# 100816. DOI: j.uclim.2021.100816.

80. Chang K.-T., Merghadi A., Yunus A.P., Pham B.T., Dou J. Evaluating scale effects of topographic variables in landslide susceptibility models using GIS-based machine learning techniques. Scientific Reports, 2019. V. 9. \# 12296. DOI: 10.1038/s41598-01948773-2.

81. Chase D.Z., Chase A.F. Caracol, Belize, and changing perceptions of Ancient Maya society. Journal of Archaeological Research, 2017. V. 25. No 3. P. 185-249. DOI: 10.1007/s10814-016-9101-z.

82. Chen Q., Liu G., Ma X., Mariethoz G., He Z., Tian Y., Weng Z. Local curvature entropybased 3D terrain representation using a comprehensive Quadtree. ISPRS Journal of Photogrammetry and Remote Sensing, 2018. V. 139. P. 30-45. DOI: 10.1016/j. isprsjprs.2018.03.001.

83. Chen W., Xie X., Wang J., Pradhan B., Hong H., Tien Bui D., Duan Z., Ma J. A comparative study of logistic model tree, random forest, and classification and regression tree models for spatial prediction of landslide susceptibility. Catena, 2017. V. 151. P. 147160. DOI: $10.1016 /$ j.catena.2016.11.032.

84. Chu H.-J., Chen Y.-C., Ali M.Z., Höfle B. Multi-parameter relief map from highresolution DEMs: a case study of mudstone badland. International Journal of Environmental Research and Public Health, 2019. V. 16. No 7. \# 1109. DOI: 10.3390/ijerph 16071109.

85. Chudley T.R., Christoffersen P., Doyle S.H., Abellan A., Snooke N. High accuracy UAV photogrammetry of ice sheet dynamics with no ground control. Cryosphere, 2019. V. 13. No 3. P. 955-968. DOI: 10.5194/tc-2018-256.

86. Cimoli E., Marcer M., Vandecrux B., Bøggild C.E., Williams G., Simonsen S.B. Application of low-cost UASs and digital photogrammetry for high-resolution snow depth mapping in the Arctic. Remote Sensing, 2017. V. 9. No 11. \# 1144. DOI: 10.3390 /rs9111144.

87. Clapuyt $F$., Vanacker $V$., van Oost $K$. Reproducibility of UAV-based earth topography reconstructions based on Structure-from-Motion algorithms. Geomorphology, 2016. V. 260. P. 4-15. DOI: 10.1016/j.geomorph.2015.05.011.

88. Clarke K.C., Romero B.E. On the topology of topography: a review. Cartography and Geographic Information Science, 2017. V. 44. No 3. P. 271-282. DOI: 10.1080/ 15230406. 2016.1164625.

89. Clubb F.J., Mudd S.M., Attal M., Milodowski D.T., Grieve S.W.D. The relationship between drainage density, erosion rate, and hilltop curvature: implications for sediment transport processes. Journal of Geophysical Research: Earth Surface, 2016. V. 121. No 10. P. 1724-1745. DOI: 10.1002/2015JF003747. 
90. Clubb F.J., Mudd S.M., Milodowski D.T., Valters D.A., Slater L.J., Hurst M.D., Limaye A.B. Geomorphometric delineation of floodplains and terraces from objectively defined topographic thresholds. Earth Surface Dynamics, 2017. V. 5. P. 369-385. DOI: 10.5194/ esurf-5-369-2017.

91. Collin A., Hench J.L., Pastol Y., Planes S., Thiault L., Schmitt R.J, Holbrook S.J., Davies N., Troyer $M$. High resolution topobathymetry using a Pleiades-1 triplet: Moorea Island in 3D. Remote Sensing of Environment, 2018. V. 208. P. 109-119. DOI: 10.1016/j.rse. 2018.02.015.

92. Colucci R.R., Boccali C., Žebre M., Guglielmin M. Rock glaciers, protalus ramparts and pronival ramparts in the south-eastern Alps. Geomorphology, 2016. V. 269. P. 112-121. DOI: 10.1016/j.geomorph.2016.06.039.

93. Conway S.J., Balme M.R. A novel topographic parameterization scheme indicates that martian gullies display the signature of liquid water. Earth and Planetary Science Letters, 2016. V. 454. P. 36-45. DOI: 10.1016/j.eps1.2016.08.031.

94. Copping J.P., Stewart B.D., McClean C.J., Hancock J., Rees R. Does bathymetry drive coastal whale shark (Rhincodon typus) aggregations? PeerJ, 2018. V. 6. \# e4904. DOI: $10.7717 /$ peerj. 4904 .

95. Cucchiaro S., Cazorzi F., Marchi L., Crema S., Beinat A., Cavalli M. Multi-temporal analysis of the role of check dams in a debris-flow channel: linking structural and functional connectivity. Geomorphology, 2019. V. 345. \# 106844. DOI: 10.1016/j. geo morph.2019.106844.

96. Cucchiaro S., Maset E., Cavalli M., Crema S., Marchi L., Beinat A. How does coregistration affect geomorphic change estimates in multi-temporal surveys? GIScience and Remote Sensing, 2020. V. 57. No 5. P. 611-632. DOI: 10.1080/15481603.2020. 1763048.

97. Cunha N.S., Magalhães M.R., Domingos T., Abreu M.M., Küpfer C. The land morphology approach to flood risk mapping: an application to Portugal. Journal of Environmental Management, 2017. V. 193. P. 172-187. DOI: 10.1016/j.jenvman.2017. 01.077.

98. Cunha N.S., Magalhães M.R., Domingos T., Abreu M.M., Withing K. The land morphology concept and mapping method and its application to mainland Portugal. Geoderma, 2018. V. 325. P. 72-89. DOI: 10.1016/j.geoderma.2018.03.

99. Dabski M., Zmarz A., Pabjanek P., Korczak-Abshire M., Karsznia I., Chwedorzewska K.J. UAV-based detection and spatial analyses of periglacial landforms on Demay Point (King George Island, South Shetland Islands, Antarctica). Geomorphology, 2017. V. 290. P. 29-38. DOI: 10.1016/j.geomorph.2017.03.033.

100. Dai C., Durand M., Howat I.M., Altenau E.H., Pavelsky T.M. Estimating river surface elevation from ArcticDEM. Geophysical Research Letters, 2018. V. 45. No 7. P. $3107-$ 3114. DOI: 10.1002/2018GL077379.

101. Dai C., Howat I.M. Measuring lava flows with ArcticDEM: application to the 2012-2013 eruption of Tolbachik, Kamchatka. Geophysical Research Letters, 2017. V. 44. No 24. P. 12133-12140. DOI: 10.1002/2017GL075920.

102. Dai C., Howat I.M., Freymueller J.T., Vijay S., Jia Y. Characterization of the 2008 phreatomagmatic eruption of Okmok from ArcticDEM and InSAR: deposition, erosion, and deformation. Journal of Geophysical Research: Solid Earth, 2020. V. 125. No 6. \# e2019JB018977. DOI: 10.1029/2019JB018977.

103. Dai W., Hu G., Huang N., Zhang P., Yang X., Tang G. A contour-directional detection for deriving terrace ridge from open source images and digital elevation models. IEEE Access, 2019a. V. 7. P. 129215-129224. DOI: 10.1109/ACCESS.2019.2940437. 
104. Dai W., Na J., Huang N., Hu G., Yang X., Tang G., Xiong L., Li F. Integrated edge detection and terrain analysis for agricultural terrace delineation from remote sensing images. International Journal of Geographical Information Science, 2020. V. 34. No 3. P. 484-503. DOI: 10.1080/13658816.2019.1650363.

105. Dai W., Yang X., Na J., Li J., Brus D., Xiong L., Tang G., Huang X. Effects of DEM resolution on the accuracy of gully maps in loess hilly areas. Catena, 2019b. V. 177. P. 114-125. DOI: 10.1016/j.catena.2019.02.010.

106. Dall'Asta E., Forlani G., Roncella R., Santise M., Diotri F., Morra di Cella U. Unmanned aerial systems and DSM matching for rock glacier monitoring. ISPRS Journal of Photogrammetry and Remote Sensing, 2017. V. 127. P. 102-114. DOI: 10.1016/j.isprsjprs. 2016.10.003.

107. Danchenkov A., Belov N., Stont Z. Using the terrestrial laser scanning technique for aeolian sediment transport assessment in the coastal zone in seasonal scale. Estuarine, Coastal and Shelf Science, 2019. V. 223. P. 105-114. DOI: 10.1016/j.ecss.2019.04.044.

108. De Michele C., Avanzi F., Passoni D., Barzaghi R., Pinto L., Dosso P., Ghezzi A., Gianatti R., Della Vedova $G$. Using a fixed-wing UAS to map snow depth distribution: an evaluation at peak accumulation. Cryosphere, 2016. V. 10. No 2. P. 511-522. DOI: 10.5194/tc-10-511-2016.

109. De Waele J., Fabbri S., Santagata T., Chiarini V., Columbu A., Pisani L. Geomorphological and speleogenetical observations using terrestrial laser scanning and 3D photogrammetry in a gypsum cave (Emilia Romagna, N. Italy). Geomorphology, 2018. V. 319. P. 47-61. DOI: 10.1016/j.geomorph.2018.07.012.

110. Dehecq A., Millan R., Berthier E., Gourmelen N., Trouve E. Elevation changes inferred from TanDEM-X data over the Mont-Blanc area: impact of the X-band interferometric bias. IEEE Journal of Selected Topics in Applied Earth Observations and Remote Sensing, 2016. V. 9. No 8. P. 3870-3882. DOI: 10.1109/JSTARS.2016.2581482.

111. Dekavalla M., Argialas D. Evaluation of a spatially adaptive approach for land surface classification from digital elevation models. International Journal of Geographical Information Science, 2017. V. 31. No 10. P. 1978-2000. DOI: 10.1080/13658816. 2017.1344984.

112. Dekavalla M., Argialas D. Object-based classification of global undersea topography and geomorphological features from the SRTM30_PLUS data. Geomorphology, 2017. V. 288. P. 66-82. DOI: 10.1016/j.geomorph.2017.03.026.

113. Deng $Y$. New trends in digital terrain analysis: landform definition, representation, and classification. Progress in Physical Geography, 2007. V. 31. No 4. P. 405-419. DOI: 10.1177/0309133307081291.

114. Dharumarajan S., Hegde R., Singh S.K. Spatial prediction of major soil properties using Random Forest techniques - a case study in semi-arid tropics of South India. Geoderma Regional, 2017. V. 10. P. 154-162. DOI: 10.1016/j.geodrs.2017.07.005.

115. Dhingra R.D., Barnes J.W., Yanites B.J., Kirk R.L. Large catchment area recharges Titan's Ontario Lacus. Icarus, 2018. V. 299. P. 331-338. DOI: 10.1016/j.icarus. 2017.08.009.

116. Dirscherl M., Rossi C. Geomorphometric analysis of the 2014-2015 Bárðarbunga volcanic eruption, Iceland. Remote Sensing of Environment, 2018. V. 204. P. 244-259. DOI: $10.1016 /$ j.rse.2017.10.027.

117. Dornik A., Drăguţ L., Urdea P. Classification of soil types using geographic object-based image analysis and random forests. Pedosphere, 2018. V. 28. No 6. P. 913-925. DOI: 10.1016/S1002-0160(17)60377-1.

118. Dos Reis A.A., Franklin S.E., de Mello J.M., Acerbi F.W. Jr. Volume estimation in a 
Eucalyptus plantation using multi-source remote sensing and digital terrain data: a case study in Minas Gerais State, Brazil. International Journal of Remote Sensing, 2019. V. 40. No 7. P. 2683-2702. DOI: 10.1080/01431161.2018.1530808.

119. Drăgut L., Dornik A. Land-surface segmentation as a method to create strata for spatial sampling and its potential for digital soil mapping. International Journal of Geographical Information Science, 2016. V. 30. No 7. P. 1359-1376. DOI: 10.1080/ 13658816.2015. 1131828.

120. Duan X., Li L., Zhu H., Shen $Y$. A high-fidelity multiresolution digital elevation model for Earth systems. Geoscientific Model Development, 2017. V. 10. No 1. P. 239-253. DOI: 10.5194/gmd-10-239-2017.

121. Duszyński F., Jancewicz K., Kasprzak M., Migoń P. The role of landslides in downslope transport of caprock-derived boulders in sedimentary tablelands, Stołowe Mts, SW Poland. Geomorphology, 2017. V. 295. P. 84-101. DOI: 10.1016/j.geomorph. 2017.06.016.

122. Elez J., Silva P.G., Huerta P., Perucha M.Á., Civis J., Roquero E., Rodríguez-Pascu M.A., Bardaji T., Giner-Robles J.L., Martínez-Graña A. Quantitative paleotopography and paleogeography around the Gibraltar Arc (South Spain) during the Messinian Salinity Crisis. Geomorphology, 2016. V. 275. P. 26-45. DOI: 10.1016/j.geomorph.2016.09.023.

123. Eltner A., Kaiser A., Castillo C., Rock G., Neugirg F., Abellán A. Image-based surface reconstruction in geomorphometry - merits, limits and developments. Earth Surface Dynamics, 2016. V. 4. No 2. P. 359-389. DOI: 10.5194/esurf-4-359-2016.

124. Ely J.C., Graham C., Barr I.D., Rea B.R., Spagnolo M., Evans J. Using UAV acquired photography and structure from motion techniques for studying glacier landforms: application to the glacial flutes at Isfallsglaciären. Earth Surface Processes and Landforms, 2017. V. 42. No 6. P. 877-888. DOI: 10.1002/esp.4044.

125. Evans $D$. Airborne laser scanning as a method for exploring long-term socioecological dynamics in Cambodia. Journal of Archaeological Science, 2016. V. 74. P. 164-175. DOI: 10.1016/j.jas.2016.05.009.

126. Evans I.S. General geomorphometry, derivatives of altitude, and descriptive statistics. Spatial Analysis in Geomorphology. London: Methuen, 1972. P. 17-90. DOI: 10.4324/9780429273346-2.

127. Ewertowski M.W., Tomczyk A.M., Evans D.J.A., Roberts D.H., Ewertowski W. Operational framework for rapid, very-high resolution mapping of glacial geomorphology using low-cost unmanned aerial vehicles and structure-from-motion approach. Remote Sensing, 2019. V. 11. No 1. \# 65. DOI: 10.3390/rs11010065.

128. Fa $W$., Cai Y., Xiao Z., Tian $W$. Topographic roughness of the northern high latitudes of Mercury from MESSENGER Laser Altimeter data. Geophysical Research Letters, 2016. V. 43. No 7. P. 3078-3087. DOI: 10.1002/2016GL068120.

129. Fabbri S., Sauro F., Santagata T., Rossi G., de Waele J. High-resolution 3-D mapping using terrestrial laser scanning as a tool for geomorphological and speleogenetical studies in caves: an example from the Lessini mountains (North Italy). Geomorphology, 2017. V. 280. P. 16-29. DOI: 10.1016/j.geomorph.2016.12.001.

130. Fan B., Tao W., Qin G., Hopkins I., Zhang Y., Wang Q., Lin H., Guo L. Soil micro-climate variation in relation to slope aspect, position, and curvature in a forested catchment. Agricultural and Forest Meteorology, 2020. V. 290. \# 107999. DOI: 10.1016/j. agrformet.2020.107999.

131. Favalli M., Fornaciai A. Visualization and comparison of DEM-derived parameters: application to volcanic areas. Geomorphology, 2017. V. 290. P. 69-84. DOI: 10.1016/ j.geomorph.2017.02.029. 
132. Feizizadeh B., Blaschke T., Tiede D., Moghaddam M.H.R. Evaluating fuzzy operators of an object-based image analysis for detecting landslides and their changes. Geomorphology, 2017. V. 293. Pt. A. P. 240-254. DOI: 10.1016/j.geomorph.2017. 06.002.

133. Fissore C., Dalzell B.J., Berhe A.A., Voegtle M., Evans M., Wu A. Influence of topography on soil organic carbon dynamics in a Southern California grassland. Catena, 2017. V. 149, 1. P. 140-149. DOI: 10.1016/j.catena.2016.09.016.

134. Florinsky I.V. Combined analysis of digital terrain models and remotely sensed data in landscape investigations. Progress in Physical Geography, 1998. V. 22. No 1. P. 33-60. DOI: $10.1177 / 030913339802200102$.

135. Florinsky I.V. Digital Terrain Analysis in Soil Science and Geology. 2nd ed. Amsterdam: Academic Press, 2016. 486 p.

136. Florinsky I.V. An illustrated introduction to general geomorphometry. Progress in Physical Geography, 2017a. V. 41. No 6. P. 723-752. DOI: 10.1177/0309133317733667.

137. Florinsky I.V. Spheroidal equal angular DEMs: the specificity of morphometric treatment. Transactions in GIS, 2017b. V. 21. No 6. P. 1115-1129. DOI: 10.1111/ tgis. 12269.

138. Florinsky I.V. Geomorphometry on the surface of a triaxial ellipsoid: towards the solution of the problem. International Journal of Geographical Information Science, 2018. V. 32. No 8. P. 1558-1571. DOI: 10.1080/13658816.2018.1461220.

139. Florinsky I.V., Bliakharskii D.P. Detection of crevasses by geomorphometric treatment of data from unmanned aerial surveys. Remote Sensing Letters, 2019a. V. 10, 4. P. 323332. DOI: 10.1080/2150704X.2018.1552809.

140. Florinsky I.V., Bliakharskii D.P. The 2017 catastrophic subsidence in the Dålk Glacier, East Antarctica: unmanned aerial survey and terrain modelling. Remote Sensing Letters, 2019b. V. 10. No 4. P. 333-342. DOI: 10.1080/2150704X.2018.1552810.

141. Florinsky I.V., Filippov S.V. Three-dimensional terrain modeling with multiple-source illumination. Transactions in GIS, 2019. V. 23. No 5. P. 937-959. DOI: 10.1111/ tgis.12546.

142. Florinsky I.V., Filippov S.V. Three-dimensional geomorphometric modeling of the Arctic Ocean submarine topography: a low-resolution desktop application. IEEE Journal of Oceanic Engineering, 2021. V. 46. No 1. P. 88-101. DOI: 10.1109/JOE.2020.2969283.

143. Florinsky I.V., Kurkov V.M., Bliakharskii D.P. Geomorphometry from unmanned aerial surveys. Transactions in GIS, 2018a. V. 22. No 1. P. 58-81. DOI: 10.1111/tgis.12296.

144. Florinsky I.V., Pankratov A.N. A universal spectral analytical method for digital terrain modeling. International Journal of Geographical Information Science, 2016. V. 30. No 12. P. 2506-2528. DOI: 10.1080/13658816.2016.1188932.

145. Florinsky I.V., Skrypitsyna T.N., Luschikova O.S. Comparative accuracy of the AW3D30 DSM, ASTER GDEM, and SRTM1 DEM: a case study on the Zaoksky testing ground, Central European Russia. Remote Sensing Letters, 2018b. V. 9. No 7. P. 706-714. DOI: 10.1080/2150704X.2018.1468098.

146. Florinsky I.V., Skrypitsyna T.N., Trevisani S., Romaikin S.V. Statistical and visual quality assessment of nearly-global and continental digital elevation models of Trentino, Italy. Remote Sensing Letters, 2019. V. 10. No 8. P. 726-735. DOI: 10.1080/2150704X. 2019.1602790.

147. Flynn T., Rozanov A., de Clercq W., Warr B., Clarke C. Semi-automatic disaggregation of a national resource inventory into a farm-scale soil depth class map. Geoderma, 2019. V. 337. P. 1136-1145. DOI: 10.1016/j.geoderma.2018.11.003.

148. Foroutan M., Marshall S.J., Menounos B. Automatic mapping and geomorphometry extraction technique for crevasses in geodetic mass-balance calculations at Haig Glacier, 
Canadian Rockies. Journal of Glaciology, 2019. V. 65. No 254. P. 971-982. DOI: 10.1017/jog.2019.71.

149. Franklin $J$. Predictive vegetation mapping: geographic modelling of biospatial patterns in relation to environmental gradients. Progress in Physical Geography, 1995. V. 19. No 4. P. 474-499. DOI: 10.1177/030913339501900403.

150. Franklin S.E. Interpretation and use of geomorphometry in remote sensing: a guide and review of integrated applications. International Journal of Remote Sensing, 2020. V. 41. No 19. P. 7700-7733. DOI: 10.1080/01431161.2020.1792577.

151. Freeland T., Heung B., Burley D.V., Clark G., Knudby A. Automated feature extraction for prospection and analysis of monumental earthworks from aerial LiDAR in the Kingdom of Tonga. Journal of Archaeological Science, 2016. V. 69. P. 64-74. DOI: 10.1016/ j.jas.2016.04.011.

152. Freitas H.R.A., Freitas C.D.C., Rosim S., Oliveira J.R.F. Drainage networks and watersheds delineation derived from TIN-based digital elevation models. Computers and Geosciences, 2016. V. 92. P. 21-37. DOI: 10.1016/j.cageo.2016.04.003.

153. Fugazza D., Scaioni M., Corti M., d'Agata C., Azzoni R.S., Cernuschi M., Smiraglia C., Diolaiuti G.A. Combination of UAV and terrestrial photogrammetry to assess rapid glacier evolution and conditions of glacier hazards. Natural Hazards and Earth System Sciences, 2018. V. 18. No 4, P. 1055-1071. DOI: 10.5194/nhess-18-1055-2018.

154. Fuss C.E., Berg A.A., Lindsay J.B. DEM fusion using a modified $k$-means clustering algorithm. International Journal of Digital Earth, 2016. V. 9. No 12. P. 1242-1255. DOI: 10.1080/17538947.2016.1208685.

155. Gabrlik P., La Cour-Harbo A., Zalud L., Janata P. Calibration and accuracy assessment in a direct georeferencing system in UAS photogrammetry. International Journal of Remote Sensing, 2018. V. 39. No 15/16. P. 4931-4959. doi:10.1080/01431161.2018. 1434331.

156. Gaffey C., Bhardwaj A. Applications of unmanned aerial vehicles in cryosphere: latest advances and prospects. Remote Sensing, 2020. V. 12. No 6. \# 948. DOI: 10.3390/rs 12060948.

157. Gallant J.C., Hutchinson M.F. A differential equation for specific catchment area. Water Resources Research, 2011. V. 47. No 5. \# W05535. DOI: 10.1029/2009WR008540.

158. Gallay M., Hochmuth Z., Kan̆uk J., Hofierka J. Geomorphometric analysis of cave ceiling channels mapped with 3D terrestrial laser scanning. Hydrology and Earth System Sciences, 2016. V. 20. No 5. P. 1827-1849. DOI: 10.5194/hess-2016-74.

159. Gallwey J., Eyre M., Tonkins T., Coggan J. Bringing Lunar LiDAR back down to Earth: mapping our industrial heritage through deep transfer learning. Remote Sensing, 2019. V. 11. No 17. \# 1994. DOI: 10.3390/rs11171994.

160. Gao Y., Wang W., Yao T., Lu N., Lu A. Hydrological network and classification of lakes on the Third Pole. Journal of Hydrology, 2018. V. 560. P. 582-594. DOI: 10.1016/ j.jhydrol.2018.03.062.

161. García-Romero L., Delgado-Fernández I., Hesp P.A., Hernández-Calvento L., VieraPérez M., Hernández-Cordero A.I., Cabrera-Gámez J., Domínguez-Brito A.C. Airflow dynamics, vegetation and aeolian erosive processes in a shadow zone leeward of a resort in an arid transgressive dune system. Aeolian Research, 2019. V. 38. P. 48-59. DOI: 10.1016/ J.AEOLIA.2019.03.006.

162. Garosi Y., Sheklabadi M., Besalatpour A.A., Pourghasemi H.R., Conoscenti C., van Oost $K$. Comparison of the different resolution and source of controlling factors for gully erosion susceptibility mapping. Geoderma, 2018. V. 330. P. 65-78. DOI: 10.1016/j. geoderma. 2018.05.027. 
163. Garrison T.G., Houston S., Alcover Firpi O. Recentering the rural: lidar and articulated landscapes among the Maya. Journal of Anthropological Archaeology, 2019. V. 53. P. 133-146. DOI: 10.1016/j.jaa.2018.11.005.

164. Garstki K. Virtual representation: the production of 3D digital artifacts. Journal of Archaeological Method and Theory, 2017. V. 24. No 3. P. 726-750. DOI: 10.1007/ s10816-016-9285-z.

165. Gatter R., Cavalli M., Crema S., Bossi G. Modelling the dynamics of a large rock landslide in the Dolomites (eastern Italian Alps) using multi-temporal DEMs. PeerJ, 2018. V. 6. \# e5903. DOI: 10.7717/peerj.5903.

166. Gaucherel C., Frelat R., Salomon L., Rouy B., Pandey N., Cudennec C. Regional watershed characterization and classification with river network analyses. Earth Surface Processes and Landforms, 2017. V. 42. No 13. P. 2068-2081. DOI: 10.1002/esp.4172.

167. Gevaert C., Persello C., Nex F., Vosselman G. A deep learning approach to DTM extraction from imagery using rule-based training labels. ISPRS Journal of Photogrammetry and Remote Sensing, 2018. V. 142. P. 106-123. DOI: 10.1016/j. isprsjprs. 2018.06.001.

168. Gheyle W., Stichelbaut B., Saey T., Note N., van den Berghe H., van Eetvelde V., van Meirvenne M., Bourgeois J. Scratching the surface of war. Airborne laser scans of the Great War conflict landscape in Flanders (Belgium). Applied Geography, 2018. V. 90. P. 55-68. DOI: 10.1016/j.apgeog.2017.11.011.

169. Ghorbanzadeh O., Blaschke T., Gholamnia K., Meena S., Tiede D., Aryal J. Evaluation of different machine learning methods and deep-learning convolutional neural networks for landslide detection. Remote Sensing, 2019. V. 11. No 2. \# 196. DOI: 10.3390/rs1 1020196.

170. Gibson M.J., Glasser N.F., Quincey D.J., Mayer C., Rowan A.V., Irvine-Fynn T.D. Temporal variations in supraglacial debris distribution on Baltoro Glacier, Karakoram between 2001 and 2012. Geomorphology, 2017. V. 295. P. 572-585. DOI: 10.1016/j. geomorph. 2017.08.012.

171. Gillings M., Hacıgüzeller P., Lock G. (eds.) Archaeological Spatial Analysis: A Methodological Guide. London: Routledge, 2020.512 p. DOI: 10.4324/9781351243858.

172. Gindraux S., Boesch R., Farinotti D. Accuracy assessment of digital surface models from unmanned aerial vehicles' imagery on glaciers. Remote Sensing, 2017. V. 9. No 2. \# 186. DOI: $10.3390 /$ rs9020186.

173. Gomez C. Understanding volcanic geomorphology from derivatives and wavelet analysis: a case study at Miyakejima Volcano, Izu Islands, Japan. Journal of Volcanology and Geothermal Research, 2018. V. 354. P. 57-66. DOI: 10.1016/j.jvolgeores.2018.02.007.

174. Gonzalez C., Rizzoli P. Landcover-dependent assessment of the relative height accuracy in TanDEM-X DEM products. IEEE Geoscience and Remote Sensing Letters, 2018. V. 15. No 12. P. 1892-1896. DOI: 10.1109/LGRS.2018.2864774.

175. González-García J., Gómez-Espinosa A., Cuan-Urquizo E., García-Valdovinos L.G., Salgado-Jiménez T., Cabello J.A.E. Autonomous underwater vehicles: localization, navigation, and communication for collaborative missions. Applied Sciences, 2020. V. 10. No 4. \# 1256. DOI: 10.3390/app10041256.

176. González-Moradas M.d.R., Viveen W. Evaluation of ASTER GDEM2, SRTMv3.0, ALOS AW3D30 and TanDEM-X DEMs for the Peruvian Andes against highly accurate GNSS ground control points and geomorphological-hydrological metrics. Remote Sensing of Environment, 2020. V. 237. \# 111509. DOI: 10.1016/j.rse.2019.111509.

177. Gorini M.A.V., Mota G.L.A. Dealing with double vagueness in DEM morphometric analysis. International Journal of Geographical Information Science, 2016. V. 30. No 8. P. 1644-1666. DOI: 10.1080/13658816.2016.1150484. 
178. Goudge T.A., Milliken R.E., Head J.W., Mustard J.F., Fassett C.I. Sedimentological evidence for a deltaic origin of the western fan deposit in Jezero crater, Mars and implications for future exploration. Earth and Planetary Science Letters, 2017. V. 458. P. 357-365. DOI: 10.1016/J.EPSL.2016.10.056.

179. Grieve S.W.D., Mudd S.M., Hurst M.D., Milodowski D.T. A nondimensional framework for exploring the relief structure of landscapes. Earth Surface Dynamics, 2016. V. 4. No2. P. 309-325. DOI: 10.5194/esurf-4-309-2016.

180. Grimm K., Tahmasebi Nasab M., Chu X. TWI computations and topographic analysis of depression-dominated surfaces. Water, 2018. V. 10. No 5. \# 663. DOI: 10.3390/ w10050663.

181. Grohmann C.H. Evaluation of TanDEM-X DEMs on selected Brazilian sites: comparison with SRTM, ASTER GDEM and ALOS AW3D30. Remote Sensing of Environment, 2018. V. 212. P. 121-133. DOI: 10.1016/j.rse.2018.04.043.

182. Grohmann C.H., Garcia G.P.B., Affonso A.A., Albuquerque R.W. Dune migration and volume change from airborne LiDAR, terrestrial LiDAR and Structure from MotionMulti View Stereo. Computers and Geosciences, 2020. V. 143. \# 104569. DOI: 10.1016/j.cageo. 2020.104569.

183. Groom J., Bertin S., Friedrich H. Evaluation of DEM size and grid spacing for fluvial patch-scale roughness parameterisation. Geomorphology, 2018. V. 320. P. 98-110. DOI: 10.1016/J.GEOMORPH.2018.08.017.

184. Gruber F.E., Baruck J., Geitner C. Algorithms vs. surveyors: a comparison of automated landform delineations and surveyed topographic positions from soil mapping in an Alpine environment. Geoderma, 2017. V. 308. P. 9-25. DOI: 10.1016/j.geoderma.2017.08.017.

185. Guida D., Cuomo A., Palmieri $V$. Using object-based geomorphometry for hydrogeomorphological analysis in a Mediterranean research catchment. Hydrology and Earth System Sciences, 2016. V. 20. No 9. P. 3493-3509. DOI: 10.5194/hess-20-3493-2016.

186. Guirado E., Alcaraz-Segura D., Rigol-Sánchez J.P., Gisbert J., Martínez-Moreno F.J., Galindo-Zaldívar J., González-Castillo L., Cabello J. Remote-sensing-derived fractures and shrub patterns to identify groundwater dependence. Ecohydrology, 2018. V. 11. No 6. \# e1933. DOI: 10.1002/eco.1933.

187. Guisado-Pintado E., Jackson D.W.T., Rogers D. 3D mapping efficacy of a drone and terrestrial laser scanner over a temperate beach-dune zone. Geomorphology, 2019. V. 328. P. 157-172. DOI: 10.1016/j.geomorph.2018.12.013.

188. Guo Y., Liu Y., Oerlemans A., Lao S., Wu S., Lew M.S. Deep learning for visual understanding: a review. Neurocomputing, 2016. V. 187. P. 27-48. DOI: 10.1016/j.neucom. 2015.09.116.

189. Guo Z., Adhikari K., Chellasamy M., Greve M.B., Owens P.R., Greve M.H. Selection of terrain attributes and its scale dependency on soil organic carbon prediction. Geoderma, 2019. V. 340. P. 303-312. DOI: 10.1016/j.geoderma.2019.01.023.

190. Guevara M., Arroyo C., Brunsell N., Cruz C.O., Domke G., Equihua J., Etchevers J., Hayes D., Hengl T., Ibelles A., Johnson K., de Jong B., Libohova Z., Llamas R., Nave L., Ornelas J.L., Paz F., Ressl R., Schwartz A., Victoria A., Wills S., Vargas R. Soil organic carbon across Mexico and the conterminous United States (1991-2010). Global Biogeochemical Cycles, 2020. V. 34. No 3. \# e2019GB006219. DOI: 10.1029/ 2019GB006219.

191. Guevara M., Vargas R. Downscaling satellite soil moisture using geomorphometry and machine learning. PLoS ONE, 2019. V. 14. No 9. \# e0219639. DOI: 10.1371/journal. pone. 0219639. 
192. Guyot A., Hubert-Moy L., Lorho T. Detecting neolithic burial mounds from LiDARderived elevation data using a multi-scale approach and machine learning techniques. Remote Sensing, 2018. V. 10. No 2. \# 225. DOI: 10.3390/rs10020225.

193. Hayes A.G., Birch S.P.D., Dietrich W.E., Howard A.D., Kirk R.L., Poggiali V., Mastrogiuseppe M., Michaelides R.J., Corlies P.M., Moore J.M., Malaska M.J., Mitchell K.L., Lorenz R.D., Wood C.A. Topographic constraints on the evolution and connectivity of Titan's lacustrine basins. Geophysical Research Letters, 2017. V. 44. No 23. P. 1174511753. DOI: $10.1002 / 2017$ GL075468.

194. Heckmann T., Cavalli M., Cerdan O., Foerster S., Javaux M., Lode E., Smetanova A., Vericat $D$., Brardinoni $F$. Indices of sediment connectivity: opportunities, challenges and limitations. Earth-Science Reviews, 2018. V. 187. P. 77-108. DOI: 10.1016/j.earscirev. 2018.08.004.

195. Hendrickx H., Vivero S., de Cock L., de Wit B., de Maeyer P., Lambiel C., Delaloye R., Nyssen J., Frankl A. The reproducibility of SfM algorithms to produce detailed digital surface models: the example of PhotoScan applied to a high-alpine rock glacier. Remote Sensing Letters, 2019. V. 10. No 1. P. 11-20. DOI: 10.1080/2150704X.2018.1519641.

196. Hengl T., Reuter H.I. (eds.) Geomorphometry: Concepts, Software, Applications. Amsterdam: Elsevier, 2009. 765 p.

197. Hengl T., Leenaars J.G.B., Shepherd K.D., Walsh M.G., Heuvelink G.B.M., Mamo T., Tilahun H., Berkhout E., Cooper M., Fegraus E., Wheeler I., Kwabena N.A. Soil nutrient maps of Sub-Saharan Africa: assessment of soil nutrient content at $250 \mathrm{~m}$ spatial resolution using machine learning. Nutrient Cycling in Agroecosystems, 2017a. V. 109. No 1. P. 77-102. DOI: 10.1007/s10705-017-9870-x.

198. Hengl T., Mendes de Jesus J., Heuvelink G.B.M., Ruiperez Gonzalez M., Kilibarda M., Blagotić A., Wei S., Wright M.N., Geng X., Bauer-Marschallinger B., Guevara M.A., Varga R., MacMillan R.A., Batjes N.H., Leenaars J.G.B., Ribeiro E., Wheeler I., Mantel $S$., Kempen $B$. SoilGrids 250m: global gridded soil information based on machine learning. PLoS ONE, 2017b. V. 12. No 2. \# e0169748. DOI: 10.1371/journal. pone.0169748.

199. Hengl T., Miller M.A.E., Križan J., Shepherd K.D., Sila A., Kilibarda M., Antonijević O., Glušica L., Dobermann A., Haefele S.M., McGrath S.P., Acquah G.E., Collinson J., Parente L., Sheykhmousa M., Saito K., Johnson J.-M., Chamberlin J., Silatsa F.B.T., Yemefack M., Wendt J., MacMillan R.A., Wheeler I., Crouch J. African soil properties and nutrients mapped at $30 \mathrm{~m}$ spatial resolution using two-scale ensemble machine learning. Scientific Reports, 2021. V. 11. \# 6130. DOI: 10.1038/s41598-021-85639-y.

200. Hengl T., Nussbaum M., Wright M.N., Heuvelink G.B.M., Gräler B. Random forest as a generic framework for predictive modeling of spatial and spatio-temporal variables. PeerJ, 2018. V. 6. \# e5518. DOI: 10.7717/peerj.5518.

201. Hergarten S., Robl J., Stüwe K. Tectonic geomorphology at small catchment sizes extensions of the stream-power approach and the $\chi$ method. Earth Surface Dynamics, 2016. V. 4. No 2. P. 1-9. DOI: 10.5194/esurf-4-1-2016.

202. Heung B., Ho H.C., Zhang J., Knudby A., Bulmer C.E., Schmidt M.G. An overview and comparison of machine-learning techniques for classification purposes in digital soil mapping. Geoderma, 2016. V. 265. P. 62-77. DOI: 10.1016/j.geoderma.2015.11.014.

203. Hodúl M., Bird S., Knudby A., Chénier R. Satellite derived photogrammetric bathymetry. ISPRS Journal of Photogrammetry and Remote Sensing, 2018. V. 142. P. 268-277. DOI: 10.1016/j.isprsjprs.2018.06.015.

204. Hofierka J., Gallay M., Bandura P., Šašak J. Identification of karst sinkholes in a forested karst landscape using airborne laser scanning data and water flow analysis. Geomorphology, 2018. V. 308. P. 265-277. DOI: 10.1016/j.geomorph.2018.02.004. 
205. Hofierka J., Gallay M., Onačillová K., Hofierka J. Jr. Physically-based land surface temperature modeling in urban areas using a 3-D city model and multispectral satellite data. Urban Climate, 2020. V. 31. \# 100566. DOI: 10.1016/j.uclim.2019.100566.

206. Hong H., Llia L., Tsangaratos P., Chen W., Xu C. A hybrid fuzzy weight of evidence method in landslide susceptibility analysis on the Wuyuan area, China. Geomorphology, 2017. V. 290. P. 1-16. DOI: 10.1016/j.geomorph.2017.04.002.

207. Hooshyar M., Wang D., Kim S., Medeiros S.C., Hagen S.C. Valley and channel networks extraction based on local topographic curvature and $k$-means clustering of contours. Water Resources Research, 2016. V. 52. No 10. P. 8081-8102. DOI: 10.1002/ 2015 WR018479.

208. Horáček M., Samec P., Minár J. The mapping of soil taxonomic units via fuzzy clustering - a case study from the Outer Carpathians, Czechia. Geoderma, 2018. V. 326. P. 111-122. DOI: 10.1016/j.geoderma.2018.04.012.

209. Horn B.K.P. Hill shading and the reflectance map. Proceedings of the IEEE, 1981. V. 69. No 1. P. 14-47. DOI: 10.1109/PROC.1981.11918.

210. Horn C., Ivarsson O., Lindhé C., Potter R., Green A., Ling J. Artificial intelligence, 3D documentation, and rock art - approaching and reflecting on the automation of identification and classification of rock art images. Journal of Archaeological Method and Theory, 2021. V. 28. DOI: 10.1007/s10816-021-09518-6.

211. Houser C., Bishop M., Wernette P. Multi-scale topographic anisotropy patterns on a barrier island. Geomorphology, 2017. V. 297. P. 153-158. DOI: 10.1016/j.geomo rph.2017.09.026.

212. Howat I.M., Porter C., Smith B.E., Noh M.-J., Morin P. The reference elevation model of Antarctica. Cryosphere, 2019. V. 13. No 2. P. 665-674. DOI: 10.5194/tc-13-665-2019.

213. Hu G., Dai W., Li S., Xiong L., Tang G. A vector operation to extract second-order terrain derivatives from digital elevation models. Remote Sensing, 2020. V. 12. No 19. \# 3134. DOI: $10.3390 /$ rs12193134.

214. Hu G., Dai W., Li S., Xiong L., Tang G., Strobl J. Quantification of terrain plan concavity and convexity using aspect vectors from digital elevation models. Geomorphology, 2021. V. 375. \# 107553. DOI: 10.1016/j.geomorph.2020.107553.

215. Hu Q., Zhou Y., Wang S., Wang F. Machine learning and fractal theory models for landslide susceptibility mapping: case study from the Jinsha River Basin. Geomorphology, 2020. V. 351. \# 106975. DOI: 10.1016/j.geomorph.2019.106975.

216. Huang H., Chen X., Wang X., Wang X., Liu L. A depression-based index to represent topographic control in urban pluvial flooding. Water, 2019. V. 11. No 10. \# 2115. DOI: 10. 3390/w11102115.

217. Huang P.-C., Lee K.T. Distinctions of geomorphological properties caused by different flow-direction predictions from digital elevation models. International Journal of Geographical Information Science, 2016. V. 30. No 2. P. 168-185. DOI: 10.1080/ 13658816.2015.1079913.

218. Hurskainen P., Adhikari H., Siljander M., Pellikka P., Hemp A. Auxiliary datasets improve accuracy of object-based land use/landcover classification in heterogeneous savanna landscapes. Remote Sensing of Environment, 2019. V. 233. \# 111354. DOI: 10.1016/j. rse.2019.111354.

219. Ibanez D.M., Almeida-Filho R., Miranda F.P. Analysis of SRTM data as an aid to hydrocarbon exploration in a frontier area of the Amazonas Sedimentary Basin, northern Brazil. Marine and Petroleum Geology, 2016. V. 73. P. 528-538. DOI: 10.1016/j.marpe tgeo. 2016.03.024.

220. Idrees M.O., Pradhan B. A decade of modern cave surveying with terrestrial laser 
scanning: a review of sensors, method and application development. International Journal of Speleology, 2016. V. 45. No 1. P. 71-88. DOI: 10.5038/1827-806X.45.1.1923.

221. Inomata T., Triadan D., Pinzón F., Burham M., Ranchos J.L., Aoyama K., Haraguchi T. Archaeological application of airborne LiDAR to examine social changes in the Ceibal region of the Maya lowlands. PLoS ONE, 2018. V. 13. No 2. \# e0191619. DOI: 10.1371/journal. pone.0191619.

222. Iwahashi J., Kamiy I., Matsuoka M., Yamazaki D. Global terrain classification using 280m DEMs: segmentation, clustering and reclassification. Progress in Earth and Planetary Science, 2018. V. 5. \# 1. DOI: 10.1186/s40645-017-0157-2.

223. Jacobs L., Dewitte O., Poesen J., Sekajugo J., Nobile A., Rossi M., Thiery W., Kervyn M. Field-based landslide susceptibility assessment in a data-scarce environment: the populated areas of the Rwenzori Mountains. Natural Hazards and Earth System Sciences, 2018. V. 18. P. 105-124. DOI: 10.5194/nhess-18-105-2018.

224. Jacobs L., Kervyn M., Reichenbach P., Rossi M., Marchesini I., Alvioli M., Dewitte O. Regional susceptibility assessments with heterogeneous landslide information: slope unitvs. pixel-based approach. Geomorphology, 2020. V. 356. \# 107084. DOI: 10.1016/j.geomorph. 2020.107084.

225. Jain A.O., Thaker T., Chaurasia A., Patel P., Singh A.K. Vertical accuracy evaluation of SRTM-GL1, GDEM-V2, AW3D30 and CartoDEM-V3.1 of 30-m resolution with dual frequency GNSS for lower Tapi Basin India. Geocarto International, 2018. V. 33. No 11. P. 1237-1256. DOI: 10.1080/10106049.2017.1343392.

226. Jakobsson M., Mayer L.A., Bringensparr C., Castro C.F., Mohammad R., Johnson P., Ketter T., Accettella D., Amblas D., An L., Arndt J.E., Canals M., Casamor J.L., Chauché N., Coakley B., Danielson S., Demarte M., Dickson M.-L., Dorschel B., Dowdeswell J.A., Dreutter S., Fremand A.C., Gallant D., Hall J.K., Hehemann L., Hodnesdal H., Hong J., Ivaldi R., Kane E., Klaucke I., Krawczyk D.W., Kristoffersen Y., Kuipers B.R., Millan R., Masetti G., Morlighem M., Noormets R., Prescott M.M., Rebesco M., Rignot E., Semiletov I., Tate A.J., Travaglini P., Velicogna I., Weatherall P., Weinrebe W., Willis J.K., Wood M., Zarayskaya Y., Zhang T., Zimmermann M., Zinglersen K.B. The International Bathymetric Chart of the Arctic Ocean version 4.0. Scientific Data, 2020. V. 7. No 176. \# 14. DOI: 10.1038/s41597-020-0520-9.

227. James M.R., Robson S., d'Oleire-Oltmanns S., Niethammer U. Optimising UAV topographic surveys processed with structure-from-motion: ground control quality, quantity and bundle adjustment. Geomorphology, 2017. V. 280. P. 51-66. DOI: 10.1016/j. geomorph. 2016.11.021.

228. Jancewicz K., Migoń P., Kasprzak M. Connectivity patterns in contrasting types of tableland sandstone relief revealed by Topographic Wetness Index. Science of the Total Environment, 2019. V. 656. P. 1046-1062. DOI: 10.1016/j.scitotenv.2018.11.467.

229. Jenčo M., Fulajtár E., Bobálová H., Matečný I., Saksa M., Kožuch M., Gallay M., Kaňuk $J$., Píš $V$., Oršulová $V$. Mapping soil degradation on arable land with aerial photography and erosion models, case study from Danube Lowland, Slovakia. Remote Sensing, 2020. V. 12. No 24. \# 4047. DOI: 10.3390/rs12244047.

230. Jenny $B$. Terrain generalization with line integral convolution. Cartography and Geographic Information Science, 2020. V. 48. No 1. P. 78-92. DOI: 10.1080/15230406. 2020. 1833762.

231. Jenny B., Heitzler M., Singh D., Farmakis-Serebryakova M., Liu J.C., Hurni L. Cartographic relief shading with neural networks. IEEE Transactions on Visualization and Computer Graphics, 2020. V. 27. No 2. P. 1225-1235. DOI: 10.1109/TVCG.2020. 3030456. 
232. Karachevtseva I.P., Kozlova N.A., Kokhanov A.A., Zubarev A.E., Nadezhdina I.E., Patratiy V.D., Konopikhin A.A., Basilevsky A.T., Abdrakhimov A.M., Oberst J., Haase I., Jolliff B.L., Plescia J.B., Robinson M.S. Cartography of the Luna-21 landing site and Lunokhod-2 traverse area based on Lunar Reconnaissance Orbiter Camera images and surface archive TV-panoramas. Icarus, 2017. V. 283. P. 104-121. DOI: 10.1016/j.icarus. 2016.05.021.

233. Karátson D., Yepes J., Favalli M., Rodríguez-Peces M.J., Fornaciai A. Reconstructing eroded paleovolcanoes on Gran Canaria, Canary Islands, using advanced geomorphometry. Geomorphology, 2016. V. 253. P. 123-134. DOI: 10.1016/j. geomorph.2015.10.004.

234. Kasprak A., Bransky N.D., Sankey J.B., Caster J., Sankey T.T. The effects of topographic surveying technique and data resolution on the detection and interpretation of geomorphic change. Geomorphology, 2019. V. 333. P. 1-15. DOI: 10.1016/J.GEOMORPH. 2019.02.020.

235. Kasprak A., Caster J., Bangen S.G., Sankey J.B. Geomorphic process from topographic form: automating the interpretation of repeat survey data in river valleys. Earth Surface Processes and Landforms, 2017. V. 42. No 12. P. 1872-1883. DOI: 10.1002/esp.4143.

236. Kasvi E., Salmela J., Lotsari E., Kumpula T., Lane S.N. Comparison of remote sensing based approaches for mapping bathymetry of shallow, clear water rivers. Geomorphology, 2019. V. 333. P. 180-197. DOI: 10.1016/j.geomorph.2019.02.017.

237. Kennelly P.J., Patterson T., Jenny B., Huffman D.P., Marston B.E., Bell S., Tait A.M. Elevation models for reproducible evaluation of terrain representation. Cartography and Geographic Information Science, 2021. V. 48. No 1. P. 63-77. DOI: 10.1080/ 15230406.2020. 1830856.

238. Keylock C.J., Singh A., Passalacqua P., Foufoula-Georgiou E. Evaluating landscape complexity and the contribution of non-locality to geomorphometry. Journal of Geophysical Research: Earth Surface, 2021. V. 126. No 4. \# e2020JF005765. DOI: 10.1029/2020JF005765.

239. Khosravi K., Pham B.T., Chapi K., Shirzadi A., Shahabi H., Revhaug I., Prakash I., Tien Bui D. A comparative assessment of decision trees algorithms for flash flood susceptibility modeling at Haraz watershed, northern Iran. Science of the Total Environment, 2018. V. 627. P. 744-755. DOI: 10.1016/j.scitotenv.2018.01.266.

240. Kim Y.J., Nam B.H., Youn H. Sinkhole detection and characterization using LiDARderived DEM with logistic regression. Remote Sensing, 2019. V. 11. No 13. \# 1592. DOI: $10.3390 /$ rs 11131592 .

241. Kizyakov A., Khomutov A., Zimin M., Khairullin R., Babkina E., Dvornikov Y., Leibman $M$. Microrelief associated with gas emission craters: remote-sensing and field-based study. Remote Sensing, 2018. V. 10. No 5. \# 677. DOI: 10.3390/rs10050677.

242. Kizyakov A., Zimin M., Sonyushkin A., Dvornikov Y., Khomutov A., Leibman M. Comparison of gas emission crater geomorphodynamics on Yamal and Gydan Peninsulas (Russia), based on repeat very-high-resolution stereopairs. Remote Sensing, 2017. V. 9. No 10. \# 1023. DOI: 10.3390/rs9101023.

243. Knitter D., Braun R., Clare L., Nykamp M., Schütt B. Göbekli Tepe: a brief description of the environmental development in the surroundings of the UNESCO World Heritage Site. Land, 2019. V. 8. No 4. \# 72. DOI: 10.3390/land8040072.

244. Koriche S.A., Rientjes T.H.M. Application of satellite products and hydrological modelling for flood early warning. Physics and Chemistry of the Earth, Parts $A / B / C$, 2016. V. 93. P. 12-23. DOI: 10.1016/j.pce.2016.03.007.

245. Korzeniowska K., Pfeifer N., Landtwing S. Mapping gullies, dunes, lava fields, and 
landslides via surface roughness. Geomorphology, 2018. V. 301. P. 53-67. DOI: 10.1016/ j.geomorph.2017.10.011.

246. Kraaijenbrink P.D.A, Meijer S.W., Shea J.M., Pellicciotti F., De Jong S.M., Immerzeel $W . W$. Seasonal surface velocities of a Himalayan glacier derived by automated correlation of unmanned aerial vehicle imagery. Annals of Glaciology, 2016a. V. 57. No 71. P. 103-113. DOI: 10.3189/2016AoG71A072.

247. Kraaijenbrink P.D.A., Shea J.M., Litt M., Steiner J.F., Treichler D., Koch I., Immerzeel $W . W$. Mapping surface temperatures on a debris-covered glacier with an unmanned aerial vehicle. Frontiers in Earth Science, 2018. V. 6. \# 64. DOI: 10.3389/feart.2018.00064.

248. Kraaijenbrink P.D.A., Shea J.M., Pellicciotti F., de Jong S.M., Immerzeel W.W. Objectbased analysis of unmanned aerial vehicle imagery to map and characterise surface features on a debris-covered glacier. Remote Sensing of Environment, 2016b. V. 186. P. 581-595. DOI: 10.1016/j.rse.2016.09.013.

249. Lajczak A., Zarychta R., Watek G. Changes in the topography of Krakow city centre, Poland, during the last millennium. Journal of Maps, 2021. V. 17. DOI: 10.1080/17445647. 2020.1823253.

250. Lane B.A., Pasternack G.B., Dahlke H.E., Sandoval-Solis S. The role of topographic variability in river channel classification. Progress in Physical Geography, 2017. V. 41. No 5. P. 570-600. DOI: 10.1177/0309133317718133.

251. Lavagnino A.C., Bastos A.C., Amado Filho G.M., de Moraes F.C., Araujo L.S., de Moura R.L. Geomorphometric seabed classification and potential megahabitat distribution in the Amazon continental margin. Frontiers in Marine Science, 2020. V. 7. \# 190. DOI: 10.3389/fmars.2020.00190.

252. Lecours V., Dolan M.F.J., Micallef A., Lucieer V.L. A review of marine geomorphometry, the quantitative study of the seafloor. Hydrology and Earth System Sciences, 2016a. V. 20. No 8. P. 3207-3244. DOI: 10.5194/hess-20-3207-2016.

253. Lecours V., Brown C.J., Devillers R., Lucieer V.L., Edinger E.N. Comparing selections of environmental variables for ecological studies: a focus on terrain attributes. PLoS ONE, 2016b. V. 11. No 12. \# e0167128. DOI: 10.1371/journal.pone.0167128.

254. Lecours V., Devillers R., Edinger E.N., Brown C.J., Lucieer V.L. Influence of artefacts in marine digital terrain models on habitat maps and species distribution models: a multiscale assessment. Remote Sensing in Ecology and Conservation, 2017a. V. 3. No 4. P. 232-246. DOI: 10.1016/j.envsoft.2016.11.027.

255. Lecours V., Devillers R., Lucieer V.L., Brown C.J. Artefacts in marine digital terrain models: a multiscale analysis of their impact on the derivation of terrain attributes. IEEE Transactions on Geoscience and Remote Sensing, 2017b. V. 55. No 9. P. 5391-5406. DOI: 10.1109/TGRS.2017.2707303.

256. Lecours V., Devillers R., Simms A.E., Lucieer V.L., Brown C.J. Towards a framework for terrain attribute selection in environmental studies. Environmental Modelling and Software, 2017c. V. 89. P. 19-30. DOI: 10.1016/j.envsoft.2016.11.027.

257. Legleiter C.J., Harrison L.R. Remote sensing of river bathymetry: evaluating a range of sensors, platforms, and algorithms on the Upper Sacramento River, California, USA. Water Resources Research, 2019. V. 55, 3. P. 2142-2169. DOI: 10.1029/2018WR0 23586.

258. Lei S., Chen H., Bian Z., Liu Z. Evaluation of integrating topographic wetness index with backscattering coefficient of TerraSAR-X image for soil moisture estimation in a mountainous region. Ecological Indicators, 2016. V. 61. No 2. P. 624-633. DOI: 10.1016/j. ecolind. 2015.10. 013.

259. Leitão J.P., Moy de Vitry M., Scheidegger A., Rieckermann J. Assessing the quality of digital elevation models obtained from mini unmanned aerial vehicles for overland flow 
modelling in urban areas. Hydrology and Earth System Sciences, 2016. V. 20. No 4. P. 1637-1653. DOI: 10.5194/hess-20-1637-2016.

260. Li H., Zhao J. Evaluation of the newly released worldwide AW3D30 DEM over typical landforms of China using two global DEMs and ICESat/GLAS data. IEEE Journal of Selected Topics in Applied Earth Observations and Remote Sensing, 2018. V. 11. No 11. P. 4430-4440. DOI: 10.1109/JSTARS.2018.2874361.

261. Li S., Xiong L., Tang G., Strobl J. Deep learning-based approach for landform classification from integrated data sources of digital elevation model and imagery. Geomorphology, 2020. V. 354. \# 107045. DOI: 10.1016/j.geomorph.2020.107045.

262. Li Y., Li Y., Lu X., Harbor J. Geomorphometric controls on mountain glacier changes since the Little Ice Age in the Eastern Tien Shan, Central Asia. Annals of the American Association of Geographers, 2017. V. 107. No 2. P. 284-298. DOI: 10.1080/24694452. 2016.1248552.

263. Li Z., Zhu Q., Gold C. Digital Terrain Modeling: Principles and Methodology. New York: CRC Press, 2005. 323 p.

264. Liang J., Shen S., Gong J., Liu J., Zhang J. Embedding user-generated content into oblique airborne photogrammetry-based 3D city model. International Journal of Geographical Information Science, 2017. V. 31. No 1. P. 1-16. DOI: 10.1080/ 13658816.2016.1180389.

265. Libohova Z., Winzeler H.E., Lee B., Schoeneberger P.J., Datta J., Owens P.R. Geomorphons: landform and property predictions in a glacial moraine in Indiana landscapes. Catena, 2016. V. 142. P. 66-76. DOI: 10.1016/j.catena.2016.01.002.

266. Lin Y., Prentice S.E., Tran T., Bingham N.L., King J.Y., Chadwick O.A. Modeling deep soil properties on California grassland hillslopes using LiDAR digital elevation models. Geoderma Regional, 2016. V. 7. P. 67-75. DOI: 10.1016/J.GEODRS.2016.01.005.

267. Lindsay J.B. Efficient hybrid breaching-filling sink removal methods for flow path enforcement in digital elevation models. Hydrological Processes, 2016a. V. 30. No 6. P. 846-857. DOI: 10.1002/hyp.10648.

268. Lindsay J.B. The practice of DEM stream burning revisited. Earth Surface Processes and Landforms, 2016b. V. 41. No 5. P. 658-668. DOI: 10.1002/esp.3888.

269. Lindsay J.B. Whitebox GAT: a case study in geomorphometric analysis. Computers and Geosciences, 2016c. V. 95. P. 75-84. DOI: 10.1016/j.cageo.2016.07.003.

270. Liu K., Ding H., Tang G., Song C., Liu Y., Jiang L., Zhao B., Gao Y., Ma R. Large-scale mapping of gully-affected areas: an approach integrating Google Earth images and terrain skeleton information. Geomorphology, 2018. V. 314. P. 13-26. DOI: 10.1016/j. geomorph. 2018.04.011.

271. Liu K., Song C., Ke L., Jiang L., Ma R. Automatic watershed delineation in the Tibetan endorheic basin: a lake-oriented approach based on digital elevation models. Geomorphology, 2020a. V. 358. \# 107127. DOI: 10.1016/j.geomorph.2020.107127.

272. Liu K., Song C., Ke L., Jiang L., Pan Y., Ma R. Global open-access DEM performances in Earth's most rugged region High Mountain Asia: a multi-level assessment. Geomorphology, 2019. V. 338. P. 16-26. DOI: 10.1016/j.geomorph.2019.04.012.

273. Liu K., Song C., Wang J., Ke L., Zhu Y., Zhu J., Ma R., Luo Z. Remote sensing-based modeling of the bathymetry and water storage for channel-type reservoirs worldwide. Water Resources Research, 2020b. V. 56. No 11. \# e2020WR027147. DOI: 10.1029/2020WR027147.

274. Liu Y., Gong W., Hu X., Gong J. Forest type identification with random forest using Sentinel-1A, Sentinel 2A, multi-temporal Landsat-8 and DEM data. Remote Sensing, 2018. V. 10. No 6. \# 946. DOI: 10.3390/rs10060946. 
275. Loro M., Arce R.M., Ortega E. Identification of optimal landforms to reduce impacts on the landscape using LiDAR for hosting a new highway. Environmental Impact Assessment Review, 2017. V. 66. P. 99-114. DOI: 10.1016/j.eiar.2017.06.006.

276. Loye A., Jaboyedoff M., Theule J.I., Liébault F. Headwater sediment dynamics in a debris flow catchment constrained by high-resolution topographic surveys. Earth Surface Dynamics, 2016. V. 4. No 2. P. 489-513. DOI: 10.5194/esurf-4-489-2016.

277. Lu S., Liu B., Hu Y., Fu S., Cao Q., Shi Y., Huang T. Soil erosion topographic factor (LS): accuracy calculated from different data sources. Catena, 2020. V. 187. \# 104334. DOI: 10.1016/j.catena.2019.104334.

278. Lu X., Yang K., Lu Y., Gleason C.J., Smith L.C., Li M. Small Arctic rivers mapped from Sentinel-2 satellite imagery and ArcticDEM. Journal of Hydrology, 2020. V. 584. \# 124689. DOI: $10.1016 /$ j.jhydrol.2020.124689.

279. Luo L., Wang X., Guo H., Lasaponara R., Zong X., Masini N., Wang G., Shi P., Khatteli H., Chen F., Tariq S., Shao J., Bachagha N., Yang R., Yao Y. Airborne and spaceborne remote sensing for archaeological and cultural heritage applications: a review of the century (1907-2017). Remote Sensing of Environment, 2019. V. 232. \# 111280. DOI: 10.1016/j.rse.2019.111280.

280. Luo W., Jasiewicz J., Stepinski T., Wang J., Xu C., Cang X. Spatial association between dissection density and environmental factors over the entire conterminous United States. Geophysical Research Letters, 2016. V. 43. No 2. P. 692-700. DOI: 10.1002/ 2015 GL066941.

281. Luо $W$., Liu C.-C. Innovative landslide susceptibility mapping supported by geomorphon and geographical detector methods. Landslides, 2018. V. 15. No 3. P. 465-474. DOI: 10.1007/s10346-017-0893-9.

282. Luo W., Xu X., Liu W., Liu M., Li Z., Peng T., Xu C., Zhang Y., Zhang R. UAV based soil moisture remote sensing in a karst mountainous catchment. Catena, 2019. V. 174. P. 478-489. DOI: 10.1016/j.catena.2018.11.017.

283. Lv G., Xiong L., Chen M., Tang G., Sheng Y., Liu X., Song Z., Lu Y., Yu Z., Zhang K., Wang M. Chinese progress in geomorphometry. Journal of Geographical Sciences, 2017. V. 27. No 11. P. 1389-1412. DOI: 10.1007/s11442-017-1442-0.

284. Ma L., Liu Y., Zhang X., Ye Y., Yin G., Johnson B.A. Deep learning in remote sensing applications: a meta-analysis and review. ISPRS Journal of Photogrammetry and Remote Sensing, 2019. V. 152. P. 166-177. DOI: 10.1016/j.isprsjprs.2019.04.015.

285. Mallalieu J., Carrivick J., Quincey D., Smith M., James W. An integrated Structure-fromMotion and time-lapse technique for quantifying ice-margin dynamics. Journal of Glaciology, 2017. V. 63. No 242. P. 937-949. DOI: 10.1017/jog.2017.48.

286. Mallet F., Marc V., Douvinet J., Rossello P., Joly D., Ruy S. Assessing soil water content variation in a small mountainous catchment over different time scales and land covers using geographical variables. Journal of Hydrology, 2020. V. 591. \# 125593. DOI: 10.1016/ j.jhydrol.2020.125593.

287. Malone B.P., Jha S.K., Minasny B., McBratney A.B. Comparing regression-based digital soil mapping and multiple-point geostatistics for the spatial extrapolation of soil data. Geoderma, 2016. V. 262. P. 243-253. DOI: 10.1016/j.geoderma.2015.08.037.

288. Malone B.P., Styc Q., Minasny B., McBratney A.B. Digital soil mapping of soil carbon at the farm scale: a spatial downscaling approach in consideration of measured and uncertain data. Geoderma, 2017. V. 290. P. 91-99. DOI: 10.1016/j.geoderma.2016. 12.008 .

289. Marchese F., Bracchi V.A., Lisi G., Basso D., Corselli C., Savini A. Assessing fine-scale distribution and volume of Mediterranean algal reefs through terrain analysis of multi- 
beam bathymetric data. A case study in the Southern Adriatic continental shelf. Water, 2020. V. 12. No 1. \# 157. DOI: 10.3390/w12010157.

290. Marchi L., Comiti F., Crema S., Cavalli M. Channel control works and sediment connectivity in the European Alps. Science of the Total Environment, 2019. V. 668. P. 389-399. DOI: 10.1016/j.scitotenv.2019.02.416.

291. Marques K., Demattê J., Miller B.A., Lepsch I. Geomorphometric segmentation of complex slope elements for detailed digital soil mapping in Southeast Brazil. Geoderma Regional, 2018. V. 14. \# e00175. DOI: 10.1016/j.geodrs.2018.e00175.

292. Martini L., Picco L., Iroumé A., Cavalli M. Sediment connectivity changes in an Andean catchment affected by volcanic eruption. Science of the Total Environment, 2019. V. 692. P. 1209-1222. DOI: 10.1016/j.scitotenv.2019.07.303.

293. Masini N., Gizzi F.T., Biscione M., Fundone V., Sedile M., Sileo M., Pecci A., Lacovara $B$., Lasaponara $R$. Medieval archaeology under the canopy with LiDAR. The (re)discovery of a medieval fortified settlement in Southern Italy. Remote Sensing, 2018. V. 10. No 10. \# 1598. DOI: 10.3390/rs10101598.

294. Mather A.E., Fyfe R.M., Clason C.C., Stokes M., Mills S., Barrows T.T. Automated mapping of relict patterned ground: an approach to evaluate morphologically subdued landforms using unmanned-aerial-vehicle and structure-from-motion technologies. Progress in Physical Geography, 2019. V. 43. No 2. P. 174-192. DOI: 10.1177/ 030913331 8788966.

295. Maxwell A.E., Sharma M., Kite J.S., Donaldson K.A., Thompson J.A., Bell M.L., Maynard S.M. Slope failure prediction using random forest machine learning and LiDAR in an eroded folded mountain belt. Remote Sensing, 2020. V. 12. No 3. \# 486. DOI: $10.3390 /$ rs 12030486 .

296. Maxwell A.E., Warner T.A. Is high spatial resolution DEM data necessary for mapping palustrine wetlands? International Journal of Remote Sensing, 2019. V. 40. No 1. P. 118 137. DOI: $10.1080 / 01431161.2018 .1506184$.

297. McBratney A.B., Minasny B., Stockmann U. (eds.) Pedometrics. Cham: Springer, 2018. 720 p. DOI: $10.1007 / 978-3-319-63439-5$.

298. Meddens A.J.H., Vierling L.A., Eitel J.U.H., Jennewein J.S., White J.C., Wulder M.A. Developing $5 \mathrm{~m}$ resolution canopy height and digital terrain models from WorldView and ArcticDEM data. Remote Sensing of Environment, 2018. V. 218. P. 174-188. DOI: 10.1016/j.rse.2018.09.010.

299. Medvedev A., Telnova N., Alekseenko N., Koshkarev A., Kuznetchenko P., Asmaryan S., Narykov A. UAV-derived data application for environmental monitoring of the coastal area of Lake Sevan, Armenia with a changing water level. Remote Sensing, 2020. V. 12. No 22. \# 3821. DOI: 10.3390/rs12223821.

300. Meles M.B., Younger S.E., Jackson C.R., Du E., Drover D. Wetness index based on landscape position and topography (WILT): modifying TWI to reflect landscape position. Journal of Environmental Management, 2020. V. 255. \# 109863. DOI: 10.1016/j. jenvman. 2019.109863.

301. Menna F., Agrafiotis P., Georgopoulos A. State of the art and applications in archaeological underwater 3D recording and mapping. Journal of Cultural Heritage, 2018. V. 33. P. 231-248. DOI: 10.1016/j.culher.2018.02.017.

302. Mertes J.R., Gulley J.D., Benn D.I., Thompson S.S., Nicholson L.I. Using structure-frommotion to create glacier DEMs and orthoimagery from historical terrestrial and oblique aerial imagery. Earth Surface Processes and Landforms, 2017. V. 42. No 14. P. 23502364. DOI: $10.1002 /$ esp.4188.

303. Middleton M., Heikkonen J., Nevalainen P., Hyvönen E., Sutinen R. Machine learning- 
based mapping of micro-topographic earthquake-induced paleo-Pulju moraines and liquefaction spreads from a digital elevation model acquired through laser scanning. Geomorphology, 2020. V. 358. \# 107099. DOI: 10.1016/j.geomorph.2020.107099.

304. Midgley N.G., Tonkin T.N., Graham D.J., Cook S.J. Evolution of high-Arctic glacial landforms during deglaciation. Geomorphology, 2018. V. 311. P. 63-75. DOI: 10.1016/j. geomorph.2018.03.027.

305. Migoń P., Jancewicz K., Różycka M., Duszyński F., Kasprzak M. Large-scale slope remodelling by landslides - geomorphic diversity and geological controls, Kamienne Mts., Central Europe. Geomorphology, 2017. V. 289. P. 134-151. DOI: 10.1016/j. geomorph. 2016. 09.037.

306. Migoń P., Kasprzak M. Pathways of geomorphic evolution of sandstone escarpments in the Góry Stołowe tableland (SW Poland) - insights from LiDAR-based high-resolution DEM. Geomorphology, 2016. V. 260. P. 51-63. DOI: 10.1016/j.geomorph.2015.08. 022 .

307. Mills S.C., Le Brocq A.M., Winter K., Smith M., Hillier J., Ardakova E., Boston C.M., Sugden D., Woodward J. Testing and application of a model for snow redistribution (Snow_Blow) in the Ellsworth Mountains, Antarctica. Journal of Glaciology, 2019. V. 65. No 254. P. 957-970. DOI: 10.1017/jog.2019.70.

308. Minár J., Evans I.S., Jenčo M. A comprehensive system of definitions of land surface (topographic) curvatures, with implications for their application in geoscience modelling and prediction. Earth-Science Reviews, 2020. V. 211. \# 103414. DOI: 10.1016/j.earscirev. 2020. 103414.

309. Minár J., Krcho J., Evans I.S. Geomorphometry: quantitative land-surface analysis. Reference Module in Earth Systems and Environmental Sciences. Amsterdam: Elsevier, 2016. DOI: 10.1016/B978-0-12-409548-9.10260-X.

310. Minasny B., McBratney A.B. Digital soil mapping: a brief history and some lessons. Geoderma, 2016. V. 264. Pt. B. P. 301-311. DOI: 10.1016/j.geoderma.2015.07.017.

311. Misiuk B., Lecours V., Bell T. A multiscale approach to mapping seabed sediments. PLoS ONE, 2018. V. 13. No 2. \# e0193647. DOI: 10.1371/journal.pone.0193647.

312. Mithan H.T., Hales T.C., Cleall P.J. Supervised classification of landforms in Arctic mountains. Permafrost and Periglac Processes, 2019. V. 30. No 3. P. 131-145. DOI: 10.1002/ppp.2015.

313. Mitusov A.V., Burian L., Khrisanov V.R. Distribution of local landforms at head and end points of gullies on different grid spacing. Catena, 2017. V. 159. P. 159-170. DOI: 10.1016/ j.catena.2017.08.010.

314. Mohamed M.A. Classification of landforms for digital soil mapping in urban areas using LiDAR data derived terrain attributes: a case study from Berlin, Germany. Land, 2020. V. 9. No 9. \# 319. DOI: 10.3390/land9090319.

315. Mölg N., Bolch T. Structure-from-motion using historical aerial images to analyse changes in glacier surface elevation. Remote Sensing, 2017. V. 9. No 10. \# 1021. DOI: $10.3390 /$ rs9101021.

316. Mondal A., Khare D., Kundu S., Mukherjee S., Mukhopadhyay A., Mondal S. Uncertainty of soil erosion modelling using open source high resolution and aggregated DEMs. Geoscience Frontiers, 2017. V. 8. No 3. P. 425-436. DOI: 10.1016/j.gsf.2016.03.004.

317. Moon S., Perron J.T., Martel S.J., Holbrook W.S., St. Clair J. A model of threedimensional topographic stresses with implications for bed-rock fractures, surface processes, and landscape evolution. Journal of Geophysical Research: Earth Surface, 2017. V. 122. No 4, 823-846. DOI: 10.1002/2016JF004155.

318. Moore I.D., Grayson R.B., Ladson A.R. Digital terrain modelling: a review of 
hydrological, geomorphological and biological applications. Hydrological Processes, 1991. V. 5. No 1. P. 3-30. DOI: 10.1002/hyp.3360050103.

319. Moreno-Gómez M., Liedl R., Stefan C., Moreno-Gómez M., Liedl R., Stefan C. A new GIS-based model for karst dolines mapping using LiDAR; application of a multidepth threshold approach in the Yucatan Karst, Mexico. Remote Sensing, 2019. V. 11. No 10. \# 1147. DOI: $10.3390 /$ rs11101147.

320. Morlighem M., Williams C.N., Rignot E., An L., Arndt J.E., Bamber J.L., Catania G., Chauché N., Dowdeswell J.A., Dorschel B., Fenty I., Hogan K., Howat I., Hubbard A., Jakobsson M., Jordan T.M., Kjeldsen K.K., Millan R., Mayer L., Mouginot J., Noël B.P.Y., O'Cofaigh C., Palmer S., Rysgaard S., Seroussi H., Siegert M.J., Slabon P., Straneo F., van den Broeke M.R., Weinrebe W., Wood M., Zinglersen K.B. BedMachine v3: complete bed topography and ocean bathymetry mapping of Greenland from multibeam echo sounding combined with mass conservation. Geophysical Research Letters, 2017. V. 44. P. 11051-11061. DOI: 10.1002/2017GL074954.

321. Moudrý V., Lecours V., Gdulová K., Gábor L., Moudrá L., Kropáček J., Wild J. On the use of global DEMs in ecological modelling and the accuracy of new bare-earth DEMs. Ecological Modelling, 2018. V. 383. P. 3-9. DOI: 10.1016/j.ecolmodel.2018.05.006.

322. Mulder V.L., Lacoste M., Richer-de-Forges A.C., Arrouays D. GlobalSoilMap France: high-resolution spatial modelling the soils of France up to two meter depth. Science of the Total Environment, 2016a. V. 573. P. 1352-1369. DOI: 10.1016/j.scitotenv.2016.07. 066.

323. Mulder V.L., Lacoste M., Richer-de-Forges A.C., Martin M.P., Arrouays D. National versus global modelling the $3 \mathrm{D}$ distribution of soil organic carbon in mainland France. Geoderma, 2016b. V. 263. P. 16-34. DOI: 10.1016/j.geoderma.2015.08.035.

324. Müller R.D., Qin X., Sandwell D.T., Dutkiewicz A., Williams S.E., Flament N., Maus S., Seton $M$. The GPlates Portal: cloud-based interactive 3D visualization of global geophysical and geological data in a web browser. PLoS ONE, 2016. V. 11. No 3. \# e0150883, DOI: 10.1371/journal.pone.0150883.

325. Muthusamy M., Rivas Casado M., Butler D., Leinster P. Understanding the effects of digital elevation model resolution in urban fluvial flood modelling. Journal of Hydrology, 2021. V. 596. \# 126088. DOI: 10.1016/j.jhydrol.2021.126088.

326. Nachappa T.G., Kienberger S., Meena S.R., Hölbling D., Blaschke T. Comparison and validation of per-pixel and object-based approaches for landslide susceptibility mapping. Geomatics, Natural Hazards and Risk, 2020. V. 11. No 1. P. 572-600. DOI: 10.1080/ 19475705.2020.1736190.

327. Nagy-Reis M.B., Estevo C.A., Setz E.Z.F., Ribeiro M.C., Chiarello A.G., Nichols J.D. Relative importance of anthropogenic landscape characteristics for Neotropical frugivores at multiple scales. Animal Conservation, 2017a. V. 20. No 6. P. 520-531. DOI: $10.1111 /$ acv.12346.

328. Nagy-Reis M.B., Nichols J.D., Chiarello A.G., Ribeiro M.C., Setz E.Z.F. Landscape use and co-occurrence patterns of neotropical spotted cats. PLoS ONE, 2017b. V. 12. No 1.\# e0168441. DOI: 10.1371/journal.pone.0168441.

329. Nevalainen P., Middleton M., Sutinen R., Heikkonen J., Pahikkala T. Detecting terrain stoniness from airborne laser scanning data. Remote Sensing, 2016. V. 8. No 9. \# 720. DOI: $10.3390 /$ rs 8090720 .

330. Newman D.R., Lindsay J.B., Cockburn J.M.H. Evaluating metrics of local topographic position for multiscale geomorphometric analysis. Geomorphology, 2018. V. 312. P. 4050. DOI: 10.1016/j.geomorph.2018.04.003.

331. Nicoll T., Brierley $G$. Within-catchment variability in landscape connectivity measures in 
the Garang catchment, upper Yellow River. Geomorphology, 2017. V. 277. P. 197-209. DOI: $10.1016 /$ j.geomorph.2016.03.014.

332. Nicu I.C., Asăndulesei A. GIS-based evaluation of diagnostic areas in landslide susceptibility analysis of Bahluieţ River Basin (Moldavian Plateau, NE Romania): are Neolithic sites in danger? Geomorphology, 2018. V. 314. P. 27-41. DOI: 10.1016/j. geomorph. 2018.04.010.

333. Niculiţa $M$. Automatic landslide length and width estimation based on the geometric processing of the bounding box and the geomorphometric analysis of DEMs. Natural Hazards and Earth System Sciences, 2016. V. 16. No 8. P. 2021-2030. DOI: 10.5194/ nhess-16-2021-2016.

334. Niculiţă $M$. Geomorphometric methods for burial mound recognition and extraction from high-resolution LiDAR DEMs. Sensors, 2020. V. 20. No 4. \# 1192. DOI: 10.3390/s2004 1192.

335. Niculiţă M., Mărgărint M.C., Cristea A.I. Using archaeological and geomorphological evidence for the establishment of a relative chronology and evolution pattern for Holocene landslides. PLoS ONE, 2019. V. 14. No 12. \# e0227335. DOI: 10.1371/journal. pone. 0227335 .

336. Noriega-Londoño S., Restrepo-Moreno S.A., Vinasco C., Bermúdez M.A., Min K. Thermochronologic and geomorphometric constraints on the Cenozoic landscape evolution of the Northern Andes: Northwestern Central Cordillera, Colombia. Geomorphology, 2020. V. 351.\# 106890. DOI: 10.1016/j.geomorph.2019.106890.

337. Novaczek E., Devillers R., Edinger E. Generating higher resolution regional seafloor maps from crowd-sourced bathymetry. PLoS ONE, 2019. V. 14. No 6. \# e216792. DOI: 10.1371/ journal.pone.0216792.

338. Nussbaum M., Spiess K., Baltensweiler A., Grob U., Keller A., Greiner L., Schaepman M.E., Papritz A. Evaluation of digital soil mapping approaches with large sets of environmental covariates. Soil, 2018. V. 4. No 1. P. 1-22. DOI: 10.5194/soil-4-1-2018.

339. O'Loughlin F.E., Paiv R.C.D., Durand M., Alsdorf D.E., Bates P.D. A multi-sensor approach towards a global vegetation corrected SRTM DEM product. Remote Sensing of Environment, 2016. V. 182. P. 49-59. DOI: 10.1016/j.rse.2016.04.018.

340. O'Neil G.L., Goodall J.L., Watson L.T. Evaluating the potential for site-specific modification of LiDAR DEM derivatives to improve environmental planning-scale wetland identification using Random Forest classification. Journal of Hydrology, 2018. V. 559. P. 192-208. DOI: 10.1016/j.jhydrol.2018.02.009.

341. O'Neil G.L., Saby L., Band L.E., Goodall J.L. Effects of LiDAR DEM smoothing and conditioning techniques on a topography-based wetland identification model. Water Resources Research, 2019. V. 55. No 5. P. 4343-4363. DOI: 10.1029/2019WR024784.

342. O'Reilly D., Evans D., Shewan L. Airborne LiDAR prospection at Lovea, an Iron Age moated settlement in central Cambodia. Antiquity, 2017. V. 91. No 358. P. 947-965. DOI: 10.15184 /aqy.2017.69.

343. Orti M.V., Negussie K., Corral-Pazos-de-Provens E., Höfle B., Bubenzer O. Comparison of three algorithms for the evaluation of TanDEM-X data for gully detection in Krumhuk Farm (Namibia). Remote Sensing, 2019. V. 11. No 11. \# 1327. DOI: 10.3390/rs111113 27.

344. Owono F.M., Ntamak-Nida M.-J., Dauteuil O., Guillocheau F., Njom B. Morphology and long-term landscape evolution of the South African plateau in South Namibia. Catena, 2016. V. 142. P. 47-65. DOI: 10.1016/j.catena.2016.02.012.

345. Pacheco-Ruiz R., Adams J., Pedrotti F. 4D modelling of low visibility underwater archaeological excavations using multi-source photogrammetry in the Bulgarian Black 
Sea. Journal of Archaeological Science, 2018. V. 100. P. 120-129. DOI: 10.1016/j. jas.2018. 10.005.

346. Padarian J., Minasny B., McBratney A.B. Using deep learning for digital soil mapping. Soil, 2019. V. 5. No 1. P. 79-89. DOI: 10.5194/soil-5-79-2019.

347. Pánek T., Břežný M., Kapustová V., Lenart J., Chalupa V. Large landslides and deepseated gravitational slope deformations in the Czech Flysch Carpathians: new LiDARbased inventory. Geomorphology, 2019. V. 346. \# 106852. DOI: 10.1016/j.geomorph. 2019.106852.

348. Papageorgaki I., Nalbantis I. Classification of drainage basins based on readily available information. Water Resources Management, 2016. V. 30. No 15. P. 5559-5574. DOI: 10.1007/s11269-016-1410-y.

349. Papworth H., Ford A., Welham K., Thackray D. Assessing 3D metric data of digital surface models for extracting archaeological data from archive stereo-aerial photographs. Journal of Archaeological Science, 2016. V. 72. P. 85-104. DOI: 10.1016/j.jas. 2016.05.005.

350. Patton N.R., Ellerton D., Shulmeister J. High-resolution remapping of the coastal dune fields of south East Queensland, Australia: a morphometric approach. Journal of Maps, 2019. V. 15. No 2. P. 578-589. DOI: 10.1080/17445647.2019.1642246.

351. Patton N.R., Lohse K.A., Godsey S.E., Crosby B.T., Seyfried M.S. Predicting soil thickness on soil mantled hillslopes. Nature Communications, 2018. V. 9. \# 3329. DOI: 10.1038/s41467-018-05743-y.

352. Peckham S.D., Stoica M., Jafarov E., Endalamaw A., Bolton W.R. Reproducible, component-based modeling with TopoFlow, a spatial hydrologic modeling toolkit. Earth and Space Science, 2017. V. 4. No 6. P. 377-394. DOI: 10.1002/2016ea000237.

353. Pedersen G.B.M. Semi-automatic classification of glaciovolcanic landforms: an objectbased mapping approach based on geomorphometry. Journal of Volcanology and Geothermal Research, 2016. V. 311. P. 29-40. DOI: 10.1016/j.jvolgeores.2015.12.015.

354. Pedersen G.B.M., Grosse P., Gudmundsson M.T. Morphometry of glaciovolcanic edifices from Iceland: types and evolution. Geomorphology, 2020. V. 370. \# 107334. DOI: 10.1016/j.geomorph.2020.107334.

355. Pejović M., Nikolić M., Heuvelink G.B.M., Hengl T., Kilibarda M., Bajat B. Sparse regression interaction models for spatial prediction of soil properties in 3D. Computers and Geosciences, 2018. V. 118. P. 1-13. DOI: 10.1016/j.cageo.2018.05.008.

356. Penižek V., Zádorová T., Kodešová R., Vaněk A. Influence of elevation data resolution on spatial prediction of colluvial soils in a Luvisol region. PLoS ONE, 2016. V. 11. No 11.\# e0165699. DOI: 10.1371/journal.pone.0165699.

357. Petrasova A., Harmon B., Petras V., Tabrizian P., Mitasova H. Tangible Modeling with Open Source GIS. 2nd ed. Cham: Springer, 2018. 202 p. DOI: 10.1007/978-3-31989303-7.

358. Piccini C., Marchetti A., Rivieccio R., Napoli R. Multinomial logistic regression with soil diagnostic features and land surface parameters for soil mapping of Latium (Central Italy). Geoderma, 2019. V. 352. P. 385-394. DOI: 10.1016/j.geoderma.2018.09.037.

359. Piermattei L., Carturan L., de Blasi F., Tarolli P., Dalla Fontana G., Vettore A., Pfeifer N. Suitability of ground-based SfM-MVS for monitoring glacial and periglacial processes. Earth Surface Dynamics, 2016. V. 4. No 2. P. 425-443. DOI: 10.5194/esurf-4-425-2016.

360. Pijl A., Bailly J.-S., Feurer D., El Maaoui M.A., Boussema M.R., Tarolli P. TERRA: Terrain Extraction from elevation Rasters through Repetitive Anisotropic filtering. International Journal of Applied Earth Observation and Geoinformation, 2020. V. 84. \# 101977. DOI: 10.1016/J.JAG.2019.101977. 
361. Pike R.J. Geomorphometry - diversity in quantitative surface analysis. Progress in Physical Geography, 2000. V. 24. No 1. P. 1-20. DOI: 10.1177/030913330002400101.

362. Pike R.J. Digital terrain modeling and industrial surface metrology: converging realms. Professional Geographer, 2001. V. 53. No 2. P. 263-274. DOI: 10.1111/00330124.00284.

363. Podgórski J., Kinnard C., Pętlicki M., Urrutia R. Performance assessment of TanDEM-X DEM for mountain glacier elevation change detection. Remote Sensing, 2019. V. 11. No 2. \# 187. DOI: $10.3390 /$ rs11020187.

364. Polidori L., El Hage M. Digital elevation model quality assessment methods: a critical review. Remote Sensing, 2020. V. 12. No 21. \# 3522. DOI: 10.3390/rs12213522.

365. Popa C.N., Knitter D. From environment to landscape. Reconstructing environment perception using numerical data. Journal of Archaeological Method and Theory, 2016. V. 23. No 4. P. 1285-1306. DOI: 10.1007/s10816-015-9264-9.

366. Porter C., Morin P., Howat I., Noh M.-J., Bates B., Peterman K., Keesey S., Schlenk M., Gardiner J., Tomko K., Willis M., Kelleher C., Cloutier M., Husby E., Foga S., Nakamura H., Platson M., Wethington M. Jr., Williamson C., Bauer G., Enos J., Arnold G., Kramer W., Becker P., Doshi A., D'Souza C., Cummens P., Laurier F., Bojesen M. ArcticDEM. Harvard Dataverse, 2018. DOI: 10.7910/DVN/OHHUKH.

367. Pourtaghi Z.S., Pourghasemi H.R., Aretano R., Semeraro T. Investigation of general indicators influencing on forest fire and its susceptibility modelling using different data mining techniques. Ecological Indicators, 2016. V. 64. P. 72-84. DOI: 10.1016/j.eco lind.2015.12.030.

368. Puliti S., Hauglin M., Breidenbach J., Montesano P., Neigh C.S.R., Rahlf J., Solberg S., Klingenberg T.F., Astrup R. Modelling above-ground biomass stock over Norway using national forest inventory data with ArcticDEM and Sentinel-2 data. Remote Sensing of Environment, 2020. V. 236. \# 111501. DOI: 10.1016/j.rse.2019.111501.

369. Purinton B., Bookhagen B. Validation of digital elevation models (DEMs) and comparison of geomorphic metrics on the southern Central Andean Plateau. Earth Surface Dynamics, 2017. V. 5. No 2. P. 211-237. DOI: 10.5194/esurf-5-211-2017.

370. Qin C.-Z., Wu X.-W., Jiang J.-C., Zhu A-X. Case-based formalization and reasoning method for knowledge in digital terrain analysis: application to extracting drainage networks. Hydrology and Earth System Sciences, 2016. V. 20. No 8. P. 3379-3392. DOI: 10.5194/ hess-20-3379-2016.

371. Qin C.-Z., Ai B.-B., Zhu A-X., Liu J.-Z. An efficient method for applying a differential equation to deriving the spatial distribution of specific catchment area from gridded digital elevation models. Computers and Geosciences, 2017. V. 100. P. 94-102. DOI: 10.1016/j. cageo.2016.12.009.

372. Qin L., Xu W., Tian Y., Chen B., Wang S. A river channel extraction method for urban environments based on terrain transition lines. Water Resources Research, 2018. V. 54. No 7. P. 4887-4900. DOI: 10.1029/2018WR023095.

373. Queen C.W., Nelson F.E., Gunn G.E., Nyland K.E. A characteristic periglacial landform: automated recognition and delineation of cryoplanation terraces in eastern Beringia. Permafrost and Periglacial Processes, 2021. V. 32, No 1. P. 46-35. DOI: 10.1002/ ppp.2083.

374. Ragettli S., Bolch T., Pellicciotti F. Heterogeneous glacier thinning patterns over the last 40 years in Langtang Himal, Nepal. Cryosphere, 2016. V. 10. No 5. P. 2075-2097. DOI: 10.5194/tc-10-2075-2016.

375. Rahmati O., Ghorbanzadeh O., Teimurian T., Mohammadi F., Tiefenbacher J.P., Falah F., Pirasteh S., Ngo P.-T.T., Tien Bui D. Spatial modeling of snow avalanche using 
machine learning models and geo-environmental factors: comparison of effectiveness in two mountain regions. Remote Sensing, 2019. V. 11. No 24. \# 2995. DOI: 10.3390/rs 11242995.

376. Rahmati O., Pourghasemi H.R., Melesse A.M. Application of GIS-based data driven random forest and maximum entropy models for groundwater potential mapping: a case study at Mehran Region, Iran. Catena, 2016. V. 137. P. 360-372. DOI: 10.1016/j. catena.2015.10.010.

377. Ramcharan A., Hengl T., T Nauman., Brungard C., Waltman S., Wills S., Thompson J. Soil property and class maps of the conterminous United States at 100-meter spatial resolution. Soil Science Society of America Journal, 2018. V. 82. No 1. P. 186-201. DOI: 10.2136/sssaj 2017.04.0122.

378. Ren Z., Zielke O., Yu J. Active tectonics in 4D high-resolution. Journal of Structural Geology, 2018. V. 117. P. 264-271. DOI: 10.1016/j.jsg.2018.09.015.

379. Richards-Rissetto $H$. What can GIS + 3D mean for landscape archaeology? Journal of Archaeological Science, 2017. V. 84. P. 10-21. DOI: 10.1016/j.jas.2017.05.005.

380. Riza S., Sekine M., Kanno A., Yamamoto K., Imai T., Higuchi T. Modeling soil landscapes and soil textures using hyperscale terrain attributes. Geoderma, 2021. V. 402. \# 115177. DOI: 10.1016/j.geoderma.2021.115177.

381. Rizzoli P., Martone M., Gonzalez C., Wecklich C., Borla Tridon D., Bräutigam B., Bachmann M., Schulze D., Fritz T., Huber M., Wessel B., Krieger G., Zink M., Moreira $A$. Generation and performance assessment of the global TanDEM-X digital elevation model. ISPRS Journal of Photogrammetry and Remote Sensing, 2017. V. 132. P. 119139. DOI: $10.1016 /$ j.isprsjprs.2017.08.008.

382. Robbins S.J., Watters W.A., Chappelow J.E., Bray V.J., Daubar I.J., Craddock R.A., Beyer R.A., Landis M.E., Ostrach L.R., Tornabene L., Riggs J.D., Weaver B.P. Measuring impact crater depth throughout the Solar system. Meteoritics and Planetary Science, 2017. V. 53. No 4. P. 583-637. DOI: 10.1111/maps.12956.

383. Romero B.E., Clarke K.C. Exploring uncertainties in terrain feature extraction across multi-scale, multi-feature, and multi-method approaches for variable terrain. Cartography and Geographic Information Science, 2018. V. 45. No 5. P. 381-399. DOI: 10.1080/15230406. 2017.1335235.

384. Rossini M., Di Mauro B., Garzonio R., Baccolo G., Cavallini G., Mattavelli M., De Amicis M., Colombo R. Rapid melting dynamics of an alpine glacier with repeated UAV photogrammetry. Geomorphology, 2018. V. 304. P. 159-172. DOI: 10.1016/j.geomorph. 2017.12.039.

385. Rotnicka J., Dłużewski M., Dąbski M., Rodzewicz M., Włodarski W., Zmarz A. Accuracy of the UAV-based DEM of beach-foredune topography in relation to selected morphometric variables, land cover, and multitemporal sediment budget. Estuaries and Coasts, 2020. V. 43. No 8. P. 1939-1955. DOI: 10.1007/s12237-020-00752-x.

386. Roudier P., Malone B.P., Hedley C.B., Minasny B., McBratney A.B. Comparison of regression methods for spatial downscaling of soil organic carbon stocks maps. Computers and Electronics in Agriculture, 2017. V. 142. Pt. A. P. 91-100. DOI: 10.1016/j.compag. 2017.08.021.

387. Różycka M., Jancewicz K., Migoń P., Szymanowski M. Tectonic versus rock-controlled mountain fronts - geomorphometric and geostatistical approach (Sowie Mts., Central Europe). Geomorphology, 2021. V. 373. \# 107485. DOI: 10.1016/j.geomorph.2020. 107485.

388. Runyon K.D., Bridges N.T., Ayoub F., Newman C.E., Quade J.J. An integrated model for dune morphology and sand fluxes on Mars. Earth and Planetary Science Letters, 2017. V. 457. P. 204-212. DOI: 10.1016/J.EPSL.2016.09.054. 
389. Sam L., Bhardwaj A., Kumar R., Buchroithner M.F., Martín-Torres F.J. Heterogeneity in topographic control on velocities of Western Himalayan glaciers. Scientific Reports, 2018. V. 8. \# 12843. DOI: 10.1038/s41598-018-31310-y.

390. Samsonov T., Koshel S., Walther D., Jenny B. Automated placement of supplementary contour lines. International Journal of Geographical Information Science, 2019. V. 33. No 10. P. 2072-2093. DOI: 10.1080/13658816.2019.1610965.

391. Sărăşan A., Józsa E., Ardelean A.C., Drăguţ L. Sensitivity of geomorphons to mapping specific landforms from a digital elevation model: a case study of drumlins. Area, 2019. V. 51. No 2. P. 257-267. DOI: 10.1111/area.12451.

392. Sarmento E.C., Giasson E., Webster E.J., Flores C.A., Hasenack H. Regional disaggregating conventional soil maps with limited descriptive data: a knowledge-based approach in Serra Gaúcha, Brazil. Geoderma Regional, 2017. V. 8. P. 12-23. DOI: 10.1016/ j.geodrs.2016.12.004.

393. Šašak J., Gallay M., Kaňuk J., Hofierka J., Minár J. Combined use of terrestrial laser scanning and UAV photogrammetry in mapping alpine terrain. Remote Sensing, 2019. V. 11. No 18. \# 2154. DOI: 10.3390/rs11182154.

394. Scholten T., Goebes P., Kühn P., Seitz S., Assmann T., Bauhus J., Bruelheide H., Buscot F., Erfmeier A., Fischer M., Härdtle W., He J.-S., Ma K., Niklaus P.A., Scherer-Lorenzen M., Schmid B., Shi X., Song Z., von Oheimb G., Wirth C., Wubet T., Schmidt K. On the combined effect of soil fertility and topography on tree growth in subtropical forest ecosystems - a study from SE China. Journal of Plant Ecology, 2017. V. 10. No 1. P. 111-127. DOI: 10.1093/ jpe/rtw065.

395. Schumann G.J.-P., Bates P.D. The need for a high-accuracy, open-access global DEM. Frontiers in Earth Science, 2018. V. 6. \# 225. DOI: 10.3389/feart.2018.00225.

396. Seier G., Kellerer-Pirklbauer A., Wecht M., Hirschmann S., Kaufmann V., Lieb G.K., Sulzer $W$. UAS-based change detection of the glacial and proglacial transition zone at Pasterze Glacier, Austria. Remote Sensing, 2017. V. 9. No 6. \# 549. DOI: 10.3390/ rs9060549.

397. Sevara C., Verhoeven G., Doneus M., Draganits E. Surfaces from the visual past: recovering high-resolution terrain data from historic aerial imagery for multitemporal landscape analysis. Journal of Archaeological Method and Theory, 2018. V. 25. No 2. P. 611-642. DOI: 10.1007/s10816-017-9348-9.

398. Shary P.A. Land surface in gravity points classification by a complete system of curvatures. Mathematical Geology, 1995. V. 27. No 3. P. 373-390. DOI: 10.1007/BF 02084608.

399. Shary P.A., Sharaya L.S., Mitusov A.V. Fundamental quantitative methods of land surface analysis. Geoderma, 2002. V. 107. No 1/2. P. 1-32. DOI: 10.1016/S0016-7061(01) 00136-7.

400. Shary P.A., Sharaya L.S., Mitusov A.V. Predictive modeling of slope deposits and comparisons of two small areas in Northern Germany. Geomorphology, 2017. V. 290. P. 222-235. DOI: 10.1016/j.geomorph.2017.04.018.

401. Shen Q., Wang Y., Wang X., Liu X., Zhang X., Zhang S. Comparing interpolation methods to predict soil total phosphorus in the Mollisol area of Northeast China. Catena, 2019. V. 174. P. 59-72. DOI: 10.1016/j.catena.2018.10.052.

402. Shi $W$., Deng $S$., $X u W$. Extraction of multi-scale landslide morphological features based on local $G_{i}^{*}$ using airborne LiDAR-derived DEM. Geomorphology, 2018. V. 303. P. 229-242. DOI: 10.1016/j.geomorph.2017.12.005.

403. Shi Y., Katzschner $\mathrm{L}$., $\mathrm{Ng}$ E. Modelling the fine-scale spatiotemporal pattern of urban heat island effect using land use regression approach in a megacity. Science of the Total Environment, 2018. V. 618. P. 891-904. DOI: 10.1016/j.scitotenv.2017.08.252. 
404. Shi Y., Lau K.K.-L., $N g$ E. Incorporating wind availability into land use regression modelling of air quality in mountainous high-density urban environment. Environmental Research, 2017. V. 157. P. 17-29. DOI: 10.1016/j.envres.2017.05.007.

405. Silva O.L., Bezerra F.H.R., Maia R.P., Cazarin C.L. Karst landforms revealed at various scales using LiDAR and UAV in semi-arid Brazil: consideration on karstification processes and methodological constraints. Geomorphology, 2017. V. 295. P. 611-630. DOI: 10.1016/ J.GEOMORPH.2017.07.025.

406. Silva S.H.G., de Menezes M.D., Owens P.R., Curi N. Retrieving pedologist's mental model from existing soil map and comparing data mining tools for refining a larger area map under similar environmental conditions in Southeastern Brazil. Geoderma, 2016. V. 267. P. 65-77. DOI: 10.1016/j.geoderma.2015.12.025.

407. Singh K.K., Frazier A.E. A meta-analysis and review of unmanned aircraft system (UAS) imagery for terrestrial applications. International Journal of Remote Sensing, 2018. V. 39. No 15/16. P. 5078-5098. DOI: 10.1080/01431161.2017.1420941.

408. Sîrbu F., Drăguţ L., Oguchi T., Hayakawa Y., Micu M. Scaling land-surface variables for landslide detection. Progress in Earth and Planetary Science, 2019. V. 6. \# 44. DOI: 10.1186/s40645-019-0290-1.

409. Skrypitsyna T.N., Florinsky I.V., Beloborodov D.E., Gaydalenok O.V. Mud volcanism at the Taman Peninsula: multiscale analysis of remote sensing and morphometric data. Remote Sensing, 2020. V. 12. No 22. \# 3763. DOI: 10.3390/rs12223763.

410. Smith M.W., Carrivick J.L., Quincey D.J. Structure from motion photogrammetry in physical geography. Progress in Physical Geography, 2016. V. 40. No 2. P. 247-275. DOI: $10.1177 / 0309133315615805$.

411. Sofia G. Combining geomorphometry, feature extraction techniques and earth-surface processes research: the way forward. Geomorphology, 2020. V. 355. \# 107055. DOI: 10.1016/ j.geomorph.2020.107055.

412. Song X.-D., Brus D.J., Liu F., Li D.-C., Zhao Y.-G., Yang J.-L., Zhang G.-L. Mapping soil organic carbon content by geographically weighted regression: a case study in the Heihe River Basin, China. Geoderma, 2016. V. 261. P. 11-22. DOI: 10.1016/j.geoderma. 2015.06.024.

413. Sowers D.C., Masetti G., Mayer L.A., Johnson P., Gardner J.V., Armstrong A.A. Standardized geomorphic classification of seafloor within the United States Atlantic canyons and continental margin. Frontiers in Marine Science, 2020. V. 7. No 9. DOI: 10.3389/fmars.2020. 00009.

414. Strobl P. The new Copernicus digital elevation model. GSICS Quarterly, 2020. V. 14. No 1. P. 17-18. DOI: 10.25923/enp8-6w06.

415. Stumpf F., Schmidt K., Goebes P., Behrens T., Schönbrodt-Stittc S., Wadouxd A., Wei X., Scholten T. Uncertainty-guided sampling to improve digital soil maps. Catena, 2017. V. 153. P. 30-38. DOI: 10.1016/j.catena.2017.01.033.

416. Sun X.-L., Wang H.-L., Zhao Y.-G., Zhang C., Zhang G.-L. Digital soil mapping based on wavelet decomposed components of environmental covariates. Geoderma, 2017. V. 303. P. 118-132. DOI: 10.1016/j.geoderma.2017.05.017.

417. Szymanowski M., Jancewicz K., Różycka M., Migoń P. Geomorphometry-based detection of enhanced erosional signal in polygenetic medium-altitude mountain relief and its tectonic interpretation, the Sudetes (Central Europe). Geomorphology, 2019. V. 341. P. 115-129. DOI: 10.1016/j.geomorph.2019.05.022.

418. Tabrizian P., Baran P.K., van Berkel D., Mitasova H., Meentemeyer R. Modeling restorative potential of urban environments by coupling viewscape analysis of lidar data with experiments in immersive virtual environments. Landscape and Urban Planning, 2020. V. 195. \# 103704. DOI: 10.1016/j.landurbplan.2019.103704. 
419. Tadono T., Nagai H., Ishida H., Oda F., Naito S., Minakawa K., Iwamoto H. Generation of the $30 \mathrm{~m}$-mesh global digital surface model by ALOS PRISM. International Archives of the Photogrammetry, Remote Sensing and Spatial Information Sciences, 2016. V. 41. Pt. B4. P. 157-162. DOI: 10.5194/isprsarchives-XLI-B4-157-2016.

420. Tanyas H., Rossi M., Alvioli M., van Westena C.J., Marchesini I. A global slope unitbased method for the near real-time prediction of earthquake-induced landslides. Geomorphology, 2019. V. 327. P. 126-146. DOI: 10.1016/j.geomorph.2018.10.022.

421. Tapete D., Banks V., Jones L., Kirkham M., Garton D. Contextualising archaeological models with geological, airborne and terrestrial LiDAR data: the Ice Age landscape in Farndon Fields, Nottinghamshire, UK. Journal of Archaeological Science, 2017. V. 81. P. 31-48. DOI: 10.1016/j.jas.2017.03.007.

422. Tarolli P., Sofia G. Human topographic signatures and derived geomorphic processes across landscapes. Geomorphology, 2016. V. 255. P. 140-161. DOI: 10.1016/j.geomorph. 2015.12.007.

423. Tarolli P., Cao W., Sofia G., Evans D., Ellis E.C. From features to fingerprints: a general diagnostic framework for anthropogenic geomorphology. Progress in Physical Geography, 2019. V. 43. No 1. P. 95-128. DOI: 10.1177/0309133318825284.

424. Tarolli P., Cavalli M., Masin R. High-resolution morphologic characterization of conservation agriculture. Catena, 2019. V. 172. P. 846-856. DOI: 10.1016/j.catena. 2018.08.026.

425. Tesch P., Reece R.S., Pope M.C., Markello J.R. Quantification of architectural variability and controls in an Upper Oligocene to Lower Miocene carbonate ramp, Browse Basin, Australia. Marine and Petroleum Geology, 2018. V. 91. P. 432-454. DOI: 10.1016/j. marpetgeo. 2018.01.022.

426. Theodoratos N., Seybold H., Kirchner J.W. Scaling and similarity of a stream-power incision and linear diffusion landscape evolution model. Earth Surface Dynamics, 2018. V. 6. No 3. P. 79-808. DOI: 10.5194/esurf-6-779-2018.

427. Thistlewood H.M.A., Gill P., Beers E.H., Shearer P.W., Walsh D.B., Rozema B.M., Acheampong S., Castagnoli S., Yee W.L., Smytheman P., Whitener A.B. Spatial analysis of seasonal dynamics and overwintering of Drosophila suzukii (Diptera: Drosophilidae) in the Okanagan-Columbia Basin, 2010-2014. Environmental Entomology, 2018. V. 47. No 2. P. 221-232. DOI: 10.1093/ee/nvx178.

428. Thompson S., Benn D., Mertes J., Luckman A. Stagnation and mass loss on a Himalayan debris-covered glacier: processes, patterns and rates. Journal of Glaciology, 2016. V. 62. No 233. P. 467-485. DOI: 10.1017/jog.2016.37.

429. Thornton J.M., Mariethoz G., Brunner P. A 3D geological model of a structurally complex Alpine region as a basis for interdisciplinary research. Scientific Data, 2018. V. 5. \# 180238. DOI: 10.1038/sdata.2018.238.

430. Tien Bui D., Shirzadi A., Shahabi H., Chapi K., Omidavr E., Pham B.T., Asl D.T., Khaledian H., Pradhan B., Panahi M., Ahmad B.B., Rahmani H., Gróf G., Lee S. A novel ensemble artificial intelligence approach for gully erosion mapping in a semi-arid watershed (Iran). Sensors, 2019. V. 19. No 11. \# 2444. DOI: 10.3390/s19112444.

431. Tomczyk A.M., Ewertowski M.W. Surface morphological types and spatial distribution of fan-shaped landforms in the periglacial high-Arctic environment of Central Spitsbergen, Svalbard. Journal of Maps, 2017. V. 13. No 2. P. 239-251. DOI: 10.1080/17445647. 2017.1294543.

432. Tong R., Purser A., Guinan J., Unnithan V., Yu J., Zhang C. Quantifying relationships between abundances of cold-water coral Lophelia pertusa and terrain features: a case study on the Norwegian margin. Continental Shelf Research, 2016. V. 116. P. 13-26. DOI: 10.1016/j.csr. 2016.01.012. 
433. Tonkin T.N., Midgley N.G., Cook S.J., Graham D.J. Ice-cored moraine degradation mapped and quantified using an unmanned aerial vehicle: a case study from a polythermal glacier in Svalbard. Geomorphology, 2016. V. 258. P. 1-10. DOI: 10.1016/j. geomorph.2015.12.019.

434. Toso C., Madricardo F., Molinaroli E., Fogarin S., Kruss A., Petrizzo A., Pizzeghello N.M., Sinapi L., Trincardi F. Tidal inlet seafloor changes induced by recently built hard structures. PLoS ONE, 2019. V. 14. No 10. \# e0223240. DOI: 10.1371/journal. pone. 0223240 .

435. Toth C., Jóźków G. Remote sensing platforms and sensors: a survey. ISPRS Journal of Photogrammetry and Remote Sensing, 2016. V. 115. P. 22-36. DOI: 10.1016/j.isprsjprs. 2015.10.004.

436. Tozer B., Sandwell D.T., Smith W.H.F., Olson C., Beale J.R., Wessel P. Global bathymetry and topography at 15 arc seconds: SRTM15+. Earth and Space Science, 2019. V. 6. No 10. P. 1847-1864. DOI: 10.1029/2019EA000658.

437. Trevisani S., Cavalli M. Topography-based flow-directional roughness: potential and challenges. Earth Surface Dynamics, 2016. V. 4. No 2. P. 343-358. DOI: 10.5194/esurf4-343-2016.

438. Vajedian S., Motagh M. Extracting sinkhole features from time-series of TerraSARX/TanDEM-X data. ISPRS Journal of Photogrammetry and Remote Sensing, 2019. V. 150. P. 274-284. DOI: 10.1016/j.isprsjprs.2019.02.016.

439. Valentine A.P., Kalnins L.M. An introduction to learning algorithms and potential applications in geomorphometry and Earth surface dynamics. Earth Surface Dynamics, 2016. V. 4. P. 445-460. DOI: 10.5194/esurf-4-445-2016.

440. Valeriano M.M., Rossetti D.F. Regionalization of local geomorphometric derivations for geological mapping in the sedimentary domain of central Amazônia. Computers and Geosciences, 2017. V. 100. P. 46-56. DOI: 10.1016/j.cageo.2016.12.002.

441. Van der Sluijs J., Kokelj S.V., Fraser R.H., Tunnicliffe J., Lacelle D. Permafrost terrain dynamics and infrastructure impacts revealed by UAV photogrammetry and thermal imaging. Remote Sensing, 2018. V. 10. No 11.\# 1734. DOI: 10.3390/rs10111734.

442. Van Nieuwenhuizen N., Lindsay J.B., DeVries B. Automated mapping of transportation embankments in fine-resolution LiDAR DEMs. Remote Sensing, 2021. V. 13. No 7. \# 1308. DOI: $10.3390 /$ rs13071308.

443. Vassilaki D.I., Stamos A.A. TanDEM-X DEM: comparative performance review employing LIDAR data and DSMs. ISPRS Journal of Photogrammetry and Remote Sensing, 2020. V. 160. P. 33-50. DOI: 10.1016/j.isprsjprs.2019.11.015.

444. Vaz D.A., Silvestro S., Sarmento P.T.K., Cardinale M. Migrating meter-scale bedforms on Martian dark dunes: are terrestrial aeolian ripples good analogs? Aeolian Research, 2017. V. 26. P. 101-116. DOI: 10.1016/j.aeolia.2016.08.003.

445. Veitinger J., Purves R.S., Sovilla B. Potential slab avalanche release area identification from estimated winter terrain: a multi-scale, fuzzy logic approach. Natural Hazards and Earth System Sciences, 2016. V. 16. No 10. P. 2211-2225. DOI: 10.5194/nhess-16-2211-2016.

446. Vermeulen D., van Niekerk A. Machine learning performance for predicting soil salinity using different combinations of geomorphometric covariates. Geoderma, 2017. V. 299. P. 1-12. DOI: 10.1016/j.geoderma.2017.03.013.

447. Villaça C.V.N., Crósta A.P., Grohmann C.H. Morphometric analysis of Pluto's impact craters. Remote Sensing, 2021. V. 13. No 3. \# 377. DOI: 10.3390/rs13030377.

448. Viloria J.A., Viloria-Botello A., Pineda M.C., Valera A. Digital modelling of landscape and soil in a mountainous region: a neuro-fuzzy approach. Geomorphology, 2016. V. 253. P. 199-207. DOI: 10.1016/J.GEOMORPH.2015.10.007. 
449. Wagnon P., Shea J.M., Immerzeel W.W., Kraaijenbrink P., Shrestha D., Soruco A., Arnaud Y., Brun F., Berthier E., Sherpa S.F. Reduced melt on debris-covered glaciers: investigations from Changri Nup Glacier, Nepal. Cryosphere, 2016. V. 10. No 4. P. 1845-1858. DOI: 10.5194/tc-10-1845-2016.

450. Vincent S., Lemercier B., Berthier L., Walter C. Spatial disaggregation of complex soil map units at the regional scale based on soil-landscape relationships. Geoderma, 2018. V. 311. P. 130-142. DOI: 10.1016/j.geoderma.2016.06.006.

451. Waagen $J$. New technology and archaeological practice. Improving the primary archaeological recording process in excavation by means of UAS photogrammetry. Journal of Archaeological Science, 2019. V. 101. P. 11-20. DOI: 10.1016/j.jas. 2018.10.011.

452. Wadoux A.M.J.-C. Using deep learning for multivariate mapping of soil with quantified uncertainty. Geoderma, 2019. V. 351. P. 59-70. DOI: 10.1016/j.geoderma.2019.05.012.

453. Wadoux A.M.J.-C., Brus D.J., Heuvelink G.B.M. Accounting for non-stationary variance in geostatistical mapping of soil properties. Geoderma, 2018. V. 324. P. 138-147. DOI: 10.1016/j.geoderma.2018.03.010.

454. Wadoux A.M.J.-C., Padarian J., Minasny B. Multi-source data integration for soil mapping using deep learning. Soil, 2019. V. 5. No 1. P. 107-119. DOI: 10.5194/soil-5107-2019.

455. Walker S.J., Wilkinson S.N., van Dijk A.I.J.M., Hairsine P.B. A multi-resolution method to map and identify locations of future gully and channel incision. Geomorphology, 2020. V. 358. \# 107115. DOI: 10.1016/j.geomorph.2020.107115.

456. Wang J., Cheng W., Zhou C., Zheng X. Automatic mapping of lunar landforms using DEM-derived geomorphometric parameters. Journal of Geographical Sciences, 2017. V. 27. No 11. P. 1413-1427. DOI: 10.1007/s11442-017-1443-z.

457. Wang J., Kreslavsky M.A., Liu J., Head J.W., Zhang K., Kolenkina M.M., Zhang L. Quantitative characterization of impact crater materials on the Moon: changes in topographic roughness and thermophysical properties with age. Journal of Geophysical Research: Planets, 2020. V. 125. No 10. \# e2019JE006091. DOI: 10.1029/2019JE 006091.

458. Wang $S$., Hu Q., Wang F., Ai M., Zhong $R$. A microtopographic feature analysis-based LiDAR data processing approach for the identification of Chu tombs. Remote Sensing, 2017. V. 9. No 9. \# 880. DOI: 10.3390/rs9090880.

459. Watson C.S., Quincey D.J., Smith M., Carrivick J., Rowan A.V., James M. Quantifying ice cliff evolution with multi-temporal point clouds on the debris-covered Khumbu Glacier, Nepal. Journal of Glaciology, 2017. V. 63. No 241. P. 823-837. DOI: 10.1017/jog.2017.47.

460. Wei H., Zhou G., Fu S. Efficient Priority-Flood depression filling in raster digital elevation models. International Journal of Digital Earth, 2018. V. 12. No 4. P. 415-427. DOI: $10.1080 / 17538947.2018 .1429503$.

461. Westoby M.J., Dunning S.A., Woodward J., Hein A.S., Marrero S.M., Winter K., Sugden $D . E$. Interannual surface evolution of an Antarctic blue-ice moraine using multi-temporal DEMs. Earth Surface Dynamics, 2016. V. 4. No 2. P. 515-529. DOI: 10.5194/esurf-4515-2016.

462. Wiekenkamp I., Huisman J.A., Bogena H.R., Lin H.S., Vereecken H. Spatial and temporal occurrence of preferential flow in a forested headwater catchment. Journal of Hydrology, 2016. V. 534. P. 139-149. DOI: 10.1016/j.jhydrol.2015.12.050.

463. Wigmore O., Mark B. Monitoring tropical debris-covered glacier dynamics from highresolution unmanned aerial vehicle photogrammetry, Cordillera Blanca, Peru. Cryosphere, 2017. V. 11. No 6. P. 2463-2480. DOI: 10.5194/tc-11-2463-2017. 
464. Wilson J.P. Digital terrain modeling. Geomorphology, 2012. V. 137. No 1. P. 107-121. DOI: j.geomorph.2011.03.012.

465. Wilson J.P. Environmental Applications of Digital Terrain Modeling. Chichester: WileyBlackwell, 2018. 360 p.

466. Wilson J.P., Gallant J.C. (eds.) Terrain Analysis: Principles and Applications. New York: Wiley, 2000. $479 \mathrm{p}$.

467. Wing O.E.J., Bates P.D., Neal J.C., Sampson C.C., Smith A.M., Quinn N., Shustikova I., Domeneghetti A., Gilles D.W., Goska R., Krajewski W.F. A new automated method for improved flood defense representation in large-scale hydraulic models. Water Resources Research, 2019. V. 55. P. 11007-11034. DOI: 2019WR025957.

468. Wölfl A.-C., Snaith H., Amirebrahimi S., Devey C.W., Dorschel B., Ferrini V., Huvenne V.A.I., Jakobsson M., Jencks J., Johnston G., Lamarche G., Mayer L., Millar D., Pedersen T.H., Picard K., Reitz A., Schmitt T., Visbeck M., Weatherall P., Wigley R. Seafloor mapping - the challenge of a truly global ocean bathymetry. Frontiers in Marine Science, 2019. V. 6. \# 283. DOI: 10.3389/fmars.2019.00283.

469. Woodrow K., Lindsay J.B., Berg A.A. Evaluating DEM conditioning techniques, elevation source data, and grid resolution for field-scale hydrological parameter extraction. Journal of Hydrology, 2016. V. 540. P. 1022-1029. DOI: 10.1016/j.jhydrol.2016.07.018.

470. Wu Q., Chen Y., Wilson J.P., Liu X., Li H. An effective parallelization algorithm for DEM generalization based on CUDA. Environmental Modelling and Software, 2019. V. 114. P. 64-74. DOI: 10.1016/j.envsoft.2019.01.002.

471. $W u Q$., Deng $C$., Chen $Z$. Automated delineation of karst sinkholes from LiDAR-derived digital elevation models. Geomorphology, 2016. V. 266. P. 1-10. DOI: 10.1016/j. geomorph. 2016.05.006.

472. Xiang J., Li S., Xiao K., Chen J., Sofia G., Tarolli P. Quantitative analysis of anthropogenic morphologies based on multitemporal high-resolution topography. Remote Sensing, 2019. V. 11. No 12. \# 1493. DOI: 10.3390/rs11121493.

473. Xiang T.-Z., Xia G.-S., Zhang L. Mini-unmanned aerial vehicle-based remote sensing: techniques, applications, and prospects. IEEE Geoscience and Remote Sensing Magazine, 2019. V. 7. No 3. P. 29-63. DOI: 0.1109/MGRS.2019.2918840.

474. Xiong L.-Y., Jiang R.-Q., Lu Q.-H., Yang B.-S., Li F.-Y., Tang G.-A. Improved PriorityFlood method for depression filling by redundant calculation optimization in local microrelief areas. Transactions in GIS, 2019. V. 23. No 2. P. 259-274. DOI: 10.1111/ tgis. 12516.

475. Xiong L.-Y., Tang G.-A., Strobl J., Zhu A-X. Paleotopographic controls on loess deposition in the Loess Plateau of China. Earth Surface Processes and Landforms, 2016. V. 41. No 9. P. 1155-1168. DOI: 10.1002/esp.3883.

476. Xiong L.-Y., Tang G.-A., Zhu A.-X., Qian Y.-Q. A peak-cluster assessment method for the identification of upland planation surfaces. International Journal of Geographical Information Science, 2017. V. 31. No 2. P. 387-404. DOI: 10.1080/13658816. 2016.1205193.

477. Xu H., van der Steeg S., Sullivan J., Shelley D., Cely J.E., Viparelli E., Lakshmi V., Torres $R$. Intermittent channel systems of a low-relief, low-gradient floodplain: comparison of automatic extraction methods. Water Resources Research, 2020. V. 56. No 9. \# e2020WR027603. DOI: 10.1029/2020WR027603.

478. Xue Y., Jing Z., Kang S., He X., Li C. Combining UAV and Landsat data to assess glacier changes on the central Tibetan Plateau. Journal of Glaciology, 2021. V. 67. DOI: 10.1017/jog.2021.37.

479. Yamafune K., Torres R., Castro F. Multi-image photogrammetry to record and 
reconstruct underwater shipwreck sites. Journal of Archaeological Method and Theory, 2017. V. 24. No 3. P. 703-725. DOI 10.1007/s10816-016-9283-1.

480. Yamazaki D., Ikeshima D., Tawatari R., Yamaguchi T., O’Loughlin F., Neal J.C., Sampson C.C., Kanae S., Bates P.D. A high-accuracy map of global terrain elevations. Geophysical Research Letters, 2017. V. 44. No 11. P. 5844-5853. DOI: 10.1002 /2017GL072874.

481. Yang X., Tang G., Meng X., Xiong L. Classification of karst Fenglin and Fengcong landform units based on spatial relations of terrain feature points from DEMs. Remote Sensing, 2019. V. 11, 16. \# 1950. DOI: 10.3390/rs11161950.

482. Yao H., Qin R., Chen $X$. Unmanned aerial vehicle for remote sensing applications - a review. Remote Sensing, 2019. V. 11. No 12.\# 1443. DOI: 10.3390/rs11121443.

483. Yeomans C.M., Middleton M., Shail R.K., Grebby S., Lusty P.A.J. Integrated object-based image analysis for semi-automated geological lineament detection in southwest England. Computers and Geosciences, 2019. V. 123. P. 137-148. DOI: 10.1016/j.cageo.2018. 11.005 .

484. Yue L., Shen H., Zhang L., Zheng X., Zhang F., Yuan Q. High-quality seamless DEM generation blending SRTM-1, ASTER GDEM v2 and ICESat/GLAS observations. ISPRS Journal of Photogrammetry and Remote Sensing, 2017. V. 123. P. 20-34. DOI: 10.1016/j. isprsjprs.2016.11.002.

485. Zabihi M., Mirchooli F., Motevalli A., Darvishan A.K., Pourghasemi H.R., Zakeri M.A., Sadighi F. Spatial modelling of gully erosion in Mazandaran Province, northern Iran. Catena, 2018. V. 161. P. 1-13. DOI: 10.1016/j.catena.2017.10.010.

486. Žabota B., Repe B., Kobal M. Influence of digital elevation model resolution on rockfall modelling. Geomorphology, 2019. V. 328. P. 183-195. DOI: 10.1016/j.geomorph. 2018.12.029.

487. Zhai R., Lu K., Pan $W$., Dai S. GPU-based real-time terrain rendering: design and implementation. Neurocomputing, 2016. V. 171. P. 1-8. DOI: 10.1016/j. neucom. 2014.08.108.

488. Zhang F., Zhou Q., Li Q., Wu G., Liu J. An enhanced approach for surface flow routing over drainage-constrained triangulated irregular networks. Transactions in GIS, 2018. V. 22. No 1. P. 43-57. DOI: 10.1111/tgis.12294.

489. Zhang H., Yao Z., Yang Q., Li S., Baartman J.E.M., Gai L., Yao M., Yang X., Ritsema C.J., Geissen $V$. An integrated algorithm to evaluate flow direction and flow accumulation in flat regions of hydrologically corrected DEMs. Catena, 2017. V. 151. P. 174-181. DOI: 10.1016/j.catena.2016.12.009.

490. Zhang H., Zhang P., Prush V., Zheng D., Zheng W., Wang W., Liu C., Ren Z. Tectonic geomorphology of the Qilian Shan in the northeastern Tibetan Plateau: insights into the plateau formation processes. Tectonophysics, 2017. V. 706-707. P. 103-115. DOI: 10.1016/j.tecto. 2017.04.016.

491. Zhang L., Zhang L., Du B. Deep learning for remote sensing data: a technical tutorial on the state of the art. IEEE Geoscience and Remote Sensing Magazine, 2016. V. 4. No 2. P. 22-40. DOI: 10.1109/MGRS.2016.2540798.

492. Zhang S., Foerster S., Medeiros P., Araújo J.C., Motagh M., Waske B. Bathymetric survey of water reservoirs in north-eastern Brazil based on TanDEM-X satellite data. Science of the Total Environment, 2016. V. 571. P. 575-593. DOI: 10.1016/j.scitotenv.2016.07.024.

493. Zhao D., Wu Z., Zhou J., Zhang K., Luo X., Wang M., Liu Y., Zhu C. From $10 \mathrm{~m}$ to 11000 $\mathrm{m}$, automatic processing multi-beam bathymetric data based on PGO method. IEEE Access, 2021. V. 9. P. 14516-14527. DOI: 10.1109/ACCESS.2021.3051909. 
494. Zhong C., Liu Y., Gao P., Chen W., Li H., Hou Y., Nuremanguli T., Ma H. Landslide mapping with remote sensing: challenges and opportunities. International Journal of Remote Sensing, 2020. V. 41. No 4. P. 1555-1581. DOI: 10.1080/01431161. 2019.1672904.

495. Zhou G., Liu X., Fu S., Sun Z. Parallel identification and filling of depressions in raster digital elevation models. International Journal of Geographical Information Science, 2017. V. 31. No 6. P. 1061-1078. DOI: 10.1080/13658816.2016.1262954.

496. Zhou G., Sun Z., Fu S. An efficient variant of the Priority-Flood algorithm for filling depressions in raster digital elevation models. Computers and Geosciences, 2016. V. 90. Pt. A. P. 87-96. DOI: 10.1016/j.cageo.2016.02.021.

497. Zhou X., Li W., Arundel S.T. A spatio-contextual probabilistic model for extracting linear features in hilly terrains from high-resolution DEM data. International Journal of Geographical Information Science, 2019. V. 33. No 4. P. 666-686. DOI: 10.1080/ 13658816.2018 .1554814$.

498. Zhou Y., Li Z., Li J. Slight glacier mass loss in the Karakoram region during the 1970s to 2000 revealed by KH-9 images and SRTM DEM. Journal of Glaciology, 2017. V. 63. \# 238. P. 331-342. DOI: 10.1017/jog.2016.142.

499. Zumpano $V$., Pisano L., Parise $M$. An integrated framework to identify and analyze karst sinkholes. Geomorphology, 2019. V. 332. P. 213-225. DOI: 10.1016/j.geomorph. 2019.02.013.

500. Zwolak K., Wigley R., Bohan A., Zarayskaya Y., Bazhenova E., Dorshow W., Sumiyoshi M., Sattiabaruth S., Roperez J., Procto A., Wallace C., Sade H., Ketter T., Simpson B., Tinmouth N., Falconer R., Ryzhov I., Abou-Mahmoud M.E. The autonomous underwater vehicle integrated with the unmanned surface vessel mapping the Southern Ionian Sea. The winning technology solution of the Shell Ocean Discovery XPRIZE. Remote Sensing, 2020. V. 12. No 8. \# 1344. DOI: 10.3390/rs12081344. 
СОДЕРЖАНИЕ

\section{АТЛАСНОЕ И ГЕОИНФОРМАЦИОННОЕ \\ КАРТОГРАФИРОВАНИЕ}

Черкасов А.A.

Атласная информационная система «Большие города России»: особенности разработки и возможности применения

Кузнечова Т.И.

Информационно-картографическое обеспечение исследования потенциальных трансформаций геосистем для цифрового атласа «Байкальский регион: общество и природа»

Нокелайнен T.C.

Школьное атласное картографирование для образования в интересах устойчивого развития: тема «Лесные ресурсы мира и сохранение их биоразнообразия»

Спесивиев Д.С., Ларин Е.Г.

Разработка картографического веб-сервиса природного парка «Кондинские озера»

Вольхин Д.А., Воронин И.Н., Собокарь Н.А.

Опыт картографирования Крымского регионального рынка СМИ

Цыдыпова М.В.

Создание научно-образовательного геопортала

Бурятского государственного университета

Лебедева М.Г., Корнилов А.Г., Петина М.А., Вендина Т.Н.

«Географический атлас Белгородской области: природа, общество, хозяйство» как информационная основа реализации политики устойчивого развития региона

Грушина А.В., Тесленок С.А., Муштайкин А.П.

Использование современных технологий для создания электронного атласа административного района

Нокелайнен T.C.

Картографирование сезонной автотранспортной доступности

Арктического региона России

\section{НОВЫЕ МЕТОДЫ И ПОДХОДЫ В КАРТОГРАФИИ И ГЕОИНФОРМАТИКЕ}

Обухов Л.А., Паниди Е.А.

О контроле корректности при геокодировании почтовых адресов 
Карпик А.П., Лисиикий Д.В., Осипов А.Г., Савиных В.Н.

Геокогнитивные методы обеспечения анализа и прогнозирования социально-

экономического развития территорий

Рьльский И.А., Груздев Р.В., Котова Т.В.

Расчет гравитационных поправок с использованием данных воздушного лазерного сканирования

Фазилова Д.Ш., Магдиев Х.Н.

Создание и обновление высотной основы топографических карт в национальной

пространственной системе координат: на примере Ферганской долины

Yalbacheva M.M.

The assessment of the Bostanliq district (Uzbekistan Republic)

based on the wind energy potential

Щербакова Т.К., Супрунчук И.П.

Использование ГИС-технологий для оценки уровня географического

образования региона (на примере олимпиады СКФУ «45 параллель»)

Шеремет Э.А., Калуиякова Н.Н., Дехнич В.С.

Визуальные свойства ландшафтов и методы их оценки с применением ГИС

(на примере Белоградчишских скал (Болгария))

Кадочников А.А.

Разработка системы сбора данных для мониторинга состояния

атмосферного воздуха в Красноярском крае

Нарожняя А.Г.

Морфометрический анализ рельефа бассейнов рек Крыма

с использованием ГИС

Hasan M.

Using Social Media Data to Map Mortar Shells Falling in Damascus, Syria

Кондратьева М.А., Чащиин А.Н.

Оценка эрозионной опасности рельефа на основе цифрового моделирования

Самсонов Т.Е., Якимова О.П.

Анализ эффективности ограничивающих метрик алгоритмов

геометрического упрощения на основе экспертной оценки детализации линий

Якимова О.П., Самсонов Т.Е., Потемкин Д.А., Усманова Э.

Инструменты для оценки детализации карт для геоинформационной системы QGIS 
Ивлиева Н.Г., Манухов В.Ф., Примаченко Е.И.

Об использовании ГИС-инструментария в практическом курсе математикокартографического моделирования

Козин С.С., Макеев С.М., Маркин Д.О.

Моделирование процесса позиционирования источников радиосигналов в геоинформационных системах

Карпачевский А.М., Титов Г.С.

Проектирование базы пространственно-временных данных о магистральных электрических сетях России

Грибок М.В.

Выбросы загрязняющих веществ в атмосферу от стационарных источников: анализ возможностей визуализации с помощью интерактивной инфографики

Гафуров А.М., Ермолаев О.П., Усманов Б.М., Хомяков П.В.

Создание высокоточных цифровых моделей высот с использованием ГНСС-БПЛА

Гизатуллин А.T.

Разработка методики предупреждения природных пожаров по данным дистанционного зондирования на примере лесов Красноярского края

Рьгалова Н.В., Плуталова Т.Г.

Оценка связи NDVI степной растительности и радиального прироста сосны ленточных боров в засушливых условиях юга Западной Сибири

Украинский П.А.

Эмпирический метод определение оптимального размера случайной точечной выборки для оценки площадей земельных угодий по космическим снимкам

Тесленок К.С., Тесленок С.А., Терешкин И.П., Дмитриев П.С.

Возможности использования сервиса Google (Мои карты) для картографической визуализации туристических маршрутов

Флоринский И.В.

Геоморфометрия сегодня 


\section{CONTENTS $^{1}$}

\section{ATLAS AND GEOINFORMATION}

MAPPING

Aleksandr A. Cherkasov

Atlas information system «Big cities of Russia»: features

Tatiana I. Kuznetsova

Information-cartographic support for studying of potential transformations

Nokelaynen T.S.

School atlas mapping for education for sustainable development: topic

"World forest resources and biodiversity conservation"

Spesivtsev D.S., Larin E.G.

Design and development of the Kondinsky lakes nature park's web map service

Volkhin D.A., Voronin I.N., Sobokar N.S.

Tsydypova M.V.

Creation of a scientific and educational geoportal

Lebedeva M.G., Kornilov A.G., Petina M.A., Vendina T.N.

«Geographical atlas of the Belgorod region: nature, society, economy» as an

Grushina A.W., Teslenok S.A., Mushtaykin A.P.

Using modern technologies to create an electronic atlas

Nokelaynen T.S.

Mapping of seasonal road transport accessibility in the Arctic

\section{NEW METHODS AND APPROACHES IN CARTOGRAPHY AND GEOINFORMATICS}

Obuhov L., Panidi E.

Toward correctness control of postal addresses geocoding 
Karpik A.P., Lisitsky D.V., Osipov A.G., Savinykh V.N.

Geo-cognitive methods of providing analysis and forecasting

Fazilova D.Sh., Magdiev K.N.

Creating and updating of topographic maps height base in the new national

Yalbacheva M.M.

The assessment of the Bostanliq district (Uzbekistan Republic)

based on the wind energy potential

Shcherbakova T.K., Suprunchuk I.P.

The use of GIS technologies to assess the level of geographical education

in the region (on the example of the NCFU olympiad «45 parallel»)

Sheremet E.A., Kalutskova N.N., Dekhnich V.S.

Visual characteristics of landscapes and methods for their assessment on GIS

(Belogradchik rocks (Bulgaria) as an example)

Kadochnikov A.A.

Development of data collection system for monitoring the atmospheric air state

Narozhnyaya A.G.

Morphometric analysis of the Crimean river basins relief by using GIS

Hasan $M$.

Using Social Media Data to Map Mortar Shells Falling in Damascus, Syria

Kondrateva M.A., Chashchin A.N.

Assessment of erosion risk of relief based on the digital modeling

Samsonov T.E., Yakimova O.P.

Analysis of the effectiveness of constraining metrics of geometric simplification

algorithms based on expert evaluation of line detail

Yakimova O.P., Samsonov T.E., Potemkin D.A., Usmanova E.

QGIS processing tool for spatial data detail assessment

Ivlieva N.G., Manukhov V.F., Primachenko E.I.

About using GIS tools in the practical course of mathematical 
Kozin S.S., Makeev S.M., Markin D.O.

Modeling the process of positioning of radio signal sources

Karpachevskiy A.M., Titov G.S.

Spatio-temporal database design for backbone power grid

Gribok M.V.

Air pollution from stationary sources: analysis of visualization capabilities using interactive infographics

Gafurov A.M., Yermolayev O.P., Usmanov B.M.,

Khomyakov P.V.

Creation of high-precision digital elevation models using the GNSS UAV

Gizatullin A.T.

Development of natural fire prevention method based on remote sensing data:

Rygalova N.V., Plutalova T.G.

Estimation of the relation of NDVI steppe vegetation and radial growth of

Ukrainskiy P.A.

Empirical method for estimation of the optimum size of random

point samples for assessment areas of land cover from

space images

Teslenok K.S., Teslenok S.A., Tereshkin I.P., Dmitriyev P.S.

Possibilities of using Google (My maps) for cartographic visualization 


\section{Серия конференций ИнтерКарто. ИнтерГИС}

ИнтерКарто 1 - Москва, 23-25 мая 1994 г.

ИнтерКарто 2 - Иркутск, 26-29 июня 1996 г.

ИнтерКарто 3 - Новосибирск, 27-31 января 1997 г.

ИнтерКарто 4 - Барнаул, 1-4 июля 1998 г.

ИнтерКарто 5 - Якутск, 17-19 июня 1999 г.

ИнтерКарто 6 - Апатиты, Мурманской обл., 22-24 августа 2000 г.

ИнтерКарто 7 - Петропавловск-Камчатский, 30 июля - 1 августа 2001 г.

ИнтерКарто 8 - Хельсинки (Финляндия), Санкт-Петербург, 28 мая - 1 июня 2002 г.

ИнтерКарто 9 - Новороссийск, Севастополь (Украина), 25-29 июня 2003 г.

ИнтерКарто. ИнтерГИС 10 - Владивосток, Чанчунь (Китай), 12-19 июля 2004 г.

ИнтерКарто. ИнтерГИС 11 - Ставрополь, Домбай, Будапешт (Венгрия), 25 сентября - 3 октября 2005 г.

ИнтерКарто. ИнтерГИС 12 - Калининград, Берлин (Германия), 25-31 августа 2006 г.

ИнтерКарто. ИнтерГИС 13 - Ханты-Мансийск, Йеллоунайф (Канада), 12-24 августа 2007 г.

ИнтерКарто. ИнтерГИС 14 - Саратов, Урумчи (Китай), 24 июня - 1 июля 2008 г.

ИнтерКарто. ИнтерГИС 15 - Пермь, Гент (Бельгия), 29 июня - 5 июля 2009 г.

ИнтерКарто. ИнтерГИС 16 - Ростов-на-Дону, Зальцбург (Австрия), 3-8 июля 2010 г.

ИнтерКарто. ИнтерГИС 17 - Белокуриха, Алтайский край, Денпасар (Индонезия), 14-19 декабря 2011 г.

ИнтерКарто. ИнтерГИС 18 - Смоленск, Сен-Дье-де-Вож (Франция), 26 июня - 4 июля 2012 г.

ИнтерКарто. ИнтерГИС 19 - Курск, Богота (Колумбия), 2-7 февраля 2013 г.

ИнтерКарто. ИнтерГИС 20 - Белгород, Харьков (Украина), Кигали (Руанда), Найроби (Кения), 23 июля - 6 августа 2014 г.

ИнтерКарто. ИнтерГИС 21 - Краснодар, Сочи, Сува (Фиджи), 12-19 ноября 2015 г.,

ИнтерКарто. ИнтерГИС 22 - Веллингтон (Новая Зеландия), Мельбурн (Австралия), Протвино (Московская обл.), 31 августа - 14 сентября 2016 г.

ИнтерКарто. ИнтерГИС 23 - Южно-Сахалинск, Сеул (Республика Корея), Вашингтон (США), 26 июня - 7 июля 2017 г.

ИнтерКарто. ИнтерГИС 24 - Петрозаводск (Республика Карелия), 19-22 июля, Бонн (Германия), 24-28 июля, Анкоридж (США), 30 июля - 1 августа 2018 г.

ИнтерКарто. ИнтерГИС 25 - Мурманск, 30 января - 2 февраля, Токио (Япония), 20 июля 2019 г.

ИнтерКарто. ИнтерГИС 26 - Ташкент (Узбекистан), 1-2 июня, Пятигорск (Россия), 24-26 сентября, Тбилиси (Грузия), 28-29 сентября, 2020

ИнтерКарто. ИнтерГИС 27 - Апатиты (Мурманская область), 21-23 августа, Нур-Султан (Казахстан), 27 августа 2021 г. 


\section{InterCarto. InterGIS conference series}

InterCarto 1 - Moscow, May 23-25, 1994

InterCarto 2 - Irkutsk, June 26-29, 1996

InterCarto 3 - Novosibirsk, January 27-31, 1997

InterCarto 4 - Barnaul, July 1-4, 1998

InterCarto 5 - Yakutsk, June 17-19, 1999

InterCarto 6 - Apatity, Murmansk Province, August 22-24, 2000

InterCarto 7 - Petropavlovsk-Kamchatsky, July 30 - August 1, 2001

InterCarto 8 - Helsinki (Finland), St.-Petersburg, May 28 - June 1, 2002

InterCarto 9 - Novorossijsk, Sevastopol (Ukraine), June 25-29, 2003

InterCarto. InterGIS 10 - Vladivostok, Changchun (China), July 12-19, 2004

InterCarto. InterGIS 11 - Stavropol, Dombai, Budapest (Hungary), September 25 - October 3, 2005

InterCarto. InterGIS 12 - Kaliningrad, Berlin (Germany), August 25-31, 2006

InterCarto. InterGIS 13 - Khanty-Mansiysk, Yellowknife (Canada), August 12-24, 2007

InterCarto. InterGIS 14 - Saratov, Urumqi (China), June 24 - July 1, 2008

InterCarto. InterGIS 15 - Perm, Ghent (Belgium), June 29 - July 5, 2009

InterCarto. InterGIS 16 - Rostov-on-Don, Salzburg (Austria), July 3-8, 2010

InterCarto. InterGIS 17 - Belokurikha, Altaysky Kray, Denpasar (Indonesia), December 14-19, 2011

InterCarto. InterGIS 18 - Smolensk, St. Die des Vosges (France), June 26 - July 4, 2012

InterCarto. InterGIS 19 - Kursk, Bogota (Colombia), February 2-8, 2013

InterCarto. InterGIS 20 - Belgorod, Kharkov (Ukraine), Kigali (Rwanda), Nairobi (Kenya), July 23 - August 6, 2014

InterCarto. InterGIS 21 - Krasnodar, Sochi, Suva (Fiji), November 12-19, 2015

InterCarto. InterGIS 22 - Wellington (New Zealand), Melbourne (Australia), Protvino, Moscow Region, August 31 - September 14, 2016

InterCarto. InterGIS 23 - Yuzhno-Sakhalinsk, Seoul (Republic of Korea), Washington DC (USA), June 26 - July 7, 2017

InterCarto. InterGIS 24 - Petrozavodsk (Republic of Karelia), July 19-22, Bonn (Germany), July 24-28, Anchorage (USA), July 30 - August 1, 2018

InterCarto. InterGIS 25 - Murmansk, January 30 - February 2, Tokyo (Japan), July 20, 2019

InterCarto. InterGIS 26 - Tashkent (Uzbekistan), June 1-2, Pyatigorsk, September 24-26, Tbilisi (Georgia), September 28-29, 2020

InterCarto. InterGIS 27 - Apatity (Murmansk region), August 21-23, Nur-Sultan (Kazakhstan), August 27, 2021 


\title{
ИнтерКарто. ИнтерГИС
}

\section{ГЕОИНФОРМАЦИОННОЕ ОБЕСПЕЧЕНИЕ УСТОЙЧИВОГО РАЗВИТИЯ ТЕРРИТОРИЙ}

\author{
Материалы Международной конференции \\ Апатиты (Мурманская область), \\ 21-23 августа, \\ Нур-Султан (Казахстан), \\ 27 августа 2021 г.
}

TOM 27

ЧАСТЬ 2

Оформление обложки К.В. Саутенков

Корректор Н.П. Репухова

Компьютерная вёрстка О.Г. Полевич

Подписано в печать 30.09.2021.

Географический факультет МГУ имени М.В. Ломоносова

119234, Москва, ГСП1, Ленинские горы, д. 1, ауд. 2209, научно-исследовательская лаборатория комплексного картографирования тел.: +7(495)939-23-54

e-mail: intercarto@yandex.ru

сайт издания: http://intercarto.msu.ru/ 